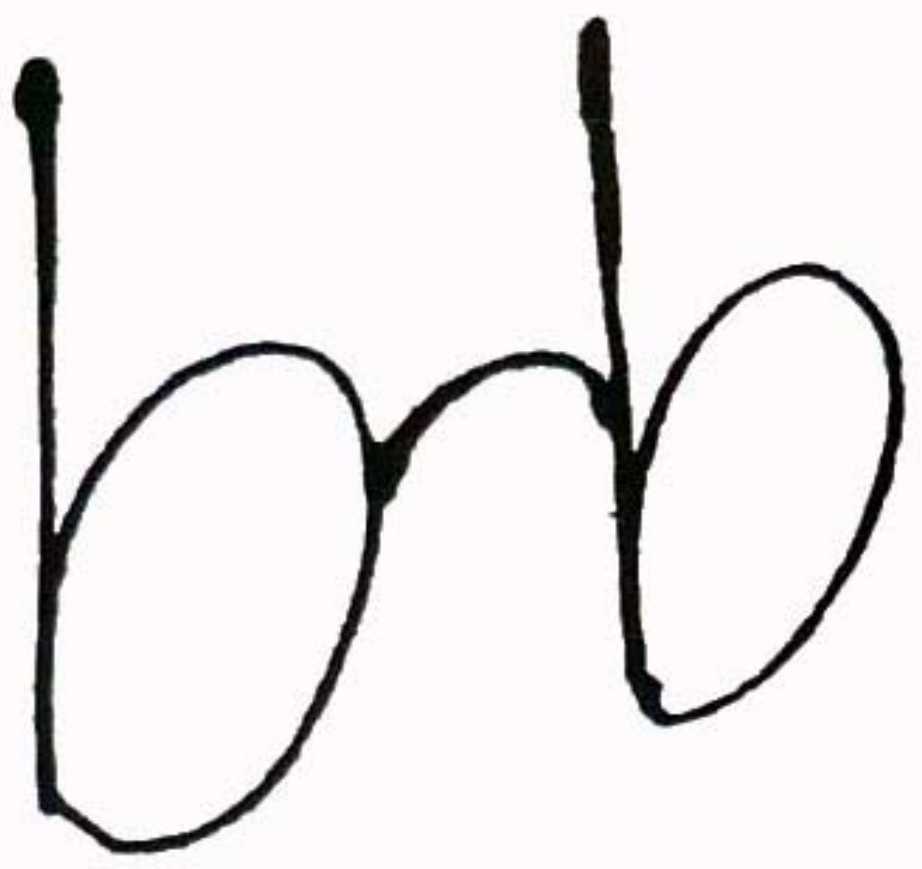

\title{
INFLUENCIA DE LA SBZ/RDA EN LA EVOLUCIÓN DE LOS ELEMENTOS DEL DISEÑO GRÁFICO EN ALEMANIA: COMPOSICIÓN, TIPOGRAFÍA E IMAGEN. UNA PROPUESTA METODOLÓGICA
}

Doctorando:

Directores:
Elena Gutiérrez Rodríguez José Luis Martín Montesinos Jimena González del Río Cogorno

UNIVERSIDAD POLITÉCNICA DE VALENCIA

Escuela Técnica Superior de Ingeniería del Diseño.

Departamento de Ingeniería Grática

Valencia, Octubre 2011 


\section{RESUMEN}

La calidad e importancia del diseño gráfico desarrollado en Alemania en la primera mitad del siglo XX está fuera de toda duda, así como sus aportaciones al panorama gráfico internacional. La Segunda Guerra Mundial y la división de Alemania tras la firma de la Capitulación supusieron una gran brecha en la evolución del mismo. El objeto de la presente investigación es determinar la evolución del lenguaje visual -y con ello de los diferentes elementos del diseño gráficodentro de la República Democrática Alemana, en relación con la evolución experimentada en los años previos y con el sistema social y político existente.

Para lograrlo, tras un análisis cualitativo basado en la bibliografía disponible, se procede al análisis del lenguaje visual de una muestra de 525 carteles desarrollados a lo largo de toda la historia de la RDA. A fin de realizar una investigación metódica diseñaremos un sistema de análisis del lenguaje visual propio, tomando como punto de partida los sistemas de análisis existentes más relevantes. Paralelamente analizaremos la tipografía diseñada y producida dentro de la VEB Typoart, siendo esta la única empresa dedicada al desarrollo de tipos.

Los datos obtenidos nos permiten establecer una evolución y periodización del diseño y su relación tanto con la evolución del diseño previo a 1945 como con los acontecimientos socio-políticos más relevantes. 


\section{SUMMARY}

The quality and importance of graphic design developed in Germany in the first half of the XXth Century, as well as its contribution to the international graphic scene, is beyond all doubt. The Second World War and the division of Germany after the signature of the Capitulation signature created a clear breach in its evolution. The aim of this research is to determine the development of visual language -alongside the different elements of graphic design- in the German Democratic Republic, in relationship with the evolution experimented in the previous years and with the existing social and political system

To achieve it, after a qualitative analysis based on the available literature, we proceeded to analyze the visual language of a sample of 525 posters developed along the GRD history. In order to carry out a methodical research

we designed a self system to examine the visual language taking as a starting point the most relevant existent analysis systems. At the same time we explore the typography designed and produced inside the VEB Typoart, the only enterprise dedicated to the development of types.

The obtained dates make it possible to stabilize an evolution line and the periods of design and its relationship with the evolution of the design before 1945 as well as with the most relevant social and political events. 


\section{RESUM}

La qualitat i importància del disseny gràfic desenvolupa a Alemanya en la primera meitat del segle XX està fora de tot dubte, així com les seues aportacions al panorama gràfic internacional. La Segona Guerra Mundial i la divisió d'Alemanya després de la signatura de la Capitulació van suposar una gran bretxa en l'evolució del mateix. L'objecte de la present investigació és determinar l'evolució del Ilenguatge visual -i amb açò dels diferents elements del disseny gràfic- dins de la República Democràtica Alemanya, en relació amb l'evolució experimentada en els anys previs amb el sistema social i polític existent.

Per a aconseguir-ho, després d'una anàlisi qualitativa basada en la bibliografia disponible, es procedeix a l'anàlisi del Ilenguatge visual d'una mostra de 525 cartells desenvolupats al llarg de tota la història de la RDA. A fi de realitzar una investigació metòdica dissenyarem un sistema d'anàlisi del Ilenguatge visual propi, prenent com a punt de partida els sistemes d'anàlisis existents més rellevants. Paral-lelament analitzarem la tipografia dissenyada i produïda dins de la VEB Typoart, sent aquesta I'única empresa dedicada al desenvolupament de tipus.

Les dades obtingudes ens permeten establir una evolució i periodització del disseny i la seua relació tant amb l'evolució del disseny previ a 1945 com amb els esdeveniments soci-polítics més rellevants. 


\section{AGRADECIMIENTOS}

Quisiera agradecérselo en primer lugar a mis directores de tesis, José Luis y Jimena por su apoyo y sus correcciones. A losé Luis Martín por abrirme la puerta al mundo de la tipografía. A la Stiftung zur Aufarbeitung der SED-Diktatur y en especial a Maria Jung por su inestimable ayuda en la recopilación de bibliografía de la RDA, al DDR-Museum, Museum für Druckkunst y otros tantos museos e instituciones alemanes por su disposición y rapidez en atender a todas mis consultas. A todos los anticuarios por guardar esos libros que tan útiles me han sido. A Sylke Wunderlich, por abrir el camino al diseño gráfico de la RDA y su generosidad. A Ricardo Gutiérrez, aquí por sus clases de estadística, más adelante porque además es mi padre. A Marcos Dopico por su labor de «arqueología tipográfica».

No tengo sitio para enumerar la larga lista de razones por las que agradecer a mi familia y amigos que hayan estado ahí todo este tiempo, y que sigan estándolo después de todo, que al fin y al cabo es lo único de lo que no podría haber prescindido. 


\section{Índice}

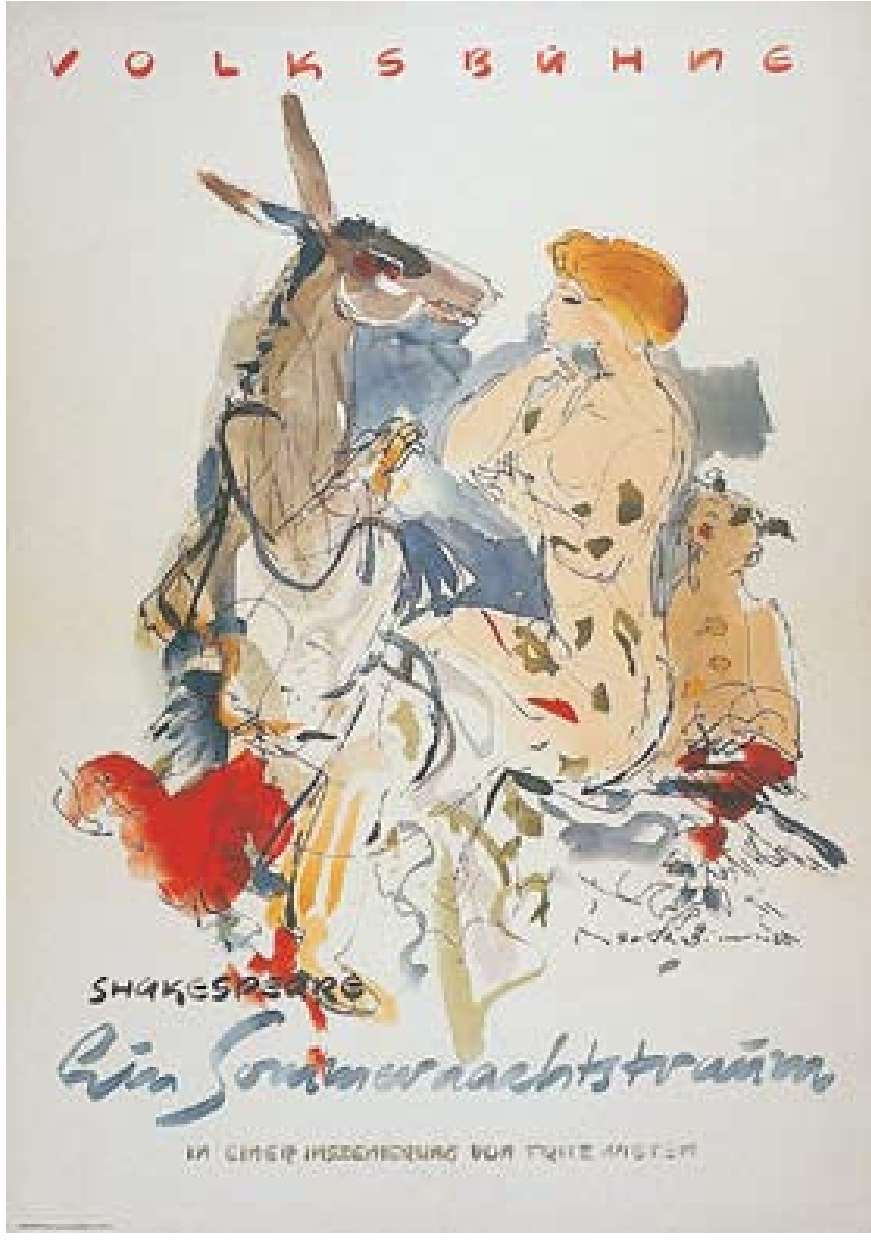




\section{INTRODUCCIÓN}

0.1 INTRODUCCIÓN

O.2 METODOLOGÍA

0.3 ESTRUCTURA DE LA INVESTIGACIÓN

\section{PRIMERA PARTE}

1. Marco teórico y estado de la cuestión

1.1 CONCEPTO DE DISEÑO GRÁFICO

1.2 ANÁLISIS Y CLASIFICACIÓN DEL DISEÑO GRÁFICO

1.2.1 Estructura de análisis según Luz Vilchis Esquivel

1.2.2 Estructura de análisis según Wucius Wong

1.2.3 Estructura de análisis según Donis $\mathrm{A}$. Dondis

1.2.4 Estructura de análisis según Robin Landa

1.2.5 Estructura de análisis según Ellen Lupton y Jennifer Cole Phillips

1.2.6 Estructura de análisis según María Acaso

1.2.7 Comparación de las estructuras de análisis

1.2.8 Otras taxonomías de interés

1.3 RETÓRICA VISUAL

1.3.1 Figuras retóricas

1.3.2 Clasificación de las figuras retóricas

SEGUNDA PARTE

2. Evolución del diseño gráfico alemán previo a 1945

1. ANALISIS DE LAS CARACTERISTICAS DEL DISEÑO GRAFICOALEMAN PREVIO A 1945

2.1.1 Plakatstil

2.1.1.1. Composición

2.1.1.2. Tipografía

2.1.1.3. Imagen

2.1.2 Industria y Diseño. Werkbund Institut 2.1.2.1. Composición

2.1.2.2. Tipografía

2.1.2.3 Imagen

2.1.3. Expresionismo

2.1.3.1. Composición

2.1.3.2. Tipografía

2.1.3.3. Imagen

2.1.4. El diseño en los periodos bélicos. Primera Guerra Mundial

2.1.4.1. Composición 
2.1.5. John Heartfield y el Dadaísmo

3.2 CONTEXTO POLÍTICO

2.1.5.1. Composición

3.2.1 Fundamentos ideológicos

3.2.2 Partidos políticos

2.1.5.2. Tipografía

3.2.3 Estructura política

2.1.5.3. Imagen

3.2.4 Sistema electoral

2.1.6. Las aportaciones de la Bauhaus

3.2.5 Promoción y propaganda

3.2.6 Ministerio para la Seguridad Nacional

2.1.6.3. Composición

2.1.6.4. Tipografía

3.3 CONTEXTO ECONÓMICO

2.1.6.5. Imagen

2.1.7. El Funcionalismo y la Nueva Tipografía

3.3.1 Planes estatales y consumo

3.3.2 Cronología de los planes

3.3.3 Periodización de la economía de la RDA

3.3.4 Organización empresarial

2.1.7.2. Tipografía

3.3.5 Regulación y fomento del trab

2.1.7.3. Imagen

3.3.6 Regulación del comercio y clases de consumo

3.3.6.1 Handelsorganization.

3.3.6.2 Comercios especiales

3.3.7 Política de precios
3.4 CONTEXTO SOCIO CULTURAL

2.1.8.2. Tipografía

2.1.8.3. Imagen

2.2 EVOLUCIÓN DEL DISEÑO GRÁFICO PREVIO A 1945

3.4 CONTEXTO SOCIO CULTURAL

3.4.1 Contexto social

3.4.1.1 Demografía y politicas sociales

3.4.1.2 Religión

3.4.1.3 Deporte

3.4.1.4 Sistema educativo

3.4.2 Asociaciones de masas , FDGB)

3.4.2.2 Gesellschaft für Deutsch-Sowjetische Freundschaft (Sociedad para la amis- 146 tad alemano-soviética, DSF DTSB

3.4.2.3 Deutscher Turn- und Sportbund (Unión de Gimnasios y Deportes Alemana, 147

3.4.2.4 Freie Deutsche Jugend (Juventud Libre Alemana, FDJ)

3.4.2.5 Junge Pioniere/Thä/mannpioniere (Jóvenes pioneros/Pioneros Thälmann, JP) 148

3.4.2.6 Otras Organizaciones de Masas 148

3.4.3 Contexto cultural

3.4.4 Promoción y difusión cultural

149 nacional".

3.1.3.2.1 Cronología y periodos de la identidad alemana y la "cuestión 103

3.1.4 Periodización histórica de la RDA

3.4.5 Crítica, censura y protesta 


\section{El diseño tipográfico}

5.1 CRITERIOS DE ANÁLISIS TIPOGRÁFICO

5.2 TIPOGRAFÍAS DE LA VEB TYPOART

5.2.1. Tipografía romana renacentista francesa

5.2.2. Tipografía romana barroca

5.2.3. Tipografía romana neoclásica

5.2.4. Tipografía egipcia

5.2.5. Tipografía palo seco

5.2.6. Tipografía variantes de la letra romana

5.2.7. Tipografía manuscrita

5.2.8. Tipografía caligráfica

5.2.9. Tipografías quebradas

5.2.10. Otras tipografías

\subsubsection{Colocación}

6.1.3.7 Perspectiva

6.1.4 Anatomía del mensaje

6.1.4.1 Representación

6.1.4.2 Abstracción

6.1.4.3 Retórica Visual

6.2 ANÁLISIS DE EJEMPLOS DE LA MUESTRA

6.2.1 Muestra 1

6.2.1.1 Datos técnicos

6.2.1.2 Elementos básicos

6.2.1.3 Sintaxis

6.2.1.4 Anatomía del mensaje

6.2.2 Muestra 2

6.2.2.1 Datos técnicos

6.2.2.2 Elementos básicos

6.2.2.3 Sintaxis

6.2.2. 4 Anatomía del mensaje

6.2.3 Muestra 3

6.2.3.1 Datos técnicos

6.2.3.2 Elementos básicos

6.2.3.3 Sintaxis

6.2.3.4 Anatomía del mensaje

6.2.4 Muestra 4

6.2.4.1 Datos técnicos

6.2.4.2 Elementos básicos

6.2.4.3 Sintaxis

6.2.4.4 Anatomía del mensaje

6.2.5 Muestra 5

6.2.5.1 Datos técnicos

6.2.5.2 Elementos básicos

6.2.1.3 Sintaxis

6.2.1.4 Anatomía del mensaje

\section{Análisis e interpretación de los datos}

7.1 DATOS TÉCNICOS

7.1.1 Datos la muestra

7.1.2 Hitos históricos

7.1.3 Distribución según género 
7.2.1 Código morfológico 296

7.2.1 Código cromático 302

7.2.3 Código tipogrático 307

7.3 SINTAXIS $\quad 320$

7.3.1 Estrategia $\quad 320$

7.3.2 Énfasis $\quad 322$

$\begin{array}{ll}7.3 .3 \text { Ritmo } & 325\end{array}$

7.3.4 Equilibrio $\quad 330$

7.3.5 Unidad 333

\begin{tabular}{ll} 
7.3.6 Colocación & 338 \\
\hline & 333
\end{tabular}

7.3.7 Perspectiva 347

$\begin{array}{ll}\text { 7.4 ANATOMIA DEL MENSAJE } & 348\end{array}$

7.4.1 Representación 348

7.4.2 Abstracción $\quad 352$

7.4.4 Retórica 356

\section{CUARTA PARTE}

8. Conclusiones 361

8.1. CONTRASTE DE HIPÓTESIS 363

8.2 CONCLUSIONES GENERALES 374

8.2.1 Descripción del lenguaje visual del diseño grático de la SBZ/RDA 374

8.2.2 Líneas de tendencia en la evolución del diseño de la RDA en relación con las 381 tendencias previas

8.2.3 Reflejo de los acontecimientos históricos y políticos en las tendencias del diseño 387

\section{Fuentes}

9.1 FUENTES BIBLIOGRÁFICAS 391

9.2. FUENTES GRÁFICAS 402

9.2.1 Por autor $\quad 402$

9.2.2 Autor desconocido 409

\section{ANEXOS}

I. Traducciones y abreviaturas

\begin{tabular}{ll} 
II. Tipografías de la VEB Typoart & 417 \\
\hline
\end{tabular}

III. Datos de análisis $\quad 469$

IV. Índice de tablas y gráficos $\quad 521$

$\begin{array}{ll}\text { V. DIN } 16518 & 529\end{array}$ 
PRIMERA PARTE 
o. Introducción

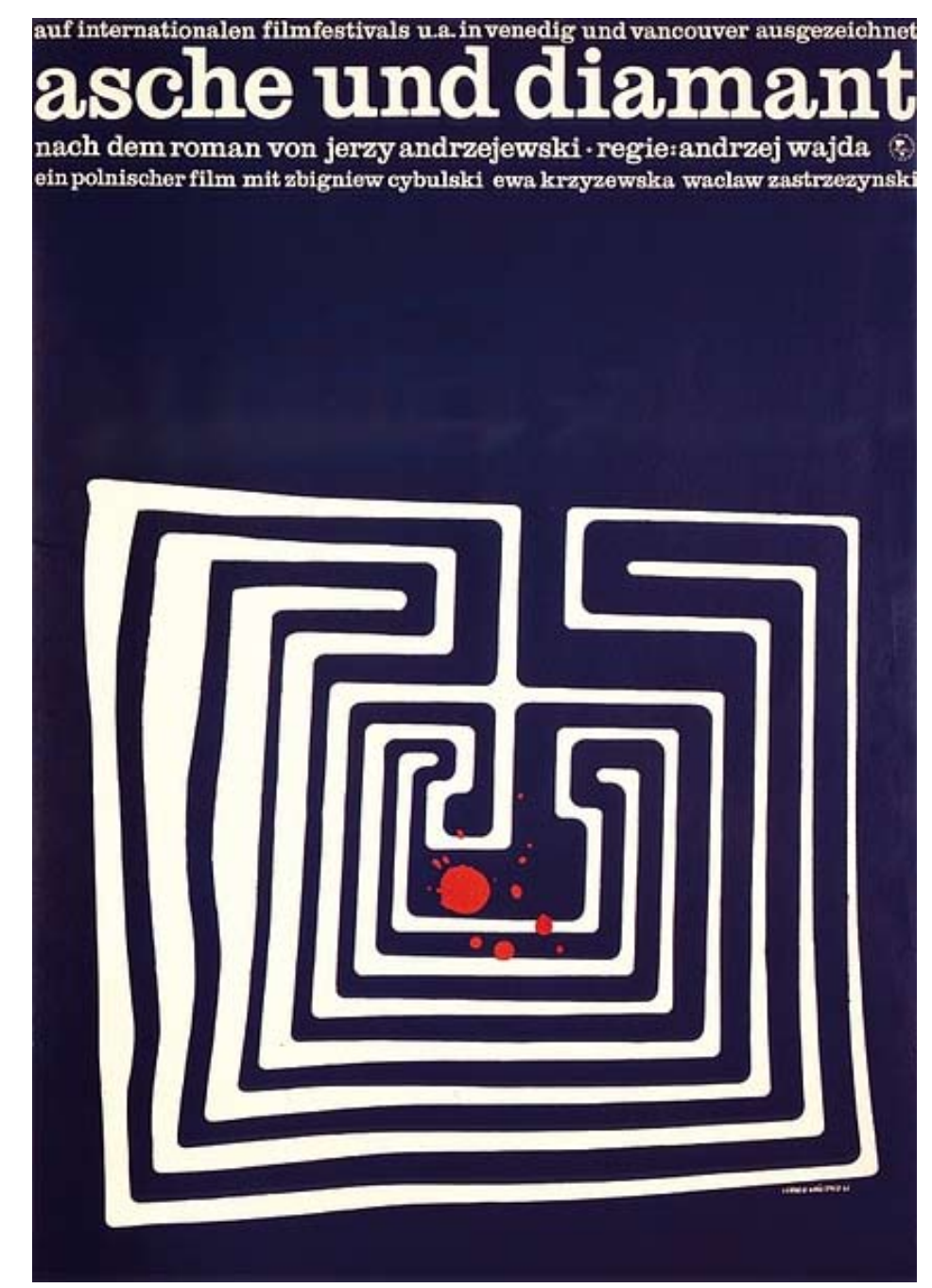


0.1 INTRODUCCIÓN

La presente investigación surge de la necesidad de conocimiento de un pasado artístico reciente poco conocido y estudiado. Mientras que el diseño gráfico alemán previo a la Segunda Guerra Mundial y posteriormente en la República Federal Alemana (RFA) es objeto de numerosos monográficos y está presente en todas las publicaciones realizadas sobre la evolución del diseño gráfico, el realizado en la Alemania oriental apenas ha sido tenido en cuenta fuera de su contexto más próximo.

El primer acercamiento al tema de la investigación surge de un catálogo de diseño de envases de productos de con sumo habitual de la RDA. Partiendo de la asociación generalizada de diseño gráfico con el deseo de vender, publicitar y difundir, ¿qué sentido tiene seguir creando diseños en un sistema socializado en el cual no existe libre competencia como es el caso de la RDA? ¿Qué es lo que ocurre cuando, en un país como Alemania, con una amplia cultura de diseño gráfico, parte de este deja de necesitar vender el producto? Tras abordar los primeros textos de referencia esta cuestión se irá transformando de un qué, que ya ha sido tratado con cierta amplitud, a un cómo.

La investigación exige una objetividad libre de apriorismo y de prejuicios ideológicos. El marco de investigación a que nos enfrentamos tiene una fuerte componente sociopolítica para la cual resulta muy beneficiosa nuestra condición de meros observadores externos con conocimientos únicamente teóricos sobre el mismo.

La calidad y gran importancia del diseño gráfico ${ }^{1}$ desarrollado en Alemania en la primera mitad del siglo XX está fuera de toda duda, no en vano numerosos autores consideran el cartel de las cerillas Priester creado en 1905 por Lucian Bernhard un hito en la historia mundial del diseño gráfico, en el cual se «sustituyó la simplificación y reducción del naturalismo en la comunicación gráfica por un lenguaje de forma y señal más avanzado» (Meggs, 2000: 249).

Tras la firma de la Capitulación, Alemania irá poco a poco recuperando su pulso, y con él surgirán nuevas necesidades de diseños gráficos en forma de carteles, libros o empaquetamientos, pero parte de ella lo hará en un sistema político y social radicalmente diferente a aquel en el que se había desarrollando en los años previos a la guerra. El historiador alemán Stefan Wolle (1999) afirma que en todos los aspectos de la vida de la República Democrática Alemana (RDA) estaban presionados por las demandas del Estado.

1. Pese a que el término «diseño gráfico» no fue acuñado por el americano William Addison Dwiggins hasta 1922, para el tema de la investigación considerarenos 
Esto nos hace suponer que, en base a esta diferencia de sistema político y al poder ejercido por el mismo, el diseño gráfico tomará aquí un rumbo propio e independiente al establecido en la evolución del diseño previo a la guerra. El objeto de la presente investigación es determinar la evolución del lenguaje visual $-y$ con ello de los diferentes elementos del diseño gráfico- dentro de la SBZ/RDA², en relación con la evolución experimentada en los años previos y con el sistema social y político existente. como tal hasta 1949. Entre 1945 y esta fecha se denomina Sozialistische soviética SBZ), de tal modo que soviética, SBZ), de tal modo que el periodo temporal objeto de duci, desce debe denominarse SBZRDA pese a que por razones de economía de étúnicam ocasiones nos refiran

3. «El papel de imprimir, colores o tipografías dependían de la disponibilidad, y eran gradualmente mejorados pieza a pieza. Las pulsaciones deben su apariencia a los impresores, que daban a los textos facilitados una forma más o menos agradable. La mayoría imprimían con tipografía de plomo o de madera en imprentas de tipografía o litográficas, ya que las máquinas de offset estaban

disponibles solo condicionalmente».

Wunderlich, 2007: 11
Podríamos enunciar los objetivos de la siguiente forma:

1. Describir el lenguaje visual del diseño gráfico en la SBZ/RDA ción del diseño en ese periodo

3. Relacionar estas líneas de tendencia con las tendencias experimentadas en las décadas previas a la guerra

4. Determinar la influencia que tuvo el estado en las posibles variaciones de estas tendencias

Las hipótesis de las que partimos al enfrentarnos a la investigación son las siguientes:

1. No existen relaciones significativas entre el diseño gráfico previo a la RDA y el diseño gráfico desarro-

2. Las decisiones gubernamentales no solo se reflejaron en la temática de los carteles, sino que afectaron al lenguaje visual.

3. El lenguaje visual se vio afectado por la estructura económica de la RDA.

4. La creación tipográfica de la VEB Typoart dominó el panorama gráfico por ser la única empresa socializada dedicada al diseño y producción de tipografía, con diseños adaptados a las necesidades reales ${ }^{3}$.

Conscientes de la problemática de abarcar el diseño gráico en todas sus expresiones tomaremos como base de análisis de la investigación el cartel. Esta elección se justifica a dos niveles, por una parte, debido a que según afirmaba el teórico germanoriental Helmut Rademacher (1975: 15): «aunque los medios de expresión gráfica han aumentado, permanece e incluso se incrementa la predilección por los carteles. Una de las particularidades del diseño gráfico es el gran número de disciplinas que entra en juego en él», lo que convierte al cartel en un elemento representativo dentro del diseño gráfico. Los numerosos catálogos publicados con este objeto, hacen de los carteles un elemento de estu-
2. Establecer unas líneas de tendencia en la evolullado dentro de ella. dio preferencial gracias a la extensa documentación disponible en forma de catálogos. Frente a otros elementos como el diseño de envases, cuya documentación técnica pocas veces resulta accesible, nos encontramos aquí con un objeto de estudio fácilmente clasificable temporalmente y cuyo autor es en la mayor parte de las veces conocido.

Finalmente destacar que los estudios sobre diseño gráfico alemán previo a la Segunda Guerra Mundial consultados, hacen referencia fundamentalmente al diseño de carteles, lo que justifica una vez más la elección de este elemento como objeto de la muestra. 


\subsection{METODOLOGIA.}

Nos enfrentamos en este caso a lo que se ha dado en denominar una investigación en el diseño, puesto que se realiza desde fuera y operando únicamente como observador. Esta investigación pertenece a las denominadas investigaciones documentales y experimentales ya que por una parte nos apoyaremos en fuentes documentales y finalmente en la observación de la muestras. Igualmente podemos decir que se trata de una investigación exploratoria debido a que que «su propósito es destacar los aspectos esenciales de una problemática determinada» (Pelta Resano, 2008: 72)

Desde el punto de vista metodológico nos enfrentamos, como hemos dicho, a la investigación desde dos perspectivas; una primera de análisis cualitativo basado en la bibliografía disponible, mediante el cual estableceremos un marco teórico, y una segunda parte en la cual realizamos un análisis cuantitativo basándonos en un análisis estadístico descriptivo, el cual, partiendo previamente de un marco de referencia, nos permita refutar o falsificar las hipótesis de partida.

En esta primera parte, al acopio de material bibliográfico, le seguirá el abordaje de los primeros textos de referencia que establezcan la viabilidad de la hipótesis de la investigación.

Al tema de investigación hemos de acercarnos desde perspectivas de autores de gran prestigio cuya elección se ha basado bien en su relevancia dentro de sus campos de investigación, bien en la adecuación de las mismas al tema de la investigación. Si bien en campos como el diseño gráfico en la RDA la bibliografía disponible es relativamente limitada, lo que reduce notablemente la necesidad de discriminar información, otros, como el análisis del diseño gráfico, cuentan con una extensa bibliografía.

Hemos escogido por tanto aquellos autores cuyo prestigio no sólo esté fuera de toda duda, sino cuyas obras se acerquen al tema desde el punto de vista del análisis globa de la disciplina. Autores como Quentin Newark, Michae Beirut o Yves Zimmerman, grandes teóricos del diseño gráfico y consultados en la realización de la investigación, han quedado fuera de la selección debido a que su acercamiento a la misma no resulta adecuado al objetivo de la investigación. Entre los autores seleccionados destacan: 
ANÁLISIS DEL DISENO GRÁFICO:

- Dra. María Acaso, profesora titular de Educación Artística en la Facultad de Bellas Artes de la Universidad Complutense de Madrid.

- Donis Dondis, profesora asociada de Comunicación en la Boston University School of Public Communication y directora de su Summer Term Public Communication Institute.

- Robin Landa, profesora de la Facultad de Diseño de Busch en la Kean University y autora de varios libros de diseño gráfico.

- Ellen Lupton, diseñadora gráfica, comisaria artística y directora del programa de diseño gráfico en el Master of Fine Art de Maryland Institute College of Art (MICA) y Jennifer Cole Phillips profesora de diseño gráfico en la misma universidad.

- Dra. Luz Vilchis Esquivel, profesora de la Escuela Nacional de Artes Plásticas de la UNAM de México y autora de la tesis «Relaciones dialógicas en el diseño gráfico».

- Wucius Wong, conservador del Museo de Arte de Hong Kong y catedrático de la Escuela de Diseño Swire del Politécnico de Hong Kong.

EVOLUCIÓN DEL DISEÑO GRÁFICO ALEMÁN:

- Dr. Jeremy Aynsley, doctor por el Royal College of Art y profesor de diseño gráfico en la misma escuela donde supervisa las investigaciones del departamento de historia del diseño.

- Richard Hollis, diseñador gráfico y tipógrafo británico dedicado al estudio y difusión de la disciplina como editor de arte y autor de obras de historia del diseño.

- Philip B. Meggs, diseñador gráfico y profesor de la Virginia Commonwealth University, es autor de una de las historias de diseño gráfico más influyentes.

- Enric Satué, profesor de la Universitat Pompeu Fabra, Premio Nacional de Diseño y Miembro de la Reial Acadèmia Catalana de Belles Arts de Sant Jordi. Es autor de varios libros de historia del diseño nacional e internacional.

\section{MARCO DE REFERENCIA HISTÓRICO}

- Dr. Wilhelm Bleek, politólogo y profesor de ciencias políticas en la Universidad de Bochum.

- Dra. Hope M. Harrison, doctora especializada en la Guerra Fría y la historia de Alemania Oriental, profesora de Historia y Asuntos Internacionales en la Universidad George Washington y directora del Instituto de Europa, Rusia y Eurasia en Estudios GWU.

- Dr. Matthias Judt, licenciado en historia económica por la Humboldt-Universität e investigador del Zentrum für Zeithistorische Forschung Postdam (Centro de Investigación Histórica de Postdam).

- Dra. Annette Kaminsky, investigadora del Stiftung zur Aufarbeitung der SED-Diktatur (Institución para el Tratamiento de la Dictadura del SED).

- Dr. Hermann Weber, doctor en filosofía, profesor de ciencias políticas e historia contemporánea y director del campo de trabajo «Historia y política de la RDA» en la Universidad de Mannheim.

- Stefan Wolle, historiador especializado en la RDA investigador del Stiftung zur Aufarbeitung der SEDDiktatur.

DISENO GRÁFICO EN LA RDA

- Albert Kapr, tipógrafo director y profesor de la Hochschule für Grafik und Buchkunst de Leipzig (Escuela Superior de Artes Gráficas y del Libro HGBL), director de la VEB Typoart y autor de numerosos manuales y libros de tipografía en la RDA.

- Dr. Hellmut Rademacher, historiador y germanista por la Humboldt-Universität, responsable de la colección de carteles del Museum für Deutsche Geschichte (Museo de Historia Alemana) y autor de numerosos estudios sobre el cartel y el diseño gráfico.

- Simone Tippach-Schneider, publicista e historiadora del Arte por la Humboldt-Universität especializada en la RDA, editora de la revista alemana sobre publicidad y diseño gráfico "Neue Werbung».

- Verband Bildender Künstler (Asociación de Artistas Plásticos) cuya sección de diseño gráfico editó y realizó la práctica totalidad de estudios sobre diseño gráfico en la RDA.

- Dra. Sylke Wunderlich, autora de la tesis «Plakatkunst in der SBZ, DDR 1945/1949-1969: geschichtliche Entwicklung und Gestaltung eines künstlerischen Mediums» (Arte del cartel en la SBZ, DDR 1945/1949-1969: historia del desarrollo y la creación de un medio artístico), única tesis redactada sobre el tema desde el punto de vista gráfico. 
Nos apoyaremos en el uso de tablas y gráficos sintetizadores de los resultados obtenidos a fin de poder realizar observaciones y conclusiones globales y de poder relacionar los diferentes estudios realizados sobre un mismo tema. Del mismo modo, y puesto que la mayoría de las obras consultadas están en alemán, lengua que no nos es propia, las citas textuales que pudieran dar lugar a dobles interpretaciones se reflejaran en ambos idiomas, de tal modo que permita la lectura independiente. Con el fin de simplificar la lectura y a modo de apoyo se añaden dos anexos en los cuales se recogen las traducciones realizadas sobre instituciones, obras o escuelas y de sus correspondientes siglas.

Establecido de este modo un marco de referencia acometeremos la realización de un estudio estadístico. Para asegurarnos la realización de un examen sistemático y científico de los elementos de la muestra procederemos a la creación de un modelo propio de análisis del diseño gráfico cuyos parámetros y valores quedarán claramente definidos previamente a la exploración de la muestra.

Como en todo trabajo basado en la estadística descripiva necesitamos establecer una muestra de análisis de la población -cartel diseñado en la SBZ/RDA-. En esta investigación optaremos por la selección de una muestra no probabilística, o muestra dirigida. La razón para este tipo de selección es por un lado temporal; para poder analizar una evolución necesitamos asegurarnos que cubrimos la totalidad del espacio temporal de una forma relativamente uniforme, y por otra parte porque la influencia de aquellos elementos que fueron objeto de exposiciones y publicaciones será mayor, y con ello más representativo, que aquellos que no lo fueron.

Seleccionaremos una muestra cualitativa según casos típicos. Para determinar el criterio de elección de casos típicos tendremos en cuenta que la práctica totalidad de los diseñadores pertenecían a la Verband Bildender Künstler Asociación de Artistas Plásticos, VBK), y esta era la encargada de la realización de concursos y exposiciones sobre carteles. En un primer momento se observó la posibilidad de considerar aquellos elementos que obtuvieran alguna distinción en los premios de los concursos organizados por a asociación, sin embargo, según datos de Sylke Wunderlich (2007: 43), únicamente en el concurso de «Beste Plakate» (Mejores carteles) en las «24 ediciones del concurso se habrían elegido 9975 carteles, 1292 serían elegidos por el jurado como los mejores y 2372 mencionados y premiados», un número excesivamente elevado como muestra.
En 1989, con motivo de los 40 años de RDA, la VBK realizará una exposición retrospectiva de los carteles desde 1945. Para ello seleccionarán un total de 226 carteles. Posteriormente a la reunificación la Verband der Grafik-Designer (Asociación de diseñadores Gráficos, VGD), realizará, junto con otras asociaciones de diseñadores, una selección de carteles entre los premiados como «mejor cartel» de 130 carteles.

Finalmente se considerará la selección realizada por la doctora Sylke Wunderlich para la exposición «Überklebt: Plakate aus der DDR» (Superpuesto: Carteles de la RDA).

La escasa valoración de los carteles publicitarios y de carácter económico hace que estos estén relegados en todas las selecciones realizadas dentro de la RDA, por lo que se añadirán a la muestra la selección de 32 carteles realizada por la publicista e historiadora del arte Simone Tippach-Schneider, en su libro «Das grosse Lexikon der DDR-Werbung: Kampagnen und Werbesprüche, Macher und Produkte, Marken und Warenzeichen». (La gran enciclopedia de la publicidad de la RDA: Campañas y eslóganes, fabricantes y productos, marcas y marcas registradas).

Consideraremos las obras seleccionadas para estas publicaciones retrospectivas una muestra adecuada para la investigación a realizar. Como era de esperar un alto porcentaje de los carteles han sido seleccionados en varias de ellas, lo que supone una muestra total de 525 elementos. 


\subsection{ESTRUCTURA DE LA INVESTIGACION}

Siguiendo las pautas de la metodología planteada estructuramos la investigación en cuatro partes. En la primera parte estableceremos un marco teórico en el que se desarrollan los conceptos generales de diseño gráfico, las propuestas de análisis y clasificación del diseño gráfico y retórica.

La segunda parte está constituida por el análisis cualitativo y documental en base a los estudios más relevantes. De su análisis surge la definición de un contexto sociopolítico y de un estado previo del arte, necesarios para poder establecer las conexiones entre estos y el diseño gráfico de la

RDA, para terminar con un repaso de la literatura científica sobre este último

En la tercera parte nos ocuparemos del análisis cuantitativo. Tras el diseño de la investigación procederemos al análisis e interpretación de los datos obtenidos a partir de este. La investigación se completará con la descripción y análisis del diseño tipográfico creado en la RDA.

La cuarta parte corresponde a la redacción de las conclusiones, incluyendo el contraste de las hipótesis con las pruebas estadísticas realizadas y el cumplimiento de los objetivos.

A nivel de esquema la investigación se ha estructurado de la siguiente manera:

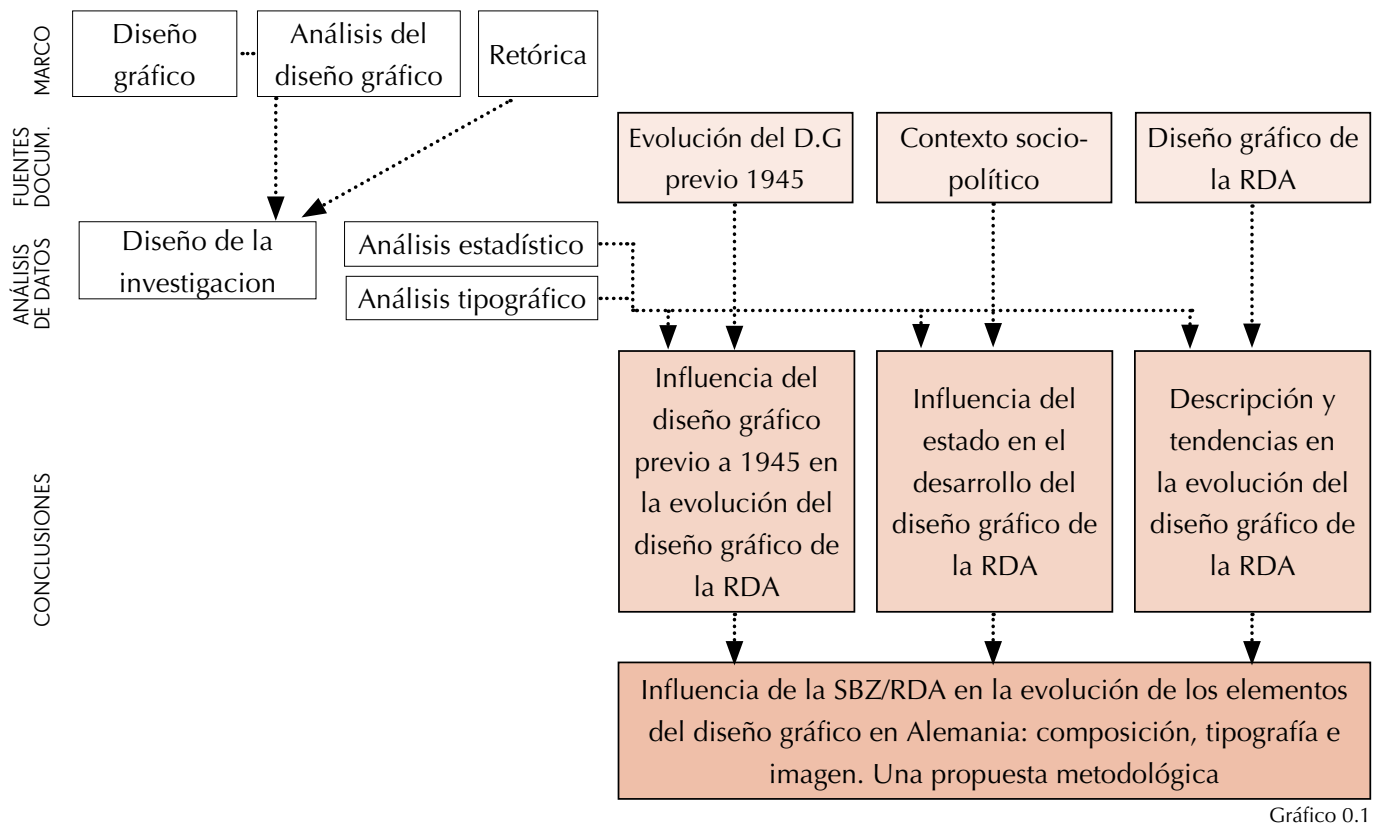


1. Marco teórico y estado de la cuestión

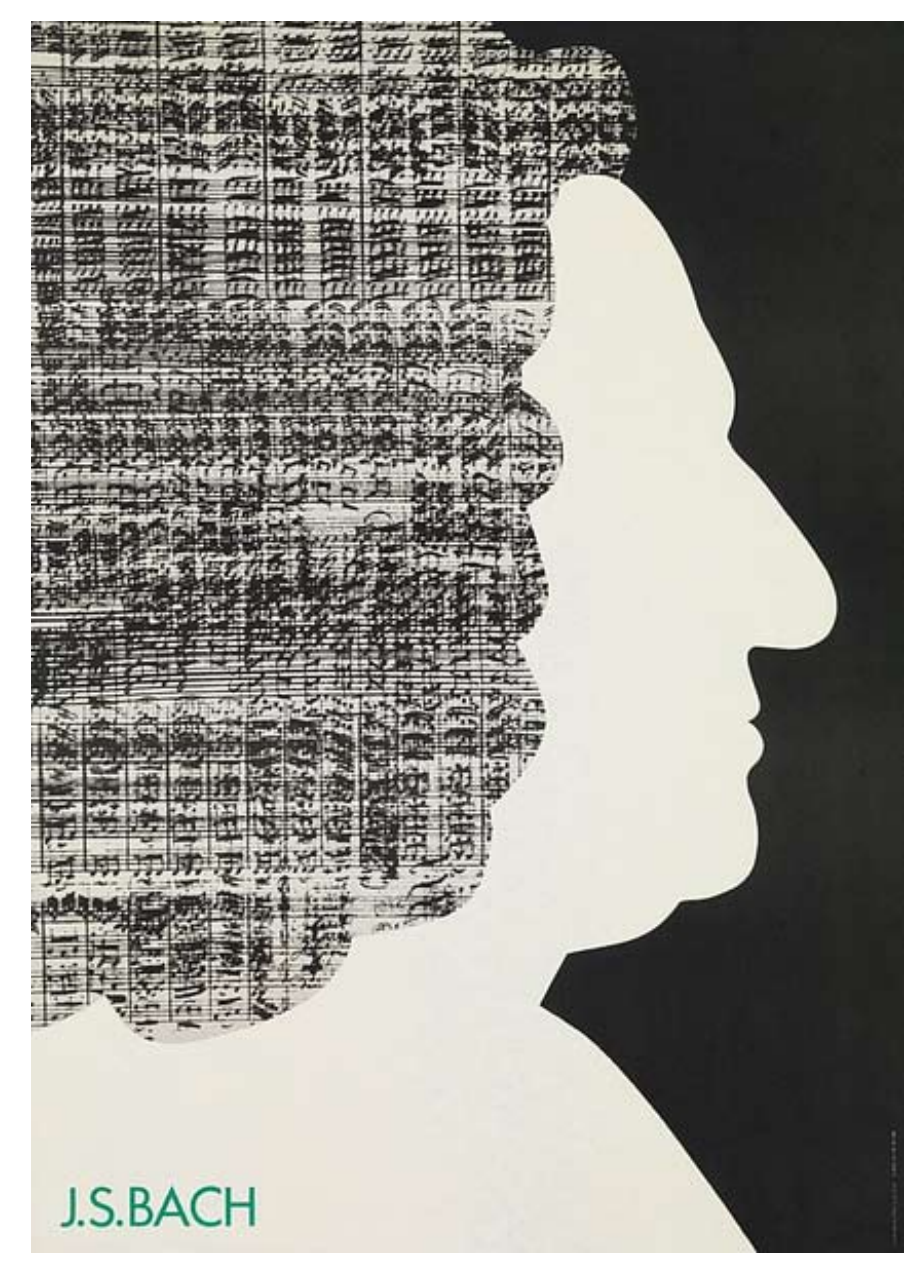




\subsection{CONCEPTO DE DISEÑO GRÁFICO}

Comenzaremos por situar el marco teórico en el que se desarrolla la investigación. Esta se realizará en el ámbito del diseño gráfico, por lo que hemos de empezar situando este término. La denominación de «diseño gráfico»le ha sido atribuida al americano William Addison Dwiggins para definir su actividad profesional en 1922. Pese a lo tardío de este término, para el tema de la investigación consideraremos diseño gráfico todo el diseño posterior a 1905.

Desde 1922 se han sucedido numerosas definiciones para intentar abarcar la totalidad del concepto que le es asociado. Richard Hollis (2000: 7) lo explicaba de la siguiente manera:

«El diseño gráfico puede consistir en signos, como las letras del alfabeto, o formar parte de un sistema mayor, como las señales de tráfico. Cuando se juntan, los elementos gráficos -las líneas de un dibujo o los puntos de una fotografía- forman imágenes. El diseño gráfico es el arte de concebir proyectos de expresión visual».

La doctora Vilchis Esquivel $(2006: 217,218)$ amplía esta definición incluyendo el concepto de comunicación:

«El diseño gráfico, lo defino como la disciplina proyectual orientada hacia la resolución de problemas de comunicación visual, se identifica con la acción humana de organizar elementos formales, es praxis transcendente, porque se origina en el propio agente y termina fuera de él, es poiesis creativa porque agrega al ser algo que no existía (...). Diseño gráfico, amplío, también es comunicación, y por ello, configura mensajes que el hombre requiere para establecer un orden significativo con una definición material y expresiva».

En la misma línea sitúa Jorge Frascara (2000a: 5) su ámbito de influencia ya que afirma que:

«(...) el diseño de comunicación visual se ocupa de la construcción de mensajes visuales con el propósito de afectar el conocimiento, las actitudes y el comportamiento de la gente. Una comunicación llega a existir porque alguien quiere transformar una realidad existente en una realidad deseada».

Jorge Frascara introduce así en su definición la función que le es implícita. Para Yves Zimmermann (1998: 29) esta finalidad «es la referencial porque, para empezar, los elementos básicos de un diseño gráfico son representaciones de alguna realidad. El lenguaje (la tipografía) es una representación fonética, y la imagen (la fotografía, la ilustración) es una representación visual de la realidad». 
A modo de conclusión nos remitimos a las palabras de Jorge Frascara (2000b: 13-14), para quien:

«(...) el diseño grafico es la acción de concebir, programar, proyectar y realizar comunicaciones visuales, producidas en general por los medios industriales y destinadas a transmitir mensajes específicos a grupos determinados. Aunque diseño gráfico es la denominación más adoptada el título más apropiado y descriptivo es Diseño de la comunicación visual ya que pián presentes los tres elementos necesaios para definir que actividad:

Un método: diseño

Un objetivo: comunicación

Un campo: el visual

Por tarto podemos decir que el diseño gráfico es la actividad que mediante un método especifico (diseño) construye mensajes (comunicación) con medios visuales».

\subsection{ANÁLISIS Y CLASIFICACIÓN DEL DISEÑO GRÁFICO}

Nos hemos referido anteriormente a varias definiciones del concepto de diseño gráfico, limitando con ello el marco de la investigación. Nos interesa especialmente la afirmación de Wucius Wong (1995: 41) según la cual «el lenguaje visual es la base de la creación del diseño", así como la de Bruno Munari (1987: 84) quien escribe:

«Si hemos de estudiar la comunicación visual convendrá examinar este tipo de mensaje y analizar sus componentes. Podemos dividir el mensaje, como antes, en dos partes: una es la información propiamente dicha, que lleva consigo el mensaje y la otra es el soporte visual. El soporte visual es el conjunto de elementos que hacen visible el mensaje, todas aquellas partes que se toman en consideración y se analizan, para poder utilizarlas con la mayor coherencia respecto a la información».

Es precisamente el estudio de este soporte visual y su evolución en un determinado periodo el objeto de la presente investigación.

Por tanto, trataremos de describir aquí las estructuras de análisis establecidas por diversos autores. No obstante hemos de tener en cuenta la opinión de Wong (1995: 41) cuando escribe que:

«Hay numerosas formas de interpretar el lenguaje visual. A diferencia del lenguaje hablado o escrito, cuyas leyes gramaticales están más o menos establecidas, el lenguaje visual carece de leyes obvias. Cada teórico del diseño puede poseer un conjunto de descubrimientos distintos por completo».

De la misma opinión se muestra Dondis (2008: 25), quien -sobre lo que ella denomina alfabeticidad visual-, opina que «nunca podrá ser un sistema lógico tan neto como el del lenguaje. Los lenguajes son sistemas construidos por el hombre para codificar, almacenar y descodificar informaciones. Por tanto, su estructura tiene una lógica que la alfabeticidad visual es incapaz de alcanzar».

\subsubsection{Estructura de análisis según Luz Vilchis Esquivel}

Especialmente ilustrativa resulta la propuesta de la doctor Luz Vilchis Esquivel (2006: 221), profesora de la Escuela Nacional de Artes Plásticas de la UNAM de México, quien concibe:

«(...) el lenguaje visual desde una traspolación de las teorías lingüísticas, así defino entre sus componentes: el signo visua que, como el signo escrito, remite a un signo oral y a signo intelectuales; la intencionalidad como dirección del mensaje; los códigos visuales como vehículos del concepto del lenguaje visual; la estrategia discursiva (consciente o no) que elabora los conceptos pertinentes y la orientación persuasiva».

Asímismo, es objeto de la presente investigación el análisis de la anatomía del diseño gráfico, no de su hermenéutica, por lo que nos ceñiremos al análisis de los signos visuales y de sus códigos.

En primer lugar le reconoce al diseño gráfico, como lenguaje visual, una gramática propia (2006: 223-225) y describe:

«los componentes de lo diseñado, desde las unidades gráficas mínimas hasta su estructura y las relaciones particulares de esta para construir los diversos discursos. (...) En esta gramática designo la articulación como toda actividad o forma de organización de significantes y significados para configurar nuevas unidades de sentido; la base son las posibilidades sintácticas de la forma y sus interrelaciones. Es así que postulo en esta esquematización de la gramática visual:

- Bases de articulación: en las que comprendo los principios de diagramación o condiciones de fragmentación geométrica del espacio y los principios de normalización que definen los formatos o soportes del diseño.

- Articulación formal: donde integro el alfabeto visual que define los elementos morfológicos (...), los elementos dimensionales (..) y los elementos estructurales (...).

- Articulación conceptual: en la cual incluyo las leyes de composición o normas de configuración (...); los valores estructurales o cualidades formales (...), así como sus posibles variaciones o alteraciones (...), características semánticas o significados de configuración (...).

- Grado de iconicidad: que asigno al nivel de realismo de una imagen en comparación con el objeto que ell representa, (...), es decir, la relación entre realidad y experiencia (...). 
- Grado de figuratividad: que refiero a la designación de los valores de representación de la forma de objetos o seres del mundo conocidos a través de la percepción visual $(\ldots) »$.

Como resumen podríamos establecer dicha gramática visual de la siguiente manera:

\begin{tabular}{|c|c|}
\hline \multirow{2}{*}{ BASES DE ARTICULACIÓN } & Soporte \\
\hline & Fragmentación geométrica \\
\hline \multirow{17}{*}{ ARTICULACIÓN FORMAL } & Punto \\
\hline & Línea \\
\hline & Contorno \\
\hline & Plano \\
\hline & Volumen \\
\hline & Escala \\
\hline & Medida \\
\hline & Color \\
\hline & Textura \\
\hline & Perspectiva \\
\hline & Dirección \\
\hline & Simetría \\
\hline & Regularidad \\
\hline & Yuxtaposición \\
\hline & Interposición \\
\hline & Secuencialidad \\
\hline & Agrupamiento \\
\hline \multirow{4}{*}{ ARTICULACIÓN CONCEPTUAL } & Leyes de composición \\
\hline & Valores estructurales \\
\hline & Alteraciones \\
\hline & Características semánticas \\
\hline \multicolumn{2}{|l|}{ GRADO DE ICONICIDAD } \\
\hline GRADO DE FIGURATIVIDAD & \\
\hline
\end{tabular}

1.2.2 Estructura de análisis según Wucius Wong

Wucius Wong (1995: 42) establece su propia teoría sobre el lenguaje visual, la cual:

«(...) comienza con una lista de los elementos del diseño. (...) En realidad, los elementos están muy relacionados entre sí y no pueden ser fácilmente separados en nuestra experiencia visual general. Tomados por separado, pueden parecer bastante abstractos, pero reunidos determinan la apariencia definitiva y el contenido de un diseño».
Estos elementos serán los siguientes:

- Elementos conceptuales: punto, línea, plano y volumen

- Elementos visuales: «cuando dibujamos un objeto en un papel, empleamos una línea visible para representar una línea conceptual. La línea visible tiene no solo largo, sino también ancho. Su color y su textura quedan determinados por los materiales que usamos y por la forma en que los usamos» (Wong, 1995: 42). Estos son la forma, la medida, el color y la textura. Todos los elementos visuales constituyen lo que llamamos forma, que en este sentido abarca también el tamaño, color y textura

- Elementos de relación: dirección, posición, espacio y gravedad. Todos ellos configuran la estructura.

- Elementos prácticos: representación (realista, estilizada o semiabstracta), significado, función.

Todos estos elementos debemos considerarlos dentro de los marcos de referencia en los que están integrados y en su relación con el plano de la imagen, lo que nos proporciona una estructura de la siguiente manera:

\begin{tabular}{|l|l|}
\hline \multirow{4}{*}{ ELEMENTOS CONCEPTUALES } & Punto \\
\cline { 2 - 2 } & Línea \\
\cline { 2 - 2 } & Plano \\
\cline { 2 - 2 } & Volumen \\
\hline \multirow{4}{*}{ ELEMENTOS VISUALES (FORMA) } & Forma \\
\cline { 2 - 2 } & Medida \\
\cline { 2 - 2 } & Color \\
\cline { 2 - 2 } ELEMENTOS DE RELACIÓN & Textura \\
\hline \multirow{3}{*}{ (ESTRUCTURA) } & Dirección \\
\cline { 2 - 2 } & Posición \\
\cline { 2 - 2 } & Espacio \\
\cline { 2 - 2 } & Gravedad \\
\hline \multirow{3}{*}{ ELEMENTOS PRÁCTICOS } & Representación \\
\cline { 2 - 2 } & Significado \\
\cline { 2 - 2 } & Función \\
\hline
\end{tabular}

1.2.3 Estructura de análisis según Donis A. Dondis

Al hablar de la sintaxis de la imagen Donis A. Dondis (2008: 28) establece una serie de elementos básicos que componen el diseño y que son:

«(...) el punto, o unidad visual mínima, señalizador y marcador del espacio: la línea, articulante fluido e infatigable de 
la forma, ya sea en la flexibilidad del objeto o en la rigidez del plano técnico; el contorno, los contornos básicos como el círculo, el cuadrado, el triángulo, y sus infinitas variantes, combinaciones y permutaciones dimensionales y planas; la dirección, canalizadora del movimiento que incorpora y refleja el carácter de los contornos básicos, la circular, la diagonal y la perpendicular; el tono, presencia o ausencia de luz, gracias al cual vemos; el color, coordenada del tono con la añadidura del componente cromático, elemento visual más emotivo y expresivo; la textura óptica o táctil, carácter superficial de los materiales visuales; la escala o proporción, tamaño relativo y medición; la dimension $y$ el moviniento, tan frecuer involucrados en la expresión

El siguiente nivel lo establece la composición, sintaxis que en el lenguaje implica una disposición ordenada y aquí «sólo puede significar la disposición ordenada de partes» (Dondis, 2008: 33). Dentro de esta sintaxis aparecen los conceptos de equilibrio, tensión, nivelación y aguzamiento, atracción y agrupamiento, positivo y negativo.

En lo que Dondis (2008: 83) define como anatomía del mensaje visual considera que:

«expresamos y recibimos mensajes visuales a tres niveles: representacionalmente -aquello que vemos y reconocemos desde el entorno y la experiencia-; abstractamente -cualidad cinestética de un hecho visual reducido a sus componentes visuales y elementales básicos, realzando los medios más directos, emocionales y hasta primitivos de confección del mensaje-, simbólicamente -el vasto universo de sistemas de símbolos codificados que el hombre ha creado arbitrariamente y al que adscribe un significado».

Dentro del nivel representacional analizamos el nivel del valor figurativo de la representación.

\begin{tabular}{|l|l|}
\hline \multirow{4}{*}{ ELEMENTOS BÁSICOS } & Punto \\
\cline { 2 - 2 } & Línea \\
\cline { 2 - 2 } & Contorno \\
\cline { 2 - 2 } & Dirección \\
\cline { 2 - 2 } & Color \\
\cline { 2 - 2 } & Textura \\
\cline { 2 - 2 } & Escala o Proporción \\
\cline { 2 - 2 } & Dimensión \\
\cline { 2 - 2 } & Movimiento \\
\hline
\end{tabular}

\begin{tabular}{|l|l|}
\hline \multirow{4}{*}{ SINTAXIS } & Equilibrio \\
\cline { 2 - 2 } & Tensión \\
\cline { 2 - 2 } & Nivelación y aguzamiento \\
\cline { 2 - 2 } & Atracción y agrupamiento \\
\cline { 2 - 2 } & Positivo y negativo \\
\hline \multirow{3}{*}{ ANATOMÍA DEL MENSAJE } & Representacional \\
\cline { 2 - 2 } & Abstracción \\
\cline { 2 - 2 } & Simbolismo \\
\hline
\end{tabular}

1.2.4 Estructura de análisis según Robin Landa

La profesora de la Facultad de Diseño de Busch en la Kean University, Robin Landa, realiza un análisis basado igualmente en los elementos formales: la línea, la forma -en la cual se incluye la relación figura fondo y la tipografía-, el color y la textura; y en los principios de diseño.

«Los principios básicos son absolutamente interdependientes. El balance está en la estabilidad y en la creación de equilibrio (...). La unidad es un diseño entero en el que los elementos están relacionados unos con otros; la proximidad (...), la similitud (...), y continuidad (...) son claves de la unidad. Dentro de la unidad, hay una gran variedad de elementos adicionales que añaden interés y emoción. El énfasis en la organización visual jerárquica aumenta la claridad en la comunicación. El ritmo se utiliza para ayudar a crear un flujo de un elemento a otro y para añadir una pulsación visual de emoción y flujo» (Robin Landa 2011: 79).

Capítulo aparte merece para Landa (2011: 193) las reglas de composición, las cuales define como «la forma, toda la propiedad espacial y la estructura resultante de la intención de visualización y la ordenación de los elementos gráficos (texto y elementos visuales) en relación unos con otros y con el formato, dando sentido a la comunicación visual siendo convincente y expresiva». Es por tanto que debemos analizar el elemento sobre el cual recae el énfasis de la estructura básica: en el texto, la imagen o sinergia entre ambos, y las estrategias de composición, que pueden ser: espontánea, directrices creativas conducidas formalmente, directrices creativas conducidas por el medio, directrices creativas conducidas por el estilo.

En la composición considera lo que denomina «las tres A»; acción -que puede ser a través de la dinámica (contraste), a través del contraste (contrapunto), relación con la línea media, relación con los bordes y a través del movimiento- arreglo (colocación) -alineación del texto, flujo y manipulación del espacio gráfico- y articulación. El 
esquema propuesto por Robin Landa podría resumirse del siguiente modo:

\begin{tabular}{|l|l|}
\hline \multirow{4}{*}{ ELEMENTOS FORMALES } & Línea \\
\cline { 2 - 2 } & Forma \\
\cline { 2 - 2 } & Figura/Fondo \\
\cline { 2 - 2 } & Tipografía \\
\cline { 2 - 2 } & Color \\
\cline { 2 - 2 } & Textura \\
\hline \multirow{4}{*}{ PRINCIPIOS DE DISEÑO } & Balance \\
\cline { 2 - 2 } & Unidad \\
\cline { 2 - 2 } & Ritmo \\
\hline \multirow{4}{*}{ REGLAS DE COMPOSICIÓN } & Énfasis \\
\cline { 2 - 2 } & Estrategias \\
\cline { 2 - 2 } & Acción \\
\cline { 2 - 2 } & Colocación \\
\cline { 2 - 2 } & Articulación \\
\hline
\end{tabular}

1.2.5 Estructura de análisis según Ellen Lupton y Jennifer Cole Phillips

Ellen Lupton y Jennifer Cole Phillips (2009: 13) establecen un sistema similar, en el cual:

«(...) el punto, la línea y el plano son los ladrillos del diseño. A partir de estos elementos, los diseñadores crean imágenes, iconos, texturas, patrones, diagramas, animaciones y sistemas tipográficos. (...) Reproducir los tonos de una imagen fotográfica requiere su traducción a trazos puramente gráficos, ya que casi todos los métodos de impresión -desde la litografía a la impresión láser- trabajan con tintas sólidas».

Entre estos elementos básicos se establecen relaciones de ritmo, equilibrio, escala -en lo que Wong denominaba como marcos de referencia y plano de la imagen-. Considera igualmente la textura, tanto del soporte como la textura virtual de lo representado. Otro concepto reiterativo en todos los análisis es el del color. Finalmente destaca la relación entre la figura y el fondo.

\begin{tabular}{|l|l|}
\hline \multirow{2}{*}{ ELEMENTOS BÁSICOS } & Punto \\
\cline { 2 - 2 } & Línea \\
\cline { 2 - 2 } & Plano \\
\cline { 2 - 2 } & Color \\
\hline & Textura \\
\hline
\end{tabular}

\begin{tabular}{|l|l|}
\hline \multirow{2}{*}{ RELACIÓN } & Ritmo \\
\cline { 2 - 2 } & Equilibrio \\
\cline { 2 - 2 } & Escala \\
\cline { 2 - 2 } & Figura/fondo \\
\hline
\end{tabular}

1.2.6 Estructura de análisis según María Acaso

Mucho más escueto, por último, el análisis propuesto por María Acaso (2006: 49) establece que:

"Aunque de forma no tan estructurada como el resto de los lenguajes, el visual se articula a través de dos grandes grupos de herramientas con las que construimos los significantes y significados de los mensajes y con los que organizamos, ordenamos y jerarquizamos esos elementos. A las primeras las llamamos herramientas de configuración, y a las segundas, herramientas de organización».

Dentro de las herramientas de configuración considera el tamaño, la forma -tanto del continente como del contenido-, el color, la iluminación y la textura. Las herramientas de organización abarcan la composición y la retórica visual. Estas herramientas son válidas para el análisis del lenguaje visual, no necesariamente del diseño gráfico, por lo que es necesario tener en cuenta las particularidades de este.

\begin{tabular}{|c|l|}
\hline \multirow{4}{*}{$\begin{array}{c}\text { HERRAMIENTAS DE } \\
\text { CONFIGURACIÓN }\end{array}$} & Forma \\
\cline { 2 - 2 } & Tamaño \\
\cline { 2 - 2 } & Color \\
\cline { 2 - 2 } & lluminación \\
\cline { 2 - 2 } & Textura \\
\hline HERRAMIENTAS DE & Composición \\
\cline { 2 - 2 } ORGANIZACIÓN & Retórica Visual \\
\hline
\end{tabular}




\subsection{Comparación de las estructuras de análisis}

Para poder sacar unas conclusiones comunes realizamos la siguiente tabla en la que se contemplan todas las estructuras analizadas según conceptos análogos:

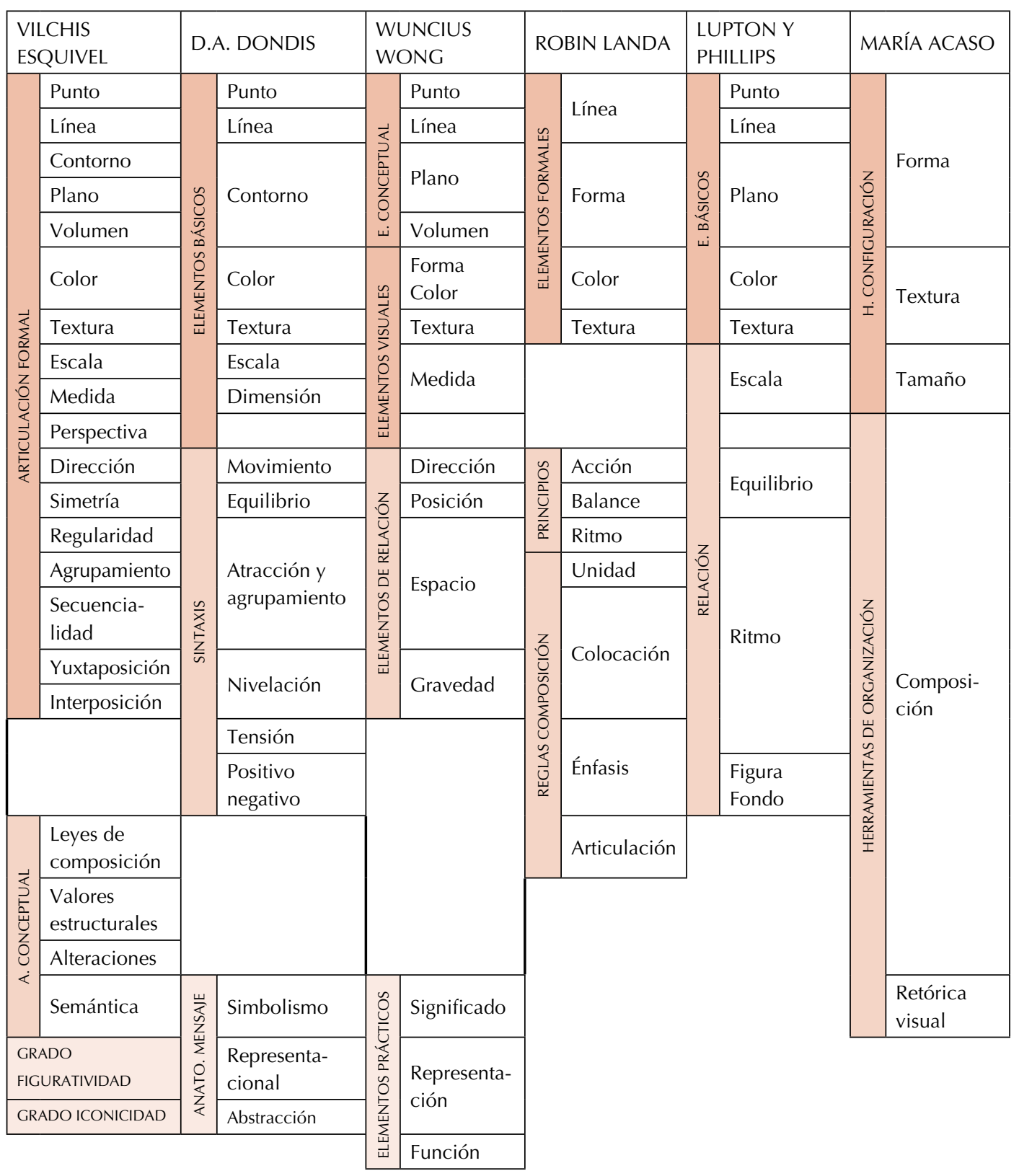

Tabla 1.7

\subsubsection{Otras taxonomías de interés}

El análisis basado en puntos, líneas y formas (constante en todas las propuestas estudiadas), resulta muy completo desde el punto de vista de que todos los elementos, desde la imagen fotográfica a la tipografía, se puede reducir a los mismos, pero resulta poco práctico. Para ello establece Vilchis (2006: 225-226) una base de códigos mediante los cuales se establece la comunicación gráfica:

«Los códigos que considero en esta taxonomía son:

- código morfológico: donde comprendo los esquemas formales abstractos (plecas, planos, contornos o llamadas) y los esquemas formales figurativos (dibujos, ilustraciones o vinetas) (...),

- código cromático: que integro por los esquemas de color adjudicados a un determinado diseño (...),

- código tipográfico: en el cual incluyo los textos (...)

- código fotográfico: que determino por las imágenes fotográficas (...)».

\begin{tabular}{|l|l|}
\hline \multirow{4}{*}{ CÓDIGO MORFOLÓGICO } & Esquemas formales abstractos \\
\cline { 2 - 2 } CÓDIGO CROMÁTICO & Esquemas formales figurativos \\
\hline & Intensidad \\
\cline { 2 - 2 } & Valor dinámico \\
\cline { 2 - 2 } & Legibilidad por contraste \\
\cline { 2 - 2 } Cuminosidad \\
\cline { 2 - 2 } & Reflexión \\
\cline { 2 - 2 } & Significación \\
\hline \multirow{5}{*}{ CÓDIGO TIPOGRÁFICO FOTOGRÁFICO } & Tamaño \\
\cline { 2 - 2 } & Valor \\
\cline { 2 - 2 } & Grano y trama \\
\cline { 2 - 2 } & Forma \\
\cline { 2 - 2 } & Orientación \\
\cline { 2 - 2 } & Estructura \\
\cline { 2 - 2 } & Estilización \\
\hline & Tomas \\
\cline { 2 - 2 } & Encuadres \\
\cline { 2 - 2 } & Escalas \\
\cline { 2 - 2 } & Grados de definición \\
\cline { 2 - 2 } & Tramados \\
\cline { 2 - 2 } & Iconicidad \\
\hline &
\end{tabular}


Al estudiar la composición resulta especialmente interesante la categorización que realiza Dondis (2008: 130) sobre las técnicas visuales:

"No hay porqué concebir las técnicas visuales como elecciones para construir y analizar, o sólo esto último, todo lo que vemos. Es posible modificar los extremos de significado con grados menores de intensidad, como la gradación de tonos de gris entre el blanco y el negro (...). Sería imposible enumerar aquí todas las técnicas visuales disponibles o dar definiciones acertadas de las mismas. En esto, como en todos los escalones de la estructura de los medios visuales, la interpretación personal es un factor muy importante. Pese a estas limitaciones, puede definirse cada técnica y su contraria en forma de dipolo».

Estos dipolos establecen a su vez una distinción entre composiciones en las que prima el contraste y las composiciones armónicas.

La clasificación tipográfica, por su complejidad y por las condiciones particulares de la tipografía en la RDA, cuya variedad mecánica disponible era notablemente limitada, merece un capítulo aparte, limitándonos aquí a su clasificación según los criterios establecidos en la norma DIN 16.518 -por ser esta la norma alemana- y a las particularidades según González del Río Cogorno (2010):

- Familia tipográfica (mayúsculas, cursiva, negrita, subrayado)

- Composición del texto (espacio entre letras y palabras, orientación, longitud de línea, columnas, interlínea, márgenes y sangría)

- Alineación (justificada, centrada, izquierda, derecha)

\subsection{RETÓRICA VISUAL}

Todos los autores consultados coinciden en otorgarle al diseño gráfico una componente semántica, a la cual hacen referencia como simbolismo, significación, hermenéutica o retórica visual. Si atendemos a la opinión de Martín Montesinos $(2008,202)$ :

"el diseño gráfico pretende unir desde sus orígenes el lenguaje de la imagen y el de la palabra, porque los aspectos descriptivos de la imagen se complementan con aquellos que son narrativos y propios de la palabra. Estas dos propiedades no son exclusivas, sino que se solapan en parte. Incluso sometidas a cierta sintaxis, pueden llegar a intercambiarse, ya que la imagen al relacionarse con otras en un mismo campo visual pueden narrar, mostrando aspectos distintos e interrelaciones entre las imágenes que forman parte de un todo».
De la misma opinión se muestra Vilchis (2006: 201) quien afirma que:

«(...) artes tradicionales como la ilustración y la tipografía cuyas relaciones formales jugaron un papel importante en e Renacimiento, establecen en el cartel los vínculos que sientan las bases del imaginario visual de lo diseñado, y marcan el paradigma de representación letra/imagen que señala la cultura visual».

Es dentro de esta dualidad donde toma importancia la retórica visual.

María Acaso (2006: 92) define la retórica visual como «la herramienta de organización que se utiliza para interconectar los distintos significados de los componentes del producto visual». Ya en 1964 R. Barthes consciente de que la utilización de la retórica en el campo visual acuñó el término de retórica visual «por el que se entiende un sistema de organización del lenguaje visual en el que el sentido figurado de los elementos representados organiza el contenido del mensaje» (citado en Acaso 2006: 93).

\subsubsection{Figuras retóricas}

Al igual que la retórica lingüística, la visual se fundamenta en una serie de figuras retóricas. No es objeto de esta investigación un análisis exhaustivo de las figuras retóricas, sin embargo procederemos a la definición de las más importantes según establece en su clasificación María Acaso:

Metáfora: según expone Francisco Calles (2001: 93) «podemos decir que la metáfora no es propiamente una sustitución de sentido, sino una modificación del contenido semántico de los términos asociados (...). Las metáforas transportan el sentido de una palabra resultando de la intersección un cambio de sentido (3er significado)».

Alegoría: implica la existencia de varias metáforas simultáneamente

Metonimia: supone una sustitución en la cual existe un criterio de contigüidad, como es el caso de tomar el objeto por el material del que está construido.

Calambur: o trampantojo supone un engaño visual implícito, como el que nos encontramos en una representación de perspectiva.

Prosopopeya: según Acaso (2006: 96) «la prosopopeya o personificación es una de las figuras retóricas más utilizadas en las representaciones visuales comerciales, y consiste en 
otorgar a objetos inanimados o animales, valores animados o humanos».

Figuras de comparación: Para ello es necesario que se presenten al menos dos componentes en la misma representación, los cuales pueden estar en concepto de oposición, de paralelismo o de gradación:

Oposición: figura que implica relación entre dos componentes de la misma representación los cuales se enfrentan explícitamente.

Paralelismo: supone, al igual que la oposición, relación entre dos componentes, los cuales se asemejan entre sí

Gradación: «Figura retórica consistente en una sucesión de expresiones que van acentuando por grados el mismo significado» (María Moliner, 2008: 227)

Repetición: Supone la clonación de elementos con un sentido pretendido.

Epanadiplosis: figura retórica en la cual el principio y el fin coinciden en una misma escena.

Hipérbole: creación de una exageración de un determinado elemento para dotarlo de magnitud.

Préstamo: figura en la cual se toma una figura de un tema que no es propio para argumentar un discurso.

Elipsis: consiste en la eliminación intencionada de parte del discurso, de tal modo que se transforma el significado.

Sinécdoque: Sean Hall (2007: 42) expone que «la relación entre la parte y el todo es uno de los tipos existentes de sinécdoque. Otros tipos son las relaciones entre miembro y clase, entre una especie y su género o entre un individuo y un grupo", es decir, asignar a un objeto mediante otro debido a una relación de coexistencia e inmediación.

\subsubsection{Clasificación de las figuras retóricas}

Varias de estas figuras hacen referencia a conceptos similares. Gui Bonsiepe (1965: 206) decía que «según la teoría clásica, la esencia de una figura retórica consiste en un distanciamiento del uso normal del discurso con el propósito de hacerlo más efectivo» y las diferenciaba entre figuras de:

- contenido SEMIÓTICO (SEMÁNTICA); es decir, del significado

- posición SINTAXIS (SINTÁCTICA); es decir, de la forma del signo

\begin{tabular}{|c|c|c|}
\hline \multirow{13}{*}{ SEMÁNTICA } & \multirow{3}{*}{ Figuras contrarias } & Antítesis (significados opuestos en una oración) \\
\hline & & Exadversión (aseveración por doble negación) \\
\hline & & Conciliación (unión de contradictorios) \\
\hline & \multirow{4}{*}{ Figuras comparativas } & Gradación \\
\hline & & Hipérbole \\
\hline & & Metáfora \\
\hline & & Subexpresión \\
\hline & \multirow{2}{*}{ Figuras sustitutivas } & Metonimia \\
\hline & & Sinécdoque \\
\hline & \multirow{4}{*}{ Figuras pragmáticas } & Diálogo ficticio \\
\hline & & Discurso directo \\
\hline & & Conversión de un argumento a favor \\
\hline & & Asteísmo (réplicas irrelevantes a un argumento) \\
\hline \multirow{9}{*}{ SINTÁCTICA } & \multirow{4}{*}{ Figuras transpositivas } & aposición (inserciones explicativas) \\
\hline & & atomización (tratar partes dependientes como independientes) \\
\hline & & paréntesis (encerrar una oración en otra) \\
\hline & & inversión o anástrofe (cambio de lugar de una palabra- énfasis) \\
\hline & Figuras privadas & Elipsis \\
\hline & \multirow{4}{*}{ Figuras repetitivas } & aliteración (repetir una letra o sonido) \\
\hline & & Isofonía (repetición de sonidos) \\
\hline & & Paralelismo ( repetir el mismo ritmo en proposiciones u oraciones) \\
\hline & & Repetición \\
\hline
\end{tabular}

Por su parte Acaso las clasifica del siguiente modo:

\begin{tabular}{|c|l|}
\hline \multirow{4}{*}{ SUSTITUCIÓN } & Metáfora \\
\cline { 2 - 2 } & Alegoría \\
\cline { 2 - 2 } & Metonímia \\
\cline { 2 - 2 } & Calambur \\
\cline { 2 - 2 } & Prosopopeya \\
\hline \multirow{4}{*}{ COMPARACIÓN } & Oposición \\
\cline { 2 - 2 } & Paralelismo \\
\cline { 2 - 2 } & Gradación \\
\hline \multirow{4}{*}{ ADJUNCIÓN } & Repetición \\
\cline { 2 - 2 } & Epanadiplosis \\
\cline { 2 - 2 } & Hipérbole \\
\cline { 2 - 2 } & Préstamo \\
\hline SUPRESIÓN & Elipsis \\
\hline
\end{tabular}

El análisis de estas estructuras de análisis propuestas po teóricos del diseño gráfico nos resulta de gran utilidad en la redacción de nuestra propuesta de análisis propia, que realizaremos en el capítulo 6 como base para el estudio estadístico. 
2. Evolución del diseño gráfico alemán previo a 1945

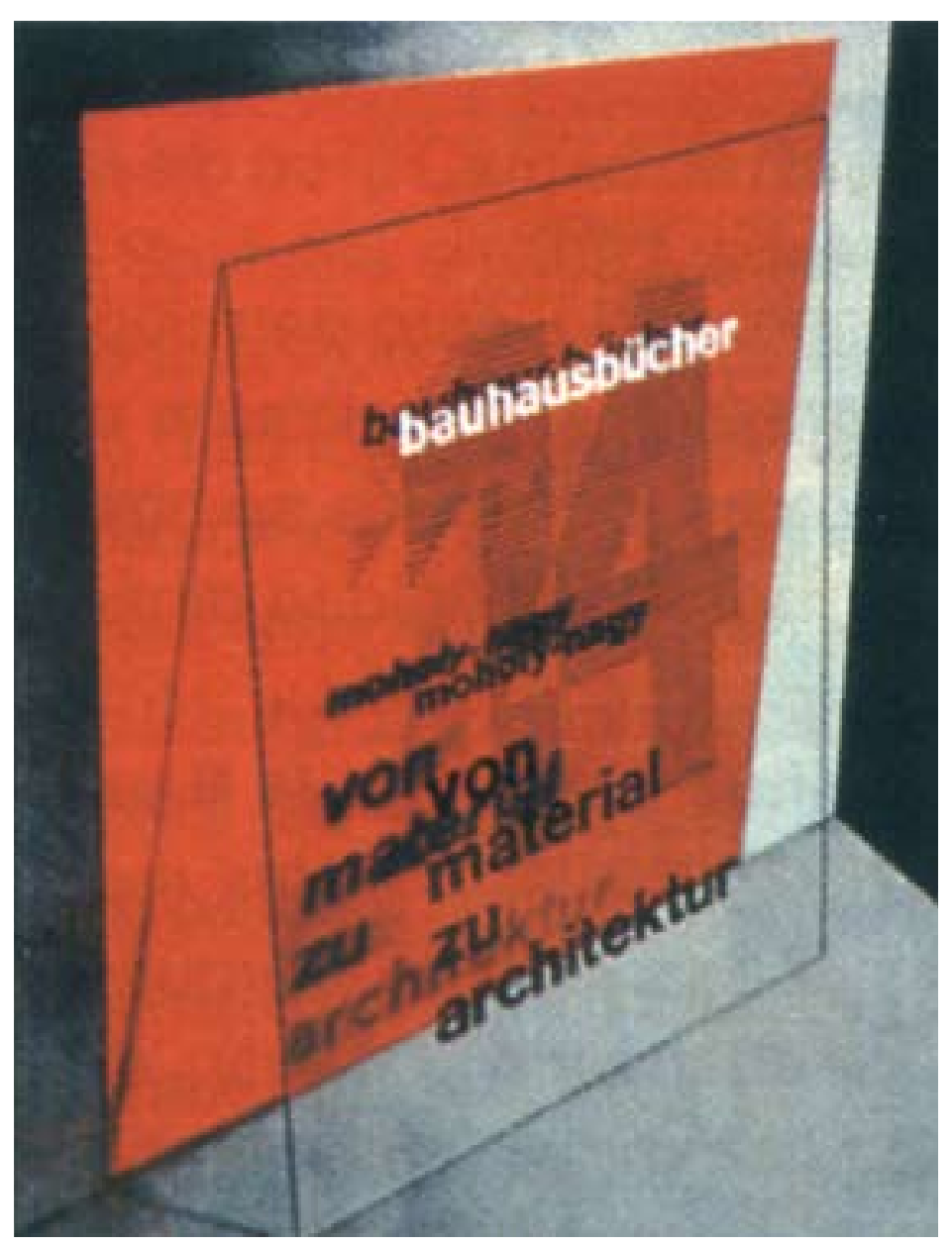


Como se ha descrito, el objeto de esta investigación es definir la influencia que tuvo la constitución de la República Democrática Alemania en la evolución que experimentaba el diseño gráfico en Alemania. Esto nos obliga a definir primero cual era el panorama del diseño gráfico alemán en la primera mitad del siglo XX hasta el final de la Segunda Guerra Mundial.

Nos acercaremos al diseño gráfico desde dos niveles: un primer nivel de análisis sistemático de todos los movimientos, escuelas y estilos comprendidos en este espacio de tiempo, definidos sobre una misma estructura a parti de la composición, la tipografía y la imagen; y un segundo nivel en el cual relacionaremos los periodos entre sí, de tal modo que podamos observar las tendencias en la evolución gráfica desde cada una de estas categorías y su interrelación en los periodos históricos en los que se desarrollaron.

Desde finales del siglo XIX, gracias a la reforma producida por la difusión del movimiento Arts \& Crafts en Europa, se producirá un progresivo interés por el diseño de carteles y las artes gráficas en general que llevará al historiador del arte Julius Meier-Graefe (1896, citado en Aynsley 2000: 34) a anunciar que «el cartel se ha puesto de moda: artistas, amantes del arte y museos los coleccionan». En 1905, Lucian Bernhard diseñaría el cartel de cerillas Priester, en el cual «sustituyó la simplificación y reducción del naturalismo en la comunicación gráfica por un lenguaje de forma y señal más avanzado» (Meggs, 2000: 249). Es por eso que consideraremos este momento como punto de partida de la investigación. La elección de 1945 como punto final vendrá determinada, qué duda cabe, por el final de la Segunda Guerra Mundial que supuso una brecha sin parangón en la evolución de las expresiones artísticas.

Los resultados obtenidos a partir de esta investigación nos permiten establecer un marco del estado del diseño gráfico en Alemania finalizada la guerra, y como tal, un punto de partida para comprender el diseño que se desarrollaría posteriormente en la Alemania dividida. 
El interés final de este capítulo es relacionar los diferentes estilos y movimientos que se produjeron en Alemania en el ámbito del diseño gráfico durante este periodo, proponiendo unas líneas de evolución e interrelación entre ellos.

Pero para que estas relaciones se puedan establecer de forma científica es necesario delimitar los rasgos propios de cada uno de ellos según unos parámetros definidos previamente. El Handbuch der Werbung (Manual de la Publicidad) publicado por el Autorenkolektiv (Colectivo de Autores (1968: 279, citado por Rademacher: 1975: 21) establecía que «una característica fundamental de las obras del diseño gráfico es la unidad de imagen y tipografía en una composición. Esta relación es un requisito único e inseparable. Se apoya generalmente en las leyes básicas de la composición estética. Imagen y tipografía están en un intercambio de efectos mutuo comunicativo y creativo».

Serán por tanto estos tres parámetros los aquí propuestos:

-La composición como el "arte de agrupar las figuras y accesorios para conseguir el mejor efecto, según lo que se haya de representar» (RAE, 2006: 374), es decir, la colocación de los elementos de diseño.

-La tipografía que, atendiendo a la definición dada por Stanley Morison (1998: 95), se entendería como «el arte de disponer correctamente el material de imprimir, de acuerdo con un propósito específico: el de colocar las letras, repartir el espacio y organizar los tipos con vistas a prestar al lector la máxima ayuda para la comprensión del texto», si bien, tal y como veremos más adelante, la comprensión del texto en ocasiones puede no ser la finalidad principal de la tipografía.

-La imagen, se trata quizás del concepto más amplio de los tres, ya que engloba el uso del color, la forma y la iconografía, así como el tipo de imagen (ilustración o fotografía) y el tratamiento que se realiza de las mismas, lo que María Acaso (2006: 49) definiría como herramientas de configuración: "[aquellas] con las que construimos los significantes y significados de los mensajes (tamaño, forma, color, iluminación y textura)».

\subsubsection{Plakatstil}

El comienzo del siglo XX traería consigo en Alemania un cambio en la producción industrial hacia una economía expansionista que ya en 1876 F. Reuleaux (1876, citado en de Fusco 1985: 100) había vaticinado que estaría basada en «el reconocimiento generalizado del rol de la máquina y la importancia de la calidad por encima de todo, contrario a billig und schlecht (barato y malo)».

Enric Satué (1993: 114) explica como

El desarrollo de la industria alemana alrededor de la idea de nacionalidad tan tardíamente surgida precisaba de una imaginería comercial y publicitaria propia, sin encuadrarla excesivamente en los estilos adoptados por el resto de burguesías europeas de aquel momento, tan ajenas al ideal colectivo germano».

Es por esto que mientras en la Europa de principio de siglo el modernismo gozaba de una gran popularidad, Alemania buscaba un diseño propio acorde a su propia realidad industrial.

Este ideal industrial se puede observar ya en la obra de los primeros cartelistas alemanes, Otto Fischer y Ludwig Sütterlin, cuya tipografía y marcada geometría se aleja notablemente de la imagen modernista.

En 1905, el diseño de carteles alemán dará un giro con el diseño de cartel de cerillas Priester de Lucian Bernhard. Este nuevo estilo de cartel, influenciado por la obra de los Beggarstaff Brothers ingleses, se reducía al uso de una imagen del producto acompañada de tipografía potente y sería conocida como Sachplakat (cartel objeto), primer paso en la transición al racionalismo.

\subsubsection{Composición}

El rasgo principal de la composición de estos carteles es su simplificación en la comunicación, la búsqueda de la esencia del producto; imagen y nombre, con los mínimos datos informativos y libre de ornamentos. Al contrario que en el modernismo, el cartel se reduce a su función informativa; es un medio de comunicación en el cual la plástica se utiliza únicamente por su capacidad de comunicación universal.

El resultado es de una gran sencillez, pero sin perder de vista su finalidad, tal y como matiza Philip B. Meggs (2000: 249):

«Los diseñadores de carteles (...) conscientes de la necesidad de mantener una referencia pictórica si sus carteles intentaran

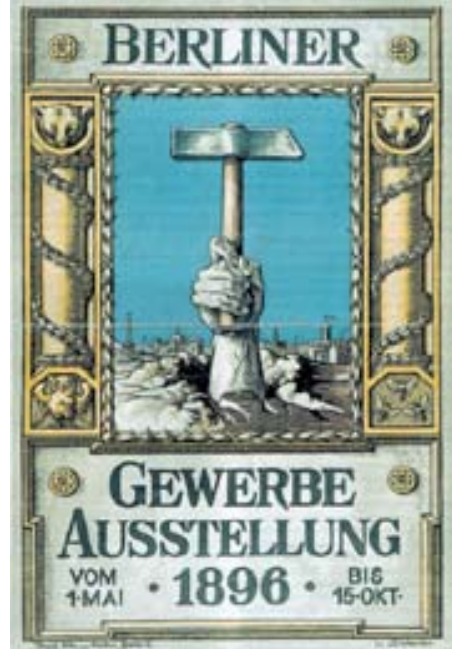

SÜTTERLIN, Ludwig (1896

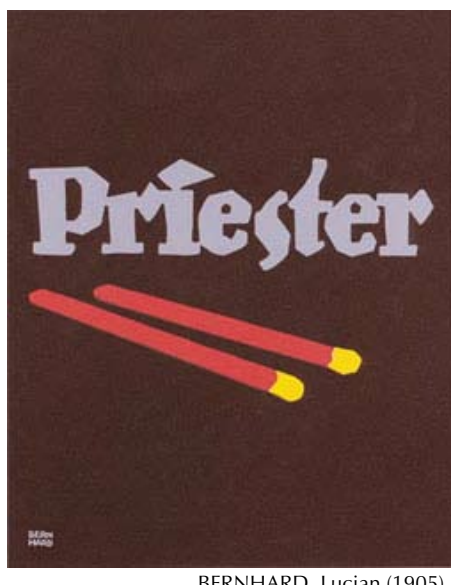

BERNHARD, Lucian (1905) 


\subsubsection{Tipografía}

ABCDEFGHIJKLMNOPQRST

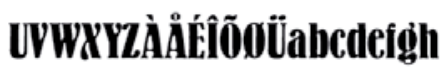

ijkilmnopqrsturwxyzàåcî̃õ

\section{viid1234561890(\$£€.,,?)}

BERNHARD, Lucian (1911). Bernhard Antiqu

La búsqueda de la esencia de la comunicación en los Sachplakat se traslada también a la tipografía, lo que se traduce en una reducción su ornamento. Es por eso que será la tipografía de palo seco la más frecuente. Este uso de alfabetos potentes, dibujados con fuertes trazos de pincel resulta muy acorde a la fuerza de la imagen.

Sin embargo la fuente diseñada por Bernhard -la Bernhard Antiqua - no será de palo seco, sino que se trata de una tipografía romana con influencia gótica en los remates, aunque cabe destacar, tal y como señala Satué (2007: 92), que «El perfil de los signos de este alfabeto Bernhard Antiqua es deliberadamente tembloroso e irregular, probalemente para dar a entender así su origen manual y caligráfico, así como su función ideal, orientada al uso de grandes cuerpos para carteles y anuncios».

\subsubsection{Imagen}

El uso de la imagen en los carteles pertenecientes al Plakatstil sintetiza la base del estilo, en ellos los productos se representan icónicamente, eliminando todos los ornamentos superficiales y apostando por imágenes simples cuyo impacto reside en la monumentalidad de las formas y en los colores planos fuertes. Para poder obtener estos colores saturados los carteles debían recurrir a la impresión litográfica, en la cual llegaban a usar hasta 16 colores de tinta creados especialmente para los carteles.

El color será una de las características más reconocibles mediante su tratamiento plano en figuras, sombras y fondos, al tiempo que la producción exclusiva de las tintas lo convertía en emblemático. A este respecto, Jeremy Aynsley (2000: 78) concluye que:

«(Del desarrollo de nuevas tintas) se obtuvo un rango distintivo de colores, inicialmente brillantes con fuertes contrastes, pero posteriormente los trabajos fueron realizados en sofisticadas combinaciones de colores terciarios, grises fríos y verdes».

Posteriormente, Hohlwein incluirá en sus diseños texturas y patrones a las masas de color.
En esta búsqueda de una imagen industrial y comercial propia, Hermann Muthesius crea en 1907 el Werkbund Institut. Influido por la obra del Arts \& Crafts de William Morris ${ }^{4}$ el Instituto tiene como propósito vincular el trabajo artesano con el industrial, pero sin las alusiones románticas de movimiento inglés y con un objetivo claro de funcionalidad y racionalidad en el cual el valor de las máquinas era reconocido y potenciado mediante el diseño.

En este punto resulta interesante la reflexión de Renato de Fusco (1985: 106):

«El diseño industrial debe encontrar sus propios valores en una simplificación que favorezca unas relaciones proporcionales nítidas de las partes individuales. Método que era válido para un estilo moderno, además de responder a las exigencias de la producción mecánica».

Entre los logros asociados al Werkbund figura la relación entre industria y diseño y el plantearse la importancia de la creación de una imagen corporativa.

Cuando en 1919, en un libro conmemorativo de los 25 años de la compañía de cigarros Manoli, perteneciente a Werkbund, Bernhard analiza el cartel alemán, basa su éxito en tres puntos:

1. Su capacidad para atraer la atención,

2. El uso de tipografía efectivas que relacionan la letra con la marca,

3. Figuras contorneadas que crean un gran impacto visual.

\subsubsection{Composición}

Para Peter Behrens, una de las figuras más importantes del Werkbund, una decoración rica era inaceptable para formas obtenidas mecánicamente. De este modo la composición busca un equilibrio entre el lenguaje formal y el pragmatismo tecnológico. Aynsley (2000: 37) lo explica cuando afirma que:

«Las aportaciones del diseño alemán (en las exposiciones internacionales) a otras naciones europeas era la manera de cómo su nuevo ideal estético podía ser llenado sistemáticamente por la combinación de la eficiencia de los métodos productivos, incluida la producción mecánica y la estandarización con un interés en la simplificación formal».
4. William Morris fue el máximo exponente del movimiento Arts \& Crafts, caracterizado por dotar de los ideales de la cultura artesanal a la producción industrial.

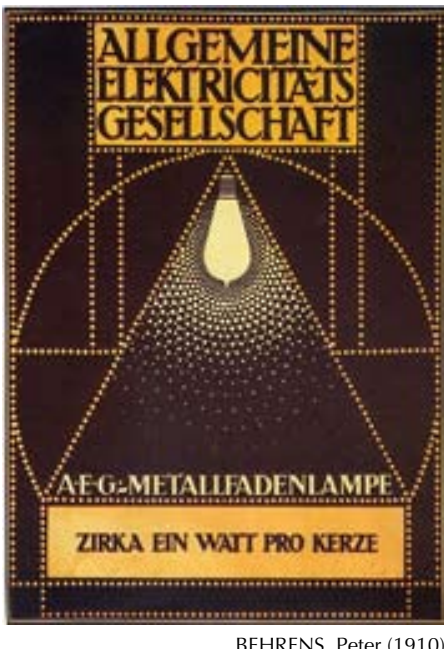

BEHRENS, Peter (1910) 
Es por tanto que, en sus composiciones, Behrens articula el espacio mediante una cuadrícula acorde a la producción mecánica. La organización visual se establece mediante una geometría de círculos concéntricos, cuadrados y rectángulos en proporción $1 \times 1,5$ basada en los modelos geométricos del arquitecto holandés J.L. Mathieu Lauweriks quien componía sus diseños mediante subdivisiones y repeticiones de una estructura básica formada por un círculo inscrito en un cuadrado.

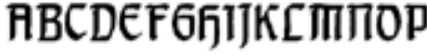 QRSTUDDXY3abcoefg bijklimnopqrstuowxyz 0123456780}

\section{OHRENS, Pet (1902) Behrensschit}

ABCDEFGHI|KLMNOPQRSTUV WXYZabcdefghijklmnopqrstuvwxyz $1234567890(., . ! ? \& \$ € €)$ EHMCKE, Fritz Helmuth (1909). Ehmcke Antiqua

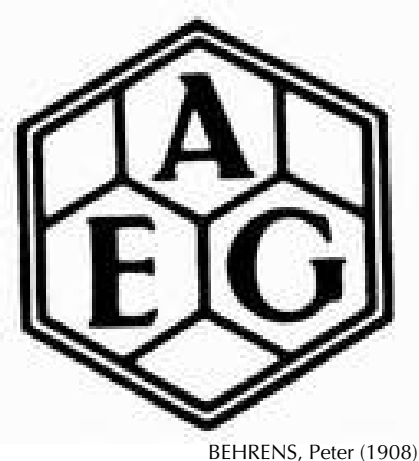

\subsubsection{Tipografía}

Las mayores aportaciones en el campo tipográfico vienen de la mano de Behrens y Ehmcke, quienes apuestan por tipografías no alemanas -entendiendo por alemana tipografía gótica- por su mayor legibilidad. Sin embargo no lo desnudaba completamente de ornamento, sino que, según Aysley (2000: 74) tanto Behrens como Ehmcke «vuelven a la Florencia del s. XV para sus composiciones, adoptando un estilo basado en motivos geométricos repetidos, bordes y formas contrastadas».

Behrens hacía un especial énfasis en el poder de la tipografía como elementos de identificación corporativa. Al mismo tiempo, pese ha haber diseñado tipos romanos, apuesta por la tipografía de palo seco la cual popularizó y expandió su uso a ámbitos anteriormente desconocidos como el diseño editorial.

\subsubsection{Imagen}

Desde los primeros momentos del Werkbund quedaron definidas dos ramas diferenciadas en cuanto al tratamiento de la imagen, una de ellas más racional encabezada por Muthesius en la cual lo que primaba era la estandarización del diseño; adecuándolo a su reproducción mecánica y por tanto con un menor ornamento, y otra, de la mano de Henry Van der Velde, en la que se fomentaba la expresión artística individual.

Meggs (2000: 227) explica como «Behrens intentó mediar los dos extremos, pero su trabajo para la AEG mostró fuertes tendencias hacia la estandarización», lo cual no significa que eliminara el ornamento de sus imágenes, sino que lo geometrizaba y abstraía.

\subsubsection{Expresionismo}

Con una conciencia y organización de grupo activista, los expresionistas se caracterizaron por representar las respuestas personales y subjetivas ante los hechos, más allá de lo meramente objetivo. Desarrollan un estilo político caracterizado por su fuerte idealismo y su intención de cambiar la estructura de clases, de ahí su contenido social y antimilitar. Los expresionistas alemanes formaron dos grupos, por un lado die Brücke, creado en Dresden en 1905, y der Blaue Reiter, de Munich en 1911.

Si bien algunos autores, como Itanel Bastos (1998), afirman que los expresionistas «al final dejaron algunos carteles notables pero ninguna marca duradera sobre el diseño", conviene tener en cuenta que dos de los fundadores de Blaue Reiter -Wassily Kandisnky y Paul Klee-fueron profesores de la Bauhaus en su primera etapa como escuela.

\subsubsection{Composición}

Sus composiciones combinan el sentimiento y la ciencia lo real y lo abstracto, dándole una gran importancia al contenido simbólico. La comunicación con el espectador se establece mediante la exageración y desproporción de los temas, que aluden a la naturaleza propia de lo representado, y por tanto su forma y apariencia real carece de importancia. El carácter individual de las obras expresionistas evita la posesión de unas reglas compositivas, más allá de la libertad del artista.

\subsubsection{Tipografía}

Las letras eran frecuentemente dibujadas a mano libremente o especialmente diseñadas para la publicidad -en lo que hoy en día entendemos como lettering-con ese sentido de expresión individual característico del grupo que la redacción de UTD (2000) pone de manifiesto al explicar cómo «desde un punto de vista formal la utilización de los distintos alfabetos no pasa de tener un objetivo informativo y universal pero reflejando el sentido individual dañado por la industrialización y los políticos».

\subsubsection{Imagen}

La ilustración utilizada es agresiva y de fuertes contrastes como medio de captar la atención. En ella se muestra un interés plástico por el movimiento, el color y su significado
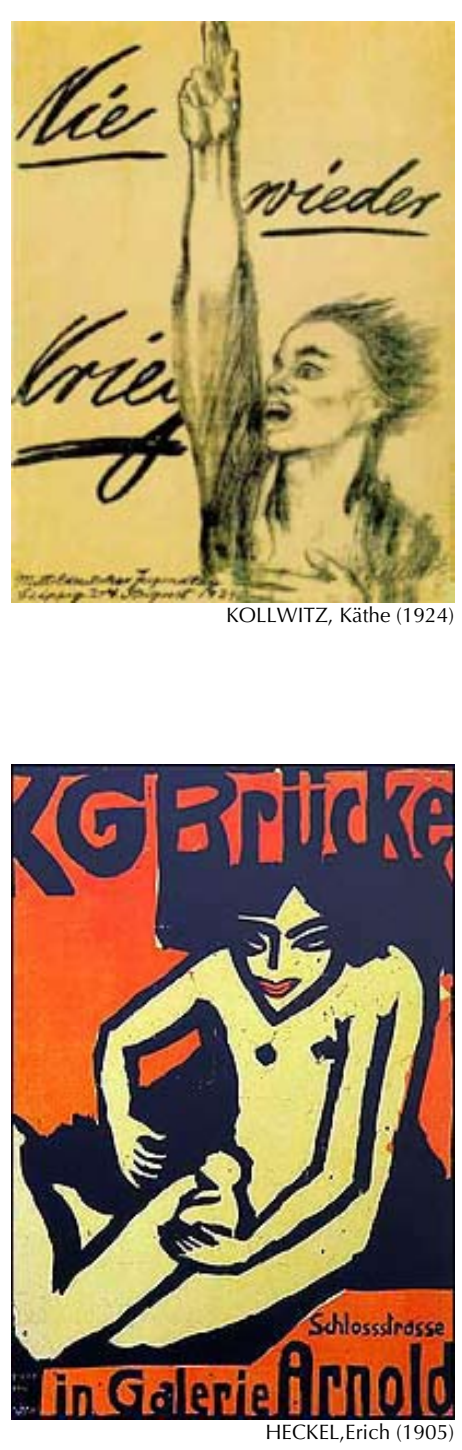
mientras que se abstrae de la forma, la cual se desproporciona y exagera.

Sin embargo el uso de la imagen difiere entre los dos grupos expresionistas, mientras die Brücke, de temática naturalista y primitiva, emplea un vocabulario estético muy simplificado con colores brillantes y trazo grueso, los artistas del Blaue Reiter eran más espirituales en sus obras, se preocupaban en cómo representar; las formas, los colores, y el ritmo que con ellos se marcaba mediante los contrastes entre líneas fuertes y suaves.

2.1.4. El diseño en los periodos bélicos. Primera Guerra Mundial

5. La denominación de «diseño gráfico» no aparecería hasta 1922 y Suro no se extendería en Europa hasta años más tarde.

Con el comienzo de la Primera Guerra Mundial los gobiernos constataron la capacidad del cartel ${ }^{5}$ para crear una dores alemanes se pusieron al servicio del gobierno creanpropaganda de guerra eficiente, de tal modo que los diseñado carteles cuya principal finalidad -en Alemania, donde el alistamiento era obligatorio- era la recaudación de fondos.

Para Richard Hollis (2000: 32) «las virtudes del Sachplakat -simplicidad, imágenes concentradas, colores lisos, sombras unificadas, tipos dibujados con cuidado- dio a sus obras una unidad gráfica que no se encontraba en los carteles de otros países».

\subsubsection{Composición}

Los carteles de la Primera Guerra Mundial continúan con la tradición del Sachplakat de integración entre texto e imagen, simplificación de formas y uso de un lenguaje gráficamente económico. La propaganda bélica, sin embargo, no vende un producto sino que trata de movilizar a la población, por lo que la función simbólica tiene una gran importancia.

Este simbolismo se expresa de diferentes formas, tal y como refleja Meggs (2000: 251):

«(...) los carteles de guerra de Klinger expresaban ideas complejas con símbolos pictográficos simples. Curiosamente, Bernhard adoptó un enfoque medieval en varios carteles de guerra, como el cartel litográfico dibujado a mano en tinta roja y negra para el séptimo empréstito de guerra. En una expresión casi primitiva del antiguo espíritu germano, Bernhard representó un puño cerrado en una armadura medieval».

\subsubsection{Tipografía}

Conscientes de la importancia de despertar el sentimiento patriótico mediante sus carteles, los diseñadores de propaganda, si bien continuaron con la tradición tipográfica del Plakatstil, dotaron a los remates góticos -hasta el momento apenas insinuados- de una gran importancia, fundamentada en su capacidad evocadora de la identidad alemana.

En este punto resultan interesantes las observaciones que hace Philipp Luild (2003) al respecto:

"Etiquetar a la gótica de fractura como letra alemana es absurdo, pues es tan poco alemana como el estilo gótico (...) con todo, existen unas cuantas objeciones que relacionan la letra gótica más estrechamente con Alemania»,

explicado como esta relación nace a partir de que:

«En 1493, Anton Koberger imprime su obra Schedelsche Weltchronik (Crónica Mundial de Schedel) en la ciudad alemana de Núremberg.(...) La sabia decisión de Koberger tendría consecuencias de gran alcance. Debido a la asociación de cada una de las lenguas a una tipografía adaptada, a estas se les dotaba de un tinte nacionalista(...). Esta costumbre de componer en latín con la romana y en alemán con la gótica de fractura se convierte a partir de ese momento en una ley tácita firmemente establecida que predominará en Alemania hasta 1941, especialmente en las obras científicas.»

\subsubsection{Imagen}

El simbolismo que caracterizó al cartel bélico alemán se potenciaba mediante la iconicidad de las imágenes y el uso de colores planos acordes al Plakatstil, aunque, en el diseño de sus carteles propagandísticos, Hohlwein empieza a utilizar imágenes más naturalistas dentro de la simplicidad.

La imagen fotográfica, que será verdaderamente relevante durante la Segunda Guerra Mundial, empieza a vislumbrarse ahora como un arma de comunicación potente debido a su gran capacidad gráfica y su velocidad de reproducción en blanco y negro. Será en este momento que se realicen los primeros montajes fotográficos.

\subsubsection{John Heartfield y el Dadaísmo}

El dadaísmo surge como grupo activista en 1916 y se disuelve en 1921, fecha a partir de la cual actuarán de forma individual. El grupo creado en Suiza, se proclamaba el antiarte y se definía por su carácter provocativo y antiburgués con un marcado desdén por la tradición.

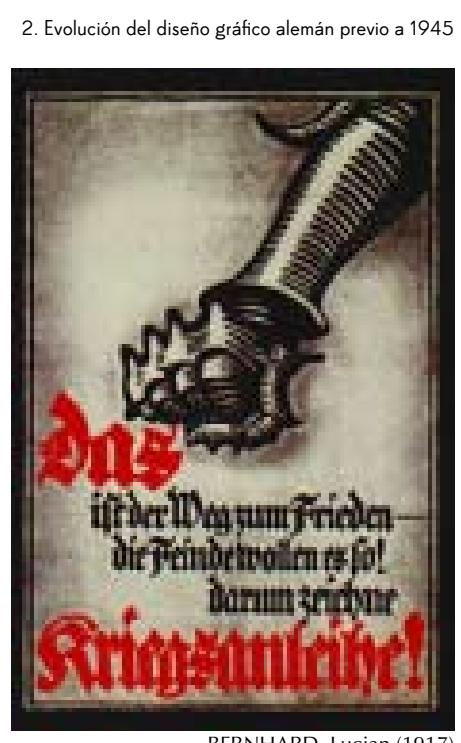

BERNHARD, Lucian (1917)

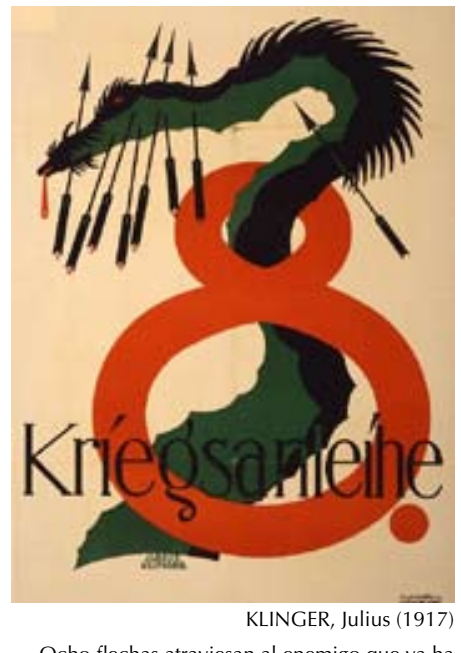

Ocho flechas atraviesan al enemigo que ya ha
sido herido en 7 ocasiones en la octova campaña 
El movimiento dadaísta se desarrolló en un primer momento como un movimiento literario, guiados por el poeta Tristan Tzara, de ahí que conforme un estilo político que intenta cambiar la estructura de clases. Su mayor aportación al diseño gráfico es el uso de la fotografía en la propaganda política por su capacidad de persuasión al tiempo que es considerada el medio moderno de comunicación ya que no establece la diferencia de clases, que la pintura, por su elevado coste, suponía.

Estas cualidades descritas, junto con el marcado izquierdismo del grupo, hizo que los artistas Dadá gozaran de gran prestigio en la RDA. Heartfield, uno de los mayores exponentes del dadaísmo por sus fotomontajes era un reconocido militante comunista que continuó trabajando en la RDA donde gozó de gran reconocimiento a partir de mediados de los años 50.

\subsubsection{Composición}

De naturaleza anarquista, las composiciones son libres, no según unos ejes verticales horizontales que lo hicieran más adecuados para su reproducción según los medios tradicionales, sino que los elementos se disponían libremente sobre planchas de escayola. De este modo conseguían composiciones definidas por su contenido, no por unas normas preestablecidas. Otro elemento característico del movimiento Dadá es el uso de símbolos que permitía una economía de lenguaje.

\subsubsection{Tipografía}

Los artistas del movimiento Dadá utilizaban todo tipo de letras en sus composiciones en las que mezclaban diferentes modelos de tipografías y ornamentos sin orden aparente.

Los mayores contribuciones tipográficas vendrían de la

The NeW TYPOGRAPhY dJFER5 FROM The OLd JN ThAT JI TRJES FOR The FOAST т̈ме TO deVelop JIS FORM FROM The FenciJon of the Text. JAN ISChJChOLL

\section{RbCDEFGHIJLLMNOPQR5TUWW/XYX50}

คеЈر०Чœ 1234567890 tipografía fonética sobre la base de adaptar los alfabetos a experimentos óptico-fonéticos. Para Satué (1993: 153) «el resultado (del alfabeto fonético de Kurt Schwitters), sin embargo, es un conjunto bastante caótico aunque gráficamente atractivo».

Estos experimentos tipográficos, utilizados para crear imágenes atractivas, quedaban relegados cuando lo que se anteponía era la claridad del mensaje, de tal modo que, Heartfield, en sus montajes utilizaba habitualmente la tipografía Kabel, de mayor legibilidad.

\subsubsection{Imagen}

El nexo común de los dadaístas serán los montajes en los que se combinaba tipografía e imagen -fotografía-. Los primeros fotomontajes, técnica de la que se promulgaron inventores, fueron realizados con materiales de desecho y fotografías obtenidas de revistas y periódicos que se yuxtaponían de forma poética o absurda.

Los fotomontajes políticos más significativos serían los creados por Heartfield quien realizaba collages absurdos y surrealistas mediante la unión de imágenes o partes de imágenes que retocaba posteriormente. Sus diseños de copia-pega evolucionaron hacia otros realizados a partir de sus propias fotografías. En palabras de Aysley (2000: 167) "Sus montajes se basan en una dialéctica de tesis, antítesis y síntesis, en las cuales el espectador debe resolver el significado mediante el reconocimiento de contradicciones evidentes».

El simbolismo característico de los artistas Dadá se manifiesta especialmente en la obra de Heartfield. John Evans (1992: 15) lo reduce a «cuatro mecanismo satíricos para comunicar su mensaje: metamorfosis; hibridación; contrastes entre grande y pequeño, alto y bajo (metáforas de escala); y desenmascaramiento, a través de la discordancia entre la imagen y la cita».

\subsubsection{Las aportaciones de la Bauhaus}

«La Bauhaus, antes realidad, es hoy fábula» afirmaba Tomás Maldonado (1971: 175), sintetizando así la controversia idealización a la que la ya mítica escuela de arquitectura y diseño se ha visto sometida desde su desaparición en 1933. En lo que sí que parecen ponerse de acuerdo los estudiosos del tema es en su contribución a la homologación profesional del diseño gráfico, para lo cual resultó determinante la creación de unos estudios propios, asociados fundamentalmente a la enseñanza de la tipografía, la fotografía y la composición.

Pese a todo, ni el diseño gráfico ni la tipografía formaron parte del programa desde el comienzo -en la primera etapa la tipografía únicamente se impartía como parte de Vorkurs (Curso previo)- sino que su aparición en las enseñanzas de la Bauhaus derivó de la idea de Walter Gropius, primer director de la escuela, de aplicar el arte a la producción industrial y al consumo. A modo de resumen, podemos establecer los siguiente periodos en la enseñanza del diseño
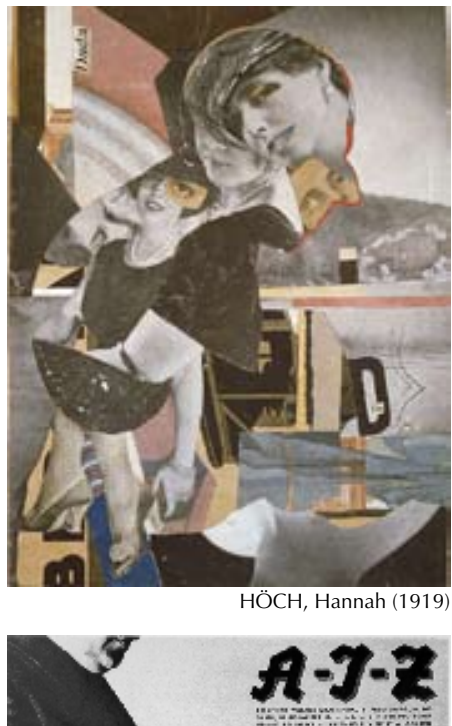
DER SINN DES
HITLERGRUSSES:

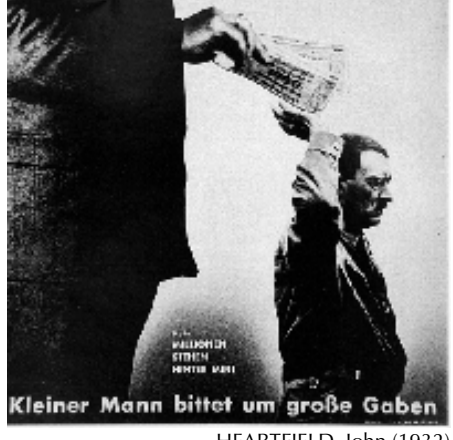


gráfico basándonos en las fases de la Bauhaus y su interre-

lación con la sociedad alemana definidas por Maldonado (1971: 181):

\begin{tabular}{|c|c|c|c|c|c|c|}
\hline AÑO & PERIODO & ESTILO & INTENCIÓN & DISEÑO GRÁFICO & PROFESOR & CARACTERÍSTICAS \\
\hline $\begin{array}{l}1919- \\
1924\end{array}$ & $\begin{array}{l}\text { WEIMAR. } \\
\text { Gropius }\end{array}$ & Expresionismo & Artesanía & $\begin{array}{l}\text { Tipografía } \\
\text { como parte del } \\
\text { adiestramiento }\end{array}$ & $\begin{array}{l}\text { Johannes } \\
\text { Itten }\end{array}$ & $\begin{array}{l}\text { Expresionista. } \\
\text { Experimentos } \\
\text { estéticos. Poca } \\
\text { legibilidad }\end{array}$ \\
\hline \multirow[t]{2}{*}{$\begin{array}{l}1925- \\
1930\end{array}$} & \multirow[t]{2}{*}{$\begin{array}{l}\text { DESSAU. } \\
\text { Gropius y } \\
\text { Meyer }\end{array}$} & \multirow[t]{2}{*}{$\begin{array}{l}\text { Funcio- } \\
\text { nalismo/ } \\
\text { racionalismo }\end{array}$} & \multirow[t]{2}{*}{ Industria } & $\begin{array}{l}\text { Taller de impresión y } \\
\text { publicidad }(\mathrm{G})\end{array}$ & $\begin{array}{l}\text { Herbert } \\
\text { Bayer }\end{array}$ & $\begin{array}{l}\text { Legibilidad. Tipo- } \\
\text { grafía elemental. } \\
\text { Rojo y negro. Foto } \\
\text { y material tipográ- } \\
\text { fico. No simetría }\end{array}$ \\
\hline & & & & $\begin{array}{l}1927 \text { Taller de } \\
\text { publicidad (M) }\end{array}$ & \multirow{2}{*}{$\begin{array}{l}\text { Joost } \\
\text { Schmidt } \\
\text { Y Walter } \\
\text { Peterhans }\end{array}$} & \multirow{2}{*}{$\begin{array}{l}\text { Fotografía. } \\
\text { Organización } \\
\text { exposiciones. } \\
\text { Espacios } \\
\text { tridimensionales }\end{array}$} \\
\hline $\begin{array}{l}1930- \\
1933\end{array}$ & $\begin{array}{l}\text { BERLÍN. } \\
\text { Mies Van der } \\
\text { Rohe }\end{array}$ & Racionalismo & & $\begin{array}{l}\text { Taller de Tipografía, } \\
\text { publicidad. } \\
\text { Taller de Fotografía }\end{array}$ & & \\
\hline
\end{tabular}

Tabla 2.1

Como podemos observar en el cuadro, el estilo de la escuela fue evolucionando desde el expresionismo de los primeros profesores llamados a dar clase por Gropius - que según Mario de Micheli (1971: 89) eran artistas «del expresionismo, sobre todo de la línea lírica, la línea del Blaue Reiter»- al racionalismo, pasando por el funcionalismo.

Este cambio vendrá marcado por la influencia del artista Theo van Doesburg, fundador del grupo De Stijl, y la incorporación de Lázló Moholy-Nagy como director del curso preliminar la Bauhaus. Las vanguardias soviéticas, y su afán por mostrar sus obras mediante conferencias y exposiciones calaron fuertemente en esta nueva etapa racionalista. Para Satué (1993: 156)

«Tras la revolución gráfica que a través de la fotografía y la tipografía ha divulgado el grupo constructivista desde 1918, estos dos lenguajes de comunicación visual son utilizados por la Bauhaus como el exponente visible de la renovación y modernización de la gráfica publicitaria».

El tipo de enseñanza multidisciplinar característica de la Bauhaus permitió igualmente que el diseño gráfico se relacionase con la arquitectura, el diseño industrial y el teatro, de tal modo que según Gulio Carlo Argan (1951: 155) «con la reforma de la tipografía, de la publicidad, del teatro, la Bauhaus agranda ilimitadamente la esfera de su influencia sobre a las costumbres y usos de la sociedad».

Precisamente esa influencia será parte responsable de la «fábula», haciendo que se convirtiera no solo en objeto de estudio artístico, sino también político; cerrada por el régimen nazi y posteriormente cuestionada por el gobierno comunista.

Cabe recordar, que los emplazamientos en los que se había situado la escuela (Weimar, Dessau y Berlín) pasaron a formar parte de la República Democrática Alemana tras la Segunda Guerra Mundial, razón por la cual se vio sometida al análisis oficial del régimen socialista, quien variaría de postura a lo largo de la historia. Su actitud frente a la Bauhaus se establecía desde una perspectiva política y de su influencia sobre "el estilo de vida socialista», pasando del rechazo al ensalzamiento, que la convierte en objeto de numerosas exposiciones y de estudio, Ilegando incluso a rehabilitar la Bauhaus de Dessau destruida durante la guerra.

Wolfgang Thöner (2005), colaborador científico de la Stiftung Bauhaus Dessau (Fundación de la Bauhaus de Dessau), establece la siguiente cronología:

\begin{tabular}{|l|l|l|}
\hline Año & Periodo & Características \\
\hline $\begin{array}{l}1945- \\
1950\end{array}$ & «Primero años de la RDA » & $\begin{array}{l}\text { La Bauhaus era considerada como algo positivo que la nueva sociedad } \\
\text { debía adjuntar, dándole especial importancia a su posición como vícti- } \\
\text { ma de la dictadura nazi. }\end{array}$ \\
\hline $\begin{array}{l}1951- \\
1955\end{array}$ & $\begin{array}{l}\text { «Bauhaus como un extraño, } \\
\text { un fenómeno hostil» }\end{array}$ & $\begin{array}{l}\text { Los conceptos modernistas difundidos en la escuela entraban en contra- } \\
\text { dicción con el «realismo socialista» fomentado por el gobierno socia- } \\
\text { lista, lo que la convirtió en objeto de rechazo en la primera mitad de } \\
\text { los 50’. }\end{array}$ \\
\hline $\begin{array}{l}1955- \\
1970\end{array}$ & «La recepción de la Bauhaus \\
en la era del NÖSL» & $\begin{array}{l}\text { Se experimenta una vuelta al funcionalismo y a la Bauhaus especialmen- } \\
\text { te en el terreno arquitectónico fomentada por la traducción al alemán } \\
\text { del escritor soviético Leonid Pazitnov «Die schöpferische Erbe des Bau- } \\
\text { hauses» («La fértil tierra de la Bauhaus». }\end{array}$ \\
\hline
\end{tabular}

Según Frank Whitford (1991: 199) el cambio de visión se produjo debido a que en los primeros años 50 :

«El programa de la escuela estaba dirigido a una economía capitalista y lo enseñaban unos artistas cuya obra era formalista. Hacia finales de los sesenta, apareció en la RDA una nueva y sutil interpretación de la Bauhaus. Según esta nueva línea, la escuela había intentado llevar a cabo un conjunto de ideales socialistas pero estaba predestinada al fracaso porque la sociedad capitalista en la que se hallaba le hizo la vida imposible».

De cualquier manera el interés estatal por la Bauhaus se centra en sus ideas socialistas, de ahí que presten especial atención al periodo con Meyer como director, por ser este un marxista declarado. 
Las intenciones de la escuela quedarían definidas por Gropius (1926: 110, citado en Aynsley 2000) :

"Aprender a llevar el diseño de objetos hacia una relación vital con la tradición y la forma que busque desarrollar una nueva actitud hacia el diseño que es (...):

- La limitación de caracterizar formas y colores primarios legibles para todo el mundo.

- La simplicidad en la multiplicidad; uso económico del espacio, material, tiempo y dinero.

- La creación de tipos estandarizados para la comodidad práctica del uso diario es una necesidad social».

Será con Moholy-Nagy como director del curso preliminar y Herbert Bayer como profesor de impresión y publicidad, cuando se produzcan los mayores avances compositivos, que se derivarán de la revisión de la composición clásica -que denominaba «estático-concéntrica»- hacia una composición "dinámico-excéntrica», en la cual la lectura es conducida gradualmente de unos elementos a otros.

Ellen Lupton (2002: 28) analiza cómo:

"Una retícula organiza el espacio según unos ejes x e y. La retícula, un forma estructural que invade el arte y el diseño de la Bauhaus, articula el espacio según un tramado de oposiciones: vertical y horizontal, arriba y abajo, ortogonal y diagonal, e izquierda y derecha. Otra oposición implicada en la retícula es la oposición entre la continuidad y la discontinuidad».

Estos contrastes de tamaño y orientación creaban una jerarquía visual, que junto con el uso de los filetes de impresor, supuso un avance hacia el funcionalismo; el diseño concebido para ser reproducido a máquina.

En las composiciones realizadas en este periodo se puso de relieve la eficacia visual que se derivaba de la forma, formato, color y disposición de las formas tipográficas, mediante las cuales se fijaban los contenidos en forma de imágenes.

En la última época de la Bauhaus, con Joost Schmidt como profesor del taller de publicidad y tipografía, a la combinación de texto y fotografía se le añadiría la creación de espacios tridimensionales en perspectiva que formaban un espacio en el que presentar un producto.

\subsubsection{Tipografía}

Independientemente de los resultados de las actuaciones en el campo de la tipografía, cuyo «aporte en lo referente al diseño de tipografías es, en el mejor de los casos, modesto» según Miguel Catopodis (2009), hay que reconocer a la Bauhaus su revisión de la tipografía y composición de la época, en una búsqueda del espíritu racionalista. MoholyNagy (1925, citado en Satué 1993: 152) escribía que «la Bauhaus ha profundizado todos los problemas que conciernen a la tipografía y ha reconocido justas las argumentaciones aducidas a favor de la escritura unitaria».

El concepto de escritura unitaria, impulsada por Herbert Bayer, se basaba en las opiniones de Adolf Loos sobre la contradicción en la lengua alemana ${ }^{6}$ entre la lengua escrita y hablada y en el libro «Sprache und Schrift» (Lenguaje y Escritura) del Dr. Porstmann, e implantaba el uso de la caja baja como único tipo. La unidad de la escritura abarcaba, además de al tamaño, a la forma de los tipos, apostando por una geometrización de los mismos. Este es el caso del alfabeto Universal de Herbert Bayer Ilamado así porque esperaba trascender las normas culturales al basarse en normas atemporales y objetivas, en oposición con la letra gótica de uso tradicional en la lengua alemana. Esta rígida fórmula ha sido objeto de numerosas críticas que la han tildado de formalista y de poco adecuada a los usos de la lengua.

Para Moholy-Nagy, sin embargo, la tipografía era una herramienta de la comunicación y como tal, su prioridad absoluta debía ser la legibilidad y la claridad, siendo la tipografía de palo seco la que consideraba más adecuada.

\subsubsection{Imagen}

La importancia de la fotografía en el diseño gráfico de la Bauhaus también vendría de la mano de Moholy-Nagy quien destacaba el poder de la fotografía como medio en el diseño gráfico para transmitir una idea. Como miembro junto con otros artistas alemanes del movimiento conocido como "Nueva Fotografía», influyó notablemente en el uso de la misma que se realizó en la Bauhaus. Una explotación adecuada de la herramienta pasaba según Moholy-Nagy por el uso de diferentes técnicas fotográficas:

\section{Typophoto}

Según el propio Moholy-Nagy (1925: 95-96)

«La tipografía es una información traducida a caracteres de impresión.

La fotografía es la representación visual de lo ópticamente perceptible.

La typophoto es la información representada visualmente de la manera más precisa.
6. En la lengua alemana el uso de las mayúsculas no se reduce al comienzo de frase y a los nombres propios, sino que se utiliza en todos los sustantivos.

abcdefahi

jklmnopar

stuvwxyz

a

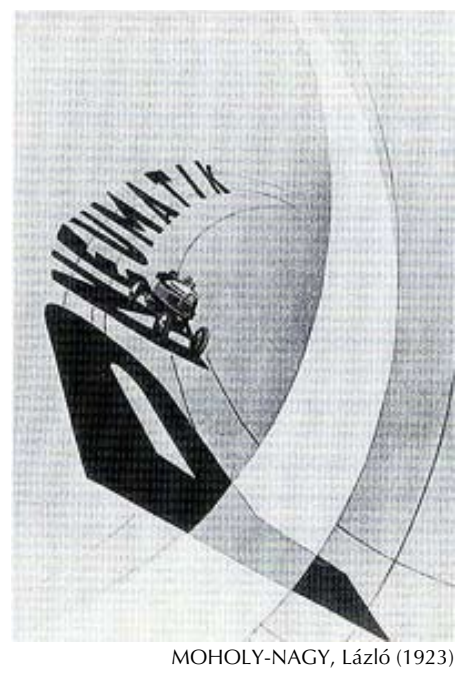


(...) La tipografía de Gutenberg (...) se desplaza exclusivamenfotográfico, sin embargo, alcanza ahora una nueva dimensión, conocida en la actualidad como dimensión total».

La efectividad de la fotografía en combinación con la tipografía reside en la objetividad del mensaje, que de este modo no depende de la interpretación del espectador.

\section{Fotoplástica}

Denominaba «fotoplástica» a la técnica del collage como una manera más creativa y funcional de explotación de la fotografía. La fotoplástica se basaba en los intentos dadaístas de crear una imagen a partir de fragmentos de distintas de ellas. Moholy-Nagy (1926: 126) consideraba que:

«Este procedimiento posibilita a la representación de una suprarrealidad constituida de manera orgánica. Sus aplicaciones prácticas son incontables, entre otras, puede utilizarse como medio publicitario, en el cartel y en la propaganda política».

\section{Modulador espacio luz}

Moholy-Nagy se muestra interesado por los experimentos cinéticos realizados mediante reflectores de luz en movimiento y en sus posibilidades en la fotografía mediante las variaciones de los claroscuros.

\section{Fotograma}

Se denomina así al aspecto más experimental de captura de imágenes sin objetivo ni lente. Su valor, para Moholy-Nagy (1925: 88), reside en que «este método hace patente un tipo de creación lumínica en el que la luz, en cuanto nuevo medio para la creación, se emplea de manera autónoma, del mismo modo que ocurre en la pintura con el color y en la música con el sonido». Esta técnica consiste en la colocación de objetos un papel fotosensible que se expone a la luz de forma que crean sobre este juegos de luces y sombras mediante los cuales se crean espacios.

En la «Era Meyer» la enseñanza de la fotografía estaba a cargo de Walter Peterhans, en franca oposición a MoholyNagy y su experimentación, y más volcado en la realización de fotos técnicamente perfectas.

\subsubsection{El Funcionalismo y la Nueva Tipografía}

Las vanguardias artísticas tuvieron una gran influencia en el diseño gráfico de los años 20 tanto dentro de la Bauhaus como fuera de ella, especialmente en cuanto al componente abstracto y geométrico de muchas de ellas.
Serán precisamente la Bauhaus y el constructivismo las primeras influencias que tendría Jan Tschichold cuando comienza a practicar la nueva tipografía en 1923. En 1925 publicará su artículo de «Elementare Typographie» (Tipografía Elemental) para la revista «Typographische Mitteilungen» (Comunicaciones Tipográficas) sobre el concepto de «Nueva tipografía». El título del manifiesto lo relacionaba con el Stilj holandés donde la asimetría en la composición tipográfica y la abstracción venían siendo utilizadas desde hacía años. Finalmente en 1928 lo vuelve a publicar, esta vez con una orientación didáctica en el libro de texto «Die neue Typographie» (La Nueva Tipografía) ${ }^{7}$.

La visión funcionalista del diseño supone la eliminación del ornamento, su reducción a su función de comunicación cuyo objetivo debe ser transmitir el mensaje de la manera más breve posible. Tschichold afirmaba (1987: 65) que «tanto la naturaleza como la tecnología nos enseñan que la «forma» no es independiente, sino que crece de la función (propósito), de los materiales usados (orgánicos o técnicos) y de cómo son usados».

\subsubsection{Composición}

El objetivo del diseño gráfico es la comunicación que debe realizarse de la forma más directa posible. Esta comunicación se logra ordenando los contenidos y la forma en que éstos se expresan, la cual, según Tschichold (1987: 64) debe ser replanteada ya que "como norma ya no leemos tranquilamente línea a línea, sino que echamos un vistazo rápido a todo el conjunto, y solo si nos despierta el interés lo estudiamos en detalle». Para atraer la atención y al mismo tiempo organizar los contenidos utiliza reglas, barras y cajas para enfatizar o estructurar la imagen.

La organización simétrica -reposada- es artificial. La composición de la época debía tener un diseño asimétrico cinético como expresión del movimiento de la máquina. Esta composición asimétrica la consigue mediante la alineación al margen izquierdo -en el caso de la escritura europea- con longitudes de línea desiguales. La lectura central no tiene sentido ya que empezamos la lectura desde uno de los lados. La forma debe surgir de la función, no estar preconcebida por ningún tipo de concepto.

Tschichold abogaba por el dominio del espacio tipográfico, tanto del negro como del espacio libre blanco al afirmar (1987: 72) que «la nueva tipografía usa la efectividad del fondo de forma deliberadas, y considera el espacio en
7. Publicada en castellano en 2003 por la editorial valenciana Campgràfic.

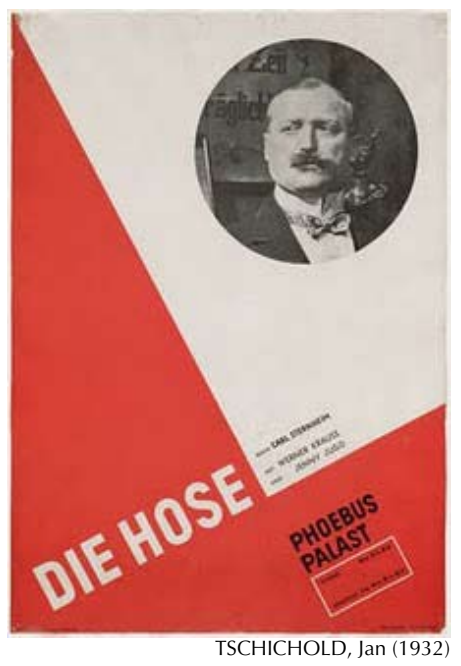




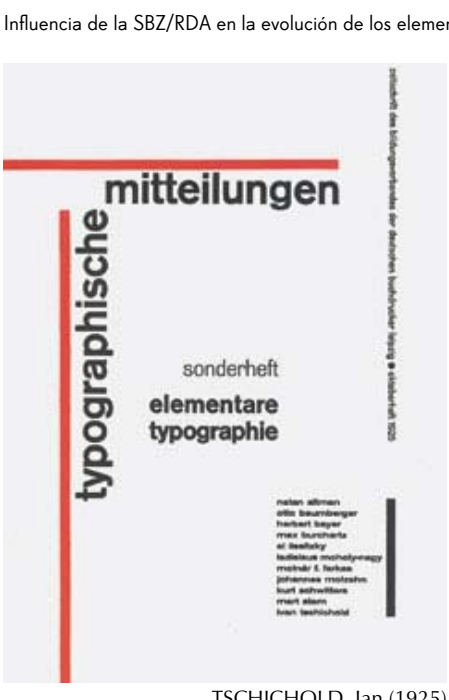

TSCHICHOLD, Jan (1925)

8. Irónicamente, Tschichold defensor de la tipografía de palo seco en «La Nueva Tipografía pasaría a la posteridad por la tipografía Sabon, de tipo romano.

\section{ABCDEFGHIJKLMNO} PQRSTUWWXYZÀÅÉÎ abcdefghijklmnopqr stuvwxyzàåéîõøü\&1 234567890(\$£.,!?)

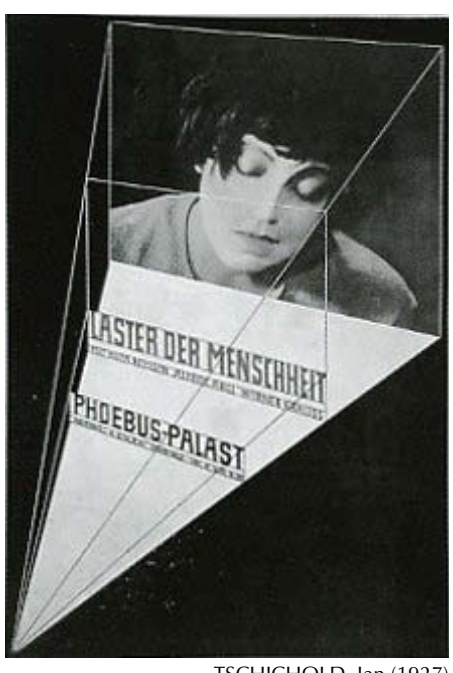

blando en el papel como elementos formales tanto como as áreas de tipografía negra» Sobre este fondo se organiza el texto que se jerarquiza "a través del uso de diferentes tamaños de letra, pesos, situación en relación al espacio, color, etc». (Íbidem: 70)

\subsubsection{Tipografía}

El mayor logro en tipografía universal basada en los imperativos teóricos de la época sería diseñado fuera de la Bauhaus por Paul Renner en su tipografía Futura, ya que la tipografía de palo seco es un pilar fundamental del Funcionalismo.

La esencia de la nueva tipografía es la claridad, en contra de la cualidad principal de la vieja tipografía, en la cual primaba la belleza. Esta debe ser elemental y sin embellecimiento de modo que el tipo moderno será el tipo de palo seco $^{8}$ en todas sus variantes, y será el contraste de la mancha de negro de estas variantes la que consiga la imagen expresiva que busca.

Las tipografías con ornamentos, tales como los remates o las prolongaciones de la gótica, no son adecuadas a estos conceptos de claridad, como tampoco lo son las letras con connotaciones nacionales como la fraktur, poco acordes al espíritu de la época. Sin embargo no rechaza utilizar otras tipografías como medio de llamar la atención.

\subsubsection{Imagen}

Los diseños funcionalistas de los años 20 se caracterizan por la geometrización de las imágenes y sus perfiles agudizados. Tschichold a su vez apuesta por la eliminación de todos los adornos excepto de las figuras geométricas básicas cuando su uso esté justificado y el uso de filetes gruesos para la organización del texto. Utiliza una ilustración agresiva y de fuertes contrastes -luz y oscuridad, grande pequeño, vacío y sólido-, pero será la imagen fotográfica, por su objetividad, la preferida.

Uso del color dependerá de sus cualidades físicas naturales; el rojo, debido a su mayor luminosidad adelanta el objeto dentro de la composición, sin embargo no se aceptan las asociaciones habituales de los colores con sentimientos por no considerarlas naturales:

"La combinación de negro y rojo no es, por supuesto, la única posibilidad, como se ha supuesto habitualmente de forma errónea, pero es elegida frecuentemente debido a su gran intensidad. El color debe ser usado, en general, para ayudar a expresar el propósito del trabajo» (Tschichold, 1987: 73).
2.1.8. El diseño en los periodos bélicos. El Tercer Reich

Al igual que había ocurrido en la Primera Guerra Mundial el gobierno nacionalsocialista utiliza el diseño gráfico para su propaganda. Sin embargo ya no hace uso de la evolución que el diseño gráfico había experimentado en Alemania sino que promueve una vuelta a los valores de la artesanía y al neoclasicismo debido a la identificación que existía del modernismo con la República de Weimar.

Sin embargo, según Aysley (2000: 181) «las cualidades estéticas y estilísticas de mucha de la propaganda en el $3^{\circ}$ Reich significa una simplificación más que un rechazo total del diseño moderno que le precedió», para ello se basa en los estudios arquitectónicos realizados por Barbara MillerLane y Robert Taylor en los cuales:

«(...) sugerían que una visión más representativa sería que los nacionalsocialistas habían implementado un antimodernismo selectivo, acorde a los requerimientos industriales y oficiales de arte, diseño y manufacturados y esto estaba lejos de una franca ruptura con el pasado».

Con la creación en 1933 del Reichsministerium für Volksaufklärung und Propaganda (Ministerio de Educación y Propaganda) dirigido por Joseph Goebbels, el diseño gráfico deberá ceñirse a la legislación de Die Werbung für Staat, Kultur und Wirtschaft (Publicidad para el Estado, la Cultura y la Economía). Igualmente se crearía la Reichskulturkammer (Cámara de Cultura del Reich) y el National Sozialistische Reichfachschaft Deutsche Werbefachleute (División del Imperio Nacionalsocialista de Expertos en Publicidad Alemana) que controlaba todos los estados de publicidad desde la comercial hasta la propagandística. De tal modo que el diseño gráfico pasaba a estar bajo control. Esto, junto a motivos políticos o de raza, supuso la emigración de una gran parte de los diseñadores gráficos durante la Segunda Guerra Mundial.

\subsubsection{Composición}

Oficialmente el modernismo era rechazado y considerado como una cosa del pasado. Lo consideraban un arte degenerado y contrario al espíritu nacional, por su carácter internacional. Como parte de la propaganda se organizaron multitud de exposiciones ridiculizando el modernismo y mostrando el arte nacional que en un primer momento se consideró que podía ser el expresionismo. Finalmente e estilo oficial asumido para los propósitos nacionales será el

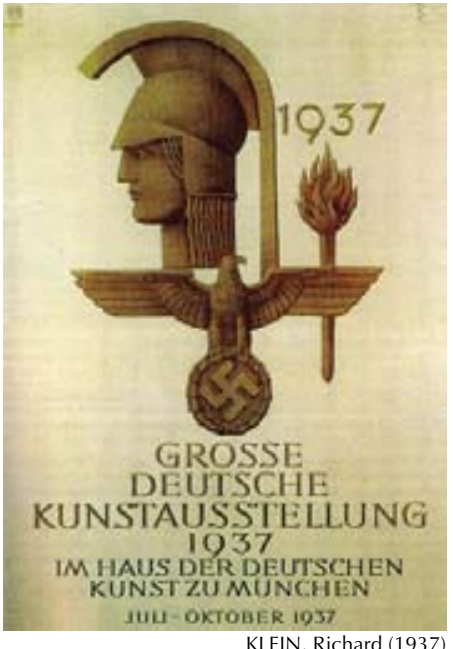

KLR 1937 Riv Richard (1937) 
neoclasicismo, caracterizado por su marcado eje central y simetría.
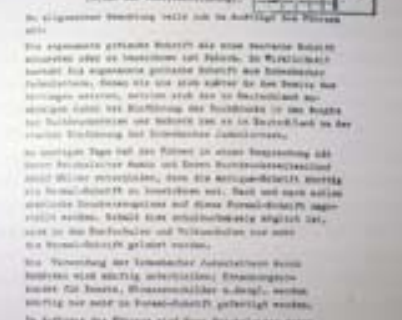

ilu $=$

BORMANN, Martin (1941)

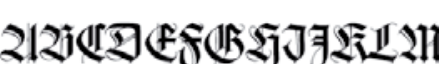

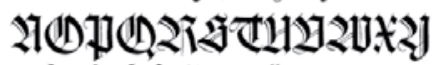

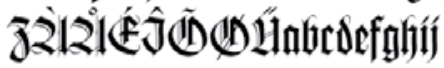

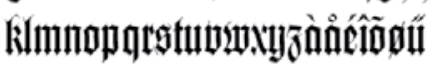

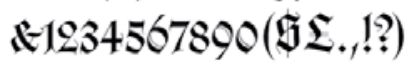
$\mathrm{KOCH}$, Rudolf (1926). Wilhelm Klingspor Gotisch

9. Die sogenannte gotische Schrift als eine deutsche Schrift anzusehen oder zubezeichnen ist falsch. In Wirklichkeit besteht die sogenannte gotische Schrift aus sogenannte gotische Schrift aus
Schwabacher Judenlettern. (...) Am heutigen Tag hat der Führer [...] entschieden, daß die AntiquaSchrift künftig als Normal-Schrift zu
Schists bezeichnen sei.

\subsubsection{Tipografía}

Los años del $3^{\circ}$ Reich serán muy agitados en el campo de la tipografía. El concepto «degenerado» se aplicará aquí a una imagen abstracta de las letras, por lo que se decantan por una tipografía acorde con el espíritu nacional. Heinrich Wieynck, profesor de tipografía en Dresden en los años 30, abogaba por las letras caligráficas, góticas y romanas.

El gusto por la letra góticas se justificaba, según Gustav Stresow (1937, citado en Aysley 2000: 188), en que:

«(...) la textura condensada de las líneas de la fraktur reduce la longitud de las palabras frecuentemente monosilábicas de la lengua alemana, y armoniza con el ritmo de las vocales y consonantes de la ortografía alemana; resumiendo, está «sincronizado» con la lengua alemana».

En resumen, son más legibles por ser más expresivas, y más económicas al ser condensadas. De ahí que se produzca un revival de las tipografías fraktur de Rudolf Koch, sin que eso suponga una vuelta a la tipografía artesanal de pequeña escala.

En el uso de la tipografía gótica, fue determinante que en una primera etapa, el ministerio de Goebbels obligara al uso de tipografía gótica o romana clásica -aunque la Futura se mantuvo para usos oficiales, debido, probablemente, a que gozaba de la predilección del Führer. Sin embargo, a mitad de la Segunda Guerra Mundial se retiró la gótica como letra oficial y esta pasó a ser considerada «letra judía».

El 3 de enero de 1941 Martin Bormann publicará el siguiente edicto:

"La llamada letra gótica que era considerada como una letra alemana es falso. (...) En realidad la llamada letra gótica se trata de letras judías Schwabacher. En el día de hoy el Führer (...) ha decidido que la que debe ser tratada como letra normal sea la tipografía romana» ${ }^{9}$.

Explicación oficial de escasa credibilidad, ya que las vinculaciones judías de la letra Schwabacher son, cuando menos, dudosas, por lo que parece más plausible la explicación que da el profesor de lenguas clásicas Juan José Marcos (2008):

«La verdadera razón de este cambio seguramente es muy distinta: hay que tener en cuenta que en enero de 1941, Alemania había conquistado la mayor parte de Europa y la gótica alemana se había convertido en una barrera en la comunicación con los nuevos «vasallos» de las zonas ocupados que estaban acostumbrados a la antiqua que era mucho más legible».

\subsubsection{Imagen}

La fotografía, que ya había sido utilizada tímidamente como medio propagandístico en la Primera Guerra Mundial, pasa a tener una gran relevancia en esta segunda guerra por su capacidad para transmitir gracias a la objetividad que se le suponía pese a que en ocasiones era retocado mediante aerógrafos. Según Hollis (2000: 105) «la fotografía demostró ser un medio gráfico de mucho más efectivo de protesta por las atrocidades que las ilustraciones caricaturizadas utilizadas en la Primera Guerra Mundial».

El uso de los colores rojo negro y blanco era mayoritario en la propaganda por su identificación con el partido. Hollis (2000: 106) definirá la elección de estos colores como que «el nacionalsocialismo tenía que estar representado en blanco y rojo: blanco para la pureza racial aria, y para su programa social, tenía que ser el mismo rojo que le había impresionado (a Hitler) en un mitin marxista».

\subsection{EVOLUCIÓN DEL DISEÑO GRÁFICO PREVIO A 1945}

Partiendo de las características descritas en el capítulo anterior de los estilos y movimientos en el campo del diseño gráfico previo a 1945 podemos establecer unas pautas en la evolución del diseño según los criterios de composición tipografía e imagen.

\subsubsection{Evolución de la composición}

Tal y como hemos definido al comienzo, al hablar de composición nos estamos refiriendo a la colocación de los distintos elementos de diseño. A fin de poder establecer una comparación entre ellos, hemos adoptado un mismo lenguaje mediante el cual se determina la ubicación de la imagen y el texto, el eje de la composición y las guías que la estructuran. De este modo podemos determinar los rasgos comunes y las líneas de tendencia que se establecieron en el campo de la composición.

A continuación muestran los esquemas anteriormente descritos, definidos a partir de ejemplos característicos de cada estilo. Únicamente los diseños de la Primera Guerra Mundial no han sido analizados, ya que en ellos se mantiene el esquema compositivo del Sachplakat.

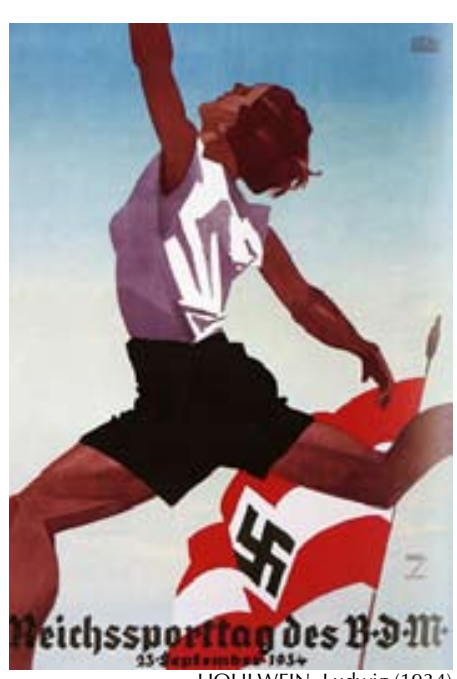

(a) 


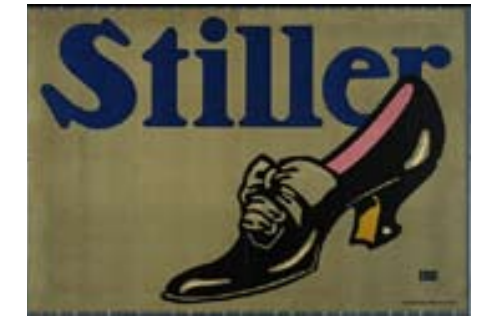

BERNHARD, Lucian (1907) SACHPLAKAT
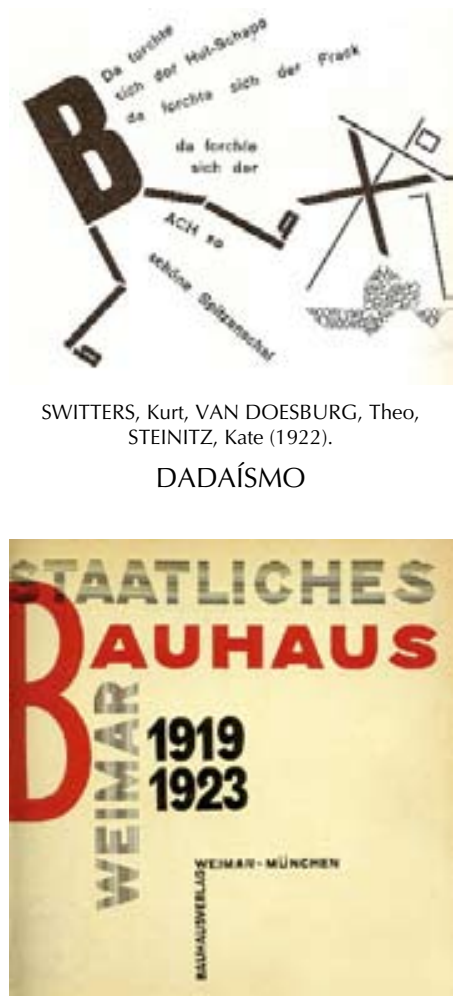

MOHOLY-NAGY, Lázó (1923) BAUHAUS

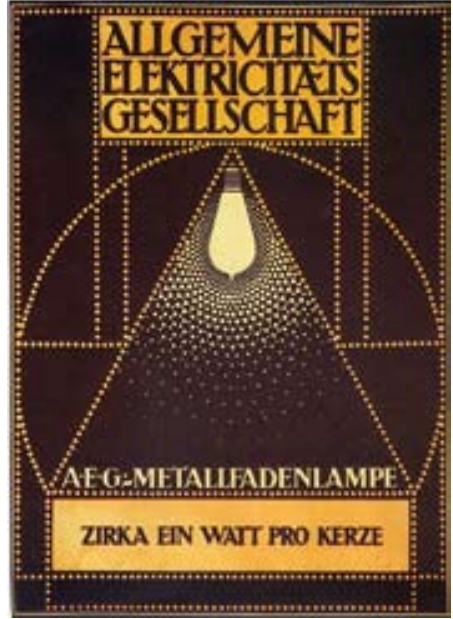

BeHRENS, Peter (1910) WERKBUND INSTITUT

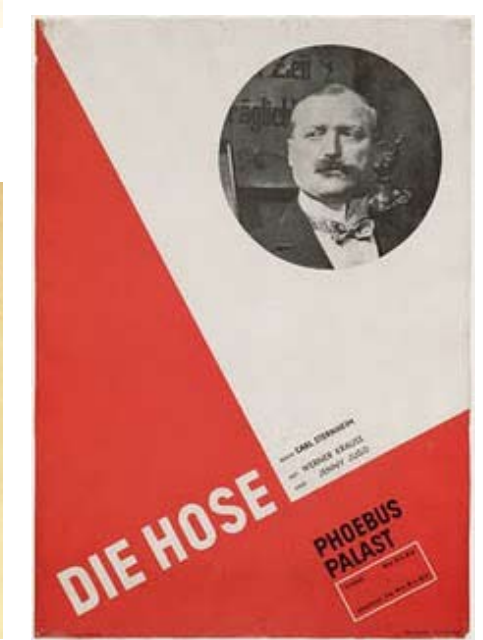

TSCHICHOLD, Jan (1932) NUEVA TIPOGRAFÍA
FUNCIONALISMO

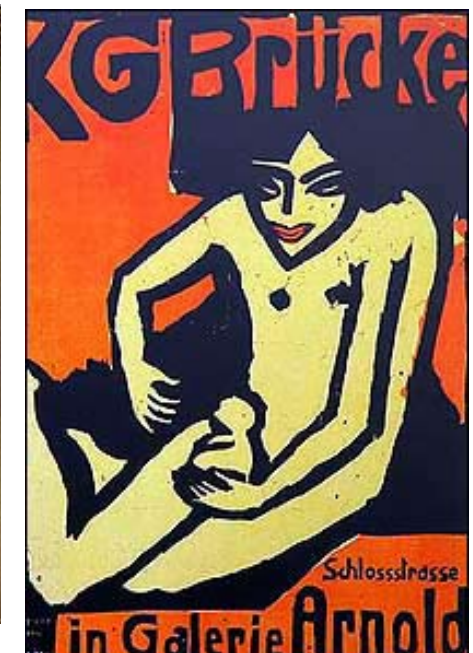

HECKEL,Erich (1905 EXPRESIONISMO

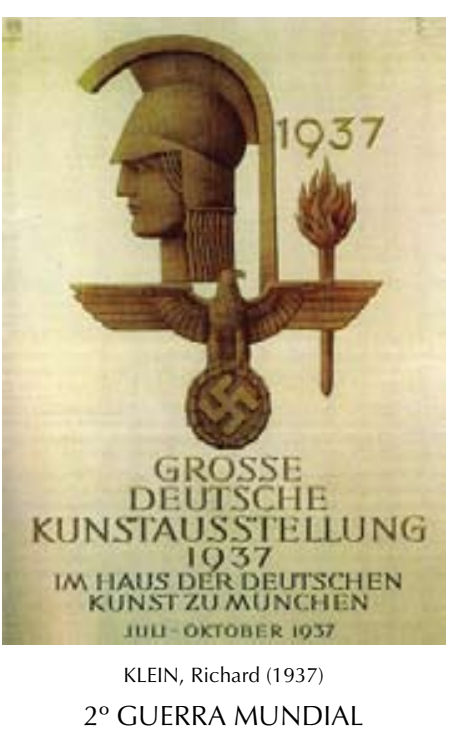

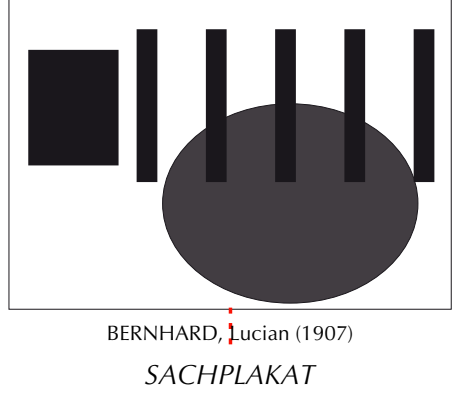

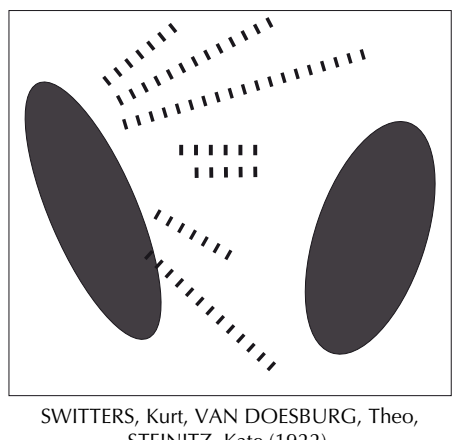
DADÁ́SMO

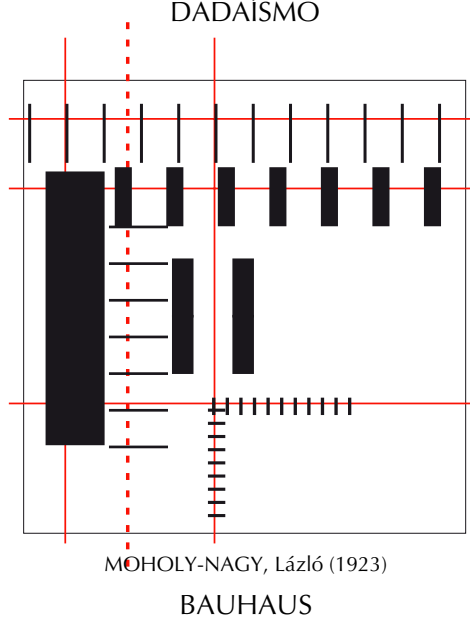

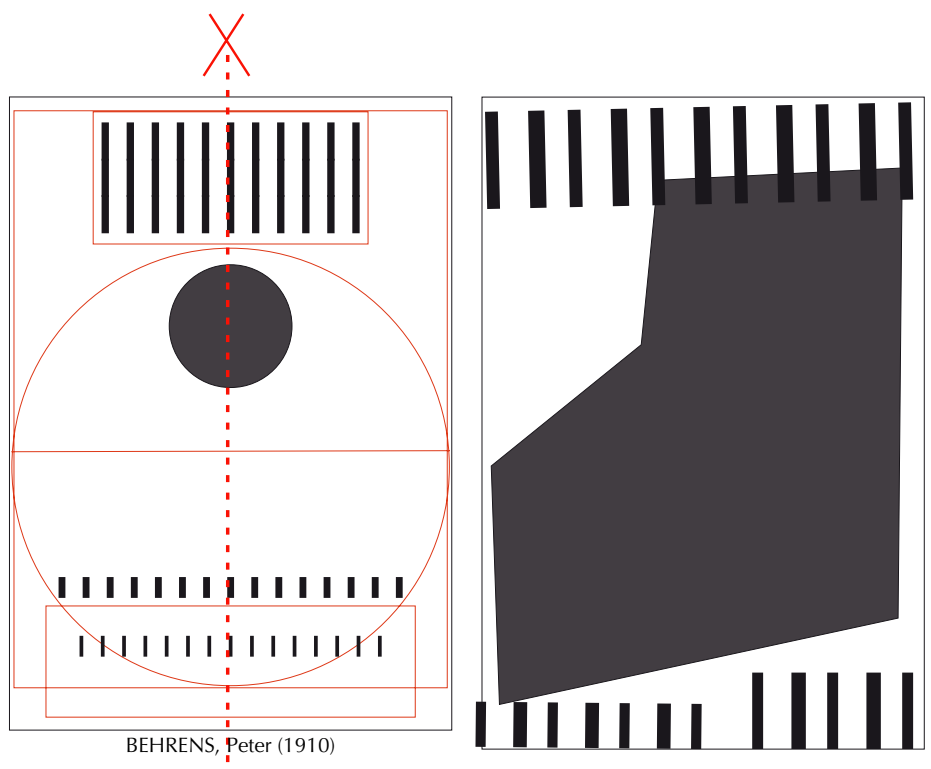

WERKBUND INSTITUT

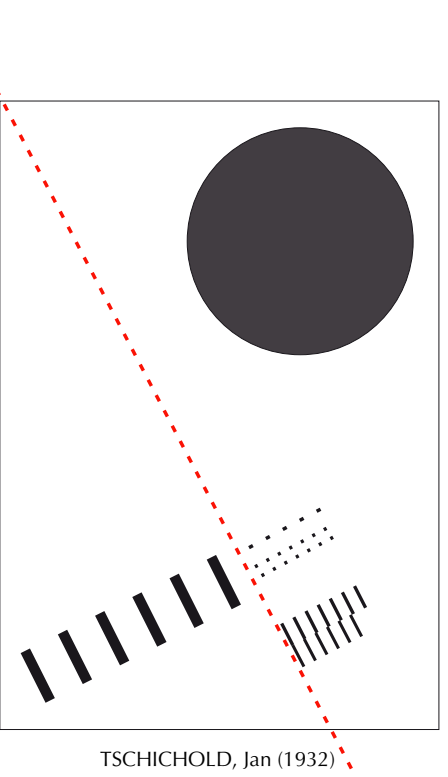

TSCHICHOLD, Jan (1932)'
NUEVA TIPOGRAFÍA. FUNCIONALISMO
HECKEL,Erich (1905)
EXPRESIONISMO

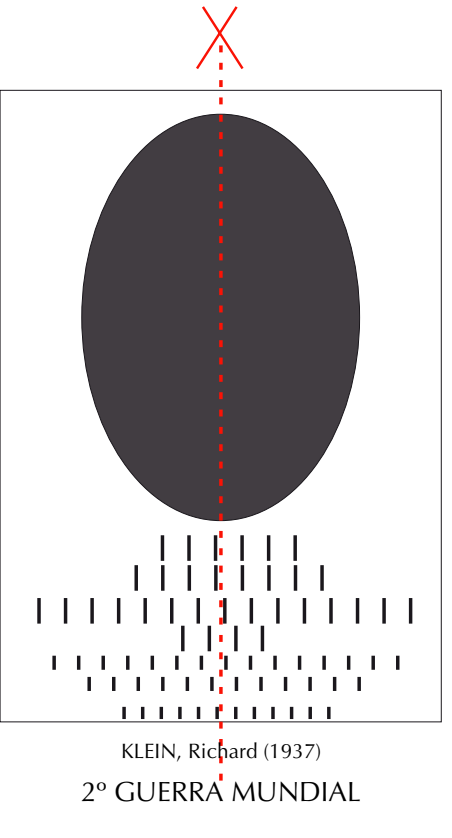


Los carteles del Sachplakat, debido a la simplicidad característica de los mismos, carecen de unas reglas compositivas claramente definidas. Si bien se tiende a un equilibrio central, este no está claramente establecido mediante un eje de simetría, sino que se deduce del reparto del peso de las figuras y los tipos.

No es este el caso de las composiciones dadaístas y expresionistas, donde la anarquía de los elementos es pretendidamente evidente, buscando una libertad total en la organización de las partes.

A excepción de estos grupos de vanguardia, el cartel en Alemania experimenta una progresiva racionalización que lo hacía más adecuado a su reproducción mecánica, llegando a la máxima expresión durante la Bauhaus. La racionalización que se refleja en el establecimiento de ejes y cuadrículas, irá cambiando paulatinamente su estructura. Mientas en la Werkbund se mantenía la composición clásica con eje de simetría central, en el caso de la Bauhaus podemos observar como este se excentriza, buscando una composición dinámica que culminará con el cinetismo de la composición funcionalista. Si en los dos primero casos primaba su adecuación a la reproducción mecánica, para los artistas de la Nueva Tipografía esta queda supeditada a la función.

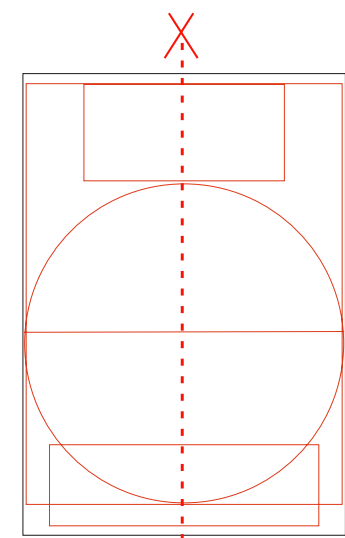

Eje de simetría central Estructura definida y evidenciada

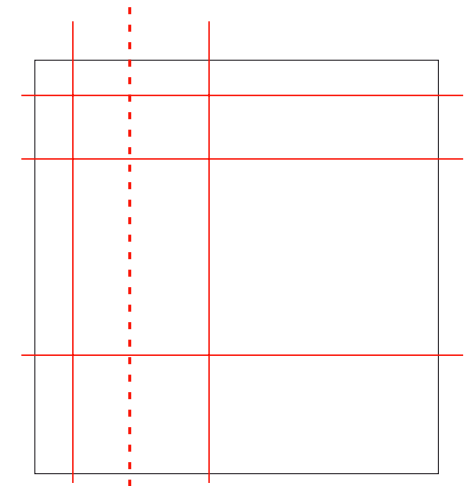

Eje vertical descentrado Estructura definida no evidenciada

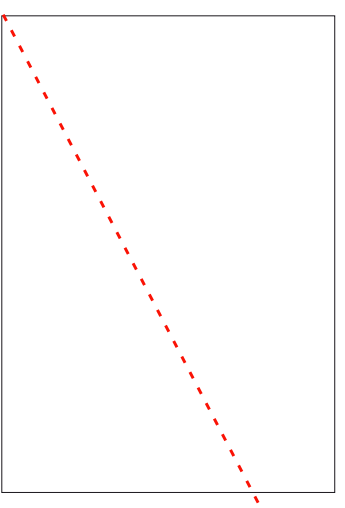

Eje descentrado y oblicuo Estructura no definida

\subsubsection{Evolución de la tipografía}

A lo largo del primer capítulo hemos podido constatar como el concepto de «legibilidad», tan presente siempre entre los diseñadores de tipos, constituía en Alemania un debate entre la representación del espíritu nacional frente a la «universalidad» del diseño.

Partiendo de la consideración de letra gótica como letra «alemana», los diseñadores de tipos fueron eliminando el ornamento progresivamente hasta establecer la tipografía de palo seco como la más adecuada. Esta evolución tuvo dos momentos de inflexión producidos por los dos conflictos bélicos en los que la identidad nacional cobró de nuevo una gran importancia.

Hemos tomado como muestra representativa de la tipografía diseñada a lo largo de la primera mitad del siglo XX los siguientes tipos:

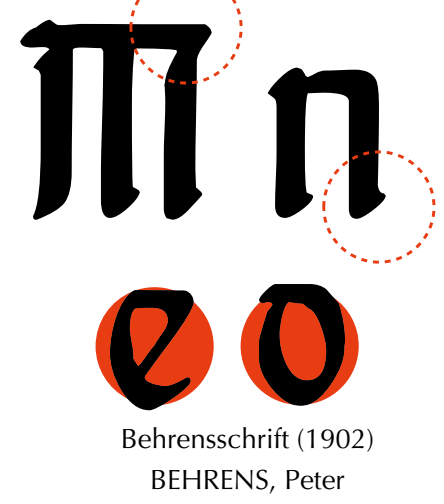

BEHRENS, Peter
$\mathrm{M}$

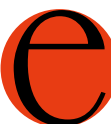

Ehmcke Antiqua (1909) EHMCKE, Fritz Hellmut
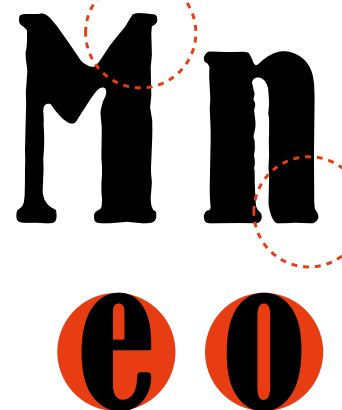

Bernhard Antiqua (1911) BERNHARD, Lucian

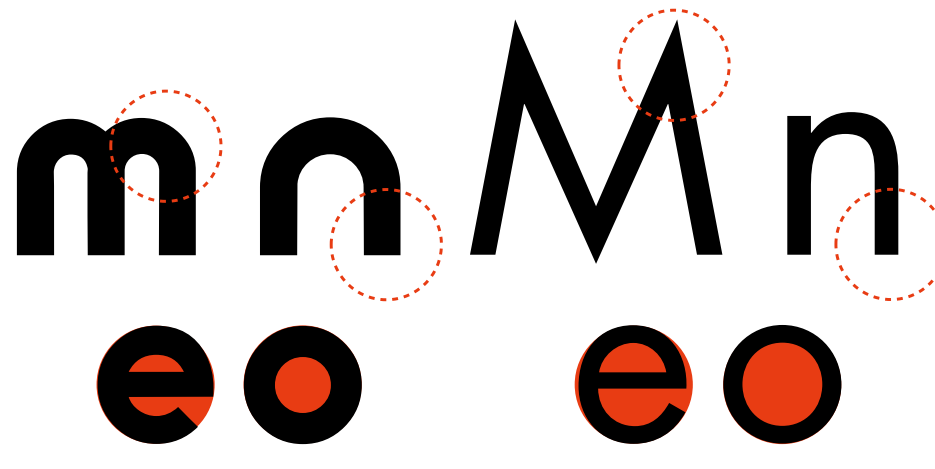

Universal (1925) BAYER, Herbert
Futura (1927) RENNER, Paul

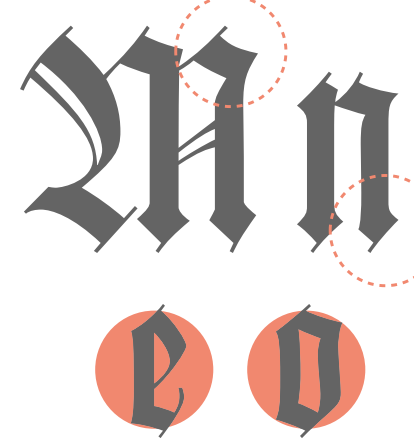

Wilhelm Klingspor Gotisch (1926) $\mathrm{KOCH}$, Rudolf 
De este modo quedan reflejados todos los movimientos principales de este periodo, con dos excepciones; por un lado el expresionismo, ya que la propia esencia del grupo suponía el uso de la letra dibujada a mano sin unas normas fijas, y por otro lado el Dadaísmo debido al carácter experimental de la tipografía fonética.

Superponiendo los remates de la $\mathrm{M}$ y la $\mathrm{n}$ podemos constatar cómo éstos han ido reduciéndose al mismo tiempo que paulatinamente abandonan las características propias de los tipos góticos hacia remates romanos. La gótica Wilhelm Gotisch Kingspor, diseñada en 1926 por Rudolf Koch nos sirve como referencia en los remates, de ahí que se use un trazo punteado para diferenciarla. Sin embargo no podemos tomarla en cuenta en la evolución de los tipos debido a que su uso no derivó de una evolución lógica del diseño, sino de los intereses de exaltación nacional propios de los periodos bélicos.
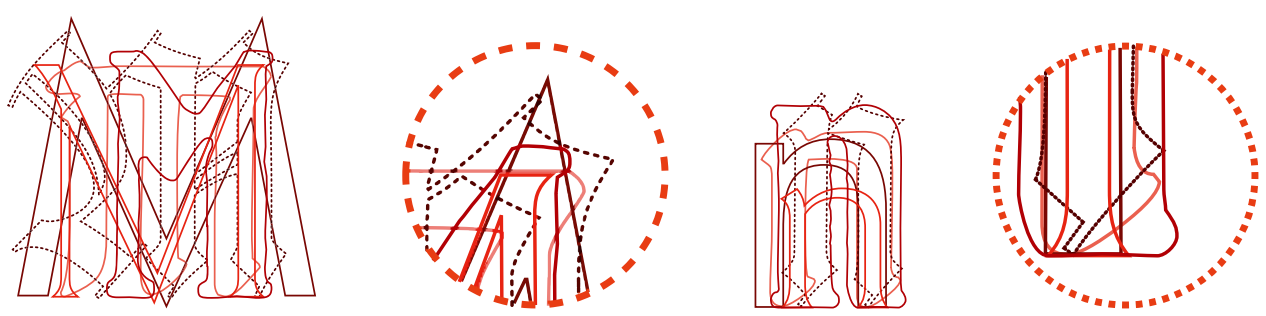

Gráfico 2.4

La geometrización estricta de los tipos en la que se tradujo el espíritu racionalista para la Bauhaus no puede sin embargo considerarse derivado una evolución racional de los tipos, ya que como podemos observar en el siguiente gráfico supone un momento puntual, que sería abandonado poco después en pos de una mayor legibilidad.
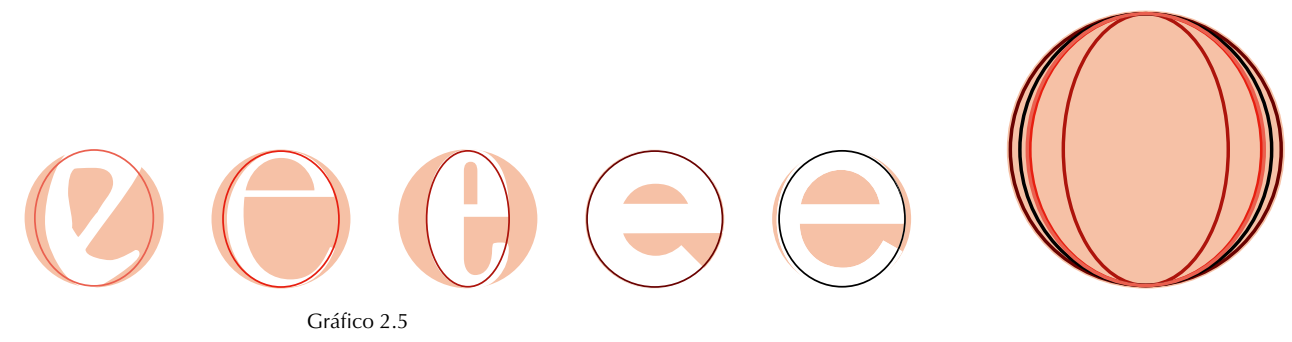

2.2.3. Evolución de la imagen

Lo complejo del concepto de imagen dificulta una comparación análoga a la realizada para la composición y la tipografía, por lo que hemos optado por reducir el análisis a cuatro variables. La gradación de todas ellas oscila entre la abstracción y el figuratismo de la imagen, estableciendo en cada uno de ellos a su vez 4 niveles:

-Simplificación; entendiendo como tal una reducción de los elementos que componen la imagen, de tal modo que a mayor simplificación, mayor abstracción

Geometrización; que se traduce en una esquematización geométrica de las formas, lo que supone que a mayo geometrización, menor figuratismo.

Color; establecido en niveles según el número de ellos, desde el uso del blanco y negro, al uso de toda la gama cromática, pasando por la tricromía característica de ciertos periodos.

Iconicidad; es decir, la semejanza entre la realidad y la imagen representada, lo que supone que a mayor iconicidad tenga esta, más figurativa será.
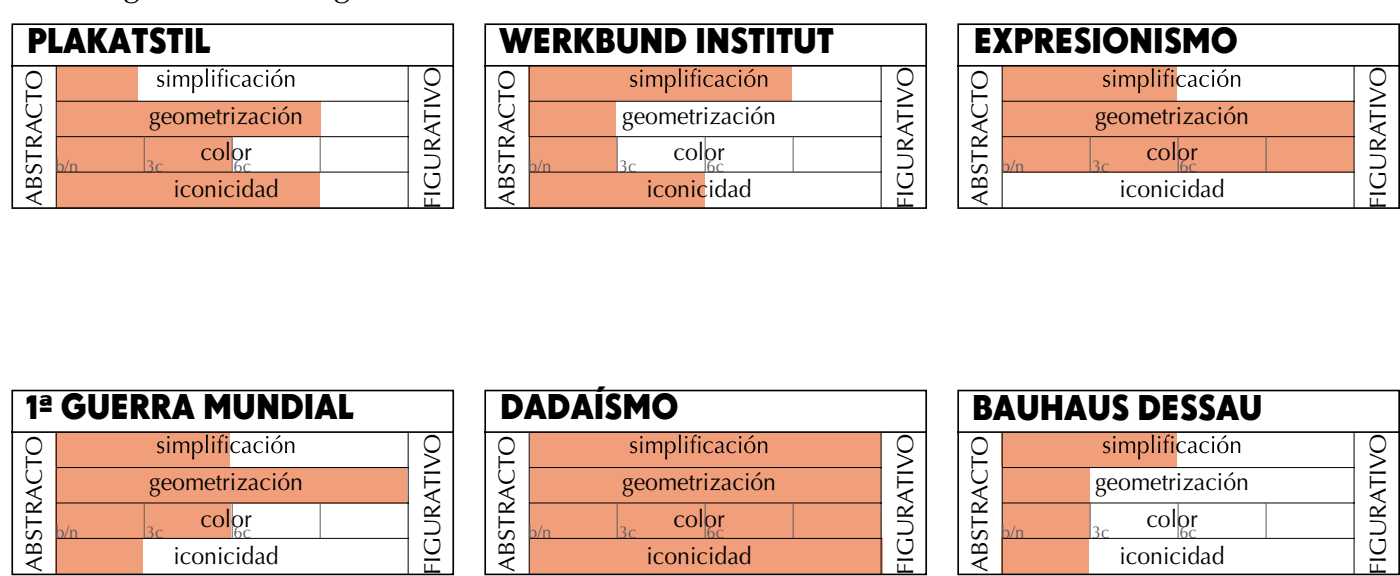

\section{DADAISMO}

\begin{tabular}{ll}
\hline & simplificación \\
\cline { 2 - 3 } & geometrización \\
\hline
\end{tabular}

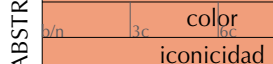

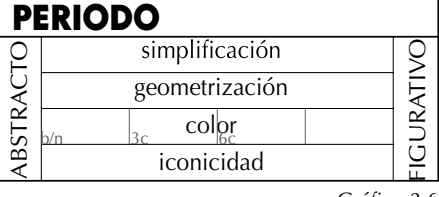

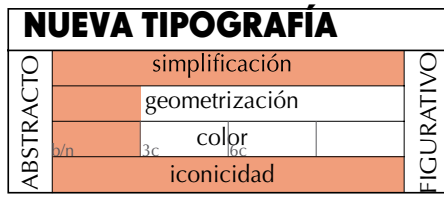

BAUHAUS BERLIN

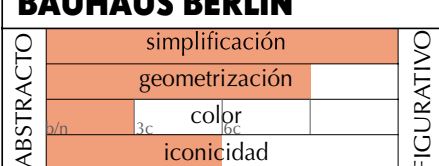

2a GUERRA MUNDIAL

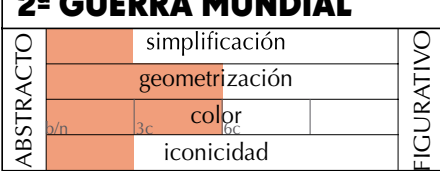



parte de los periodos analizados. La simplificación, tanto de formas como de color, se puede considerar una cualidad común a lo largo de la primera mitad de siglo XX en Alemania, especialmente en el uso del color, donde la tricromía y los colores planos son un recurso continuo a lo largo de todo este periodo.
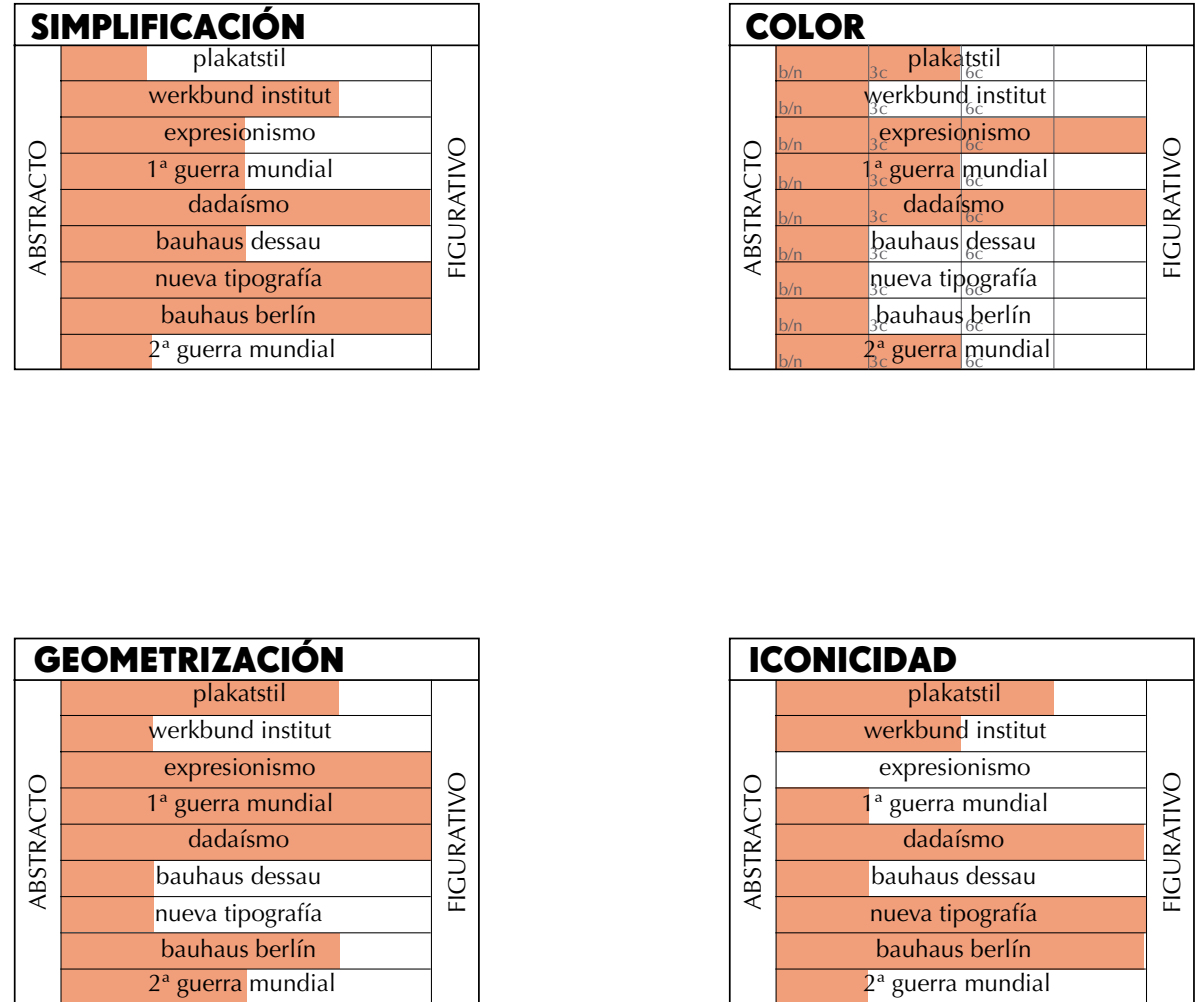

Gráfico 2.8

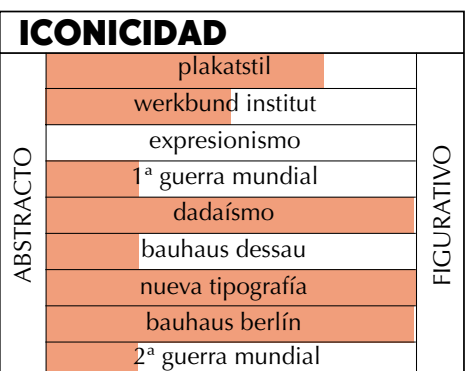

\subsubsection{Conclusiones}

A modo de sinopsis realizaremos unos gráficos que nos permiten tener una visión global del diseño de la primera mitad del siglo XX en Alemania. La información de estos gráficos deriva directamente de lo expuesto en el presente capítulo, por lo que su función es meramente sintética, de tal modo que sirva de referencia para la redacción y elaboración de la investigación por su utilidad para establecer relaciones con la evolución del diseño gráfico en la SBZ/RDA.

El primero de ellos sintetiza los rasgos de cada estilo siguiendo el siguiente esquema sin establecer comparaciones entre ellos:

ESTILO / MOVIMIENTO
\begin{tabular}{|l|l|}
\hline$\cdot$ Aportaciones al desarrollo del diseño gráfico \\
\hline Composición & \\
\hline Tipografía & \\
\hline Imagen & \\
\hline
\end{tabular}

Los gráficos relativos a composición, tipografía e imagen ponen en relación unos estilos con otros. El eje vertical establece un desarrollo cronológico y el horizontal uno cualitativo según el concepto descrito. Mediante estos gráficos podemos comprender las tendencias en la evolución del diseño gráfico alemán (representadas por líneas discontinuas), así como las relaciones y características comunes de cada estilo (asociados mediante óvalos).

Tanto el cuadro como el gráfico se completan con un eje histórico que nos permite relacionar los distintos acontecimientos con las tendencias en el diseño, evidenciando a la influencia de éstos en el desarrollo del diseño.

Quedan así definidos los antecedentes en el plano del diseño gráfico del que se partirán tras la creación de la RDA, los movimientos y las tendencias que se experimentaron en los años previos a la Segunda Guerra Mundial en Alemania. 


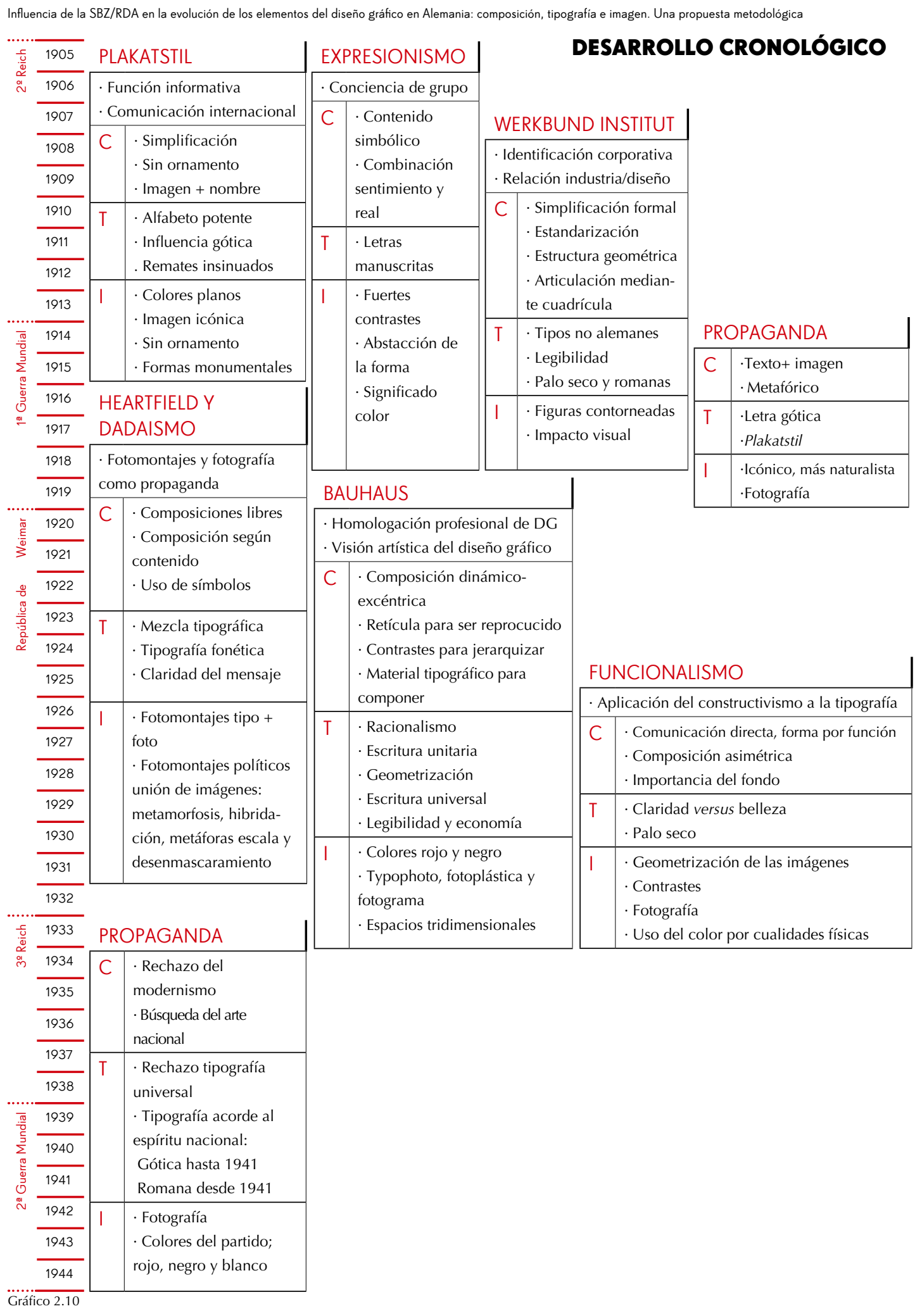

\section{COMPOSICIÓN}

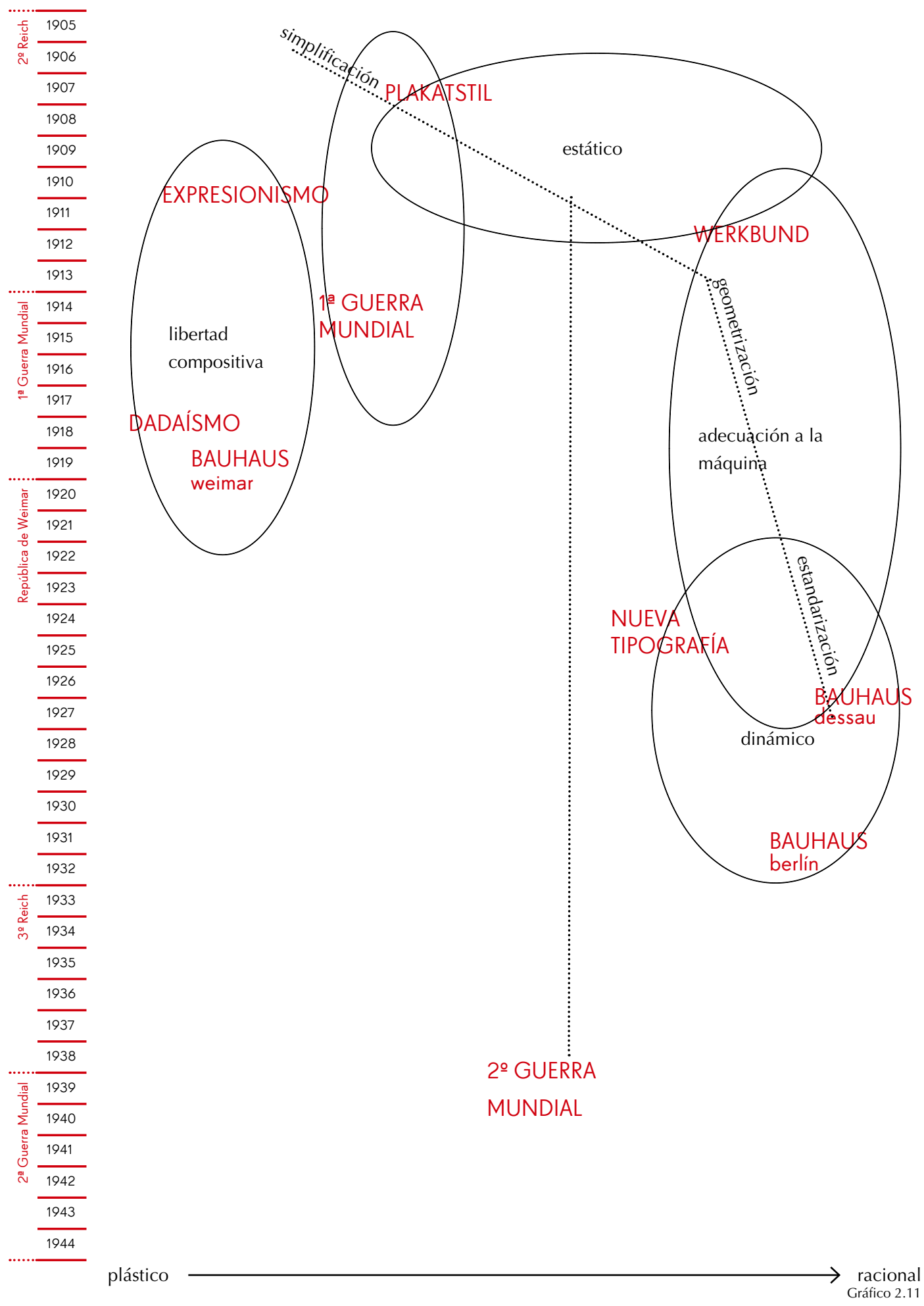




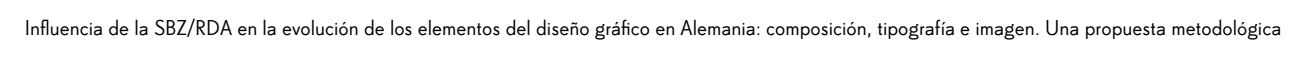

\section{TIPOGRAFÍA}

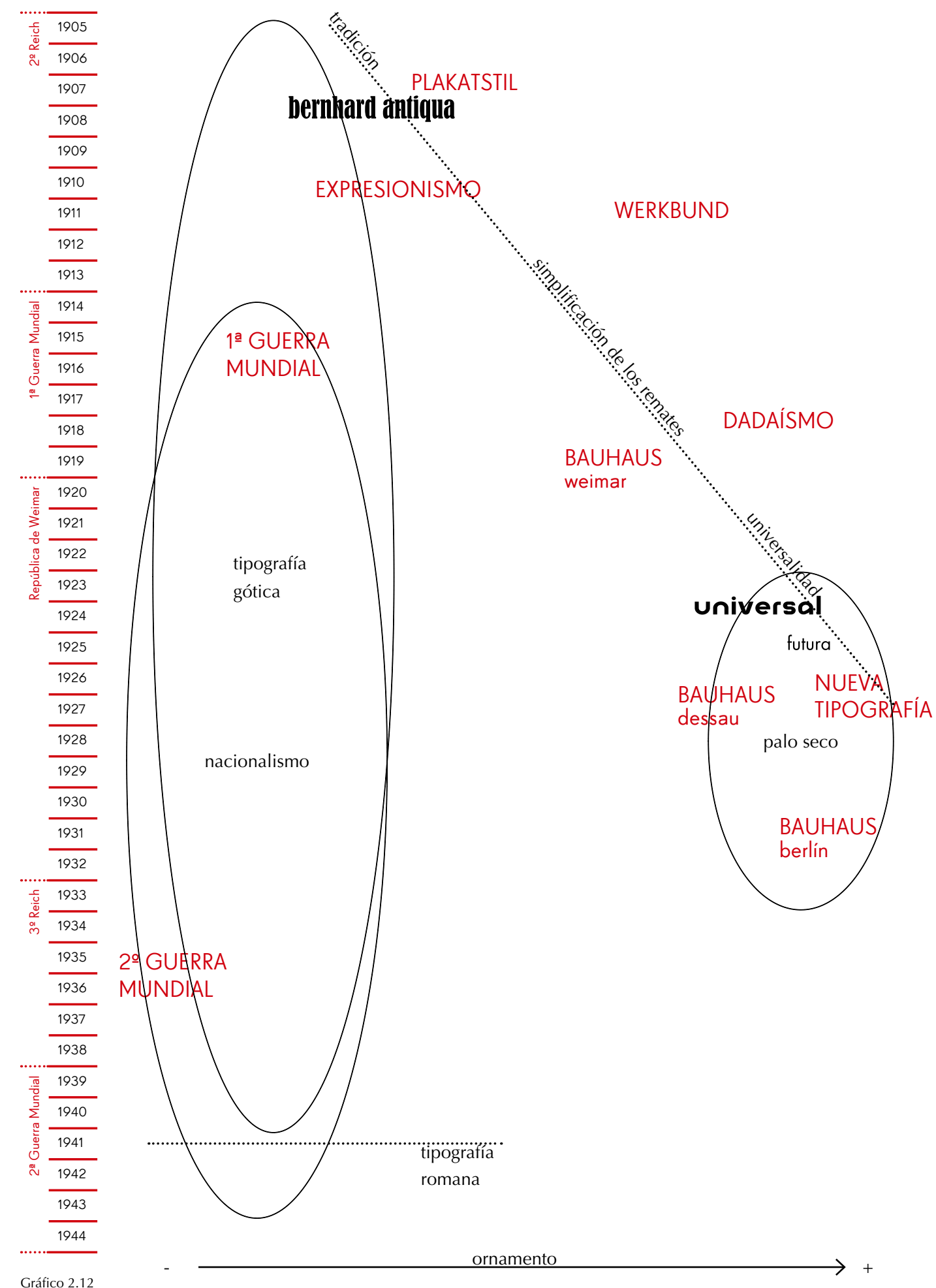

IMAGEN

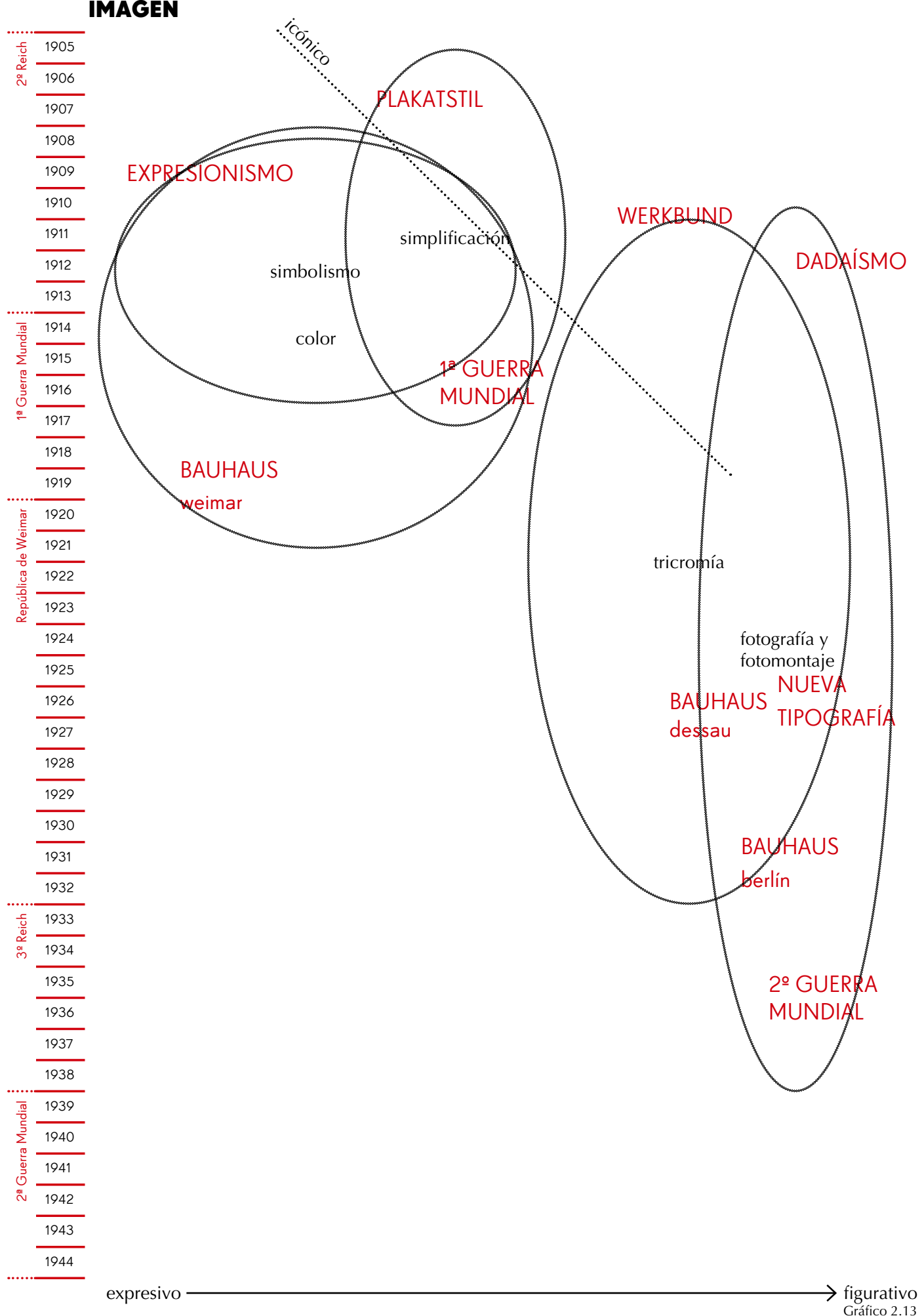


TERCERA PARTE 
3. Contexto socio-político

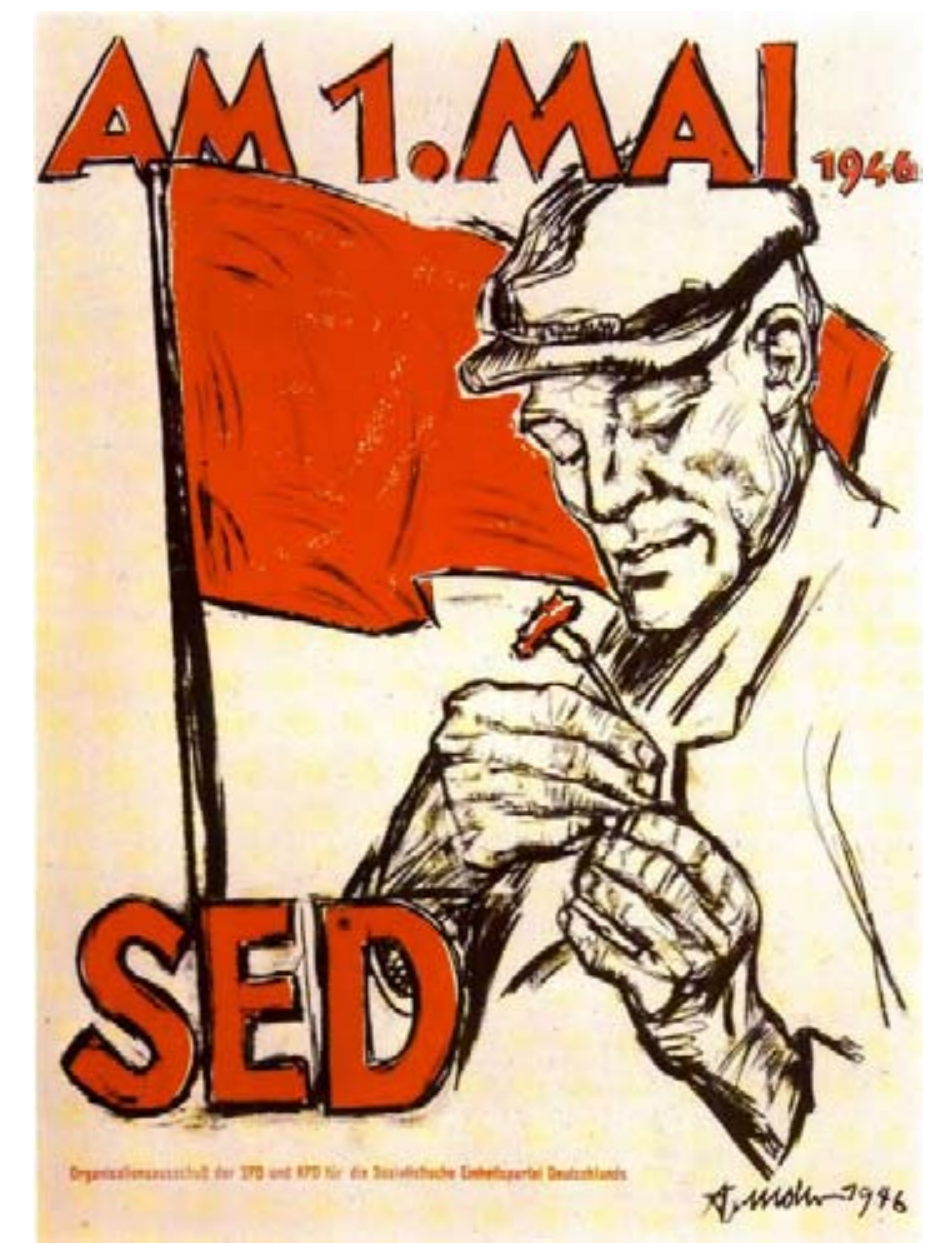


Toda expresión artística debe ser observada dentro de su contexto para poder ser entendida. Este es sin duda el caso del diseño gráfico ${ }^{10}$, y aún más cuando, como es el caso de diseño realizado en la República Democrática Alemana, es el propio gobierno el responsable del mismo, tanto sea por el control ejercido sobre el mismo como por ser el promotor del diseño, mediante la propaganda y la socialización de las empresas.

El objetivo de este capítulo será pues establecer el ámbito histórico, social, político, económico y cultural de los 40 años de gobierno de la RDA, definiendo unas características y periodos claros en los que poder enclavar el diseño gráfico realizado en cada uno de ellos.

\subsection{CONTEXTO HISTÓRICO}

En los años 70, bajo la dirección de Erich Honecker, la RDA vivió una época de exaltación de su propia identidad como estado, poniendo un gran énfasis en su propia historia y en sus figuras. Personajes como Ernst Thälmann, político comunista fusilado por el régimen nazi, serían objeto de numerosos monumentos, obras literarias, películas y por supuesto, carteles.

Si bien no es objeto de esta investigación un análisis detallado de todas las figuras y hechos que acaecieron en sus años de existencia, sí que se pretende definir el marco histórico del mismo, resaltando los hechos más importantes, ya que esto nos permitirá conocer la influencia que tuvieron sobre el diseño gráfico.

\subsubsection{Desarrollo de la RDA}

El 8 de mayo de 1945 Alemania firma la Capitulación de la Segunda Guerra Mundial. Tras la firma, las grandes potencias se encuentran en las conferencias de Teherán y Malta para decidir el trato al Estado alemán, convencidos de la importancia de establecer un control militar sobre Alemania. En la Conferencia de Potsdam celebrada en agosto de 1945 se definen las fronteras territoriales de Alemania y sus políticas de ocupación. Según la profesora Hope M. Harrison (1993) «aunque las zonas de ocupación en Alemania estaban en manos de funcionarios de cuatro países diferentes, se esperaba aplicar políticas similares en sus respectivas regiones para fomentar las condiciones uniformes en toda Alemania». 
Posteriormente los territorios del área occidental se convertirían en la Trizona, administrada por EE UU, Gran Bretaña y Francia, y el área oriental pasaría a formar parte de la Sowjetischen Besatzungszone (Zona de Ocupación Soviética, SBZ). Con esta división, el diseño gráfico alemán, que hasta el momento había gozado de una notable unidad, evolucionaría de forma independiente a ambos lados de la frontera, creándose una diferenciación entre los diseños occidentales y los orientales. Para la administración de Alemania bajo la SBZ se crearía la Sowjetische Militäradministration in Deutschland (Administración Militar Soviética en Alemania, SMAD). Bajo la dirección de la SMAD, los partidos políticos existentes se vieron obligados a unificarse en un único partido político, el Sozialistischen Einheitspartei Deutschlands (Partido unitario Socialista Alemán, SED).

A medida que pasaba el tiempo los estados de la Trizona, especialmente americanos e ingleses, fueron conscientes de

11.In the wake of the communist coup in Czechoslovakia in February 1948, the Western Allies decided Germany democratic, capitalist. and therefore safeguarded against communism. Accordingly, they chose to extend Marshall Plan aid to Germany and Berlin, fully aware that this was in violation of the WWII Potsdam Agreements, which stipulated that all zones of Germany and Berlin must be treated equally. In order to make the economic aid useful, they also announced that they would reform the old, weakly valued currency, the Reichsmark, and replace it with the Deutschmark. Finally, they called for the formation of a sovereign and united Wes German government.
Finalmente el gobierno de Alemania Occidental entraría en vigor el 24 de mayo de 1949 bajo el nombre de República Federal Alemana, RFA. Como reacción a la creación de la RFA, la URRS sustituirá el 7 de Octubre de 1949 la SMAD por la Sowjetische Kontrollkommission (Comisión de Control Soviético, SKK) que pasará la administración al régimen de la República Democrática Alemana. La RDA con capital en la zona oriental de Berlín, tendrá como primer presidente a Wilheim Pieck. Estos primeros años tras la división de Alemania serían años de gran actividad propagandísitica en la RDA con la creación numerosos carteles denunciando la ocupación de Alemania por parte de las potencias occidentales.

Dentro de este marco de tensiones entre los Bloques Oriental y Occidental, la URRS buscaba dejar una puerta abierta a una potencial Alemania reunificada, por lo que en los primeros años la RDA no se propuso como un estado socialista. Sin embargo, el rechazo por parte de las potencias occidentales a la "Nota de Stalin», en 1952, en la que se proponía la reunificación alemana y el retiro de las potencias de ocupación, supuso un cambio de actitud. Hermann Weber (1985: 213) relata cómo:

«La integración de la RDA en el Bloque del Este debía consumarse ante todo mediante amplios cambios estructurales y a semejanza del sistema en las otras Democracias Populares (a imagen del modelo de la URRS). La señal para ello en la RDA la dio la II Asamblea de partido del SED del 9 al 12 de julio de 1952 con el lema "Construcción del socialismo».

Efectivamente, en su artículo primero la Constitución de 1949 no establecía relación alguna al socialismo, sino que rezaba «Alemania es una república democrática indivisible, se compone de los estados alemanes» (RDA, 1949) pero en opinión de Wilheim Bleek (2009):

«(...) en realidad el camino para el establecimiento de un sistema política y económicamente independiente, siguiendo e ejemplo soviético -al igual que en el lado occidental según el ejemplo de los aliados del Oeste- había sido establecido hacía bastante tiempo».

Walter Ulbricht, desde 1950 secretario general del SED será el responsable de la adecuación del sistema político y económico al sistema soviético al establecerlo como programa. A partir de este momento

"La RDA cogió el tren de una sociedad socialista, no solamente desde un punto de vista de legalidad política, sino también en cualificaciones de formación, de trabajo y con ello estableció estados sociales. Ciertos perfiles, como los económicos y los técnicos, ascendían en los cargos políticos. Constitucionalmen-

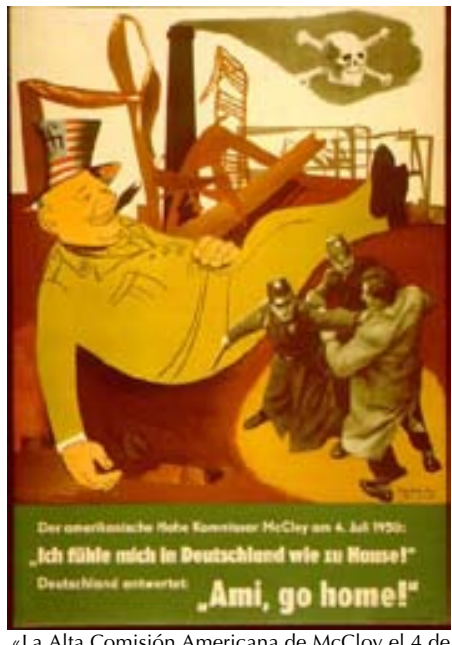

julio de 1950:
iEn Alemania me siento como en casa!
Alemania responde: SCHAW, Graetz (1950) 

der nicht mehr nur politische Rechtg/äubigkeit, sondern auch fachliche Qualifikationen über berufliche und damit gesellschaftliche Stellung entschied. Fachleute, wie Ökonomen und Techniker, rückten in politische Führungsstellungen auf. Verfassungsrechtlich festgeschrieben wurden die gesellschaftlichen und wirtschattlichen Veränderungen 1968 in einer neuen, der zweiten Verfassung der DDR. Auf organisatorischem Gebiet trug sie dem einschneidenden staatsrechtlichen Wandel seit 1949 Rechnung, fixierte die politische Dominanz der SED, die Allgemeingültigkeit des Marxismu Leninismus als herrschender Ideologie und die staatliche Führungsrolle des Staatsrates. (Bleek, 2009) te se fijarían estos cambios sociales y económicos, en 1968, en una segunda Constitución de la RDA. En el terreno organizativo se consideraron varios cambios estatales desde la de 1949, se fijó el dominio político del SED, la generalidad (universalidad) del marxismo-leninismo como ideología dominante y el rol de guía del estado del consejo de estado» ${ }^{12}$ (Bleek, 2009).

Desde este momento la RDA se reconoce como estado socialista, y esto pasa a ser un elemento clave del diseño gráfico, tanto del político, cuyos carteles recordaban insistentemente la componente socialista y marxista del estado, como los que no lo eran, con veladas alusiones y simbolismos.

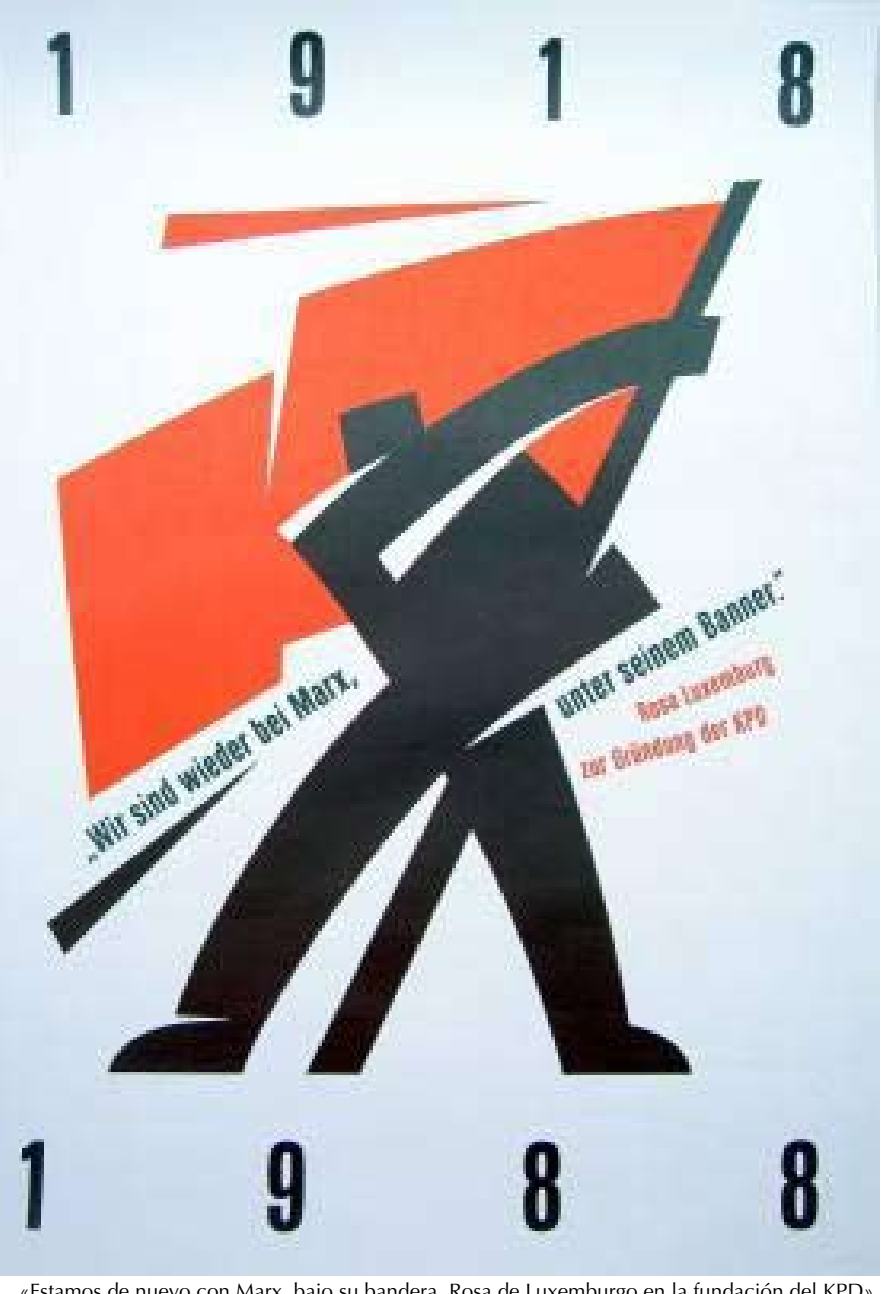

VEB orange (1988).
En virtud de la «Construcción del socialismo» se aprueba la Ley de Demokratisierung des Aufbaus un der Arbeitsweise der staatlichen Organe (Democratización de la Estructura y el Funcionamiento de los Órganos del Estado), según la cual las antiguas provincias se dividieron en distritos, todos ellos de similar tamaño e importancia, en su búsqueda de una gestión más eficiente. Se creará el Ministerium für Staatssicherheit (Ministerio de Seguridad Estatal, MfS), más conocido como Stasi para la vigilancia de los ciudadanos de la RDA y en especial de los disidentes.

Otra consecuencia importante del rechazo a la «Nota de Stalin» y de la creación de unas fuerzas armadas en la RFA será la creación de una zona de exclusión de $5 \mathrm{~km}$ a lo largo de la línea de demarcación de la RDA con la RFA. La imposibilidad de atravesar la frontera por este punto supuso que Berlín se convirtiera en la única vía de escape para aquellos ciudadanos que querían abandonar el país, por lo que ya en 1953 Ulbricht se mostró partidario de la construcción de un muro de separación entre Berlín Oriental y Berlín Occidental.

Desde Moscú se oponían a esta solución aludiendo dificultades técnicas y psicológicas sobre la población, y a que el «cierre de la frontera también daría a las potencias occidentales una herramienta de propaganda contra los comunistas y daría lugar a un enfriamiento de las relaciones Este-Oeste, que los soviéticos -pese a su retórica- trataban de evitar» (Harrison, 1993), alentándoles a moderar su política comunista con el fin de hacerla más atractiva a su población para que permanecieran en la RDA. El entonces dirigente de la URRS, Nikita Khrushchov proponía a Berlín Oriental como estandarte y escaparate del comunismo, al tiempo que intentaba convencer a las potencias aliadas de liberar Berlín Occidental. También desde el Politburó se instaba al gobierno a tomar medidas para mejorar las condiciones de vida de sus ciudadanos. Obviando estas recomendaciones, la decisión que se tomará en Junio de 1953 será la de aumentar los estándares de regulación del trabajo $^{13}$ siguiendo el modelo del «Nuevo Rumbo» soviético.

Este aumento en la producción fue tan exigente que los obreros de la Stalinallee ${ }^{14}$, unos 10.000 , se congregaron ante la casa del ministerio en la Leipzigerstraße para exigir negociaciones con el estado. "El ministro de Industria Fritz Selbmann, el único de la dirección del SED que tuvo el valor de dirigirse a los trabajadores y hablarles, fue abucheado. La masa sin jefe, ansiaba la dimisión del gobierno, de la marcha de protesta surgiría un levantamiento»
13. El aumento en los estándares de la regulación de empleo suponían un aumento en la XIII Reunión del Comité Centrat del SED, celebrada el 13 de mayo de 1953, se estableció un aumento en la producción de un $10 \%$

14. La Stalinallee, hoy KarlMarx-Allee, se concibió como estandarte del socialismo en agradecimiento a Stalin "por liberar a Alemania de Hitler". En la nueva avenida se construyeron numerosos edificios que debían establecer los símbolos del futuro con su arquitectura monumenta convirtiéndolo en uno de los proyectos más importantes de RDA con abundante decoración RDA, con abundante decoración hasta las citas políticas los relieves se decoraron las fachadas. 
(Weber, 1985: 239). El 17 de junio de 1953 los tanques soviéticos aplacaron las revueltas. Se estableció el estado de excepción y se prohibieron las manifestaciones y las reuniones. Como consecuencia, para evitar futuras revueltas, se llevaron presas a cientos de personas con fuertes represalias. Tal y como señala Fritsche (2008: 24) «la gente estaba horrorizada de que el gobierno hubiera atacado a su propia población con tanques soviéticos». La rebelión fracasó. El número de víctimas de los levantamientos son aún desconocidos, 23 según el SED -más de 360 según otras fuentes- practicándose alrededor de 5000 detenciones, 20 de los cuales fueron condenados a muerte.

Según múltiples autores, la desproporción y autoridad con la que se aplacaron los levantamientos de 1953 fueron claves para entender la sumisión con la que la población de la RDA aceptó el levantamiento del «Muro antifascista», en agosto de 1961. El número de exilios que se habían producido en 1953 era de 331.390 personas, muchos de ellos gente joven, científicos y técnicos. El número de huidos totales el 13 de agosto de 1961 era de 2.691.270 según los datos del Bundesministerium für Gesamtdeutsche Fragen de Bonn (Ministerio para la Cuestión de la Unidad Alemana de Bonn). Esta situación preocupaba a la dirección del gobierno, encabezada desde 1960 por Walter Ulbricht, quien tomó decisiones.

La frontera que separaba los dos estados alemanes había sido vigilada desde 1946 para impedir el tráfico ilegal de personas y mercancías, pero podía ser atravesada diariamente por asuntos familiares o de trabajo, especialmente en Berlín, dónde un amplio número de personas vivían y trabajaban en lados diferentes de esta. La frontera se cerró oficialmente como "protección antifascista», sin aviso previo, la noche del 12 al 13 de agosto de 1961, pese a las palabras de Ulbricht en la conferencia de prensa del 15 de junio, en las que afirmaba que «nadie tiene la intención de construir un muro». Las contínuas negativas de las potencias aliadas a liberar Berlín Occidental, mientras no hubiera elecciones libres en la RDA, Ilevaron a Khrushchov a ceder finalmente a la construcción del Muro.

Sin embargo, en opinión de Fritsche (2008: 24):

«(...) no toda la población criticó la construcción del Muro. Aquellos que vivían en el Este pero trabajaban en el Oeste tenían un mayor poder adquisitivo que los que los trabajadores de Berlín Este. Es por eso que algunos vieron la construcción del Muro justa».
Estas opiniones habían sido fomentadas desde el gobierno del SED, ya que tal y como relata Weber (1985: 322):

«Los nuevos jefes en materia económica hicieron a los Grenzgänger ${ }^{15}$ responsables de la miseria, para dirigir la cóler de la población hacia ese círculo. Los 53.000 habitantes de Berlín Este y alrededores, que aún trabajaban en Berlín Oeste recibirían represalias. El SED consideraba que los Grenzgänger suponían una pérdida de producción anual de millones».

Inmediatamente tras la construcción del Muro de Berlín la RDA se hizo dependiente de las importaciones masivas de productos de primera necesidad de la Unión Soviética para garantizar su abastecimiento a la población. Lentamente la situación a mediados de los años sesenta fue mejorando, e abastecimiento se estabilizó y las familias tuvieron acceso a mayores bienes de consumo, como aparatos de televisión o neveras, incluso se introdujo la semana laboral de 5 días. Según Stefan Wolle (1999: 40) «muchos ciudadanos de entonces RDA Ilamaron a los años 60 si no la edad de oro al menos un tiempo de resurgimiento, un nuevo comienzo con muchas esperanzas». Después de grandes esfuerzos se comenzaban a notar los efectos positivos en la calidad de vida y eso se trasladó a los carteles y a la propaganda, que proclamaban el éxito del sistema.

En conjunto, política y socialmente, los años 60 fueron años de relativa estabilidad en los que el nivel de vida de los ciudadanos de la RDA se incrementaría notablemente. No en vano, según alega Bleek (2009) «con el fin de un éxito económico indiscutible, Ulbricht propagaba a final de los años 60 el «modelo RDA» como ejemplo de todas las sociedades socialistas desarrolladas industrializadas, y entraría con ello en conflicto ideológico con el KPdSU ${ }^{16}$ ». El propio Ulbricht (1968, citado en Weber 1985: 393) afirmaría que:

uel sistema económico del socialismo en la RDA es, desde una perspectiva histórica, el empleo íntegro de una sociedad altamente industrializada en la prioridad interna y fuerza motriz de los conocimientos de la producción y de la dinámica de la revolución científico-técnica».

Sin embargo, el invierno de 1969 fue extremadamente frío y tuvo al país bajo la nieve durante varios meses, lo que supuso que el abastecimiento a la población se viera fuertemente afectado. El carbón se terminó y el final de año sorprendió a las ciudades sin luz. Tal y como relata Weber (1985: 402):

«(...) así entró la RDA en los años 70 con grandes problemas. No habían conseguido en los años 60 llegar a alcanzar los niveles de vida de la RFA más bien había aumentado el descontento de la RDA, dada la distancia entre los dos estados alemanes».
15. Por Grenzgänger se entendía a aquellas personas que cruzaban diariamente la frontera por motivos de trabajo

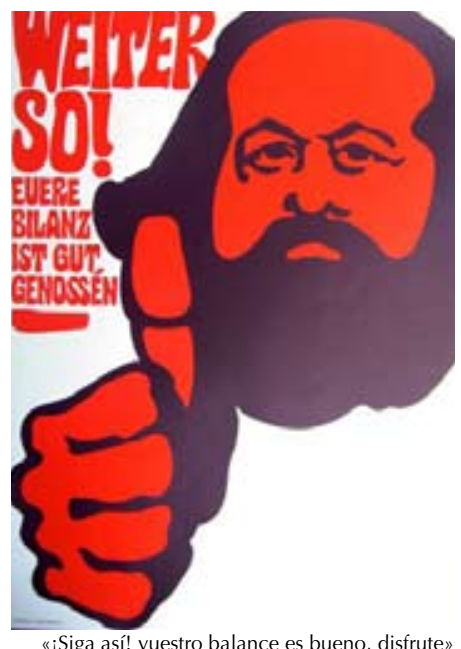

EEB orange.(desc.e)

16. KPdSU. Kommunistische Partei der Sowjetunion. Partido comunista de la Unión Soviética 
Este era el panorama cuando el Politburó del Comité Central del SED se reunió para analizar la marcha de la primera mitad de año de 1970 . Se analizaba la estructura política interna y los planes económicos. Willi Stoph, presidente del Consejo de Ministros, señaló los problemas con el abastecimiento de carbón y reclamó una subida de la producción de los bienes de consumo para el abastecimiento de la población, así como una estabilidad en los precios de los bienes de consumo. Durante el verano de 1970 se sucederían las críticas a Ulbricht, que terminarían con su cese en el cargo de primer Secretario el, 3 de mayo de 1971, en favor de Erich Honecker.

El cambio de la Secretaría del Partido del Ulbricht a Erich Honecker sería considerado por los observadores del Oeste como un cambio positivo, si bien autores como Wolle (1999: 62) afirman que «a Honecker le faltaba todo lo que distingue a un hombre de estado. Incluso en los fuertemente retocados y coloreados retratos que decoraron todos los despachos administrativos de la RDA aparecía reprimido e inseguro».

No obstante, tanto en el Este como en el Oeste se decidió dar una oportunidad al nuevo Jefe de Gobierno. En su discurso inaugural, este defendió que:

«El deber fundamental se basa en una continua mejora del nivel de vida material y cultural de la población sobre la base de una alta velocidad de desarrollo de la producción socialista, de la mejora de la productividad, del progreso científico y técnico y del crecimiento de la productividad en el trabajo ${ }^{17}$ (Honecker, 1986, citado en Wolle, 1999: 61).

Y efectivamente supuso un cambio sustancial en la vida diaria de los ciudadanos; productos hasta el momento prohibidos como la música «beat» o los jeans, se introdujeron en la RDA. No obstante, la reivindicación de una moda socialista, en contraste con la moda occidental, considerada símbolo del capitalismo y de la decadencia, eran una tónica habitual de la política del SED y se trasladaban al diseño gráfico por su rápida asociación con el sistema que representaban. Esta apertura se realizaba en ocasiones de forma tangencial; la televisión de la RFA, o las divisas de marcos alemanes, no estaban directamente permitidas, pero tampoco directamente prohibidas.

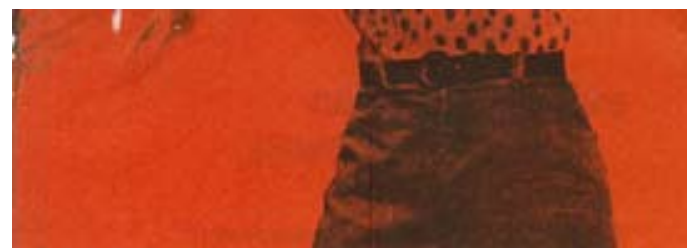

\section{ALLES HAT SEINE GRENZEN}

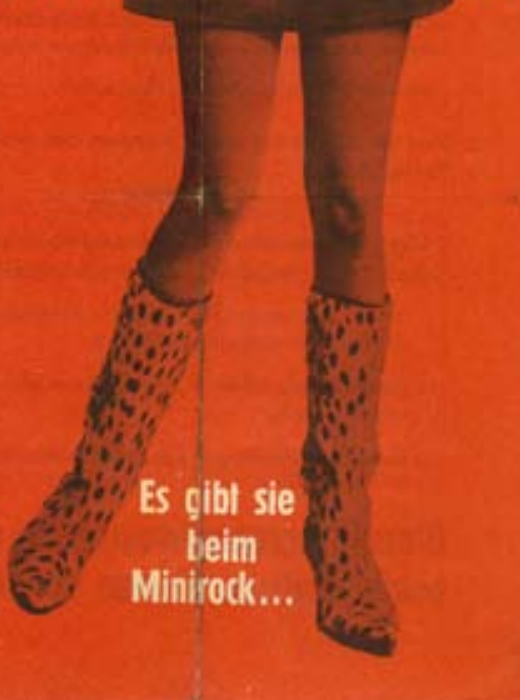

A un nivel político, el principio que reinaba en la sucesión era el principio de continuidad. Tal y como refier Bleek (2009),

«(...) no supuso ninguna ocupación dramática en los cargos de dirección, no obstante, la influencia de los tecnócratas sería
rechazada. Los principios de la política sobre técnica y la ideología sobre la ciencia serían inequívocamente restablecidos. E partido y la dirección de estado conjuraron la eterna amistad con el KPdSU y la URRS ${ }^{18}$

Las correcciones de rumbo a la política de Ulbricht supusieron incluso la modificación en 1974 de la Constitución de 1968

Bajo la dirección de Honecker se sucedería una nueva ola de militarización de la sociedad, en especial dentro del sistema educativo, desde la guardería a la universidad. Podríamos resumir que la era Honecker se caracterizaría por un lado, por las luchas contra el capitalismo y el incremento de la vigilancia revolucionaria y, por otro, por una distensión política en el ámbito de la vida diaria. Si bien en este periodo los estándares de vida seguían por debajo de la RFA, eran con mucho los más altos del Bloque del Este. Hay que reseñar que la política de Honecker buscaba la legitimación del sistema mediante la política de consumo y

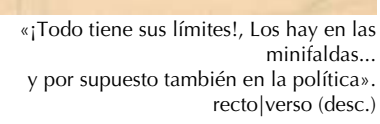

18. (...) es kam zu keinen dramatischen Umbesetzungen in den Fuhrungsgremien, der Einfluss zurückgedrängt. Der Primatoch Politik gegenüber der Technik und der loologie gegenüber Wissenschaft wurde eindeutio wiederhergestellt. Die Partei- und Staatsführung beschwor die "ewige Freundschaft" mit der KPdSU und der UdSSR. 
social. Tal y como relata Bleek (2009) «el éxito, es decir, la prevención del fracaso en los campos de política económica y social tenían un inmenso significado para la estabilidad del Régimen, que necesitaba el directo consentimiento de los ciudadanos».

La política establecida en los años 80 buscaba situar a la RDA no solo a la cabeza de los países comunistas, sino a escala mundial. «Esta ambición se sobrexigía bajo las condiciones de una recesión económica a escala mundial y a la vista de los limitados recursos del rígido sistema de planeamiento de la RDA. Los agujeros debieron ser tapados mediante créditos millonarios de la Alemania del Oeste ${ }^{19}$ (Bleek, 2009) y esto supuso el desmoronamiento de la estabilidad del régimen. Las reformas realizadas por Gorbachov con la Perestroika y el Glasnost, pusieron al régimen del SED bajo una mayor presión. La represión cultural se incrementó fuertemente, al tiempo que crecía el descontento entre la población.

7 de octubre de 1989 se celebraron las manifestaciones por el 40 aniversario de la fundación de la RDA, a las que sucedieron numerosas manifestaciones en varias ciudades alemanas contra el régimen y exigiendo elecciones libres. La más numerosa, la de Leipzig, con cerca de 70.000 manifestantes que gritaban «Wir sind das Volk» («Nosotros somos el pueblo»), no fue intervenida por la policía, y es que tal y como alega Sánchez León (1989) «a diferencia de lo que ocurrió en 1953 en Berlín-Este, o en 1956 en Budapest o 1968 en Praga, las tropas soviéticas y del Pacto de Varsovia no se atrevieron a aplastar el otoño germanoOriental de 1989 para no poner en peligro la credibilidad internacional de la Perestroika soviética». Al no ser intervenidos por la policía el número de protestas aumentó. Los manifestantes portaban retratos de Gorbachov y consignas a favor de la Perestroika y en contra del régimen de Honecker. Como consecuencia, unos días más tarde, el 18 de octubre, el comité central del SED decidía la dimisión de Honecker y proponía como nuevo secretario general a Egon Krenz.

Bajo las órdenes de Egon Krenz las protestas continuaron, teniendo lugar el 4 de octubre en Berlín la manifestación más numerosa de la historia de la RDA con cerca de 1 millón de personas exigiendo democracia y elecciones libres.

El 11 de octubre Hungría abrió sus fronteras con Austria, permitiendo que numerosos ciudadanos abandonaran la RDA por esta vía. Ante tales acontecimientos el Ministerio del Interior decide dar la orden de redactar una «una normativa de viajes que debía permitir salir legalmente a los ciudadanos que querían abandonar el país de forma permanente y que hasta la fecha lo estaban haciendo a través de los países vecinos, hermanos socialistas» (Martí Font, 2009: 10)

Esa misma noche, el 9 de noviembre, el miembro de Politburó Günther Schabowsky dará una conferencia de prensa para promulgar la nueva regulación de viajes. De ella se desprende erróneamente la opinión de que los ciudadanos del la RDA podían pasar libremente a la RFA.

En su entrevista concedida por el aniversario de la caída del Muro de Berlín, el entonces presidente de la RFA, Helmut Kohl (2009: 2) relata:

"Finalmente el Muro cayó de forma completamente pacífica, sin un tiro, sin derramamiento de sangre. Fue como un milagro. La protesta pacífica de las personas de la República Democrática Alemana (RDA) había ido cobrado impulso de forma lenta pero continuada, a lo largo de los meses; y finalmente, era ya incontenible. El obstinado régimen del Partido Socialista Unificado (SED) de la RDA, que hasta el último momento había rechazado reformas fundamentales, fracasó por la voluntad de libertad de las personas, tal como Konrad Adenauer, el prime canciller de la República Federal de Alemania (RFA), había pronosticado hacía 40 años

El 18 de abril de 1990 se celebrarán en la RDA las primeras elecciones libres, en las cuales ganará CDU con un $47 \%$ de los votos. Las manifestaciones que siguieron a la caída del Muro ya no tenían por lema «Wir sind das Volk» («Nosotros somos el pueblo»), sino «Wir sind ein Volk» («Nosotros somos un pueblo»).

La caída del Muro supuso únicamente una rendija abierta hacia la reunificación alemana, pero no había nada decidido la noche del 9 de noviembre de 1989, sino que fue necesario un largo proceso político hasta conseguir la unidad el 3 de octubre de 1990

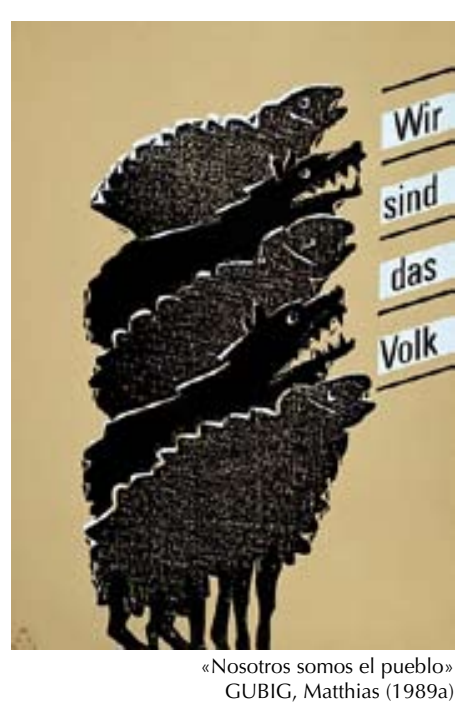




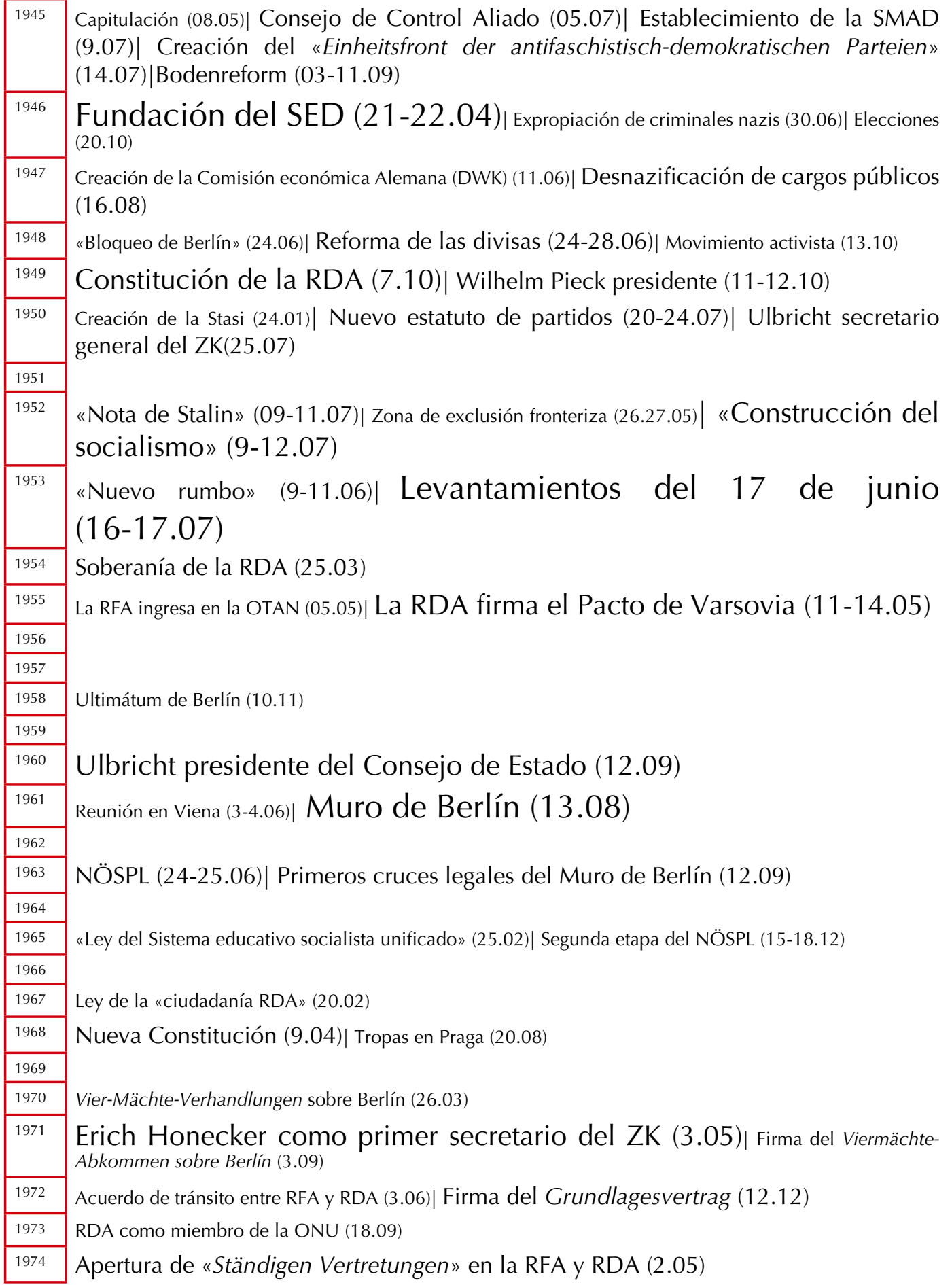

Erich Honecker secretario general del SED (18-22.05)| Honecker presidente del Consejo de Estado $(29.10)$

Reforma de la Ley de Derecho Penal (28.06)

X Asamblea del SED (11-16.04)

Crédito de 1000 millones de marcos de la RFA a la RDA (29.06

Crédito de 950 millones de marcos de la RFA a la RDA (25.07)

Gorbachov jefe de estado de la URRS (10.03)

Visita oficial de Honecker a la RFA (7-11.09)

Eliminación de fortificaciones Hungría-Austria (2.05)| Alemanes abandonan RDA por Hungría (10.09)| Manifestaciones de Leipzig (02.10)| Celebraciones del 40 aniversario RDA (6-7.10)| Manifestaciones de Leipzig (09.10)| Egon Krenz secretario general de la RDA (18.10)| Caída del Muro de Berlín (09.11)

Primeras elecciones libres (08.03)| Comienzo de las «Zwei-plus-vier Gespräche» (05.05)| Unificación monetaria (01.06)| Reunificación (31.08)

i. Estableceremos una cronología jerarquizada de los acontecimientos más relevantes que tuvieron lugar en la RDA. Para ello tendremos en cuenta las cronologías y periodos establecidos por los siguientes autores: y la cronologí e Wablecida por Die Bundesbeaftragte für die Untshe; des Statssicherheistsdienstes der ehemaligen Deutschen Demokratischen Republik (El Comisionado Federal para la Documentación del Serviciode Seguridad del Estado de la antigu República Democrática Alemana

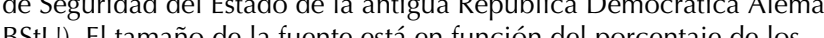


Como consecuencia del bloqueo los franceses asumieron que la amenaza soviética era superior a la alemana lo que le llevó a unirse a británicos y americanos en la Trizona al mismo tiempo que convenció a todas las potencias occidentales de la amenaza comunista, lo que desencadenó la formación de la Organización del Tratado del Atlántico Norte (OTAN) en abril de 1949.

La Guerra Fría marcó las pautas de la política internacional a principio de los años 50 y marcaría las pautas en las relaciones de la URRS con sus países satélites. La fórmula de dominio soviético que había imperado hasta el momento dejó de ser válida para la política de distensión establecida por Georgi M. Malenkov, en 1953, según la cual se:

«(...) había proclamado la fórmula de la coexistencia pacífica entre los Estados socialistas y capitalistas, principio del Nuevo Rumbo en política exterior. Esta estrategia para prevenir un conflicto armado entre las dos potencias mundiales exigía vínculos contractuales fundamentales entre los países del Comecon ${ }^{21}$. La práctica del dominio estalinista y sus instrumentos estaban desacreditados, eran un obstáculo para la distensiô por ello que ser cuidadosamente desmontados a fecha fija, pues no había que excluir el peligro de desarrollos nacionales en las democracias populares»(Robel, 1986: 377).

En opinión de Wolle (1999: 141):

«La historia muestra, que no había unas reglas establecidas en las relaciones entre el poder hegemónico y los satélites. En tres ocasiones -1953, 1956 y 1968- intervino la Unión Soviética con violencia militar, a pesar de las terribles pérdidas de prestigio internacional en las revueltas de la RDA, de los húngaros y de los checoslovacos».

En el caso de los levantamientos de 1953 la no intervención occidental se vio motivada a que los EE UU decidieron no arriesgarse a otra guerra mundial, cuestionando los soviéticos sobre Berlín Este y Alemania del Este. Según Harrison (1999) «esta fue una primera indicación de que los EE UU pretendían en gran medida mantener su propia esfera de influencia y no injerir en los asuntos de riesgo soviéticos». En un intento de justificar retrospectivamente estas incursiones, en 1968 se impondrá en todo el Bloque del Este la «Doctrina Brezhnev», según la cual todos los países miembros del Pacto de Varsovia tienen obligación de prestar ayuda militar en caso de que el orden socialista se vea amenazado por fuerzas internas o externas.

Las consecuencias más relevantes de la "política de distensión» de Malenkov sería la firma de los países de Comecon del «Tratado de amistad, cooperación y asistencia Mutua» conocido como «Pacto de Varsovia» el 14 de mayo

\section{RGW}

Kraft der Gemeinsamkeit

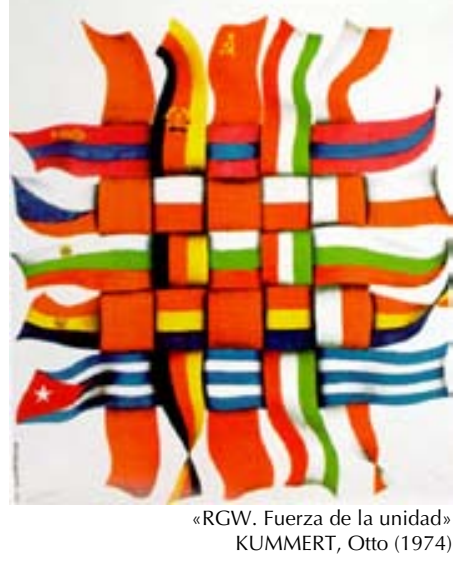

21. Consejo de Ayuda Mutua Económica. Organización de cooperación económica entre la URRS y los países socialistas para el fomento de relaciones comerciales (en 1950 integrado por Albania, Bulgaria, Checoslovaquia, Hungría, Polonia, RDA, Rumanía, URRS) 
de 1955, al que la RDA se uniría un año más tarde. En él se comprometían a la unión de fuerzas, en caso de guerra, y al estacionamiento de tropas rusas en la RDA, Checoslovaquia, Polonia y Hungría en tiempos de paz. La segunda consecuencia sería el cambio a la modalidad de «igualdad de derechos», en lo que Robel (1986: 378) define como «convertir paulatinamente a los países satélites (según el estalinismo), en países hermanos -aunque menores- y librarlos de su condición de simples receptores de órdenes».

La RDA era un caso especial dentro de los países satélites en su relación con la URRS, tal y como explica Wolle (1999, 142):

"Cada tendencia de separación traía forzosamente a la orden del día la cuestión de la unidad alemana y con ella amenazaba la constelación de fuerzas bipolar de la política mundial. La estabilidad en Alemania constituía la pierda angular de la política de relajación mundial y la RDA era la provincia de Moscú más importante, no solo como la que más exitos económicos mostraba, sino también como ejemplo en política exterior. La Alemania. (...) nada sería más falso que querer reducir las relaciones entre la RDA y la Unión Soviética a un dominio político y militar».

Debido a estos motivos, pese a la Constitución de la RDA como estado en 1949, no será hasta 1955 cuando la URRS reconozca la plena soberanía de esta. La decisión final de otorgar la plena soberanía vendría motivada, según Pieck (2009), por que «la URRS transpasó la plena soberanía a la RDA para impedir la integración política y militar de la RFA (en política exterior) por caminos diplomáticos, tras los definitivos fracasos de sus esfuerzos ( Nota de Stalin»)». Meses después permitirá la creación de unas fuerzas armadas de la RDA.

El reconocimiento de la plena soberanía de la RDA no significará, ni mucho menos, la independencia de esta con la Unión Soviética, tal y como se deriva de las reiteradas peticiones de permiso a la construcción del Muro de Berlín en los años 50 y a que este no se construyera hasta que el entonces dirigente de la URRS, Nikita Khrushchov, no cediera a ello. En Berlín Oriental no se tomaban decisiones en contra o sin tener en cuenta la opinión de Moscú. Resulta bastante elocuente a este respecto la cantidad de carteles que se produjeron en la RDA con motivos o reivindicaciones rusas, así como conmemoraciones de los sucesos más importantes de la historia de la URRS. Pero las relaciones entre ambos irían evolucionando; en una primera época de la RDA el seguimiento de la política soviética se realizaba casi de forma irracional, se consideraba a Stalin el salvador, gracias al cual se había podido derrotar al imperialismo a Hitler. Sin embargo, en 1956 Khrushchov retira su monumento y eso supone una pequeña crisis de creencia en el comunismo de todo el mundo y en la RDA una «eliminación controlada del pasado».

El proceso de destalinización comenzó oficialmente en 1956, bajo la denuncia de «culto a la personalidad» por considerarlo un exceso superficial. En opinión de Robel (1986: 367) «el totalitarismo de la ideología estalinista, es decir su afán de abarcar tanto la vida pública como la privada y de tomar las normas y las opiniones de Stalin prácticamente como la máxima encarnación de la razón (... quedó así destruido». En 1961 se sucede una segunda ola de destalinización en los países satélites soviéticos; se retiraron su retratos, sus obras se alejaron de las bibliotecas y de las revistas. La Stalinallee se convertiría en Karl-MarxAllee y Stalinstadt en Eisenhüttenstadt. Este proceso continuará hasta la destitución de Nikita Khrushchov en 1964. No obstante, en opinión de autores como Sandoz (1971: 197) «con excepción del año 1956, caracterizado por una ligera disminución de la presión sobre los intelectuales, la RDA no ha conocido nunca ni siquiera al comienzo de una verdadera destalinización» y continúa (1971: 200) «no es precisamente casualidad el que Alemania Oriental solo se haya decidido mucho tiempo después que los demás países socialistas a publicar los textos en que fueron condenados los crímenes de Stalin», cuya figura protagonizará numerosos carteles hasta bien avanzada la historia de la RDA.

El éxito económico experimentado a mediados de los años 60 supondría que Ulbricht considerara el «modelo RDA» como el modelo socialista, lo que le llevaría a entra en conflicto ideológico con el KPdSU, produciéndose un cierto alejamiento del la Unión Soviética. En ocasiones la RDA se constituía como estandarte y protección del comunismo, censurando libros y películas que estaban permitidos en la URRS. El mismo tiempo las figuras y símbolos más populares como el Sputnik, Juri Gagarin o la torre Spasskij del Kremlin con su estrella roja vendrían de la Unión Soviética.

Estos éxitos, y la larga lucha de la RDA por su reconocimiento como estado tendrían sus frutos. A finales de la Era Ulbricht, Sandoz (1971: 205) escribe:

"¿Cómo ignorar también los éxitos de indiscutibles de la RDA en otros terrenos? (...) Numerosos estados, en particular en el mundo árabe, han establecido relaciones diplomáticas con la 
RDA sin preocuparse de las severas advertencias lanzadas por Bonn. Es una evidencia, hoy reconocida y aceptada por Bonn, que la RDA existe aunque se le niegue, quizá provisionalmente, un reconocimiento explícito, de iure. Y finalmente las potencias imperialistas incluso, y en primer lugar lo Estados Unidos, reconocen a la RDA (...). La soberanía, tantas veces reclamada por la RDA, de hecho le ha sido reconocida. Es un resultado que cuenta».

En opinión de Weber (1985: 404):

«El relevo de Walter Ulbricht en mayo de 1971 supuso una profunda brecha en el desarrollo de la RDA. Bajo su nuevo Primer secretario (a partir de 1976 secretario general) Erich Honecker reconocería al SED absolutamente ligado al modelo soviético así como al rol de guía de la URRS. Esto sin embargo no suponía un retorno a la total dependencia de los años 50, sino que subordinaba a la RDA a la estrategias y tácticas generales de la Unión Soviética».

El 1 de agosto de 1975 se firmará el Acta Final de Helsinki propuesta en la Conferencia para la Seguridad y el Trabajo conjunto en Europa. Dicho acta se publicará en el periódico de la RDA y en la misma se aseguraba el derecho a entrar y salir en todos los territorios de los países firmantes entre los que se encontraba la RDA por motivos personales o laborables. «Si bien Erich Honecker firmó el Acta, esta no entró en vigor en la RDA hasta 1989, y todos los que alegaron dicho derecho en su intento de cruzar la frontera sufrieron serias consecuencias» (Fritsche, 2008: 30). Pese a la política de identidad nacional de Honecker, este abrió más líneas de comunicación con occidente que ninguno de sus predecesores. Bajo su mandato la RDA entraría en la ONU y se establecerían relaciones diplomáticas con EE UU.

En la cumbre de los países del Pacto de Varsovia celebrada en 1986, Gorbachov anunciará la política soviética de liberalización. Como hemos visto, el nuevo dirigente de la Unión Soviética comenzaría una política de transparencia Glasnost) y reestructuración económica (Perestroika) con el fin de modernizar y preservar el sistema socialista. Sin embargo estos cambios no fueron del agrado de los dirigentes del SED -quienes llegaron a bloquear la distribución de prensa soviética en la RDA- pese a que sus efectos positivos en la apertura de los países socialistas fueran evidentes, tal y como se demostró con la visita de Honecker a Francia en 1988, con la que parecía haber sido superado con éxito le largo aislamiento internacional.

Cronologia y periodos de las relaciones internacionales

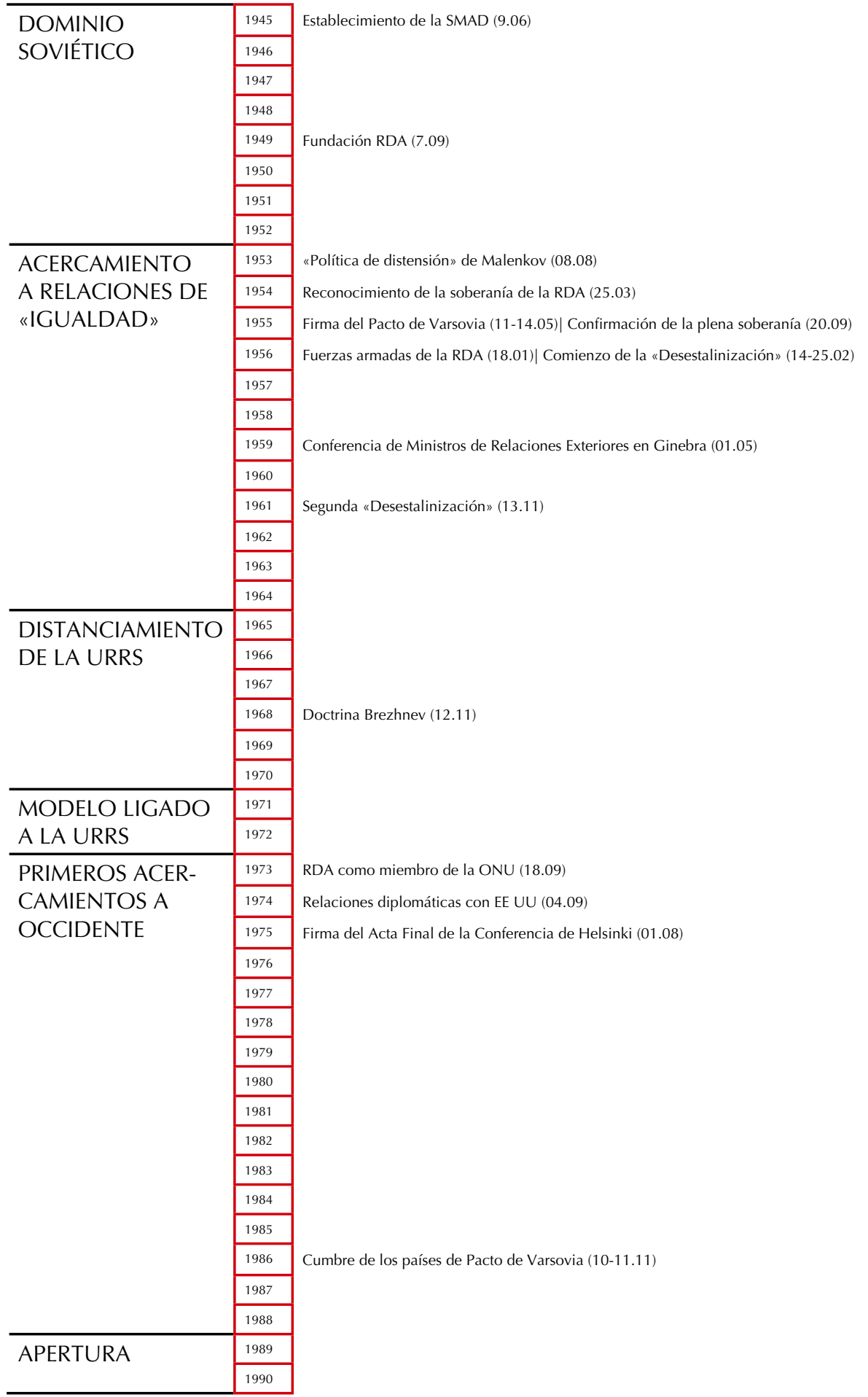


La RFA nuevamente antepondría la realización de elecciones libres en la RDA a cualquier paso de acercamiento, rechazando así la formación de una confederación.

Con la llegada al poder de Khrushchev en la URRS en lación de la Segunda Guerra Mundial supusieron la división de un país con una larga historia conjunta. A lo largo de los 40 años en los que estuvo dividida se sucedieron numerosos intentos de acercamiento y división. Los enfrentamientos se producían entre dos sistemas económicos diferentes, pero con una atención especial centrada en la zona Occidental de Berlín.

Ya en 1946 la SMAD constituye la Deutsche Grenzpolizei (Policía fronteriza alemana, DGP) para vigilar la frontera entre ambos territorios. La parte más vulnerable, y por extensión la más polémica sería la correspondiente a Berlín Occidental, aislada dentro de la SBZ, tal y como se demostró en el llamado «Bloqueo de Berlín».

Los primeros esfuerzos por conseguir una Alemania unificada los realizarían desde Moscú tres años después, en 1952, en lo que se conoce como la «Nota de Stalin». En ella se proponía el abandono de todas las fuerzas de ocupación del territorio alemán para conseguir una «Alemania neutral y reunificada». Según esta nota las 4 fuerzas de ocupación debían comprometerse a retirarse en el plazo de un año, y si bien se permitiría la creación de unas fuerzas armadas, Alemania debía permanecer neutral, no pudiendo establecer alianzas militares. Helmut Kohl (2009: 2) reflexionaría sobre el tema que:

Fue correcto que, en respuesta a la «Nota de Stalin» de marzo de 1952, los aliados occidentales, de acuerdo con el canciller federal, exigieran elecciones libres en toda Alemania como requisito para dar pasos ulteriores, pues la condición de Stalin era una Alemania neutral. Adenauer partía, con razón de que una Alemania neutral crearía un vacío de poder en Europa que llenaría la Unión Soviética».

Tras el fracaso de la «Nota de Stalin» la RDA no realizará más intentos de unión hasta 5 años más tarde, en los que se establecerá la idea de una confederación. Según el Bundesministerium für innerdeutsche Beziehungen (2000: 3786):

«La formación de una confederación entre la República Federal Alemana y la RDA se propuso por el SED en los años 1956-1965, primero como la mejor y luego la única manera de reunificación alemana. En una confederación se mantendría invariable el imperio y sistema social de la RDA y sería reconocido por el derecho internacional ${ }^{22}$
958, este enviará una nota al embajador americano en Berlín que sería conocida como el «Ultimátum de Berlín». En ella acusaba a las tropas Aliadas de violaciones de los acuerdos de Potsdam y les daba 6 meses para desmilitarizar Berlín Occidental y declararlo ciudad libre. La nota aseguraba que:

«El Gobierno soviético cree que sería sensato reconocer la situación prevaleciente en el mundo y crear unas relaciones normales de la convivencia de todos los estados, para desarrollar el comercio interaciona, para contruir relacio países sobre la base de los bien conocidos principios del respeto mutuo por las otras soberanías y la integridad territorial, la no agresión, la no injerencia en los los asuntos internos de los demás, igualdad y beneficio mutuo ${ }^{23}$ (Khrushchev, 1958)

La amenaza en caso de no cumplirse la evacuación en el periodo establecido consistía según Loth (1986b: 487) en "que pondría en manos de la RDA el control de las vías de acceso aliadas a Berlín Oeste y que apoyaría a la RDA en la salvaguarda de sus derechos de control». El Ultimátum no sería aceptado por un temor a un «tentativa de expansionismo soviético». En un nuevo intento de acercamiento Khrushchev volverá a plantear el "Ultimátum de Berlín» en la reunión en Viena con el presidente John F. Kennedy, nuevamente sin éxito.

Konrad Adenauer, canciller de Alemania Occidenta desde 1949 hasta 1963, había seguido una política muy dura hacia la RDA, con quien mantuvo unas relaciones comerciales mínimas y se negó a reconocer su régimen y a mantener relaciones diplomáticas con ella en un esfuerzo por aislarla a nivel internacional. Es muy interesante la reflexión que hace Loth (1986b: 483), según el cual:

«(...) no tenían la intención de pagar el precio exigido por los dirigentes soviéticos de reconocer el régimen del SED como interlocutor con igualdad de derechos. en vez de ello, y con la pretensín de convertirse en los únicos portavoces legítimos hacia una reunificación en paz y libertad, es decir dentro de marco de la Alianza Occidental, obligados por la fuerza y cohesión de Occidente a aceptar un día tal concesión unilateral».

De la misma opinión se muestra Harrison (1993) quien afirma que con ello esperaba «en última instancia conducirla a su colapso bajo la presión. La construcción del Muro de

Berlín, sin embargo, hizo que Willy Brandt y otros políticos

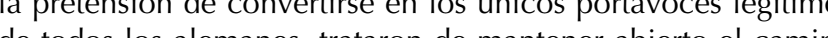

23. The Soviet Government believes that it would be sensible to recognize the situation prevailing in the world and to create normal relations for the co-existence of all states, to develop international trade, to build relations between our countries on the basis of the wellknown principles of mutual respect for one another's sovereignty and territorial integrity, nonaggression, non-interference in one another's 列

Khrushchev, 1958) zur Wiedervereinigung Deutschlands vorgeschlagen. Da in einer K. das Herrschafts- und Gesellschaftssystem
in der DDR unverändert erhalten geblieben und völkerrechtlich anerkannt worden wäre.

$$
\begin{aligned}
& \text { inisterium für innerdeutsche } \\
& \text { Beziehungen, 2000: } 3786 \text { ) }
\end{aligned}
$$


de Alemania Occidental creyeran que las expectativas de Adenauer eran peligrosamente poco realistas».

Con la construcción del Muro de Berlín las potencias occidentales «constataron aliviadas que los dirigentes soviéticos no pretendían en realidad otra cosa que asegurar su esfera de dominio y no ampliar esta más allá de las fronteras centroeuropeas ya existentes» (Loth 1986b: 489). Si bien hasta el momento la postura de la RFA se había basado en la reunificación como paso previo a la distensión, con la construcción del Muro se consideraría la distensión como un paso previo ineludible a la reunificación. Eso conllevó un cambio en la política occidental con la RDA hacia una política de «cambio mediante el acercamiento», en una esperanza de arreglar las relaciones entre las dos Alemanias. Durante dos años no hubo ninguna posibilidad de atravesar la frontera.

En 1963 se permite que los ciudadanos del Oeste visitaran a sus familiares del Este durante las navidades, a partir de 1964 se permitió también que los pensionistas del Este visitaran el Oeste, o permisos de visita en caso de fallecimiento o enlace familiar. Poco después de la construcción del Muro, la «línea de demarcación» entre las dos Alemanias se convertiría en una zona de gran actividad propagandísitica. Ambos estados arrojaban folletos al otro lado de la frontera desde el aire en opinión de Arthur (2010):

"Quizás más brillantemente, la RDA imprimía y enviaba botes masivos de folletos de propaganda a Alemania Occidental con el lema Schluß damit! (¡Basta de esto!), instando a los ciudadanos de la República Federal a realizar protestas Ilamando a la finalización de las incursiones de propaganda occidental en el Este».

Pronto estas visitas a la RDA se convirtieron en una importante fuente de dinero, tal y como relata Ingolf Wernicke (2007: 9):

«El 1 de diciembre de 1964 se impuso el cambio mínimo de moneda para visitantes. Al entrar en la RDA o en Berlín Oriental todos los berlineses (excepto niños y jubilados) tenían que cambiar 3 DM y los ciudadanos federales y extranjeros 5 DM al cambio de 1 a 1 . El dinero cambiado no podta ser vueto a camcambio de 1 a 1 . El dinero cambiado no podía serv biar o sacado de la RDA. (...) Desde 1968 todos los que visitaban Berlín Oriental tenían que cambiar 5 DM y los que visitaban la RDA 10 DM. En 1973 el cambio obligatorio se duplicó, pero al año siguiente se volvió a bajar».

En la década de los 70 se firmarán diversos acuerdos de acercamiento, como el de "Vier-Mächte-Verhandlungen» (Tratados de las Cuatro Potencias) en el cual el gobierno soviético reconocería el establecimiento de «lazos espe- ciales» entre Berlín Oeste y la RFA, a cambio de que la parte occidental ratificase que este no pertenecía a la RFA. En los primeros años de la década el gobierno de Moscú presionó fuertemente a Ulbricht para la firma de acuerdos, finalmente este se vería obligado a dejar el puesto en favor de Honecker

Con el cambio de gobierno las relaciones entre ambos estados mejorarán notablemente, según Gordeeva (2001a) «aunque es menos rígido que Ulbricht, según lo evidenciado por su buena voluntad de firmar acuerdos con el Oeste, que han abierto algo la RDA y han hecho las vidas de sus ciudadanos más fáciles, Honecker fue comunista convencido hasta su muerte». Honecker firmará el Grundlagesvertrag (Tratado Básico) según el cual «aceptaban la negativa a cimentar la división de Alemania conforme al Derecho internacional, si bien siguieron esforzándose en conseguir el grado máximo de separación» (Loth, 1986b: 501). Con la firma del Grundlagesvertrag la RDA y la RFA se comprometían a desarrollar una igualdad de derechos fundamental para las relaciones normales entre vecinos.

Como consecuencia de estos acercamientos se establecerán por primera vez «Ständigen Vertretungen» (Representantes Permanentes) de ambos estados en las capitales inversas. Esta solución se derivó según Harrison (1993) de que:

«Alemania Occidental aún se negaba a reconocer la RDA como un estado de derecho, soberano, ya que sus líderes no eran elegidos libremente. Así, en lugar del intercambio de embajadores y del establecimiento de embajadas en sus respectivas capitales, Alemania Occidental se comprometió a intercambiar Representantes Permanentes y establecer las Misiones Permanentes».

Sin embargo esta apertura en las negociaciones conllevó consecuencias negativas en la política interna, ya que según Wolle (1999: 96):

«En la dirección de la RDA creció la preocupación fundada, de que las negociaciones con los enemigos de clases del Oeste podía hacer palidecer la vieja imagen del enemigo de la Guerra Fría. Establecieron la consigna en el mundo de que en vista de la relajación política, necesaria y legalmente se acentuaba la guerra de clases ideológicas. La dialéctica del sistema de discusión exigía una alta vigilancia política» ${ }^{24}$.

En la vida diaria, el acercamiento de los años 70 sería muy notable ya que el hecho de que los habitantes de la RDA tuvieran acceso a la televisión federal supuso que, en el día a día, la distancia entre los dos países fuera mucho
24. Bei der DDR- Führung wuchs die berechtigte Sorge, die Verhandlungen mit dem westliche Klassenfeind könnte die alten Feindbilder des Kalten Krieges verblassen lassen. Sie setzte die Parole in die Welt, angesichts der politischen Entspannung verschärfe sich notwendigweise und gesetzmäilg der ideologische Syssenkampieindersetzung erfordere Systemauseindersetzung erfordere 
menor que la política, compartiendo unas mismas figuras, música e incluso anglicismos. «Era ante todo la televisión y la radio del Oeste la que veían y escuchaban regularmente los ciudadanos de la RDA, y con ello establecía diariamente la subsistente cohesión de la nación como ningún otro medio puesto a prueba» (Heydemann, 2009) Estas difusiones de televisión se admitieron resignadamente como legales en el 9 pleno del ZK de mayo de 1973, aunque intentaron dificultarse mediante el usos de dos sistemas de televisión en color, lo que impedía a los ciudadanos de la RDA ver la televisión federal en color, no obstante a partir de 1977 se produjeron en la RDA televisiones con el doble sistema de color.

En los 80 se permitirían las visitas a la RFA por cuestiones familiares, a aquellas personas que no fueran todavía pensionistas y en 1981 se permitió visitar la RDA con pasaporte RFA a los antiguos disidentes de la RDA. Progresivamente se fueron aumentando las posibilidades de atravesar la frontera en ambos sentidos. En 1983 y 84 fueron concedidos 2 millones de marcos de crédito de la RFA para la mejora de las carreteras de unión en el lado oriental y el desmontaje de las minas antipersona de la frontera. «Sin embargo, llegó a estar claro que estos dispositivos habían sido substituidos por los sistemas de amonestadores electrónicos casi impenetrables» (Gordeeva, 2001b).

Con todo, en estos años la política del SED hacia la RFA como miembro de la OTAN fue muy crítica llegando a cancelar visitas oficiales de alto nivel como muestra de protesta hacia la política militar de la RFA. En 1987 las relaciones habían mejorado notablemente, llegando Honecker a visitar Bonn para la firma de acuerdos de cooperación en materia de ciencia, tecnología y de protección del medio ambiente, visita que llevaba siendo pospuesta desde 1981. Si bien la visita fue muy cordial en el ámbito oficial, hubo varias manifestaciones bajo el lema «el Muro debe desaparecer».

Finalmente los acontecimientos ya descritos conllevarían a la caída del Muro en noviembre de 1989 y a la reunificación de Alemania un año más tarde.

3.1.3.2.1 Cronología y periodos de las relaciones entre las dos alemanias

\begin{tabular}{|c|c|c|}
\hline \multirow{8}{*}{$\begin{array}{l}\text { TENSIONES ENTRE } \\
\text { AMBOS BLOQUES }\end{array}$} & 1946 & \multirow{3}{*}{$\begin{array}{l}\text { La SMAD constituye la DGP en la SBZ (1.12) } \\
\text { La SMAD impone el «Blogueo de Berlín» (24.06) }\end{array}$} \\
\hline & 1947 & \\
\hline & 1948 & \\
\hline & 1949 & \multirow{3}{*}{ Fin «Bloqueo de Berlín»(12.05)| Creación RFA (24.05)| Creación RDA (07.10) } \\
\hline & 1950 & \\
\hline & 1951 & \\
\hline & 1952 & \multirow[t]{2}{*}{ «Nota de Stalin» (10.03)| Frontera de demarcación con la RFA (26.05) } \\
\hline & 1953 & \\
\hline \multirow{7}{*}{$\begin{array}{l}\text { INTENTOS FRUSTRA- } \\
\text { DOS DE DISTENSIÓN } \\
\text { "REUNIFICACIÓN } \\
\text { COMO PASO PREVIO } \\
\text { A LA DISTENSIÓN" }\end{array}$} & 1954 & \multirow{6}{*}{$\begin{array}{l}\text { Propuesta de Confederación entre la RDA y la RFA (27.07)| Nueva Ley de pasaportes (11.12) } \\
\text { Ultimátum de Berlín (10.11) }\end{array}$} \\
\hline & 1955 & \\
\hline & 1956 & \\
\hline & 1957 & \\
\hline & 1958 & \\
\hline & 1959 & \\
\hline & 1960 & Requisitos de autorización para viajar de la RFA a Berlín Oriental (08.09) \\
\hline \multirow[t]{2}{*}{ MURO DE BERLÍN } & 1961 & \multirow[t]{2}{*}{ Reunión de Viena (04.06). Muro de Berlín (13.08) } \\
\hline & 1962 & \\
\hline \multirow{7}{*}{$\begin{array}{l}\text { PRIMEROS } \\
\text { ACERCAMIENTOS } \\
\text { “DISTENSIÓN COMO } \\
\text { PASO PREVIO A LA } \\
\text { REUNIFICACIÓN" }\end{array}$} & 1963 & \multirow{5}{*}{$\begin{array}{l}\text { Primeros acuerdos de traspaso de la frontera entre RFA y RDA (17.12) } \\
\text { Introducción de cambio forzoso para los ciudadanos RFA que entren en la RDA (25.12) }\end{array}$} \\
\hline & 1964 & \\
\hline & 1965 & \\
\hline & 1966 & \\
\hline & 1967 & \\
\hline & 1968 & \multirow[t]{2}{*}{ Requisitos de visado y pasaporte para pasar de la RFA a la RDA (11.06) } \\
\hline & 1969 & \\
\hline \multirow{12}{*}{$\begin{array}{l}\text { ACUERDOS ENTRE } \\
\text { AMBOS ESTADOS }\end{array}$} & 1970 & \multirow{2}{*}{$\begin{array}{l}\text { Reunión Willy Brant y Willi Stoph (19.03)| Comienzo de las negociaciones de "Vier Mächte" (26.03)| } \\
\text { Reunión Willy Brant y Willi Stoph (21.05) } \\
\text { Firma del Acuerdo de "Vier Mächte" (03.09) }\end{array}$} \\
\hline & 1971 & \\
\hline & 1972 & \multirow{10}{*}{$\begin{array}{l}\text { Firma del Contrato de Transporte entre RDA y RFA (26.05)| Acuerdos de Transito entre RDA y RFA } \\
\text { (03.06)| Firma del Tratado Fundamental (21.12) } \\
\text { Entrada en vigor del Grundlagenvertrag (21.06) } \\
\text { Apertura de los «Ständigen Vertretungen» (02.05) }\end{array}$} \\
\hline & 1973 & \\
\hline & 1974 & \\
\hline & 1975 & \\
\hline & 1976 & \\
\hline & 1977 & \\
\hline & 1978 & \\
\hline & 1979 & \\
\hline & 1980 & \\
\hline & 1981 & \\
\hline \multirow{7}{*}{$\begin{array}{l}\text { AUMENTO DE } \\
\text { INTERCAMBIOS }\end{array}$} & 1982 & \multirow{7}{*}{$\begin{array}{l}\text { Ampliación del catálogo de emotivos familiares» para viajar a la RFA (11.02)| Garantía de impunidad } \\
\text { RDA para refugiados en RFA previos a 1980 (18.06) } \\
\text { Honecker visita RFA (28.04)| Strauss visita la RDA (24.07) } \\
\text { Cierre del «Ständige Vertretung» en Berlín Oriental (05.06)| Crédito de la RFA a la RDA (25.07) } \\
\text { La RDA amplia las posibilidades de viajar por asuntos familiares urgentes (09.02)| Convenio Cultural } \\
\text { (06.05) } \\
\text { Visita oficial de Honecker a la RFA (07.09) }\end{array}$} \\
\hline & 1983 & \\
\hline & 1984 & \\
\hline & 1985 & \\
\hline & 1986 & \\
\hline & 1987 & \\
\hline & 1988 & \\
\hline \multirow{2}{*}{$\begin{array}{l}\text { APERTURA Y } \\
\text { UNIDAD }\end{array}$} & 1989 & \multirow{2}{*}{$\begin{array}{l}\text { Paso libre entre RDA y RFA (09.11)| Programa de } 10 \text { puntos de H. Kohl (28.11) } \\
\text { Comienzo de las «Zwei-plus-vier Cespräche» (05.05)| Unificación monetaria (01.06)| Reunificación } \\
\text { (31.08) }\end{array}$} \\
\hline & 1990 & \\
\hline
\end{tabular}


«La RDA no fue nunca una nación distinta, sino una nación escindida. No surgió mediante el acto autónomo y revolucionario que significa la promulgación de una constitución, sino a causa de la ocupación soviética y del orden constitucional a causa de la ocupación sovietica y del orden constitucional decretado por ella Por consiguiente, la RDA no fue sino un sistema económico independiente, configurado según los principios del socialismo de Estado. No tenía más que una identidad económica» (Claus Offe 1990: 146).

No muy diferente era el caso de la RFA, la cual según Axel Schildt (2009) «fue el resultado, tras la Segunda Guerra Mundial, de las confrontaciones entre los bloques del Este y el Oeste y, por tanto, no suponía ninguna soberanía completamente legal». Será por esto que la identidad alemana y la «cuestión nacional» sea objeto de la política de ambos gobiernos.

En su reflexión sobre el cine histórico producido en la RDA Thorsten Schilling (2006: 11) considera que:

«Por un lado había que responder a la pregunta ¿Cómo fue posible? por otro lado era necesario representar visualmente la Soviética. De acuerdo Soviética. De acuerdo con esta interpretación todas las fuerzas antifascistas habían encontrado su hogar en la RDA, mientras que la República Federal Alemana (RFA) era el reducto de los seguidores incorregibles del régimen nazi y de los nuevos agitadores bélicos».

Esta consideración histórica que se reproducía en el cine no era más que un reflejo de la que se daba a nivel polítiCo, realizando una amplia revisión de la historia alemana y manteniendo únicamente lo que estuviera acorde a los propósitos socialistas. De este modo fueron eliminados símbolos de la herencia prusiana en Berlín, tales como la estatua ecuestre del rey prusiano Federico el Grande, o un palacio de 500 años de la Dinastía de Hohenzollern por ser un símbolo de la «represión feudal». Los carteles producidos en la RDA tenían como tema fundamental reclamar la paz y rechazar y denunciar la violencia y la guerra.

Tras la proclamación del la «Construcción del socialismo» en la Asamblea de 1952 el SED suprimió la división de los 5 Länder:

«todos desarrollados a lo largo de tradiciones históricas, fueron abolidos y se establecieron 15 distritos administrativos. Esta mediada le dio al gobierno central en Berlín Este un control mucho mayor sobre las actividades de estos distritos, los cuales eran mucho más pequeños, e igualmente importante, le permitieron romper con otro aspecto de la despreciable historia burguesa alemana» (Gordeeva, 2001c).
La visita estatal de Ulbricht a Egipto en 1966 acabó con el aislamiento político de la RDA. Si bien el Bundesministerium für innerdeutsche Beziehungen (2000: 1133) considera que:

«(...) el pronto reconocimiento diplomático de Camboya, Irak, Sudán, Yemen del Sur, Siria y Egipto (mayo-julio de 1969) fue menos uncédito inmediato de la política exterior de 1969), Su, menos un crédito inme dis la RDA, que una consecuenciac de 1967, durante la cual la República Democrática Alemana (como, con la excepción de Rumania, todos los países socialistas de la comunidad) incondicionalmente había tomado la posición árabe».

Independientemente de las razones de este reconocimiento, se establecería como un logro primero entre los funcionarios de la RDA y posteriormente entre la población generando un sentimiento de identidad de la RDA. Un año más tarde Walter Ulbricht intentaría «el reconocimiento legal de la RDA como condición previa a posteriores conversaciones en torno a la distensión» (Loth 1986b: 499) pero este sería rechazado. El gobierno de la RDA entonces proclamó la ciudadanía de la RDA independiente. Con esta medida, la RDA comenzó a practicar una política de nueva reafirmación y delimitación ideológica en respuesta a la política de la RFA que reconocía una única ciudadanía alemana.

Con el cambio de jefatura a Honecker las cosas no cambiaron mucho, en el VIII Congreso de partido se defendió la RDA como una "nación socialista alemana», mientras que la RFA era una «nación burguesa alemana» que se debían regir por los principios de coexistencia pacífica. Mientras la RFA se esforzaba por enfatizar la unidad histórica, la política de Honecker fomentaba campañas por la identidad socialista a lo largo de Alemania del Este. Pese al reconocimiento internacional tras el Grundlagesvertrag, la política del SED sería de reafirmación de la naturaleza socialista del estado.

La apertura a la radiotelevisión de la RFA en 1973 conIlevaría, según Wolle (1999: 97) a la difusión de «los productos importados de la RFA que venían anunciados por figuras destacadas de occidente, lo cual supuso la respuesta del Ministerio de lanzar la propaganda nada nos relaciona con la imperialista RFA, todo con nuestra patria socialista». La diferenciación con la RFA se fomentaba incluso en el uso del lenguaje, con palabras de uso exclusivo de la RDA como Broilen (Pollo asado). Se publicaban diccionarios con cerca de 2000 palabras de alemán RDA y se luchaba contra el uso de anglicismos. 
Esta exaltación de la identidad RDA culminaría con la reforma de la Constitución en 1974, modificada para incrementar el sentimiento de desarrollo independiente, que eliminaba todas las referencias en el documento sobre la «nación alemana» y sobre la herencia nacional alemana. El artículo 1 redactado en 1968 como (RDA, 1968) «la RDA es un estado socialista de la nación alemana» pasó a ser (RDA, 1974) «la RDA es una estado socialista de los obreros y campesinos».

Tras la IX Asamblea de partido en 1976, se iría un paso más lejos, eliminando todas las figuras de la historia prusiana y el concepto de Alemania; el hotel "Deutschland» de Leipzig cambiaría a «Hotel am Ring», otros personajes históricos como los reformadores Karl vom Stein, Karl August von Hardenberg, Gerhard von Scharnhorst, y el fundador de la Universidad de Berlín, Wilhelm von Humboldt, serían reclamados como ancestros históricos de la RDA. Los libros de texto se reformarían eliminando la relación de la RDA con Alemania, y especificando que Alemania había existido solo hasta 1945 y a partir de entonces se convertiría en dos estados política y socialmente independientes.

El 13 de octubre de 1980, en la apertura del año político, Honecker declararía (citado en Wolle 1999: 99) que «la razón principal (de los problemas entre la RDA y la RFA) son los sucesivos intentos de la RFA, su relación con la RDA, de despreciar los principios de soberanía de nuestro estado bajo infracción del Grundlagesvertrag» presentando, entre otras peticiones, nuevamente la del reconocimiento de la ciudadanía de la RDA y la conversión de los «Ständige Vertretungen», en embajadas. Con esto Honecker buscaba el reconocimiento como nación más allá de sus fronteras, pero estas peticiones no serían atendidas hasta 1989.

3.1.3.2.1 Cronología y periodos de la identidad alemana y la "cuestión nacional».

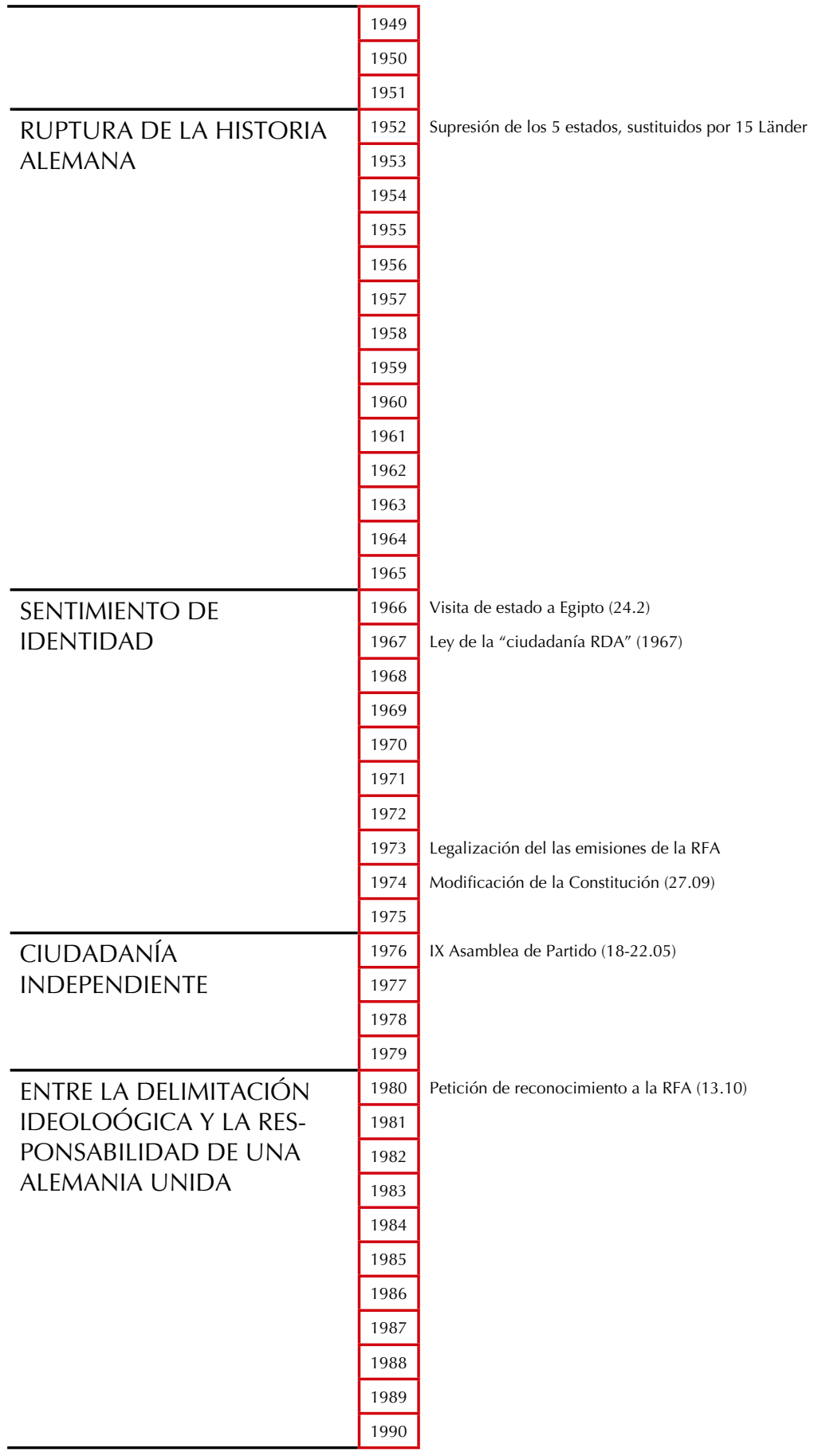


3.1.4.1 Periodos de evolución

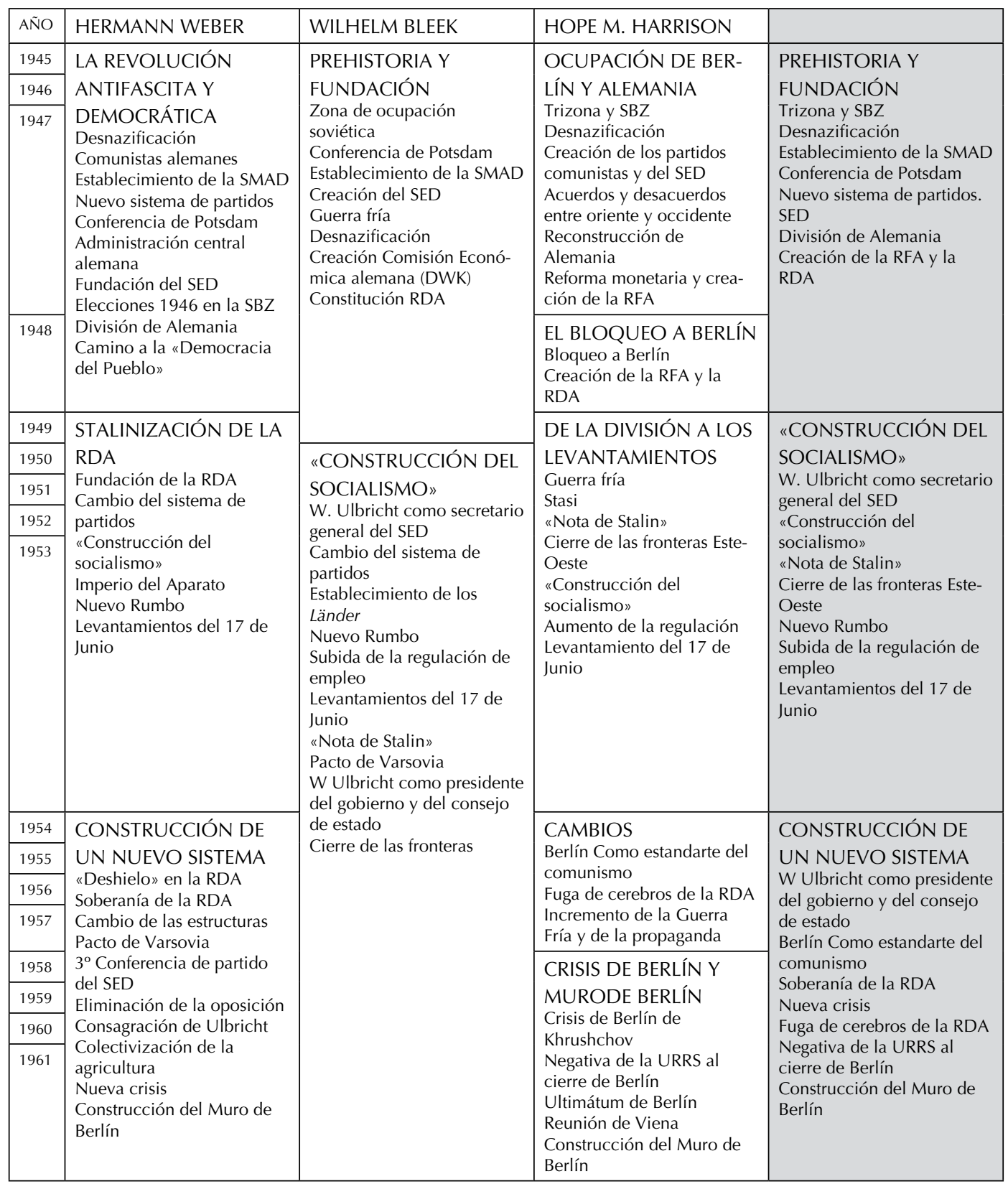

\begin{tabular}{|c|c|c|c|c|}
\hline AÑO & HERMANN WEBER & WILHELM BLEEK & HOPE M. HARRISON & \\
\hline 1962 & \multirow{4}{*}{$\begin{array}{l}\text { FIJACIÓN DE LA RDA } \\
\text { Cese de 1961 } \\
\text { Intentos de estabilidad } \\
\text { VI partido del SED } \\
\text { NOSPL } \\
\text { Sistema educativo } \\
\end{array}$} & \multirow{9}{*}{\begin{tabular}{|l|} 
SISTEMA ULBRICHT \\
NÖSPL \\
Nueva constitución y socie- \\
dad socialista \\
Modelo RDA \\
Cese de Ulbricht como \\
primer secretario del ZK \\
\end{tabular}} & \multirow{23}{*}{$\begin{array}{l}\text { DÉCADA 60, } 70 \text { Y } 80 \\
\text { Primeras visitas a RFA en } \\
1963 \text { hasta } 1972 \\
\text { Normalización de las } \\
\text { relaciones con la URRS } \\
\text { «Ostpolitik» } \\
\text { Acuerdos de Berlín } \\
\text { Grundlagesvertrag } \\
\text { Represión }\end{array}$} & \multirow{9}{*}{$\begin{array}{l}\text { SISTEMA ULBRICHT } \\
\text { NÖSPL } \\
\text { Modelo RDA } \\
\text { Reforma política } \\
\text { Nueva constitución y socie- } \\
\text { dad socialista } \\
\text { Nueva crisis } \\
\text { Cese de Ulbricht como } \\
\text { primer secretario del ZK }\end{array}$} \\
\hline 1963 & & & & \\
\hline 1964 & & & & \\
\hline 1965 & & & & \\
\hline 1966 & \multirow{5}{*}{$\begin{array}{l}\text { INTENTO DE MODELO } \\
\text { ULBRICHT } \\
\text { Reforma política } \\
\text { Política de frontera } \\
\text { Constitución } 1968 \\
\text { Primavera de Praga } \\
\text { Nueva crisis } \\
\end{array}$} & & & \\
\hline 1967 & & & & \\
\hline 1968 & & & & \\
\hline 1969 & & & & \\
\hline 1970 & & & & \\
\hline 1971 & \multirow{5}{*}{$\begin{array}{l}\text { AJUSTE A LA URRS } \\
\text { Sustitución de Ulbricht } \\
\text { Cambios en el partido } \\
\text { Problemas económicos y } \\
\text { sociales } \\
\text { Ajuste a la URRS y demar- } \\
\text { cación del Oeste }\end{array}$} & \multirow{10}{*}{$\begin{array}{l}\text { CORRECIONES } \\
\text { DE RUMBO DE } \\
\text { HONECKER } \\
\text { VIII Asamblea- Honecker } \\
\text { Cambios en la Constitución } \\
\text { Nuevo programa de partido } \\
\text { Pertenencia a la ONU } \\
\text { IX Asamblea- unidad de la } \\
\text { política económica y social } \\
\text { Estabilidad en el consumo }\end{array}$} & & \multirow{10}{*}{$\begin{array}{l}\text { ERA HONECKER } \\
\text { VIII Asamblea- Honecker } \\
\text { Cambios en la Constitución } \\
\text { Nuevo programa de partido } \\
\text { Ajuste a la URRS y demar- } \\
\text { cación del Oeste } \\
\text { Pertenencia a la ONU } \\
\text { IX Asamblea- unidad de la } \\
\text { política económica y social } \\
\text { Estabilidad en el consumo } \\
\text { Política cultural represiva }\end{array}$} \\
\hline 1972 & & & & \\
\hline 1973 & & & & \\
\hline 1974 & & & & \\
\hline 1975 & & & & \\
\hline 1976 & \multirow{5}{*}{$\begin{array}{l}\text { DESARROLLO DE LAS } \\
\text { CRÍTICAS } \\
\text { II Asamblea } \\
\text { Nuevo programa de partido } \\
\text { Política cultural represiva } \\
\text { Estancamiento de la } \\
\text { economía }\end{array}$} & & & \\
\hline 1977 & & & & \\
\hline 1978 & & & & \\
\hline 1979 & & & & \\
\hline 1980 & & & & \\
\hline 1981 & \multirow{10}{*}{$\begin{array}{l}\text { PROBLEMA RDA } \\
\text { X Asamblea } \\
\text { Sistema político desde } 1981 \\
\text { Transición al comunismo } \\
\text { Círculos de la estabilidad }\end{array}$} & \multirow{9}{*}{$\begin{array}{l}\text { CRISIS Y CAÍDA DEL } \\
\text { IMPERIO SED } \\
\text { RDA como ejemplo } \\
\text { Recesión mundial } \\
\text { Represión cultural } \\
\text { Apertura de Hungría } \\
\text { Protestas en Leipzig } \\
\text { Egon Krenz }\end{array}$} & & \multirow{9}{*}{$\begin{array}{l}\text { CRISIS Y CAÍDA DEL } \\
\text { MURO } \\
\text { Recesión mundial } \\
\text { Transición al comunismo } \\
\text { Apertura de Hungría } \\
\text { Manifestaciones en la RDA } \\
\text { Egon Krenz } \\
\text { Conferencia de prensa } \\
\text { Apertura del Muro }\end{array}$} \\
\hline 1982 & & & & \\
\hline 1983 & & & & \\
\hline 1984 & & & & \\
\hline 1985 & & & \multirow{6}{*}{$\begin{array}{l}\text { CAÍDA DEL MURO } \\
\text { Reformas de Gorbachov } \\
\text { Apertura de Hungría } \\
\text { Manifestaciones en la RDA } \\
\text { Conferencia de prensa } \\
\text { Apertura del muro } \\
\text { Unidad Alemana }\end{array}$} & \\
\hline 1986 & & & & \\
\hline 1987 & & & & \\
\hline 1988 & & & & \\
\hline 1989 & & & & \\
\hline 1990 & & $\begin{array}{l}\text { CAMBIO DEMOCRÁTI- } \\
\text { CO Y FIN RDA } \\
\text { Protestas } \\
\text { Elecciones libres } \\
\text { Unidad Alemana }\end{array}$ & & $\begin{array}{l}\text { UNIDAD ALEMANA } \\
\text { Elecciones libres } \\
\text { Unidad Alemana }\end{array}$ \\
\hline
\end{tabular}

ii. Teniendo en cuenta los aspectos mostrados hasta el momento, resulta útil establecer unos periodos históricos de la RDA basándonos en características comunes y en los periodos definidos por los investigadoTabla 3.5 res Weber, Bleek y Harrison. 
3.1.4.2 Periodos históricos iii

\begin{tabular}{|c|c|c|c|c|}
\hline AÑO & DESARROLLO & REL.INTERNACIONALES & RFA/RDA & IDENTIDAD \\
\hline 1945 & \multirow{4}{*}{$\begin{array}{l}\text { PREHISTORIA Y } \\
\text { FUNDACIÓN } \\
\text { Trizona y SBZ } \\
\text { Desnazificación } \\
\text { Establecimiento de la SMAD } \\
\text { Conferencia de Potsdam } \\
\text { Nuevo sistema de partidos. } \\
\text { SED } \\
\text { División de Alemania } \\
\text { Creación de la RFA y la } \\
\text { RDA }\end{array}$} & \multirow{8}{*}{$\begin{array}{l}\text { DOMINIO SOVIÉTICO } \\
\text { Absoluta dependencia de } \\
\text { las decisiones de Moscú }\end{array}$} & \multirow{10}{*}{$\begin{array}{l}\text { TENSIONES ENTRE } \\
\text { AMBOS BLOQUES } \\
\text { Intentos agresivos de deli- } \\
\text { mitación y liberización de } \\
\text { Berlín Occidental }\end{array}$} & \\
\hline 1946 & & & & \\
\hline 1947 & & & & \\
\hline 1948 & & & & \\
\hline 1949 & \multirow{5}{*}{$\begin{array}{l}\text { "Construcción del } \\
\text { socialismo» } \\
\text { W. Ulbricht como secretario } \\
\text { general del SED } \\
\text { "Construcción del } \\
\text { socialismo»" } \\
\text { «Nota de Stalin» } \\
\text { Cierre de las fronteras Este- } \\
\text { Oeste } \\
\text { Nuevo Rumbo } \\
\text { Subida de la regulación de } \\
\text { empleo } \\
\text { Levantamientos del } 17 \text { de } \\
\text { Junio }\end{array}$} & & & \\
\hline 1950 & & & & \\
\hline 1951 & & & & \\
\hline 1952 & & & & RUPTURA DE LA HIS- \\
\hline 1953 & & \multirow[t]{12}{*}{$\begin{array}{l}\text { ACERCAMIENTO } \\
\text { A RELACIONES DE } \\
\text { "IGUALDAD" } \\
\text { Reconocimiento de la } \\
\text { soberanía y toma propia de } \\
\text { decisiones, pero con con- } \\
\text { sentimiento de Moscú } \\
\text { Firma del Pacto de Varsovia }\end{array}$} & & $\begin{array}{l}\text { TORIA ALEMANA } \\
\text { Desvinculación con el } \\
\text { pasado histórico alemán, } \\
\text { fundamentalmente con el } \\
\text { Nazismo. }\end{array}$ \\
\hline 1954 & \multirow{8}{*}{$\begin{array}{l}\text { CONSTRUCCIÓN DE } \\
\text { UN NUEVO SISTEMA } \\
\text { W Ulbricht como presidente } \\
\text { del gobierno y del consejo } \\
\text { de estado } \\
\text { Berlín Como estandarte del } \\
\text { comunismo } \\
\text { Soberanía de la RDA } \\
\text { Nueva crisis } \\
\text { Fuga de cerebros de la RDA } \\
\text { Negativa de la URRS al } \\
\text { cierre de Berlín } \\
\text { Construcción del Muro de } \\
\text { Berlín }\end{array}$} & & & \\
\hline 1955 & & & \multirow{6}{*}{$\begin{array}{l}\text { INTENTOS FRUSTRA- } \\
\text { DOS DE DISTENSIÓN } \\
\text { Intentos diplomáticos de la } \\
\text { URRS a un Berlín neutral. } \\
\text { Negativa occidental sin una } \\
\text { reunificación previa }\end{array}$} & \\
\hline 1956 & & & & \\
\hline 1957 & & & & \\
\hline 1958 & & & & \\
\hline 1959 & & & & \\
\hline 1960 & & & & \\
\hline 1961 & & & Muro DE BERLÍN & \\
\hline 1962 & \multirow{8}{*}{$\begin{array}{l}\text { SISTEMA ULBRICHT } \\
\text { NÖSPL } \\
\text { Modelo RDA } \\
\text { Reforma política } \\
\text { Nueva Constitución y socie- } \\
\text { dad socialista } \\
\text { Nueva crisis } \\
\text { Cese de Ulbricht como } \\
\text { primer secretario del ZK }\end{array}$} & & \multirow{8}{*}{$\begin{array}{l}\text { PRIMEROS } \\
\text { ACERCAMIENTOS } \\
\text { "DISTENSIÓN COMO } \\
\text { PASO PREVIO A LA } \\
\text { REUNIFICACIÓN" }\end{array}$} & \\
\hline 1963 & & & & \\
\hline 1964 & & & & \\
\hline 1965 & & \multirow{5}{*}{$\begin{array}{l}\text { DISTANCIAMIENTO DE } \\
\text { LA URRS } \\
\text { Éxito económico y estable- } \\
\text { cimiento del "modelo RDA" } \\
\text { en conflicto con la URRS }\end{array}$} & & \\
\hline 1966 & & & & SENTIMIENTO DE \\
\hline 1967 & & & & $\begin{array}{l}\text { IDENTIDAD } \\
\text { Primeros reconcimientos }\end{array}$ \\
\hline 1968 & & & & como nación y sentimiento \\
\hline 1969 & & & & \\
\hline
\end{tabular}

\begin{tabular}{|c|c|c|c|c|}
\hline AÑO & DESARROLLO & REL.INTERNACIONALES & RFA/RDA & IDENTIDAD \\
\hline 1970 & & & \multirow{12}{*}{$\begin{array}{l}\text { ACUERDOS ENTRE } \\
\text { AMBOS ESTADOS } \\
\text { Acuerdos fundamentales, } \\
\text { de tránsito, telecomunica- } \\
\text { ciones y primeras aperturas } \\
\text { diplomáticas }\end{array}$} & \\
\hline 1971 & \multirow{10}{*}{$\begin{array}{l}\text { ERA HONECKER } \\
\text { VIII Asamblea- Honecker } \\
\text { Cambios en la Constitución } \\
\text { Nuevo programa de partido } \\
\text { Ajuste a la URRS y demar- } \\
\text { cación del Oeste } \\
\text { Pertenencia a la ONU } \\
\text { IX Asamblea- unidad de la } \\
\text { política económica y social } \\
\text { Estabilidad en el consumo } \\
\text { Política cultural represiva }\end{array}$} & MODELO LIGADO A & & \\
\hline 1972 & & LA URRS & & \\
\hline 1973 & & \multirow{16}{*}{\begin{tabular}{|l} 
PRIMEROS ACER- \\
CAMIENTOS A \\
OCCIDENTE \\
Primeras relaciones con \\
occidente y representación \\
internacional en la ONU
\end{tabular}} & & \\
\hline 1974 & & & & \\
\hline 1975 & & & & \\
\hline 1976 & & & & CIUDADANÍA \\
\hline 1977 & & & & INDEPENDIENTE \\
\hline 1978 & & & & $\begin{array}{l}\text { Diterenciación historica de } \\
\text { Alemania y de la RFA }\end{array}$ \\
\hline 1979 & & & & \\
\hline 1980 & & & & ENTRE LA DELIMITA- \\
\hline 1981 & \multirow{9}{*}{$\begin{array}{l}\text { CRISIS Y CAÍDA DEL } \\
\text { Muro } \\
\text { Recesión mundial } \\
\text { Transición al comunismo } \\
\text { Apertura de Hungría } \\
\text { Manifestaciones en la RDA } \\
\text { Egon Krenz } \\
\text { Conferencia de prensa } \\
\text { Apertura del Muro }\end{array}$} & & & CIÓN IDEOLÓGICA Y \\
\hline 1982 & & & \multirow{7}{*}{$\begin{array}{l}\text { AUMENTO DE } \\
\text { INTERCAMBIOS } \\
\text { Aumento de las posibilida- } \\
\text { des de atravesar la frontera }\end{array}$} & LA RESPONSABILIDAD \\
\hline 1983 & & & & DE UNA ALEMANIA \\
\hline 1984 & & & & \\
\hline 1985 & & & & \\
\hline 1986 & & & & \\
\hline 1987 & & & & \\
\hline 1988 & & & & \\
\hline 1989 & & \multirow[t]{2}{*}{ APERTURA } & \multirow[t]{2}{*}{ APERTURA Y UNIDAD } & \\
\hline 1990 & $\begin{array}{l}\text { UNIDAD ALEMANA } \\
\text { Elecciones libres } \\
\text { Unidad Alemana }\end{array}$ & & & \\
\hline
\end{tabular}

iii. Esquema resumen de los periodos históricos de la RDA tanto dentro como fuera de sus fronteras. 
La estructura política en la que se anclará la RDA variará a lo largo de los años, con las sucesivas reformas de los partidos y las nuevas vías de desarrollo que se irán abriendo en las Asambleas de Partido tal y como hemos visto en los apartados anteriores. No obstante, existen unos parámetros ideológicos y estructurales generales que prevalecieron en la mayor parte de su historia.

La propaganda política constituye parte fundamental del 25. «Die Deutsche Demokratische Republik ist ein sozialistischer Staat deutscher Orion. Sie ist die pollitsche Stadt und land, die gemeinsam unter Führung der Arbeiterklasse und ihrer marxistisch-leninistischen Parte den Sozialismus verwirklichen

Der Hauptstadt der Deutschen

Demokratischen Republik ist Berlin.

Die Staatsflagge der Deutschen Demokratischen Republik besteht aus den Farben Schwarz-RotGold und trägt auf beiden Seiten in der Mitte das Staatswappen der Deutschen Demokratischen Republik.

Das Staatswappen der Deutschen Demokratischen Republik besteht aus Hammer und Zirkel, umgebe von einem Ährenkranz, der im unteren Teil von einem schwarz-rotgoldenen Band umschlungen ist».

(RDA, 1968)

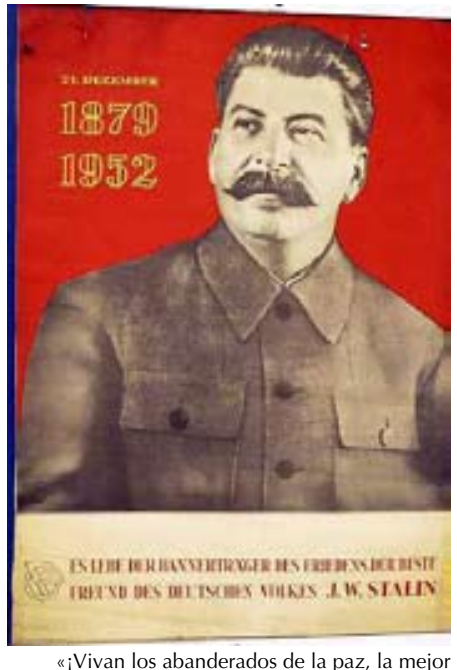

an los abanderados de la paz, la mejor
amiga del pueblo alemán! I.W.Staling diseño gráfico de este periodo. Con ella se pretende adoctrinar a la población sobre el socialismo, la clase trabajadora y la lucha de clases. Los carteles tendrán una iconografía propia adaptada a los fundamentos ideológicos y políticos del sistema de la RDA.

\subsubsection{Fundamentos ideológicos}

En su Constitución de 1968 (RDA, 1968), artículo 1, se definiría que:

"La RDA es un estado socialista de la nación alemana. Es la organización política de los trabajadores de la ciudad y el trabajadora y su partido marxista-leninista.

La capital de la RDA es Berlín.

La bandera del estado de la RDA es de colores negro rojo y oro y lleva en el centro de ambas caras el escudo de la RDA.

El escudo de la RDA consiste en un martillo y un compás rodeados por una corona de espigas en cuya parte inferior se encuentra una bandera negro-roja-dorada» ${ }^{25}$.

El uso de estos colores negro rojo y dorado será un recurso constante en los carteles propagandísticos, así como el 任bolo del socialismo. Brevemente definiremos que el socialismo se entiende como el paso previo al comunismo en las enseñanzas de Karl Marx y Friedrich Engels. Tal y como defiende Norman MacKenzie (1969: 11) «toda teoría socialista supone una crítica moral del orden social existente al que opone la idea de una sociedad libre de injusticias y de los constreñimientos de la desigualdad». De este modo, tal y como expresa Juan Ferrando Badía (1980: 336) «los regímenes marxistas son una de las posibles expresiones políticas de las sociedades basadas en el dominio de la clase proletaria, al sufrirse los efectos de la revolución industrial».

Según el «Manifiesto Comunista» de Karl Marx las condiciones del proletariado son consecuencia del sistema social ya que: campo que realizan juntos el socialismo bajo la guía de la clase
«(...) surgen nuevas técnicas de producción que abren nuevas perspectivas para aumentar la riqueza y el dominio del hombre sobre la naturaleza, y con ellas aparecen nuevas clases sociales que piden cambios en la organización social y económica en detrimento de la antigua clase dominante» (MacKenzie, 1969: 53).

Sin embargo las obras de Marx y Engels son de tipo filosófico, no instrucciones para un gobierno socialista, de ta modo, que tal y como escribe Gérard Sandoz (1971: 178) «ningún modelo (de estructura político-económica) se parece exactamente al otro, y es ciertamente innegable que el Estado socialista de la nación alemana (...), con todo y proclamarse fiel al modelo soviético, vive según sus propios criterios y desarrolla organismos e intereses autónomos». Parte de la función de la propaganda política consistía en la educación en los valores socialistas y en crear una cultura socialista, por lo que se esforzaban en la difusión de la imagen de los principales ideólogos y políticos.

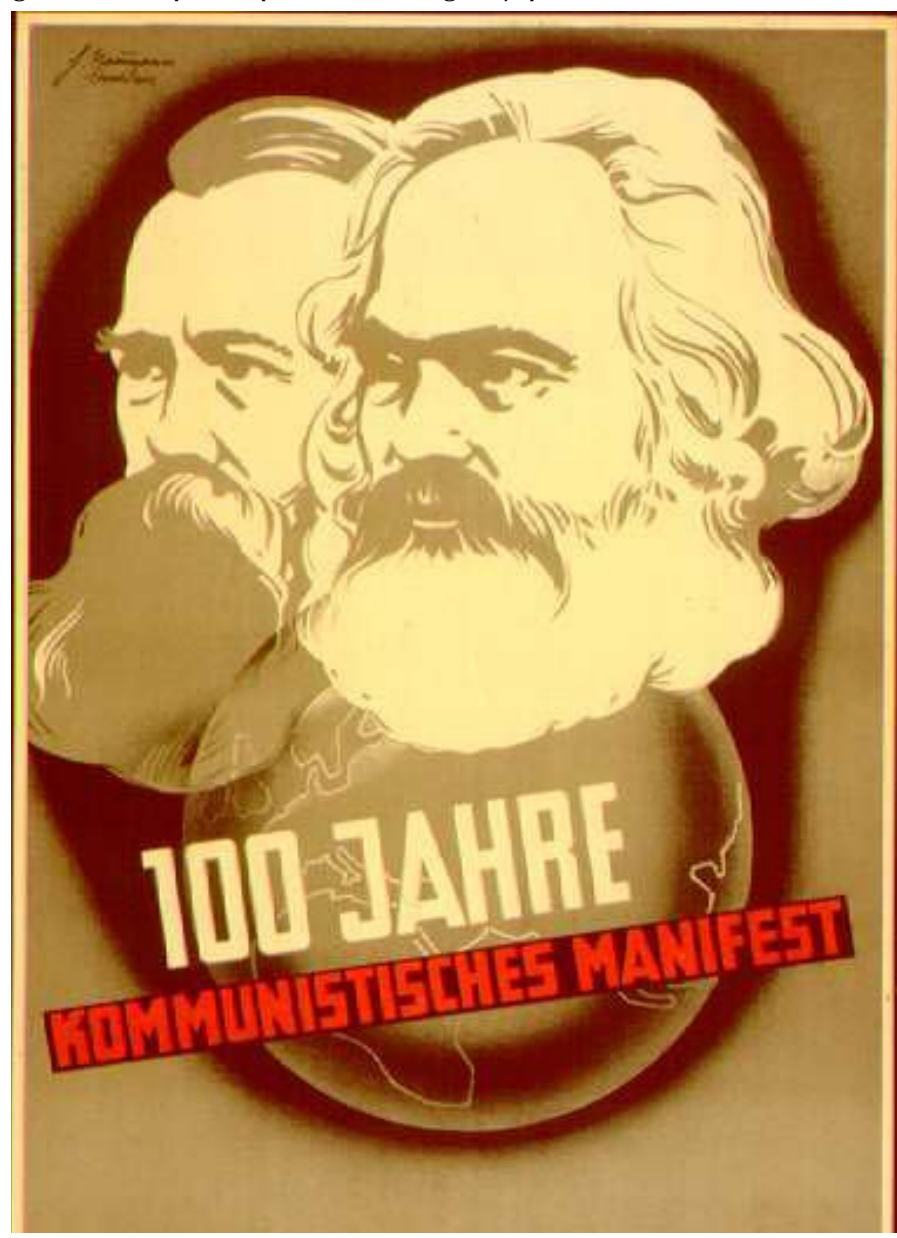


En la Constitución de 1968 se refería al «partido marxista-leninista», con lo que se anclaba la guía reivindicativa del Partido del SED. Para entender el concepto de partido marxista-leninista nos remitimos a Juan Ferrando Badía (1980: 358), quien resume la idea leninista del Estado de la siguiente manera:

«(...) el Poder del Estado como capacidad fundamental en la institucionalización del Estado Socialista. Y esta experiencia (...) se produjo precisa y únicamente por medio del modelo soviético de dominación, cuyo fundamento, en primera instancias se halla en la radical alteración de las relaciones de poder-dominación, en un cambio sustancial de los papeles de clase».

En el caso de la República Democrática Alemana conviene recordar que, tal y como lamenta Fritsche (2008: 21) «todas las acciones parten del pueblo y son para el pueblo. Pero en el socialismo real de la RDA los intereses del pueblo estaban influenciados por el estado. Las elecciones no fueron libres y legítimas».

\subsubsection{Partidos políticos}

A las elecciones celebradas en la RDA, los partidos se presentarían en una lista unitaria conformada a partir de 1950 por el conocido como Nationale Front ${ }^{26}$ (Frente Nacional, $\mathrm{NF})^{8}$. En el Nationale Front estaban integrados los partidos políticos y las organizaciones de masas. Al presentarse todos los partidos bajo una única lista, los carteles de la propaganda electoral estarán destinados a buscar el sentimiento de la población como parte del sistema político.

Bajo el control de la SMAD, los partidos políticos existentes -el Kommunistische Partei Deutschlands (Partido Comunista Alemán, KPD) y el Sozialdemokratische Partei Deutschlands (Partido Socialdemocrático de Alemania, SPD)- se verían obligados a unificarse en un único partido, el Sozialistischen Einheitspartei Deutschlands (Partido unitario Socialista Alemán, SED). De este momento de alianza se extraería el símbolo del SED, compuesto por la unión de dos manos frente a una bandera roja.

Existían sin embargo más partidos políticos, en opinión de Stefan Wolle (1999: 177) «mientas que en la unión soviética se había establecido desde 1918 un estricto sistema de partido único, existía en la RDA como residuo del orden antifascista-democrático también cuatro denominados Partidos amigos». Estos cuatro partidos serán:

- Christlich-Demokratische Union (Unión cristiano demócrata, CDU),
- Liberal-Demokratische Partei Deutschlands (Partido Democrático Liberal de Alemania, LDPD),

- National-Demokratische Partei Deutschlands (Partido Democrático Nacional de Alemania, NDPD)

- Demokratische Bauernpartei Deutschlands (Partido de Campesinos Democrático de Alemania, DBD).

No todos los autores justifican la existencia de estos partidos como residual, Sandoz (1971: 182) es de la opinión que «los partidos burgueses autorizados también a formarse por los soviéticos desde 1945 (...) están destinados, en opinión de la Unión Soviética, a movilizar a favor del nuevo régimen a las clase medias y ante todo a los campesinos, a los que se supone, en principio, hostiles».

Pese a la existencia de estos partidos políticos, bajo el término "el Partido» se entendía inequívocamente el SED compuesto de "camaradas» y "colegas» y dentro de las escuelas y universidades «jóvenes amigos». Los carteles propagandísticos del Partido no están destinados a recla mar el voto, sino que estarán dirigidos a crear un clima de involucración de la sociedad con el Partido. La pertenencia al Partido facilitaba las cosas a todos los niveles, desde las guarderías y colegios a la vida profesional, donde los puestos altos estaban reservados para los miembros de este. Los secretarios generales del SED eran por tanto la figura de mayor poder dentro de la RDA:

- Wilhelm Pieck (1946-1950)

- Walter Ulbricht (1950-1971)

- Erich Honecker (1971-1989)

- Egon Krenz (1989-1990)

En sus 43 años de existencia el Partido organizaría 11 Parteitag (Asambleas de Partido) y 3 Parteikonfernz (Conferencias de Partido).

«En ninguna de ellas hubo discusiones controvertidas o ningún tipo de altercado. Cada palabra dicha públicamente era concienzudamente censurada (...) aparentemente se ajustaban firmemente las elecciones ahí celebradas a las reglas democráticas y requerían un gran despliegue formal $»^{27}$ (Wolle, 1999: 159 .

Los órganos del Partido de mayor relevancia eran el Comité Central (Zentralkomitee, ZK) y el Politburó:

\section{Will \\ Stasiopfer (1976)}

27. Kontroverse Diskussionen oder gar Auseinandersetzunge gab es auf ihnen keine. Jedes öffentlich gesprochene Wort war sorgfältig zensuriert (...) Äußerlich entsprachen die dortigen Wahlen streng demokratischen Regeln und erforderten viel formalistischen

Aufwand.

(Wolle, 1999: 159)
«Trabajamos y planeamos por nuestro fut VEB orange. (desc.b)
Vol 


\section{Comité Central}

El Comité Central del SED es «entre las Asambleas de Partido, el máximo órgano del Partido y dirige sus actividades. Representa al Partido en sus relaciones con otros partidos y organizaciones» (SED, 1976, Art. 39 citado en BiB 2000: 1540). Los asuntos más importantes se discutirían en las ZK-Tagungen (Asambleas del ZK), posteriormente se establecería el ZK-Plenum (Pleno del ZK). Por ley debían reunirse al menos una vez cada medio año, pero tal y como relata Wolle (2000: 161) «en la práctica se reunían más a menudo, entre 3 y 4 veces cada medio año. Su verdadero poder residía en que eran los encargados de decidir los miembros y candidatos del Politburó así como la ratificación de otras funciones importantes».

Los presidentes de las organizaciones de masas, los miembros de los consejos de ministros y altos cargos de los órganos, así como directores de los combinados partían de las decisiones del ZK.

Los presidentes del ZK eran elegidos entre los miembros del mismo, siendo elegible cualquier miembro de más de seis años de antigüedad. Según datos de Herbst, Ranke y Winker (1994: 7775), éstos fueron:

- Fritz Lange (1948-1958)

- Ernst Wabra (1958-1961)

- Hans Jendretzky (1961-1963)

- Heinz Matthes (1963-1977)

- Albert Stief (1977-1989)

POLITBURÓ

El Politburó es el máximo órgano ejecutivo del Partido político. Herbst, Ranke y Winker (1994: 9449) lo definen como «el más alto órgano de decisión del SED y, de facto, el órgano de poder supremo de la RDA».

Se reunían semanalmente para decidir, según expone Fritsche (2008: 77) «las cuestiones políticas y económicas más importantes que serían puestas en práctica por el gobierno», también Herbst, Ranke y Winker (1994: 9455) son de la misma opinión al afirmar que «todas las decisiones políticas y personales básicas e importantes eran tomadas en estas reuniones a puerta cerrada». Al contrario que el ZK de las juntas del Politburó no se constituían protocolos de fe sino los llamados protocolos de acuerdos.

Los miembros del Politburó eran presentados por el secretario general del SED y elegidos por el Comité Central.

Un rol importante dentro del «imperio del SED», era el jugado por las organizaciones de masas. Según el Bundesministerium für innerdeutsche Bezihungen (2000: 4387) eran:

«(...) asociaciones, con cuya ayuda el Partido Socialista Unificado (SED) trataba de organizar todos los grupos sociales y estratos de la sociedad según sus situaciones sociales específicas, intereses y actividades. Las organizaciones de masas debían movilizar a sus miembros tanto en los logros de las metas fijadas por el Partido en sus decisiones y planes económicos, como también ofrecerles la oportunidad de representar sus intereses específicos, organizados y controlados» ${ }^{28}$

Tal era la importancia de estas organizaciones de masas, que varias de ellas formarían parte de la política de RDA:

Freie Deutsche Jugend (Juventud Libre Alemana FDJ)

- Demokratischer Frauenbund Deutschlands (Unión de Mujeres Democrática de Alemania, DFD

- Freier Deutscher Gewerkschaftsbund (Unión de Sindicatos Libres Alemanes, FDGB

- Kulturbund (Unión Cultural, KB)

- Vereinigung der gegenseitigen Bauernhilfe (Asociación de Campesinos de Ayuda Mutua, VdgB)

Los altos puestos de las organizaciones de masas podían ser simultáneamente miembros del Partido. Tal y como ponen de relieve Herbst, Ranke y Winker (1994: 10176)

"(...) en las últimas elecciones con listas unitarias de 1986,

de los 61 escaños del FDGB 58 eran miembros del SED, de los 37 escaños de la FDJ pertenecían 35 a SED y uno a CDU, de 37 J 32 DFD 29 eran del SED, unod los 32 del DAD 29 de del NDPD, de los 14 del VdgB eran 12 miembros del SED. Asi se aseguraba el SED en caso de necesidad una absoluta mayoría de los votos, ya que 276 de los escaños pertenecían a ese partido».

\subsubsection{Estructura política}

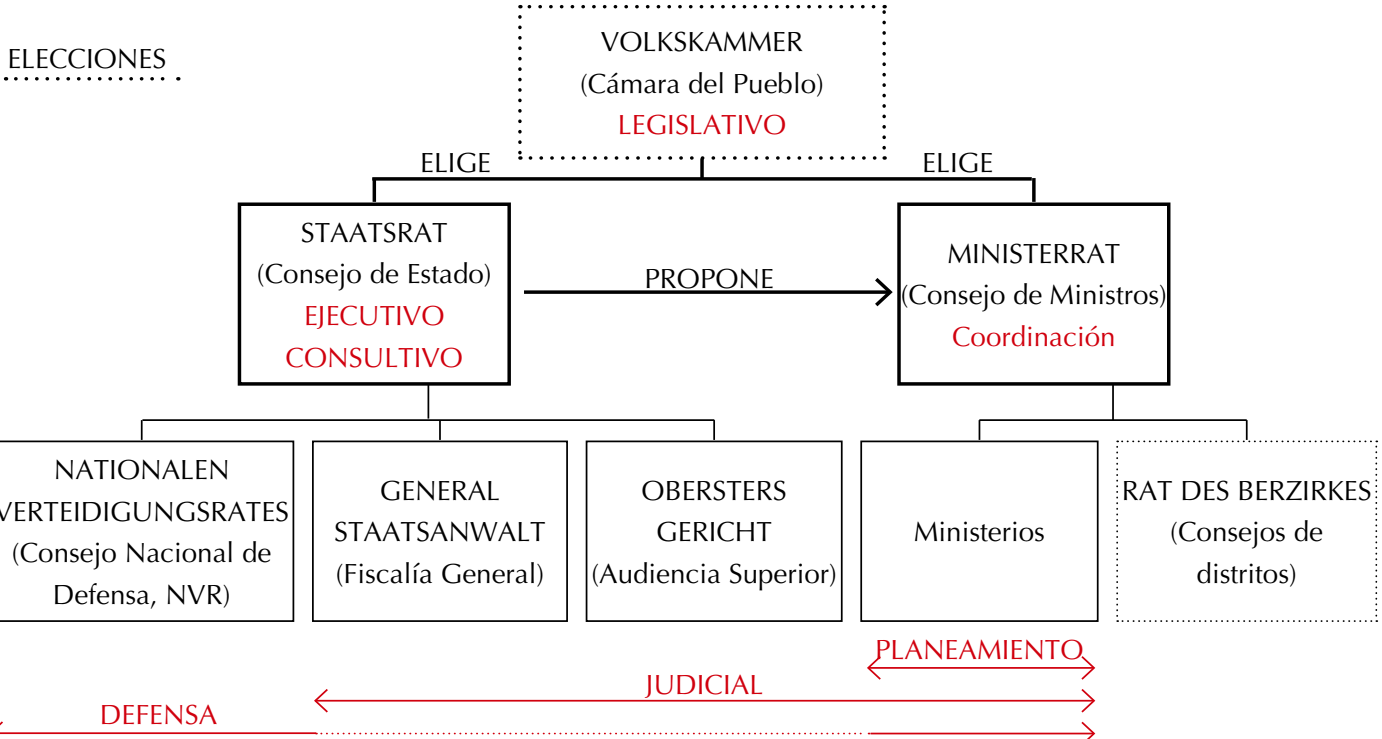

28. Verbände, mit deren Hilfe die Sozialistische Einheitspartel Deutschlands (SED) versuch alle sozialen Gruppen und anknüpfend an deren spezifische soziale Situationen, Interessen und Aktivitäten, zu organisiere Die Massenorganisationen sollen. ihre Mitglieder sowohl für das Erreichen der von der Partei in deren Beschlüssen und in den Volkswirtschaftsplänen gesetzten Ziele mobilisieren, als auch diesen die Möglichkeit bieten, ihre

spezifischen Interessen organisiert (Bundesministerium für innerdeutsche
Bezihungen, 2000: 4387) und kontrolliert vertreten zu können. 


\section{CONSEJO DE ESTADO}

29. Die Volkskammer ist das oberste staatliche Machtorgan der Deutschen Demokratische Republik. Sie entscheidet in ihren Plenarsitzungen über die Grundfragen der Staatspolitik.
Die Volkskammer ist das einzze Die Volkskammer ist das einzig
verfassungs- und gesetzgebende Organ in der Deutschen Organ in der Deutschen
Demokratischen Republik. Niemand kann ihre Rechte einschränken. Die Volkskammer verwirklicht in Einheit von Beschlußfassung und Durchführung.

$$
\text { (RDA, 1968) }
$$

En la Constitución de 1968 (RDA, 1968), artículo 48, definía las atribuciones de la Cámara del Pueblo:

1. «La Cámara del Pueblo es el órgano supremo del poder el estado de la República Democrática Alemana. En sus sesiones plenarias se decide sobre las cuestiones fundamentales de la política estatal.

2. La Cámara del Pueblo es el único órgano constitucional y legislativo en la República Democrática Alemana. Nadie puede limitar sus derechos.

La Cámara del Pueblo materializa en su actividad el principio de unidad de la toma de decisiones y ejecución» 29

Según Herbst, Ranke y Winker (1994: 10178) «no era un parlamento en el sentido clásico, en la práctica resultó ser más bien como una ratificación de la Asamblea, cuyas funciones legislativas estaban muy limitadas desde el principio por la concepción política del SED».

El poder de la Cámara del Pueblo residía en que era la responsable de la designación del Staatsrat (Consejo de Estado) y del Ministerrat (Consejo de Ministros). La Cámara del Pueblo estuvo integrada en sus primeras elecciones por la Einheitsliste (Lista Unitaria), y a partir de 1950 por el Nationale Front. El predominio del SED en estas listas suponía, como señala Fritsche (2008: 77) que «la mayoría para las decisiones políticas del SED estaba asegurada».

Los escaños de la Cámara estaban repartidos de la siguiente manera, según datos de Herbst, Ranke y Winker (1994: 10174-10176):

\begin{tabular}{|c|c|c|c|c|c|c|c|c|c|c|c|c|}
\hline & 岕 & $\stackrel{\supset}{\partial}$ & $\begin{array}{l}0 \\
0 \\
0\end{array}$ & 号 & 全 & 合 & $\overline{\mathrm{O}}$ & 㟔 & 3 & $\frac{\infty}{\frac{0}{0}}$ & 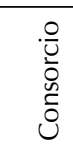 & $\underline{\tilde{u}}$ \\
\hline 1949-1963 & 100 & 60 & 60 & 40 & 30 & 30 & 20 & 15 & 15 & 5 & 5 & \\
\hline 1963-1990 & 127 & 52 & 52 & 61 & 52 & 52 & 37 & 32 & & 14 & & 21 \\
\hline
\end{tabular}

Tabla 3.7

La Cámara del Pueblo estuvo presidida, según datos de Herbst, Ranke y Winker (1994: 10183)

- Johannes Dieckmann (LDPD, 1949-1969)

- Gerald Götting (CDU, 1969-1976)

- Horst Sindermann (SED, 1976-1989)

- Günther Maleuda (DBD, 1989-1990)

- Sabine Bergmann Pohl (CDU, 1990)
En la Constitución de 1968 (RDA, 1968), artículo 66, se definía las atribuciones del Consejo de Estado:

1. «El Consejo de Estado reúne como un órgano de la Cámara del Pueblo entre asambleas de la Cámara de Pueblo, todas las tareas básicas que se deriven de las leyes y decisiones de la Cámara del Pueblo. Él es responsable de sus acciones ante la Cámara del Pueblo.

2. El Presidente del Consejo de Estado sustenta jurídicamente la República Democrática Alemana. El Consejo de Estado decide el cierre de los tratados de la República Democrática Alemana. Éstos serán ratificados por el Presidente del Consejo de Estado. El Consejo de Estado anuncia los tratados ${ }^{30}$

El Consejo de Estado era elegido por la Cámara del Pueblo al comienzo de cada legislatura. Las funciones que desempeñaba las resume el Bundesministerium für innerdeutsche Bezihungen (2000: 6221) en:

- «(...) la representación internacional de la RDA y el derecho de ratificación y denuncia de los tratados internacionales $(\ldots)$

- el apoyo de los Volksvertretungen (Representaciones de Pueblo) locales y el fomento de su actividad en la formación de la sociedad (...) la licitación para las elecciones a los Volksvertretungen de todos los niveles;

- la adopción de decisiones fundamentales sobre la defensa nacional y la organización con la ayuda del Nationalen Verteidigungsrates der DDR (Consejo Nacional de Defensa, NVR), cuyos miembros son nombrados por el Consejo de Estado y

- la supervisión permanente de la constitucionalidad y la legalidad en las actividades de la Corte Suprema y el Fiscal General y el ejercicio de la amnistía y el indulto» ${ }^{31}$.

El Consejo de Estado estuvo presidido, según datos de Herbst, Ranke y Winker (1994: 9846):

- Walter Ulbricht (1960-1973)

- Willi Stoph (1973-1976)

Erich Honecker (1976-1989)

- Egon Krenz (1989)

Manfred Gerlach (1989-1990 en funciones)

- Sabine Bergmann-Pohl (1990 en funciones)

Consejo de Ministros

En la Constitución de 1968 (RDA, 1968), artículo 78, se definía las atribuciones del Consejo de Ministros:

1. «El Consejo de Ministros organiza, en nombre de la Cámara del Pueblo, el desempeño de las tareas política, económica, cultural y social, así como de protección
30. (1)Der Staatsrat erfüllt als Organ der Volkskammer zwischen den Tagungen der Volkskammer alle grundsätzlichen Aufgaben, die sich. aus den Gesetzen und Beschlüsse der Volkskammer ergeben. Er ist der Volkskammer für seine Tätigkeit verantwortlich.

(2) Der Vorsitzende des Staatsrates vertritt die Deutsche Demokratische Republik völkerrechtlich. Der Staatsrat entscheidet über den Abschluß der Staatsverträge der Deutschen Demokratischen Republik. Sie werden vom Vorsitzenden des Staatsrates ratifiziert. Der Staatsrat kündigt Staatsverträge.

31. (...) die völkerrechtliche Vertretung der DDR und das Recht der Ratifizierung und Kündigung von Staatsverträgen (

die Unterstützung der örtlichen

Volksvertretungen und die

Gestaltung der Gesellschaft (...) die

Ausschreibung der Wahlen zu de

Volksvertretungen aller Ebenen;

grundsätzlicher Beschlüsse zur Landesverteidigung und dere Organisation mit Hilfe des

ionalen Verteidigungsrates der DDR (NVR), dessen Mitglieder vom . berufen werden;

die standige Autsicht über die Verfassungsmäßigkeit und des Obersten Gerichts sowie des Generalstaatsanwalts sowie die Ausübung des Amnestie- und Begnadigungsrechtes.

isterium für innerdeutsche
Bezihungen, 2000: 6221) 
32. (1)Der Ministerrat organisiert im Auftrage der Volkskammer die Erfüllung der politischen ökonomischen, kulturellen und sozialen sowie die ihm übertragenen Verteidigungsaufgaben des sozialistischen Staates. Er ist ein kollektiv arbeitendes Organ. (2) Der Ministerrat arbeite wissenschaftlich begründete Prognosen aus, organisiert die Gestaltung des ökonomischen Systems des Sozialismus und leitet die planmäßige Entwicklung der Volkswirtschaft. asignado por el Estado socialista. Es un órgano colectivo de trabajo.

2. El Consejo de Ministros trabaja en la elaboración de pronósticos científicamente fundamentados, organizados en el diseño del sistema económico del socialismo y dirige el desarrollo planificado de la economía ${ }^{32}$.

Los reglamentos definidos por el Consejo de Ministros se hacen en cumplimiento de las leyes y decisiones de la Cámara del Pueblo y los decretos del Consejo de Estado. Su función se reduce a coordinar, supervisar y encargar las actividades de los ministerios, otras autoridades centrales y los consejos de los distritos. Según Fritsche (2008: 77) "establecía las directrices de la política del SED en todos los campos».

El presidente del Consejo de Ministros es propuesto por el Consejo de Estado y aprobado por la Cámara del Pueblo. Los miembros del Consejo de Ministros son elegidos cada cuatro años por la Cámara del Pueblo.

El Consejo de Ministros estuvo presidido, según datos de Herbst, Ranke y Winker (1994: 9073):

- Otto Grotewohl (SED, 1949-1964)

- Willi Stoph (SED, 1964-1973)

- Horst Sindermann (SED, 1973-1976)

- Willi Stoph (SED, 1976-1989)

- Hans Modrow (SED/PDS, 1989-1990)

- Lothar de Maizière (CDU, 1990)

\subsubsection{Sistema electora}

Tal y como hemos descrito en el primer apartado, los partidos políticos establecían unas listas únicas a las elecciones bajo el nombre de Frente Nacional. Los candidatos del NF a cada circunscripción electoral se decidían por consenso interno, de tal modo que las papeletas de la votación estaban ya establecidas el día de las elecciones con los miembros del NF y eventualmente algún candidato independiente.

En las elecciones, convocadas cada 4 años hasta las modificaciones de la Constitución de 1974, que se ampliaría a 5 años, se decidían los miembros de la Cámara del Pueblo. Los ciudadanos de la RDA estaban obligados a votar, numerosos carteles recordaban a los ciudadanos su obligación al tiempo que reforzaban el carácter «democrático del sistema». El sistema de votación consistía en aceptar o rechazar a los candidatos propuestos en la lista. Según el Bundesministerium für innerdeutsche Beziehungen (2000: 6861):
«Las elecciones tenían en la RDA una función diferente que en los Estados democráticos. No tenían la tarea de lograr un decisión de la gente sobre lo que debería llevar a cabo las diversas fuerzas políticas que compiten por un tiempo limitado por el gobierno. (...)La función de las elecciones es confirmar el pode político, demostrar la unidad ideológica y política a la gente y la movilización de las masas, según los actuales objetivos políticos de los dirigentes del SED ${ }^{33}$
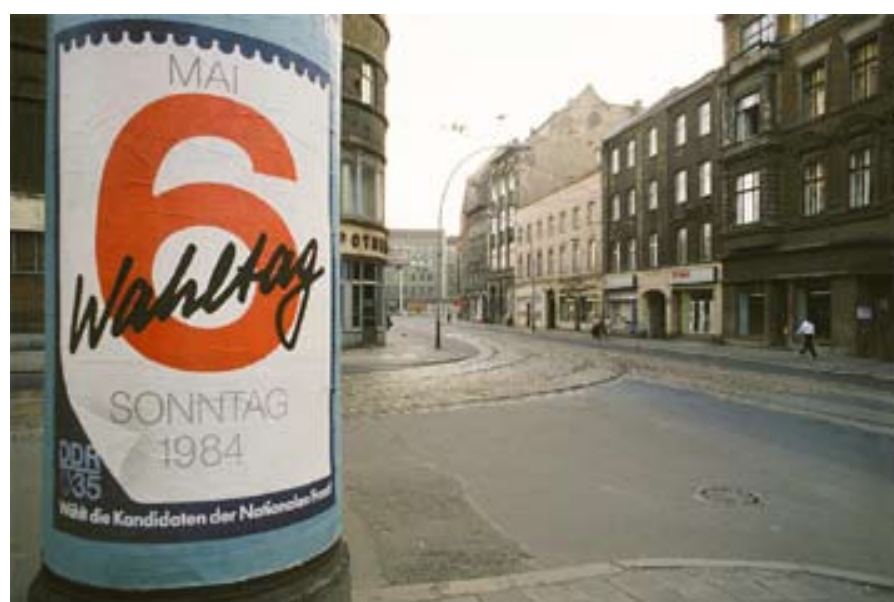

Es por ello que las papeletas electorales, por defecto, aparecían conforme a los candidatos presentados, para aceptarla simplemente era necesario depositarla en la urna electoral. El modo de rechazar a los candidatos era tachar todos los nombres, lo cual suponía que «se iba a la cabina electoral, para tachar la lista unitaria la Stasi registraba que no se estaba de acuerdo con la línea del Partido y el sistema socialista» Fritsche (2008: 97). De la misma opinión es Wolle (1999: 194) cuando relata:

«(...) quien quisiera establecer alguna modificación o rechazar totalmente la oferta debía visitar una cabina electoral, la cual estaba situada en una esquina de la habitación posible de vigilar, y bajo los ojos de la Comisión electoral al completo. Cuando sus miembros, normalmente funcionarios y empleados locales le conocían, debía contar con perjuicios personales o incluso con que su nombre se encontraría en las actas del MfS».

Regularmente, los resultados de estas elecciones establecían un apoyo al gobierno de un 99\% de la población.

\subsubsection{Promoción y propaganda}

Parte del éxito del sistema se basaba en la aprobación de sus ciudadanos, el modo de conseguirlo; la promoción y propaganda del sistema socialista a todos los niveles de la vida. A ello se refiere Sandoz (1971: 209) cuando relata:
33 Die Wahlen haben in der DDR eine andere Funktion als in demokratischen Staaten. Sie haben nicht die Aufgabe, eine Entscheidung des Volkes darüber herbeizuführen, welche der verschiedenen, miteinander konkurrierenden politischen Kräfte für begrenzte Zeit die Regierungsmacht ausüben sollen. (...) Die Funktion der Wahlen besteht in der plebiszitären Bestätigung der Inhaber der politischen Macht, der Demonstration der ideologischpolitischen Einheit des Volkes und der Mobilisierung der Volksmassen für die jeweils aktuellen politischen Zielsetzungen der SED-Führung.

\section{(Bundesministerium für innerdeutsche
Beziehungen 2000: 6861)}

(6a Elecciones. Escoja a los candidatos de

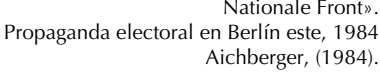


«La prensa de la RDA pedía a los monitores de las colonias de vacaciones que actuaran de modo que los chicos y las chicas adquieran una actitud consci $R D A$, a la clase obrera y a su partido marxista-leninista. Las vacaciones colectivas de los trabajadores en las casa de reposo pertenecientes a la organización sindical sirven igualmente para inculcar a los participantes nociones de la ideología dominante. El Estado y el Partido están presentes en todas partes y nada escapa a su vigilancia: ni el teatro, ni el cine, ni la literatura y en todos estos terrenos reina una estricta sincronización reflejo, como se dice en la RDA, de la socialista».

El diseño gráfico juega un papel fundamental en la propaganda de esta época, ya que está presente en los carteles, las revistas, los folletos, los libros e incluso en los periódicos, todos ellos base de propaganda en un momento en el cual la televisión no está tan extendida. La influencia de la propaganda en la vida diaria será parte del siguiente apartado «contexto-sociocultural», refiriéndonos aquí a los aspectos políticos y organizativos de esta.

Según define Wilfried Schulz (2000: 618):

«El propósito fundamental de la agitación y la propaganda del Partido es dotar a la clase obrera y trabajadores de las ideas revolucionarias del marxismo-leninismo, que conducen a la aplicación con éxito de nuestras ideas en el mundo, que se unan al espíritu de los ideales comunistas y al poder político revolucionario».

Para ello existía un amplio despliegue organizativo a todos los niveles:

\begin{tabular}{|c|c|}
\hline \multirow[t]{2}{*}{ POLITBURÓ } & $\begin{array}{l}\text { Miembro del P. para la ideología, visión científica del mundo, ciencia, cultura y } \\
\text { educación }\end{array}$ \\
\hline & Miembro del P. para la agitación y propaganda de los medios de comunicación \\
\hline \multirow{3}{*}{ COMITÉ CENTRAL } & Miembro del ZK para la propaganda \\
\hline & Miembro del ZK para la agitación \\
\hline & Comisión de la agitación del Politburó y del departamento occidental \\
\hline \multirow{4}{*}{ INSTITUTOS CENTRALES } & Akademie für Gesellschaftswissenschaften (Academia de Estudios Sociales, AfG) \\
\hline & Parteihochschule «Karl Marx» (Escuela del partido Karl Marx, PHS) \\
\hline & $\begin{array}{l}\text { Zentralinstitut für Sozialistische Wirtschaftsführung (Instituto Central para la Gestión } \\
\text { Económica Socialista, ZSW) }\end{array}$ \\
\hline & $\begin{array}{l}\text { Institut für Internationale Politik und Wirtschaft (Instituto de Política Internacional y } \\
\text { Economáa, IPW) }\end{array}$ \\
\hline $\begin{array}{l}\text { DEPARTAMENTOS DE } \\
\text { DISTRITO }\end{array}$ & Secretario de Agitación y Propaganda \\
\hline
\end{tabular}

Tabla 3.8
Todos los cargos en materia de propaganda asistían periódicamente a procesos de formación, pero también debían hacerlo otros funcionarios, en especial los de las organizaciones de masas, poniéndose a su disposición numerosas publicaciones, diarios propagandísticos y libros de texto. El papel de las organizaciones de masas en estas funciones era fundamental, ya que tal y como expone Schulz $(2000,626)$ : «Cientos de miles de agitadores y propagandistas, la pasión cotidiana y la política de la propagación de SED en todo el país... no se puede sustituir», por lo que se les entregaban multitud de libros, folletos, películas, exposiciones, carteles y fotos con los que llegar a la población.

\subsubsection{Ministerio para la Seguridad Nacional}

Durante el control de la SMAD, ya existían fuertes sistemas de seguridad en la SBZ. Tras la constitución del la RDA estos se conformarán en el Ministerium für Staatssicherheit (Ministerio de Seguridad del Estado, MfS), conocido entre la población como la Stasi. El propósito del MfS, tal y como explica Bleek (2009) era extenderse «como una espada y escudo del Partido al servicio de la vigilancia de todos los ciudadanos de Alemania Oriental, en especial la supresión de todos los movimientos de oposición cada vez más extendidos», es decir, garantizar las reivindicaciones, derechos y exigencias del SED. EI MfS se creó siguiendo e ejemplo soviético de la Checá, la Comisión Extraordinaria de Todas las Rusias para Combatir la Contrarrevolución y el Sabotaje.

Para el establecimiento de sus funciones nos remitiremos a Helmut Caspar (2009: 225):

«El MfS era el brazo largo del SED, sus misiones y competencias nunca estuvieron claramente definidas, y no estaba bajo ninguna ley ni control parlamentario, en resumidas cuentas el MfS era la espada y escudo de Partido en el Estado (...). Al MfS le incumbían la supervisión de la población y de los oponentes (enemigos-personas negativas), dirigir la lucha contra los llamados Republikflucht (Escapados de la República) y el control de los tránsitos de viaje así como los contactos de los ciudadanos de la RDA con el Oeste. Fuera de esto llevaba un extenso espionaje en el extranjero. En los años 80 no había a penas ningún terreno de la vida social en la RDA en el que la Stasi no tuviera un ojo y en el cual no se hubiera infiltrado».

Para realizar este cometido el MfS contaba con un amplio número de funcionarios en una rígida estructura organizativa en departamentos. Según los datos publicados por el BStU, al comienzo del MfS había aproximadamente 

los órganos centrales estatales y la promoción de los logros de política juvenil; y el Hauptabteilung XIX era responsable del correo y la telegrafía.

Un papel fundamental en el funcionamiento del MfS sería el jugado por los Inoffiziellen Mitarbeiter (Trabajadores no Oficiales, IM). Estos eran ciudadanos anónimos, los cuales tras una charla de reclutamiento pasaban a ser informadores de la Stasi bajo un seudónimo. Con estas informaciones se realizaban Operativer Vorgang (Procesos Operativos, OV). El OV era el proceso según el cual el Operativen Personenkontrolle (Personal de control operativo, OPK) establecía mediante actas quién era quién. Según el BStU existían un mínimo de 600.000 IM registrados entre 1949 y 1989.

\subsection{CONTEXTO ECONOMICO}

El sistema económico, y en especial la política de consumo constituyó a lo largo de la existencia de la RDA una piedra angular de la política del SED. El consumo, si bien era libre, estaba condicionado fuertemente por los planes económicos estatales -lo que convertía al gobierno, una vez más, en el mayor creador de publicidad y propaganda- y su relevancia venía dada por un lado como muestra del bienestar de la nación, y por otro lado como reivindicación de la mayor eficacia del control socialista de los recursos sobre la de la economía de mercado.

El objetivo del presente subcapítulo es determinar los periodos económicos que se sucedieron a lo largo de la historia de la RDA, los planes y programas que se promovieron y la organización tanto empresarial como comercial. Conocer la realidad económica en la que se desarrolló el diseño gráfico en cada momento nos permitirá establecer las características comunes que se derivan de ella.

\subsubsection{Planes estatales y consumo}

Los últimos años de la guerra estuvieron marcados por las cartillas de racionamiento y por la carestía en el abastecimiento, en ocasiones debido a la falta de materia prima $y$ en ocasiones a la imposibilidad de transporte. Estas condiciones se mantuvieron una vez finalizada la guerra estableciéndose en la Sowjetische Besatzungszone un nuevo sistema de racionamiento en categorías por lugar de residencia y necesidades calóricas ${ }^{34}$.

En 1945 se realiza la Bodenreform (Reforma de la Tierra) bajo el lema "Junkerland im Bauernhand» (Tierra del yunque en manos campesinas) según la cual los latifundios eran expropiados sin recibir indemnización y divididos en pequeñas parcelas para «nuevos campesinos». Como medio de promoción del trabajo en el campo, encontraremos numerosos carteles de esta época protagonizada por orgullosos campesinos. Sin embargo, dicha reforma tuvo serias consecuencias en el abastecimiento de los alimentos, ya que según Kaminsky (1999: 13) «en numerosas ocasiones a los nuevos campesinos les faltaban conocimientos agrarios, lo que bajó dramáticamente el rendimiento de las hectáreas» ${ }^{35}$.

La producción de alimentos sería por tanto el tema central de la II Asamblea del SED en 1947 en la que se establece un plan según el cual esta debe llegar al 56\% de la

\section{国}

Incrementad vuestras cosechas de maiz DEWAG. (desc.b)

34. El criterio seguido era que los habitantes del campo tenían la posibilidad de cultivar sus propios alimentos, lo que no era el caso de los habitantes de las ciudades. Las necesidades caloricas estaban divididas en categorías según el trabajo desarrollado y el control de las mismas era estricto para evitar un uso inadecuado de ellas.

35. Da den Neubauern (...) oftmals landwirtschaftliche Kenntnisse fehlten, sanken die Hektarerträge dramatisch. 
37. SAG era la denominación utilizada para las empresas en la zona SBZ/RDA creadas por las fuerzas de ocupación soviéticas con el fin de reparar los daños de la guerra. La más importante sería la Mina de Uranio Wismut SAG.

38. La industria pesada supondría el 58\% de la inversión frente al $15 \%$ de la industria mecánica o el 6,4\% de la industria ligera. producción anterior a la guerra ${ }^{36}$. El lema de dicha asamblea sería «mehr produzieren, gerechter verteilen, besser leben» (producir más, repartir más justamente, vivir mejor) y como medida para aumentar la productividad se instauraría la Orden N134, la cual consistía en un sistema de salarios acoplados al rendimiento del trabajo. Las inversiones se realizaron fundamentalmente en la industria básica por exigencias de la Unión Soviética quien controlaba la economía de la RDA a través de las Sowjetische Aktiengesellschaft (Sociedades Anónimas Soviéticas, SAG) ${ }^{37}$.

En junio de 1948 se realiza la Währungsreform (Reforma de Divisas) en las dos Alemanias mediante la cual se establece en la RDA el Mark Deutscher Notenbank (Billete de Marco Alemán, MDN) como moneda de curso legal, el cual será sustituido en 1968 por el DDR-Mark. Simultáneamente se instaura la economía planificada cuyo primer plan será el «plan bianual de restablecimiento y desarrollo de la economía de paz 1949/1950» basado en el aumento en la productividad. Todas estas acciones tuvieron consecuencias sobre las empresas de la SBZ/RDA, ya que según Siegfried Kupper (1999: 107):

«La estructura de las propiedades del campo, la industria y el sector servicios sería cambiada sustancialmente desde la fundación de la RDA. A consecuencia de las reformas socioeconómicas cada vez más ciudadanos abandonaron la SBZ/RDA, y la evasión de empresas tuvo entre 1946-1949 su punto más alto»

El primer plan quinquenal (1951-1955), aprobado en la III Asamblea del SED en 1950, persigue que se doble la producción del año 1936, potenciando la industria pesada y la creación de una base industrial con grandes proyectos como la planta siderúrgica de Stalinstadt ${ }^{38}$. El plan contemplaba también la mejora del abastecimiento que permitiera una normalización de la vida y la supresión de las cartillas de racionamiento en 1953.

En los primeros años de la posguerra, las exportaciones de la RDA, como parte de la SBZ, debían ser desviadas hacia Europa del Este. No será hasta comienzos de los 50 que se establezca la estructura de estas relaciones comerciales dentro del marco del Rates für gegenseitige Wirtschaftshilfe (Consejo para la Ayuda Económica Mutua, RGW), según la cual la RDA debía pagar las importaciones de materia prima con productos industriales terminados. A partir de 1955 se reestructuran estos acuerdos de modo que cada país del bloque socialista produzca un determinado tipo bienes; la RDA maquinaria pesada y agrícola, la República
Socialista de Checoslovaquia máquinas, alimentos y industria ligera...

La Guerra Fría, y con ella la carreara armamentística tuvo serias consecuencias en la economía de la RDA. Para Kaminsky (1999) este rearme no había sido tenido en cuenta en el plan quinquenal y fue en detrimento de la mejora del abastecimiento a la población. Para poder costearlo el gobierno redujo las subvenciones y subió los precios y los Arbeitsnormung ${ }^{39}$. El suministro de productos de necesidad diaria funcionaba a duras penas debido a una política económica centrada en la industria metalúrgica en la que la producción de otros bienes era secundaria (Fritsche, 2008)

EI SED, consciente entonces de la fuerza que se derivaba de los problemas de abastecimiento y de la insatisfacción de la población, tomó dos decisiones; por un lado creó el Sicherheitsapparat (Aparato de Seguridad) y por otro lado se sublevó al Neue Kurs soviético relajando la política intern y apostando por el consumo «para construir en los próximos tiempos una seria mejora de la situación económica y de las relaciones políticas en la RDA y sobre esa premisa subir notablemente el nivel de vida de la clase trabajadora y todos los trabajadores» ${ }^{40}$ (SED, 1954; citado en Kaminsky.1999: 20). Las SAG se transfieren en propiedad de la RDA. De este modo el plan quinquenal que se había establecido 1950 sería modificado para producir más bienes de consumo. Para Kaminsky (1999: 21) el balance del prime plan quinquenal no fue positivo, «los estándares de 1936 no serían conseguidos ni en el rendimiento del trabajo ni en el nivel de vida».

El segundo plan quinquenal (1956-1960) se dirigió a la modernización de la economía y de la sociedad a través de una «revolución científico-técnica» que permitiese una mejora del abastecimiento y de la calidad de vida así como una aumento del $40 \%$ en la producción de bienes de consumo. Finalmente, en junio de 1958 se eliminaron las cartillas de racionamiento.

El gobierno, en el V Congreso del SED en 1958 y a la luz de los buenos resultados del desarrollo al finales de los cincuenta, decidió convertir el segundo Plan Quinquenal en e «Plan Septenal de la paz, el bienestar y la felicidad» según el cual los bienes de consumo no se debían reducir a la alimentación, sino también a los aparatos domésticos. Durante la primera mitad del plan los esfuerzos se concentraron en los grandes bienes de consumo lo que hizo que muchos pequeños bienes, como abrelatas o cordones, escaseasen.
39. Los Arbeitnormung (Regulaciones de trabajo) establecían la cantidad de trabajo la que correspondía un sueldo, de modo que al subir dichos estándare era necesario producir más par percibir el mismo sueldo
40.[...] in der nächsten Zeit eine ernsthafte Verbess der wirtschaftlichen Lage und der politischen Verhältnisse in der Deutschen Demokratischen Republik zu erreichen und auf dieser Grundlage die Lebenshaltung der Arbeiterklasse und aller Werktätigen bedeutend zu heben.

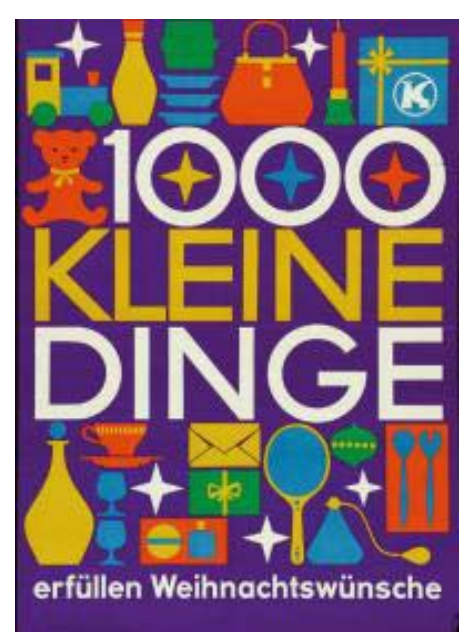

Dequenas cosas llenan sus descos
navideño navideños
DEWAG Handelswerbung Berlin (1965) 
El reparto equilibrado de la producción y la facilidad de acceso a la misma fueron dos temas importantes, objeto de la propaganda estatal, en la segunda mitad de la década de los 50. Se promovía la venta por correo como medio para evitar la necesidad de recorrer los comercios en búsqueda de la mercancía. El equilibrio entre el abastecimiento a las zonas rurales y urbanas y en especial mejorar la calidad de vida en el campo mediante la construcción de Complejos de Abastecimiento tenía una gran relevancia ya que según Kaminsky (1999: 29) «una gran parte de los tres millones del Este que emigraron o fueron expulsados de la SBZ estaban asentados en el campo ${ }^{41}$. Por todo el país se deistribuyeron carteles publicitando estos centros y promoviendo una "compra eficiente».

41. Da auf dem Lande Großteil der etwa drei Millionen aus dem Osten in die SBZ Geflüchteten und Vertriebenen angesiedelt worden war

asc. Consted elige... nosotros se lo mandamos a nuestro sistema de enés Kaminsky (desc)

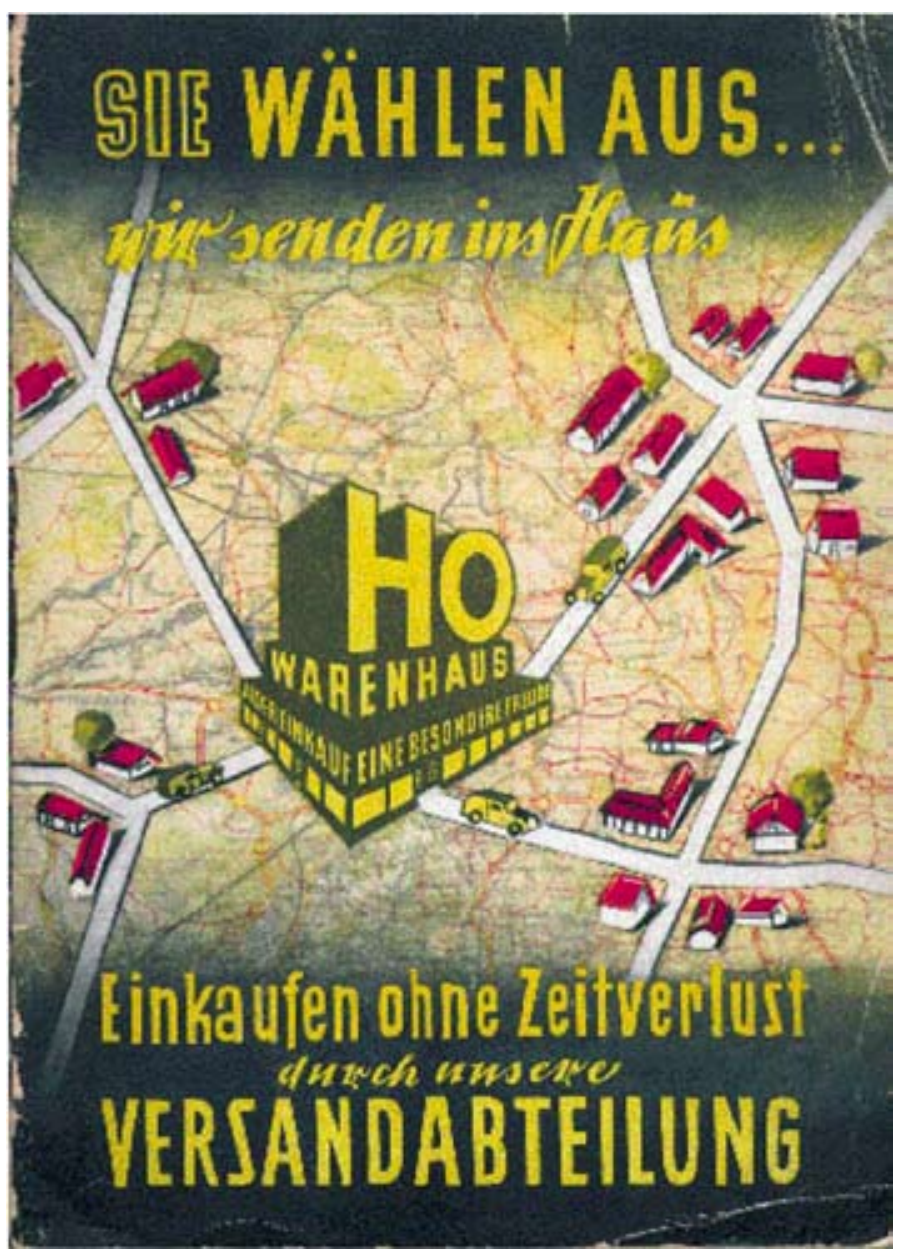

El bienestar conseguido a finales de los 50 dio sus frutos y el número de exilios en 1959 fue el más bajo desde 1949 (143.917 personas) lo que hizo pensar al SED que había llegado el momento de la reforma socialista de la agricultura y de los oficios privados. Para Sigfried Kupper (1999: 110) «la socialización de la agricultura fue un fracaso económico, la producción industrial no correspondió a las altas pretensiones del plan, acabar con los agujeros en el abastecimiento ${ }^{42}$.

En 1961 dos sucesos cambiaron el desarrollo de la economía de la RDA, en primer lugar la Resolución del Politburó de marzo y, en segundo lugar, la construcción del Muro antifascista. Mediante la resolución del Politburó el régimen del SED obtenía todos los derechos de organización y, en consecuencia, «el derecho a decidir sobre cualquier cuestión. Ningún terreno de la política de consumo estaba libre de intervención. Los berlineses del Este se veían incapaces de regular su consumo correctamente ${ }^{43}$ (Heldmann, 2004 308). Para Kaminsky (1999: 26) «la economía privada, los oficios y el comercio estaban limitados por las posibilidades de abastecimiento lo que suponía que entre ellos debían establecerse unas relaciones de corto plazo que la compleja estructura burocrática estatal no pudo sustituir trayendo como consecuencia una nueva crisis».

A lo largo del segundo Plan Quinquenal se había puesto de manifiesto que el método estalinista de producción no resultaba adecuado para la revolución científico-técnica que se pretendía llevar a cabo. Este hecho, junto con la libertad de movimientos que supuso la construcción de Muro, fueron piezas claves en la reestructuración política, de productividad y de producción con la que el gobierno intentó superar el retraso respecto a la RFA y a otras poten cias del Oeste en 1963. El Neuen Ökonomischen Systems (Nuevo Sistema Económico, NÖSPL) pretendía superar el modelo económico estalinista caracterizado por un conjunto de planes centralizados, de tal forma que las autoridade centrales (Consejo de Ministros, Junta Central de Planificación, ministerios industriales) delegarían la toma de decisiones a instancias intermedias (Asociaciones industriales y a las firmas), llevándose a cabo para ello una reforma de precios y del sistema de incentivos para las firmas.

La nueva organización de la industria fusionaba los lugares de producción industrial en «Kombinaten» ${ }^{44}$. El NÖSPL promocionaba muy fuertemente la industria básica mientras que desatendía la industria de los bienes de consumo lo cual influyó negativamente en la economía y en el grado de satisfacción de la población. Tal y como hemos visto anteriormente, los años 60 serían años de cierto bienestar, sin embargo, autores como Kupper (1999: 114) consideran que
42.Die Kollektivierung der wirtschaftlichen Mißerfolg, die industrielle Produktion blieb hinter den hohen Planvorgaben züruck, die Verorgungslücken wuchsen.

43. Die behielt sich dementsprechend auch das Recht vor, jede Einzelnfrage zu entscheiden. Kein Bereich der Konsumpolitik war vor Eingriffen sicher. Zugleich sahen sich die Ostberliner Herrscher außerstand Konsum umfassend zu regel

44. Nombre que recibían las asociaciones de empresas con un mismo dominio de producción 
«en 1970 una gran parte de la población de la RDA vivía en una relativa pobreza».

Con el cambio a Honecker como secretario general del SED, el asunto principal de la VIII Asamblea de 1971 sería la mejora de los niveles de vida de la población y de la productividad. Las conclusiones se resumían en dos puntos: mejora del abastecimiento de bienes de consumo y promoción de la construcción de viviendas. Erich Honecker se mostró partidario de prever únicamente la utilización de aquello que previamente hubiera sido producido, sin embargo, según Kupper (1999: 115) «durante los años sesenta la RDA seguirá consumiendo más de lo que producía».

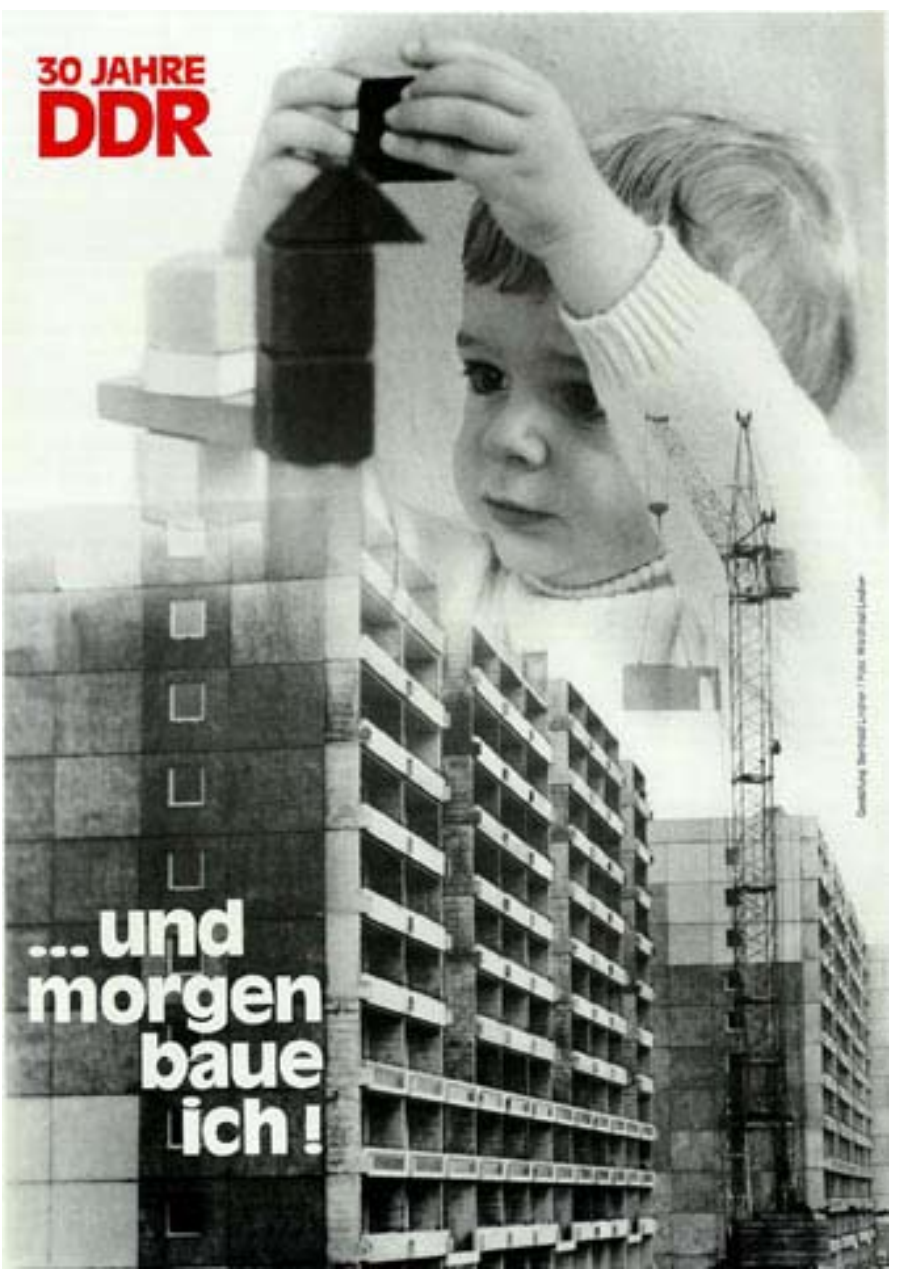

La construcción de viviendas sería precisamente la clave fundamental de la política social del SED en las X jornadas del ZK del SED, en octubre de 1973. Durante la segunda guerra mundial el $65 \%$ de las edificaciones habían sido destruidas, acarreando importantes problemas en el acceso a la vivienda. Para evitar la especulación fue disuelto e mercado de vivienda libre y se crearon varios programas de promoción de viviendas, con su consiguiente difusión mediante carteles con imágenes de los bloques de viviendas característicos de los países socialistas.

La forma de habitar también debía ser reflejo del estilo de vida socialista «el periódico estatal Neues Deutschland llamó a los diseñadores de la RDA a rechazar la arquitectura modernista, que consideraban el equivalente a la americanización de la Alemania del Oeste, y por el contrario emular a sus colegas soviéticos, reciclando las tradiciones estéticas locales para surgir con una síntesis contemporánea, que supuso los estilos de bloques del Este bajo la firma de realismo socialista»(Castillo, 2007: 288).

La RDA era pobre en materias primas, las cuales debía importar de la URSS, haciendo que su límite de crecimiento económico dependiera ampliamente de los dictados del gobierno soviético. Cuando en 1976 la crisis del petróleo supuso la subida de los precios del mismo y la reducción de la cantidad exportada, las repercusiones en la RDA no fueron únicamente económicas, tal y como se demostró con la firma del Schlußakte (Acta de Cierre) de los Procesos de Helsinki que eliminó las esperanzas de apertura hacia el Oeste.

La subida de los precios hizo que de los 150 millones de divisas empleadas en la importación de productos como café o cacao antes de 1976 se pasase a 700 millones. Para evitar que el abastecimiento del extranjero siguiera subiendo la dirección del SED decidió frenar la importación de alimentos subiendo el precio de venta de los productos importados, lo que supuso que la población buscase medios alternativos para acceder a ella. La estabilidad de los precios al consumo de los productos de necesidad básica era un compromiso constante del gobierno el cual los mantenía mediante subvenciones cuya cantidad tuvo que multiplicarse por 6 en la última década de la RDA. 


\begin{tabular}{|c|c|c|}
\hline HALBJAHRSPLAN & 1948 & \multirow{10}{*}{$\begin{array}{l}\text { Vivienda «Besser leben, schöner Wohnen» } \\
\text { Venta por correo «Moderne Menschen kaufen modern» }\end{array}$} \\
\hline \multirow{2}{*}{$\begin{array}{l}\text { ZWEIJAHRPLAN } \\
\text { Reestablecimiento de la economía de paz }\end{array}$} & 1949 & \\
\hline & 1950 & \\
\hline \multirow[t]{5}{*}{ ERSTER FÜNFJAHRPLAN } & 1951 & \\
\hline & 1952 & \\
\hline & 1953 & \\
\hline & 1954 & \\
\hline & 1955 & \\
\hline \multirow{5}{*}{$\begin{array}{l}\text { ZWEITER FÜNFIAHRPLAN } \\
\text { Wissenschaftlich-technische Revolution. }\end{array}$} & 1956 & \\
\hline & 1957 & \\
\hline & 1958 & \multirow{10}{*}{$\begin{array}{l}\text { Wohnungsbauprogramm des Siebens-Jahrsplan } \\
\text { Programm der } 1.000 \text { kleinen Dinge (des tägliches Bedarfs) } \\
\text { Wohlstand, Schönheit, Glück (Plaste...des Wunder der Chemie) } \\
\text { Alles für das Land "Die Stadt hilft das Land» } \\
\text { Die Frauen, der Frieden und der Sozialismus. } \\
\text { Technik in Haushalt } \\
\text { Campañas por el consumo de alimentos sanos } \\
\text { Campañas de moda socialista }\end{array}$} \\
\hline & 1959 & \\
\hline & 1960 & \\
\hline \multirow{2}{*}{$\begin{array}{l}\text { SIEBENJAHR PLAN DES FRIEDENS, DES } \\
\text { WOHLSTANDS UND DES GLÜCKS. } \\
\text { "Überholen und einholen" }\end{array}$} & 1961 & \\
\hline & 1962 & \\
\hline \multirow{5}{*}{$\begin{array}{l}\text { NEUEN ÖKONOMISCHEN SYSTEMS } \\
\text { DER PLANUNG UND LEITUNG. NÖS }\end{array}$} & 1963 & \\
\hline & 1964 & \\
\hline & 1965 & \\
\hline & 1966 & \\
\hline & 1967 & \\
\hline \multirow{3}{*}{$\begin{array}{l}\text { ÖKONOMISCHEN SYSTEMS DES } \\
\text { SOCIALISMUS. ÖSS }\end{array}$} & 1968 & \multirow{22}{*}{$\begin{array}{l}\text { Hobbies «Hilf dich selbst» } \\
\text { Muebles «Immer aktuell- für jede Wohnungpassend» } \\
\text { Alimentación sin aditivos "Optimierte Nahrung» }\end{array}$} \\
\hline & 1969 & \\
\hline & 1970 & \\
\hline \multirow{5}{*}{$\begin{array}{l}\text { FÜNFJAHRPLAN FÜR DIE ENTWIC- } \\
\text { KLUNG DER VOLKSWIRTSCHAFT DER } \\
\text { DDR }\end{array}$} & 1971 & \\
\hline & 1972 & \\
\hline & 1973 & \\
\hline & 1974 & \\
\hline & 1975 & \\
\hline \multirow[t]{5}{*}{ FÜNFJAHRPLAN } & 1976 & \\
\hline & 1977 & \\
\hline & 1978 & \\
\hline & 1979 & \\
\hline & 1980 & \\
\hline \multirow[t]{9}{*}{ FÜNFJAHRPLAN } & 1981 & \\
\hline & 1982 & \\
\hline & 1983 & \\
\hline & 1984 & \\
\hline & 1985 & \\
\hline & 1986 & \\
\hline & 1987 & \\
\hline & 1988 & \\
\hline & 1989 & \\
\hline
\end{tabular}

iV. Desde que en 1948 se instaurase en la SBZ/RDA la economía planificada, toda la materia de producción y promoción quedaría articulada desde el gobierno mediante planes y programas dentro de los mismos, y consecuentemente producirían un gran número de carteles y diseños. Los programas de fomento del consumo gozarían de gran importancia en la década de los 60 haciendo que resulte necesario por tanto establecer una cronología de los mismos que permita situar los fines propagandísticos de cada etapa debido a la influencia que estos programas tuvieron en el diseño gráfico, si bien según Albrecht (1962: 22, citado en Kaminsky, 1999: 42) «las medidas publicitarias estaban insuficientemente simultaneadas con los planes.(...) Así por ejemplo se estimulaban necesidades, para cuya satisfacción sin embargo no existían posibilidades de política nacional».

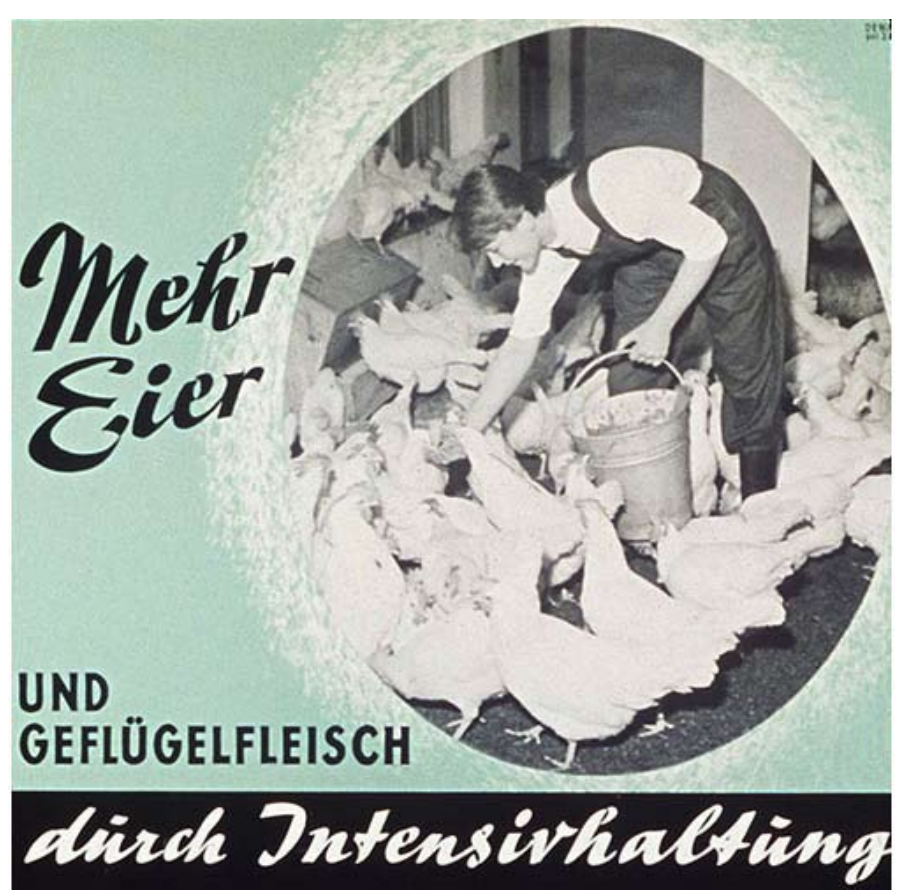


3.3.3 Periodización de la economía de la RDA v

\begin{tabular}{|c|c|c|c|c|}
\hline AÑO & KAMINSKY & KUPPER & JUDT & \\
\hline 1945 & \multirow{8}{*}{$\begin{array}{l}\text { DE LA SOCIEDAD } \\
\text { DE RACIONAMIEN- } \\
\text { TO AL CAMBIO DE } \\
\text { CONSUMO } \\
\text {-Cartillas de racionamiento } \\
\text { Bodenrreform } \\
\text {-Zeit der Erfolg } \\
\text { Reforma de las divisas } \\
\text {-Establecimiento de la } \\
\text { economía planificicada } \\
\text {-Carrera armamentistica } \\
\text { Establecimiento del «Neue } \\
\text { Kurs» } \\
\text {-Levantamientos del } 17 \text { junio } \\
1953\end{array}$} & \multirow{6}{*}{$\begin{array}{l}\text { RECONSTRUC- } \\
\text { CIÓN, REPARACIÓN, } \\
\text { EXPROPIACION } \\
\text { 'Reconstrucción, reparación y } \\
\text { restructuración de los bienes } \\
\text {-Inversiones en industria pesa- } \\
\text { da por exigencias de la Unión } \\
\text { Soviética. } \\
\text {.Puntos más altos en la evasión } \\
\text { de empresas. }\end{array}$} & \multirow{9}{*}{$\begin{array}{l}\text { REPARACIONES Y } \\
\text { DESMONTAJE } \\
\text { - Expropiación de la Indus- } \\
\text { triai (1944/46) } \\
\text { - Bodenreform (1945) } \\
\text { - Reforma de Divisas (1948) } \\
\text {.Plan bianual (1949/50) } \\
\text {. Plan Quinquenal (1951) } \\
\text { " «Construcción del } \\
\text { socialismo". } \\
\text {-Reconstrucción } \\
\text { - Estructura industrial } \\
\text { basada en la industria } \\
\text { primaria. }\end{array}$} & \multirow{9}{*}{ 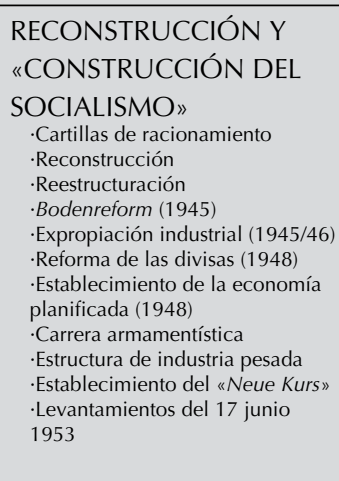 } \\
\hline 1946 & & & & \\
\hline 1947 & & & & \\
\hline 1948 & & & & \\
\hline 1949 & & & & \\
\hline 1950 & & & & \\
\hline 1951 & & \multirow{11}{*}{ 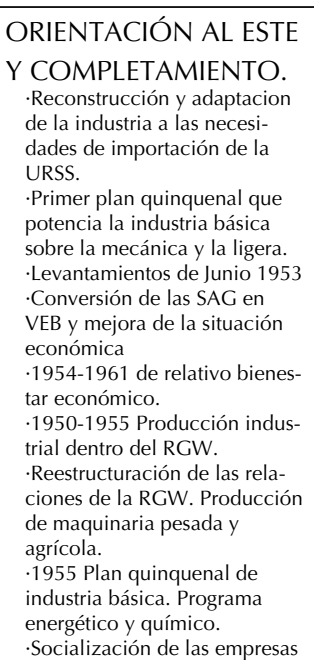 } & & \\
\hline 1952 & & & & \\
\hline 1953 & \multirow{8}{*}{ 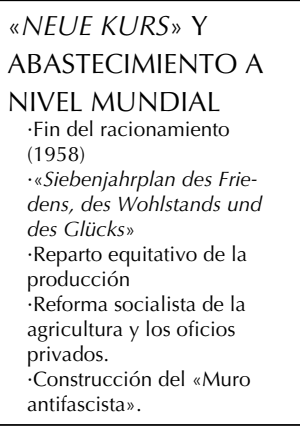 } & & & \\
\hline 1954 & & & \multirow{8}{*}{$\begin{array}{l}\text { ENTRE EL «NEUE } \\
\text { KURS» Y LA CONS- } \\
\text { TRUCCIÓN DEL } \\
\text { MURO } \\
\text {-Reconstrucción, estructu- } \\
\text { ración y reparaciones } \\
\text { - Regulaciones de trabajo } \\
\text {-Levantamientos de junio } \\
\text { 1953 } \\
\text {-Descentralización de los } \\
\text { procesos de decisión. }\end{array}$} & \multirow{8}{*}{ 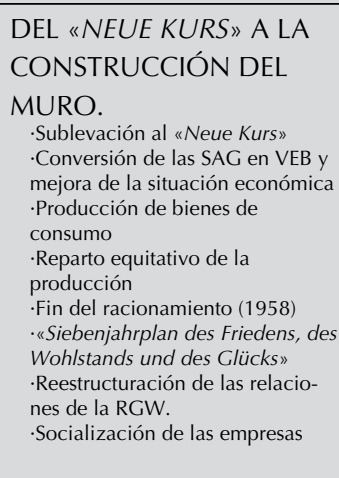 } \\
\hline 1955 & & & & \\
\hline 1956 & & & & \\
\hline 1957 & & & & \\
\hline 1958 & & & & \\
\hline 1959 & & & & \\
\hline 1960 & & & & \\
\hline 1961 & \multirow{10}{*}{$\begin{array}{l}\text { CONSOLIDACIÓN } \\
\text { A LA SOMBRA DEL } \\
\text { Muro } \\
\text {-Desaparición de la econo- } \\
\text { mía privada } \\
\text {-Modernización de la vida } \\
\text { doméstica } \\
\text { Calidad en la alimentación } \\
\text {-OCioy yiempo libre } \\
\text {-NÖSL }\end{array}$} & & & \\
\hline 1962 & & \multirow{9}{*}{$\begin{array}{l}\text { INSERCIÓN DE REFOR- } \\
\text { MAS Y EXIGENCIA } \\
\text { DEL PROGRESO DE LA } \\
\text { INDUSTRIA. } \\
\text {-NÖS 1963-1967 } \\
\text {.OSS 1967-1977 } \\
\text { Creación de “Kombinaten» } \\
\text { industriales "Dos } \\
\text { Desproporción entre los } \\
\text { recursos a la industria y el } \\
\text { abastecimiento a la población. }\end{array}$} & \multirow{9}{*}{$\begin{array}{l}\text { CONSOLIDACIÓN, } \\
\text { INSERCIÓN DE LA } \\
\text { REFORMA Y CAÍDA } \\
\text { DE ULBRICHT } \\
\text {-Reforma política. } \\
\text {-Creación de } \\
\text { "Kombinaten» } \\
\text {-Reforma económica } \\
\text { buscando una mayor } \\
\text { eficiencia } \\
\text {-Reforma de los precios. } \\
\text {-Cambio de Ulbrichta a } \\
\text { Honecker }\end{array}$} & \multirow{9}{*}{$\begin{array}{l}\text { CONSOLIDACIÓN, } \\
\text { INSERCIÓN DE LA } \\
\text { REFORMA Y CAÍDA DE } \\
\text { ULBRICHT } \\
\text {-Desaparición de la economía } \\
\text { privada. } \\
\text {-Aumento en la calidad de vida. } \\
\text {-Reforma politica. NÖSL } \\
\text { - Reestructuración industrial } \\
\text {-Cambio de Ulbricht a Honecker }\end{array}$} \\
\hline 1963 & & & & \\
\hline 1964 & & & & \\
\hline 1965 & & & & \\
\hline 1966 & & & & \\
\hline 1967 & & & & \\
\hline 1968 & & & & \\
\hline 196 & & & & \\
\hline 970 & & & & \\
\hline
\end{tabular}

\begin{tabular}{|c|c|c|c|c|}
\hline AÑO & KAMINSKY & KUPPER & JUDT & \\
\hline 1971 & \multirow{5}{*}{$\begin{array}{l}\text { DE LA SATISFACCIÓN } \\
\text { DE LAS NECESIDA- } \\
\text { DES INDIVIDUALES } \\
\text { A LOS «PROGRESOS } \\
\text { SOCIALISTAS» } \\
\text {-Comienzo de la era } \\
\text { Honecker } \\
\text {.Promoción de la vivienda } \\
\text {-Motorización }\end{array}$} & \multirow{19}{*}{$\begin{array}{l}\text { ORIENTACIÓN AL } \\
\text { CONSUMO, INTEN- } \\
\text { TOS DE INTENSIFI- } \\
\text { CACIÓN, AUMENTO } \\
\text { DE LA FUERZA DE } \\
\text { EXPORTACIÓN. } \\
\text {-Cambio de Ulbricht a } \\
\text { Honecker } \\
\text {.Plan orientado al aumento del } \\
\text { nivel de vidade le la población. } \\
\text {-Aumento de la industria de } \\
\text { buenes de consumo } \\
\text {-Crisis de la importación de } \\
\text { materias primas. } \\
\text {-Aumento de la calidad } \\
\text { de la producción yd le las } \\
\text { tecnología a través de la } \\
\text { microelectrónica. } \\
\text {-Monopolio socialista del ciclo } \\
\text { de producción. }\end{array}$} & \multirow{10}{*}{ 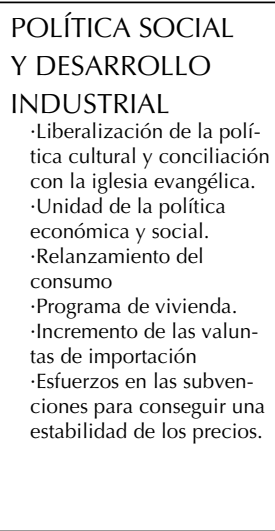 } & \multirow{5}{*}{\begin{tabular}{|l|} 
POLÍTICA SOCIAL Y \\
DESARROLLO \\
-COmienzo de la era Honecker \\
-Promoción de la vivienda \\
-Motorización \\
-Plan orientado al aumento del \\
nivel de vidad de la población. \\
-Unidad de la politica económic \\
y socialal.
\end{tabular}} \\
\hline 1972 & & & & \\
\hline 1973 & & & & \\
\hline 1974 & & & & \\
\hline 1975 & & & & \\
\hline 1976 & \multirow{14}{*}{$\begin{array}{l}\text { LA DÉCADA DE LA } \\
\text { CRISIS } \\
\text {-Crisis del petróleo } \\
\text {-Ampliación del comercio } \\
\text { de productos de \&lujom. }\end{array}$} & & & \multirow{14}{*}{$\begin{array}{l}\text { CRISIS } \\
\text { - Crisis del petróleo y de las mate- } \\
\text { rias primas (1976) } \\
\text { Crisis del abastecimiento (1982) } \\
\text {-Crisis de los créditos }\end{array}$} \\
\hline 1977 & & & & \\
\hline 1978 & & & & \\
\hline 1979 & & & & \\
\hline 1980 & & & & \\
\hline 1981 & & & \multirow{9}{*}{$\begin{array}{l}\text { DECADENCIA Y } \\
\text { LETARGO } \\
\text {-Crisis en el abastecimien- } \\
\text { to (1982) } \\
\text {-Crisis de créditios de la } \\
\text { RDA. } \\
\text { - Mayores esfuerzos en } \\
\text { las subvenciones para } \\
\text { conseguir una estabilidad } \\
\text { de los precios. }\end{array}$} & \\
\hline 1982 & & & & \\
\hline 1983 & & & & \\
\hline 1984 & & & & \\
\hline 1985 & & & & \\
\hline 1986 & & & & \\
\hline 1987 & & & & \\
\hline 1988 & & & & \\
\hline 1989 & & & & \\
\hline
\end{tabular}

$v$. Teniendo en cuenta los aspectos mostrados hasta el momento,

Tabla 3.10 resulta útil establecer unos periodos económicos de la RDA basándonos en características comunes y en los periodos definidos por los investigadores Kaminsky, Kupper y Judt. La Dr. Annette Kaminsky es colaboradora científica en el Stiftung zur Aufarbeitung der SED-Diktatur (Institución para el Tratamiento de la dictadura del SED), Siegfried Kupper es autor de "Ziele und Folgen des zentralgelenkten sektoralen und regionalen Strukturwandels in der DDR-Planwirtschaft» $\mathrm{y}$ «DDR und Dritte Welt», el Dr Matthias Judt es licenciado en historia económica por la Humboldt-Universität e investigador del Zentrum für Zeithistorische Forschung Postdam (Centro de investigación historica de Postdam). 


\subsubsection{Organización empresarial}

Los planes estatales eran definidos en las Asambleas del SED que establecían las líneas que debía seguir la Plankommission (Comisión de planificación estatal) a la hora de decidir que mercancías debían ser producidas y que materias primas serían necesarias para ello. Todas las carencias de producción debían ser tratadas en las sesiones del Comité Central y del Politburó de tal modo que se pudieran organizar las reservas estatales, las exportaciones a la URSS o los intercambios regionales.

La organización de la producción agraria e industrial de la RDA se realizó siguiendo el ejemplo soviético. La reforma agraria de 1946 dividió el campo en pequeños terrenos. Los campesinos debían organizarse en Landwirtschaftliche Produktionsgenossenschaft (Cooperativas de producción agrícola, LPG) cuya producción era controlada estatalmente con el funcionamiento de una gran empresa.

Las empresas se organizaban en Volkseigener Betriebe (Empresas Socializadas, VEB). Las empresas de la DDR se fueron estatalizando paulatinamente mediante la expropiación de las propiedades pasando a ser administradas por el estado. Según Siegfried Kupper (1999: 110) «en 1950 había todavía sobre 304.000 oficios privados con 858.000 empleados (sin contar aprendices), en 1960 tan solo sobre 173.000 con 434.000 trabajadores; estos números volverán a dividirse por la mitad hasta la caída de la RDA». En 1972 se expropian todas las empresas privadas, cooperativas de trabajadores y empresas de artesanos.

Con la expropiación de las empresas todo el diseño gráico y publicidad de los productos pasaba a estar, directa o indirectamente, controlado por el gobierno, de tal modo que encontramos diversos ejemplos en los cuales, conjuntamente con el producto, se promovía el estilo de vida socialista.

Las pequeñas y medianas empresas se fusionaron a lo argo de los años 50 debido al principio del SED de creación de grandes empresas en lugar de establecer relaciones multilaterales entre empresas pequeñas. Las empresas con un mismo campo de producción se asociaban en Vereinigungen Volkseigener Betriebe (Asociación de Empresas Socializada, VVB) -que a partir de 1963 se convertirían en Kombinaten- y en Vereinigungen organisationseigener Betriebe (Asociación de Empresas de Organización Propia, $\mathrm{VOB})$.
Aplicado al campo del diseño gráfico, encontramos, por ejemplo, la VEB Typoart de Dresden, primera fundición tipográfica socializada de la RDA y la de mayor relevancia resultado de la fusión de tres fundiciones: Berlín, Leipzig y Dresden. La VEB Typoart formaba parte a su vez de la VOB Zentrag, Zentrale Druckerei-, Einkaufs- und Revisionsgesellschaft mbH (Central de Empresas de Impresión, Compra y Revisión), que era la encargada de la coordinación de todas las empresas de impresión y publicación, y dentro de sistema era responsable del desarrollo de los tipos que eran necesitados por los publicistas.

Así mismo, se encargaba del diseño gráfico la VOB Deutsche Werbe- und Anzeigengesellschaft (Agrupación alemana de publicidad y anuncios, DEWAG), responsable de la propaganda gubernamental, así como de la publicidad, la agitación cultural, política y económica. La DEWAG aglutinaba 8 empresas de publicidad y fue creada para garantizar el monopolio de la publicidad exigido por el SED.

3.3.5 Regulación y fomento del trabajo

De la regulación del trabajo se encargaba la Wissenschaft liche Arbeitsorganisation (Organización de la Ciencia del Trabajo, WAO) mediante la creación de Arbeitsnormung cuya finalidad era la racionalización del trabajo y aumento de la productividad. Igualmente establecía las necesidades de estudios y periodos formativos y de las remuneraciones.

El plan económico de 1947 perseguía un aumento de la productividad del $30 \%$ basándose en el ejemplo soviético. Como medio para conseguir este aumento se crea los Betriebsleisungen (Dirección de Empresas) y el Aktivistenbewegung (Movimiento Activista) cuyo lema era «So wie wir heute arbeiten, werden wir morgen leben (und einkaufen), (Tal y como trabajemos hoy, viviremos mañana (y compraremos)). En la primera mitad de 1948 se organizaron 140 organizaciones activistas con 13000 socios, sin embargo la gran mayoría de los trabajadores estaban a la expectativa ${ }^{45}$ Tras la sobreproducción del 387\% conseguida por Hennecke se emprendieron numerosas empresas activistas que fueron fuertemente promocionadas por el gobierno.

Los activistas tenían un lugar central en la política económica con la misión de incrementar la productividad del trabajo. Bajo el lema "iAprender de la Unión Soviética significa aprender a vencer!» integraron los "Stachanowschulen», métodos de trabajo soviéticos de aumento de la producción. A partir de los activistas se

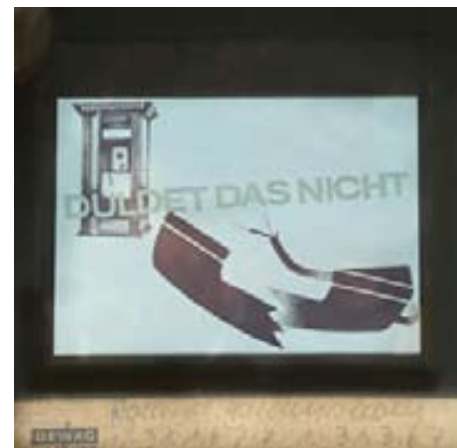

«No lo consientas"
DEWAG (1967)

45. Funcionarios del partido y sindicatos prepararon en octubre de 1948 en Lugau un coto de extracción de carbón en el cual se pretendía demostrar los resultados de la norma 234 y como mediante buena organización trabajo y un uso racional de los podía podía obtener más carbón. Adolf del movimiento al conseguir un aumento del $387 \%$ en l extracción de carbón en Kart-liebknechtSchach. 
desarrollaron nuevas organizaciones de movimientos de masas como el «Neuerer-Bewegung» (Nuevo Movimiento), el «Rationalisatoren- und Erfinderbewegung» (Movimiento de Racionalizadores e Inventores) o la «Brigada de Trabajo Socialista». Los activistas funcionarían hasta 1989 y según Herbst (1994: 7711) «al menos 2/3 de sus miembros serían reconocidos con el "Aktivist der sozialistischen Arbeit» (Activista del Trabajo Socialista) al menos una vez durante su vida laboral por la Freier Deutscher Gewerkschaftsbund (Unión de Sindicatos Libres Alemanes, FDGB)

3.3.6 Regulación del comercio y clases de consumo

\subsubsection{Handelsorganization.}

En los primeros años de la RDA, marcados por la escasez de abastecimiento, el mercado negro tenía una gran importancia. Para combatir el mercado negro, en noviembre 1948 abrirá sus puertas la primera Handelsorganization (Organización de Mercado Estatal, HO) donde se podrán adquirir los productos a un precio fijo, sin necesidad de vales, fuera del mercado negro. Hasta 1958, año en que se suprimen las cartillas de racionamiento, la $\mathrm{HO}$ tendrá el monopolio de la administración de la mercancía, a unos precios fijos. Este sistema suponía acabar con el comercio privado de modo que el comercio estuviera completamente articulado desde el estado. Bajo la organización de la HO se encontraba la Konsumgenossenschaften der DDR (Cooperativa de Consumo de la RDA) cuyos establecimientos Konsum gozaron de tal popularidad que su nombre se generalizó a todas las tiendas de alimentación.

La crisis de 1952 y el reparto insuficiente de mercancías pusieron a los comercios privados al borde del colapso económico y pudieron ser absorbidos por el $\mathrm{HO}$. A finales de los años 50 los problemas, más que en el abastecimiento, radicaban en el reparto de la producción, en especial en las diferencias existentes entre la ciudad y en el campo. Para poder distribuir correctamente la producción era necesario conocer el mercado, para lo cual se decide llevar a cabo una investigación del mercado socialista en el Fachinstitut für den Binnenhandel (Instituto Técnico de Comercio Interior).

Sin embargo, mientras que las necesidades por cabeza de los productos básicos eran fáciles de computar, los productos estimulantes, como el alcohol, el tabaco o el café, y en especial los textiles e industriales, entrañaban una gran dificultad. Para ello se crea en 1961 en Leipzig el Instituto de Investigación de Necesidades (Institut für Bedarfsforschung), (a partir de 1966 Ilamado Institut fü Marktforschung (Instituto de Investigación del Mercado).

\subsubsection{Comercios especiales}

En las $\mathrm{HO}$ se podían adquirir productos de consumo de necesidad diaria, normalmente de producción propia, a bajo precio. A partir de 1959 la población había comenzado a ahorrar y demandaba productos de «lujo». Para poder ofrecer productos del Oeste a los ciudadanos de la RFA en la RDA se crea en 1962 los Intershop, donde se debía pagar en Marcos alemanes. Hasta 1974 estaba prohibido que los ciudadanos de la RDA poseyeran divisas de otras monedas. A partir de entonces también los ciudadanos del Este pudieron comprar en estos establecimientos pagando con Forumscheck.

En 1966 aparecen los Delikat-Läden para ofrecer productos más selectos como la piña en lata o los champiñones. Estos productos, al contrario que los de necesidad básica tenían un precio muy elevado. Según explica Kaminsky (1999: 92) «las tiendas especiales, como Intershop, Genex, Delikat o Exquisit mejoraban el abastecimiento solo a corta distancia y agravaban el descontento de la población sobre la injusticia en el reparto de la mercancía».

En 1977 Politburó decidió a través del ZK del SED ampliar los mercados de Delikat y Exquisit con la siguiente limitación; solo el $40 \%$ de los productos podían ser importados, el $60 \%$ restante debía estar empaquetado en el estilo correspondiente a las mercancías nacionales. Honecker pretendía con esto acabar con la polarización en dos grupos producida por los Intershop, a los que consideraba que «no eran ningún compañero estable del socialismo. Naturalmente no pasamos por alto, que los ciudadanos de la RDA que no posean divisas, en cierto modo se encuentran en desventaja sobre los que sí que disponen de ellas. Con esa cuestión hemos considerado y decidido ampliar la red de comercios Exquisit. También el número de Delikat será aumentado» (Neue Züricher Zeitung, 1998, citado en Kaminsky, 1999: 97).

Los artículos escasos, como los coches, muebles modernos, televisores, ropa de moda o frutas exóticas no se producían suficientemente y se adquirían mediante una lista de espera. Estos bienes se otorgaban a los clientes con buenas 
Otra vía de acceso a los productos escasos, como el café y el chocolate eran los paquetes de la RFA. Durante 80 siguieron las discrepancias ente oferta y demanda por lo que el turismo de compra ya se reducía al ámbito privado, sino que los propios comercios lo efectuaban de tal modo que a finales de la década todo estaba disponible, aunque no siempre en los comercios oficiales.

\subsubsection{Política de precios}

Todos los productos en la RDA tenían un Einzelhandelsverkaufspreis (Precio de Venta Unitario, EVP). La economía planificada fijaba el EVP mediante el sistema económico articulado centralmente. Este precio era fijado estatalmente y no podía ser variado por el mercado de tal modo que el precio de los productos venía impreso en el empaquetamiento. Para el establecimiento del EVP consideraron dos categorías, una de productos de necesidad básica con precios asequibles y otros de lujo con precios elevados. Lo que no quedaba claro era como se relacionaban estas categorías, que pertenecía a cada cual y si existían categorías intermedias (Heldmann, 2004).

La reforma de precios que se realizó en el NÖSPL se reducía a los precios de transferencia entre las empresas y pese al nuevo énfasis en la flexibilidad de precios, la jefatura política introdujo desde la partida, y constantemente reiteró al respecto, una importante restricción: los precios de los productos al por menor, o sea, el precio de venta a los consumidores, no podía subir.

\subsubsection{Contexto social}

3.4.1.1 Demografía y politicas sociales

La decisión del cierre de las fronteras para evitar la emigración tenía claramente una base demográfica. Año a año Alemania Oriental perdía población. Si nos remitimos a los datos expuestos por Wolle (1999: 181):

«Entre 1950 y 1989, se había reducido la población en un total de 2,02 millones de personas. La causa principal para ello sería las huidas al Oeste. Incluso la construcción del Muro, el 13 de agosto de 1961, no hizo subir la curva demográfica hacia 13 de agosto de 1961, no hizo subir la curva demográfica hacia
arriba. En las dos décadas de 1970 hasta 1989 se perderían otros 733.000 habitantes».

Tras un pequeño aumento de la población recién finalizada la guerra el retroceso se hizo evidente. Las razone que exponen Peter y Ursula Ludz (2000: 1511) son que:

«(...) Este es el resultado de las pérdidas, especialmente en los hombres en las dos guerras mundiales, la caída en las tasas de natalidad durante la Gran Depresión, los fracasos de nacimiento durante la guerra y tras ella, el reasentamiento y la migración en el período de posguerra así como una esperanza de vida cada vez más alta y una tasa de natalidad en descenso».

El resultado; una población cada vez más envejecida y un porcentaje de población activa (de los 15 a los 60 para las mujeres y hasta los 65 para los hombres) extremadamente bajo. Varios autores apuntan a esta razón la causante de las políticas de integración de la mujer en el mundo de trabajo. Thorsten Schilling (2006: 26) sostiene que:

«En la RDA, la emancipación del hombre y de la mujer era un derecho garantizado constitucionalmente. El gobierno se complacía en mencionar que, al contrario de lo que ocurría en Occidente, las mujeres de Alemania Oriental gozaban de una emancipación real, dado que, por ejemplo, no existía ninguna diferenciación en los sueldos de hombres y mujeres. (...) La na diferenciación en los sueldos de hombres y mujeres. (...) La
proclamación de la igualdad de género tenía sobre todo funproclamación de la igualdad de género tenía sobre todo fundamentos económicos. A fin de hacer frente a la falta crónica de mano de obra en la economía nacional de la RDA, la par-
ticipación de la mujer en dominios laborales del hombre era imprescindible».

Es por eso que la igualdad de género y la introducción de la mujer en el mundo del trabajo suponía parte importante de la política social y económica, y tendría su reflejo en el diseño y la propaganda socialista. Los carteles en los cuales se mostraban mujeres desempeñando trabajos tradi-
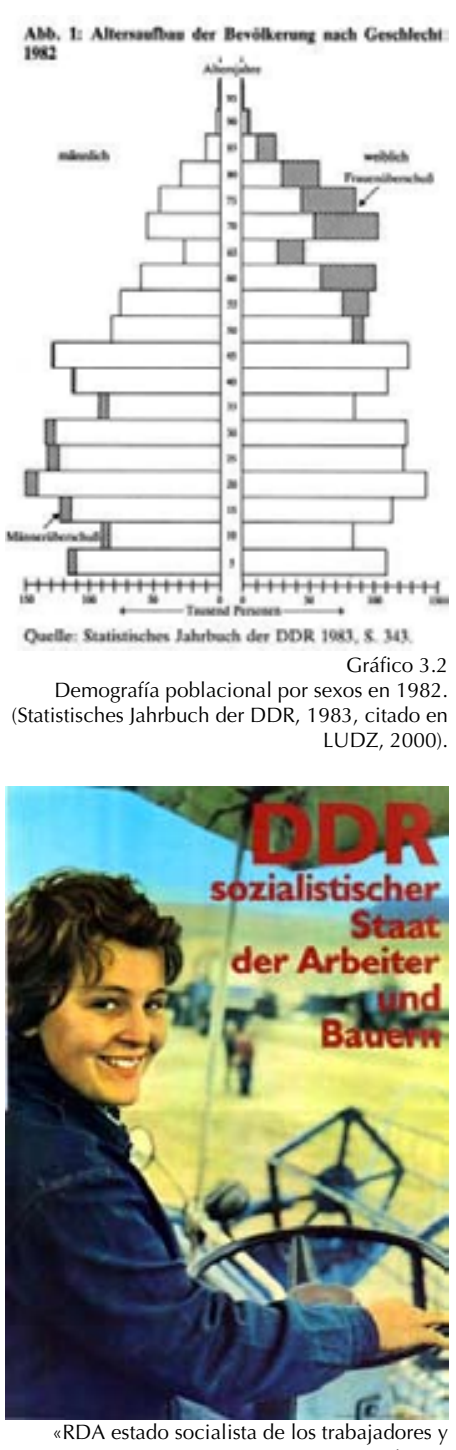

«RDA estado socialista de los trabajadores
campesinos
Calvin (desc). 
cionalmente reservados a los hombres eran habituales. No obstante Schilling (2006: 25) también apunta a que esta pretendida igualdad no era tal, ya que:

«Para darse cuenta de que la sociedad era, sin embargo, dominada por los hombres, alcanza echar un vistazo a la estructura personal de los gremios más poderosos del partido y del gobierno. Eran integrados, salvo contadas excepciones, exclusivamente por hombres. Este desequilibrio se encontraba también en el nivel gerencial de muchas empresas e instituciones».

Los datos que refleja el Zentrales Forschungsinstitut für Arbeit (1989) ratifican ese desequilibrio:

\begin{tabular}{|c|c|c|}
\hline Grupo de sueldo $^{46}$ & $\begin{array}{c}\text { Porcentaje de la población activa } \\
\text { masculina }\end{array}$ & $\begin{array}{c}\text { Porcentaje de la población activa } \\
\text { femenina }\end{array}$ \\
\hline 4 & 3.3 & 13.4 \\
\hline 5 & 18.4 & 43.3 \\
\hline 6 & 35.0 & 29.4 \\
\hline 7 & 32.8 & 11.9 \\
\hline 8 & 10.2 & 1.9 \\
\hline 9 & 0.3 & 0.1 \\
\hline
\end{tabular}

Tabla 3.11

46. El concepto de «grupo de sueldo» se introdujo en la economía planificada a finales de los años 70. Con esta medida se equiparaban los sueldos a grupos de producción; el sueldo bruto en 1988 del grupo 4 era 899 Mark, el del grupo 5101 My el del $91275 \mathrm{M}$
Sin embargo, tal y como ponen de manifiesto Helga Stephan y Eberhard Wiedemann (1990: 557):

«En el oeste de Alemania, las diferencias de ingresos entre hombres y mujeres han sido mucho más fuertes. Por lo tanto, la brecha de ingresos entre las mujeres de la antigua Alemania del Este a los salarios de las mujeres en el Oeste de Alemania es inferior a la brecha salarial entre los hombres».

Según su estudio las mujeres de la RDA cobrarían de media un $83.2 \%$ del salario de un hombre, mientras que en la RFA este sueldo se reduciría al 70,01\%.

Según el Anuario Estadístico de la RDA en 1983 de la población total de 16.702 .000 , estaban en edad de trabajar 10.684.000, con una población activa económicamente de 8.813 .000 de los cuales 4.472 .000 eran hombres y 4.341.000 mujeres. Según Ludz (2000: 1517) «estas cifras muestran, entre otras cosas, que en la RDA la tasa de empleo es muy alta y que aprox. el 50 de la población activa son mujeres».

ndependientemente de las razones para su integración en el trabajo, y de la no paridad en los altos cargos ni en los grupos de sueldo, los datos apuntan a una tendencia social hacia la igualdad de géneros. Según los datos delFrauenreport (Informe sobre la mujer) de Winkler, realizado en 1989, ya desde 1975 la presencia de las mujeres en los estudios superiores era cercana al $50 \%$ y muy superior en las Fachschulen (Escuelas técnicas), llegando al 72,6\% en 1985. En 1990 se publicó un Sozialreport (Informe social) en el cual se revelaba que el reparto de las tareas domésticas, en 1988 (año del estudio), era equitativo entre hombres y mujeres. Al igual que para fomentar la incorporación de la mujer en el trabajo, se realizaron númerosos carteles para reivindicar el papel social de la mujer, ya fuera este el tema principal del diseño, como de forma tangencial, buscando siempre una igualdad de sexos en el diseño.

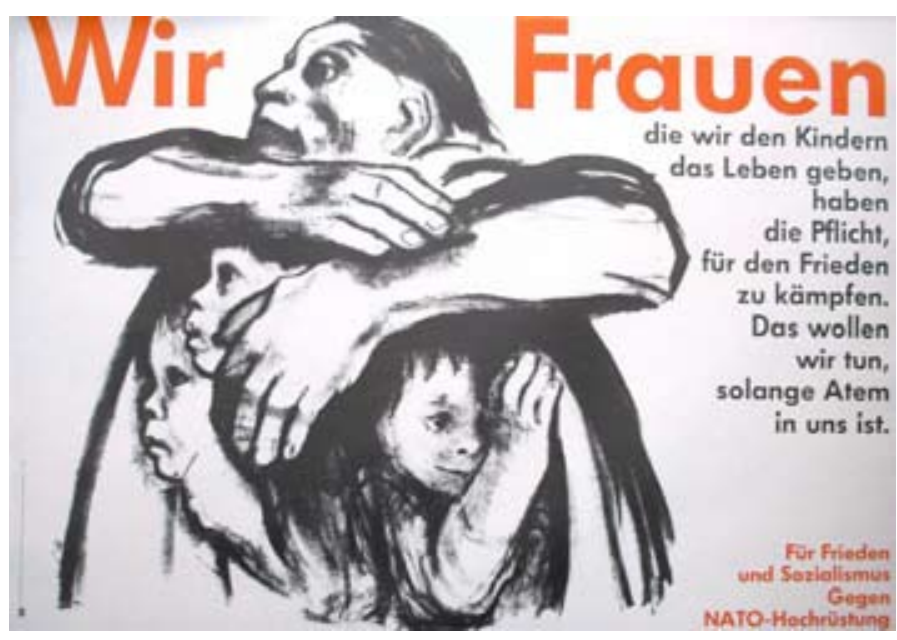

Los datos poblacionales preocupaban a la dirección de SED, con lo que establecieron varios programas de fomento de la natalidad, «madres radiantemente felices con niños sanos en brazos pertenecían a las imágenes favoritas de la propaganda socialista» (Wolle, 1999: 291), sin embargo el éxito de las campañas sería bastante limitado, tal y como podemos observar en el gráfico. La tendencia imperante en la RDA hacia una disminución de los matrimonios y a un aumento de los divorcios supuso que las uniones fueran parte de las campañas. Como resultado, la edad de los matrimonios disminuiría

«(...) en parte como resultado de las políticas sociales (prestamos sin intereses a las parejas jóvenes, ser prioridad en la asignación de viviendas). La edad media del matrimonio en 1981 es de 26,9 años para los hombres y 24,2 años para las mujeres. Esta edad ha ido disminuyendo cada vez más a lo largo de los años. En 1970 la edad media de matrimonio de los hombres era 27,5 añs, las muir comparativos para 1960: 27,6 y 25,0, para 1952: 30.5 y 27.3 ) (Ludz, 2000: 1520).

El modelo de familia predominante será el de 1 y 2 hijos con una progresiva disminución del número de hijos carac-
Thes mujeres, que damos la vida a los ninos, tenemos la obligación de luchar por la paz. Eso queremos hacer mientras nos quede
diento. Por la paz y el socialismo contra el alto armamento de la OTAN,
VEB orange, (Wir Frauen)

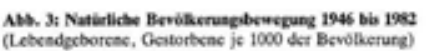

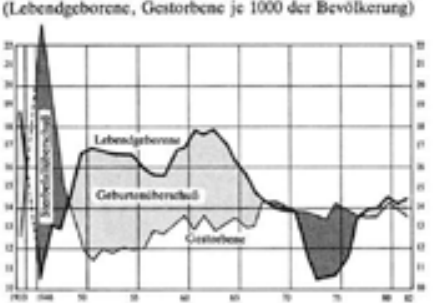
Movimiento poblacional natural entre 1946 y
1982. Lebendgeborene (natalidad) y Gestorben mortalidad) cada 1000 habitantes 
terística de las sociedades industrializadas. Según los datos del ya mencionado Frauenreport, en 1955 el $40,9 \%$ de las madres con hijos tenían 1 hijo, el 29,6\% dos hijos, el 15,1\% tres hijos y el 14,4\% más de 3 . En 1989 las madres con 1 y 2 hijos habían aumentado al 49,5 y 37,9\% respectivamente, disminuyendo las de más hijos a un 11,4 y $4,8 \%$. Resulta interesante, en comparación con otros países occidentales el alto porcentaje de madres solteras, que Ilegaron a suponer un 33,6\% de la natalidad en 1989.

3.4.1.2 Religión

Este alto número de madres solteras es un buen reflejo del laicismo de Alemania del Este. Atendiendo a los datos de Wolle (1999: 410-411):

«El SED la tenía [a la iglesia] como adversario, sobre todo a la unión de las iglesias evangélicas en la RDA con 5,1 millones de integrantes en 1989. Eso suponía una cantidad cercana al 30\% de la población. En las ocho iglesias miembro había 7385 congregaciones con 4704 parroquias, de las cuales 684, es decir, el $14,5 \%$ estaban vacantes.(...) Esos números documentan por un lado del peso considerable de la iglesia evangélica. Por el otro lado habla de la secularización masiva en la RDA, cuando se piensa que el porcentaje de la poblaci a la iglesia evangélica en 1950 , era todavía del $80,4 \%$, y que en menos de una generación se ha reducido a menos de un tercio».

El peso de la iglesia católica era aún menor, suponiendo cerca del 6,1\% de la población.

La voladura de la iglesia universitaria de Leipzig para construir la Karl-Marx Universität, como monumento a la concepción científica del mundo, se entenderá como un símbolo del progresismo gubernamental. Tal y como afirma Heydemann (1999) «pese a un amplio intercambio de opiniones entre el estado y la iglesia el 6 de marzo de 1978, las relaciones entre ambas partes permanecieron problemáticas. Esto se mostró, solo medio años después, por la entrada en vigor de las clases de servicio militar como materia escolar obligatoria en las escuelas superiores».

\subsubsection{Deporte}

Al respecto de los planes y programas sociales del gobierno Wolle (1999: 44) afirma que tenían como meta «el fomento de la personalidad socialista desarrollada: limpia, inteligente, progresista, sana, deportiva y en los carteles casi siempre también rubia». Efectivamente, la imagen de la población que se transmitía en la propaganda de la RDA es la de una sociedad deportiva y en buena forma física. Es por tanto que se promueve el deporte como parte del estilo de vida socialista, buscando su efectividad a dos niveles; por un lado una sociedad sana y deportiva suponía un aumento de la producción y una garantía de fuerza y salud, al tiempo que genera una conciencia patriótica. Por otro lado, enfocado hacia una política exterior, el deporte se usaba como demostración de la superioridad del sistema socialista de la RDA.

Como parte del fomento de la cultura del deporte este fue incluido en la «Ley sobre la participación de la juventud en la formación del desarrollo de la sociedad socialista y sobre su promoción en todas las facetas del la RDA» de 1974 artículo 34: «la cultura física y de deporte pertenecen a la vida de la juventud en la sociedad socialista.(...) El estado socialista garantiza la cultura física y el deporte en todos los aspectos de la vida de la juventud y fomenta la actividad de la DTSB como iniciador y organizador del deporte».

La Deutscher Turn- und Sportbund (la Unión de Gimnasios y Deportes Alemana, DTSB) se creó en 1957 para sustituir al Deutscher Sportausschuß (Comité de Deporte Alemán, DSA). Con ello se modificó el sistema de organización deportiva basado en el modelo soviético de Betriebssportgemeinschaft (Equipos Deportivos de Empresa, BSG y Sportvereinigung (Sociedades Deportivas, SV) mediante el cual los equipos se organizaban siguiendo sectores industriales; S.V Chemie (de la industria química) o S.V. Lokomotive (de la industria ferroviaria). Este sistema de organización deportiva no consiguió despertar el interés del público de tal modo que el DTSB lo sustituye organizando subdivisiones regionales en vez de empresariales. Esta nueva estructura supuso un ingente incremento de los socios; de apenas un millón y medio en 1961 a casi tres millones y medio en 1983.

Con la aprobación de la ley de 1974 el gobierno se hacía responsable del fomento del deporte con lo que creó comisiones deportivas formadas por funcionarios de la DTSB e integrantes de las dirigencias sindicales, de producción salud, empleo y educación y se crearon internados deportivos y centros de entrenamiento para la formación de atletas.

\subsubsection{Sistema educativo}

En 1965 se aprueba la «Gesetz über das einheitliche sozialistische Bildungssystem» (Ley sobre el Sistema Educativo 
47. «Allseitig und harmonisch entwickelten sozialistischen

Persönlichkeiten, die bewußt das gesellschaftliche Leben gestalten, die Natur verändern und ein erfülltes, glückliches, menschenwürdiges Leben führen, zu bilden und zu erziehen. Insbesondere sollen sie befähigt werden, die technische Revolution zu meistern und an der Entwicklung der Sozialistischen Demokratie mitzuwirken.

Dazu sollen sie eine moderne Allgemeinbildung und eine hohe Spezialbildung sowie Charakterzüge im Sinne der sozialistischen, Moral erwerben

Durch die gemeinsame, einheitliche Bildungs- und

Erziehungsarbeit des sozialistischen Staates und aller gesellschaftlichen Kräfte sollen die Kinder, ugendlichen und Erwachsenen befähigt werden, als gute Staatsbürger wertvolle Arbeit zu leisten, ständig weiter zu lernen, sich gesellschaftlich zu betätigen, mitzuplanen und Verantwortung zu übernehmen, gesund zu leben, die Freizeit sinnvoll zu nutzen, Sport zu treiben und die Kunste zu pflegen. Bildungshesetz allen Büg und reiche Recht auf Bilduris gleichermaßen die gesellschastiche Pflicht zur Bildung einschließti.

$$
\begin{aligned}
& \text { geinschließt». } \\
& \text { Hartmut Vogt, 2000: 1974) }
\end{aligned}
$$

Unitario Socialista), Hartmut Vogt (2000: 1974) expone sobre el tema, que tiene por objetivo:

«(...) educar y desarrollar a todos los ciudadanos en una personalidad socialista y armónica, en todos los aspectos, para llevar una vida plena y feliz con dignidad. En particular, deberían ser capaces de hacer frente a la revolución tecnológica y de participar en el desarrollo de la democracia socialista. Para ello, se les da una educación moderna y de alta educación especial y unos rasoos de carácter en el sentido de la moral socialista. yediante la formación común y uniforme a los niños, aloles. Mediante la formación cor y unifor de a centes y adultos a cargo del Estado socialista y de todas las fuerzas sociales, se es capaz de crear buenos ciudadanos capaces de desarrollar su trabajo, de estar constantemente aprendiendo, de ser activos en la sociedad y de asumir la responsabilidad para vivir sano, usar el tiempo sabiamente, ejercitar y cultivar las artes. Para ello, la Constitución y la ley de educación garantizan incluye el derecho social a la educación ${ }^{47}$.

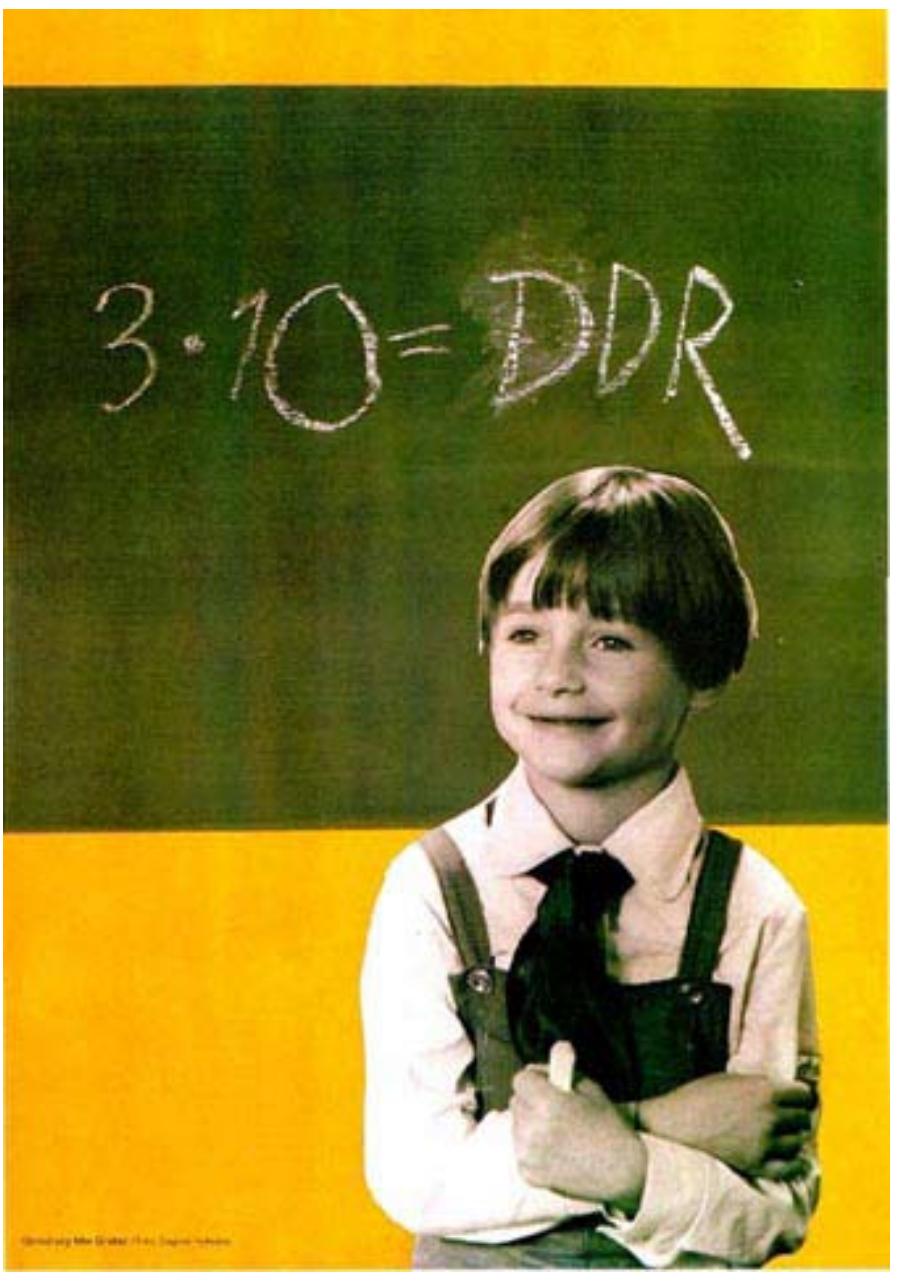

La calidad y preocupación por la educación y la formación profesional dio sus frutos en la Alemania socialista que pronto se complacería de sus logros en este terreno con el uso frecuente de imágenes de escuelas y estudiantes en sus carteles.

A modo de esquema el Sistema educativo de la RDA funcionaría de la siguiente manera:

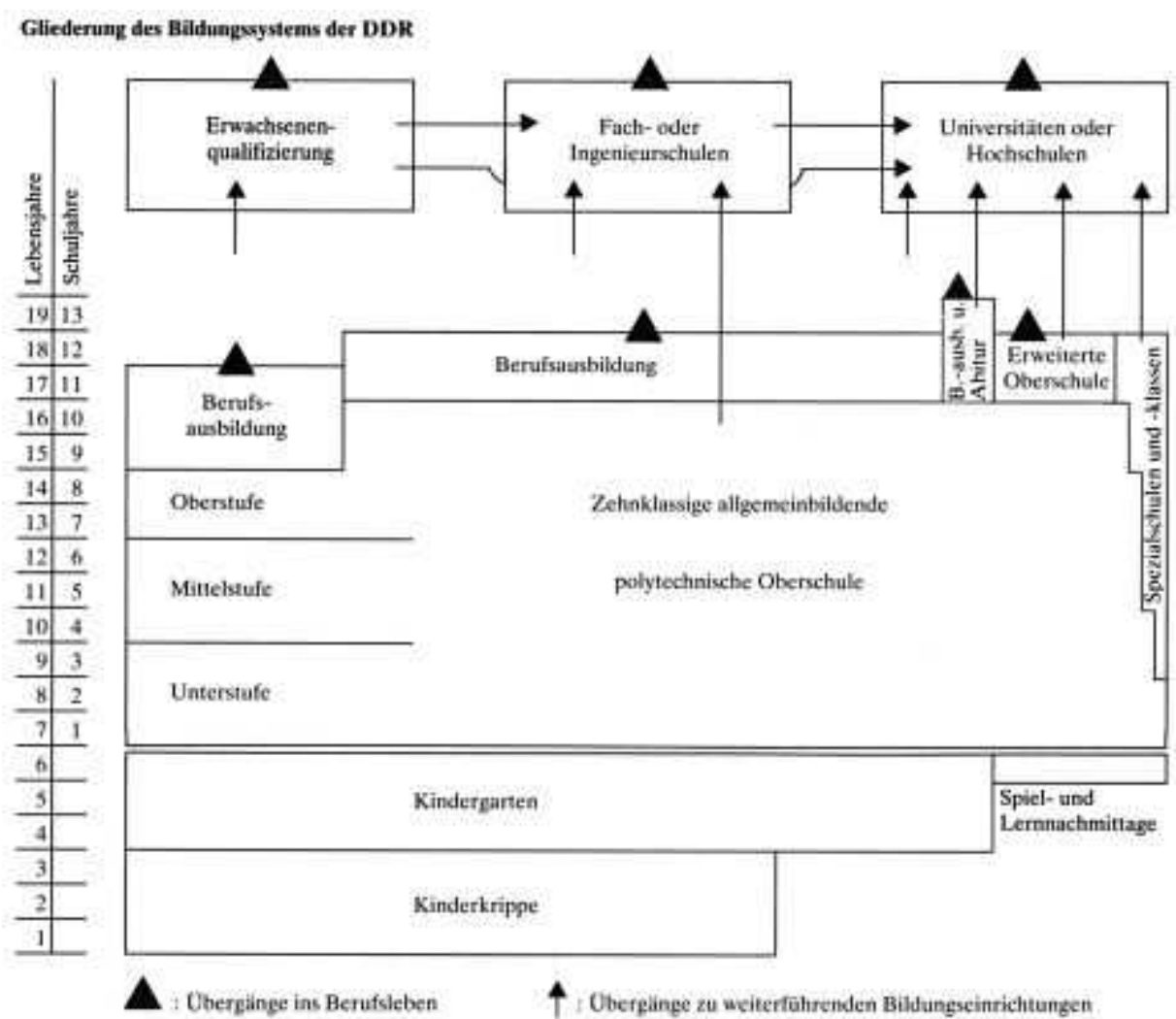

- Kinderkrippe y Kindergarten (guardería y jardín de infancia): «para que las mujeres pudieran trabajase llevaban a los niños desde su primer año de vida o antes a la guardería. De los 3 a los 6 años iban al jardín de infancia» (Fritsche, 2008: 60).

- Polytechnische Oberschule (Escuela Superior Politécnica, POS), estructurada en tres niveles. En estas escuelas se estudiaría ruso como lengua extranjera. Posteriormente se podía acceder a cursos de Berufsausbildung (Formación Profesional) o a la universidad tras realizar el Beruf mit Abitur (Trabajo con bachillerato, BmA) o la Erweiterte Oberschule (Escuela Superior Avanzada, EOS).
Esquema del sistema de formación de la la RDA. 
- Erweiterte Oberschule (Escuela Superior Avanzada, EOS). Iban a estas escuelas los que querían acceder a la universidad. Según relata Fritsche (2008: 60) «solo podían los estudiantes con capacidades distinguidas. Alumnos que se hubieran decidido por el servicio al Ministerio de Seguridad o que sus padres fueran miembros del partido estaban aceptados para la Abitur. La admisión en la EOS dependía en ocasiones de las posiciones políticas de los padres».

- Spezialschulen (Escuelas Especiales). En ellas se estudiaban materias especiales de matemáticas, ciencias naturales, idiomas, música y deporte. Estos alumnos podían acceder a la universidad directamente.

- Erwachsenenqualifizierung (Cualificación de Adultos), Fach- o Ingenieurschulen (Escuelas Técnicas o de Ingenieros) y la universidad o Hochschulen (Escuelas Superiores), eran los estudios superiores que te cualificaban para la vida profesional. Las mujeres podían acceder a ellos tras finalizar la escuela, mientras que los hombres debían realizar primero tres años de servicio militar obligatorio.

En 1967 se aprueba, en las conferencias sobre educación superior, que la orientación a la educación universitaria se haga basada en las necesidades de la industria. Según el Staatssekertariat für Westdeutschefragen (1969: 33), en el curso 1968/69:

«(...) cerca de 30.000 estudiaban pedagogía, 27.700 ciencias de la tecnología, 14.000 derecho y economía, 9.000 matemáticas y ciencias naturales, 7.000 agrónomos y 12.000 médicos. (...) en la RDA había 150 estudiantes por cada 10.000 (en comparación con los 132 por 10000 de 1966) lo que sitúa a la RDA a la cabeza mundial».

Pese a las facilidades que pudieran suponer determinadas afiliaciones políticas, el gobierno de la RDA afirmaría que todo ciudadano tiene derecho a un estudio superior a condición de que supere el Abitur, de tal modo que se complacían de que «el porcentaje de estudiantes procedentes de familiar de trabajadores era por ejemplo en 1967 el 46\%» (Staatssekertariat für Westdeutschefragen 1969: 34) (en comparación según sus datos con del 5,3\% en la RFA). La Constitución del 1968 (art 26.1) obligaba a asegurar una estructura de la población con la posibilidad de acceder a las más altas educaciones en base a los principios de éxito.

Entre los estudios superiores en el campo de las Artes Gráficas destacaba la Hochschule für Grafik und Buchkunst
Leipzig (Escuela Superior de Artes Gráficas y del Libro de Leipzig, HGBL), escuela a la que pertenecieron la mayor parte de los tipógrafos que ejercieron en la RDA. La Escuela que se fundó como Academia de Dibujo, Pintura y Arquitectura en 1764, se reconvirtió tras la guerra en Escuela de Artes Gráficas y del Libro, donde la pintura gozaría de gran prestigio hasta el punto de desarrollarse un grupo de artistas que se conocieron como la «Escuela de Leipzig» y que influiría en las corrientes artísticas de la RDA. En los años 70, y bajo la dirección del tipógrafo Albert Kapr la tipografía y el diseño editorial se convertirían en puntos fuertes de la escuela. Al mismo tiempo era la única escuela que contaba con estudios de fotografía con grado de diplomatura. En 1963 el gobierno decide cortar los trabajos de publicidad y cierra casi todas las escuelas de diseño, menos las dedicadas a la edición de libros y a la tipografía.

\subsubsection{Asociaciones de masas}

Las asociaciones de masas fueron un elemento fundamental de la sociedad de la RDA. Tenían una fuerte componente política pero eran sobre todo organizaciones sociales y de tiempo libre, sobre todas ellas destaca los clubes juveniles, en los cuales se alternaban actividades al aire libre con discoteca y debates sobre política y sociedad. La participación en dichos clubes era libre, pero con una fuerte promoción gubernamental, ya que tal y como relata Wolle (1999: 184) «una parte importante de su influencia era que los miembros de la FDJ podían acceder pronto a las instituciones de educación superior, recreación y facilidades deportivas, y en última instancia oportunidades de carrera». La presenci de las asociaciones de masas en la día a día era evidente, ya que constituían uno de los principales creadores de propaganda. La difusión de las asociaciones de masas y de sus actividades mediante carteles era parte de la escena diaria en Alemania Oriental y estaban estrechamente ligados a los ideales del partido.

3.4.2.1 Freier Deutscher Gewerkschaftsbund (Unión de Sindicatos Libres Alemanes, FDGB)

La FDGB era la asociación de masas más grande e importante de la RDA, con casi 9.5 millones de socios en 1987. Todas las decisiones que afectaran a la vida laboral debían contar con su consentimiento. Según explica Hartmut Zimmermann (2000, 2611):

«Además de la información sobre la tareas de trabajo del plan anual, tenían sobre todo las atribuciones de gestionar una

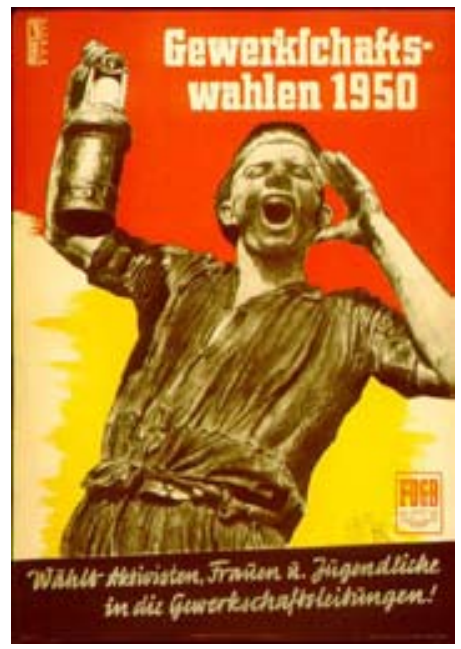

«Elecciones a los sindicatos 1950. iEscoja
activistas, mujeres y jóvenes en la Unión de Deutsches Historisches Museum (1949) 
política social, la formación profesional, proyectos culturales y educativos, las formas salariales aplicables asignación del fondo de premios y las medidas especiales de apoyo para las mujeres y los jóvenes».

Las asignaciones de los premios era una de las medidas que más poder le daba a la organización ya que estos servían de

«(...) recompensa al rendimiento individual, la evaluación 48. Im Lohn sollen die individuelle Leistung, die volkswirtschattlich-politische Bewertung der spezifischen Qualifikation sow Werkëtigen Qualifikation der Werktätigen Qurch die Anwendung dieser Crundsätze entstehenden, stark grusten Entlohnungssystem wird das Ziel verfolgt, sowohl einen ständigen Anreiz zur Steigerung der individuellen Arbeitsleistung zu bieten als auch die Arbeitskräfte entsprechend den ökonomischen Zielsetzungen zu lenken.

económico-político de la tarea específica de trabajo y las cualificaciones de los trabajadores. Mediante la aplicación de estos princip emergentes, el sistema d calificado tiene como objetivo permanente para aumentar la eficacia del trabajo individual, así como para guiar a los empleados con los objetivos económicos» ${ }^{48}$ (Hartmut Zimmermann, 2000: 2613).

También Wolle (1999: 181) reconoce la importancia de os incentivos de los premios «la FDGB realizaba sus actividades especialmente en dos ámbitos de la unidad sindical de la RDA: los pagos de los premios y la formación de las vacaciones». Y es que la FDGB era la rama del gobierno dedicada al control de las actividades recreativas. Eran los encargados de la creación de una red de Lugares de Vacaciones y Residencias para los trabajadores y tenían un poder tal, que la inscripción en un hotel si no era a través de los sindicatos era prácticamente imposible. Esta red estaba recogida en la Constitución de 1968 (RDA, 1968), en la cual se garantiza el derecho a las vacaciones al tiempo que se organizan las mismas:

Artículo 34: Todo ciudadano de la RDA tiene derecho al tiempo libre y al ocio. Este derecho se garantiza:

- A través del control legal del tiempo de trabajo diario y semanal

- A través de vacaciones anuales pagadas

- A través del desarrollo programado de la red de asociaciones populares de centros de recreo y vacaciones».

3.4.2.2 Gesellschaft für Deutsch-Sowjetische Freundschaft (Sociedad para la Amistad Alemano-soviética, DSF)

La DSF era tras la FDGB la segunda organización de masas de la RDA por tamaño con cerca de 6,4 millones de socios en 1988. Su objetivo era dar a conocer la cultura y sociedad rusa en la RDA y ayudar en la construcción de la cultura alemana con base soviética. En la III Asamblea de partido celebrada en 1951 crearían el conocido lema «Von der Sowjetunion lernen, heißt siegen lernen» (Aprender de la Unión Soviética, significa aprender a vencer). Según el Bundesministerium für Innerndeutsche Beziehungen (2000, 2928):
«A partir de entonces, la labor ideológica se llevaba a cabo en tres direcciones principales: la evidencia del surgimiento de la Unión Soviéti la Unión Soviética en la primera potencia mundial, la explicación de la importancia de la estrecha alianza entre la RDA y la URSS; y el aprovechamiento de la experiencia de la Unión
Soviética en la «Construcción del socialismo»/comunismo».

3.4.2.3 Deutscher Turn- und Sportbund (Unión de Gimnasios y Deportes Alemana, DTSB)

La DTSB fue una organización que agrupaba a todos los atletas y la tercera en la RDA en número de socios. Hemos hablado anteriormente de la función del DTSB como comité deportivo para el fomento del deporte a nivel profesional cuya meta era alcanzar la excelencia deportiva.

A nivel social destaca su labor de animar a hacer ejercicio con regularidad especialmente a niños y jóvenes. Contaban con un programa bien elaborado para la detección y selección de los niños en edad escolar con talento talentos para su formación en escuelas de alto rendimiento deportivo.

3.4.2.4 Freie Deutsche Jugend (Juventud Libre Alemana, FDJ)

La FDJ era la asociación más popular en la RDA, estaba integrada por jóvenes de los 14 a los 25 años, y tal y como refleja Wolle (1999: 183) «la FDJ marcó como ninguna otra organización la vida diaria de la RDA». El objetivo políticoideológico de la FDJ fue la influencia en todos los ámbitos de la vida de los jóvenes en Alemania Oriental, la propagación del marxismo-leninismo y la puesta en práctica de la conducta socialista. En las organizaciones de la FDJ se alternaban actividades al aire libre con discoteca y debates sobre política y sociedad. Pertenecían al FDJ en 1989 el 76\% de los jóvenes alemanes, pero según los datos de Wolle «pertenecían en la Escuela superior politécnica a la FDJ sobre el $90 \%$ mientras que en la Escuela superior avanzada eran casi el 100\%». Wolle se refiere con esto a los privilegios que suponían la pertenencia a estas organización, Arnold Freiburg (2000: 2558) resalta, sin embargo, que parte de las funciones de la organización era «evaluar los resultados del aprendizaje, el orden y la disciplina de cada estudiante miembro de la organización».

Destaca entre las actividades de la FDJ la organización de manifestaciones y concentraciones multitudinarias en los Ilamados Nationales Jugendfestival der DDR (Festivales Juveniles Nacionales de la RDA), cuyo impacto en la sociedad alemano oriental se evidencia en su gran difusión no

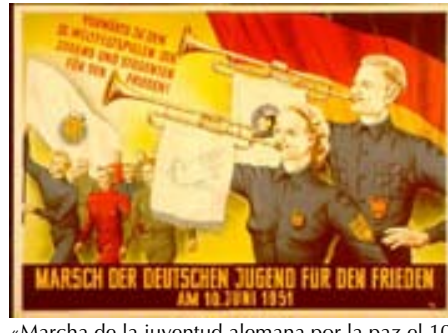

de Junio de 1951
GF (195 


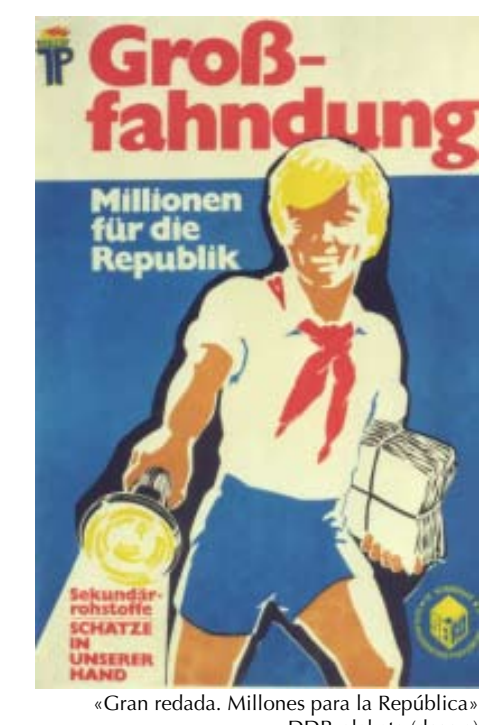

DRR-plakate (desc.
DDán solo mediante carteles, sino también mediante la edición de sellos conmemorativos.

\subsubsection{Junge Pioniere/Thälmannpioniere (Jóvenes Pioneros/} Pioneros Thälmann, JP)

La organización de los Jóvenes Pioneros era la única organización de masas infantil permitida en la RDA. Pertenecían a los JP los niños de los 6 a los 14 años. Su labor en el adoctrinamiento de la juventud como miembro de la nueva sociedad socialista es mencionado por todos los autores, y se refleja en su Estatuto de la organización de Pioneros «Ernst Thälmann» (1987, citado en Fritsche, 2008: 42): «nuestro saludo Pionero dice: Por la paz y el socialismo¡estad preparados!-jsiempre preparados! Damos el saludo pionero mientras elevamos la mano derecha con los dedos cerrados sobre la cabeza».

En 1952 recibe el nombre Ernst Thälmann en memoria del jefe del Kommunistische Partei Deutschlands (Partido Comunista de Alemania, KPD) durante la República de Weimar, que fue asesinado en un campo de concentración. De la primera a la $3^{\circ}$ clase se denominaban Jóvenes Pioneros y llevaban el pañuelo azul y de la $4^{\circ}$ a la $7^{\circ}$ Thälmannpioniere cuyo pañuelo era rojo, indumentaria con la que se representa a la infancia de la RDA en un alto número de imágenes propagandísiticas.

\subsubsection{Otras organizaciones de masas}

Existían en la RDA otras organizaciones de masas entre las que destacan:

- Kulturbund der DDR (Unión Cultural de la RDA), organización cuyo fin era involucrar al público en os ideales socialistas.

- Demokratische Frauenbund Deutschlands (Unión de Mujeres Democráticas de Alemania, DFD) con el objetivo de la promoción de la mujer.

- Gesellschaft für Sport und Technik (Sociedad para el Deporte y la Tecnología, GST) cuya tarea más urgente era reclutar y preparar a los jóvenes para el servicio en el ejército.

- Volkssolidarität (Solidaridad popular, VS)

- Verband der Kleingärtner, Siedler und Kleintierzüchter (Asociación de los Pequeños Jardineros, Rancheros y Criadores de Animales Pequeños, VKSK)
- Vereinigung der gegenseitigen Bauernhilfe (Asociación de Campesinos de Ayuda Mutua, VdgB)

- Kammer der Technik (Cámara de Tecnología, KDT)

- Nationales Olympisches Komitee der DDR (Comité Olímpico Nacional de la RDA, NOK)

- Landwirtschaftliche Produktions-Genossenschaften (Cooperativas de Producción Agrícola, LPG)

- Bund der Evangelischen Kirchen in der DDR (Asociación de Iglesias Evangélicas en la RDA, BEK)

- Domowina-Bund Lausitzer Sorben (Federación de Sorabos de Lusacia)

- Deutsches Rotes Kreuz der DDR (Cruz Roja Alemana de la RDA)

3.4.3 Contexto cultural

Como hemos visto anteriormente el control gubernamenta abarcaba todos los aspectos de la vida. El ámbito cultura era por supuesto parte fundamental de la vida -por tanto del control- de la RDA. Mientras Sandoz (1971: 209) habla de la estricta sincronización del arte reflejo, como se dice en la RDA, de la «realidad socialista», otros autores como Bernardo Subercaseaux (1991: 139-140) van más allá afirmando que:

«El caso de la ex República Democrática Alemana constituye un ejemplo de la fagocitación del arte desde la esfera política y del poder. En las artes plásticas hasta la década de los 70 predominó el arte de partido, de agitación y de propaganda. El régimen favorecía, con parcialidad indisimulada, la tendencia a la pintura figurativa, al mismo tiempo que oprimía y desincentivaba a pintores abstractos y constructivistas, o a todos aquellos que cultivaban su propia interioridad. Creció así, por una parte, en Alemania Oriental una arte realista forzado (...) un arte de encargo, impregnado de política y retórica. En la RDA se fue creando entonces una cultura socialista nacional».

Hasta tal punto era importante esta dependencia, que quedó reflejado en la Constitución. Mientras que en la de 1949 (RDA, 1949) aparecía:

«Artículo 34: El arte, la ciencia y su enseñanza son libres. El estado toma como obligación y compromiso su protección, especialmente contra el abuso como intención de contradecir el mandato y el espíritu de la Constitución.»

Casi 20 años más tarde, (RDA: 1968) se recogía en su artículo 18:

1. «La cultura nacional socialista pertenece a los fundamentos de la sociedad socialista. La RDA fomenta y protege la cultura socialista, la cual sirve a la paz, el humanismo y el desarrollo de la comunidad socialista. Lucha contra 
49. (1) Die sozialistischen Nationalkultur gehört zu den Grundlagen der sozialistischen Gesellschaft. Die Deutsche Demokratische Republik fördert und schützt die sozialistische Kultur, die dem Frieden, dem Humanismus und der Entwicklung der sozialistischen Menschengemeinschaft dient. Sie bekämpft die imperialistische Unkultur, die der psychologischen Kriegführung und der Herabwürdigung des Menschen dient. Die sozialistische Gesellschaft fördert das kulturvolle Leben der Werktätigen, pflegt alle humanistischen Werte der nationalen Kulturerbes und der Weltkultur und entwickelt die sozialistische Nationalkultur als Sache des ganzen

(2) Die Förderung der Künste, der künstlerischen Interessen und Fähigkeiten aller Werktätigen und die Verbreitung künstlerischer Werke und Leistungen sind Obliegenheiten des Staates und aller gesellschaftlichen Kräfte. Das künstlerische Schaffen beruht auf einer engen Verbindung der Kulturschaffenden mit dem Leben des Volkes.

(3) Körperkultur, Sport und Touristik als Elemente der sozialistischen Kultur dienen der alseilgen Korperlichen und geistigen

(RDA, 1968 la barbarie imperialista la cual sirve para la guerra psicológica y la desautorización de los hombres.

La sociedad socialista fomenta la vida cultural de los trabajadores, cultiva todos los valores humanistas del patrimonio cultural nacional y mundial y desarrolla la cultura nacional socialista como asunto de la totalidad del pueblo.

2. El fomento del arte, de los intereses artísticos y talento de todos los trabajadores y la difusión de las obras y producciones artísticas son obligación del estado y fuerzas sociales. Los logros artísticos se basan en una relacic estrecha de los artistas con la vida del pueblo.

3. La cultura del cuerpo, deporte y turismo son elementos de la cultura socialista y ha de servir al desarrollo corporal y del alma del pueblo» ${ }^{49}$

El concepto al que hace alusión la Constitución de «la lucha contra la barbarie imperialista», en la cual se presentan los valores de la paz socialista enfrentándose al monstruo del capitalismo, es recurrente en el diseño gráfico protagonizando numerosos carteles de gran simbolismo.

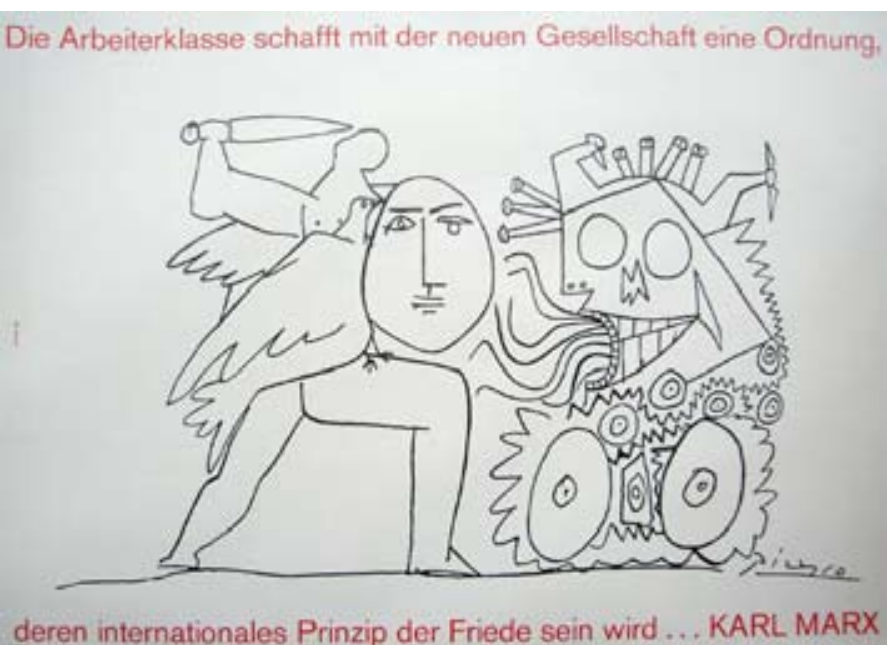

Este cambio en la Constitución vendría derivado del «debate sobre el formalismo» que se realizó en los años 50 como consecuencia de la III Asamblea del SED en la cual se defendió que «para ello (para luchar contra las fuerzas imperialistas) se establece el cometido de una política cultural decidida, un radical cambio de todos los terrenos de la vida cultural para conseguir acabar definitivamente con la tibieza y los acuerdos» (Neues Deutschland, 1950, citado en Gärtner 1979: 89).
Sobre este suceso reflexiona el Goethe Institut (2004) con motivo de la exposición de arte de la RDA en la Nueva Galería Nacional de Berlín:

«Terminada la guerra y el dominio nazi, los artistas se conec taron con el modernismo clásico y las corrientes de los primeros años del siglo $X X$, proceso que fue interrumpido en los años 50 por el llamado funesto debate sobre el formalismo. La RDA como Estado, osó diseñar una teoría artística; el denominado realismo socialista. Los artistas no siguieron esta pauta y se replegaron a modelos pictóricos históricos y hasta renacentistas. Pero, los que decidieron vivir como pintores ahí tuvieron que dedicarse a hacer una pintura tradicionalista y figurativa. Los que no escogieron este camino tuvieron que resignarse al aislamiento y la emigración interna e incluso correr el peligro de perder su nacionalidad».

No podemos obviar que en un sistema económico como el de la RDA el cliente de los artistas era el propio estado, lo que les hacía extraordinariamente dependientes de este y de sus decisiones.

El Dr. Eugen Blume (2003), comisario de la mencionada exposición, explica que «el fenómeno fue que la RDA como estado osó elaborar una teoría obligatoria para los artistas, empeñaron ingentes cantidades de historiadores de arte para que concibieran las pautas teóricas del denominado realismo socialista como ejemplo a seguir por los artistas».

Sin embargo, la postura oficial desde la RDA consideraba que «para las artes ilustradas supuso una gran ayuda en esta importante fase el desarrollo del arte y de la teoría del arte soviético» (Hannelore Gärtner, 1979: 91), desarrollándose la teoría del realismo socialista alemán a imagen y semejanza del soviético. A modo de esquema general podemos concluir como características básicas que se trata de un arte:

Destinado a los trabajadores, y por tanto que busca su rápida compresión, defendiéndose como «arte proletario».

- De temática tradicional ya que «una nueva cultura alemana no se puede crear sobre la nada. Debe valerse de las mejores tradiciones de nuestro pueblo (...) no se puede crear una nueva cultura alemana sin tradición nacional» (Becher, 1952, citado en Gärtner 1979: 90) y de escenas cotidianas en las cuales se elevaba al trabajador común presentándolo como admirable.

- Representación gráfica debía ser figurativa ya que como explica Blume (2003) «la pintura abstracta era considerada en el Oeste como la encarnación del 
artista libre, en el este el realismo era la encarnación de la imagen humanista del hombre y por tanto no se debía renunciar a él».

- Debía estar acorde a las metas establecidas en cada momento por el gobierno, ayudando a su difusión. Así por ejemplo en la segunda mitad de los 60 momento en el cual según Wolle (2008: 45) «el conflicto específico entre el intento de una modernización claramente funcional y el miedo a una conmoción del sistema de poder estuvieron su punto álgido (...) nada se nombraba sin sistema de instalación científico, plan de red o lenguaje de programación. Las cosas más sencillas se establecían según modelos matemático-económicos, inflacionistas necesidades de abreviaturas señalizaban racionalidad y velocidad».

Estos cuatro rasgos, adaptados a cada disciplina, eran válidos para todas las facetas culturales y constantes en casi toda la historia de la RDA. Cuatro rasgos que determinarán igualmente el diseño gráfico de la RDA. Entre todas las técnicas pictóricas destacará el uso de los grabados en todas sus versiones, por supuesto también en la realización de los carteles.

Con las reformas introducidas por Gorbachov a mediados de los 80 los jóvenes artistas de la RDA trataron de liberarse y de expresarse de nuevas formas. Uno de los progresos más importantes se realizará dentro de la literatura. El barrio de Prenzlauer Berg de Berlín atrajo a una nueva generación de gente joven underground de expresión punk atrayendo igualmente a muchas de las figuras que habían sido desterradas oficialmente de la cultura del la RDA. Esta ola de libertad se reflejó en todas las disciplinas, tal y como explica el Goethe Institut (2004):

«Solo a partir de 1985 alguno (de los artistas abstractos) pudieron expresarse libremente, como Cornelio Schleime (...) la lobreguez y la pesadumbre son temas del trabajo fotográfico y pictórico de finales de la década del 80. Los jóvenes ahora rompen con la obligación de pintar de forma tradicional».

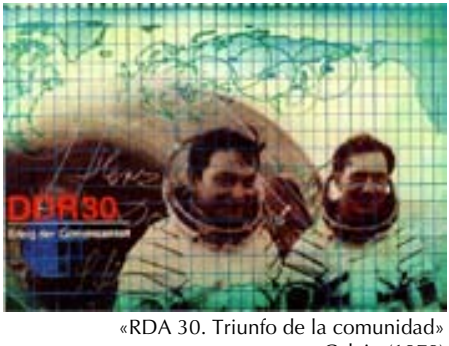

Más allá del «realismo socialista», la vida social y cultural de la RDA estaría siempre con la vista puesta en la Unión Soviética; un gran número de las figuras infantiles de la RDA estaban sacadas de la literatura rusa, y las figuras más populares las marcaría en gran medida la URRS.

Dentro del marco de la Guerra Fría cobraría una gran mportancia la carrera espacial en la que se sumieron EE UU y la URRS. Mediante el lanzamiento de cohetes y satélites se demostraba su capacidad tecnológica con lo que supuso un vehículo propagandístico de gran importancia. El lanzamiento del Sputnik supuso el comienzo de la etapa cósmica soviética y tuvo una gran repercusión en la RDA, los Jungpionere le cantaban «Hejo, Sputnik, hoch am Himmelszelt, sag, was siehst du bei der Reise um die Welt?» (Wolle 1999: 40) (Oh, Sputnik, en lo alto de la cúpula celeste, dime ¿qué ves en tu viaje alrededor del Mundo?). Los viajes cosmonáuticos y sus protagonistas figurarían en gran número de carteles, programas televisivos y publicidad como símbolo del progreso y de la capacidad tecnológica socialista:

\begin{tabular}{|l|}
\hline 1957 \\
\hline 1961 \\
\hline 1978 \\
\hline
\end{tabular}
Lanzamiento del Sputnik 1 (04.10) Lanzamiento del Sputnik 2 con la perra Laika a bordo(03.11)

1978 Sigmund Jähn. Primer cosmonauta alemán en el espacio

3.4.4 Promoción y difusión cultural

Un rasgo característico del gobierno del SED era su interés por aumentar el nivel cultural de la clase obrera y por crear una atmósfera de inquietud creativa, imaginación crítica y educación ideológica, en la cual se desarrollasen todas las formas artísticas para la consecución de una vida rica y diversa. Con este espíritu de «fortalecer las relaciones de la clase obrera con el arte» el FDGB creará a partir de 1959 los Arbeiterfestspiele (Festivales de los Trabajadores, AF), festivales de cultura que se organizaban con el apoyo del FD las uniones de artistas, el DTSB y el «Frente Nacional».

Tal y como definen Herbst, Ranke y Winkler (1994 7764), en los AF:

«Hasta finales de los años 60, prevalecían ante todo las intenciones culturales y políticas, con los AF se promovía simultáneamente la sincronización del arte entre profesionales y aficionados y atraer a los mejores artistas aficionados a la categoría de arte profesional. En los 70 años este rumbo se corrige. El festival se convierte en muestra de las fuerzas culturales y creativas de la clase obrera y toma un carácter cada vez más de festival popular. En los AF sin embargo, siempre hubo manifestaciones artísticas de a (n) que se convirtieron en un acontecimiento popular en la República Democrática Alemana se celebraron por primera vez en los AF».

Como vemos, las organizaciones de masas tenían un papel fundamental en la difusión cultural, tanto las relacionadas directamente con la cultura como la KB, como las que no lo estaban. Al mismo tiempo estas organizaciones 
servían para garantizar el método creativo del «realismo socialista», lo que Caspar (2009: 193-194) define como «el desarrollo de una cultura antifascista y democrática».

En 1976 se construye el Palast der Republik (Palacio de la República), espacio de exposición permanente y la obra más cara de la RDA, concebida como el palacio del pueblo, en el cual se podían ver los cuadros más conocidos de los artistas de la RDA mientras se escuchaba «formaciones musicales internacionalmente conocidas», al mismo tiempo disponía de locales de ocio y se convirtió en palabras de Wolle, (1999: 71) en «un símbolo de la Era Honecker: una escenificación de la pequeña RDA como obra de arte conjunta. Entre las vinaterías de la orilla del Spree y los Bistró de las plantas superiores, se hacía realidad el estado de la pequeña gente. El Palast era la RDA soñada».

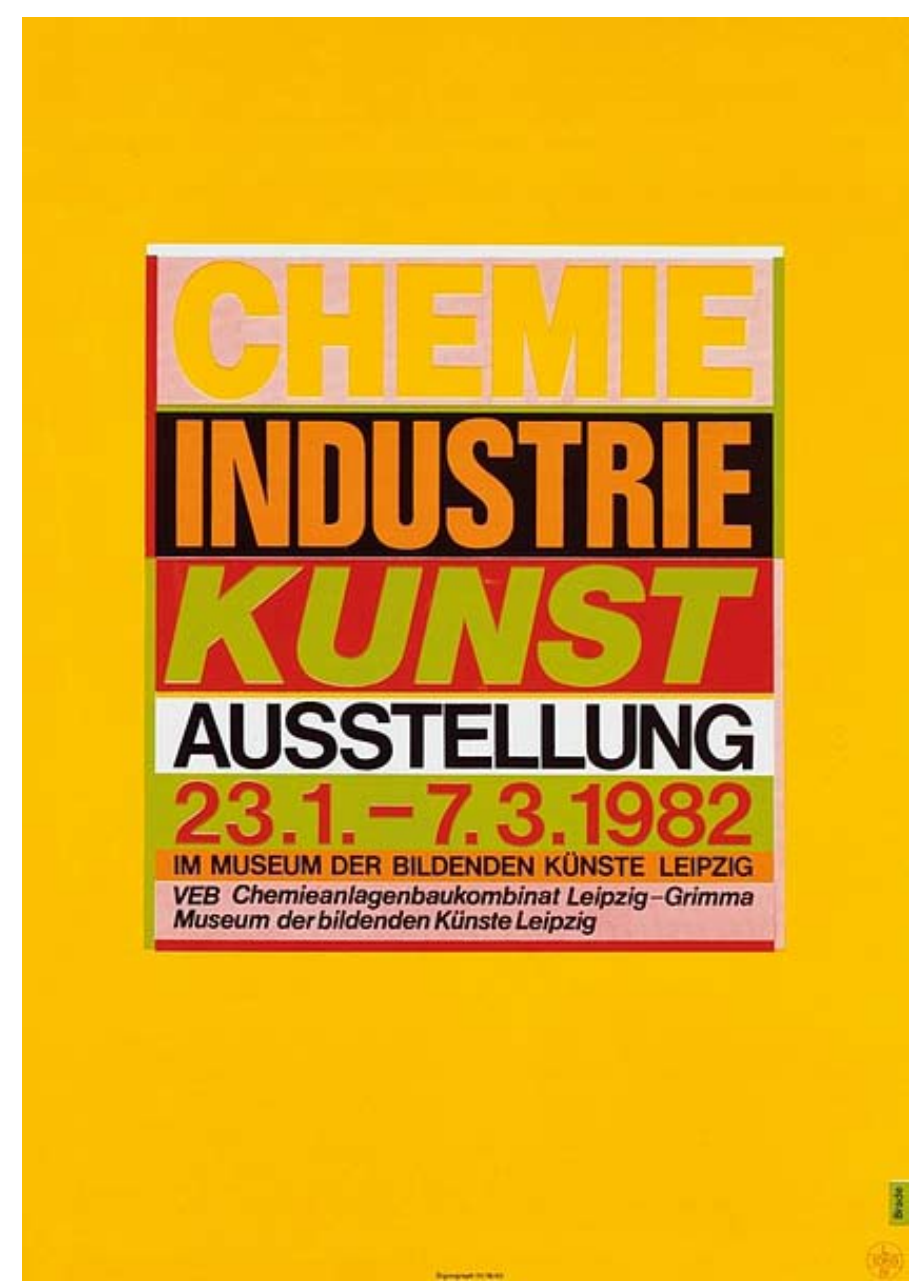

Junto con las exposiciones permanente se fomentaban las «Kunstausstellung der DDR» (Exposiciones de Arte de la RDA), exposiciones quinquenales en la ciudad de Dresden con temas tan amplios como pintura, escultura, moda, diseño, artes aplicadas, fotografía y artesanía. Estas exposiciones gozaban de una gran popularidad, tal y como muestra el aumento del número de visitantes de 74.000 en su primera edición de 1946 a 1,1 millones en la X edición de 1988

Igualmente se puso un gran énfasis en la edición literaria, con fuertes subvenciones para poder llegar a la base de la sociedad. Los libros tenían una cuidada edición y se realizaban carteles para el fomento de la lectura a todos los niveles sociales. La ya mencionada Escuela de Leipzig se ocupaba prioritariamente de los temas históricos y de actualidad social. En torno a la Escuela de Leipzig se crearon varias Empresas Socializadas de edición como la VEB Bibliographisches Institut Leipzig (VEB Instituto Bibliográfico de Leipzig) o la VEB Fachbuch Verlag Leipzig (VEB Editorial de Libros Profesionales de Leipzig). Los libros de arte eran fuertemente promovidos, siendo una larga tradición en ciudades de Alemania del Este como Dresden y Leipzig. La Feria del Libro de Leipzig, que data de 1600 continuó en la era de la RDA. En ella se organizaban premios a los «libros más bellos» como parte del plan de fomento de la edición literaria.

La industria cinematográfica de la RDA, a cargo de la DEFA como única productora, merece un punto aparte, «sobre todo porque las películas de la DEFA son, con su lenguaje formal y visual, una reproducción genuina de la compleja sociedad de la RDA y representan una referencia muy valiosa para la indagación de los fenómenos políticos, estéticos y de cultura cotidiana de la historia del país» (Thomas Krüger, 2006: 3) y, por supuesto, por ser una importante creadora de carteles.

La producción cinematográfica fue evolucionando hacia una dependencia casi total de las decisiones políticas de SED debido a que, tal y como relata Reiner Rother (2006: 6):

«A una fase de películas innovadoras y críticas le seguía indefectiblemente la reacción política. Carreras profesionales fueron drásticamente frenadas o destruidas, y los autores y directores reaccionaron eligiendo temas supuestamente seguros de la resistencia antifascista o de la historia en general. Los temas de actualidad eran considerados especialmente riesgosos. La tarea encargada a la DEFA era la representación de la historia y el presente, según la ideología del partido. La realidad de la RDA debía aparecer de manera positiva».

\section{Woche des Buches 1962}

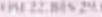

ich lese

du liest

er liest

sie liest

es liest

\section{wir \\ esen}

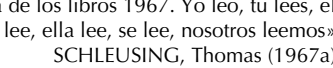


Estos temas «seguros» se resumían en: Historia, Trabajo y vida cotidiana, Mujer y emancipación y los Niños y jóvenes. Desde el punto de vista estético y formal «Una característica de las películas DEFA era la alta profesionalidad de los oficios (...). La aversión por la experimentación, por toda radicalidad formal, por riesgos en la narración, es típica de los estudios cinematográficos exitosos, y tuvo un carácter especial en la DEFA dadas las consideraciones políticas y el control superior ejercido por el partido» (Rother, 2006: 7).

3.4.5 Crítica, censura y protesta

Las críticas o muestras de opiniones divergentes de la opinión gubernamental en Alemania Oriental estaban totalmente prohibidas y eran perseguidas. Las expresiones artísticas, políticas o filosóficas debían seguir la línea establecida por el gobierno. Tal y como lamenta Sandoz (1971: 197) «es en la RDA dónde el «realismo socialista» cosecha sus mejores triunfos hasta el punto de impedir toda creación libre», en el mismo sentido se expresa Subercaseaux (1991: 140), «no se permitía ninguna publicación [filosófica] que no elogiara la «Construcción del socialismo» y llamara a la lucha contra las fuerzas imperialistas, que no celebrara a la RDA, sus aportaciones y éxitos, como una verdadera victoria de los ideales humanísticos y que no declarara finalmente el marxismo como la ideología más avanzada del siglo XX».

Esta imposibilidad de publicar las obras fuera de las directrices establecidas, llevó a un gran número de científicos, artistas y pensadores a abandonar la RDA para poder expresarse libremente. Resulta interesante en este punto los datos que aporta Sandoz (1971: 198) al respecto:

«Hans Meyer, un viejo comunista, uno de los mejores críticos literarios de Alemania, intérprete sutil de la obra de Bertolt Brecht, lo ha experimentado. Como Bloch, se ha decidido a abandonar la RDA y a publicar sus obras en Alemania Occidental. Estos casos no son aislados. El profesor Robert Havermann, químico eminente que sitúa en sus escrito filosóficos igualmente en la línea del humanismo marxista, se ha convertido también en una víctima del socialismo prusiano al que había abiertamente (...) Martin Bieler, uno la RDA, ha preferido la huida, tras haber sido expuesto a mil vejaciones por parte de las autoridades, que no apreciaban su espíritu liberal. El caso del poeta y cantante Wolf Biermann no es menos significativo. Al igual que su amigo Robert Havemann, ha sido expulsado del SED, su nombre no es mencionado y se ha convertido en un non person en el significado exacto que Georges Orwell había dado de este término».
Aquellos que quisieron permanecer y publicar en la RDA hubieron de resignarse a seguir las pautas gubernamentales. Pese a este control podemos encontrar formas sutiles de crítica o protesta. Este es el caso del uso de figuras mitoló gicas en las obras literarias, que podrían estar relacionado con esta forma de expresión crítica, ya que en opinión de Marta Fernández Bueno (2009: 138) «una de las razones que podrían explicar la proliferación de obras de carácter histórico, mitológico o intertextual en la RDA es la consideración de que esa era la única vía para expresar un pensamiento crítico con las propias circunstancias poéticas y sociales».

La clase cultural estaba sometida a una estrecha vigilancia, pero no eran en absoluto el único grupo que se encontraba bajo control. La extensa red de la Stasi, en especial la compuesta por los Inoffizielle Mitarbeiter, suponía que los ciudadanos no confiaban en poder expresar sus opiniones públicamente por miedo a las represalias; la imposibilidad de subir en sus trabajos o incluso de depender de los auxilios.

Hasta los últimos años de la RDA solo unos pocos se atrevían a protestar contra el gobierno. Eran los conocidos como Bürgerrechtler. Fritsche (2008: 97) se refiere a ellos como aquellos «que se encargaban de criticar la política del SED. La RDA no era un estado democrático y ellos lo denunciaban con panfletos y debates. El trabajo de los Bürgerrechtler era combatido por el gobierno de la RDA». Los Bürgerrechtles eran arrestados o extraditados a la RFA ara que no pudieran protestar contra la RDA.

En los años 80 la situación fue cambiando y tal y como relata el Bundesministerium für innerdeutsche Bezieheungen $(2000,1661)$ :

«A pesar de las represalias cada vez se juntaba más la gente en acciones de octavillas o protestas para mostrar su insatisfacción contra la guía política. En Berlín y otras ciudades se fundaron Umweltbibliotheken que publicaban sus propias revistas. Umwet bibliotheken que publicaban sus propias revistas. ilegal. A part ilegal. A partir de 1989 cada vez más gente se solidarizaba con los Bürgerrechtler y se encontraban en las iglesias para discuti sobre la situación del país».

No será hasta la última década de la RDA, que el diseño gráfico tome una cierta importancia en los movimientos de protesta con la realización de un número más significativo de carteles y panfletos. El hecho de que se eligieran las iglesias como lugar de encuentro se deriva de que esta tomo un papel activo en la oposición al gobierno. Tal y como

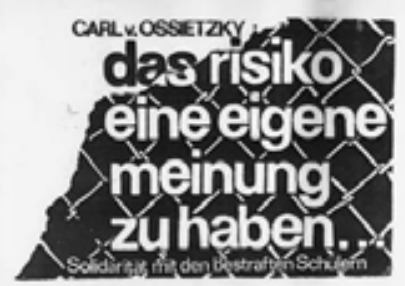

«El riesgo de tener opinión propia... Solidarida con los estudiantes multados lugend opposition der DDR (desc) 
relata Wolle (1999: 423) «hacia finales de los años 70 surgió un inestable triángulo de relación entre iglesia, estado y pequeños grupos activos, los cuales se dedicaban a un trabajo global por la paz, el medio ambiente y los derechos humanos».

Finalmente nos referiremos a la censura en los medios de comunicación, para la cual se dispuso un amplio operativo. Los medios de comunicación suponían un importante instrumento de la propaganda gubernamental, para lo que era necesario controlar todo lo que éstos publicaban. La prensa escrita era el medio de comunicación más difundido, tanto los periódicos como la amplia oferta de revistas destinadas a todos los grupos de población. La televisión tenía un alcance mucho menor.

Todos los medios de comunicación eran dependientes del estado. Para ello estaban todos centralizados en el Politburó organizado en diversos órganos:

- la oficina de prensa, bajo la supervisión del presidente del Consejo de Ministros,

- un comité Estatal de Radio y Televisión del Consejo de Ministros,

- la Agencia estatal de noticias y fotografía del Allgemeiner Deutscher Nachrichtendienst (Servicio de Información General Alemán, ADN).

Para asegurarse el control de la comunicación se tomaron algunas directrices entre las que destacan:

- «Política de personal: los puestos de responsabilidad han de recaer en empleados cuyas convicciones políticas coincidan con las del estado (...)

- La distribución de la prensa era monopolio del estado, de modo que se podría detener su propagación en cualquier momento». (Bundesministerium für innerdeutsche Beziehungen, 2000: 4412).

No obstante la libertad de expresión estaba contemplada expresamente en la Constitución (RDA, 1968):

"Artículo 27: Todo ciudadano de la RDA tiene derecho, de arreglo a los principios de esta Constitución, a expresar su opinión libre y públicamente. Este derecho no será limitado por ninguna relación servicio ni trabajo. Nadie puede ser discriminado por hacer uso de Este derecho.

La libertad de prensa, radio y televisión está garantizada».

El control que se ejercía sobre los medios de comunicación tuvo que ser justificado en el comentario oficial a la Constitución como «prevención de los abusos de los medios de comunicación», incluso se introdujo en el Código Penal de 1968 donde se recogía la propaganda subversiva como ofensa punible.

La realidad política, social, económica y cultural de la SBZ/RDA fue determinante y variable en cada momento de su historia, por lo que hemos descrito aquí sus aspectos más relevantes y los hemos relacionado temporalmente, de tal modo que podamos establecer la correspondencia que tuvieron con el diseño gráfico creado a lo largo de la RDA.

Hemos descrito igualmente la estructura económica propia, que nos va a permitir conocer como esta se tradujo en la creación del diseño gráfico. 
4. Marco teórico: El diseño gráfico de la RDA

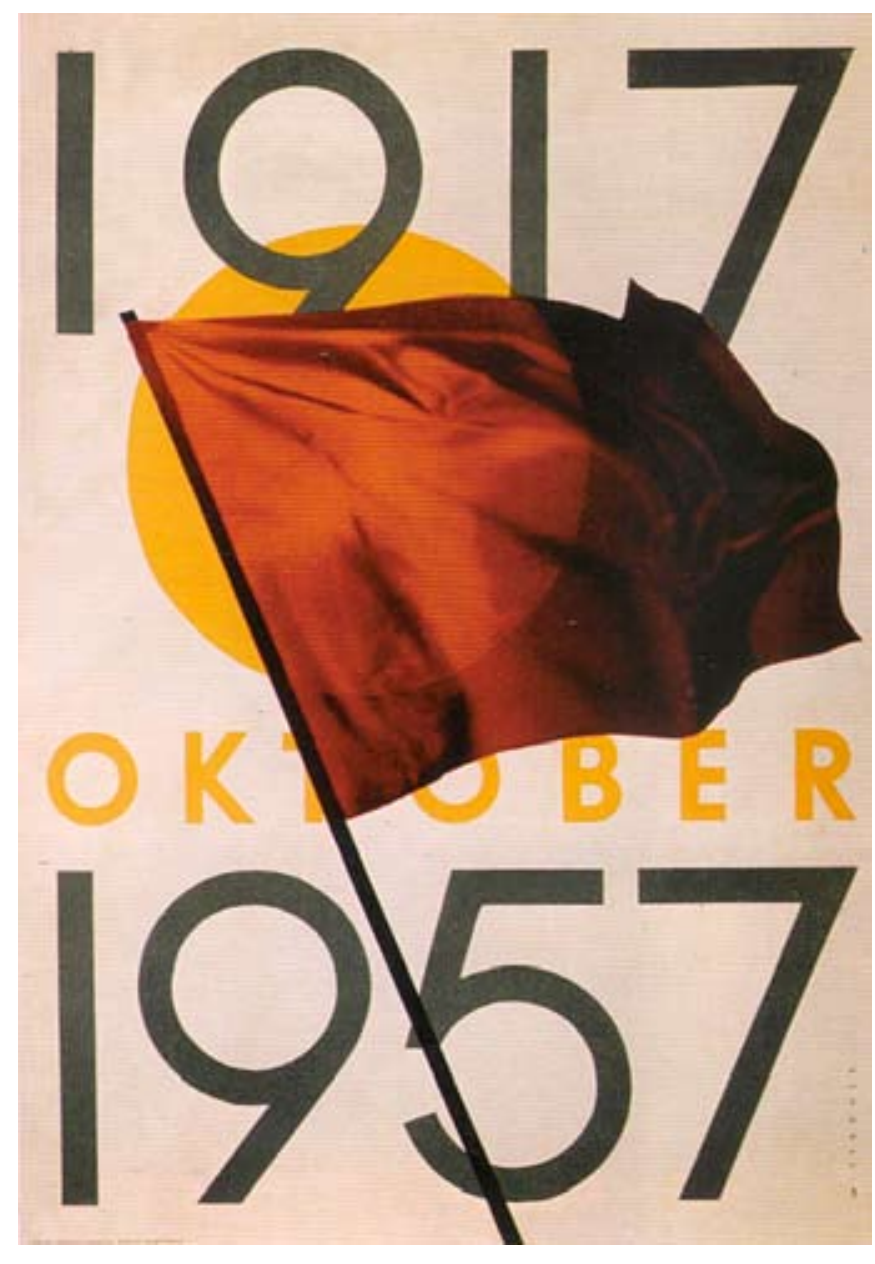


Antes de entrar a realizar un análisis cuantitativo resulta conveniente establecer un marco teórico sobre el desarrollo del diseño gráfico y del arte del cartel en la RDA basándonos en los estudios realizados tanto desde dentro como en las retrospectivas que se han publicado en los últimos años.

Debido a la estructura política y social, los estudios realizados previos a 1989, tienen una gran componente oficial, ya que eran producidos desde las instituciones y empresas dedicadas al diseño, como es el caso de la VEB Typoart en el diseño de tipografías o de la Verband Bildender Künst ler (Asociación de Artistas Plásticos, VBK), mientras que los posteriores corresponden a investigaciones privadas o académicas.

4.1. CONSIDERACIÓN DE DISEÑO GRÁFICO EN LA RDA

Hemos definido en el primer capítulo el marco teórico en el que nos encontramos al hablar de diseño gráfico. Queremos apuntar brevemente aquí el marco de la disciplina dentro de la RDA. La consideración del diseño gráfico como categoría propia dentro del arte ha sido objeto de numerosos debates y ha experimentado una evolución en su percepción a lo largo de las décadas. Recordando las palabras de D.A Dondis (2008: 15):

"(...) el mayor escollo para este esfuerzo [de un nuevo enfoque sobre la experiencia visual] es la clasificación de las artes visuales en artes aplicadas y bellas artes. En cualquier momento de la historia su definición cambia y se altera pese a lo cual hay dos factores constantes de diferenciación: la utilidad y la estética».

Estas constantes sitúan al diseño gráfico desde la perspectiva contemporánea más cercana a las artes aplicadas que a las bellas artes, mientras que en la Escuela de la Bauhaus se consideraba que esta separación era artificial, situándose todas las categorías a igual distancia. Es probable que la actual visión de la disciplina sea deudora de la Hochschule für Gestaltung de Ulm (HfG) que acabaría entendiendo «el diseño como una actividad con una problemática y unos requerimientos singulares, específicos y propios, característicos de su ejercicio y de la finalidad que persigue. Consideran, además que la profesión ya había alcanzado su plena madurez y que no necesitaba del concurso de la madre superiora del arte para valerse por sí misma» (Zimmermann 2003: 60). 
La componente especial del diseño gráfico dentro del arte no siempre fue valorada en el ámbito de la Alemania Oriental, ya que como lamentará posteriormente el teórico de la VBK, Helmut Rademacher (1989: 14), en un primer momento:

«La crítica de arte pertinente persistía -si es que alguna vez trató de forma exhaustiva el cartel- en sus medidas unilaterales y no podía entender criterios de los aspectos particulares de creación de carteles. Pero estos ya se habían perfilado hacía tiempo, en los años 20: la concentración de las composiciones con una única acentuación, la idea puesta en práctica lacónicamente mediante una imagen, una clara estructura de imagen, la integración de imagen y tipografía, un fuerte carácter de apariencia e interpelación».

Escaso reconocimiento del diseñador gráfico más allá de la agitación y la propaganda en los primeros años de la SBZ/RDA será también motivo de queja de Max Lingner formula (1950, citado en Wunderlich, 2007: 41):

«(...)el cartel, el cual se cuelga en un muro habla a todos, pertenece al campo de las artes plásticas. Como otras divisiones de las actividades plásticas está sujeto a similares requisitos ideológicos y formales. Un cartel, como un dibujo, solo es realmente bueno cuando resulta comprensible a las poco educadas masas y al mismo tiempo es del disfrute de los refinados estetas. Seguramente tienen los carteles y las pinturas ciertas peculiaridades técnicas (...). Pero por desgracia serán tratados los carteles para la mayoría de los artistas plásticos como un pariente pobre al que uno solo puede inclinarse ocasionalmente, jes muy injusto!».

En 1953 se fundará la sección de «diseño gráfico» dentro de la VBK, uno de cuyos más importantes debates residía en la función y el rol que desempeñaba el diseño gráfico y su distinción dentro de las artes plásticas. La necesidad de este debate Helmut Rademacher (1975: 5) la atribuía a que «al fin y al cabo el diseño gráfico tiene la mira puesta tanto en su función como en su naturaleza estética». Le reconocen su fuerte componente funcional, pero sin por ello renunciar a la estética. Según expresa Otto Arpke (Archiv, 13, citado en Rademacher 1975: 5) «un cartel alberga menos pretensiones como trabajo artístico que como propósito. Se reconocer su valor mediante su propósito, así puede ser una obra de arte», es decir, su valor artístico reside en el cumplimento de su propósito.

Este valor intrínseco en la función supone que Rademacher no encuentre justificable la separación que realiza la HfG ya que (1975: 11) «en la sociedad socialista se da una determinada consideración de clases y social y no está objetivamente justificado el divorcio las artes ilustradas de las artes aplicadas. Aquí no hay una separación del arte bajo el aspecto del utilitarismo ${ }^{50}$. Resulta conveniente tener en cuenta aquí que todas las categorías artísticas tenían en la sociedad socialista una componente educadora en base a los dictados del «realismo socialista» o que supone que sea el arte en general, y no el diseño gráfico, el que tenga una óptica particular en la RDA. Debido a la afirmación de Rademacher todas las categorías artísticas se desarrollan unitariamente en la RDA, sin por ello restarle importancia a cada una de ellas por sí misma, analizando los problemas estéticos que le son intrínsecos.

La VBK perseguía igualmente el cometido de dotar de una calidad artística a los trabajos más allá de su componente informativa, pero no pretende observar la realidad artística como un problema con una solución teórica global, del modo que había ocurrido en la Bauhaus o en el Deutsche Werkbund, sino que los artistas gozarían dentro de la Asociación de libertad creativa. Esta sección se encargará igualmente de la difusión y promoción del diseño gráfico, por lo que en 1975 publicará un extenso catálogo sobre su categoría, la primera en la historia de la RDA, en la cual se analiza el papel de este dentro del arte y la sociedad.

Aquí definirán su postura sobre el diseño gráfico del siguiente modo (Rademacher, 1975: 42-43):

«El diseño gráfico se basa en cuatro ideas fundamentales:

1. la configuración del diseño gráfico es un factor de efecto visual para la realización de una intención comunicativa. (...)

2. la legitimidad general estética sirve también para el diseño gráfico, el cual se entiende como una categoría específica de las artes plásticas.

3. el perfil específico y el valor cultural del diseño grafico serán válidos por su carácter protagonista en sociedad.

4. el diseño gráfico está relacionado con otras categorías del arte plástico en una realidad inseparable. Dentro de esta unidad lleva continuas relaciones mutuas e impulso para el desarrollo y enriquecimientos cualitativos de todas las categorías».

Coinciden en reconocer al diseño gráfico como parte integrante de las artes plásticas y como tal de la cultura de la RDA, así como en su capacidad formadora de opinión y por tanto de la sociedad de la RDA; es decir, le reconocen al diseño gráfico un papel fundamental en el desarrollo de la personalidad socialista y por su capacidad movilizadora. Gracias a esto los diseñadores gráficos gozarían, pasados los primeros años, de un gran prestigio dentro de la
50. In der sozialistischen Gesellschaft wird daher die inglich sozial- oder und objektiv nich cheidung der bildenden von der angewandten Kunst überwunden. 
RDA, donde se puso una gran atención a su formación a su difusión, ya que tal y como refleja Rademacher (1975: 12) «El diseño gráfico penetra en todas las esferas de la cultura, y coge de este modo no solo impulso de ella, sino que vuelve en un intercambio de opiniones dialéctico y las retroalimenta».

En la presentación de la exposición «Im blick der Massen» sobre el papel del cartel en la RDA, Conrad, Kuhrmann y Ludwig (2002: 4) se plantean igualmente el rol del diseño gráfico en la sociedad socialista. En su opinión:

«(...) se quedan anticuados los sistemas de competencia y comercialización. Los carteles deben ahora ante todo surtir un efecto esclarecer efecto comercial retrocedió rápidamente. En cambio volvieron a un primer plano otras formas: el cartel político con fines propagandistas, el cartel económico orientado hacia la propaganda de la producción, y los carteles de manifestaciones ganaron una gran importancia mediante su calidad artística».

El cambio en la finalidad y la función del diseño gráfico entre la Alemania previa a la guerra y la RDA debe tener, en opinión de Klaus Wittkugel, su reflejo en la forma (1954, citado en Rademacher, 1975: 47) ya que en Alemania Oriental:

«(..) los creadores tenemos otros deberes que en el capitalismo. Por eso debemos ir por otros caminos para alcanzar nuestra meta. El capita caminos para alcanzar nuestra competitiva de los empresarios mediante los proyectos más originales posibles... entonces no solamente era importante que los creadores estuvieran convencidos de las necesidad de su trabajo..., de forma que predominara la forma y solo subordinadamente se explicaba con el contenido».

\subsubsection{Promoción del diseño}

Tal y como hemos visto en el contexto social, el arte, en todas sus expresiones, gozó de una gran popularidad y con ello de una gran difusión a lo largo de la historia de la RDA. En 1958, para la IV. Deutschen Kunstausstellung (IV. Exposición de Arte Alemán), aparecieron por primera vez junto con los trabajos de pintura, grabado y escultura trabajos de diseño gráfico. Wittkugel escribiría (1959, citado en Rademacher, 1975: 14): «queremos enseñar el arte en el socialismo. Por ello queremos aclarar a todos los hombres que no solo las artes pictóricas pertenecen al arte».

Conrad, Kuhrmann y Ludwig (2002: 4) le conceden a la $\checkmark B K$ el mérito de la profusión a partir de este momento de «exposiciones masivas de diseño gráfico, como la realizada en la Alexanderplatz con más de 70 autores de renombre. Con esto se le concede al diseño gráfico una relevancia pública y artística que nunca antes había tenido».

Otro elemento determinante en la difusión del diseño gráfico será la organización de concursos, entre los que destacan los concursos a "Beste Plakate» (Mejores Carteles) que se organizaron a partir de 1964 a instancias de Peterpaul Weis y Helmut Rademacher (1964, citado en Wunderlich 2007: 40) quienes piden «presentar anualmente en las salas del $\mathrm{MfDG}^{51}$-a ser posible en el hall central- una exposición especial organizada bajo el lema «los mejores carteles artísticos de la RDA del año», con fórmulas similares a las efectuadas, también desde el VBK por Klaus Wittkugel y Hans Baltzer con las que se acercaba el diseño gráfico a los creadores, público y clientes».

Todos estos concursos de carteles gozarán de gran popularidad y proyección, tal y como expone Wunderlich (2007: 34) las participaciones en ellos serían por diferentes motivos:

«(...) a veces mediante participación libre, a veces invitados. Todos conjuntamente tenían una amplia divulgación, tanto las candidaturas como los resultados: importantes revistas especializadas y asociaciones discutían mediante diapositivas y numerosos participantes encontraban el camino a las imprentas. Sin embargo no todos los concursos se documentaron mediante catálogos de modo que se pudiera hacer hoy un juicio definitivo sobre las capacidades de los carteles presentados».

Finalmente en 1966 llegaría la primera convocatoria del concurso "Die besten Plakate des Jahres» (Los mejores carteles del año). Tal y como relata Wunderlich (1996: 41-42):

«360 carteles de diferentes temas eran juzgados por los 28 miembros del jurado y el resultado sería mostrado en una exposición (...). Los carteles estarían divididos en grupos; el principal de todos el de los trabajos políticos. Detrás estaban los cartele económicos, de películas, de eventos y exposiciones, de teatro y carteles para propaganda social y deportiva. Las categorías de los grupos iría cambiando con los años, influenciado por el significado de los temas de los carteles y las modificaciones de la importancia social. Esta categorización funcionó hasta 1979, en 1980 para la 15 convocatoria y bajo las medidas tomadas por el entonces presidente de la sección central de diseño gráfico de VBK Jochen Fiedler, las categorías serían: Cartel político, carte social, teatro y cine, exposiciones y eventos, cartel publicitario. El concurso tendría también un nuevo título Die 100 besten Plakate des Jahres (Los 100 mejores carteles del año)» ${ }^{52}$.

A partir de su 22 convocatoria se concederá un premio especial a un artista joven, cuya presencia entre artistas
51. Museum fur Deutsche Museo de Historia
52. En su etapa como «Die besten Plakate des Jahres» el jurado era fijo y estaba compuesto por Hans Baltzer, Peterpaul Weiss y Klaus Wittkugel, Dietrich Kaufmann, Werner Klemke, Siegrried Kraft, Herbert Prüget, Pau Rosié, Horst Wendt entre otros, del Ministerio de Cultura -Justus Liebig-, del VBK -Helmut Obst-, los teóricos Bernhard Nowak, Fre Tamme, Hellmut Rademacher y lopresentantes de las imprentas y 1979 el número de mieme a partir jurado se limitaŕa a 12 que debín er variados cada año. 
consagrados pasaba a menudo desapercibida, de tal modo que mediante este premio se le daba la oportunidad a los creadores de menos de 35 años de una mayor repercusión.

La repercusión e influencia de estos concursos permanece fuera de toda duda tal y como reflejan las respuestas dadas por varios artistas a la pregunta efectuada con motivo de la exposición «128 Plakate aus 30 Jahren Wettbewerb «die 100 besten Plakate des Jahres»» (128 Carteles de 30 años del concurso «los 100 mejores carteles del año») sobre la significación que tuvo su participación en el concurso para su trabajo creativo (Verband der Grafik-Designer, 1996: 24) a la cual Helmut Brade responde «un estímulo. Una agradable forma de comunicación con los colegas de profesión». En la misma tónica responden Jochen y Jutta Fiedler para los cuales «una causa significativa era el intercambio de reconocimientos en el circulo de colegas».

4.1.2 El cartel, un elemento característico.

Dentro del diseño gráfico realizado en la Alemania Oriental los carteles tuvieron una especial relevancia, tal y como se desprende de las palabras de Helmut Rademacher (1975: 15): «aunque los medios de expresión gráfica han aumentado, permanecen e incluso se incrementa la predilección por los carteles. Una de las particularidades del diseño gráfico es el gran número de disciplinas que entra en juego en él». Esto situaba al cartel como el elemento más destacado y desarrollado del diseño gráfico en la RDA.

El éxito de los carteles se basa en su gran capacidad comunicativa y en la economía con la que se produce dicha comunicación. Según explica Wunderlich (2007: 10):

«(...) un cartel puede unir, como cosa más significativa, las intenciones de los anunciantes con las capacidades artísticas del creador. Es un medio de comunicación prevalecientemente impreso en papel para los anuncios públicos, el cual eśá tendido para la percepción vi dido para la percepción visual del observador, y trabaja con abreviaturas ópticas. El cartel funciona como medio entre el anunciante y el consumidor, trasmite mensajes, los cuales pueden gustar o no. Serán percibidos por los sentidos, consciente o inconscientemente».

En la misma tónica se expresan Conrad, Kuhrmann y Ludwig (2002: 23) al afirmar que «el cartel de la RDA suponía un proceso de comunicación entre el creador, el promotor y la población (....). Así serán pegados los carteles también en columnas anunciadoras, pero mediante el monopolio de un único partido. Se pegaban en paredes y zonas de construcción». No en vano afirmaba Erhard Frommhold (1979:112) que «el factor de comunicación solo es válido en la psicología de masas cuando el cartel juegue un rol dominante en la vida civilizada de la ciudad y el campo». Los carteles formaban parte del paisaje urbano tanto en las paredes y columnas como en la decoración de los escaparates gracias a -pero también fomentando- la calidad de los mismos. Esta calidad en el diseño de carteles se vio promovida no solo por la gran cantidad generada, sino también por los concursos, las asociaciones de artistas a las que pertenecían prácticamente todos los creadores y las exposiciones de carteles.

Al hablar de calidad no podemos confundirnos con una calidad material, ya que tal y como explica Wunderlich (2007: 10) «al contrario aparecían curiosamente hechos a mano, dibujados, incluso a veces los tipos, a menudo de escritura manual, muchos con buenas fotos débilmente impresas, predominantemente en papel fibroso, que no siempre podían aguantar el viento y el tiempo».

\section{2 ÁMBITOS DEL DISEÑO GRÁFICO}

Los carteles alemanes tenían antes de la RDA una función principalmente comercial, mientras que esta pasará ahora un segundo plano. Según explica Rademacher (1975: 30) el cartel se moverá ahora en los siguientes terrenos:

- «En el plano político y social: Representación del estado y la sociedad, la agitación política y la propaganda información y formador de opiniones, la producción de propaganda social, también principalmente la aclaración respecto a la protección del trabajo y de la salud, información e instrucciones médicas y de política social, la propaganda de un estilo de vida sano y similar.

- En el plano económico: La publicidad para la industria comercio, prestación de servicios y así asociar las instrucciones e informaciones potencialmente necesarias para los consumidores, la publicidad de exportación y la representación internacional.

- En el plano cultural: La comunicación cultural y científica, la general y en ocasiones especial publicidad e información cultural.

- A parte de esto sirve el diseño gráfico para intereses individuales».

4.2.1 Plano político y social

Entre todos los usos para los que se destinaba el diseño gráfico el más relevante es sin duda el político y social. Es aquí donde el cartel juega un rol fundamental en la propa- 
ganda política y la agitación, pero sobre todo como educador de las masas. Conrad, Kuhrmann y Ludwig (2002: 27) escriben:

«El cartel político tenía lugar para la interpretación del SED del socialismo real existente. Servía para la fijación de la sabiduría del estado mediante los carteles de los sucesos recurrentes anuales (1 mayo, día de la mujer, aniversario de la república) o igualmente para las elecciones. El contenido ideológico del cartel político se cartel politico será especialmente comprensible en la interpretación de la construcción del Muro y el enlace de esos sucesos con la militarización de la sociedad».

A pesar de su relevancia social muchos autores coinciden en considerar la calidad general de los carteles políticos como baja, tal y como se desprende de las palabras de Conrad, Kuhrmann y Ludwig (2002: 27) que considera que «mientras que muchos carteles políticos eran de la menor calidad artísticas, se destinaban a este terreno los mejores recursos para su creación: eso significaba una mayor aportación en papeles satinado, mayores tiradas y una reproducción en impresión de 4 tintas».

La aparente falta de calidad de los carteles políticos parece provenir de la primacía de su espíritu agitador y de fácil comprensión, lo que suponía que la mayor parte de los carteles fuera monocorde en su forma de agitación. Esta falta de multiplicidad de temas la lamentaba Hans Baltzer en su discurso inaugural de una exposición en 1954 (14, citado en Wunderlich 2007: 13):

«Esta pregunta la hago las organizaciones de masas FDGB, FDJ, etc.: ¿cuándo desaparecerán finalmente los carteles de gemelos univitelinos o trillizos? Los conocemos ya todos. Para una asamblea de partido o una conferencia de delegados se dan la mano. Una está siempre a la derecha y la otra a la izquierda. Para el mes de la amistad alemana soviética o actos similares van ustedes una al lado del otro y sostienen firmemente una bandera. Para una bandera. Para un tercer hombre. Ahŕ está el trillizo unificado por una fresadora vertical alrededor de la cual hay flores. Eso es únicamente símbolos de la miseria y no tiene nada que ver con el realismo».

Del mismo modo se expresa Joachim Sommermeier (1986: 17-18) sobre la unicidad retórica:

"¿Qué símbolos, alegorías, atributos y metáforas se encuentran en los carteles por la paz?: Símbolos animales; la paloma estará presente en el $18 \%$ de los carteles como símbolo predominante (...), simbolismo de las armas y militares (...), el símbolo de la cruz (...), simbolismo mediante esqueletos y cráneos (...), demás símbolos de la guerra y el dolor y figuras infantiles».
La falta de variedad en la retórica de los primeros carteles políticos no responde a una falta de imaginación por parte de los creadores, sino a la prevalencia de su fácil compresión mediante el uso de recursos conocidos, "así encontramo una y otra ver en los carteles metáforas como izamientos de bandera, abismos de puentes excesivamente monumentales, soles salientes, el pan prometido del sembrador en el campo, bellas ciudades que surgen de las ruinas, el rostro de las personas enfrentada al futuro, símbolos a los cuales aspiraba la realidad de la nueva sociedad» (Rademacher, 1989: 11). Se realizaron, no obstante, carteles excepcionales dentro de las pautas simbólicas establecidas, como es e caso del proyecto de Arno Mohr para la primera manifestación de mayo de 1946 en el cual su retórica se transmitía dentro de una expresión gráfica pensada que acusaba un estilo.

Más optimista se muestra Wunderlich (2007: 13-14) quien considera que :

«Los inicios de los carteles políticos de la SBZ y primera RDA son múltiples. El lenguaje de los carteles es variable, rico de conceptos pictóricos y soluciones fotográficas de los precursores Arno Mohr y John Heartfield, sobre signos simbólicos o abstraídos y formas abstractas de la clase de diseño gráfico de Burg Gievichenstein, el cual no esconde su referencia hacia el cartel de los años 20 y primeros 30, hasta trabajos de arte de Fred Gravenhorst tanto objetivos como expresivos. Las inconfundibles tipografías escritas a mano los hacen reconocibles».

Los cambios políticos y sociales que tuvieron lugar en los años sesenta tuvieron su reflejo en los carteles, especialmente en lo relativo a la temática, tal y como afirma Rademacher (1989: 19) «Esto quiere decir en el caso del carte político que debe ajustarse a las peticiones de significados básicos y duraderos y desempeñar más y más una función de representación visual y comunicativa, la cual esté integrada en un mayor complejo político de trabajo de masas». Los carteles con una temática de agitación que habíamos encontrado en los primeros años se cambian ahora a una fijación de los valores, con temáticas tales como solidaridad, respeto al medio ambiente, afianzamiento de la paz... Estos últimos tuvieron una repercusión especial, con exposiciones especializadas organizadas por la sección de diseño gráfico de la VBK y por el ministerio de cultura y con una calidad latente que les hizo ganadores de varios concursos de la ONU sobre el tema.

Según relata Wunderlich (2007: 15):

«Esta nostalgia de las personas por la paz, que se manifestaba con ayuda de los carteles, habían empezado en los años 50. Con

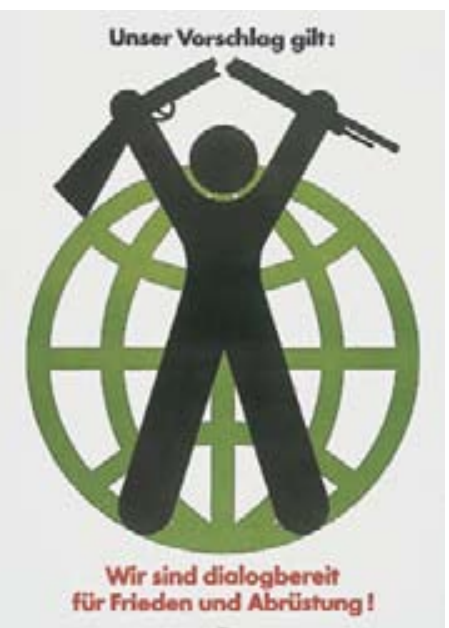

VOIGT, Gerhard (1982 
el trasfondo de una amenazante guerra atómica, los inminentes $y$ cada vez mayores conflictos entre Este y Oeste llamaban a to sección de diseño gráfico de la VBK, a sus socios y artistas, a crear carteles por la paz y contra la guerra atómica».

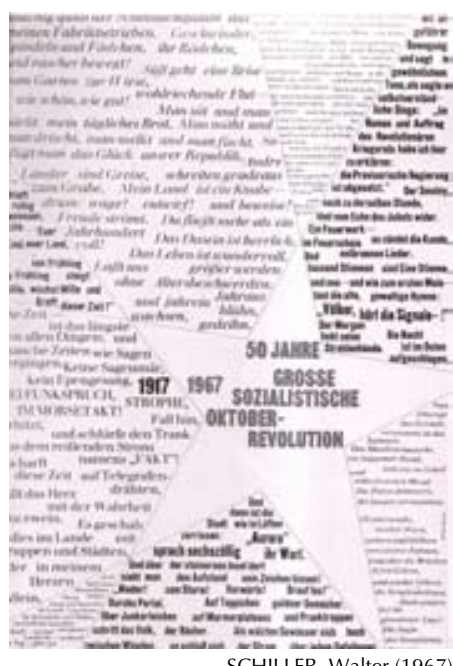

Estos significados básicos y duraderos de los que hablaba Rademacher se traducen en el plano de los homenajes en el paso del ensalzamiento personal propio de los años 40 y 50, con las figuras de Lenin, Thälmann o Stalin a la rememoración grandes momentos históricos. Un gran ejemplo de esto será el cartel de Walter Schiller de 1967 para conmemorar el 50 aniversario de la revolución de octubre, compuesto totalmente por tipografía. En opinión de Rademacher (1989) en estos carteles los artistas ponían un especial cuidado para darles el mayor valor artístico posible, ya que eran sometidos a muchos análisis y críticas. También Wunderlich aprecia la calidad de estos carteles al afirmar (2007: 21) que «significativos aniversarios serían anunciados con impresionante simbolismo, lucidez y sencillez (...), que implicaban habilidades gráficas sólidas y se han quedado grabados en la memoria».

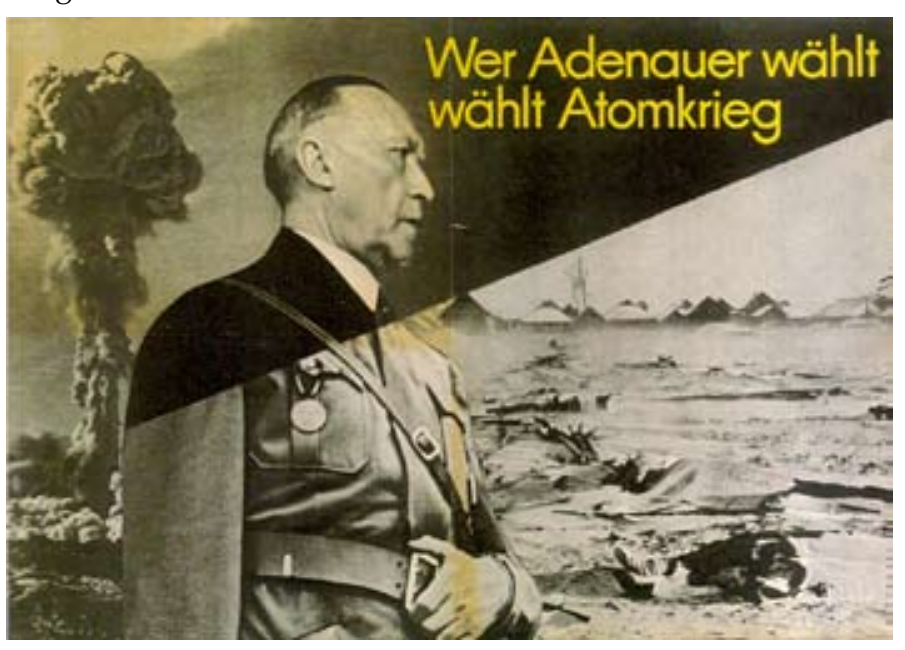

La fotografía, y en especial los montajes fotográficos tendrían una gran presencia en el campo del cartel político por su capacidad evocadora, crítica y de apariencia realista. Tal y como relata Frommhold (1979: 119) «el fotomontaje soviético se puso en primera fila desde los años 20 a los 40 desde Gustav Kluzis a Alexander Shitomirski debido a su detalle narrativo y espectáculo emocional de los montajes de fotos y carteles fotográficos» ${ }^{53}$. Estos montajes se habían empezado a utilizar con fines políticos en Alemania durante la Primera Guerra Mundial y especialmente por los Dadaístas y las obras de John Heartfield, quien continuará
Fotomontage hat von den zwanziger Jahren bis Anfang der vierziger Jahre Shitomirski das erzäh zu Alexander die gefühlvoll appellierende Überzeugung in der Fotomontage und im Fotopla -junto con Klaus Wittkugel- con esta forma de expresión en la RDA.

Precisamente Klaus Wittkugel -fundador de la VBK y presidente la sección de diseño gráfico- será uno de los máximos exponentes del cartel político de la RDA, en cuya obra se refleja en gran medida la tradición artística alemana. Según explica su biógrafo Erhard Frommhold (1979: 122):

«El cartel ornamental, pintoresco, está con él a la altura de una cultura de diseño gráfico imaginativa, pictórica y abstracta. Utiliza el color en todas sus intensidades, inventa adornos sensibles, decoración, marcas y logotipos, reúne con ellos el tema hacia una abstracción decorativa. A decir verdad este tipo de arte desde Lucian Bernhard y Julius Klinger siempre ha sido un punto fuerte del cartel alemán. Pero Wittkugel también lo extiende a lo político. Lo que anteriormente se contaba en carteles educativos de forma expresiva e incluso expresionista, o e cartel como elementos obligatoriamente agitador, Wittkuget lo lleva a fórmulas: lleva a fómulas: diferentes tamaños de números histónic ficativos, repeticiones sugestivas de emblemas de fama mundial, las banderas como símbolos, la acumulación de letras en un orden constructivo $»^{54}$.

En su búsqueda del desarrollo de una personalidad socialista otra parte importante de estos carteles son aquellos de temática social en los cuales se perseguía fundamentalmente el fomento de una vida sana, solidaria y con un alto valor de la educación. Persiguiendo este fin como «medios gráficos se utilizaban tanto dibujos, emblemas como también fotos alteradas según su uso, que hablaban directamente al espectador» (Wunderlich, 2007: 37). Se trata de una finalidad muy determinada para la cual, según opina Jochen Fiedler (1986: 24) «el lenguaje de la imagen de estos carteles debe ser compresible, artísticamente exagerado, irónico y satírico. Las ilustraciones en las que se muestran las consecuencias a menudo es más impresionante que el modelo de los héroes positivos».

\subsubsection{Plano económico}

El plano económico lo integran la publicidad para la industria, comercio y la prestación de servicios. Tal y como hemos visto anteriormente la RDA contaba con un sistema socialista de economía planificada y estaba fuertemente centralizado lo que suponía la práctica ausencia de economía competitiva, lo que plantea la cuestión de por qué entonces había publicidad. La explicación según Simone Tippach-Schneider (2004: 8) la encontramos en que «(...) s
54. Das ornamental-malerische Plakat ist bei ihm auf der Höhe einer ideenreichen, zeichnerisch abstrahierenden gebrauchsgrafischen Kultur. Er setzt Farben in allen Lautstärken ein, er erfindet sinnfällige Ornamente, Dekore, Zeichen oder Signete, er rafft mit ihnen das Thema zu einem dekorativen Abstraktum. Zwar diese Art seit Lucian Bernhard oder Julius Klinger immer eine Stärke des deutschen Plakates gewesen. Wittkugel weitet aber diese Seite auch ins Politische aus. Was früher im didaktischen Plakat expressiv oder gar expressionistisch erzahlt oder dem Plakat als agitatorisch aufgenotigt wurde, bringt Wittkugel auf Formeln: unterschiedliche Grösse von historischen Bedeutungszahlen, suggestiv wirkende Wiederholungen von weltbekannten Emblemen, Fahnene als Signalzeichen, die Haufung von Buchstaben in einer konstruktiven Ordnung.

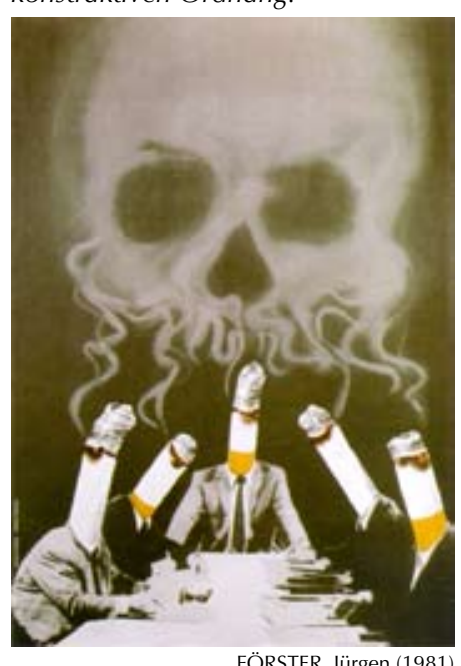

FÖRSTER, Jürgen (1981 el término es la publicidad más amplia, es decir, como parte 
de la cultura de los productos básicos, que también genera significados, pautas culturales y símbolos ${ }^{6}$.

Sylke Wunderlich (2007: 32) defiende una postura similar, al tiempo que puntualiza que:

«Varias veces ha sido defendida la opinión de que en la RDA no había publicidad. Esto debe ser revisado incluso respecto a la publicidad económica, tal y como ya han evidenciado diferentes publicaciones. Para empezar se estaba convencido de sus necesidades e incentivaban la producción de una metodología de la publicidad socialista, así se veía teóricamente la publicidad económicay.

La publicidad en la RDA estaba fuertemente asociada a la política gubernamental, tal y como se desprende de las palabras de Alexander Abusch (1954: 1, citado en Wunderlich 2007: 32):

No deseamos los viejos y sobrealborotados anuncios al servicio del capitalismo, que intenta imponer la producción de baja calidad. Lo que deseamos es una publicidad bella con espíritu socialista, que haga conocida la mercancía de la mayor calidad, que afine las necesidades de los obreros y ayude a acentuar su sentido para la calidad.(...) La publicidad ajusta el carácter de los trabajadores y campesinos socialistas».

Podríamos concluir que según Simone Tippach-Schneider (2004: 6) «para el comercio en la RDA la publicidad era necesaria: debían animar a la compra de las mercancías, informar a los consumidoras y propagar el modelo de consumo ${ }^{55}$, sin olvidar, según Conrad, Kuhrmann y Ludwig (2002: 23) que la «en la RDA realmente existió cartel

55. Man kommt der Antwort näher, wenn dagegen der Begiff Werbung weiter gefasst wird nämlich als Teil der Warenkultur, be der auch Bedeutungen, kulturelle Muster und Zeichen erzeugt werden. wig consumo, sin embargo este tenía siempre una menor significación».

Esta consideración particular de la función de la publicidad como escaparate de la economía socialista jugaba un importante papel en el mercado internacional, donde presentaba sus productos, pero que según lamenta TippachSchneider (2004: 7) «(...) desgraciadamente para productos y servicios los cuales se vendían en el extranjero a cambio de moneda extranjera había publicidad que sin embargo estaba dirigida a los vendedores y no a los consumidores».

Debido a este uso como escaparate la publicidad iba habitualmente muy por delante de las posibilidades reales de producción. Wunderlich (2007: 34) se refiere a ello cuando dice que «la publicidad de productos tuvo que luchar desde en principio con enormes dificultades, se prometían cosas que no estaban con la calidad satisfactorias, cuando no eran absolutamente inasequibles. Con la economía planificada, expropiación de las producciones privadas y centralización de la economía difícilmente se podía estar en condiciones de reaccionar al mercado», o como escribe Albrecht (1962: 22, citado en Kaminsky, 1999: 42) «las medidas publicitarias estaban insuficientemente simultaneadas con los planes.(...) Así por ejemplo se estimulaban necesidades, para cuya satisfacción sin embargo no existían posibilidades de política nacional».

En la misma línea se pronuncia Tippach-Schneider (2004: 6) quien afirma que:

«La escasez de material y problemas con la industria proveedora llevaron a permanentes dificultades en el aseguramiento de la calidad. Cada vez menos tenían las empresas individualmente una influencia directa en la elección de los consumidores. Máquinas anticuadas y la fobia a la innovación de la economía planificada influyeron negativamente no solo en la calidad de los productos, sino a la motivación de los productores. Con la centralización del comercio mediante la construcción de las centralización del comercio mediante la construcción de las ción directa de los productores y los consumidores».

El resultado de estas dificultades de ajustar publicidad $y$ mercado sería que se pasará de una publicidad de productos individuales a las campañas masivas de productos, con una especial intensificación en la década de los 60, con la aparición en el mercado de la RDA de nuevos productos tales como electrodomésticos, productos de camping nuevos cosméticos y materiales sintéticos. Según relata Wunderlich (2007: 34) «a partir de 1970 vivió a publicidad una cesura, la cual sería por decirlo así, nuevamente una incorporación de los medios publicitarios pequeños en la empresa establecida en el Kombinat DEWAG-Werbung (...) se reforzó la tendencia de hacer publicidad de grupos de productos o cadenas comerciales como HO, Konsum o Exquisit». Esto sería válido hasta el año 1975 en el que se hizo efectiva una prohibición de la publicidad dentro de las fronteras, que sin embargo siguió permitiendo la publicidad de los productos fuera de ellas.

Previamente a esta fecha la función de la publicidad en la RDA había evolucionando con el paso de los años y de los planes. Atendiendo a la opinión Conrad, Kuhrmann y Ludwig (2002: 23) «la historia del cartel de consumo de la RDA se parte hasta aquí en dos fases: la primera va hasta los años 60 , que hacía propaganda todavía de productos concretos. En una segunda fase se suprime ese clásica campo de ocupación, y solo surgen carteles de información en forma de orientación al consumidor general». Pese a que el elemento publicitado variase en estas dos fases no así lo hizo la forma de publicidad. La teoría publicitaria en la RDA se basaba en 
la información. Según el libro de la publicidad publicado en 1968 por el Autorenkollektiv (colectivo de autores) (29, citado en Wunderlich, 33) «esta informaciones debían ser objetivas y fieles, despertar la atención y el interés. En ellas las ventajas de las mercancías y servicios se presentaban, basaban y convencían, activaban los negocios de compra, enseñaba y alejaba falsos conceptos».

Desde el punto de vista formal esta información objetiva se traducía en el uso mayoritario de la imagen fotográfica buscando este fin de la información objetiva, la cual trasladaba al observador autenticidad y construía una supuesta realidad; podía presentar al público el producto claramente y suponía un componente fomentador de la venta. Sin embargo en opinión de Wunderlich (2007: 33) «predominantemente se publicitaba mediante trazados mesurados, fotos sobrecargadas las cuales más bien causaban desorden que informaban objetivamente. Por otro lado existen interesantes láminas con ideas gráficas notables, figuras publicitarias actuando llenas de humor o zonificaciones objetivas-constructivas», como es el caso del cartel diseñado por Klaus Klemke para la cámara "Werra» con una creación gráfica constructiva orientada en las láminas de la Nueva Tipografía. Igualmente crítica con la realización del ideal de fidelidad y objetividad se muestra Tippach-Schneider (2004: 7) quien opina que:

«(...) bajo comportamiento de la RDA y libre de competencia se cambio la simbología de la publicidad. Los consumidores no debían en la mayoría de los casos elegir sus productos entre diferentes fabricantes. La figura y ponderación de las mercancías y productores se desplazó directamente a favor de la representación de contenidos vitales y culturales. En la publicidad había dibujos de compradores y consumidores y querían reproducir la imagen del consumidor, que se tematizaba bajo juventud, salud, cocina, comida, vivienda, vacaciones y tiempo libre».
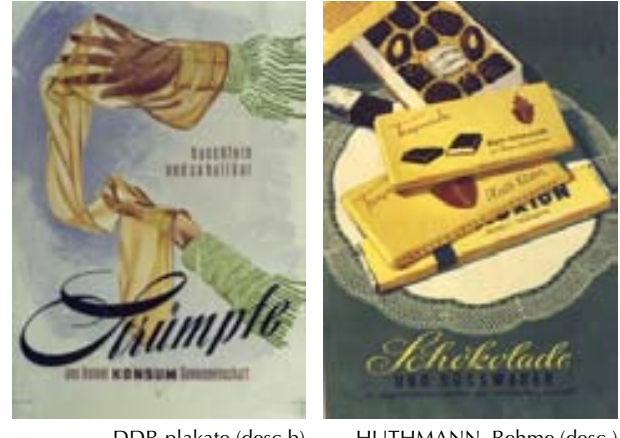

DDR-plakate (desch)
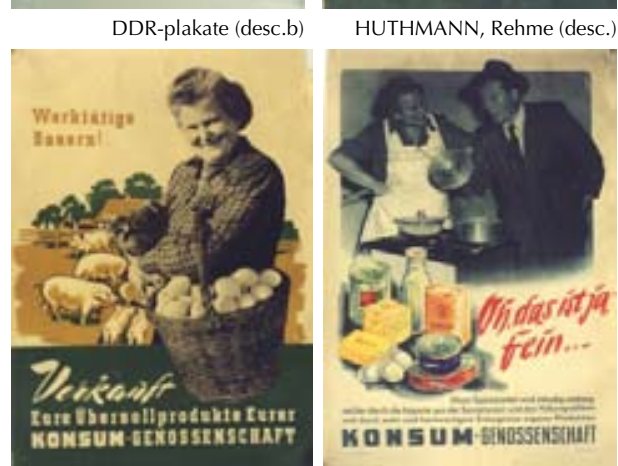

DDR-plakate (1954)

DDR-plakate 1950

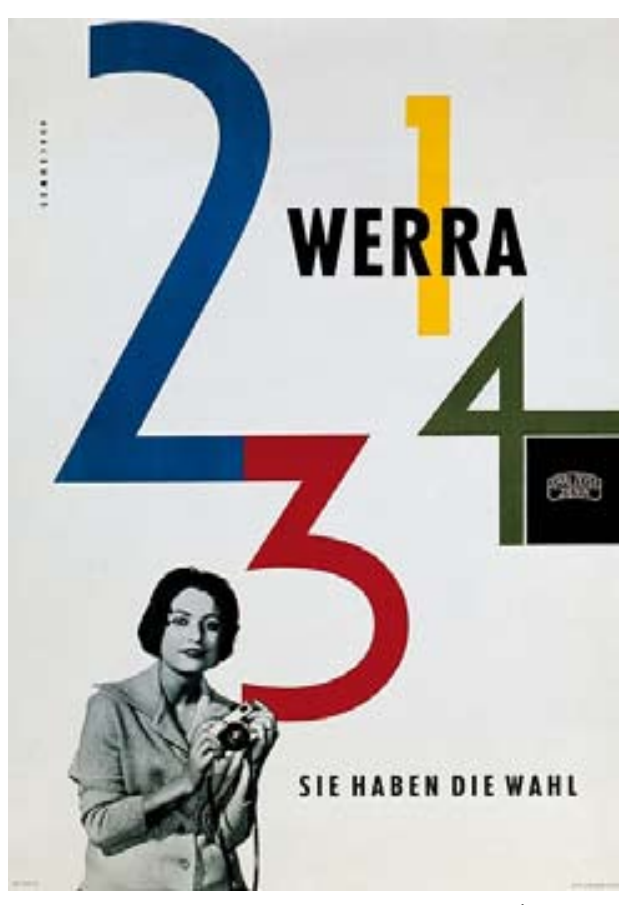

LEMKE, Klaus $(1959$

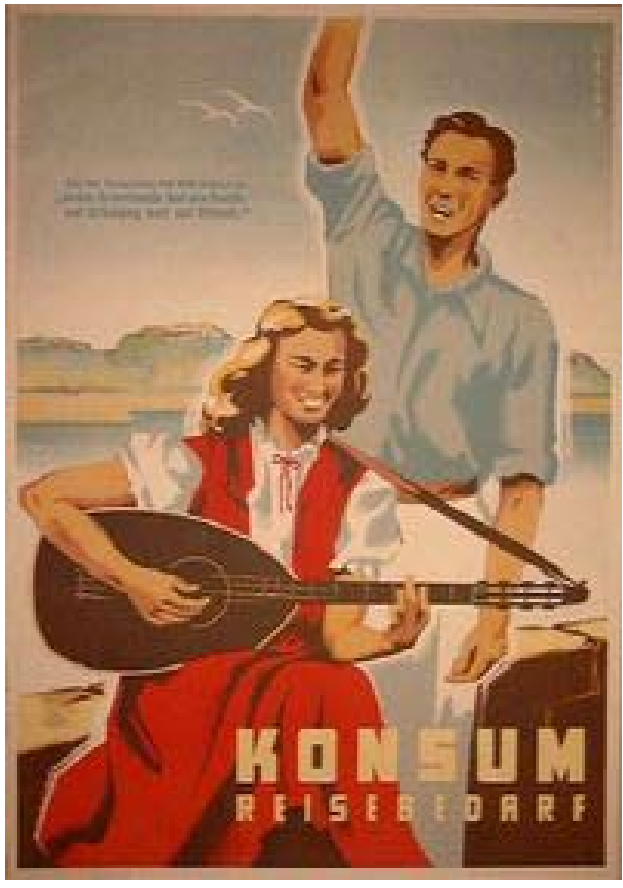

REHMEN, Rolf 1950

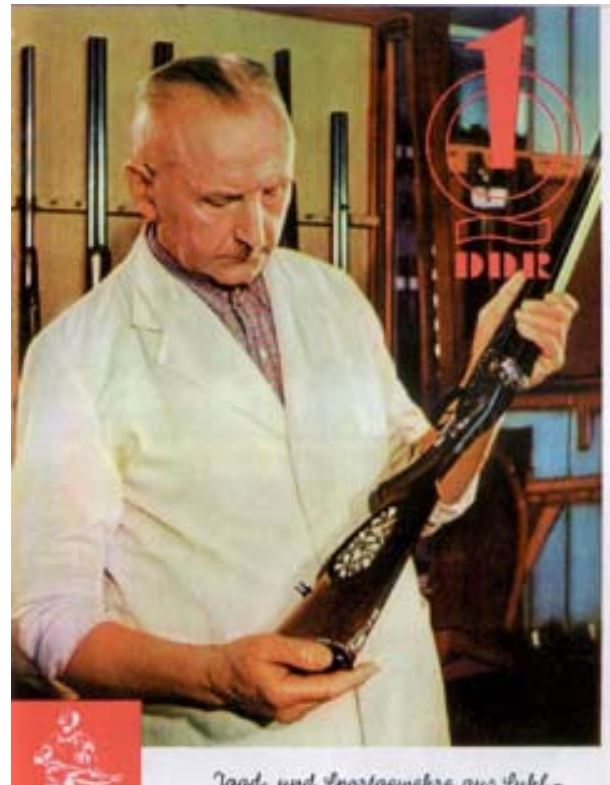

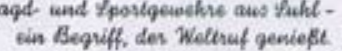
EEB ERNST-THALMANN-WERK SUHL

TIPPACH-SCHNEIDER, Simone (1959) 
desarrollada por Moholy-Nagy, y en los carteles para teatro

Se integra el plano cultural todo el diseño gráfico realizado para la promoción de exposiciones, películas, teatro, las comunicaciones científicas y de fomento del deporte.

Pese a no tener un papel destacado dentro de la producción gráfica de la RDA como lo tuvo el cartel político, sí que lo tendrá desde el punto de vista artístico. La formación gráfica más rica la encontraremos dentro de los carteles de

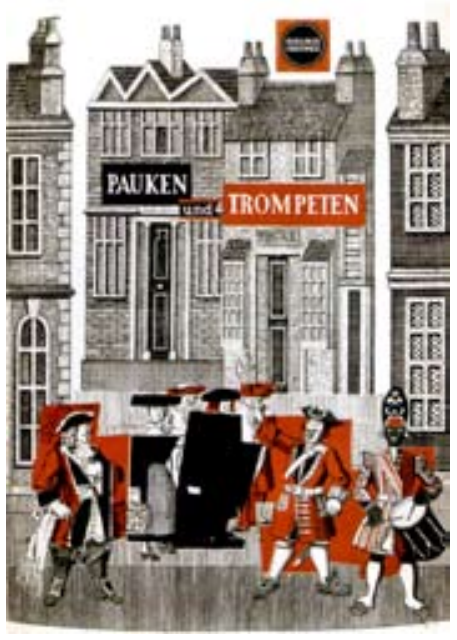

APPEN, Karl von (1955)

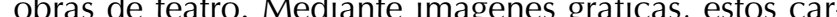
teles hacen referencia a la obra, los intérpretes, la escenografía. Más allá de la mera publicidad de la obra los carteles se entienden como una presentación de las mismas cuya principal razón de ser es llamar la atención. En opinión de Wunderlich (2007: 25) «el cartel de teatro de la Alemania del Este llama la atención mediante su configuración. Aparece pictórico, gráfico, tipográfico o fotográfico, debajo de ellos están montajes o collages los cuales captan la atmósfera y la idiosincrasia de la obra». Gracias a la expresividad de las imágenes los textos tienen aquí una menor relevancia de la que tendrán en el cine, con una mayor profusión de datos relacionados con la película anunciada. En ambos casos la finalidad última del cartel es despertar la curiosidad, pero mientras en el teatro prima fundamentalmente la imagen, en el cine existe una mayor conjunción de imagen, estructura y tipografías de fácil comprensión.

El abanico gráfico utilizado en los carteles para teatro es muy amplio y abarca prácticamente todo tipo de expresión. Según relata Wunderlich (2007: 26):

«(...) la inmensidad de multiplicidad de ideas, impregnaciones de obras literarias, de directores y actores permanece en la memoria. Ahí muestran los pias capacida pias capacidades, dibujos, pinturas, apuntes de ideas, citando ocasionalmente otos antistas y debiendo poco a la fotografía la cual dominaba en los años 60 los carteles sobre todo de la RFA. Solo ocasionalmente serán aplicadas las fotos en los trabajos de pruebas, fotomontajes o fotos históricas».

Destacan entre todos los carteles los realizados por Werner Klemke para el Deutschen Theater Berlin (Teatro Alemán de Berlín) mediante los cuales dotó al cartel de teatro de una nueva dimensión.

En los carteles culturales de la RDA encontraremos numerosas alusiones y reminiscencias de la historia gráfica de la antigua Alemania. Tal es el caso de los carteles anunciadores del Zoo, cuya simplificación de la composición nos traslada a la realizada por los artistas del Plakatstil con un uso de la tipografía descendiente del realizado por la Typophoto diseñados por Volker Pfüller en los que realiza «una fuerte manipulación de las formas, una acentuada letra manuscrita y una sutil espíritu de forma, la cual es deudora del arte del cartel alemán y de la pintura expresionista anterior a la primera guerra mundial»(Wunderlich, 2007: 24).

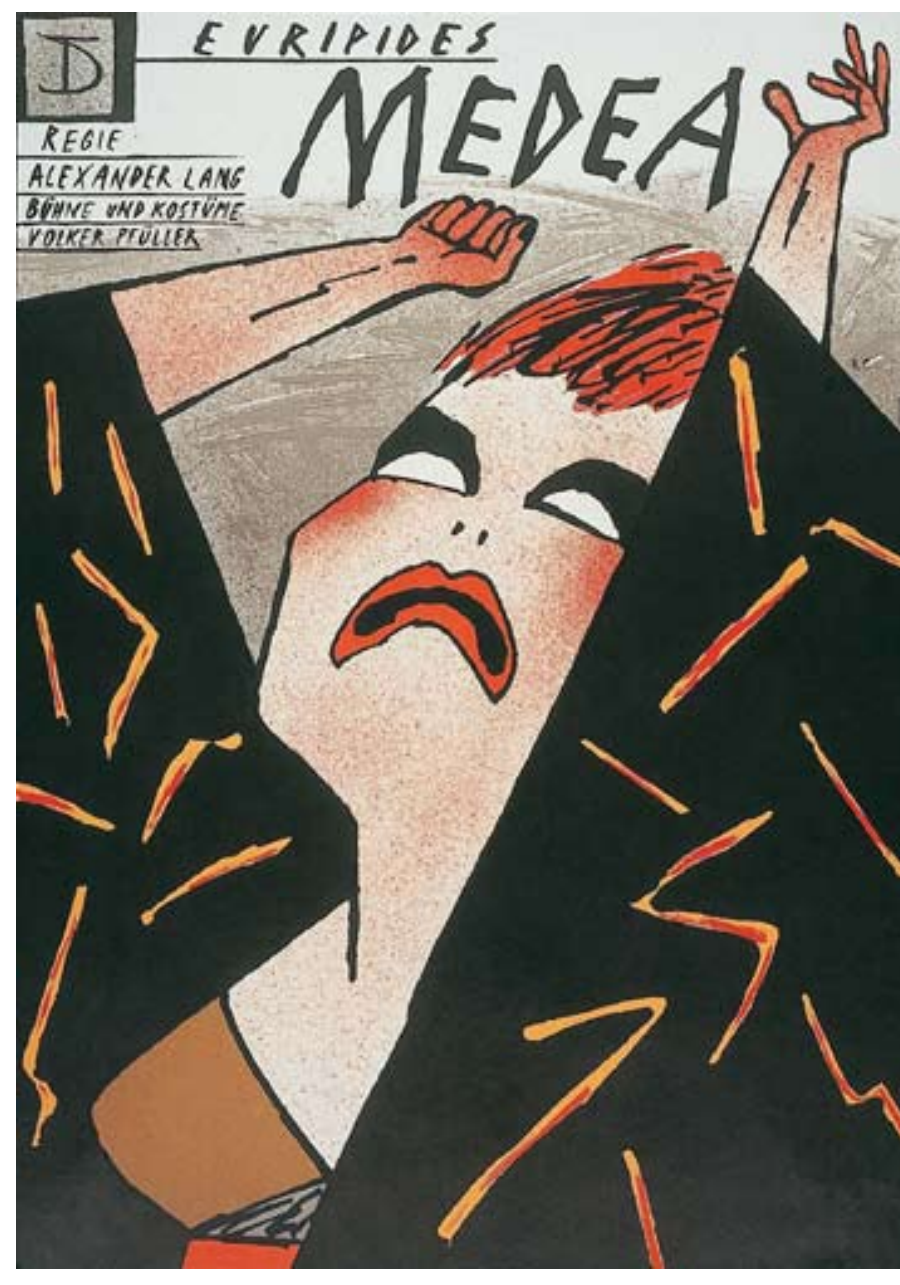

La influencia de la Nueva Tipografía la encontramos fundamentalmente en los carteles realizados para las exposiciones, en los cuales «es significativa una sencilla y abstraída gran forma en concierto con una tipografía objetiva» (Wunderlich, 2007: 18). El ejemplo más claro lo hayamos en los carteles de «iga-plakat» de Siegfried Kraft cuyo logo se basaba en minúsculas de colores superpuestas. Otro gran exponente de las composiciones objetivas es el cartel «Qualität» realizado en 1950 por Klaus Wittkugel, que sin embargo, en opinión de Wunderlich (2007: 18) «la lámina 
objetivamente reducida muestra el camino en una dirección, la cual desgraciadamente estaba demasiado poco encaminado: una foto en combinación con diferentes tipografías, las cuales lucen distanciadas».

En los carteles anteriormente mencionados tiene gran relevancia el simbolismo de las imágenes en conjunción con la tipografía, y con ello la retórica visual, ya que como afirma Hilmar Frank (1989: 50) «con la evaluación de los carteles se llega espontáneamente a hablar de su poder metafórico o símbolo» ${ }^{56}$. Si bien antes hablábamos del reducido grupo de símbolos usados en el cartel político, en los culturales se permite una mayor variación con el uso de antiguos y nuevos símbolos como El megáfono de Georg Baus, la musa en Maxkarl Beyer o la mariposa en Wilhelm Deffke.

Era muy importante también el campo de la publicidad de conciertos, músicos, artistas o festivales «con originales realizaciones, ya sean con ayuda de vistosas tipografías creativas o fuertes grabados con alto efecto evocador» (Wunderlich, 2007: 21), que simultaneaban la publicidad con los carteles de imagen de los grupos. Los mismos carteles que anunciaban un concierto servían de envoltorio de los discos. Mediante superposiciones, montajes, exploraciones, encajes de tipografía letra manuscrita realizaban espectaculares láminas en las cuales rebasaban la frontera entre cartel y grabado.

Pese a la gran relevancia del deporte y de sus logros en la vida de la RDA, esta importancia no se trasladó a sus carteles, los cuales, en opinión de Wunderlich (2007: 35) «(...) están acuñados con un naturalismo trivial, dibujos aficionados y elección tipográfica sin gusto y desordenadas», de tal modo que salvo excepciones el nivel de estos carteles nunca se pudo acercar al nivel general del diseño de la RDA.

\subsection{DESARROLLO DEL ARTE DEL CARTEL}

El diseño gráfico en la Sowjetischen Besatzungszone (Zona de ocupación soviética, SBZ) tendrá su primera expresión en los carteles políticos y revolucionarios del final de la guerra. Rademacher (1989: 10) relata que «en el verano de 1945 aparecen los primeros carteles, que en su creación de artes plásticas amplifican las declaraciones políticas. El deber de la mayor parte del lenguaje gráfico se destinaba a la movilización de las personas al montaje, al afianzamiento de las condiciones vitales materiales elementales a través de la aplicación única de la fuerza, a menudo también ella relacionado el ajuste de cuentas con los crímenes del fascismo de Hitler». Este uso del cartel únicamente como medio de agitación supone, según Wunderlich (2007: 11) que «su creación artística no está en primer plano, sino la palabra impresa».

Junto con esta facilidad de entendimiento hay que considerar que en los duros años de la posguerra la escasez de material era una constante en todas las facetas de la vida de la RDA y por supuesto también en la producción gráfica. Según relata Wunderlich (2007: 11):

«El papel de imprimir, colores o tipografías dependían de la disponibilidad, y eran gradualmente mejorados pieza a pieza. Las pulsaciones deben su apariencia a los impresores, que daban a los textos facilitados una forma más o menos agradable. La mayoría imprimían con tipografía de plomo o de madera en imprentas de tipografía o litográficas, ya que las máquinas de offset estaban disponibles solo condicionalmente. En algunos casos se esforzaban en el cartel de texto un tipógrafo de apoyo como Horst Erich Wolter».

El resultado es que estos carteles artísticamente poco pretenciosos y de imágenes fáciles «carecen en general de la acalorada dinámica que había sido característica en el cartel proletario-revolucionado anterior a 1933 (...). El nuevo contenido político no había encontrado aún, como tantas veces en la historia del arte, un lenguaje formal artístico propio. (...) También permanecía en este tiempo mayormente descuidado el problema imagen-tipografía» (Rademacher, 1989: 11). A falta de un lenguaje propio muchos de los carteles de los primeros años de la SBZ/RDA volverán al lenguaje gráfico previo a la guerra. En opinión de Wunderlich (2007: 10-11):

«(...) sus ideas [de los diseñadores Alemanes de la primera mitad de siglo], así como el impulso del cartel suizo o los trabajos de la Avantgarde constituyeron el germen formal para el escenario que se desarrollaría a partir de 1945 en la SBZ y a partir de 1949 en la RDA. En los primeros años de postguerra serían las bases políticas y artísticas en desarrollo del denominado arte del cartel».

Rademacher (1989) encuentra igualmente a esta influencia en el trabajo de artistas como Georg Baus, Johannes Boehland, Wilhelm Deffke, Herbert Enke, Walter Funkat, Wilhelm Lachnit, Dorothea Mönkemeyer-Corty, Max Schwimmer que se vincula con la experiencia cartelista de los años precedentes. Parte de esta explicación la encontramos en las palabras de Wunderlich (2007: 11) en que afirma que:

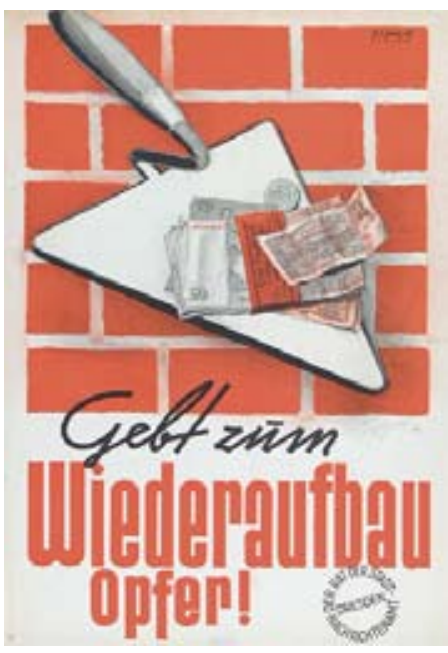

PETZOLD, Willy (1946) 
«Los viejos artistas como Willy Petzold, Heinz Völkel, Kurt Fiedler, Host Naumann y Willhelm Schubert realizaron los primeros encaros. Ellos segurn estado mos de la imagen de los años 20 y pimeros 30. La diversioaños 20 y primeros 30. La diversidad artística no estaba concretada a comienzos de la SBZ. Eso valía para todos los clientes y posibilidades de consumo de cultura: conciertos, exposiciones, teatro y entretenimiento general».

Esta continuidad gráfica será válida hasta 1948, año en

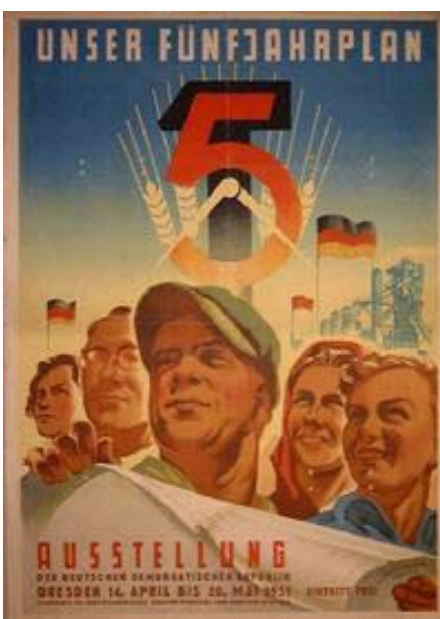

NAUMANN, Horst (1951) el que las tensiones entre los Bloques del Este y Oeste y la guerra fría repercutieron en la cultura. El dirigente de la sección de cultura de la SMAD Alexander Dymschitz declara que las tendencias formales en la pintura alemana de decadencia burguesa, subjetivismo e irracionalismo serán reprimidas. Ya pertenecía a la ideología política desde 1946 pero no habían tenido hasta ese momento ninguna repercusión en el arte. Wunderlich (2007: 12) afirma que «sobretodo estaban las artes plásticas en el plano de la crítica, los carteles permanecieron respetados en un primer momento. A pesar de todo había tendencias en la prensa, de discutir críticamente las presuntas maneras de creación formal de los carteles. Se hablaba de deficiente forma de estilo, manera de expresión formal del pasado, abstracto, juego intelectual con números y formas». Estos carteles se consideran formalistas e influenciados por la Neue Sachlichkeit, lo cual estaría categorizado burgués y decadente. La solución gubernamental para la cuestión de estilo será, según Rademacher (1975: 35) «documentar, también para el diseño gráfico, la premisa metódica del realismo socialista como una base segura».

Sin embargo, el factor de impacto que se le exigía al diseño gráfico le dotó de una mayor diversidad formal que al resto de las artes. A esta relativa libertad contribuyó también el hecho de que la discusión sobre el diseño gráfico de los años 50 vaya evolucionando desde una consideración «básica estética y estrechamente dogmática de indiferenciación artística en la cual no estaban suficientemente separados los criterios específicos de una única categoría artística, se pasa a una distinción» (Rademacher, 1989: 13). Estas se realizaban en el marco de una discusión artística y sobre las características particulares del diseño gráfico que le confirió categoría con la creación de la sección de diseño gráfico de la VBK en 1953 y un año más tarde con la fundación de la revista especializada «Neue Werbung» (Nueva Publicidad) la cual se inicia con discusiones sobre el cartel político.

«Los carteles de los años 50 serán un reflejo de los retos del país la reconstrucción del las zonas devastadas por la guerra- las nuevas estructuras y la construcción de una sociedad socialista» (Conrad, Kuhrmann y Ludwig, 2002: 6). Con esta ampliación de temas relacionados con el Aufbau des Sozialismus (Construcción del Socialismo) Ilegarán los grandes maestros del cartel. En opinión de Rademacher $(1989,15)$ :

«Ellos le concedieron al cartel un perfil polifacético, llenos de fantasía y temático, le dieron la diferenciación de sus caligrafía personal y sus conceptos artísticos (...). Por primera vez se considerará y creará el cartel como un trabajo artístico, el cual junto con del desempeño de un deber comunicativo concreto realiza imágenes artísticas e influye como proceso cultural en el conjunto de la sociedad".

Es también en este momento cuando se comiencen los concursos y exposiciones sobre carteles.

A lo largo de los años 50 se empieza a experimentar en la RDA con las posibilidades de las técnicas fotográficas y de fotomontajes, pese a que según lamenta Rademacher (1989: 17) «estaban preparados antes [en la escuela de la Bauhaus] para ser un elemento creador excelente arte del cartel proletario revolucionado, desde entonces sin embargo de acuerdo con la discusión artística se considera como formalmente en descrédito». Sin embargo poco a poco se empieza a introducir en los carteles de la RDA como elemento transmisor de realidad, en los que destacan las obras de Wittkugel y Heartfield.

Dentro del debate sobre el realismo socialista, la década de los 50 supondrá el paso desde el repertorio de los años 20 hacia el estilo del neoclasicismo, y no será hasta los años 60 que se modernice la apariencia del cartel y se libere del debate sobre el arte socialista y de la condena a las expresiones artísticas denominadas burguesas. En opinión de Rademacher (1975: 19):

«En los años 60 el diseño de carteles sufriría un cambio que permanece hasta el final de la RDA. Se hará muy notable en el terreno cultural (teatro, música, cine, exposiciones), donde desempeña una función que no puede hacer ningún otro medio, al menos no en su totalidad. Esto supone una competencia artística que incrementa su valor».

En 1973 se realizan los primeros acercamientos a occidente de la RDA estableciendo relaciones con ellos y obteniendo representación internacional en la ONU, así como la firma de los primeros acuerdos con la RFA y esto se traslada a la expresión gráfica, que de un ámbito nacional pasa a buscar formar parte del desarrollo mundial. «Los carteles para el Weltfestspiele der Jugend und Studenten (Festival

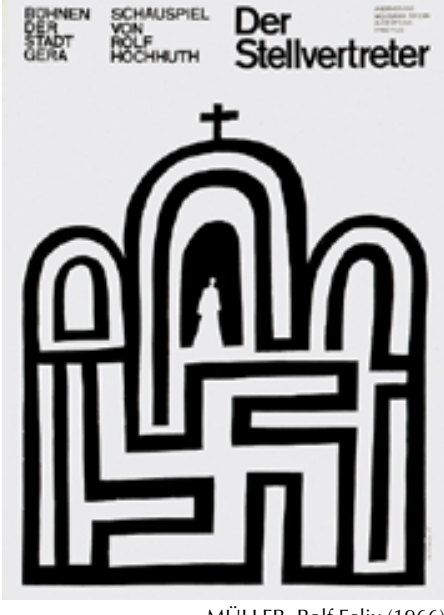

MÜLLER, Rolf Felix (1966) 
Mundial de la Juventud y los Estudiantes) de 1973 que tuvo lugar en Berlín Oriental el cual se muestra (...) mediante formas relacionadas con el PopArt y amigo de los colores» (Conrad, Kuhrmann y Ludwig, 2002: 14).

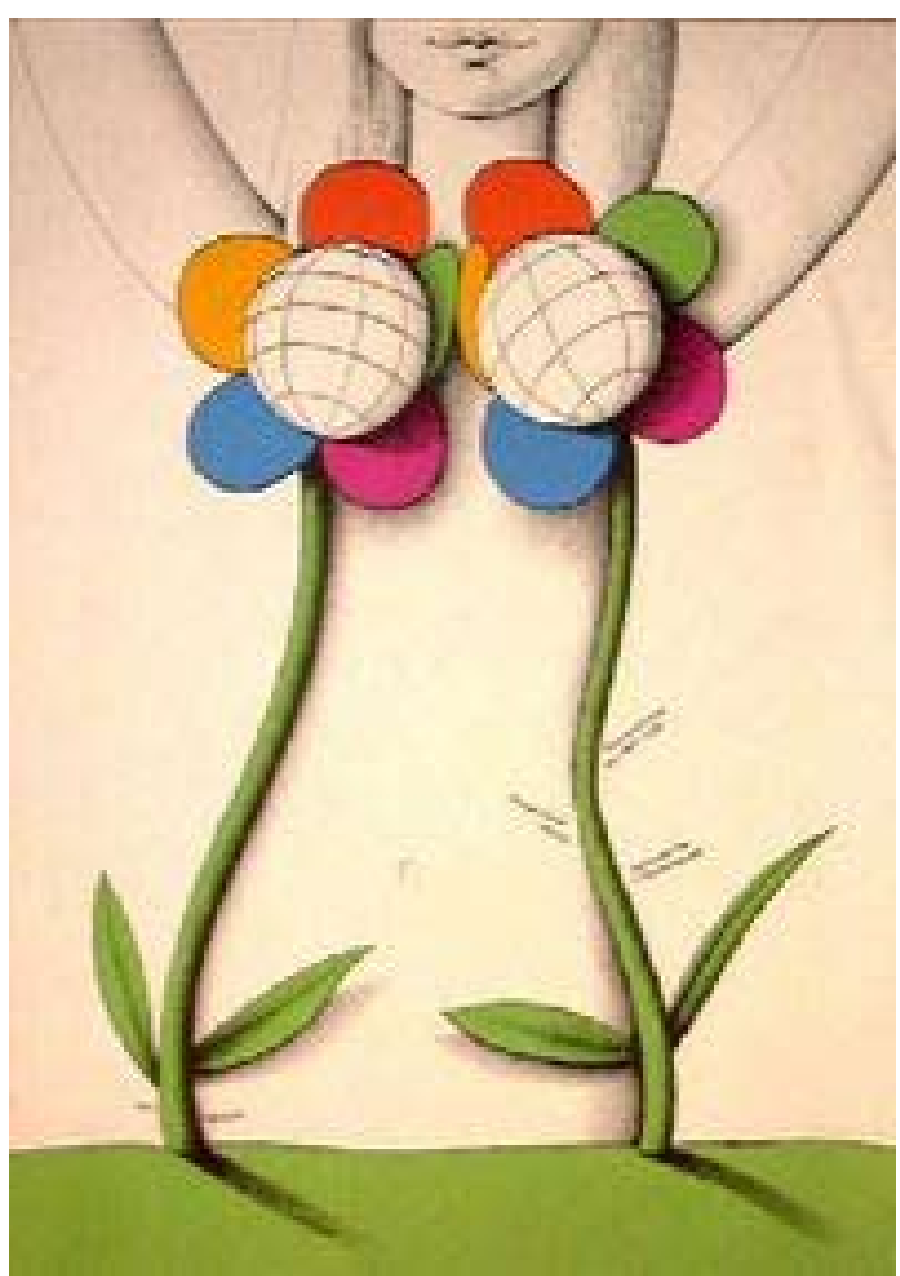

Esta apertura supuso que estéticamente los años 70 se caracterizan por la ampliación de medios artísticos: Incorporación de la cultura pop, gran presencia del fotomontaje, una tendencia a la abstracción y una creciente creación tipográfica que tendrá su punto álgido en la década siguiente, con numerosos concursos que animaban el interés por nuevas creaciones y tipografías. En estas dos décadas se desarrollarán un buen número de carteles basados en la tipografía. Rademacher (1975: 23) relata como:

«Los carteles con arte tipográfico pueden tener efectos complementarios mediante la aplicación múltiple y modulada del color, el empleo de tipografías estructuradas contrastadas cro- máticamente, mediante el uso de formas elementales orientadas separadas en la composición de la frase, conscripciones o huecos de superficies o campos con decoración de círculos y líneas, cos de superficies o campos con decoración de círculos y líneas,
encabezamientos, líneas ciegas, retículas, ornamentos caligráficos, que alcanzan como ornamentos y llevan al proyecto una elegancia estética sublime».

Pero el uso acertado y elaborado de la tipografía no se reducía únicamente a este tipo de composiciones sino a aquellas en las que servía como un elemento más de la composición y en las cuales:

«Título, tiempo, lugar y horarios de apertura se mostraban con tipografías vistosas. Los diseñadores eran expertos en este campo, es decir en la relación con la tipografía como emisor de significados. Las tipografías podían proporcionar ambientes como imágenes, estimular tensiones y dar consejos de estilos históricos. (...) En ese oficio se encuentran trabajos tipográficos, los cuales se componen de múltiples tipografías de diferente clase, las cuales imágenes o símbolos están de adorno. Helmut Brade, Kart-Heinz Drescher, Horst Feiler, Rolf F. Müller, Klaus Rähm, Walter Schiller y Gert Wunderlich resultaron como maestros de su especialidad» (Wunderlich, 2007: 19).

Al igual que había ocurrido a comienzos de la RDA en la década de los 80 el cartel político volverá a destacar por su capacidades comunicativas en una década marcada por los cambios de política internacional. Sin embargo estos carteles destacarán por su conceptualismo, según relata Rademacher (1989: 22) «antes valía la comprensibilidad de su declaración en un primer vistazo como un criterio decisivo para un buen cartel, es ahora más considerado como un compañero de conversación para el observador». En ellos se busca chocar y sorprender al observador mediante elementos sobreexpuestos y efectos simultáneos. También la espontaneidad artística será cada vez más habitual, será el momento de experimentar.

La creación gráfica de la RDA estará orientada desde el comienzo «tanto a corrientes formales del pasado como a los desarrollos fundamentales dentro y fuera del país. Los artistas cogen estímulos del arte libre, como la abstracción y la construcción, objetividad, expresividad o tendencias realistas» (Wunderlich, 2007: 44). Estos estímulos suponen en ocasiones que el diseño gráfico caiga a veces en el influjo de tendencias de moda, las cuales, según lamenta Rademacher (1975: 18) se pueden entender en una primera mirada como «modernas y actuales, muestran en realidad habitualmente formas solo aparentemente asimiladas, las cuales han sido establecidas sin ninguna necesidad interna para ser formadas, y que incluso puede que no le vayan 
Junto con el realismo gráfico, el simbolismo será otra constante en el diseño gráfico, especialmente en aquellos casos con proyección internacional. Superado el simplismo simbólico de los carteles políticos de los primeros años, pasaran a general un diálogo con el espectador en el cual «los carteles de la RDA rechazan sus aplicaciones directas, se caracterizan como emblemas de su tiempo, transmiten ideales socialistas, propuestas de valor y sentimientos vitales, pero también la historia y la conciencia de sí mismo de sus creadores y consumidores». (Wunderlich, 2007: 45)

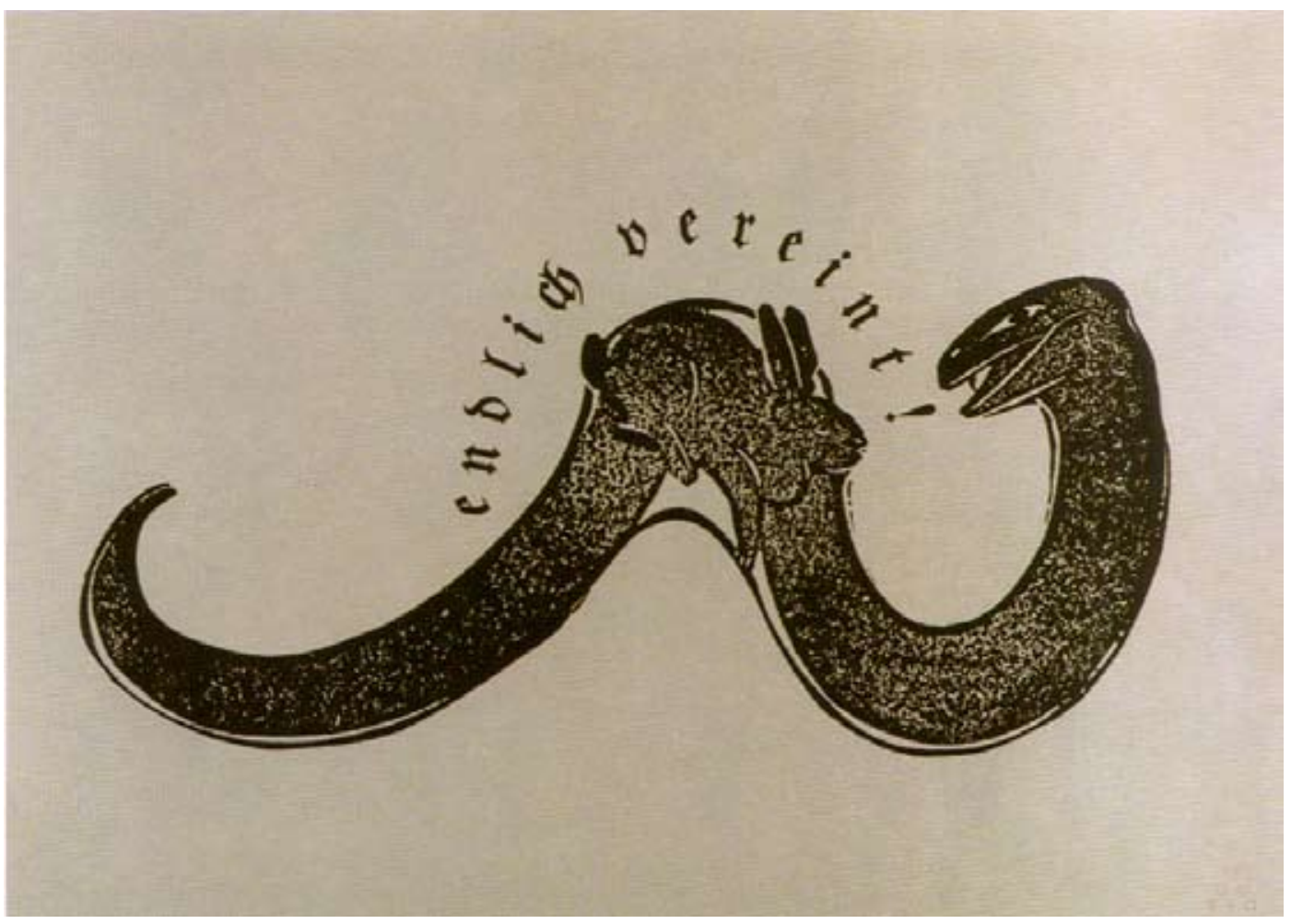

GUBIG, Matthias (1989b)

\subsection{CREACION TIPOGRAFICA}

Tal y como hemos visto en la organización empresarial de la RDA, la encargada del desarrollo de tipos que eran necesitados era la VEB Typoart. Poco después de su fundación Herbert Thannhaeuser, director creativo de la VEB Typoart publica un folleto (aprox. 1949) en el cual explica que:

«Los dos dueños de las fundaciones Schelter \& Giescke de Leipzig y Schriftgiess de Dresden, han sido amalgamadas el año pasado en una nueva empresa que es conocida bajo el nombre de VEB Typoart Dresden. La nueva empresa está produciendo tipografías, matrices y normas de latón. La eficiencia de la nueva empresa se ha incrementado en todos los ámbitos. El incremento no se restringe al incremento de la capacidad, sino que gana un

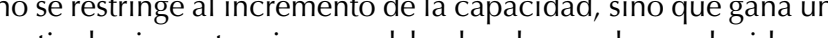
particular importancia con el hecho de que lo producido por la VEB Typoart, las buenas letras, no son solo una comodidad
ordinaria, sino que son diseñadas en cooperación con expertos competentes y tratada como una realización de valor cultural».

Con esta declaración de intenciones la VEB Typoart se inicia con esa doble visión de empresa al servicio de unas necesidades, pero también contemplando su componente artística. Thannhaeuser se encargará en esta primera época de la creación de numerosas tipografías de edición pero se le criticará, según explica Jay Rutherford (2006), «que su programa de tipos de Typoart estaba dominado unilateralmente por sus diseños».

Para entender el funcionamiento de la VEB Typoart hemos de tener en cuenta por un lado, que la creación editorial gozaba en Alemania de una gran tradición que se mantiene y potencia en la RDA. Parte del éxito estará basado en e correcto uso de la tipografía para el propósito perseguido. Para Thannhaeuser (a. 1949):

«(...) no solo se crean los símbolos con los que se compone una palabra; al mismo tiempo, esa palabra, esas líneas, se convierten en una expresión gráfica. Y esa expresión es la imagen verdadera de nuestra cultura gráfica. Cualquier publicación que cogemos en nuestras manos -no importa si se trata de un libro, periódico, catálogo, invitación o programa teatral, gaceta o documento- muestra claramente que significado gráfico estamos usando, cómo tramitamos el contenido de la información que queremos publicar».

El elemento más característico de la promoción editorial eran las ferias de libros entre las que destaca la Feria del Libro de Leipzig, que data de 1600 continuó en la era de la RDA. En ella se organizaban premios a los «libros más bellos» y se organizaban concursos regulares de diseño de tipos, cuyos ganadores trabajarían con la VEB Typoart para producir sus diseños. 
Este alto interés en el campo editorial tuvo repercusión en de la creación de tipos junto con el hecho de que a su vez el tipógrafo Albert Kapr -sucesor de Thannhaeuser como director creativo de la VEB Typoart en 1963-fuese 57. La «Escuela de Leipzig» era el nombre con el que se conocía
la Hochschule für Grafik und Buchkunst de Leipzig (Escuela Superior de Artes Gráficas y del Libro, HGBL).

director de la llamada «Escuela de Leipzig ${ }^{57}$ que en los años 70 tuvo en la tipografía y el diseño editorial sus puntos fuertes de la escuela. Esto supuso que, en opinión de Karp y Schäfer (1989: 25) fuera:

«(...) una suerte que en la RDA haya un gran número de tipógrafos bien formados, teniendo en cuenta los costes de tiempo que la formaci to que la formación de ción de diferentes artistas y entran en juego diferentes escuelas. (...).Y todos saben que sin tipografía no se puede hacer [diseño gráfico], y muchos tienen la ambición, también en este importante terreno, de conseguir algo artísticamente válido».

El diseño editorial le supuso a la tipografía un fuerte empujón y fue un pilar de apoyo fundamental para su desarrollo y reconocimiento, pero también en el diseño gráfico más allá del editorial, la tipografía adquiría un gran valor. Rademacher (1975: 22) afirmaba que:

«(...) la tipografía tiene una doble función como el principal medio de formación, cuando no también imprescindible por único. Por un lado es la portadora de la información. Por otro tiene un factor estético y trae hasta aquí un efecto gráfico y un valor que puede ser guiado por su formación y composición. El círculo de tensiones entre su racionalidad y su efectividad emocional abarca desde la sobria objetividad, rigurosidad constructiva hasta intensidades de sentimiento cargadas de emoción y agitaciones fluidas, desde acordes de bellezas clásicas armónicamente simétricos hasta trabajos decorativos o a grotescos juegos, desde una estética sensiblemente inspirada en la caligrafía hasta una monumentalidad masiva».

Pese a los recortes efectuados por el gobierno en el mundo publicitario, tal y como recuerda en una entrevista el tipógrafo Karl-Heinz Lange (2007) «los diseñadores de tipos de Alemania del Este gozaban del respeto del gobierno». Este respeto les permitió que mientras que los trabajos creativos de cine, y arquitectura tenían que hacer acuerdos con la censura gubernamental, los diseñadores de tipos disfrutaban una cierta libertad artística. De acuerdo con Lange (2007), «Type quería decir producción, eso es independiente de la ideología. Type tiene contenido, es legible y cuando es leído el contacto tiene el significado, no es responsable de para que se use la tipografía».

Por otra parte la realidad económica de la RDA marcada por las dificultades de abastecimiento obligaba a una gran planificación de las empresas para obtener el máximo bene- ficio de sus escasos recursos. Todo ello dio lugar a bajo la dirección de Albert Kapr -sucesor de Thannhaeuser como director creativo en 1963- se crease un programa para establecer un programa racional de creación de tipos acorde con las posibilidades y necesidades existentes. Retrospectivamente Karp y Schäfer (1989: 11) reconocerán que en los años 70 y «desde 1945 se han creado al menos 2000 nuevas tipografías de plomo en el mundo de la escritura latina. La mayoría de esas tipografías responden a modas pasajeras, plagios de tipografías de éxito (...) $)^{58}$. A esta racionalización en el programa hace también referencia Lange (2007) quien afirma que:

«el principio frugalidad y efectividad nos condujo a trabaja con representantes de las empresas de impresión para desarrollar un programa de tipos que aunase todos los requerimientos importantes; una romana de transición para literatura como la Garamond, una clásica como la Bodoni o Didot, luego una egipcia, por ejemplo la Claredon. Tenía que haber algo significativo de cada estilo. Naturalmente también de palo seco, en diferentes estilos, como Helvetica y Futura. La Zentrag ${ }^{59}$ incluso pediría imitaciones de tipos hechos en el oeste y cuya licenci no podía afrontar».

Podríamos concluir que en el campo de la tipografía la RDA se movía entre dos tensiones, por un lado el valor que le conferían a la tipografía fundamentalmente por su aportación al campo editorial y por otro lado la escasez de recursos con el que contaban para su desarrollo. Todo esto llevó a que se realizara un gran esfuerzo de síntesis tipográfica con motivo del paso de la tipografía de plomo a la tipografía de fotocomposición en los años 60 y 70 . Este cambio conlleva la necesidad de redibujar los tipos para una nueva tecnología que implicaba unos requisitos en el diseño ante desconocidos.

«Para evitar las sobreiluminaciones fotográficas y con ello las redondeces de los ángulos y las esquinas, estos rasgos enfrentados debían dibujarse exagerados. Se debieron agrandar los puntos y adelgazar los trazos coincidentes en ángulos puntiagudos para impedir los raspados en la construcción de cortes de luz de la película. Los trazos finos se reforzarán ya que de otro modo los trazos serían frágiles». (Karp y Schäfer, 1989: 10)

Con el fin de combatir estas deformaciones y mejorar la calidad de los tipos se concibió en el año 1978 un acuerdo para el desarrollo de tipos de fotocomposición con ayuda de un equipo para la confección de datos geométricos. En este acuerdo se tenía en cuenta la magnitud de la tarea que suponía este paso, por lo que se consideró básico desarrollar un programa racional de tipos según el cual se consideraba que para una pequeña imprenta eran suficientes 5 tipogra-
58. (...) seit 1945 entstanden hach einer groben Schätzung mindestens 2000 neue Satzschriften für den Bleisatz in der lateinschrittigen Welt. Die meisten dieser Schriften waren schnell vergangliche Modeschriften, Plagiate von Erfolgsschiften und nicht asterener und miderwertiger Most.

59. Zentrag, Central de Empresas de Impresión, Compra y Revisión, era la encargada de la coordinación de todas las empresas de impresión y publicación. 
«La mayor parte de las imprentas así como diversos diseñadores gráficos consultados eran de la opinión de que Typoart debía primero planificar un número de 15 familias de texto y 20 de fantasía. (...) De los deseos y peticiones de las imprentas y editoriales se estableció finalmente el Programm des Schriftschaffens bis zum Jahre 1985 (Programa de Desarrollo de Tipos hasta el Año 1985) que se estableció con metas estéticas muy diversas» Karp y Schäfer (1989: 11).

Este estudio, del cual partirían las tipografías que se desarrollaron, resulta muy ilustrativo, ya que supone un análisis interno de las necesidades y los usos tipográficos en la RDA. Muchas de las tipografías que se habían desarrollado en los años anteriores nunca llegaron a ver la luz o desaparecieron rápidamente, quedando patente aquí cuales fueron las más relevantes, así como el sistema de clasificación y racionalización utilizado para ello. La necesidad de meditación sobre las tipografías a desarrollar parte según Karp y Schäfer (1989: 21). «La tipografía como parte principal portadora de información necesita en la reglas del incremento comunicativo mediante la imagen sobre la base de la claridad visual, de la concentración de la información amplificada, la obtención del objeto que atrae la mirada orientada a la publicidad, o la fuerza de estimulación emocional emotiva».

Por un lado se consideró la necesidad de contar tanto con tipografías clásicas como con creaciones propias. Las réplicas de varias tipografías clásicas se consideraron un importante pilar de apoyo. «Para la búsqueda de tipografías clásicas se integró primero las experiencias de las menciones anuales de los «libros más bellos de la RDA. Las tipografías más habituales en los libros premiados eran la Garamond y Baskerville» (Karp y Schäfer (1989: 13). Junto con la Garamond y la Baskerville se desarrollarían la Walbaum, la Bodoni la Kis-Antiqua, la Janson-Antiqua y la Prillwitz.

Resulta conveniente destacar que se trataba de un trabajo de réplica, no de copia en el cual:

1. «Rehuimos copiar las réplicas ya existentes de otras fundiciones y otras fábricas productores de tipos, no solo por razones morales, sino también porque es más interesante y fructífero internarse en la propia fuente

2. Antes de realizar los nuevos dibujos de las tipografías históricas deben ser contempladas y estudiadas todas las impresiones originales disponibles, escoger a las mejores y leer toda bibliografía relativa

3. También el proyecto de una réplica es una habilidad creadora y conlleva decisiones artísticas, ya que ya los distintos grados de tipografía diferentes artistas son disdistintos grados de tipografía diferentes artistas son dis-
tintos en forma y anchura». (Karp y Schäfer (1989: 13)

Los tipos desarrollados se basarían en cubrir todas las necesidades reales, tanto de tipografía de edición como tipografías creativas, dividiéndola en las siguientes categorías:

- Antiquaschriften (tipografías romanas): «Estas tipografías nombradas serán desarrolladas para libros, tanto para los dedicados a la literatura así como los de los de arte y ciencias populare ciencias populares, (Karp y Schäfer (1989: 15) Entran en estas tipografias: Garamond-Antiqua, Kis-Antiqua, Baskerville, Fleischmann-Antiqua, Prillwitz-Antiqua Walbaum-Antiqua, Leipziger Antiqua, Primus, Schmalfette-Antiqua, Bembo y Fette-Antiqua.

- Groteskschriften (tipografías de palo seco): «Serán para la literatura técnica, la publicidad, de fantasía, así como para libros de arte y de divulgación científica» (Karp y Schäfer (1989: 14) dentro de estas se desarrollarán: y Schäfer (1989: 14) dentro de estas se desarrollarân:
Maxima, Super-Grotesk, Minima, Norma Steinschrift

- Tipografías para periódicos: Resulta muy esclarecedora la consideración de los periódicos como una categoría en sí misma, ya que consideran que "las Tipografías para periódicos exigen características sustancialmente diferentes de las de los libros. Deben ante todos ser muy legibles y poseer un gran dibujo. Los pequeños punzones y trazos finos no harán una impresión clara en los fibrosos papeles de los periódicos. La impresión debe ser impersonal, neutral y científica, ya que la misma tipografía base servirá para textos de política, economía deporte y cultura». (Karp y Schäfer, 1989: 14). Desarrollará para esta finalidad la Primus, Magna y Timeless.

- Tipografía para la publicidad. Se trata tanto de tipografías creativas como de egipcia o variantes de la romana cuya finalidad es Ilamar la atención, para lo cual «todo está permitido si no va contra el mal gusta. En ciertos tipos para publicidad se puede renunciar a la legibilidad siempre y cuando con una lectura más lenta se pueda distinguir una única palabra» (Karp y Schäfer (1989: 14). Se destinan para la publicidad: Quadro, Hogarth-Schrift, Eckmann, Zyklop, Neutra, Egyptienne, Nidor, Liberta, Publica, Kleopatra, Biga, Molli, Stentor.

- Frakturschriften. Tipografías quebradas que abarcan la gótica, la rotunda, la fraktur y la Schwabacher y que durante siglos fueron definidas como «tipografía alemana». En este punto quieren aclarar Karp y Schäfer (1989: 15) que «de ningún modo puede tenerse en cuenta el miope decreto del fascista "Reichschatzmeisters》 del 23. 1. 1941 tras el cual debían ser todas las impresiones del estado en «Normalschrift» (tipografía romana), y que pierde muchas formas bellas y nacionales. Natural- 
mente permanece también en la RDA la escritura latina o romana como tipografía e impresión oficial, ya que es más práctica en su trabajo conjunto internacional y comprensión. Así las tipografías góticas pueden radiar como tipografías especiales un fuerte atractivo estético y por ello ser usada como escritura edición en textos para los que es apta». Serán de este tipo Luthersche Fraktur, Caslon-Gotisch, Schwabacher y Unger Fraktur.

Basándonos en los muestrarios publicados por la VEB Typoart a lo largo de su existencia estas son las tipografías producidas:

\begin{tabular}{|c|c|c|c|}
\hline TIPOGRAFíA & AÑO & DISEÑADOR & CLASE \\
\hline Admira & 1940 & & IV \\
\hline Agitator & 1960 & W. Eickhoff & VIII \\
\hline Akropolis & 1938 & Ludwig Wagner & IV \\
\hline Aktuell & & & IX \\
\hline Ambassador & 1938 & Martin Wilke & VII \\
\hline Arabella-Favorit & 1939 & Arno Drescher & VIII \\
\hline Baskerville & 1982 & Volker Küster/ Peter Greinke & III \\
\hline Biga & 1985 & Fritz Richter & VI \\
\hline Borgis & & & III \\
\hline Caslon-Gotisch & & Erhard Kaiser (R) & X.a. \\
\hline DIN-Norm-Spiegelschrift & 1925 & & VI \\
\hline Druckhaus & & & IV \\
\hline Echo & & & \\
\hline Eckmann & & Werner Schulze (R) & X.e. \\
\hline Egyptienne & & Hans-Peter Greinke & V \\
\hline Erler Versalien & 1953 & Herbert Thannhaeuser & VII \\
\hline Exquisit & & & II \\
\hline Faust Antiqua & 1962 & Albert Kapr & VII \\
\hline Fette Antiqua & & Barbara Cain (R) & IV \\
\hline Fleischmann & 1951 & Georg Belwe & III \\
\hline Fundamental Grotesk & 1931 & Arno Drescher & VI \\
\hline Helion & & & \\
\hline Hogarth Script & & Harald Brödel & IX \\
\hline Impuls & 1954 & Paul Zimmermann & VIII \\
\hline Initialen & & & \\
\hline Junior & 1936 & Hans Heimbeck & IX \\
\hline Kis Antiqua & & Hildegard Korger (R) & III \\
\hline Kleopatra & & Erhard Kaiser & VI \\
\hline Kolonel & & & I \\
\hline Kurier & 1939 & Herbert Thannhaeuser & VIII \\
\hline Leipziger Antiqua & 1970 & Albert Kapr & III \\
\hline & & & \\
\hline
\end{tabular}

\begin{tabular}{|c|c|c|c|}
\hline TIPOGRAFÍA & AÑO & DISEÑADOR & CLASE \\
\hline Liberta-Antiqua & 1961 & Herbert Thannhaeuser & $\mathrm{VII}$ \\
\hline Lotto & 1955 & Herbert Thannhaeuser & VIII \\
\hline Luthersche Fraktur & & V. Küster/H. Lemme (R) & X.d. \\
\hline Manutius Antiqua & 1935 & Arno Drescher & $\mathrm{v}$ \\
\hline Magna & 1965 & Herbert Thannhaeuser & $\|$ \\
\hline Maxima & 1964-71 & Gert Wunderlich & $\mathrm{VI}$ \\
\hline Meister Antiqua & 1952 & Herbert Thannhaeuser & VII \\
\hline Minima & 1984 & Karl-Heinz Lange & VI \\
\hline Minister & 1929 & Carl Albert Fahrenwaldt & II \\
\hline Mimosa & 1914 & & VII \\
\hline Molli & & Harald Brödel & VI \\
\hline Neutra & 1968 & Albert Kapr (R) & $\mathrm{v}$ \\
\hline Nidor & & Harald Brödel & $\mathrm{v}$ \\
\hline Norma Steinschrift & & Harald Brödel & VI \\
\hline Pergamon Antiqua & 1932 & Alfons Schneider & IV \\
\hline Polo & & Carl Pohl & VIII \\
\hline Prillwitz & 1987 & A. Kapr/Werner Schulze (R) & IV \\
\hline Primus Antiqua & 1962 & Karl-Heinz Lange & III \\
\hline Publica & 1983 & Karl-Heinz Lange & VII \\
\hline Quadro & & Erhard Kaiser & VI \\
\hline Ramona & 1939 & H. R. Möller & \\
\hline Rautendelein & 1908 & & IX \\
\hline Roesner Versalien & 1960 & W. Roesner & VII \\
\hline Saskia & 1932 & Jan Tschichold & VII \\
\hline Schmalfette Antiqua & & Barbara Cain (R) & IV \\
\hline Schreibmaschinen-Schrift & & & $\mathrm{v}$ \\
\hline Schwabacher & & Herbert Lemme (R) & X.c. \\
\hline Sinkwitz & 1950 & Paul Sinkwitz & X.a \\
\hline Splendor & 1930 & Wilhelm Berg & VIII \\
\hline Stentor & 1964 & Heinz Schumann & VIII \\
\hline Super Grotesk & $\begin{array}{c}\text { Aprox. } \\
1930\end{array}$ & Arno Drescher & VI \\
\hline Technotyp & 1951 & Herbert Thannhaeuser & $\mathrm{v}$ \\
\hline Thannhaeuser Schrift & 1934 & Herbert Thannhaeuser & VII \\
\hline Thomas Schrift & 1956 & F. Thomas & \\
\hline Timeless & 1982 & Werner Schulze & III \\
\hline Tschörtner Antiqua & 1955 & Helmut Tschörtner & II \\
\hline Typo Skript & 1968 & Hildegard Korger & VIII \\
\hline Typoart-Didot & 1958 & Herbert Thannhaeuser ( $R$ ) & IV \\
\hline Typoart-Garamond & 1955 & Herbert Thannhaeuser (R) & II \\
\hline Walbaum & 1984 & Hans-Peter Greinke & IV \\
\hline Zyklop & & Fritz Kossack & VII \\
\hline
\end{tabular}


A lo largo de esta segunda parte hemos descrito el marco eórico de referencia basándonos en la bibliografía disponible a dos niveles; por un lado los estímulos a los que se vio expuesto el diseño gráfico de la RDA -es decir, el diseño gráfico previo a la Segunda Guerra Mundial y el contexto socio-político de la SBZ/RDA- y por otro el diseño gráfico propio de la SBZ/RDA. Queda por tanto así realizado el análisis cualitativo, a falta del análisis cuantitativo, objeto de la siguiente parte de la investigación. 
SEGUNDA PARTE 
5. El diseño tipográfico

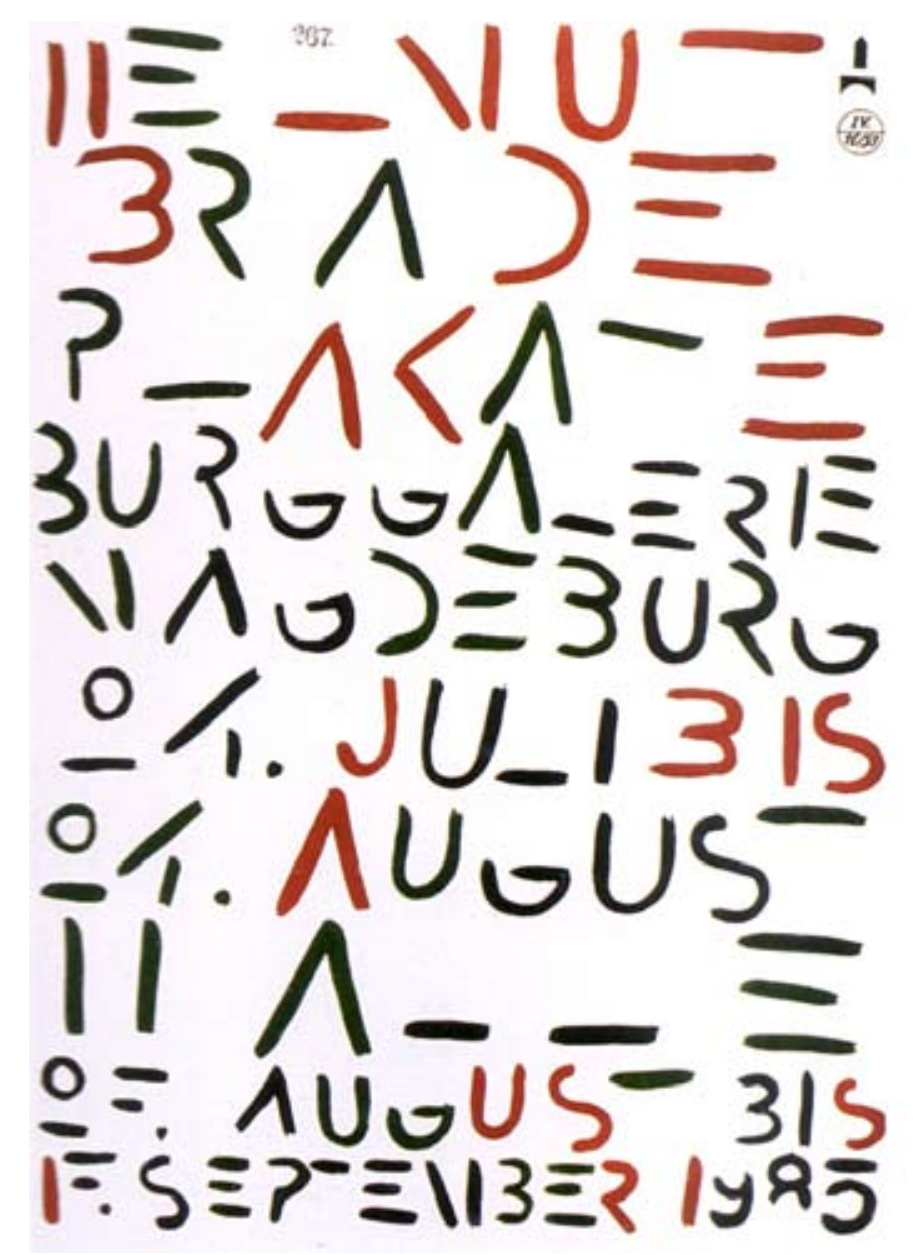


Tal y como acabamos de ver era la única empresa, la VEB Typoart, la encargadas del diseño y producción de tipos de la RDA, lo que supuso que la práctica totalidad de la tipografía disponible saliera de esta fundición.

Es por esta razón que nos enfrentemos a una variedad tipográfica mecánica propia relativamente limitada que es necesario conocer. En 1978, en un intento de adaptar la producción tipográfica a la tecnología disponible, la VEB Typoart se embarca en la tarea de desarrollar los tipos de fotocomposición. Puesto que se trataba de una ardua tarea fotocomposición. Puesto que se trataba de una ardua tarea las tipografías que debían ser las reproducidas. Según exponen Kapr y Schäfer (1989: 11):

«la mayor parte de las imprentas, así como diversos diseñadores gráficos consultados, eran de la opinión de que Typoart debía planificar primero un número de 15 familias de edición y 20 creativas. Ese número responde a las capacidades propias previstas y era notablemente mayor a la obra de Typoart en e tiempo de la tipografía de plomo. De los deseos y peticiones de las imprentas y editoriales se estableció finalmente el «Programm des Schriftschaffens bis zum Jahre 1985» (Programa de la Creación Tipográfica hasta el Año 1985) que se estableció con metas estéticas muy diversas»

Basándose en los estudios realizados se realizarían finalmente 42 tipografías para fotocomposición que abarcaban la totalidad de clases tipográficas. Estudiaremos brevemente estas tipografías, puesto que fueron las consideradas por los propios diseñadores, creadores e impresores como las más útiles y relevantes. El orden en el que se presentan responde al establecido en el muestrario de tipos de fotocomposición creado por Kapr y Schäfer en 1989 y que se basa en la clasificación de los tipos.

Puesto que se trata de una obra realizada en Alemania realizamos la clasificación tipográfica según la norma alemana DIN 16518, teniendo en cuenta que:

«el origen de la clasificación alemana DIN 16518 por el Deutsches Institut für Normung en 1964, es debido sin duda a la necesidad de los usuarios en habla alemana de una nomenclatura propia, próxima a su entorno cultural y etimológico, por lo que, aunque asimila en su totalidad el esquema Vox-ATypl, se percibe una mayor necesidad descriptiva a través de la adjetivación sucesiva de la raíz romana» (Martín Montesinos, 2011).

No es objeto de esta investigación el análisis de dicha norma, pero sí que describiremos a modo de resumen las siguientes características básicas utilizando la traducción realizada por Josep M Pujol (2010): 


\begin{tabular}{|c|c|c|c|c|c|c|}
\hline & & MODULACIÓN & TERMINACIONES & PROPORCIÓN & FORMA & VOX-ATypl \\
\hline- & $\begin{array}{l}\text { ROMANA RENACEN- } \\
\text { TISTA VENECIANA } \\
\text { Venezianische } \\
\text { Renaissance-Antiqua }\end{array}$ & $\begin{array}{l}\text { Débil y gradual } \\
\text { Eje oblicuo } \\
\text { Trazo transversal e } \\
\text { oblicuo }\end{array}$ & $\begin{array}{l}\text { Fuertes } y \text { angulosos } \\
\text { Ascendente con remate } \\
\text { ollicuo }\end{array}$ & $\begin{array}{l}\text { Ascendentes = } \\
\text { Mayúsculas }\end{array}$ & & 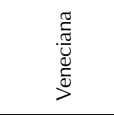 \\
\hline$=$ & $\begin{array}{c}\text { ROMANA } \\
\text { RENACENTISTA } \\
\text { FRANCESA } \\
\text { Französische } \\
\text { Renaissance-Antiqua }\end{array}$ & $\begin{array}{l}\text { Medio y con eje } \\
\text { oblicuo }\end{array}$ & $\begin{array}{l}\text { Redondeados y con } \\
\text { ascendente con rema- } \\
\text { te oblicuo }\end{array}$ & $\begin{array}{l}\text { Ascendentes > } \\
\text { Mayúsculas }\end{array}$ & & $\frac{\pi}{\frac{\pi}{\pi}}$ \\
\hline$\equiv$ & $\begin{array}{c}\text { ROMANA } \\
\text { BARROCA } \\
\text { Barock-Antiqua }\end{array}$ & $\begin{array}{l}\text { Medio-alto y con } \\
\text { eje vertical o casi } \\
\text { vertical }\end{array}$ & $\begin{array}{l}\text { Curvas insinuadas } \\
\text { y ascendente con } \\
\text { remate oblicuo }\end{array}$ & & & $\frac{\mathscr{\varpi}}{\dddot{\varpi}}$ \\
\hline$\geq$ & $\begin{array}{c}\text { ROMANA } \\
\text { NEOCLÁSICA } \\
\text { Klassizistische Antiqua }\end{array}$ & Alta y eje vertical & $\begin{array}{l}\text { Rectos y rectangula- } \\
\text { res con apenas curvas }\end{array}$ & & & 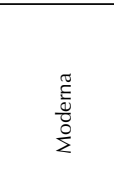 \\
\hline$>$ & $\begin{array}{l}\text { EGIPCIAS } \\
\text { Serifenbetonte } \\
\text { Linear-Antiqua }\end{array}$ & Sin diferenciación & Muy marcados & Gran ojo medio & & 苋 \\
\hline$s$ & $\begin{array}{c}\text { LETRA DE PALO } \\
\text { SECO } \\
\text { Serifenlose } \\
\text { Linear-Antiqua }\end{array}$ & Sin diferenciación & Sin remates & & & 苑 \\
\hline $\bar{\Sigma}$ & $\begin{array}{l}\text { VARIANTES } \\
\text { DE LA LETRA } \\
\text { ROMANA } \\
\text { Antiqua-Varianten }\end{array}$ & & Remates triangulares & & & 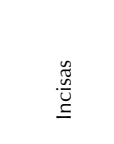 \\
\hline$\overline{\bar{s}}$ & 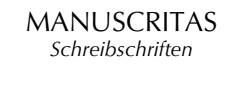 & & & & & 总 \\
\hline$\underline{x}$ & $\begin{array}{l}\text { LETRA } \\
\text { CALIGRÁFICA } \\
\text { Handschriftliche } \\
\text { Antiqua } \\
\end{array}$ & & & & & 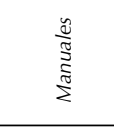 \\
\hline$\times$ & TIPOGRAFÍAS QU & EBRADAS (Gebroche & Schriften) & & & \\
\hline & a. Gótica (Gotisch) & & Forma diamante & Esbelto & Quebrados & 荧 \\
\hline & $\begin{array}{l}\text { b. Gótica redonda } \\
\text { (rotunda) (Rundgotisch) }\end{array}$ & & & & Redondeada & \\
\hline
\end{tabular}

\begin{tabular}{|l|l|l|l|l|l|l|}
\hline & & MODULACIÓN & TERMINACIONES & PROPORCIÓN & FORMA & VOX-ATypl \\
\hline & c. Schwabacher & & $\begin{array}{l}\text { Menos remate que la } \\
\text { gótica }\end{array}$ & $\begin{array}{l}\text { Ancha } \\
\text { Redondeada con } \\
\text { impactos }\end{array}$ & \\
\hline & d. Fraktur & & & $\begin{array}{l}\text { Estrecha y } \\
\text { puntiaguda }\end{array}$ & $\begin{array}{l}\text { Curvada a un } \\
\text { lado, recta al otro }\end{array}$ & \\
\hline & e. Variantes de la fraktur & & & & & \\
\hline
\end{tabular}

Realizaremos un análisis sistemático de los atributos formales de los tipos atendiendo a los criterios expuestos por Phil Baines (2002: 50) quien considera que «para referirse a los diferentes elementos del diseño de un tipo se recurre al uso de una serie de términos específicos. Antes de fijarnos en las fuentes de tipos conviene examinar, siquiera brevemente, esos atributos formales».

Escuetamente describiremos cada una de estos atributos:

- Construcción; entendiendo como tal la configuración del trazo de cada componente del tipo así como, en su caso, las referencias a las herramientas utilizadas.

- Forma, analizando el tratamiento y las variaciones posibles de cada una de esas componentes, curvas y rectas.

- Proporciones; tanto de los caracteres en sí mismos como de su relación unos con los otros. Atiende igualmente a la construcción básica dentro de las líneas de referencia.

- Modulación; «se caracteriza por ser rítmica, basada en la alternancia del trazo fino y el trazo grueso, y presenta una gama infinita de grados de aplicación» (Martín y Mas, 2001: 90)

- Espesor o grosor; «atributo que describe el grosor de las formas a través de una fuente de caracteres completa, imponiendo su color o impacto global. La diferencia relativa entre grosor y perfil dentro de los caracteres individuales se incluye en los atributos de modulación (Baines, 2002: 51)

- Terminaciones; análisis de los remates, ganchos y gotas.

- Caracteres clave; aquellos que cuyo tratamiento define los tipos.

- Decoración; recursos ornamentales para realzar tipos de letras

Hemos visto que muchas de las tipografías consistían en réplicas de tipografías de prestigio cuya licencia no podían afrontar, al igual que el hecho de que estas se hacían como réplica, no como copia, por lo que consideraremos las diferencias formales entre los originales y sus réplicas. 


\subsection{TIPOGRAFÍAS DE LA VEB TYPOART}

5.2.1. Tipografía romana renacentista francesa

\section{A e o n d J a g}

ales de la tipografía
Typoart Garamond

TYPOART GARAMOND (1955, Herbert Thannhaeuser)

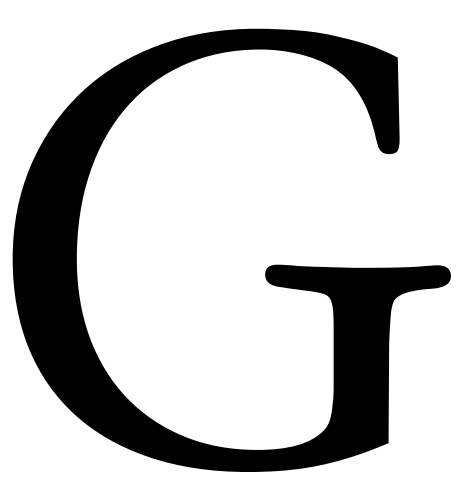

800 JAHRE LEIPZIGER MESSE

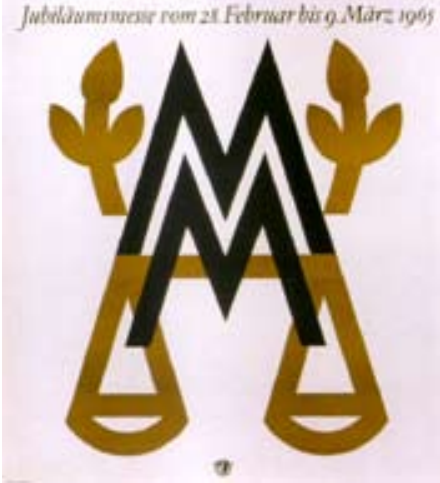

HILLER, Günter (1964) la versión cursiva de
Typoart-Garamond
Clasificación y referentes

La tipografía Typoart-Garamond es un tipo clasificado como romano renacentista francés (clase II) según la norma DIN 16518, denominadas garaldas según la clasificación VoxATypl. La familia desarrollada por la VEB Typoart está constituida por un juego de caja alta, caja baja, cifras de caja alta y cifras elzevirianas con los grosores regular y seminegra así como cursiva. Igualmente tendrá, junto a su juego de caracteres latinos, otro de caracteres cirílicos.

La tipo Garamond diseñada por Claude Garamond en torno a 1540 tenía como «precursores históricos la Antiqua de Nikolaus Jenson creada en 1470 en Venecia y algunas tipográficas del editor e impresor Aldus Manutius de Venecia» (Kapr y Schäfer, 1989: 60) y supuso una gran aportación al diseño de tipos de la época y según Martín y Mas (2001: 56) «marca lo que se ha dado en Ilamar la Edad de Oro de la tipografía francesa». La VEB Typoart realizará dos reediciones a cargo de Herbert Thannhaeuser, una de plomo creada en 1955 a partir de impresiones históricas y posteriormente la Typoart-Fotosatz-Garamond.

Por sus características y legibilidad la Typoart-Garamond estaba especialmente recomendada para su uso «ante todo en las bellas artes, pero se puede utilizar perfectamente para creación de impresos de todas las artes» (Kapr y Schäfer, 1989: 61).

Atributos formales

El alfabeto Typoart-Garamond es un tipo de construcción continua. Su tratamiento de las curvas es continuo con un aspecto redondo ligeramente cuadrado. Las astas verticales tienen bordes paralelos y con las astas transversales relativamente centrada.

Basándonos en su estructura nos encontramos con una tipografía con un amplio ojo medio, y una altura de los ascendentes mayor que la de los descendentes y que la altura de las mayúsculas. Es una tipografía de proporción ancha basada en las proporciones de las capitales cuadradas romanas.

La modulación tiene un contraste medio y una transición en el trazo armónica y gradual. El color general de la Typoart-Garamond es medio y sus remates son sutilmente lobulados, por su parte los trazos ascendentes tienen remates oblicuos. Los remates específicos del anillo de la a, la oreja de la $r$ o la c son en forma de gota. Característico de esta tipografía resulta los brazos terminales de la $T$, oblicuo en un lado y sensiblemente vertical en el otro, al igual que ocurre en la $E$, vertical en el remate del brazo superior $y$ oblicuo en el inferior.

El tipo Garamond original destaca por su ojo medio equilibrado. Igualmente destaca el control de los recursos tipográficos, que según Martín y Mas (2001: 56):

«(...) se plasma en una modulación más controlada. Esta modulación disminuirá el grosor y conseguirá un contraste más armónico entre trazos finos $y$ gruesos $y$ ofrecerá unos traz rasgos más per y contenidos, cuidadosa y detalladamente trabajadas en sus uniones. (...) la Garamond conservará la modulación oblicua de la escritura».

En la Garamond desarrollada por la VEB Typoart la modulación resulta menos contrastada, con un trazo fino notablemente más grueso que en el original. Se diferencian igualmente ambas tipografías en los remates, más curvados en la réplica y con mayor inclinación en los ascendentes. Otra diferencia fundamental la encontramos en el eje de la $O$, y de las mayúsculas, prácticamente vertical, mientras que en el resto de las letras minúsculas se mantiene oblicuo. Probablemente las diferencias más Ilamativas respecto de su antecesora sean las generadas en la / mayúscula y la minúscula. En el caso de la / nos encontramos con un trazo descendente más cerrado y con mayor relevancia de la gota al igual que ocurre en el ascendente de la $f$.

\section{MAGNA (1965, Herbert Thannhaeuser)}

\section{Clasificación y referentes}

La tipografía Magna es un tipo romano renacentista francés (clase II) según la norma DIN 16518, denominadas garaldas según la clasificación Vox-ATypl. La familia está constituida por un por un juego de caja alta, caja baja, cifras de caja alta y cifras elzevirianas con los grosores regular y seminegra con su versión en cursiva de la regular. Igualmente
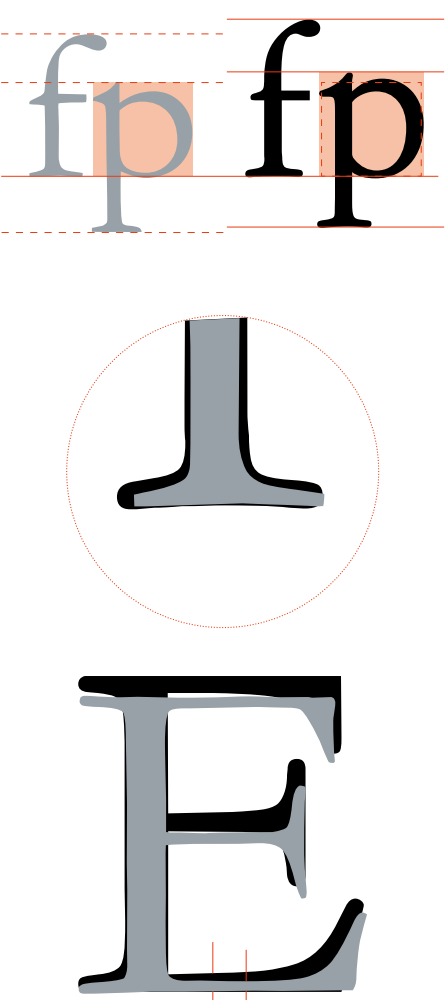

Comparación entre la tipografía Garamond la direncia de proporciones entre observa remates más curvados y la differencia de trazo 
tendrá, junto a su juego de caracteres latinos, otro de caracteres cirílicos regular.

El alfabeto diseñada por Herbert Thannhaeuser fue concebida para su uso como tipografía de edición de periódicos y revistas. De su adaptación a la fotocomposición se encargaría Karl-Heinz Lange. Según relata Jay Rutherford (2006) «su significación internacional no se reducía a la producción de libros en Checoslovaquia sino también a variantes cirílicas que serían dibujadas posteriormente por Albert Kapr».

\section{A e o n d Jag}

Atributos formales

La tipografía Magna es un tipo de construcción continua, con un tratamiento de las curvas continuo y redondeces ligeramente cuadradas. Las astas verticales tienen los bordes paralelos, al igual que las transversales, sensiblemente centradas en su posición.

En una búsqueda de legibilidad en impresiones de poca calidad tiene un gran ojo medio, con unos ascendentes y descendentes muy cortos. La altura de las ascendentes es ligeramente superior a la de los descendentes y a la altura de las mayúsculas. La anchura de los caracteres es media, con una tendencia a la verticalidad más evidente en las minúsculas, lo que según Kapr y Schäfer (1989: 99) supone que «sea fácil de leer y permita la fluidez así como una rápida comprensión del artículo».

El contraste del trazo es medio con el eje constructivo de contraste ligeramente inclinado. La transición entre el grosor y el perfil es gradual. Pese a que el grosor del trazo no es excesivamente grueso, la estrechez de los caracteres dota a la Magna de un color tipográfico medio.

Los remates de los pies son modulados con las esquinas sutilmente redondeadas. Los remates de los ascendentes tienen el trazo inclinado con los bordes despuntados. El remate de la $a$, c y $r$ tiene forma de gota, por su parte los remates de la $T, E$ y $F$ son verticales, salvo el pie de la $E$ que es inclinado.
Los caracteres capitales se apoyan en la línea base salvo la $Q$, de cola larga, y la J que se prolonga bajo esta. Encontramos otra particularidad en la gran altura del perfil de la e respecto del de la $a$.

PRIMUS (1950, Karl-Heinz Lange)

Clasificación y referentes

La tipografía Primus es un tipo romano renacentista francés (clase II) según la norma DIN 16518, denominadas garaldas según la clasificación Vox-ATypl. La familia está constituida por un por un juego de caja alta, caja baja, cifras de caja alta y cifras elzevirianas con grosores regular y seminegra, una versión en cursiva regular y otra condensada seminegra.

Se trata de una tipografía diseñada originalmente por Karl-Heinz Lange como tipografía para periódico, por lo que buscará un carácter neutro e impersonal, así como su legibilidad en impresiones de baja calidad.

\section{A eond Jag}

Atributos formales

La tipografía Primus es un tipo de construcción continua con un tratamiento de las curvas continuo y redondeces ligeramente cuadrado. Las astas verticales tienen los bordes paralelos, al igual que las transversales, centradas en su posición, tanto en las mayúsculas como las minúsculas, con el perfil de la a horizontal.

Buscando la legibilidad en impresiones de poca calidad tiene un ojo medio elevado y un gran contrapunzón, con lo que la proporción cuadrada de la anchura respecto de la altura. Los ascendentes y descendentes son relativamente cortos, estando la alineación inferior a menor distancia. La altura de las ascendentes es ligeramente superior a la altura de las mayúsculas.

El contraste del trazo es medio con el eje constructivo de contraste ligeramente inclinado. La transición entre e grosor y el perfil es gradual. Este escaso contraste dota a la tipografía de un color tipográfico oscuro.

Los remates de los pies son clásicos, con proporción cuadrangular, pero con uniones mediante curvas. Los rema-

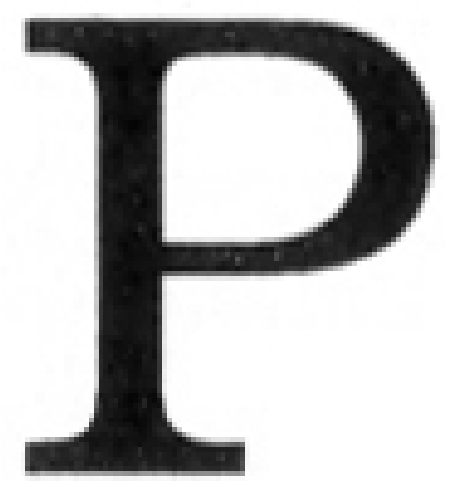

\section{-}

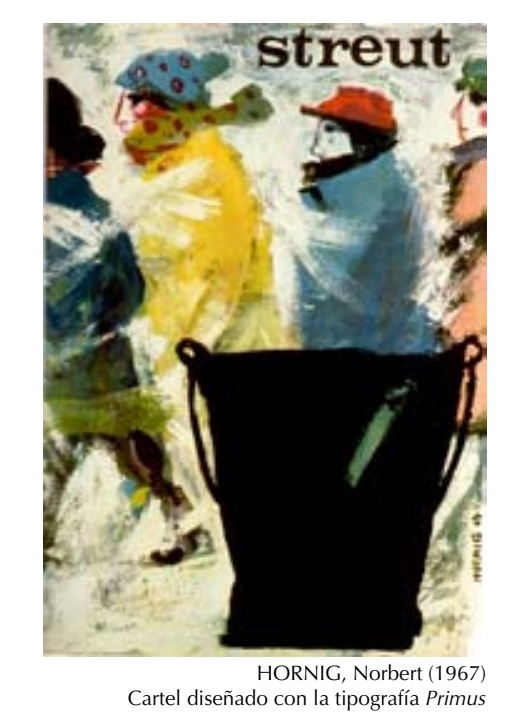


tes de los ascendentes tienen el trazo casi horizontal y de aspecto robusto. El remate de la a, c y $r$ tiene forma de gota con lóbulo redondo. Por su parte los remates de la $T, E$ y $F$ son ligeramente inclinados. Los caracteres capitales se apoyan en la línea base salvo la $Q$, de cola larga y decorada.

\subsubsection{Tipografía romana barroca}

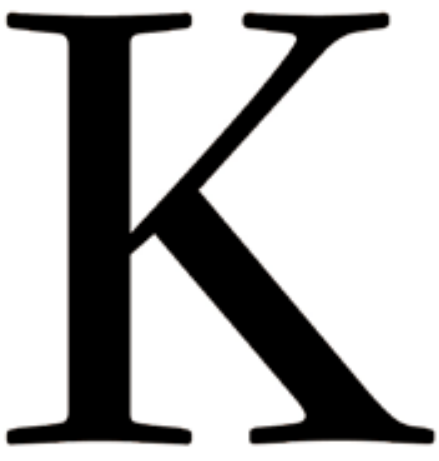

KIS ANTIQUA (Hildegard Korger)

Clasificación y referentes

La tipografía Kis Antiqua es un tipo romano barroco (clase III) según la norma DIN 16518, denominadas reales según la clasificación Vox-ATypl. La familia está constituida por un por un juego de caja alta, caja baja, cifras de caja alta y cifras elzevirianas con grosor regular y su versión en cursiva.

Se realiza una réplica de la tipografía Holländischen Antiqua diseñada por el húngaro Nikolaus Kis para su uso en la impresión de una biblia calvinista, por su gran legibilidad. Está destinada a su uso en la literatura artística.

\section{A eond Jag}

Análisis de los atributos formales de la tipografía
Kis Antiqua

Woche des Buches 1967

ich lese

du liest

er liest

sie liest

esliest

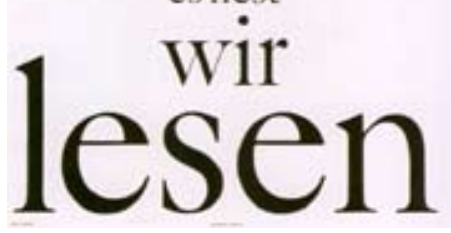

SCHIEUSING Cartel diseñado con la version redonda de la de letra para enfatizar el mensaje

\section{Atributos formales}

La tipografía Kis Antiqua es un tipo de construcción continua, con un tratamiento de las curvas continuo y redondo, tan solo el trazo de la a es más quebrado en su trazo curvo. Las astas verticales tienen los bordes paralelos, al igual que las transversales, sensiblemente centradas en su posición en la caja alta. El asta horizontal de la e se encuentra muy elevada, mientras que el trazo inclinado de la a, característico del ductus humanista, se encuentra notablemente bajo.

La anchura de los caracteres es estrecha, lo que dota a la Kis Antiqua de una apariencia relativamente esbelta. La altura de la $\mathrm{x}$ es ligeramente elevada con ascendentes y descendentes proporcionados. La altura de las mayúsculas es menor que la de los ascendentes.

El contraste del trazo es alto con el eje constructivo de contraste vertical. La transición entre trazos es fuerte. La esbeltez de los caracteres se contrarresta con un mayor espacio entre los mismo, otorgándole un color tipográfico medio.

Los remates de los pies son clásicos, con los trazos curvos poco marcados y un aspecto general horizontal. Los remates de los ascendentes tienen el trazo inclinado con los bordes despuntados y ligeramente redondeados. El remate de la $a$, c y $r$ tiene forma de gota notablemente redondeada. Los remates de las letras mayúsculas, como la $T, E, F, S$ y $Z$ son oblicuos.

Los caracteres capitales se apoyan en la línea base salvo la $Q$, de cola larga, y la / que se prolonga bajo esta. Como caracteres destacados encontramos la $W$, cuya unión central se encuentra rematada como el resto de los ascendentes, y la $M$, con astas no paralelas entre sí y con diferente grado de inclinación.
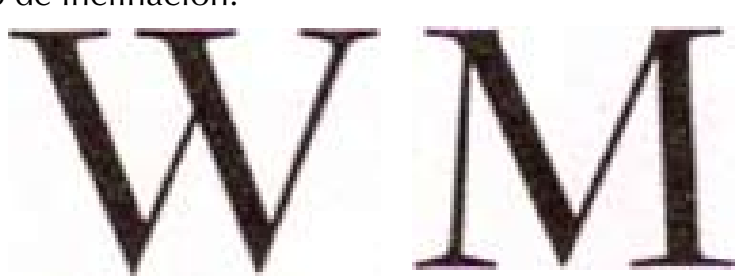

FLEISCHMANN (1951, Georg Belwe)

Clasificación y referentes

El alfabeto Fleischmann es un tipo romano barroco (clase III) según la norma DIN 16518, denominadas reales según la clasificación Vox-ATypl. La familia está constituida por un juego de caja alta, caja baja, cifras de caja alta y cifras elzevirianas con grosor regular únicamente y con una versión en cursiva.

Basada en la tipografía romana diseñada por Johann Michael Fleischmann en el siglo XVIII, esta adaptación de Georg Belwe está destinada a su uso en textos políticos.

\section{A e ond J a g}

Atributos formales

La tipografía Fleischmann es un tipo de construcción continua, con un tratamiento de las curvas continuo y redondo ligeramente cuadrado. Las astas verticales tienen los bordes 
paralelos, al igual que las transversales, sensiblemente centradas en su posición.

$A B C D E$ FGHIFK LCMCNOP शRSTU ขroXฯ iipografía Fleischmann cursiva en la que
destacan los remates decorados.

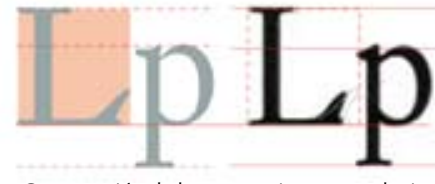

Comparación de las proporciones entre la tipo
Fleischmann original (en gris) y la réplica

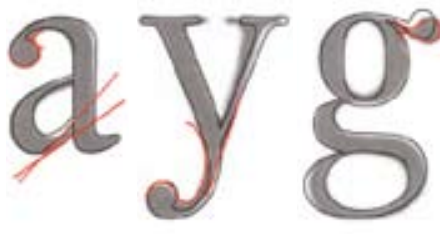

Los remates de la tipogratía diseñada por Typoart
están menos marcados de lo que lo estaban en la tipografía original, dando un aspecto $\mathrm{m}$ selifica aquí la decoración mediante curvatura
del descendente de la $y$.

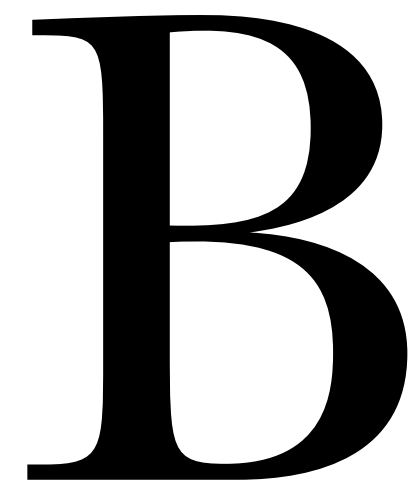

a anchura de los caracteres es normal, con una proporción relativa en las capitales generalmente regular. La altura de la $x$ es ligeramente elevada con ascendentes y descendentes proporcionados. La altura de las mayúsculas es menor que la de los ascendentes.

El contraste del trazo es alto con el eje constructivo de contraste vertical. La transición entre el grosor y el perfil es gradual. El alto contraste entre el trazo grueso y el fino dota al alfabeto Fleischmann de un color tipográfico medio.

Los remates de los pies son modulados con bordes despuntados y un aspecto general horizontal. Los remates de los ascendentes tienen el trazo inclinado con los bordes despuntados. El remate de la a, c y $r$ tiene forma de gota con lóbulo redondo. Resultan característicos de esta tipografía ciertos remates como los de la $T, E, F, S$ y $Z$, con un juego cóncavo-convexo decorativo.

Los caracteres capitales se apoyan en la línea base salvo la $Q$, de cola larga, y la / que se prolonga bajo esta. Finalmente destacar la influencia de la letra caligráfica en la composición de las mayúsculas cursivas, con remates retorcidos con gran presencia del lóbulo redondo en su extremo.

En el diseño de la réplica se mantuvieron las proporciones de las líneas de referencia, no obstante es notable la diferencia de la proporción de los caracteres, más esbeltos en la tipografía adaptada por Belwe. Para la adaptación se simplifican muchos de los elementos decorativos característicos de la Fleischmann original, tales como la descendente de la y, o las uniones con los remates en forma de lóbulo redondo de caracteres como la a o la $g$.

BASKERVILLE (1982, Volker Küster y Peter Greinke)

\section{Clasificación y referentes}

La tipografía Baskerville es un tipo romano barroco (clase III) según la norma DIN 16518, denominadas reales según la clasificación Vox-ATypl. La familia está constituida por un por un juego de caja alta, caja baja, cifras de caja alta y cifras elzevirianas con grosor regular y seminegra y con una versión en cursiva regular.

Basada en el alfabeto romana diseñada por John Baskerville a mediados del siglo XVIII, esta adaptación de Volker Küster y Peter Greinke cuenta, según Kapr y Schäfer (1989: 70) con un juego de «seminegra como variante libre y artís- ticamente tratada». Es una de las tipografías más habituales en los libros de la RDA y está destinada a su uso en textos de Bellas Artes y literatura artística.

\section{A e ond Jag}

Atributos formales

La tipografía Baskerville es un tipo de construcción continua, con un tratamiento de las curvas continuo y redondeado. Las astas verticales tienen los bordes paralelos, al igual que las transversales, las cuales están centradas en la caja alta y notablemente elevada en el trazo horizontal de la e.

La anchura de los caracteres es regular, con un ligero estrechamiento del tipo que da lugar a un efecto más dinámico del tipo. El ojo medio está proporcionado respecto de la altura total y los ascendentes y descendentes tiene la misma dimensión, al igual que la altura de las mayúsculas.

El contraste del trazo es elevado, con eje axial. La transición entre el grosor y el perfil es fuerte y con un color tipográfico medio.
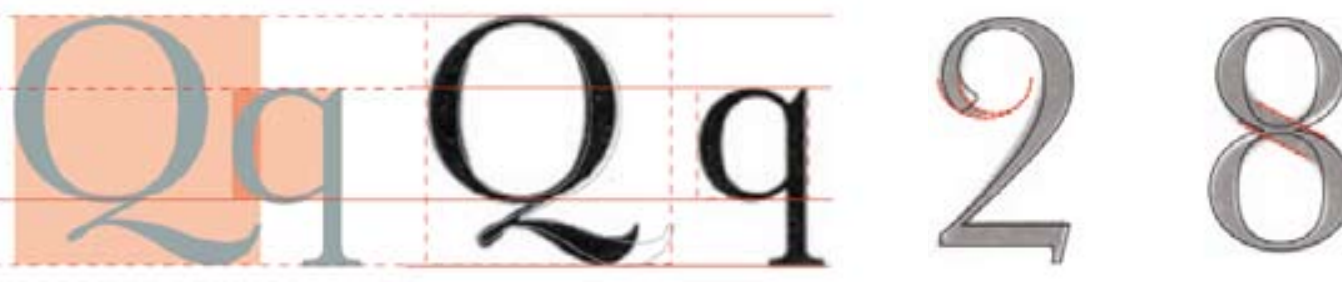

Se trata de una tipografía con remates de pie clásicos y con los remate de la a, c y $r$ en forma de gota. Los remates de los ascendentes tienen el trazo inclinados ligeramente con los bordes despuntados. Como elementos característicos de esta tipografía nos encontramos la g, cuyo ojal inferior no se cierra completamente y la cola de la $Q$, más decorada de lo habitual.

Los caracteres capitales se apoyan en la línea base salvo la $Q$ y la J, que se prolonga bajo esta. Mientras que en los caracteres minúsculos se mantiene la proporción original se estilizan las mayúsculas. Las mayores diferencias entre la réplica y el original se encuentran en las cifras, tales como el 2 o el 8.
Comparación entre la tipo Baskerville original en gris en las proporiones $y$ contorno en las 
Clasificación y referentes.

La tipografía Timeless es un tipo romano barroco (clase III) según la norma DIN 16518, denominadas reales según la clasificación Vox-ATypl. La familia está constituida por un por un juego de caja alta, caja baja, cifras de caja alta y cifras elzevirianas con los grosores regular y seminegra y negra, con su versión en cursiva de los dos primeros. Igualmente tendrá, junto a su juego de caracteres latinos, otro de caracteres cirílicos con los grosores regular y seminegra tanto en redonda como cursiva y otro de caracteres griegos regular y seminegra, con versión cursiva únicamente con grosor regular.

El alfabeto Timeless se concibe especialmente para textos científicos, de ahí que se desarrollaran los caracteres cirílicos y griegos. El alfabeto Timeless de 1982 suponía una adaptación de el tipo del periódico inglés Times de Stanley Morison, si bien apenas sería utilizada para su reproducción en periódicos en la RDA, sino que se destinaba a los textos científicos.

\section{A e o n d J a g}

tipografía
Timeless

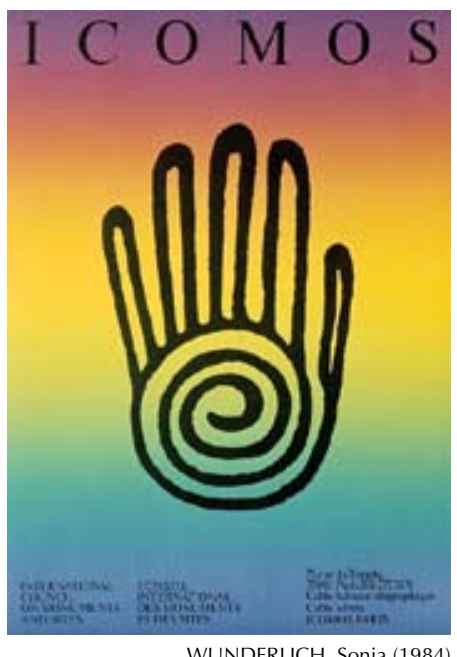

WUNDERLLCH, Sonja (1984
Cartel diseñado con la versión redonda de con la versión redonda de la
tipografía Timeless regular.

\section{Atributos formales}

La tipografía Timeless es un tipo de construcción continua, con curvas continuas sensiblemente redondas. Las astas verticales tienen los bordes paralelos y las astas horizontales están centradas.

Destaca en ambas tipografías su gran legibilidad incluso en pequeños tamaños gracias a su amplio ojo medio. Los caracteres curvos rebasan ampliamente las líneas base y media buscando una percepción homogénea de todos los caracteres, ya que según Hochuli (2007: 18):

«El círculo y el triángulo dan la sensación de ser más pequenos que el cuadrado, aun cuando la altura sea exactamente la misma. Para que parezcan igual de altos, los ángulos y los arcos deben sobrepasar ligeramente la línea base, ya sea por encima o por debajo».

La alineación superior y la altura de las mayúsculas es la misma, pero destaca la acentuación de los trazos ascendentes respecto de los descendentes, de menor tamaño. Igual- mente es notable la relativa estrechez de los caracteres de caja baja.

El trazo y la modulación tienen un contraste relativamente alto entre las partes finas y las gruesas con una transición suave en la caja baja y más abrupto en la caja alta. Cuenta con remates clásicos propios de las romanas barrocas. Los remates de las ascendentes son oblicuos, con un ángulo aproximado de $30^{\circ}$ y los remates de las letras $c$, a y $r$ son en forma de gota y los de la $T$ y la $E$ son simétricos y oblicuos. Todos los caracteres de las mayúsculas permanecen apoyados en su línea base salvo la cola de la $Q$ que abarca la totalidad de la profundidad de los descendentes.
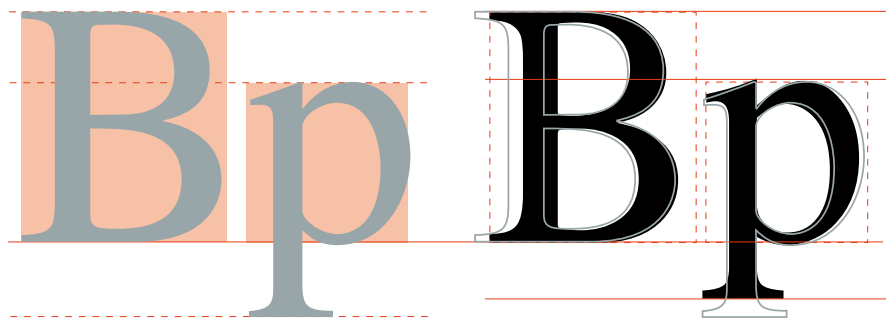

Los rasgos distintivos de la Times Roman como son el asta alta y recta de la $G$ y la curvatura inferior del bucle de la $P$ permanecen en el alfabeto Timeless. Las diferencias fundamentales las encontramos en la proporción y las líneas de referencia, siendo el tipo de la VEB Typoart notablemente más esbelta que la Times Roman, y sus descendentes de menor tamaño. Finalmente, mientras que en el alfabeto de Morison los remates de los ascendentes están achaflanados en sus bordes, la tipografía Timeless tiene los ángulos vivos.

\section{A eondaJg}

LEIPZIGER ANTIQUA (1970-73, Albert Kapr)

Clasificación y referentes

La tipografía Leipziger Antiqua es un tipo romano barroco (clase III) según la norma DIN 16518, denominadas reales según la clasificación Vox-ATypl. La familia está constituida por un por un juego de caja alta, caja baja, cifras de caja alta y cifras elzevirianas con grosor regular y seminegra y una versión en cursiva regular.
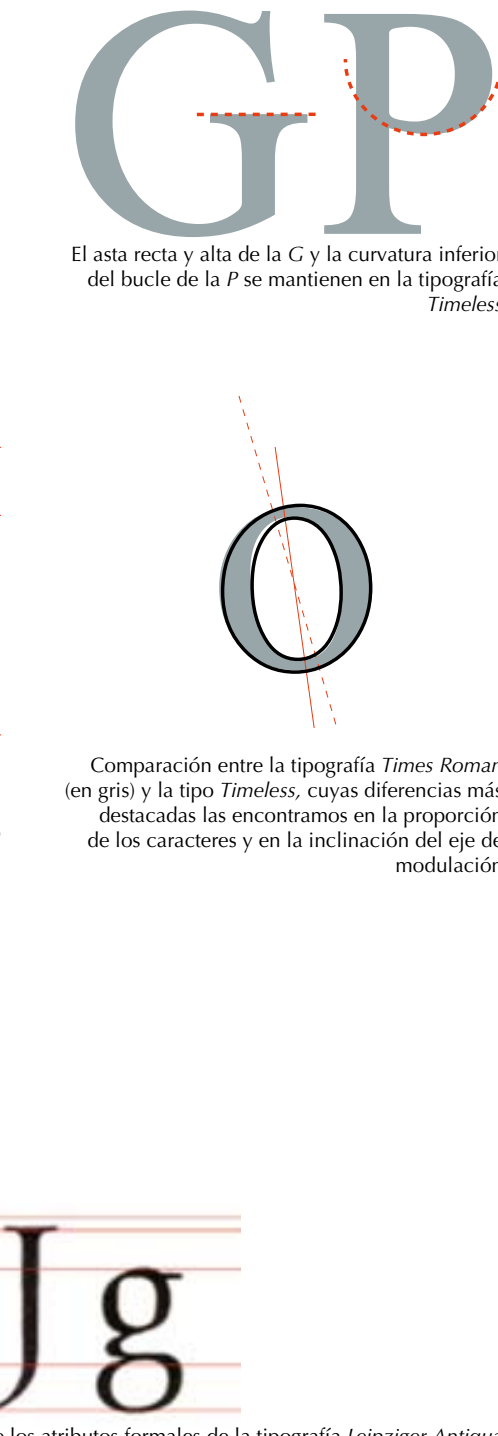

Comparación entre la tipografíá Times Roman 作 modulación 


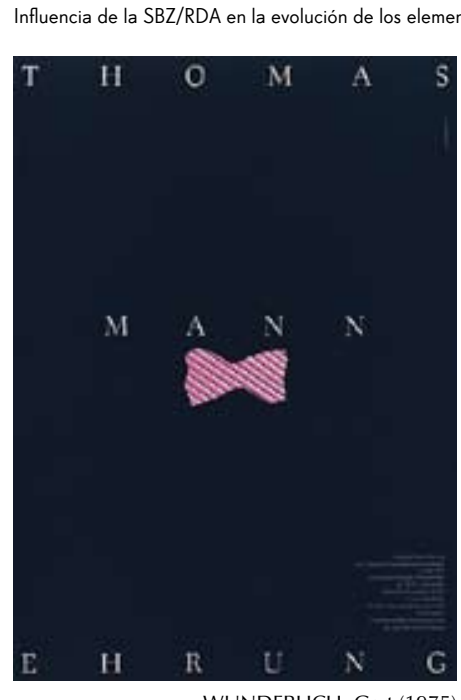

WUNDERLLCH, Gert (1975)
Cartel diseñado con la tipografía Leipziguer
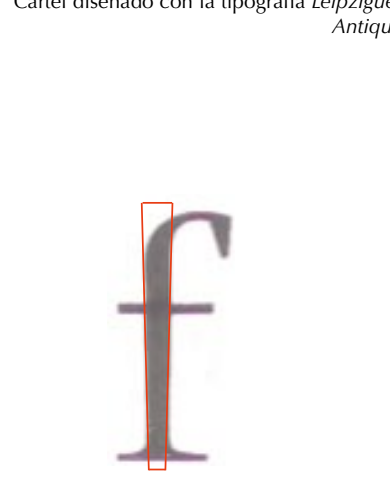

son paralelos sino que
tienen forma de cuña

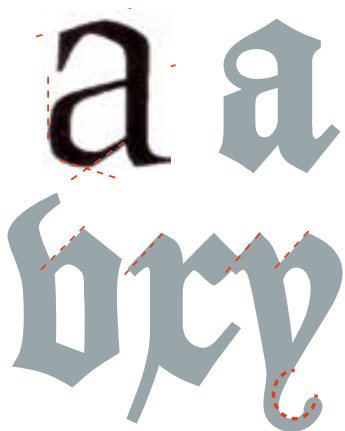

VXY

Aparecen ciertos paralelismos en el trazado laramente quebrado de la tipografía Leipziger
lipografía gótica, paral lismos que se repiten
en la formación de los remates asimétricos.
Se trata de una tipografía diseñada originalmente por el profesor Albert Kapr y presentada en la Internationale Buchkunst-Ausstellung Leipzig (Exposición internacional del arte editorial de Leipzig, IBA) en 1959 donde ganaría el concurso de nuevas tipografías de texto con lo que comenzará su colaboración con la VEB Typoart. En opinión del propio Kapr (1989: 95) el alfabeto «debe su atractivo a las casi clásicas estrecheces y formas llenas de fuerza, que conducen a una impresión general armónica al tiempo que no niegan su origen en la escritura de pluma ancha». Su uso habitual era la literatura política, libros de divulgación científica y de texto, así como en libros ilustrados.

Atributos formales

La tipografía Leipziger Antiqua es un tipo de construcción continua, con un tratamiento de las curvas ligeramente quebrado y redondeces cuadradas. Las astas verticales tienen los bordes sutilmente oblicuos con la base más estrecha. Este juego se repite en los trazos verticales de los caracteres de caja baja, ligeramente oblicuos haciendo que sean más estrechos en la parte baja. Las astas transversales se encuentran centradas en su posición.

La anchura de los caracteres es estrecha, con un ojo medios ligeramente elevado con ascendentes y descendentes proporcionados. La altura de las mayúsculas es menor que la de los ascendentes.

El contraste del trazo es alto con el eje constructivo de contraste inclinado. La transición entre el grosor y el perfil es fuerte y se efectúa mediante trazos quebrados. La estrechez de los caracteres junto con su trazo grueso dota a la Leipziger Antiqua de un color tipográfico oscuro.

Los remates de los pies son clásicos. Los remates de los ascendentes tienen el trazo ligeramente inclinado con los bordes despuntados. El remate de la a, c y $r$ tiene forma de gancho. Resultan característicos de esta tipografía ciertos remates como los de la $T, E, F, S$ y $Z$ con la cara exterior del mismo recta y la interior inclinada.

Los caracteres capitales se apoyan en la línea base salvo la $Q$, de cola larga, y la J que se prolonga bajo esta. El tipo Leipziger tiene un fuerte carácter gracias al trazo ligeramente quebrado y que se pone de manifiesto especialmente en caracteres como la a, y la asimetría de los remates de letras como la $v, y$ y $x$, que los relaciona con los trazos de la letra gótica

\subsubsection{Tipografía romana neoclásica}

PRILLWITZ (1962, Albert Kapr y Werner Schulze)

Clasificación y referentes

La tipografía Prillwitz es un tipo romano neoclásico (clase IV) según la norma DIN 16518, denominadas didonas según la clasificación Vox-ATypl. La familia está constituida por un por un juego de caja alta, caja baja, cifras de caja alta y cifras elzevirianas con grosor regular y seminegra y su versión en cursiva regular.

Se trata de una réplica de una tipografía existente, la cual, tal y como indican Kapr y Schäfer (1989: 83) «fue planteada por el conocido editor de Leipzig Georg Joachim Göschen para los trabajos de Herder, Goethe, Schiller y Wieland». Se recomienda para su uso en la en la literatura artística, de divulgación científica y libros de texto.

\section{A eond Jag}

Atributos formales

La tipografía Prillwitz es un tipo de construcción continua con un tratamiento de las curvas continuo y redondeces con tendencia cuadrada. Las astas verticales tienen los bordes paralelos, al igual que las transversales, sensiblemente centradas en su posición en la caja alta y baja.

La anchura de los caracteres es estrecha, lo que dota a la Prillwitz de una apariencia esbelta. La altura de la x es elevada al tiempo que la altura de los ascendentes es mayor que la de los descendentes y que la altura de las mayúsculas.

El contraste del trazo es muy alto con el eje constructivo axial. La transición entre trazos es abrupta y tiene un color tipográfico oscuro.

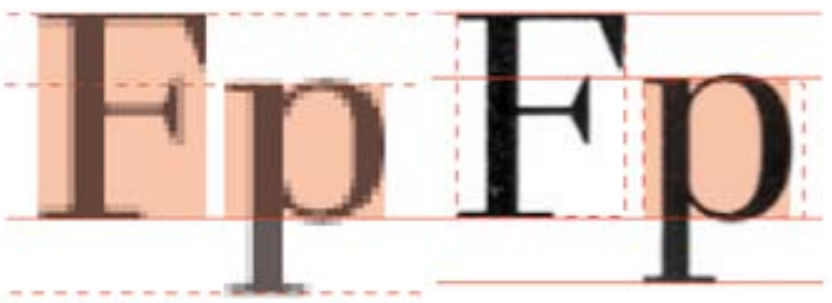

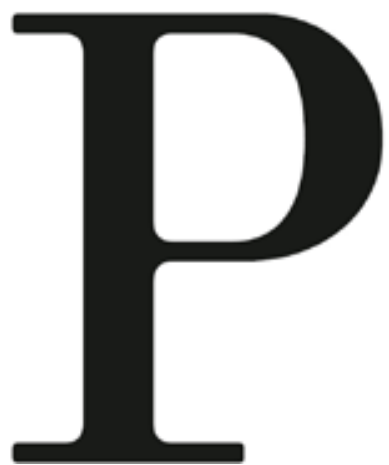

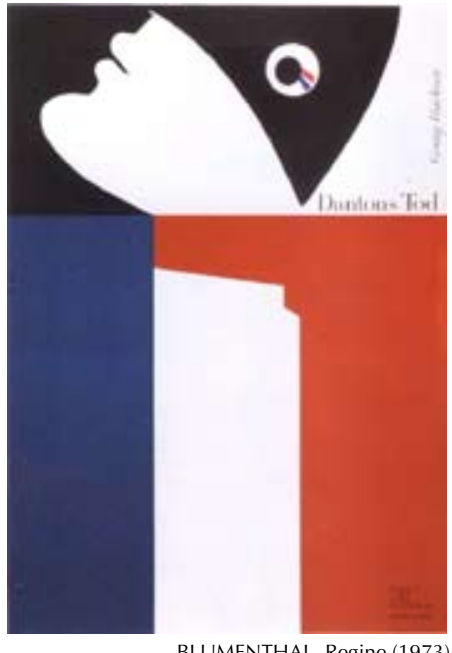

Cartel diseñado con la versión redonda de la tipografia Prillwitz. 
Los remates de los pies son filiformes, así como los de los trazos ascendentes, marcadamente horizontales. El remate de la a, c y $r$ tiene forma de gota con lóbulo redondeado, mientras que la $g$ tiene un gancho filiforme. Los remates de las letras mayúsculas son verticales en su cara exterior y oblicuos en la cara interior. Los caracteres capitales se apoyan en la línea base salvo la $Q$, de cola larga y la J.

WALBAUM (1984, Hans-Peter Greinke)

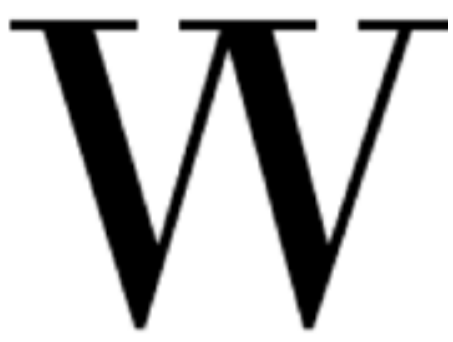

Clasificación y referentes

La tipografía Walbaum es un tipo romano neoclásico (clase IV) según la norma DIN 16518, denominadas didonas según la clasificación Vox-ATypl. La familia está constituida por un por un juego de caja alta, caja baja, cifras de caja alta y cifras elzevirianas con grosor regular y seminegra y su versión en cursiva de ambos grosores.

Se realiza una réplica de la tipografía de 1800 de J. A. Justus Erich Walbaum para su uso en la en la literatura artística y como tipografía artística.

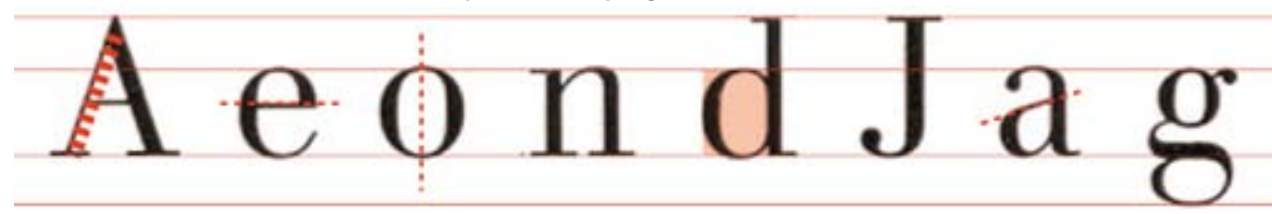

\section{Atributos formales}

La tipografía Walbaum es un tipo de construcción continua,

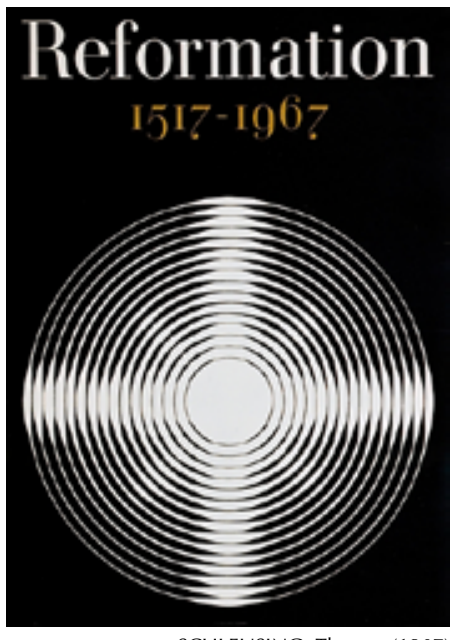

SCHLEUSING, Thomas (1967) tipografio Walla nam y cifras elziverianascon un tratamiento de las curvas continuo y redondeces ligeramente cuadradas. Las astas verticales tienen los bordes paralelos, al igual que las transversales, sensiblemente centradas en su posición en la caja alta. El perfil de la e es horizontal y se encuentra relativamente centrado, al igual que el trazo inclinado de la a.

La anchura de los caracteres es estrecha, lo que dota a la Walbaum de una apariencia esbelta. La altura de la $x$ es equilibrada con ascendentes y descendentes proporcionados y coincidentes con la altura de las mayúsculas.

El contraste del trazo es muy alto con el eje constructivo axial. La transición entre trazos es abrupta y tiene un color tipográfico medio.

Los remates de los pies son filiformes, así como los de los trazos ascendentes, marcadamente horizontales. El remate de la $a$, c y $r$ tiene forma de gota notablemente redondeada. Los remates de las letras mayúsculas, como la $T, E, F, S$ y $Z$ son verticales en su cara exterior y curvos en la interior.

Los caracteres capitales se apoyan en la línea base salvo la $Q$, de cola larga. Como caracteres destacados encontramos la $W$, tanto en caja alta como baja, que muestra claramente su formación mediante dos $V$, y cuya unión central se encuentra rematada. La unión de los trazos de la $K$ se resuelve aquí mediante la creación de un pequeño perfil.

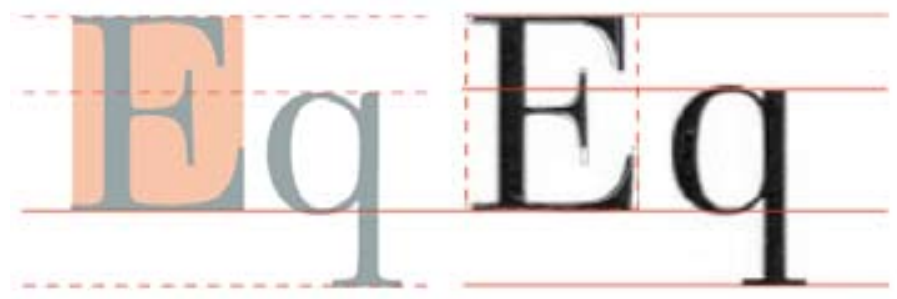

Las proporciones no varían significativamente entre el original y la réplica, si no que en este caso la mayor variación la encontramos en los remates, más exactamente en la transición entre el trazo y el remate, que mientras que en el tipo original se realizaba mediante pequeñas curvas que les conferían un aspecto más clásico, aquí se realizan de forma abrupta.

\section{Aconderge}

FETTE ANTIQUA (Barbara Cain)

Clasificación y referentes

La tipografía Fette Antiqua es un tipo romano neoclásico (clase IV) según la norma DIN 16518, denominadas didonas según la clasificación Vox-ATypl. La familia está constituida por un por un juego de caja alta, caja baja y cifras de caja alta con grosor negra y su versión en cursiva.

Se trata de una réplica del tipo producida por la fundición Schelter \& Giesecke, absorbida posteriormente por la VEB Typoart, de la cual destacan Kapr y Schäfer (1989: 92) que «el encanto especial de la escritura se basa en el extremo contraste entre el trazo horizontal y el vertical. En pequeños

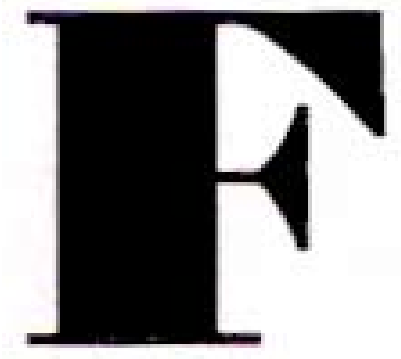




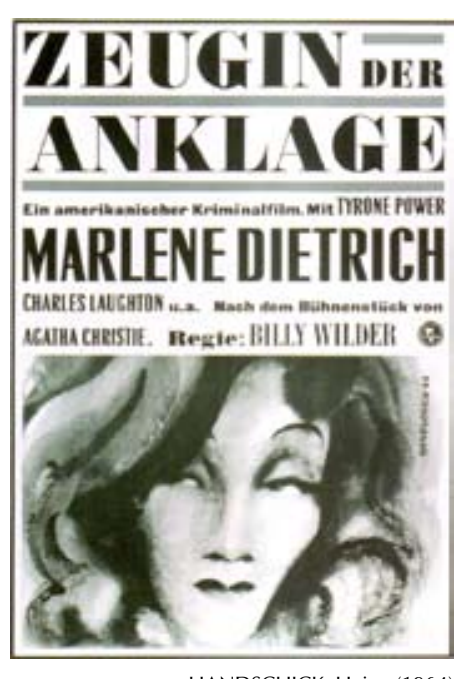

Cartel diseñado con la tipografíá Fette Antiqua
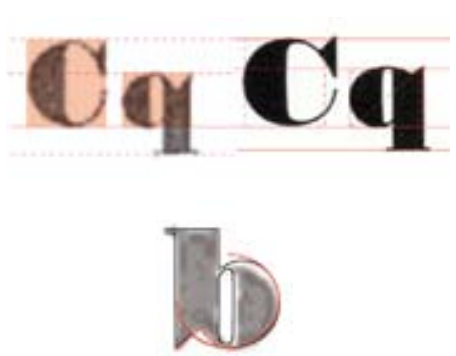

Comparativa entre las proporciones y el trazado
de la tipografía Fette Antiqua original (en gris

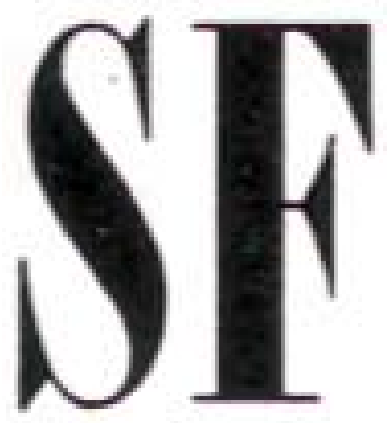

grados aparecen los tejidos gruesos de los tipos como perlas en una cadena tipográfica». Se recomienda su uso para la publicidad así como titulares de periódicos y revistas.

Atributos formales

La tipografía Fette Antiqua es un tipo de construcción continua, con un tratamiento de las curvas continuo y redondeces geométricas. Las astas verticales tienen los bordes paralelos, al igual que las transversales, sensiblemente centradas en su posición en la caja alta y baja.

Los caracteres tienen una proporción ancha, lo que dota, junto con los fuertes contrastes, a la Fette Antiqua de una apariencia pesada. La altura de la $x$ es relativamente elevada, con ascendentes y descendentes proporcionados y coincidentes con la altura de las mayúsculas.

El contraste del trazo es extremadamente alto con el eje constructivo axial. La transición entre trazos es abrupta y tiene un color tipográfico muy oscuro debido al grosor del trazo.

Los remates de los pies son filiformes, así como los de los trazos ascendentes, marcadamente horizontales. El remate de la a, c y $r$ tiene forma de gota con lóbulo redondo. Los remates de las letras mayúsculas, como la $T, E, F, S$ y $Z$ son verticales en su cara exterior y con un ángulo de $45^{\circ}$ en su cara interior.

La réplica acentúa sus trazado geométrico ensanchando su proporción y ajustando las curvas a la circunferencia. Esta geometrización supone unos elementos más marcados con y disminuye la distancia en las uniones entre curvas y rectas.

\section{SCHMALFETTE ANTIQUA (Barbara Cain)}

\section{Clasificación y referentes}

a tipografía Schmalfette Antiqua es un tipo romano neoclásico (clase IV) según la norma DIN 16518, denominadas didonas según la clasificación Vox-ATypl. La familia está constituida por un por un juego de caja alta, caja baja y cifras de caja alta con grosor negra y su versión en cursiva.

Barbara Cain realiza aquí una réplica de las tipografías condensadas seminegras creadas hacia 1830 por Vicent Figgins y William Thorowgood en Inglaterra cuyas mayúsculas gozaron de gran popularidad en las fundiciones francesas y alemanas bajo el nombre de Aldinen. Como la Fette
Antiqua su uso se destina para la publicidad y los titulares de periódicos.

\section{Hen hag}

Atributos formales

La tipografía Schmalfette Antiqua es un tipo de construcción continua, con un tratamiento de las curvas continuo y redondo. Las astas verticales tienen los bordes paralelos, al igual que las transversales, marcadamente centradas en su posición en la caja alta y baja.

Los caracteres tienen una proporción muy estrecha y esbelta, debido a lo cual, y junto con el gran grosor de trazo, tiene un color tipográfico oscuro. La altura de la x es elevada, con ascendentes coincidentes con la altura de las mayúsculas y menores que los descendentes.

El contraste del trazo es extremadamente alto con el eje constructivo axial. La transición entre trazos es abrupta y tiene un color tipográfico muy oscuro debido al grosor de trazo.

Los remates de los pies son filiformes, así como los de los trazos ascendentes, marcadamente horizontales. El remate de la $a$, c y $r$ tiene forma de gota con lóbulo redondo. Los remates de las letras mayúsculas, como la $T, E, F, S$ y $Z$ son verticales en su cara exterior y oblicuos en su cara interior.

Los caracteres capitales se apoyan en la línea base salvo la $Q$, de cola larga. Comparte con la Fette Antiqua el gancho de pie ascendente de la a y la $R$, mientras que el arco de la c es más abierto.

\subsubsection{Tipografía egipcia}

\section{NEUTRA (1968, Albert Kapr)}

\section{Clasificación y referentes}

La tipografía Neutra es una tipografía egipcia (clase V) según la norma DIN 16518, denominadas mecanas según la clasificación Vox-ATypl. La familia está constituida por un por un juego de caja alta, caja baja, cifras de caja alta y cifras elzevirianas con grosor regular y seminegra y negra.

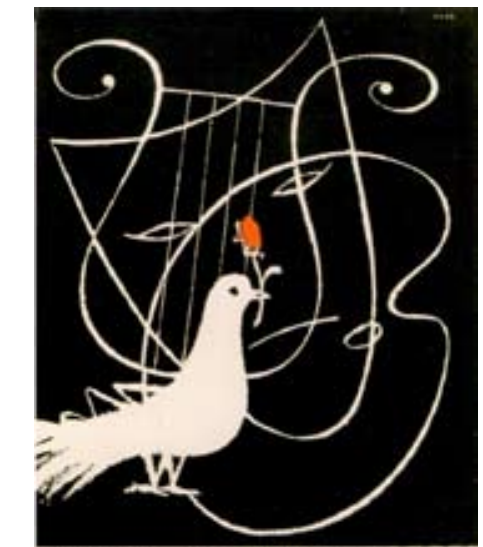

2. ILSTJIIGLR KIISTLLR

AUER, Erika (1956)
Cartel diseñado con la tipografía Schmalette

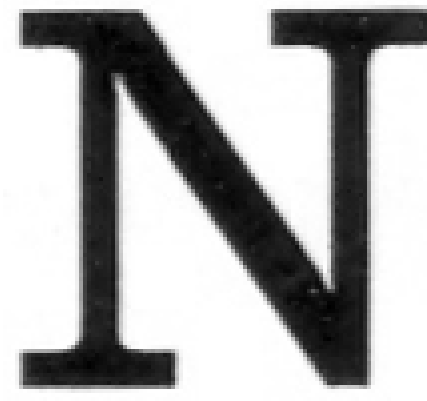


Se trata de una réplica que toma como base la tipografía Claredon que Albert Kapr encontró en una fundición de Leipzig. Según el mismo relata (1989: 122) «el nombre neutra debe significar su renuncia a toda personalidad en la impresión». Su variante regular puede ser utilizada como tipografía de edición en revistas y catálogos, mientras que la seminegra y negra se destina a titulares y publicidad.

\section{A e o nd Jag}

Nografía

Atributos formales

La tipografía Neutra es un tipo de construcción continua, con un tratamiento de las curvas continuo y redondo. Las astas verticales tienen los bordes paralelos, al igual que

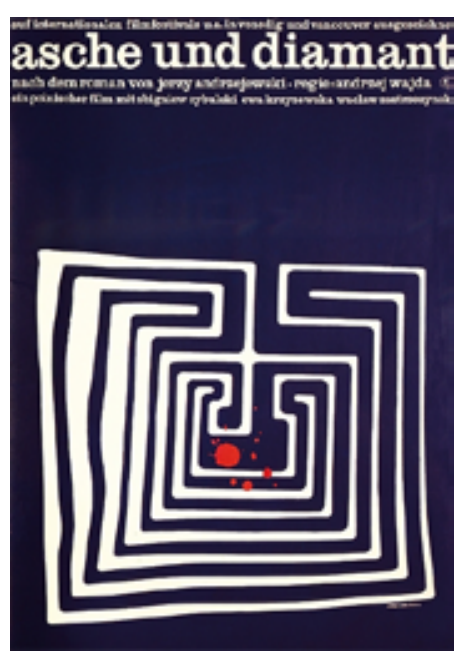
GRÜTTNER, Erhard (1965
Cartel diseñado con la tipografía Neutra las transversales, centradas en su posición en la caja alta y baja.

La proporción de los caracteres es equilibrada, con un ojo medio elevado y gran contrapunzón. Los ascendentes y descendentes son de igual tamaño y menores que la altura de las mayúsculas.

El trazo es relativamente homogéneo, con leves estrechamientos en los encuentros para clarificar los caracteres. Los remates de los pies son cuadrangulares con pequeños arcos en su encuentro con el asta. Los remates de las verticales están levemente inclinados en su cara superior, mientas que la inferior permanece horizontal. El remate de la $a, c$ y $r$ tiene forma de gota con lóbulo redondo. Los remates de las letras mayúsculas son verticales en ambas caras, con encuentros curvos con los brazos. Los caracteres capitales se apoyan en la línea base salvo la $Q$, de cola larga. Además del gran contrapunzón se distingue el alfabeto neutra por el gancho de pie ascendente de la $a$, la $R$ y la $Q$.

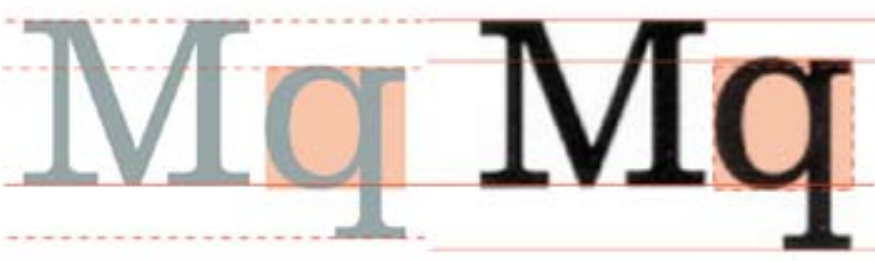

Con una altura de las $\mathrm{x}$ ligeramente más amplia, la Neutra guarda las proporciones de la Claredon, siendo las diferencias entre ambas más sutiles, tales como el encuentro entre el trazo y el lóbulo redondo de letras como la a, o el bucle de la $c$ más cerrado. Igualmente se destacará en mayor medida el gancho de pie de la a y la $R$ en el tipo diseñada por la VEB Typoart.

EGYPTIENNE (Hans-Peter Greinke)

\section{Clasificación y referentes}

La tipografía Egyptienne es un tipo de los denominados egipcias (clase V) según la norma DIN 16518, denominadas mecanas según la clasificación Vox-ATypl. La familia está constituida por un por un juego de caja alta, caja baja, cifras de caja alta con grosor extragrueso.

Basada en el tipo diseñada por Adrian Frutiger en 1956 en fotocomposición se desarrolla únicamente la versión extragruesa para tipografías destacadas de los periódicos, carteles y publicidad.

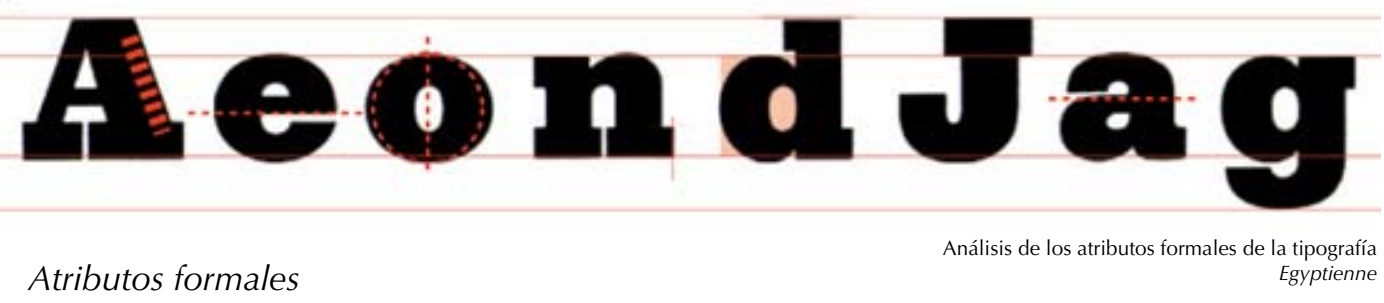

La tipografía Egyptienne es un tipo de construcción continua, con un tratamiento de las curvas continuo y redondeces geométricas. Las astas verticales tienen los bordes paralelos, al igual que las transversales, centradas en su posición en la caja alta y baja.

La proporción de los caracteres es muy ancha, lo que junto a la elevada altura del ojo medio le proporciona legibilidad pese al grosor del trazo. Los ascendentes y descendentes son de pequeño tamaño, siendo estos últimos algo mayores. La altura de las mayúsculas es la misma que la de los ascendentes.

Pese a ser una letra clasificada como egipcia, el grosor del trazo no es completamente homogéneo ya que esto haría que tuviera una apariencia muy pesada y poco clara. Esta diferenciación es más evidente en los caracteres de las mayúsculas como la $A$ o la $N$.
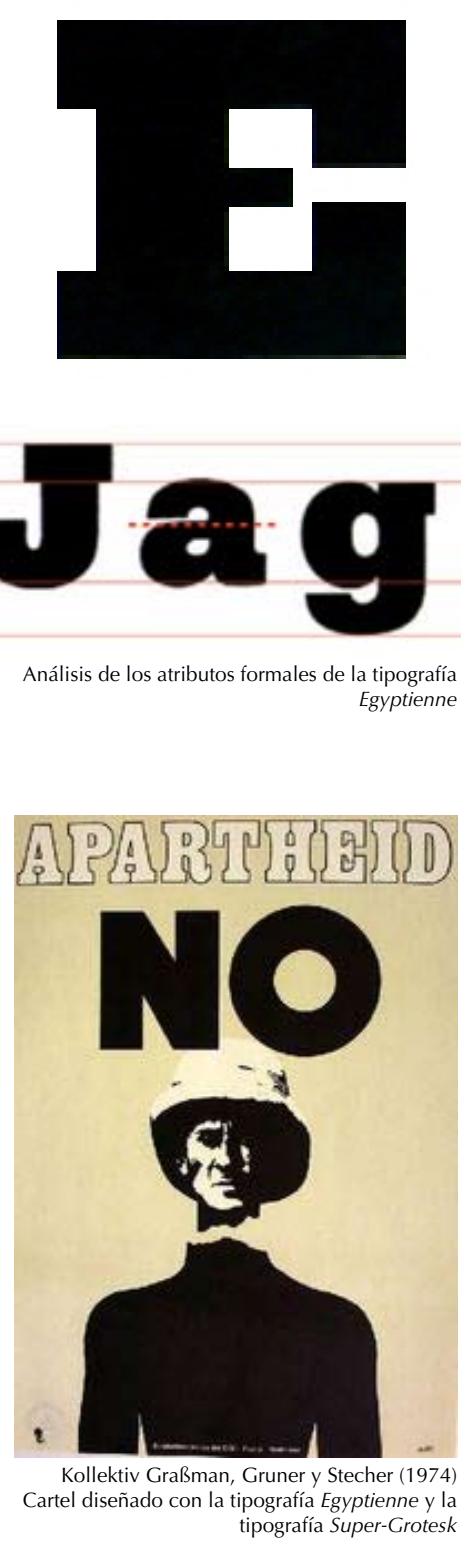
Los remates de los pies son cuadrangulares y con gran presencia, así como los de los trazos ascendentes cuya anchura ocupa casi la totalidad del trazo. El remate de la a, c y $r$ se reduce a la prolongación del trazo. Los remates de las letras mayúsculas son verticales en ambas caras. Los caracteres capitales se apoyan en la línea base salvo la $O$ de cola larga, a diferenciación del alfabeto diseñada por Frutiger.

La versión extragruesa diseñada por Typoart no mantiene las proporciones del alfabeto de Frutiger sino que los caracteres se ensanchan debido al mayor grosor del trazo y la altura de los ascendentes se disminuye hasta alcanzar la altura de las mayúsculas.

\section{Hgbigh}

NIDOR (Harald Brödel)

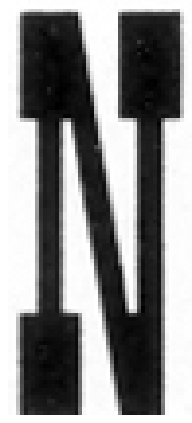

Clasificación y referentes

La tipografía Nidor es un tipo de los denominados egipcias (clase V) según la norma DIN 16518, denominadas mecanas según la clasificación Vox-ATypl. La familia está constituida por un por un juego de caja alta, caja baja, cifras de caja alta con grosor regular.

Se desarrolló la tipografía a partir de la encontrada en una caja de muestras de una fundición desarrollada probablemente en la segunda mitad del siglo XIX debido a sus características formales muy similares a las tipografías denominadas de «estilo italiano» diseñadas en esta época. Su diseño es similar al de la tipo Playbill diseñada en 1938 por Robert Harling. Estas tipografías gozarían de gran popularidad por su utilización en carteles para Westerns.

Su uso se destina a los carteles y la publicidad, ya que tal y como afirma Kapr y Schäfer (1989: 127) «su problema como tipo de publicidad es que no tiene buena legibilidad, pero llama la atención y se graba en la memoria».

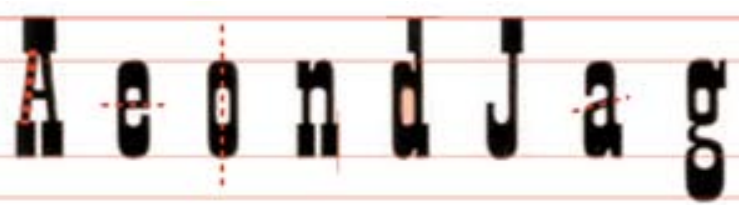

Atributos formales

La tipografía Nidor es un tipo de construcción continua, con un tratamiento de las curvas continuo y redondeces cuadradas. Las astas verticales tienen los bordes paralelos, al igual que las transversales, centradas en su posición en la caja alta y baja.

La proporción de los caracteres es muy estrecha, que en combinación con los gruesos remates dificultan su legibilidad. El ojo medio es algo elevado, con los ascendentes, descendentes y altura de las mayúsculas de igual tamaño.

El grosor del trazo, homogéneo en la parte central del caracter, se ensancha notablemente en la parte inferior y superior del mismo, enfatizando la apariencia de tipografía de Western de la que le dotan los remates.

Los remates de los pies son cuadrangulares y con gran presencia, así como los de los trazos ascendentes. El remate de la $a, c$ y $r$ se reduce a la prolongación del trazo. Los remates de las letras mayúsculas son verticales en ambas caras. Los caracteres capitales se apoyan en la línea base salvo la $Q$, de cola larga.

\subsubsection{Tipografía palo seco}

\section{MAXIMA (1970, Gert Wunderlich)}

\section{Clasificación y referentes}

La tipografía Maxima es un tipo de palo seco (clase VI) según la norma DIN 16518, denominadas lineales neogrotescas según la clasificación Vox-ATypl. La familia está constituida por un por un juego de caja alta, caja baja, cifras de caja alta y cifras elzevirianas con los grosores fino, regular, seminegra, negra y extra gruesa, con su versión en cursiva de los tres primeros. Se realizan dos juegos de Maxima condensada con los grosores regular y seminegra así como uno sombreado (Maxima licht schattiert). Igualmente tendrá, junto a su juego de caracteres latinos, otro de caracteres cirílicos con los grosores regular y seminegra tanto en redonda como cursiva y otro de caracteres griegos regular y seminegra ambos con sus versiones redonda y cursiva.

Kapr y Schäfer (1989: 105) observaban que "cuanto mayor es la aportación de las tipografías de palos seco a la tipografía general, tanto más difícil es diseñar una nueva

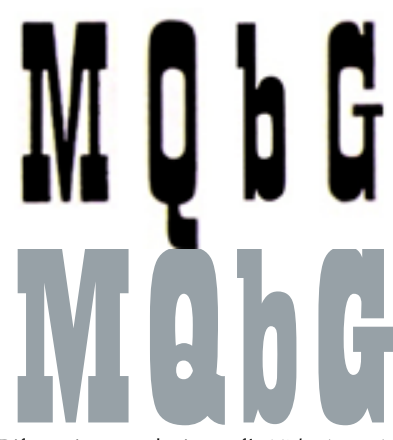

Plerencias entre la tipografífí Nidor (negro) y homogéne

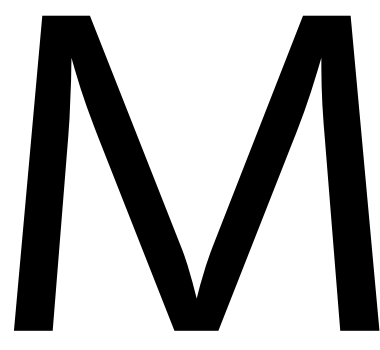


tipografía de palo seco ya que el espacio libre ya se va ocupando. Gert Wunderlich ha logrado aportar algunas ideas originales. Los trazos relativamente afilados de las minúsculas de la Maxima y sus combinaciones con mayúsculas en la proporción de las romanas renacentistas dan una atractivo gráfico interesante». La Maxima está construida como la mayor familia tipográfica de Typoart. Su ámbito de empleo es prácticamente ilimitado con un uso habitual como tipografía de edición. Repetidamente eran galardonados como "los libros más bellos de la RDA» libros compuestos con esta tipografía.

\section{A e o n d J a g}

Atributos formales

Der gewöhnliche

Faschismus Einfilmvon

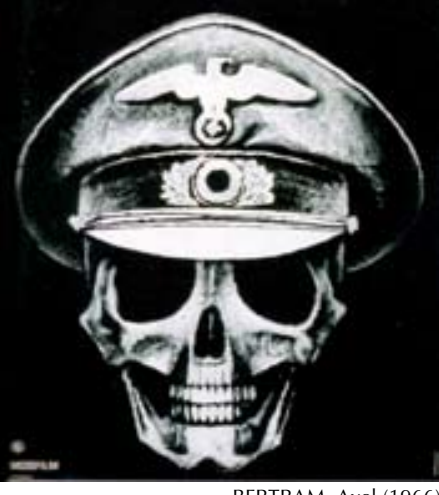

Cartel diseñado con la tipografía Maxima en sus versiones regular y fina
vina

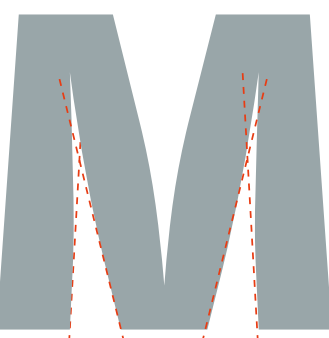

La tipografía Maxima es un tipo de construcción continua, con un tratamiento de las curvas continuo y redondo ligeramente cuadrado. Las astas verticales tienen los bordes paralelos, al igual que las transversales, centradas en su posición.

Destaca en su estructura la amplitud del ojo medio, que supone la más de la mitad del área haciendo que los ascendentes y descendentes sean muy cortos. La altura de las ascendentes es ligeramente superior a la de los descendentes y a la altura de las mayúsculas.

En una búsqueda de una mayor legibilidad la estructura de las minúsculas se estrecha, lo que permite una mayor condensación del texto y por tanto abarcar una mayor longitud de texto con un golpe de vista. Tal y como exponen Kapr y Schäfer (1989) las proporciones de las mayúsculas están relacionadas con las mayúsculas de la columna trajana y de los monumentos renacentistas.

Como letra de palo seco el trazo no está contrastado, al menos aparentemente, ya que un análisis más cercano nos muestra como se han contrarrestado las ilusiones ópticas en los encuentros entre rectas y curvas y en los ángulos agudos. Hay que tener en cuenta que se trata de un tipo diseñado para la fotocomposición, lo que según expone Baines (2002; 85), «con las fotomatrices era necesario hacer ciertos ajustes en los detalles del carácter, para compensar las propiedades particulares de la luz». Es por eso que para contrarrestar los efectos de la fotografía las caras interiores de los vértices agudos se curvaban hacia el interior.
El color tipográfico general es medio. Dentro de las letras de palo seco la Maxima tiene una tendencia humanista que encontramos en el trazado de la $a$, de dos pisos, mientras que la $g$ es de un solo piso. Los vértices de la $A$ o la $M$ son rectos, la $G$ carece de espuela y la $Q$ tiene cola corta, la cual, no obstante, sobresale de la línea base, al igual que la $/$.

\section{SUPER-GROTESK (aprox. 1930, Arno Drescher)}

Clasificación y referentes.

La tipografía Super-Grotesk es un tipo de palo seco (clase VI) según la norma DIN 16518, denominadas lineales geométricas según la clasificación Vox-ATypl. La familia está constituida por un juego de caja alta, caja baja, cifras de caja alta y cifras elzevirianas con los grosores light, regular, seminegra y negra así como cursiva regular.

La popularidad del tipo Super la convirtió en la tipografía más utilizada de la RDA. Teniendo en cuenta la opinión de Kapr y Schäfer (1989: 114) surge de la «Neuen Sachlichkeit y del movimiento de la Bauhaus una dirección hacia la vuelta de las formas simples y claras. Este desarrollo permanece, no sin repercusión, en la formación de tipos. Esa hasta hoy inalterada popularidad de las formas marcadamente constructiva no se trata de ninguna moda pasajera».

Sumándose a esta tendencia el profesor Arno Drescher elabora su tipografía Super, la cual será redibujada por KarlHeinz Lange para su versión de fotocomposición, permaneciendo hasta este momento según el diseño original. E Profesor Drescher había creado esta popular tipografía en los años 30 para la fundición AG Dresden, una de las fundiciones que compondrán posteriormente la VEB Typoart.

A lo largo de los años de la RDA sería una tipografía con un amplio espectro que alcanzaba desde periódicos, revistas, ilustraciones, libros de texto hasta fantasía y publicidad grafica y carteles.

Son muy evidentes las similitudes de la Super Grotesk con la Futura diseñada por Paul Renner, y según expone Norbert du Vinage, (1987, citado en Anon) «a pesar de que siguió los mismos principios de diseño que la Futura, no ha alcanzado hoy en día su calidad tipográfica. Si nosotros sin embargo hemos decidió rediseñar la Super y no adquirir una licencia para el alfabeto de Paul Renner, es debido a que la legendaria Futura no puede satisfacer todas las demandas de nuestro tiempo».
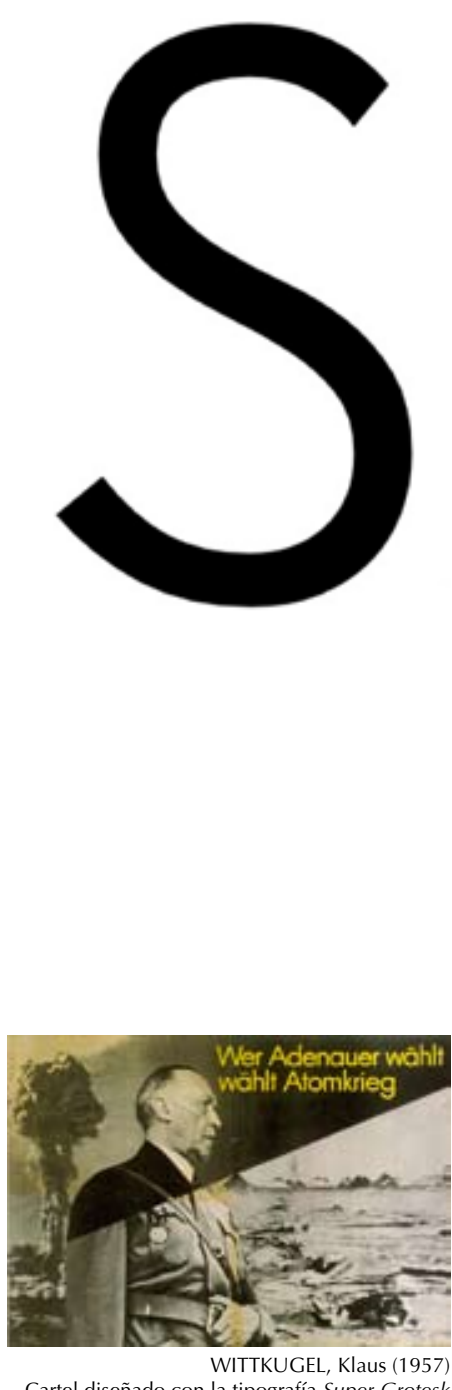

Cartel diseñado con la tipografía Super-Grotesk
en su versión fina 


\section{Aeondlag}

de la tipografía
Super-Grotesk

La tipografía Super es un tipo de construcción continua, con curvas continuas y geométricas. Las astas verticales son completamente rectas y de bordes paralelos y las astas horizontales están centradas.

Tiene un marcado aspecto geométrico lo que dota al tipo de una proporción ancha, si bien la proporciones relativas de las capitales son las de las capitales cuadradas romanas. La altura del ojo medio ocupa poco espacio en relación con los trazos ascendentes, muy amplios también en su relación con los trazos descendentes, de escasa altura. No obstante en su reelaboración para la fotocomposición Karl-Heinz Lange agranda el ojo medio en una búsqueda de una mayor legibilidad.

El trazo es homogéneo, aunque que según reconocen

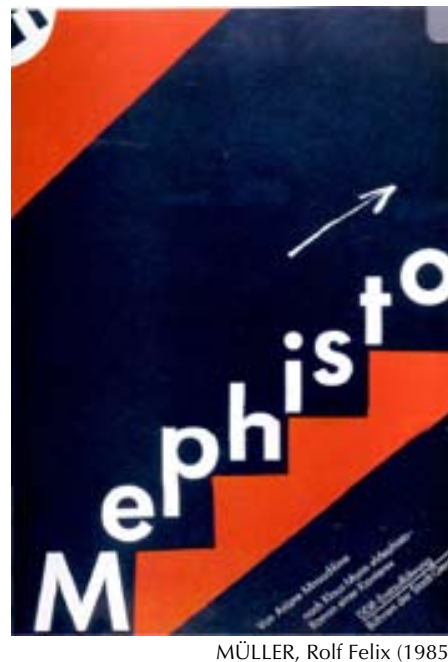
Kapr y Schäfer (1989: 114) «Ni son las formas constructivas, ni los grosores de trazo iguales. Se trata más bien de una múltiple compensación de ilusiones ópticas a las que sucumbe nuestro ojo. Una unión entre un círculo y una línea con un trazo realmente igual de grueso daría una impresión muy desigual y desmañada», es por eso que persiste de la modulación en el trazo en los encuentros entre curvas y rectas. Esta modulación la encontramos también en el diseño de la Futura diseñada por Paul Renner en 1927, el cual consideraba (1930: 32 citado en Burke 2000: 96) que «en las intersecciones de curva y asta se originan manchas $y$, al final, el asta, aunque esté alineada por la parte superior con la tangente horizontal a la curva, parecerá que en realidad se extienda por debajo del vértice del círculo. Por tanto, quienquiera que desee crear una escritura constructiva para el ojo humano no podrá conseguirlo con construcciones geométricas elementales»

Como tipografía geométrica tiene los caracteres de la a y la $g$ de un solo piso más cercano a la construcción mediante rectas y círculos. La cola del la $Q$ corta el anillo quedando apoyada como el resto de las mayúsculas en la línea base.

Encontramos el alejamiento del trazado puramente geométrico del que habla Renner en los encuentros de los vértices, que a diferencia de la tipografía Futura en la cual estas aristas son vivas, en la Super se trata de vértices truncados. Mientras que la $j$ minúscula de la tipografía Futura es un sencillo trazo recto ya que «Renner insistió en que la similitud temática entre los caracteres construidos sobre principios geométricos les reportaría congruencia» (Burke, 2000: 95), en el caso de la Super no pierde su curvatura inferior, algo más semejante al trazado humanista. Sin embargo, las letras $t$ y $s$ se mantendrán estrictamente simétricos, frente a su composición más estilizada en la diseñada por Paul Renner.
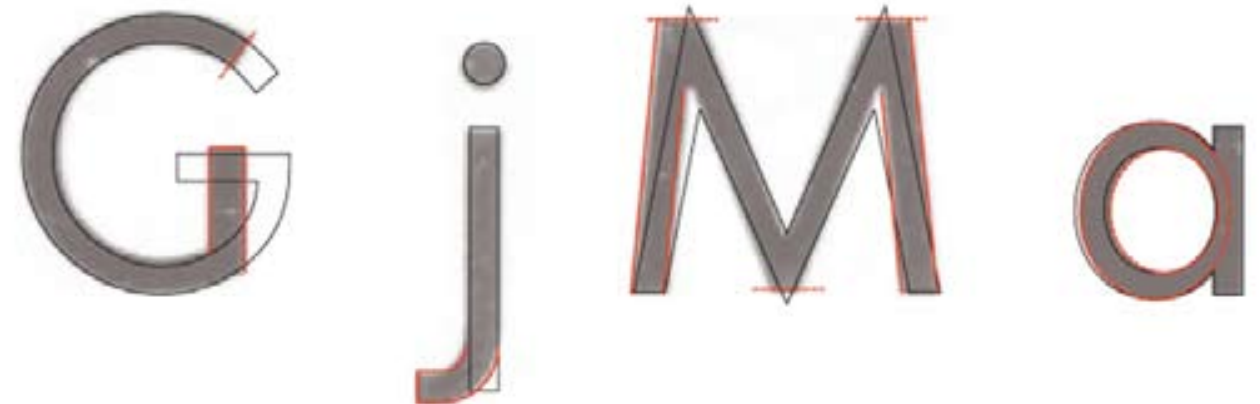

En su adaptación a la Futura se produce un mayor alejamiento de una geometría pura al buscar una proporción más estilizada con una altura de la $x$ es notablemente más amplia que en el alfabeto Futura. El trazado de la $G$, sin filete horizontal, supone la diferencia más evidente entre ambas tipografías, y contituyó al mismo tiempo la mayor innovación en su adaptación en fotocomposición.

MINIMA (1984, Karl-Heinz Lange)

Clasificación y referentes

La tipografía Minima es un tipo de palo seco (clase VI) según la norma DIN 16518, denominadas lineales humanistas según la clasificación Vox-ATypl. La familia está constituida por un por un juego de caja alta, caja baja y cifras de caja alta con los grosores regular y seminegra.

El alfabeto se diseñó desde el comienzo como una tipografía para ser utilizada en listines telefónicos, por lo que primaba la legibilidad a tamaños de letra muy pequeños, ya que esto podía suponer un ahorro de papel de entre 30 y $40 \%$.
Comparativa del trazado de la tipografía Futura. contorno negro) y super-Crotessk, en la cual las
transiciones se realizan de forma más abruptá

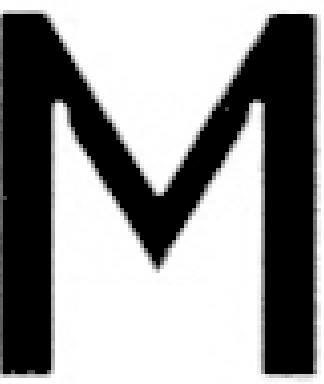


El tipo Minima es un tipo de construcción continua, con un tratamiento de las curvas continuo y redondo. Las astas verticales tienen los bordes paralelos, al igual que las transversales en las mayúsculas, centradas en su posición, mientras que en las minúsculas son oblicuas.

Sus líneas de referencia destacan por la gran amplitud del ojo medio, dejando poco espacio a los ascendentes y descendentes. Al mismo tiempo la altura de las ascendentes es ligeramente superior a la de los descendentes y a la altura de las mayúsculas. La proporción de los caracteres es de gran esbeltez, para favorecer una menor ocupación de A०0 GKR

Minima en los cuales la decoración se ha teducido al mínimo y se sitúan de tal forma que
resulten lo más consdensados posible.

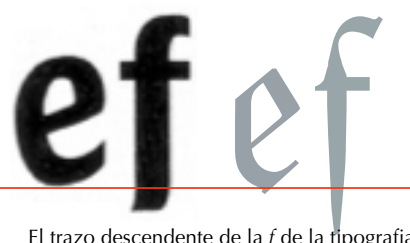

El trazo descendente de la $f$ de la tipografia
Minima se asemeja al de la tipografía de fractura

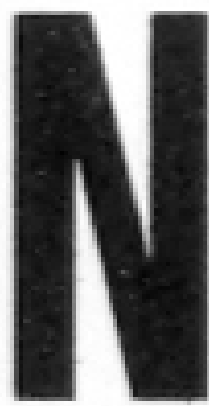
espacio.

Aparentemente carece de modulación de trazo, así como de remates. Por su destino a pequeño tamaño resulta muy evidente aquí la corrección realizada en la cara interior de los vértices para compensar el efecto de las matrices de fotocomposición

Se refleja el ductus humanista en el trazado de ciertos caracteres, como la a y la $g$, de dos pisos. Encontramos característicos el trazado del bucle abierto de la $\mathrm{R}$, la $\mathrm{G}$ sin filete horizontal o el trazado de la K, cuyos trazos no llegan a tocarse. En una búsqueda de ahorro de espacio se diseñan unas mayúsculas con diéresis especiales, en las cuales estas no sobresalen de la altura de las mayúsculas.

El trazado de la f, con un trazo descendente típico de as tipografías quebradas es un elemento destacado de este alfabeto.

\section{NORMA-STEINSCHRIFT (Harald Brödel)}

Clasificación y referentes

La tipografía Norma-Steinschrift es un tipo de palo seco (clase VI) según la norma DIN 16518, denominadas lineaestá constituida por un por un juego de caja alta, caja baja y cifras de caja alta con un único grosor.

El nombre de Norma se debe a la impersonalidad que se le suponía y a su capacidad para combinar con cualquier otra tipografía. Según relatan Kapr y Schäfer (1989: 121) «con su aspecto estrecho y grosor semigrueso es la Norma una solución bienvenida para titulares con escasa anchura de espacio. También ha encontrado su espacio en la publicidad y para las creaciones destacadas objetivamente». les grotescas según la clasificación Vox-ATypl. La familia

\section{A eond Jag}

Atributos formales

Ańlisis de los atributos formales de la tipografía Norma-Steinschriet

La tipografía Norma es un tipo de construcción continua, con un tratamiento de las curvas continuo y redondo, con marcado acercamiento a formas rectangulares. Las asta verticales tienen los bordes paralelos, al igual que las transversales en las mayúsculas -centradas en su posición-, y en la e, mientras que la de la a es oblicua.

Cuenta con un ojo medio muy amplio y altura de ascendentes, descendentes y mayúsculas equivalente. Es característica de esta tipografía la esbeltez de los caracteres, así como su trazo homogéneo y grueso, lo que conjuntamente le dota de un color tipográfico muy oscuro.

Se refleja el ductus humanista en el trazado de dos pisos de la a. Todas las mayúsculas se apoyan en la línea base, salvo la J.

\section{MOLLI (Harald Brödel)}

Clasificación y referentes

La tipografía Molli es un tipo de palo seco (clase VI) según la norma DIN 16518, denominadas lineales grotescas según la clasificación Vox-ATypl. La familia está constituida por un por un juego de caja alta, caja baja y cifras de caja alta con un único grosor.

La tipografía se diseñó como elemento masivo y juvenil pero que no espantase al gusto más conservador y destinada a su uso en la publicidad y titulares.

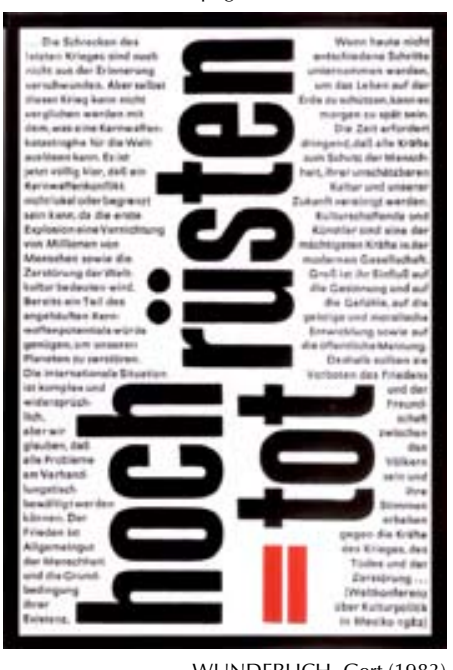

WUNDERLICH, Gert (1983)
Cartel tipográfico diseñado con la tipografía
Norma-Steinschri

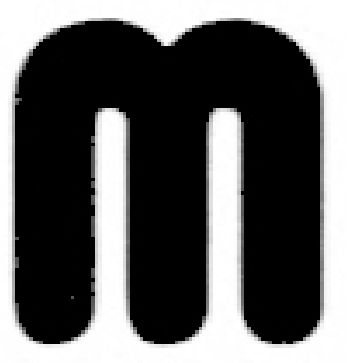

\section{ieond Jag}

Atributos formales

a tipografía Molli es un tipo de construcción continua, con un tratamiento de las curvas continuo y redondeces relativamente cuadradas. Las astas verticales tienen los bordes paralelos, al igual que las transversales, centradas en su 
posición. También son sensiblemente horizontales los perfiles de la a y la e.

Tiene un ojo medio amplio con ascendentes y descendente proporcionadas e iguales a la altura de las mayúsculas. Los caracteres son claramente estilizados.

Aparentemente carece de modulación de trazo, siendo este grueso lo que le concede un color tipográfico muy oscuro. Carece igualmente de remates, pero destaca en esta tipografía las terminaciones redondeadas de los trazos y de los vértices.

\subsubsection{Tipografía variantes de la letra romana}

\section{PUBLICA (1981-83, Karl-Heinz Lange)}

Clasificación y referentes

La tipografía Publica es una variante de las tipografías romanas (clase VII) según la norma DIN 16518, denominadas incisas según la clasificación Vox-ATypl. La familia está constituida por un por un juego de caja alta, caja baja, cifras de caja alta y cifras elzevirianas con grosores regular, seminegra y negra y una versión en regular.

Se desarrolla a partir de unos bocetos presentados a unos premios internacionales de tipografía en 1971. Tal y como cuenta Leslie Kuo (2007) «cuando Typoart le pidió una imitación de la Optima de Herman Zapf, Lange se propuso diseñar un tipo con calidad suficiente para enseñar al propio Zapf. Incluso se las apañó para ir a la RDA tan pronto como estuvo lista con la excusa de un cumpleaños de un tío. Su tipografía Publica obtuvo la aprobación de Zapf» e que incluso ganó una medalla en la Bienal de Diseño Gráfico de Brno en 1984. Su uso se destina fundamentalmente a la publicidad, el diseño gráfico, revistas y carteles.

\section{A e ondJag}

Atributos formales

La tipografía Publica es un tipo de construcción continua, con un tratamiento de las curvas continuo y redondeado. Las astas verticales tienen los bordes cóncavos. Los perfiles sin embargo si tienen bordes paralelos y se encuentran centrados en su posición.

Tiene un ojo medio relativamente equilibrado, con ascendentes y descendentes equidistantes. La altura de las mayúsculas es inferior a la altura de las ascendentes. La proporción de los caracteres es estrecha, pese a lo cual tiene un color tipográfico relativamente claro, debido al amplio contrapunzón de los caracteres.

El contraste del trazo es muy sutil, dando aspecto de trazo homogéneo y si bien carece de remates, los bordes de los trazos se ensanchan ligeramente en sus bordes.

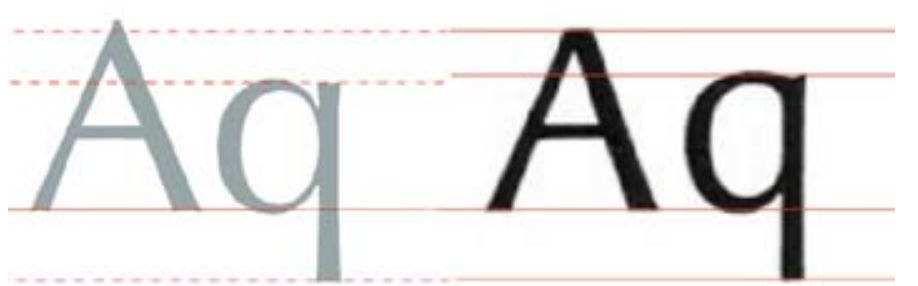

El bucle de la $R$ y el ojal inferior de la $g$ no llegan a cerrarse. Este mismo juego se repite en la cola de la $Q$, la cual es independiente y supone el único elemento de las mayúsculas situado por debajo de la línea base. Esta característica de la Publica no la encontramos en la Optima. Si bien ambas tipografías tienen muchas similitudes, también son notables las diferencias: los bordes cóncavos de las astas están más pronunciados en el alfabeto diseñada por Hermann Zapf quien curva todos los bordes del trazo, mientras que en la Publica, únicamente los trazos verticales cuentan con esta curvatura. La tipografía Optima deja una mayor constancia de los elementos que componen cada carácter mientras que las transiciones son más suaves de la Publica.

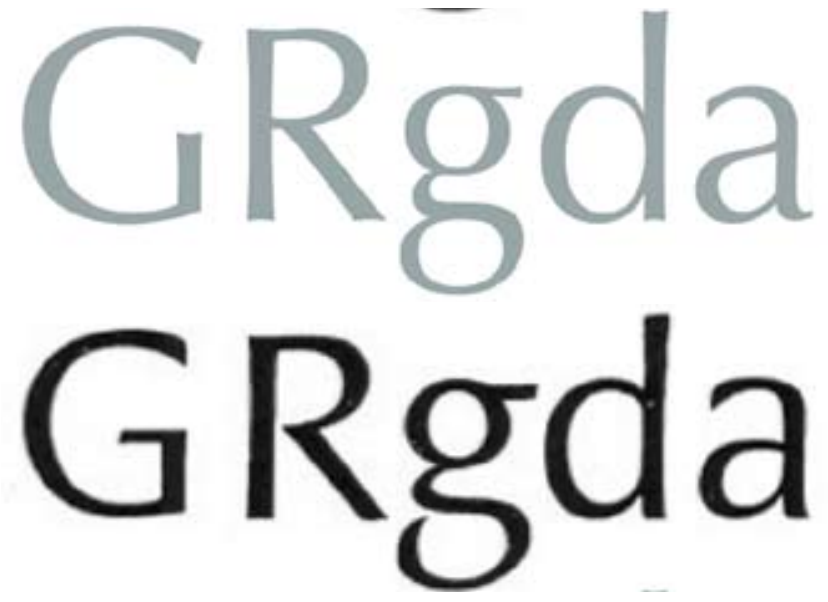




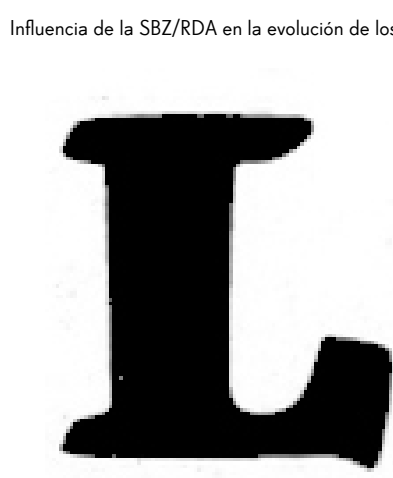

LIBERTA (1958-61, Herbert Thannhaeuser)

Clasificación y referentes

La tipografía Liberta es una variante de las tipografías romanas (clase VII) según la norma DIN 16518, denominadas incisas según la clasificación Vox-ATypl. La familia está constituida por un por un juego de caja alta, caja baja y cifras de caja alta con grosor extragrueso y su versión en cursiva.

La tipografía original diseñada por Thannhaeuser contaba con mas grosores de tipos, pero por "cuestiones técnicas» solo se producirá el grosor extragrueso en fotocomposición. Su uso se destina fundamentalmente a la publicidad.

\section{AeondJag}

Atributos formales

La tipografía Liberta es un tipo de construcción continua, con un tratamiento de las curvas continuo y redondeado. Las astas verticales tienen los bordes no paralelos, con la base más estrecha. Los perfiles sin embargo si tienen bordes paralelos y se encuentran centrados en su posición.

Tiene un ojo medio elevado y ascendentes y descendentes equidistantes, al igual que la altura de las mayúsculas. La proporción de los caracteres es muy ancha, dándole un aspecto pesado.

El contraste del trazo es elevado debido al fuerte grosor del trazo, y el eje constructivo de contraste vertical. La transición entre el grosor y el perfil es gradual. Este fuerte grosor de trazo dota a la tipografía Liberta de un color tipográfico relativamente oscuro.

Los remates de los pies tienen un trazado irregular y redondeado con proporciones cuadrangulares y terminaciones oblicuas. Los remates de los ascendentes tienen el trazo inclinado con los bordes despuntados. Resultan característicos los remates de la $g, c, r$, los cuales, junto con los remates de las trasversales de las mayúsculas, y el descendente de la $g$ y la $y$ tienen forma de diamante con vértices redondeados. Los caracteres capitales se apoyan en la línea base salvo la / que se prolonga bajo esta.

\section{Heond $\mathrm{F}$ ag}

ECKMANN (Werner Schulze)

Clasificación y referentes

La tipografía Eckmann es un tipo a medio camino entre las tipografías romanas y las tipografías quebradas Schwabacher (clases VII y X.c) según la norma DIN 16518, denominadas incisas y góticas según la clasificación Vox-ATypl. La familia está constituida por un por un juego de caja alta, caja baja y cifras de caja alta con grosor regular.

Se trata de una réplica del tipo jugendstil diseñada a comienzos de siglo por Otto Eckmann de la cual Kapr y Schäfer destacan (1989: 130) que «es digna de tomarse en cuenta su compromiso con las letras de fractura y que vivió en los primeros años de nuestro siglo un fantástico éxito de venta, el cual tuvo el punto álgido en la ola de nostalgia en los años 70». Se destina a las impresiones artísticas.

\section{Atributos formales}

La tipografía Eckmann es un tipo de construcción continua con un tratamiento de las curvas redondeado y quebrado. Las astas verticales tienen los bordes cóncavos y se curvan hacia el interior de los caracteres. Las astas transversales son oblicuas y curvadas y se encuentran elevadas respecto de la posición media.

La anchura de los caracteres muy estrecha y esbelta en los caracteres de caja baja y caja alta. La altura de la x es elevada con ascendentes coincidentes con la altura de las mayúsculas y de mayor tamaño que los descendentes.

El contraste del trazo es muy alto con el eje constructivo inclinado y una transición entre trazos abrupta y con reminiscencias del trazado de los tipos Schwabacher. Tiene un color tipográfico oscuro.

Los remates son insinuados mediante una pequeña apertura de los bordes de las astas. Resulta característico los bucles abiertos de todos los caracteres a excepción de la $o$, tanto minúscula como mayúscula, la $Q$ y la $R$. Todos los caracteres capitales se apoyan en la línea base.

La proporción de la réplica es muy similar a la del original, siendo su mayor diferencia la decoración de los elementos
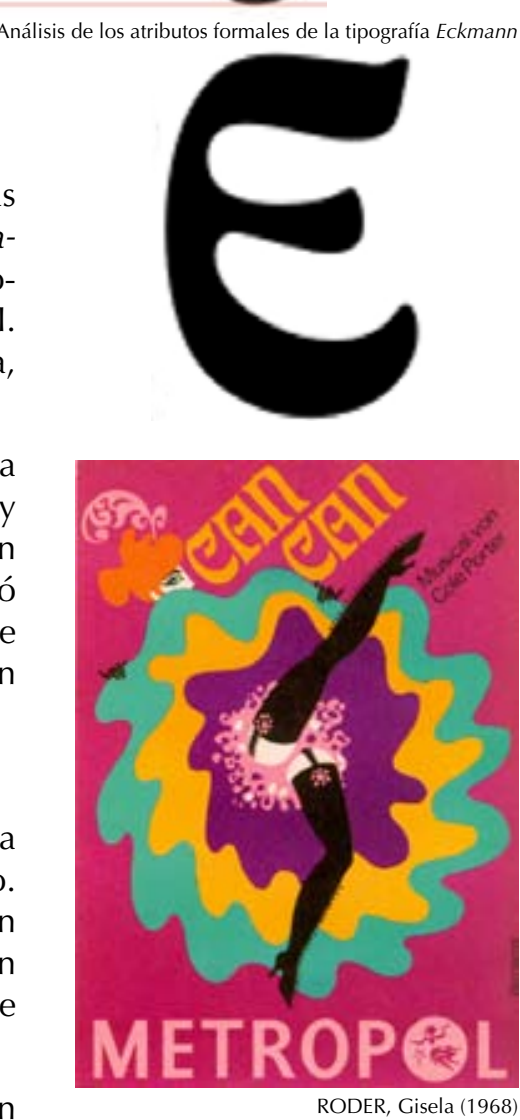

on la tipografía Eckmann por

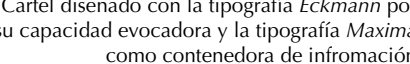
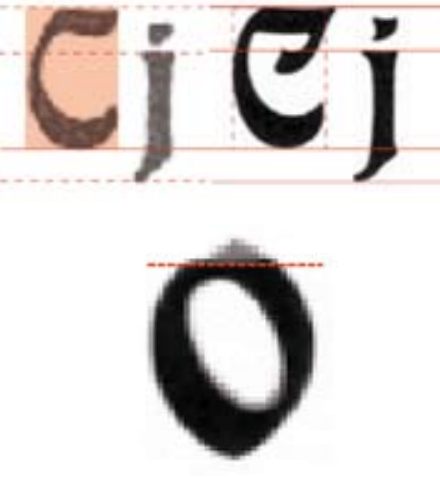

Omparativa entre las proporciones, el rrazado
decoración de la tipografía Eckmann origina 
de caja alta, con un gran número de elementos decorativos añadidos respecto del tipo original, así como el truncamiento horizontal superior de las curvas de los caracteres.

\subsubsection{Tipografía manuscrita}

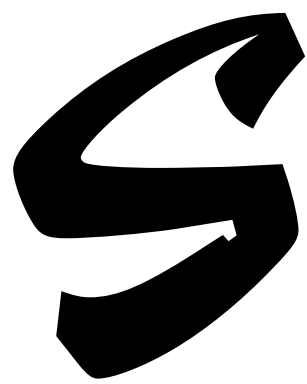

STENTOR (1964, Heinz Schumann)

Clasificación y referentes

a tipografía Stentor es un tipo de los denominados manuscritos (clase VIII) según la norma DIN 16518, denominadas escriptas según la clasificación Vox-ATypl. La familia está constituida por un por un juego de caja alta, caja baja y cifras de caja alta con un único grosor

Imita el trazo realizado con pincel y su uso está destinado al terreno creativo, la publicidad y las revistas.

\section{Acond $7 a g$}

Atributos formales

La tipografía Stentor es un tipo de construcción continua con referencias al trazo manual realizado con pincel. El tratamiento de las curvas es continuo y ovalado. En su alusión a la letra manuscrita los anillos y las astas no llegan a tocarse permaneciendo muchas de las curvas abiertas. Las astas verticales tienen los bordes no paralelos, con ángulo variable según la dirección del trazo y una tendenciaz a la oblicuidad. Las astas transversales son ascendentes y con tendencia al ángulo agudo en su trazo.

Las letras capitales son notablemente anchas debido a la decoración de los caracteres, con una proporción relativa de capitales generalmente regulares. Por su parte en las letras minúsculas predomina la verticalidad y condensación tipográfica lo que dota al alfabeto Stentor de un color negro. El ojo medio es muy amplio y destaca la gran altura de los ascendentes en comparación con la profundidad de los descendentes. La altura de las mayúsculas y la alineación superior son coincidentes.

Al igual que en la tipografía manual realizada con un pincel ancho la modulación es muy contrastada entre el grosor y el perfil de la letra con una transición abrupta entre ambos. El eje constructivo de contraste es relativamente vertical, variando según el trazado de cada caracter.

Como tipografía manuscrita la Stentor carece de remates más allá de los ganchos de cabeza o de pie, derivados de la escritura manual en forma de uña. Del mismo modo los trazos ascendentes se conforman con forma de lazo y por tanto sin remate a excepción de la d, con un remate de trazo inclinado.

Finalmente destacar que al imitar el trazado realizado con un pincel se han realizado alteraciones en el trazo imitando las irregularidades del trabajo artesanal, en este caso mediante la rotura del trazo principalmente en la unión entre el asta y el gancho de pie.

\subsubsection{Tipografías caligráficas}

\section{HOGARTH-SCRIPT (Harald Brödel)}

\section{Clasificación y referentes}

La tipografía Hogarth-Script es un tipo caligráfico manuscrito a pluma (clase IX) según la norma DIN 16518, denominadas manuales según la clasificación Vox-ATypl. La familia está constituida por un juego de caja alta y baja y otro de cifras de caja alta, tanto en su versión regular como en semi-negra.

Hogarth-Script, dibujada por Harald Brödel toma su nombre del caricaturista inglés del siglo XVIII William Hogarth debido a la popularidad de los tipos caligráficos ingleses de esta época. Su ámbito de uso será la creación y la publicidad, ya que tal y como explican Kapr y Schäfer (1989: 143) «Todavía hoy la asocian los observadores con la una elegancia y sutil seriedad atemporales»

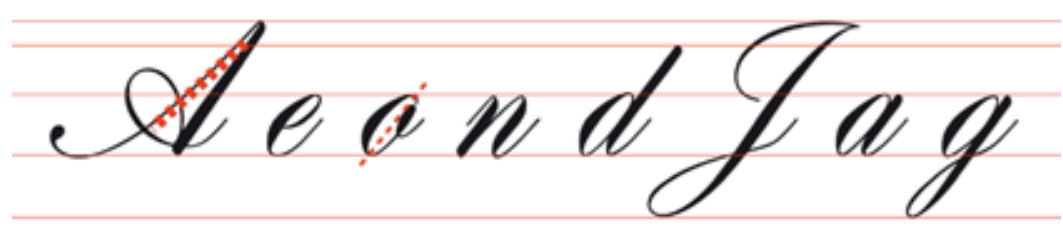

Análisis de los atributos formales de la tipografía Hogarth Scrip

Atributos formales

La tipografía Hogarth-Script es un tipo de construcción continua referenciado a la escritura con plumilla. Tiene curvas continuas de aspecto ovalado. Las astas verticales tienen 
bordes convexos y las astas transversales están curvadas y son ascendentes.

a relación entre las líneas de referencia está notablemente proporcionada, con espacios casi idénticos entre el ojo medio, los rasgos ascendentes y los descendentes. No obstante ambos trazos serán tratados de forma libre lo que supone que no estén alineados los rasgos ascendentes y descendentes curvos y los rectos como medio para potenciar los rasgos caligráficos. En el caso del tipo Hogarth la altura de las mayúsculas es sensiblemente superior a la alineación superior.

Como la mayoría de las tipografías caligráficas tiene el eje inclinado hacia la derecha y los caracteres enlazados entre sí. La modulación del trazo está fuertemente contrastada como reflejo del movimiento de la pluma. La transición en el cambio de grosor es abrupta tanto en la caja alta y la baja, con un ductus quebrado, diferente según Martín Montesinos (2008: 245) al «ductus continuo de la mayoría de las familias inglesas».

El color tipográfico resultante es relativamente oscuro debido a la escasa altura del ojo medio, lo que le confiere un aspecto denso en este espacio.

La decoración de las mayúsculas imitando el movimiento de la mano es propio de las letras caligráficas, y si bien en este caso destaca el cierre en espiral de letras como la $O$.

\subsubsection{Tipografías quebradas}

\section{LUTHERSCHE FRAKTUR (Volker Küster y Herbert Lemme)}

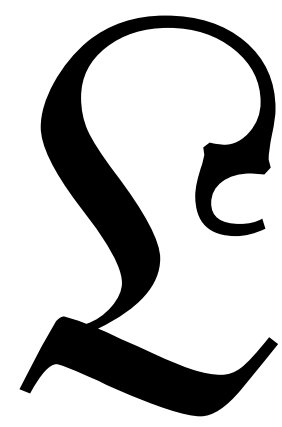

Clasificación y referentes

La tipografía Luthersche Fraktur es un tipo quebrado de la categoría de las de fractura (clase X.d) según la norma DIN 16518, denominadas góticas según la clasificación VoxATypl. La familia está constituida por un juego de caja alta, caja baja, cifras de caja alta y cifras elzevirianas con grosor regular y semigrueso.

Toma su nombre no de la reforma religiosa, sino de la fundición Lutherschen Giesserei de Frankfurt, y desde la VEB Typoart se recomienda su uso para la publicidad y las creaciones en las que se quiera resaltar las relaciones históricas.

\section{$\mathfrak{A} \mathfrak{C} \mathfrak{n} \mathfrak{d} \mathfrak{a} \mathfrak{g}$}

Atributos formales

Análisis de los atributos formales de la tipografía Luthersche Fraktur

La tipografía Luthersche Fraktur es un tipo de construcción continua referenciado a la escritura con pluma plana, con un tratamiento de las curvas híbrido entre trazos quebrados y trazos curvos. Las astas verticales tienen los bordes paralelos y mientras que unas son verticales otras se curvan notablemente. Las astas transversales son oblicuas y curvadas y se encuentran elevadas respecto de la posición media.

La anchura de los caracteres muy estrecha y esbelta en los caracteres de caja baja y algo menos estrecha en los caracteres de caja alta. La altura de la $\mathrm{x}$ es elevada con ascendentes coincidentes con la altura de las mayúsculas y de mayor tamaño que los descendentes. El ascendente de la $d$ está inclinado y curvado y no ocupa la totalidad de la altura de los ascendentes.

El contraste del trazo es muy alto con el eje constructivo inclinado y una transición entre trazos abrupta la cual se remarca con pequeños engrosamientos del trazo. Tiene un color tipográfico oscuro.

Los remates de los pies tienen forma de diamante en el comienzo del trazado, y filiformes con una marcada inclinación en los finales. Los remates de los ascendentes ascendentes tienen forma de $V$ curvada. Los remates de las letras mayúsculas son muy decorados, curvos y retorcidos.

Los caracteres capitales no se apoyan en la línea base sino que una gran parte de ellos tiene elementos decorativos situados por debajo de esta. Las cifras responden a trazado característico de las cifras romanas, sin elementos decorativos que las asocien con las tipografías góticas.

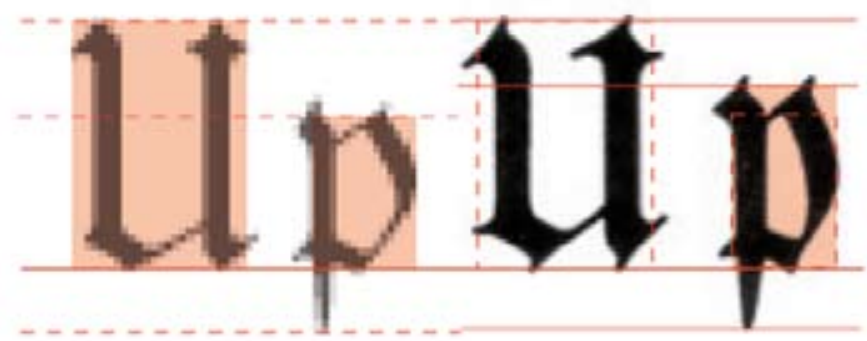

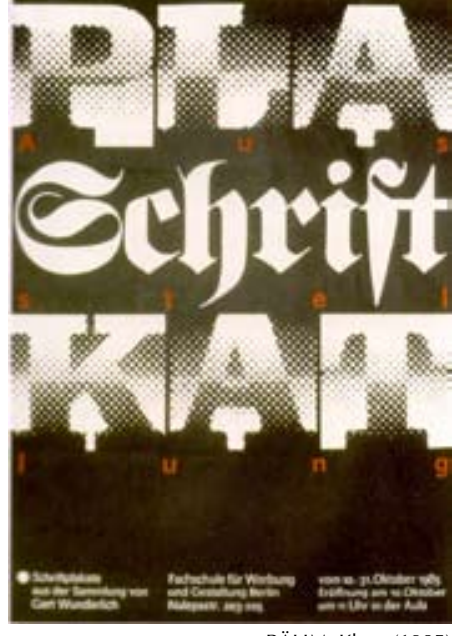

Cartel diseñado con la tipografía Luthersche Fraktur

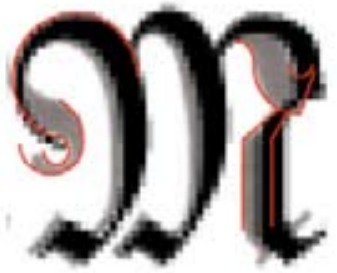

Comparativa entre la decoración de los

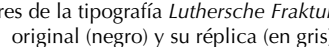


La proporción de la réplica es marcadamente más vertical en los caracteres de caja baja, rasgo que se acentúa por las curvas menos marcadas y más verticales en letras como la a o la $p$. La diferencia más evidente la encontramos en los caracteres de caja baja, que en el tipo diseñada por Typoart son mucho más ricamente decorados, con trazos que se retuercen.

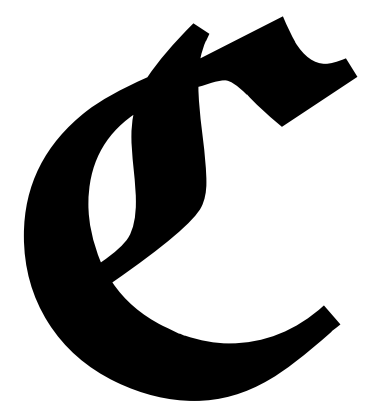

\section{CASLON-GOTISCH (Erhard Kaiser)}

Clasificación y referentes

La tipografía Caslon-Gotisch es un tipo quebrado de la categoría de las góticas (clase X.a) según la norma DIN 16518, denominadas igualemente góticas según la clasificación Vox-ATypl. La familia está constituida por un por un juego de caja alta, caja baja, cifras de caja alta y cifras elzevirianas con grosor regular.

Se realiza una réplica del tipo de William Caslon para su uso en la literatura religiosa.

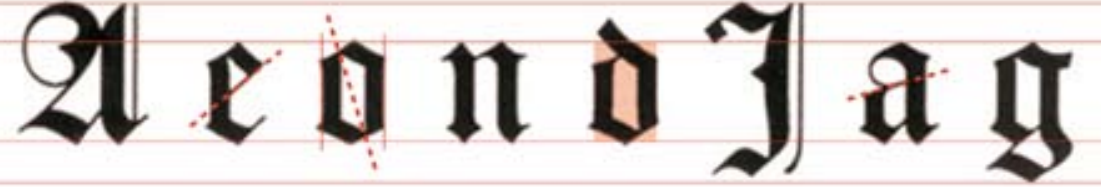

Atributos formales

La tipografía Caslon-Gotisch es un tipo de construcción continua referenciado a la escritura con pluma plana, con un tratamiento de las curvas quebrado y carente de redondeces en caja baja. Las astas verticales tienen los bordes paralelos y ligeramente curvados hacia el interior de los caracteres. Las astas transversales son oblicuas y se encuentran elevadas respecto de la posición media.

La anchura de los caracteres muy estrecha y esbelta en os caracteres de caja baja, mientras que la caja alta tiene proporción cuadrada. La altura de la $\mathrm{x}$ es elevada con ascendentes y descendentes proporcionados y coincidentes con la altura de las mayúsculas. El ascendente de la d está inclinado y no ocupa la totalidad de la altura de los ascendentes.

El contraste del trazo es muy alto con el eje constructivo inclinado y una transición entre trazos abrupta. Tiene un color tipográfico oscuro.

Los remates de los pies tienen forma de diamante, mientras que los ascendentes tienen forma de $\mathrm{V}$, así como los de los trazos ascendentes, marcadamente horizontales. El remate de la a se realiza mediante un trazo curvo cerrado, mientras que la c y la $r$ carecen de remate tiene forma de gota notablemente redondeada. Los remates de las letras mayúsculas son muy decorados y curvos.

Los caracteres capitales no se apoyan en la línea base, sino que una gran parte de ellos tiene elementos decorativos situados por debajo de esta.

Las proporciones no varían significativamente entre el original y la réplica, siendo esta última algo más ancha. Los trazos de la réplica son más curvados y decorados de lo que lo son en el original.

\section{Dop Oap}

\section{SCHWABACHER (Herbert Lemme)}

Clasificación y referentes

La tipografía Schwabacher es un tipo quebrado de la categoría de las denominadas letras Schwabacher (clase X.c) según la norma DIN 16518, denominadas góticas según la clasificación Vox-ATypl. La familia está constituida por un por un juego de caja alta, caja baja, cifras de caja alta y cifras elzevirianas con grosor regular.

Se configuró este alfabeto basándose en impresiones his tóricas de esta tipografía popular en el siglo XV y su uso se destinó fundamentalmente a la literatura popular alemana.

\section{IeOnd I a g

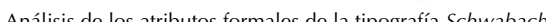

Atributos formales

La tipografía Schwabacher es un tipo de construcción continua referenciado a la escritura con pluma plana, con un tratamiento de las curvas quebrado y redondeado en elementos como al o, mientras que otras como la u permanece carente de curvas. Las astas verticales tienen los bordes 
paralelos y las astas transversales son oblicuas y se encuentran elevadas respecto de la posición media.

La anchura de los caracteres es ligeramente estrecha en los caracteres de caja baja, mientras que la caja alta tiene proporción ancha. La altura de la x es elevada con ascen-
450.JAHRESTAG oes beut/d)en 23 auternttieges

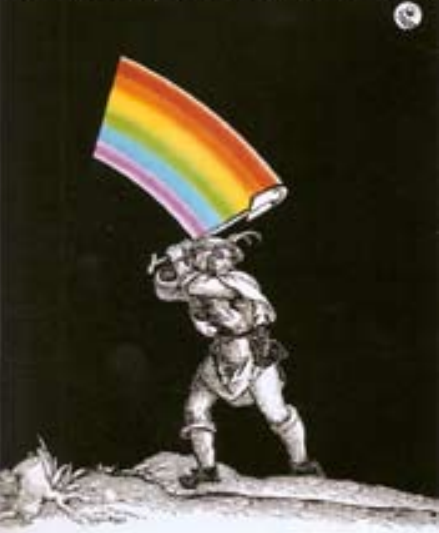

LEUCHTE, Frank (1974) Cartel diseñado con la tipogris dentes y descendentes proporcionados y coincidentes con la altura de las mayúsculas. El ascendente de la $d$ está inclinado y es ligeramente inferior a la altura de los ascendentes.

El contraste del trazo es muy alto con el eje constructivo inclinado $45^{\circ}$ y una transición entre trazos abrupta que marca, gracias a pinzamientos en el trazado de la curva, ejes perpendiculares al eje constructivo. Tiene un color tipográfico oscuro.

Los remates de los pies, más sutiles de los de la Caslon Gotisch, tienen reminiscencias de los remates en forma de diamante, pero quedan reducidos en su mayoría a un gancho en ángulo. También el remate de los ascendentes en forma de $V$ es muy sutil en este alfabeto. Los caracteres $u$, $w$ e $y$ carecen de remate en el brazo derecho, que se soluciona con una prolongación del trazo que cierra la curva. Los remates de las letras mayúsculas son muy decorados y curvos.

Los caracteres capitales no se apoyan en la línea base, sino que una gran parte de ellos tiene elementos decorativos situados por debajo de esta.

\subsubsection{Otras tipografías}

\section{KLEOPATRA (aprox. 1985, Erhard Kaiser)}

Clasificación y referentes.

La tipografía Kleopatra no pertenece de manera clara a ningún grupo de la norma DIN 16518, mientras que es considerada de fantasía según la clasificación Vox-ATypl. La familia está constituida por un por un juego de caja alta, caja baja y cifras de caja alta con un único grosor.

La tipografía gano el primer premio de tipografías distinguidas en 1985 y según Kapr y Schäfer 1989: 135) «la tipografía puede estar inspirada en la joyería y la arquitectura de la edad antigua por sus asociaciones formales con meandros en formas de laberinto» y su uso se destinó al diseño gráfico
Atributos formales

La tipografía Kleopatra es un tipo de construcción continua con curvas continuas sensiblemente redondas. Las astas verticales tienen los bordes paralelos y las astas horizontales están centradas. Los trazos retorcidos y desdobladas son el elemento característico de esta tipografía en la cual no prima la legibilidad sino su capacidad de atracción.

Estos retorcimientos se producen gracias a la existencia de un amplio ojo medio, con escasa longitud de ascendentes y descendentes y caracteres estrechos. El trazo es sensiblemente homogéneo y carece de remates. Su trazo grueso y desdoblado da lugar a un alfabeto con un color tipográfico oscuro.

El trazo doble, que en ocasiones asemeja la apariencia de una tipografía hueca y sombreada, dota a la Kleopatra de una apariencia homogénea y unitaria a todo el sistema.

\section{ZYKLOP (aprox. 1985, Fritz Kossack)}

\section{Clasificación y referentes.}

La tipografía Zyklop no pertenece de manera clara a ningún grupo de la norma DIN 16518, mientras que es considerada de fantasía según la clasificación Vox-ATypl. La familia está constituida por un por un juego de caja alta y cifras de caja alta con un único grosor.

La tipografía gano el tercer premio de tipografía ornamental en 1985 y según Kapr y Schäfer 1989: 136) «sus redondeadas y fluidas formas recuerdan a los elementos del Jugendstil». Su uso de destinó al diseño.

\section{Atributos formales}

La tipografía Zyklop es un tipo de construcción continua con curvas continuas y redondeadas adaptadas a formas rectangulares. Las astas verticales tienen los bordes paralelos y las astas horizontales están centradas. La ausencia de caja baja hace que las únicas líneas de referencia sean la línea base y la alineación superior. Bajo la línea base únicamente sobresale la cola larga de la $Q$. Los caracteres son estrechos.

El trazo es contrastado, pero este se realiza de forma atípica, ya que afecta únicamente a los perfiles superiores de los caracteres, siendo todo el resto del trazado homogéneo. Es en este engrosamiento superior donde encontramos su semejanza con la decoración del jugendstil. 
El tipo Zyklop carece de remates en la mayor parte de sus elementos, no obstante permanecen los remates superiores de los mismos para acentuar el engrosamiento característico del alfabeto. Así la letra $X$ tendrá remates en los extremos superiores del mismo y carece de ellos en los inferiores.

La geometría de los caracteres, fuera del engrosamiento superior es la propia de la letra de palo seco, únicamente se distingue la $A$, cuyo trazado es más similar a la letra gótica que a la tipografía sin remates.

\section{QUADRO (Erhard Kaiser)}

Clasificación y referentes.

La tipografía Quadro no pertenece de manera clara a ningún grupo de la norma DIN 16518, mientras que es considerada de fantasía según la clasificación Vox-ATypl. La familia está constituida por un por un juego de caja alta y cifras de caja alta con un único grosor.

Se trata de una tipografía pensada para la publicidad por su capacidad para llamar la atención.

Atributos formales

La tipografía Quadro es un tipo de construcción continua, con curvas continuas y geométricas. El trazo rectilíneo de la fuente se compone de una serie de trazos homogéneos y paralelos entre sí que componen conjuntamente cada una de las astas, bucles y perfiles

Los caracteres se ajustan completamente a un módulo cuadrado situado siempre por encima de la línea base. Son caracteres compactos y sin contrapunzón en los cuales son los espacios entre las líneas que componen los trazos los que dan la información necesaria para el reconocimiento de las diferentes letras, las cuales se simplifican al máximo eliminando cualquier detalle innecesario para su identificación.

\section{BIGA (1985, Fritz Richter)}

Clasificación y referentes.

La tipografía Biga no pertenece de manera clara a ningún grupo de la norma DIN 16518, mientras que es considerada de fantasía según la clasificación Vox-ATypl. La familia está constituida por un por un juego de caja alta y cifras de caja alta con un único grosor.

El alfabeto gano el segundo premio de tipografía ornamental en 1985. Kapr y Schäfer 1989: 138) destacan de la misma que «dependiendo de la luz tiene mayor efecto espacial o aparece más plana». Su uso se destinó a la publicidad con buena legibilidad y a las líneas de texto decoradas.

Atributos formales

La tipografía Biga es un tipo de construcción continua, con curvas continuas y geométricas. Tiene la apariencia de una tipografía sombreada doblemente en la cual se elimina e trazado principal, quedando definida por su sombra.

La geometría básica de este trazado insinuado es similar a la tipografía Maxima, aunque su geometricidad es más evidente en la Biga, en la cual los tipos están ajustados al módulo cuadrado y permanecen íntegramente sobre la línea base.

El sombreado doble, le da una apariencia de elementos en 3 dimensiones compuestos por dos perfiles separados entre sí, y confiere a la Biga de una apariencia homogénea en la cual prima su capacidad atractiva, sin por ello renunciar a la legibilidad.

Una vez descrito el diseño tipográfico, como parte fundamental y tal y como hemos dicho, sometida a unos condicionantes propios en la estructura económica de la RDA pasaremos a realizar un análisis estadístico de los carteles, dentro de los cuales analizaremos igualmente la presencia de las tipografías aquí descritas. 
6. Diseño de la investigación

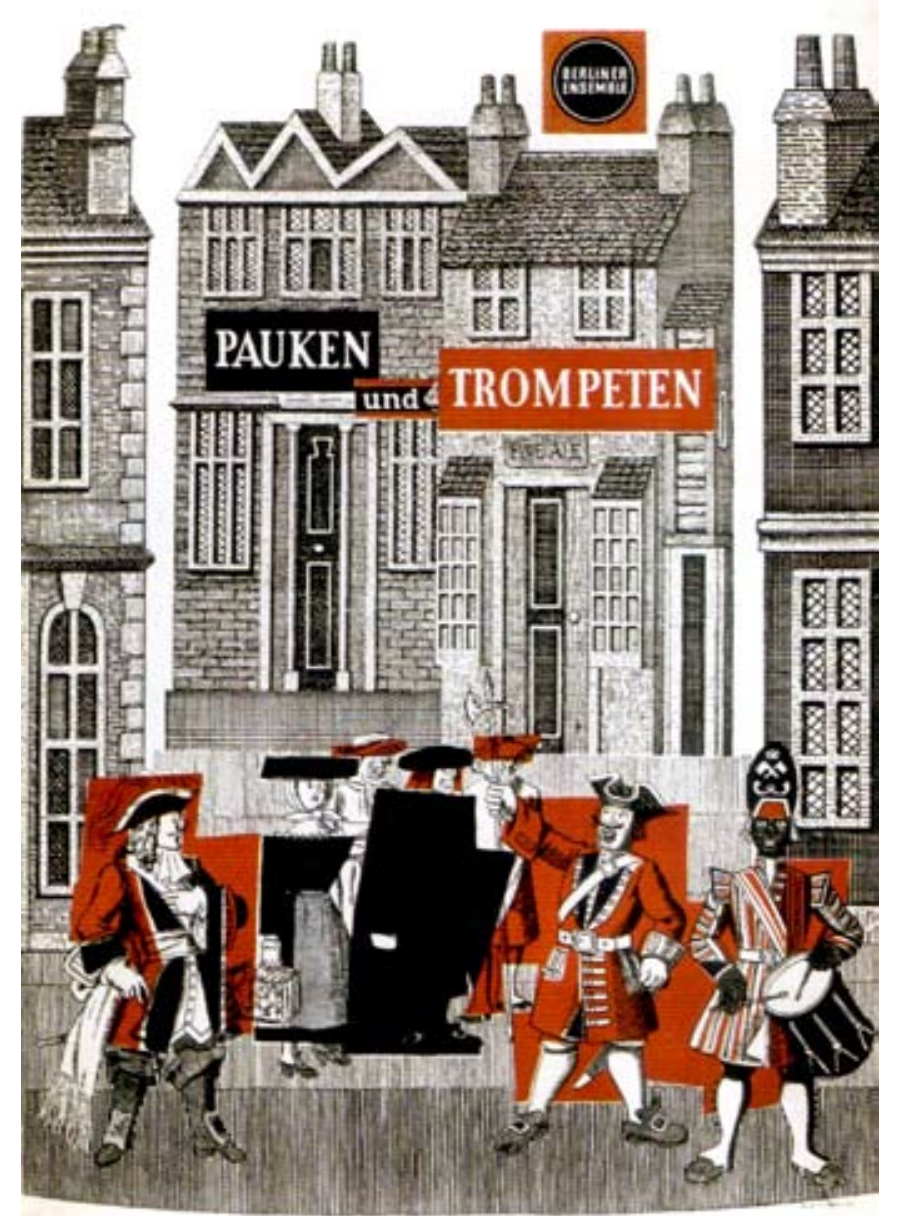




\subsection{ESTRUCTURA DE ANÁLISIS}

La presente investigación se basa en el estudio estadístico de los elementos que componen el diseño gráfico de un determinado periodo para determinar su evolución. Es por tanto prioritaria la elaboración de una tabla de análisis y recogida de datos completa, sistemática y estructurada que nos permita relacionar los valores entre sí.

Como hemos visto en el primer capítulo en el que establecíamos el marco teórico y estado de la cuestión, el lenguaje visual carece de unas leyes obvias e indiscutibles, sino que hay tantas estructuras de análisis como teóricos se han centrado en el tema.

Consideramos la adecuación de realizar un modelo propio como base para nuestra investigación, con parámetros adecuados al tema de la misma y que nos permita diseña una estrategia para recabar todos los datos necesarios. Para garantizar la objetividad del análisis es necesario que se trate de un modelo con una estructura clara cuyos valores asignables a cada variable sean fijos y su significado quede previamente establecido

La estructura básica propuesta es la siguiente:
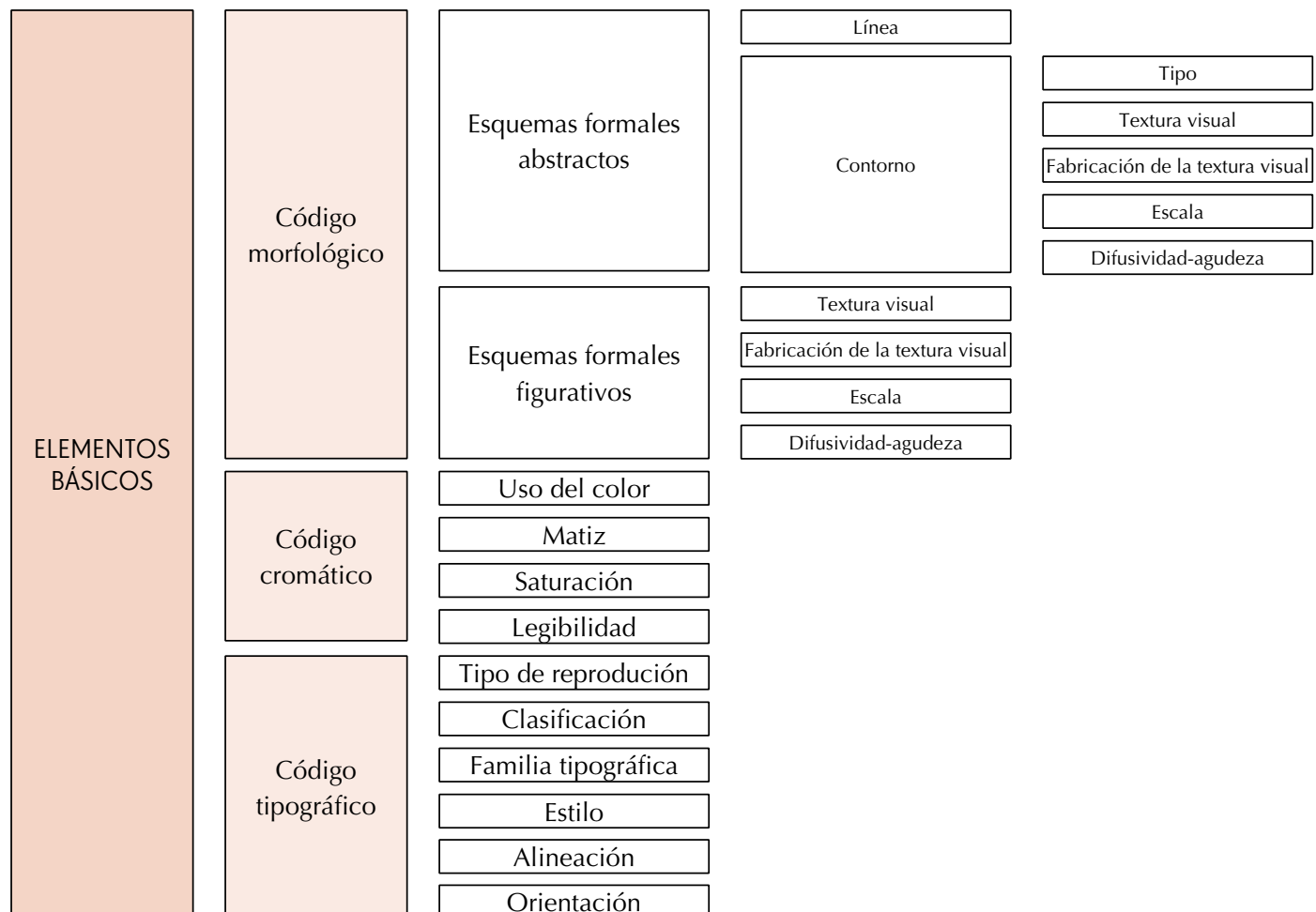

Difusividad-agudeza 


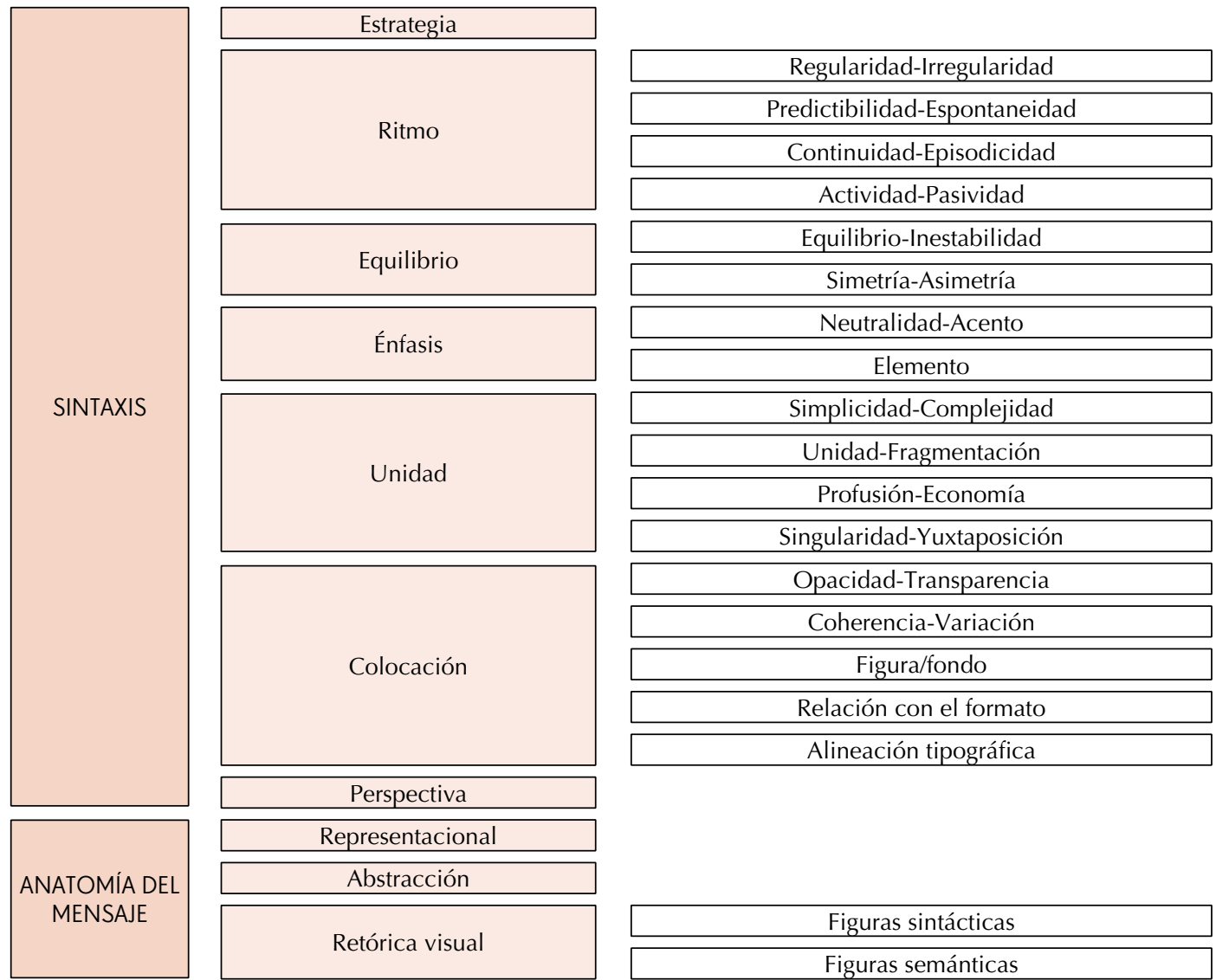

Gráfico 6.1

Todos los parámetros deben de tener un valor asociado para evitar lecturas erróneas de los datos, de tal modo que se asignará el valor 0 a aquellos elementos que no estén presentes en el diseño.

A continuación describiremos uno a uno los parámetros de análisis definiendo claramente los valores que les pueden ser asociados a cada uno de ellos. Un amplio número de parámetros se establece según una dicotomía entre dos valores, uno de los cuales supone armonía compositiva frente a otro que implica contraste. Los valores posibles para estos parámetros serán 1, 2, 3 según si están más cercanos al primer concepto (1), a igual distancia (2) o al segundo concepto (3), es decir, más cercanos a la armonía (1) o al contraste (3)
Resulta fundamental, no solo para realizar un correcto análisis, sino también para comprobar la correcta elección de la muestra, la redacción de una «ficha técnica» de cada uno de los elementos que componen la investigación.

A cada uno de estos elementos se le asociará un código, compuesto por el año, la inicial de apellido y el nombre del autor (indicándose con la letra $\mathrm{A}$ en caso de que se trate de un autor anónimo) y dos cifras correlativas con la siguiente estructura: AAAA_AN_00, de tal modo que exista una relación biunívoca entre código y elemento.

Los datos técnicos que se recogerán de cada elemento son los siguientes:

- Año de realización.

- Autor: con el formato APELLIDO, Nombre.

- Título.

- Tipo de impresión.

- Fuente: en aquellos casos en los que un elemento forme parte de varias selecciones se mostrará aquella en la que se presente con calidad.

- Género: simplificado en cultural (comunicación cultural y científica), político (propaganda política y social, así como elementos comunicadores del estado o de homenaje) y económico (publicidad para la industria y el comercio).

\subsubsection{Elementos básicos}

Los elementos básicos de un sistema son aquellas unidades gráficas mínimas que lo componen. En el diseño gráfico estas unidades mínimas; punto, línea, plano, color..., se combinan para dar lugar a la tipografía y las imágenes. Analizaremos los elementos básicos clasificándolos previamente según tres códigos de elementos; código morfológico, código cromático y código tipográfico, entendiendo como código un sistema de signos dentro de un mensaje. Cada uno de estos códigos puede presentarse repetidamente en un mismo diseño, por lo que se analizarán separadamente el elemento principal y el secundario.

\subsubsection{Código morfológico}

\section{Esquemas formales abstractos:}

Aquellos elementos formales no representativos, diferenciándolos en líneas (que abarca el punto) y contornos. 
el total del abanico cromático, independientemente de su correspondencia con la realidad, o de tintas planas, cuando se haga uso de varios matices cromáticos, pero sin gradación de valor ni de saturación. Cuando sobre un fondo plano nos encontramos con un número limitado de colores entre los cuales no se producen combinaciones nos encontramos en casos de 3 colores, dicromía o monocromía, dependiendo de si se utilizan 3, 2 o 1 color.

Nos referimos al código cromático predominante de diseño, más allá del código de cada uno de sus elementos.

- Matiz: el nombre del color que consideraremos como colores substractivos primarios y secundarios (azul, amarillo, rojo, naranja, verde y violeta, junto con el blanco y negro).

- Valor: hace referencia al nivel de luminosidad (claro, medio, oscuro).

- Saturación: brillo u opacidad de un color (mate, medio, brillante).

- Legibilidad por contraste: alta, media, baja. Estos valores responderán a los criterios establecidos en la tabla de Karl Borggrafe sobre la legibilidad de los colores (Favre y November, 1979: 50).

- Tipo de reproducción: si se trata de rotulación manual o de impresión mecánica, entendiendo como tal no solo los tipos de plomo, sino también los tipos de fotocomposición.

- Clasificación: según las normas establecidas en la norma DIN 16528 por ser esta la norma de referencia alemana. Las características básicas de esta norma han sido definidas en el «Capítulo 5. Diseño tipográfico», por lo que no consideramos necesario reproducirlas aquí.

- Familia tipográfica: Nombre de la familia tipográfica diseñada por la VEB Typoart. Aquellas familias de diferente procedencia se representarán con el valor 0 independientemente de la familia a la que pertenezcan.

- Estilo: cada variante de una misma familia de tipos (fina, regular, seminegra, negra, extragruesa, cursiva, redonda, condensada, extendida).

- Alineación: dentro del propio bloque de texto (justificada, izquierda, derecha, centrada, asimétrica o arracada). Las alineaciones tipográficas globales se analizarán como parte de la composición.

\subsubsection{Código tipográfico}

\begin{tabular}{|c|c|}
\hline \multicolumn{2}{|c|}{$\begin{array}{c}\text { LEGIBILIDAD DE LOS COLORES } \\
\text { POR CONTRASTE FIGURA } \\
\text { FONDO }\end{array}$} \\
\hline Orden & Colores \\
\hline 1 & Negro-amarillo \\
\hline 2 & Amarillo-negro \\
\hline 3 & Verde-blanco \\
\hline 4 & Rojo-blanco \\
\hline 5 & Negro-blanco \\
\hline 6 & Blanco-azul \\
\hline 7 & Azul-amarillo \\
\hline 8 & Azul-blanco \\
\hline 9 & Blanco-negro \\
\hline 10 & Verde-amarillo \\
\hline 11 & Negro-naranja \\
\hline 12 & Rojo-naranja \\
\hline 13 & Naranja-negro \\
\hline 14 & Amarillo-azul \\
\hline 15 & Blanco-verde \\
\hline 16 & Negro-rojo \\
\hline 17 & Azul-naranja \\
\hline 18 & Amarillo-verde \\
\hline 19 & Azul-rojo \\
\hline 20 & Amarillo-rojo \\
\hline 21 & Blanco-rojo \\
\hline 22 & Rojo-negro \\
\hline 23 & Blanco-naranja \\
\hline 24 & Negr-verde \\
\hline 25 & Naranja-blanco \\
\hline 26 & Naranja-azul \\
\hline 27 & Amarillo-naranja \\
\hline 28 & Rojo-naranja \\
\hline 29 & Rojo-verde \\
\hline 30 & Verde-naranja \\
\hline & \\
\hline
\end{tabular}

Tabla 6.1

nos netos (agudeza) o sin una clara definición de borde (difusividad)

\subsubsection{Código cromático}

Definimos en primer lugar el uso del color característico de la composición. En los niveles más altos de representación cromática se encuentran el uso realista, cuando abarque 
- Orientación: vertical, horizontal, oblicua o adaptada, cuando responda a orientaciones propias.

6.1.3 Sintaxis

Abarca las estrategias estructurales y compositivas del diseño.

\subsubsection{Estrategia}

Nos referimos con esto a las directrices creativas con la que se plantea la comunicación visual y en la que estará basada la composición. Esta puede ser conducida formalmente, lo que supone el uso de contrastes, ilusiones ópticas, retórica..., conducida por el medio, es decir, mediante el uso y tratamiento de la imagen fundamentalmente, o conducida por el estilo, tanto pictórico como de referencias históricas.

\subsubsection{Ritmo}

El patrón con el que se estructuran los elementos de la composición:

\section{Regularidad-irregularidad:}

Para que se presente un patrón de regularidad es necesario que se reproduzca una repetición de elementos, por lo que no es un parámetro válido para todas las unidades. Hablaremos de regularidad en el diseño cuando se produzca una uniformidad de elementos según un orden rítmico. Cuando se produzcan desviaciones respecto de este orden estaremos hablando de irregularidad.

\section{Predictibilidad-espontaneidad:}

Depende, al igual que la regularidad, de la repetición de elementos. Se refiere con ello a la adecuación de los elementos a un plan establecido, más allá de si este responde a un patrón homogéneo o no. Cuando estos se relacionen según este plan estaremos hablando de predictibilidad, en oposición a la espontaneidad, cuando no respondan a ninguna regla aparente.

\section{Continuidad-episodicidad:}

Todos los elementos que conforman una composición se encuentran relacionados unos con otros. Según el nivel de conexión que se establezca entre un paso y otro de la comunicación estaremos hablando de una composición continua, cuando la relación entre ellos sea evidente, o episódica, cuando no lo sea.

\section{Pasividad-actividad:}

La actividad implica una composición en la cual se represente el movimiento, en contraposición de la pasividad cuando este no aparezca. En aquellos casos en los que se represente la realización de una actividad que implique movimiento, pero este no se represente explícitamente, estaremos hablando de niveles medios de actividad.

\subsubsection{Equilibrio}

Atañe a la relación de los elementos dentro de la composición y con los límites de la misma.

\section{Equilibrio-inestabilidad:}

Hablamos de equilibrio visual cuando el peso de los elementos se distribuye de manera uniforme o proporcional en el espacio. En caso contrario estaremos ante una composición inestable.

\section{Simetría-asimetría:}

La distribución proporcionada de los elementos puede estar sujeta a un eje de simetría o no, lo que supone relaciones simétricas o asimétricas.

\subsubsection{4 Énfasis}

Un dato importante a la hora de analizar el lenguaje visual es determinar cual es el elemento principal en el que recáe la comunicación y con qué nivel de énfasis se destaca este elemento respecto del resto.

\section{Neutralidad-acento:}

Nos referimos con esto al nivel de intensidad con el que se enfatiza un elemento clave en el diseño. En aquellos casos en los que la comunicación se encuentre en clara gradación respecto del resto de la composición estaremos hablando de acento, frente a neutralidad en aquellos casos en los que no se destaque ningún elemento respecto del resto.

\section{Elemento:}

Se define aquí cómo se conduce la información: mediante el texto, mediante la imagen o sinergia entre ambas. 


\section{Relación con el formato:}

\section{Simplicidad-complejidad:}

Analiza la complejidad visual de la composición, entre una técnica visual directa en la que prima la simplicidad, a una gran profusión de elementos que nos indica complejidad.

\section{Unidad-fragmentación}

Más allá de la imagen global del diseño sus elementos se pueden observar en su completitud, lo que indica unidad, o fragmentadas y descompuestas.

\section{Profusión-economía:}

La economía supone un orden visual sintético, directo y frugal, en contraposición a un estilo recargado y ornamentado con gran profusión de detalles.

\section{Singularidad-yuxtaposición:}

Entenderemos que en una composición prima la singularidad cuando sea un único elemento aquel en el que recaiga la comunicación visual. Si la estrategia del mensaje exige que varias unidades independientes sean portadoras de información estaremos hablando de yuxtaposición.

\subsubsection{Colocación}

\section{Opacidad-transparencia:}

Con ello analizamos el modo de yuxtaposición de los elementos, entre aquellos que permiten un detalle visual a través del cual es posible ver -transparencia- y aquellos que no -opacidad-.

\section{Coherencia-variación:}

Se establecen relaciones de coherencia cuando se desarrolla una composición dominada por una aproximación visual y temática uniforme y consonante. Cuando se producen aproximaciones no temáticas, o las unidades temáticas no se agrupan conjuntamente, estaremos hablando de variación.

\section{Figura/fondo:}

En la relación que se establece entre las figuras y el fondo se pueden dar varias situaciones: que sea una relación estable con una clara diferenciación entre ambas o ambigua en la cual no se define claramente que corresponde a figura y que al fondo, sino que dependiendo de la situación esta correspondencia pueda ser reversible.
Establecemos aquí como se comportan los elementos en relación con los bordes del formato: superación, cuando nos encontremos ante estructuras independientes de los límites del marco, ajuste, cuando la composición esté contenida completamente dentro del marco o remarcación, cuando la estrategia se base en enfatizar los límites del mismo.

\section{Alineación tipográfica:}

Hemos visto la alineación tipográfica dentro del código tipográfico. Aquí nos referiremos a la alineación tipográfica como elemento de la composición, pudiendo ser: de contorno, cuando sigue el contorno de una imagen, ejes, cuando se encuentre alineada respecto de una línea, tanto central como cualquier otra línea compositiva, alineaciones internas de imagen y texto, en las cuales le entremezcla el texto con la imagen, receptivas, siguiendo direcciones marcadas por otros elementos de la composición, o intuitivas, cuando responda a estrategias espontaneas.

\subsubsection{Perspectiva}

Con ello nos referimos al uso de la composición y la imagen para crear una perspectiva profunda, o la ausencia de elementos o estructuras que aporten profundidad, en cuyo caso nos encontramos ante perspectiva plana.

\subsubsection{Anatomía del mensaje}

Analizamos aquí los recursos que utiliza el diseño para transmitir el mensaje.

6.1.4.1 Representación

Con ello nos referimos al grado de figuratividad con el que se representa la imagen. Desde el grado más alto valor de verosimilitud, a la condición no figurativa, establecemos los siguientes niveles: hiperrealismo, realismo, mesorrealismo, surrealismo, abstraccionismo.

\subsubsection{Abstracción}

O grado de iconicidad, según la relación entre la representación y la imagen que representa. Cuando se produzcan relaciones directas estaremos hablando de isomorfismo frente al amorfismo en el cual no se produzca identifica- 
ción formal entre representación y realidad. En un punto intermedio se encuentra el mesomorfismo.

6.1.4.3 Retórica Visual

Debido a la gran cantidad de figuras retóricas existentes y a la sutileza en las diferencias entre varias de ellas, consideraremos únicamente la presencia de figuras retóricas según las siguientes clases generales:

\section{Figuras semánticas:}

Aquellas que atañen al significado de los elementos del diseño gráfico, es decir, que exista una determinada relación entre el elemento representado y su significado en el mensaje. Esta relación puede ser:

- De sustitución; cuando el elemento que se pretende significar sea sustituido por otro. Pertenecen a esta categoría la metáfora, alegoría, metonimia, sinécdoque y prosopopeya.

- De comparación; cuando se presenten figuras con significados relativos entre ellas que pueden ser contrarios o de gradación de significados contrarios.

\section{Figuras sintácticas:}

Aquellas que tienen lugar en el modo en el cual se representa el signo, y pueden ser:

- De supresión; cuando se elimina conscientemente parte de la información, como es el caso de la elipsis.

- Repetitivas: tanto de los elementos formales como tipográficos o compositivos. Abarca la aliteración, isofonía, paralelismo y repetición.

- De adjunción: aquellas en las cuales la forma del signo añade significado sobre el propio signo, pueden ser epanadiplosis, hipérbole o prestamo.

- De transposición: aquellas en las cuales se altera el orden lógico de la narración, como son la aposición, atomización, paréntesis, inversión o anástrofe. 


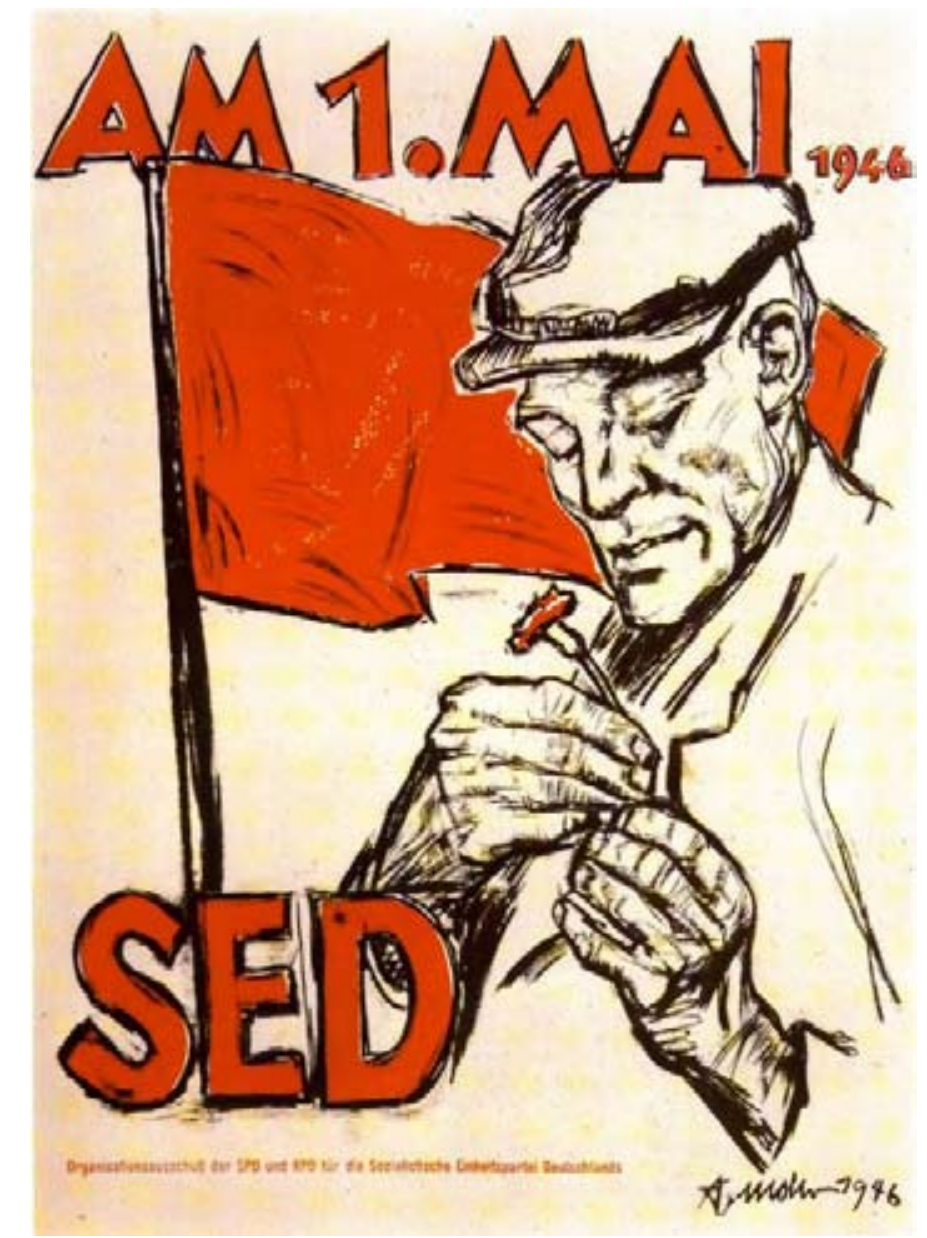

MOHR, Arno (1946)

Esquema figurativo principal Esquema figurativo secundario

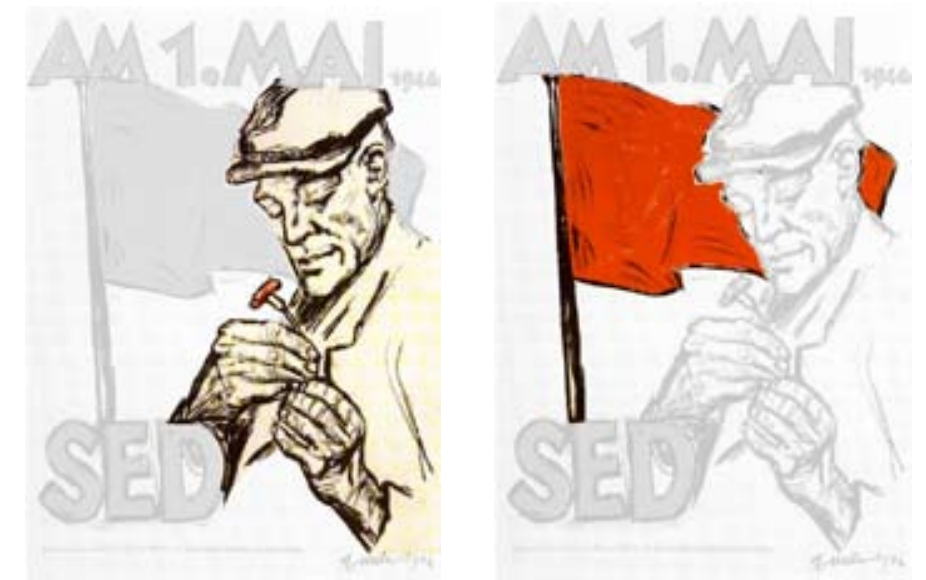

\subsection{ANALISIS DE EJEMPLOS DE LA MUESTRA}

Después de haber establecido un sistema propio con el que analizamos los 525 carteles de la muestra, procederemos al análisis de 5 elementos de la misma - uno de cada décadaa modo de ejemplo y como ilustración del sistema.

6.2.1 Muestra 1

\subsubsection{Datos técnicos}

Código: 1946_MA_00

Año: 1946

Autor: Arno Mohr

Título: 1. Mai 1946

Tipo de impresión: Litografía

Fuente: Überklebt- Plakate aus der DDR

Género: Político

\begin{tabular}{|c|c|c|c|c|c|c|}
\hline \multicolumn{7}{|c|}{ FICHA TÉCNICA } \\
\hline CÓDIGO & AÑO & AUTOR & TÍTULO & TIPO DE IMPRESIÓN & FUENTE & GÉNERO \\
\hline 1946_MA_00 & 1946 & MOHR, Arno & 1. Mai 1946 & Litografía & Überklebt-Plakate aus der DDR & Político \\
\hline
\end{tabular}

6.2.1.2 Elementos básicos

CÓDIGO MORFOLÓGICO

\section{Esquemas formales abstractos:}

El cartel analizado carece de elementos formales abstractos, tanto de líneas como de contornos, por lo que todos los valores referidos a estos parámetros tendrán valor 0 .

\begin{tabular}{|c|c|c|c|c|c|c|c|c|c|c|c|}
\hline \multicolumn{12}{|c|}{ ESQUEMAS FORMALES ABSTRACTOS } \\
\hline \multirow{2}{*}{$\begin{array}{l}\text { LÍNEA } \\
\text { PPAL }\end{array}$} & \multirow{2}{*}{$\begin{array}{l}\text { LÍNEA } \\
\text { SEC }\end{array}$} & \multicolumn{5}{|c|}{ CONTORNO PPAL } & \multicolumn{5}{|c|}{ CONTORNO SEC } \\
\hline & & TIPO & $\begin{array}{l}\text { DIFUSIVIDAD } \\
\text { AGUDEZA }\end{array}$ & $\begin{array}{l}\text { TEXTURA } \\
\text { VISUAL }\end{array}$ & $\begin{array}{l}\text { FABRI- } \\
\text { CACIÓN }\end{array}$ & ESCALA & TIPO & $\begin{array}{l}\text { DIFUSIVIDAD } \\
\text { AGUDEZA }\end{array}$ & $\begin{array}{l}\text { TEXTURA } \\
\text { VISUAL }\end{array}$ & $\begin{array}{l}\text { FABRICA- } \\
\text { CIÓN }\end{array}$ & ESCALA \\
\hline 0 & 0 & 0 & 0 & 0 & 0 & 0 & 0 & 0 & 0 & 0 & 0 \\
\hline
\end{tabular}

Esquemas formales figurativos:

La figura principal -un hombre que se coloca un clavel en el ojal- se trata de una imagen con contornos netos, es decir, aguda y con una textura visual espontanea, ya que es parte básica de la información, si la eliminásemos se perdería parte de ella. El medio de fabricación es mediante dibujo y tiene una escala relativa mayor que la figura secundaria.

La figura secundaria la constituye la imagen de una bandera roja ondeando cuyos bordes también son agudos. En este caso la textura visual es decorativa, ya que si bien el color rojo nos aporta mucha información, esta se encuen- 
tra en el plano de la retórica, no morfológico. Su modo de fabricación igualmente es el dibujo y su escala relativa respecto de la figura principal es menor.

\begin{tabular}{|c|c|c|c|c|c|c|c|}
\hline \multicolumn{7}{|c|}{ ESQUEMAS FORMALES FIGURATIVOS } \\
\hline $\begin{array}{c}\text { DIFUSIVIDAD } \\
\text { AGUDEZA }\end{array}$ & $\begin{array}{c}\text { TEXTURA } \\
\text { VISUAL }\end{array}$ & FABRICACIÓN & ESCALA & $\begin{array}{c}\text { DIFUSIVIDAD } \\
\text { AGUDEZA }\end{array}$ & $\begin{array}{c}\text { TEXTURA } \\
\text { VISUAL }\end{array}$ & FABRICACIÓN & ESCALA \\
\hline 3 & Espontanea & Dibujo & Mayor & 3 & Decorativa & Dibujo & Menor \\
\hline
\end{tabular}

CÓDIGO CROMÁTICO

Consideramos que el uso del color es de dicromía, ya que sobre un fondo de un color plano se utilizan dos tintas que no se combinan entre sí.

\section{Color principal}

El color principal de la imagen es el rojo, con un valor medio en cuanto a su luminosidad y saturación media. Su legibilidad por contraste, en este caso el fondo, de color beige, es alta.

\section{Color secundario}

El negro es el segundo color presente en la muestra, con una luminosidad oscura y un nivel de saturación medio. Su nivel de legibilidad por contraste, igualmente con el fondo de color beige, es alta.

\begin{tabular}{|c|c|c|c|c|c|c|c|c|}
\hline \multicolumn{10}{|c|}{ CÓDIGO CROMÁTICO } \\
\hline \multicolumn{1}{|c|}{ COLOR PRINCIPAL } & \multicolumn{5}{c|}{ COLOR SECUNDARIO } \\
\hline USO DEL COLOR & MATIZ & VALOR & SATURACIÓN & LEGIBLIDAD & MATIZ & VALOR & SATURACIÓN & LEGIBILIDAD \\
\hline Dicromía & Rojo & Medio & Medio & Alta & Negro & Oscuro & Medio & Alta \\
\hline
\end{tabular}

Tabla 6.5

\section{CÓDIGO TIPOGRÁFICO}

\section{Tipografía principal}

Se trata de una tipografía reproducida manualmente con las características formales de la tipografía de clase VI o tipografía de palo seco. Al tratarse de una tipografía manual no corresponde a ninguna familia en particular. Las letras están dibujadas con contorno negro y relleno en color rojo, por lo que consideramos que se trata de una tipografía decorada. En cuanto a su disposición, se encuentra alineada a la izquierda y su orientación es horizontal.

\section{Tipografía secundaria}

Pese a su pequeño tamaño podemos deducir que nos encontramos ante una tipografía de reproducción mecánica de clase VI. Podemos afirmar, con un cierto nivel de seguridad,

que se trata de la tipografía Norma Steinschrift en su versión
A eond Jag

ipográfica entre la muestra y la
tipografía Norma Steinschrift regular. Su orientación es horizontal, pero al componerse en una sola línea carece de alineación interna.

\begin{tabular}{|c|c|c|c|c|c|}
\hline \multicolumn{6}{|c|}{ CÓDIGO TIPOGRÁFICO } \\
\hline \multicolumn{6}{|c|}{ TIPOGRAFíA PRINCIPAL } \\
\hline REPRODUCCIÓN & CLASIFICACIÓN & FAMILIA & ESTILO & ALINEACIÓN & ORIENTACIÓN \\
\hline Manual & $\mathrm{VI}$ & 0 & Decorada & Izquierda & Horizontal \\
\hline \multicolumn{6}{|c|}{ TIPOGRAFÍA SECUNDARIA } \\
\hline REPRODUCCIÓN & CLASIFICACIÓN & FAMILIA & ESTILO & ALINEACIÓN & ORIENTACIÓN \\
\hline Mecánica & $\mathrm{VI}$ & Norma Steinschrift & Regular & 0 & Horizontal \\
\hline
\end{tabular}

\subsubsection{Sintaxis}

\section{ESTRATEGIA}

La estrategia básica de la comunicación es la retórica, apoyada por el contraste visual que se establece entre la figura del hombre y la bandera, por lo que podemos concluir que se trata un diseño conducido formalmente.

\section{RITMO}

No se presentan en la composición elementos que permitan establecer un ritmo, por lo que los valores referentes a regularidad y predictibilidad no tienen cabida en este análisis y por tanto serán igual a 0 .

El nivel de conexión establecido entre los diferentes pasos de la comunicación es alto, por lo que podemos afirmar que se trata de una composición continua. La imagen muestra la realización de actividad, tanto el hombre que se coloca una flor como la bandera que ondea, sin embargo no se refleja el movimiento de forma explícita, por lo que el nivel de actividad de la imagen es medio (2).

\begin{tabular}{|c|c|c|c|}
\hline \multicolumn{4}{|c|}{ RITMO } \\
\hline $\begin{array}{c}\text { REGULARIDAD } \\
\text { IRREGULARIDAD }\end{array}$ & $\begin{array}{l}\text { PREDICTIBILIDAD } \\
\text { ESPONTANEIDAD }\end{array}$ & $\begin{array}{c}\text { CONTINUIDAD } \\
\text { EPISODIIIDAD }\end{array}$ & $\begin{array}{c}\text { PASIVIDAD } \\
\text { ACTIVIDAD }\end{array}$ \\
\hline 0 & 0 & 1 & 2 \\
\hline
\end{tabular}

\section{EQUILIBRIO}

Los elementos de la composición se encuentran distribuidos de tal modo que la escala mayor y con mayor profusión de detalles de la figura humana se compensa con el peso cromático de la bandera y de la tipografía roja para configurar una composición relativamente equilibrada pese a tratarse de un sistema marcadamente asimétrico.

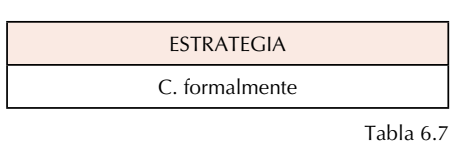

Tabla 6.7

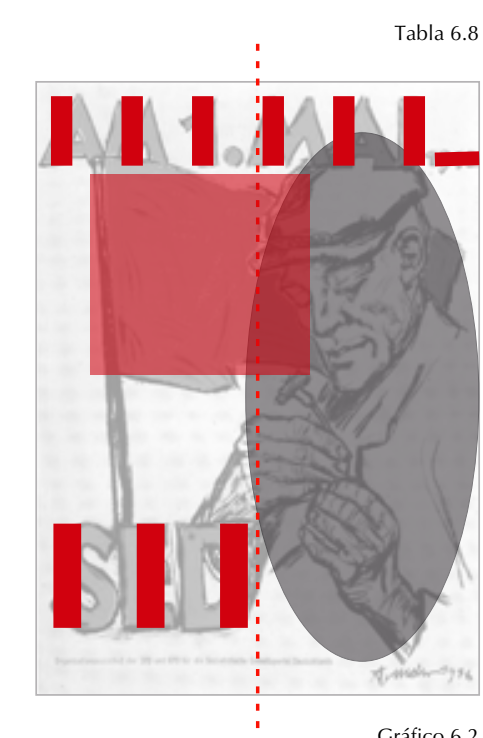

Gráfico 6.2 
Tabla 6.9

\begin{tabular}{|c|c|}
\hline \multicolumn{2}{|c|}{ EQUILIBRIO } \\
\hline EQUILIBRIO-INESTABILIDAD & SIMETRÍA-ASIMETRÍA \\
\hline 2 & 3 \\
\hline
\end{tabular}

\section{ÉNFASIS}

\begin{tabular}{|c|c|}
\hline \multicolumn{2}{|c|}{ ÉNFASIS } \\
\hline $\begin{array}{c}\text { NEUTRALIDAD } \\
\text { ACENTO }\end{array}$ & ELEMENTO \\
\hline 2 & Imagen \\
\hline
\end{tabular}

Podemos afirmar que el énfasis de la comunicación recae en la imagen, sin embargo la gradación con la que este se produce no es muy marcada, ya que la tipografía de gran tamaño y fuerte contraste entra en competencia con esta, por lo que podemos hablar de un nivel de énfasis medio.

\section{UNIDAD}

La comunicación se produce en el cartel de Arno Mohr mediante la combinación de una tipografía potente con dos imágenes, una potente cromáticamente y la otra rica en detalle, por lo que hemos de hablar de un nivel de complejidad medio, al igual que el nivel de singularidad de la composición. Esta combinación entre elementos detallados y elementos simplificados nos hacen hablar de un nivel de economía en la comunicación medio.

Por su parte estos elementos están mostrados sin fragmentar, sino que aparece todo el contenido posible dentro de los límites de la imagen, por lo que se trata de una composición unitaria.

Tabla 6.11

\begin{tabular}{|c|c|c|c|}
\hline \multicolumn{4}{|c|}{ UNIDAD } \\
\hline $\begin{array}{c}\text { SIMPLICIDAD } \\
\text { COMPLEIDAD }\end{array}$ & $\begin{array}{c}\text { UNIDAD } \\
\text { FRAGMENTACIÓN }\end{array}$ & $\begin{array}{c}\text { PROFUSIÓN } \\
\text { ECONOMÍA }\end{array}$ & $\begin{array}{c}\text { SINGULARIDAD } \\
\text { YUXTAPOSICIÓN }\end{array}$ \\
\hline 2 & 1 & 2 & 2 \\
\hline
\end{tabular}

\section{COLOCACIÓN}

Tanto las figuras formales como la tipografía son elementos cuya yuxtaposición se produce mediante opacidad y si bien las imágenes están agrupadas conjuntamente en el centro de la composición, el texto se encuentra dividido por la imagen, por lo que debemos hablar de un nivel de coherencia medio.

La relación entre la figura y el fondo es estable, sin dar lugar a juegos de lectura entre ambas. La alineación tipográfica es sensiblemente a eje, siendo el eje el margen izquierdo del cartel.

Todos los elementos se ajustan a los límites marcados por los bordes, dejando un pequeño margen entre el final de la imagen y el del contorno.

\begin{tabular}{|c|c|c|c|c|}
\hline \multicolumn{5}{|c|}{ COLOCACIÓN } \\
\hline $\begin{array}{c}\text { OPACIDAD } \\
\text { TRANSPARENCIA }\end{array}$ & $\begin{array}{c}\text { COHERENCIA } \\
\text { VARIACIÓN }\end{array}$ & FIGURAFONDO & REMARCA & $\begin{array}{c}\text { ALINEACIÓN } \\
\text { TIPOGRÁFICA }\end{array}$ \\
\hline 1 & 2 & Estable & Ajusta & Ejes \\
\hline
\end{tabular}

\section{PERSPECTIVA}

Las sombras que detallan la figura humana así como las que muestran las ondulaciones de la bandera especifican que se trata de una imagen realizada en perspectiva.

\subsubsection{Anatomía del mensaje}

\section{REPRESENTACIÓN Y ABSTRACCIÓN}

La profusión de detalles, especialmente en la imagen del hombre suponen un nivel realista de representación, al igual que podemos hablar de isomorfismo en la abstracción, ya que no hay discrepancias notables entre la forma representada y la realidad.

\section{RETÓRICA VISUAL}

\section{Figuras semánticas}

Son especialmente destacadas las figuras retóricas que afectan al significado de los diferentes elementos. El hombre porta una gorra que lo identifica como trabajador, al tiempo que se coloca un clavel, lo que sirve como metáfora de su adhesión al partido socialista del SED.

Por su parte la bandera roja, símbolo de los movimientos socialistas y comunistas, refleja las celebraciones del $1^{\circ}$ de mayo, día del trabajador. Todas estas figuras retóricas están comprendidas dentro de las figuras semánticas de sustitución, al tiempo que el refuerzo de la comunicación mediante varios elementos paralelos implican figuras de comparación.

\section{Figuras sintácticas}

El uso de figuras sintácticas no es tan evidente, pero la composición en dos partes independientes del texto reflejan la existencia de figuras de transposición.

\begin{tabular}{|c|c|c|c|c|c|}
\hline \multicolumn{5}{|c|}{ RETÓRICA VISUAL } \\
\hline \multicolumn{2}{|c|}{ FIGURAS SEMÁNTICAS } & \multicolumn{4}{c|}{ FIGURAS SINTÁCTICAS } \\
\hline DE SUSTITUCIÓN & DE COMPARACIÓN & DE SUPRESIÓN & REPETITIVAS & DE ADJUNCIÓN & DE TRANSPOSICIÓN \\
\hline Sí & Sí & 0 & 0 & 0 & Sí \\
\hline
\end{tabular}




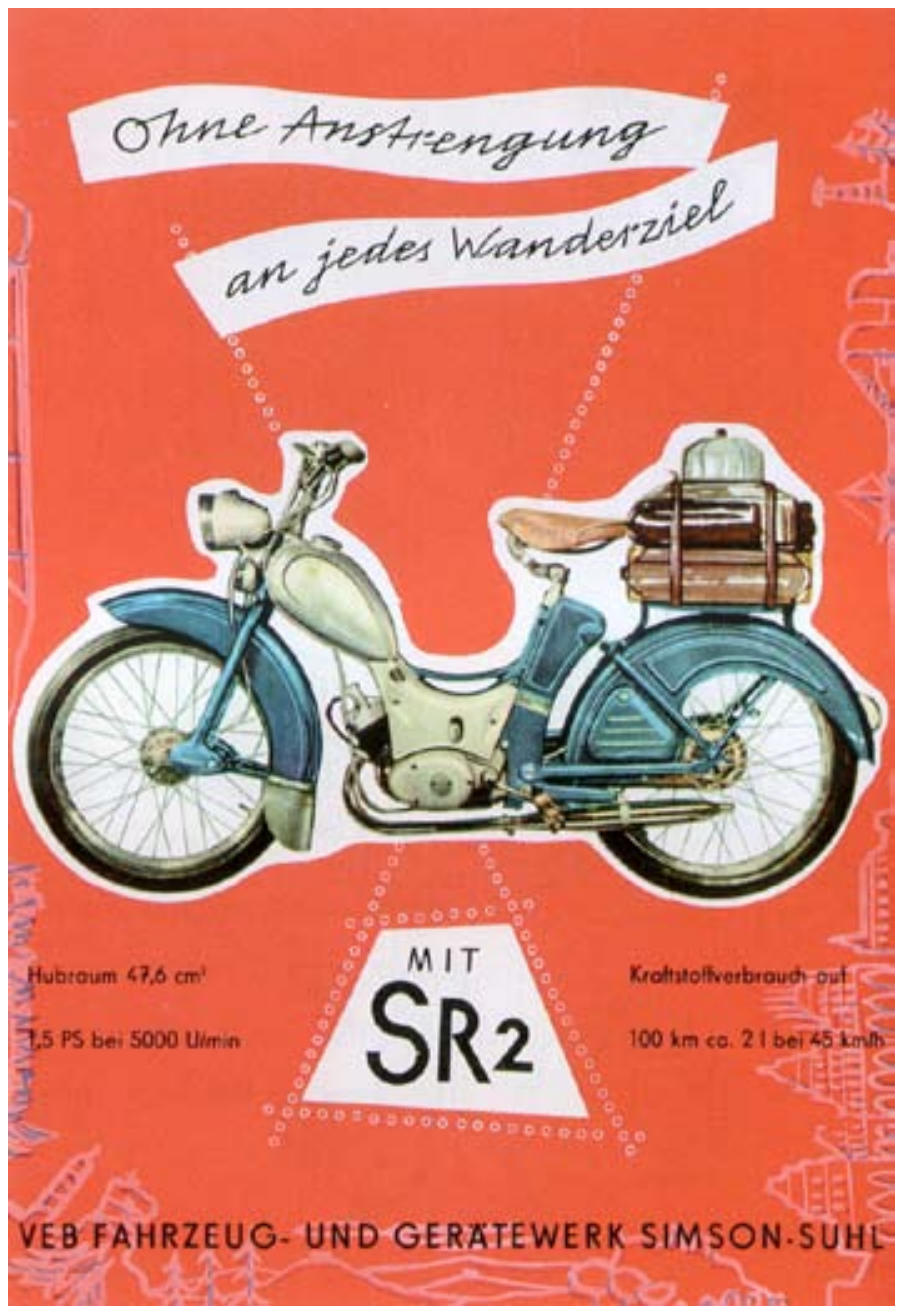

\subsubsection{Muestra 2}

6.2.2.1 Datos técnicos

Código: 1958_A_00

Año: 1958

Autor: Anónimo

Título: VEB Fahrzeug und Gerätewerk Simson Suhl

Tipo de impresión: Desconocido

Fuente: $D D R$-Werkbund

Género: Económico
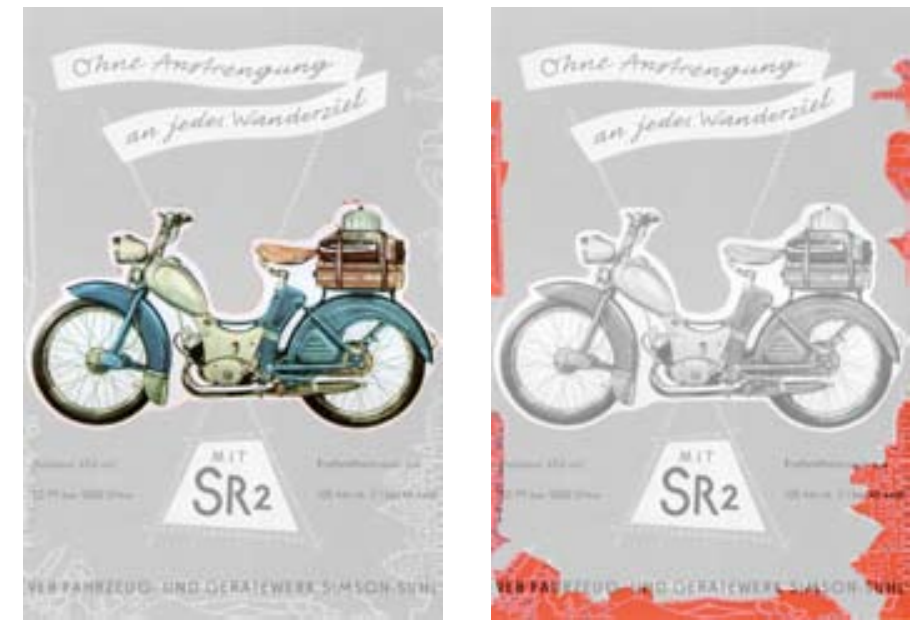

\begin{tabular}{|c|c|c|c|c|c|c|}
\hline \multicolumn{7}{|c|}{ FICHA TÉCNICA } \\
\hline CÓDIGO & AÑO & AUTOR & TíTULO & TIPO DE IMPRESIÓN & FUENTE & GÉNERO \\
\hline $1958 \_$A_00 & 1958 & Anónimo & VEB Fahrzeug und Gerătewerk Simson Suhl & 0 & DDR-Werkbund & Económico \\
\hline
\end{tabular}

\subsubsection{Elementos básicos}

\section{CÓDIGO MORFOLÓGICO}

\section{Esquemas formales abstractos:}

Acompañando unos esquemas figurativos a modo de elemento principal, nos encontramos con varios esquemas formales abstractos; por un lado las líneas que se cruzan formando una $X$, cuya formación mediante circulos alineados nos hacen considerarlas líneas tácitas, y por otro un trapecio en la intersección de las líneas y dos bandas contenedoras del texto.

\begin{tabular}{|c|c|c|c|c|c|c|c|c|c|c|c|}
\hline \multicolumn{12}{|c|}{ ESQUEMAS FORMALES ABSTRACTOS } \\
\hline \multirow{2}{*}{$\begin{array}{l}\text { LINEEA } \\
\text { PPAL }\end{array}$} & \multirow{2}{*}{$\begin{array}{l}\text { LINEAA } \\
\text { SEC }\end{array}$} & \multicolumn{5}{|c|}{ CONTORNO PPAL } & \multicolumn{5}{|c|}{ CONTORNO SEC } \\
\hline & & TIPO & $\begin{array}{l}\text { DIFUSIVIDAD } \\
\text { AGUDEZA }\end{array}$ & $\begin{array}{l}\text { TEXTURA } \\
\text { VISUAL }\end{array}$ & $\begin{array}{l}\text { FABRI- } \\
\text { CACIÓN }\end{array}$ & ESCALA & TIPO & $\begin{array}{l}\text { DIFUSIVIDAD } \\
\text { AGUDEZA }\end{array}$ & $\begin{array}{c}\text { TEXTURA } \\
\text { VISUAL }\end{array}$ & $\begin{array}{l}\text { FABRICA- } \\
\text { CIÓN }\end{array}$ & ESCALA \\
\hline Tácita & Tácita & $\begin{array}{c}\text { Rectilí- } \\
\text { nea }\end{array}$ & 3 & $\begin{array}{c}\text { Esponta- } \\
\text { nea }\end{array}$ & Dibujo & $\begin{array}{l}\text { Equiva- } \\
\text { lente }\end{array}$ & $\begin{array}{l}\text { Irre- } \\
\text { gular }\end{array}$ & 3 & Espontanea & Dibujo & $\begin{array}{l}\text { Equiva- } \\
\text { lente }\end{array}$ \\
\hline
\end{tabular}

Esquemas formales figurativos:

Nos encontramos con un cartel con una figura principal claramente destacada frente al resto; la imagen de la motocicleta anunciada, dibujada con gran realismo con un fondo blanco que se recorta sobre el fondo rojo principal. La textura de la imagen es parte integrante de la misma, siendo una textura espontanea.

La imagen secundaria la encontramos rodeando el marco del diseño. Se trata de un dibujo difuso de varios elementos paisajísticos y cuya textura la compone el fondo, por lo que la consideraremos decorativa. 
Influencia de la SBZ/RDA en la evolución de los elementos del diseño gráfico en Alemania: composición, tipografia e imagen. Una propuesta metodológica

\begin{tabular}{|c|c|c|c|c|c|c|c|}
\hline \multicolumn{8}{|c|}{ ESQUEMAS FORMALES FIGURATIVOS } \\
\hline \multicolumn{4}{|c|}{ FIGURA PPAL } & \multicolumn{4}{|c|}{ FIGURA SEC } \\
\hline $\begin{array}{l}\text { DIFUSIVIDAD } \\
\text { AGUDEZA }\end{array}$ & $\begin{array}{c}\text { TEXTURA } \\
\text { VISUAL }\end{array}$ & FABRICACIÓN & ESCALA & $\begin{array}{c}\text { DIFUSIVIDAD } \\
\text { AGUDEZA }\end{array}$ & $\begin{array}{l}\text { TEXTURA } \\
\text { VISUAL }\end{array}$ & FABRICACIÓN & ESCALA \\
\hline 3 & Espontanea & Dibujo & Mayor & 1 & Decorativa & Dibujo & Menor \\
\hline
\end{tabular}

Frente a un fondo de color plano se ilustra una imagen con un uso realista del color, lleno de matices y detalles por lo que hablamos de un uso del color realista.

\section{Color principal}

El color principal de la imagen es el rojo, con un valor medio en cuanto a su luminosidad y saturación media. Su legibilidad por contraste, con el blanco sobre el que se recortan las figuras es alta.

\section{Color secundario}

Otros dos colores tienen una gran presencia sobre este fondo, por un lado el blanco que remarca las figuras y por otro el azul de la figura. Por su mayor contraste y presencia consideraremos el blanco como el color secundario. La legibilidad por contraste en los casos en los que el blanco se dibuja sobre el rojo es baja.

\begin{tabular}{|c|c|c|c|c|c|c|c|c|}
\hline \multicolumn{10}{|c|}{ CÓDIGO CROMÁTICO } \\
\hline USO DEL COLOR & MATIZ & VALOR & SATURACIÓN & LEGIBILIDAD & MATIZ & VALOR & SATURACIÓN & LEGIBILIDAD \\
\hline Realista & Rojo & Medio & Medio & Alta & Blanco & Claro & Medio & Baja \\
\hline
\end{tabular}

CÓDIGO TIPOGRÁFICO

\section{Tipografía principal}

Se trata de una tipografía reproducida manualmente a juzgar por la irregularidad de caracteres como la s, unas veces reproducida con trazo caligráfico de un solo arco y otras con doble arco. Sus características formales la clasifican como tipografía manuscrita de clase VIII. Su orientación se adapta a las banderolas y tiene una alineación asimétrica.

\section{Tipografía secundaria}

La tipografía con la que se muestran los datos técnicos, así como la empresa de fabricación es una tipografía de reproducción mecánica y clase VI. Pertenece a la familia de la tipografía Super-Grotesk, con grosor regular y en su prime-

ra versión como tipografía de plomo, también denominada

ABCDEFGHIJK LMNOPQRSTUVW

XYZAOU

Comparación entre la tipografía de la muestra y
la tipografía Super Buch Grotesk
Super Buch Grotesk. Este texto más técnico tiene orientación horizontal y está alineado a la izquierda.

\begin{tabular}{|c|c|c|c|c|c|}
\hline \multicolumn{5}{|c|}{ CÓDIGO TIPOGRÁFICO } \\
\hline \multicolumn{7}{|c|}{ TIPOGRAFÁ PRINCIPAL } \\
\hline REPRODUCCIÓN & CLASIFICACIÓN & FAMILIA & ESTILO & ALINEACIÓN & ORIENTACIÓN \\
\hline Manual & VIII & 0 & Regular & Asimétrica & Adaptada \\
\hline \multicolumn{7}{|c|}{ TIPOGRAFíA SECUNDARIA } \\
\hline REPRODUCCIÓN & CLASIFICACIÓN & FAMILIA & ESTLO & ALINEACIÓN & ORIENTACIÓN \\
\hline Mecánica & VI & Super Croteskt & Regular & Centrada & Horizontal \\
\hline
\end{tabular}

\subsubsection{Sintaxis}

\section{ESTRATEGIA}

La estrategia básica de la comunicación es mediante el uso de contrastes, y la retórica, por lo que se trata un diseño conducido formalmente.

RITMO

No se presentan en la composición elementos que permitan establecer un ritmo, por lo que los valores referentes a regularidad y predictibilidad no tienen cabida en este análisis y por tanto serán igual a 0.

El nivel de conexión establecido entre los diferentes pasos de la comunicación es alto, conducido mediante líneas tácitas que conectan los elementos entre sí, por lo que podemos afirmar que se trata de una composición continua. No se muestra la realización de ninguna actividad ni movimiento por lo que se trata de una composición pasiva.

\begin{tabular}{|c|c|c|c|}
\hline \multicolumn{4}{|c|}{ RITMO } \\
\hline $\begin{array}{c}\text { REGULARIDAD } \\
\text { IRREGULARIDAD }\end{array}$ & $\begin{array}{c}\text { PREDICTBIILIDAD } \\
\text { ESPONTANEIDAD }\end{array}$ & $\begin{array}{c}\text { CONTINUIDAD } \\
\text { EPISODIIIDAD }\end{array}$ & $\begin{array}{c}\text { PASIVIDAD } \\
\text { ACTIVIDAD }\end{array}$ \\
\hline 0 & 0 & 1 & 1 \\
\hline
\end{tabular}

EQUILIBRIO

Los elementos de la composición se encuentran distribuidos de tal modo que existe una cierta simetría -rota por las bandas superiores y por la imagen no simétrica que se muestra en el centro-, es decir, un nivel de simetría medio, pero que sin duda nos permite hablar de una composición equilibrada.

\begin{tabular}{|c|c|}
\hline \multicolumn{2}{|c|}{ EQUILIBRIO } \\
\hline EQUILIBRIO-INESTABIIIDAD & SIMETRÍA-ASIMETRÍA \\
\hline 1 & 2 \\
\hline
\end{tabular}

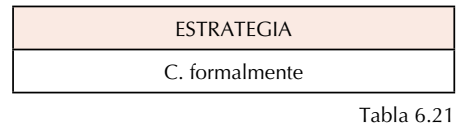




\section{ÉNFASIS}

\begin{tabular}{|c|c|}
\hline \multicolumn{2}{|c|}{ ÉNFASIS } \\
\hline $\begin{array}{c}\text { NEUTRALIDAD } \\
\text { ACENTO }\end{array}$ & ELEMENTO \\
\hline 3 & Imagen \\
\hline
\end{tabular}

Podemos afirmar que el énfasis de la comunicación recae en la imagen, con un alto nivel de acento al tratarse de una composición central con los elementos atados entre sí mediante la estrategia de estar colocados sobre contornos blancos con un fuerte contraste con el fondo rojo.

\section{UNIDAD}

La comunicación se produce mediante el uso de esquemas formales figurativos y esquemas formales abstractos por lo que hablamos de un nivel de simplicidad medio. Los elementos figurativos se muestran completos, por lo que predomina la unidad.

La motocicleta, elemento principal de la composición y artículo publicitado, se representa con un gran nivel de detalle, por lo que se trata de un orden visual profuso.

Pese a que sea un único sistema el que lleve el peso de la comunicación, este se complementa con cuadros de texto y una imagen que remarca el límite de la imagen, por lo que existe yuxtaposición de elementos.

\begin{tabular}{|c|c|c|c|}
\hline \multicolumn{4}{|c|}{ UNIDAD } \\
\hline $\begin{array}{c}\text { SIMPLIIIDAD } \\
\text { COMPLEIIDAD }\end{array}$ & $\begin{array}{c}\text { UNIDAD } \\
\text { FRAGMENTACIÓN }\end{array}$ & $\begin{array}{c}\text { PROFUSIÓN } \\
\text { ECONOMÍA }\end{array}$ & $\begin{array}{c}\text { SINGULARIDAD } \\
\text { YUXTAPOSICIÓN }\end{array}$ \\
\hline 2 & 1 & 1 & 3 \\
\hline
\end{tabular}

\section{COLOCACIÓN}

Las figuras no se superponen entre sí, pero se encuentran recortadas sobre el fondo utilizando la opacidad y sin ambigüedades entre la figura y el fondo. La información se agrupa notablemente en el eje vertical siguiendo un esquema: eslogan, imagen, datos técnicos, nombre de la empresa, por lo que podemos hablar de un nivel alto de coherencia.

Los bordes se encuentran remarcados por la figura secundaria que muestra la imagen de un paisaje y la tipografía responde a alineaciones internas, en este caso la disposición de las bandas.

\begin{tabular}{|c|c|c|c|c|}
\hline \multicolumn{5}{|c|}{ COLOCACIÓN } \\
\hline $\begin{array}{c}\text { OPACIDAD } \\
\text { TRANSPARENCIA }\end{array}$ & $\begin{array}{c}\text { COHERENCIAA } \\
\text { VARIACIÓN }\end{array}$ & FIGURAFONDO & REMARCA & $\begin{array}{c}\text { ALINEACIÓN } \\
\text { TIPOGRÁFICA }\end{array}$ \\
\hline 1 & 1 & Estable & Remarca & $\begin{array}{c}\text { Alineaciones } \\
\text { internas }\end{array}$ \\
\hline
\end{tabular}

\section{PERSPECTIVA}

El realismo de la motocicleta supone la creación de perspectiva profunda.

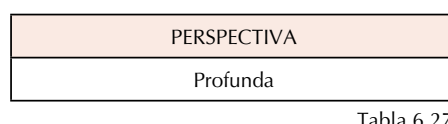

\subsubsection{Anatomía del mensaje}

\section{REPRESENTACIÓN Y ABSTRACCIÓN}

La profusión de detalle de la imagen principal suponen un nivel realista de representación, al igual que podemos hablar de isomorfismo en la abstracción, ya que hay una marcada semejanza entre la forma representada y la realidad.

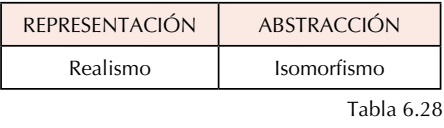

\section{RETÓRICA VISUAL}

\section{Figuras semánticas}

La figura de la motocicleta rodeada por un paisaje en e que se alternan ciudades, pueblos y diferentes entornos naturales muestran mediante sustitución las posibilidades y autonomía del elementos publicitado. Esta idea se refuerza mediante la comparación establecida entre el detalle con el que se representa la motocicleta frente a lo difuminado del paisaje.

\section{Figuras sintácticas}

Las figuras repetitivas son tanto formales, de aquellos elementos con los que se estructura la composición, como figurativos, con la repetición de los perfiles urbanos. Este perfil, que rodea la imagen supone el uso de epanadiplosis, en el cual el principio y el fin coincide. La figura de transposición se muestra sutilmente en la organización tipográfica del eslogan.

\begin{tabular}{|c|c|c|c|c|c|}
\hline \multicolumn{5}{|c|}{ RETÓRICA VISUAL } \\
\hline \multicolumn{5}{|c|}{ FIGURAS SEMÁNTICAS } & \multicolumn{4}{c|}{ FIGURAS SINTÁCTICAS } \\
\hline DE SUSTITUCIÓN & DE COMPARACIÓN & DE SUPRESIÓN & REPETITIVAS & DE ADJUNCIÓN & DE TRANSPPOSICIÓN \\
\hline Sí & Sí & 0 & Sí & Sí & Sí \\
\hline
\end{tabular}




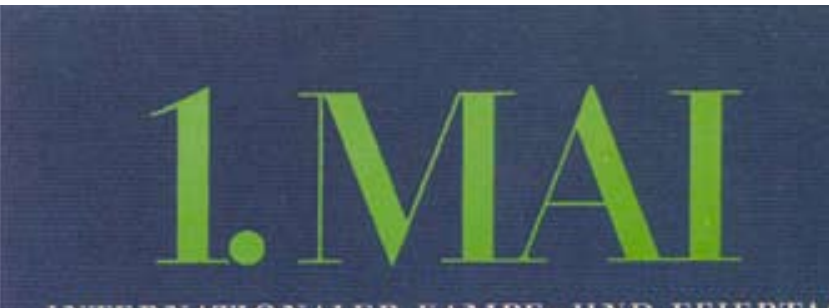

INTERNATIONALER KAMPF - UND FEIERTAG DER ARBEITERKLASSE

KIPPNICK, Heinz (1965)

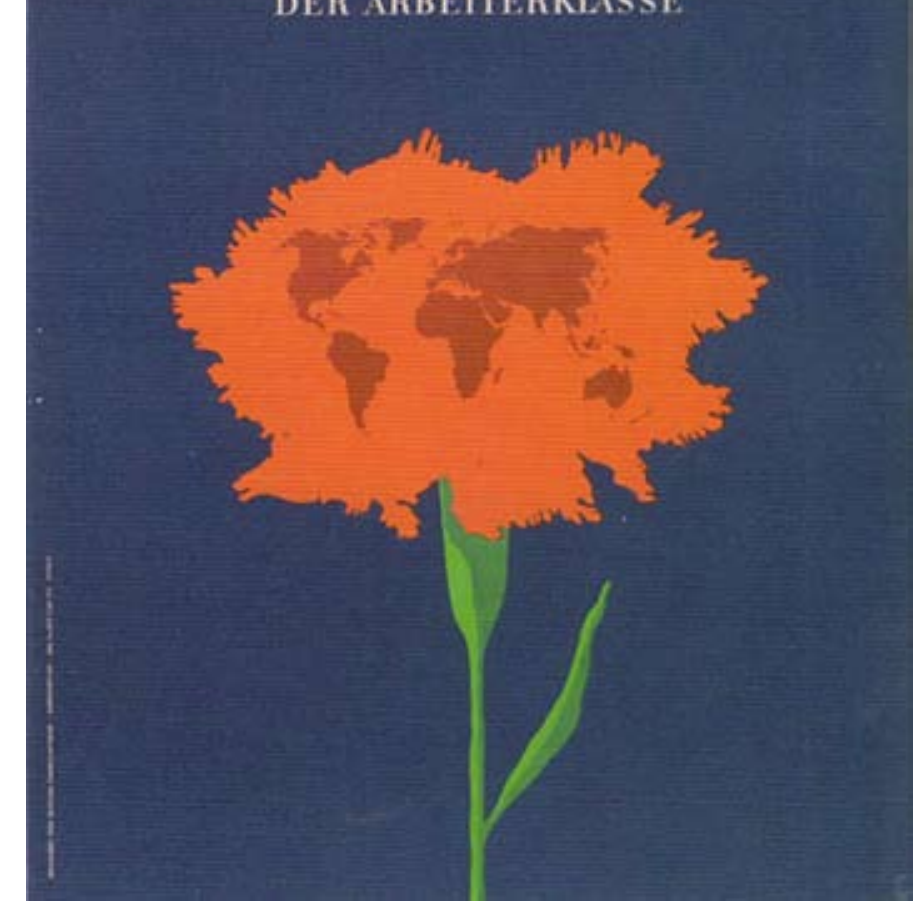

Esquema figurativo principal Esquema figurativo secundario
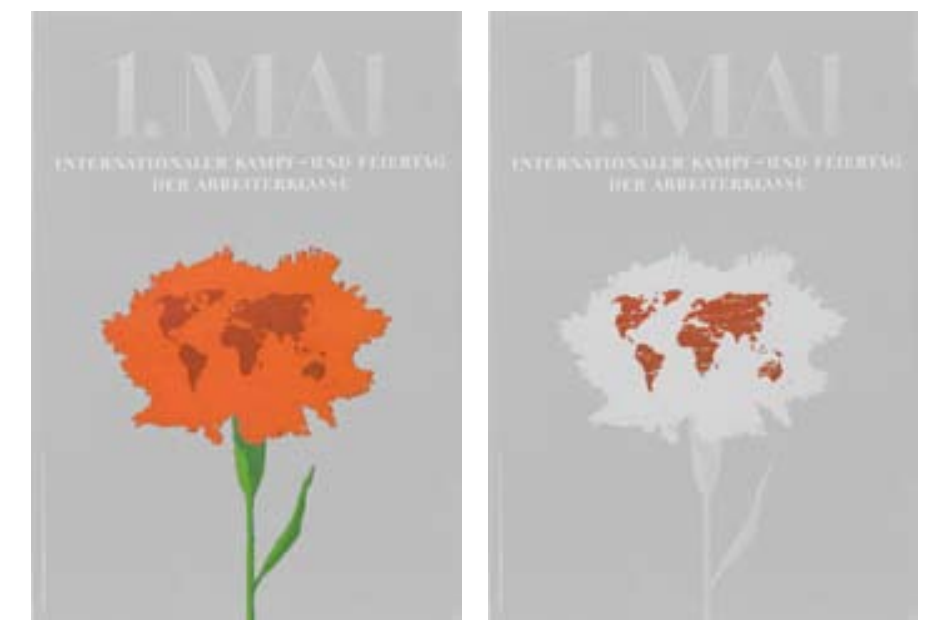

\subsubsection{Muestra 3}

6.2.3.1 Datos técnicos

Código: 1965_KH_00

Año: 1965

Autor: Heinz Kippnick

Título: 1. Mai Internationale Kampf- und Feiertag der

Arbeiterklasse

Tipo de impresión: Offset

Fuente: Überklebt- Plakate aus der DDR

Género: Político

\begin{tabular}{|c|c|c|c|c|c|c|}
\hline \multicolumn{7}{|c|}{ FICHA TÉCNICA } \\
\hline CÓDIGO & AÑO & AUTOR & TíTULO & TIPO DE IMPRESIÓN & FUENTE & GÉNERO \\
\hline 1965 KH_00 & 1965 & $\begin{array}{c}\text { KIPPNICK, } \\
\text { Heinz }\end{array}$ & $\begin{array}{c}\text { 1. Mai Internationale Kampf-und } \\
\text { Feiertag der Arbeiterklasse }\end{array}$ & Offset & $\begin{array}{c}\text { Überklebt-Plakate aus } \\
\text { der DDR }\end{array}$ & Político \\
\hline
\end{tabular}

6.2.3.2 Elementos básicos

\section{CÓDIGO MORFOLÓGICO}

\section{Esquemas formales abstractos:}

El cartel analizado carece de elementos formales abstractos, tanto de líneas como de contornos, por lo que todos los valores referidos a estos parámetros tendrán valor 0 .

\begin{tabular}{|c|c|c|c|c|c|c|c|c|c|c|c|}
\hline \multicolumn{12}{|c|}{ ESQUEMAS FORMALES ABSTRACTOS } \\
\hline \multirow[b]{2}{*}{$\begin{array}{l}\text { LIÍNEA } \\
\text { PPAL }\end{array}$} & \multirow[b]{2}{*}{$\begin{array}{l}\text { LÍNEA } \\
\text { SEC }\end{array}$} & \multicolumn{5}{|c|}{ CONTORNO PPAL } & \multicolumn{5}{|c|}{ CONTORNO SEC } \\
\hline & & TIPO & $\begin{array}{l}\text { DIFUSIVIDAD } \\
\text { AGUDEZA }\end{array}$ & $\begin{array}{l}\text { TEXTURA } \\
\text { VISUAL }\end{array}$ & $\begin{array}{l}\text { FABRI- } \\
\text { CACIÓN }\end{array}$ & ESCALA & TIPO & $\begin{array}{l}\text { DIFUSIVIDAD } \\
\text { AGUDEZA }\end{array}$ & $\begin{array}{l}\text { TEXTURA } \\
\text { VISUAL }\end{array}$ & $\begin{array}{l}\text { FABRICA- } \\
\text { CIÓN }\end{array}$ & ESCALA \\
\hline 0 & 0 & 0 & 0 & 0 & 0 & 0 & 0 & 0 & 0 & 0 & 0 \\
\hline
\end{tabular}

\section{Esquemas formales figurativos:}

La figura principal representa mediante un dibujo de contornos bien definidos y con textura visual espontanea, ya que si la eliminásemos desaparecería con ella la imagen, la simplificación de un clavel.

Dentro de esta, y a una escala relativa mucho menor, nos encontramos con la silueta del mapa del mundo, dibujada igualmente con contornos claros y definidos, y con una textura visual espontanea.

\begin{tabular}{|c|c|c|c|c|c|c|c|}
\hline \multicolumn{7}{|c|}{ ESQUEMAS FORMALES FIGURATIVOS } \\
\hline $\begin{array}{c}\text { FIFUSIVIDAD } \\
\text { AGUDEZA }\end{array}$ & $\begin{array}{c}\text { TEXTURA } \\
\text { VISUAL }\end{array}$ & FABRICACIÓN & ESCALA & $\begin{array}{c}\text { DIFUSIVIDAD } \\
\text { AGUDEZA }\end{array}$ & $\begin{array}{c}\text { TEXTURA } \\
\text { VISUAL }\end{array}$ & FABRICACIÓN & ESCALA \\
\hline 3 & Espontanea & Dibujo & Mayor & 3 & Decorativa & Dibujo & Menor \\
\hline
\end{tabular}


CÓDIGO CROMÁTICO

Consideramos que el uso del color es de tintas planas, que se utilizan, sobre un fondo plano, 5 colores sin gradación ni combinación entre ellos.

\section{Color principal}

La presencia de un número limitado de colores planos dificulta la jerarquización de los mismos. Consideramos el rojo como color principal debido a que es este el portador de la información. Tiene un valor medio en cuanto a su luminosidad y saturación media. Su legibilidad por contraste, en este caso el fondo de color azul oscuro, es media.

\section{Color secundario}

El fondo, de color azul oscuro es el color secundario, con un nivel de saturación medio y una legibilidad por contras-

te, tanto con el rojo como con el verde, media.

\begin{tabular}{|c|c|c|c|c|c|c|c|c|}
\hline \multicolumn{10}{|c|}{ COLDIGO CROMÁtICO } \\
\hline USO DEL COLOR & MATIZ & VALOR & SATURACIÓN & LEGBBILIDAD & MATIZ & VALOR & SATURACIÓN & LEGIBILIDAD \\
\hline Tintas planas & Rojo & Medio & Medio & Media & AZul & Oscuro & Medio & Media \\
\hline
\end{tabular}

Tabla 6.33

\section{CÓDIGO TIPOGRÁFICO}

\section{Tipografía principal}

Se trata de una tipografía reproducida de forma mecánica y clasificada como tipografía romana neoclásica, clase IV según la norma DIN 16518. Su diseño no corresponde a ninguna familia producida por la VEB Typoart. Tiene disposición horizontal y centrada.

\section{Tipografía secundaria}

Utiliza una única tipografía, variando únicamente el color y el tamaño de los caracteres.

\begin{tabular}{|c|c|c|c|c|c|}
\hline \multicolumn{7}{|c|}{ CÓDIGO TIPOGRÁFICO } \\
\hline \multicolumn{7}{|c|}{ TIPOGRAF́A PRINCIPAL } \\
\hline REPRODUCCIÓN & CLASIFICACIÓN & FAMILIA & ESTILO & ALINEACIÓN & ORIENTACIÓN \\
\hline Mecánica & IV & 0 & Regular & Centrada & Horizontal \\
\hline \multicolumn{7}{|c|}{ TIPOGRAFíA SECUNDARIA } \\
\hline REPRODUCCIÓN & CLASIFICACIÓN & FAMILIA & ESTILO & ALINEACIÓN & ORIENTACIÓN \\
\hline 0 & 0 & 0 & 0 & 0 & 0 \\
\hline
\end{tabular}

\subsubsection{Sintaxis}

\section{ESTRATEGIA}

La estrategia básica de la comunicación es la retórica, y una estructura compositiva basada en el dominio del eje central por lo que podemos concluir que se trata un diseño conducido formalmente.

\section{RITMO}

No se presentan en la composición elementos que permitan establecer un ritmo, por lo que los valores referentes a regularidad y predictibilidad no tienen cabida en este análisis y por tanto serán igual a 0 .

El nivel de conexión establecido entre los diferentes pasos de la comunicación muy elevado, por lo que podemos afirmar que se trata de una composición continua. Tanto la composición como la imagen representada reflejan pasividad.

\begin{tabular}{|c|c|c|c|}
\hline \multicolumn{4}{|c|}{ RITMO } \\
\hline $\begin{array}{c}\text { REGULARIDAD } \\
\text { IRREGULARIDAD }\end{array}$ & $\begin{array}{c}\text { PREDICTIBILIDAD } \\
\text { ESPONTANEIDAD }\end{array}$ & $\begin{array}{c}\text { CONTINUIDAD } \\
\text { EPISODICIDAD }\end{array}$ & $\begin{array}{c}\text { PASIVIIDAD } \\
\text { ACTIVIDAD }\end{array}$ \\
\hline 0 & 0 & 1 & 1 \\
\hline
\end{tabular}

\section{EQUILIBRIO}

Los elementos de la composición se encuentran distribuidos a lo largo de un eje vertical y centrado que lo estructura claramente con un orden estable y simétrico. Esta simetría sin embargo se ve rota por la presencia de una hoja, a un único lado de la imagen.

\begin{tabular}{|c|c|}
\hline \multicolumn{2}{|c|}{ EQUILIBRIO } \\
\hline EQUILIBRIO INESTABILIDAD & SIMETRÍA ASIMETRÍA \\
\hline 1 & 2 \\
\hline
\end{tabular}

\section{ÉNFASIS}

Podemos afirmar que el énfasis de la comunicación recae en la imagen con un énfasis marcado, derivado de la situación centrada de la misma y de su fuerte contraste cromático con el fondo.

\section{UNIDAD}

La comunicación se produce mediante la combinación de una tipografía potente en dimensión, pero neutra en detalles ornamentales, con una imagen que resulta de la combinación de dos imágenes diferentes que se unen componiendo

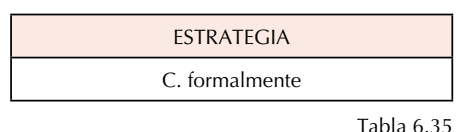

Tabla 6.35

(n) 
una unidad, por lo que podemos hablar de simplicidad y singularidad en la composición.

Por su parte la imagen se muestra con una gran economía de detalle, reduciéndose únicamente a contornos.

Tabla 639

\begin{tabular}{|c|c|c|c|}
\hline \multicolumn{4}{|c|}{ UNIDAD } \\
\hline $\begin{array}{c}\text { SIMPLIIIDAD } \\
\text { COMPLEIDAD }\end{array}$ & $\begin{array}{c}\text { UNIDAD } \\
\text { FRAGMENTACIÓN }\end{array}$ & $\begin{array}{c}\text { PROFUSIÓN } \\
\text { ECONOMÍA }\end{array}$ & $\begin{array}{c}\text { SINGULARIDAD } \\
\text { YUXTAPOSICIÓN }\end{array}$ \\
\hline 1 & 1 & 3 & 1 \\
\hline
\end{tabular}

\section{COLOCACIÓN}

Tanto las figuras formales como la tipografía son elementos cuya yuxtaposición se produce mediante opacidad, y cuya colocación se realiza mediante la agrupación de elementos similares, situándose la tipografía en la parte superior y la imagen centrada, por lo que debemos hablar de un nivel de coherencia alto.

La relación entre la figura y el fondo es estable, sin dar lugar a juegos de lectura entre ambas. La alineación tipográfica sigue marcadamente el eje central.

La composición se estructura dentro de los límites del marco.

60

\begin{tabular}{|c|c|c|c|c|}
\hline \multicolumn{5}{|c|}{ COLOCACIÓN } \\
\hline $\begin{array}{c}\text { OPACIDAD } \\
\text { TRANSPARENCIA }\end{array}$ & $\begin{array}{c}\text { COHERENCIA } \\
\text { VARIACIÓN }\end{array}$ & FIGURAFONDO & REMARCA & $\begin{array}{c}\text { ALINEACIÓN } \\
\text { TIPOGRÁFICA }\end{array}$ \\
\hline 1 & 1 & Estable & Ajusta & Ejes \\
\hline
\end{tabular}

\section{PERSPECTIVA}

PERSPECTIVA

\begin{tabular}{|c|c|}
\hline REPRESENTACIÓN & ABSTRACCIÓN \\
\hline Surrealismo & Isomorfismo \\
\hline
\end{tabular}

Tabla 6.42

Las sombras que detallan el tallo de la flor, así como el color utilizado en la representación del mapa mundial que dan la apariencia de ser las sombras de las hojas, nos indican que se trata de una representación en perspectiva.

\subsubsection{Anatomía del mensaje}

\section{REPRESENTACIÓN Y ABSTRACCIÓN}

La figura se representa únicamente mediante sus contornos, sin detallar su interior, por lo que nos encontramos con un nivel de representación por debajo de la realidad. Sin embargo este contorno se adecua completamente a la imagen real, por lo que se trata de una representación isomórfica.

\section{RETÓRICA VISUAL}

\section{Figuras semánticas}

Nuevamente destacan sobre todas las demás las figuras de sustitución, en la cual la imagen del clavel representa la lucha de la clase obrera, dentro de la cual se sitúa el mapa del mundo, como símbolo de su alcance internacional.

\section{Figuras sintácticas}

La metáfora a la que aludíamos como figura semántica tiene su reflejo en la forma del signo, ya que ambas imágenes se disponen de tal modo que su primera apariencia es la de configurar un único elemento.

\begin{tabular}{|c|c|c|c|c|c|}
\hline \multicolumn{5}{|c|}{ RETÓRICA VISUAL } \\
\hline \multicolumn{2}{|c|}{ FIGURAS SEMÁNTICAS } & \multicolumn{4}{c|}{ FIGURAS SINTÁCTICAS } \\
\hline DE SUSTITUCIÓN & DE COMPARACIÓN & DE SUPRESIÓN & REPETITIVAS & DE ADJUNCIÓN & DE TRANSPOSICIÓN \\
\hline Sí & 0 & 0 & 0 & Sí & Sí \\
\hline
\end{tabular}




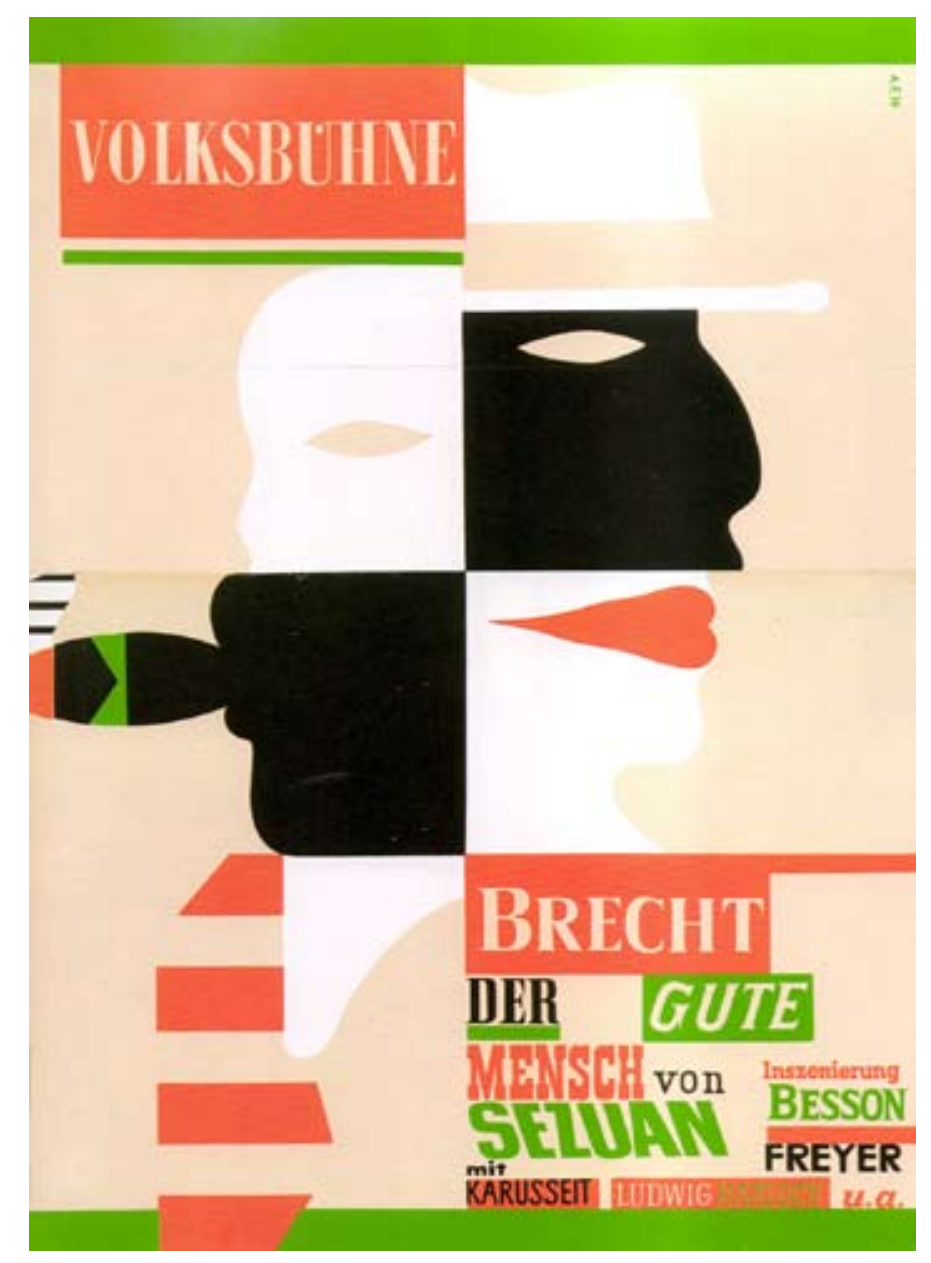

6.2.4 Muestra 4

FREYER, Achim (1970)

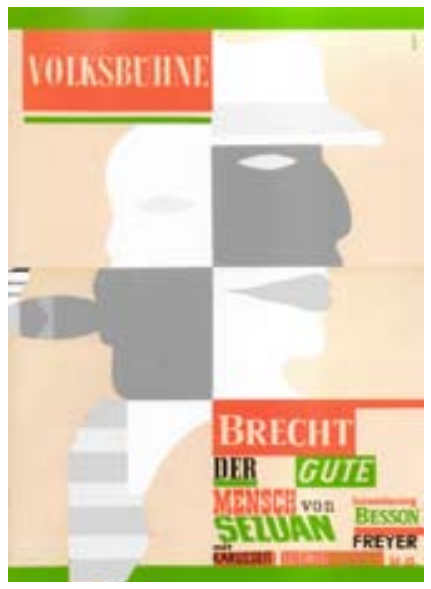

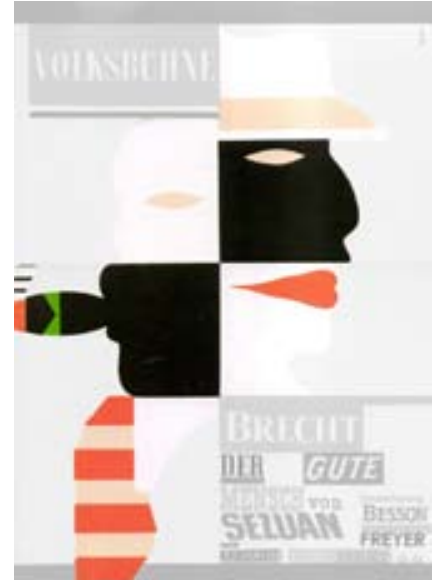

\subsubsection{Datos técnicos}

Código: 1970_FA_00

Año: 1970

Autor: Achim Freyer

Título: Brecht -Der gute Mensch von Sezuan

Tipo de impresión: Litografía

Fuente: Überklebt- Plakate aus der DDR

Género: Político

\begin{tabular}{|c|c|c|c|c|c|c|}
\hline \multicolumn{7}{|c|}{ FICHA TÉCNICA } \\
\hline CÓDIGO & AÑO & AUTOR & Título & TIPO DE IMPRESIÓN & FUENTE & GÉNERO \\
\hline 1970_FA_00 & 1970 & FREYER, Achim & $\begin{array}{l}\text { Brecht -Der gute Mensch } \\
\text { von Sezuan }\end{array}$ & Serigrafía & Überklebt-Plakate aus der DDR & Cultural \\
\hline
\end{tabular}

6.2.4.2 Elementos básicos

\section{CÓDIGO MORFOLÓGICO}

\section{Esquemas formales abstractos:}

El cartel analizado presenta numerosos elementos formales, la mayor parte de ellos percibidos debido al contraste entre figuras, más que a la presencia real de ellos, como es el caso de las líneas que dividen el cartel en una retícula. Se presentan igualmente líneas sólidas que enfatizan mediante subrayado.

Varios de los elementos tipográfico se muestran dentro de formas geométricas regulares con un contorno marcado y de textura espontanea ya que se realizan en un único color sin diferenciación entre contorno y fondo.

\begin{tabular}{|c|c|c|c|c|c|c|c|c|c|c|c|}
\hline \multicolumn{12}{|c|}{ ESQUEMAS FORMALES ABSTRACTOS } \\
\hline \multirow[b]{2}{*}{$\begin{array}{l}\text { LÍNEA } \\
\text { PPAL }\end{array}$} & \multirow[b]{2}{*}{$\begin{array}{c}\text { LÍNEA } \\
\text { SEC }\end{array}$} & \multicolumn{5}{|c|}{$\begin{array}{l}\text { CONTORNO PPAL } \\
\end{array}$} & \multicolumn{5}{|c|}{ CONTORNO SEC } \\
\hline & & TIPO & $\begin{array}{l}\text { DIFUSI- } \\
\text { VIDAD } \\
\text { AGUDEZA }\end{array}$ & $\begin{array}{l}\text { TEXTURA } \\
\text { VISUAL }\end{array}$ & $\begin{array}{l}\text { FABRI- } \\
\text { CACIÓN }\end{array}$ & ESCALA & TIPO & $\begin{array}{l}\text { DIFUSI- } \\
\text { VIDAD } \\
\text { AGUDEZA }\end{array}$ & $\begin{array}{l}\text { TEXTURA } \\
\text { VISUAL }\end{array}$ & $\begin{array}{l}\text { FABRICA- } \\
\text { CIÓN }\end{array}$ & ESCALA \\
\hline Tácita & Sólida & $\begin{array}{c}\text { Geomé- } \\
\text { trica }\end{array}$ & 3 & $\begin{array}{c}\text { Esponta- } \\
\text { nea }\end{array}$ & Dibujo & $\begin{array}{c}\text { Equiva- } \\
\text { lente }\end{array}$ & $\begin{array}{l}\text { Geomé- } \\
\text { trica }\end{array}$ & 3 & Espontanea & Dibujo & $\begin{array}{l}\text { Equiva- } \\
\text { lente }\end{array}$ \\
\hline
\end{tabular}

\section{Esquemas formales figurativos:}

La figura central está formada mediante la unión de diferentes fragmentos de imágenes que componen una única. Sus contornos están definidos claramente y su textura es espontanea, ya que no es independiente del borde. La imagen es de reproducción pictórica y compuesta por fragmentos con una relación de equivalencia en la escala. 
ESQUEMAS FORMALES FIGURATIVOS

\begin{tabular}{|c|c|c|c|c|c|c|c|}
\hline \multicolumn{7}{|c|}{ FIGURA PPAL } & \multicolumn{4}{c|}{ FIGURA SEC } \\
\hline $\begin{array}{c}\text { DIFUSIVIDAD } \\
\text { AGUDEZA }\end{array}$ & $\begin{array}{c}\text { TEXTURA } \\
\text { VISUAL }\end{array}$ & FABRICACIÓN & ESCALA & $\begin{array}{c}\text { DIFUSIVIDAD } \\
\text { AGUDEZA }\end{array}$ & $\begin{array}{c}\text { TEXTURA } \\
\text { VISUAL }\end{array}$ & FABRICACIÓN & ESCALA \\
\hline 3 & Espontanea & Dibujo & Equivalente & 0 & 0 & 0 & 0 \\
\hline
\end{tabular}

Se trata de un cartel en el cual el uso del color es claramente de tintas planas.

\section{Color principal}

Al tratarse de una composición mediante tintas planas resulta difícil establecer una jerarquía cromática, si bien la información principal la encontramos en los elementos de color rojo, por lo que lo consideraremos principal. Este tiene un valor y saturación medio, así como una legibilidad por contraste, en la cual el color beige se muestra sobre el fondo rojo, media.

\section{Color secundario}

Siguiendo el mismo criterio, será el verde el color secundario, con valor y saturación media, al igual que la legibilidad por contraste.

\begin{tabular}{|c|c|c|c|c|c|c|c|c|}
\hline \multicolumn{1}{|c|}{ CÓDIGO CROMÁTICO } \\
\hline USO DEL COLOR & MATIZ & VALOR & SATURACIÓN & LEGIBILIDAD & MATIZ & VALOR & SATURACIÓN & LEGIBILIDAD \\
\hline Tintas planas & Rojo & Medio & Medio & Media & Verde & Medio & Medio & Media \\
\hline
\end{tabular}

Tabla 6.47

\section{VOLRSBUIINE}

\section{CÓDIGO TIPOGRÁFICO}

\section{Tipografía principal}

Buth und Schriit

Gesammelie Werke de

Comparación tipográfica entre la muestra y la
tipografía Pergamon Antiqua Schmallhalbfet

\section{MFNSH von is}

\section{IIt contintir}

Comparación tipográfica entre la muestra y la
tipografía Nidor
Se trata de una tipografía reproducida mecánicamente con las características formales de la tipografía de clase IV o tipografía neoclásica. Corresponde con la tipografía Pergamon Antiqua en su versión condensada. No se puede establecer su alineación ya que se encuentra condensado en una única línea orientada horizontalmente.

\section{Tipografía secundaria}

Nos encontramos ante una tipografía de reproducción mecánica de clase $\mathrm{V}$ de la familia Nidor en su versión regular. Su orientación es horizontal, pero al componerse en una sola línea carece de alineación interna.

\begin{tabular}{|c|c|c|c|c|c|}
\hline \multicolumn{7}{|c|}{ CÓDIGO TIPOGRÁFICO } \\
\hline \multicolumn{7}{|c|}{ TIPOGRAFÁ PRINCIPAL } \\
\hline REPRODUCCIÓN & CLASIFICACIÓN & FAMILIA & ESTILO & ALINEACIÓN & ORIENTACIÓN \\
\hline Mecánica & IV & Pergamon Antiqua & Condensada & 0 & Horizontal \\
\hline \multicolumn{7}{|c|}{ TIPOGRAFÍA SECUNDARIA } \\
\hline REPRODUCCIÓN & CLASIFICACIÓN & FAMILLA & ESTLO & ALINEACIÓN & ORIENTACIÓN \\
\hline Mecánica & $V$ & Nidor & Regular & 0 & Horizontal \\
\hline
\end{tabular}

\subsubsection{Sintaxis}

\section{ESTRATEGIA}

La estrategia básica de la comunicación es la retórica, apoyada por el contraste visual de la figura fragmentada, por lo que podemos concluir que se trata un diseño conducido formalmente.

\section{RITMO}

El ritmo se presenta aquí mediante la fragmentación de la imagen, el cual responde a un patrón establecido que no se ajusta a normas estrictamente regulares.

El nivel de conexión establecido entre los diferentes pasos de la comunicación es alto al estructurarse todo dentro de una misma retícula, por lo que podemos afirmar que se trata de una composición continua. La imagen se muestra sin actividad, pero su configuración le dota de dinamismo por lo que lo consideraremos en un nivel medio.

\begin{tabular}{|c|c|c|c|}
\hline \multicolumn{4}{|c|}{ RITMO } \\
\hline $\begin{array}{c}\text { REGULARIDAD } \\
\text { IRREGULARIDAD }\end{array}$ & $\begin{array}{l}\text { PREDICTIBILIDAD } \\
\text { ESPONTANEIDAD }\end{array}$ & $\begin{array}{l}\text { CONTINUIDAD } \\
\text { EPISODIIIDAD }\end{array}$ & $\begin{array}{c}\text { PASIVIDAD } \\
\text { ACTIVIDAD }\end{array}$ \\
\hline 2 & 1 & 1 & 2 \\
\hline
\end{tabular}

EQUILIBRIO

Los elementos de la composición se encuentran distribuidos de tal modo que el peso queda repartido de forma equilibrada a ambos lados del eje central. Este eje queda claramente definido, dando un falso aspecto de simetría en la imagen, mientras que la tipografía se encuentra en clara asimetrí.

\begin{tabular}{|c|c|}
\hline \multicolumn{2}{|c|}{ EQUILBRIO } \\
\hline EQUILBRIO-NESTABILIDAD & SIMETRÍA-ASIMETRÍA \\
\hline 1 & 2 \\
\hline
\end{tabular}

ÉNFASIS

Podemos afirmar que el énfasis de la comunicación recae en la imagen, sin embargo la variación tipográfica, así como

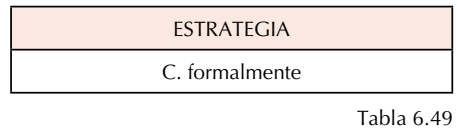

Tabla 6.49

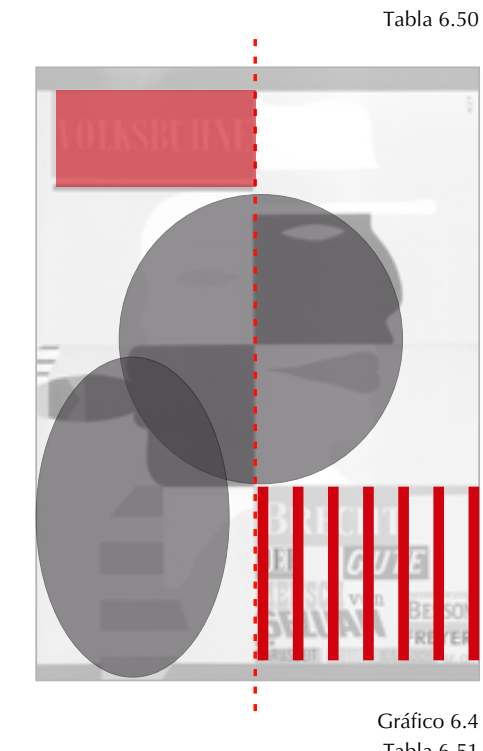

Gráfico 6.4
Tabla 6.51 
su situación en cajetines con un fuerte contraste produce una cierta distorsión, por lo que podemos hablar de un nivel de énfasis medio.

UNIDAD

Se realiza la comunicación mediante estos dos elementos, la tipografía y la imagen, ambos con un fuerte peso en la composición, lo que hace que exista una yuxtaposición de elementos. Lo más destacado es la fragmentación de la imagen, compuesta de diversos elementos independientes entre sí dibujados con gran economía.

Tabla 6.53

\begin{tabular}{|c|c|c|c|}
\hline \multicolumn{4}{|c|}{ UNIDAD } \\
\hline $\begin{array}{c}\text { SIMPLIIIDAD } \\
\text { COMPLEIIDAD }\end{array}$ & $\begin{array}{c}\text { UNIDAD } \\
\text { FRAGMENTACIÓN }\end{array}$ & $\begin{array}{c}\text { PROFUSIÓN } \\
\text { ECONOMÍA }\end{array}$ & $\begin{array}{c}\text { SINGULARIDAD } \\
\text { YUXTAPOSIIIIÓN }\end{array}$ \\
\hline 2 & 3 & 1 & 2 \\
\hline
\end{tabular}

COLOCACIÓN

Tanto las figuras formales como la tipografía son elementos cuya yuxtaposición se produce mediante opacidad y si bien las imágenes están agrupadas conjuntamente en el centro de la composición, el texto se encuentra dividido por la imagen, por lo que debemos hablar de un nivel de coherencia medio.

La relación entre la figura y el fondo es ambigua, ya que el fondo beige tanto sirve como plano en el cual se configuran los elementos, como se transforma en parte de la imagen o en tipografía. La alineación tipográfica responde a la retícula compositiva, por lo que hablamos de alineación receptiva.

Los elementos no se distribuyen completamente dentro de los márgenes, sino que en ocasiones lo superan.

\begin{tabular}{|c|c|c|c|c|}
\hline \multicolumn{5}{|c|}{ COLOCACIÓN } \\
\hline $\begin{array}{c}\text { OPACIDAD } \\
\text { TRANSPARENCIA }\end{array}$ & $\begin{array}{c}\text { COHERENCIA } \\
\text { VARIACIÓN }\end{array}$ & FIGURA/FONDO & REMARCA & $\begin{array}{c}\text { ALINEACIÓN } \\
\text { TIPOGRÁFICA }\end{array}$ \\
\hline 1 & 2 & Ambiguo & Supera & Receptivas \\
\hline
\end{tabular}

PERSPECTIVA

La imagen carece de sombras o elementos que denoten profundidad, por lo que se trata de una perspectiva plana.

\subsubsection{Anatomía del mensaje}

\section{REPRESENTACIÓN Y ABSTRACCIÓN}

La ausencia de detalles nos indican un nivel de represen-

tación surrealista, mientras que la abstracción es media, ya

\begin{tabular}{|c|c|}
\hline REPRESENTACION & ABSTRACCION \\
\hline Surrealismo & Mesomorfismo \\
\hline
\end{tabular}

que si bien las diferencias con la realidad son evidentes, permite un fácil reconocimiento de esta.

\section{RETÓRICA VISUAL}

\section{Figuras semánticas}

En este caso nos encontramos predominantemente con figuras de comparación, entre los elementos situados a la derecha y los de la izquierda, lo bueno y lo malo, representado mediante el tabaco.

\section{Figuras sintácticas}

En el uso de figuras sintácticas se refleja la comparación en el uso de figuras repetitivas, al tiempo que se hace uso de la elipsis en partes de la figura. La disposición tipográfica fragmentada, haciendo uso de diversas tipografías y disposiciones alude a figuras de transposición.

\begin{tabular}{|c|c|c|c|c|c|}
\hline \multicolumn{5}{|c|}{ RETÓRICA VISUAL } \\
\hline \multicolumn{2}{|c|}{ FIGURAS SEMÁNTICAS } & \multicolumn{4}{c|}{ FIGURAS SINTÁCTICAS } \\
\hline DE SUSTITUCIÓN & DE COMPARACIÓN & DE SUPRESIÓN & REPETITIVAS & DE ADJUNCIÓN & DE TRANSPOSICIÓN \\
\hline Sí & Sí & Sí & Sí & 0 & Sí \\
\hline
\end{tabular}




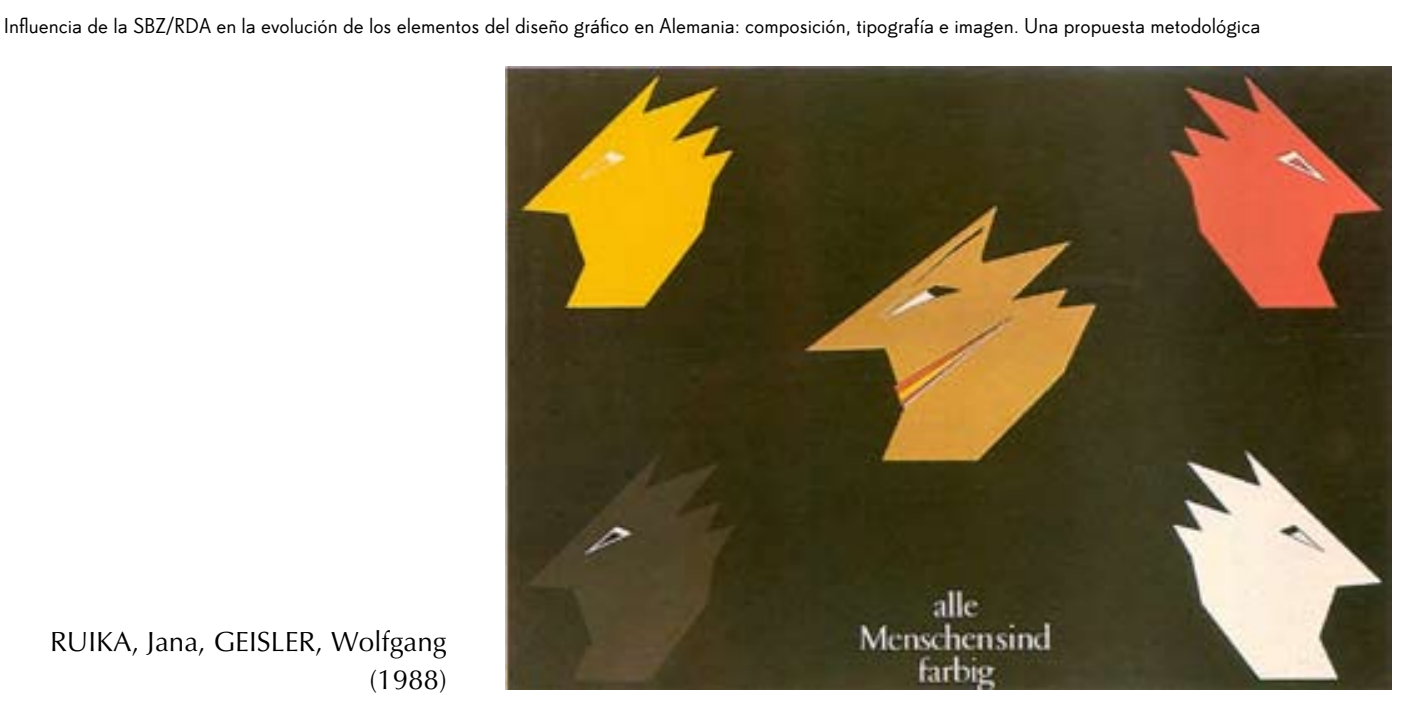

6.2.5 Muestra 5

\subsubsection{Datos técnicos}

Código: 1988_RJ_00

Año: 1988

Autor: Jana Ruika y Wolfgang Geisler

Título: alle Menschen sind farbig

Tipo de impresión: Desconocido

Fuente: P40

Género: Político

\begin{tabular}{|c|c|c|c|c|c|c|}
\hline \multicolumn{7}{|c|}{ FICHA TÉCNICA } \\
\hline CÓDIGO & AÑO & AUTOR & TítULO & TIPO DE IMPRESIÓN & FUENTE & GÉNERO \\
\hline 1988_R__00 & 1988 & RUIKA, Jana, GEISLER, Wolfgangr & alle Menschen sind farbig & 0 & P 40 & Cultural \\
\hline
\end{tabular}

Tabla 6.58

\subsubsection{Elementos básicos}

\section{CÓDIGO MORFOLÓGICO}

\section{Esquemas formales abstractos:}

El cartel analizado carece de elementos formales abstractos, tanto de líneas como de contornos, por lo que todos los valores referidos a estos parámetros tendrán valor 0 .

\begin{tabular}{|c|c|c|c|c|c|c|c|c|c|c|c|}
\hline \multicolumn{10}{|c|}{ CONTORNO PPAL } \\
\hline \multirow{2}{*}{$\begin{array}{c}\text { LINEA } \\
\text { PPAL }\end{array}$} & $\begin{array}{c}\text { LíNEA } \\
\text { SEC }\end{array}$ & $\begin{array}{c}\text { TIPO } \\
\text { DIFUSIVIDAD } \\
\text { AGUDEZA }\end{array}$ & $\begin{array}{c}\text { TEXTURA } \\
\text { VISUAL }\end{array}$ & $\begin{array}{c}\text { FABRL- } \\
\text { CACIÓN }\end{array}$ & ESCALA & TIPO & $\begin{array}{c}\text { DIFUSIVIDAD } \\
\text { AGUDEZA }\end{array}$ & $\begin{array}{c}\text { TEXTURA } \\
\text { VISUAL }\end{array}$ & $\begin{array}{c}\text { FABRICA- } \\
\text { CIÓN }\end{array}$ & ESCALA \\
\hline 0 & 0 & 0 & 0 & 0 & 0 & 0 & 0 & 0 & 0 & 0 & 0 \\
\hline
\end{tabular}

\section{Esquemas formales figurativos:}

La composición se basa en la repetición de una misma figura en la cual varía el color. Esta figura se define claramente y tiene una textura visual espontanea, ya que no existe diferencia entre contorno y decoración. El método de fabricación es el dibujo y todas ellas se encuentran en una relación de escala equivalente.

\begin{tabular}{|c|c|c|c|c|c|c|c|}
\hline \multicolumn{7}{|c|}{ ESQUEMAS FORMALES FIGURATIVOS } \\
\hline $\begin{array}{c}\text { DIFUSIVIDAD } \\
\text { AGUDEZA }\end{array}$ & $\begin{array}{c}\text { TEXTURA } \\
\text { VISUAL }\end{array}$ & FABRICACIÓN & ESCALA & $\begin{array}{c}\text { DIFUSIVIDAD } \\
\text { AGUDEZA }\end{array}$ & $\begin{array}{c}\text { TEXTURA } \\
\text { VISUAL }\end{array}$ & FABRICACIÓN & ESCALA \\
\hline 3 & Espontanea & Dibujo & Equivalente & 0 & 0 & 0 & 0 \\
\hline
\end{tabular}

\section{CÓDIGO CROMÁTICO}

El uso del color es el de tintas planas; sobre un fondo negro se sitúan las figuras cada una de ellas con un color representativo.

\section{Color principal}

El color principal de la imagen es el negro, color de fondo, con un valor oscuro en cuanto a su luminosidad y saturación media. Su legibilidad por contraste depende del color de la figura, con predominancia de la legibilidad alta.

\section{Color secundario}

El color secundario es el rojo, con un valor de luminosidad medio y baja saturación. Su legibilidad por contraste sobre el fondo negro es alta.

\begin{tabular}{|c|c|c|c|c|c|c|c|c|}
\hline \multicolumn{9}{|c|}{ CÓDIGO CROMÁTICO } \\
\hline \multicolumn{5}{|c|}{ COLOR PRINCIPAL } & \multicolumn{4}{|c|}{ COLOR SECUNDARIO } \\
\hline USO DEL COLOR & MATIZ & VALOR & SATURACIÓN & LEGIBILIDAD & MATIZ & VALOR & SATURACIÓN & LEGIBIIIDAD \\
\hline Tintas planas & Negro & Oscuro & Medio & Alta & Rojo & Medio & Mate & \\
\hline
\end{tabular}

\section{CÓDIGO TIPOGRÁFICO}

Utiliza una única tipografía en un único bloque. Es una tipografía de reproducción mecánica y clase II, romana renacentista francesa. Pertenece a la familia Tschörtner Antiqua en su versión regular. Se dispone de forma centrada y con orientación horizontal.

\begin{tabular}{|c|c|c|c|c|c|}
\hline \multicolumn{7}{|c|}{ CÓDIGO TIPOGRÁFICO } \\
\hline \multicolumn{7}{|c|}{ TIPOGRAFIA PRINCIPAL } \\
\hline REPRODUCCIÓN & CLASIFICACIÓN & FAMILIA & ESTLO & ALINEACIÓN & ORIENTACIÓN \\
\hline Mecánica & $\|$ & Tschörtner Antiqua & Regular & Centrada & Horizontal \\
\hline
\end{tabular}




\begin{tabular}{|c|c|c|c|c|c|}
\hline \multicolumn{7}{|c|}{ TIPOGRAFÍA SECUNDARIA } \\
\hline REPRODUCCIÓN & CLASIFICACIÓN & FAMILIA & ESTLO & ALINEACIÓN & ORIENTACIÓN \\
\hline 0 & 0 & 0 & 0 & 0 & 0 \\
\hline
\end{tabular}

Tabla 6.62

\subsubsection{Sintaxis}

\section{ESTRATEGIA}

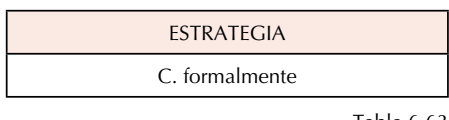

La estrategia básica de la comunicación es la estructura compositiva, apoyada por la retórica y el contraste visual, por lo que podemos concluir que se trata un diseño conducido formalmente.

RITMO

Las diferentes figuras se colocan siguiendo un patrón radial por lo que debemos hablar de una composición predictible, sin embargo, fuera de este patrón, esta estructura no se traduce en una regularidad rígida.

El nivel de conexión establecido entre los diferentes pasos de la comunicación es alto, por lo que podemos afirmar que se trata de una composición continua. Las imágenes que se disponen no muestran la realización de ninguna actividad, sin embargo la estructura compositiva les dota de cierto movimiento.

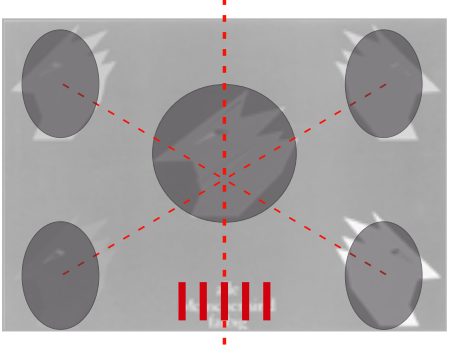

\begin{tabular}{|c|c|c|c|}
\hline \multicolumn{4}{|c|}{ RITMO } \\
\hline $\begin{array}{c}\text { REGULARIDAD } \\
\text { IRREGULARIDAD }\end{array}$ & $\begin{array}{l}\text { PREDICTIBLIIDAD } \\
\text { ESPONTANEIDAD }\end{array}$ & $\begin{array}{c}\text { CONTINUIDAD } \\
\text { EPISODICIDAD }\end{array}$ & $\begin{array}{c}\text { PASIVIDAD } \\
\text { ACTIVIDAD }\end{array}$ \\
\hline 2 & 1 & 1 & 2 \\
\hline
\end{tabular}

\section{EQUILIBRIO}

Los elementos de la composición se encuentran distribuidos de tal modo que la distribución del peso es completamente equilibrada. El eje central queda claramente marcado por la situación de una figura y la tipografía. Esta figura central tiene una clara dirección, lo que rompe lo que de otro modo sería una composición de marcada estructura simétrica.

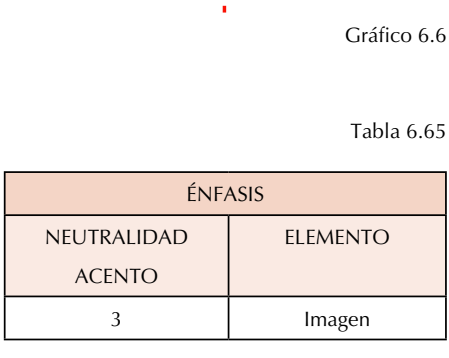

\begin{tabular}{|c|c|}
\hline \multicolumn{2}{|c|}{ EQUILIBIO } \\
\hline EQUILIBRIO-INESTABILIDAD & SIMETRÍA-ASIMETRÍA \\
\hline 1 & 2 \\
\hline
\end{tabular}

\section{ÉNFASIS}

Podemos afirmar que el énfasis de la comunicación recae en la imagen de forma muy marcada, tanto por el contraste cromático respecto del fondo como por su estructura.
UNIDAD

La comunicación se produce mediante la repetición de imágenes fragmentadas con una misma estructura, lo que dota de simplicidad al conjunto al tiempo que permite conformar una composición singular. Estas figuras se representan con una gran economía de detalles.

\begin{tabular}{|c|c|c|c|}
\hline \multicolumn{4}{|c|}{ UNIDAD } \\
\hline $\begin{array}{c}\text { SIMPLICIDAD } \\
\text { COMPLEIDAD }\end{array}$ & $\begin{array}{c}\text { UNIDAD } \\
\text { FRAGMENTACIÓN }\end{array}$ & $\begin{array}{c}\text { PROFUSIÓN } \\
\text { ECONOMÍA }\end{array}$ & $\begin{array}{c}\text { SINGULARIDAD } \\
\text { YUXTAPOSICIÓN }\end{array}$ \\
\hline 1 & 3 & 3 & 1 \\
\hline
\end{tabular}

COLOCACIÓN

Tanto las figuras formales como la tipografía son elementos cuya yuxtaposición se produce mediante opacidad. Igualmente podemos hablar de coherencia en la colocación ya que los elementos de encuentran agrupados de forma homogénea.

La relación entre la figura y el fondo es estable, sin dar lugar a juegos de lectura entre ambas. La alineación tipográfica es sensiblemente a eje, siendo el eje el margen izquierdo del cartel. La estructura compositiva se ajusta claramente a los límites definidos por el borde del cartel.

\begin{tabular}{|c|c|c|c|c|}
\hline \multicolumn{5}{|c|}{ COLOCACIÓN } \\
\hline $\begin{array}{c}\text { OPACIDAD } \\
\text { TRANSPARENCIA }\end{array}$ & $\begin{array}{c}\text { COHERENCIA } \\
\text { VARIACIÓN }\end{array}$ & FIGURAFONDO & REMARCA & $\begin{array}{c}\text { ALINEACIÓN } \\
\text { TIPOGRÁFICA }\end{array}$ \\
\hline 1 & 1 & Estable & Ajusta & Ejes \\
\hline
\end{tabular}

PERSPECTIVA

La ausencia de sombras y gradación nos indican que se trata de una representación de perspectiva plana.

\subsubsection{Anatomía del mensaje}

\section{REPRESENTACIÓN Y ABSTRACCIÓN}

La ausencia de detalles en la representación de las figuras suponen un nivel surrealista de representación, al igual que podemos hablar de amorfismo en la abstracción, ya que apenas hay similitudes entre la forma representada y la realidad.

\section{RETÓRICA VISUAL}

\section{Figuras semánticas}

La base de la comunicación la componen las figuras semánticas. Se trata de un cartel en el cual se reivindica la igualdad 
de las personas independientemente de su color de piel, por o que se utilizan figuras de sustitución y de comparación al representar el mismo rostro en 5 ocasiones, sin diferencias entre sí más que el color de las mismas.

\section{Figuras sintácticas}

El uso de figuras sintácticas es paralelo al de las figuras semánticas, ya que se basa en la repetición de elementos al tiempo que las características formales de los mismos, en este caso el color, les aportan significado.

\begin{tabular}{|c|c|c|c|c|c|}
\hline \multicolumn{5}{|c|}{ RETÓRICA VISUAL } \\
\hline FIGURAS SEMÁNTICAS & \multicolumn{4}{c|}{ FIGURAS SINTÁCTICAS } \\
\hline DE SUSTITUCIÓN & DE COMPARACIÓN & DE SUPRESIÓN & REPETITIVAS & DE ADJUNCIÓN & DE TRANSPOSICIÓN \\
\hline Sí & Sí & 0 & Sí & Sí & Sí \\
\hline
\end{tabular}

Tabla 6.71

Siguiendo el modelo de análisis aquí propuesto, y del mismo modo que se han realizado estos 5 ejemplos de la muestra, procederemos al análisis de los 525 carteles de la muestra, cuyos datos quedan mostrados en el «Anexo III» y cuyos resultados se reflejan en el siguiente capítulo. 
7. Análisis e interpretación de los datos

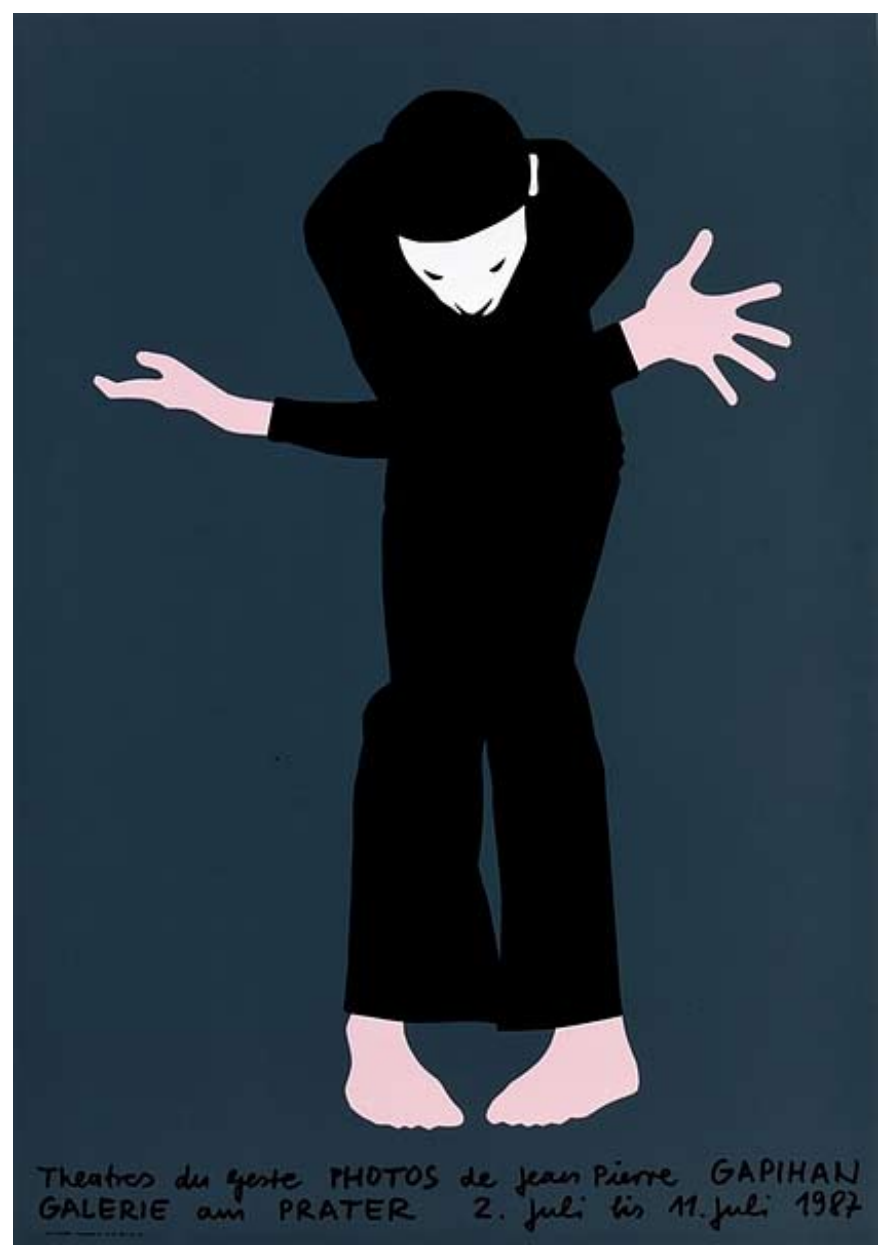


Todos los datos obtenidos del análisis de la muestra han sido sometidos a un análisis estadístico para poder comprobar el valor de sus parámetros para cada año y la tendencia establecida entre ellos.

Como refuerzo para lograr una descripción objetiva se establecen líneas de tendencia estadística basadas en las medias móviles para periodos de 5 años. La media móvil

aplica una línea de tendencia curva para mostrar los valores de los datos mientras atenúa las fluctuaciones de los datos para mostrar con mayor claridad la pauta o la tendencia basándose en la siguiente ecuación:

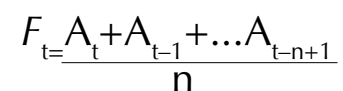

donde $\mathrm{A}$ es el valor de cada periodo y $\mathrm{n}$ el número de periodos.

\subsection{DATOS TÉCNICOS}

7.1.1 Datos la muestra

En esta investigación hemos optado por la selección de una muestra no probabilística -o muestra dirigida- como medio para asegurarnos la selección de una muestra representativa y homogénea temporalmente. Hemos seleccionado una muestra cualitativa según casos típicos basada en selecciones previas realizadas por autores de prestigio:

- TIPPACH-SCHNEIDER, Simone (2004): Das grosse Lexikon der DDR-Werbung: Kampagnen und Werbesprüche, Macher und Produkte, Marken und Warenzeichen. Schwarzkopf \& Schwarzkopf, Berlin.

- Verband der Grafik-Designer (1996): 128 Plakate aus 30 Jahren Wettbewerb «die 100 besten Plakate des Jahres». Berlín

- WUNDERLICH, Sylke (2007): Überklebt: Plakate aus der DDR. Ausstellung der Landeshauptstadt Schwerin im Schleswig-Holstein-Haus 24. Augus bis 21. Oktober 2007. Verlagsgruppe Schwerin Schwerin.

- Zentralvorstand des Verbandes Bildender Künstler der DDR, edit (1989): P40. Plakate von 1945 bis zum Gegenwart. Eine Ausstellung im 40. Jahr der $D D R$. Graphischer Grossbetrieb, Leipzig. 
Hemos analizado un total de 525 carteles diseñados por 216 artistas diferentes cuya distribución a lo largo del periodo analizado es la siguiente:

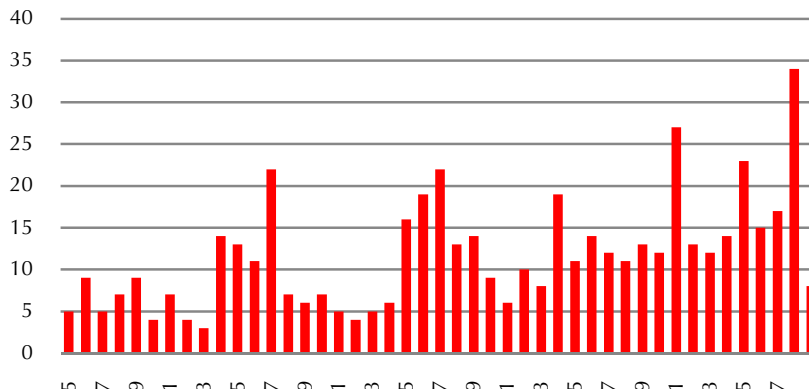

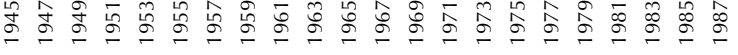

Gráfico 7.1

Si bien la distribución de la misma no es homogénea a lo largo de toda la historia de la RDA -probablemente debido a que tanto la producción de carteles como su conservación tampoco lo fue- nos encontramos con elementos suficientes de todos los periodos.

7.1.2 Hitos históricos

Para poder relacionar la evolución del diseño gráfico con la realidad socio-política de la RDA establecemos un gráfico con los hitos más importantes de la historia de la RDA basado en la tabla 3.1 «Cronología de la RDA», en el cual la altura del gráfico indica la transcendencia según los autores investigados.

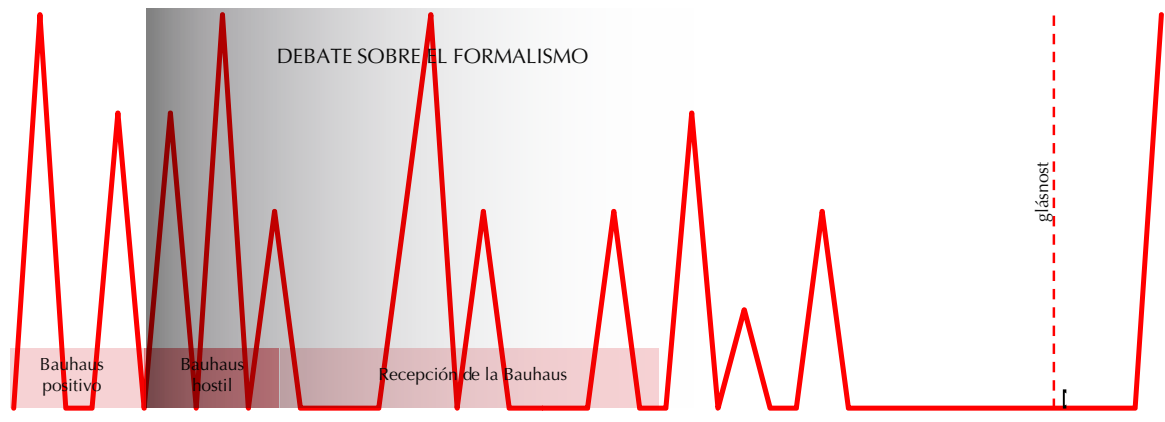

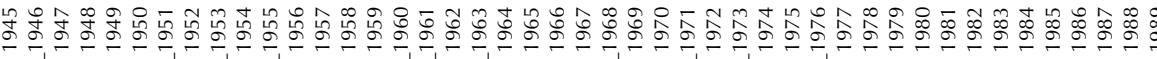

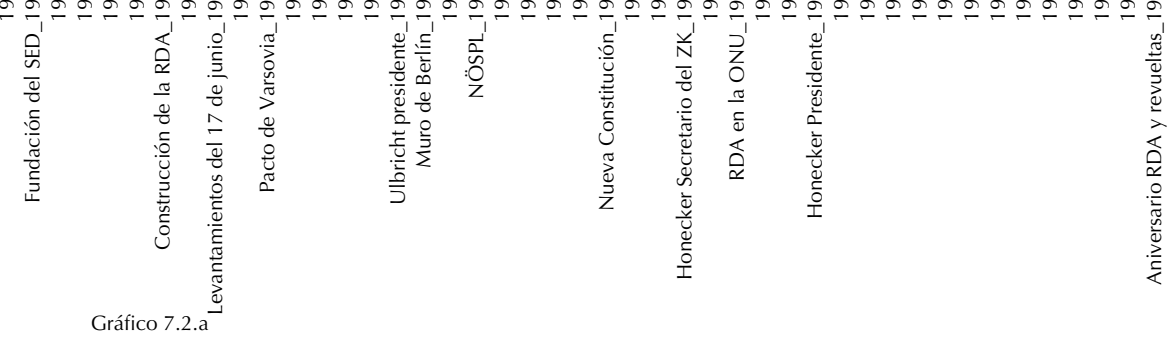

Igualmente añadiremos al esquema aquellas consideraciones artísticas y culturales decretadas a nivel gubernamental descritas en el capítulo 3.4. Contexto socio-cultural. El debate sobre el formalismo que comenzó a principios de los años 50 y que permaneció vigente hasta casi los años 70 es un elemento fundamental que debe ser tenido en cuenta en la interpretación de los datos, así como la postura gubernamental sobre la escuela de la Bauhaus, desde el desprestigio hasta su enaltecimiento.

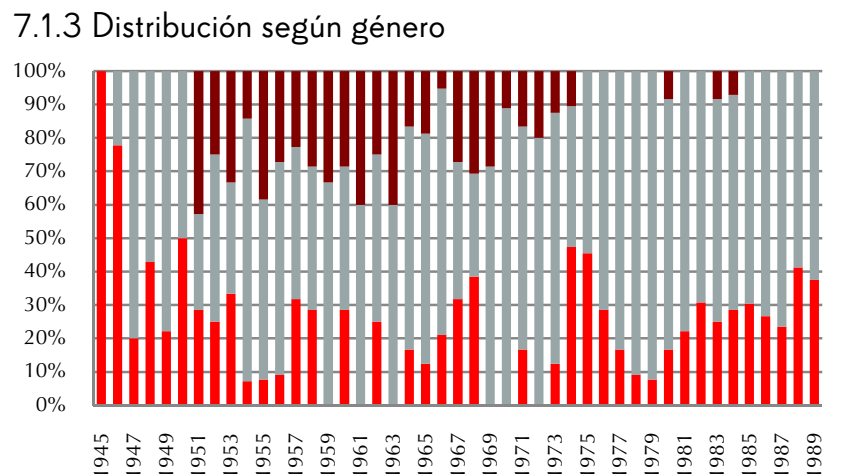

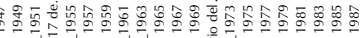

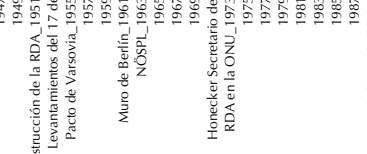

Gráfico 72

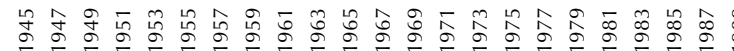

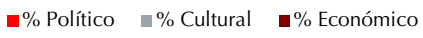

Gráfico 7.3

La mayor parte de los carteles destacados por la Verband Bildender Künstler y por la Dr. Wunderlich se engloban en el género de carteles culturales, sin embargo podemos observar una mayor presencia de carteles políticos en aquellos momentos de la RDA con mayor agitación, tales como los primeros años de posguerra -donde el cartel político supone un amplio porcentaje del diseño realizadoel comienzo de la década de los 50 -coincidiendo con la Construcción del socialismo-, la construcción del Muro de Berlín, la aprobación de la constitución de 1968, el cambio Honecker como presidente del Consejo y la entrada de la RDA en la ONU a mediados de los 70. Con la apertura de la RDA al panorama internacional, los carteles políticos sustituyen su carácter nacional por el de los acontecimientos internacionales y los movimientos solidarios. El último hito lo supondrá la celebración de los 40 años de RDA a finales de los 80.

El escaso porcentaje de carteles de carácter económico presente en las selecciones globales sobre diseño gráfico de la RDA -inferior al $6 \%$ del total de la colección- supuso la necesidad de añadir un conjunto específico de carteles de carácter económico al total de la muestra, al tiempo que pone en evidencia la escasa representatividad que tuvieron dentro del diseño de la RDA. 
Al mismo tiempo, a partir de 1974, los carteles económicos se reducen a la información sobre ferias de muestras, desapareciendo la promoción de productos dentro del territorio. Esto supone su presencia muy esporádica y en un bajo porcentaje -inferior al $10 \%$ - lo que no permite una lectura clara y objetiva de los datos obtenidos. Por esto el análisis sobre los carteles económicos se reduce al periodo comprendido entre 1951 y 1974 , donde contamos un porcentaje de datos continuo y suficientemente representativo.

Al igual que en el caso de los carteles económicos, la presencia de carteles políticos no es continua en la muestra, sino que varios momentos de la historia no cuentan con elementos de esta categoría. Para evitar falsas interpretaciones de los gráficos, se sitúan bandas en color rojo claro en aquellos años en los que carecemos de datos, de tal modo que nos permita distinguir entre datos de valor 0 y ausencia de datos.

7.1.4 Medio de reproducción

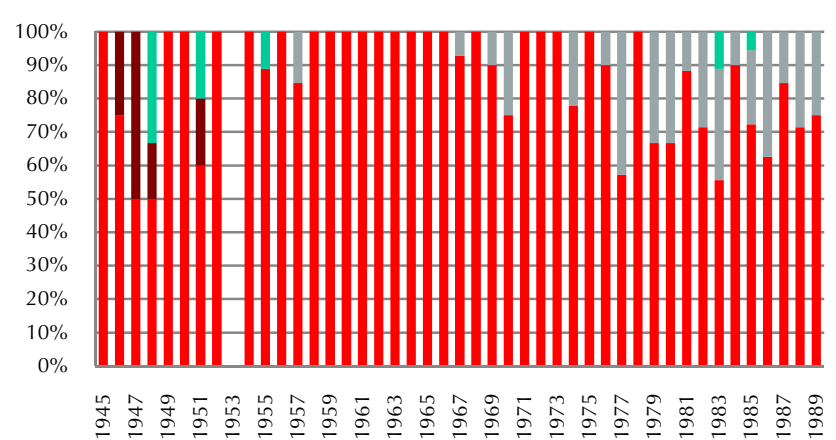

El modo de reproducción mayoritario será mediante máquinas de Offset, con una breve presencia de litografías a comienzo durante la SBZ y la paulatina introducción de serigrafía a finales de los años 60.

El sistema Offset es un procedimiento de impresión indirecta con un coste de realización de la plancha no muy elevado y especialmente rentable para grandes tiradas. También la impresión en imprenta de plomo tuvo una relativa importancia en los primeros años debido a la accesibilidad y economía de las mismas.

Las litografías que gozaron de gran popularidad a comienzos de siglo debido a que permitía obtener un buen número de copias de un mismo trabajo, apenas estará presente durante los primeros años de la SBZ, desapareciendo por completo tras 1951.
La serigrafía, por ser un sistema de impresión que transfiere la tinta directamente al soporte a través de una fina malla en red, solo es efectiva en imágenes cromáticamente sencillas, pero cuenta con la ventaja de que permite la impresión de colores vivos con gran resistencia y permanencia al aire libre.

Esta resistencia supuso un elemento determinante para su paulatina introducción en la reproducción de los carteles a partir de finales de los años 60. 
7.2 ELEMENTOS BÁSICOS

7.2.1 Código morfológico

59. Los datos se reflejan en primer lugar en gráficos distinguiendo entre los diferentes géneros (cultural, económico y político), rotulados en redonda, y a continuación en un único gráfico general que engloba los datos de totalidad de la muestra, rotulado en negrita.

TIPO DE ESQUEMAS FORMALES 59

CULTURALES

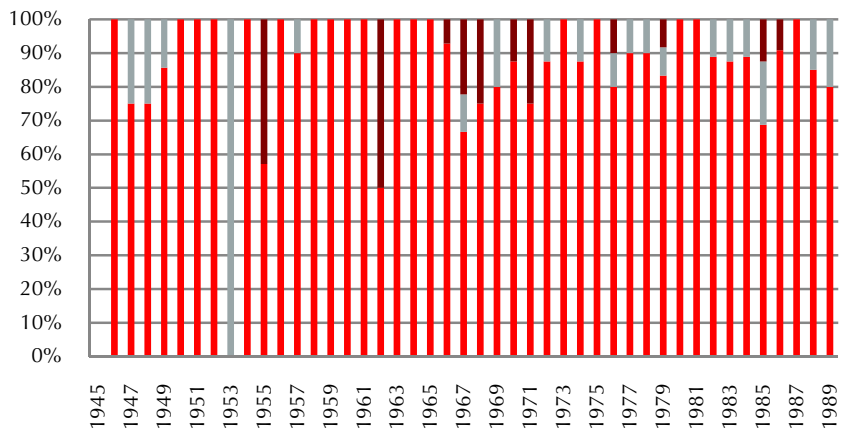

ECONÓMICOS

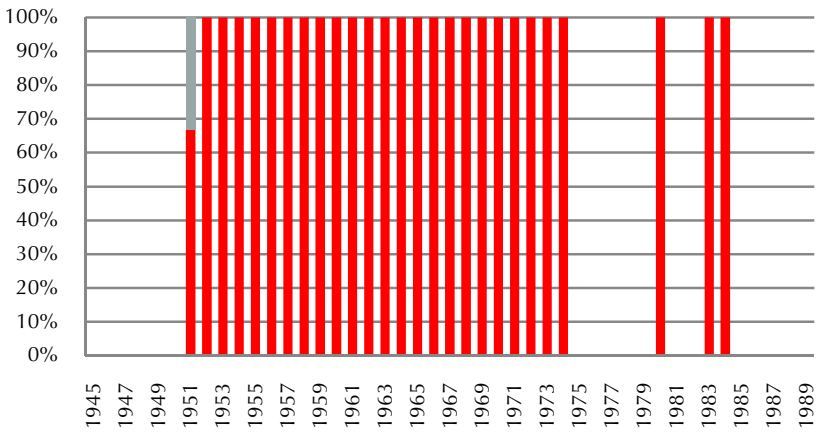

POLÍTICOS

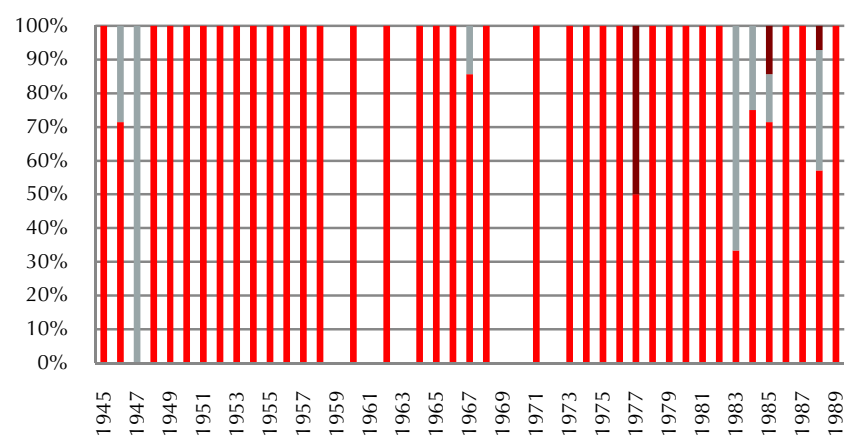

GENERAL

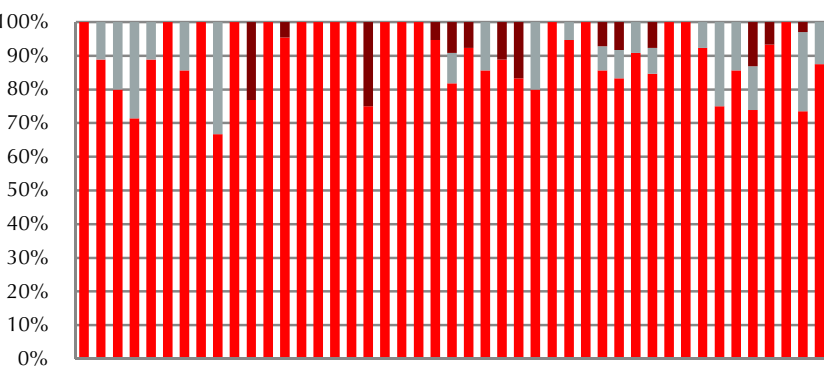

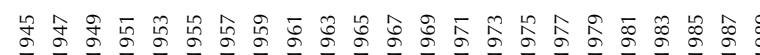

Gráfico 7.5

La presencia de esquemas formales no figurativos no implica la ausencia de esquemas formales figurativos. Si analizamos globalmente los esquemas formales, nos encontramos que en una media superior al $70 \%$-llegando incluso al $100 \%$ en varios periodos los carteles de la muestracuentan con esquemas formales figurativos, los cuales en su mayoría suponen el elemento formal principal, contando con los elementos formales abstractos como elemento de apoyo.

Esta tendencia es especialmente notable en la década de los 50 y 60, donde la única alternativa a los esquemas formales figurativos residía en carteles exclusivamente tipográficos.

Llama la atención el absoluto dominio de los esquemas figurativos en el plano económico, donde la imagen se presenta prácticamente como único medio de transmisión de la comunicación

La mayor libertad en cuanto a esquemas morfológicos tendrá lugar dentro del plano cultural, donde pese la escasa presencia de otros tipos de morfología, esta es prácticamente continua a lo largo de todo el periodo analizado. El caso contrario lo encontramos en el plano político, donde los carteles no figurativos se reducen a periodos determinados; los primero años de posguerra y la última década de la RDA. 
CULTURALES

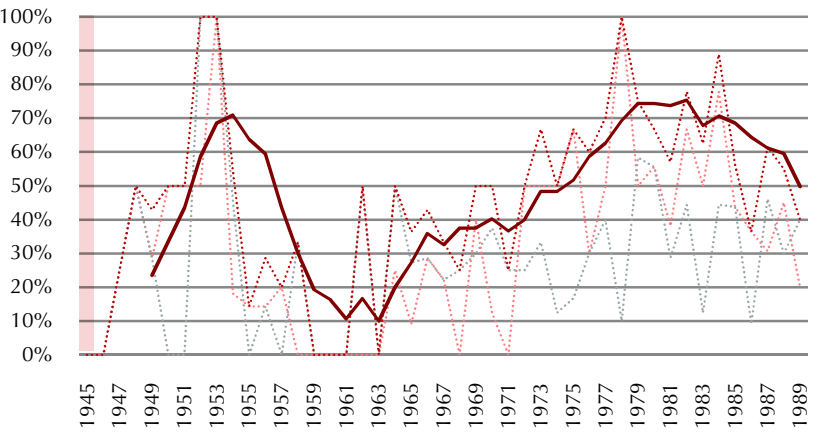

ECONÓMICOS

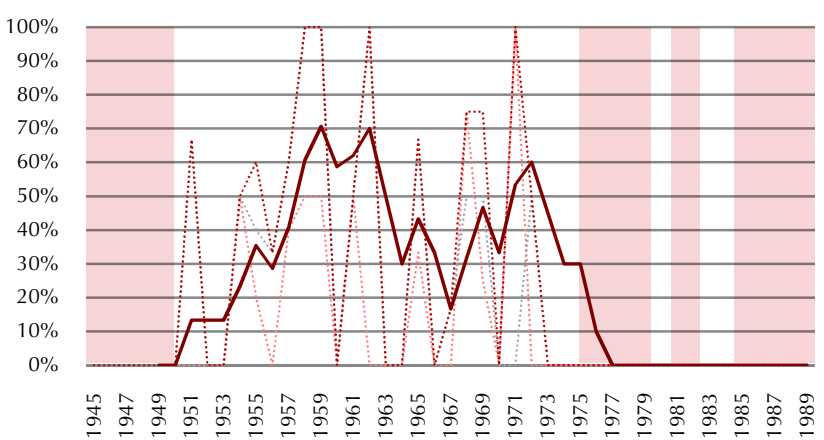

POLÍTICOS

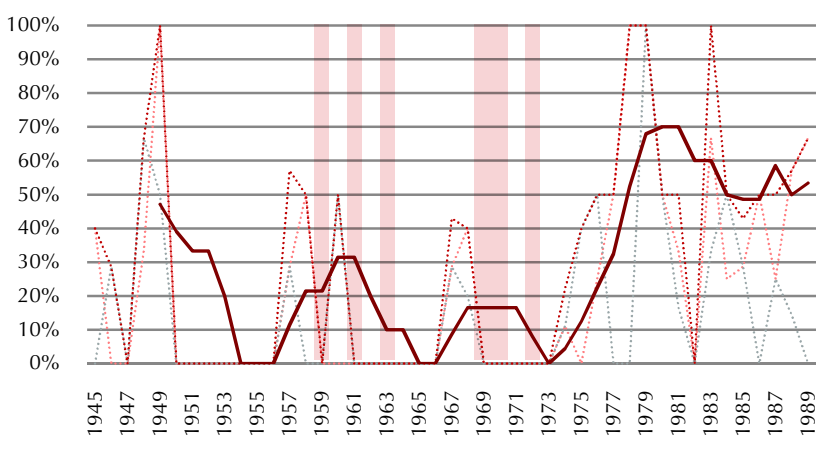

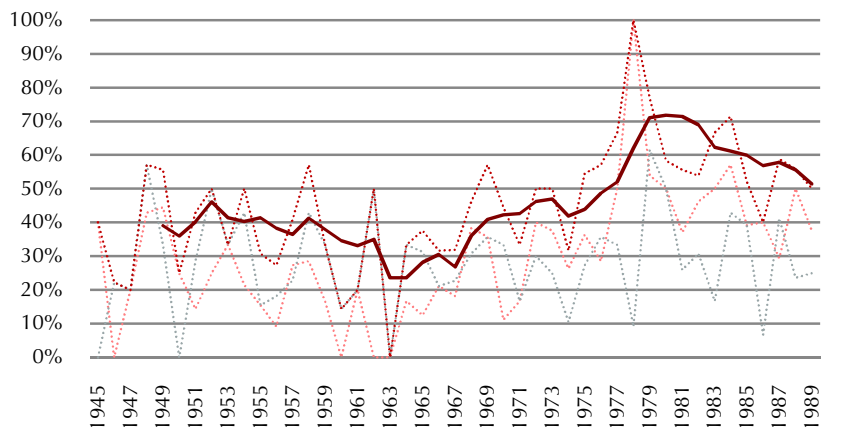

................. \% con línea

$\%$ con contorno

c.......... \% esquemas no figuratives

5 per. media móvil (\% esquemas no figurativos

La presencia de esquemas formales no figurativos, tales como líneas o contornos tendrá su punto álgido a comienzo de los 80 , hasta el momento, y a excepción de una considerable presencia a comienzo de los años 50, tendrá una escasa representación, especialmente en los años 60 dónde apenas aparece en el $30 \%$ de la muestra.

Este esquema se produce de forma notablemente más destacada en los carteles culturales. Aquí nos encontramos con presencia de elementos formales no figurativos en porcentajes cercanos al $70 \%$ en los periodos anteriormente descritos, mientras que a comienzo de los años 60 ronda entre el 10 y el $20 \%$.

La misma gráfica se repite en el plano político, con una ausencia total de elementos no figurativos en la primera mitad de los años 50. En el plano económico sin embargo no se observa esta diferenciación tan marcada, sino que fluctúa en torno al $50 \%$ a lo largo de todo el periodo. 
CULTURALES

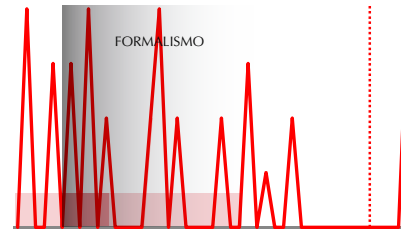

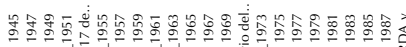

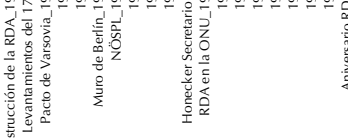

Gráfico 7.2.1

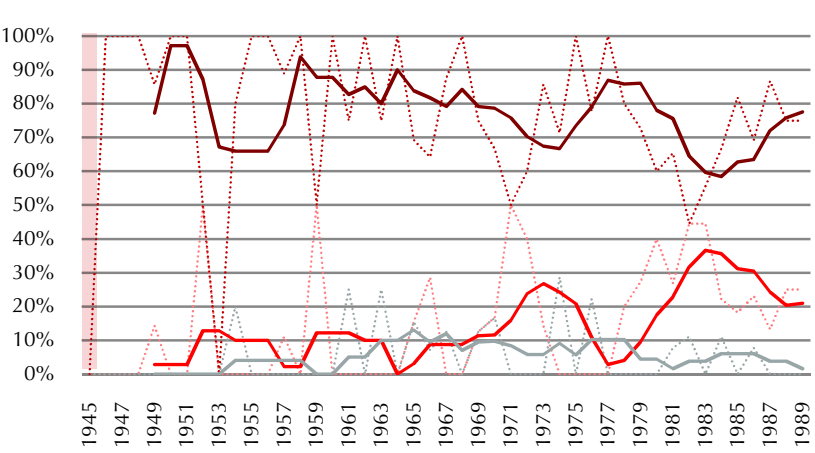

ECONÓMICOS

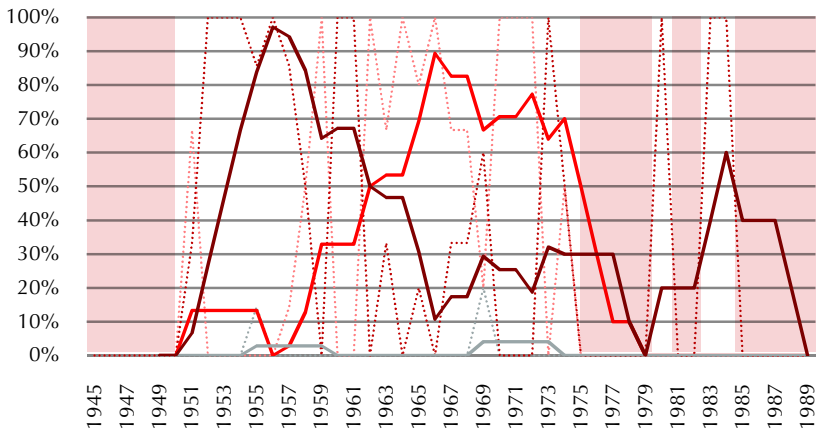

POLÍTICOS

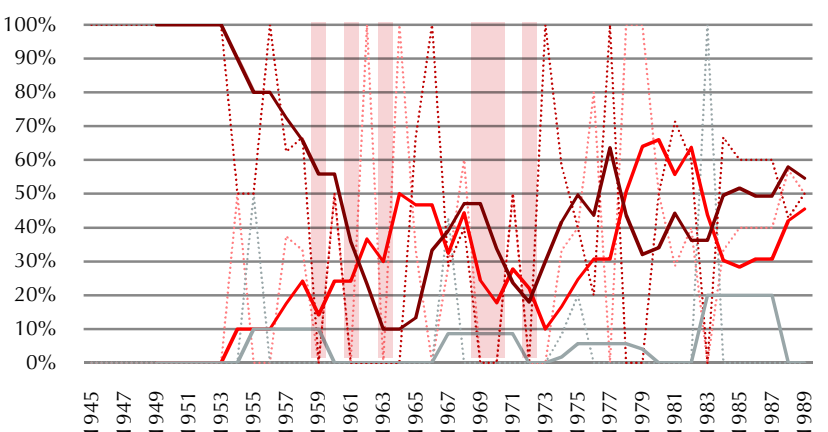

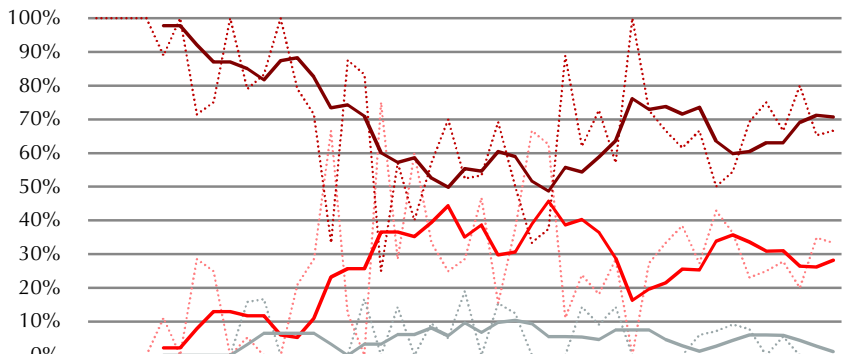

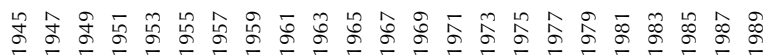

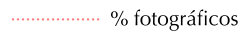

(\% fotográficos) 5 per. media móvil (\% histórico)

Hemos analizado los esquemas formales figurativos según 7 tipos de fabricación diferente que pueden ser clasificados de la siguiente manera:

- Fotográficos: aquellos que implican el uso de una cámara fotográfica, lo que abarca los fotomontajes, fotografías y las alteraciones fotográficas.

- Históricos: los provenientes de material histórico, independientemente de su modo de reproducción.

- Pictóricos: aquellos realizados manual o digitalmente por un artista o diseñador e incluye dibujos, grabados, sobrepinturas y collage.

Dentro de los medios de representación figurativos sin duda destacan los medios pictóricos, casi exclusivos en los años 50. Poco a poco se irán introduciendo los medios fotográficos que gozarán de una gran popularidad en los años 60, aunque a nivel global no le permitió superar la presencia de elementos pictóricos en ningún momento de la historia de la RDA. Es también en la década de los años 60 cuando el uso de material histórico tenga una mayor presencia, con porcentajes situados entre el $10 \%$ y el $20 \%$ de los carteles analizados.

El cartel cultural estará dominado casi exclusivamente por las imágenes pictóricas, sin embargo es aquí donde el material histórico se utilizará con mayor frecuencia.

El plano económico presenta una fuerte simetría en su uso de la imagen; previamente a 1962 los dibujos dominaban casi exclusivamente los carteles publicitarios, mientras que a partir de esta fecha la fotografía cogerá el relevo suponiendo más del $70 \%$ de los carteles.

Los carteles políticos se reparten a partir de esta fecha a partes iguales entre ambos tipos de reproducción, con una escasa presencia del material histórico. 


\section{USO DEL COLOR}

CULTURALES

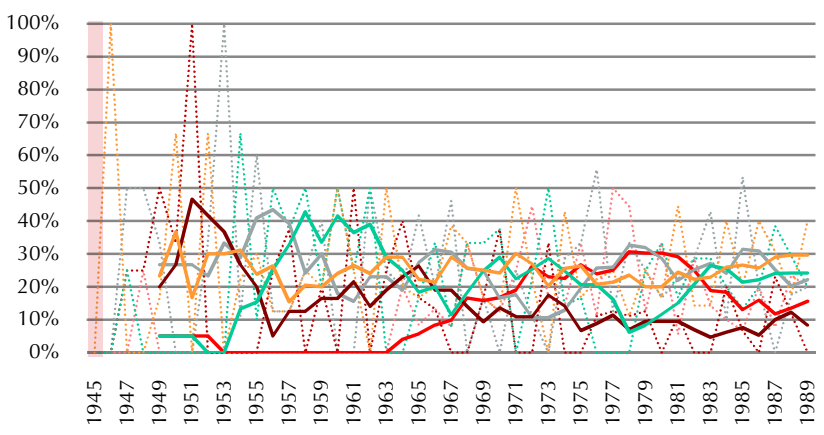

ECONÓMICOS

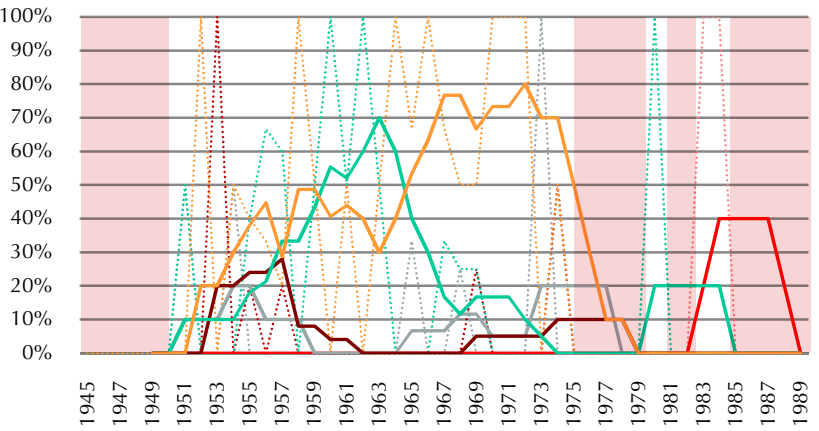

POLÍTICOS

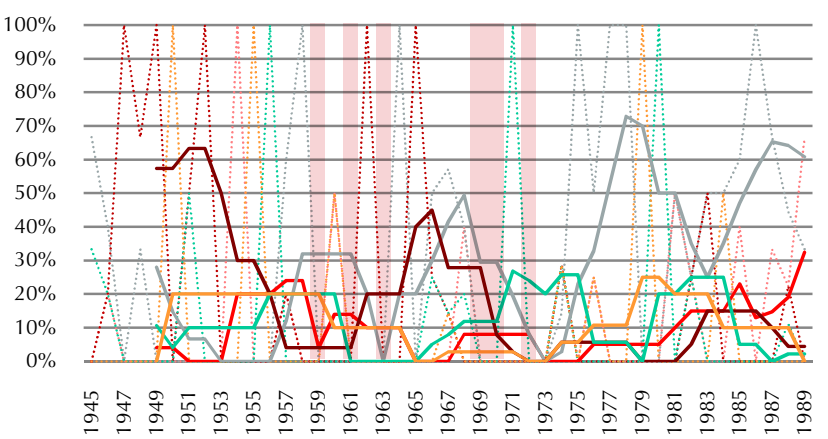
por los colores planos del Sachsplakat. uso del color. ciones cromáticas.
$90 \%$
$80 \%$

$60 \%$
$50 \%$

$30 \%$

$20 \%$

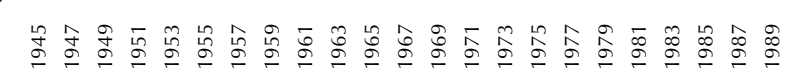

— 5 per. media móvil $(\%$

monocromía) 5 per. media móvil (\% 3 colores 5 per. media móvil (\% tintas planas)
5 per. media móvil (\% realistal

El uso que se ha hecho del color ha sido un elemento característico de todos los movimientos alemanes previos a 1945 desde el uso simbólico de los expresionistas a la presencia de colores según sus cualidades físicas propio del funcionalismo -que lo reducía habitualmente a 3 colores- pasando

En la RDA no se percibe como claramente mayoritariamente ningún uso del color, si bien podemos decir que existe una mayor predilección por el uso de un número limitado de tintas ya que globalmente el número de carteles en los que se utilizan menos de tres colores diferentes supone más de la mitad. Llama la atención el incremento de los carteles monocromáticos a partir de mitad de los 60, momentos de recuperación económica que podrían presuponer un mayor

El uso de gamas cromáticas realistas no tendrá ningún peso especial, pese al debate sobre el formalismo, un periodo en el que destacará la presencia de tintas planas.

En el plano cultural podemos hablar de total libertad compositiva en cuanto al uso del color, ya que encontramos porcentajes muy equilibrados de todos los tipos de utiliza-

No es este el caso de los carteles económicos, donde primero las tintas planas y posteriormente el realismo serán claramente las tónicas dominantes. Los carteles políticos por su parte aparecerán reducidos a la presencia de 2 ó 3 colores independientes entre sí 
CULTURALES

ECONÓMICOS

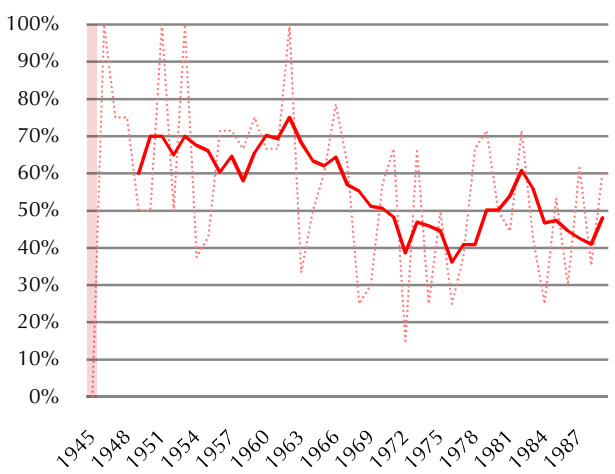

POLÍTICOS

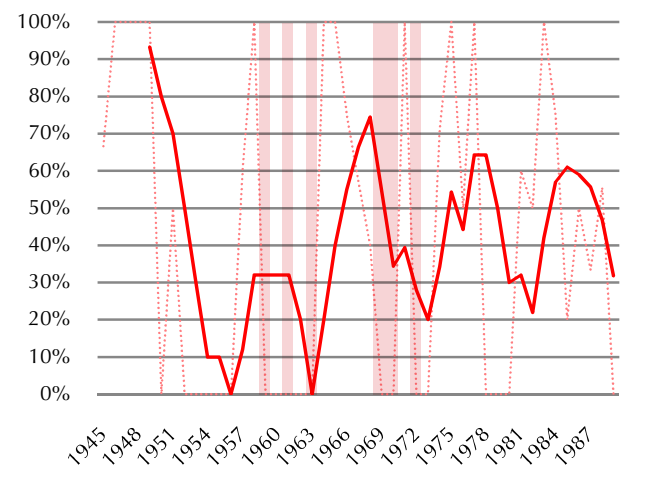

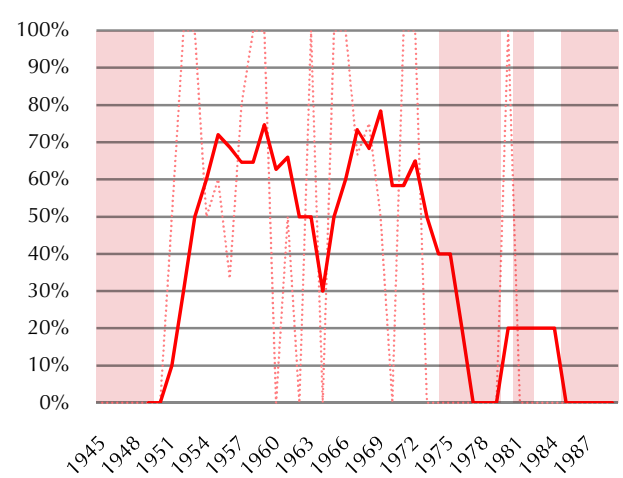

GENERAL

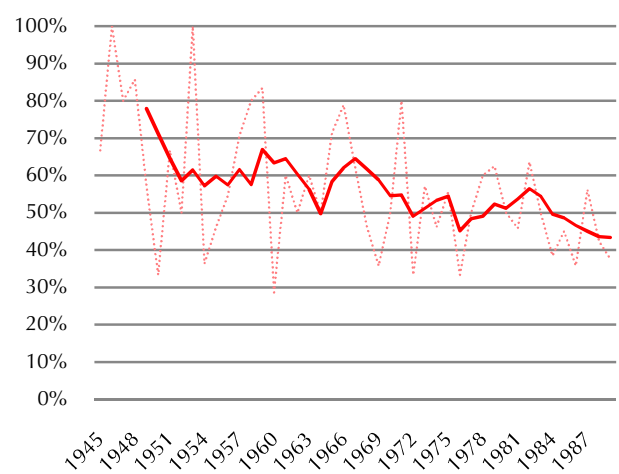

presencia de rojo

5 rojo

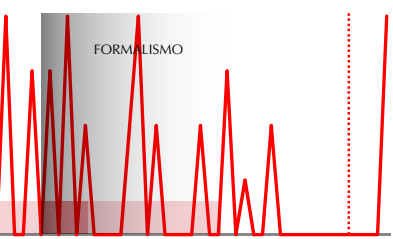

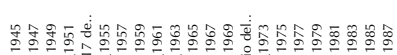

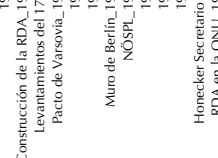

Gráfico 7.9 do a su fuerte asociación con el sistema político dominante en la RDA y con la revolución. Hablamos de presencia de rojo en un cartel, cuando este color aparece, no como parte del espectro cromático de la imagen, sino como elemento portador de la información, ya sea como factor simbólico, como contraste o como medio para captar la atención.

A nivel global el rojo aparece a lo largo de toda la historia en más del $50 \%$ de los elementos analizados, observándose no obstante una tendencia a la baja respecto de los primeros años en los que suponía porcentajes muy elevados a los últimos años en los que más de la mitad de los carteles dejaron paso al uso de otros colores.

Los acontecimientos históricos y políticos tienen repercusión en el uso del color rojo en todos los géneros analizados, siendo más evidente en aquellos carteles de contenido meramente político, campo en el cual el color rojo estará de cambio. En el cartel económico no se observan grandes diferencias derivadas de los acontecimientos, sino que su presencia se mantiene homogéneamente elevada.

\section{USO DEL ROJO COMO COLOR PRINCIPAL}

CULTURALES

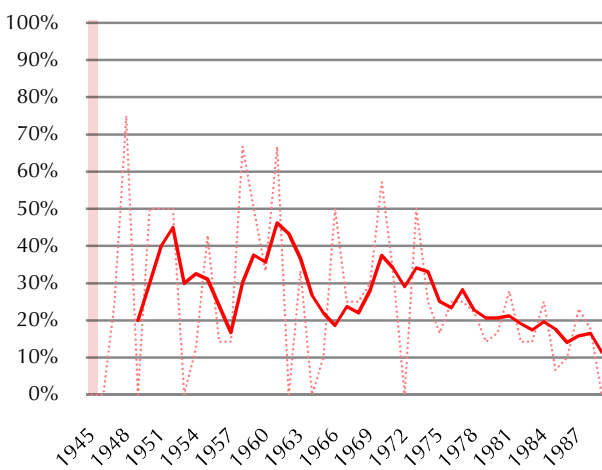

POLÍTICOS

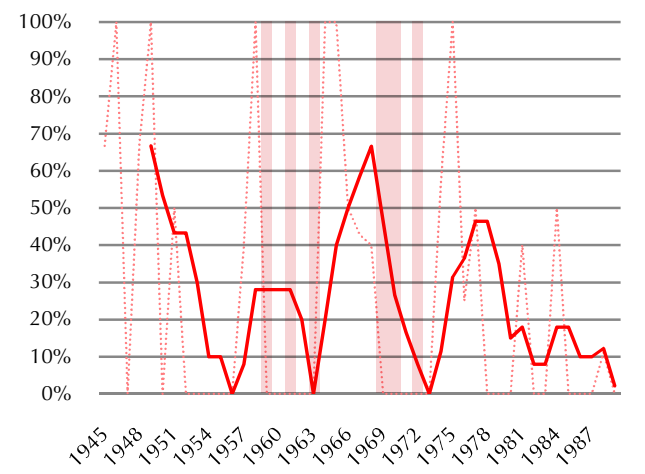

ECONÓMICOS

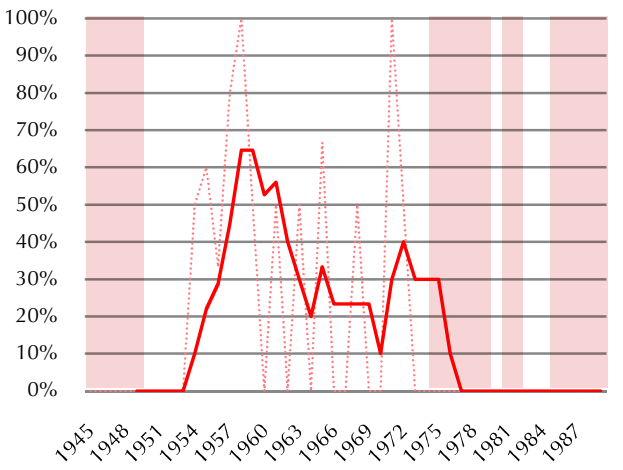

GENERAL

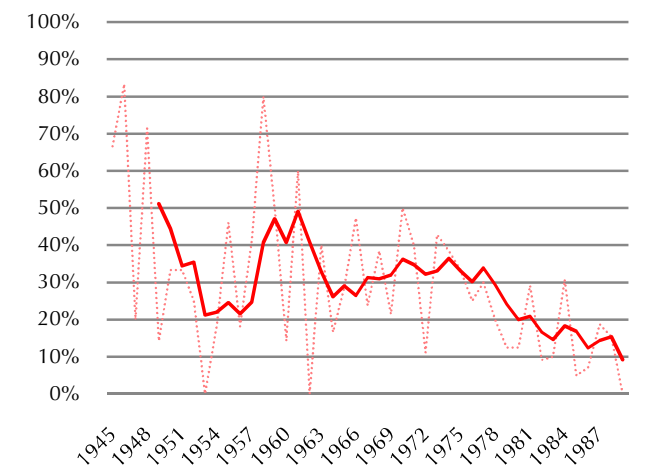

En el uso del color rojo como color principal observamos una tendencia a la baja muy marcada en la última década. Esta tendencia se presenta en todos los géneros, si bien en el plano cultural el declive comenzó en los años 70, mientas que en el político no se percibe hasta varios años más tarde.

Es en el uso del color rojo como color principal dónde queda patente su uso simbólico en los carteles políticos, donde apenas encontramos diferencia entre su presencia general y su uso principal en las primeras décadas analizadas. 
CULTURALES

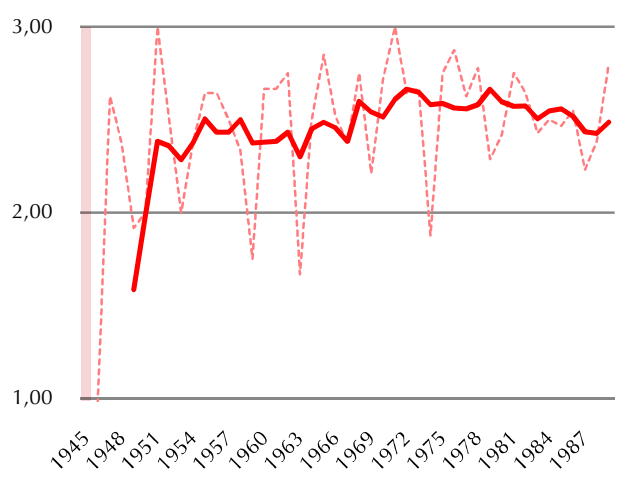

POLÍTICOS

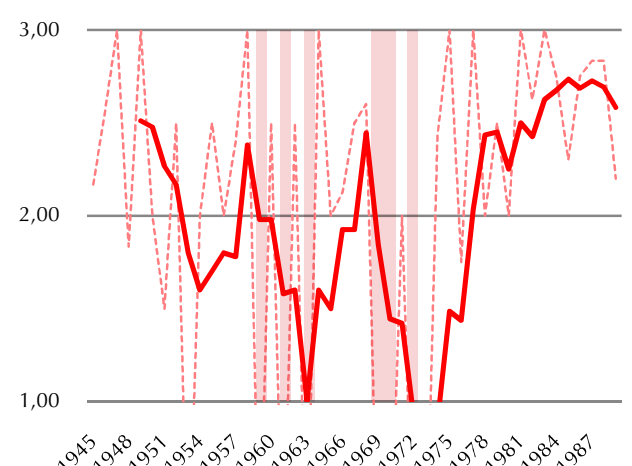

ECONÓMICOS

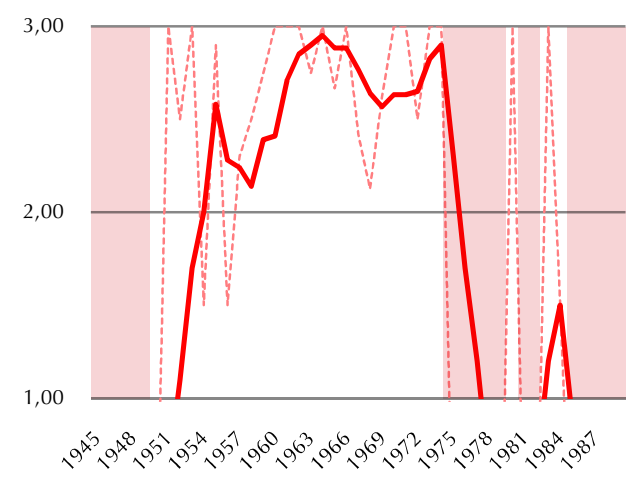

GENERAL

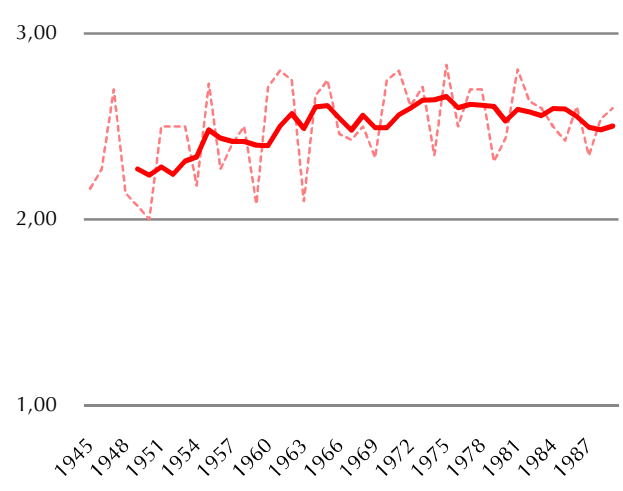

legibilidad

5 per. media móvil (legibilidad)

\section{LEYENDA EJE VERTICAL}

$\mathbf{1}=$ Legibilidad baja
$\mathbf{2}=$ Legibilidad media

$3=$ Legibilidad alta
La legibilidad cromática se mantiene a lo largo de toda la muestra en niveles bastante elevados, si bien podemos observar una cierta tendencia al alza, es decir, a un mayor contraste entre los colores contiguos.

Una alta legibilidad cromática supone una mejor percepción de la información, lo cual es especialmente importante cuando las calidades materiales son malas, ya que permite una mayor claridad del mensaje en condiciones adversas.

\subsubsection{Código tipográfico}

\section{TIPO DE REPRODUCCIÓN}

CULTURALES

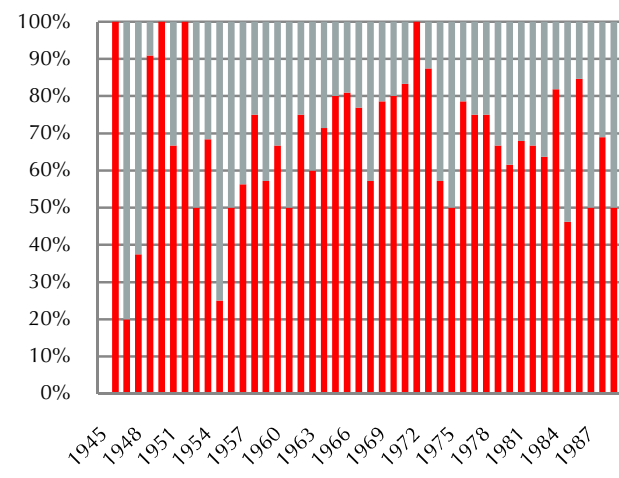

POLÍTICOS

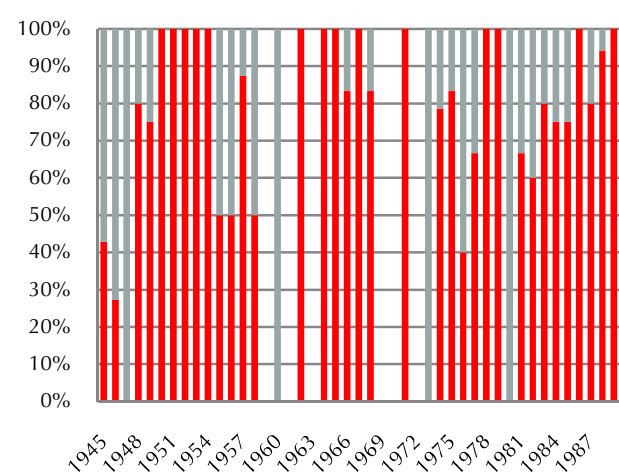

ECONÓMICOS

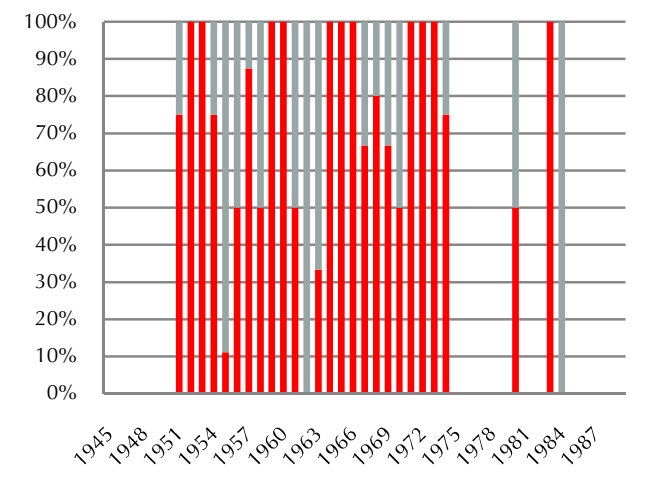

GENERAL

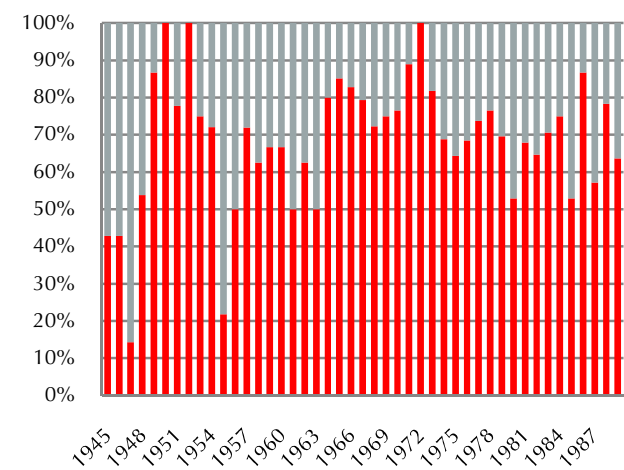

Pasados los años de posguerra la reproducción mecánica ya fuera mediante tipos de plomo ya mediante fotocomposición será la nota predominante en los carteles de la RDA, no obstante, no podemos despreciar la presencia de tipografía manual, que ronda entre el $30 \%$ y el $50 \%$ de la producción en varios momentos de la RDA.

No se aprecian diferencias significativas en la predilección de tipos de reproducción según los diferentes géneros. Resulta llamativo el monopolio de la tipografía reproducida manualmente en 1961, año de la construcción del Muro de Berlín, tanto en el cartel político como económico, mucho menos evidente en el cultural.
Mecánica

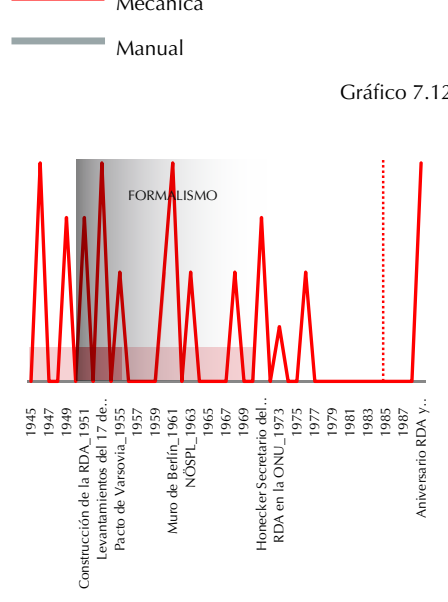


CULTURALES

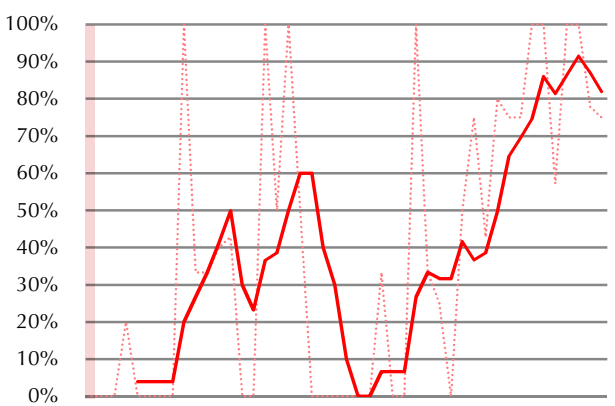

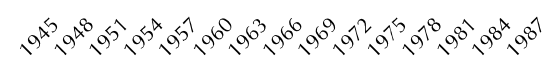

POLÍTICOS

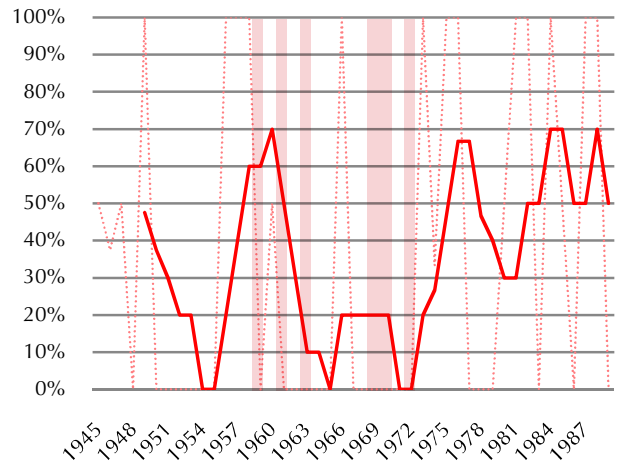

ECONÓMICOS

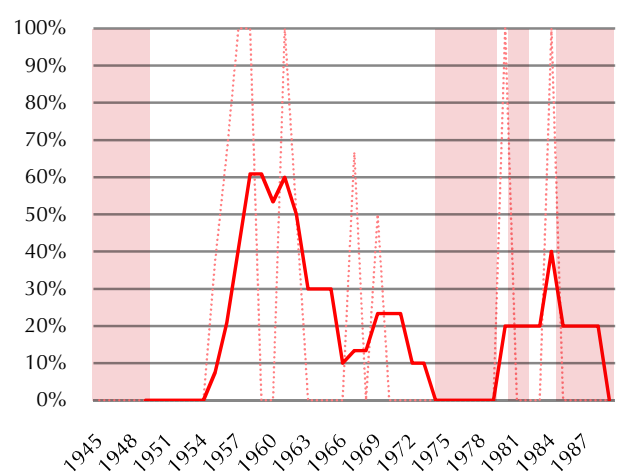

GENERAL

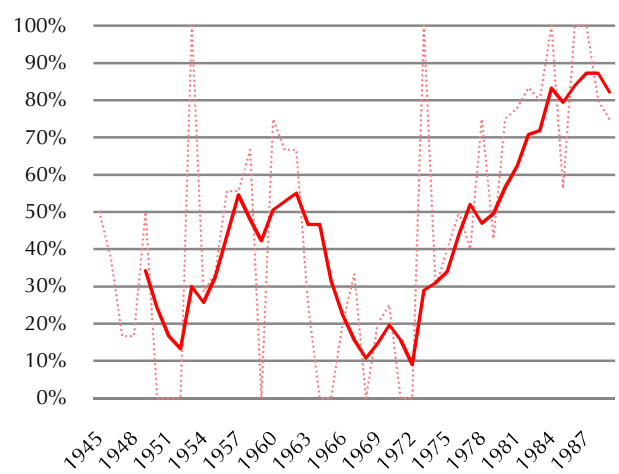

Tipografías manuales clase VII y IX per. media móvil (tipografías
manuales clase $V(I I Y$ IX) Grático 7.13

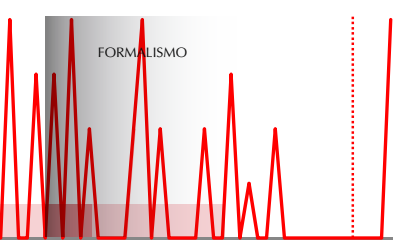

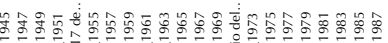

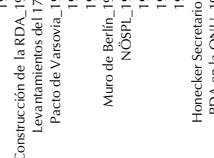

Dentro de la escritura realizada de forma manual, solo las clasificadas como VIII y IX responden a tipografías asociadas a la escritura manual (manuscrita y caligráfica respectivamente), el resto de ellas responden a escrituras de tipos habitualmente mecánicos pero realizados de forma manual. En los primeros años de SBZ/RDA la presencia de tipografías de estas dos familias es muy escasa, aumentando a mediados de los años 50. Esta tendencia se verá truncada a comienzo de los años 60, de nuevo desciende el uso de las mismas a finales de los 60 observándose una notable ascensión a partir de este momento, hasta suponer la práctica totalidad de las tipografías manuales.

Este esquema se repite en mayor o menor medida en todos los géneros analizados, si bien en el plano político se percibe una presencia de las escrituras manuales de clase Gráfico 7.2.b dentro de las manuales implica necesariamente un descenso de las tipografías de otras clasificaciones reproducidas manualmente.

PRESENCIA DE TIPOGRAFÍAS DE CLASE VIII Y IX EN LOS CARTELES DE LA MUESTRA
CULTURALES

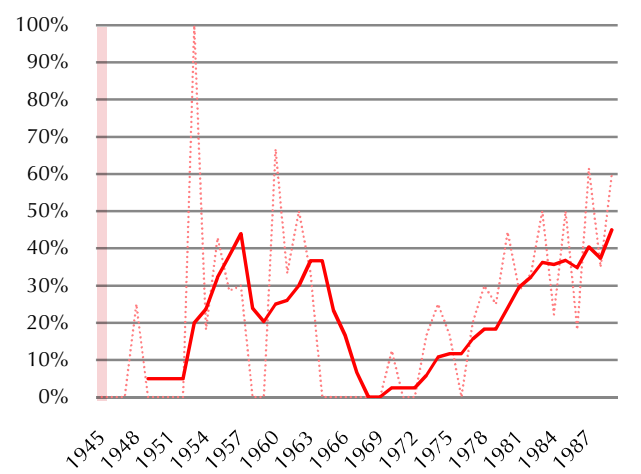

POLÍTICOS

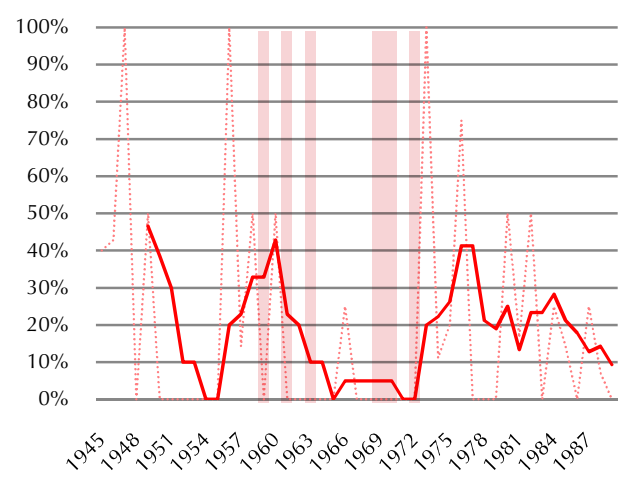

ECONÓMICOS

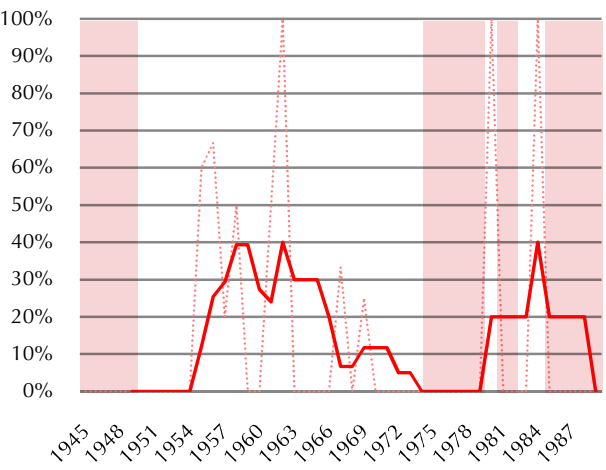

GENERAL

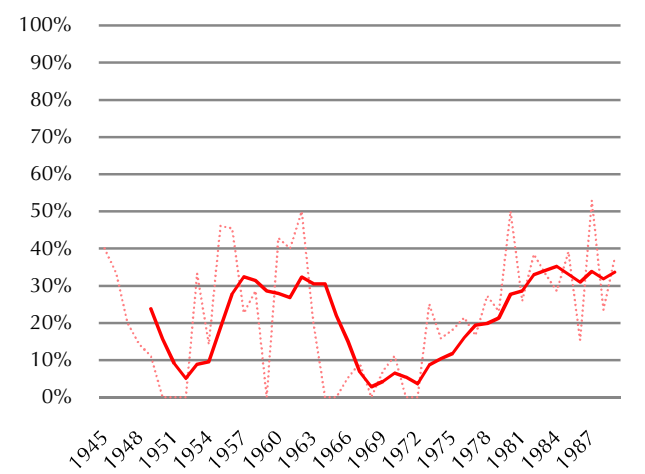

Si tenemos en cuenta la presencia de estas tipografías dentro de la muestra total este incremento final, si bien es sensible, es menos notable de lo que era dentro de las tipografías manuales. Se muestra una predilección por las tipografías manuales en los primeros años de la SBZ, entre 1955 y 1965, y un aumento paulatino a partir de mediados de los años 70 , mientras que su presencia en la segunda mitad de la década de los 60 es muy escasa.

Estas predilecciones son especialmente evidentes en el plano político, donde suponen un gran porcentaje en la SBZ, a finales de los 50 y la primera mitad de los 70 . 
PORCENTAIE DE TIPOGRAFÍA MECÁNICA PRODUCIDA POR LA VEB TYPOART

CULTURAIES

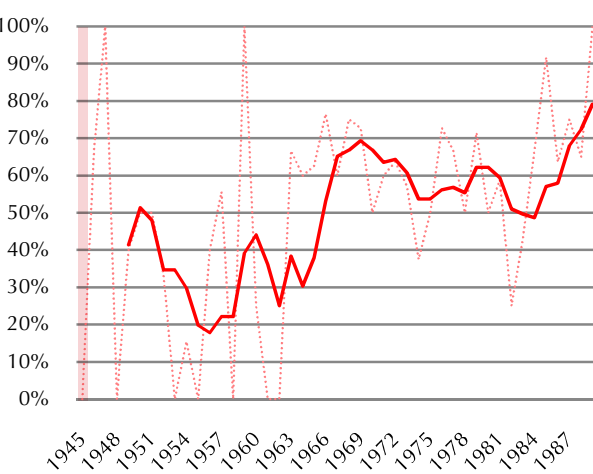

POLÍTICOS

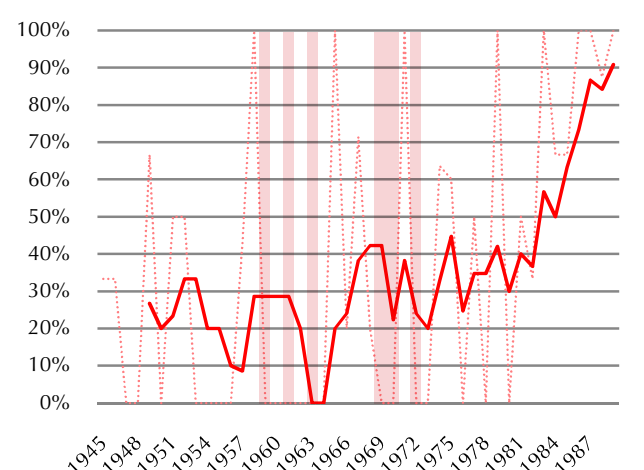

ECONÓMICOS

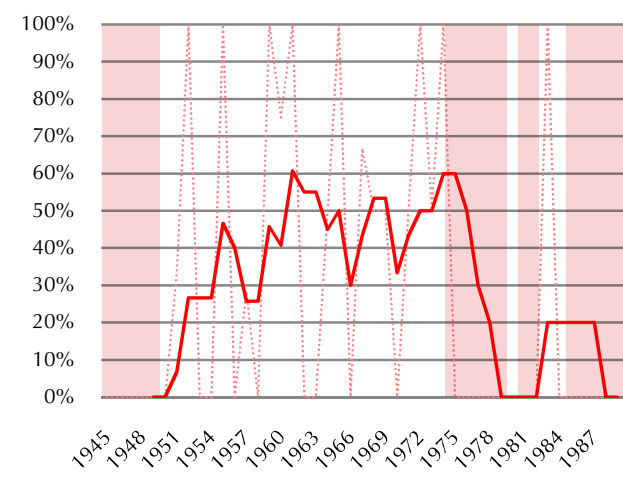

GENERAL

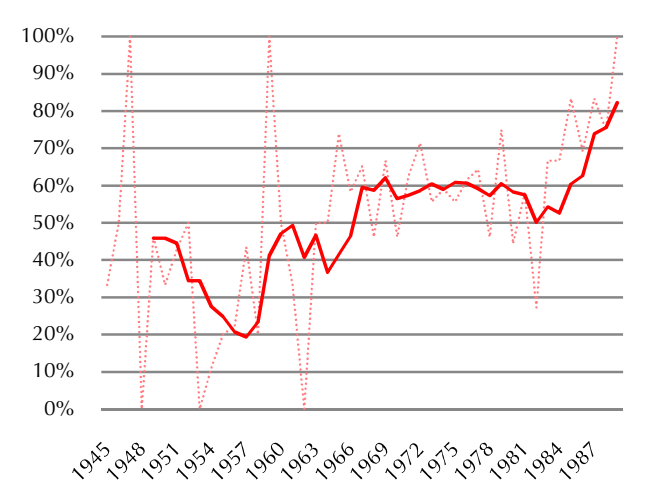

PORCENTAJE DE TIPOGRAFÍA DE LA VEB TYPOART EN LOS CARTELES DE LA MUESTRA
CULTURAL

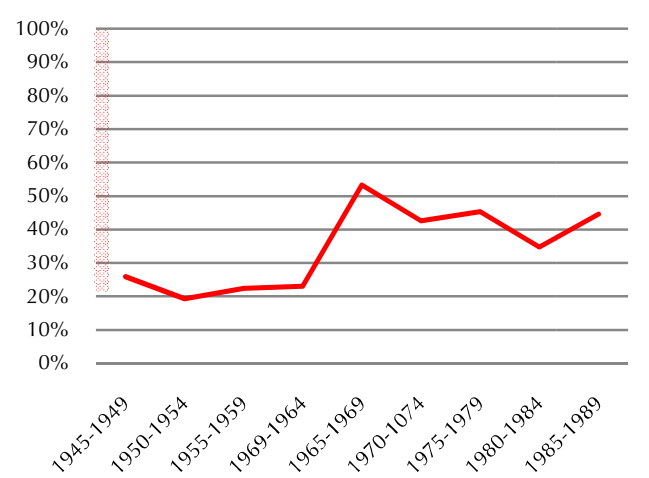

POLÍTICO

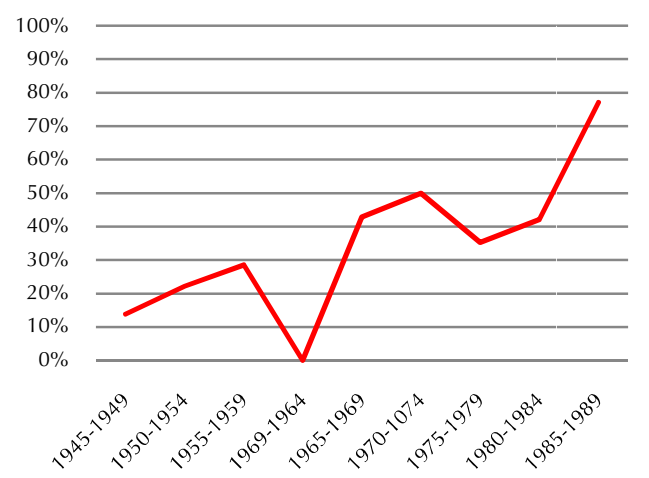

ECONÓMICOS

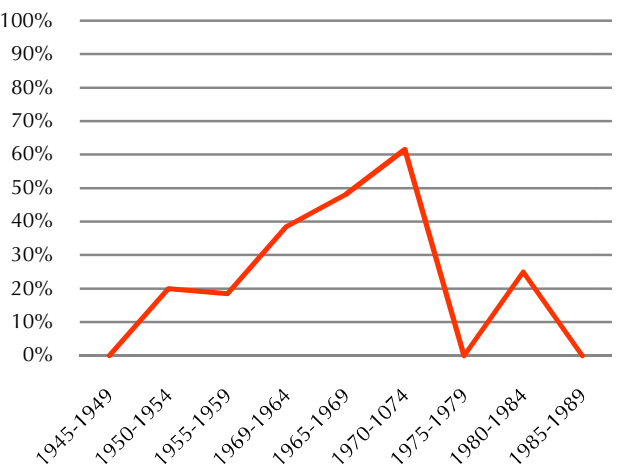

GENERAL

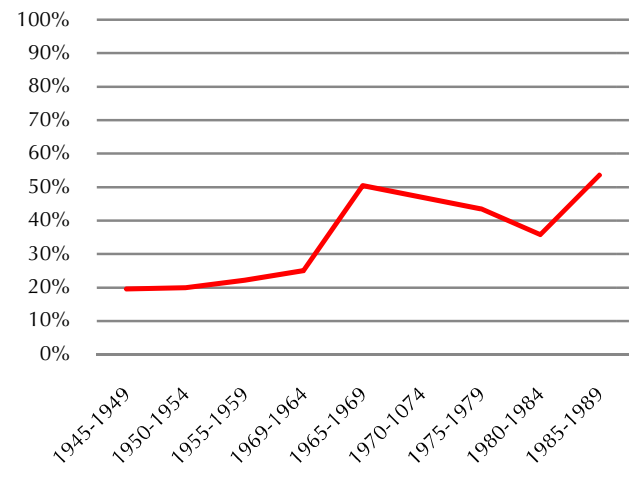

$\%$ VEB Typoart Gráfico 7.1
Si contamos con la presencia de tipografía diseñada por la VEB Typoart dentro del total de los carteles esta diferenciación entre los carteles políticos y los carteles culturales es más evidente, mientras que en los primeros el aumento de estas tipografías dentro de las mecánicas supone un aumento directo en el porcentaje de carteles en los que aparece, en los culturales este efecto se ve mitigado por el aumento de carteles con tipografías manuales.

Serán las tipografías manuales las responsables también de la diferencia que encontramos en la publicidad económica, cuyo incremento de tipografía de la VEB Typoart en el total de carteles diseñados respecto de la tipografía mecánica se debe al detrimento de la presencia de tipografías manuales en este campo. 
DISTRIBUCIÓN DEL USO DE TIPOGRAFÍAS SEGÚN CLASIFICACIÓN

\section{CULTURALES}

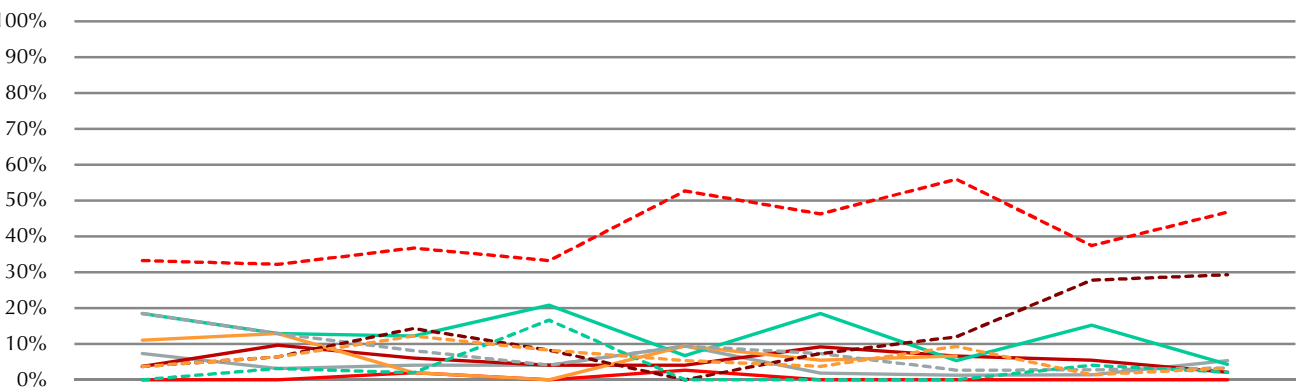

$\begin{array}{lllllllll}1945-1949 & 1950-1954 & 1955-1959 & 1969-1964 & 1965-1969 & 1970-1074 & 1975-1979 & 1980-1984 & 1985-1989\end{array}$

\section{ECONÓMICOS}

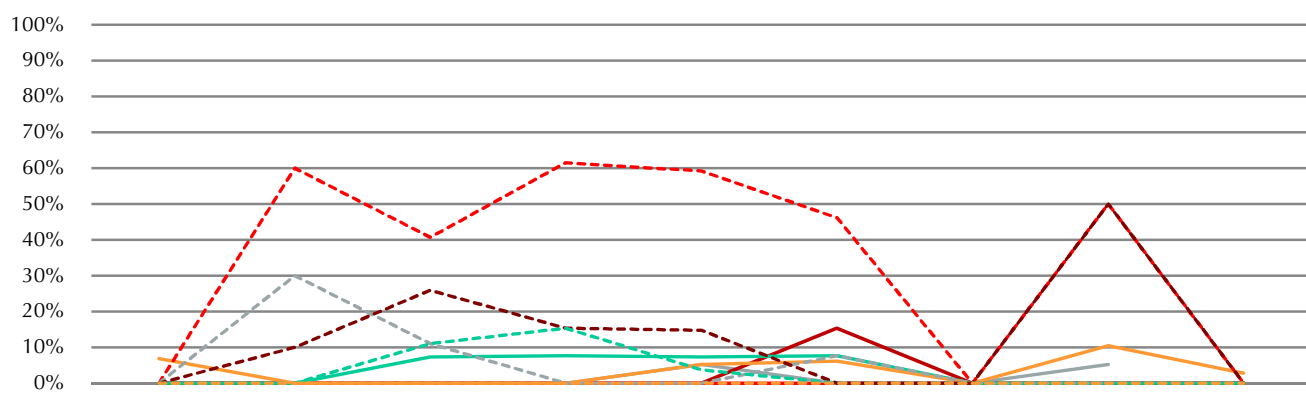

$\begin{array}{lllllllll}1945-1949 & 1950-1954 & 1955-1959 & 1969-1964 & 1965-1969 & 1970-1074 & 1975-1979 & 1980-1984 & 1985-1989\end{array}$

\section{POLÍTICOS}

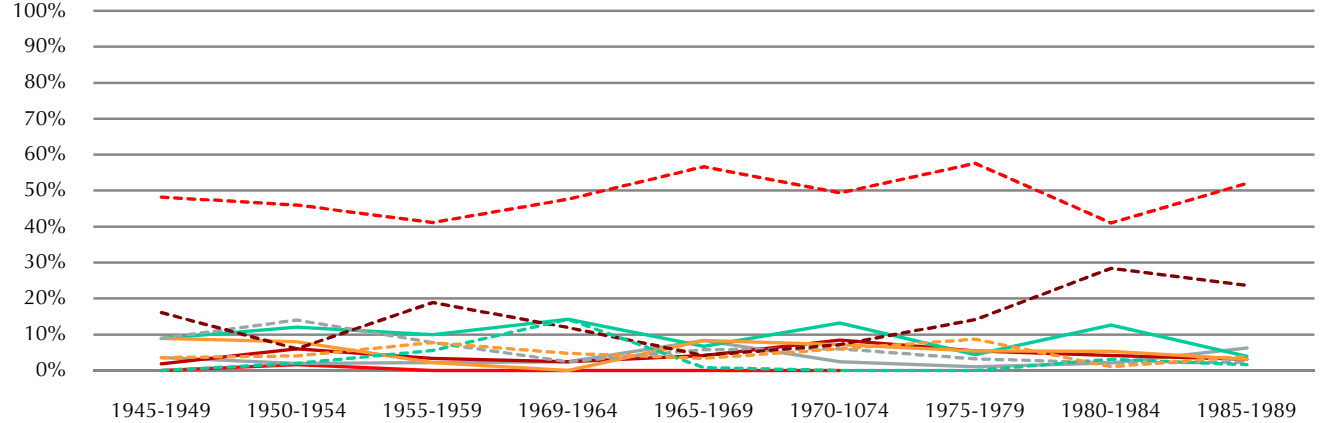

\section{GENERAL}

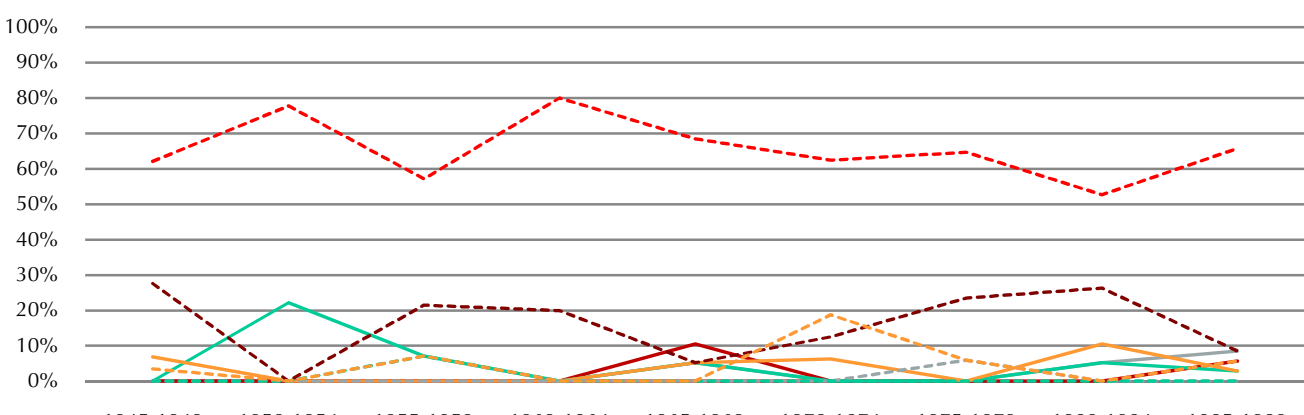

$\begin{array}{lllllllll}1945-1949 & 1950-1954 & 1955-1959 & 1969-1964 & 1965-1969 & 1970-1074 & 1975-1979 & 1980-1984 & 1985-1989\end{array}$

En la elección tipográfica podemos observar que la tipografía de palo seco (clase VI) permanece como la más utilizada en la RDA, muy por encima de cualquier otra clase de tipografía. Con un porcentaje de utilización muy inferior a la tipografía de palo seco, la tipografía manuscrita será globalmente la segunda tipografía más habitual en los carteles de la RDA, con importante presencia en el periodo entre 1955 y 1964 y en la primera mitad de la década de los 80. Dentro de las denominadas tipografías romanas predomina el uso de la tipografía de clase IV «romana neoclásica», que supuso hasta el $20 \%$ de la tipografía utilizada en el plazo 1950-54. La tipografía gótica gozará de mayor popularidad en la primera mitad de la década de los 70, con una aparición cercana al $20 \%$.

El desarrollo de los carteles políticos y culturales es muy similar, sin distinciones notables entre los dos géneros en cuanto al uso de la tipografía. En el plano económico se produce una mayor presencia, casi constante de tipografías de palo seco, así como manuscritas. Aparecen aquí en mayor medida las tipografías caligráficas (clase IX) y las variantes de la romana (clase VII). 
DISTRIBUCION DEL USO DE TIPOGRAFÍAS SEGÚN CATEGORÍAS DE CLASIFICACIÓN

CULTURALES

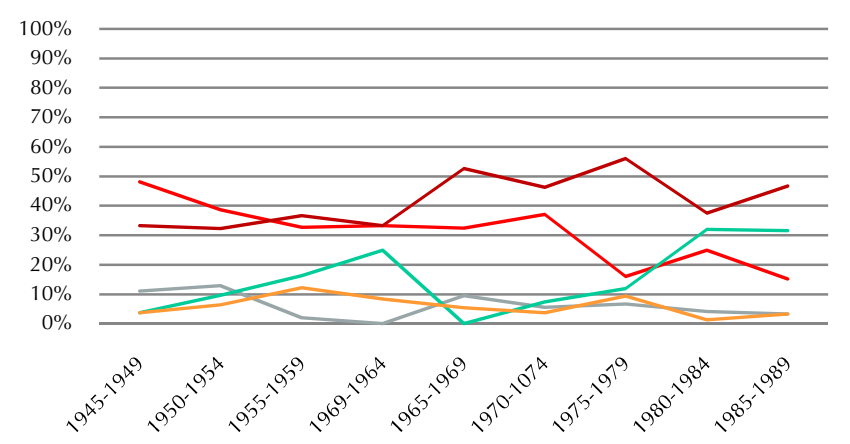

ECONÓMICOS

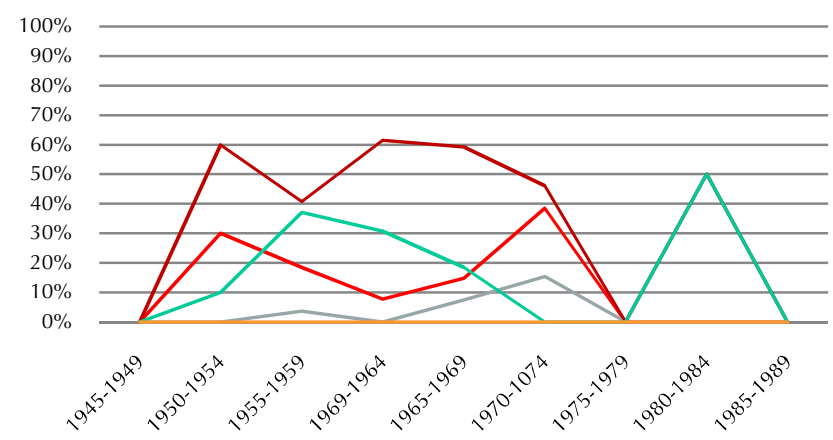

POLÍTICOS

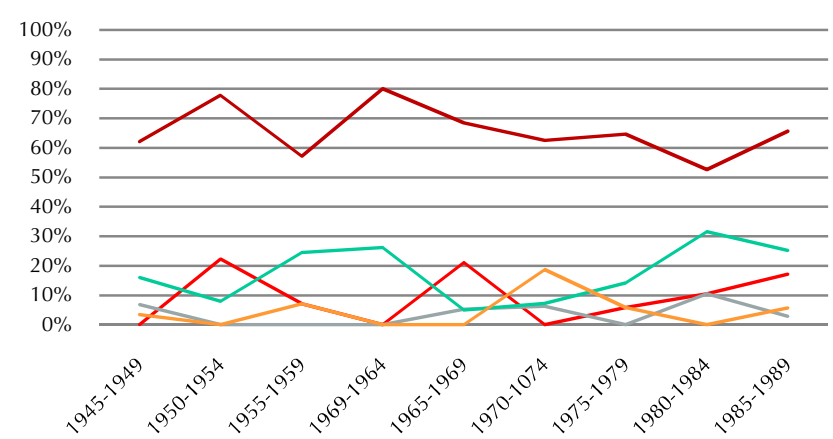

\section{GENERAL}

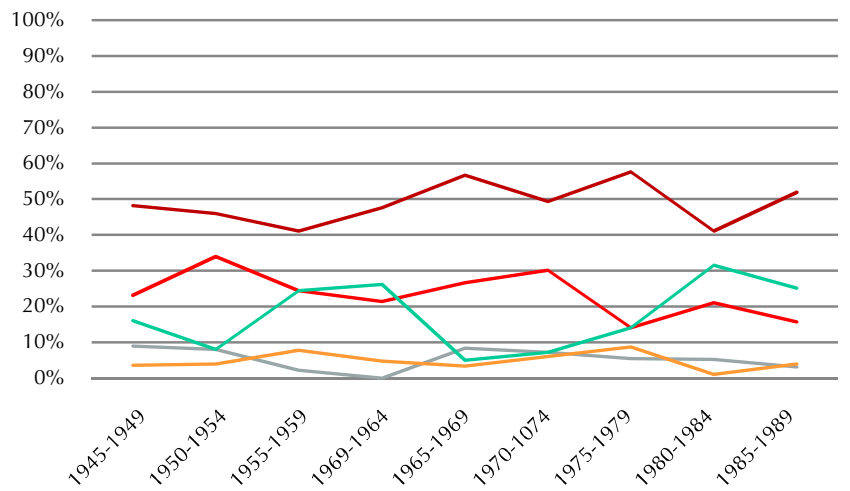

Para poder realizar una comparación más global agruparemos las clases en 5 grupos basándonos en la clasificación efectuada por la Vox-ATypl:

Roman: clases III, III IV incluyendo aquí las variantes de la letra romana, clase VII.

- Mecanas: clase V.

- Lineales: clase VI.

- Caligráficas: clases VIII y IX.

- Góticas: clase X.

De este modo podemos observar que la tipografía de palo seco sigue siendo la más utilizada frente a cualquier otro tipo de tipografía, con una tendencia en aumento en los carteles culturales, mientras que en los carteles políticos pierde terreno a favor de tipografías manuscritas. La tipografía romana tendrá una gran presencia en los carteles culturales, la cual irá perdiendo a medida que van aumentando las grotescas y manuscritas, mientras que apenas tiene relevancia en los carteles políticos.

La tipografía quebrada no pierde presencia tras el edicto de 1941 en el que se prohibía su uso rondando el 10\% de los carteles culturales y llegando al $20 \%$ en los carteles políticos. Únicamente en el ámbito económico pierde su presencia.

Los carteles publicitarios utilizan tipografías lineales en combinación con tipografías caligráficas hasta los años 70 y con tipografías romanas a partir de este momento. 
TIPO DE REPRODUCCIÓN DE CADA CLASE TIPOGRÁFICA

CULTURALES

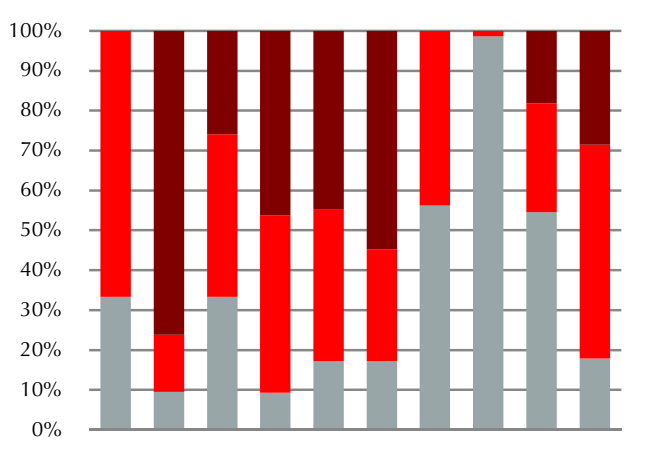

POLÍTICOS

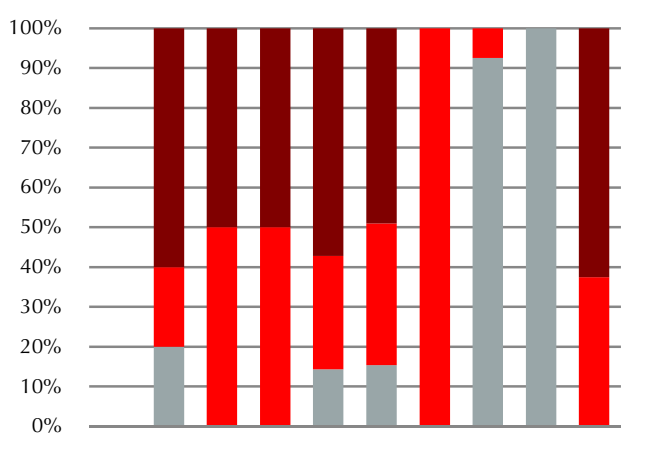

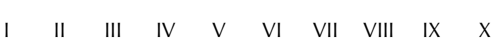

ECONÓMICOS

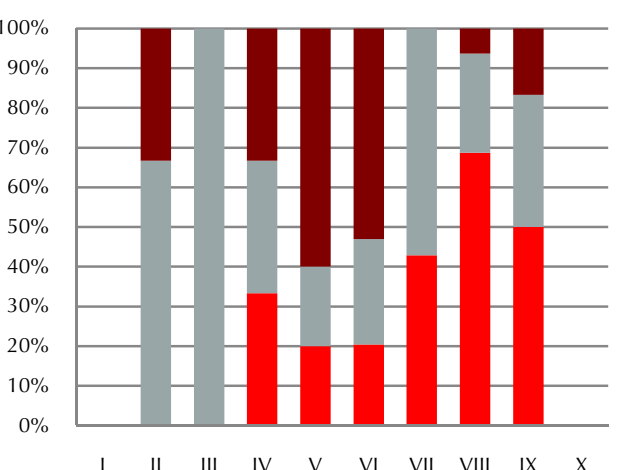

GENERAL

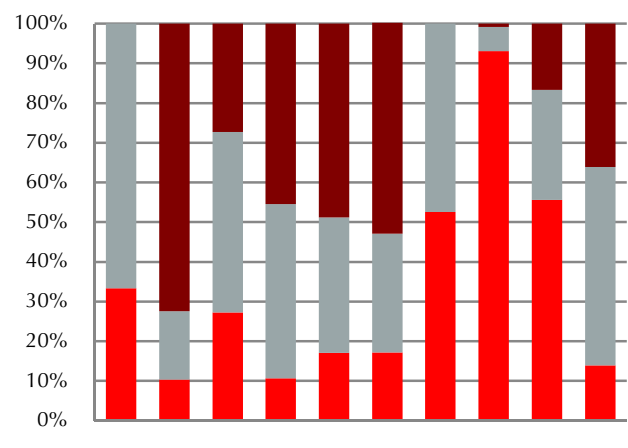

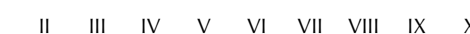

ORIGINALIDAD DE LOS DISEÑOS DE LA VEB TYPOART UTILIZADOS EN LOS CARTELES

CULTURAL
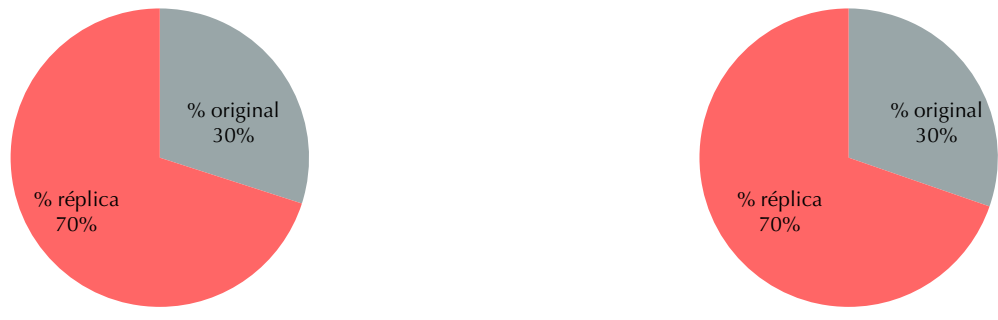

POLÍTICO

GENERAL
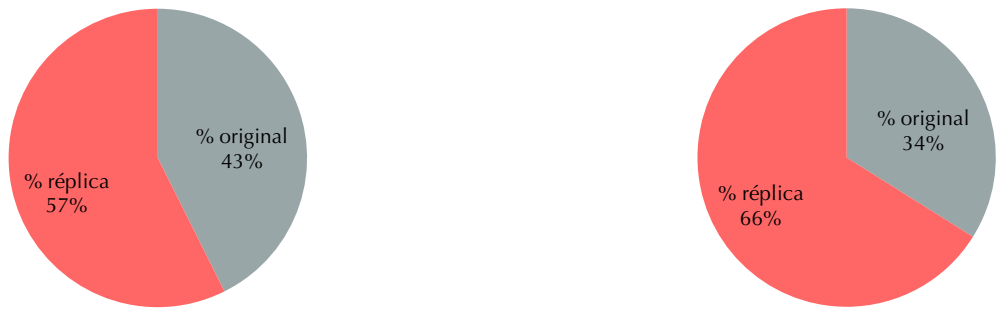

Dentro de las tipografías producidas por la VEB Typoart muchas de ellas consistían en réplicas de tipografías famosas, o de tipografías de fundiciones anteriores a las que compusieron la VEB Typoart, siendo una pequeña porción de ellas las diseñadas originalmente por los creadores de la empresa.

Las réplicas de tipografías tuvieron mayor relevancia en el diseño de carteles de la que tuvieron las tipografías creadas originalmente por la VEB Typoart, pese a que el número de creaciones originales suponga algo más de la mitad de las tipografías producidas su presencia en los carteles analizados apenas supone el $34 \%$.

En los carteles políticos se evidencia una mayor afición a las tipografías diseñadas originalmente dentro de la RDA aumentando este porcentaje hasta el $43 \%$. 
CULTURALES

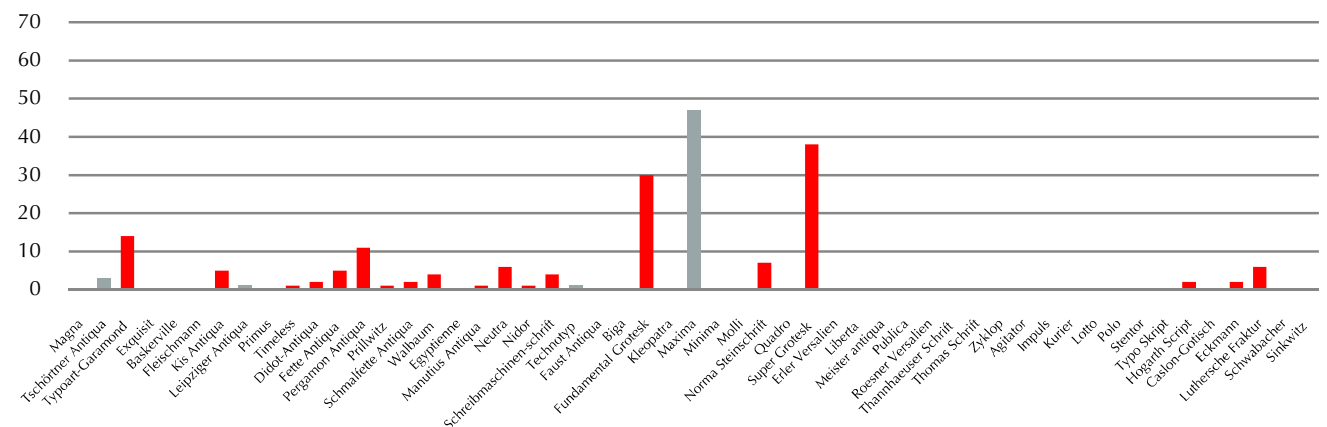

ECONÓMICOS

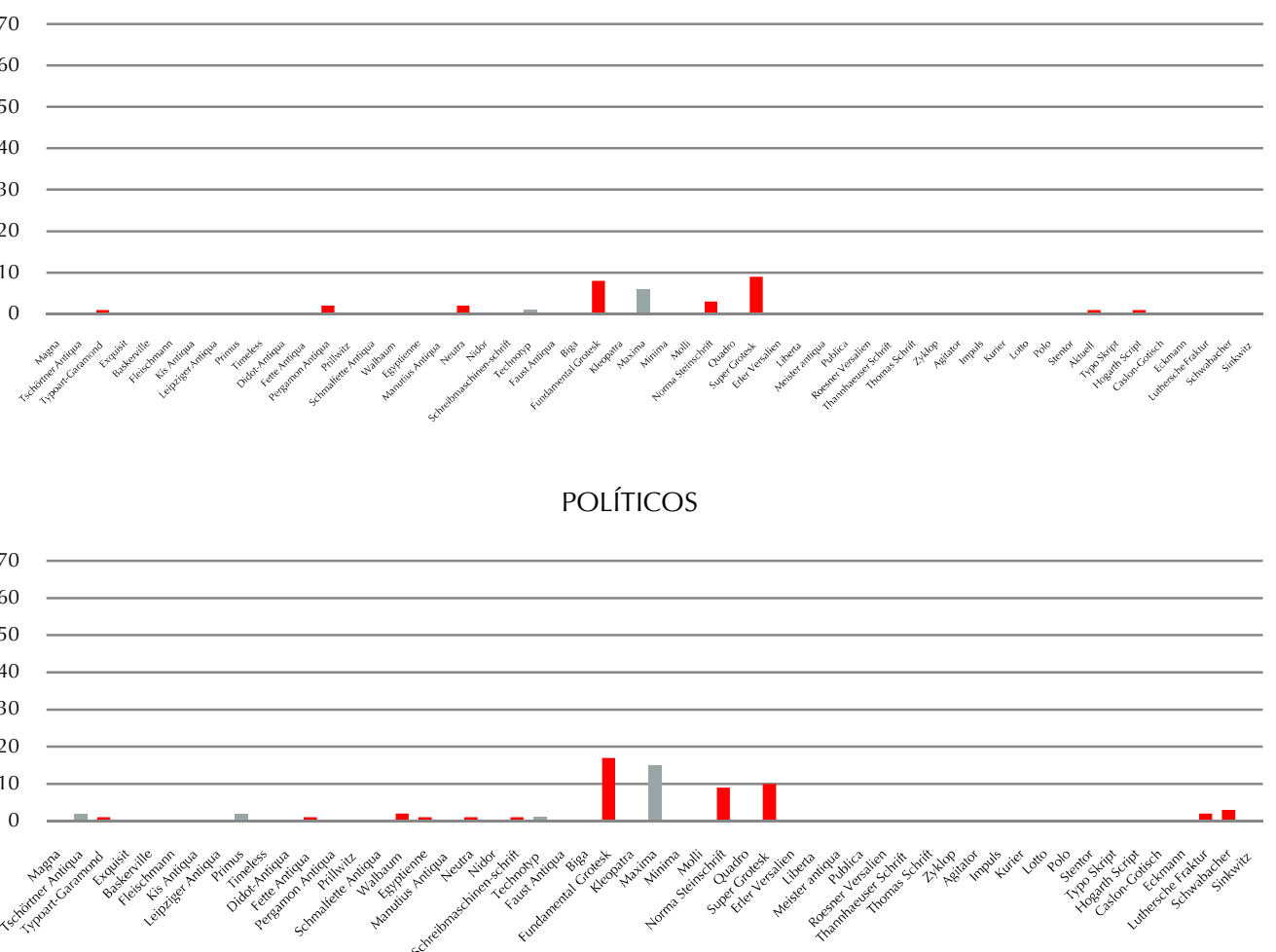

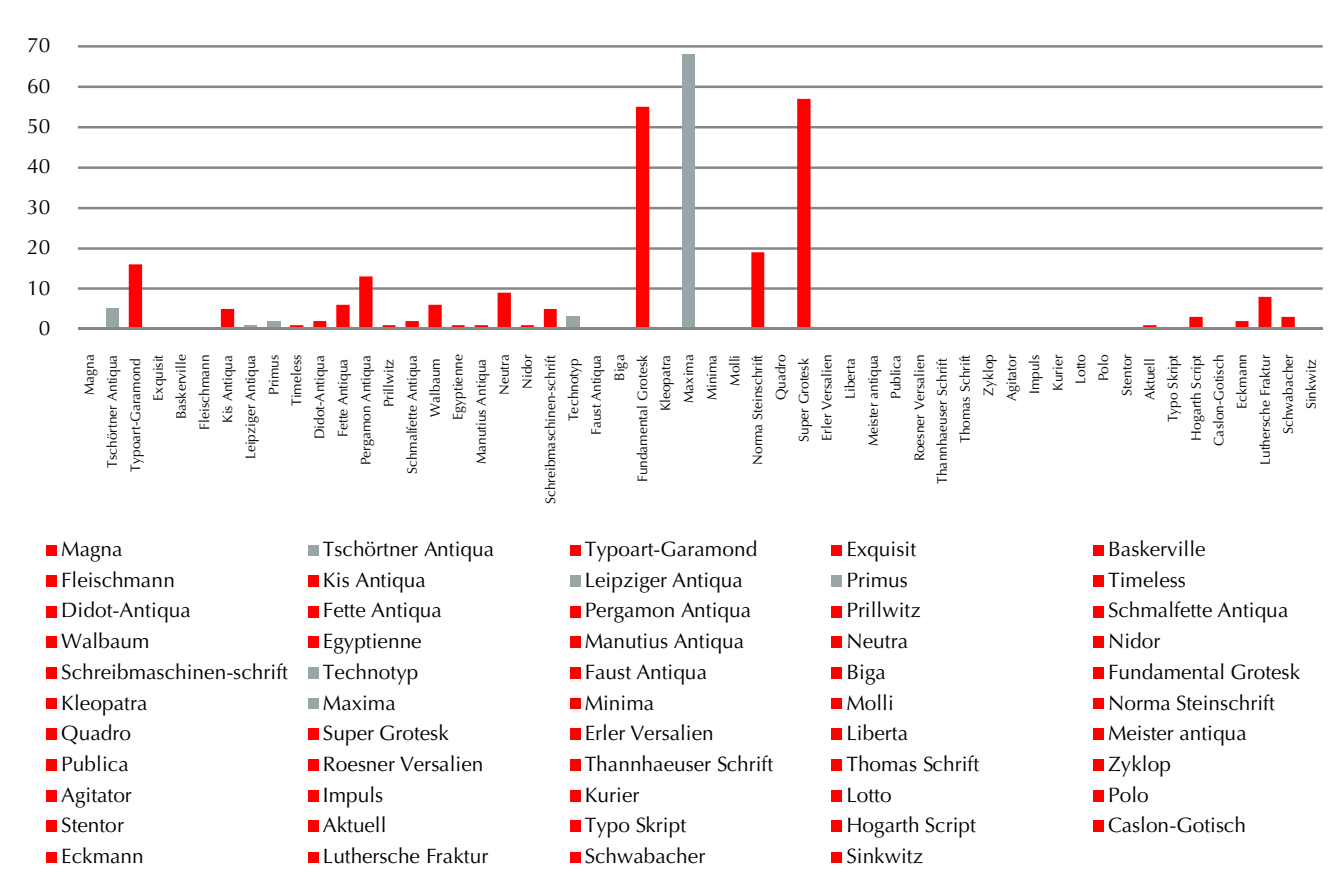

Gráico 7.21

Muchas fueron las tipografías diseñadas por la VEB Typoart y que abarcaron la práctica totalidad de clasificaciones tipográficas para poder comprender todos los usos posibles. En su uso como diseño gráfico de carteles, no todas las tipografías tienen la misma presencia, siendo las tipografías Maxima, Fundamental Grotesk y Super Grotesk las tipografías de mayor éxito, con una representación muy superior a resto de las tipografías, muchas de las cuales no aparecen en ningún elemento de la muestra.

Esta predilección es mucho más evidente en los carteles culturales, mientras que en los carteles económicos y políticos están más homogéneamente repartidos entre las diferentes tipografías diseñadas. 
7.3.1 Estrategia

CULTURALES

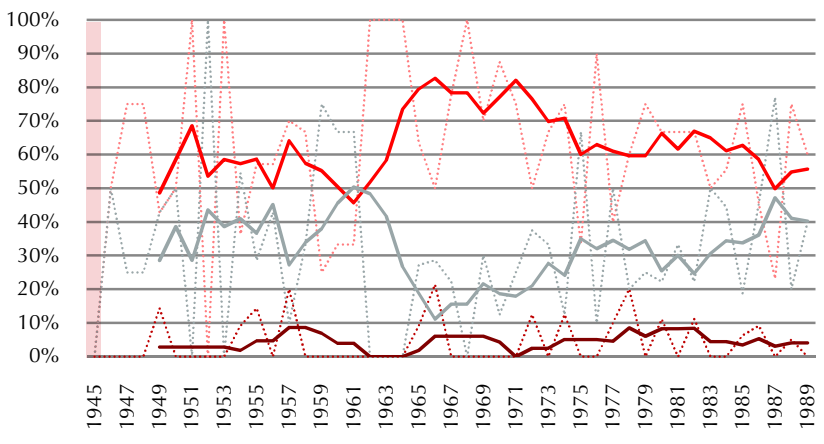

ECONÓMICOS

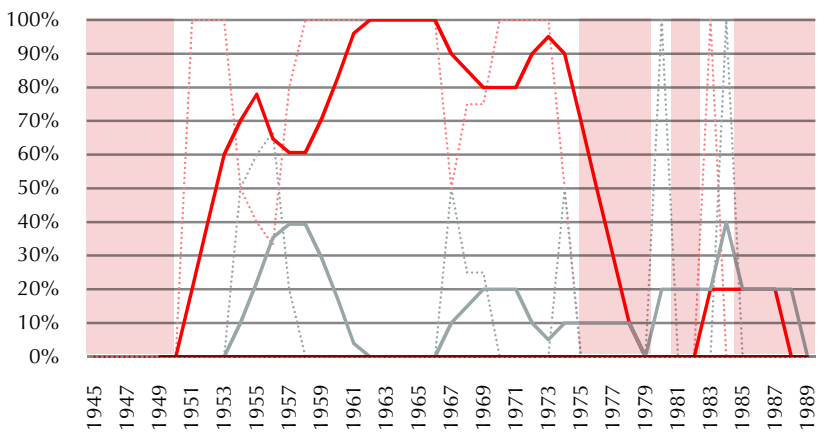

POLÍTICOS

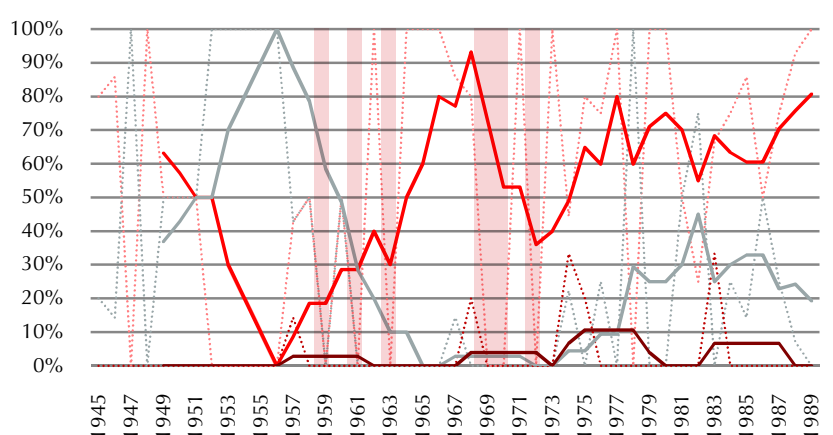

$100 \%$

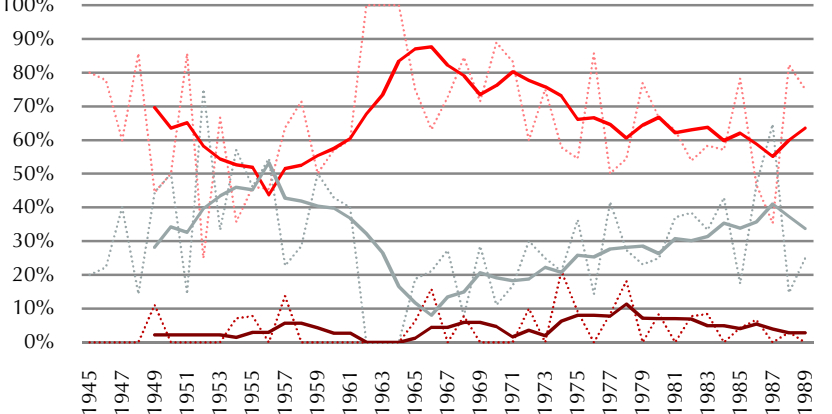

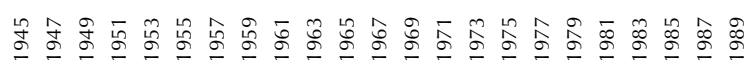

La estrategia de comunicación predominante es la formal si bien en los años 50 la comunicación mediante el medio, es decir mediante el tratamiento de la imagen, tendrá una gran presencia e incluso será la estrategia predominante en 1956. A mediados de los años 60 se diseñan el mayor número de carteles conducidos formalmente, con medias cercanas al 90\%. A partir de este momento la tendencia será a la baja, a beneficio de los carteles conducidos por el medio. La estrategia conducida por el estilo es minoritaria, pero se hace más importante en los años 70.

Encontramos aquí una fuerte distinción entre géneros, ya que los carteles políticos estarán conducidos durante los años 50 casi exclusivamente por el medio, cediendo después el terreno a las estrategias formales. Sin embargo los carteles publicitarios del género económico estarán dominados por la estrategia formal durante todo el periodo analizado. Aquí no tendrá cabida la comunicación conducida por el estilo.

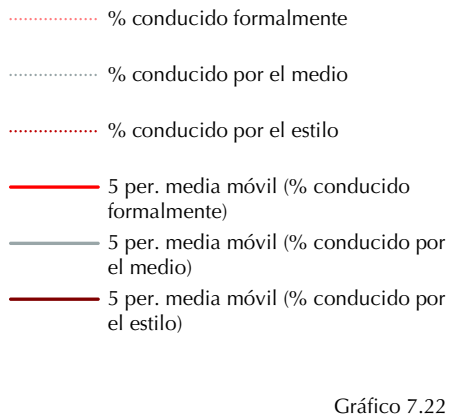

Gráfico 7.22

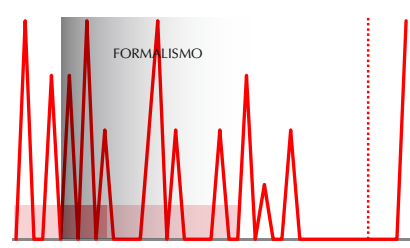

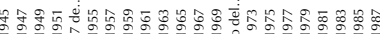

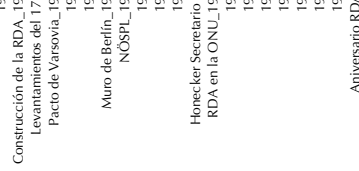

Gráfico 7.2.b 


\section{ELEMENTO DE COMUNICACIÓN}

CULTURALES

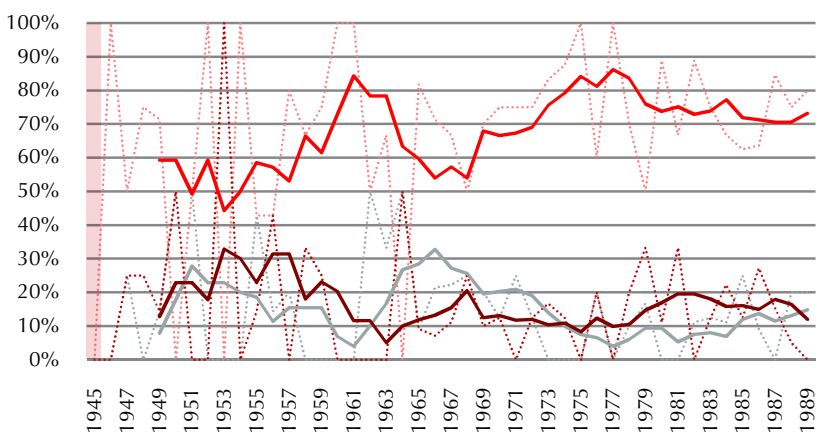

ECONÓMICOS

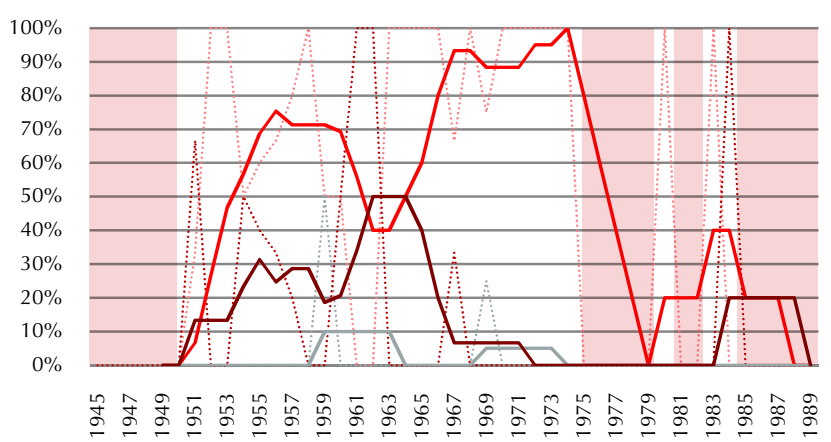

POLÍTICOS

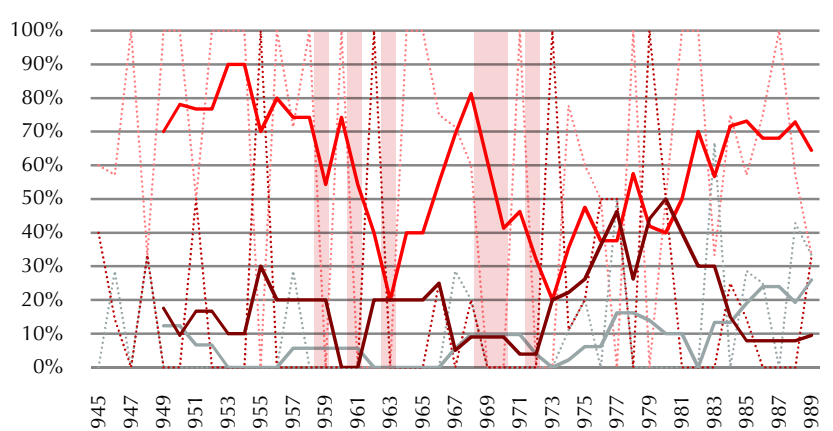

$90 \%$

$70 \%$

$60 \%$
$50 \%$

$50 \%$

$30 \%$

$0 \%$

$10 \%$

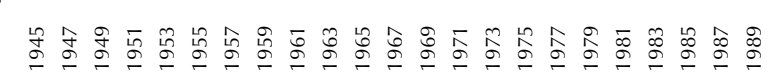

El elemento mayoritariamente portador de la información

es la imagen, pero cabe destacar el incremento de carteles cuyo elemento principal es la tipografía a comienzo de los años 60 -que se mantendrá a lo largo de toda la década- y el porcentaje de carteles en los cuales se establece una sinergia entre imagen y texto, casi continuo en toda la RDA.

Los carteles tipográficos tienen una gran presencia en el plano cultural de comienzos de los años 60 y en los carteles políticos de la última década, mientras que apenas tienen peso en el plano económico. Es en este género sin embargo donde se establece un mayor porcentaje de diseños basados en la sinergia entre imagen y tipografía. 
CULTURALES

2,00

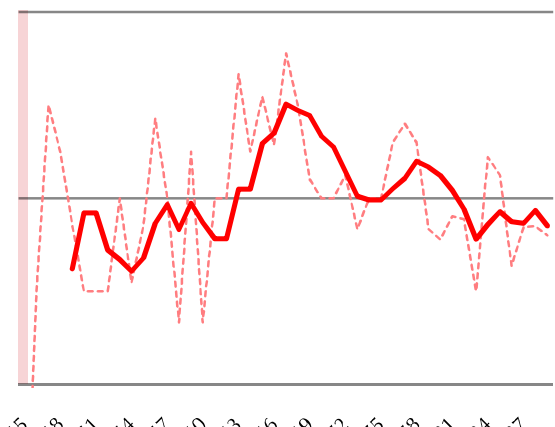

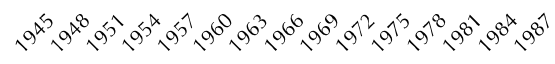

POLÍTICOS

3,00

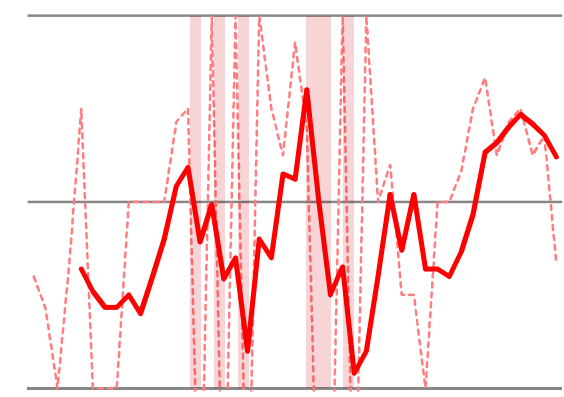

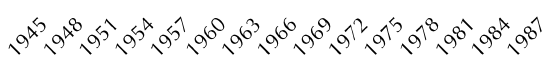

ECONÓMICOS

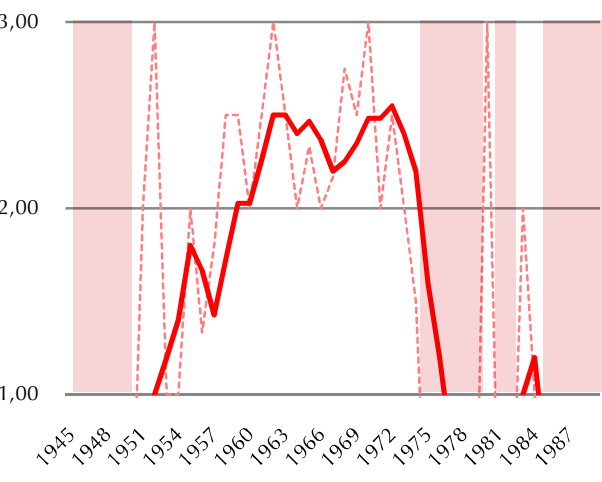

GENERAL
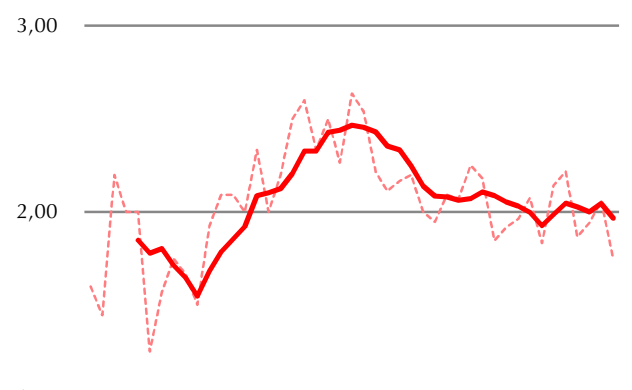

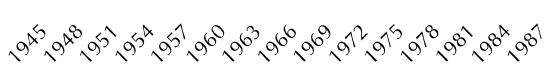

... Nivel de énfasis

5 per. media móvil (Nivel de énfasis)

\section{LEYENDA EJE VERTICAL}

$1=$ Neutralidad

$2=$ Medio

Gráfico 7.24
El nivel de énfasis, que nos indica el nivel de armonía o contraste con el cual se destaca el elemento portador de información sigue una tendencia muy clara entre los primeros carteles y especialmente los de los años 50 con una clara armonía y escaso énfasis, a carteles con un importante contraste en los años 60. A partir de los años 70 se regularizará la situación a igual distancia de la armonía que del contraste.

Esta tendencia la podemos encontrar en todos los planos analizados. La mayor diferencia la encontramos en los carteles políticos de la última década, con una clara tendencia hacia el acento que se aleja de la tendencia general hacia la equidistancia.

\section{REGULARIDAD}

CULTURALES

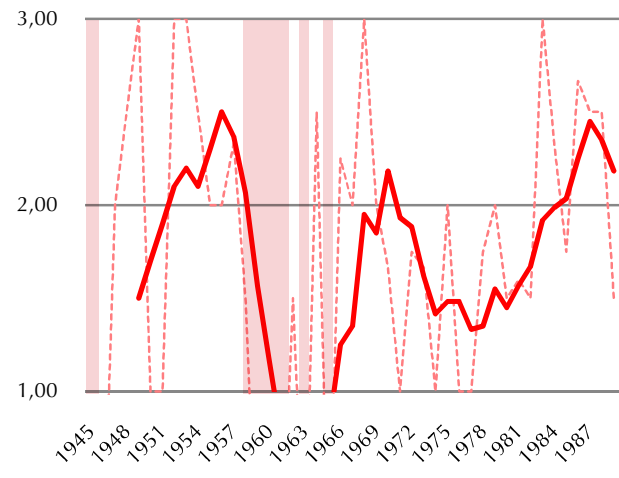

POLÍTICOS

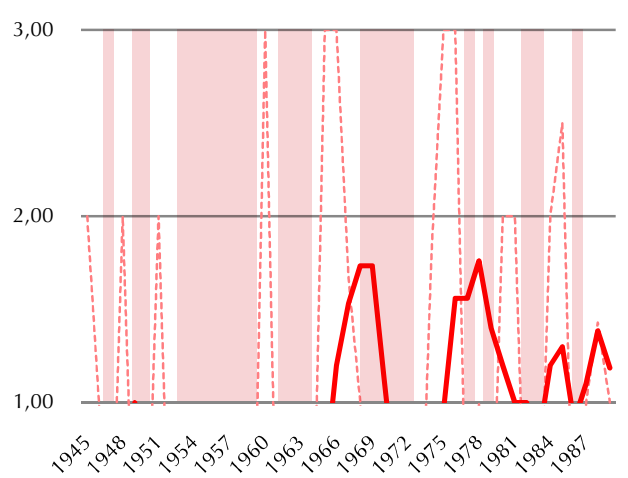

ECONÓMICOS

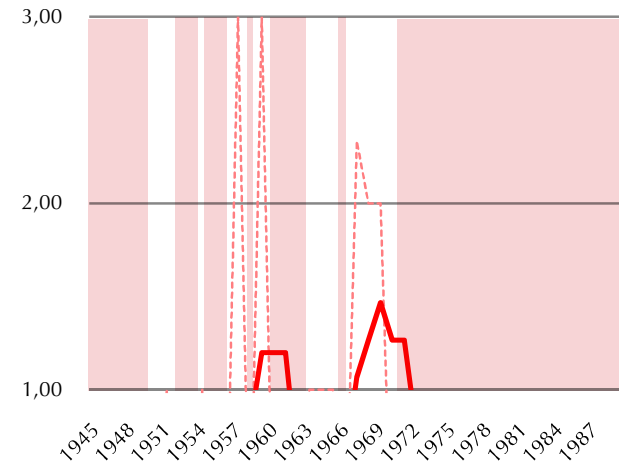

GENERAL

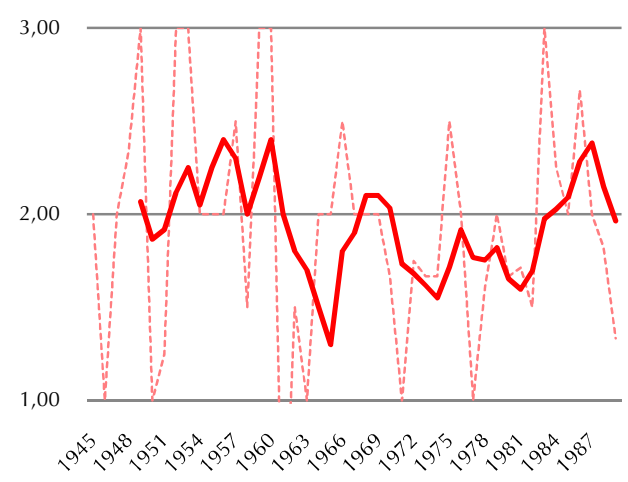

En cuanto al ritmo de los elementos nos encontramos nuevamente con dos etapas, una primera etapa hasta los años 70 con una mayor tendencia a la irregularidad -hay que tener en cuenta aquí la no presencia de elementos que establezcan ritmo en los años 61 y 63, lo que supone un falso descenso en la irregularidad- y un mayor predominio de la regularidad en los años 70 que permanecerá hasta el último lustro de la RDA.

Analizando por géneros nos encontramos que en el plano político no se muestra esta variación en la tendencia, sino que permanece equidistante de forma casi continua. La escasez de elementos que desarrollen un ritmo en los carteles económicos no permite una lectura clara de estos datos.
Nivel de regularidad

5 per. med
regularidad)

\section{LEYENDA EJE VERTICAL}

$\mathbf{1}=$ Regularidad
$\mathbf{2}=$ Medio

$3=$ Irregularida 
CULTURALES

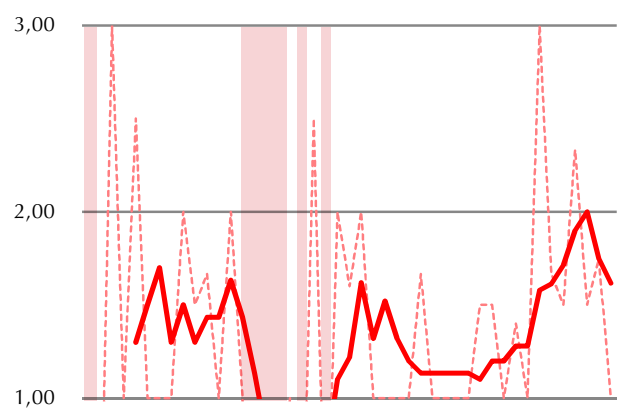

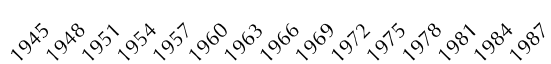

POLÍTICOS

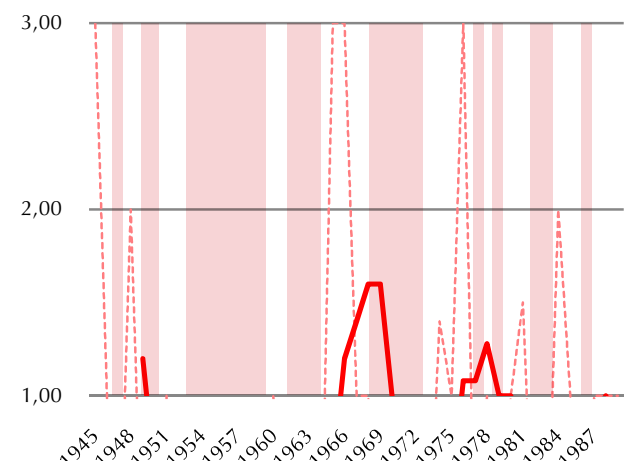

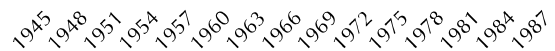

ECONÓMICOS

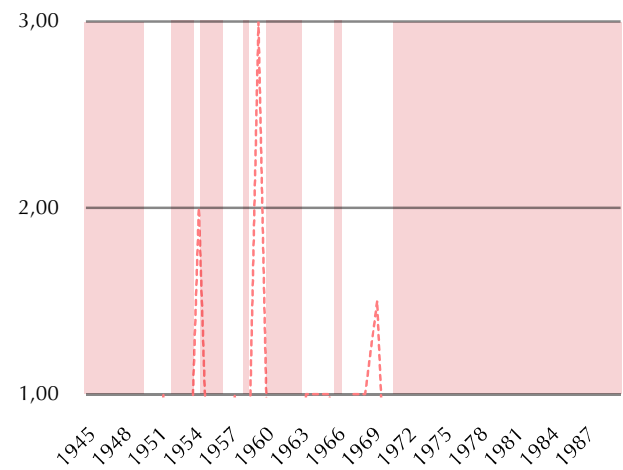

GENERAL

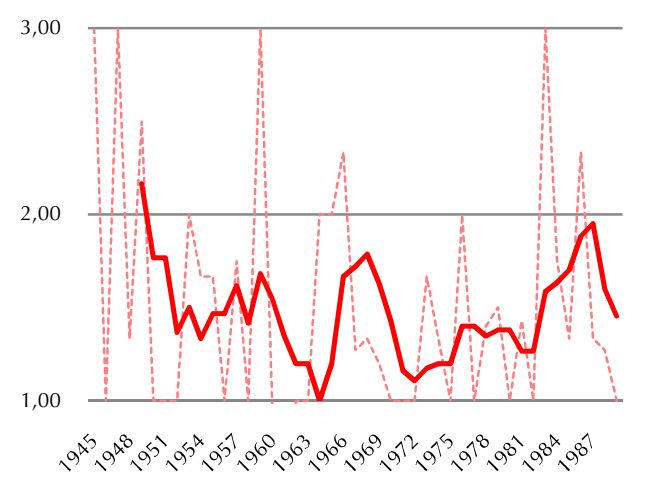

Nivel de predictibilidad

5 per. media móvil (Nivel de
predictibilidad)

LEYENDA EJE VERTICAL

$1=$ Predectible

3= Espontáneo
Globalmente podemos observar que la irregularidad de los elementos no responde a una espontaneidad en los mismos, sino que mayoritariamente están sujetos a un plan. Hallamos una mayor espontaneidad en los primeros y los últimos años de la RDA, con una breve tendencia hacia ella a mediados de los años 60 , pero siempre predominando la predictibilidad. En los carteles políticos esta predictibilidad está más presente suponiendo la mayor parte de los elementos de la muestra.
CULTURALES

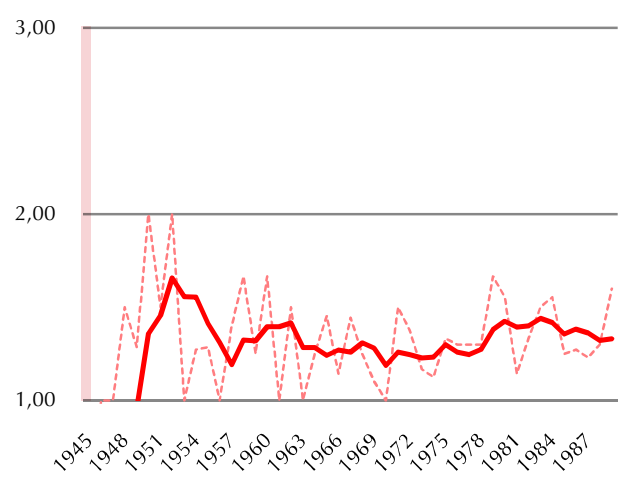

POLÍTICOS

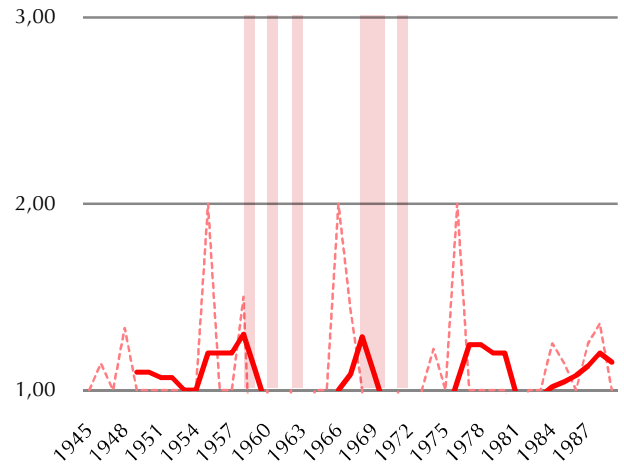

ECONÓMICOS

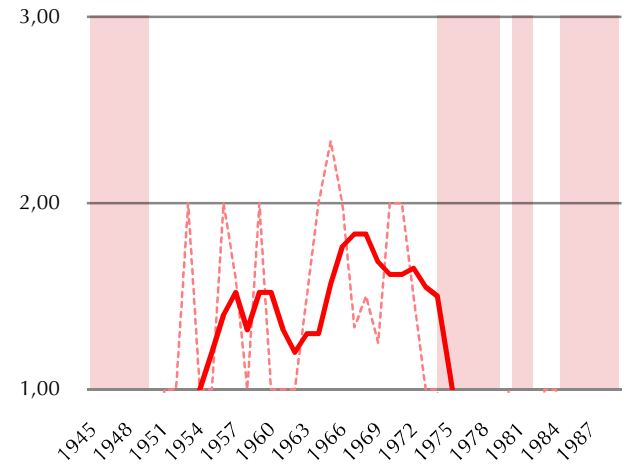

GENERAL

3,00

2,00

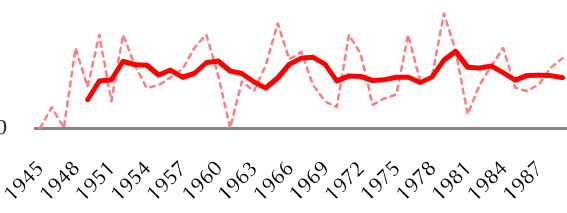

Existe a lo largo de toda la RDA una tendencia continua y homogénea a la continuidad entre los diferentes elementos del diseño sin variaciones importantes a lo largo de la historia, apenas una tenue inclinación hacia la episodicidad en los primeros años de la RDA.

Serán los carteles económicos los que tengan una mayor presencia de elementos estructurados episódicamente, y más marcadamente continua en el caso de los carteles políticos.
Nivel de continuidad

5 per. media móvil (nivel de
continuidad)

LEYENDA EJE VERTICAL

$1=$ Continuida

$=$ Medio

$=$ Episodicidad 
CULTURALES

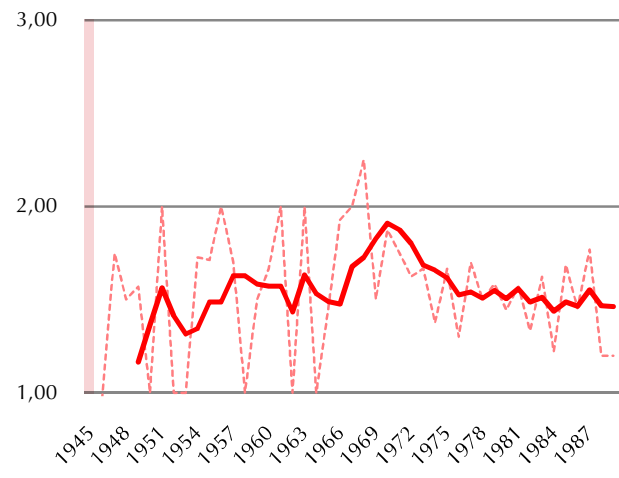

POLÍTICOS

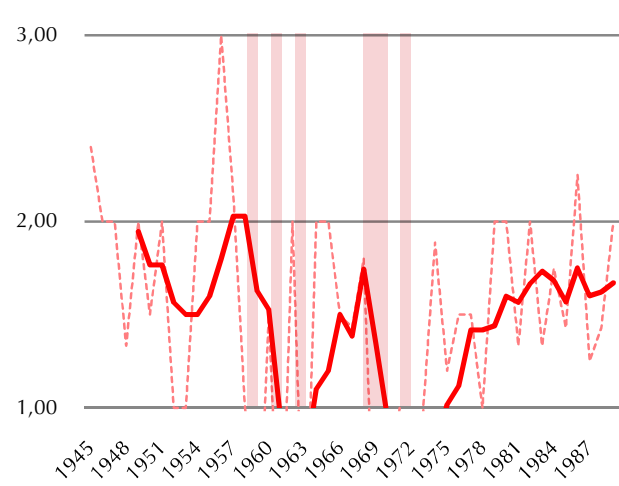

ECONÓMICOS

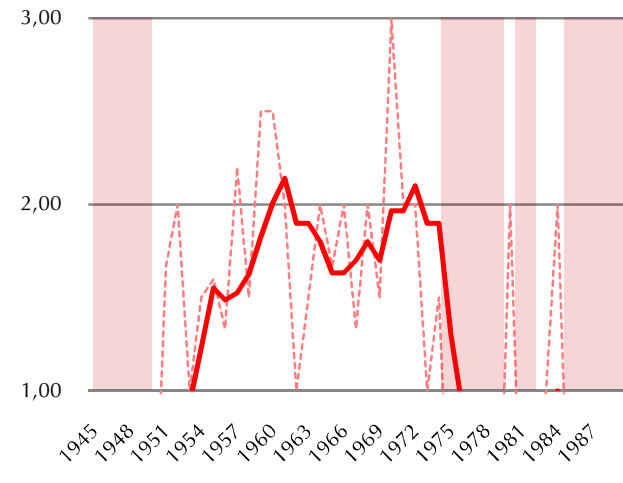

GENERAL

3,00

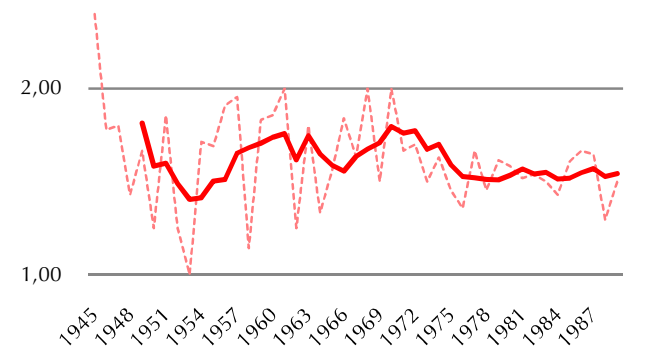

Nivel de pasividad

5 per. me
pasividad)

\section{LEYENDA EJE VERTICAL}

$\mathbf{1}=$ Pasividad
$\mathbf{2}=$ Medio

$3=$ Actividad

Grá́ico 7.28
Tras los primeros años de mayor dinamismo los años $50 \mathrm{se}$ manifiestan mayoritariamente como carteles pasivos, con una tendencia a la actividad en el cambio de década de los 60 y 70, con una vuelta a la pasividad a final de la RDA.

Los carteles culturales muestran una mayor pasividad que los políticos y económicos, donde rondan un nivel medio, nivel asociado a la muestra de actividades sin que el movimiento esté explícito.
CULTURALES

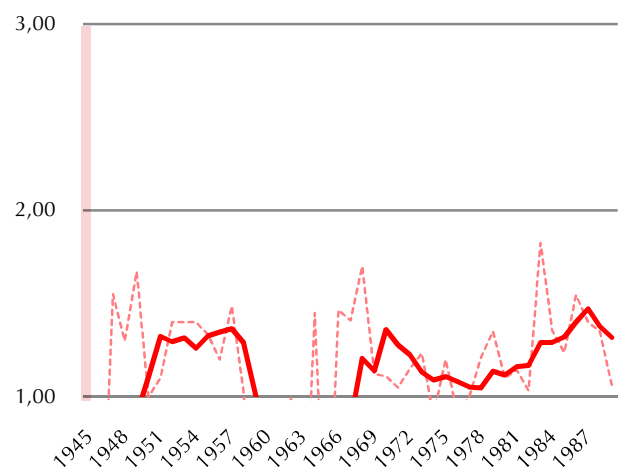

POLÍTICOS

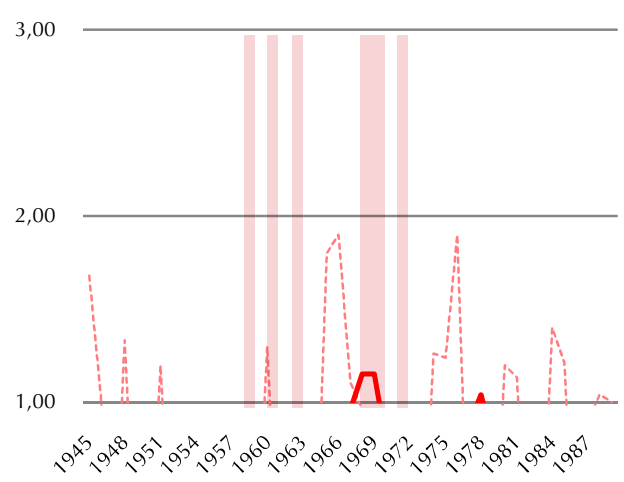

ECONÓMICOS

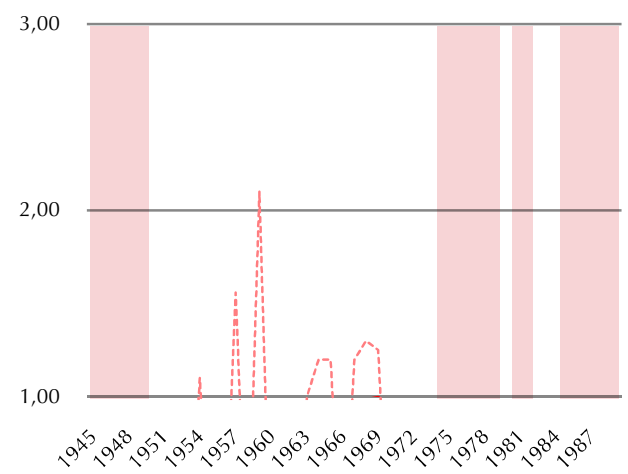

GENERAL

3,00

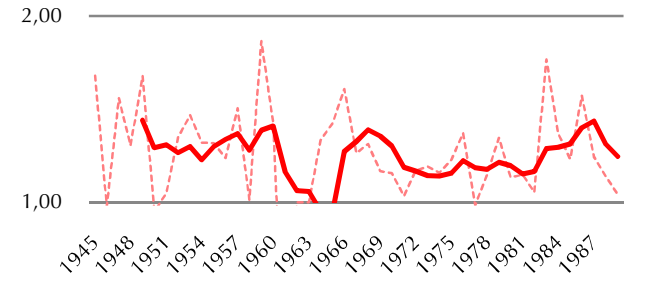

Globalmente nos encontramos con unas composiciones armónicas en cuanto al ritmo y continuidad entre elementos, con una fuerte diferencia a elementos más rítmicamente armónicos en la primera mitad de la década de los años 60.

\section{Nivel de continuidad}

5 per. media móvil (nivel de
continuidad)

\section{LEYENDA EJE VERTICAL}

$\mathbf{1}=$ Continuida

3= Episodicida 
EQUILIBRIO

CULTURALES

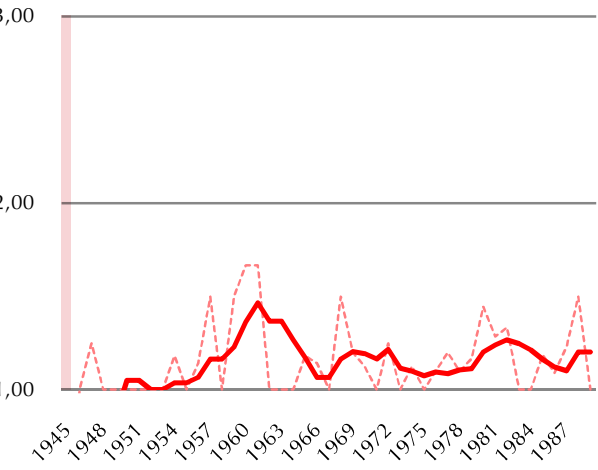

POLÍTICOS

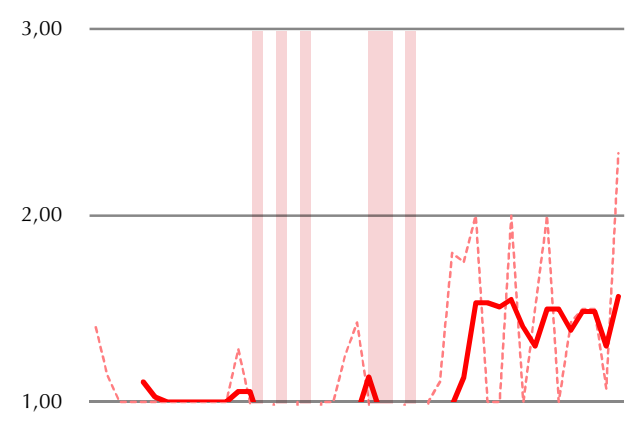

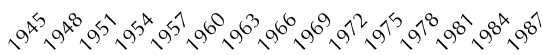

ECONÓMICOS

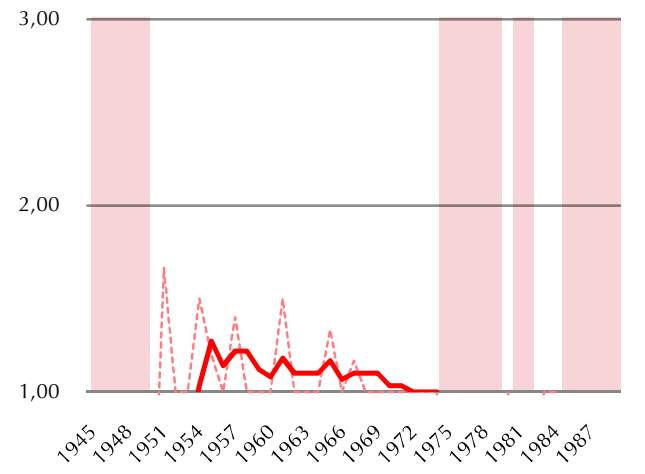

GENERAL

3,00

2,00

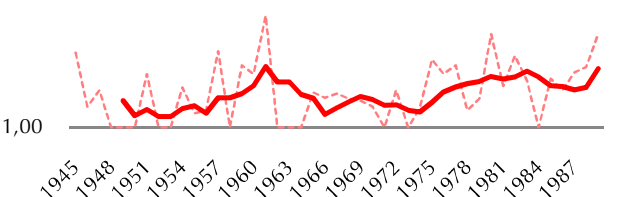

Nivel de equilibrio

5 per. me
equilibrio)

LEYENDA EJE VERTICAL

$1=$ Equilibrio

$\mathbf{2}=$ Medio

$3=$ Inestabilidad

Gráfico 7.30
La composición es predominantemente equilibrada, con una tenue tendencia hacia composiciones menos equilibradas a comienzo de los años 60 y en los años 80 .

La tendencia hacia el equilibrio es especialmente en el panorama político y es en este género donde la distinción entre los primeros y los últimos carteles es más marcada, siendo las primeras décadas casi exclusivamente equilibrados y más desequilibrados desde 1974.

En los carteles económicos por el contrario el equilibrio es una tónica general y casi constante, si bien se aprecia una tendencia hacia un mayor equilibrio.
CULTURALES

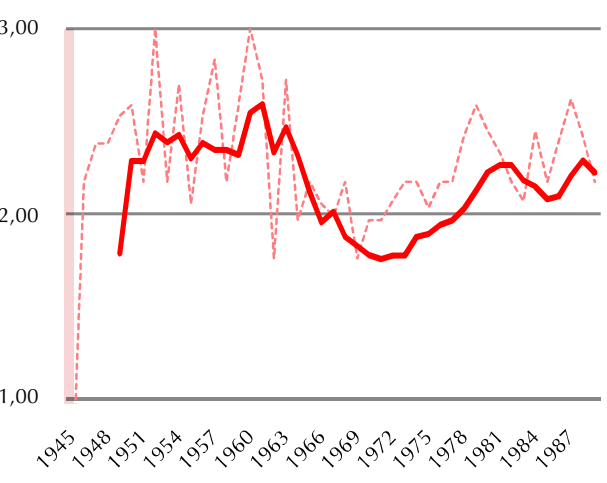

POLÍTICOS

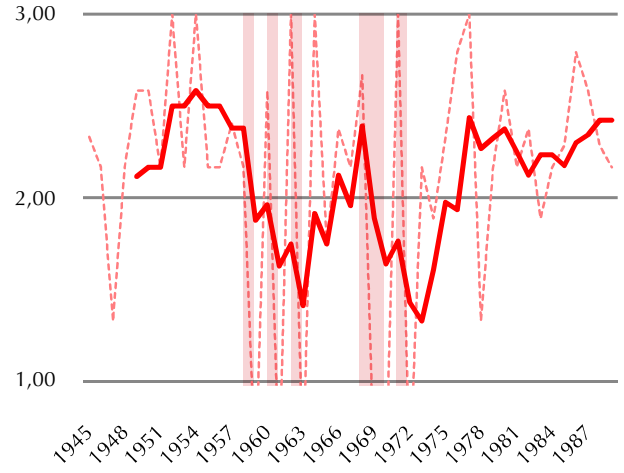

ECONÓMICOS

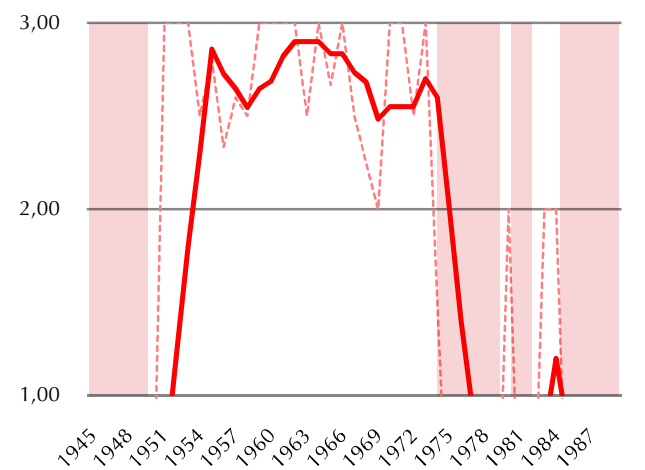

GENERAL

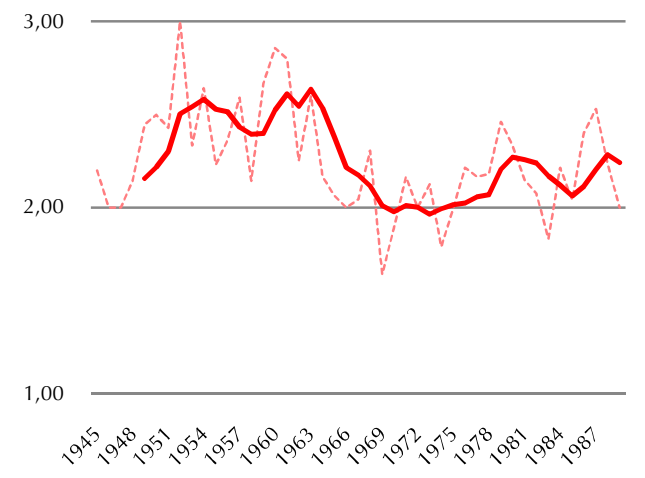

3,00

Nivel de simetría
El equilibrio del que hablábamos no corresponde en ningún modo con composiciones simétricas, ya que pasados los primeros años de la SBZ y hasta mediados de los años 60 podemos hablar de composiciones marcadamente asimétricas. A partir de este momento y hasta la década de los 80 nos encontramos con una mayor tendencia hacia la simetría, que volverá a la asimetría en la última década. Es una tendencia general en todos los planos analizamos, con un gran énfasis en el plano económico.
EENDA EJE VERTICAL

$\mathbf{1}=$ Simetría

$2=$ Medio

Gráfico 7.3 
ARMONÍA EN EL EQUILIBRIO

CULTURALES

2,00

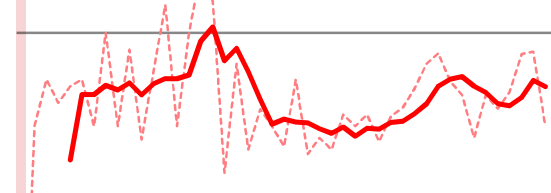

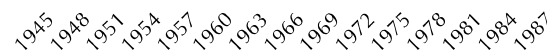

POLÍTICOS

3,00

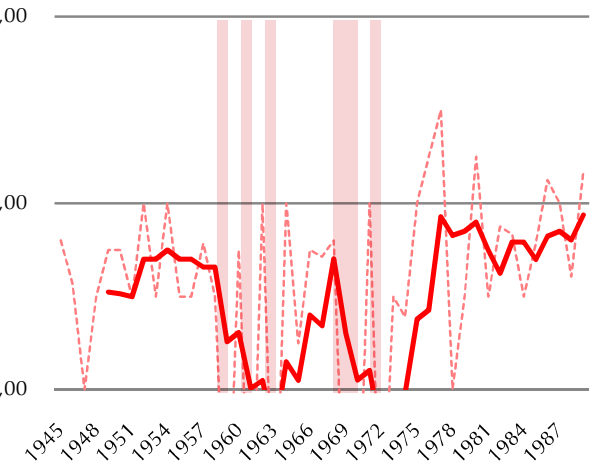

ECONÓMICOS

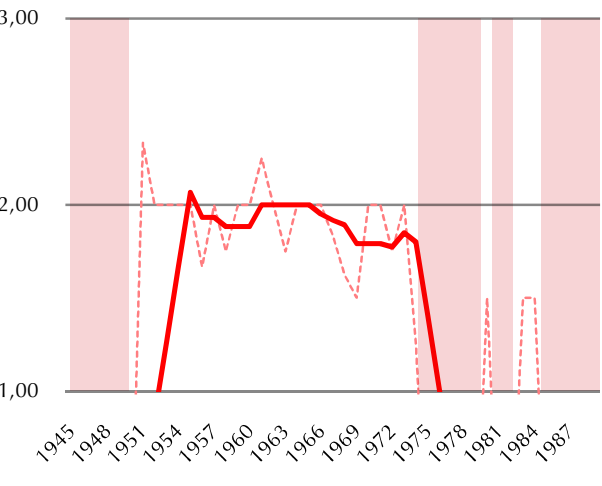

GENERALES

3,00

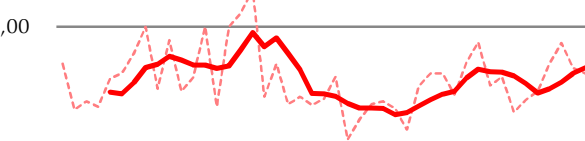

1,00

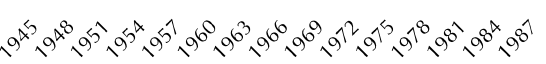

Nivel de armonía en el equilibrio

5 per. media móvil (nivel de armonía
en el equilibrio)

\section{LEYENDA EJE VERTICAL}

$1=$ Armónico

$\mathbf{2}=$ Medio

$3=$ Contrastado
Con todo esto podemos determinar que en cuanto al equilibrio, los carteles de la RDA tienen una leve tendencia hacia la armonía, pero cercana a la equidistancia entre armonía y contraste. Al igual que en el ritmo podemos hablar de un periodo más contrastado entre 1950 y 1960, y otro más armónico entre 1965 y 1980.

Esta tendencia es relativamente homogénea en todos los géneros, si bien en el plano económico apenas se observan variaciones en el nivel de armonía en el equilibrio en todo el periodo analizado.

\subsubsection{Unidad}

SIMPLICIDAD
CULTURALES

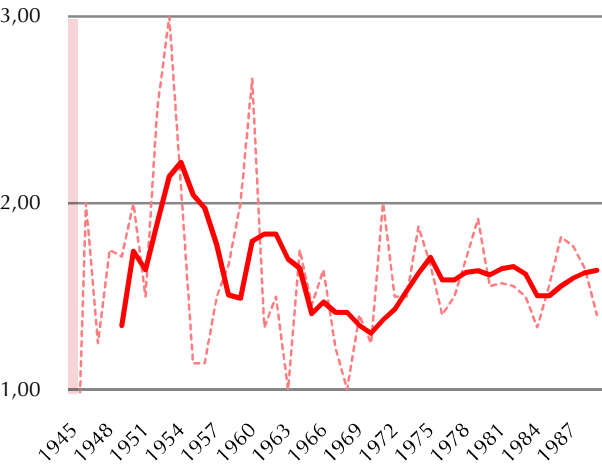

POLÍTICOS

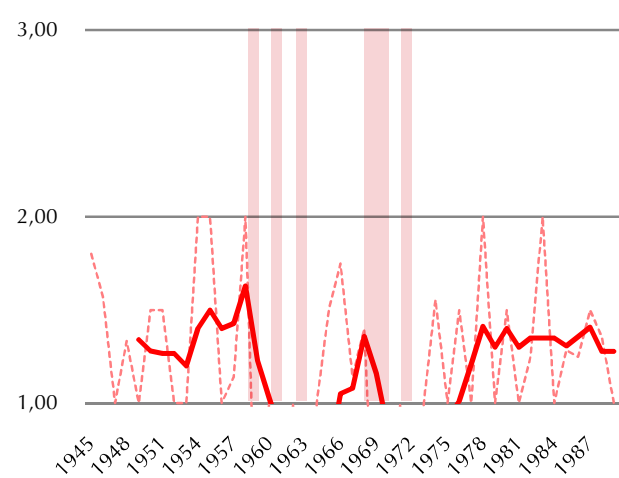

ECONÓMICOS

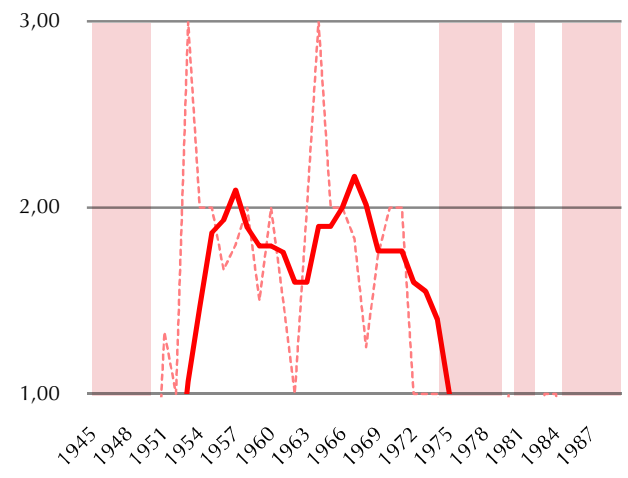

GENERAL

3,00

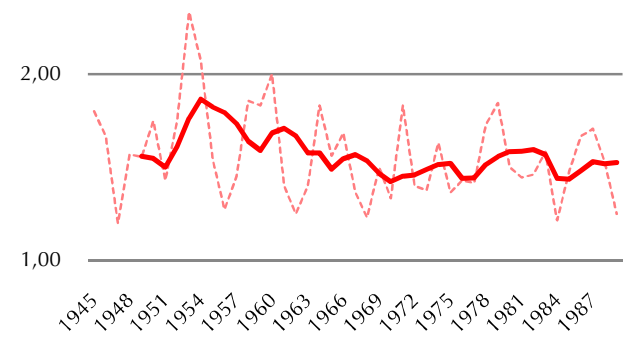

Partiendo de una mayor complejidad compositiva, la tendencia a partir de la segunda mitad de los años 50 es hacia una simplicidad relativa, que permanece a lo largo de toda la historia de la RDA.

Nivel de simplicidad 5 per. media
simplicidad)

LEYENDA EJE VERTICAL $\mathbf{1}=$ Simplicidad
$\mathbf{2}=$ Medio

$3=$ Complejidad

Si lo analizamos por géneros existe una gran diferencia entre los carteles políticos, con mayor acercamiento a la simplicidad, que los económicos, donde la complejidad en la transmisión del mensaje es más habitual. 
CULTURALES

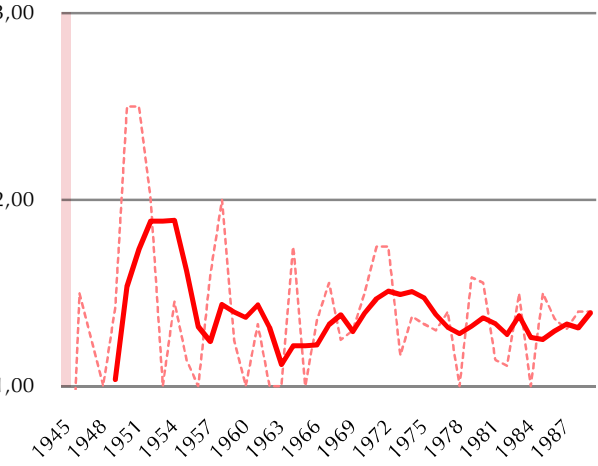

POLÍTICOS

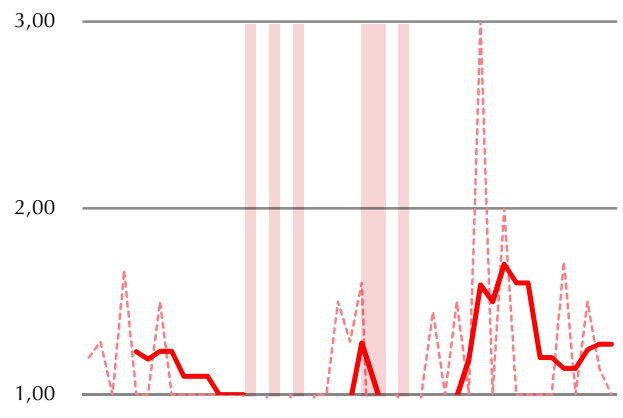

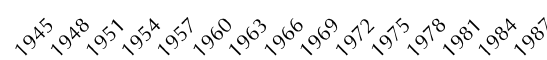

ECONÓMICOS

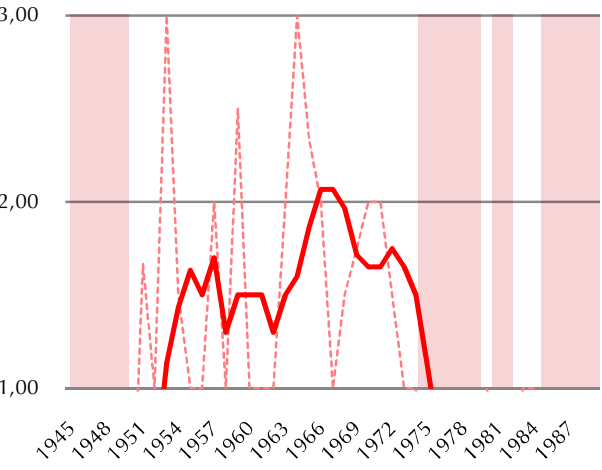

GENERAL

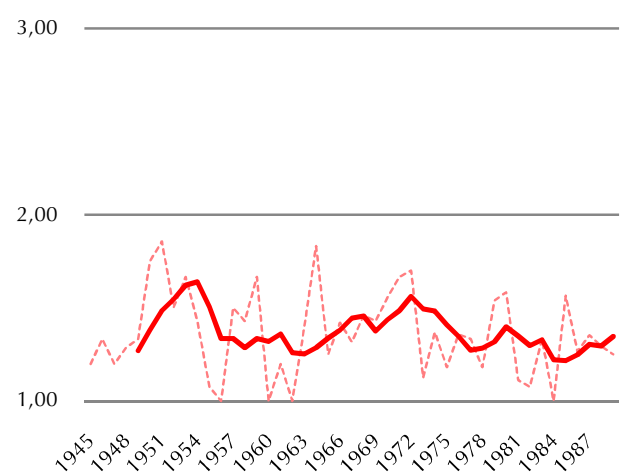

Nivel de unidad

5 per. media móvil (nivel de unidad)

\section{LEYENDA EJE VERTICAL}

$1=$ Unidad

$2=$ Medio

3= Fragmentación
Al igual que ocurre en cuanto a la complejidad, pasados los primeros años, la tendencia es hacia una comunicación unitaria del mensaje, con leves tendencias hacia la fragmentación a comienzos de los 50 y de los 70

Esta variación es más marcada en el plano cultural, mientras que la fragmentación es una tónica más generalizada en los carteles económicos, así como en los políticos del cambio de década de los 70 a los 80 .

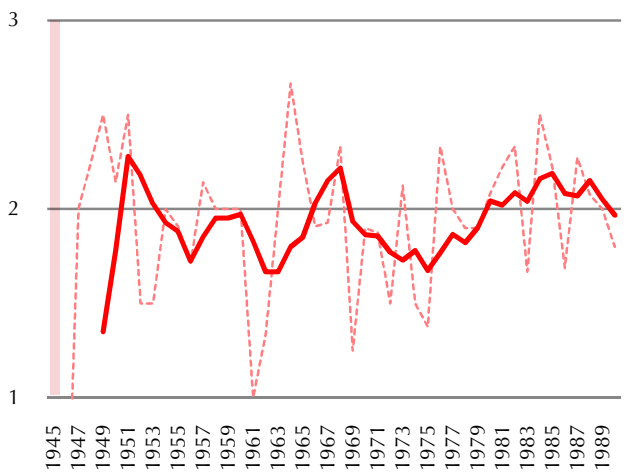

POLÍTICOS

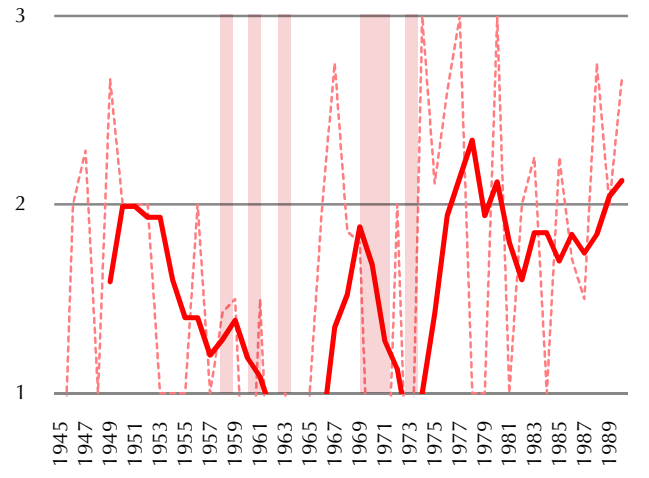

ECONÓMICOS

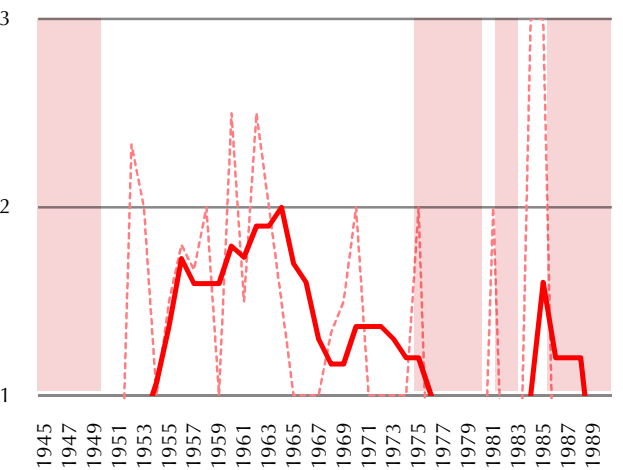

GENERAL

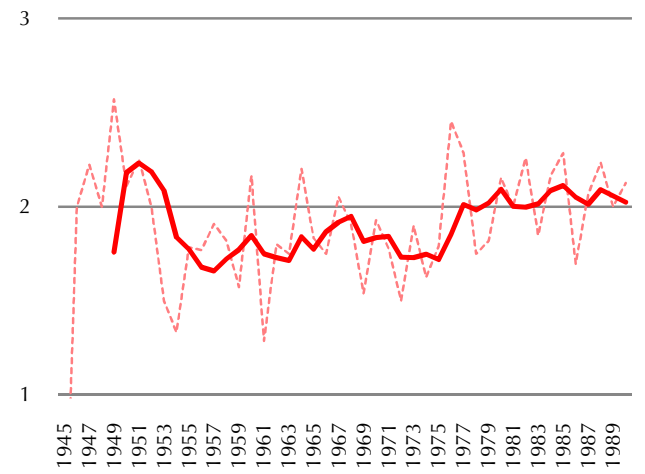

Los años de la SBZ se caracterizan por una mayor economía de los elementos, mientras que a partir de 1953 y hasta mediados de los años 70 se tiende a una mayor profusión, tendencia que se volcará, muy sutilmente a partir de este momento, manteniéndose equidistante entre la economía y la profusión.

En este parámetro encontramos muy similares las tendencias de todos los géneros, si bien es muy evidente el giro hacia la profusión de los carteles económicos a mediados de los años 60 debido al dominio de la imagen fotográfica en este campo.
Nivel de profusión

- 5 per. media móvil (nivel de

LEYENDA EJE VERTICAL

$1=$ Profusión

$3=$ 


\section{CULTURALES}

3,00

2,00

100

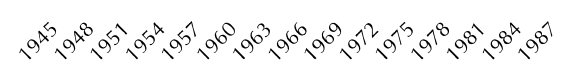

POLÍTICOS

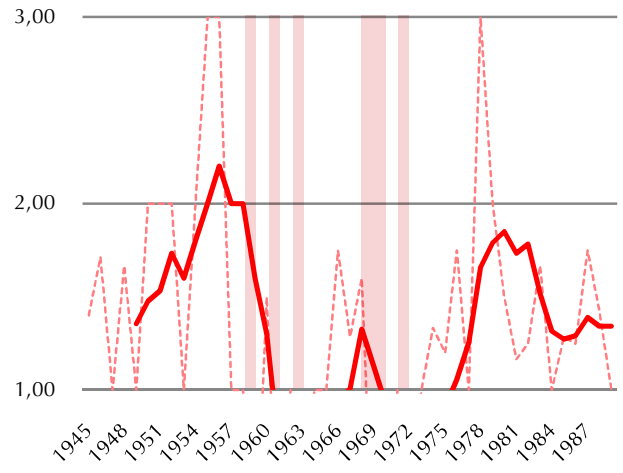

ECONÓMICOS

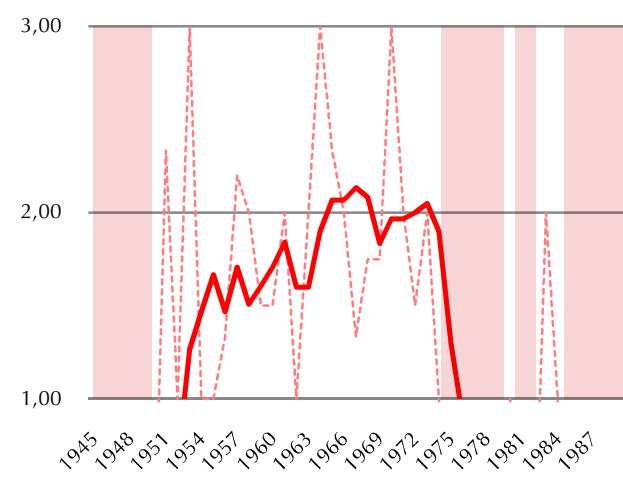

GENERAL

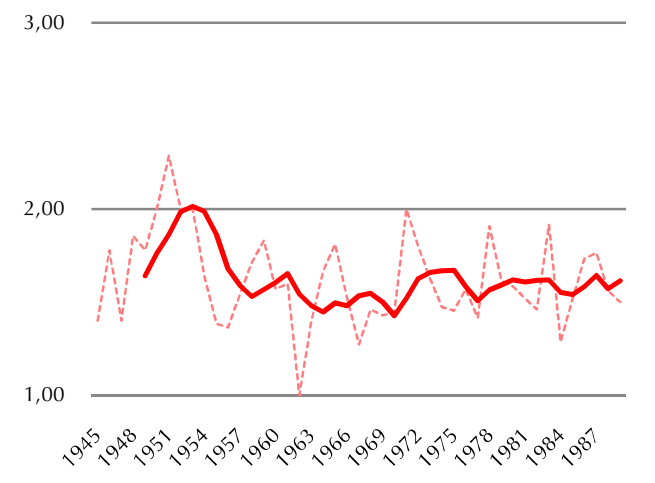

CULTURALES

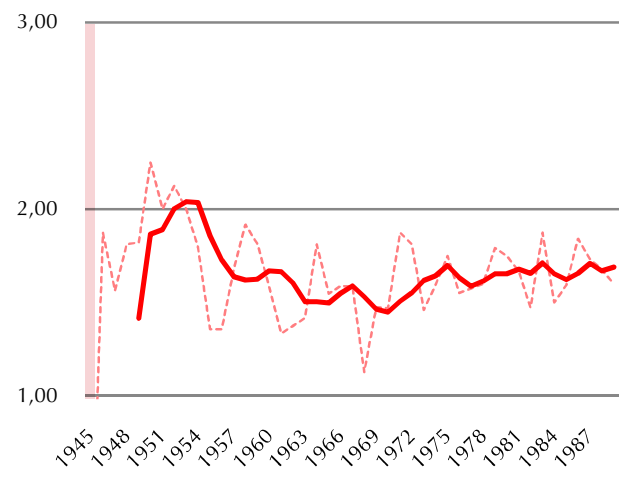

POLÍTICOS

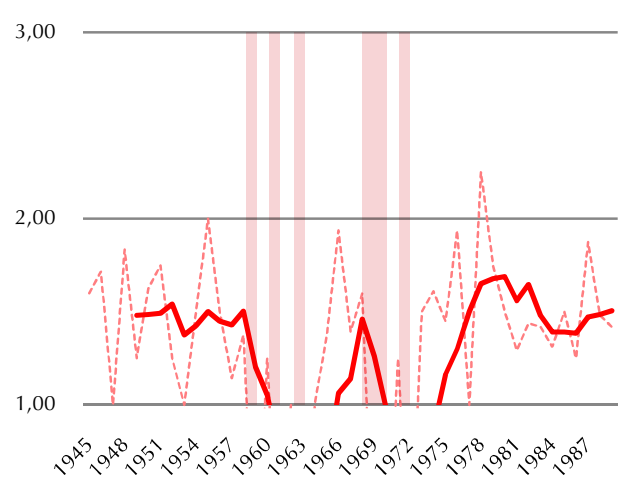

ECONÓMICOS

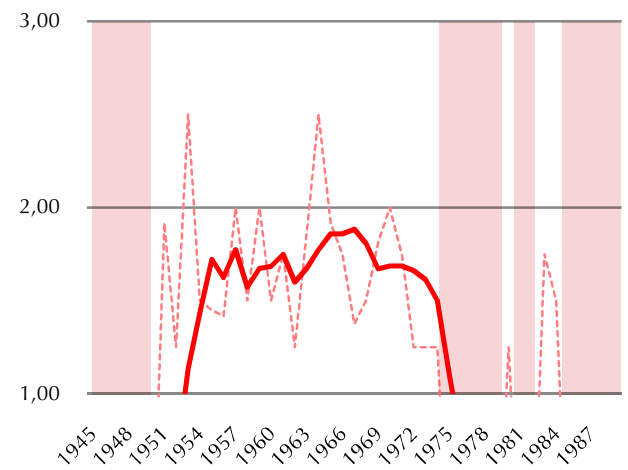

GENERAL

3,00

2,00

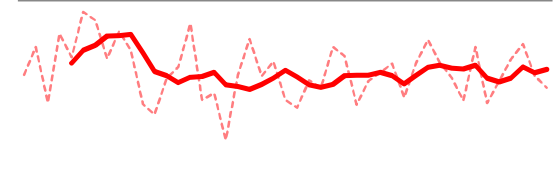

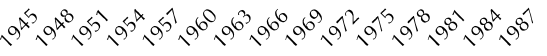

\section{Nivel de singularidad}

5 per. media móvil (nivel de
singularidad)

LEYENDA EJE VERTICAL

$\mathbf{1}=$ Singularida

$2=$ Medio

En este aspecto encontramos dos tendencias claras y diferenciadas, entre una mayor yuxtaposición hasta 1953 y desde entonces hasta mediados de los años 70 se caracteriza por la singularidad. Pasado este momento se equilibra en mayor medida, pero con predominancia de la singularidad.

Gráfico 7.36 Únicamente discrepa de esta línea el plano económico, en el cual encontraremos una tendencia creciente hacia la yuxtaposición de elementos, especialmente notable en la década de los 60.
La unidad permanece globalmente armónica, con un mayor acercamiento al contraste hasta 1953 y un periodo más marcadamente armónico a partir de este momento.

Como hemos visto en los parámetros previos, diverge de esta tónica el cartel económico, el cual tenderá hacia un mayor contraste, si bien este permanece por debajo de nivel medio en todo el periodo analizado.

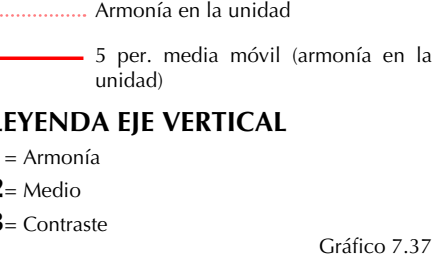

LEYENDA

$3=$ Contras 


\section{CULTURALES}

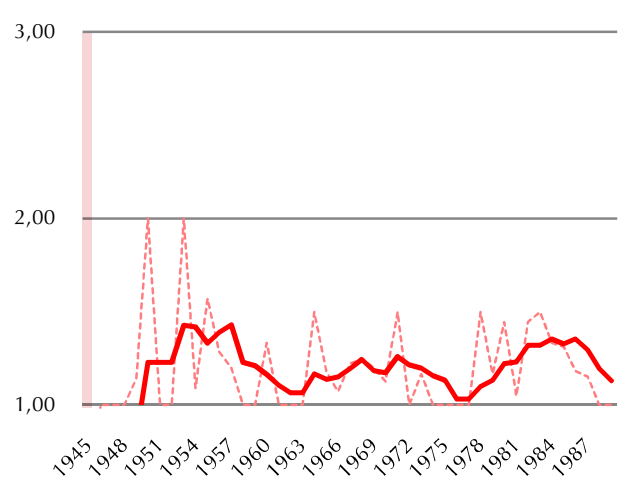

POLÍTICOS

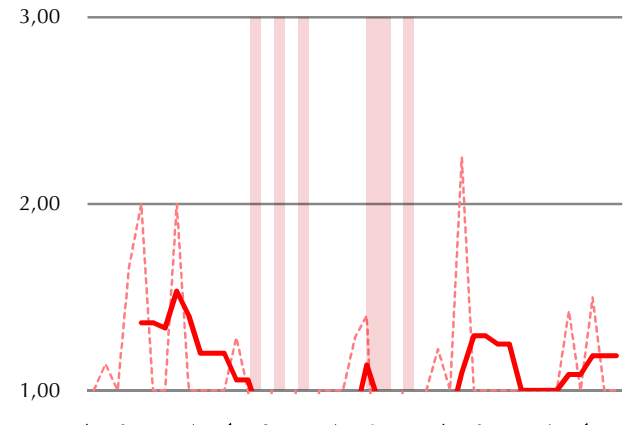

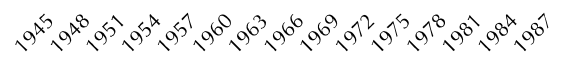

ECONÓMICOS

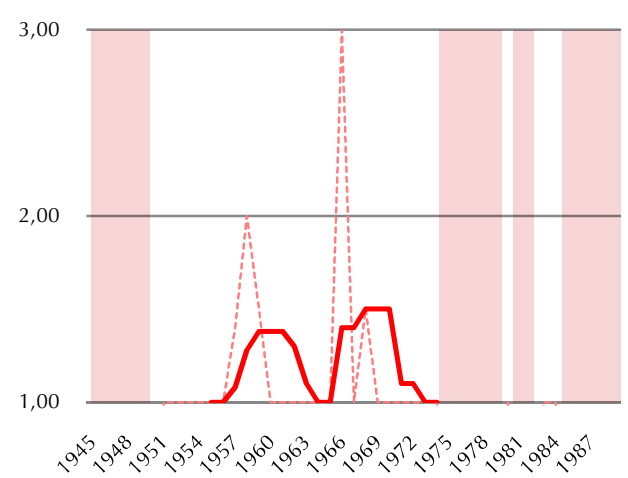

GENERALES

2,00

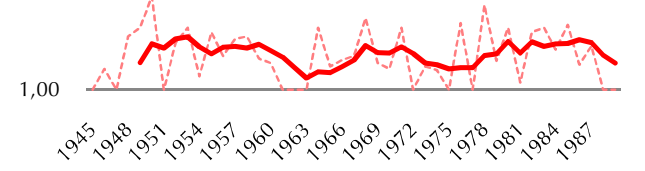

Nivel de pasividad

5 per. media móvil (nivel de LEYENDA EJE VERTICAL

$1=$ Pasividad

$\mathbf{2}=$ Medio
$\mathbf{3}=$ Actividadidad

Gráfico 7.38
La opacidad es la tónica general de los carteles de la muestra, con un uso de la transparencia casi esporádico y más notorio en el periodo previo a 1953.

Destaca el uso de la transparencia únicamente en el plano económico y en momentos puntuales.

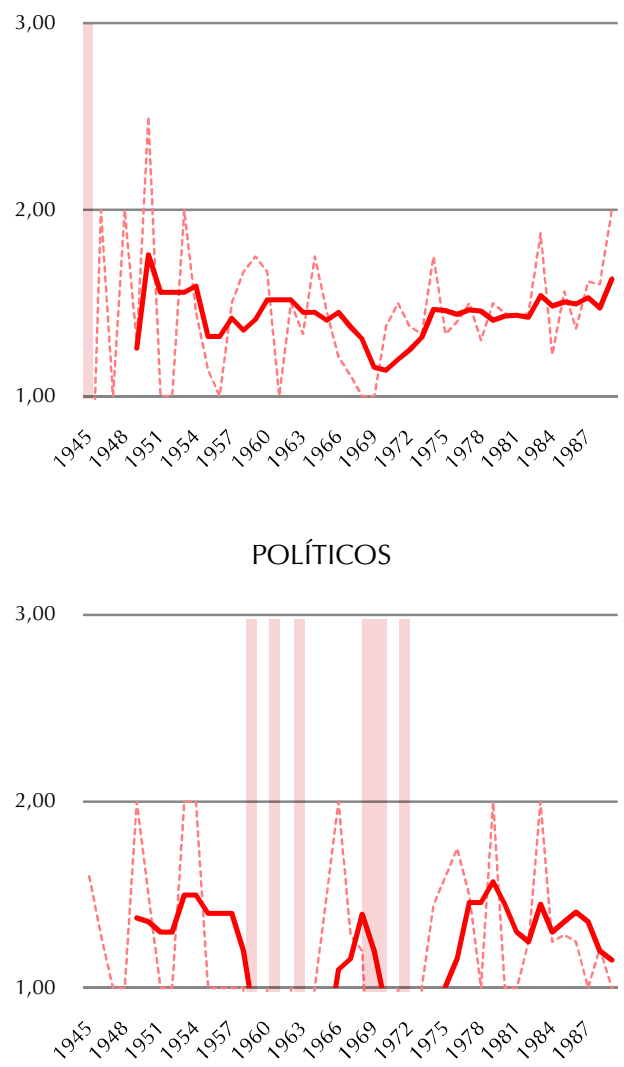

ECONÓMICOS

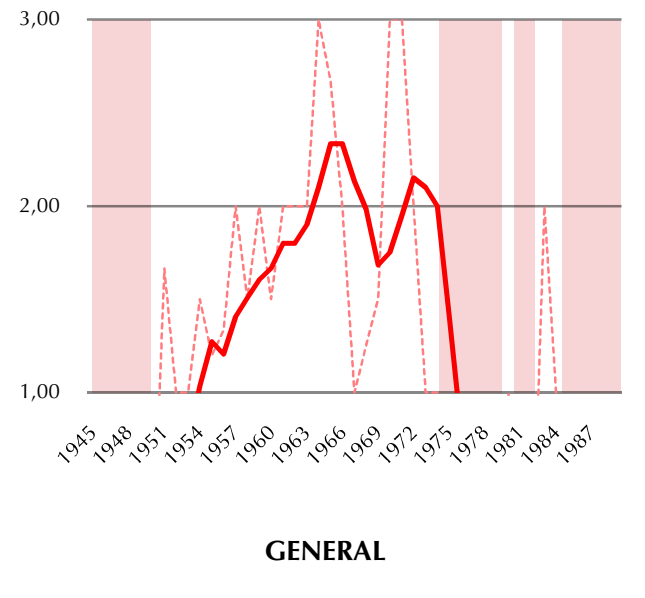

3,00

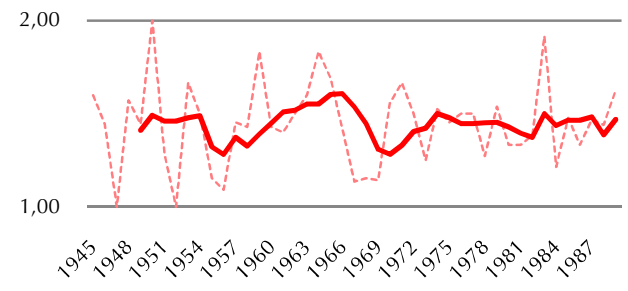

La coherencia en la colocación de los elementos es otra tónica habitual de los carteles de la RDA, que permanece prácticamente invariable a lo largo de toda su historia, sutilmente más variada en los años de la SBZ.

Los carteles económicos suponen la mayor diferencia en este parámetro, ya que tienen una clara tendencia hacia la variación.
Nivel de coherencia

5 per. media móvil (nivel de
coherencia)

\section{LEYENDA EJE VERTICAL}

$1=$ Coherencia

$2=$ Medio
$3=$ Variació

Variación 
CULTURALES

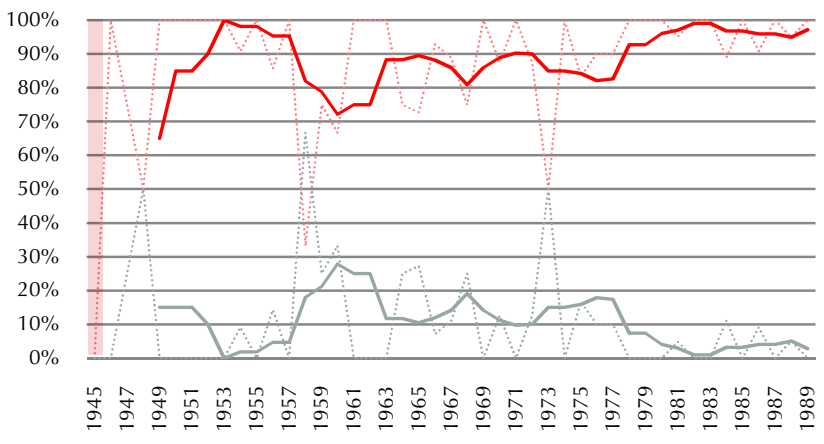

\section{ECONÓMICOS}

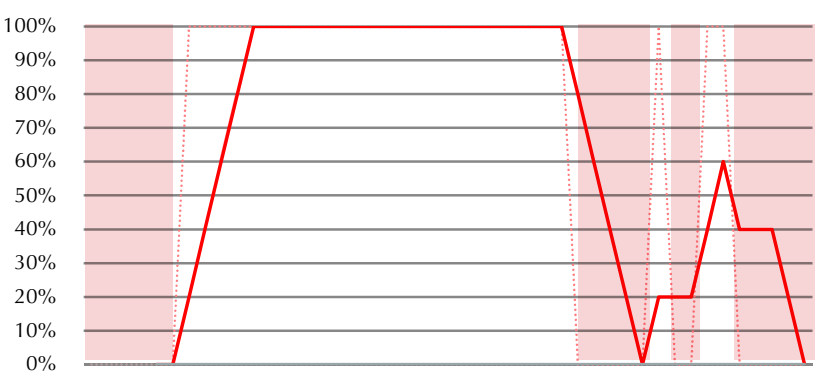

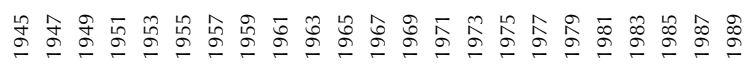

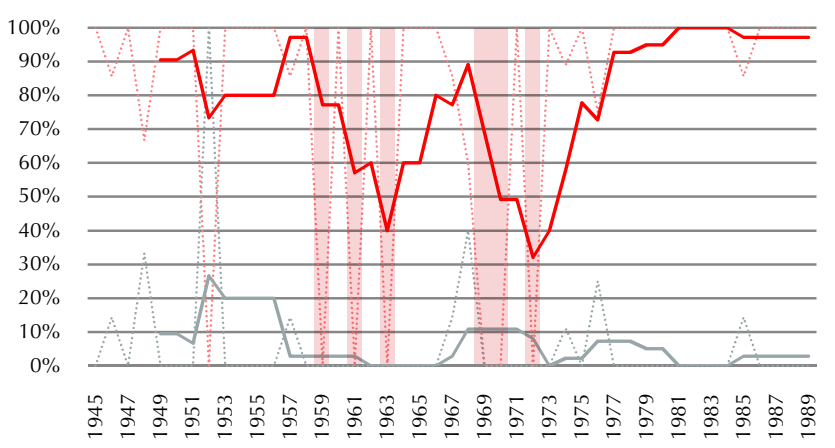

3\%

$10 \%$
$0 \%$

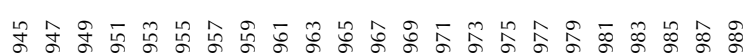

La relación entre la figura y el fondo es predominantemente estable, con una mayor tendencia a la ambigüedad en el periodo entre 1957 y 1975. Pasada esta fecha el dominio de diseños estables en la relación figura fondo es casi total.

La ambigüedad de los años 60 y primeros 70 tiene lugar preferentemente en los carteles culturales y en los primeros carteles políticos, no teniendo lugar en ningún momento en los carteles económicos. 
CULTURALES

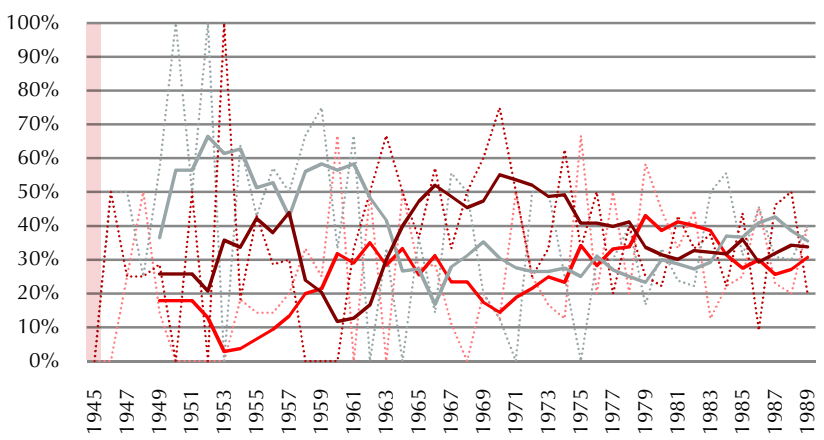

ECONÓMICOS

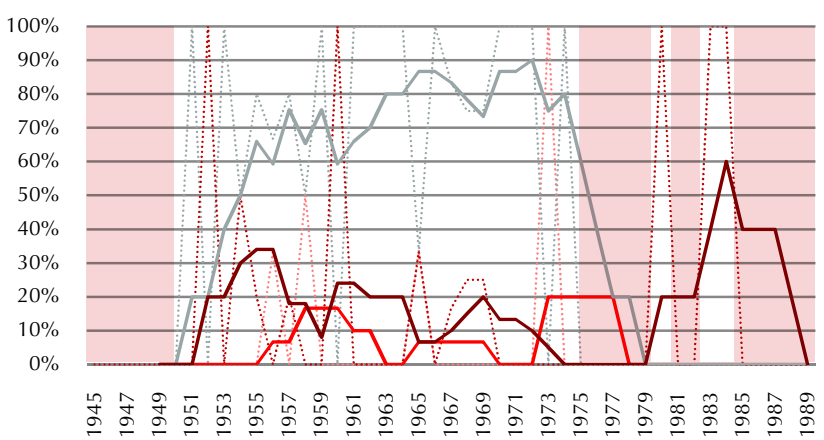

POLÍTICOS

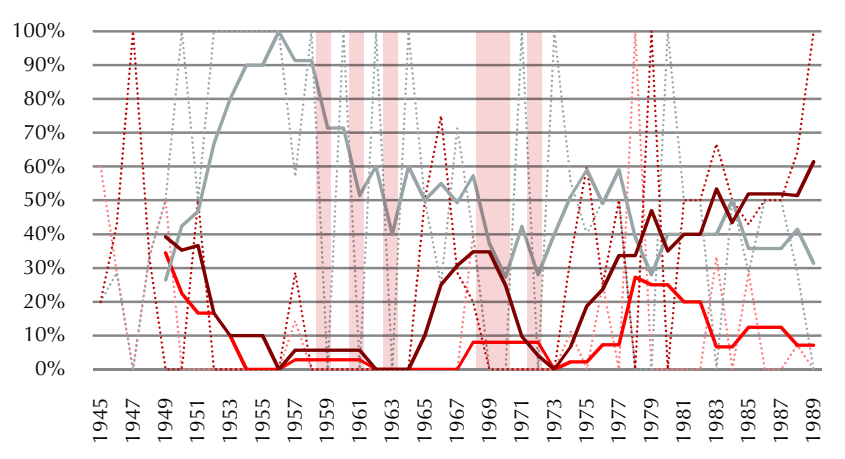

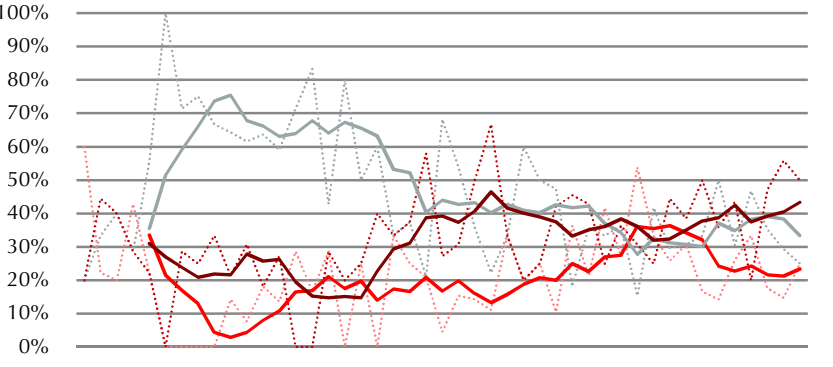

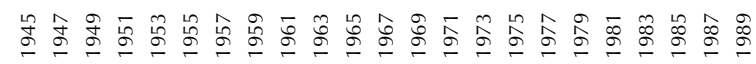

Encontramos dos tendencias claras en la relación con el marco, una primera, hasta mediados de los años 60 en la cual la composición supera el marco, y una segunda, a partir de este momento, en la cual la composición se ajusta a los límites. A lo largo de todo el periodo analizado la composición en la cual se remarcan los límites va ganando presencia, hasta los años 80 en que esta tendencia retrocede sensiblemente.

Si lo diferenciamos por géneros es evidente la diferenciación entre carteles económicos y políticos, en los cuales predominan ampliamente las composiciones en las que se supera el marco, y los carteles culturales, con un abanico más amplio de relaciones.

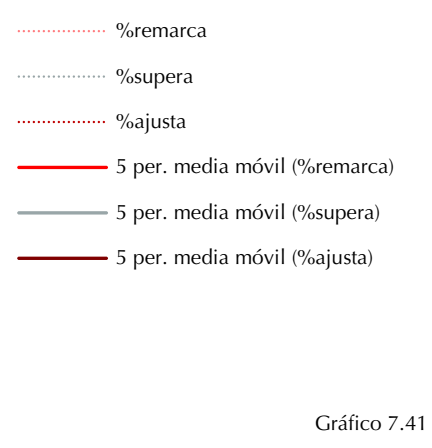

Grático 7.41 
CULTURALES

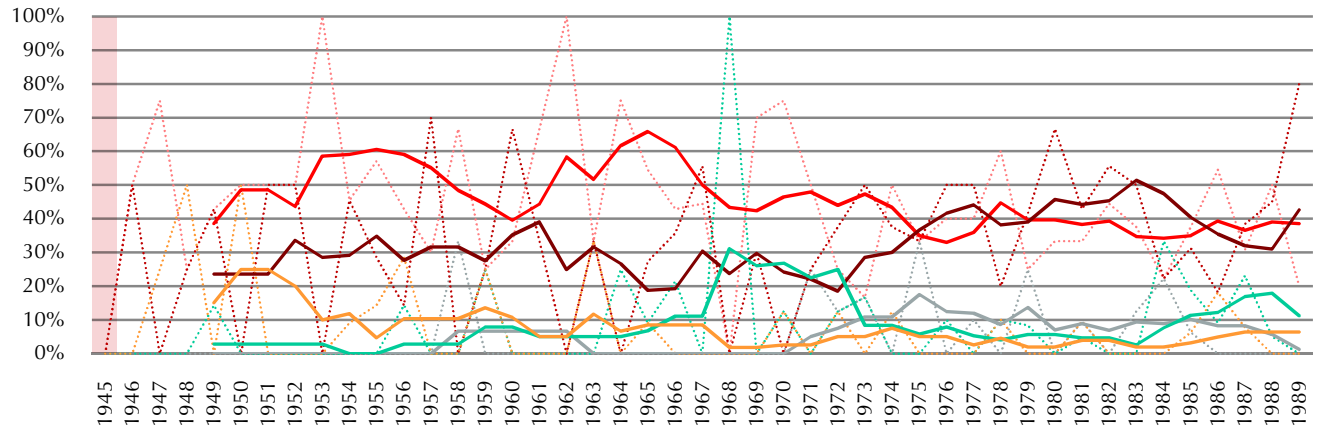

ECONÓMICOS

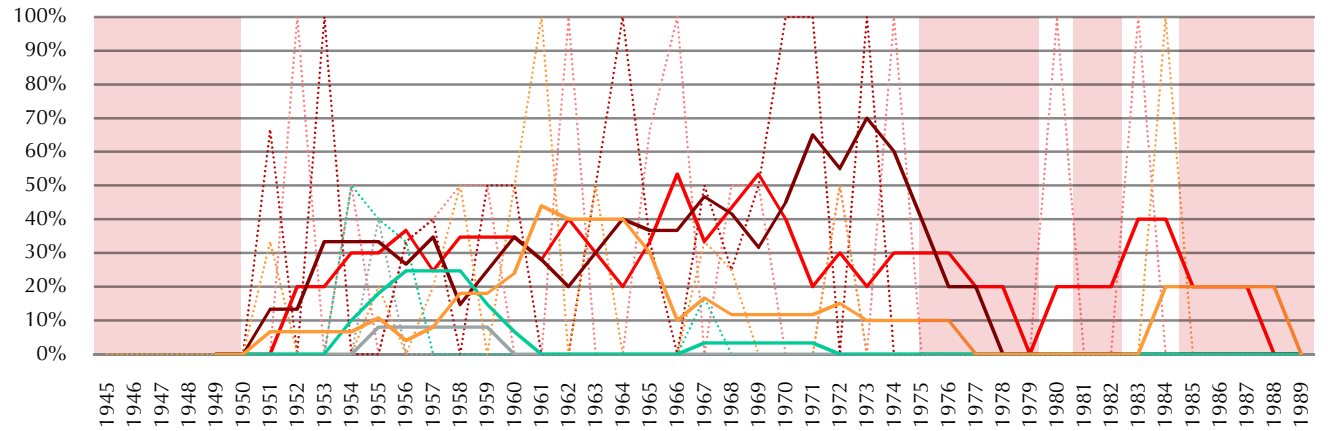

POLÍTICOS

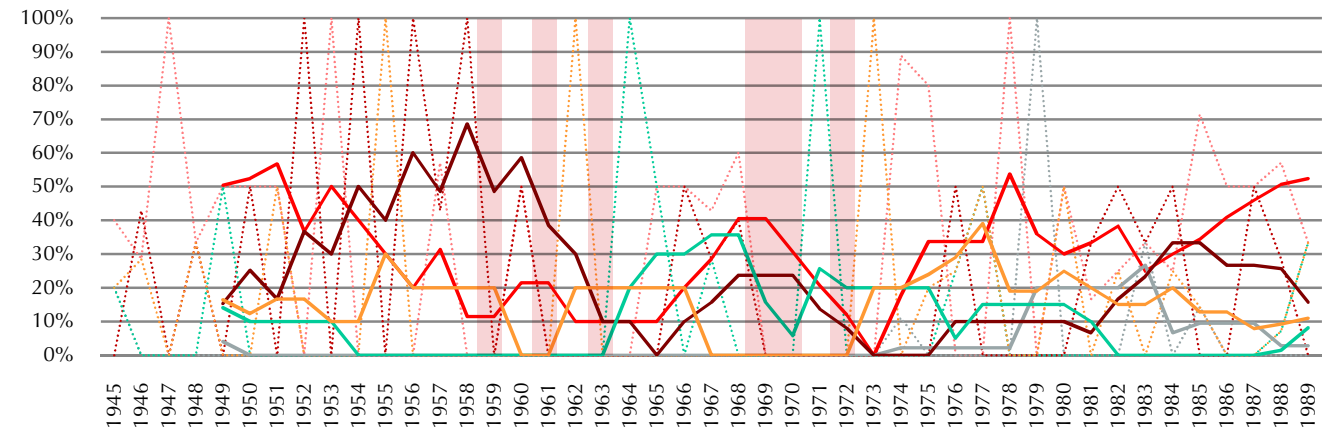

$90 \%$

$80 \%$
$70 \%$

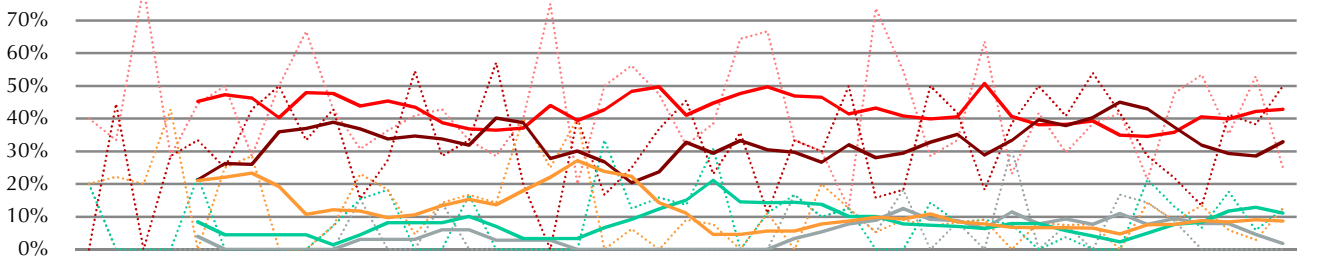

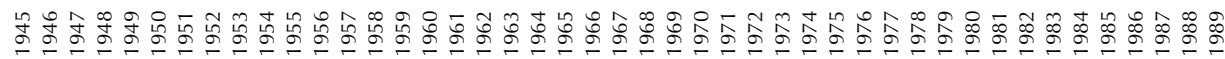

Las alineaciones a ejes, seguidas de las intuitivas son la tónica predominante en todo el periodo analizado, sin grandes variaciones temporales. Sin embardo si que se observa unas mayores variaciones en los otros tipos de alineaciones tipográficas. Mientras las alineaciones internas y receptivas tuvieron su momento álgido en la década de los 60, la década de los 70 experimentará un aumento de las alineaciones de contorno, que si bien alcanzaron porcentajes muy bajos del total, supuso un cambio notable.

Los carteles culturales acusan un mayor dominio de las alineaciones tipográficas a ejes o intuitivas, mientras que se produce un mayor reparto más equitativo en el caso de los carteles económicos y políticos.

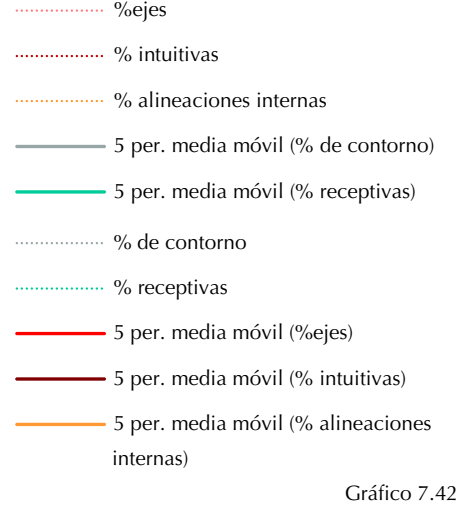

Gráfico 7.42 
CULTURALES

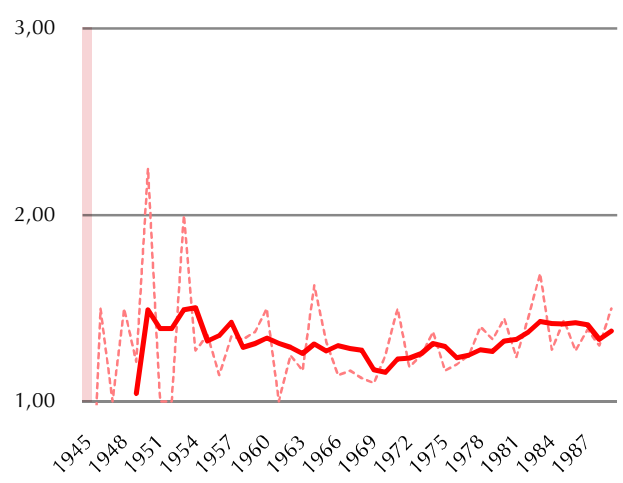

POLÍTICOS

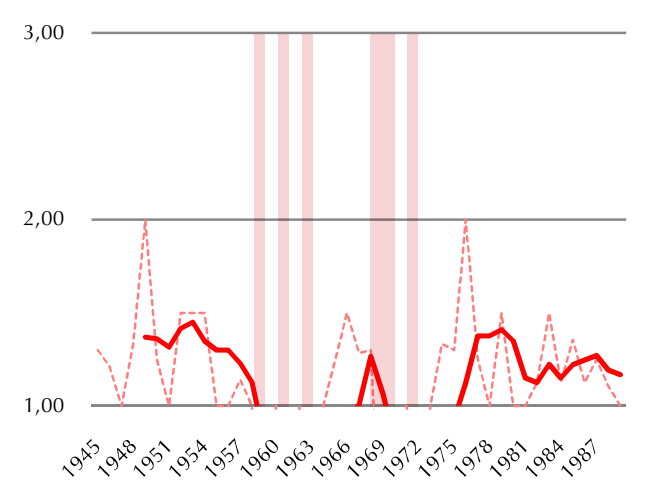

ECONÓMICOS

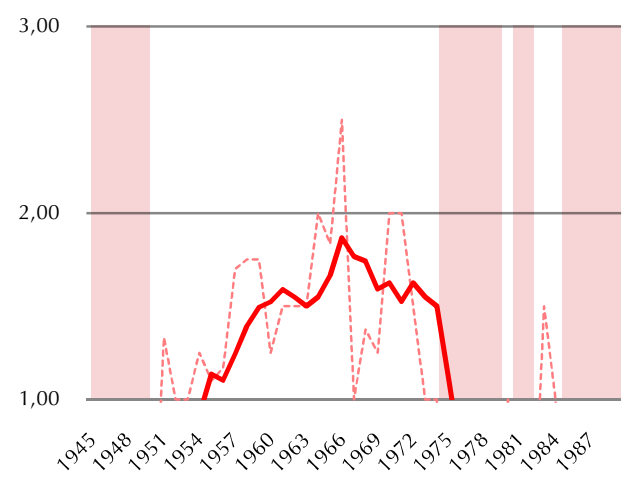

GENERAL

3,00

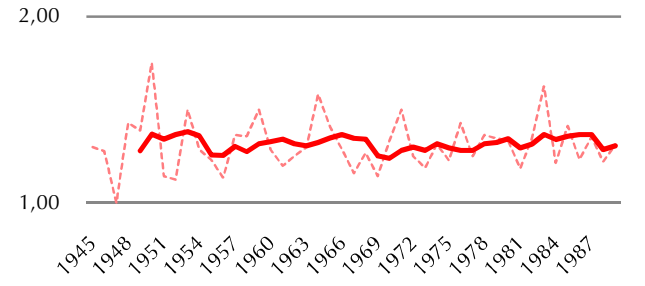

CULTURALES

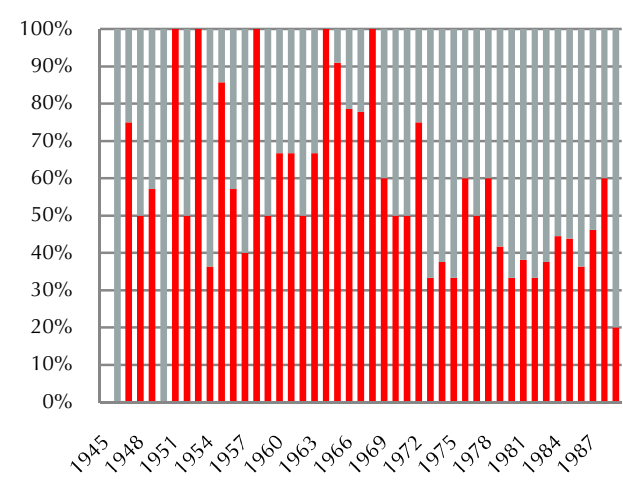

POLÍTICOS

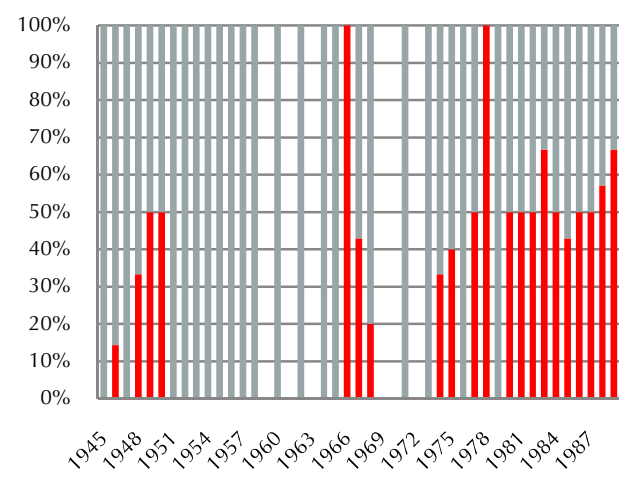

ECONÓMICOS

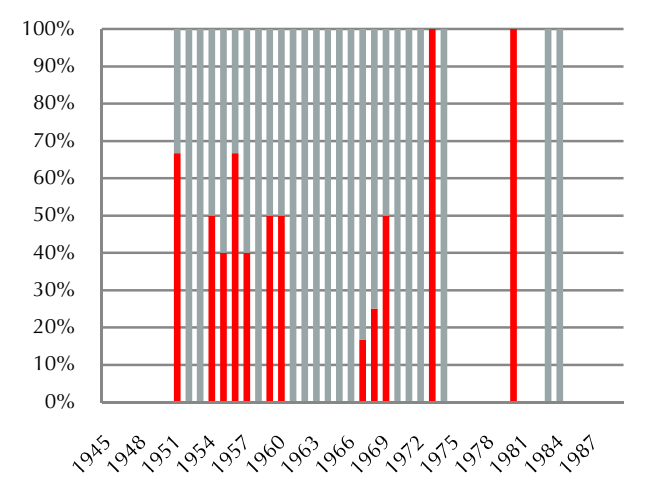

GENERAL

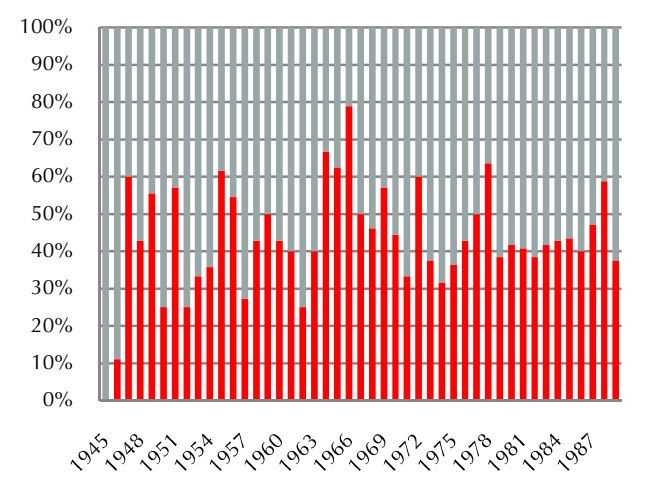

Nivel de armonía en la colocación A nivel general podemos hablar de una colocación homo-

5 per. media móvil (nivel de

\section{LEYENDA EJE VERTICAL}

$1=$ Armonía

$3=$ Contraste

géneamente armónica a lo largo de toda la muestra. No obstante se percibe un mayor contraste en la colocación de los primeros años, más notable en los carteles políticos y culturales.

Gráfico 7.43 Se destaca notablemente el plano económico, que sufre una evolución contraria al resto de los géneros. Mientras en el panorama cultural y político los años 60 acusaron una leve tendencia hacia una mayor armonía, los carteles económicos se distinguen por su tendencia hacia el contraste, con niveles cercanos al 2,5 en 1966.
Las tendencias a representaciones menos realistas tiene su reflejo en el uso de la perspectiva, en la cual la perspectiva plana tendrá una notable presencia en la década de los años 60. Los primeros carteles apenas consideraran la perspectiva plana, declinándose por la profundidad en sus representaciones.

La ausencia de perspectiva es más habitual en los carteles culturales, con una notablemente baja presencia en los carteles económicos. El género político experimentará una gran diferencia entre los carteles previos a 1965, con casi total ausencia de imágenes planas, y posteriores a 1965, donde estas supondrán cerca de la mitad de los elementos de la muestra. 


\subsection{ANATOMÍA DEL MENSAJE}

7.4.1 Representación

TIPO DE REPRESENTACIÓN

CULTURALES

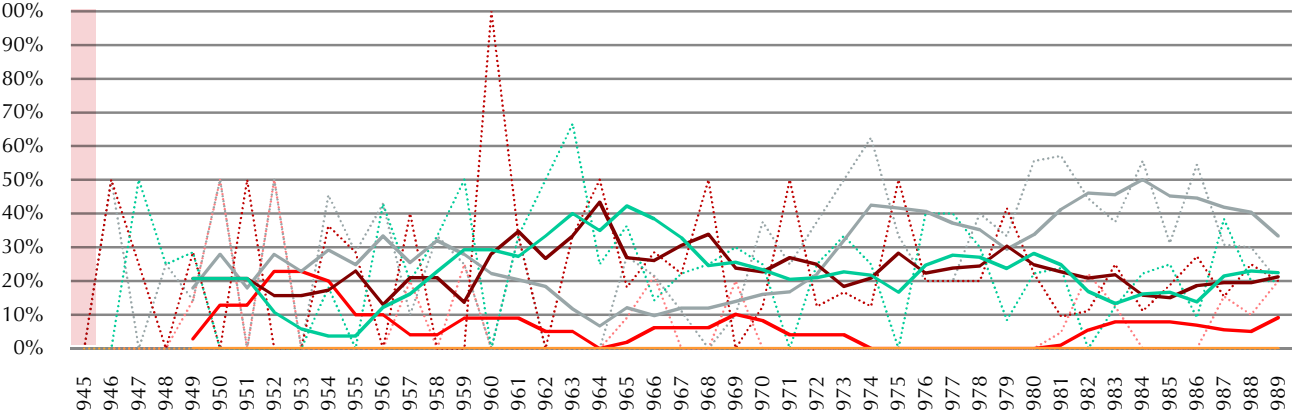

ECONÓMICOS

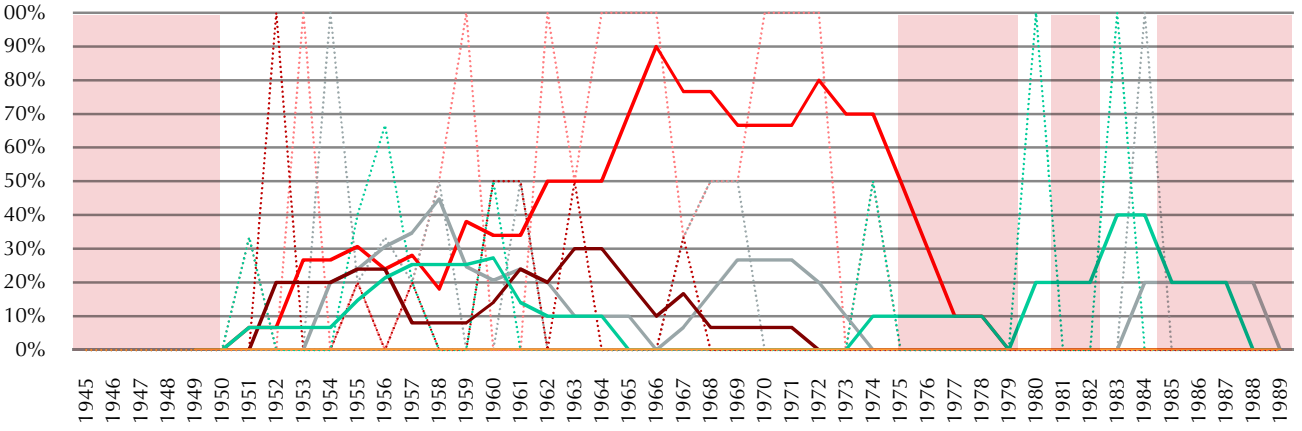

POLÍTICOS

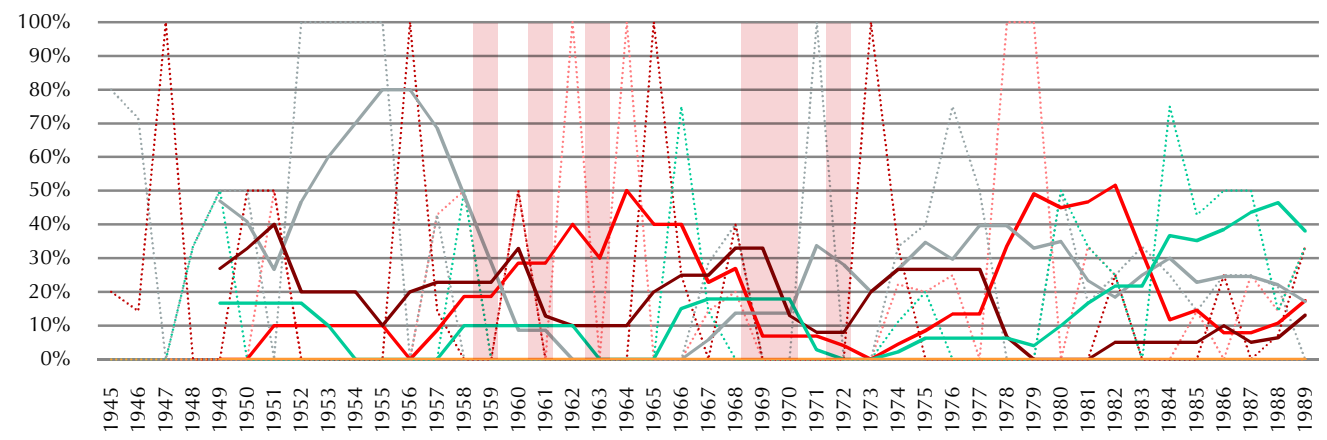

\section{GENERAL}

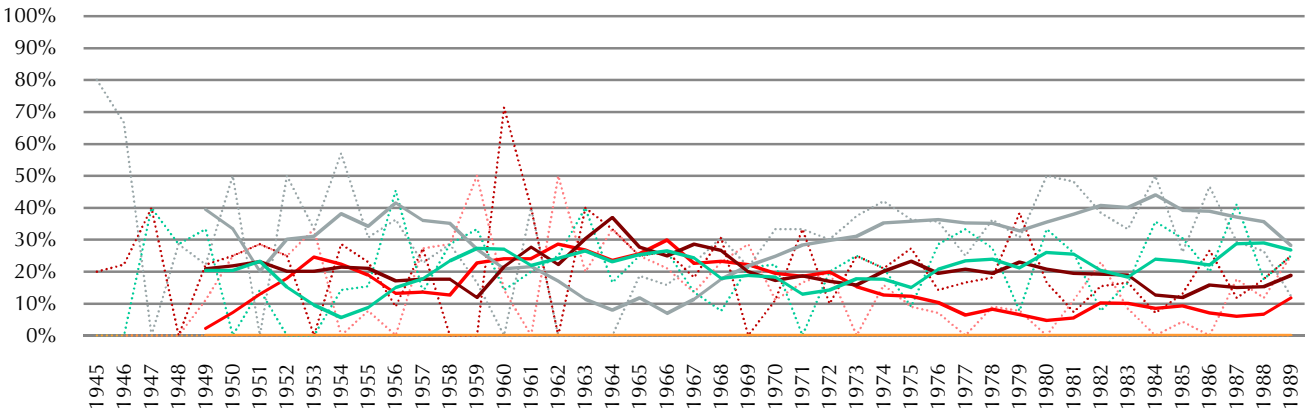

Si atendemos al tipo de representación destaca sobre todos el realismo, que tan solo pierde importancia en los años 60, cuando se imponen tendencias de representación menos realistas. Es especialmente representativa la total ausencia de abstraccionismo en los elementos de la muestra.

Si tenemos en cuenta los diferentes géneros, las tendencias más realistas -realismo e hiperrealismo- tienen un mayor peso en los carteles políticos y económico, mientras que las menos realistas se concentran en los carteles culturales.
............. \% hiperrealismo \% realismo

... \% surrealismo 5 per. media móvil (\% abstraccionismo 
CULTURALES

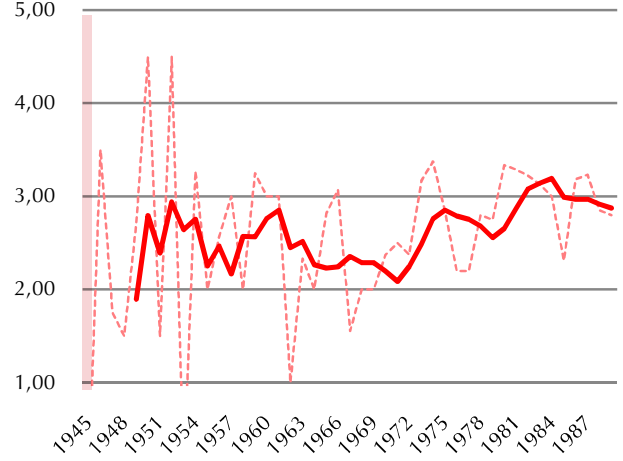

POLÍTICOS

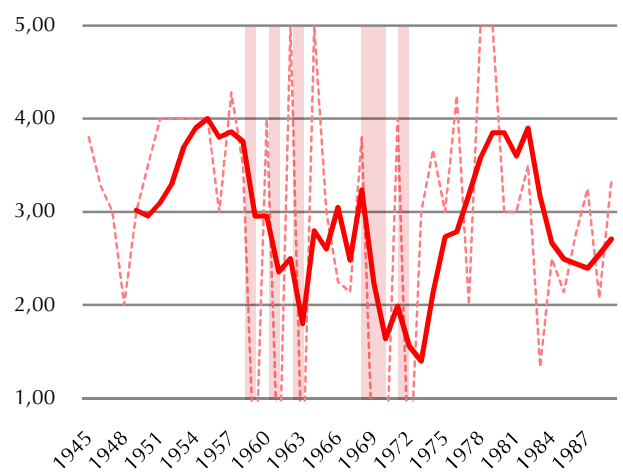

ECONÓMICOS

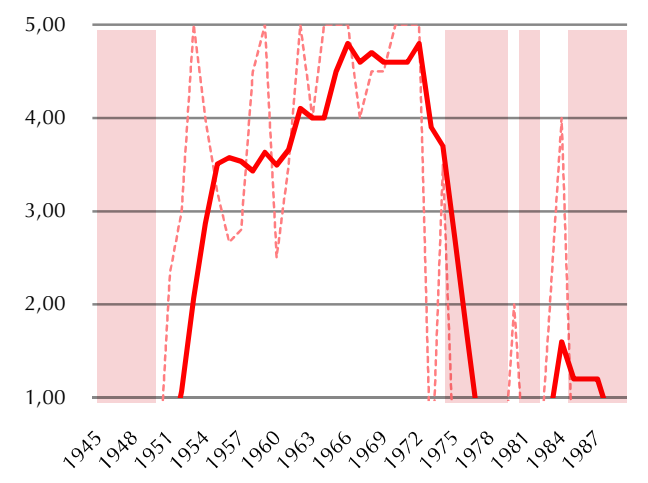

GENERAL

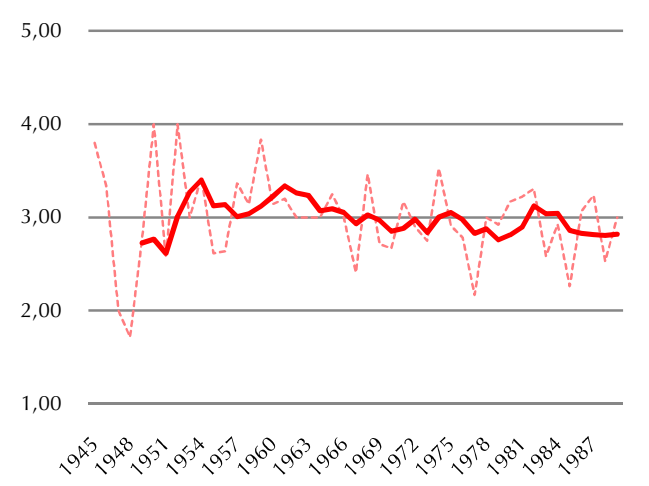

Nivel de representación 5 per. media móvil (nivel de
representación)

LEYENDA EJE VERTICAL

$\mathbf{1}=$ Abstraccionismo

$2=$ Surrealismo
$3=$ Mesorrealismo

$3=$ Mesorrealismo
$4=$ Realismo

$4=$ Realismo

$\mathbf{5}=$ Hiperrealismo
El nivel de representación ronda el mesorrealismo a lo largo de toda la historia de la RDA, con periodos más cercanos al realismo en los años 50 y al surrealismo en los años 60.

El nivel de realismo de los carteles políticos, y en especial de los económicos es muy superior a la media, al tiempo que los carteles publicitarios no experimentaron la tendencia hacia niveles de representación más bajos, sino mucho más altos, debido al predominio de la imagen fotográfica a partir de los años 60. 


\section{TIPO DE ABSTRACCIÓN}

CULTURALES

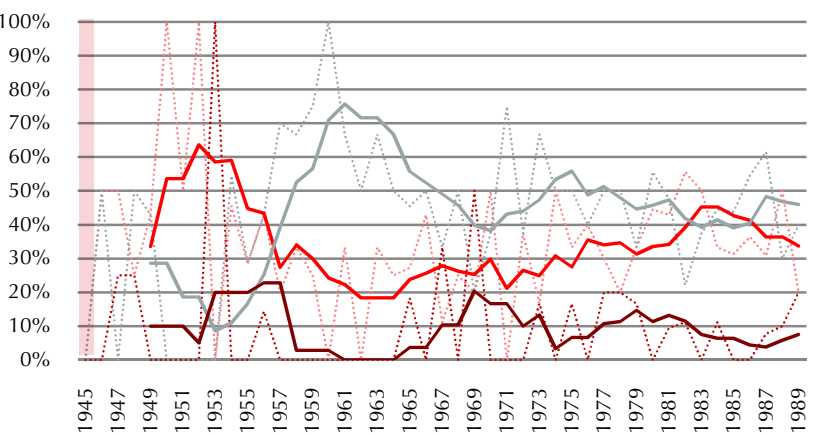

ECONÓMICOS

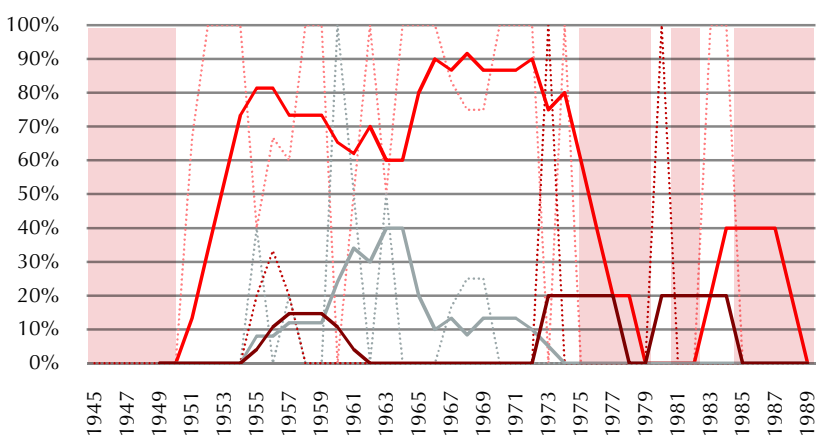

POLÍTICOS

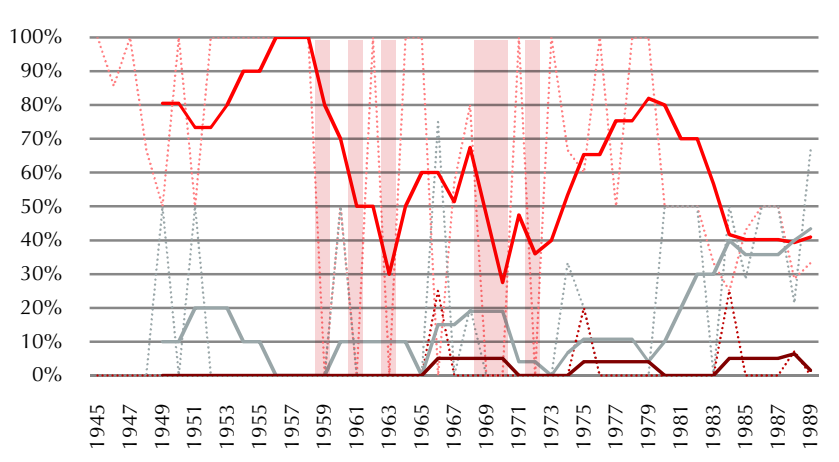

$100 \%$

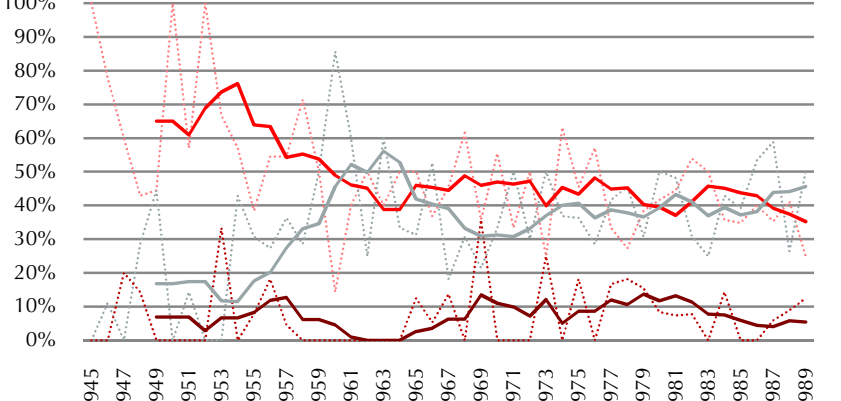

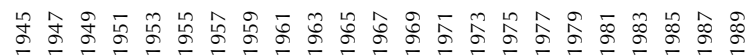

Hasta los años 60 el isomorfismo era destacadamente la forma de abstracción más habitual, con una amplia mayoría de las representaciones, a partir de este momento se amplían las representaciones mesomórficas, con una presencia destacada durante esta década, y que se igualarán a partir de los años 70. Las representaciones amórficas tendrán una muy baja presencia en los carteles de la RDA a lo largo de toda su historia.

Al igual que ocurría con el tipo de representación, los carteles políticos y económicos contarán con un nivel de abstracción notablemente más cercano a la realidad que los carteles culturales, y el isomorfismo será la tendencia predominante de estos géneros.
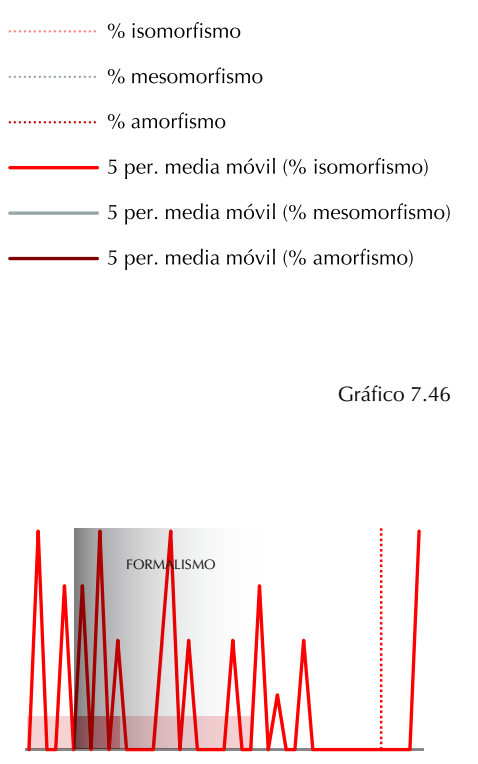

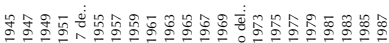

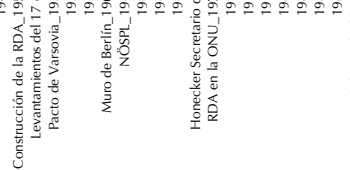

Gráfico 7.2.b 
CULTURALES

2,00

1,00

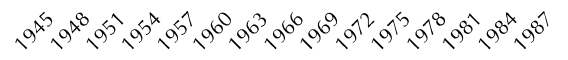

POLITICOS

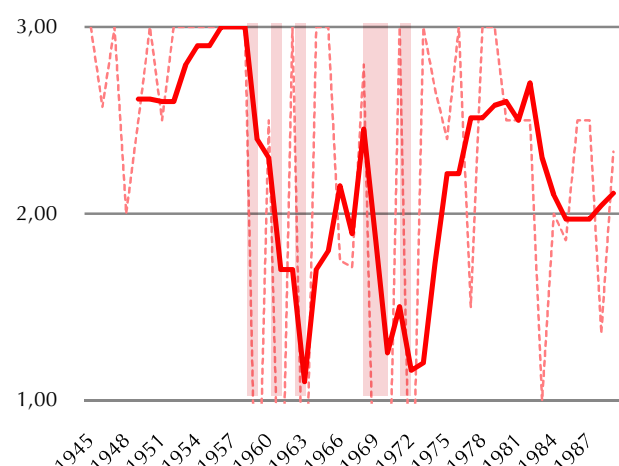

ECONÓMICOS

1,00

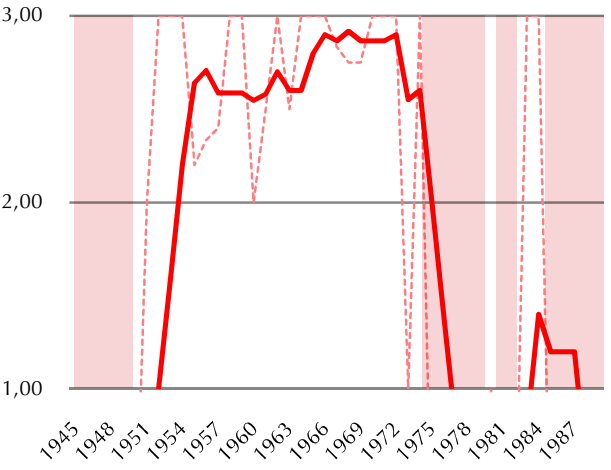

GENERAL

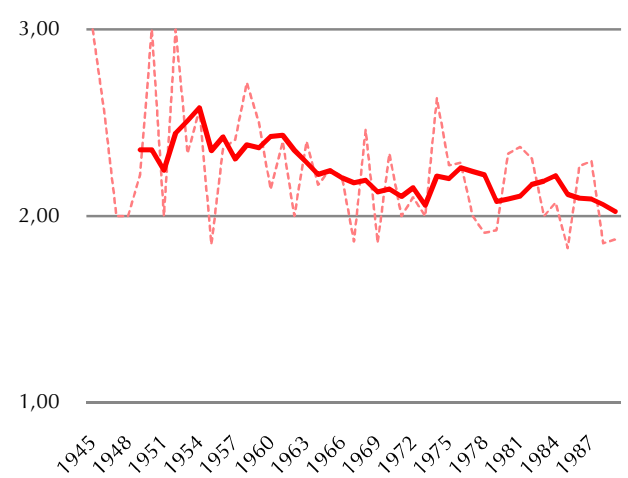

Nivel de abstracción

5 per. media móvil (nivel de
abstracción)

\section{LEYENDA EJE VERTICAL}

$\mathbf{1}=$ Amorfismo
$\mathbf{2}=$ Mesomorfismo
$3=$ sonotis

$3=$ Isomorfirmo

Gráfico 7.47
El nivel de abstracción general de los carteles de la RDA es cercano al isomorfismo a lo largo de toda la historia, si bien podemos observar una tendencia hacia el mesomorfismo.

Los gráficos de cada género son notablemente diferentes en su nivel de abstracción; mientras los carteles culturales rondan el mesomorfismo durante todo el periodo, con un mayor nivel de abstracción en el intervalo de los años 60 y primeros 70 los carteles políticos y culturales tendrán un elevado nivel de isomorfismo. Tan solo en los años 80 podemos hablar de tendencias menos ajustadas a la realidad en los carteles políticos. 
CULTURALES

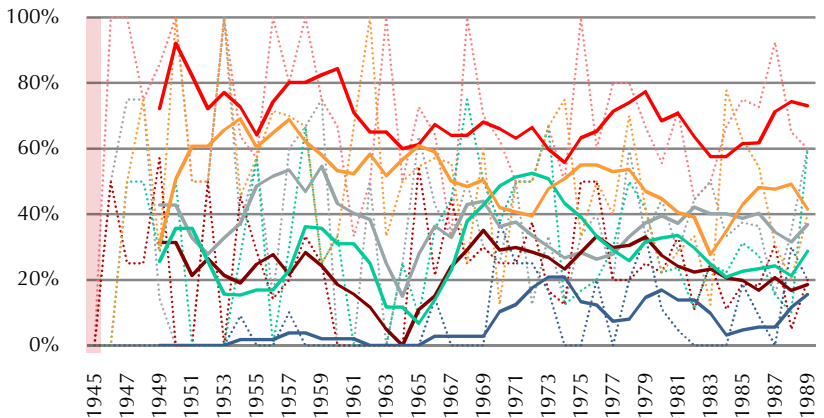

ECONÓMICOS

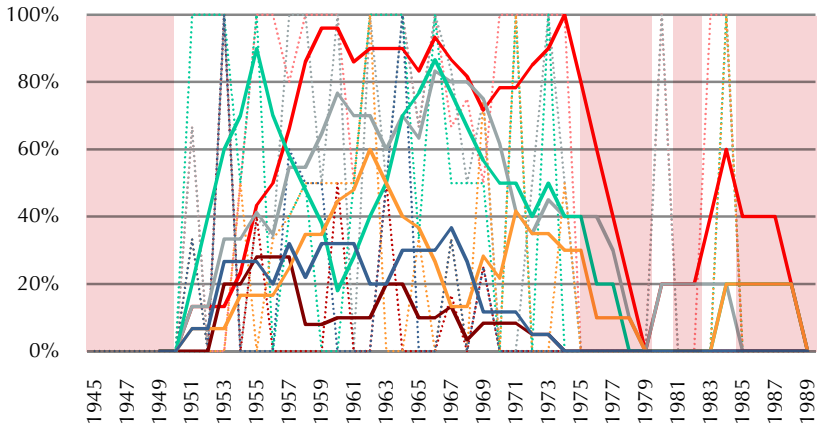

POLÍTICOS

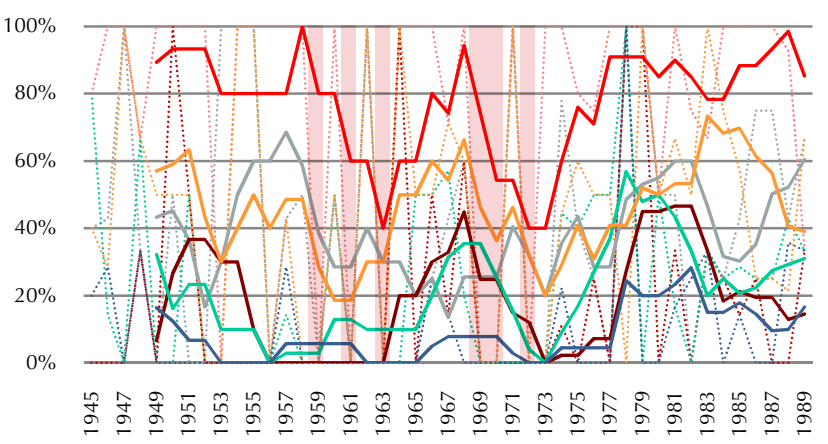

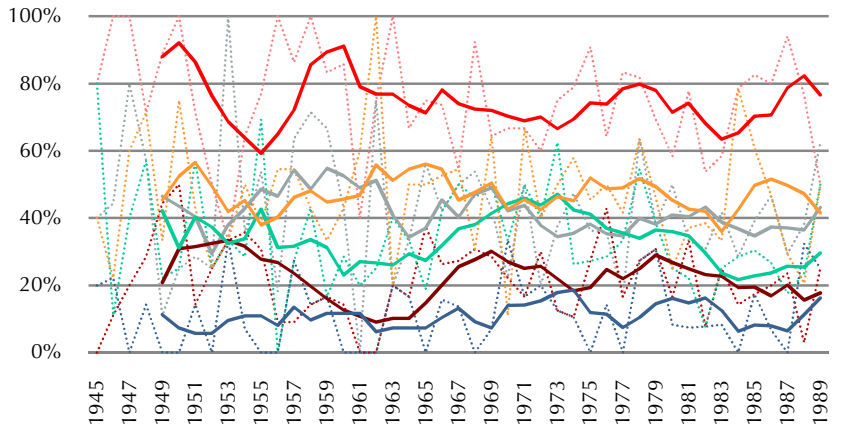

\% DE SUSTITUCIÓN

DE COMPARACIÓN

\% DE SUPRESIÓN

$\%$ REPETITIVAS

\% DE ADIUNCIÓN

\% DE TRANSPOSICIÓN

La retórica más habitual la encontraremos en las figuras de sustitución tales como las metáforas y metonimias, seguida por las figuras de adjunción. Fuera de esto no encontramos unas tendencias claras en el uso de la retórica, más allá de un cierto aumento a partir de los años 70 de las figuras sintácticas tales como de repetición y supresión, que habían cedido mucho terreno en la década anterior. Sorprendentemente en los años 50 se observa un decrecimiento de las figuras de sustitución, cuyo nivel en los primeros años de la SBZ era cercano al $100 \%$.

Este decrecimiento viene marcado por el cartel económi$\mathrm{CO}$, ya que sus niveles en el resto de los géneros permanece muy alto hasta finales de los años 50 . El predominio de las figuras de sustitución es más evidente en los carteles políticos, y es en el plano económico donde ceden terreno a otras figuras, como las de comparación y repetición. 
CUARTA PARTE 
8. Conclusiones

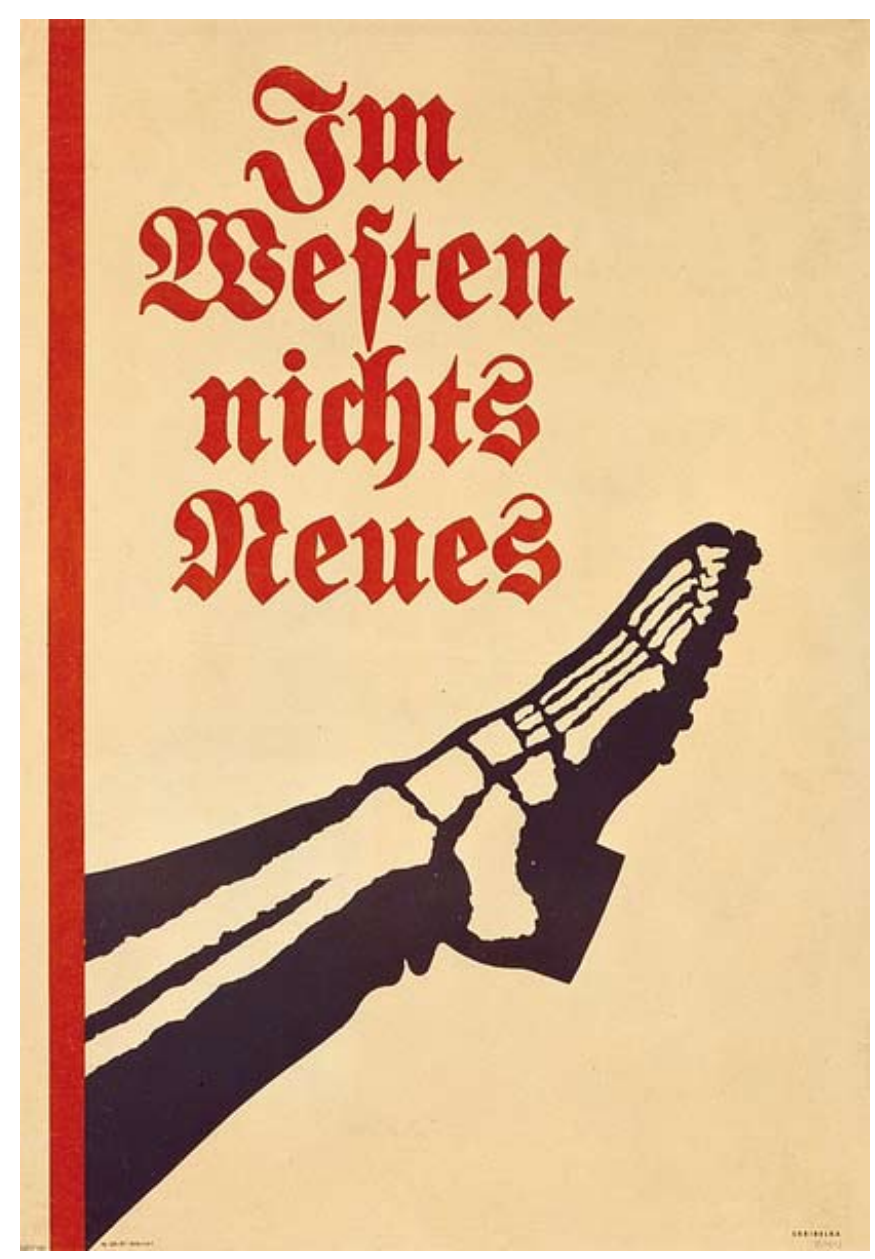


El análisis de los datos en la investigación se ha estructurado en dos partes claramente diferenciadas. Por un lado el análisis del lenguaje visual, basándonos en una propuesta metodológica propia, de los elementos que componen la muestra y que nos permite hacer -a través del cartel- un recorrido por el diseño gráfico de la RDA a lo largo de tiempo y de sus diferentes categorías. Aquí buscábamos definir unas líneas de tendencia que nos permitiera establecer una evolución, así como unas características comunes y poder relacionar el diseño gráfico que se desarrolló en la RDA con el que tuvo lugar en la Alemania previa a la Segunda Guerra Mundial. Por otro lado realizamos un análisis de las tipografías diseñadas o producidas por la VEB Typoart ya que suponían un elemento prediseñado y con identidad propia que se establecía de antemano y que limitaba el diseño gráfico.

A priori puede parecer que un sistema social y de gobierno como el establecido en la Alemania Oriental pudiera haber roto completamente con la tradición artística previa -considerada como «expresión formal del pasado»- para establecer unas normas y estilos propios e identificativos, pero los resultados indican que la ruptura no fue tal y que muchos de los principios compositivos establecidos en los movimientos previos a 1945 permanecieron vigentes en la RDA.

[H 1] No existen relaciones significativas entre el diseño gráfico previo a la RDA y el diseño gráfico desarrollado dentro de ella.

Esta primera hipótesis general cubre los aspectos formales del lenguaje visual en cuanto a sus aspectos más generales de reglas compositivas, uso de la tipografía y de la imagen. Revisamos cada una de las hipótesis específicas que derivan de esta para concretar un poco más:

[H 1.1] No existe relación significativa entre los esquemas compositivos basados en la racionalidad hacia los que tendían los movimientos predominantes antes de la Segunda Guerra Mundial y los esquemas compositivos de la RDA.

Tal y como hemos visto la composición basada en la simplicidad y unicidad de los carteles del Sachplakat fue dando paso a una progresiva racionalización y adecuación a la máquina, en la cual los elementos se estructuraban mediante retículas, propio de movimientos como el Werkbund y 
la Bauhaus para finalmente buscar un funcionalismo que se traducía en composiciones dinámicas y descentradas sin estructura definida. Esta evolución se verá frenada por el ascenso del partido Nazi al poder, que estableció unas composiciones clásicas y basadas en la simetría.

Son muchos los elementos que entran en juego cuando hablamos de composición, por lo que concretaremos más específicamente:

[H 1.1.1] No se mantuvieron en la RDA los esquemas compositivos unitarios y con un énfasis claro en el elemento portador de información

Globalmente podemos considerar que esta hipótesis es falsa. La unidad compositiva de los carteles es una tónica global en la Alemania Oriental. Esta unidad se refleja en todas las categorías de forma bastante uniforme, aunque no así en el tiempo. Los primeros años de posguerra -más ajetreados y de cambios- experimentaron una mayor yuxtaposición de elementos en los que recaía la información llegando a medias de singularidad-yuxtaposición de 2,3360 en 1952 y de armonía en la unidad de 1,92 en 1950. Pasado este momento la composición se iría controlando hacia composiciones más armónicas en su unidad, con valores situados en torno al 1,6.

Desde el punto de vista del énfasis tampoco podemos considerar esta hipótesis como válida, si bien aquí sí que podemos hablar de una mayor diferenciación no solo temporal, sino de categorías. Temporalmente podremos hablar de un mayor énfasis en la composición pasada la primera década y con un énfasis especial en los años 60 y 70. Será solo a partir de 1956 que podamos hablar globalmente de carteles con una composición en la que prime el acento por encima de la neutralidad. Sin embargo esta tónica era habitual en el cartel político varios años antes, pero sobre todo con un nivel de acento más elevado, con medias superiores al 2,5 .

Podemos considerar finalmente que las aportaciones del Sachplakat siguieron siendo válidas en la RDA, e incluso supusieron una referencia explícita en numerosos carteles como el diseñado para el Zirkus Aeros por Günter Schiller en 1970 o los carteles de Hubert Riedel.
[H 1.1.2] No se mantuvieron en la RDA las composiciones dinámicas y descentradas hacia las que tendía la Nueva Tipografía ni se impusieron las normas clásicas y simétricas de los carteles del régimen Nazi.

Pese a las pequeñas variaciones que se pudieron experimentar especialmente en los carteles políticos de los últimos años, podemos hablar de unas composiciones marcadamente armónicas y equilibradas como tónica general con valores que rara vez superaban el 1,25. Este equilibrio no se tradujo en composiciones simétricas sino que predominaban las composiciones equilibradas no simétricas en las cuales el equilibrio viniera determinado por el establecimiento de contrapesos en la composición.

El nivel de simetría se mantiene muy por encima del 2 (es decir, más cercano a la asimetría), durante prácticamente todo el periodo, a excepción de la segunda mitad de los años 60 en que se encuentra algo por debajo del 2, siendo de cualquier modo la asimetría la tónica predominante en la RDA.

Con esto podemos decir que se verifica la hipótesis de que no se continuó la evolución compositiva dirigida hacia composiciones dinámicas, las cuales acusaban desde la Verband Bildender Künstler (Asociación de Artístas Plásticos, VBK) de un marcado formalismo, ni se mantuvo la composición simétrica establecida durante la Guerra.

[H 1.1.3] Las estructuras compositivas de los carteles de la RDA no se mantuvieron adaptadas a la función del diseño tal y como era la tendencia predominante culminada por el funcionalismo.

Fuera de formalismos compositivos preestablecidos podemos considerar que esta hipótesis es falsa atendiendo a la escasa adaptación de las composiciones a reglas compositivas fijas como la simetría o los patrones rítmicos regulares. Tal y como hemos especificado anteriormente la simetría no dominará las composiciones, del mismo modo que no lo hará un orden rítmico regular prefijado.

Cuando se disponen varios elementos dentro de una misma composición, estos no seguirán una estructura rítmica regular establecida, si bien tampoco podemos hablar de composiciones arrítmicas y descontroladas. Tan solo en la década de los 70 las composiciones tienden a una mayor regularidad (con valores no obstante superiores al 1, 67) permaneciendo fuera de este periodo siempre por encima del 2. Sin embargo, al atender a la predictibilidad y secuen- 
cialidad estos valores descienden notablemente a medias cercanas al 1,5, lo que nos hace entender que si bien las composiciones eran irregulares se mantenían dentro de unas estructuras previas.

Otro dato que nos permite deducir la adecuación de la composición a la función es la diferenciación de las características compositivas según los diferentes géneros analizados, especialmente llamativa en el caso de los carteles económicos, cuyo desarrollo según parámetros como la continuidad, la simetría, la singularidad o la unidad es claramente independiente del resto de los géneros.

Desde el punto de vista de la composición los carteles de la RDA se diseñaron atendiendo a su función, adecuando la composición a los elementos con los que se estructura la comunicación, más allá de unas reglas fijas establecidas, por lo que esta hipótesis es falsa.

[H 1.2] No se mantuvo la predilección por el uso de la tipografía predominantemente de palo seco por su universalidad como tipografía.

Estadísticamente podemos considerar esta hipótesis falsa, ya que globalmente la tipografía de palo seco gozó de una presencia de más del $20 \%$ de media superior a la segunda clase tipográfica (habitualmente la tipografía romana). Sin embargo este uso mayoritario de la tipografía de palo seco no se debe aquí a unos criterios teóricos preestablecidos de universalidad o racionalidad del diseño.

Los criterios racionales que establecieron la creación tipográfica en la RDA no se basaron en una creación capaz de abarcar la totalidad de las necesidades artísticas, sino en la determinación de necesidades tipográficas y soluciones explícitas a ellas, de tal modo que se establecieron tipografías (réplicas o creaciones propias) que aportaban soluciones válidas a cada tipo de uso, tales como edición de libros científicos, de arte, periódicos..., teniendo en cuenta las necesidades especificas de cada tipo de reproducción.

Otro dato que certifica la no vigencia de la búsqueda de la universalidad de estos movimientos es la recurrente influencia de la letra gótica en los diseños de las nuevas tipografías -tanto romanas como de palo seco- de la RDA: Leipziger, Minima, Liberta, Zyklop e incluso en las tipografías dibujadas a mano de los primeros carteles.

De este modo podemos concluir que si bien la tipografía de palo seco gozó de la mayor popularidad en el diseño de carteles esto no se debió a un criterio teórico del modo que lo había hecho en la Nueva Tipografía o la Bauhaus, por lo que la hipótesis es válida.

[H 1.3] No se mantuvo la tendencia a la simplificación de la tipografía mediante la simplificación de los remates que tuvo lugar en la Alemania previa a la $2^{\text {a }}$ Guerra Mundial.

Hemos de distinguir aquí entre la tipografía creativa cuyo uso se destinaba a la publicidad y a diseños de la tipografía de edición. En la primera se observa una tendencia global a destacar los elementos ornamentales. Esto es notable en la realización de las réplicas de tipografías como la tipografía Eckmann, Luthersche-Fraktur o Fette-Antiqua, en las cuales se destacan sus elementos decorativos o formales.

En la tipografía de edición sin embargo sí que se observa una tendencia generalizada a la simplificación de los remates, pero esta se debió a la búsqueda de una mayor legibilidad para aquellas impresiones -habituales- en las cuales la baja calidad de la reproducción junto con papeles demasiado fibrosos podían dificultar la lectura dando un aspecto poco claro a la imagen resultante.

No podemos considerar por tanto que se diera una tendencia formal hacia la simplificación, sino que en el ámbito de la tipografía, el uso de remates y ornamentos responde a necesidades más que a parámetros estilísticos.

[H 1.4] No se mantuvieron la tendencia hacia una imagen más figurativa frente a la imagen expresiva ni la predilección por la fotografía.

El «debate sobre el formalismo» que tuvo lugar a comienzos de los años 50 y que estableció las normas artísticas del denominado realismo socialista impuso el realismo como forma de arte del estado al tiempo que rechazó las formas abstractas de expresión. Esto tendrá consecuencias directas en el diseño gráfico, de donde las imágenes amórficas escasamente llegarán al 10\% y la abstracción, rechazada explícitamente, no tendrá presencia en el diseño gráfico. El isomorfismo dominará ampliamente el panorama del diseño gráfico en los años de mayor vigencia del realismo socialista, sin embargo a partir de 1960 perderá terreno a favor del mesomorfismo.

La fotografía tuvo una presencia importante en los carteles económicos y políticos a partir de 1960, sin embargo a nivel global nunca supuso un porcentaje mayoritario de 
los esquemas formales figurativos, con una media muy por debajo de los esquemas formales figurativos pictóricos, por lo que no podemos hablar de una predilección global por la fotografía, por todo esto podemos inferir que esta hipótesis es válida. .

[H 1.5] No se mantuvo la tendencia a la simplificación del uso del color y hacia la tricromía.

El uso del color de forma realista supuso porcentajes inferiores al $20 \%$ de los carteles producidos, por lo que sí que podemos decir que se mantuvo la simplificación del color. Al mismo tiempo se produce un aumento de los carteles monocromos o dicromos, en detrimento del uso de 3 colores o de tintas planas.

Si consideramos conjuntamente aquellos carteles en los que se usan 3 o menos colores no combinados entre sí, estos suponen una amplia mayoría respecto a cualquier otro uso del color, al tiempo que tienen una tendencia al alza bastante marcada a partir de 1975, por lo que podemos considerar esta hipótesis falsa ya que se que sí existió una tendencia hacia la simplificación cromática.

[H 1.6] No tuvieron reflejo las tendencias de geometrización y simplificación de la imagen propias de los movimientos alemanes de las primeras décadas del siglo XX

El realismo socialista no impidió la presencia de imágenes simplificadas, habida cuenta de que tipos de representación por debajo del realismo, como son el mesorrealismo y el surrealismo supusieron en torno al $40 \%$ de la producción gráfica. No obstante eso da lugar a cerca del $60 \%$ de imágenes realistas e hiperrealistas, por lo que no podemos hablar de una tendencia global hacia la simplificación.

Sin embargo, cuando esta asociación la realizamos discriminando la imagen pictórica de la fotográfica, observamos que, pasados los años 50, la representación pictórica con niveles de representación inferiores al realismo supuso en los años 60 cerca del 90\% de las imágenes, es decir que una amplia mayoría de los dibujos con los que se ilustraban os carteles lo hacían simplificando la imagen, por lo que podemos decir que esta hipótesis es falsa.
[H 2] Las decisiones gubernamentales no solo se reflejaron en la temática de los carteles, sino que afectaron al lenguaje visual.

Al tratarse de un sistema político que abarcaba todas las esferas sociales, muchas de estas decisiones políticas atañían directamente al panorama artístico. Tal es el caso de denominado «debate sobre el formalismo»-cuya influencia en el diseño gráfico de los años 50 ha sido demostrada po diversos autores- pero no es el único, ya que nos encontramos con otras consideraciones que, de forma indirecta también se reflejaron en el diseño gráfico.

Indirectamente el reconocimiento gubernamental del diseño gráfico como categoría propia y la creación de la sección de diseño gráfico dentro de la VBK en 1953 tendrá un efecto positivo en la evolución del diseño gráfico, ya que su mayor difusión suponía que los carteles estuvieran sometidos a crítica, ya no era suficiente con la fácil comprensión del mensaje, sino que se le exigía una calidad artística.

Las épocas de cambio político, tales como la creación de la RDA, la construcción del Muro de Berlín, la nueva Constitución de 1968 o el cambio político a Honecker se reflejan en los carteles en forma de composiciones más accidentadas, en el uso del color rojo y de tipografías manuales como figuras retóricas de adjunción por su imagen de inmediatez. Coinciden con estos momentos también la mayor presencia de carteles políticos en las selecciones de carteles realizadas dentro de la RDA, lo que les permitía una mayor difusión. Únicamente discrepa la construcción del Muro de Berlín, cuyo reflejo a nivel político lo podríamos considera negativo, desapareciendo completamente de la muestra.

Del mismo modo se observan diferencias notables en el lenguaje visual de periodos claros históricos; Sowjetische Besatzungszone (Zona de Ocupación Soviética, SBZ) "Construcción del socialismo», Era Ulbricht, Era Honecker y Crisis cuyas características formales hemos definido en el apartado de objetivos.

A finales de los años 60 se aprueba la Ley de «Ciudadanía de la RDA», que dará paso a una época de sentimiento de identidad nacional tras una larga época de ruptura con la historia alemana especialmente notable en los años de construcción del socialismo a comienzo de los 50. Este enaltecimiento de la identidad nacional se reflejó en un incremento del $200 \%$ en el uso de la letra gótica -por su relación con la historia e identidad alemana- en los carteles políticos de los primeros años 70 respecto de los periodos 
anteriores, en los cuales esta apenas había tenido representación. Por todo esto podemos inferir que la hipótesis es válida y que las decisiones políticas tuvieron un claro reflejo en el diseño gráfico.

[H 3] El lenguaje visual se vio afectado por la estructura económica de la RDA.

La estructura económica planificada conllevará en el diseño gráfico consecuencias directas e indirectas. Indirectamente se reflejará en la disposición material tanto de equipos de reproducción, limitados al offset casi por completo hasta finales de los años 70, la ausencia de fotografía, pese a la predilección que se le presuponía por su capacidad objetiva y realista y las limitaciones cromáticas derivadas de las dificultades materiales de acceso.

Sin embargo donde más evidente es esta relación es en el campo de la tipografía. Los primeros años, de grandes limitaciones materiales, nos encontraremos con un amplio porcentaje de carteles cuya tipografía estaba reproducida manualmente, al tiempo que estas tipografías dibujadas tenían las características formales de tipografías asociadas a la reproducción mecánica, lo que nos indica que su uso no se deriva de la preferencia del dibujo manual, sino de la ausencia de posibilidades mecánicas.

La relación directa la encontramos en que el control gubernamental de la estructura económica y empresarial supuso que toda la tipografía de la RDA se realizara en una única empresa, la VEB Typoart, a cuya limitada producción debía ajustarse el diseño gráfico. Detallaremos posteriormente las características formales y su representación real en el diseño gráfico de la RDA, pero a nivel de reflejo de la estructura económica es necesario destacar la importancia de las restricciones que esto supuso en el plano creativo.

Si atendemos al porcentaje de la tipografía de reproducción mecánica que procedía de la VEB Typoart la construcción del Muro de Berlín supuso un claro hito a partir del cual -en un plazo de menos de 4 años- se incrementará en cerca del $20 \%$ en el plano general y más del $30 \%$ en el cultural el uso de tipografías propias. Las posibilidades de paso, no solo de personas, sino también de mercancías, entre la RDA y la RFA se frenaron drásticametne con el cierre de las fronteras, lo que nos hace suponer que las posibilidades de acceso a otras tipografías en los años previos, que permitía una mayor libertad creativa al abarcar un abanico mayor, se vieron así frenadas, obligando a los artistas a limitarse poco a poco a la producción propia.

Podemos concluir que tanto directa como indirectamente el lenguaje visual se vio afectado por la estructura económica de la RDA.

[H 4] La creación tipográfica de la VEB Typoart dominó el panorama gráfico por ser la única empresa socializada dedicada a diseño y producción de tipografía, con diseños adaptados a las necesidades reales.

El plano artístico se estructuró y organizó del mismo modo que lo hacían todos los ámbitos productivos. Esto suponía que se buscara, en el campo tipográfico, una sistematización del diseño y funcionamiento de este como empresa. Describiremos con más detalle la adecuación real de este sistema al terreno de la tipografía.

[H 4.1] La tipografía diseñada por la VEB Typoart supuso la tipografía predominante en los carteles de la RDA

Hemos demostrado en la hipótesis anterior que el uso de la tipografía diseñada por la VEB Typoart se derivó principalmente de la ausencia de otras tipografías disponibles. Nos encontramos con dos momentos de cambio importantes en el uso de tipografía propia, el primer hito es, tal y como hemos visto, la construcción del Muro de Berlín, seguido posteriormente del programa establecido en 1978 con meta en 1986 para la mejora de la calidad de los tipos de fotocomposición con la ayuda de un nuevo equipo para la confección de datos geométricos. Esto acabó por convertir su producción en la tipografía mecánica única, pero no ocurrirá hasta casi el final de su historia. Podemos hablar por tanto de tres periodos diferenciados en el control tipográfico de la RDA, un primer momento previo a 1961 en el que suponía cerca del $30 \%$ de la tipografía mecánica, un segundo momento entre 1961 y 1985 en que este porcentaje se elevó al $60 \%$ y el paso del 60 al 100\% en los 4 últimos años de su historia.

Si ampliamos el campo de análisis al total de la tipografía utilizada nos encontramos que a medida que se limitaban las tipografías mecánicas accesibles, aumentaba el uso de tipografías dibujadas manualmente, bien fuera porque estas no se adaptaban a las necesidades, bien por la preferencia de las tipografías manuscritas, lo que supuso que globalmente las familias producidas por la VEB Typoart no supu- 
sieran en ningún momento más del $50 \%$ de las tipografías utilizadas, lo que nos demuestra la falsedad de la hipótesis.

[H 4.2] Los criterios de uso tipográficos definidos por la VEB Typoart predeterminaron el uso que se le dio a la misma y se adaptó adecuadamente a las necesidades reales de la RDA.

61. Nombre por el que se conocía a la Zentrale Druckerei-, Einkaufs- und Revisionsgesellschaft, Central de empresas de impresión compra y revisión.

El funcionamiento empresarial de la VEB Typoart y su vinculación con el resto de empresas de edición y creativas a través de la Zentrag ${ }^{61}$ suponía una sistematización del diseño que les llevó a diseñar una estructura productiva adecuada a unas necesidades establecidas a priori. En este sistema se definían una serie de tipografías que respondían a las necesidades existentes, tales como las tipografías para periódicos, revistas, literatura política o diseño publicitario.

Dentro del diseño publicitario y creativo se establecieron as tipografías Fette Antiqua, Walbaum, Schmalfette Antiqua, Neutra, Norma-Steinschrift, Egyptienne, Liberta, Nidor, Eckmann, Kleopatra, Zyklop, Quadro, Molli, Hogarth-Script, Biga, Stentor y Luthersche Fraktur, así como la adecuación a los mismos de las tipografías Super-Grotesk y Maxima. Atendiendo a la presencia de estas tipografías dentro de los carteles de la muestra podemos afirmar que el diseño tipográfico no se adecuó a las necesidades reales del diseño gráfico, a juzgar por la escasa aceptación de que gozaron gran número de estas creaciones. Tan solo las tipografías Super-Grotesk y Maxima, cuyo uso en la publicidad y el diseño no era principal, sino derivado, tuvieron una presencia notable estando presentes en el 11 y $13 \%$ de los carteles respectivamente. Otra tipografía que gozó de gran popularidad en el diseño gráfico sería la Fundamental-Grotesk, presente en cerca del $10 \%$ de los carteles analizados, y que sin embargo no se encontrará dentro de las tipografías definidas dentro del plan, probablemente debido a su gran similitud con la tipografía Super-Grotesk.

Las 17 tipografías restantes supondrán conjuntamente menos del $11 \%$ de los carteles analizados, la mayoría de ellas presentes en menos del $1 \%$ de ellos encontrándonos incluso con 6 tipografías sin ninguna representación.

Del mismo modo nos encontramos con que en un $66 \%$ de los casos en los que se utilizaba tipografía de la VEB Typoart esta era una réplica de tipografías clásicas, frente al $33 \%$ de creaciones originales

Es especialmente notable esta discrepancia en los carteles diseñados con fines culturales, en los cuales la adaptación al tema del cartel supuso que se utilizaran más frecuente- mente tipografías cuyo uso había sido definido para otras finalidades más relacionadas con la tipografía de edición. Podemos afirmar por tanto que fuera del diseño editorial el sistema predefinido de creación tipográfica no se adecuó a las necesidades reales, por lo que la hipótesis es falsa.

[H 4.3] Los diseños de la VEB Typoart se adaptaron a las condiciones particulares de reproducción de la RDA.

Las posibilidades materiales habituales en la RDA suponían impresiones de baja calidad y papeles fibrosos y texturizados que dificultaban la legibilidad. Esto estaba presente a la hora de la creación tipográfica y se pone de manifiesto en el tratamiento de las réplicas. Al comparar las tipografías originales y las réplicas realizadas nos encontramos con un patrón constante de diferenciación entre ambas. Las adaptaciones se harán basándose en la ampliación del ojo medio a costa de la reducción de los descendentes, por lo que los ascendentes serán más amplios que los descendentes ya que hay una mayor concentración de información en la mitad superior de los caracteres, que nos permiten una mayor identificación que los descendentes. La amplitud de ojo medio permitía un mayor contrapunzón, factor clave en la legibilidad.

Finalmente se simplifican los remates y los detalles decorativos cuya percepción si la impresión no es buena, es difícil y pueden dar apariencia de mancha tipográfica. Muchas de las réplicas supusieron la reducción del contraste entre trazo grueso y fino, ya que los trazos finos conllevan un mayor riesgo de falta de claridad. Tan solo se mantiene este contraste en las tipografías neoclásicas, cuyo uso estaba destinado al arte.

Es por tanto que podemos decir que los diseños de las diferentes tipografías sí que se adaptaron a las condiciones particulares de reproducción de la RDA. 


\subsection{CONCLUSIONES GENERALES}

El diseño de la investigación aquí propuesto, abarcando no solo fuentes documentales, sino también un análisis estadístico de una muestra de población de diseño gráfico suficientemente amplia, nos permite establecer unas conclusiones generales en las cuales se definan las características del lenguaje visual propio de la RDA. Este lenguaje no es, obviamente, estable y homogéneo a lo largo de los 40 años de historia de la RDA, sino que tendrá unas características que irán variando, no solo a través del tiempo, sino también según los géneros a los que pertenecía.

8.2.1 Descripción del lenguaje visual del diseño grático de la SBZ/RDA

Hemos hablado de la existencia de una sección de diseño gráfico dentro de la VBK. Esta asociación servirá de catalizador del diseño realizado, en base a que se encargaba de su difusión y promoción, pero no suponía una escuela o movimiento al modo que habían supuesto en las décadas previas a 1945. Sin embargo sí que podemos definir unos rasgos generales por periodos, características que no son parte de reglas formales previas más allá del uso de la imagen del realismo socialista, sino que supone unas tendencias que se adaptan a las necesidades y posibilidades de cada caso.

Nos encontramos con una mayor unidad gráfica en los primeros carteles, debido a que una unidad compositiva y retórica permite aumentar la comprensión del mensaje. Esta armonía gráfica se verá potenciada por el «debate sobre el formalismo", ya que este establece unas normas generales a las que se debe de adaptar el diseño. Pasados los años 60 estas armonía se va disgregando poco a poco hacia una mayor variedad formal.

Ciertas características formales fueron permanentes a o largo de toda la existencia de la RDA. La total ausencia de representaciones abstractas y la escasa presencia de amorfismo es una constante que nos encontraremos en todo el periodo, así como el predominio de esquemas formales figurativos, siendo por tanto la imagen el elemento de comunicación principal. Otra característica común es el alto nivel de legibilidad por contraste cromático, derivado, como hemos visto, de la baja calidad material y de reproducción.
No fue un rasgo distintivo del diseño gráfico de la Alemania Oriental el establecimiento de ritmo mediante la repetición de imagenes, a juzgar tanto por la limitada representación de estos carteles en el total de la muestra como por las características compositivas de los mismos, en los cuales varios elementos en una disposición no rítmica siguen un patrón predectible. Desde la perspectiva de la transición entre los elementos que componen la comunicación, esta se realizará de forma marcadamente continua durante todas las décadas, lo que en conjunto supone una alta armonía en el ritmo de composición.

Tal y como venía siendo habitual en los periodos previos a la guerra, la tipografía de palo seco será mayoritaria en todos los ámbitos de diseño.

El uso de la retórica es el último elemento homogéneo y constante, con un claro predominio de las figuras de sustitución y con ello de las figuras semánticas frente a las sintácticas.

Cada género analizado experimenta una evolución independiente, con periodos propios, pero que a excepción del plano económico, comparten un número de similitudes suficientes como para poderlos considerar conjuntamente:

\section{Sowjetische Besatzungszone (SBZ) (1945-1950)}

El diseño realizado en estos años se nutre fundamentalmente de las tendencias previas a la guerra, al tiempo que buscan una unidad formal y simplicidad retórica para garantizar una fácil comprensión del mensaje.

Se trata predominantemente de estrategias de comunicación conducidas formalmente, en las cuales incluso encontraremos ejemplos sin presencia de elementos figurativos. Son composiciones mayoritariamente armónicas, sin un énfasis claro, en las cuales un amplio número de elementos se colocan equilibrados pero sin respetar ejes de simetría.

La representación figurativa es casi exclusivamente pictórica y figurativa, en la cual predomina la economía de detalles, lo que supone un nivel medio de representación, sin por ello renunciar al isomorfismo que facilita la comprensión visual. La escasez material supone la reducción de tintas en estos años, con un uso del color reducido en sus matices, pero no en su valor cromático, permitiendo gradaciones cromáticas. Es representativo de este periodo el uso simbólico del color rojo en un elevado número de los carteles. La dificulta de acceso material provoca en los primeros años de historia que la tipografía manual susti- 
tuya a la mecánica con letras dibujadas que imitan trazos mecánicos.

\section{Realismo socialista (1951-1957)}

Es el periodo con mayores exigencias formales derivadas de las exigencias gubernamentales que establecían el realismo socialista como único modo de expresión válido y que se basaba en el realismo pictórico y representaciones gráficas figurativas de fácil comprensión.

Por tanto, el elemento de comunicación principal de este periodo será el medio, con un dominio casi total de imágenes figurativas que sin embargo no excluirá la presencia de contornos no figurativos subordinados a estas. Las imágenes se representan realistas e isomórficas, con profusión de detalles, lo que no impide una simplificación en el uso del color, que se reduce en numerosas ocasiones a tintas planas.

Desde el punto de vista compositivo nos encontramos con estructuras complejas y con un buen número de elementos yuxtapuestos sin un énfasis claro y dispuestos de forma equilibrada pero asimétrica. Para abarcar el amplio número de elementos se opta habitualmente por una fragmentación de los mismos, dispuestos de tal forma que no se limitan al espacio compositivo, sino que superan el marco.

Se empiezan a utilizar en este momento un mayor número de tipografías mecánica, la mayor parte de ella no provenientes de la VEB Typoart, de tal modo que la tipografía manual se ajusta al dibujo de tipografías manuscritas.

\section{Simplificación (1958-1969)}

Poco a poco el control gubernamental se va reduciendo y el realismo socialista se irá diluyendo hacia una mayor simplificación en la comunicación. Se vuelve a las estrategias de comunicación formales y si bien las imágenes figurativas seguirán dominando el panorama gráfico, darán paso a una mayor variedad, de tal modo que aparecen un buen número de carteles en los que se produce una sinergia en la comunicación con combinaciones de imagen y texto, al tiempo que se realizan en esta década las primeras composiciones tipográficas, con ausencia total de imágenes.

La simplificación en la comunicación pasará por elementos unitarios y con un único elemento en el que recae la comunicación y que está claramente enfatizado. Las composiciones se simplifican hacia una mayor simetría y un ajuste al marco.
Aparecen con fuerza finalmente en este momento las imágenes fotográficas, con más intensidad en el plano político, debido a la carga de realidad que se le asocia. Fuera de la fotografía, las representaciones pictóricas acusarán claramente esta simplificación, con un nivel mayoritario de surrealismo, lo que sin embargo no se acompaña de un alto nivel de abstracción, sino que permanece en e mesomorfismo.

La tipografía manuscrita sigue teniendo una amplia representación y la letra de reproducción mecánica provendrá cada vez en porcentajes mayores de la producida por la VEB Typoart.

\section{Fragmentación (1970-1978)}

La simplificación de la década anterior se irá relajando y recuperará elementos compositivos previos. Permanecerá conducida formalmente, pero reduciendo notablemente el nivel de énfasis que recae en un único punto. Las imágenes se presentan fragmentadas y con una gran profusión de detalle, con preferencia nuevamente del dibujo frente a otras formas. Estos dibujos aumentarán su nivel de representación hacia niveles medios, manteniendo el mesomorfismo como tónica habitual.

Se mantiene respecto a la década anterior el equilibrio y simetría de la estructura, así como su ajuste a los límites de marco. La tipografía de la VEB Typoart sigue suponiendo el porcentaje mayoritario de las tipografías mecánicas utilizadas, pero al igual que ocurría en la posguerra, se dibujarán manualmente aquellas tipografías a las que no se podía acceder de forma mecánica.

\section{Libertad compositiva (1979-1989)}

La mayor variedad que se empieza a vislumbrar a partir de los años 70 llega al final de la historia de la RDA como una época de libertad compositiva si nos basamos en la mayor alternancia de valores y parámetros del análisis realizado. Sin embargo sí que se puede hablar de unas ciertas constantes, como son la estrategia conducida formalmente con un cierto nivel de unidad y singularidad en una estructura relativamente simétrica que se ajusta al marco. Pese a la amplia presencia de la fotografía, sigue predominando la imagen pictórica, con un nivel de realismo y abstracción medio. Aumenta notablemente la presencia de carteles no figurativos, al tiempo que se experimenta una simplificación cromática en la cual predominan los carteles en los que se usan menos de tres colores planos sobre un fondo. 
Finalmente se ajusta el uso de la tipografía mecánica a la tipografía diseñada y producida por la VEB Typoart. Se sucede en esta década también un fuerte incremento de la tipografía manuscrita, habitualmente de reproducción manual.

No podemos olvidarnos de las dos tendencias publicitarias, independientes de esta periodización:

\section{Publicidad plástica. (1949-1961)}

Se trata de tendencias publicitarias en las que predomina claramente la imagen pictórica figurativa en combinación con contornos formales abstractos. No se presenta un nivel de representación mayoritario, sino que existe una gran libertad en este sentido, con una mayor tendencia hacia la economía de detalle y siempre con un elevado nivel de isomorfismo y preponderancia del uso de tintas planas.

La estrategia puede ser tanto conducida formalmente como por el medio, pero se trata de composiciones no enfáticas, pese a que se presente con elementos unitarios y una tendencia hacia la singularidad frente a la yuxtaposición de elementos. Estos se colocan siguiendo principios de coherencia sin adaptarse a ningún eje ni a los límites del marco.

a tipografía mecánica no se limita a las producciones de la VEB Typoart, y tienen gran presencia las tipografías manuscritas.

\section{Publicidad descriptiva (1962-1975)}

Coincide con la supremacía en el plano económico de la imagen fotográfica, con un nivel de representación hiperrealista e isomórfico, así como el uso del color. La estrategia se conduce de este modo por el medio, con un breve incremento a comienzos de este periodo de la comunicación mediante sinergia entre imagen y texto. Se trata de composiciones complejas y fragmentadas y con una gran profusión de detalles, en las cuales sin embargo se produce un énfasis claro de la comunicación. Permanece la asimetría, pero las estructuras de este periodo se adaptan claramente a los límites del marco.

Las tipografías mecánicas provienen en su mayoría de la VEB Typoart, sin embargo se observa un alto incremento de tipografías de reproducción manual imitando las tipografías mecánicas.

\begin{tabular}{|c|c|c|c|c|c|c|}
\hline \multicolumn{2}{|c|}{ ADAPTACIÓN (45-53) } & \multicolumn{2}{|c|}{ R. SOCIALISTA (54-61) } & SIMPLIFICACIÓN (62.68) & & \\
\hline \multirow{3}{*}{$c$} & \multirow{4}{*}{ 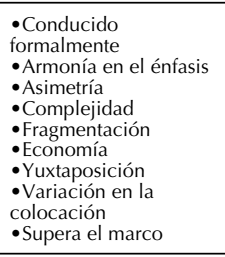 } & \multirow{3}{*}{\multicolumn{2}{|c|}{ 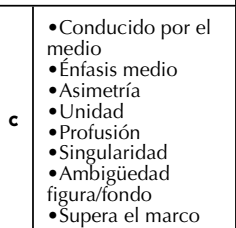 }} & \multirow{3}{*}{ 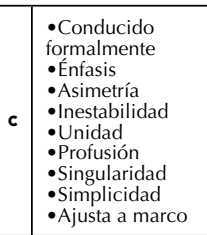 } & FRAGMENTACIÓN (69-78) & \multirow[b]{2}{*}{ LIBERTAD COMPOSIITIVA (79-89) } \\
\hline & & & & & \multirow{2}{*}{ 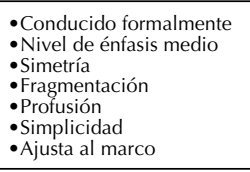 } & \\
\hline & & & & & & \\
\hline & & \multirow{2}{*}{ 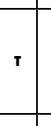 } & \multirow{2}{*}{$\begin{array}{l}\text {-Tipografía } \\
\text { manuscrita } \\
\text {-Tiporifáí mecáni- } \\
\text { ca no Typoart }\end{array}$} & \multirow{2}{*}{$\begin{array}{l}\text {-Aumento de } \\
\text { lat tipografifia de } \\
\text { Typoort de } \\
\text {-Tipografía lineal } \\
\end{array}$} & \multirow{2}{*}{ 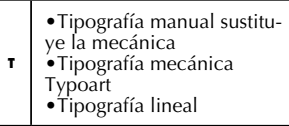 } & \\
\hline & $\begin{array}{l}\text { - Tipografías manuales } \\
\text { manuscritas } \\
\text {-Preferencia tipografía } \\
\text { romana }\end{array}$ & & & & & $\begin{array}{l}\text { - Tipografía manuscrita } \\
\text { Dyominio tipografía mecánica } \\
\text { Typoart }\end{array}$ \\
\hline & $\begin{array}{l}\text { - Presencia contornos y } \\
\text { carteles no figurativos } \\
\text { - Simbolismo cromático } \\
\text {-3 colores } \\
\text { - Mosorrealismo } \\
\text { - lsomorfismo }\end{array}$ & \multicolumn{2}{|r|}{\begin{tabular}{|l|} 
- Dominio imáge- \\
nes figurativas \\
:Tintas plaanas \\
-Simbolismo \\
cromático \\
- Mesorrealismo \\
- Mesomorfismo \\
\end{tabular}} & 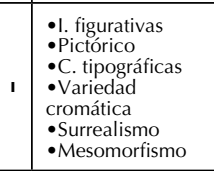 & $\begin{array}{l}\text { - Presencia carteles no } \\
\text { figurativos } \\
\text { :Pictorico } \\
\text {-Variedad cromática } \\
\text { - Mesorealisismo } \\
\text { - Mesomorfismo }\end{array}$ & 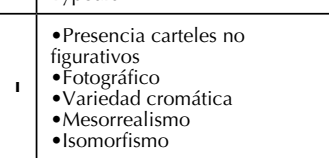 \\
\hline & I I | | | 5 | I I I & & $1111161 \mid$ & 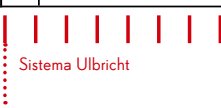 & 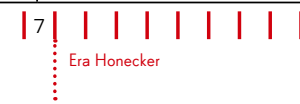 & 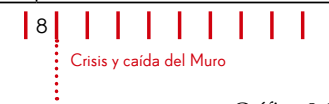 \\
\hline
\end{tabular}

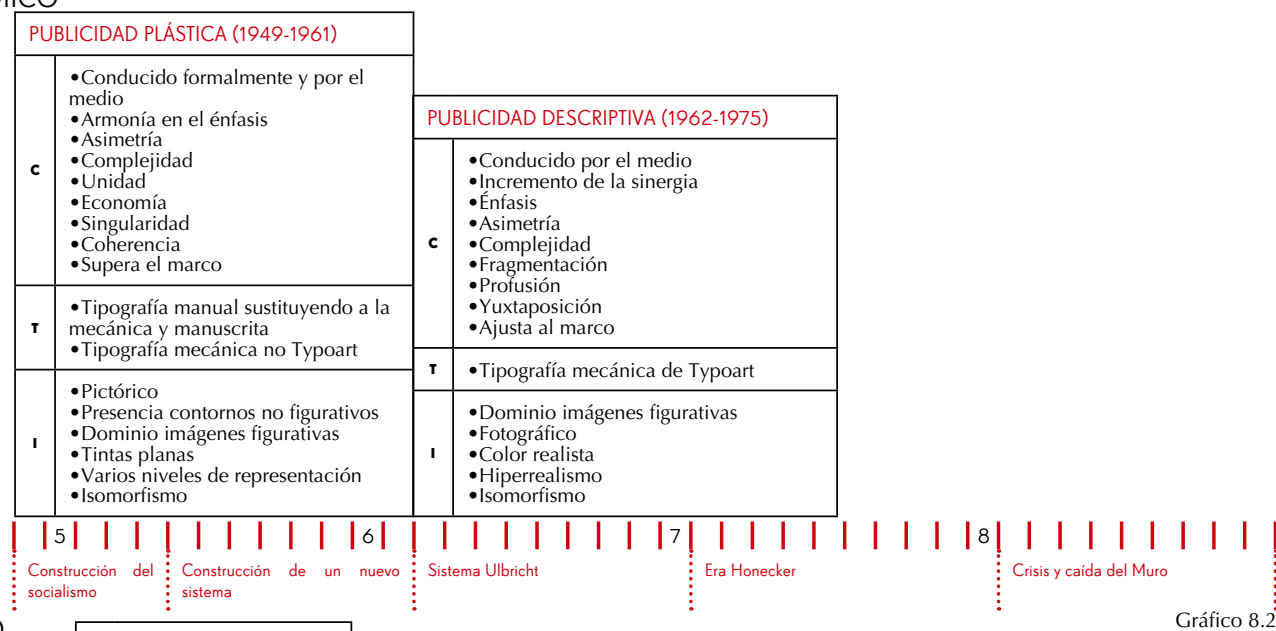

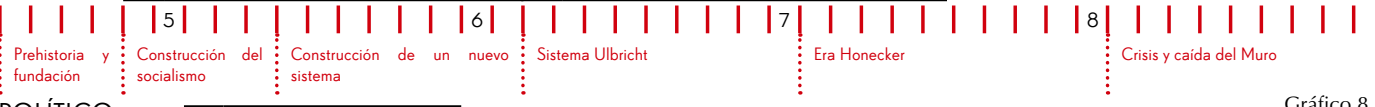

\begin{tabular}{|c|c|c|c|c|c|c|c|c|c|}
\hline \multicolumn{2}{|c|}{ POLÍTICO } & \multicolumn{2}{|c|}{ R. SOCIALISTA (51-59) } & & & & & & \\
\hline \multicolumn{2}{|c|}{ SBZ (45-50) } & \multirow{4}{*}{\multicolumn{2}{|c|}{ 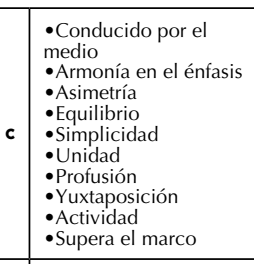 }} & \multirow{2}{*}{\multicolumn{2}{|c|}{ SIMPLIFICACIÓN (60-70) }} & & & \multicolumn{2}{|c|}{ L.COMPOSITIVA (82-89) } \\
\hline & \multirow{3}{*}{ 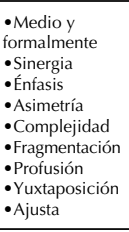 } & & & & & \multirow{2}{*}{\multicolumn{2}{|c|}{ ERAGMENTACIÓN (71-81) }} & \multirow{4}{*}{\multicolumn{2}{|c|}{ 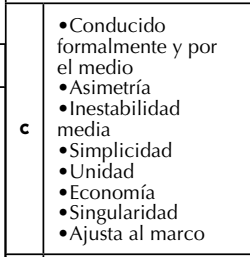 }} \\
\hline & & & & \multirow[b]{2}{*}{ c } & \multirow{2}{*}{ 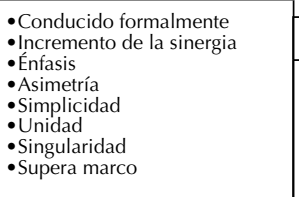 } & & & & \\
\hline & & & & & & \multirow[t]{2}{*}{$c$} & 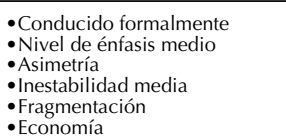 & & \\
\hline \multirow{2}{*}{$\mathbf{T}$} & \multirow{2}{*}{$\begin{array}{l}- \text { Tipografias } \\
\text { manuscritas } \\
\text { •no Typoart }\end{array}$} & \multirow{2}{*}{$T_{T}$} & \multirow{2}{*}{$\begin{array}{l}\text { - Tipografías } \\
\text { manuscritas } \\
\text {-Tipografía mecánica } \\
\text { no Typoart }\end{array}$} & \multirow{3}{*}{$\mathrm{T}$} & \multirow{3}{*}{$\begin{array}{l}\text { - Aumento de la tipografía } \\
\text { mecánica de Typoart } \\
\text { - Fuerte presencia de tipografía } \\
\text { gótica }\end{array}$} & & $\begin{array}{l}\text { - Singularidad } \\
\text { - Ajusta al marco }\end{array}$ & & \\
\hline & & & & & & & \multirow{2}{*}{$\begin{array}{l}\text { - Tipografía gótica y } \\
\text { manuscrita } \\
\text {-Tipografía mecánica Typoart }\end{array}$} & & $\begin{array}{l}\text { - Dominio tipografía } \\
\text { mecánica Typoart }\end{array}$ \\
\hline \multirow{2}{*}{\multicolumn{2}{|c|}{ 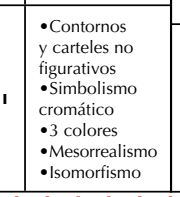 }} & \multirow{2}{*}{\multicolumn{3}{|c|}{ 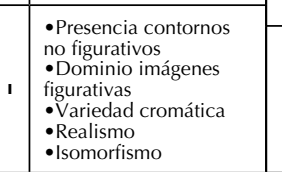 }} & & & & \multirow{2}{*}{\multicolumn{2}{|c|}{ 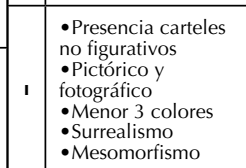 }} \\
\hline & & & & & 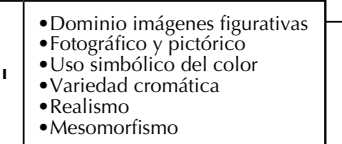 & & $\begin{array}{l}\text { - Fotoggráfico y pictórico } \\
\text { - - Sariedad cromática } \\
\text { - Rimblismo cromático } \\
\text { - Mesmomorfismo }\end{array}$ & & \\
\hline & $11 ! 15$ & & $|1| 1|1|$ & & ||||||||$l \mid$ & & $|1||||||8|$ & & |||||| \\
\hline & & & del $\begin{array}{l}\text { Construcción de } \\
\text { sistema }\end{array}$ & & Sistema Ulbricht & & Sonecter & & \\
\hline
\end{tabular}




\section{GENERAL}

\begin{tabular}{|c|c|c|c|c|}
\hline $\begin{array}{l}\text { SBZ } \\
(1945-50)\end{array}$ & $\begin{array}{l}\text { REALISMO } \\
\text { SOCIALISTA } \\
(1951-1957) \\
\end{array}$ & $\begin{array}{l}\text { SIMPLIFICACIÓN } \\
(1958-1969)\end{array}$ & $\begin{array}{l}\text { FRAGMENTACIÓN } \\
(1970-1978)\end{array}$ & $\begin{array}{l}\text { LIBERTAD } \\
\text { COMPOSITIVA } \\
\text { (1979-1989) }\end{array}$ \\
\hline COMPOSICIÓN & COMPOSICIÓN & COMPOSICIÓN & COMPOSICIÓN & COMPOSICIÓN \\
\hline $\begin{array}{l}\text {-Conducido } \\
\text { formalmente } \\
\text {-Armonía en el } \\
\text { énfasis } \\
\text {-Asimetría } \\
\text {-Economía }\end{array}$ & \multirow{5}{*}{\begin{tabular}{|l}
-Conducido por \\
el medio \\
-Armonía en el \\
énfasis \\
-Asimetría \\
•Complejidad \\
- Fragmentación \\
-Profusión \\
-Yuxtaposición \\
-Supera el \\
marco \\
\end{tabular}} & \multirow[t]{2}{*}{$\begin{array}{l}\text { - Conducido formalmente } \\
\text { - Incremento de la sinergia } \\
\text {-Énfasis } \\
\text { - Simetría } \\
\text { - Unidad } \\
\text { - Singularidad } \\
\text { - Ajusta al marco }\end{array}$} & \multirow{3}{*}{$\begin{array}{l}\text { - Conducido } \\
\text { formalmente } \\
\text { - Nivel de énfasis } \\
\text { medio } \\
\text { - Simetría } \\
\text { - Fragmentación } \\
\text { - Profusión } \\
\text { - Singularidad } \\
\text { - Ajusta al marco }\end{array}$} & $\begin{array}{l}\text { - Conducido formalmente } \\
\text { - Simetría } \\
\text { - Unidad } \\
\text { - Economía } \\
\text { - Singularidad } \\
\text { - Ajusta al marco }\end{array}$ \\
\hline -Yuxtaposición & & & & TIPOGRAFÍA \\
\hline $\begin{array}{l}\text {-Supera el } \\
\text { marco }\end{array}$ & & TIPOGRAFÍA & & \multirow{2}{*}{$\begin{array}{l}\text { - Tipografía manuscrita } \\
\text { - Dominio tipografía mecáni- } \\
\text { ca Typoart }\end{array}$} \\
\hline $\begin{array}{l}\text { marco } \\
\text { TIPOGRAF́́A }\end{array}$ & & \multirow{3}{*}{$\begin{array}{l}\text {-Aumento de la tipografía } \\
\text { mecánica } \\
\text { de Typoart } \\
\text { •Tipografía manuscrita }\end{array}$} & & \\
\hline \multirow{3}{*}{$\begin{array}{l}\text {-Tipografía } \\
\text { manual sustitu- } \\
\text { ye la mecánica } \\
\end{array}$} & & & \multirow{4}{*}{$\begin{array}{l}\text {-Tipografía manual } \\
\text { sustituye la mecánica } \\
\text { •Tipografía mecánica } \\
\text { Typoart } \\
\end{array}$} & IMAGEN \\
\hline & TIPOGRAFÍA & & & \multirow{4}{*}{$\begin{array}{l}\text { - Presencia carteles no } \\
\text { figurativos } \\
\text {-Pictórico } \\
\text { - Menor } 3 \text { colores } \\
\text { - Mesorrealismo } \\
\text { - Mesomorfismo }\end{array}$} \\
\hline & \multirow{4}{*}{$\begin{array}{l}\text { •Paso de la tipo- } \\
\text { grafía manual } \\
\text { sustituyendo } \\
\text { la mecánica } \\
\text { a tipografías } \\
\text { manuscritas } \\
\text { • Tipografía } \\
\text { mecánica no } \\
\text { Typoart } \\
\end{array}$} & IMAGEN & & \\
\hline IMAGEN & & \multirow{3}{*}{$\begin{array}{l}\text { - Dominio imágenes figurativas } \\
\text { - Fotográfico y pictórico } \\
\text { - Composiciones tipográficas } \\
\text { - Uso simbólico del color } \\
\text { - Tintas planas } \\
\text { - Surrealismo } \\
\text { - Mesomorfismo }\end{array}$} & & \\
\hline $\begin{array}{l}- \text { Presencia } \\
\text { carteles no } \\
\text { figurativos }\end{array}$ & & & \multirow{2}{*}{$\begin{array}{l}\text { - Presencia carteles no } \\
\text { figurativos } \\
\text { - Pictórico } \\
\text { - Variedad cromática } \\
\text { - Mesorrealismo } \\
\text { - Mesomorfismo }\end{array}$} & \\
\hline $\begin{array}{l}\text { •Pictórico } \\
\text { •Uso simbólico } \\
\text { del color }\end{array}$ & & & & \\
\hline - 3 colores & \begin{tabular}{|c|} 
Typoart \\
IMAGEN \\
\end{tabular} & & & \\
\hline •Isomorfismo & $\begin{array}{l}\text {-Presencia } \\
\text { contornos no } \\
\text { figurativos } \\
\text { • Dominio imá- } \\
\text { genes figurativas } \\
\text { • Tintas planas } \\
\text { - Realismo } \\
\text { - Isomorfismo } \\
\end{array}$ & & & \\
\hline 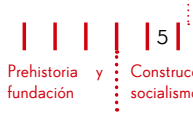 & 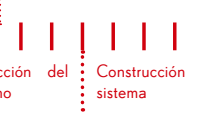 & $\begin{array}{l:ll}\text { un nuevo } & \text { Sistema Ulbricht } \\
\end{array}$ & 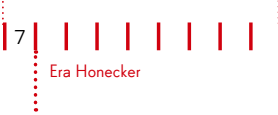 & $|8||| \underset{\text { Crisis y caida del Muro }}{\mid}|||| \mid$ \\
\hline
\end{tabular}

8.2.2 Líneas de tendencia en la evolución del diseño de la RDA en relación con las tendencias previas

Como hemos visto, se establece unas líneas de tendenci similares en los planos cultural y político que se diferencian notablemente de las derivadas de la publicidad económica. Los dos primeros se adecuan a lo que denominaremos las tendencias globales, y el segundo a las tendencias publicitarias.

La tendencia global partirá de un primer momento de continuidad con el diseño previo que se verá interrumpido drásticamente por la imposición del realismo socialista, el cual hará volver al diseño gráfico a estadios previos, en los que predomine la imagen por encima de la estructura, que se difumina debido a un escaso énfasis de la comunicación y a la yuxtaposición y complejidad de elementos dentro de un mismo diseño.

Pasados los primeros años, el control del gobierno sobre el diseño gráfico se relaja, lo que supone que se retomen las formas de expresión establecidas anteriormente al «debate sobre el formalismo", como son el énfasis y unidad en la comunicación, o las estrategias comunicativas conducidas formalmente. Esta vuelta a expresiones gráficas previas se verá reforzada por la aceptación de la Bauhaus a partir de 1955, la cual influirá en el diseño gráfico en elementos compositivos como la sinergia entre imagen y texto en la comunicación, y en una vuelta al funcionalismo con principios como la importancia del fondo compositivo, lo que da lugar a con relaciones de ambigüedad entre la figura y el fondo. Otras tendencias compositivas que se experimentaron en los movimientos previos a 1945, tales como el dinamismo o la estandarización no tendrán reflejo en la RDA.

Tampoco podemos considerar paralela la tendencia que se aprecia en la imagen, ya que mientras esta derivaba hacia un mayor figurativismo, aquí tiende hacia una simplificación formal y representacional que vuelve hacia los primeros carteles de comienzo de siglo.

A comienzos de los años 70 se observa una progresiva liberalización de las estructuras compositivas simplificadas y unitarias hacia otras menos enfáticas, en las que se tiende hacia niveles medios de énfasis, singularidad y yuxtaposición, es decir, a mayores variaciones en estos patrones.

La imagen retorna hacia el predominio del dibujo frente a la fotografía, si bien esta diferencia es menor que en los años del realismo socialista. Se vuelve a niveles medios de 
representación y abstracción con una clara simplificación cromática.

En el campo tipográfico se mantiene la supremacía de la tipografía de clase VI o tipografía de palo seco frente a cualquier otra clase, tal y como ocurría en los movimientos de la Nueva Tipografía o la Bauhaus. Sin embargo se aprecia en la RDA una tendencia hacia el aumento de las tipografías manuscritas especialmente notable en la última década, cuya presencia en los movimientos previos a la guerra se reducía al expresionismo.

Globalmente podemos concluir que de la continuidad en el diseño de los primeros años se dio un paso hacia expresiones formales anteriores al cartel moderno para retomarlo posteriormente -cuando el control gubernamental se relaja- con las características básicas de los movimientos de principio de siglo. Tras la vuelta a las formas de las primeras décadas de siglo se derivará hacia formas de expresión propias e independientes de las tendencias formales que tuvieron lugar en los años previos a la Segunda Guerra Mundial. Mientras en aquel momento las variaciones se hicieron desde una perspectiva teórica que establecía unas características formales según criterios racionales, aquí nos encontraremos con una casi total libertad compositiva en la cual los patrones formales vendrán derivados de las necesidades de comunicación y -según el caso- de las posibilidades materiales.

En el plano de la publicidad económica son estas posibilidades materiales las que establecen en mayor medida el cambio que se produce en torno a 1961, con el paso de imágenes pictóricas y tipografías manuscritas a la fotografía y la tipografía de producción propia.

\section{GENERAL}

COMPOSICION

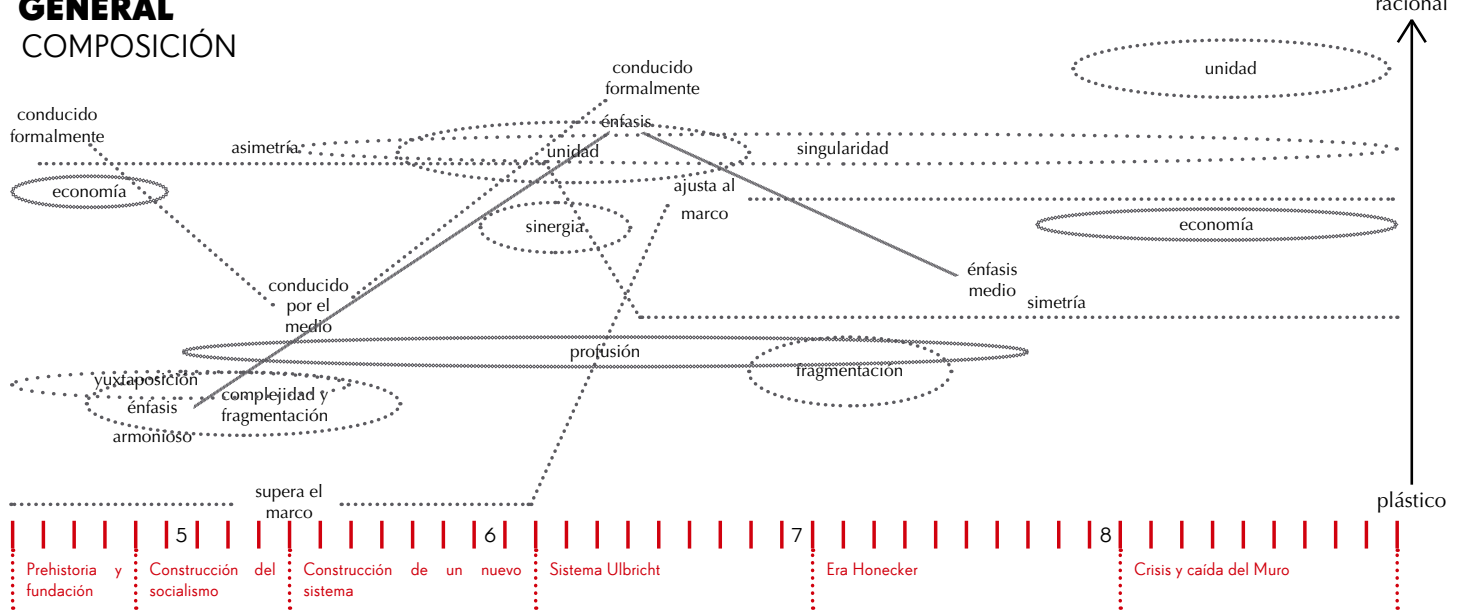

TIPOGRAFÍA

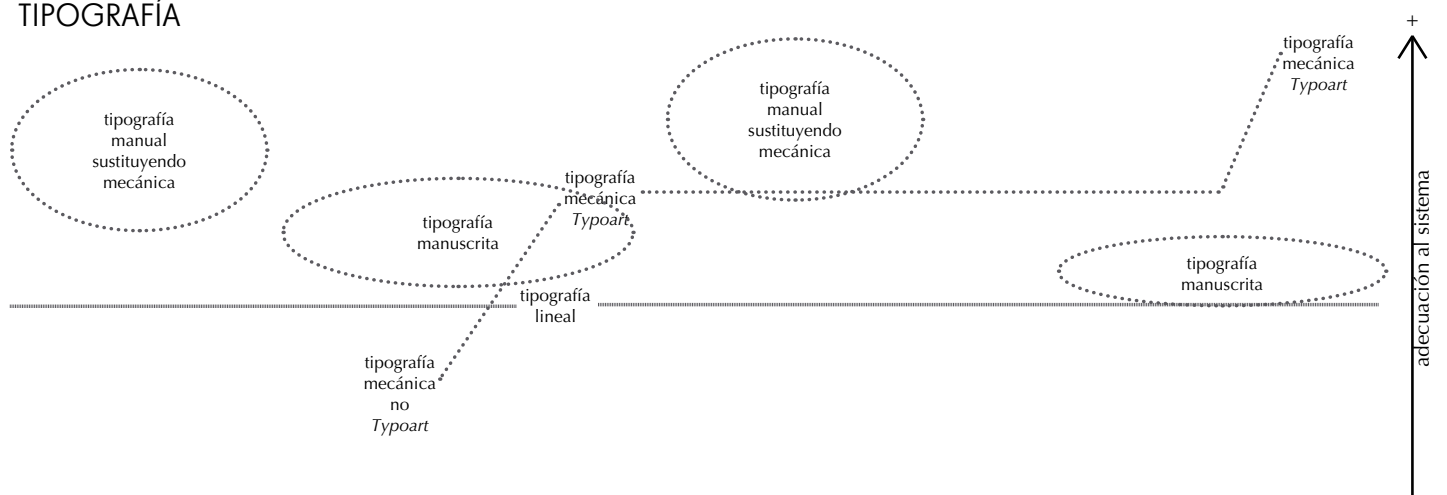

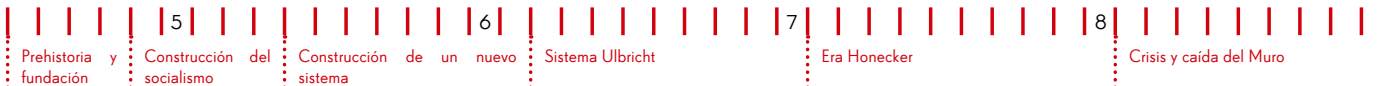
IMAGEN

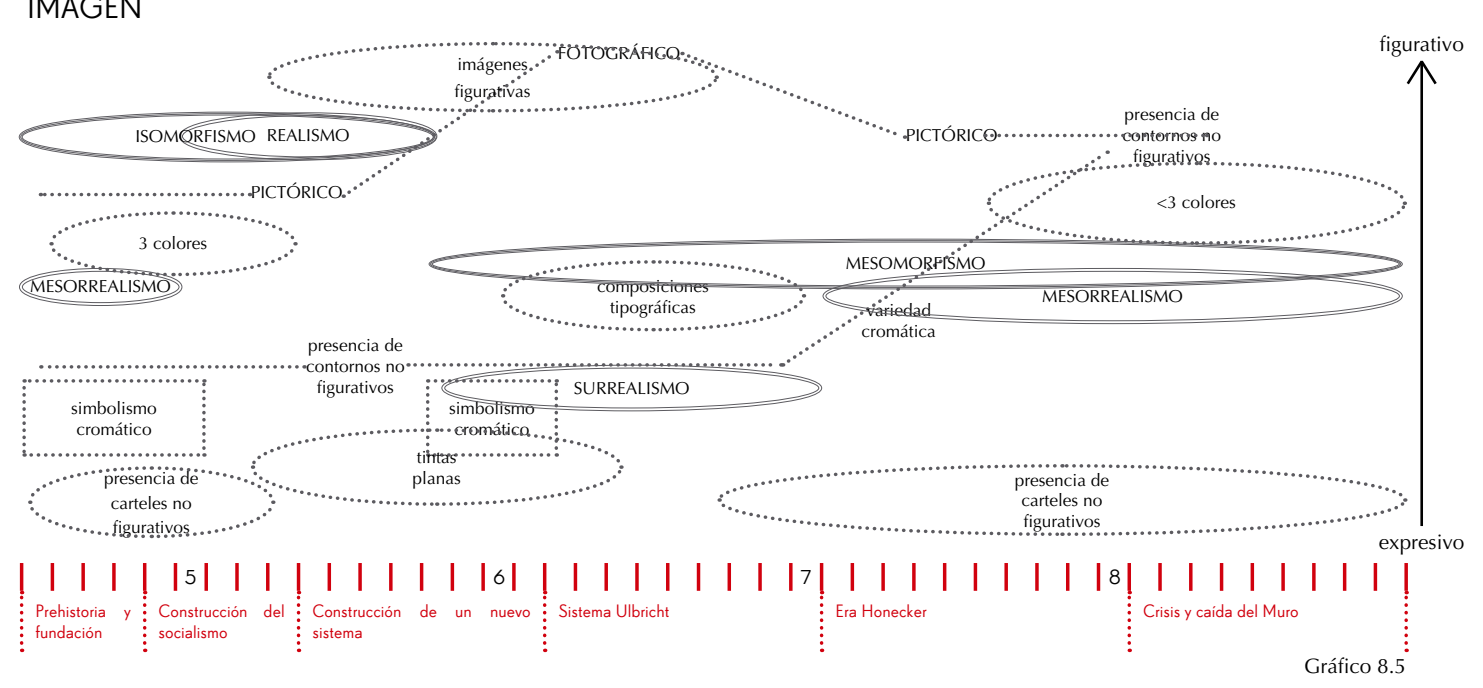


Influencia de la SBZ/RDA en la evolución de los elementos del diseño gráico en Alemania: composición, tipografia e imagen. Una propuesta metodológica

\section{COMPOSICIÓN}

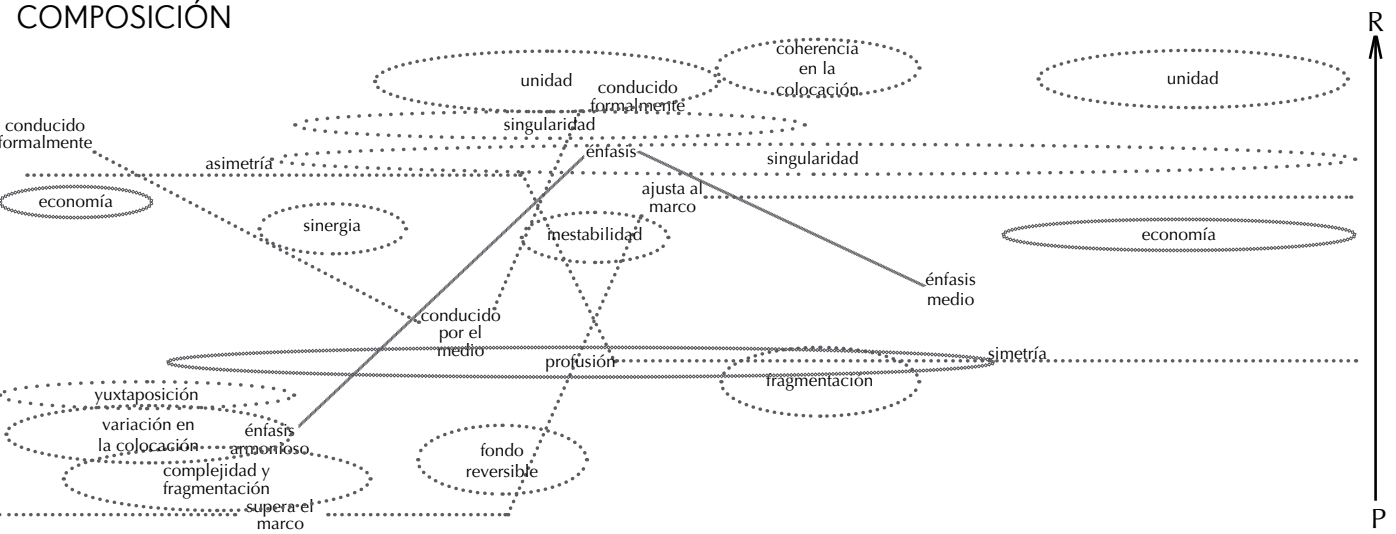

|||||| 5|||||||||| 6|||||||||| 7|||||||||| 8|||||||||| Prehistoria y
fundacion

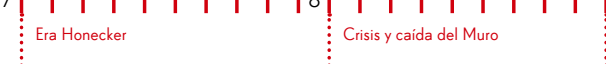

TIPOGRAFÍA

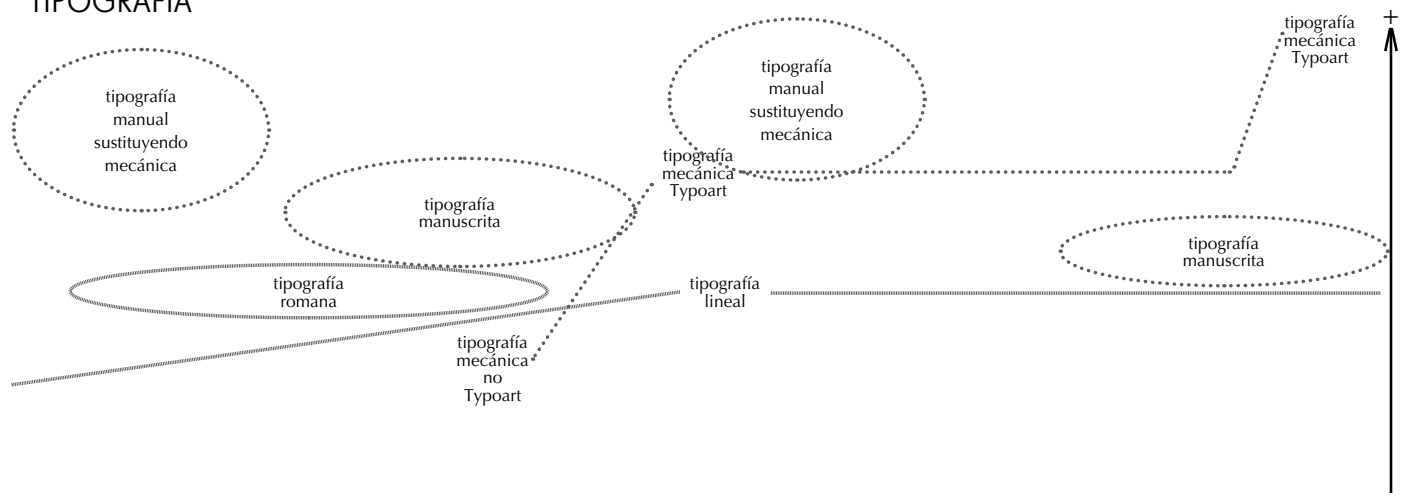

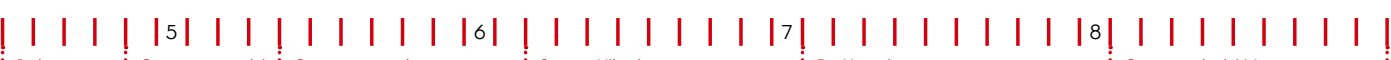

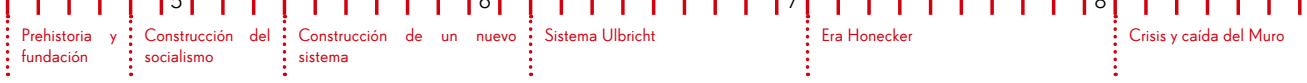

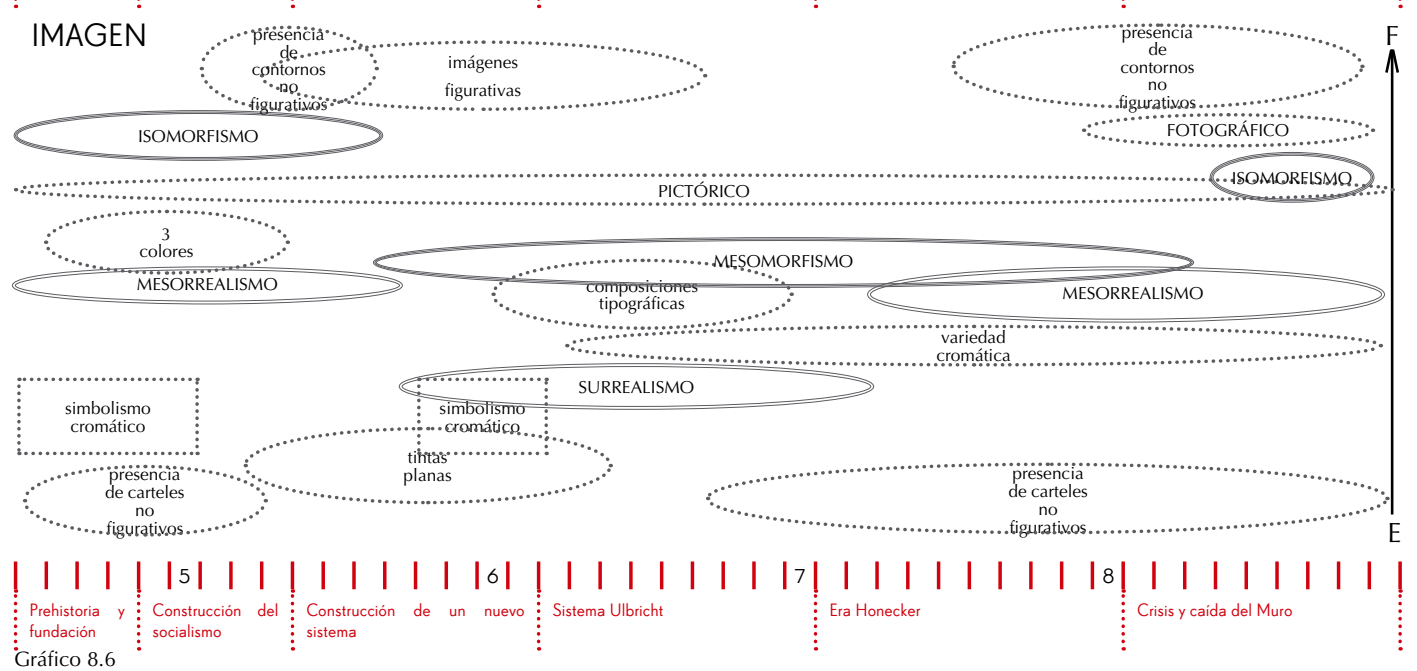

ECONÓMICO

COMPOSICIÓN

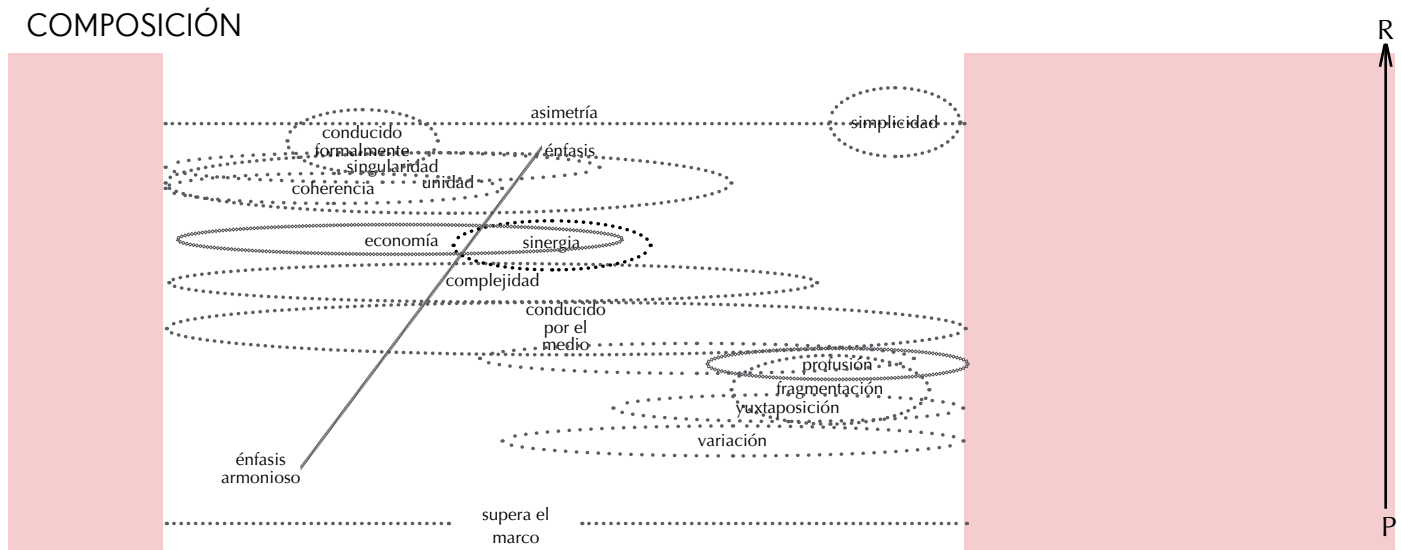

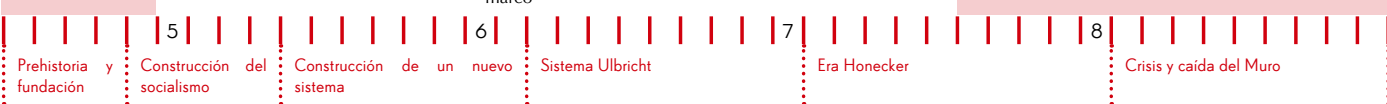

TIPOGRAFÍA

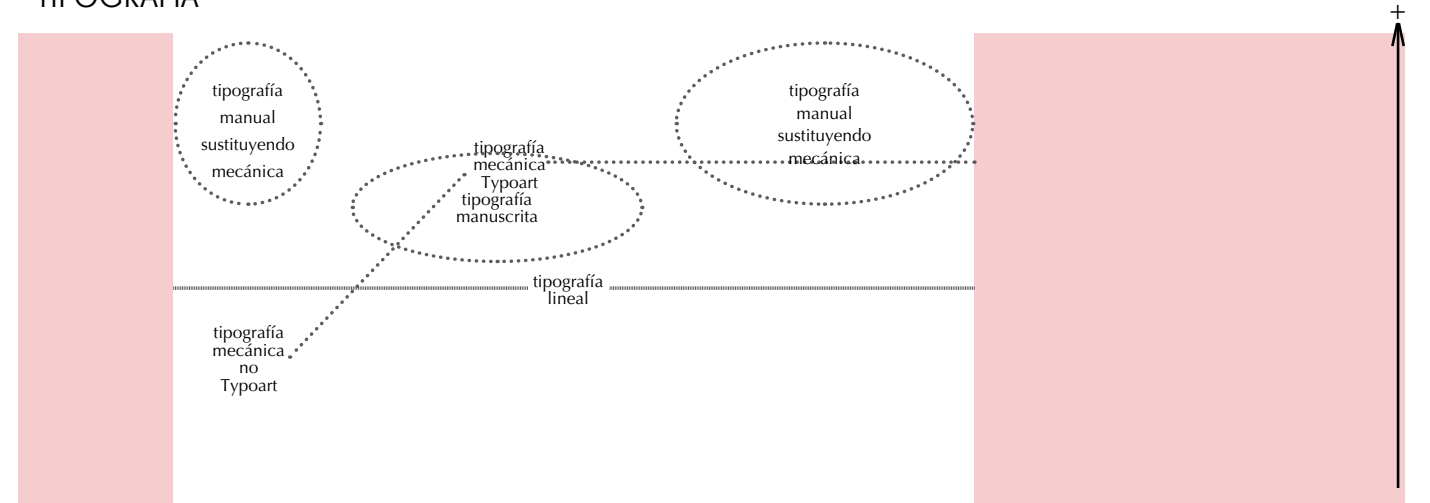

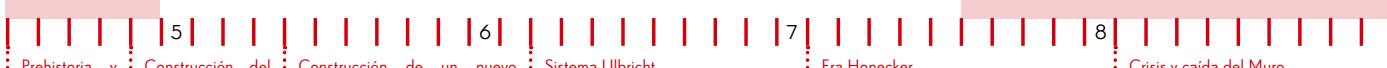

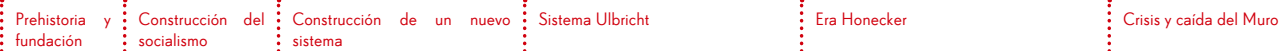

IMAGEN

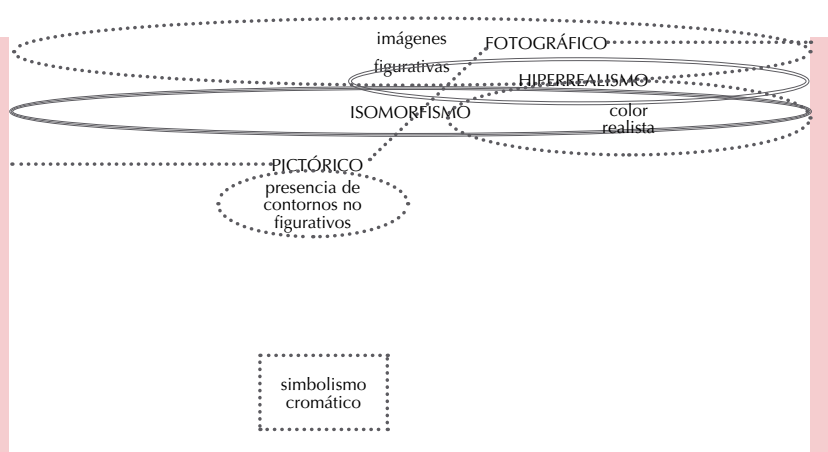

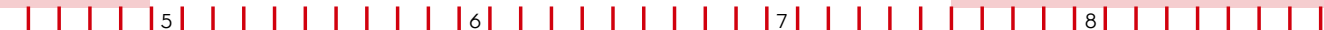

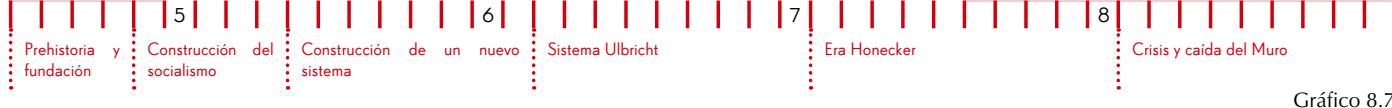


POLÍTICO

COMPOSICIÓN

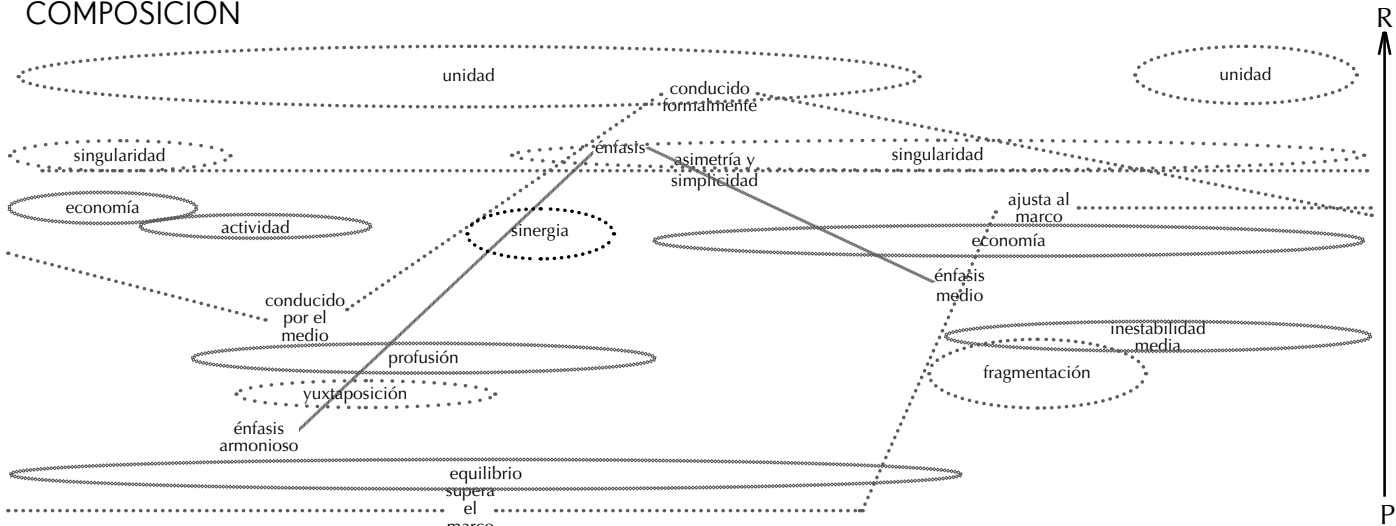

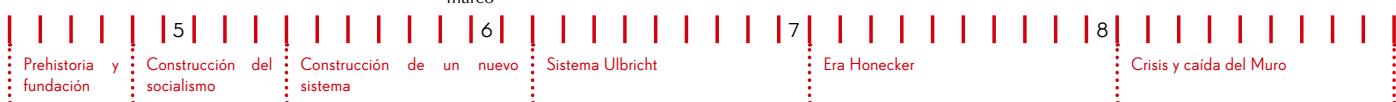
TIPOGRAFÍA

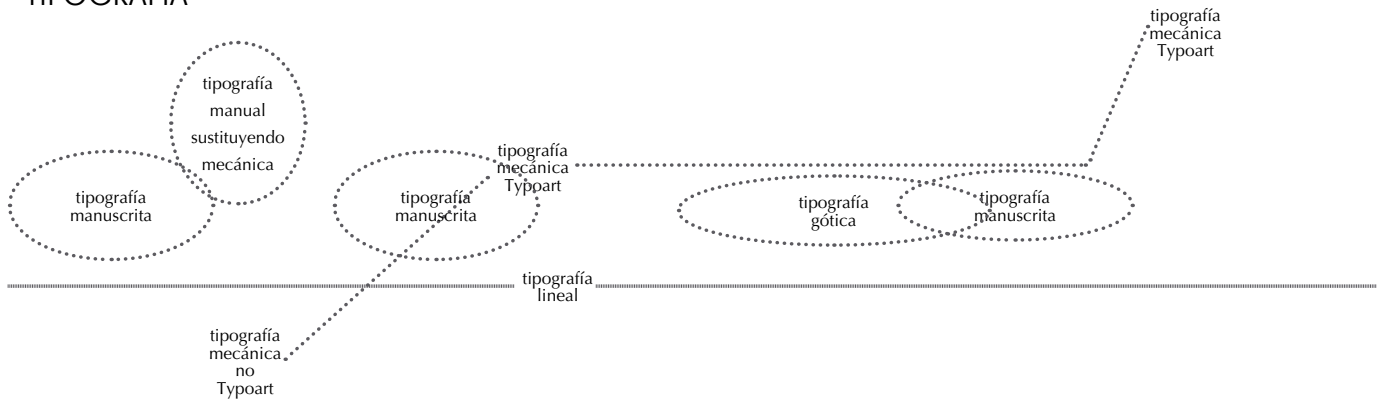

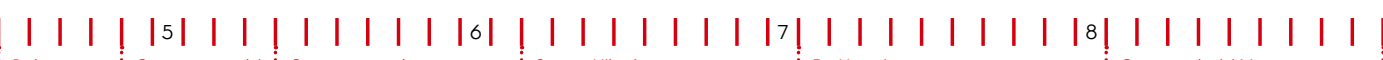

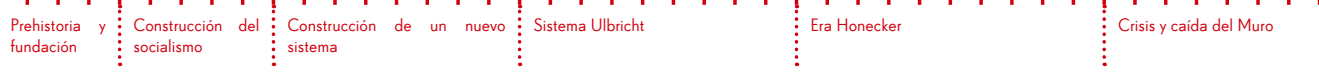
IMAGEN

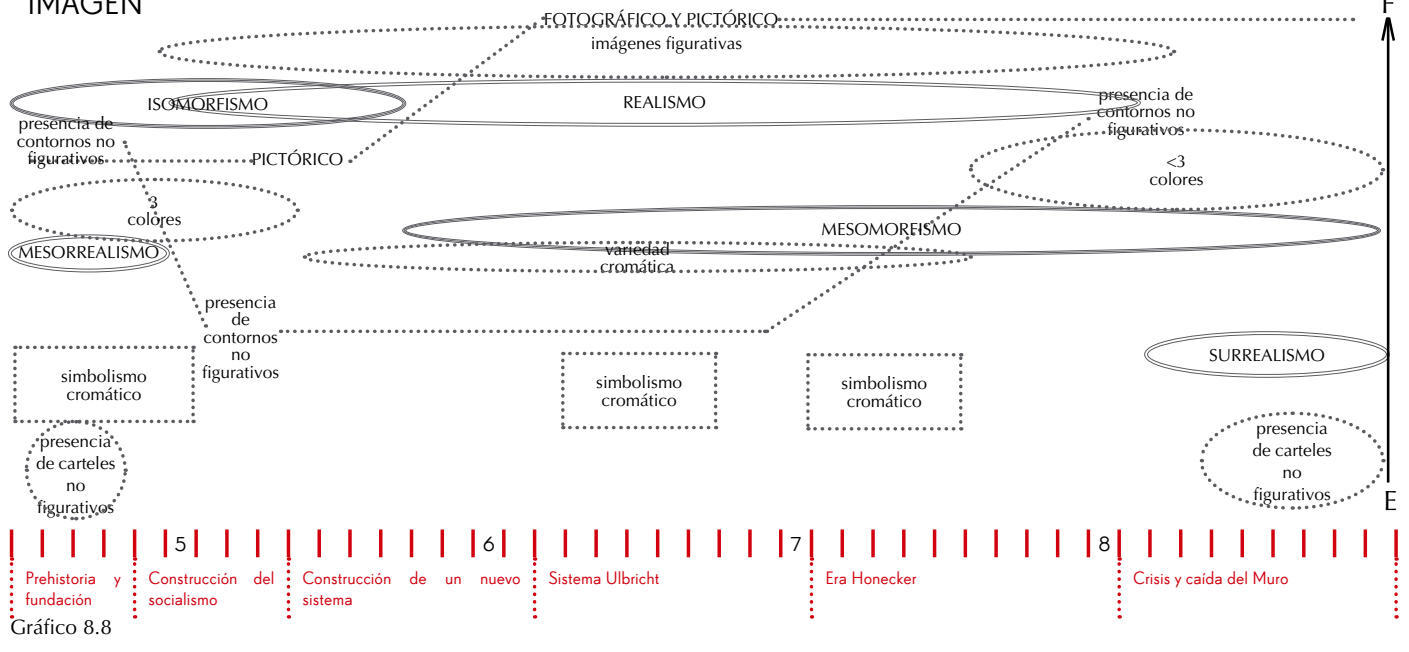

A modo de esquema, y basándonos en los mismos criterios en los que habíamos establecido las corrientes previas a 1945: composición, tipografía e imagen, podemos representar las tendencias del diseño gráfico de la RDA, según sus características generales y por géneros, de la siguiente manera:

8.2.3 Reflejo de los acontecimientos históricos y políticos en las tendencias del diseño

Hemos hablado en numerosas ocasiones de la influencia directa de las decisiones gubernamentales en materia cultural tales como el realismo socialista o las consideraciones de la Bauhaus. Igualmente hemos demostrado el efecto directo de las estructuras económicas en las posibilidades materiales y por lo tanto en el lenguaje visual de la RDA.

Sin embargo estas responden a decisiones y acontecimientos más amplios y con un claro reflejo en los periodos de diseño establecido. El lenguaje de lo que hemos dado en Ilamar la SBZ -pese a que no corresponda exactamente con el periodo histórico que culminará con la constitución de la RDA en noviembre de 1949- corresponde al propio de momentos de cambio, una llamada a la reestructuración mediante una profusión de elementos y un alto simbolismo El realismo socialista es la traducción directa de la imposición de la construcción del socialismo que atañe a todas las esferas de la vida diaria, incluida la cultural.

El cierre de las fronteras y la construcción del Muro de Berlín suponen un hito fundamental en aspectos como el tipográfico y en las tendencias en la publicidad, pero a nive global son más evidentes las diferencias entre la Era Ulbricht y la Era Honecker, siendo este último más abierto a las relaciones internacionales, lo que se tradujo en un diseño gráfico más acorde con las tendencias de su tiempo, se pasó de un diseño basado en la tradición plástica propia, a formas de expresión más modernas y con influencias de movimientos internacionales. 
9. Fuentes

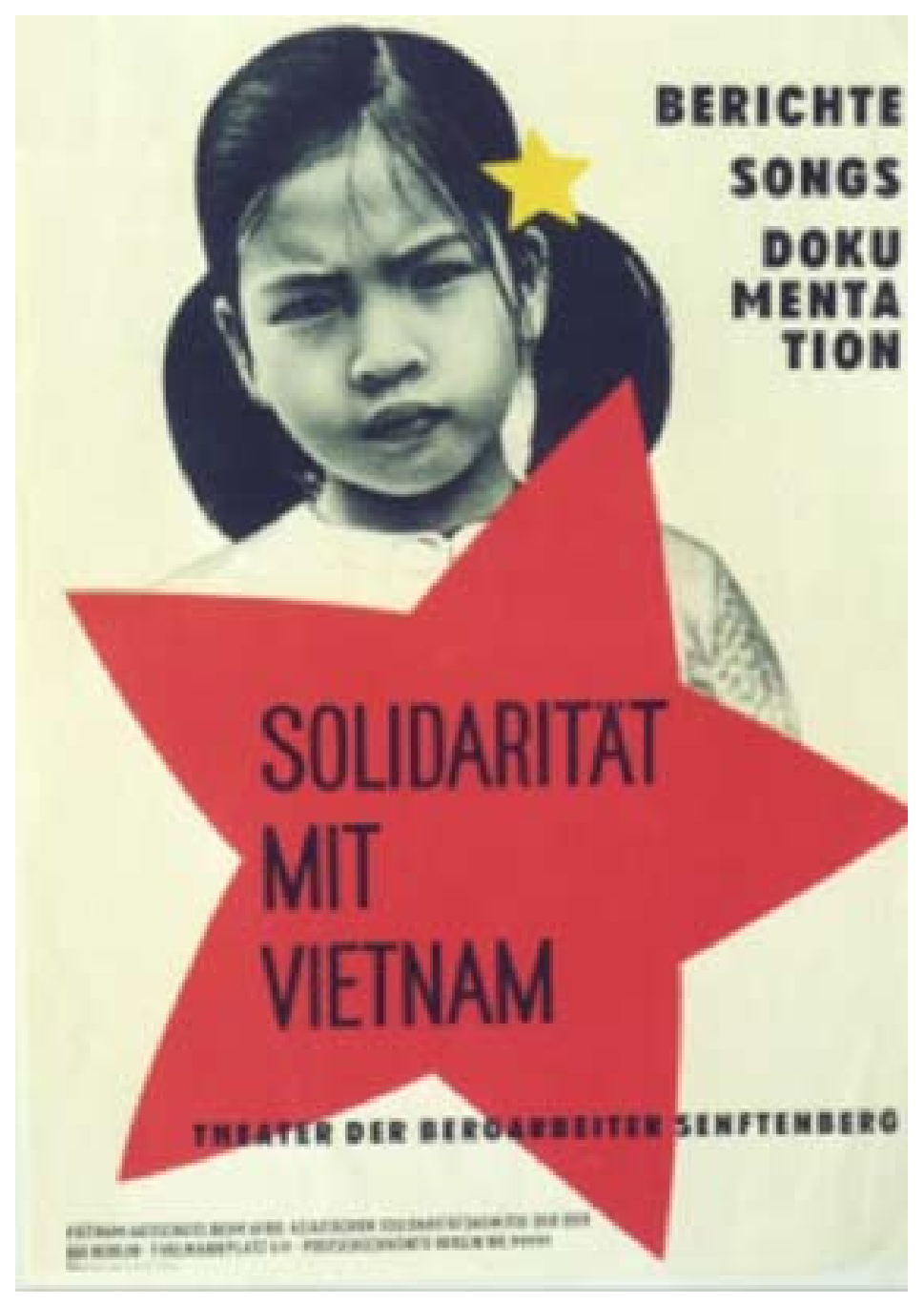


ABUSCH, Alexander (1954): Zum Geteil. En Neue Werbung. Berlín, citado en WUNDERLICH, Sylke (2007): Überklebt: Plakate aus der DDR. Ausstellung der Landeshauptstadt Schwerin im Schleswig-Holstein-Haus 24. August bis 21. Oktober 2007. Verlagsgruppe Schwerin, Schwerin.

ACASO, María (2006): El lenguaje visual. Paidós, Barcelona.

ALBRECHT, Anneliese (1962): Die Aufgaben der zentralen staatlichen Organe auf dem gebiet der sozialistischen Binnenhandelswerbung. MIM, pág. 16. Citado en: KAMINSKY, Annette (1999): Illustrierte Konsum-geschichte der DDR. Landeszentrale für politische Bildung, Thüringen.

ARGAN, Giulio Carlo (1951): Walter Gropius y la Bauhaus. Giulio Einaudi, Turín.

ARPKE, Otto: Aphorismen, en Das Plakat. Offsetsonderheft des Archivsfür Buchgewerbe und Gebrauchsgrafik, Bd 60, pág. 13, citado en RADEMACHER, Hellmut (1975): Gesellschaftliche Funktion und ästhetische Prinzipien der Gebrauchsgrafik in der sozialistischen Gesellschaft en Verband Bildender Künstler der DDR, Sekt. Gebrauchsgrafik. 1975. Gebrauchsgrafik in der DDR. VEB Verlag der Kunst, Dresden.

ARTHUR, (2010): "Everything has its Limit! Even Miniskirts...» Aerial propaganda leaflets on the inner German border, 1965-1969. recto|verso. [Web en línea] Disponible desde Internet en <http://rectoversoblog.com/2010/12/13/propaganda/\#more-612> [Consultado el 04.02.11].

AUTORENKOLLEKTIV (1968): Handbuch der Werbung, pág. 29 citado en WUNDERLICH, Sylke (2007): Überklebt: Plakate aus der DDR. Ausstellung der Landeshauptstadt Schwerin im Schleswig-Holstein-Haus 24. August bis 21. Oktober 2007. Verlagsgruppe Schwerin, Schwerin.

AYNSLEY, Jeremy (2000): Graphic Design in Germany 1890-1945. Thames \& Hudson, London.

B

BAINES, Phil (2002): Tipografía, función, forma y diseño. Ediciones Gustavo Gili, Naucalpan.

BALTZER, Hans (1954): Zur Eröffnung der Ausstellung «Das Plakat» Staatliche Museen, Berlín, en Neue Werbung, 1, citado en WUNDERLICH, Sylke (2007): Überklebt: Plakate aus der DDR. Ausstellung der Landeshauptstadt Schwerin im Schleswig-Holstein-Haus 24. August bis 21. Oktober 2007. Verlagsgruppe Schwerin, Schwerin.

BASTOS, Itanel (1998): De las cavernas a la era digital. [Web en línea]. Disponible desde Internet en: <http://www.estudiotrama.com/lecturas/historiadeldiseniografico.htm> [Consultado el 16.09.2010]. 
BECHER, J.R (1952): Verteidigung der Poesie. Berlín pág.197, citado en GÄRTNER, Hanneore (dir.)(1979): Die Künste in der Deutschen Demokratischen Republik. Aus ihrer Geschichte in drei Jahrzehnten. Henschelverlag Kunst und Gesellschaft, DDR Berlín.

BLEEK, Wilheim (2009): Die Geschichte der DDR. Bundeszentrale für politische Bildung. [Archivo en línea] Disponible desde Internet en <www.bpb.de/publikationen $>$ [Consultado el 17.02.2010].

BLUME, Eugen (2003): entrevista en el video ROSSIGNOL, A (2003): El arte en la república democrática alemana (RDA). Goethe Institut Internaciones. [Web en línea] Disponible desde Internet en <http://www.goethe.de/kue/flm/prj/kub/bdk/es3946580.htm> [Consultado el 19.11.2010].

BONSIEPE, Gui (1965): Retórica Visual/Verbal en BIERUT, Michael (2001): Fundamentos del diseño gráfico. Ediciones Infinito, Buenos Aires.

BORMANN, Martin (1941): Frakturverbots citado en RÜCK, Peter (1993): Die Sprache der Schrift. Zur Geschichte des Frakturverbots von 1941, in J. BAURMANN, J. GÜNTHER $\mathrm{U}, \mathrm{H}$. KNOOP, U (comp): Homo scribens. Perspektiven der Schriftlichkeitsforschung, hrsg, Tübingen.

BUNDESMINISTERIUM FÜR INNERDEUTSCHE BEZIEHUNGEN (ed) (2000): DDR Handbuch. Bundesministerium des Innern, Berlín.

BURKE, Christopher (2000): Paul Renner, maestro tipógrafo. Campgràfic, Valencia.

C

CALLES, Francisco (2001): Metáforas tipográficos y otras figuras en BIERUT, Michael (2001): Fundamentos del diseño gráfico. Ediciones Infinito, Buenos Aires.

CASPAR, Helmut (2009): DDR-Lexikon. Von Trabi, Broiler, Stasi und Republikflucht. ImhofZeitgeschichte, Petersberg.

CASTILLO, Greg (2007): Promoting socialist cities and citiziens. en SWETT, Pamela E.; WIESEN, S. Jonathan; ZATLIN, Jonathan R. (ed): Selling Modernity. Advertising in twentiethcentury Germany. Duke University Press, USA.

CATOPODIS, Miguel (2009): El alfabeto Universal de Bauhaus y otros mitos. [Web en línea]. Disponible desde Internet en: <www.foroalfa.org/es/articulo/201/EI_alfabeto_Universal_de_Bauhaus_y_otros_mitos> [Consultado el 16.09.2010].

CONRAD, Stephan, KUHRMANN, Anja y LUDWIG, Andreas (2002): «Im Blick der Massen». Plakate in der DDR. Eine Ausstellung des Dokumentationszentrum Alltagskultur der $D D R$. Dokumentationszentrum Alltagskultur der DDR.

DE FUSCO, Renato (1985): Historia del Diseño. Santa \& Cole, Barcelona.

DE MICHELI, Mario (1971): Gropius y sus artistas. Pág. 87-100. En COMUNICACIÓN. (1971): La Bauhaus. Alberto Corazón, Madrid.
DONDIS, Donis (2008): La sintaxis de la imagen: introducción al alfabeto visual. G. Gili Barcelona.

DU VINAGE, Norbert (1988): 40 Jahre Typoart - vier Jahrzehnte intensives Bemühen um niveauvolle Schriften, en: Papier und Druck, Leipzig 11/1988, pág. 497 citado en ANON. Typoart Super Grotesk. Elsner+Flake Fonts. [Web en línea] Disponible desde Internet en $<w w w$. fonts4ever.com/portrait_typeface.php?id=9\#familyName> [Consultado el 11.07.2011].

$\mathrm{E}$

EVANS, John (1992): John Heartfield AIZ-VI: Fotomontajes 1930-1938. Kent Fine Art, Singapore.

FAVRE, Jean-Paul y NOVEMBER, Andre (1979): Color and, und, et communication. ABC Edition, Zurich

FERNANDEZ-BUENO, Marta (2009): El recurso a motivos mitológicos en el teatro de la RDA. Revista de Filología Alemana, vol. 17 pág.127-139. [Publicación en línea] Disponible desde Internet en <revistas.ucm.es/fll/11330406/articulos/RFAL0909110127A.PDF>. [Consultado el 11.11.2010].

FERRANDO BADÍA, Juan (1980): Democracia frente a autocracia. Los tres grandes sistemas políticos. El democrático, el social-marxista y el autoritarismo. Tecnos, Madrid.

FIEDLER, Jochen (1986): Zur Funktion des sozialen Plakates im Sozialismus, en Verband Bildender Künstler (1986): Funktion und Wirkungsweise des Plakates in der sozialistischen Gesellschaft. Plakatsymposium Erfurt September 1986

FRANK, Hilmar (1986): Rhetorik des Plakates, en Verband Bildender Künstler (1986): Funktion und Wirkungsweise des Plakates in der sozialistischen Gesellschaft. Plakatsymposium Erfurt September.

FRASCARA, Jorge (2000a): Diseño gráfico para la gente. Comunicaciones de masas y cambio social. Ediciones Infinito, Buenos Aires.

FRASCARA, Jorge (2000b): Diseño gráfico y comunicación. Ediciones Infinito, Buenos Aires.

FREIBURG, Arnold (2000): Freie Deutsche Jugend (FDJ), en BUNDESMINISTERIUM FÜR INNERDEUTSCHE BEZIEHUNGEN (ed) (2000): DDR Handbuch. Bundesministerium des Innern, Berlín.

FRITSCHE, Susanne (2008): Die Mauer ist gefallen: Eine kleine Geschichte der DDR. Jaron, Berlín.

FROMMHOLD, Erhard (1979): Klaus Wittkugel: Fotografie, Gebrauchsgrafik, Plakat, AusteIlung, Zeichen. VEB Verlag der Kunst, Dresden. 
GÄRTNER, Hannelore (dir.)(1979): Die Künste in der Deutschen Demokratischen Republik. Aus ihrer Geschichte in drei Jahrzehnten. Henschelverlag Kunst und Gesellschaft, DDR Berlín.

GOETHE INSTITUT (2004): El arte en la república democrática alemana (RDA). [Web en línea] Disponible desde Internet en <http://www.goethe.de/kue/flm/prj/kub/bdk/es3946580. htm> [Consultado el 19.11.2010].

GONZÁlEZ DEL RÍO COGORNO, Jimena (2010): Teoría i història del disseny gràfic: renaixença i futuro. UPV, Valencia.

GORDEEVA, Tatyana (2001a): Honecker Era. [Web en línea] Disponible desde Internet en $<$ www.germanculture.com.ua $>$ [Consultado el 19.11.2010].

GORDEEVA, Tatyana (2001b): Relations between the two Germanys. [Web en línea] Disponible desde Internet en <www.germanculture.com.ua $>$ [Consultado el 19.11.2010].

GORDEEVA, Tatyana (2001c): The New East German Constitution and the Question of Identity. [Web en línea] Disponible desde Internet en <www.germanculture.com.ua $>$ [Consultado el 19.11.2010].

GROPIUS, Walter (1926): Bauhaus Dessau- Principles of Bauhaus Production. Bauhaus Dessau, Dessau citado en AYNSLEY Jeremy (2000): Graphic Design in Germany 1890-1945. Thames \& Hudson London.

$\mathrm{H}$

HALL, Sean (2007): Esto significa esto, esto significa aquello: semiótica: guía de los signos y su significado. Art Blume, Barcelona.

HARRISON, Hope M (1993): The cold war files. Interpreting history through documents. Wilson Center. [Archivo en línea] Disponible desde Internet en $<$ www.wilsoncenter.org/coldwarfiles> [Consultado el 6.04.2010].

HELDMANN, Philipp.(2004): Herrschaft, Wirtschaft, Anoraks: Konsumpolitik in der DDR der sechziger Jahre. Vandenhoeck \& Ruprecht, Göttingen.

HERBST, Andreas; RANKE, Winfried; WINKLER, Jürgen (comp) (1994): So funktionierte die DDR: Lexikon der Organisationen und Institutionen: Enzyklopädie der DDR. Rowohlt Taschenbuch, Reinbek.

HEYDEMANN, Günther (2009): Entwicklung der DDR bis Ende del 80er Jahre. Bundeszentrale für politische Bildung. [Archivo en línea] Disponible desde Internet en <www.bpb.de/ publikationen> [Consultado el 17.02.2010].

HOCHULI, Jost (2007): El detalle en la tipografía: letra, espacio entre letras, palabra, espacio entre palabras, línea, interlineado, caja. Campgrafic, Barcelona HOLLIS, Richard (2000): El diseño gráfico: Destino, Barcelona.
HOLLIS, Richard (2000): El diseño gráfico. Destino, Barcelona.

HONECKER, Erich (1986): Dokumente zur geschichte der SED. Bd 3:1971 bis 1986. Berlín, pág.: 24, citado en WOLLE, Stefan (1999): Die heile Welt der Diktatur. Alltag und Herrschaft in der DDR 1971-1989. Econ \& List Taschenbuch, Berlín.

J

JUDT, Matthias (1999): Periodisierung der Wirtschaft der DDR, en ECKART, Karl (comp): Die Wirtschaft im geteilten und vereinten Deutschland. Duncker \& Humblot, Berlín.

K

KAPR, Albert y SCHÄFER, Detlef (1989): Fotosatzschriften. Type-Design und Schriftherstellung. VEB Fachbuchverlag, Leipzig.

KAMINSKY, Annette (1999): Illustrierte Konsum-geschichte der DDR. Landeszentrale für politische Bildung, Thüringen.

KHRUSHCHEV, Nikita (1958): Note from the Soviet Foreign Ministry to the American Ambassador at Moscow (Thompson). Regarding Berlín (November 27). [Archivo en línea] Disponible desde Internet en <http://germanhistorydocs.ghi-dc.org> [Consultado el 15 de enero de 2011].

KOHL, Helmut (2009): El triunfo de la libertad, en El país Domingo 08.11.09. Prisa, Madrid.

KRÜGER, Thomas (2006): Geleitwort, en SCHILLING, Thorsten (2006): Paralle/welt: Film Ein Einblick in die DEFA. [Archivo en línea] Disponible desde Internet en $<$ www.bpb.de/files $>$ [Consultado el 19.11.2010].

KUO, Leslie (2007): VEB Typoart: the east german type Betriebsstätte. [Web en línea]. Disponible desde Internet en: <http://pingmag.jp/2007/10/05/veb-typoart-the-east-german-typebetriebsstatte $>$ [Consultado el 05.12.2009].

KUPPER, Siegfried (1999): Ziele und Folgen des zentralgelenkten sektoralen und regionalen strukturwandels in der DDR-Planwirtschaft, en KUHRT, Eberhad: Die Endzeit der DDR-Wirtschaft. Analysen zur Wirtschafts-, Sozial- und Umweltpolitik. Leske+Budrich, Opladen.

L

LANDA, Robin (2011): Diseño gráfico y publicidad. Fundamentos y soluciones. Anaya Madrid.

LANGE, Karl-Heinz (2007), entrevista en KUO, Leslie (2007): VEB Typoart: the east german type Betriebsstätte. [Web en línea] Disponible desde Internet en <http://pingmag.jp/2007/10/05/ veb-typoart-the-east-german-type-betriebsstatte> [Consultado el 19.11.2009].

LINGNER, Max (1950): Katalogtext. En Plakate für Aufbau und Frieden 1945-1950. DAK, Berlín, citado en WUNDERLICH, Sylke (2007): Überklebt: Plakate aus der DDR. Ausstellung der Landeshauptstadt Schwerin im Schleswig-Holstein-Haus 24. August bis 21. Oktober 2007. Verlagsgruppe Schwerin, Schwerin. 
LOTH, Wilfried (1986a): Europa después de 1945: La formación de los bloques, en BENZ, Wolfgang y GRAML, Hermann (comp.) (1986): El siglo XX. II. Europa después de la Segunda Guerra Mundial, 1945-1982. Tomo 1. Siglo XXI, Madrid

LOTH, Wilfried (1986b): Europa en la política mundial, en BENZ, Wolfgang y GRAML, Hermann (comp.) (1986): El siglo XX. II. Europa después de la Segunda Guerra Mundial, 19451982. Tomo 2. Siglo XXI, Madrid.

LUDZ, Peter y Ursula (2000): Bevölkerung, en BUNDESMINISTERIUM FÜR INNERDEUTSCHE BEZIEHUNGEN (ed) (2000): DDR Handbuch. Bundesministerium des Innern, Berlín.

LUILD, Philipp.(2003): La letra gótica entre el ser y la historia. Campgràfic, Valencia.

LUPTON, Ellen (2002): Diccionario Visual. En LUPTON, Ellen y ABBOT MILLER, J. El abc de la bauhaus y la teoría del diseño. Gustavo Gili, Sabadell.

LUPTON, Ellen, y PHILLIPS, Jennifer C. (2009): Diseño gráfico: nuevos fundamentos. Gustavo Gili, Barcelona.

MACKENZIE, Norman (1969): Breve historia del socialismo. Nueva colección labor, Barcelona.

MALDONADO, Tomás (1971): Textos, cartas, respuestas, comentarios. En COMUNICACIÓN (1971): La Bauhaus. Alberto Corazón, Madrid.

MARCOS, Juan José (2008): La letra gótica. [Publicación en línea]. Disponible desde Internet en: <http://guindo.pntic.mec.es/ jmag0042/escritura_gotica.pdf> [Consultado el 16.09.2010].

MARTí FONT, José María (2009): Una confusión abatió el muro, en El país Domingo 08.11.09. Prisa, Madrid.

MARTíN MONTESINOS, José Luis, MAS HURTANA, Montse. (2001): Manual de tipografía: del plomo a la era digital. Campgràfic, Valencia.

MARTÍN MONTESINOS, José Luis, MAS HURTANA, Montse. (2011): Manual de tipografía: del plomo a la era digital. Campgràfic, Valencia.

MARTíN MONTESINOS, José (2008): Ricard Giralt Miracle: el diálogo entre la tipografía y el diseño gráfico. Campgràfic, Valencia.

MEGGS, Philip. B. (2000): Historia del diseño gráfico. McGraw-Hill, México.

MEIER-GRAEFE, Julius (1896): citado en AYNSLEY, Jeremy (2000): Graphic Design in Germany 1890-1945. Thames \& Hudson, London.

MOHOLY-NAGY,Lázló (1925): Pintura, fotografía, cine en MOHOLY-NAGY, Lázló (1993): Pintura, fotografía, cines y otros escritos sobre fotografía. Gustavo Gili, Barcelona.

MOHOLY-NAGY,Lázló (1925): La Bauhaus y la tipografía. Citado en SATUÉ, Enric (1993): El diseño gráfico. Desde los orígenes hasta nuestros días. Alianza Editorial, Madrid.
MOHOLY-NAGY, Lázló (1926): Fotoplastische Reklame, en Offset, Buch und Werbekunst, en MOHOLY-NAGY, Lázló (1993): Pintura, fotografía, cines y otros escritos sobre fotografía. Gustavo Gili, Barcelona.

MOLINER, María (2008): Diccionario de uso del español. Edición Abreviada. E-o. Gredos, Madrid

MORISON, Stanley (1998): Principios fundamentales de la tipografía. Del Bronce, Barcelona.

MUNARI, Bruno (1987): Diseño y comunicación visual: contribución a una metodología didáctica. Gustavo Gili, Barcelona.

N

NEUE ZÜRICHER ZEITUNG (1988): Klassenspaltung in Alltagsleben der DDR. en: Neue Züricher Zeitung von 7.12.1988 Citado en: KAMINSKY, Annette (1999): Illustrierte Konsumgeschichte der DDR. Landeszentrale für politische Bildung, Thüringen.

NEUES DEUTSCHLAND (1950): Entschließung des III Parteitages der SED. ND 26.7.1950 citado en GÄRTNER, Hannelore (dir.)(1979): Die Künste in der Deutschen Demokratischen Republik. Aus ihrer Geschichte in drei Jahrzehnten. Henschelverlag Kunst und Gesellschaft, DDR Berlín.

O

OFFE, Claus (1990): Bienestar, Nación y República. Aspectos de la Vía Particular Alemana del socialismo al capitalismo. Pensamiento iberoamericano nº 18 pág. 146.

PELTA RESANO, Raquel (2008): Investigar en el diseño, en ARRAUSI, Juan (2008): Diseño e impresión de la tipografía. Ediciones CPG, Barcelona.

PUJOL, Josep M. (2010): La classificació DIN 16518 [1959/1964] de les lletres tipogràfiques. Consulta del Termcat (3.2.2010). [Pendiente de publicación]

$R$

RADEMACHER, Hellmut (1975): Gesellschaftliche Funktion und ästhetische Prinzipien der Gebrauchsgrafik in der sozialistischen Gesellschaft en Verband Bildender Künstler der DDR Sekt. Gebrauchsgrafik (1975): Gebrauchsgrafik in der DDR. VEB Verlag der Kunst, Dresden.

RADEMACHER, Hellmut (1989): Zur Entwicklung der Plakatkunst in der DDR en Zentralvorstand des Verbandes Bildender Künstler der DDR, edit (1989): P40. Plakate von 1945 bis zum Gegenwart. Eine Ausstellung im 40. Jahr der DDR. Graphischer Grossbetrieb, Leipzig.

RAE, REAL ACADEMIA ESPAÑOLA (2006): Diccionario esencial de la lengua española. Espasa Calpe, Madrid. 
RDA (1949): Die Verfassung der Deutschen Demokratischen Republik (07.10.1949). [Archivo en línea] Disponible desde Internet en $<$ www.documentarchiv.de/DDR $>$ [Consultado el 14.12.2010].

RDA (1968): Verfassung der Deutschen Demokratischen Republikvom 6. April 1968. [Archivo en línea] Disponible desde Internet en $<w w w$.documentarchiv.de/DDR $>$ [Consultado el 14.12.2010].

RDA (1974): Verfassung der Deutschen Demokratischen Republik (06.04.1968, i.d.F.v. 07.10.1974). [Archivo en línea] Disponible desde Internet en <www.documentarchiv.de/ DDR> [Consultado el 14.12.2010].

RENNER, Paul (1930): Das Formproblem der Druckschrift en Imprimatur: ein Jahrbuch für Bücherfreunde, citado en BURKE, Christopher. 2000. Paul Renner, maestro tipógrafo. Campgràfic, Valencia.

REULEAUX (1876): Briefe aus Philadelphia en DE FUSCO, Renato (1985) Historia del Diseño. Santa \& Cole, Barcelona.

ROBEL, Gert (1986): De la muerte de Stalin a la era Breznev. Los países del Comecon desde 1953, en BENZ, Wolfgang y GRAML, Hermann (comp.) (1986): El siglo XX. II. Europa después de la Segunda Guerra Mundial, 1945-1982. Tomo 2. Siglo XXI, Madrid.

ROTHER, Reiner (2006): Vorwort, en SCHILLING, Thorsten (2006): Parallelwelt: Film Ein Einblick in die DEFA. [Archivo en línea] Disponible desde Internet en <www.bpb.de/files> [Consultado el 19.11.2010].

RUTHERFORD, Jay (2006): Die Geschichte von Typoart. [Web en línea] Disponible desde Internet en <www.typoart-freunde.de $>$ [Consultado el 19.11.2009].

$\mathrm{S}$

SÁNCHEZ LEÓN, Ignacio (1989): IV Reich: 40 años de la historia de la RDA. [Publicación en línea] Disponible desde Internet en <www.bubok.com/libros/8683> [Consultado el 18.12.2010].

SANDOZ, Gérard (1971): La izquierda alemana. De Karl Marx a Willy Brand. Ediciones de Bolsillo, Barcelona.

SATUÉ, Enric (1993): El diseño gráfico. Desde los orígenes hasta nuestros días. Alianza Editorial, Madrid.

SATUÉ, Enric (2007): Arte en la tipografía y tipografía en el arte. Siruela, Madrid.

SCHILDT, Axel (2009): Politische Entschidungen und Einstellungen. Bundeszentrale für politische Bildung. [Archivo en línea] Disponible desde Internet en $<w w w . b p b . d e / p u b l i k a t i o-$ nen> [Consultado el 17.02.2010].

SCHILLING, Thorsten (2006): Parallelwelt: Film Ein Einblick in die DEFA. [Archivo en línea] Disponible desde Internet en <www.bpb.de/files> [Consultado el 19.11.2010].

SCHULZ, Wilfried (2000): Agitation und Propaganda, en BUNDESMINISTERIUM FÜR INNERDEUTSCHE BEZIEHUNGEN (ed) (2000): DDR Handbuch. Bundesministerium des Innern, Berlín.
SED (1954): Der neue Kurs und die Aufgaben der Partei. Berlín, vol. IV, pág. 449. Citado en: KAMINSKY, Annette (1999): Illustrierte Konsum-geschichte der DDR. Landeszentrale für politische Bildung, Thüringen.

SED (1976): Programm und Statut der SED, Art. 39 citado en BUNDESMINISTERIUM FÜR INNERDEUTSCHE BEZIEHUNGEN (ed) (2000): DDR Handbuch. Bundesministerium des Innern, Berlín.

SOMMERMEIER, Joachim (1986): Überlegungen zur Ikonografie der Friedensplakate der DDR- einige Wirkungsmöglichkeiten, Probleme und Tendenzen, en Verband Bildender Künstler (1986): Funktion und Wirkungsweise des Plakates in der sozialistischen Gesellschaft. Plakatsymposium. Erfurt.

STAATSSEKRETARIAT FÜR WESTDEUTSCHEFRAGEN (1969): Student und Studium in der $D D R$. Staatssekretariat für Westdeutschefragen. Berlín.

STEPHAN, Helga y WIEDEMANN, Eberhard (1990): Lohnstruktur und Lohndifferenzierung in der DDR, en ALLMENDINGER, Jutta (ed) (1990): Mitteilungenaus der Arbeitsmarkt- und Berufsforschung. Tümmels, Nürnberg. [Archivo en línea] Disponible desde Internet desde $<$ doku. iab.de/mittab/../1990_4_MittAB_Stephan_Wiedemann.pdf>[Consultado el 25.01.2011].

STRESOW, Gustav (1937): German Typography Today. Penrose Annual citado en AYNSLEY Jeremy (2000): Graphic Design in Germany 1890-1945. Thames \& Hudson, London.

SUBERCASEAUX, Bernardo (1991): Política y cultura. Desencuentros y Aproximaciones. Nueva sociedad n¹16, pág. 138-145. [Publicación en línea] Disponible desde Internet en $<$ www.nuso.org/upload/articulos/2060_1.pdf> [Consultado el 25.11.2010].

$\mathrm{T}$

THANNHAEUSER, Herbert (aprox. 1949): VEB Typoart Dresden. Drucktypen. Matrizen. Messinglinien. [Web en línea] Disponible desde Internet en <www.klingspor-museum.de $>$ [Consultado el 15.05.2011].

THÖNER, Wolfgang (2005): From an "Alien Hostile Phenomenon» to the "Poetry of the Future»: On the Bauhaus Reception in East Germany 1945-1970. GHI Bulletin Supplement 2.

TIPPACH-SCHNEIDER, Simone (2004): Das grosse Lexikon der DDR-Werbung: Kampagnen und Werbesprüche, Macher und Produkte, Marken und Warenzeichen. Schwarzkopf \& Schwarzkopf, Berlín.

TSCHICHOLD, Jan (1987): The new typography. A handbook for modern designers. University of California Press, Londres.

U

ULBRICHT, Walter (1968): Die Bedeutung und die Lebenskraft der Lehre von Karl Marx für unsere Zeit. Berlín (Ost), pág. 39, citado en WEBER, Hermann (1985): Geschichte der DDR. Dtv wissenschaft, Nördlingen. 
UTD (2000): Estilos gráficos: El periodo de las vanguardias. Unos tipos duros. Teoría y práctica de la tipografía. [Boletín en línea] Disponible cesde Internet en $<w w w$.unostiposduros. $\mathrm{com} / \mathrm{p}=135>$ [Consultado el 04.12.2009]

Verband der Grafik-Designer (1996): 128 Plakate aus 30 Jahren Wettbewerb «die 100 besten Plakate des Jahres». Stiftung Kulturfonds, Berlín.

VILCHIS ESQUIVEL, Luz (2006): Relaciones dialógicas en el diseño gráfico. Universidad Nacional Autónoma de México, Escuela Nacional de Artes Plásticas, México DF.

VOGT, Hartmut (2000): Einheitliches sozialistisches Bildungssystem, en BUNDESMINISTERIUM FÜR INNERDEUTSCHE BEZIEHUNGEN (ed) (2000): DDR Handbuch. Bundesministerium des Innern, Berlín.

W

WEBER, Hermann (1985): Geschichte der DDR. Dtv wissenschaft, Nördlingen.

WEIS, Peterpaul y RADEMACHER, Helmut (1964): Die Besten künstlerischen Plakate der DDR des Jahres. DHM Hausarchiv. Bestand MfDG, citado en WITTKUGEL, Klaus (1954): Das Blatt. Mitteilungsblatt des VBKD nr.1, citado en RADEMACHER, Hellmut (1975): Gesellschaftliche Funktion und ästhetische Prinzipien der Gebrauchsgrafik in der sozialistischen Gesellschaft en Verband Bildender Künstler der DDR, Sekt. Gebrauchsgrafik. 1975. Gebrauchsgrafik in der DDR. VEB Verlag der Kunst, Dresden.

WERNICKE, Ingolf (2007): El muro de Berlín 1961-1989, en El Muro de Berlín. Jaron, Berlín.

WHITFORD, Frank (1991): La Bauhaus. Destino, Barcelona.

WINKLER: Frauenreport citado en WOLLE, Stefan (1999): Die heile Welt der Diktatur. Alltag und Herrschaft in der DDR 1971-1989. Econ \& List Taschenbuch, Berlín.

WITTKUGEL, Klaus (1954), entrevista en Neue Werbung, $n^{\circ}$ 6, citado en RADEMACHER, Hellmut (1975): Gesellschaftliche Funktion und ästhetische Prinzipien der Gebrauchsgrafik in der sozialistischen Gesellschaft en Verband Bildender Künstler der DDR, Sekt. Gebrauchsgrafik. 1975. Gebrauchsgrafik in der DDR. VEB Verlag der Kunst, Dresden.

WOLLE, Stefan (1999): Die heile Welt der Diktatur. Alltag und Herrschaft in der DDR 19711989. Econ \& List Taschenbuch, Berlín.

WONG, Wucius (1995): Fundamentos del diseño. G. Gili, Barcelona.

WUNDERLICH, Sylke (1996): Die besten Plakate des Jahres. 30 Jahre Wettbewerb en Verband der Grafik-Designer (1996): 128 Plakate aus 30 Jahren Wettbewerb «die 100 besten Plakate des Jahres». Stiftung Kulturfonds, Berlín.

WUNDERLICH, Sylke (2007): Überklebt: Plakate aus der DDR. Ausstellung der Landeshauptstadt Schwerin im Schleswig-Holstein-Haus 24. August bis 21. Oktober 2007. Verlagsgruppe Schwerin, Schwerin.
ZENTRALES FORSCHUNGSINSTITUT FÜR ARBEIT (1989), Studie Lohnanalyse. Zentrales Forschungsinstitut für Arbeit, Dresden pág. 3. citado en WOLLE, Stefan (1999): Die heile Welt der Diktatur. Alltag und Herrschaft in der DDR 1971-1989. Econ \& List Taschenbuch, Berlín.

ZIMMERMANN,Hartmut (2000): Freier Deutscher Gewerkschaftsbund (FDGB), en BUNDESMINISTERIUM FÜR INNERDEUTSCHE BEZIEHUNGEN (ed) (2000): DDR Handbuch. Bundesministerium des Innern, Berlín.

ZIMMERMAN, Yves (1998): Del diseño. G. Gili, Barcelona.

ZIMMERMAN, Yves (2003): El arte es arte, el diseño es diseño en, Calvera, Anna. 2003. Arte? Diseño. Gustavo Gili, Barcelona. 


\subsection{FUENTES GRÁFICAS}

9.2.1 Por autor

A

AICHBERGER, Michael von (1984): East Berlin 1984, en AICHBERGER, Michael von: The other side of the wall. [Web en línea] Disponible desde Internet en $<$ www.aichberger.de/178 E-the-other-side.htm> [Consultado el 11.02.11].

APPEN, Karl von (1955): Farquhar/Brecht -Pauken und Trompeten, en WUNDERLICH, Sylke (2007): Überklebt: Plakate aus der DDR. Ausstellung der Landeshauptstadt Schwerin im Schleswig-Holstein-Haus 24. August bis 21. Oktober 2007. Verlagsgruppe Schwerin, Schwerin.

AUER, Erika (1956): 2. Fest Junger Kunstler, en WUNDERLICH, Sylke (2007): Überklebt: Plakate aus der DDR. Ausstellung der Landeshauptstadt Schwerin im Schleswig-HolsteinHaus 24. August bis 21. Oktober 2007. Verlagsgruppe Schwerin, Schwerin.

B

BAYER, Herbert (1925): Kandinsky. [Boletín en línea] Disponible desde Internet en <llyssakadour.blogspot.com/2010/02/typography-poster-and-magazine-design_23.html> [Consultado el 11.05.10].

BEHRENS, Peter (1908): AEG, en KADOUR, Llyssa-Somaya (2010): Typography, Poster and Magazine Design At the Bauhaus through the works of Herbert Bayer Version 3. [Web en línea] Disponible desde Internet en $<$ www.disenoiberoamericano.com/node/214> [Consultado el 13.05.10].

BEHRENS, Peter (1910): Allgemeine Elektricitäts Gesellschaft, en Arquitectura, Disseny i Modernitat (2010): Comparacions de les obres. [Boletín en línea] Disponible desde Internet en <elisabethmonjo.blogspot.com/2011/04/obres.html> [Consultado el 11.05.10].

BERNHARD, Lucian (1905): Priester, en GONZÁLEZ CANCELA, Diego (2011): Reelaboración Vanguardista. [Web en línea] Disponible desde Internet en < diegogonz.wordpress.com/ proyectos/proyecto-02/> [Consultado el 13.05.11].

BERNHARD, Lucian (1907): Stiller, en MOMA: The Collection. [Archivo en línea] Disponible desde internet en $<$ www.moma.org/collection/browse_results.php?criteria $=\mathrm{O} \% 3 \mathrm{ACL} \%$ 3Al\%3A4\&page_number=203\&template_id=1\&sort_order=4> [Consultado el 13.11.09].

BERNHARD, Lucian (1917): Das Kriegsanleihe!, en TYPOGRAFIE.INFO (2011): NSSchriften. [Web en línea] Disponible desde Internet en <www.typografie.info/2/showthread. php/24415-NS-Schriften/page2> [Consultado el 11.05.11].

BERTRAM, Axel (1966): Der gewöhnliche Faschismus, en WUNDERLICH, Sylke (2007): Überklebt: Plakate aus der DDR. Ausstellung der Landeshauptstadt Schwerin im SchleswigHolstein-Haus 24. August bis 21. Oktober 2007. Verlagsgruppe Schwerin, Schwerin.
BLUMENTHAL, Regine (1973): Büchner-Dantons Tod, en WUNDERLICH, Sylke (2007): Überklebt: Plakate aus der DDR. Ausstellung der Landeshauptstadt Schwerin im SchleswigHolstein-Haus 24. August bis 21. Oktober 2007. Verlagsgruppe Schwerin, Schwerin.

BORMANN, Martin (1941): Rundschreiben, en BURKE, Christopher (2000): Paul Renner, maestro tipógrafo. Campgràfic, Valencia.

BRADE, Helmut (1982): Chemie Industrie Kunst, en WUNDERLICH, Sylke: Plakat Ost. [Web en línea] Disponible desde Internet en <http://www.stiftung-plakat-ost.de/plakate/ plak_31.htm> [Consultado el 16.02.11].

BRADE, Helmut (1985): Helmut Brade Plakate, en WUNDERLICH, Sylke (2007): Überklebt: Plakate aus der DDR. Ausstellung der Landeshauptstadt Schwerin im Schleswig-HolsteinHaus 24. August bis 21. Oktober 2007. Verlagsgruppe Schwerin, Schwerin.

\section{D}

DAMM-FIEDLER, Jutta (1976): Bach, en WUNDERLICH, Sylke (2007): Überklebt: Plakate aus der DDR. Ausstellung der Landeshauptstadt Schwerin im Schleswig-Holstein-Haus 24. August bis 21. Oktober 2007. Verlagsgruppe Schwerin, Schwerin.

FÖRSTER, Jürgen (1981): o.T. (Rauchersitzung), en WUNDERLICH, Sylke (2007): Überklebt: Plakate aus der DDR. Ausstellung der Landeshauptstadt Schwerin im Schleswig-HolsteinHaus 24. August bis 21. Oktober 2007. Verlagsgruppe Schwerin, Schwerin.

FREYER, Achim (1970): Brecht -Der gute Mensch von Sezuan, en WUNDERLICH, Sylke (2007): Überklebt: Plakate aus der DDR. Ausstellung der Landeshauptstadt Schwerin im Schleswig-Holstein-Haus 24. August bis 21. Oktober 2007. Verlagsgruppe Schwerin, Schwerin.

G

GEISLER, Wolfgang (1982): Meinst du, die Russen wollen Krieg?, en WUNDERLICH, Sylke: Plakat Ost. [Web en línea] Disponible desde Internet en <http://www.stiftung-plakat-ost.de/ plakate/plak_25.htm> [Consultado el 10.02.11].

GF (1951): Marsch der deutschen Jugend für den Frieden am 10. Juni 1951. Greif Graphischer Großbetrieb, en Deutschen Historischen Museums: Sammlungen des Deutschen Historischen Museums. [Archivo en línea] Disponible desde Internet en $<$ www.dhm.de/sammlungen/ plakate/p94_2427.html> [Consultado el 11.02.11].

GRÜTTNER, Erhard (1965): Asche und Diamant en WUNDERLICH, Sylke (2007): Überklebt: Plakate aus der DDR. Ausstellung der Landeshauptstadt Schwerin im Schleswig-HolsteinHaus 24. August bis 21. Oktober 2007. Verlagsgruppe Schwerin, Schwerin.

GUBIG, Matthias (1989a): Wir sind das Volk, en WUNDERLICH, Sylke: Plakat Ost. [Web en línea] Disponible desde Internet en <http://www.stiftung-plakat-ost.de/plakate/plak_31. htm> [Consultado el 16.02.11]. 
GUBIG, Matthias (1989b): endlich vereint!, en WUNDERLICH, Sylke (2007): Überklebt: Plakate aus der DDR. Ausstellung der Landeshauptstadt Schwerin im Schleswig-HolsteinHaus 24. August bis 21. Oktober 2007. Verlagsgruppe Schwerin, Schwerin.

$\mathrm{H}$

HANDSCHICK, Heinz (1964): Zeugin der Anklage, en WUNDERLICH, Sylke (2007): Überklebt: Plakate aus der DDR. Ausstellung der Landeshauptstadt Schwerin im SchleswigHolstein-Haus 24. August bis 21. Oktober 2007. Verlagsgruppe Schwerin, Schwerin

HEARTFIELD, John (1932): Der Sinn des Hitlergrusses, en Sascha's Welt (2011): Warum der Faschismus auf fruchtbaren Boden fällt... [Boletín en línea] Disponible desde Internet en <sascha313.blog.de/2011/04/01/keineswegs-verwunderlich-neofaschisten-vielen-laenderneuropas-erneut-einfluss-gewinnen-konnten-10925548/> [Consultado el 10.04.11].

HEARTFIELD, John (1987): Niemals wieder, en DDR PLAKATE (2004): Galerie. [Archivo en línea] Disponible desde Internet en $<$ ddr-plakate.de/Bild.php?pid=142> [Consultado el 10.02.11].

HECKEL,Erich (1905): KG Brücke. [Web en línea] Disponible desde Internet en <es.wikipedia.org/wiki/Expresionismo> [Consultado el 23.10.10].

HERFURTH, Egbert (1973): Weltfestspiele, en WUNDERLICH, Sylke (2007): Überklebt: Plakate aus der DDR. Ausstellung der Landeshauptstadt Schwerin im Schleswig-HolsteinHaus 24. August bis 21. Oktober 2007. Verlagsgruppe Schwerin, Schwerin.

HILLER, Günter (1964): 800 Jahre Leipziger Messe, en WUNDERLICH, Sylke (2007): Überklebt: Plakate aus der DDR. Ausstellung der Landeshauptstadt Schwerin im SchleswigHolstein-Haus 24. August bis 21. Oktober 2007. Verlagsgruppe Schwerin, Schwerin.

HÖCH, Hannah (1919): Da-Dandy, en HAGER, Liz (2010): Hannah Höch: The "Quiet Girl" with a Big Voice (Part I). [Web en línea] Disponible desde Internet en <venetianred.net/2010/01/16/hannah-hoch-the-good-girl-with-big-scissors-part-i/> [Consultado el 10.09.10].

HOHLWEIN, Ludwig (1912): Audi. Automobil Werke mbH, en MOMA: The Collection. [Archivo en línea] Disponible desde Internet en $<$ www.moma.org/collection/browse_results. php?criteria $=\mathrm{O} \% 3 \mathrm{AAD} \% 3 \mathrm{AE} \% 3 \mathrm{~A} 2700 \&$ page_number $=18 \&$ template_id $=1$ \&sort_order $=1>$ [Consultado el 10.09.10].

HOHLWEIN, Ludwig (1912): Reichssporttag des BDM, en VANGOBOT: Archiv [Archivo en línea] Disponible desde Internet en <popartmachine.com/item/pop_art/LOC+1174590/ REICHSSPORTTAG-DES-B.D.M.-23-SEPTEMBER-1934-/-LUDWIG-HOHLWEIN,...>. [Consultado el 10.09.10].

HORNIG, Norbert (1967): streut, en WUNDERLICH, Sylke (2007): Überklebt: Plakate aus der DDR. Ausstellung der Landeshauptstadt Schwerin im Schleswig-Holstein-Haus 24. August bis 21. Oktober 2007. Verlagsgruppe Schwerin, Schwerin.

HUTHMANN, Rehme: Schokolade, en en DDR PLAKATE (2004): Galerie. [Web en línea] Disponible desde Internet en <www.ddr-plakate.de/Bild.php?pid=151> [Consultado el 16.02.11].
KIPPNICK, Heinz (1965): 1. Mai Internationale Kampf- und Feiertag der Arbeiterklasse, en WUNDERLICH, Sylke (2007): Überklebt: Plakate aus der DDR. Ausstellung der Landeshauptstadt Schwerin im Schleswig-Holstein-Haus 24. August bis 21. Oktober 2007. Verlagsgruppe Schwerin, Schwerin.

KLEIN, Richard (1937): Grosse Deutsche Kunstaustellung 1937, en WERCKMEISTER (1999): Totalitarian Art. [Web en línea] Disponible desde Internet en < faculty-web.at.northwestern. edu/art-history/werckmeister/May_20_1999/index.html> [Consultado el 11.09.10].

KLEMKE, Werner (1955): Rot und Schwarz, en WUNDERLICH, Sylke (2007): Überklebt: Plakate aus der DDR. Ausstellung der Landeshauptstadt Schwerin im Schleswig-HolsteinHaus 24. August bis 21. Oktober 2007. Verlagsgruppe Schwerin, Schwerin

KLINGER, Julius (1917): 8. Kriegsanleihe, en KAUFFER, E. McKnight (2010): Carteles de Guerra. [Boletín en línea] Disponible desde Internet en <exploradsn.blogspot.com/2010/11/ carteles-de-guerra.html> [Consultado el 11.09.10].

Kollektiv Graßman, Gruner y Stecher (1974): Apartheid NO, en WUNDERLICH, Sylke (2007): Überklebt: Plakate aus der DDR. Ausstellung der Landeshauptstadt Schwerin im Schleswig-Holstein-Haus 24. August bis 21. Oktober 2007. Verlagsgruppe Schwerin, Schwerin.

KOLLWITZ, Käthe (1924): Nie wieder Krieg, en Deutschen Historischen Museums: Sammlungen des Deutschen Historischen Museums. [Archivo en línea] Disponible desde Internet en <www.dhm.de/lemo/objekte/pict/p62-23/index.html> [Consultado el 12.09.10].

KUMMERT, Otto (1974): RGW. ZENTRALVORSTAND DES VERBANDES BILDENER KÜNSTLER DER DDR (1989): P40 Plakate von 1945 bis zur Gegenwart. Eine Ausstellung im 40. Jahr der DDR. Märkische Vloksstimme, Potsdam.

KUMMERT, Otto (1988): Dein Frieden, deine Geborgenheit. ZENTRALVORSTAND DES VERBANDES BILDENER KÜNSTLER DER DDR (1989): P40 Plakate von 1945 bis zur Gegenwart. Eine Ausstellung im 40. Jahr der DDR. Märkische Vloksstimme, Potsdam.

LEMKE, Klaus (1959), Werra, en WUNDERLICH, Sylke (2007): Überklebt: Plakate aus der DDR. Ausstellung der Landeshauptstadt Schwerin im Schleswig-Holstein-Haus 24. August bis 21. Oktober 2007. Verlagsgruppe Schwerin, Schwerin.

LEUCHTE, Frank (1974): 450. Jahrestag des deutschen Bauernkrieges, en WUNDERLICH, Sylke (2007): Überklebt: Plakate aus der DDR. Ausstellung der Landeshauptstadt Schwerin im Schleswig-Holstein-Haus 24. August bis 21. Oktober 2007. Verlagsgruppe Schwerin, Schwerin.

LUDZ, Peter y Ursula (2000): Movimiento poblacional natural entre 1946 y 1982 en LUDZ, Peter y Ursula (2000): Bevölkerung, en BUNDESMINISTERIUM FÜR INNERDEUTSCHE BEZIEHUNGEN (ed) (2000): DDR Handbuch. Bundesministerium des Innern Berlin. 
MOHOLY-NAGY, Lázló (1923a): Staatliches Bauhaus Weimar 1919-1923, en ARTE X ARTE (2001): «Bauhaus, 80 años»:vigencia de una idea. [Boletín en línea] Disponible desde Internet en <www.puntaweb.com/artexarte/abr2001/galeria2.htm > [Consultado el 13.09.10].

MOHOLY-NAGY, Lázló (1923b): Pneumatik, en MODERN TATE (2006): Albers \& MoholyNagy. From the Bauhaus to the New World. [Archivo en línea] Disponible desde Internet en $<$ www.tate.org.uk/modern/exhibitions/albersmoholy/rooms/room3.shtm $>$ [Consultado el 12.09.10].

MOHOLY-NAGY Lázló (1924): Fotograma, en JIRD (2001): Ancient contax buddies. [Web en línea] Disponible desde Internet en <www.jjrd.com/carteblanche/contax/index.html> [Consultado el 12.09.10]

MOHOLY-NAGY Lázló (1925): Fotoplástica, en MODERN TATE (2006): Albers \& MoholyNagy. From the Bauhaus to the New World. [Archivo en línea] Disponible desde Internet en <www.tate.org.uk/modern/exhibitions/albersmoholy/rooms/room3.shtm $>$ [Consultado el 12.09.10].

MOHOLY-NAGY Lázló (1930): Bauhausbücher, en JJRD (2001): Ancient contax buddies. [Web en línea] Disponible desde Internet en <www.jjrd.com/carteblanche/contax/index. html $>$ [Consultado el 12.09.10].

MOHR, Arno (1946): Am 1. Mai 1046. ZENTRALVORSTAND DES VERBANDES BILDENER KÜNSTLER DER DDR (1989): P40 Plakate von 1945 bis zur Gegenwart. Eine Ausstellung im 40. Jahr der DDR. Märkische Vloksstimme, Potsdam.

MÜLLER, Rolf Felix (1966): Hochhuth -Der Stellvertreter, en WUNDERLICH, Sylke (2007): Überklebt: Plakate aus der DDR. Ausstellung der Landeshauptstadt Schwerin im SchleswigHolstein-Haus 24. August bis 21. Oktober 2007. Verlagsgruppe Schwerin, Schwerin.

MÜLLER, Rolf Felix (1985): Mnouchkine/Mann -Mephisto, en WUNDERLICH, Sylke (2007): Überklebt: Plakate aus der DDR. Ausstellung der Landeshauptstadt Schwerin im SchleswigHolstein-Haus 24. August bis 21. Oktober 2007. Verlagsgruppe Schwerin, Schwerin.

NAUMANN, Horst (1948): Hundert Jahre Kommunistisches Manifest. Lehmannsche Druckerei, Dresden, en Deutschen Historischen Museums: Sammlungen des Deutschen Historischen Museums. [Archivo en línea] Disponible desde Internet en $<$ www.dhm.de/sammlungen/ plakate/p94_1550.html> [Consultado el 11.02.11]

NAUMANN, Horst (1951): Unser Fünfjahrplan Ausstellung der DDR, en Stadtgeschichtliches Museum Leipzig: Archiv. [Archivo en línea] <www.stadtgeschichtliches-museum-leipzig.de/site_english/voelkerschlachtdenkmal/jubilaeum2013.php> [25.04.2011]

PETZOLD, Willy (1946): Gebt sum Wiederaufbau Opfer!, en MUSEUM FOLKWANG (2007): Willy Petzold. [Web en línea] Disponible desde Internet en $<$ www.museum-folkwang. de/en/sammlung/deutsches-plakat-museum/highlights/kuenstler/willy-petzold/> [Consultado el 19.07.11].

PFÜLLER, Volker (1985): Euripides -Medea, en Newport Kutaisi Association: Medea in Art. [Web en línea] Disponible desde Internet en <www.nkta.org/Culture/literature/medea.html $>$ [Consultado el 19.07.11].

POLLOCKS, Maren (1968): Solidarität mit Vietnam, en DDR PLAKATE (2004): Galerie. [Web en línea] Disponible desde Internet en $<w w w . d d r-p l a k a t e . d e / B i l d . p h p ? p i d=123>$ [Consultado el 17.02.11].

RÄHM, Klaus (1985): Schriftplakate, en WUNDERLICH, Sylke (2007): Überklebt: Plakate aus der DDR. Ausstellung der Landeshauptstadt Schwerin im Schleswig-Holstein-Haus 24. August bis 21. Oktober 2007. Verlagsgruppe Schwerin, Schwerin.

REHMEN, Rolf (1950): Konsum-Reisbedar, en Stadtgeschichtliches Museum Leipzig: Archiv. [Archivo en línea] <www.stadtgeschichtliches-museum-leipzig.de/site_english/voelkerschlachtdenkmal/jubilaeum2013.php> [25.04.2011]

RIEDEL, Hubert (1978): Theatres du geste, en WUNDERLICH, Sylke (2007): Überklebt: Plakate aus der DDR. Ausstellung der Landeshauptstadt Schwerin im Schleswig-HolsteinHaus 24. August bis 21. Oktober 2007. Verlagsgruppe Schwerin, Schwerin.

RÖDER, Gisela (1968): Can Can, en WUNDERLICH, Sylke (2007): Überklebt: Plakate aus der DDR. Ausstellung der Landeshauptstadt Schwerin im Schleswig-Holstein-Haus 24. August bis 21. Oktober 2007. Verlagsgruppe Schwerin, Schwerin.

RUIKA, Jana y GEISLER, Wolfgang (1988): alle Menschen sind farbig, en ZENTRALVORSTAND DES VERBANDES BILDENER KÜNSTLER DER DDR (1989): P4O Plakate von 1945 bis zur Gegenwart. Eine Ausstellung im 40. Jahr der DDR. Märkische Vloksstimme, Potsdam.

S

SCHILLER, Walter (1967): 50 Jahre grosse Sozialistische Oktober-Revolution, en ZENTRALVORSTAND DES VERBANDES BILDENER KÜNSTLER DER DDR (1989): P40 Plakate von 1945 bis zur Gegenwart. Eine Ausstellung im 40. Jahr der DDR. Märkische Vloksstimme, Potsdam.

SCHLEUSING, Thomas (1967a): Woche des Buches, en ZENTRALVORSTAND DES VERBANDES BILDENER KÜNSTLER DER DDR (1989): P40 Plakate von 1945 bis zur Gegenwart. Eine Ausstellung im 40. Jahr der DDR. Märkische Vloksstimme, Potsdam.

SCHLEUSING, Thomas (1967b): Reformation 1517-1967, en WUNDERLICH, Sylke (2007): Überklebt: Plakate aus der DDR. Ausstellung der Landeshauptstadt Schwerin im SchleswigHolstein-Haus 24. August bis 21. Oktober 2007. Verlagsgruppe Schwerin, Schwerin.

SCHMIDT, Joost (1931): Dessau, en ARIAS, Andrés: Artistas de la Bauhaus. [Web en línea] Disponible desde Internet en $<$ /bauhausinformalismo.wordpress.com/artistas-de-la-bauhaus $>$ [Consultado el 09.02.11]. 
SCHRIBELKA, Rudolf (1957): Im Westen nichts Neues, en WUNDERLICH, Sylke (2007): Überklebt: Plakate aus der DDR. Ausstellung der Landeshauptstadt Schwerin im SchleswigHolstein-Haus 24. August bis 21. Oktober 2007. Verlagsgruppe Schwerin, Schwerin.

SCHRÖDER, Martin Z (2009): ZGL, en Schreibenistblei. [Web en línea] Disponible desde Internet en <www.blog.druckerey.de/?s=tag\&t=typoart $>$ [Consultado el 28.06.2011].

SCHWIMMER, Max (1956): Shakespeare- Ein Sommernachtstraum, en WUNDERLICH, Sylke (2007): Überklebt: Plakate aus der DDR. Ausstellung der Landeshauptstadt Schwerin im Schleswig-Holstein-Haus 24. August bis 21. Oktober 2007. Verlagsgruppe Schwerin, Schwerin.

SCHWITTERS, Kurt, VAN DOESBURG, Theo, STEINITZ, Kate (1922): Die Schueche Marchen, en PUJADAS, Anna: Archivo. [Archivo en línea] Disponible desde Internet en </www. annapujadas.cat/material/imatges/pintura/cp_clss7img4.htm> [Consultado el 09.02.11].

SHAW, Elisabeth, GRAETZ, René (1950): Ami go home. Ratsdruckerei, Dresden, en Deutschen Historischen Museums: Sammlungen des Deutschen Historischen Museums. [Archivo en línea] Disponible desde Internet en <www.dhm.de/sammlungen/plakate/p94_874.html> [Consultado el 09.02.11].

Statistisches Jahrbuch der DDR (1983): Demografía poblacional por sexos en 1982. s 343, en LUDZ, Peter y Ursula (2000): Bevölkerung, en BUNDESMINISTERIUM FÜR INNERDEUTSCHE BEZIEHUNGEN (ed) (2000): DDR Handbuch. Bundesministerium des Innern Berlin.

STEINBERG, Bärbel (1984): Hacks -Die Kinder, en WUNDERLICH, Sylke (2007): Überklebt: Plakate aus der DDR. Ausstellung der Landeshauptstadt Schwerin im Schleswig-HolsteinHaus 24. August bis 21. Oktober 2007. Verlagsgruppe Schwerin, Schwerin.

STEINER-WELZ, Sonja (2006): Von der Schrift und den Schriftarten. Reinhard Welz Vermittler Verlag, Mannheim.

SÜTTERLIN, Ludwig (1896): Berliner Gewerbe Ausstellung 1986, en WIKIPEDIA (2006): Vaizdas:Plakat Suetterlin96.jpg. [Web en línea] Disponible desde Internet en<lt.wikipedia. org/wiki/Vaizdas:Plakat_Suetterlin96.jpg> [Consultado el 09.02.11].

T

TSCHICHOLD, Jan (1925): Typographische mitteilungen, en MOMA: The Collection. [Archivo en línea] Disponible desde Internet en $<w w w$.moma.org/collection/browse_results.php? criteria $=\mathrm{O} \% 3 \mathrm{ADE} \% 3 \mathrm{AI} \% 3 \mathrm{~A} 1$ \&template_id =6\&sort_order=1 \&results_per_page $=80 \&$ page_ number $=18 \& U \mathrm{UC}=>$ [Consultado el 09.02.11]

TSCHICHOLD, Jan (1927): Laster der Menschheit, en OSWEGO: Jan Tschichold. [Web en línea] Disponible desde internet en <www.oswego.edu/ coughlin/NC_417/NC_417_project1/pages/page1.html $>$ [Consultado el 09.02.11].

TSCHICHOLD, Jan (1932): Die Hose, en MOMA: The Collection. [Archivo en línea] Disponible desde Internet en $<$ www.moma.org/collection/browse_results.php?criteria=O\%3ADE $\% 3 \mathrm{Al} \% 3 \mathrm{~A} 1 \&$ template_id=6\&sort_order $=1$ \&results_per_page $=80 \&$ page_number $=18 \& U \mathrm{C}=>$ [Consultado el 09.02.11].
Typografie.info: Typoart. [Web en línea] Disponible desde Internet en <www.typografie. info/2/wiki.php?title=Typoart> [Consultado el 08.12.2009]

$\mathrm{V}$

VOIGT, Gerhard (1982): Unser Vorschlag gilt: Wir sind dialogbereit für Frieden und Abrüstung, en WUNDERLICH, Sylke (2007): Überklebt: Plakate aus der DDR. Ausstellung der Landeshauptstadt Schwerin im Schleswig-Holstein-Haus 24. August bis 21. Oktober 2007. Verlagsgruppe Schwerin, Schwerin.

\section{W}

WITTKUGEL, Klaus (1957a): 1917-1958, en WUNDERLICH, Sylke (2007): Überklebt: Plakate aus der DDR. Ausstellung der Landeshauptstadt Schwerin im Schleswig-HolsteinHaus 24. August bis 21. Oktober 2007. Verlagsgruppe Schwerin, Schwerin.

WITTKUGEL, Klaus (1957b): Wer Adenauer wählt, wählt Atomkrieg, en WUNDERLICH Sylke (2007): Überklebt: Plakate aus der DDR. Ausstellung der Landeshauptstadt Schwerin im Schleswig-Holstein-Haus 24. August bis 21. Oktober 2007. Verlagsgruppe Schwerin, Schwerin.

WUNDERLICH, Gert (1975): Thomas Mann Ehrung, en WUNDERLICH, Sylke (2007): Überklebt: Plakate aus der DDR. Ausstellung der Landeshauptstadt Schwerin im SchleswigHolstein-Haus 24. August bis 21. Oktober 2007. Verlagsgruppe Schwerin, Schwerin.

WUNDERLICH，Gert (1983): hochrüsten=totrüsten, en WUNDERLICH, Sylke (2007): Überklebt: Plakate aus der DDR. Ausstellung der Landeshauptstadt Schwerin im SchleswigHolstein-Haus 24. August bis 21. Oktober 2007. Verlagsgruppe Schwerin, Schwerin.

WUNDERLICH, Sonja (1984): Icomos, en WUNDERLICH, Sylke (2007): Überklebt: Plakate aus der DDR. Ausstellung der Landeshauptstadt Schwerin im Schleswig-Holstein-Haus 24 August bis 21. Oktober 2007. Verlagsgruppe Schwerin, Schwerin.

\subsubsection{Autor desconocido}

\section{C}

Calvin (1952): Stalin, en CALVIN: German Propaganda Archive. [Archivo en línea] Disponible desde Internet en <www.calvin.edu/academic/cas/gpa/ddrposters.htm $>$ [Consultado el 11.02.11].

Calvin (1979a): 30 Jahre DDR ... und morgen baue ich!, en CALVIN: German Propaganda Archive. [Archivo en línea] Disponible desde Internet en <http://www.calvin.edu/academic/ cas/gpa/images/30ddr/30ddr-17.jpg> [Consultado el 11.02.11].

Calvin (1979b): DDR 30. Erfolg der Gemeinsamkeit, en CALVIN: German Propaganda Archive. [Archivo en línea] Disponible desde Internet en $<$ http://www.calvin.edu/academic/ cas/gpa/images/30ddr/30ddr-11.jpg> [Consultado el 16.02.11]. 
Calvin (desc.): DDR sozialistischen Staat der Arbeiter und Bauern, en CALVIN: German Propaganda Archive. [Archivo en línea] Disponible desde Internet en $<$ www.calvin.edu/academic/cas/gpa/images/30ddr/30ddr-2.jpg> [Consultado el 11.02.11]

D

DDR-plakate (desc.a): Grossfahndung. Millionen für die Republik, en DDR PLAKATE (2004): Galerie. [Web en línea] Disponible desde Internet en <www.ddr-plakate.de/Bild. php?pid=123> [Consultado el 16.02.11].

DDR-plakate (desc.b): Strümpfe. Hauchfein und so haltbar, en DDR PLAKATE (2004): Galerie. [Web en línea] Disponible desde Internet en <www.ddr-plakate.de/Bild.php?pid=147> [Consultado el 16.02.11].

DDR-plakate (1950): Oh, das ist ja fein..., en DDR PLAKATE (2004): Galerie. [Web en línea] Disponible desde Internet en <www.ddr-plakate.de/Bild.php?pid=177> [Consultado el 16.02.11].

DDR-plakate (1954): Werktätige Bauern!, en DDR PLAKATE (2004): Galerie. [Web en línea] Disponible desde Internet en $<$ www.ddr-plakate.de/Bild.php?pid=176> [Consultado el 16.02.11].

Deutsches historisches Museum (1949): Gewerkschaftswahlen 1950, en Deutschen Historischen Museums: Sammlungen des Deutschen Historischen Museums. [Archivo en línea] Disponible desde Internet en <www.dhm.de/sammlungen/plakate/p94_2256.html $>$ [Consultado el 11.02.11].

DEWAG (desc.a): Mehr Eier, en WESTDICKENBERG, Michael (2007): Intensivtierhaltung. [Boletín en línea] Disponible desde Internet en <www.flickr.com/photos/michael_ westdickenberg/3045425875/> [Consultado el 22.02.11].

DEWAG (desc.b). Mais ist das Gold der Bauern!, en WESTDICKENBERG, Michael (2007): DEWAG: Kinowerbung. [Boletín en línea] Disponible desde Internet en <www.flickr.com/ photos/michael_westdickenberg/3045426599/> [Consultado el 22.02.11].

DEWAG (1967): Duldet das nicht, en GELBGRAUMAGENTA: DEWAG. [Web en línea] Disponible desde Internet en $<$ www.gelbgraumagenta.de/gelbgraumagenta/3_dewag/dewag_01. $\mathrm{htm}>$ [Consultado el 22.02.11].

DEWAG Handelswerbung Berlin (1965):1000 kleine Dinge erfüllen Weihnachtswünsche, en SÄNGER, Johanna (2009): DDR-Plakate in der Sammlung Industrielle Gestaltung. [Publicación en línea] Disponible desde Internet en $<$ www.museumsmagazin.com/speicher/archiv/22009/berlin/part1.php> [Consultado el 22.02.11].

J

Jugendopposition in der DDR (desc.): Das Risiko eine eigene Meinung zu haben, en JUGEND OPPOSITIOM IN DER DDR (2005): Material zum Fall Ossietzky-Schule. [Web en línea] Disponible desde Internet en <www.jugendopposition.de/index.php?id=1206> [Consultado el 16.02.11].
Kaminski (desc.): HO Warenhaus. En KAMINSKY, Annette (1999): Illustrierte Konsum-geschichte der DDR. Landeszentrale für politische Bildung, Thüringen.

Pillekitsch (desc.): Mit einander geht es besser, en PILLEKITSCH (2009): Pillekitsch-Schnappschuss Nr.8. [Boletín en línea] Disponible desde Internet en <http://pillekitsch.blog. de/2009/07/25/pillekitsch-schnappschuss-nr-6584380/> [Consultado el 22.02.11].

Recto|verso (desc.b): Alles hat seine Grenzen, en ARTHUR (2010): "Everything has its Limit! Even Miniskirts...» Aerial propaganda leaflets on the inner German border, 1965-1969. [Boletín en línea] Disponible desde Internet en <http://rectoversoblog.com/2010/12/13/ propaganda/\#more-612> [Consultado el 10.02.11].

$\mathrm{S}$

Stadtgeschichtliches Museum Leipzig (1954): // Nationalkongress, en Stadtgeschichtliches Museum Leipzig: Archiv. [Archivo en línea] <www.stadtgeschichtliches-museum-leipzig.de/ site_english/voelkerschlachtdenkmal/jubilaeum2013.php> [25.04.2011]

Stasiopfer (1976): Die Partei, en STASIOPFER (2001): PDS- Fakten zur Geschichte einer Partei. [Archivo en línea] Disponible desde Internet en <www.stasiopfer.com/pdsdaten.html $>$ [Consultado el 11.02.11].

TIPPACH-SCHNEIDER, Simone (1958): VEB Fahrzeug und Gerätewerk Simson Suhl, en TIPPACH-SCHNEIDER, Simone (2004): Das grosse Lexikon der DDR-Werbung: Kampagnen und Werbesprüche, Macher und Produkte, Marken und Warenzeichen. Schwarzkopf \& Schwarzkopf, Berlín.

TIPPACH-SCHNEIDER, Simone (1959): VEB Ernst-Thälmann-Werk Suhl, en TIPPACHSCHNEIDER, Simone (2004): Das grosse Lexikon der DDR-Werbung: Kampagnen und Werbesprüche, Macher und Produkte, Marken und Warenzeichen. Schwarzkopf \& Schwarzkopf, Berlín.

VEB orange (1956): I/ Deutsches Turn- u.Sportfest, en VEB orange: Museum. [Web en línea] Disponible desde Internet en <www.veborange.de/museum.html $>$ [Consultado el 11.02.11].

VEB orange (1987): 70 Jahre Rote Oktober, en VEB orange: Museum. [Web en línea] Dis-

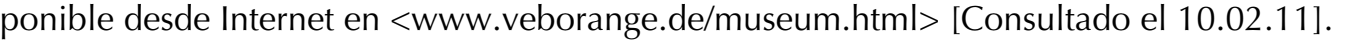

VEB orange (1988): 1918-1988, en VEB orange: Museum. [Web en línea] Disponible desde Internet en <www.veborange.de/museum.html $>$ [Consultado el 09.02.11]. 
VEB orange (desc.a): Bücher in Konsum, en VEB orange: Museum. [Web en línea] Disponible desde Internet en $<w w w . v e b o r a n g e . d e / m u s e u m . h t m l>$ [Consultado el 11.02.11].

VEB orange (desc.b): Nationale Front, en VEB orange: Museum. [Web en línea] Disponible desde Internet en $<w w w . v e b o r a n g e . d e / m u s e u m . h t m l>$ [Consultado el 11.02.11].

VEB orange (desc.c): Prinzip der Friede, en VEB orange: Museum. [Web en línea] Disponible desde Internet en <www.veborange.de/museum.html $>$ [Consultado el 16.02.11].

VEB orange (desc.d): Schluss damit!, en VEB orange: Museum. [Web en línea] Disponible desde Internet en <www.veborange.de/museum.html $>$ [Consultado el 10.02.11].

VEB orange (desc.e): Weiter so, en VEB orange: Museum. [Web en línea] Disponible desde Internet en $<w w w . v e b o r a n g e . d e / m u s e u m . h t m l>$ [Consultado el 09.02.11].

VEB orange (desc.f): Wir Frauen, en VEB orange: Museum. [Web en línea] Disponible desde Internet en $<w w w . v e b o r a n g e . d e / m u s e u m . h t m l>$ [Consultado el 11.02.11]. 
ANEXOS 


\section{ANEXO I. TRADUCCIONES Y ABREVIATURAS}

A. ADAPTACIONES AL CASTELLANO UTILIZADAS

A

\section{Aktivistenbewegung}

Allgemeiner Deutscher Nachrichtendienst

Antiqua-Varianten

Apparat

Arbeiterfestspiele

Aufbau der Sozialismus

Autorenkollektiv

Barock-Antiqua

Beste Plakate

Beruf mit Abitur

Berufsausbildung

Betriebsleitungen

Betriebssportgemeinschaft (a, BSG)

Bodenreform

Bund der Evangelischen Kirchen in der DDR

Bundesministerium für Gesamtdeutsche Fragen de Bonn

Bundesministerium für innerdeutsche Beziehungen

C

Christlich-Demokratische Union

D

Deutschen Theater Berlin

Deutsches Institut für Normung

Die besten Plakate des Jahres

Die neue Typographie

Die Werbung für Staat, Kultur und Wirtschaft

Einheitsliste
Movimiento activista

Servicio de Información General Alemán

Variantes de la letra romana

Aparato

Festivales de los Trabajadores

Construcción del Socialismo

Colectivo de Autores

Romana Barroca

Mejores Carteles

Trabajo con bachillerato

Formación Profesional

Dirección de empresa

Equipos Deportivos de Empresa

Reforma de la Tierra

Asociación de Iglesias Evangélicas en la RDA

Ministerio para la Cuestión de la Unidad Alemana de Bonn

Ministerio Federal para las Relaciones Interalemanas

Unión Cristiano Demócrata

Teatro Alemán de Berlín

Instituto Alemán de Normalización

Los mejores carteles del año

La Nueva Tipografía

Publicidad para el Estado, la Cultura y la Economía 
Einzelhandelsverkaufspreis

Elementare Typographie

Erwachsenenqualifizierung

Erweiterte Oberschule

Fachinstitut für den Binnenhande

Fachschulen

Französische Renaissance-Antiqua

Frauenreport

Freier Deutscher Gewerkschaftsbund

Freie Deutsche Jugend

G

Gebrochene Schriften

Gesellschaft für Deutsch-Sowjetische Freundschaft

Gesellschaft für Sport und Technik

Gesetz über das einheitliche sozialistische

Bildungssystem

Gotisch

Grundlagesvertrag

Handbuch der Werbung

Handelsorganitation

Handschriftliche Antiqua

Hauptabteilung

Hochschule

Hochschule für Grafik und Buchkunst Leipzig

\section{Ingenieurschulen}

Institut für Bedarfsforschung

Institut für Marktforschung

Inoffiziellen Mitarbeiter

$$
\mathrm{J}
$$

Junge Pioniere
Precio de Venta Unitario

Tipografía Elementa

Cualificación de adultos

Escuela Superior Avanzada

Instituto Técnico de Comercio Interior

Escuelas Técnicas

Romana Renacentista Francesa

Informe sobre la mujer

Unión de Sindicatos Libres Alemanes

Juventud Libre Alemana

\section{Tipografías quebradas}

Sociedad para la Amistad Alemano-soviética

Sociedad para el Deporte y la Tecnología

Ley sobre el Sistema Educativo Unitario Socialista

Gótica

Tratado Básico

\section{Manual de la Publicidad}

Organizaciones de Mercado Estatal

Letra caligráfica

Departamento principal

Escuela Superior

Escuela Superior de Artes Gráficas y del Libro de Leipzig

\section{Escuela de Ingenieros}

Instituto de Investigación de Necesidades

Instituto de Investigación del Mercado

Trabajadores no oficiales

Jóvenes Pioneros
Kammer der Technik

Kindergarten

Kinderkrippe

Klassizistische Antiqua

Kommunistische Partei Deutschlands

Kommunistische Partei der Sowjetunion

Konsumgenossenschaften der DDR

Kulturbund der $D D R$

Kunstausstellung der DDR

Landwirtschaftliche Produktionsgenossenschaft Liberal-Demokratische Partei Deutschlands

M

Mark Deuscher Notenbank

Ministerium für Staatssicherheit

Ministerrat

Museum für Deutsche Geschichte

National-Demokratische Partei Deutschlands

Nationale Front

Nationales Olympisches Komitee der DDR

National Sozialistische Reichfachschaft Deutsche Werbefachleute

Nationalen Verteidigungsrates der DDR

Neue Kurs

Neue Werbung

Neuebauern

Neuerer-Bewegung

Neuen Ökonomischen Systems

$\mathrm{O}$

Operativen Personenkontrolle

Operativer Vorgang
Cámara de Tecnología

Jardín de infancia

Guardería

Romana Neoclásica

Partido Comunista Alema

Partido Comunista de la Unión Soviética

Cooperativa de Consumo de la RDA

Unión Cultural de la RDA

Exposiciones de Arte de la RDA

Cooperativas de Producción Agrícola Partido Democrático Liberal de Alemania

Billetes de Marco Alemán

Ministerio de Seguridad Estatal

Consejo de Ministros

Museo de Historia Alemana

Partido Democrático Nacional de Alemania

Frente Nacional

Comité Olímpico Nacional de la RDA

División del Imperio Nacionalsocialista de Expertos en

Publicidad Alemana

Consejo Nacional de Defensa

Nuevo Rumbo

Nueva Publicidad

Nuevos campesinos

Nuevo Movimiento

Nuevo Sistema Económico

Personal de Control Operativo

Procesos Operativos 
Palast der Republik

Parteikonfernz

Parteitag

Plankommission

Politbüro

Polytechnische Oberschule

Programm des Schriftschaffens bis zum Jahre 1985

\section{R}

Rationalisatoren- und Erfinderbewegung

Reichskulturkammer

Reichsministerium für Volksaufklärung und

Propaganda

Republikflucht

Rundgotisch

S

Sachplakat

Schedelsche Weltchronik

Schreibschriften

Serifenbetonte Linear-Antiqua

Serifenlose Linear-Antiqua

Sicherheitsapparat

Sowjetischen Besatzungszone

Sozialistischen Einheitspartei Deutschlands

Sowjetische Kontrollkommission

Sowjetische Militäradministration in Deutschland

Sozialdemokratische Partei Deutschlands

Sozialistischen Einheitspartei Deutschlands

Sozialreport

Spezialschulen

Sportvereinigung

Staatsrat

Ständigen Vertretungen

Stiftung zur Aufarbeitung der SED-Diktatur

$\mathrm{T}$

Thälmannpioniere
Palacio de la República

Conferencias de Partido

Asambleas de Partido

Comisión de Planificación Estatal

Politburó

Escuela Superior Politécnica

Programa de Desarrollo de Tipos hasta el Año 1985

Movimiento de Racionalizadores e Inventores

Cámara de Cultura del Reich

Ministerio de Educación y Propaganda

Escapados de la República

Gótica Redonda

Cartel Objeto

Crónica Mundial de Schedel

Manuscritas

Egipcias

Letra de palo seco

Aparato de seguridad

Zona de Ocupación Soviética

Partido Unitario Socialista Alemán

Comisión de Control Soviético

Administración Militar Soviética en Alemania

Partido Socialdemocrático de Alemania

Partido unitario Socialista Alemán

Informe Social

Escuelas Especiales

Sociedades Deportivas

Consejo de Estado

Representantes Permanentes

Institución para el Tratamiento de la Dictadura del SED
$\mathrm{V}$

VEB Bibliographisches Institut Leipzig

VEB Fachbuch Verlag Leipzig

Venezianische Renaissance-Antiqua

Verband Bildender Künstler

Verband der Grafik-Designer

Verband der Kleingärtner, Siedler und Kleintierzüchter

Vereinigung der gegenseitigen Bauernhilfe

Vier Mächte

Vereinigungen organisationseigener Betrieb

$V O B$ Deutsche Werbe- und Anzeigengesellschaft

Volkseigener Betrieb

Volkssolidarität

Vorkurs

\section{W}

Währungsreform

Weltfestspiele der Jugend und Studenten

Wissenschaftliche Arbeitsorganisation

Z

Zentrale Druckerei-, Einkaufs- und Revisionsgesellschaft $\mathrm{mbH}$

Zentral Komitee

Zentrales Forschungsinstitut für Arbeit

ZK-Plenum
VEB Instituto Bibliográfico de Leipzig

VEB Editorial de Libros Profesionales de Leipzig

Romana Renacentista Veneciana

Asociación de Artistas Plásticos

Asociación de Diseñadores Gráficos

Asociación de los Pequeños Jardineros, Rancheros y

Criadores de Animales Pequeños

Asociación de Campesinos de Ayuda Mutua

Tratado de las Cuatro Potencias

Asociación de Empresas de Organización Propia

Agrupación Alemana de Publicidad y Anuncios

Empresas Socializadas

Solidaridad Popular

Curso previo

Reforma de Divisas

Festival Mundial de la Juventud y los Estudiantes

Organización de la Ciencia del Trabajo

Central de Empresas de Impresión, Compra y Revisió

Comité Central

Instituto Central de Investigación para el Trabajo

Pleno del ZK 


\section{B. ABREVIATURAS}

Asociación de Iglesias Evangélicas en la RDA

\section{Trabajo con bachillerato}

Equipos Deportivos de Empresa

Comisionado Federal para la Documentación del Servicio de Seguridad del Estado de la antigua República Democrática Alemana

Comisión Extraordinaria de Todas las Rusias para Combatir la Contrarrevolución y el Sabotaje

Unión Cristiano Demócrata

CDU Consejo de Ayuda Mutua Económica

\section{D}

Partido de Campesinos Democrático de Alemania

DEWAG Agrupación Alemana de Publicidad y Anuncios

DFD Unión de Mujeres Democrática de Alemania

DGP Policía Fronteriza Alemana

DIN Instituto Alemán de Normalización

DTSB Unión de Gimnasios y Deportes Alemana

Sociedad para la Amistad Alemano-soviética

Precio de Venta Unitario

Escuela Superior Avanzada

$\mathrm{HfG}$

HGBL

IM

J
Hochschule für Gestaltung

Escuela Superior de Artes Gráficas y del Libro de Leipzig

Trabajadores no oficiales

Jóvenes Pioneros

Cámara de Tecnología

Partido Comunista Alemán

Partido Comunista de la Unión Soviética

Partido Democrático Liberal de Alemania

Cooperativas de Producción Agrícola

Billetes de Marco Alemán

Museo de Historia Alemana

Ministerio de Seguridad Estatal

Maryland Institute College of Art

Partido Democrático Nacional de Alemania Comité Olímpico Nacional de la RDA

Nuevo Sistema Económico

Consejo Nacional de Defensa 
OPK Personal de Control Operativo

OTAN Organización del Tratado del Atlántico Norte

OV Procesos Operativos

Escuela Superior Politécnica

República Democrática Alemana

\section{Zona de Ocupación Soviética}

Partido Unitario Socialista Alemán

Comisión de Control Soviético

Administración Militar Soviética en Alemania

Partido Socialdemocrático de Alemania

Sociedades Deportivas

Asociación de Artistas Plásticos

Asociación de Campesinos de Ayuda Mutua

Empresa Socializada

Asociación de los Pequeños Jardineros, Rancheros y Criadores de Animales Pequeños

Asociación de Empresas de Organización Propia

Solidaridad Popular

Organización de la Ciencia del Trabajo 


\section{ANEXO II. TIPOGRAFÍAS DE LA VEB TYPOART}

Las siguientes fuentes tipográficas han sido extraidas de los muestrarios publicados por la VEB Typoart disponibles en:

KAPR, Albert y SCHÄFER, Detlef (1989): Fotosatzschriften. Type-Design und Schriftherstellung. VEB Fachbuchverlag, Leipzig.

SCHRÖDER, Martin Z (2009): ZGL, en Schreibenistblei. [Web en línea] Disponible desde internet en $<$ www. blog.druckerey.de/?s=tag\&t=typoart> [consultado el 28.06.2011].

STEINER-WELZ, Sonja (2006): Von der Schrift und den Schriftarten. Reinhard Welz Vermittler Verlag, Mannheim.

Typografie.info: Typoart. [Web en línea] Disponible desde internet en <www.typografie.info/2/wiki.php?title=Typoart $>$ [consultado el 08.12.2009].

TIPO I. ROMANA RENACENTISTA VENECIANA KOLONEL (desc.)

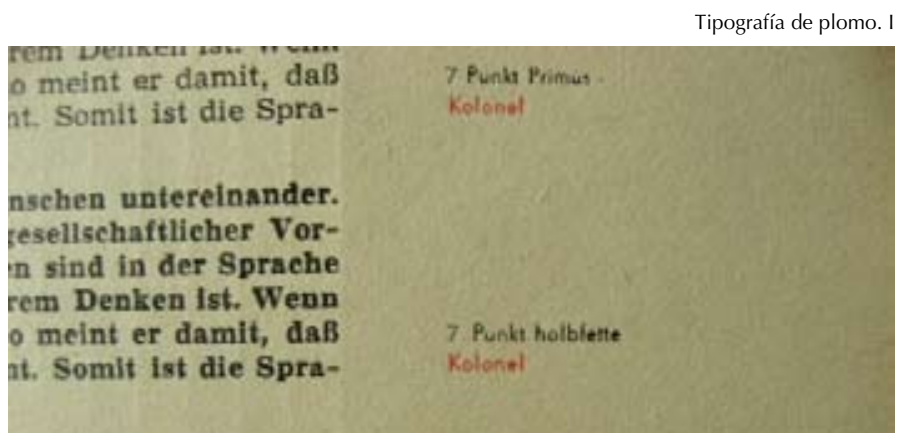

TIPO II. ROMANA RENACENTISTA FRANCESA

EXQUISIT (desc).

DIE BESTEN WÜNSCHE FÖR EIN BRPOLGRETCHES

DIETER NAUMANX / 8OS DRESDEN/ SCIWERINYR STRASSE 2

TD 7.2 Exquatit $4 / 6,5 / 6$ und op 


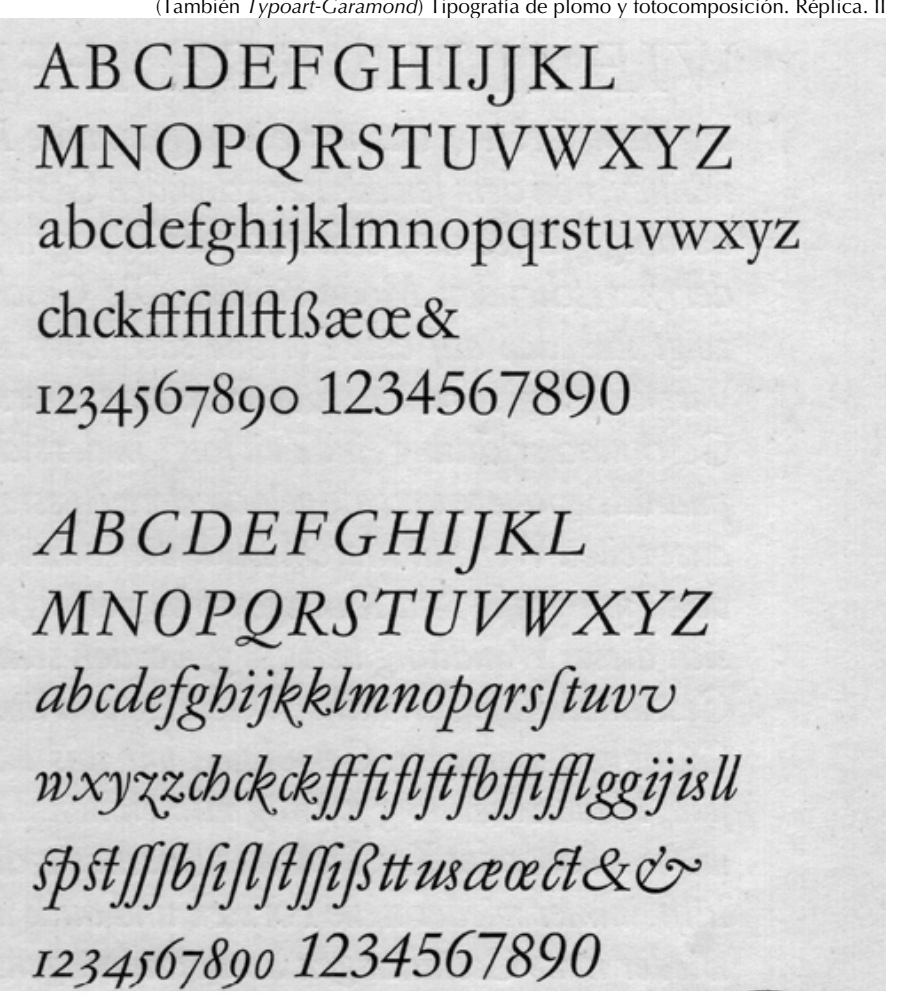

abc abc $a b c$

defghijkl defghijkl defgbijkl

mnopqrs mnopqrst mnopqrst

tuvwxyz uvwxyzß uwwxyz $\beta$

ßäöü

äöü ӓой

ABCDE ABCDEF $A B C D E F$

FGHIJK GHIJK GHIJK

LMNOP LMNOP LMNOP

QRSTU QRSTU QRSTU

VWXYZ VWXYZ $V W X Y Z$

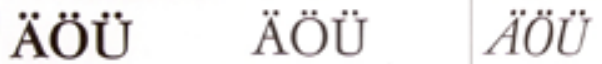

$\begin{array}{lll}123456 & 123456 & 123456\end{array}$

$\begin{array}{lll}7890 & 7890 & 7890\end{array}$

$\begin{array}{lll}\mathbf{1 2 3 4 5 6} & \mathbf{1} 23456 & 123456\end{array}$

$\begin{array}{lll}7890 & 7890 & 7890\end{array}$ abc $a b c \quad$ abc

defghijkl defghijkl defghijkl

mnop

qrstuvw

xyzß

äöü

ABCDEF

GHIJK

LMNOP

QRSTU

VWXYZ

ÄÖÜ

123456

7890

123456

7890 mnop

qrstuvw

Xyzß

äöü

$A B C D E F$

GHIJK

$L M N O P$

QRSTU

VWXYZ

$\ddot{A} O \ddot{U}$

123456

7890

123456

7890 mnop

qrstuvw

xyzß

äöü

ABCDEF

GHIJK

LMNOP

QRSTU

VWXYZ

ÄÖÜ

123456

7890

123456

7890 
ABCDEFGHIJKLMNOPQRST

UVWXYZ

LEIPZIGER ANTIQUA (1970). Albert Kapr.

Leipziger Antiqua Typoart Albert Kapr 1971

\section{ABCDEFGHIJKLMNOPQRSTUVW} abcdefghijklmnopqrstuvwxyz

Besucht die Zwinger-Museen! Alte Gemälde der National-Galerie TD 1.30. Tschörtner-Antiqua mager 6…48 p

Einladung zum Serenadenabend Gastkonzert der Berliner Philharmonie TD 1.3] Tschärtner-Kursiv mager 6...48p p

MINISTER (1929). Carl Albert Fahrenwaldt

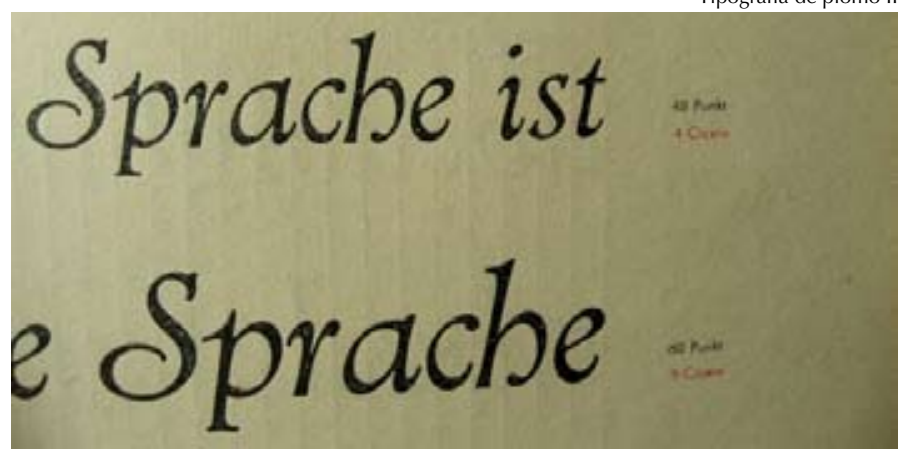
prache iste = Sprachei $=$
XYZÆÆEC

abcdefghijklmnopqrstuvwxyz

chckfffiffttß\&æœçäöü

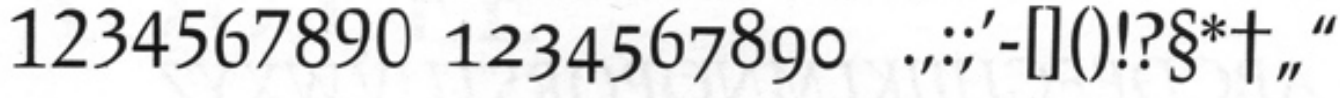
Leipziger Antiqua halbfett Typoart Albert Kapr 1973

\section{ABCDEFGHIJKLMNOPQRSTUV WXYZÆEC abcdefghijklmnopqrstuvwxyz chckfffiflftß\&æœçäöü} $12345678901234567890 ., . ;{ }^{\prime}-[]() ! ? \S *{ }^{*}$," Leipziger Kursiv Typoart Albert Kapr 1973

ABCDEFGHIJKLMNOPQRSTUVW XYZÆECC abcdefghijklmnopqrstuvwxyz chckfffiffttßむoceœçäöü

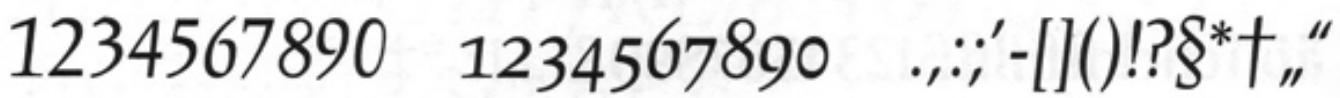




\begin{tabular}{|c|c|c|}
\hline defghijkl & defghijkl & defghijkl \\
\hline mnopqrst & minopqrst & mnopqrst \\
\hline uvwxyzß & $110 U O \times D Z \beta$ & uvwXYzß \\
\hline äöü & व̈ӧ̈̈ & äöü \\
\hline АBCDEF & ABCDEF & ABCDEF \\
\hline GHIJK & $G / I / / K$ & GHIJK \\
\hline LMNOP & LMNOP & LMNOP \\
\hline QRSTU & QRSTU & QRSTU \\
\hline VWXYZ & VWXYZ & VWXYZ \\
\hline ÄÖ̈̈ & $\ddot{A O ̈ U ̈ ~}$ & ÄÖÜ \\
\hline 123456 & 123456 & 123456 \\
\hline 7890 & 7890 & 7890 \\
\hline 123456 & 123456 & 123456 \\
\hline 7890 & 7800 & 7890 \\
\hline
\end{tabular}

Die schöngeistige Literatur

Beispiele persischer Dichtung

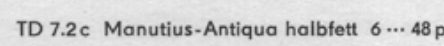

Radioaktive Elemente

Gebiete der Kernphysik

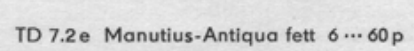

Eigenschaften des Ultraschalls

Künstliche Strahlen als Heilquelle

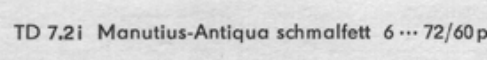

BASKERVILLE (1982). Volker Küster/Peter Greinke

abc $a b c \quad$ abc

defghijkl defghijkl defghijkl

mnopqrst mnopqrst mnopqrst

uvwxyzß uvwxyz $\beta$ uvwxyzß

äöü äö̈ äöü

ABCDEF $A B C D E F$ ABCDEF

GHIJK GHIfK GHIJK

LMNOP LMNOP LMNOP

QRSTU QRSTU QRSTU

VWXYZ VWXYZ VWXYZ

ÄÖÜ $\ddot{A} O \ddot{U}$ ÄÖÜ

\begin{tabular}{ll|l}
123456 & 123456 & 123456
\end{tabular}

\begin{tabular}{ll|l}
7890 & 7890 & $\mathbf{7 8 9 0}$
\end{tabular}

\begin{tabular}{ll|l} 
I $2345^{6}$ & $I 2345^{6}$ & $\mathbf{I} 2345^{6}$
\end{tabular}

\begin{tabular}{ll|l}
7890 & 7890 & 7890
\end{tabular} 


\section{abc $a b c$ abc abc}

defghijkl defghijkl defghijkl defghijkl mnopqrs mnopqrs mnopqrs mnopqrs tuvwxyz Bäöü tuvwxyz $\beta \ddot{a ̈ o ̈ u}$

ABCDE $A B C D E$ FGHIJK FGHIJK LMNOP $L M N O P$ QRSTU VWXYZ Aิல் 123456 7890 123456 7890 QRSTU $\ddot{A} O \ddot{U}$ 123456 7890 123456 7890 $V W X Y Z$ tuvwxyz tuvwxyz ßäöü ßäöü ABCDE ABCDE FGHIJK FGHIJK LMNOP LMNOP QRSTU QRSTU VWXYZ VWXYZ ÄÖU் ÄöÜ $123456 \quad 123456$ \begin{tabular}{l|l}
7890 & 7890
\end{tabular} $123456 \quad 12345^{6}$ \begin{tabular}{l|l}
7890 & 7890
\end{tabular} $\mathrm{abc}$ defghijkl mnopqrst uvwxyzß äöü

ABCDE $A B C D E$ FGHIJK FGHIFK

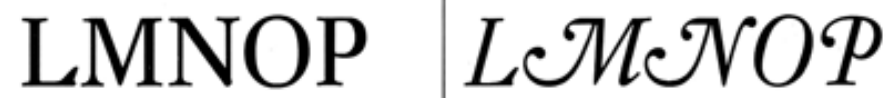
QRSTU शRSTU VWXYZ ÄÖÜ 123456 7890 I23456 7890

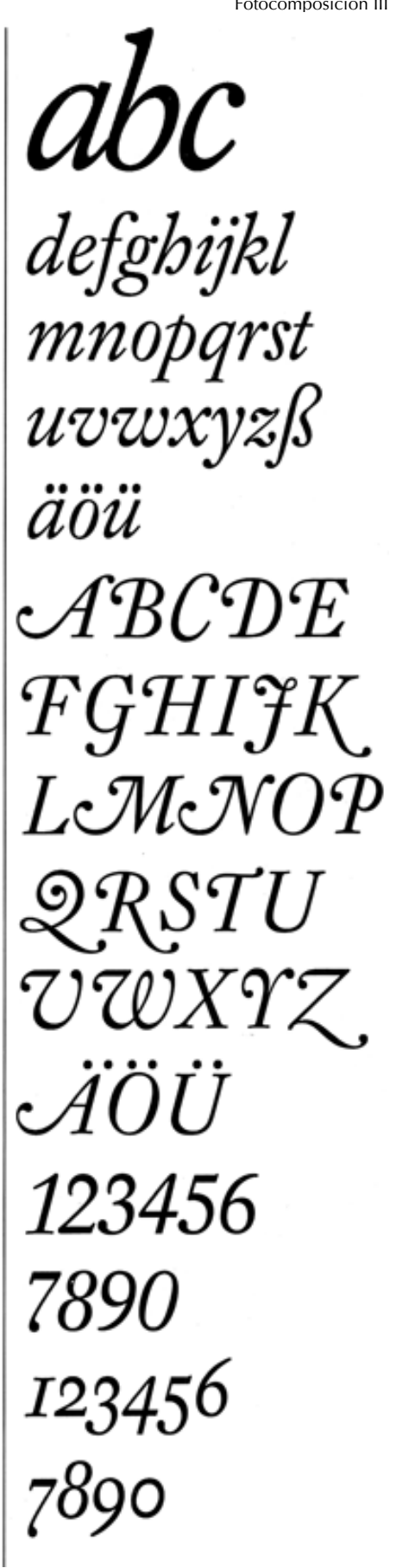




\begin{tabular}{l|l} 
abc & $a b c$ \\
defghijk1 & defgbijkl \\
mnopqrst & mnopqrst \\
uvwxyzß & uvwxyzz $\beta$ \\
äö̈ & äöi \\
ABCDEF & ABCDEF \\
GHIJK & GHIFK \\
LMNOP & LMNOP \\
QRSTU & QRSTU \\
VWXYZ & VWXYZ \\
ÄÖÜ & $\ddot{A O ̈ U ̈ ~}$ \\
123456 & 123456 \\
7890 & 7890 \\
I23456 & I23456 \\
7890 & 7890 \\
&
\end{tabular}

abc $a b c$ abc $a b c$ abc defghijkl defghijkl defghijkl defghijkl defghijkl mnopqrst mnopqrst mnopqrs mnopqrs mnopqrs uvwxyzß uvwxyz $\beta$ tuvwxyz tuvwxyz tuvwxyz äöü ӓӧ̈ ßӓöü ßäö̈ Bäöü

ABCDEF $A B C D E F$ ABCDE $A B C D E$ ABCDE GHIJK GHIJK FGHIJK FGHIJK FGHIJK LMNOP LMNOP LMNOP LMNOP LMNOP QRSTU QRSTU QRSTU QRSTU QRSTU

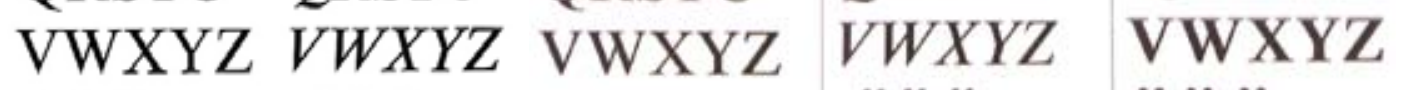
ÄÖÜ ÄÖ̈ ÄÖÜ ÄÖÜ ÄÖÜ \begin{tabular}{llll|l|l}
123456 & 123456 & 123456 & 123456 & 123456
\end{tabular} \begin{tabular}{lllll|}
7890 & 7890 & 7890 & 7890 & 7890
\end{tabular} \begin{tabular}{lll|l|l|}
$\mathrm{I} 23456$ & $I 2345^{6}$ & $\mathrm{I} 2345^{6}$ & $I 2345^{6}$ & $\mathbf{I 2 3 4 5}^{6}$
\end{tabular} \begin{tabular}{lll|l|l}
7890 & 7890 & 7890 & 7890 & 7890
\end{tabular}

BORGIS (desc.)

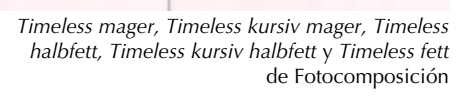

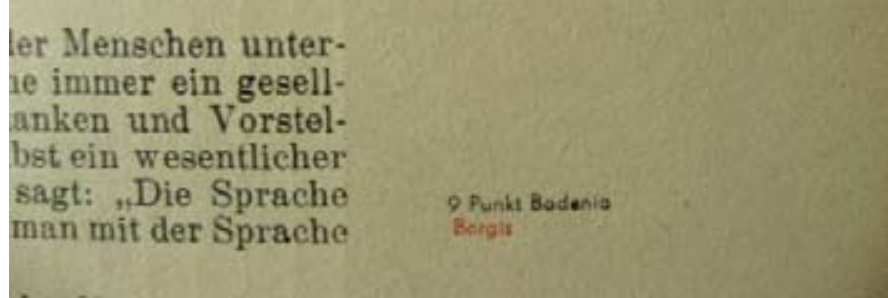


PRILLWITZ (1962). Albert Kapr/ Werner Schulze
ABCDEFGHIJ abcdefghijklmn KLMNOPQRS opqrstuvwxyzß

TUVWXYZ «I234567890\&» *1234567890!?)

Prillwitz Antiqua
ABCDEFGHIJ abcdefghijklmn KLMNOPQRS opqrstuvwxyz $\beta$ TUVWXYZ "I $234567890 \&$ \% *1234567890!?)

\section{Prillwitz Kursiv}

\section{abc $a b c$ abc} defghijkl defghijkl defghijkl mnopqrst mnopqrst mnopqrst uvwxyzß uvwxyz $\beta$ uvwxyzß äöü äöü äöü ABCDEF ABCDEF ABCDEF GHIJK GHIJK GHIJK

LMNOP LMNOP LMNOP QRSTU ORSTU QRSTU

VWXYZ VWXYZ VWXYZ

ÄÖÜ $\ddot{A} O \ddot{U}$ ÄÖÜ

$\begin{array}{llll}123456 & 125456 & 123456\end{array}$

$\begin{array}{lll}7890 & 7890 & 7890\end{array}$

$\begin{array}{llll}\text { I } 2345^{6} & I 2545^{6} & \mathbf{I} 2345^{6}\end{array}$

\begin{tabular}{l|l|l}
7890 & 7890 & 7890
\end{tabular}

\section{abc abe defohijklm defghijkl mopqret uvwXyzB äïii \\ ABCDEFC \\ HIJKLM NDPQRST UVWXYY Ǟ்̋ 123456 7894 memeptyost movoxyza $\beta$ ï̈̈̈ï ABCDEFG НИОКИМ NDPQRST UWXYY $\ddot{A} \ddot{\mathbf{D}}$ 123456 ช890}

DIDOT-ANTIQUA (1958). Herbert Thannhaeuser.

Originol-Matricen um i8ı Didot-Antiqua D.Stempel AG Frankfurt am Main

A B CDEFGHIJKLMNOPQRSTUVWXYZ abcdefghijklminopqrstuvwxy\%

Original-Yatrizen um 88,0 Dillot-Kuraiv D.Stenpel AG Franlfurt an Main ABCDEFGHIJKLMNOPORSTUVWXYZ abcdefghijklmnopqrstusw:yz 
abc

$a b c$ abc $a b c$

defghijkl mnopqrst uvwXyzß äöü

ABCDEF GHIJK LMNOP QRSTU VWXYZ ÄÖÜ 123456 7890 123456 7890 defghijkl defghijkl defghijkl mnopqrst mnopqrst mnopqrst

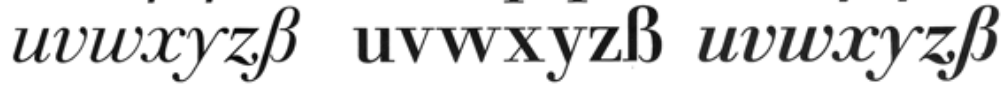
äö̈ äöü $\ddot{a} \ddot{0} \ddot{u}$ $A B C D E F$ ABCDEF ABCDEF GHIJK GHIJK GHIJK LMNOP LMNOP LMNOP QRSTU QRSTU QRSTU VWXYZ VWXYZ VWXYZ $\ddot{A O O U} \quad \ddot{\mathrm{O} O ̈} \dot{U} \quad \ddot{A O U}$ $\begin{array}{lll}123456 & 123456 \quad 123456\end{array}$ $\begin{array}{lll}7890 & 7890 & 7890\end{array}$ $\begin{array}{lll}123456 & 12345^{6} & I 23456\end{array}$ $7890 \quad 7890 \quad 7890$
DIE SPRAGHIIR IST BIN SPIFERIBULD DE

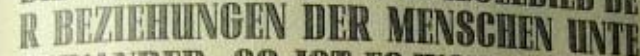
REINANDRR. SO IST HS WOHL AUCH KI

123456789012345678901284567890128

DIE SPRAGHE IST HIN SPIEGHB

III DHR BPTIHHAUNGEN DER MEN

DIE SPRACHR IST MIN SPEG

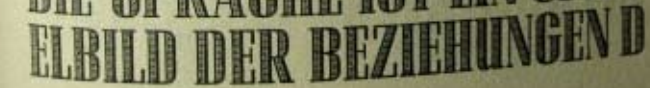

AKROPOLIS (1938). Ludwig Warner

Tipografía de plomo. IV

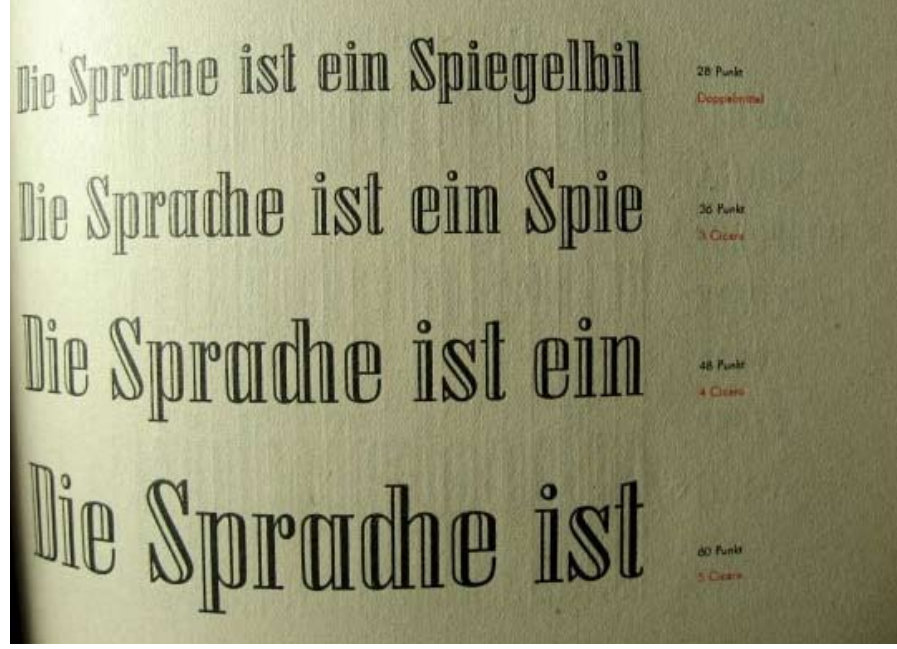

DRUCKHAUS

Tipografía de plomo. IV

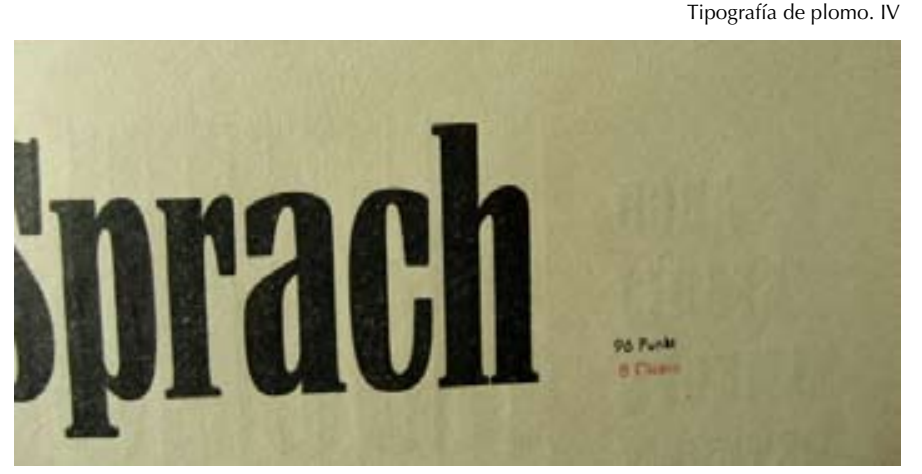


Alfons Schneider 1932 Aatiqua Pergamon Ledwig Wagner KG Leipzig

A B C D E F G H I K L M N O PQR S TUVW XYZ abcdefghijklmnopqrstuvwxyz Allons Sdineider 1992 Aeligua Perganaut kursiv Ludwig Waguer KCG Leipzig

A BCDEFGHIJKLMNOPQRSTUVWXYZ abcdefghijklmnopqrstuvwxyz

Letterpress Printing Machines

State Printing Office in Ulan Bator

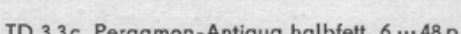

Das Studium der Materie Geschichte der Wissenschait

TD 3.3e Pergamon-Antiquo fett 6...72/60 p

Gesetzmäßigkeiten in derNatur

Ergebnisse der Weltraumiorschung

TD 3.3k Pergamon-Kursiv halbfett $6 \cdots 48$ p

Erholung an der Ostsee Im Autobus durch den Harz TD 3.31 Pergamon-Kursiv fett $6 \ldots .60 \mathrm{p}$

Buth und Shriit im Wandel der Zeiten Gesammelte Werke der deutschen Didhter TD 3.3h Pergamon-Antiqua schmalhalbfett 6...60 p

Forschung im kosmischen Raum Ihre Eriolge und weiteren Pläne

\section{ABCDEFG IIJ.KLII IOPQRST IVWXYZ ïöï abc defghijk|m nopersit IIVWXYZR äöï} 123456
7890

TIPO V. EGIPCIAS

NIDOR. Harald Brödel

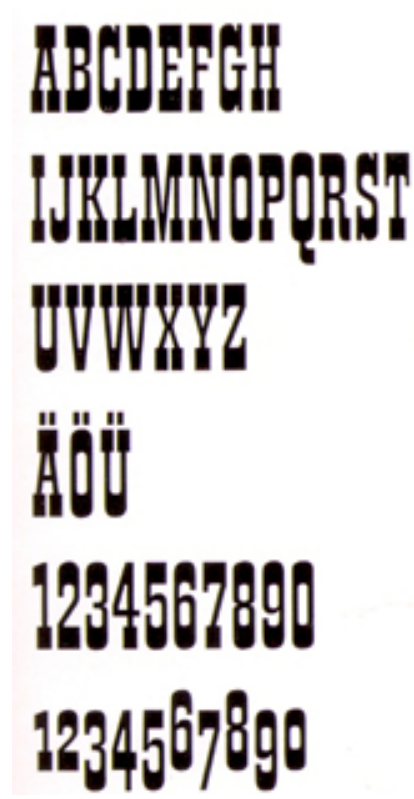

ว)ด deforgingengn qustintwy คำ "I หม่ 
Neutra Typoart Albert Kapr 1968

ABCDEFGHIJKLMNOPQRSTUVW XYZ ÄÖÜ abcdefghijklmnopqrstuvw xyz äöüchckß áèîôùç 1234567890 \&

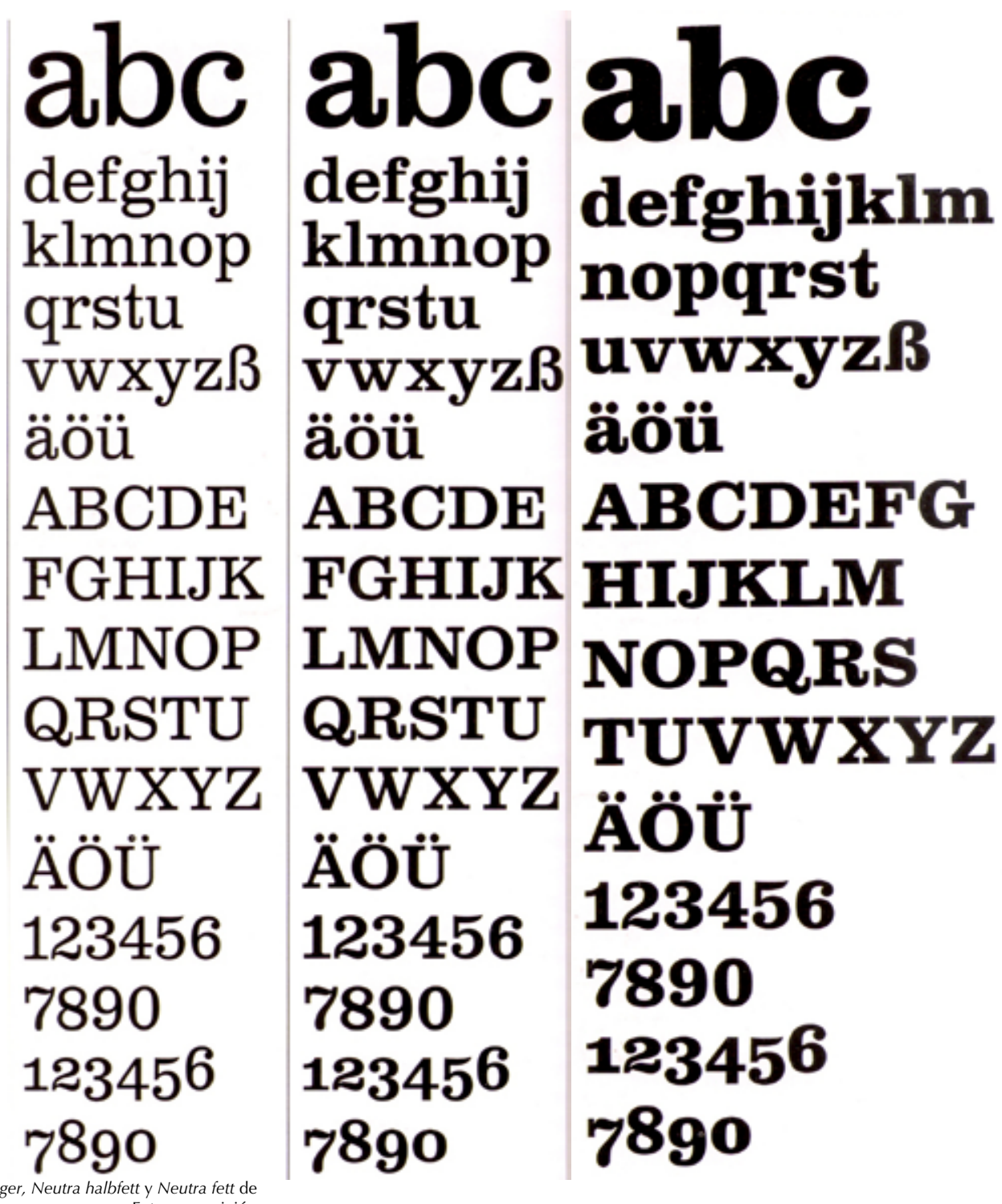

Herbert Thannhaeuser 1948 Technotyp

ABCDEFGHIJKLMN OPQRSTUVWXXZ abcdefghijklmnopqrstuvwxyz

Service for Diesel Engines

Fábrica de máquinas de coser

TD 4.1C Technotyp holbfett 6...60/48 P

Elektronische Mefjgeräte

Technische Messe in Leipzig

TD 4.1e Technotyp fett 6 $6 \cdots 72 / 60 \mathrm{p}$

Gufsstahlhiitte in Döhlen Dresdner Hochschulkurse

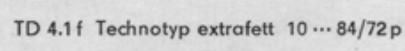

Metallboote aus Rechlin, Müritz

Neue Schiffstypen mit Weltniveau

TD 4.1] Tochnotyp-Kursiv 6...48

Maschinen für das grafische Gewerbe

Leipziger Messe, Brücke zum Welthandel

TD 4.1 T Technotyp schmalhalbett 6...60/48 p

Bröderna Lagerströms Förlag

Aktiebolaget Nordex i Stockholm 
Liebe Martinal Sel mir nicht bose, da Dir so lange nicht schrieb; meine

chre1b goulhe1t 1st Dir nicht unbekannt.

TD 4.20 Schreibmastinen-Shilits op

Wissen Sie schon, daß die "Erika” mehr als das normale Arbeitsgebiet der Kleinschreibmaschine schafft?

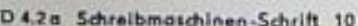

EGYPTIENNE. Hans-Peter Greinke

\section{aba ABCDEFG defghijlslm uvwayzB äöii \\ UVWXYZ \\ Äठ̈Ü \\ 128456 \\ 7890}

MANUTIUS (1935). Arno Drescher

Amo Drescher Antiqua Manutus Ludwig Wagner KG Leipzie

ABCDEFGHIJKLMNOPQRSTUVWXYZ abcdefghijklmnopqrstuvwxyz

Atno Deescher Antiqua Manufius kurssiv Ludwilg Wagnet KG Letpzig

ABCDEFGHIJKLMNOPQRSTUVWXYZ abcdefghijklmnopqrstuvwxyz

SUPER GROTESK (1930). Arno Drescher.

Tipografía de plomo y fotocomposición (Karl-Heinz Lange). Réplica Y

\section{ABCDEFGHIJK \\ LMNOPQRSTUVW \\ XYZA'OU \\ abcdefghijklmno \\ pqrstuvwxyz \\ äöüchckfffiflßáàéèêç \\ 1234567890}

ABCDEFGHIJK

LMNOPQRSTUVW

XYZAOU

abcdefghijklmno

pqrstuvwxyz

äöüchckfffiflßááéèêc

1234567890

T 102

\section{$a b c$ abc $a b c$ abc abc}

defghijkl defghijkl defghijkl defghijkl defghijkl

mnopqrst mnopqrst mnopqrst mnopqrst mnopqrst

uvwxyzß uvwxyzß uvwxyzß

äöü

äöü

äöü

ABCDEF

ABCDEF

$A B C D E F$

GHIJK

GHIJK

$G H I J K$

LMNOP

LMNOP

LMNOP

QRSTU

QRSTU

VWXYZ

VWXYZ

VWXYZ

ÄÖÜ

ÄÖÜ

ÄÖÜ

123456

7890

123456

7890

123456

7890

123456

7890
uvwXyz $\beta$ uvwxyzß

äöü

ABCDEF ABCDEF

GHIJK

LMNOP

QRSTU

VWXYZ

ÄÖÜ

123456

7890

123456

7890
GHIJK

LMNOP

QRSTU

VWXYZ

ÄÖÜ

123456

7890

123456

7890 
Foto-Ausstellung in Paris Zeitschrift für die Filmtechnik Fundamen TD 5.61 Fundamental-Kursiv fett $6 \cdots 72 / 60 \mathrm{p}$ NORMA STEINSCHRIFT. Harald Brödel

ABCDEFGHIJ KLMNOPQ abcdefghijkImnopqrstuvwxyz

Rationalisierung im Bauwesen Moderne Bauten für die Industrie Erzeugnisse von Weligelitung Maschinen für die Landwirtschaft

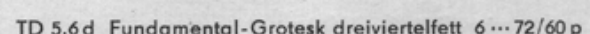

Rundfunk und Fernsehen Sportberichte aus aller Welt

5.6e Fundamential-Grotesk fett 6...72/60

Four-Colour Ofiset Planeta Super Deca

National Printing Office in Conakry (Guinea)

China mil der Kamera gesehen Was bedeutet China fïr Europäer?

La Foire-Exposition de New Delhi

Amélioration de la qualité des textiles

Werkstoffe und deren Festigkeit

Belastungsprobe der Materialien

TD 5.6k Fundamental-Kursiv halbfett $6 \ldots 48 \mathrm{p}$ Fundament RSTUVWXYZ defghijklmno Äöī pqrstuvwxyzß äouit 1234567890 MOLLI. Harald Brödel

\section{ABCDEFG} HIJKLI nOPQRST defghijklm UUwKYz nopqrst ค̈öن

123456 7890 1234567890 
ABCDEFGHIJKLMNOP QRSTUVWXYZ ÄÖÜ $1234567890 /+\varepsilon ! ?$

abcdefghijklmnopqrstu vwxyz ch äöü ffftfifl ß $1234567890,,:,,^{-}{ }^{*}$ »《

\section{ABCDEFGHIJKLMNOP QRSTUVWXYZ ÄÖÜ $1234567890 /+\varepsilon ! ?$} abcdefghijklmnopqrstu vwxyz ch äöü ffftfifl ß 1234567890 ., , , ,--*

\section{Maxima-Grotesk Kursiv Typoart Gert Wunderlich 1964-71}

\section{ABCDEFGHIJKLMNOP QRSTUVWXYZ ÄÖÜ $1234567890 /+\varepsilon ! ?$}

abcdefghijklmnopqrstu $v w x y z$ ch äöü ffftfifl ß $1234567890 ., i_{,},-* * \ll$ ABCDEFGHIJKLMNOPQRSTUVWXYZÄÖÜ abcdefghijklmnopqrstuvwxyzßäöü

$$
1234567890
$$

ABCDEFGHIJKLMNOPQRSTUVWXYZÄÖÜ abcdefghijklmnopqrstuvwxyzßäöü 1234567890

abc $a b c$ abc abc $a b c$ abc abs

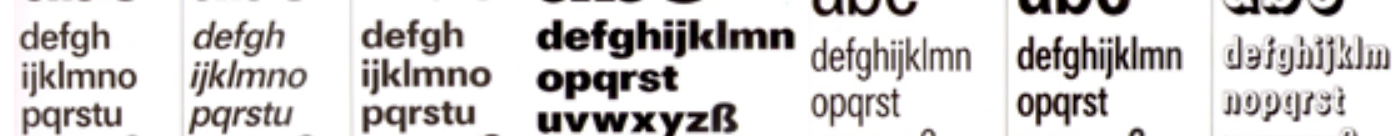

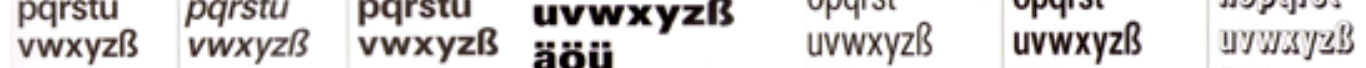
äöü

aou ABCDEF ABCDEF ABCDE GHIJK GHIJK GHIJK QRSTU QRSTU QRSTU VWXYZ VWXYZ VWXYZ ÄÖÜ ÄÖÜ ÄÖÜ \begin{tabular}{l|l|l}
123456 & 123456 & 123456
\end{tabular} $\begin{array}{lll}7890 & 7890 & 7890\end{array}$ $\begin{array}{lll}723456 & 123456 & 123456\end{array}$ \begin{tabular}{l|l|l}
7890 & 7890 & 7890
\end{tabular} \begin{tabular}{ll|l} 
àoú & äöü & äöü \\
\hline
\end{tabular} HIJKLMNOP ABCDEFG ABCDEFG ABCDEFG

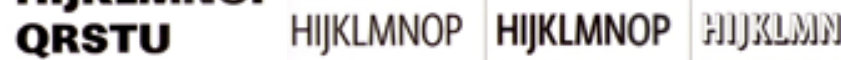
\begin{tabular}{ll|l} 
VWXYZ & QRSTU & QRSTU OPQBSTU
\end{tabular}

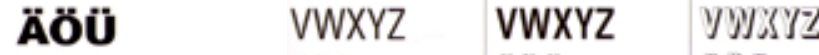
1234567890 ÄÖÜ ÄÖÜ

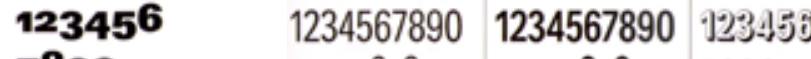
$\begin{array}{llllll}\mathbf{7 8 9 0} & 1234567890 & \mathbf{1 2 3 4 5 6 7 8 9 0} & 7390\end{array}$ 
$a b c$

defghijklm

nopqrst

uvwxyz $\beta$

äöü

ABCDEFG

HIJKLM

NOPQRST

UVWXYZ

A'O'U

123456

7890

DIN-NORM-SPIEGELSCHRIFT (1925).

- uddnэrotbloal nab iüt orüdapnulsdoiwtn]

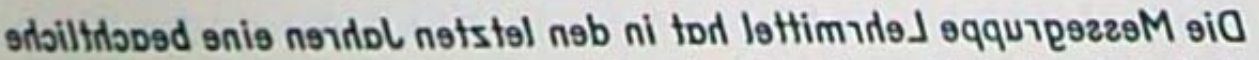

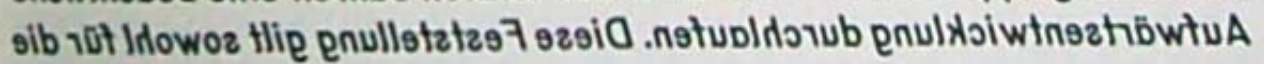

TD 5.4 DIN-Norm-Spiegelschrift 6-16p

BIGA (1985) Fritz Richter

舟愚C

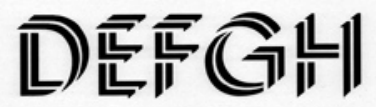

1. $\| \mathbb{K} \backslash L \mathbb{M}$

N(@)通

$\mathbb{S} \pi$ 凹l

$\mathbb{V} \mathbb{W} \mathbb{N} \mathbb{W} \mathbb{Z} \mathbb{Z}$

KLEOPATRÁ Erhard Kaiser

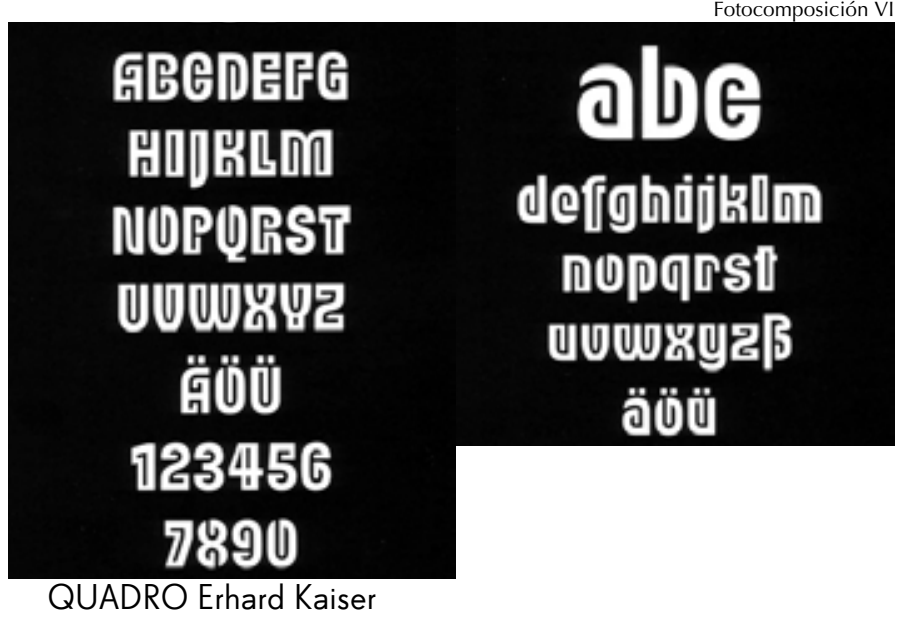

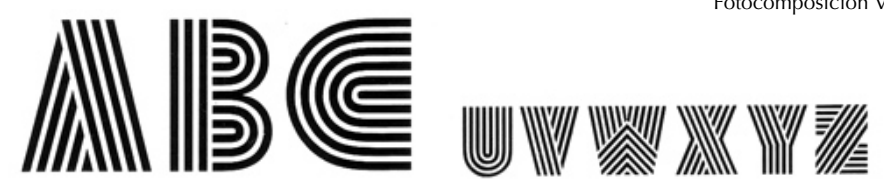

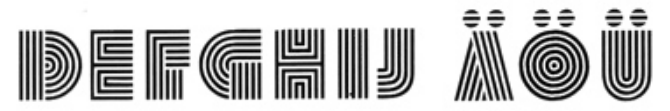

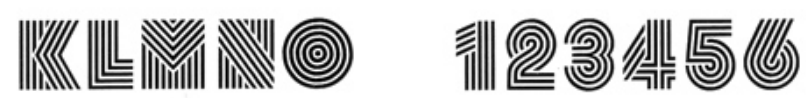

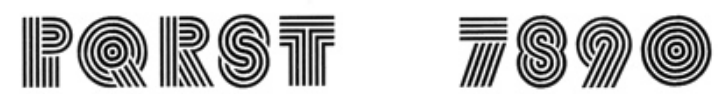


Herbert Thannhaeuser 1952 Meister-Antiqu

ABCDEFGHIJKLMNOPQRSTUVWXYZ abcdefghijklmnopqrstuvwxyz

abc $a b c$ defghijkl defghijkl mnopqrst mnopqrst uvwxyzß uvwxyz $\beta$ äöü äöu

ABCDEF $A B C D E F$ GHIJK $\quad G H I J K$ LMNOP LMNOP QRSTU QRSTU VWXYZ VWXYZ ÄÖÜ $\ddot{A} O \ddot{U}$ 123456 123456

7890 7890

123456 123456 7890 7890 abc abc defghijkl defghijkl mnopqrst mnopqrst uvwXyzß uvwxyzß äöü äöü ABCDEF ABCDEF GHIJK GHIJK LMNOP LMNOP QRSTU QRSTU VWXYZ VWXYZ ÄÖÜ ÄÖÜ 123456 7890 123456 7890
123456

7890 123456 7890 
abc abc

NORDISK KONST

B ISUTERIA Y FANTASIA

TD 6.3

Erler-Versalion

LIBERTA-ANTIQUA (1961). Herbert Thannhaeuser

locomposición (Harald Brödel). VII

ABCDEFGHIJK

LMNOPORSTUVW

XYZÄÖÜ

abcdefghijklmno

pqrstuvwxyz

äöüchckfffiflß̧áàèèç

1234567890

\section{ABCDEFGHIJK \\ LMNOPORSTUVW \\ LIBERTA \\ XYZÄÖÜ \\ abcdefghijklmno \\ pqrstuvwxyz \\ äö̈̈chckfffiflf̧ááéèèç \\ 1234567890

T 105
mager / halbfett
$T 105 \mathrm{Ka}$
Kapitälchen $8-10 \mathrm{p}$

\section{Berichte aus Liberia}

Safari durch Moçambique

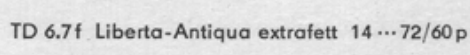

Jederzeit hilft dir das Fachbuch

Die Schrift als Künder der Wissenschaft

TD 6.7] Liberta-Kursiv mager $6 \ldots$ 48

\section{Fußbball-Weltmeisterschaft}

England und Brasilien im Finale!

TD 6.71 Liberta-Antiqua schmalfett 14 …72/60 p

Utilisez chaque chance de vente!

L'imprimerie "Tien-Bo» Hanoi (Vietnam)

TD 6.7h Liberta-Antiqua schmalhalbfett $14 \cdots 72 / 60 \mathrm{p}$ defghijklm defghijklm

nopqrst nopqrst

uvwxyzß uvwxyzß

äöii

ABCDEFG ABCDEFG

HIJKLM HIJKLM

NOPQRST NOPQRST

UVWXYZ UVWXYZ

ÄöÜ

ÄöÜ

123456

7890

123456

7890

kursiv extrafett de
fotocomposición

MIMOSA (1914)

*DAS NEUE MAGAZIN

WISSENSWERTES VON DER PHOTOKAMERA

TD 520 Mimoso moger $3 / 6 \cdot 24 \mathrm{p}$

ATOMFORSCHUNG

WISSENSCHAFT UND TECHNIK VON HEUTE

TD 5.2k Mimesa-Kursiv halbfett $3 / 6-24 \mathrm{p}$

VERKEHRSMUSEUM

GROSSE AUSSTELLUNG VON FAHRZEUGEN

TD 5.2 C Mimosa halblett $3 / 6 \cdot 24 \mathrm{p}$ 


\section{FESTKONZERT}

TD 1.4 Roesner-Versolien
$12 \cdots 36 \mathrm{p}$

DIE NEUNTE SINFONIE

ZYKLOP. Fritz Kossack

DBC uvwyyz

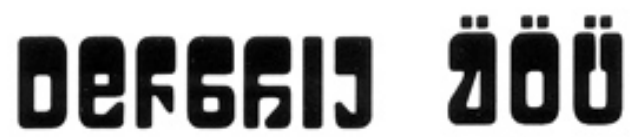

RLMNO 123456

PQRST 7890

AMBASSADOR (1938). Martin Wilke

Tipografía de plomo. VII

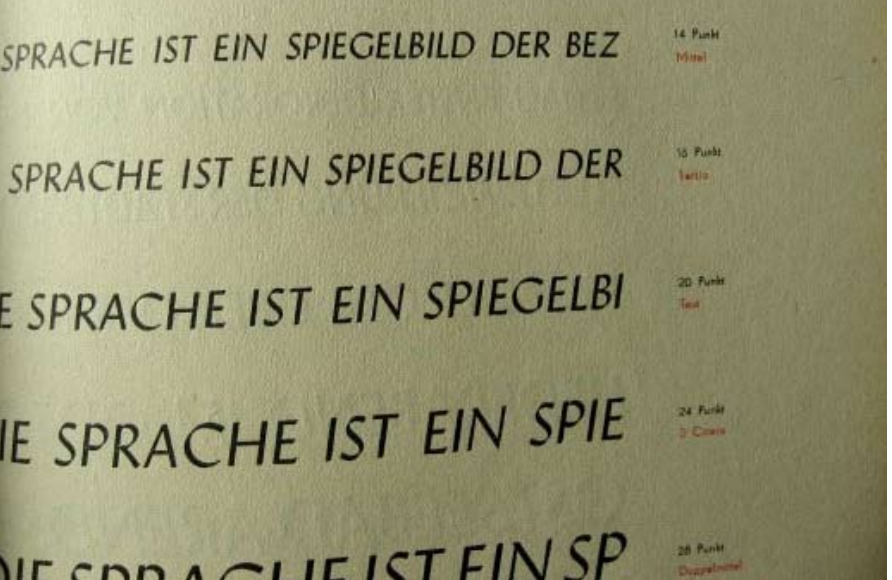

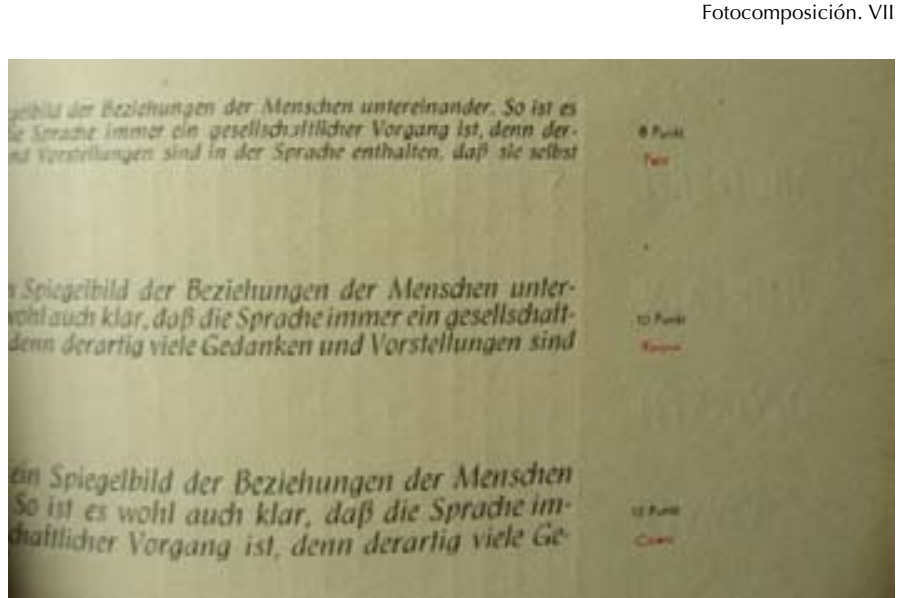

FAUST ANTIQUA (1962). Albert Kapr

Faust-Kursiv Hochschule für Grafik Albert Kapr 1962

ABCDEFGHIJKLMNOPQRSTUVW

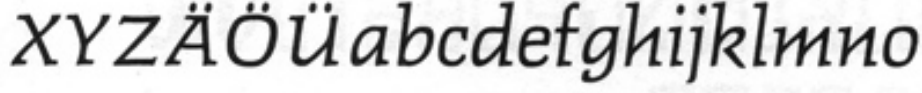
pqrstuvwxyzäöückfffißı234567890

Faust-Antiqua Hochschule für Graflk Albert Kapr 1962

ABCDEFGHIJKLMNOPQRSTUVW XYZÄÖüabcdefghijklmnopqrst uvwxyzäöüchckßfffiflft1234567890 
STENTOR (1964). Heinz Schumann

Tipografía de plomo y fotocomposición VIII

ABCDEFGみIOK 2 MNORGURS

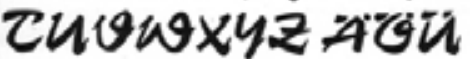

abcdefghijklmnopqrstuvwхyz äöü chck

fffiffftß áèîù̀ç 1234567890 \&

ABCDEFGJT)KLMNO RoRscuvusxyz ÄĞ̈

abcdefghijklmnopqrstuvwxyzßä̈̈̈i

1234567890

TYPO-SKRIPT (1968). Hildegard Korger

abcoefghiiklmnopqurstuvwxyz ä̈̈̈ß

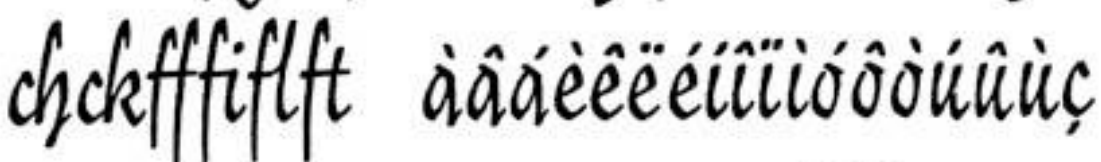

$\left.1234567890, . ; ; ! ?-^{\prime}([)]^{*}\right) \ll<\mathcal{E}$

ABCDEFGHIJKLMNOPQ

RSTUVWXYZ ÄÖÜ ÉËËE
ABCDEFGHJJKLWNOSRRSTUVWXYZÄÖÜ abcoefghijklmnopqrstuvwхухßӥ̈̈ї 1234567890

AGITATOR (1960). W. Eickhoff

AUF...

ZUR SILVESTERFEIER IM KULTURHAUS!

AGITATOR

TD $6.612 \cdots 48 \mathrm{p}$

ARABELLA-FAVORIT (1939). Arno Drescher

Urlaub in den Bergen

Mäntel fï̈ Heebst und Winter

TD 8.6 Arobella-Favorit 12-60.

KURIER (1939). Herbert Thannhaeuser

Hotel Excelsion

Gäste aus allen Welt

KURIER

POLO. Carl Pohl

ABCDEFGHIJKLMINOPQRSTUVWXYZÄÖÜ abcdefghijklmnopqrstuvw Xyzßäöü 1234567890 


\section{* Ganzim / Tandel der Z̃eit \\ Qie neunte Sintonie oon Beethoven \\ TDE: Splendor moger 8.48p \\ DerMaler Rembrandt}

Sonderschau der Gemäldegalerie

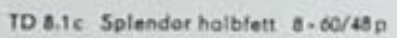

\section{Berliner Mllustrierte}

Die interessante Zeitsclırift

To 8.1. Solendor tout 8.72/200.

LOTTO (1955). Herbert Thannhaeuser.

Tipografía de plomo VIII

\section{Fufballspiel um den Europacup}

LOTTO

TD $8.414 \ldots @ Q_{8}$

TIPO IX. CALIGRÁFICA

HOGARTH SCRIPT. Harald Brödel

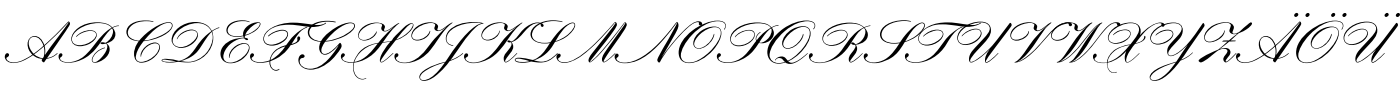
abcdefghijhlmnopqistumuxy: sä̈й 1234567890

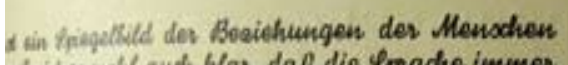

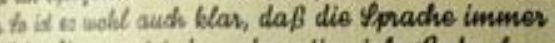

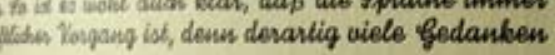

it rin Epiegelbild der Besiehungen der alveivander to ist eo wohl auch blar, dak

ho ist ein Ppiegeltild der Bea

Her untereingelbild der Besichungen

uritereinander. Ia int an ...a.e.

JUNIOR (1936). Hans Heimbeck

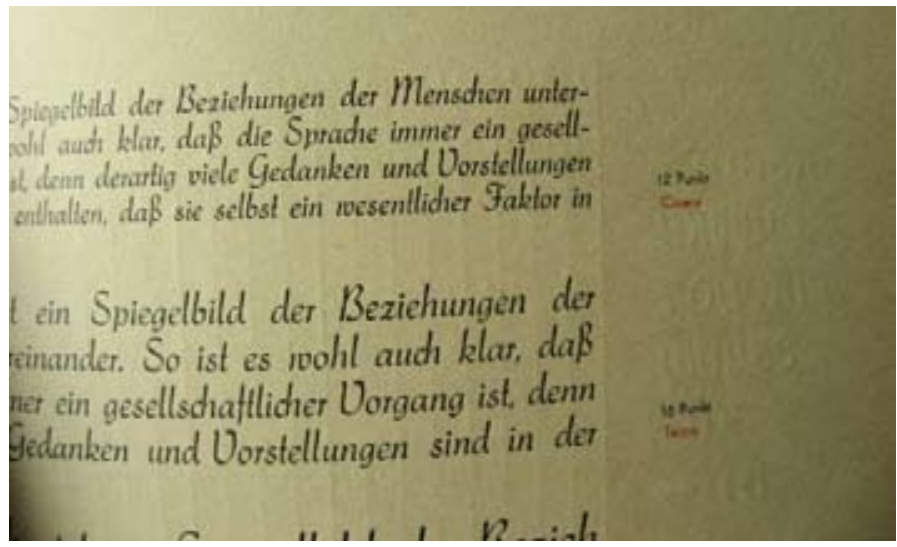

RAUTENDELEIN (1908)

Tipografía de plomo IX

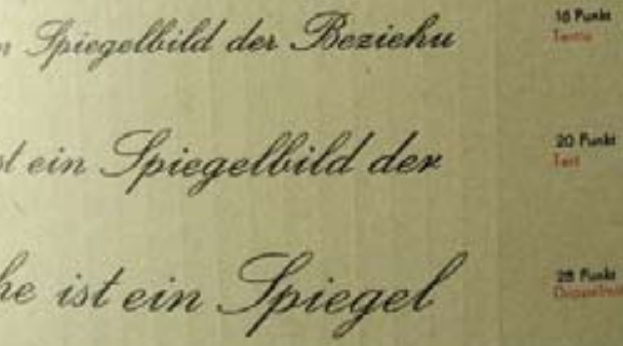




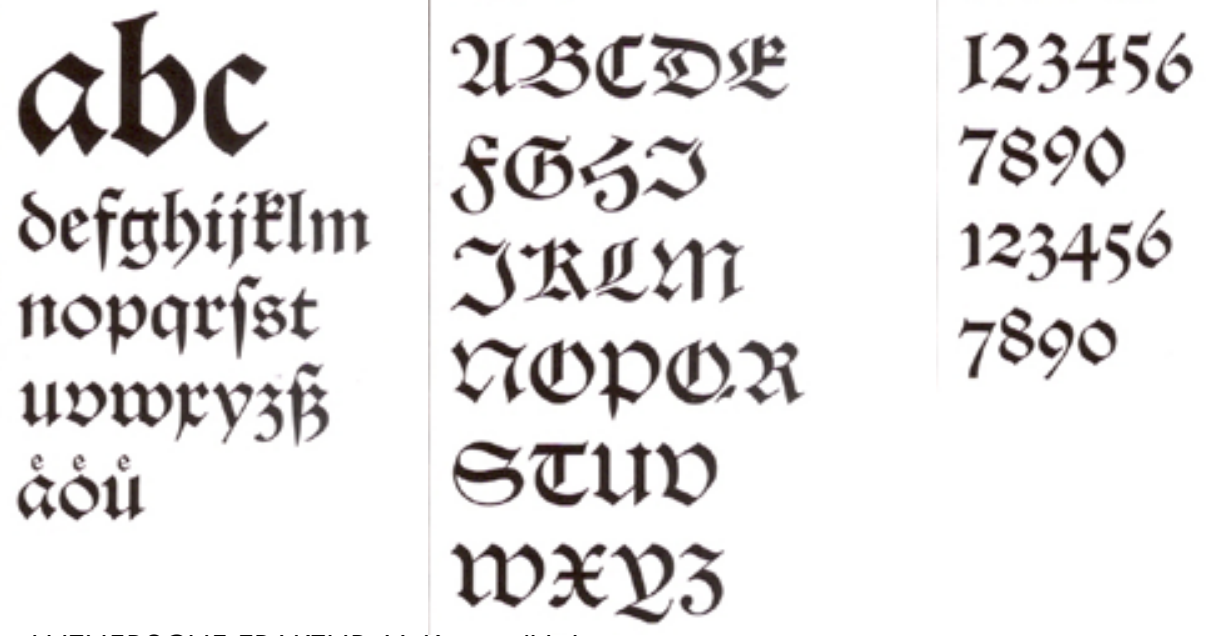

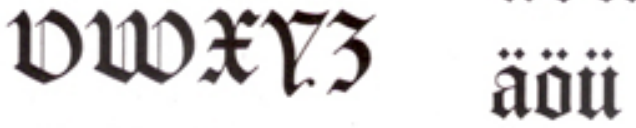

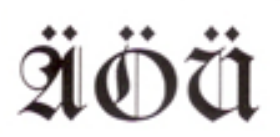

\section{0} 1234567890

SINKWITZ-GOTISCH (1942). Paul Sinkwitz

\section{Der Bergheímat-Kalender}

四as Thüringer Dolkskunit-Afiuleum

\begin{tabular}{|c|c|}
\hline ab & abc \\
\hline 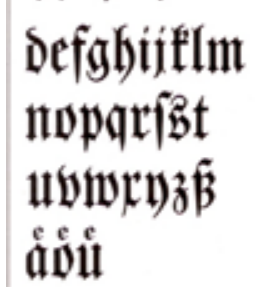 & 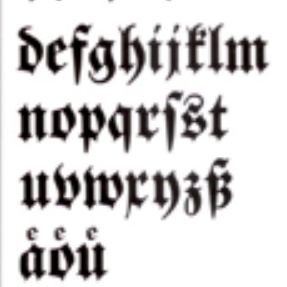 \\
\hline 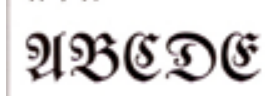 & 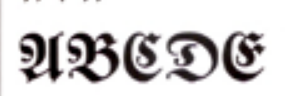 \\
\hline 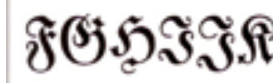 & 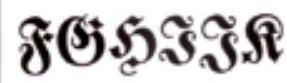 \\
\hline 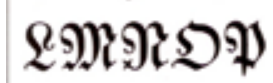 & 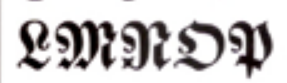 \\
\hline 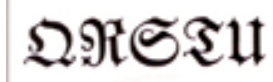 & 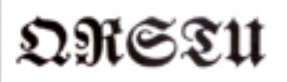 \\
\hline BZWXY & அצ'XXY \\
\hline थٔí & 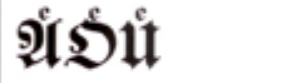 \\
\hline 3456 & 123456 \\
\hline & 7890 \\
\hline & 123456 \\
\hline & \\
\hline
\end{tabular}




\section{abc}

ABCDEFGEJK

deighijklm nopqrst

uvWxyz $\tilde{B}$

đ̊̋ő

HBCDEFG

5JJKLII

UMIIOPQRSEU

DDXYZ

abcoeighijklma opqrs IfuDaxyz chek 1234567890 IOPQRSC UVWXYZ ต̈öü

123456

7890 


\section{ANEXO III. DATOS DE ANÁLISIS}

A. FICHA TÉCNICA

\begin{tabular}{|c|c|c|c|c|c|c|}
\hline CÓDIGo & AÑO & AUTOR & Título & TIPO & FUENTE & GÉNERO \\
\hline 1946_F__00 & 1946 & FREEE, Jürgen & Nürnberg Schuldig & Ofiset & Überklebt-Plakate aus der DDR & Politico \\
\hline 1945_FK_00 & 1945 & FIEDLER, Kurt & KPD. Die Partei des Volkes & 0 & P40 & 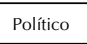 \\
\hline 1945_SW_00 & 1945 & SCHUBERT, Wilhelm & Junkerland wird Bauernland & Offset & Überklebt-Plakate aus der DDR & Politico \\
\hline 1945_SW_01 & 1945 & SCHUBERT, Wilhelm & Im Geiste Ernst Thälmanns kampfbereit & 0 & P40 & Politico \\
\hline 1945_VH_O0 & 1945 & VÖLKEL, Heinz & Thälmann Breitscheid & 0 & P40 & Politico \\
\hline 1945_VK_00 & 1945 & VÖLKEL, Heinz & Neubau Arbeit & Offset & Überklebt-Plakate aus der DDR & $\begin{array}{l}\text { Politico } \\
\text { Pand }\end{array}$ \\
\hline 1946_BJ_00 & 1946 & BOEHLAND, Johannes & 1. Deutschen Kunst Ausstellung & 0 & P40 & Cultural \\
\hline 1946_F__00 & 1946 & FIEDLER, Kurt & Vollsentscheid... Stimmt mit al! & Offiset & Überklebt-Plakate aus der DDR & Politico \\
\hline 1946_MA_00 & 1946 & MOHR, Arno & 1. Mai 1946 & Litografía & Überklebt-Plakate aus der DDR & Pollitico \\
\hline 1946_NH_00 & 1946 & NAUMANN, Horst & Ja Volksentscheid & 0 & $\mathrm{P} 40$ & Pollitico \\
\hline 1946_PW_00 & 1946 & PETZOLD, Willy & Cebt zum Wiederaufgau Opfer! & 0 & P40 & politico \\
\hline 1946_RW_00 & 1946 & RUDOLPH, Wilhelm & Wäht Liste 1 & 0 & P40 & $\begin{array}{l}\text { Politico } \\
\end{array}$ \\
\hline 1946_SM_00 & 1946 & $\begin{array}{l}\text { SCHWIMMER, Max, BAUS, } \\
\text { Georg }\end{array}$ & Leipziger Kunstausstellung & 0 & P40 & cultural \\
\hline 1946_SW_00 & 1946 & SCHUBERT, Wilhelm & $\begin{array}{l}\text { SED Das Kraftzentrum für den Neuauffau } \\
\text { Deutschlands }\end{array}$ & Offset & Überklebt- Plakate aus der DDR & Politico \\
\hline 1947_BG_00 & 1947 & BAUS, Georg & Buch-Schrift-Werbekunst & Litografía & Überklebt-Plakate aus der DDR & Cultural \\
\hline 1947_BG_01 & 1947 & BAUS, Georg & Läden und Casstrataten im Aurfbau & Litografía & Überklebt- Plakate aus der DDR & Cultural \\
\hline 1947_BM_00 & 1947 & BEYER, Maxkarl & $\begin{array}{l}\text { 1. Landesaustellung Bildender Künstler } \\
\text { Thüringens }\end{array}$ & Offset & Überklebt-Plakate aus der DDR & Cultural \\
\hline 1947_DW_00 & 1947 & DEFFKE, Wilhelm & Magdeburg lebt & 0 & $\mathrm{P} 40$ & Cultural \\
\hline 1947_RP_00 & 1947 & ROSIÉ, Paul & $\begin{array}{l}\text { Kennt lhr Euch überhaupt! Geschlechts- } \\
\text { krankheiten drohen! }\end{array}$ & Offiset & Überklebt- Plakate aus der DDR & Politico \\
\hline 1948_DW_00 & 1948 & DEFFKE, Wilhelm & Grođe Kunstaustellung Sachsen-Anhalt & Offset & Überklebt-Plakate aus der DDR & Cultural \\
\hline 1948_F__00 & 1948 & FENNEKER, losef & Offenbach - Orpheus in der Untervelt & Offiset & Überklebt-Plakate aus der DDR & Cultural \\
\hline 1948_FW_00 & 1948 & FUNKAT, Walter & Die Burg stellt aus & & Überklebt-Plakate aus der DDR & Cultural \\
\hline 1948_GF_00 & 1948 & GRAVENHORST, Fred & $\begin{array}{l}\text { Den Toten zu Ehren, den Lebenden zur } \\
\text { Plicht-WN Gedenktag }\end{array}$ & Offiset & Überklebt- Plakate aus der DDR & Pollitico \\
\hline 1948_GK_00 & 1948 & GEORGI, Klaus & Halle plant, Halle schafft & Litografía & Überklebt- Plakate aus der DDR & Cultural \\
\hline 1948_WH_00 & 1948 & WOLTER, Horst Erich & $\begin{array}{l}\text { Was will die National-Demokratische } \\
\text { Partei? }\end{array}$ & Imprenta & Überklebt- Plakate aus der DDR & Politico \\
\hline 1948_WH_01 & 1948 & WOLTER, Horst Erich & Joh. Seb. Bach Hohe Messe & Imprenta & Überklebt-Plakate aus der DDR & Politico \\
\hline 1949_BH_O0 & 1949 & BALTZER, Hans & Goethe 1749-1949 & 0 & P40 & Cultural \\
\hline 1949_BL_00 & 1949 & BARUTZKK, Lothar & 1. Mai fur Frrieden und Freiheit & Offiset & Überklebt-Plakate aus der DDR & Politico \\
\hline 1949_KG_00 & 1949 & $\begin{array}{l}\text { Klasse Gebrauchsgraphik Burg } \\
\text { Giebichenstein Halle }\end{array}$ & 2 lahresplan Friedensplan 1. Mai & Offiset & Überklebt- Plakate aus der DDR & Cultural \\
\hline 1949_MD_00 & 1949 & $\begin{array}{l}\text { MÖNKEMEYYR-CORTY, } \\
\text { Dorothea }\end{array}$ & 2. Deutsche Kunstausstellung & Offiset & Überklebt- Plakate aus der DDR & Cultural \\
\hline 1949_MH_00 & 1949 & MEINTZSCHEL, Hanjjochen & 1 ahr Sport in Sachsen FDI FDGB & Ofiset & Überklebt- Plakate aus der DDR & Cultural \\
\hline 1949_NC_00 & 1949 & NEHER, Caspar & Herr Puntila und sein Knecht Matti & 0 & P40 & Cultural \\
\hline 1949_SW_00 & 1949 & SCHUBERT, Wilhelm & Denk an uns! & 0 & P40 & Politico \\
\hline 1949_WK_O0 & 1949 & WITTKUGEL, Klaus & Goethe & Ofiset & Überklebt- Plakate aus der DDR & Cultural \\
\hline 1949_WK_01 & 1949 & $\begin{array}{l}\text { WITTKUGEL, Klaus, EBERT, } \\
\text { Oswald }\end{array}$ & mensch und arbeit & 0 & P40 & Cultural \\
\hline
\end{tabular}




\begin{tabular}{|c|c|c|c|c|c|c|}
\hline CÓDIGO & AÑo & AUTOR & TítULO & TIPO & FUENTE & GÉNERO \\
\hline 1950_GR_00 & 1950 & GRAETZ, René & Erzwingt den Frieden & Ofiset & Überklebt-Plakate aus der DDR & Pollitico \\
\hline 1950_WK_00 & 1950 & WITTKUGEL, Klaus & Das katte Herz & Ofisset & Überklebt-Plakate aus der DDR & Cultural \\
\hline 1950_WK_01 & 1950 & WITTKUGEL, Klaus & Qualität & Ofiset & Überklebt-Plakate aus der DDR & Cultural \\
\hline 1950_WP_00 & 1950 & WEIX, Peterpaul & Lenin Ausstellung & 0 & P40 & Politico \\
\hline 1951_HJ_00 & 1951 & $\begin{array}{l}\text { HEARTFIELD, John, HERZFEL- } \\
\text { DE, Wieland }\end{array}$ & Erster Deutscher Kulturkongre区 & Imprenta & Überklebt- Plakate aus der DDR & Cultural \\
\hline 1951_KS_00 & 1951 & KRAFT, Siegried & $\begin{array}{l}\text { Brillengläser von Weltur: VEB Carl } \\
\text { Zeiss lena }\end{array}$ & 0 & DDR-Werkbund & Económico \\
\hline 1951_NM__00 & 1951 & NAUMANN, Max & HO Warenhäuser & Litografía & Überklebt- Plakate aus der DDR & Económico \\
\hline 1951_PP_00 & 1951 & $\begin{array}{l}\text { PALITZSCH, Peter, HAAC- } \\
\text { KEN, Frans }\end{array}$ & Brecht-Mutter Courage und ihre Kinder & Ofiset & Überklebt- Plakate aus der DDR & Cultural \\
\hline 1951_SW_00 & 1951 & SCHUBERT, Wilhelm & $\begin{array}{l}\text { Unser Leben fordert Deutsche, vereinigt } \\
\text { Euch }\end{array}$ & Ofiset & Überklebt- Plakate aus der DDR & Politico \\
\hline 1951_WK_00 & 1951 & WITTKUGEL, Klaus & Unser Fünffahrplan & Ofiset & Überklebt-Plakate aus der DDR & Politico \\
\hline 1951_WP_00 & 1951 & WEII, Peterpaul & Leipziger Messe 1951 & 0 & P40 & Econónico \\
\hline 1952_BH_O0 & 1952 & BALTZER, Hans & Hermecke/Dostal-Doktor Eisenbart & Ofiset & Überklebt-Plakate aus der DDR & Cultural \\
\hline 1952_BH_01 & 1952 & BALTZER, Hans & Konsum & 0 & DDR-Werkbund & Económico \\
\hline 1952_HJ_00 & 1952 & $\begin{array}{l}\text { HEARTFIELD, John, HERZFEL- } \\
\text { DE, Wieland, HILL, Hainer }\end{array}$ & Das Glockenspiel des Kreml & Ofiset & Überklebt-Plakate aus der DDR & Cultural \\
\hline 1952_WK_00 & 1952 & WITTKUGEL, Klaus & Ich bin Bergmann, wer ist mehr? & Ofiset & Überklebt- Plakate aus der DDR & Politico \\
\hline 1953_KS_00 & 1953 & KRAFT, Siegfried & $\begin{array}{l}\text {... und ein Feldstecher aus lena gehört } \\
\text { dazu }\end{array}$ & 0 & Überklebt-Plakate aus der DDR & Económico \\
\hline 1953_SW_00 & 1953 & SCHUBERT, Wilhelm & Karl Marx 1818-1883 & 0 & P40 & Politico \\
\hline 1953_WR_00 & 1953 & WEYL, Roman & Zinner-Der Teufelskreels & 0 & $\mathrm{P} 40$ & Cultural \\
\hline 1954_A__00 & 1954 & Anónimo & HO-Stalinallee & 0 & DDR-Werkbund & Económico \\
\hline 1954_AK_00 & 1954 & APPEN, Karl von & Der Kaukasische Kreidekreis & 0 & P40 & Cultural \\
\hline 1954_BH__o0 & 1954 & BALTZER, Hans & Rom 11 Uhr & Ofiset & Überklebt-Plakate aus der DDR & Cultural \\
\hline 1954_BH_00 & 1954 & BALTZER, Hans & Salz der Erde & 0 & P40 & Cultural \\
\hline 1954_BH_01 & 1954 & BALTZER, Hans & Der Celiebte einer Königin & Ofiset & Überklebt-Plakate aus der DDR & Cultural \\
\hline 1954_GH_O0 & 1954 & GELL, Horst & Lebona wissenschaftiche Kosmetik & Ofiset & Überklebt-Plakate aus der DDR & Económico \\
\hline 1954_HF_O0 & 1954 & HAACKEN, Frans & Viel Lärm und nichts & Ofiset & Überklebt-Plakate aus der DDR & Cultural \\
\hline 1954_HF_01 & 1954 & HAACKEN, Frans & Nestroy-Der Zerrissene & Offset & Überklebt- Plakate aus der DDR & Cultural \\
\hline 1954_KW_00 & 1954 & KLEMKE, Werner & Die Ferien des Monsieur Hulot & Ofiset & Überklebt-Plakate aus der DDR & Cultural \\
\hline 1954_RP_00 & 1954 & ROSIÉ, Paul & Kleider machen Leute & Ofiset & Überklebt-Plakate aus der DDR & Cultural \\
\hline 1954_RP_01 & 1954 & ROSIÉ, Paul & Moulin Rouge & 0 & P40 & Cultural \\
\hline 1954_WH_00 & 1954 & WAGNER, Heinz & $\begin{array}{l}\text { Schhlu damit' Wäht die Kandidaten des } \\
\text { Friedens }\end{array}$ & Ofiset & Überklebt-Plakate aus der DDR & Pollitico \\
\hline 1954_WK_00 & 1954 & WITTKUGEL, Klaus & Ausstellung Das Plakat & Ofiset & Überklebt-Plakate aus der DDR & Cultural \\
\hline 1954_WR_00 & 1954 & WEYL, Roman & Marceau In der Volksbühne & 0 & P40 & Cultural \\
\hline 1955_A_00 & 1955 & Anónimo & Bino Würze & 0 & DDR-Werkbund & Económico \\
\hline 1955_A_01 & 1955 & Anónimo & Das lahrbuch fuir die Frau & 0 & DDR-Werkbund & Econónico \\
\hline 1955_A_02 & 1955 & Anónimo & Rotplombe & 0 & DDR-Werkbund & Econónico \\
\hline 1955_AK_o0 & 1955 & APPEN, Karl von & Farquhar/Brecht-Pauken und Trompeten & Offiset & Überklebt-Plakate aus der DDR & Cultural \\
\hline 1955_GG_00 & 1955 & GNAUCK, Günter & Borchert-Draussen vor der Tür & Imprenta & Überklebt- Plakate aus der DDR & Cultural \\
\hline 1955_H_OOO & 1955 & HEARTFIELD, John & Fordert: Verbot der Atomwaffen & Ofiset & Überklebt-Plakate aus der DDR & Politico \\
\hline 1955_H__01 & 1955 & HEARTFELL, John & Holz-Sozialaristokraten & Offset & Überklebt- Plakate aus der DDR & Cultural \\
\hline 1955_H__02 & 1955 & $\begin{array}{l}\text { HEARTFELLD, John, HERZFEL- } \\
\text { DE, Wieland }\end{array}$ & Becher-Winterschlacht & 0 & P40 & Cultural \\
\hline
\end{tabular}

\begin{tabular}{|c|c|c|c|c|c|c|}
\hline CÓDIGo & AÑO & AUTOR & Título & TIPO & FUENTE & GÉNERO \\
\hline 1955_KW_00 & 1955 & KLEMKE, Werner & Rot und Schwarz & Offiset & Überklebt-Plakate aus der DDR & Cultural \\
\hline 1955_KW_01 & 1955 & KLEMKE, Werner & Die drei Musketiere & Offiset & Überklebt-Plakate aus der DDR & Cultural \\
\hline 1955_MW_00 & 1955 & MATTHEUER, Wolfgang & Zeitgenössische Deutsche Grafik & Ofiset & Überklebt-Plakate aus der DDR & Cultural \\
\hline 1955_SF_00 & 1955 & SPRINGEFELD, Fritz & KONSUM gut ausgerüstet in den Sommer & Offiset & Überklebt-Plakate aus der DDR & Económico \\
\hline 1955_SM_00 & 1955 & $\begin{array}{l}\text { SCHULTZE, Margarete \& } \\
\text { Walter }\end{array}$ & Witto-Reiniger macht das mit Leichtigkeit & Offiset & Überklebt-Plakate aus der DDR & Económico \\
\hline 1956_A_00 & 1956 & Anónimo & Sommersandalette & Offiset & Überklebt-Plakate aus der DDR & Económico \\
\hline 1956_AE_00 & 1956 & AUER, Erika & 2. Fest junger Künstler & Offiset & Überklebt-Plakate aus der DDR & Cultural \\
\hline 1956_CK_00 & 1956 & GEFFERS, Kurt & Ehe im Schatten & 0 & P40 & Cultural \\
\hline 1956_KD_00 & 1956 & KAUFMANN, Dietrich & Peking-Oper & Offiset & Überklebt-Plakate aus der DDR & Cultural \\
\hline 1956_NH_00 & 1956 & NAUMANN, Horst & Zoo Dresden & Offiset & Überklebt-Plakate aus der DDR & Cultural \\
\hline 1956_PW_00 & 1956 & PETZOLD, Willy & Zwinger-Lotterie & Offiset & Überklebt-Plakate aus der DDR & Económico \\
\hline 1956_SF_00 & 1956 & SPRINGEFELD, Fritz & Perlonstrumpe KONSUM & Offiset & Überklebt-Plakate aus der DDR & Económico \\
\hline 1956_SG_00 & 1956 & SCHMITZ, Günter & Frohe Ferientage & Offiset & Überklebt-Plakate aus der DDR & Pollitico \\
\hline 1956_SM_00 & 1956 & $\begin{array}{l}\text { SCHULTZE, Margarete \& } \\
\text { Walter }\end{array}$ & Leipziger Messe & Offiset & Überklebt- Plakate aus der DDR & Cultural \\
\hline 1956_SM_01 & 1956 & SCHWIMMER, Max & Shakespeare -Ein Sommernachtstraum & Offiset & Überklebt- Plakate aus der DDR & Cultural \\
\hline 1956_VG_00 & 1956 & VOIGT, Gerhard & $\begin{array}{l}\text { Dessau Meisterschaftslauf für Motorràder } \\
\text { und Wagen }\end{array}$ & $\begin{array}{l}\text { Offiset } \\
\end{array}$ & Überklebt- Plakate aus der DDR & Cultural \\
\hline 1957_A_00 & 1957 & Anónimo & Esda & 0 & DDR-Werkbund & Económico \\
\hline 1957_GH_00 & 1957 & GEIL, Horst & Fit ohne abzutrocknen & Offset & Überklebt-Plakate aus der DDR & Económico \\
\hline 1957_GH_01 & 1957 & GROHMANN, Herbert & Denk an Wenckt! & Offiset & Überklebt-Plakate aus der DDR & Político \\
\hline 1957_GH_02 & 1957 & GROHMANN, Herbert & Arbeiter! In die Partei der Arbeiter & 0 & P40 & Pollitico \\
\hline 1957_GR_00 & 1957 & GRAETZ, René & Künstler wählen Frieden und Sozialismus & 0 & $\mathrm{P} 40$ & Cultural \\
\hline 1957_HB_00 & 1957 & HELLER, Bert & MacColl-Unternehmen Ölzweig & Offiset & Überklebt-Plakate aus der DDR & Cultural \\
\hline 1957_H__00 & 1957 & HEARTFIELD, John & Weg mit der Sonnenfinsterris am Rhein! & 0 & P40 & Político \\
\hline 1957_HR_00 & 1957 & HEINRICH, Rudolf & Britten-Albert Hering & Offiset & Überklebt-Plakate aus der DDR & Cultural \\
\hline 1957」H_00 & 1957 & JÜTTE, H.F. & Agfa-Viskose-Schwamm & 0 & DDR-Werkbund & Económico \\
\hline 1957_KH_00 & 1957 & KIPPNICK, Heinz & Mais ist Wurst am Stiel & Serigrafíia & Überklebt-Plakate aus der DDR & Económico \\
\hline 1957_KW_00 & 1957 & KLEMKE, Werner & Der Hauptmann von Köpenick & Offiset & Überklebt- Plakate aus der DDR & Cultural \\
\hline 1957_KW_01 & 1957 & KLEMKE, Werner & Giraudoux-Amphitryon & Offiset & Überklebt- Plakate aus der DDR & Cultural \\
\hline 1957_KW_02 & 1957 & KLEMKE, Werner & Die Rebellion der Gehenkter & 0 & P40 & Cultural \\
\hline 1957_MA_00 & 1957 & MOHR, Arno & Gorki-Die Kleinbürger & 0 & $\mathrm{P} 40$ & Cultural \\
\hline 1957_RP_00 & 1957 & ROSIÉ, Paul & Gervaise & 0 & P40 & Cultural \\
\hline 1957_SG_00 & 1957 & SCHMITZ, Günter & "wohin?""Konsum!" & Offiset & Überklebt-Plakate aus der DDR & Económico \\
\hline 1957_SR_00 & 1957 & SKRIBELKA, Rudolf & Im Westens nichts neues & Offiset & Überklebt-Plakate aus der DDR & Pollitico \\
\hline 1957_SW_00 & 1957 & SCHUBERT, Wilhelm & Du entscheidest! & 0 & P40 & 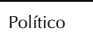 \\
\hline 1957_VG_00 & 1957 & VOIGT, Gerhard & staatl. Galerie moritzburg halle-s & Offiset & Überklebt. Plakate aus der DDR & Cultural \\
\hline 1957_WK_00 & 1957 & WITTKUGEL, Klaus & 19171957 & Offiset & Überklebt- Plakate aus der DDR & 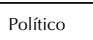 \\
\hline 1957_WK_01 & 1957 & WITTKUGEL, Klaus & Wer Adenauer wähtt wählt der Atomkrieg & Offiset & Überklebt-Plakate aus der DDR & 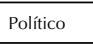 \\
\hline 1957_WP_00 & 1957 & WEI囚, Peterpaul & Austellung Deutsche Plakate 1895-1932 & Serigrafía & Überklebt-Plakate aus der DDR & Cultural \\
\hline 1958_A_00 & 1958 & Anónimo & $\begin{array}{l}\text { VEB Fahrzeug und Gerätewerk Simson } \\
\text { Suhl }\end{array}$ & 0 & DDR-Werkbund & Económico \\
\hline 1958_FH_00 & 1958 & FÖRTSCH, Hans & de filipo: Lugen haben lange Beine & Offiset & Überklebt- Plakate aus der DDR & Cultural \\
\hline 1958_KW_00 & 1958 & KLEMKE, werner & Hacks-Der Müller von Sanssouci & Offset & Überklebt- Plakate aus der DDR & Cultural \\
\hline 1958_VG_00 & 1958 & VOIGT, Gerhard & bunte erden in formender hand & 0 & P40 & Econónico \\
\hline 1958_WK_00 & 1958 & WITTKUGEL, Klaus & $\begin{array}{l}\text {... dass nie eine Mutter mehr ihren Sohn } \\
\text { beweint }\end{array}$ & 0 & P40 & Pollitico \\
\hline
\end{tabular}




\begin{tabular}{|c|c|c|c|c|c|c|}
\hline CÓDIGO & AÑO & AUTOR & Título & TIPO & FUENTE & GÉNERO \\
\hline 1958_WR_00 & 1958 & WEYL, Roman & Rehfisch/Herzog -Die Affaire Dreyfus & Ofiset & Überklebt-Plakate aus der DDR & Cultural \\
\hline 1958_WW_00 & 1958 & WOLFGRAMM, Willi? & Schlagt die Atomkrieger & $\begin{array}{l}\text { Ofiset } \\
\text { Ont }\end{array}$ & Überklebt-Plakate aus der DDR & $\begin{array}{l}\text { Politico } \\
\end{array}$ \\
\hline 1959_A_00 & 1959 & Anónimo & VEB Errst-Thälmann-Werke Suhl & 0 & DDR-Werkbund & Econónico \\
\hline 1959_Hв_00 & 1959 & HELER, Bert & Hauser IIm Himmlischen Garten & Ofiset & Überklebt-Plakate aus der DDR & Cultural \\
\hline 1959_KD_00 & 1959 & KAUFMANN, Dietrich & Othello & Ofiset & Überklebt-Plakate aus der DDR & Cultural \\
\hline 1959_LK_00 & 1959 & LEMKE, Klaus & WERRA Sie haben die Wahl & Ofiset & Überklebt-Plakate aus der DDR & Económico \\
\hline 1959_RP_00 & 1959 & ROSIÉ, Paul & Toller-Der entfesselte Wotan & 0 & P40 & Cultural \\
\hline 1959_WK_00 & 1959 & WITTKUGEL, Klaus & Steme & Ofiset & Überklebt-Plakate aus der DDR & $\begin{array}{l}\text { Cultural } \\
\end{array}$ \\
\hline 1960_AK_00 & 1960 & APPEN, Karl von & Baierl-Frau Flinz & Ofiset & Überklebt-Plakate aus der DDR & Cultural \\
\hline 1960_H_O00 & 1960 & HEARTFIELD, John & Niemals wieder! & 0 & P40 & $\begin{array}{c}\text { Polfitico } \\
\end{array}$ \\
\hline 1960_KW_00 & 1960 & KLEMKE, Werner & Lessing -Minna von Barnhelm & Offiset & Überklebt-Plakate aus der DDR & Cultural \\
\hline 1960_KW_01 & 1960 & KLEMKE, Werner & Messeschlager Cisela & 0 & DDR-Werkbund & Económico \\
\hline 1960_NH_00 & 1960 & NAUMANN, Horst & ..fange nicht terst an! & Ofiset & Überklebt-Plakate aus der DDR & 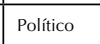 \\
\hline 1960_NL_00 & 1960 & NEUPERT, Luise \& Hans & Dederon & Ofiset & Überklebt-Plakate aus der DDR & Cultural \\
\hline 1960_NL_01 & 1960 & NEUPERT, Luise \& Hans & Dederon & Ofiset & Überklebt-Plakate aus der DDR & Económico \\
\hline 1961_A_00 & 1961 & Anónimo & Halle-Saale-Schleife & $\begin{array}{l}\text { Ofiset } \\
\text {. }\end{array}$ & Überklebt-Plakate aus der DDR & Cultural \\
\hline 1961_A_01 & 1961 & Anónimo & VEB Meissner Schurfabrik & 0 & DDR-Werkbund & Económico \\
\hline 1961_EH_00 & 1961 & ERNST, Hans-Eberhard & Wolf-Beaumarchais & Ofiset & Überklebt-Plakate aus der DDR & Cultural \\
\hline 1961_ME_00 & 1961 & MÄNNEL, Erich H. & Gerade im Sommer & 0 & DDR-Werkbund & Económico \\
\hline 1961_NH_00 & 1961 & NAUMANN, Hermann & $\begin{array}{l}\text { Brecht-Austitig und Fall der Stadt } \\
\text { Mahagonny }\end{array}$ & Ofiset & Überklebt-Plakate aus der DDR & Cultural \\
\hline 1962_A_00 & 1962 & Anónimo & Jetzt spar r rente fuir später & 0 & DDR-Werkbund & Econónico \\
\hline 1962_BG_00 & 1962 & BRANDT, Günter & Stop vergeude kein Wasser & Ofiset & Überklebt-Plakate aus der DDR & Pollitico \\
\hline 1962_H__00 & 1962 & $\begin{array}{l}\text { HORLBECK-KAPPLER, } \\
\text { Irmgard }\end{array}$ & $\begin{array}{l}\text { Reclams Universalbibliothek-Der Ausflug } \\
\text { der toten Mädchen von Anna Seghers }\end{array}$ & Ofiset & Überklebt-Plakate aus der DDR & Cultural \\
\hline 1962_RG_00 & 1962 & RÖDER, Gisela & Im Weissen Rösst & 0 & P40 & Cultural \\
\hline 1963___00 & 1963 & Anónimo & Wartburg-1000 sonder Typen & 0 & DDR-Werkbund & Econónico \\
\hline 1963_GR_00 & 1963 & GRÜTTNER, Rudolf & Gerlach -Der Knall & Ofiset & Überklebt-Plakate aus der DDR & Cultural \\
\hline 1963_KD_00 & 1963 & KAUFMANN, Dietrich & Ritter Blaubart & 0 & P40 & Cultural \\
\hline 1963_MU_00 & 1963 & MÜLLER, Utz & Weltag des Theaters & $\begin{array}{l}\text { Ofiset } \\
\end{array}$ & Überklebt-Plakate aus der DDR & $\begin{array}{l}\text { Cultural } \\
\end{array}$ \\
\hline 1963_UI_00 & 1963 & UHLCH, Inge & Unsere Heinzelmännchen & 0 & DDR-Werkbund & Económico \\
\hline 1964_A_00 & 1964 & Anónimo & Wartburg-1000 auto mobile & 0 & DDR-Werkbund & Económico \\
\hline 1964_HG_00 & 1964 & HILLER, Günter & 800 /ahre Leipzziger Messe & $\begin{array}{l}\text { Ofiset } \\
\end{array}$ & Überklebt-Plakate aus der DDR & Cultural \\
\hline 1964_HH_00 & 1964 & HANDSCHICK, Heinz & Zeugin der Anklage & Offiset & Überklebt-Plakate aus der DDR & Cultural \\
\hline 1964_RL_00 & 1964 & REHER, Lothar & Buch Club 65 & Ofiset & Überklebt-Plakate aus der DDR & Cultural \\
\hline 1964_RP_00 & 1964 & ROSIÉ, Paul & bis hierher und so weiter... & $\begin{array}{l}\text { Ofiset } \\
\end{array}$ & Überklebt-Plakate aus der DDR & Cultural \\
\hline 1964_UH_00 & 1964 & UNZNER, Heinz & Achtung Clatteis & Ofiset & Überklebt-Plakate aus der DDR & $\begin{array}{l}\text { Politico } \\
\end{array}$ \\
\hline 1965 _A_00 & 1965 & $\begin{array}{l}\text { Anónimo } \\
\end{array}$ & Charlotte Meentzen & 0 & DDR-Werkbund & Económico \\
\hline 1965_A_00 & 1965 & Anónimo & Demusa & 0 & DDR-Werkbund & Econónico \\
\hline 1965_A_01 & 1965 & Anónimo & Frisese Decken & 0 & DDR-Werkbund & Económico \\
\hline 1965_FA_00 & 1965 & FREYER, Achim & $\begin{array}{l}\text { O'Casey -Der Mond scheint auf } \\
\text { Kylenamoe }\end{array}$ & Ofiset & Überklebt-Plakate aus der DDR & Cultural \\
\hline 1965_GE_00 & 1965 & GRÜTTNER, Erhard & Asche und Diamant & Ofiset & Überklebt-Plakate aus der DDR & Cultural \\
\hline 1965_GW_00 & 1965 & GOTTSMANN, Werner & Der Boss hat sich was ausgedacht & Offiset & Überklebt-Plakate aus der DDR & Cultural \\
\hline 1965_GW_01 & 1965 & GOTTSMANN, Wener & Der Dieb von Bagdad & Ofiset & Überklebt-Plakate aus der DDR & Cultural \\
\hline 1965_HH_00 & 1965 & HANDSCHICK, Heinz & Seelenwanderung & Offiset & Überklebt-Plakate aus der DDR & Cultural \\
\hline 1965_HH_01 & 1965 & HANDSCHICK, Heinz & Der Vater des Soldates & 0 & P40 & Cultural \\
\hline
\end{tabular}

\begin{tabular}{|c|c|c|c|c|c|c|}
\hline CÓDIGO & AÑO & AUTOR & Título & TIPO & FUENTE & GÉNERO \\
\hline 1965_KH_00 & 1965 & KIPPNICK, Heinz & $\begin{array}{l}\text { 1. Mai Internationale Kampf- und Feiertag } \\
\text { der Arbeiterklasse }\end{array}$ & Offiset & Überklebt-Plakate aus der DDR & Polfitico \\
\hline 1965_KW_00 & 1965 & KLEMKE, Werner & $\begin{array}{l}\text { Shaw -Die Millionäriri } \\
\end{array}$ & 0 & $\mathrm{P} 40$ & Cultural \\
\hline 1965_NP_00 & 1965 & NAGENGAST, Peter & $\begin{array}{l}\text { Moral } 63 \\
\end{array}$ & Offset & Überklebt-Plakate aus der DDR & Cultural \\
\hline 1965_PH_00 & 1965 & PFLAUM, Harry & uuf den strassen des friedens & 0 & P40 & $\begin{array}{ll}\text { Politico } \\
\end{array}$ \\
\hline 1965_SK_00 & 1965 & SEGNER, Klaus & Der Staatsverbrecher & Offiset & Überklebt-Plakate aus der DDR & Cultural \\
\hline 1965_ST_00 & 1965 & SCHLEUSING, Thomas & Chris Barber and his lazz-Band & Ofiset & Überklebt-Plakate aus der DDR & Cultural \\
\hline 1965_ST_01 & 1965 & SCHLEUSING, Thomas & Pariser Leben, & Offiset & Überklebt-Plakate aus der DDR & Cultural \\
\hline 1966_A_00 & 1966 & Anónimo & Trabant 601 & 0 & DDR-Werkbund & Económico \\
\hline 1966_BA_00 & 1966 & BERTRAM, Axel & Der gewöhnliche Faschismus & Offiset & Überklebt-Plakate aus der DDR & Cultural \\
\hline 1966_BA_01 & 1966 & BERTRAM, Axel & My Fair Lady & Offiset & Überklebt-Plakate aus der DDR & Cultural \\
\hline 1966_F__00 & 1966 & FRITSCHE, Jo & Shakespeare-Ma区 für Ma区 & Offset & Überklebt-Plakate aus der DDR & Cultural \\
\hline 1966_CE_00 & 1966 & GRÜTTNER, Ehhard & Spartakus & Offiset & Überklebt-Plakate aus der DDR & Cultural \\
\hline 1966_HH_01 & 1966 & HANDSCHICK, Heinz & ....drauf vorbereitet? & Offiset & Überklebt-Plakate aus der DDR & Pollitico \\
\hline 1966_HK_00 & 1966 & HENNIG, Klaus & Verhindert Waldbrände & 0 & P40 & $\begin{array}{l}\text { Politico } \\
\end{array}$ \\
\hline 1966_HN_00 & 1966 & HORNIG, Norbert & 1. Mai 1966 & Offiset & Überklebt-Plakate aus der DDR & Político \\
\hline 1966_KH_00 & 1966 & KIPPNICK, Heinz & Ettern achtet darauf & Offiset & Überklebt-Plakate aus der DDR & Pollitico \\
\hline 1966_KR_00 & 1966 & KUHRT, Rolf & Shakespeare-Das wintermärchen & & Überklebt-Plakate aus der DDR & Cultural \\
\hline 1966_KR_01 & 1966 & $\begin{array}{l}\text { KNORR, Ruth } \\
\end{array}$ & Lessing-Nathan der Weise & Offset & Überklebt-Plakate aus der DDR & Cultural \\
\hline 1966_KS_00 & 1966 & KRAFT, Siegrried & 1966 sommerschau & Offiset & Überklebt-Plakate aus der DDR & Cultural \\
\hline 1966_LW_00 & 1966 & LUMPE, Wilfried & Biathlon Weltmeisterschaft DDR & Offiset & Überklebt- Plakate aus der DDR & Cultural \\
\hline 1966_MR_00 & 1966 & MÜLLER, Rolf Felix & Hochhuth-Der Stellvertreter & Offiset & Überklebt-Plakate aus der DDR & Cultural \\
\hline 1966_RP_00 & 1966 & ROSIÍ, Paul & Zirkus Olympia & Offiset & Überklebt-Plakate aus der DDR & $\begin{array}{l}\text { Cultural } \\
\end{array}$ \\
\hline 1966_SG_00 & 1966 & SCHMITZ, Günter & Zirkus Aeros Eisbärdressur & Offiset & Überklebt-Plakate aus der DDR & Cultural \\
\hline 1966_ST_00 & 1966 & SCHLEUSING, Thomas & $\begin{array}{l}\text { Hokus Pokus oder wie lasse ich meinen } \\
\text { Mann verschwinden }\end{array}$ & Offiset & Überklebt- Plakate aus der DDR & Cultural \\
\hline 1966_UW_00 & 1966 & UNFUG, Werner & Zirkus Aeros & Offiset & Überklebt-Plakate aus der DDR & Cultural \\
\hline 1966_WS_00 & 1966 & WUNDERLICH, Sonja & Woche des Buches & Offiset & Überklebt-Plakate aus der DDR & Cultural \\
\hline 1967_A_00 & 1967 & Anónimo & VEB Waschgerätewerk Schwarzenberg & 0 & DDR-Werkbund & Económico \\
\hline 1967_AH_00 & 1967 & ALEERT, Heinz & Goldina & 0 & DDR-Werkbund & Económico \\
\hline 1967_DG_00 & 1967 & DIDZUN, Gerd & Effe Berliner Schookolade & 0 & DDR-Werkbund & Económico \\
\hline 1967_F_00 & 1967 & FRITSCHE, Jo & Freiheit für Kurt Baumgarte & Offiset & Überklebt-Plakate aus der DDR & Pollitico \\
\hline 1967_GK_00 & 1967 & GEFFERS, Kurt & Wie der Stahl gehärtet wurde & Offiset & Überklebt- Plakate aus der DDR & $\begin{array}{c}\text { Cultural } \\
\end{array}$ \\
\hline 1967_GR_00 & 1967 & GRÜTTNER, Rudolf & $\begin{array}{l}\text { Brecht-Der auffaltsame Aufstieg des } \\
\text { Arturo } \mathrm{Ui}\end{array}$ & Offiset & Überklebt- Plakate aus der DDR & Cultural \\
\hline 1967_GR_01 & 1967 & GRÜTTNER, Rudolf & Gorki-Somow und andere & Offset & Überklebt-Plakate aus der DDR & Cultural \\
\hline 1967_HH_00 & 1967 & HANDSCHICK, Heinz & sporting life & 0 & $\mathrm{P} 40$ & Cultural \\
\hline 1967_HN_00 & 1967 & HORNIG, Norbert & streut & Offiset & Überklebt-Plakate aus der DDR & $\begin{array}{ll}\text { Politico } \\
\end{array}$ \\
\hline 1967_KE_00 & 1967 & KOBE, Else & Warm und wetterfest gekleidet & Offiset & Überklebt- Plakate aus der DDR & $\begin{array}{l}\text { Económico } \\
\end{array}$ \\
\hline 1967_KF_00 & 1967 & $\begin{array}{l}\text { Kollektiv Flieger Schallnau } \\
\text { Wongel }\end{array}$ & Frieden -Fortschritt-Sozzialismus & 0 & P40 & 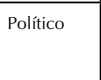 \\
\hline 1967_KH_00 & 1967 & KORGER, Hildegard & $\begin{array}{l}\text { 3. Internationaler Iohann-Sebastian-Bach } \\
\text { Wettbewerb Leipzzig }\end{array}$ & Offiset & Überklebt- Plakate aus der DDR & Cultural \\
\hline 1967_KM_00 & 1967 & KINAST, Margit & 50 lahre Sowjetmacht & Offiset & Überklebt-Plakate aus der DDR & Politico \\
\hline 1967_MR_00 & 1967 & MÜLLER, Rolf Felix & My Fair Lady & Offiset & Überklebt-Plakate aus der DDR & Cultural \\
\hline 1967_MU_00 & 1967 & MÜLLER, Utz & Weihnachtsbasar & 0 & 128 Plakate & Económico \\
\hline 1967_PH_00 & 1967 & PRÜGET, Herbert & VII. Parteitag der SED & Offiset & Überklebt-Plakate aus der DDR & Político \\
\hline 1967_PV_00 & 1967 & PFÜLLER, Volker & Hotels und Casstsätten der $\mathrm{HO}$ & Serigrafía & Überklebt-Plakate aus der DDR & Económico \\
\hline
\end{tabular}




\begin{tabular}{|c|c|c|c|c|c|c|}
\hline CÓDIGO & AÑ̃ & AUTOR & TítULO & TIPO & FUENTE & GÉNERO \\
\hline 1967_RG_00 & 1967 & RAPPUS, Gerhard & Moskauer Kammerorchester & Ofiset & Überklebt-Plakate aus der DDR & Cultural \\
\hline 1967_ST_00 & 1967 & SCHLEUSING, Thomas & Reformation 1527-1967 & Ofiset & Überklebt-Plakate aus der DDR & Cultural \\
\hline 1967_ST_01 & 1967 & SCHLEUSING, Thomas & Woche des Buches 1967 & $\begin{array}{l}\text { Ofiset } \\
\text {. }\end{array}$ & Überklebt-Plakate aus der DDR & Cultural \\
\hline 1967_SW_00 & 1967 & SCHILLER, Walter & $\begin{array}{l}50 \text { Jahre grosse sozialistische Oktober- } \\
\text { revolution }\end{array}$ & 0 & P40 & Politico \\
\hline 1967_ZL_00 & 1967 & ZIRATZKI, Lothar & Krafttahrer Fuखgänger & 0 & P40 & Político \\
\hline 1968_A_00 & 1968 & Anónimo & VEB Shirmfabrik Spezial & 0 & DDR-Werkbund & Econónico \\
\hline 1968_A_01 & 1968 & Anónimo & Ika Electrica & 0 & DDR-Werkbund & Económico \\
\hline 1968_BH_00 & 1968 & BRADE, Helmut & Kino gestern und heute & Ofiset & Überklebt-Plakate aus der DDR & Cultural \\
\hline 1968_KO_00 & 1968 & KUMMERT, Otto & $\begin{array}{l}\text { Auch er kauff schon jetzt bei } \\
\text { konsumenten }\end{array}$ & Ofiset & Überklebt-Plakate aus der DDR & Económico \\
\hline 1968_LK_00 & 1968 & LUBINA, Klaus & $\begin{array}{l}\text { Johannes Cutenberg Ehrung zum } 500 . \\
\text { Todesjahr }\end{array}$ & Ofiset & Überklebt-Plakate aus der DDR & Cultural \\
\hline 1968_LW_00 & 1968 & LUMPE, Wilfried & Sicherheit zuerst & Ofiset & Überklebt-Plakate aus der DDR & Politico \\
\hline 1968_MU_00 & 1968 & MÜLLER, Utz & Internationale groखe Grünauer & Offiset & Überklebt-Plakate aus der DDR & Cultural \\
\hline 1968_RG_00 & 1968 & RÖDER, Gisela & Porter-Can Can & Ofiset & Überklebt-Plakate aus der DDR & Cultural \\
\hline 1968_SK_00 & 1968 & SEGNER, Klaus (Gruppe 4) & 50. Jahrestag der Novemberrevolution & 0 & P40 & Politico \\
\hline 1968_WH_00 & 1968 & WENGLER, Helmut & Clas nur in den vorgesehenen Behälter & Ofiset & Überklebt-Plakate aus der DDR & Polifico \\
\hline 1968_WH_01 & 1968 & WAGNER, Heinz & Karl Marx & Ofiset & Überklebt-Plakate aus der DDR & 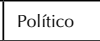 \\
\hline 1968_WK_o0 & 1968 & WITTKUGEL, Klaus & in the name of humanity & $\begin{array}{l}\text { Ofiset } \\
\end{array}$ & Überklebt-Plakate aus der DDR & Polifico \\
\hline 1968_WK_01 & 1968 & WITTKUGEL, Klaus & $\begin{array}{l}\text { Sowjetmacht +Elektrifizierung = } \\
\text { Kommunismus }\end{array}$ & 0 & 128 Plakate & Económico \\
\hline 1969_A_00 & 1969 & Anónimo & VEB Alwo & 0 & DDR-Werkbund & Económico \\
\hline 1969_BA_00 & 1969 & BODECKER, Albrecht von & Zauber der Ornaments & Ofiset & Überklebt-Plakate aus der DDR & Cultural \\
\hline 1969_BG_00 & 1969 & BROSE, Gerhard & lagd-und Trophäenschau & $\begin{array}{l}\text { Ofiset } \\
\end{array}$ & Überklebt-Plakate aus der DDR & Cultural \\
\hline 1969_FA_00 & 1969 & FREYER, Achim & Babel-Maria & 0 & P40 & Cultural \\
\hline 1969_GH_00 & 1969 & $\begin{array}{l}\text { GELL, Horst } \\
\end{array}$ & Kleine Anstrich-Fibel & 0 & DDR-Werkbund & Económico \\
\hline 1969_GM_00 & 1969 & GRÜBER, Max & Seemannsliebe & Serigrafía & Überklebt-Plakate aus der DDR & Cultural \\
\hline 1969_HE_00 & 1969 & HEINICKER, Eberhard & 550 Jahre Universität Rostock & Ofiset & Überklebt-Plakate aus der DDR & Cultural \\
\hline 1969_HH_00 & 1969 & HANDSCHICK, Heinz & Fürfzig Stufen zur Cerechtigkeit & Ofiset & Überklebt-Plakate aus der DDR & Cultural \\
\hline 1969_HLOO & 1969 & $\begin{array}{l}\text { HORLBECK-KAPPLER, } \\
\text { Irmgard }\end{array}$ & Musiktage des Berzirkes Leipzig 1969 & Offiset & Überklebt-Plakate aus der DDR & $\begin{array}{l}\text { Cultural } \\
\end{array}$ \\
\hline 1969_KD_00 & 1969 & KAUFMANN, Dietrich & Die Betteloper & Ofiset & Überklebt-Plakate aus der DDR & Cultural \\
\hline 1969_KO_00 & 1969 & KUMMERT, Otto & $\begin{array}{l}\text { Tanz- und Gesangsembreme der Geor- } \\
\text { gischen SSR }\end{array}$ & 0 & 128 Plakate & Cultural \\
\hline 1969_LS_00 & 1969 & LINKE, Siegfried & RFT dem natürilichen Hören näher & Ofiset & Überklebt-Plakate aus der DDR & Económico \\
\hline 1969_PH_00 & 1969 & PFLAUM, Harry & Eisenbahnreisen nach London & Ofiset & Überklebt-Plakate aus der DDR & Econónico \\
\hline 1969_WH_00 & 1969 & WESSLER, Horst & Tages des polnischen Films & Offset & Überklebt-Plakate aus der DDR & Cultural \\
\hline 1970_A_01 & 1970 & Anónimo & Konsum-Siffenfabrik Riesa & 0 & DDR-Werkbund & Econónico \\
\hline 1970_FA_00 & 1970 & FREYER, Achim & Brecht-Der gute Mensch von Sezuan & Serigrafía & Überklebt-Plakate aus der DDR & Cultural \\
\hline 1970_GR_00 & 1970 & GRÜTTNER, Rudolf & Fidelio & 0 & 128 Plakate & Cultural \\
\hline 1970_GR_01 & 1970 & GRÜTTNER, Rudolf & Wozzert & 0 & P40 & Cultural \\
\hline 1970_KD_00 & 1970 & KAUFMANN, Dietrich & Porgy und Bess & 0 & P40 & Cultural \\
\hline 1970_KO_00 & 1970 & KUMMERT, Otto & Puppentheater André Tahon & Ofiset & Überklebt-Plakate aus der DDR & Cultural \\
\hline 1970_PV_00 & 1970 & PFÜLLER, Volker & Avantgarde & 0 & P40 & Cultural \\
\hline 1970_SW_00 & 1970 & SCHILLER, Walter & Max Klinger Austellung & Ofiset & Überklebt-Plakate aus der DDR & Cultural \\
\hline 1970_WH_O0 & 1970 & WENDT, Horst & Marken+Zeichen & Ofisset & Überklebt- Plakate aus der DDR & Cultural \\
\hline 1971_A_00 & 1971 & Anónimo & Konsum-Seifenfabrik Riesa & 0 & DDR-Werkbund & Económico \\
\hline
\end{tabular}

\begin{tabular}{|c|c|c|c|c|c|c|}
\hline CÓDIGo & AÑO & AUTOR & Título & TIPO & FUENTE & GÉNERO \\
\hline 1971_HG_00 & 1971 & HILLER, Günter & Hiff! & 0 & 128 Plakate & Politico \\
\hline 1971_HH_00 & 1971 & HANDSCHICK, Heinz & Das wilde Kind & 0 & 128 Plakate & $\begin{array}{l}\text { Cultural } \\
\end{array}$ \\
\hline 1971_MR_00 & 1971 & MÜLLER, Rolf Felix & Villion kommt über Paris & 0 & P40 & Cultural \\
\hline 1971_ST_00 & 1971 & SCHLEUSING, Thomas & Mit Ferdinand ins Zauberland & Offiset & Überklebt-Plakate aus der DDR & $\begin{array}{l}\text { Cultural } \\
\end{array}$ \\
\hline 1971_WG_00 & 1971 & WUNDERLICH, Gert & Internationale Buchkunst-Austellung & Offiset & Überklebt-Plakate aus der DDR & Cultural \\
\hline 1972_A_00 & 1972 & Anónimo & RFT Radio-television & 0 & DDR-Werkbund & Económico \\
\hline 1972_A_01 & 1972 & Anónimo & Männer mögen's's frisch und duftigg & 0 & DDR-Werkbund & Económico \\
\hline 1972_BA_00 & 1972 & BERTRAM, Axel & $\begin{array}{l}\text { Weltfestspiele der Jugend und Studenten } \\
\text { in Berlin }\end{array}$ & 0 & $\mathrm{P} 40$ & Cultural \\
\hline 1972_DK_00 & 1972 & DRESCHER, Karl Heinz & Brecht -Leben des Galiliei & Offset & Überklebt-Plakate aus der DDR & Cultural \\
\hline 1972_FB_00 & 1972 & FRANK, Bernd & Shakespeare-Othello & Offiset & Überklebt-Plakate aus der DDR & Cultural \\
\hline 1972_KR_00 & 1972 & KUHRT, Rolf & Brecht-Der kaukasische Kreidekreis & Offiset & Überklebt-Plakate aus der DDR & Cultural \\
\hline 1972_MR_00 & 1972 & MÜLLER, Rolf Felix & Grafik Plakat Rolf F. Müller & 0 & 128 Plakate & $\begin{array}{c}\text { Cultural } \\
\end{array}$ \\
\hline 1972_PH_O0 & 1972 & PFLAUM, Harry & Rostschin - Valentin und Valentina & Offiset & Überklebt-Plakate aus der DDR & Cultural \\
\hline 1972_ST_00 & 1972 & SCHALLNAU, Thomas & Nur Pferden gibt man den Gnadenschuss & Offset & Überklebt-Plakate aus der DDR & Cultural \\
\hline 1972_VG_00 & 1972 & VOIGT, Gerhard & Händelfestspiele & 0 & P40 & Cultural \\
\hline 1973_BG_O0 & 1973 & BLENDINGER, Günter & Helft & 0 & P40 & 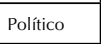 \\
\hline 1973_BR_00 & 1973 & BLUMENTHAL, Regine & Büchner-Dantons Tod & Offiset & Überklebt-Plakate aus der DDR & Cultural \\
\hline 1973_GL_00 & 1973 & $\begin{array}{l}\text { GRÜNEWALD, Lothar } \\
\end{array}$ & Verkausflager & $\begin{array}{l}\text { Offiset } \\
\end{array}$ & Überklebt-Plakate aus der DDR & Económico \\
\hline 1973_HE_00 & 1973 & HERFURTH, Egbert & Weltfestspiele & Offiset & Überklebt-Plakate aus der DDR & Cultural \\
\hline 1973_KL_00 & 1973 & Kollektiv Jamepo & Rote Lieder & 0 & P40 & $\begin{array}{c}\text { Cultural } \\
\end{array}$ \\
\hline 1973_MD_00 & 1973 & MANN, Dettef & im Konzert & 0 & 128 Plakate & Cultural \\
\hline 1973_QN_00 & 1973 & QUEVEDO, Nuria & $\begin{array}{l}\text { Weltestspiele der Jugend und Studenten } \\
\text { in Berlin }\end{array}$ & Ofiset & Überklebt-Plakate aus der DDR & Cultural \\
\hline 1973_WK_00 & 1973 & KLEMKE, Werner & Der Nu囚knacker & 0 & 128 Plakate & Cultural \\
\hline 1974_BA_00 & 1974 & BODECKER, Albrecht von & Franzzösische Plakate aus 3 Jahrhunderten & Serigrafía & Überklebt-Plakate aus der DDR & Cultural \\
\hline 1974_BA_01 & 1974 & BODECKER, Albrecht von & Zeichenkunst der deutschen Romantik & 0 & 128 Plakate & Cultural \\
\hline 1974_BA_02 & 1974 & BODECKER, Albrecht von & 450. Iahrestag des deutschen Bauerkrieges & 0 & P40 & $\begin{array}{l}\text { Politico } \\
\end{array}$ \\
\hline 1974_DJ_00 & 1974 & $\begin{array}{l}\text { DAMM-FIEDLER, Juta, } \\
\text { FIEDLER, Jochen }\end{array}$ & Venceremos! & Offset & Überklebt-Plakate aus der DDR & Pollitico \\
\hline 1974_DK_00 & 1974 & DRESCHER, Karl Heinz & Karl-Heinz Drescher Plakate & Serigrafía & Überklebt-Plakate aus der DDR & Cultural \\
\hline 1974_GE_00 & 1974 & GRÜTTNER, Erhard & Der Tod in Venedig & 0 & P40 & cultural \\
\hline 1974_GR_00 & 1974 & GRÜTTNER, Rudolf & Neruda-Clanz und Tod Joaquin Murietas & 0 & P40 & cultural \\
\hline 1974_KG_00 & 1974 & $\begin{array}{l}\text { Kollectiv Građmann/Gruner/ } \\
\text { Stecher }\end{array}$ & Aparheid No & Offset & Stadtgeschichtliches Museum Leipzig & Pollitico \\
\hline 1974_KO_00 & 1974 & KUMMERT, Otto & RGW Kraft der Gemeinsamkeit & 0 & P40 & Politico \\
\hline 1974_LF_00 & 1974 & LEUCHTE, Frank & 450. Iahre des Deutschen Bauernkrieges & Offiset & Überklebt-Plakate aus der DDR & $\begin{array}{l}\text { Político } \\
\end{array}$ \\
\hline 1974_LH_00 & 1974 & $\begin{array}{l}\text { LACHMEIER, Heidrun, } \\
\text { HENNING, H }\end{array}$ & heliopan & Offiset & Überklebt-Plakate aus der DDR & Económico \\
\hline 1974_MH_00 & 1974 & MÖHRDEL, Heinz & Tage der sozialistischen Theaterkunst & Offiset & Überklebt-Plakate aus der DDR & Cultural \\
\hline 1974_PK_00 & 1974 & PARCHE, Klaus & Winterzeit Stiefelzeit & Offiset & Überklebt-Plakate aus der DDR & Económico \\
\hline 1974_RL_00 & 1974 & $\begin{array}{l}\text { LEHMANN, Ralf-Jürgen, } \\
\text { GRÜTTEER, Rudolf }\end{array}$ & 450. Iahrestag des deutschen Bauerkrieges & 0 & P40 & 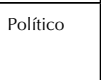 \\
\hline 1974_SE_00 & 1974 & STÜRMER-ALEX, Erika & Helft Chile! & 0 & P40 & Pollitico \\
\hline 1974_SK_00 & 1974 & SEGNER, Klaus (Gruppe 4) & Show Boat & 0 & P40 & Cultural \\
\hline 1974_ST_00 & 1974 & SCHALLNAU, Thomas & Bitte keinen Sex, wir sind Briten & 0 & $\begin{array}{l}\text { P40 } \\
\end{array}$ & Cultural \\
\hline 1974_VG_00 & 1974 & VOIGT, Gerhard & Solidaritat & 0 & 128 Plakate & Pollitico \\
\hline
\end{tabular}




\begin{tabular}{|c|c|c|c|c|c|c|}
\hline CÓDIGO & AÑO & AUTOR & TítULO & TIPO & FUENTE & GÉNERO \\
\hline 1974_WH_00 & 1974 & $\begin{array}{l}\text { WENGLER, Helmut, BILL- } \\
\text { HARDT, Thomas }\end{array}$ & Die $D D R$, das sind wir & Ofiset & Überklebt-Plakate aus der DDR & Pollitico \\
\hline 1975_BF_00 & 1975 & BÜTTNER, Feliks & Schulze Formation & Ofiset & Überklebt-Plakate aus der DDR & Cultural \\
\hline 1975_BG_00 & 1975 & BRÉCHÔT, Gunther & Brecht-Die Dreigroschenoper & Ofiset & Überklebt-Plakate aus der DDR & Cultural \\
\hline 1975_EH_00 & 1975 & ERNST, Hans-Eberhard & Cas Geheimnis & Ofiset & Überklebt-Plakate aus der DDR & Cultural \\
\hline 1975_F__00 & 1975 & FIEDLER, Jochen & weitsichtig & 0 & P40 & Político \\
\hline 1975_FM_00 & 1975 & FROTSCHER, Mathias & Links! Links! Links! & 0 & P40 & Político \\
\hline 1975_GE_00 & 1975 & GRÜTTNER, Erhard & Der Untertan & Ofiset & Überklebt-Plakate aus der DDR & Cultural \\
\hline 1975_ST_00 & 1975 & SCHLEUSING, Thomas & Die drei Musketiere & 0 & 128 Plakate & Cultural \\
\hline 1975_TK_00 & 1975 & THEWALT, Karl & Stermbild des Heute und Morgen & 0 & P40 & Polifico \\
\hline 1975_WG_00 & 1975 & WUNDERLICH, Gert & Thomas Mann Ehrung & Ofiset & Überklebt-Plakate aus der DDR & Cultural \\
\hline 1975_WG_01 & 1975 & WUNDERLICH, Gert & Tod jedem Faschismus & 0 & 128 Plakate & Politico \\
\hline 1975_WR_00 & 1975 & WENDT, Rudolf & Beffeier Freund Cenosse & 0 & P40 & $\begin{array}{c}\text { Polfitico } \\
\end{array}$ \\
\hline 1976_BH_00 & 1976 & BÜTTNER, Feliks & Literatur Klub Rostock & 0 & P40 & Cultural \\
\hline 1976_DJ_00 & 1976 & DAMM-FIEDLER, Juta & J.S. Bach & $\begin{array}{l}\text { Ofiset } \\
\end{array}$ & Überklebt-Plakate aus der DDR & Cultural \\
\hline 1976_DJ_01 & 1976 & DAMM-FIEDLER, Juta & Rosa Luxemburg & Ofiset & Überklebt-Plakate aus der DDR & Politico \\
\hline 1976_DL_00 & 1976 & DAMMBECK, Lutz & 5. Grafikbörse Leipzzig & Offiset & Überklebt-Plakate aus der DDR & Cultural \\
\hline 1976_FB_00 & 1976 & FRANK, Bernd & Schiller-Don Carlos & Ofiset & Überklebt. Plakate aus der DDR & Cultural \\
\hline 1976_GR_00 & 1976 & GRÜTTNER, Rudolf & 1. Mai 1976 & Ofiset & Überklebt-Plakate aus der DDR & Politico \\
\hline 1976_CR_01 & 1976 & GRÜTTNER, Rudolf & Goethe-Faust & 0 & P40 & Cultural \\
\hline 1976_KO_00 & 1976 & KUMMERT, Otto & IX. Partetiag der SED & 0 & 128 Plakate & $\begin{array}{l}\text { Politico } \\
\end{array}$ \\
\hline 1976_ST_00 & 1976 & $\begin{array}{l}\text { SCHLEUSING, Thomas } \\
\text { (Gruppe 4) }\end{array}$ & Kiste 76 & 0 & P40 & Cultural \\
\hline 1976_TC_00 & 1976 & TROST, Gerhard & Imperialism & Ofiset & Überklebt- Plakate aus der DDR & Politico \\
\hline 1976_VG_o0 & 1976 & VOIGT, Gerhard & Zoo Halle & Offiset & Überklebt-Plakate aus der DDR & Cultural \\
\hline 1976_WG_00 & 1976 & WUNDERLICH, Gert & Wagner-Der Ring des Nibelungen & 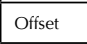 & Überklebt-Plakate aus der DDR & Cultural \\
\hline 1976_WH_00 & 1976 & WENDT, Horst & Berliner Buch Premiere-Jurek Becker & Serigrafía & Überklebt-Plakate aus der DDR & Cultural \\
\hline 1976_ZL_00 & 1976 & $\begin{array}{l}\text { ZIRATZKI, Lothar, LAUENRO- } \\
\text { TH, Enst }\end{array}$ & Arbeitsschutz Arbeitshygiene Ausstellung & Offset & Überklebt-Plakate aus der DDR & $\begin{array}{l}\text { Cultural } \\
\end{array}$ \\
\hline 1977_BA_00 & 1977 & BODECKER, Albrecht von & Lenz/Brecht-Der Hofmeister & Ofiset & Überklebt-Plakate aus der DDR & Cultural \\
\hline 1977_BC_00 & 1977 & $\begin{array}{l}\text { BUNKE, Gerh. FRANKE, } \\
\text { Clem. }\end{array}$ & Roter Oktober 1917-1977 & 0 & 128 Plakate & Pollitico \\
\hline 1977_BH_00 & 1977 & BRADE, Helmut & Büchner-Dantons Tod & 0 & P40 & Cultural \\
\hline 1977_GR_00 & 1977 & GRÜTTNER, Roswitha & Der blaue Vogel & 0 & P40 & Cultural \\
\hline 1977_GW_00 & 1977 & GEISLER, Wolfgang & Solidarität & Serigrafía & Überklebt-Plakate aus der DDR & 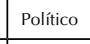 \\
\hline 1977_KR_00 & 1977 & KUHRT, Rolf & Brecht-Mutter Courage & Offset & Überklebt-Plakate aus der DDR & Cultural \\
\hline $\begin{array}{l}\text { 1977_ML_00 } \\
\end{array}$ & 1977 & MIRTSCHIN, Juta & Die traurige Nixe & 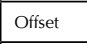 & Überklebt-Plakate aus der DDR & Cultural \\
\hline 1977_PP_00 & 1977 & PORSCH, Peter & Rote Lieder & 0 & P40 & Cultural \\
\hline 1977_ST_00 & 1977 & $\begin{array}{l}\text { SCHLEUSING, Thomas } \\
\text { (Gruppe 4) }\end{array}$ & Cabaret & 0 & P40 & $\begin{array}{l}\text { Cultural } \\
\end{array}$ \\
\hline 1977_WE_00 & 1977 & WALTER, Ekkehard & Schiller-Die Räbber & Serigrafía & Überklebt-Plakate aus der DDR & Cultural \\
\hline 1977_WG_00 & 1977 & WUNDERLICH, Gert & 100 ausgewählte Grafiken & Offset & Überklebt- Plakate aus der DDR & $\begin{array}{l}\text { Cultural } \\
\end{array}$ \\
\hline 1977_WH_00 & 1977 & WENDT, Horst & Belliner Buch Premiere-Jurek Becker & Serigrafía & 128 Plakate & Cultural \\
\hline 1978_BA__0 & 1978 & BODECKER, Albrecht von & Die Ferien des Monsieur Hulot & Offset & Überklebt-Plakate aus der DDR & Cultural \\
\hline 1978_BH_00 & 1978 & BÜTTNER, Helmut Feliks & Die Macht der Prominenten & 0 & P40 & Cultural \\
\hline 1978_BM_00 & 1978 & BUTZMANN, Manfred & Ein Platz für Baume & Ofiset & Überklebt-Plakate aus der DDR & Politico \\
\hline 1978_DL_00 & 1978 & DAMMBECK, Lutz & Grafikbörse Leipzig & 0 & 128 Plakate & Cultural \\
\hline 1978_GE_00 & 1978 & GRÜTTNER, Ehhard & Monsieur auf Abwegen & 0 & P40 & \begin{tabular}{|l|l|} 
Cultural \\
\end{tabular} \\
\hline
\end{tabular}

\begin{tabular}{|c|c|c|c|c|c|c|}
\hline cóDıco & AÑO & AUTOR & Título & TIPO & FUENTE & GÉNERO \\
\hline 1978_HM_00 & 1978 & HEROLD, Marita & berthold brecht & Offiset & Überklebt-Plakate aus der DDR & Cultural \\
\hline 1978_HR_00 & 1978 & HERFURTH, Renate & Ihre Bibliothek lädt ein & Offset & Überklebt-Plakate aus der DDR & Cultural \\
\hline 1978_KO_00 & 1978 & KUMMERT, OHto & Flüchtlingggespräche & 0 & 128 Plakate & Cultural \\
\hline 1978_NF_00 & 1978 & NEUBAUER, Frank & Bauhaus 3 & 0 & 128 Plakate & Cultural \\
\hline 1978_WE_00 & 1978 & WALTER, Ekkehard & heiricich $N$ & 0 & 128 Plakate & Cultural \\
\hline 1978_WG_00 & 1978 & WUNDERLICH, Gert & ehrung zum 50.jahrestag der grünndung & 0 & P40 & Cultural \\
\hline 1979_BA_00 & 1979 & BERTRAM, Axel & A Einstein & 0 & P40 & 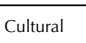 \\
\hline 1979_BA_01 & 1979 & BODECKER, Albrecht von & $\begin{array}{l}\text { XVIII. Tage der Kinder und /ugendliteratur } \\
\text { der DDR }\end{array}$ & 0 & $\mathrm{P} 40$ & Cultural \\
\hline 1979_BH_00 & 1979 & BRADE, Helmut & Für Kinder & Serigrafía & Überklebt- Plakate aus der DDR & Cultural \\
\hline 1979_BH_01 & 1979 & BRADE, Helmut & Hostr Sagert. Bühnenbilder und Bilder & Serigrafía & Überklebt- Plakate aus der DDR & Cultural \\
\hline 1979_BH_02 & 1979 & BRADE, Helmut & Spirale & 0 & $\mathrm{P} 40$ & Cultural \\
\hline 1979_BK_00 & 1979 & BECK, Karl-Heinz & Das öknonometer & Offiset & Überklebt-Plakate aus der DDR & 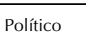 \\
\hline 1979_BW_00 & 1979 & ВÖHM, Walter & Das Tagebuch der Anne Frank & 0 & P40 & Cultural \\
\hline 1979_DG_00 & 1979 & , HOPPE, Hans Georg & Menschen Jäger & 0 & 128 Plakate & Cultural \\
\hline 1979_FB_00 & 1979 & FRANK, Bernd & Müller -Der Ваu & 0 & P40 & Cultural \\
\hline 1979_HH_00 & 1979 & HANDSCHICK, Heinz & Bin dass der Tod emh scheidet & 0 & P40 & $\begin{array}{l}\text { Cultural } \\
\text { Sal }\end{array}$ \\
\hline 1979_M__00 & 1979 & MIRTSCHIN, Jutta & Die feuerrote Blume & Offiset & Überklebt- Plakate aus der DDR & Cultural \\
\hline 1979_MR_00 & 1979 & MÜLLER, Rolf Felix & Grafik Plakat Rolf F. Müller & Offiset & Überklebt-Plakate aus der DDR & Cultural \\
\hline 1979_PV_00 & 1979 & PFÜLER, Volker & Toller-Der entiesselte Wotan & Offset & Überklebt-Plakate aus der DDR & Cultural \\
\hline 1980_A__00 & 1980 & ARNOLD, Ingo & 1. Mai 1980 & Offiset & Überklebt-Plakate aus der DDR & $\begin{array}{l}\text { Politico } \\
\end{array}$ \\
\hline 1980_BF_00 & 1980 & BÜTTNER, Feliks & Internationale Plakate & Serigrafía & Überklebt- Plakate aus der DDR & Cultural \\
\hline 1980_BM_00 & 1980 & BOFINGER, Manfred & Erfolgreich mit Cermina & Offset & Überklebt-Plakate aus der DDR & Económico \\
\hline 1980_GW_00 & 1980 & GEISLER, Werner & Berliner Ensamble & 0 & 128 Plakate & Cultural \\
\hline 1980_H__00 & 1980 & $\begin{array}{l}\text { HAUFE, Jürgen } \\
\end{array}$ & Lift & $\begin{array}{l}\text { Serigrafía } \\
\text {. }\end{array}$ & Überklebt-Plakate aus der DDR & Cultural \\
\hline 1980_HI_01 & 1980 & HAUFE, Jürgen & Kind das volkommene Geschüpf & 0 & P40 & Cultural \\
\hline 1980_KO_00 & 1980 & KUMMERT, Otto & Das Schlangenei & 0 & P40 & Cultural \\
\hline 1980_KR_00 & 1980 & KOBE, Ronald & $\begin{array}{l}\text { Der Zauberer von Oss } \\
\end{array}$ & Ofifset & Überklebt- Plakate aus der DDR & Cultural \\
\hline 1980_M__00 & 1980 & MÜCKE, Jürgen & 8.5.45 MUP & 0 & P40 & Polifico \\
\hline 1980_MR_00 & 1980 & MÜLLER, Rolf Felix & Winterferienfilm & 0 & P40 & Cultural \\
\hline 1980_PV_00 & 1980 & PFÜLLER, Volker & Bild und Szene & 0 & P40 & $\begin{array}{c}\text { Cuttural } \\
\end{array}$ \\
\hline 1980_SR_00 & 1980 & $\begin{array}{l}\text { SCHULZ, Regine, LABOWSKL, } \\
\text { Burkhard }\end{array}$ & Tschaikowski -Dorrröschen & Ofiset & Überklebt- Plakate aus der DDR & Cultural \\
\hline 1981_BA_00 & 1981 & BODECKER, Albrecht von & Venezianisches Glas & 0 & 128 Plakate & Cultural \\
\hline 1981_BH_00 & 1981 & BRADE, Helmut & Heinar Kipphard & 0 & P40 & Cultural \\
\hline 1981_BH_01 & 1981 & BRADE, Helmut & Theater Plakate & 0 & P40 & $\begin{array}{c}\text { Cultural } \\
\end{array}$ \\
\hline 1981_BH_02 & 1981 & BÜTTNER, Helmut Feliks & Eberhard Kube & 0 & P40 & Cultural \\
\hline 1981_BK_00 & 1981 & BECK, Karl-Heinz & $\begin{array}{l}\text { Unsere Solidarität den Freiheitskämpfern } \\
\text { von El Salvador }\end{array}$ & Ofiset & Überklebt- Plakate aus der DDR & Politico \\
\hline 1981_DG_00 & 1981 & DASSING, Gerda & the last photo & Offiset & Überklebt- Plakate aus der DDR & Cultural \\
\hline 1981_DL_00 & 1981 & DAMMBECK, Lutz & Filme & Offiset & Überklebt- Plakate aus der DDR & Cultural \\
\hline 1981_FB_00 & 1981 & FRANK, Bernd & Molière-Der Geizige & 0 & 128 Plakate & Cultural \\
\hline 1981_F__00 & 1981 & FÖ̈STTER, Jürgen & o.T. (Rauchersitzung) & Offset & Überklebt- Plakate aus der DDR & Polifico \\
\hline 1981_F__01 & 1981 & FIEDLER, Jochen & Kunstereignisse-Plakate und Filme & Serigrafía & Überklebt- Plakate aus der DDR & Cultural \\
\hline 1981_GE_00 & 1981 & GRÜTTNER, Ehhard & Der grođe Friedrich & 0 & P40 & Cultural \\
\hline 1981_GH_00 & 1981 & GERASCH, Hans-Georg & o.T. (Behinderung) & Ofiset & Überklebt- Plakate aus der DDR & Politico \\
\hline 1981_GR_00 & 1981 & GRÜTTNER, Roswitha & Zirkus & Offset & Überklebt-Plakate aus der DDR & Cultural \\
\hline
\end{tabular}




\begin{tabular}{|c|c|c|c|c|c|c|}
\hline CÓDIGO & AÑO & AUTOR & Título & TIPO & FUENTE & GÉNERO \\
\hline 1981_GR_01 & 1981 & GRÜTTNER, Roswitha & Die Nachtigall & Offiset & Überklebt-Plakate aus der DDR & Cultural \\
\hline 1981_GW_00 & 1981 & GEESLER, Wemer & 34. Interrationale Friedensfahrt & Offset & Überklebt-Plakate aus der DDR & Cultural \\
\hline 1981_HD_00 & 1981 & HEIDENREICH, Dieter & Die Witwe des Montiel & Ofiset & Überklebt-Plakate aus der DDR & Cultural \\
\hline 1981_HD_01 & 1981 & HEIDENREICH, Dieter & Aquarelle in der DDR & Offset & Überklebt-Plakate aus der DDR & Cultural \\
\hline 1981_HH_00 & 1981 & HANDSCHICK, Heinz & Der Tag der Heuschrecke & Offset & Überklebt. Plakate aus der DDR & Cultural \\
\hline 1981_HU_00 & 1981 & HÄNTSCH, Uwe & Don Parasol & Offiset & Überklebt-Plakate aus der DDR & Cultural \\
\hline $1981 」 \_\_00$ & 1981 & JANSONG, Joachim & $\begin{array}{l}\text { Alexander Rodtschenko Fotografien + } \\
\text { Fotomontagen }\end{array}$ & 0 & 128 Plakate & Cultural \\
\hline 1981_LK_00 & 1981 & LEMKE, Klaus & 1. Mai & 0 & $\mathrm{P} 40$ & Polfitico \\
\hline 1981_MR_00 & 1981 & MÜLLER, Rolf Felix & Plakat & 0 & 128 Plakate & Cultural \\
\hline 1981_PH_00 & 1981 & PFLAUM, Harry & UN-Friedenswettbewerb & Serigrafía & Überklebt-Plakate aus der DDR & Pollitico \\
\hline 1981_ST_00 & 1981 & $\begin{array}{l}\text { SCHLEUSING, Thomas } \\
\text { (Gruppe 4) }\end{array}$ & Spiel mir das Lied vom Tod & 0 & P40 & Cultural \\
\hline 1981_TH_00 & 1981 & $\mathrm{TICHA}$, Hans & $\begin{array}{l}\text { Tage der Kinderliteratur im Bezirk } \\
\text { Schwerin }\end{array}$ & Ofiset & Überklebt- Plakate aus der DDR & Cultural \\
\hline 1981_WG_00 & 1981 & WONGEL, Günter & Fleisch & Offset & Überklebt-Plakate aus der DDR & Cultural \\
\hline 1981_WS_00 & 1981 & WUNDERLICH, Sonja & Deutsches Rotes Kreuz & Offset & Überklebt-Plakate aus der DDR & Polfitico \\
\hline 1982_BH_00 & 1982 & BRADE, Helmut & Chemie, Industrie, Kunst & Serigrafía & Überklebt. Plakate aus der DDR & Cultural \\
\hline 1982_BH_01 & 1982 & BRADE, Helmut & Prometheus 1982 & 0 & 128 Plakate & Cultural \\
\hline 1982_BM_00 & 1982 & BOFINGER, Manfred & Tach, Kampagnero! & 0 & 128 Plakate & Pollitico \\
\hline 1982_EK_00 & 1982 & ENSIKAT, Klaus & Kinderbuchillustrationen & 0 & P40 & Cultural \\
\hline 1982_FB_00 & 1982 & FRANK, Bend & Heiner Müller nach Shakespeare MacBeth & 0 & P40 & Cultural \\
\hline 1982_GE_00 & 1982 & GRÜTTNER, Ehhard & Goethe-Faust & Serigrafía & Überklebt- Plakate aus der DDR & Cultural \\
\hline 1982_GW_00 & 1982 & GEILLER, Wolfgang & Meinst du die Russen wollen Krieg & Offiset & Überklebt-Plakate aus der DDR & $\begin{array}{ll}\text { Polfitico } \\
\end{array}$ \\
\hline 1982_HK_00 & 1982 & HERRMANN, Klaus & Clara Zetkin & 0 & 128 Plakate & Polfitico \\
\hline 1982_KO_00 & 1982 & KUMMERT, Otto & Das Beil von Wandsbeck & Ofiset & Überklebt- Plakate aus der DDR & Cultural \\
\hline 1982_PV_00 & 1982 & PFüLLER, Volker & Brecht-Baal & 0 & 128 Plakate & Cultural \\
\hline 1982_SH_00 & 1982 & SCHÜLER, Hajo & Bob Marley & Offset & Überklebt. Plakate aus der DDR & Cultural \\
\hline 1982_VG_00 & 1982 & VOIGT, Gerhard & $\begin{array}{l}\text { Unser Vorschlag gitt: Wir sind dialogbereit } \\
\text { fuir Frieden und Abristung }\end{array}$ & Ofiset & Überklebt-Plakate aus der DDR & Politico \\
\hline 1982_WH_00 & 1982 & WENGLER, Helmut & Alexis Sorbas & Ofiset & Überklebt- Plakate aus der DDR & Cultural \\
\hline 1983_вм__0 & 1983 & BÄrRICH, Meinhard & Energie verwenden! & imprenta & Überklebt- Plakate aus der DDR & Politico \\
\hline 1983_BM_01 & 1983 & BOFINGER, Manfred & Liedersommer der FDI & Offiset & Überklebt. Plakate aus der DDR & Cultural \\
\hline 1983_DK_00 & 1983 & DRESCHER, Karl Heinz & Die Perser von Aischylos & 0 & P40 & Cultural \\
\hline 1983_FB_00 & 1983 & FRANK, Bend & Silly & Offset & Überklebt- Plakate aus der DDR & Cultural \\
\hline 1983_H__OO & 1983 & HAUFE, Jürgen & Kipphardt-Bruder Eichmann & Offiset & Überklebt. Plakate aus der DDR & Cultural \\
\hline 1983_HU_00 & 1983 & HÄNTSCH, Uwe & Alles auf eine Karte & Offset & Überklebt-Plakate aus der DDR & Cultural \\
\hline 1983_LK_00 & 1983 & LEMKE, Klaus & Beste Verpackung & Serigrafía & Überklebt- Plakate aus der DDR & Cultural \\
\hline 1983_MA_00 & 1983 & $\begin{array}{l}\text { MARTIN, Anne-Christine } \\
\text { und Klaus }\end{array}$ & Messegestaltung für die $D D R$ & 0 & P40 & Económico \\
\hline 1983_NF_00 & 1983 & NEUBAUER, Frank & Hermando Leon & Serigrafía & Überklebt-Plakate aus der DDR & Cultural \\
\hline 1983_NF_01 & 1983 & $\begin{array}{l}\text { NEUBAUER, Frank (Gruppe } \\
\text { Plus) }\end{array}$ & Martinus & 0 & P40 & Polfitico \\
\hline 1983_PV_00 & 1983 & PFÜLLER, Volker & Brecht-Die Rundköpfe und die Spitzköpfe & Offiset & Überklebt-Plakate aus der DDR & Cultural \\
\hline 1983_WG_00 & 1983 & WUNDERLICH, Gert & hochrüsten $=$ totrüsten & Serigrafía & Überklebt-Plakate aus der DDR & Pollitico \\
\hline 1984_BA_00 & 1984 & BERTRAM, Axel & DT 64 & Ofiset & Überklebt- Plakate aus der DDR & Cultural \\
\hline 1984_BM_00 & 1984 & BOFINGER, Manfred & $\begin{array}{l}\text { Raus mit den US-Raketen aus } \\
\text { Westeuropa! }\end{array}$ & Ofiset & Überklebt- Plakate aus der DDR & Polfitico \\
\hline
\end{tabular}

\begin{tabular}{|c|c|c|c|c|c|c|}
\hline CÓDIGO & AÑO & AUTOR & título & TIPO & FUENTE & GÉNERO \\
\hline 1984_DL_00 & 1984 & DAMMBECK, Lutz & Robinson & 0 & 128 Plakate & Cultural \\
\hline 1984_EA_00 & 1984 & ERNST, Anneliese & Amoklauf & Offiset & Überklebt- Plakate aus der DDR & Cultural \\
\hline 1984_FJ_00 & 1984 & FIEDLER, Jochen & Fischers Fritz & Serigrafía & Überklebt. Plakate aus der DDR & Económico \\
\hline 1984_GR_00 & 1984 & GRÜTTNER, Rudolf & 1. Mai 1984 & 0 & P40 & Pollitico \\
\hline 1984_HH_00 & 1984 & HANDSCHICK, Heinz & Kunst Ausstellung & 0 & P40 & cultural \\
\hline 1984_MR_00 & 1984 & MÜLLER, Rolf Felix & $\begin{array}{ll}\text { Satiricum } 84 \\
\end{array}$ & Offiset & Überklebt-Plakate aus der DDR & Cultural \\
\hline 1984_PV_00 & 1984 & PFÜLLER, Volker & Brecht-3 Groschenoper & Offiset & Überklebt-Plakate aus der DDR & Cultural \\
\hline 1984_SB_00 & 1984 & STEINBERG, Bärbel & Hacks-Die Kinder & Offiset & Überklebt-Plakate aus der DDR & Cultural \\
\hline 1984_ST_00 & 1984 & SCHALLNAU, Thomas & Brecht-Mutter Courage und ihre Kinder & Offiset & Überklebt-Plakate aus der DDR & Cultural \\
\hline 1984_WL_00 & 1984 & WINKLER, Ludwig & Wer mit dem Feuer spielt ... & Offiset & Überklebt. Plakate aus der DDR & Politico \\
\hline 1984_WN_00 & 1984 & $\begin{array}{l}\text { WIENTZKOWSKI, Norbert, } \\
\text { KÜHN, Hans-Dieter }\end{array}$ & Der strahlende Sieger & 0 & P40 & Pollitico \\
\hline 1984_WS_00 & 1984 & WUNDERLICH, Sonja & ICOMOS & Offiset & Überklebt- Plakate aus der DDR & Cultural \\
\hline 1985_BG_00 & 1985 & BRANDT, Gernot & Der Pepperminttrieden & Offiset & Überklebt. Plakate aus der DDR & Cultural \\
\hline 1985_BH_00 & 1985 & BRADE, Helmut & Die 100 besten Plakate des /ahres 1984 & Serigrafía & Überklebt-Plakate aus der DDR & Cultural \\
\hline 1985_BH_01 & 1985 & BRADE, Helmut & Helmut Brade Plakate & Serigrafía & Überklebt. Plakate aus der DDR & Cultural \\
\hline 1985_BH_02 & 1985 & BRADE, Helmut & Shakespeare- König Johann & Offiset & Überklebt-Plakate aus der DDR & Cultural \\
\hline 1985_BM_00 & 1985 & BÄRMICH, Meinhard & Auschwitz & imprenta & Überklebt- Plakate aus der DDR & Politico \\
\hline 1985_BM_01 & 1985 & BUTZMANN, Manfred & ... und ich will bei euch wohnen & Offiset & Überklebt-Plakate aus der DDR & Político \\
\hline 1985_BM_02 & 1985 & BUTZMANN, Manfred & Nicht vergessen! & 0 & P40 & Politico \\
\hline 1985_DJ_00 & 1985 & DAMM-FIEDLER, Juta & Lene Voigt & 0 & P40 & cultural \\
\hline 1985_FA_00 & 1985 & FRITZSCH, Annette & $\begin{array}{l}\text { never again! Internationaler Auschwitz } \\
\text { Plakatwettbewerb }\end{array}$ & Offset & Überklebt-Plakate aus der DDR & Pollitico \\
\hline 1985_FB_00 & 1985 & FRANK, Bernd & Wischnewski-Optimistische Tragödie & Offiset & Überklebt-Plakate aus der DDR & Cultural \\
\hline 1985_FB_01 & 1985 & FRANK, Bend & $\begin{array}{l}\text { Werkstatt /unger Theaterschaffender } \\
\text { der } D D R\end{array}$ & Offset & Überklebt- Plakate aus der DDR & Cultural \\
\hline 1985_GE_00 & 1985 & GRÜTTNER, Erhard & Hammel-Die Preu甘en kommen & Serigrafía & Überklebt-Plakate aus der DDR & Cultural \\
\hline 1985_GM_00 & 1985 & GUBIG, Matthias & Helft den Patrioten Latein-amerikas! & 0 & 128 Plakate & Político \\
\hline 1985_GR_00 & 1985 & GAULKE, Renate & 825 Jahre Schwerin & Offiset & Überklebt- Plakate aus der DDR & Cultural \\
\hline 1985_HD_00 & 1985 & HEIDENREICH, Dieter & Auschwitz warnt! & 0 & P40 & Pollitico \\
\hline 1985_KE_00 & 1985 & KEIENBURG, Eberhard & Barlach-Der blaue Boll & Offiset & Überklebt-Plakate aus der DDR & Cultural \\
\hline 1985_KO_00 & 1985 & KUMMERT, Otto & Gala des Balletts & Offiset & Überklebt- Plakate aus der DDR & Cultural \\
\hline 1985_KR_00 & 1985 & KOBE, Roland & Händel Ehrung & 0 & $\mathrm{P} 40$ & Cultural \\
\hline 1985_MR_00 & 1985 & MÜLLER, Rolf Felix & Mnouchkine/Mann-Mephisto & Ofiset & Überklebt-Plakate aus der DDR & Cultural \\
\hline 1985_MU_00 & 1985 & MÜLER, Utz & Marken und Zeichnen aus der DDR & Offiset & Überklebt- Plakate aus der DDR & Cultural \\
\hline 1985_PV_00 & 1985 & PFÜLLER, Volker & Becher-Winterschlacht & Offiset & Überklebt-Plakate aus der DDR & Cultural \\
\hline 1985_PW_00 & 1985 & PFENNIG, Wolf-Dieter & A....wie Anfang & Offiset & Überklebt-Plakate aus der DDR & Politico \\
\hline 1985_RK_00 & 1985 & RÄHM, Klaus & Schriftplakate & Serigrafía & Überklebt-Plakate aus der DDR & Cultural \\
\hline 1986_BB_00 & 1986 & BAHRA, Bob & Braun /Aischylos -Die Perser & Offiset & Überklebt-Plakate aus der DDR & Cultural \\
\hline 1986_BG_00 & 1986 & BRÉCHÔT, Gunther & Fritz Reuter Bühne 19261986 & Offiset & Überklebt. Plakate aus der DDR & Cultural \\
\hline 1986_DG_00 & 1986 & DASSING, Gerda & Rönisch & Offiset & Überklebt-Plakate aus der DDR & Cultural \\
\hline 1986_DK_00 & 1986 & DRESCHER, Karl Heinz & Die "schönen" Plakate & 0 & P40 & Cultural \\
\hline 1986_FH_00 & 1986 & FELLER, Horst & Plakatkunst intermational & Serigrafía & Überklebt- Plakate aus der DDR & Cultural \\
\hline 1986_F__00 & 1986 & FIEDLER, Jochen & Marcus Aurelius & 0 & P40 & Cultural \\
\hline 1986 НB 00 & 1986 & HANKE, Bernd & Der dritte Weltkrieg hat keine Namen & Serigrafía & Überklebt- Plakate aus der DDR & Pollitico \\
\hline 1986_HD_00 & 1986 & $\begin{array}{l}\text { HEN, Doris, HEMMRICH, } \\
\text { Raoul }\end{array}$ & s.t. & 0 & 128 Plakate & Politico \\
\hline 1986_HH_00 & 1986 & HANDSCHICK, Heinz & Caspar David friedrich -Grenzen der Zeit & 0 & 128 Plakate $\mathrm{CL}$ & Cultural \\
\hline
\end{tabular}




\begin{tabular}{|c|c|c|c|c|c|c|}
\hline CÓDIGO & AÑO & AUTOR & Título & TIPO & FUENTE & GÉNERO \\
\hline 1986_H__00 & 1986 & HAUFE, Jürgen & Grafik und Plakate & 0 & 128 Plakate & Cultural \\
\hline 1986_KM_00 & 1986 & KUMMER, Matthias & s.t & 0 & 128 Plakate & Polfitico \\
\hline 1986_MM_00 & 1986 & MAIZZIÉRE, Michael de & Es war eimmal in Amerika & Offset & Überklebt-Plakate aus der DDR & Cultural \\
\hline 1986_PV_00 & 1986 & PFÜLLER, Volker & Totentanz & 0 & P40 & cultural \\
\hline 1986_SA_00 & 1986 & SCHIEL, Alexander & friedliche Koexistenz & Serigrafía & Überklebt-Plakate aus der DDR & Polfitico \\
\hline 1986_ZH_00 & 1986 & ZILL, Hilmar & Zoo Rostock & Offset & Überklebt-Plakate aus der DDR & Cultural \\
\hline 1987_BF_00 & 1987 & BÜTTNER, Feliks & International Year of Graphik Design & Ofiset & Überklebt-Plakate aus der DDR & $\begin{array}{l}\text { Cultural } \\
\end{array}$ \\
\hline 1987_BF_01 & 1987 & BÜTTNER, Feliks & Woche des gestischen Theaters & Offiset & Überklebt-Plakate aus der DDR & $\begin{array}{c}\text { Cultural } \\
\end{array}$ \\
\hline 1987_DK_00 & 1987 & DRESCHER, Karl Heinz & Brecht-Untergang des Egoisten Fatzer & Offiset & Überklebt- Plakate aus der DDR & Cultural \\
\hline 1987_F__00 & 1987 & FIEDLER, Jochen & icograda & Serigrafía & Überklebt-Plakate aus der DDR & Cultural \\
\hline 1987_GM_00 & 1987 & GRUND, Manfred & Brecht-Baal & Offset & Überklebt-Plakate aus der DDR & Cultural \\
\hline 1987_GR_00 & 1987 & GAULKE, Renate & $\begin{array}{l}\text {... mal andere Gesichter sehen Zoo } \\
\text { Schwerin }\end{array}$ & Offiset & Überklebt. Plakate aus der DDR & Cultural \\
\hline 1987_HE_00 & 1987 & HERFURTH, Egbert & Woche des Buches 1987 & Ofiset & Überklebt-Plakate aus der DDR & Cultural \\
\hline 1987_HJ_00 & 1987 & HAUFE, Jürgen & $\begin{array}{l}\text {... das Wissen siegt und siegt des Friedens } \\
\text { Macht }\end{array}$ & Offiset & Überklebt- Plakate aus der DDR & Pollitico \\
\hline 1987_HM_O0 & 1987 & HOFFMANN, Martin & Was weg ist, ist weg & 0 & 128 Plakate & Polfitico \\
\hline 1987_KR_00 & 1987 & $\begin{array}{l}\text { KUHRT, Rolf } \\
\end{array}$ & Beckett-Warten auf Godot & 0 & 128 Plakate & $\begin{array}{l}\text { Cultural } \\
\end{array}$ \\
\hline 1987_LC_00 & 1987 & LÖSER, Christian & Homo Faber & 0 & P40 & Polfitico \\
\hline 1987_M_00 & 1987 & MIRTSCHIN, Juta & Brecht-Die Dreigroschenoper & Offiset & Überklebt- Plakate aus der DDR & Cultural \\
\hline 1987_MW_00 & 1987 & MAERTINS, Wolfgang & 3. Design Festival Osaka & 0 & P40 & Politico \\
\hline 1987_RH_00 & 1987 & RIEDEL, Hubert & $100+1$ / ahr Plakat in Ungarn & Offset & Überklebt-Plakate aus der DDR & Cultural \\
\hline 1987_RH_01 & 1987 & RIEDEL, Hubert & $\begin{array}{l}\text { Theatres du Geste-Photos de Jean Pierre } \\
\text { Gapinhan }\end{array}$ & Serigrafía & Überklebt- Plakate aus der DDR & Cultural \\
\hline 1987_WA_00 & 1987 & WALLAT, Andreas & $\begin{array}{l}\text { Jens - Der Untergang } \\
\end{array}$ & Ofiset & Überklebt- Plakate aus der DDR & Cultural \\
\hline 1987_WA_01 & 1987 & WALLAT, Andreas & International Year of Graphik Design & Ofiset & Überklebt-Plakate aus der DDR & Cultural \\
\hline 1988_BF_00 & 1988 & BÜTTNER, Feliks & Meeresmuseum Stralsund & Offiset & Überklebt- Plakate aus der DDR & $\begin{array}{c}\text { Cultural } \\
\end{array}$ \\
\hline 1988_BH_00 & 1988 & BRADE, Helmut & $\begin{array}{l}\text { Frisch-Don luan oder die Liebe zur } \\
\text { Ceometrie }\end{array}$ & Ofiset & Überklebt- Plakate aus der DDR & Cultural \\
\hline 1988_BH_01 & 1988 & BRADE, Helmut & Keramik von Martin Mohwald & 0 & P40 & Cultural \\
\hline 1988_BH_02 & 1988 & BRADE, Helmut & $\begin{array}{l}\text { Die Empfindung des Unnmöglichen } \\
\end{array}$ & 0 & P40 & Cultural \\
\hline 1988_BM_00 & 1988 & BOFINGER, Manfred & Manfied Bofinger Grafikt fur Kinder & Serigrafía & Überklebt. Plakate aus der DDR & Cultural \\
\hline 1988_ER_00 & 1988 & EHRT, Rainer & die Revolution geht weiter & 0 & P40 & $\begin{array}{ll}\text { Polfitico } \\
\end{array}$ \\
\hline 1988_FD_00 & 1988 & FESEKE, Dieter & Black Ballet Jazz & Offset & Überklebt- Plakate aus der DDR & Cultural \\
\hline 1988_FD_01 & 1988 & FESEKE, Dieter & Hubback Diesner & 0 & 128 Plakate & Cultural \\
\hline 1988_FD_02 & 1988 & FIEDLER, Detlef & Niemen & 0 & P40 & Cultural \\
\hline 1988_F_00 & 1988 & FIEDLER, Jochen & Lasst uns die Warnungen erreuern & 0 & $\begin{array}{l}\text { P40 } \\
\end{array}$ & $\begin{array}{ll}\text { Polfitico } \\
\end{array}$ \\
\hline 1988_GE_00 & 1988 & GRÜTTNER, Ehhard & Braun-Die übergangsgesellschaft & Serigrafía & Überklebt- Plakate aus der DDR & Cultural \\
\hline 1988_GE_01 & 1988 & GRÜTTNER, Ehhard & Der letzte Kaiser & 0 & P40 & Cultural \\
\hline 1988_GM_00 & 1988 & GUBIG, Mathias & Viersigerin sucht Partner & 0 & $\mathrm{P} 40$ & Polfitico \\
\hline 1988_GR_00 & 1988 & GAULKE, Renate & $\begin{array}{l}\text { Das Erreichte ist noch nicht Das } \\
\text { Erraichbare }\end{array}$ & 0 & $\mathrm{P} 40$ & Pollitico \\
\hline 1988_GW_00 & 1988 & $\begin{array}{l}\text { GEISLER, Wolfgang, RUIKA, } \\
\text { Jana }\end{array}$ & All men are colored, ALL & Serigrafía & Überklebt- Plakate aus der DDR & Polifico \\
\hline 1988_GW_01 & 1988 & GEILER, Wolfgang & $\ldots$ gefordert ist die Tat & 0 & P40 & Polfitico \\
\hline 1988_HB_00 & 1988 & HANKE, Bernd & Mit wem lebt der letzte Sieger & Offset & Überklebt-Plakate aus der DDR & 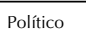 \\
\hline 1988_HE_00 & 1988 & HAAK, Eva \& Bernd & Köpenicker Ökokkirmes & Offiset & Überklebt- Plakate aus der DDR & Cultural \\
\hline 1988_HJ_00 & 1988 & HAUFE, Jürgen & Musik and Movement improvisation & 0 & P40 & $\begin{array}{l}\text { Cultural } \\
\end{array}$ \\
\hline
\end{tabular}

\begin{tabular}{|c|c|c|c|c|c|c|}
\hline CÓDIGo & AÑO & AUTOR & Título & TIPO & FUENTE & GÉNERO \\
\hline 1988_HM_00 & 1988 & HEROLD, Marita & Barlach in Güstrow & Offiset & Überklebt-Plakate aus der DDR & Cultural \\
\hline 1988_HR__00 & 1988 & HERFURTH, Renate & Prof. Dr.NARVA's Tafel der Bimensorten & Offset & Überklebt-Plakate aus der DDR & Cultural \\
\hline 1988_HU_00 & 1988 & $\begin{array}{l}\text { HOEPFNER, Ulrich, KLUGE, } \\
\text { Hans-Dieter }\end{array}$ & Braun-Die übergangsgesellschaft & Offiset & Überklebt- Plakate aus der DDR & Cultural \\
\hline 1988_KO_00 & 1988 & KUMMERT, Otto & Dein Frieden deine Geborenheit & 0 & P40 & Politico \\
\hline 1988_LK_00 & 1988 & LEMKE, Klaus & Über LEBEN & 0 & P40 & Politico \\
\hline 1988_MH_00 & 1988 & MALLK, Hans-Jürgen & $\begin{array}{l}\text { Poesie album } \\
\end{array}$ & 0 & P40 & Cultural \\
\hline 1988_PG_00 & 1988 & $\begin{array}{l}\text { PESCHEL, Gudrun } \\
\end{array}$ & Arbeitszeit Leistungzeit & 0 & P40 & Político \\
\hline 1988_PH_00 & 1988 & POLKEHN, Hanka & 7. Oktober 1949 Die grođe Chance & 0 & P40 & 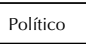 \\
\hline 1988_PP_00 & 1988 & PARTHAUNE, Peter & der Mensch liefert das Ma囚 & 0 & P40 & Politico \\
\hline 1988_PV_00 & 1988 & $\begin{array}{l}\text { PFÜLLER, Volker } \\
\end{array}$ & Johannes R. Becher & 0 & P40 & Cultural \\
\hline 1988_RH_00 & 1988 & RIEDEL, Hubert & Email Plakate Austellung & Serigrafía & $\mathrm{P} 40$ & Cultural \\
\hline 1988_R__00 & 1988 & $\begin{array}{l}\text { RUIIAA, Jana, GEISLER, } \\
\text { Wolfgang }\end{array}$ & alle menschen sind tarbig & 0 & P40 & Pollitico \\
\hline 1988 SH__OO & 1988 & SCHREIBER, Hans Ulrich & Lessing -Emilia Calotti & Offset & Überklebt-Plakate aus der DDR & Cultural \\
\hline 1988_SH_01 & 1988 & SCHÜLER, Hajo & Strauss-Salome & Offiset & Überklebt-Plakate aus der DDR & Cultural \\
\hline 1988_WH_00 & 1988 & WENGLER, Helmut & 1949-1989 & 0 & P40 & Político \\
\hline 1989_GG_00 & 1989 & Gruppe GRAPPA & Neid! Erkanneinfachalles & Serigatifia & Überklebt-Plakate aus der DDR & Politico \\
\hline 1989_GM_00 & 1989 & GUBIC, Mathias & Wir sind das Volk & Serigratía & Überklebt- Plakate aus der DDR & Pollitico \\
\hline 1989_GM_01 & 1989 & GUBIG, Matthias & endlich vereint! & Offiset & Überklebt-Plakate aus der DDR & $\begin{array}{l}\text { Politico } \\
\text { Pans }\end{array}$ \\
\hline 1989_PV_00 & 1989 & PFüLLER, Volker & Hein-Die Ritter der Tafellunde & Offiset & Überklebt- Plakate aus der DDR & Cultural \\
\hline 1989_RH_00 & 1989 & REUTER, Helga \& Ulrich & Kleidung zwischen Tracht und Mode & Offiset & Überklebt- Plakate aus der DDR & Cultural \\
\hline 1989_SB_00 & 1989 & STEINBERG, Bärbel & Machado-Pluft das Geisterlein & Offiset & Überklebt-Plakate aus der DDR & Cultural \\
\hline 1989_SO_00 & 1989 & SANDER, Otto & Schiller-Die Räuber & Offiset & Überklebt- Plakate aus der DDR & Cultural \\
\hline 1989_WG_00 & 1989 & WUNDERLICH, Gert & $\begin{array}{l}\text { Grafik Design - -Austellung des } F B \\
\text { Buchkunst / Cratik Design der HCB in } \\
\text { Moskau }\end{array}$ & Offiset & Überklebt- Plakate aus der DDR & Cultural \\
\hline
\end{tabular}




\section{B.1. Código morfológico}

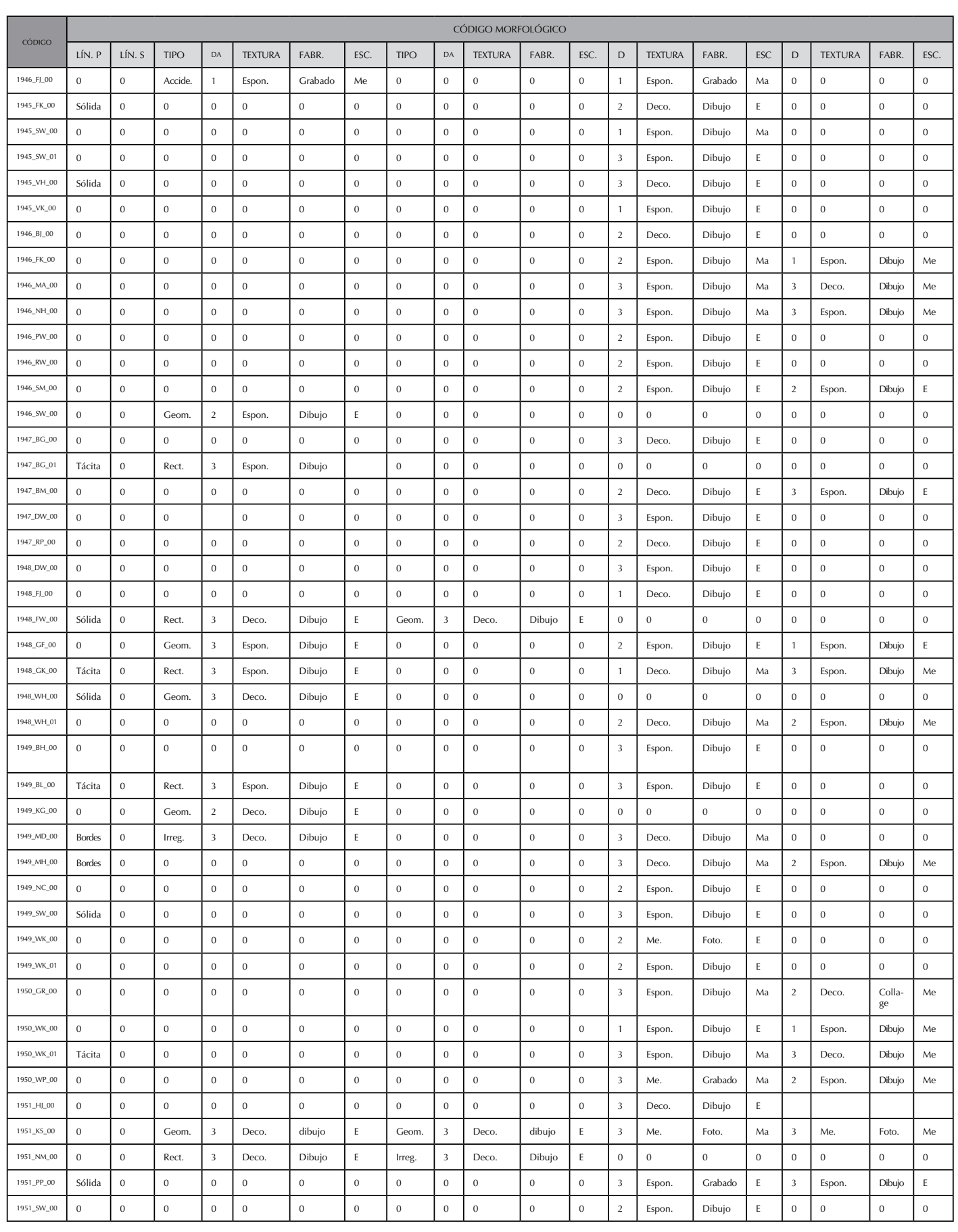

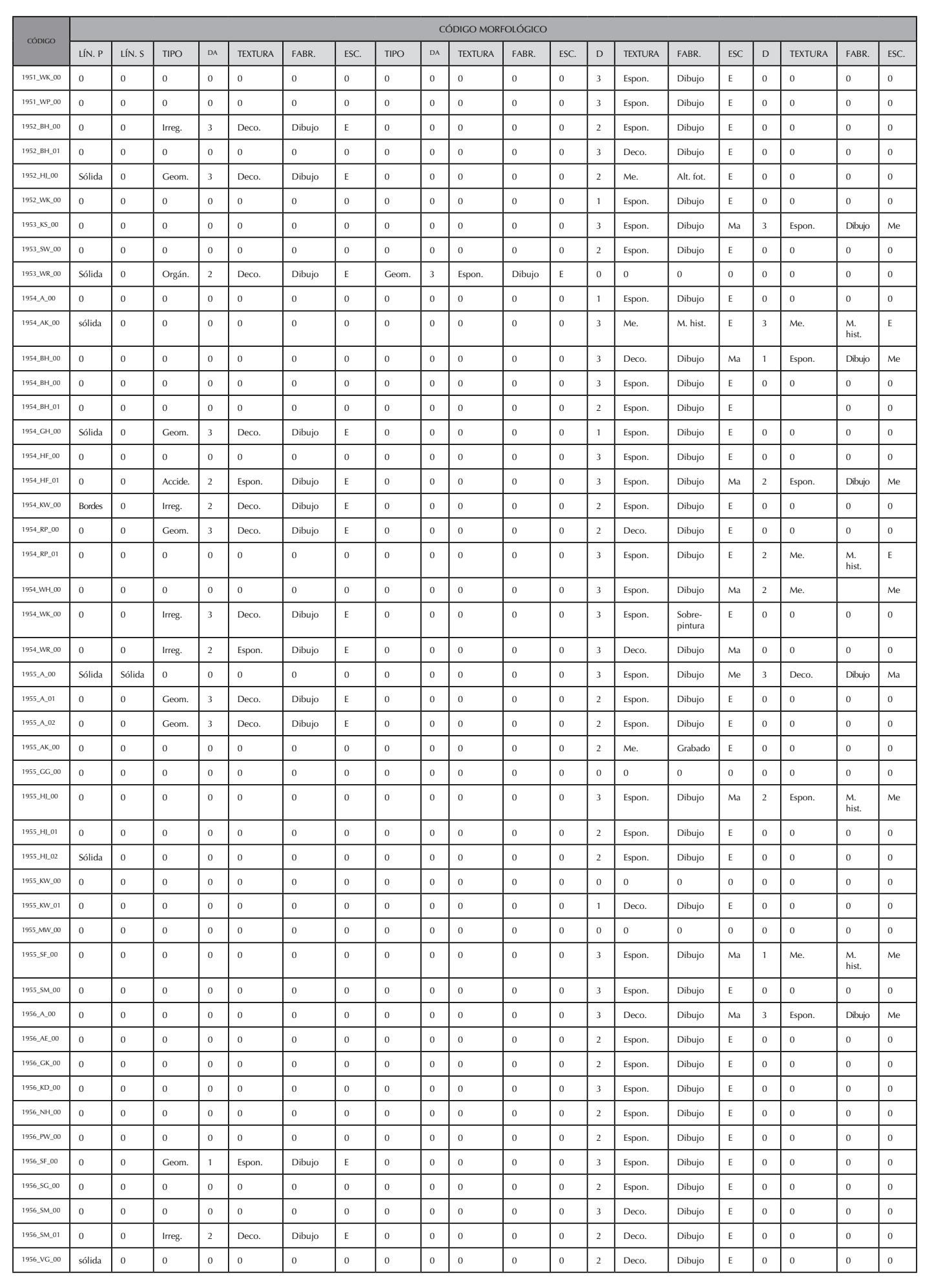


Inve ins

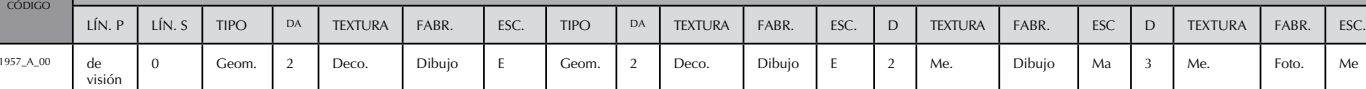

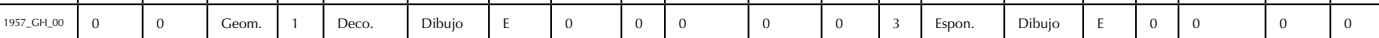

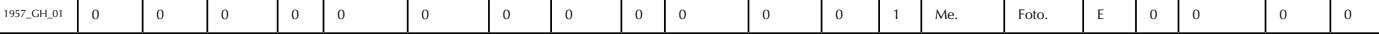

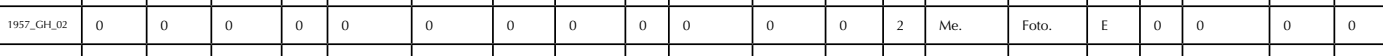

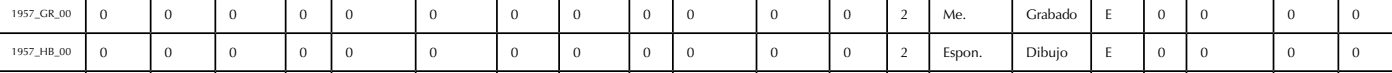

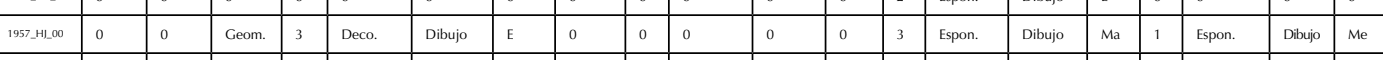

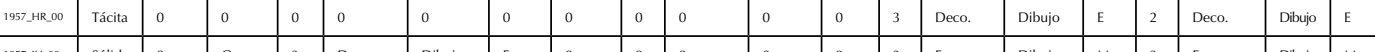

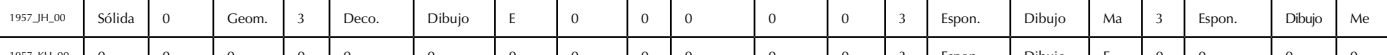

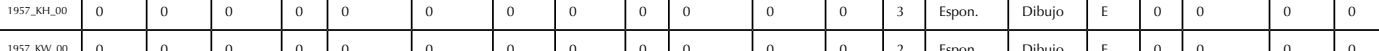

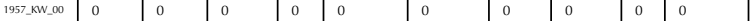

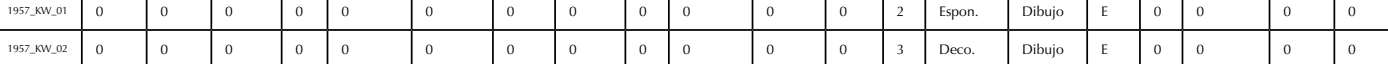

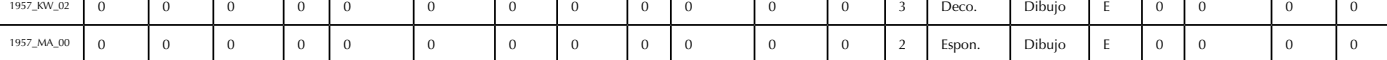

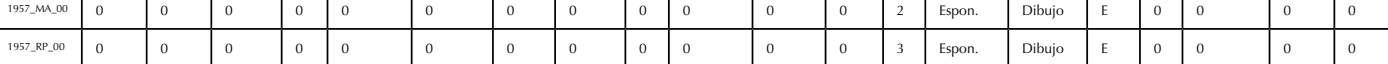

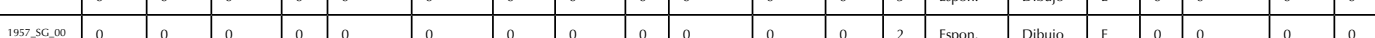

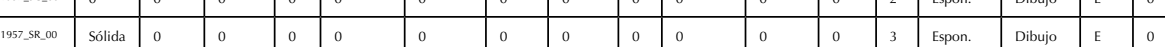

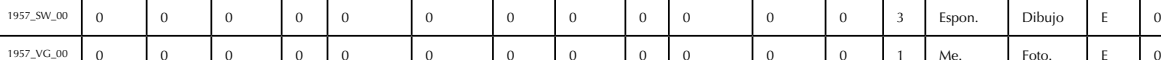

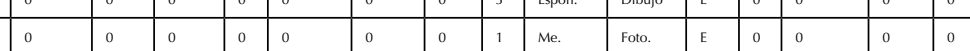

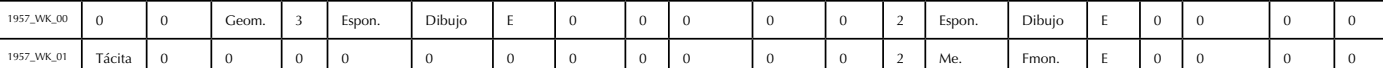

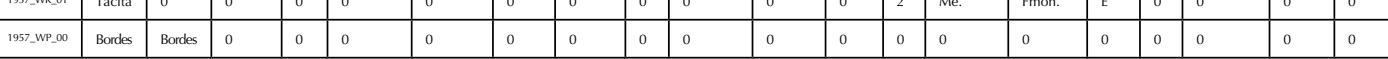

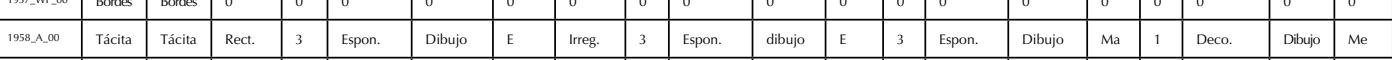

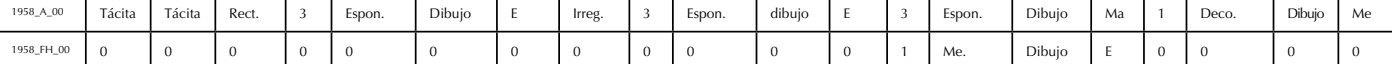

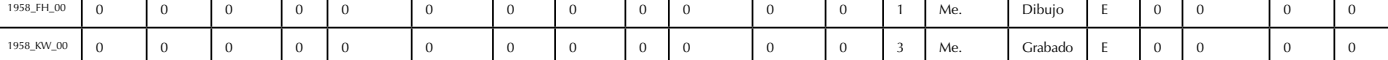

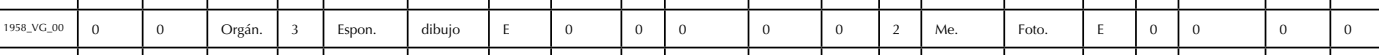

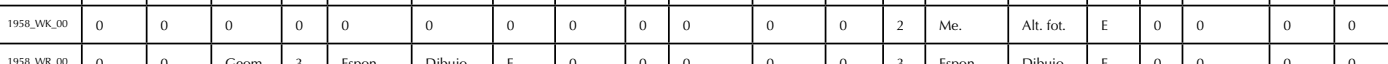

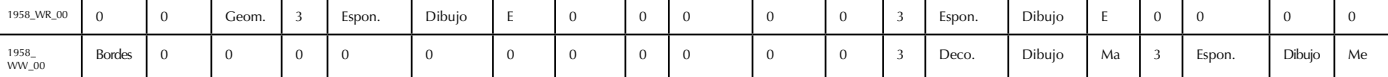

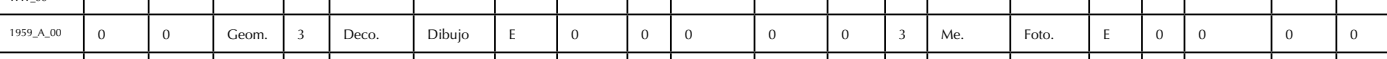

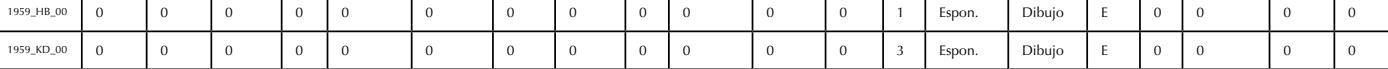

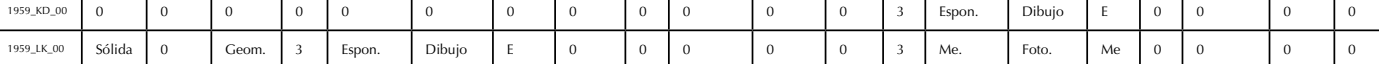

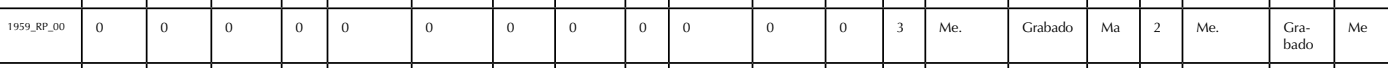

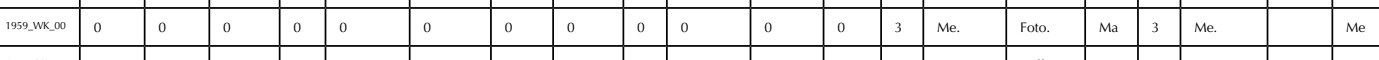

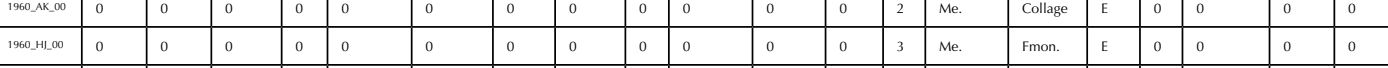

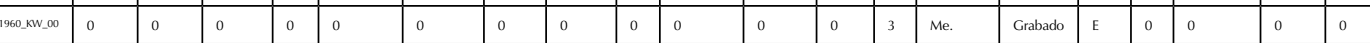

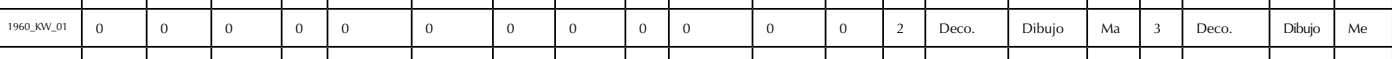

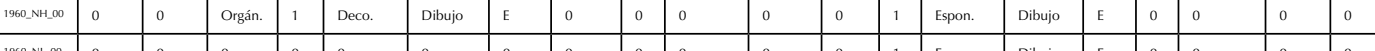

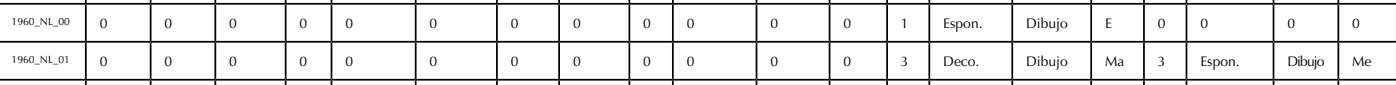

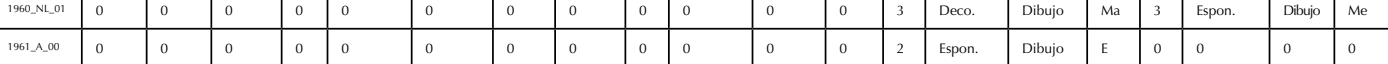

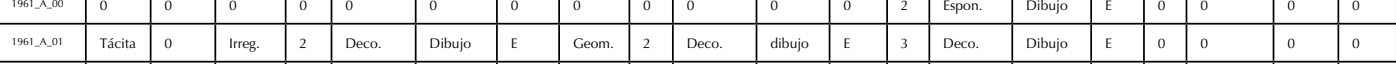

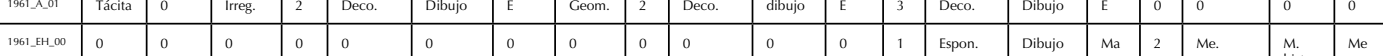

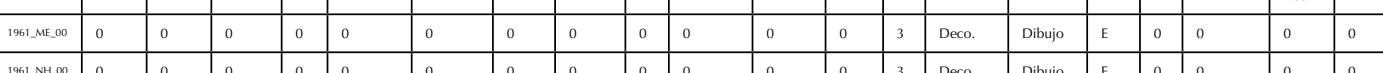

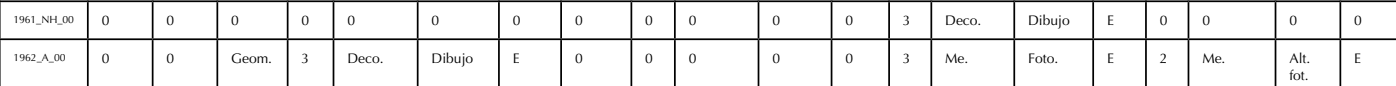

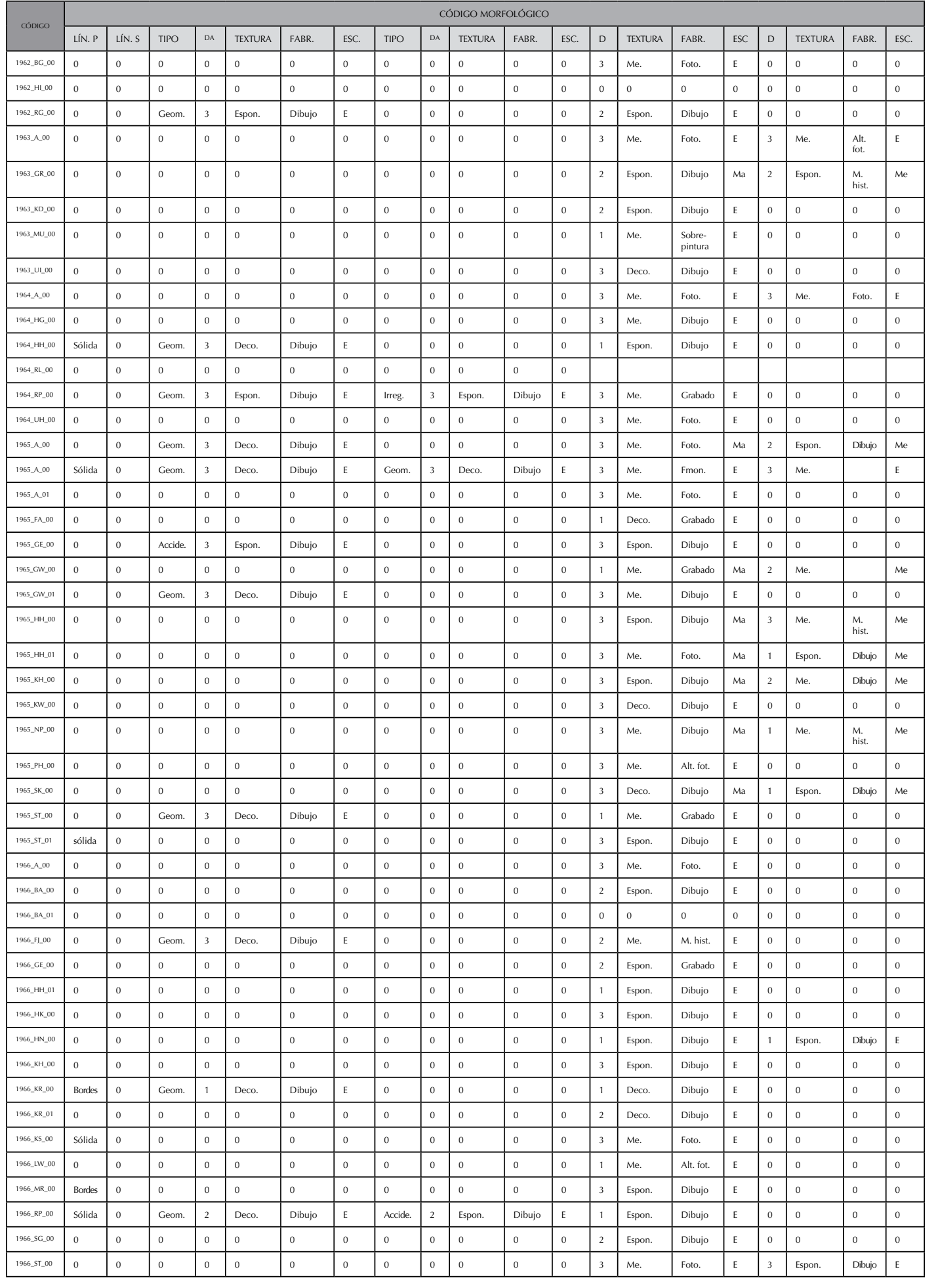




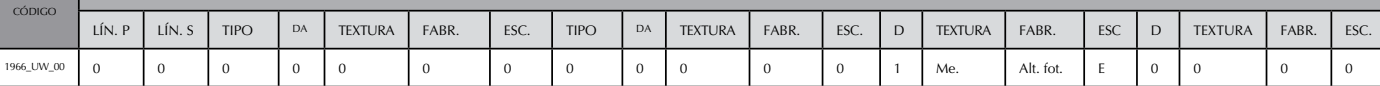

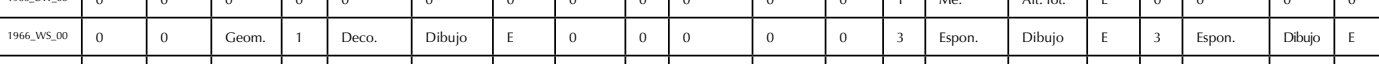

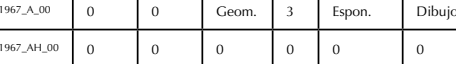

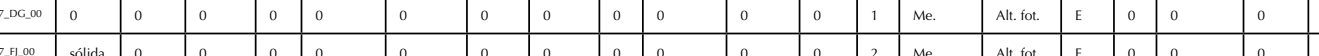

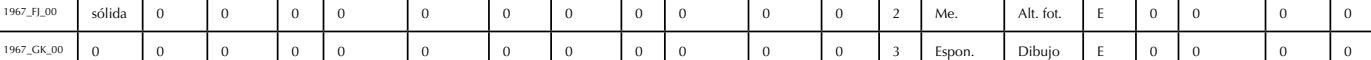

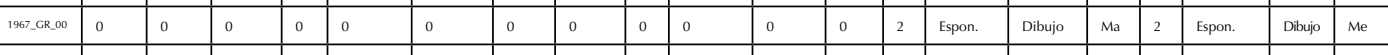

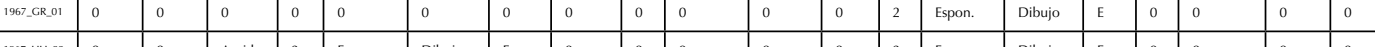

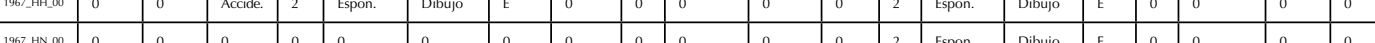
(1)

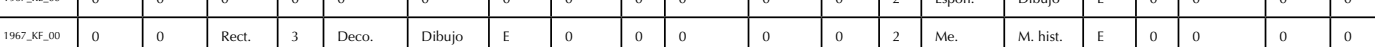

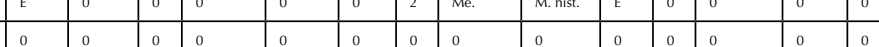

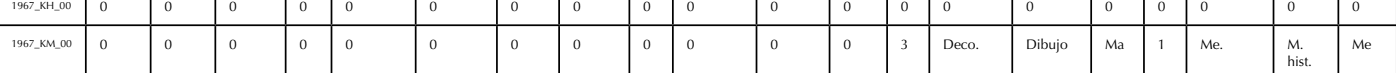

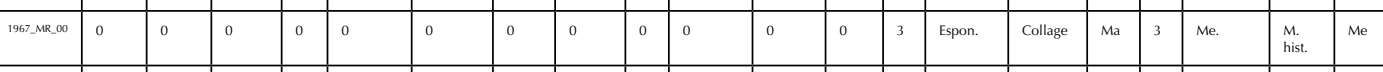

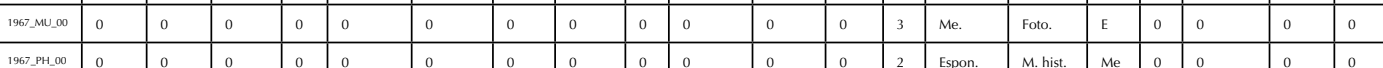

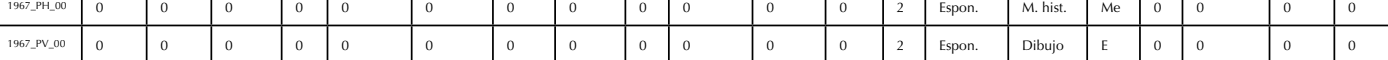

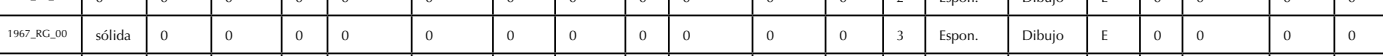

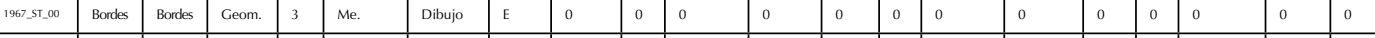

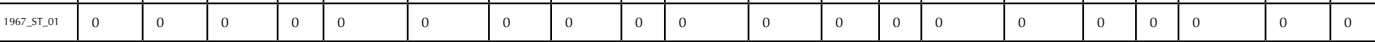

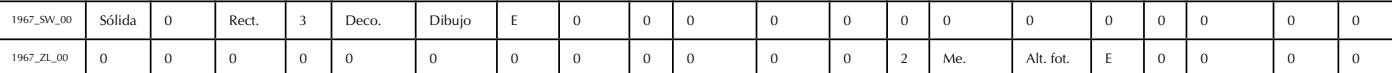

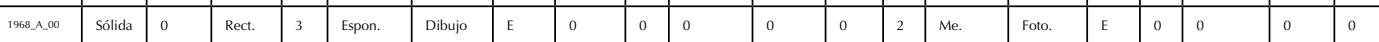

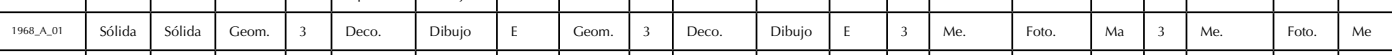

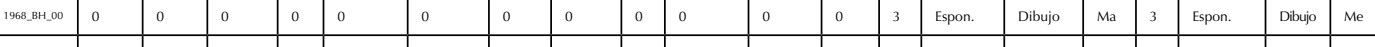

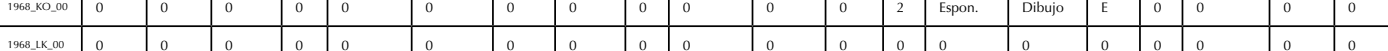

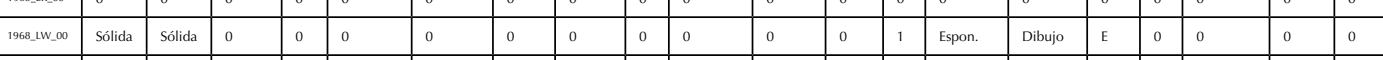

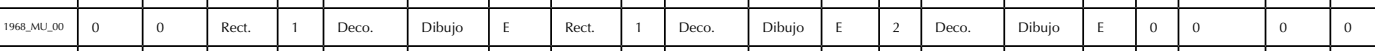

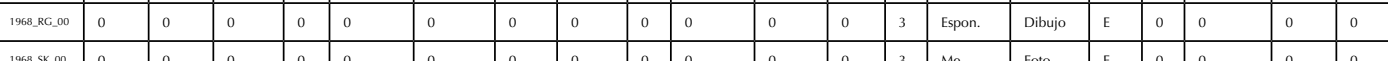

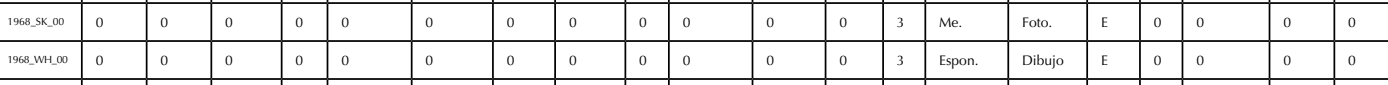

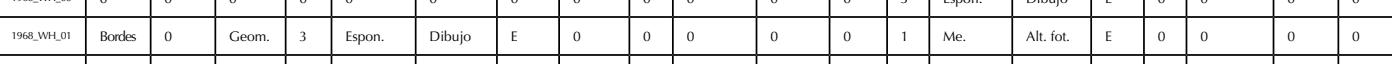

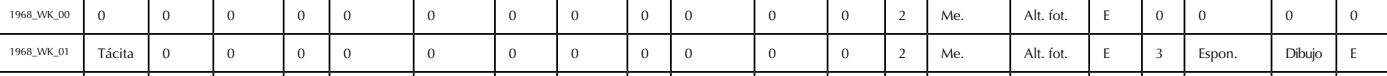

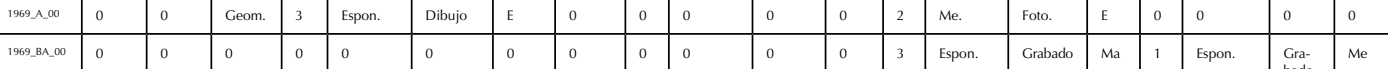

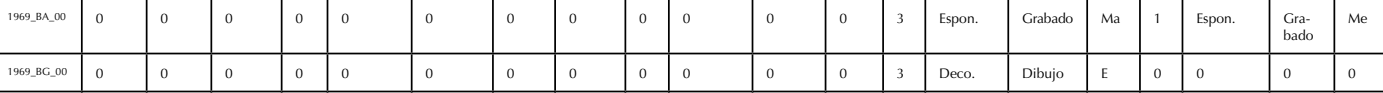

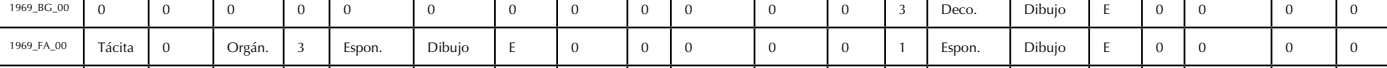

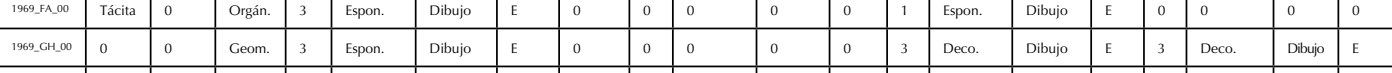

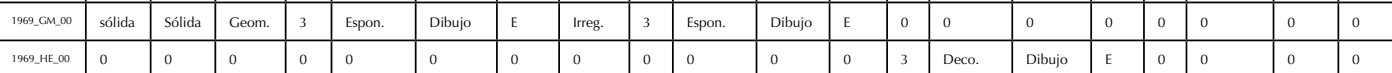

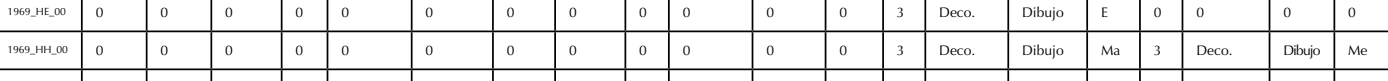

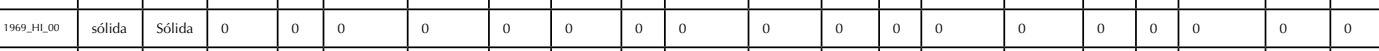

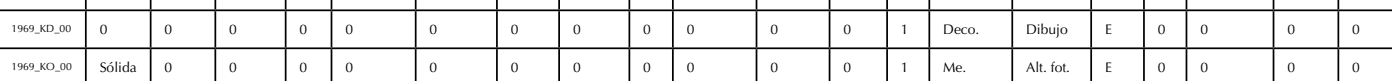

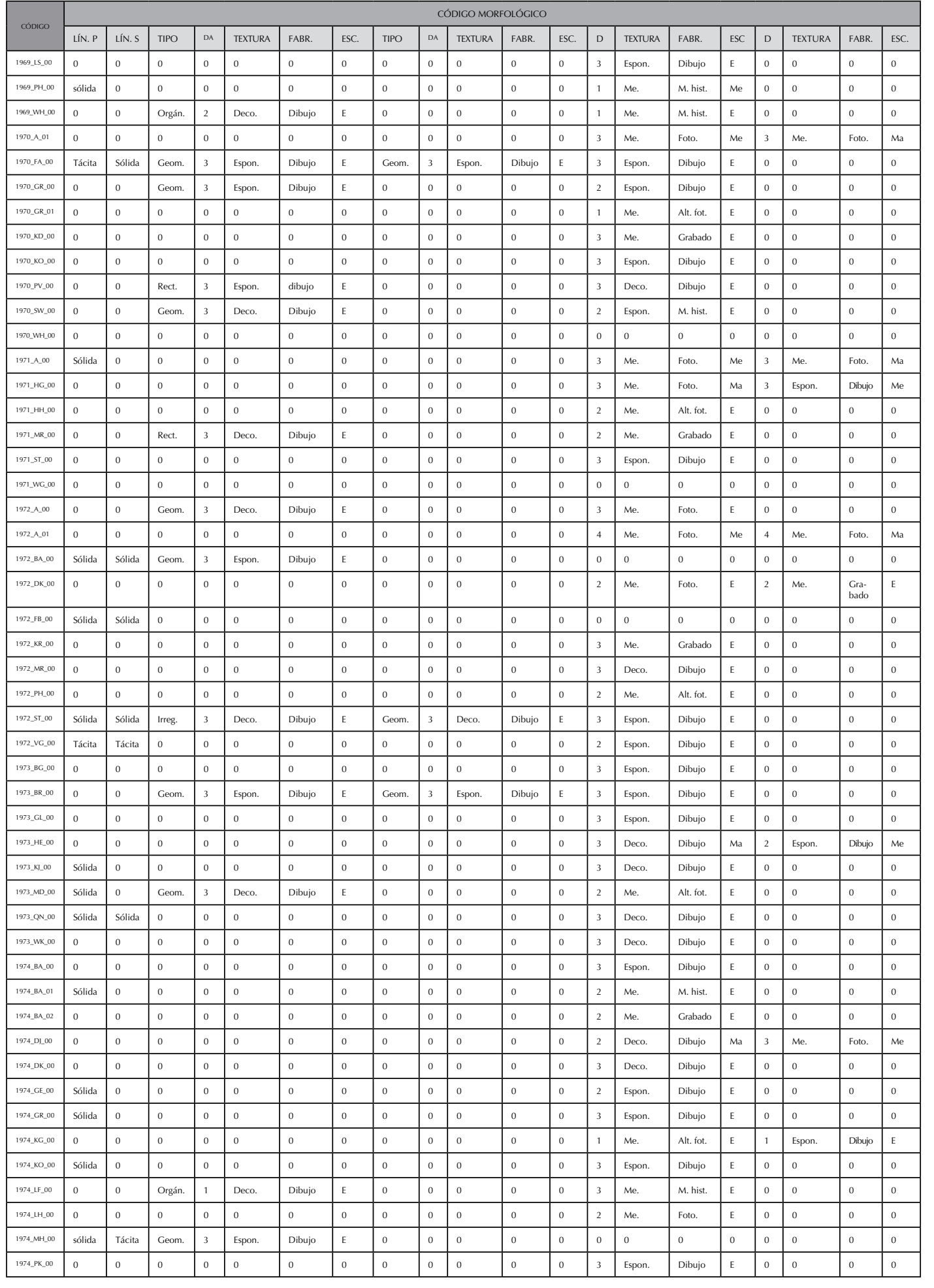




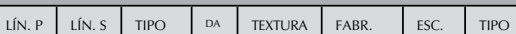

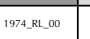

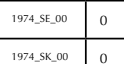
(n)

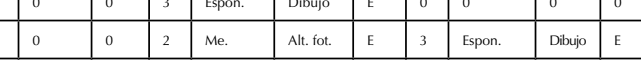

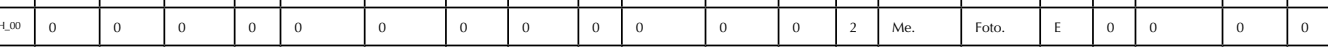

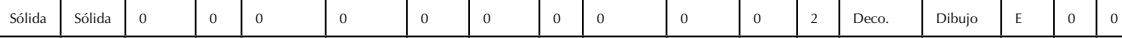

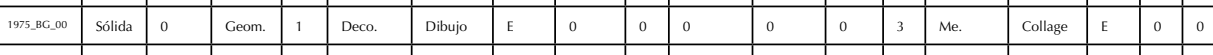

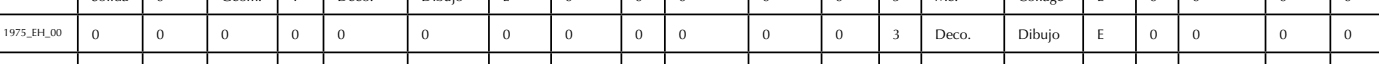

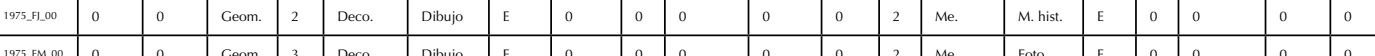

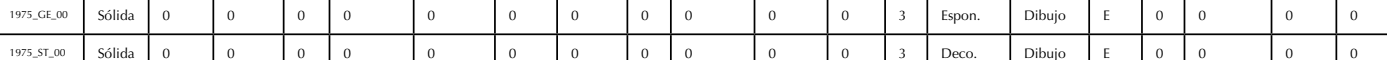

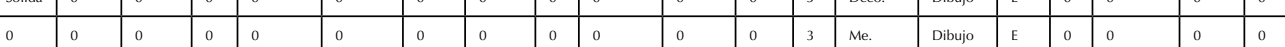

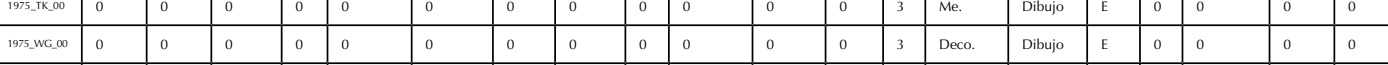

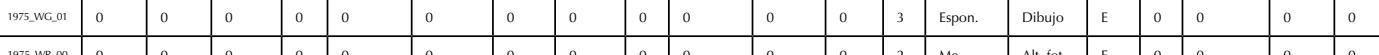

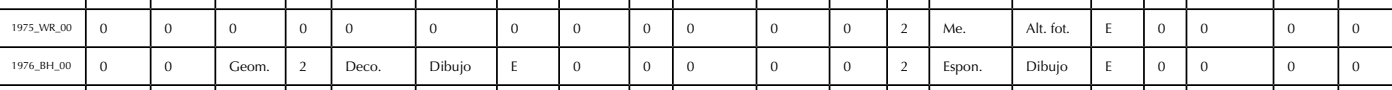

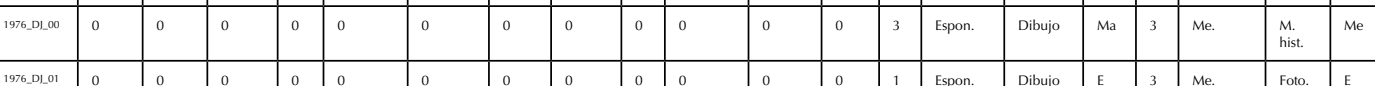

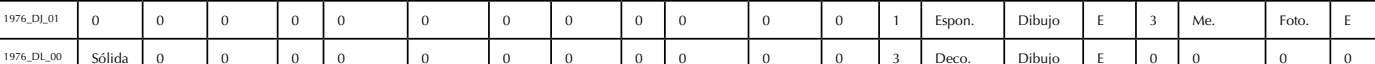

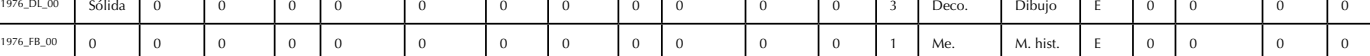

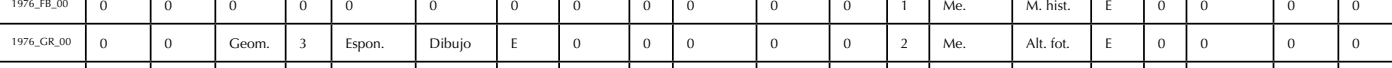

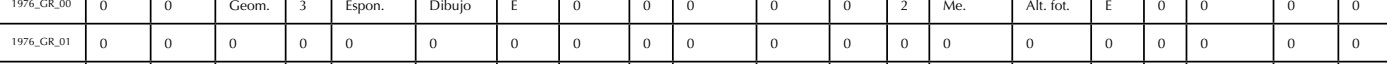

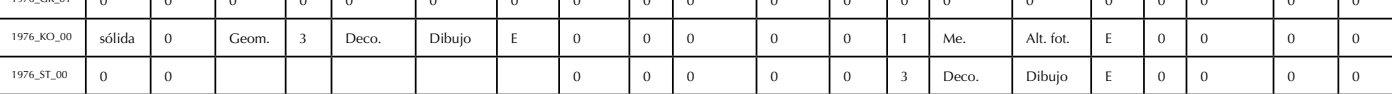

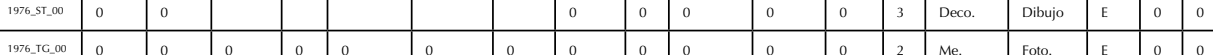

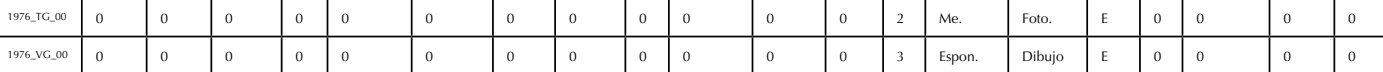

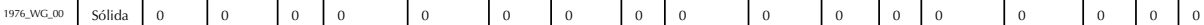

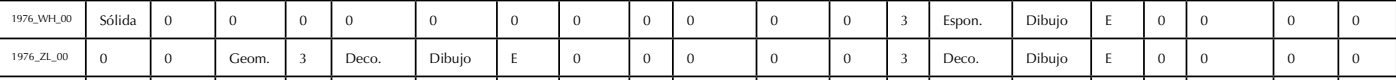

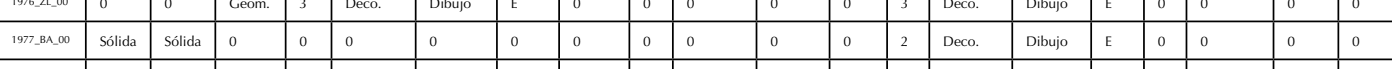

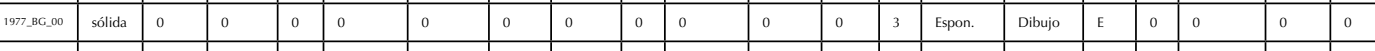

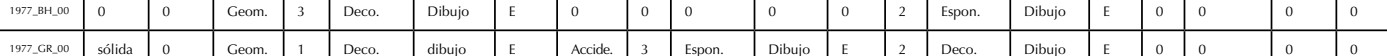

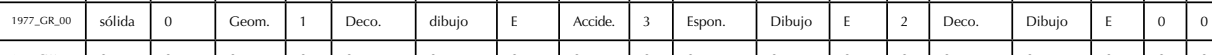

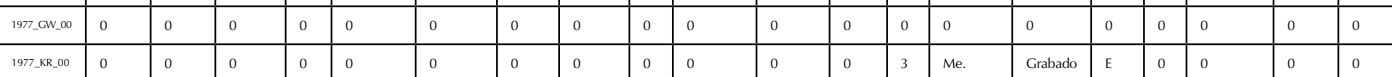

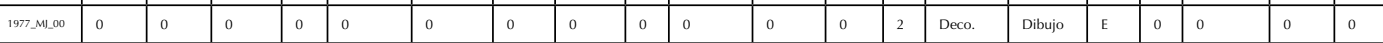

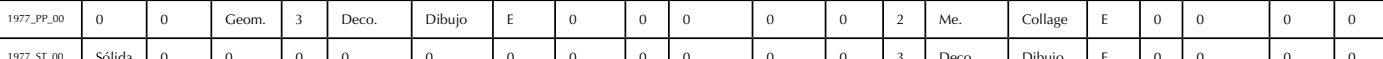

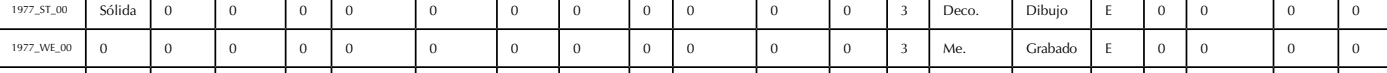

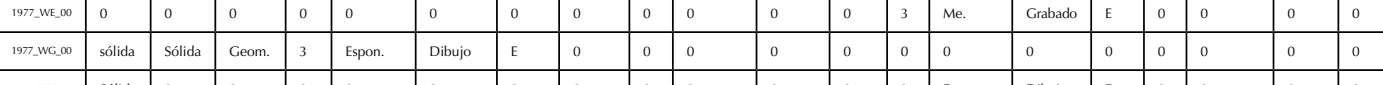

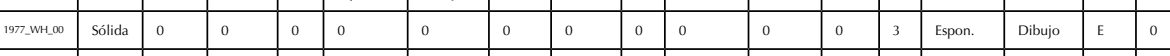

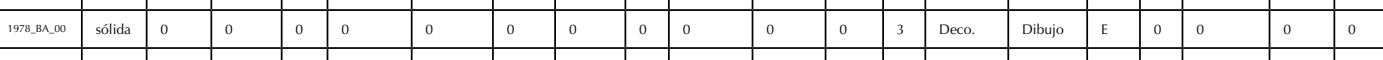

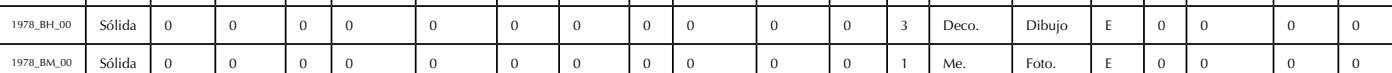

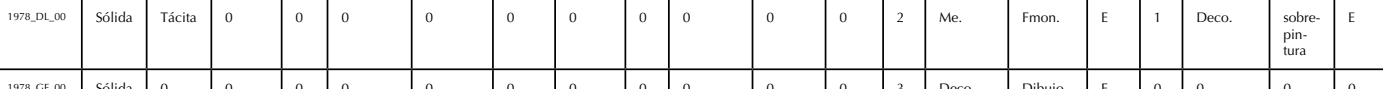

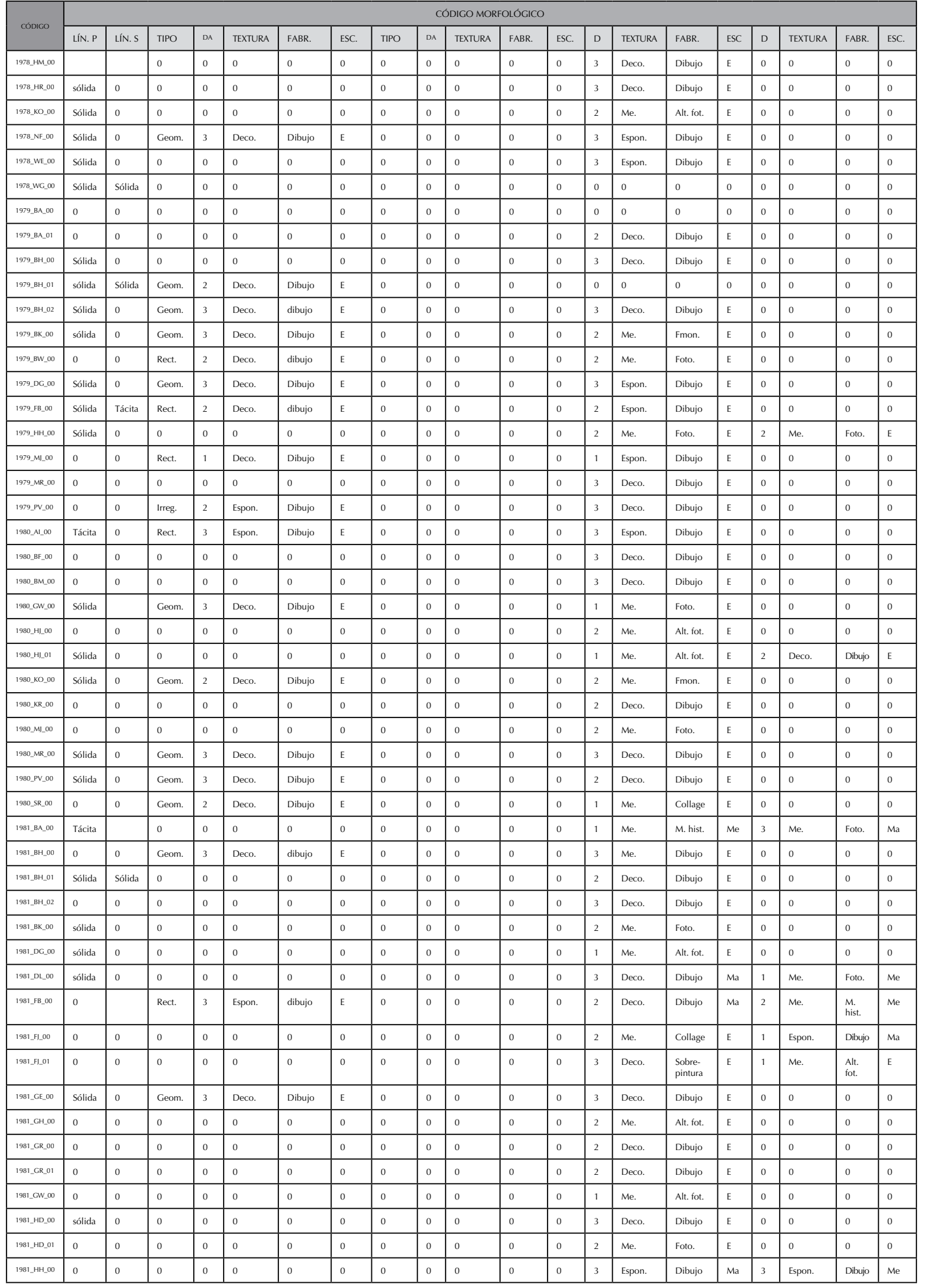




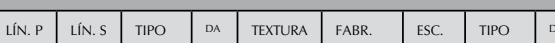

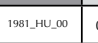
sous

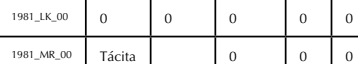

and

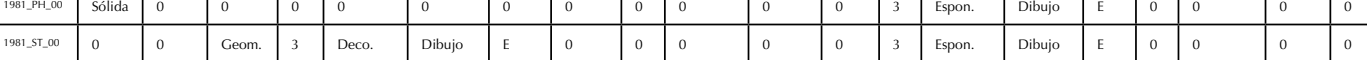

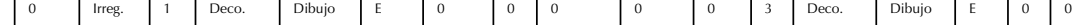

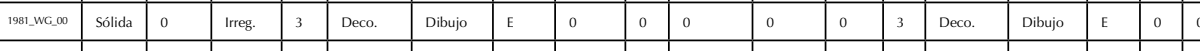

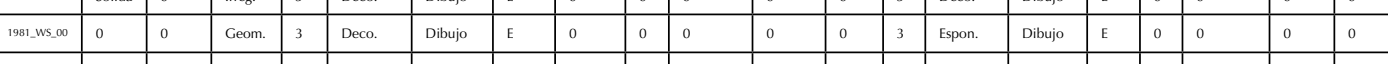

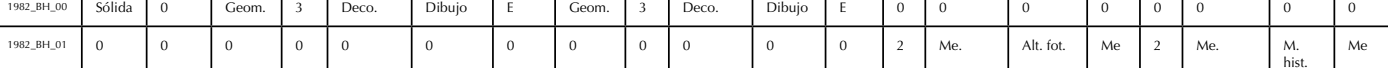

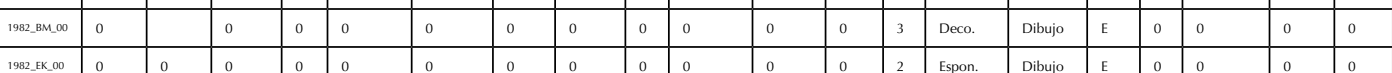

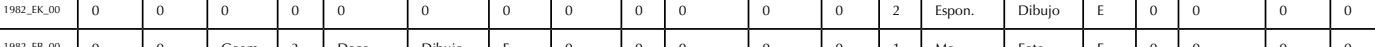

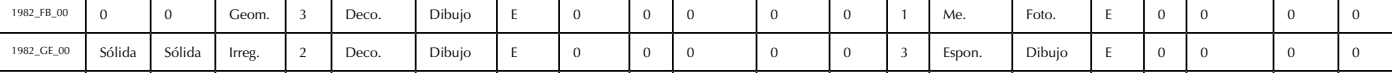

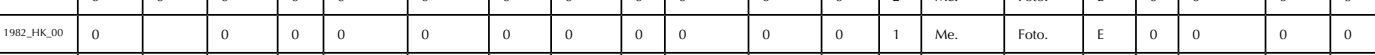

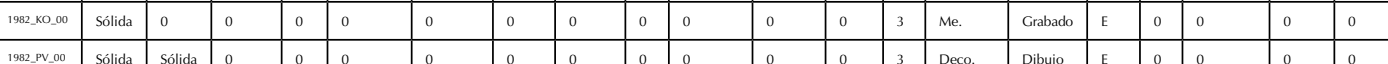

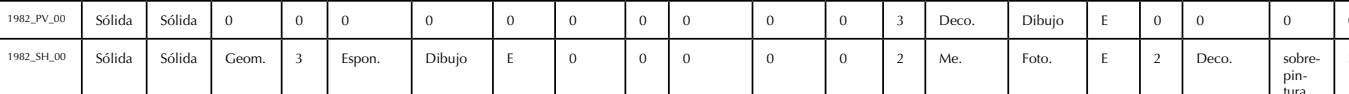

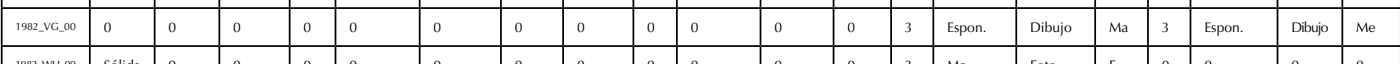

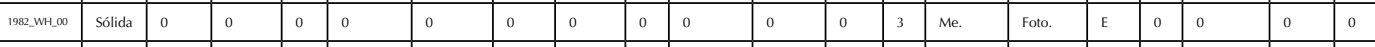

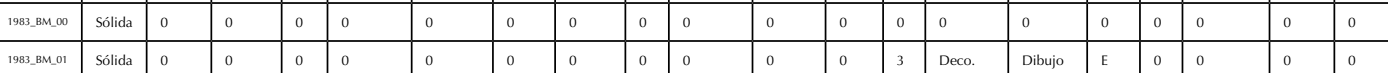

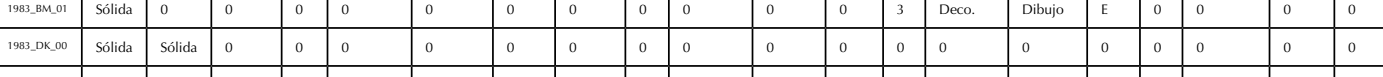

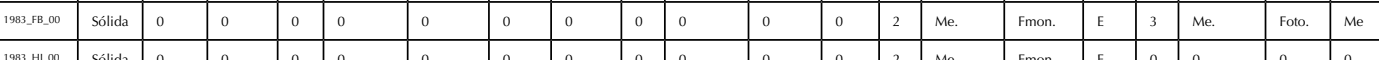

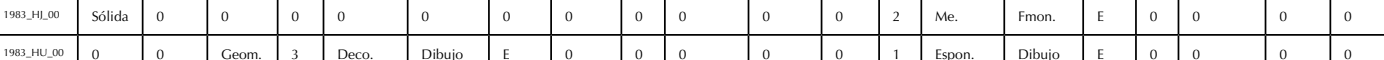

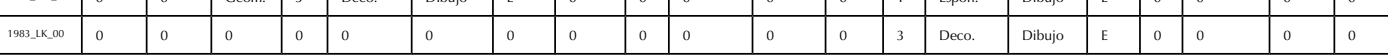

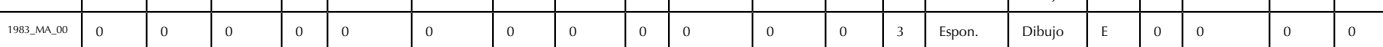

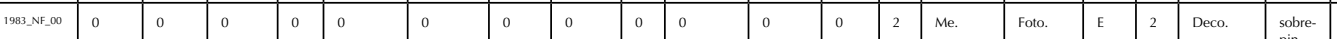

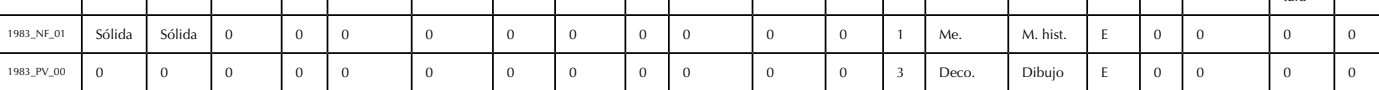

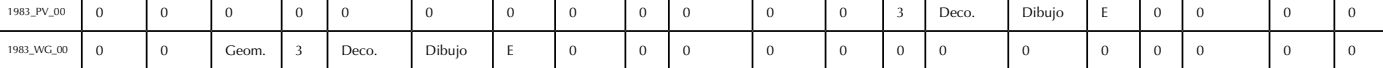

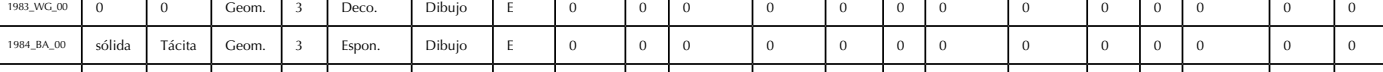

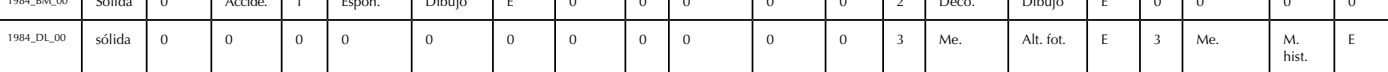

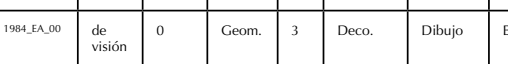

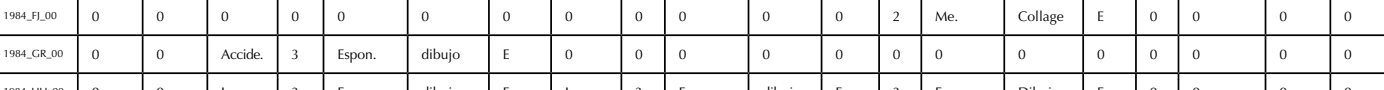

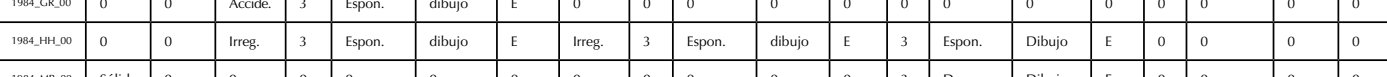

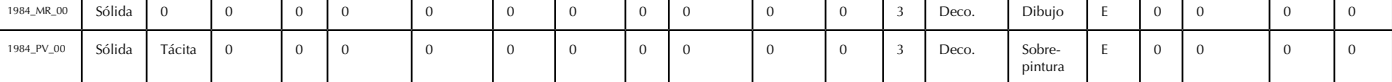

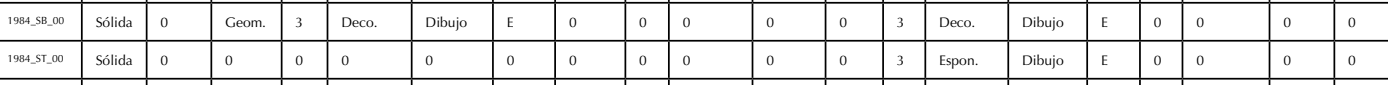

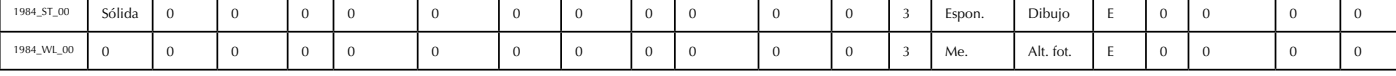

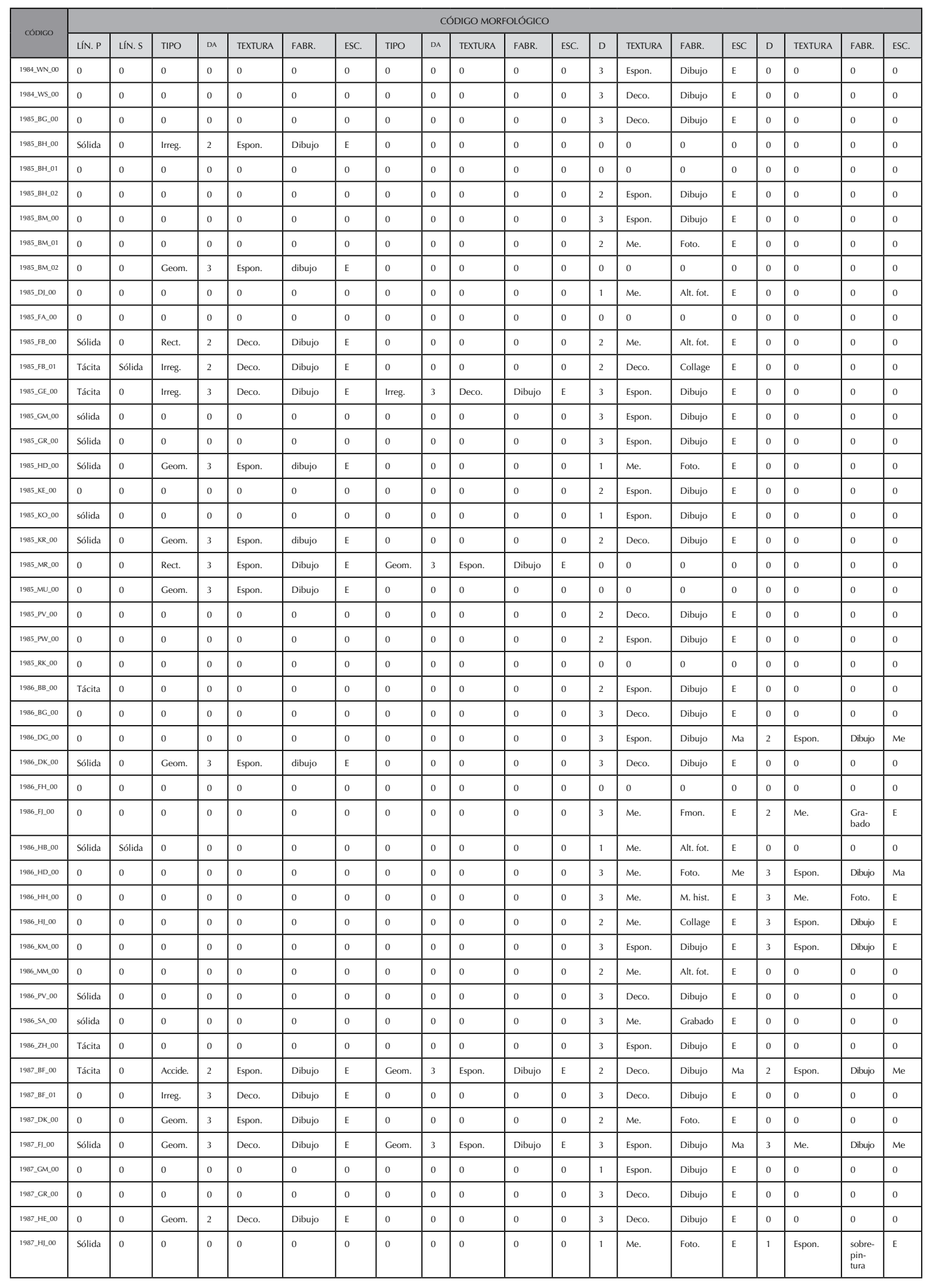




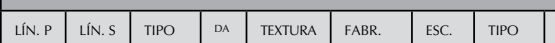

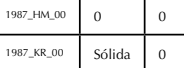

Com. 3 Epon

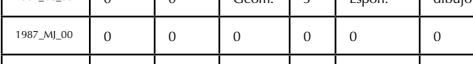

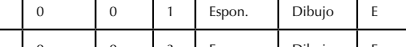

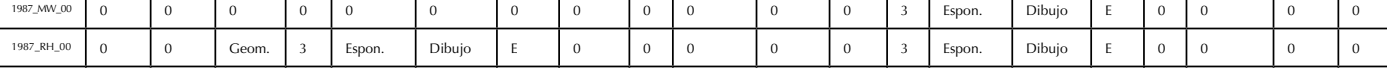

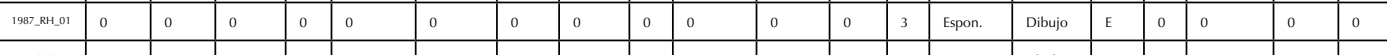

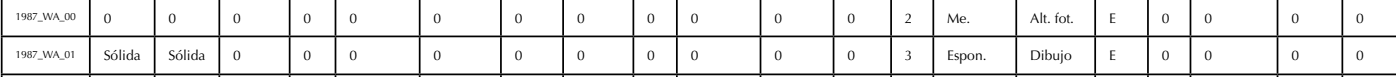

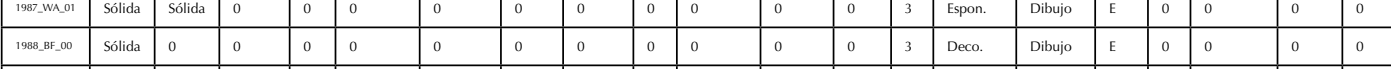

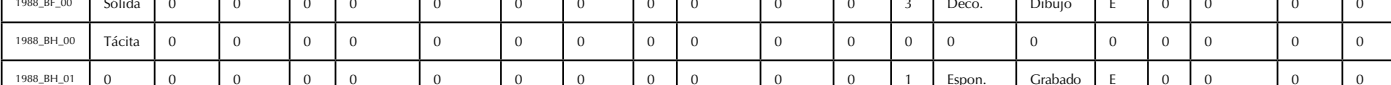

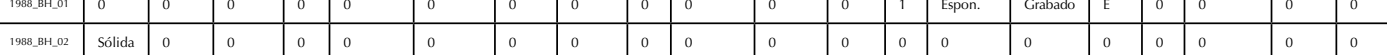

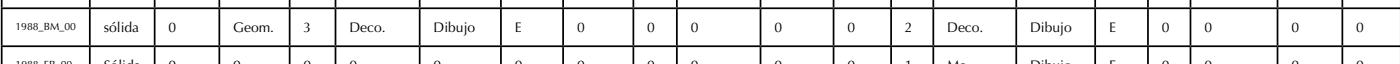

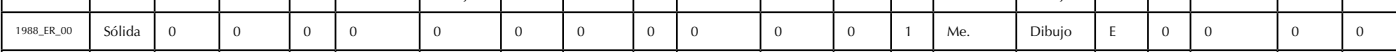

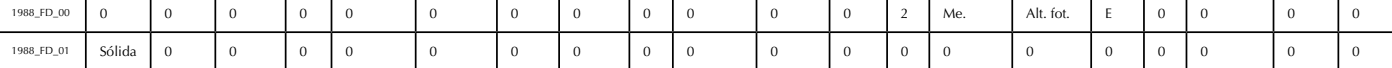

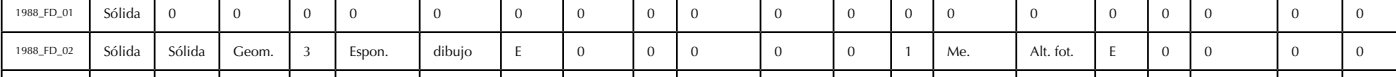

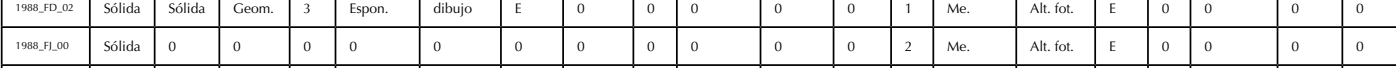

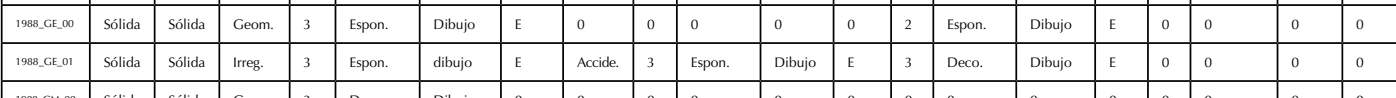

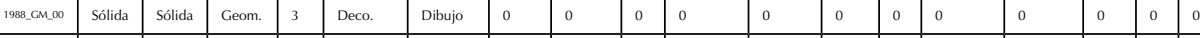

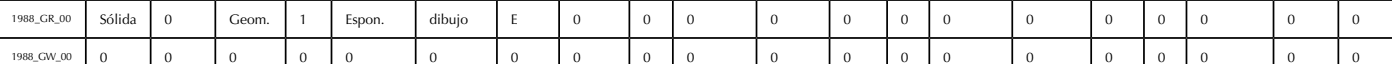

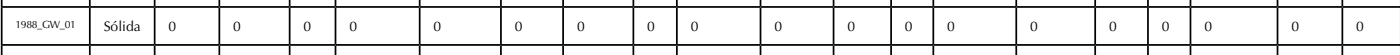

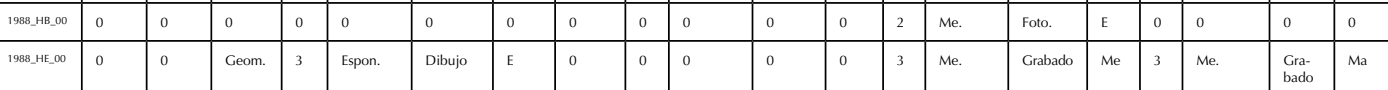

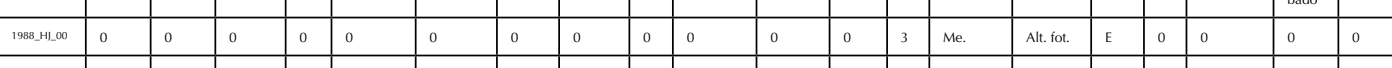

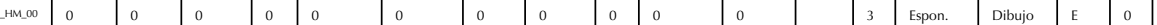

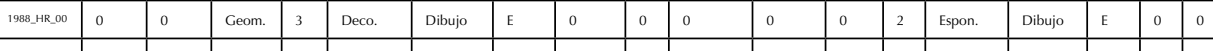

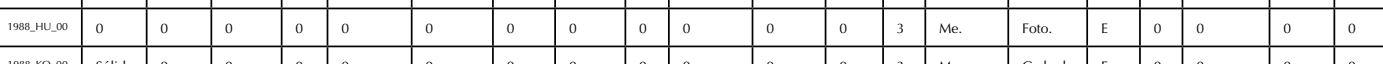

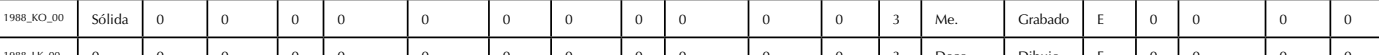

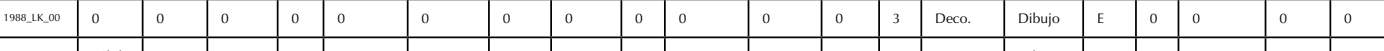

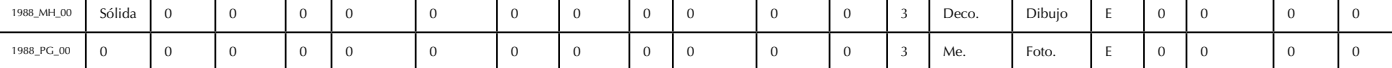

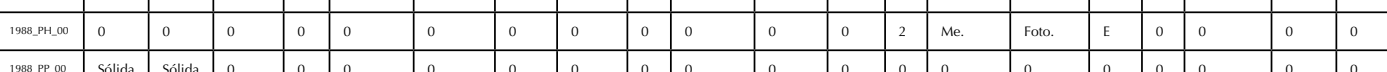

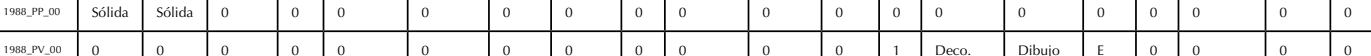

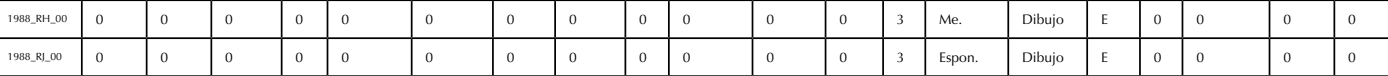

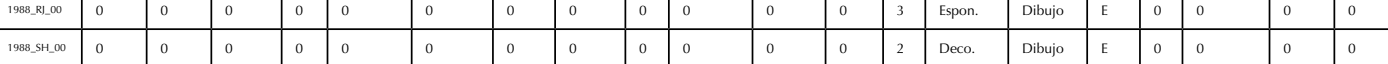

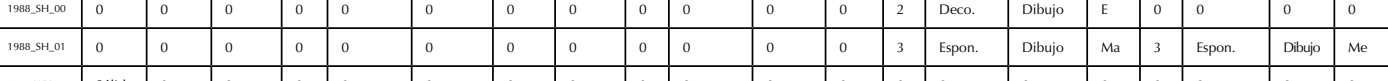

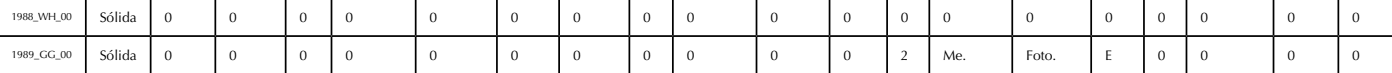

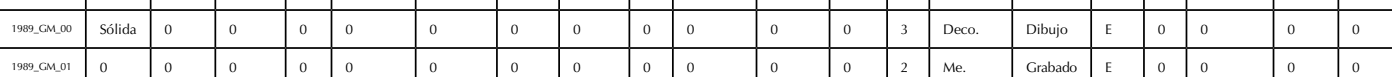

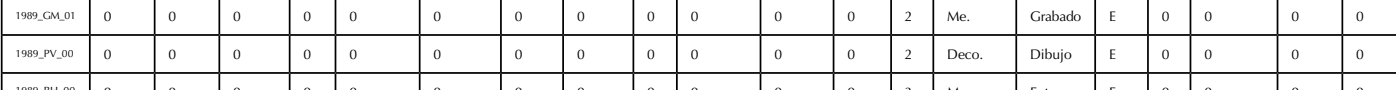

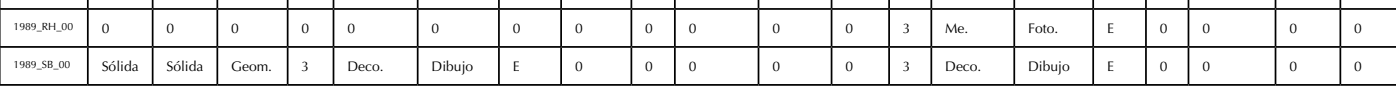

-

B.2. Código cromático y tipográfico

\begin{tabular}{|c|c|c|c|c|c|c|c|c|c|c|c|c|c|c|c|c|c|c|c|c|c|}
\hline \multirow{2}{*}{ concoso } & \multicolumn{9}{|c|}{ CóDICO CROMÁTICO } & \multicolumn{12}{|c|}{ CóDICO TIPOCRÁFCO } \\
\hline & \begin{tabular}{|l|l|} 
uso \\
\end{tabular} & MATIZ & $\mathrm{v}$ & $s$ & L & MATIZ & v & s & L & REP & $\mathrm{CLA}$ & FAMMLIA & \begin{tabular}{|l|l} 
EsT. \\
.
\end{tabular} & ALIN & ORRE. & REP. & $\mathrm{cL}$ & \begin{tabular}{|l|} 
FАМІLА \\
\end{tabular} & EST. & ALIN & ORIE. \\
\hline $196, f_{0} 00$ & \begin{tabular}{|l|l} 
Mono. \\
\end{tabular} & Rojo & m & M & B & Negro & 0 & M & 0 & ма & VIIII & 0 & Extra & 0 & Obli. & мa. & $v_{1}$ & 0 & Extra & 0 & Hori. \\
\hline 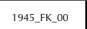 & \begin{tabular}{|l|l|} 
Dic. \\
\end{tabular} & \begin{tabular}{|l|l|} 
Rojo \\
\end{tabular} & M & M & A & \begin{tabular}{|l|} 
Negro \\
\end{tabular} & M & M & A & Me & $v_{1}$ & 0 & 0 & \begin{tabular}{|l|} 
Cont. \\
\end{tabular} & Hori. & 0 & 0 & \begin{tabular}{|l|} 
\\
\end{tabular} & $\mid$ & 0 & \begin{tabular}{|l} 
\\
\end{tabular} \\
\hline $1945 \mathrm{SW}=0 \mathrm{Co}$ & \begin{tabular}{|l|l|} 
T.pl. \\
\end{tabular} & Rojo & M & M & M & verde & o & м & M & ме & $\mathrm{v}$ & Techoolyp & Negra & \begin{tabular}{|l|l} 
Just. \\
\end{tabular} & Hori. & ма. & VIII & 0 & Reg. & 0 & Hori: \\
\hline 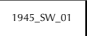 & & 0 & & & & & & & & ме & v1 & 0 & Reg. & Just. & Hori. & 0 & 0 & 0 & 10 & 0 & 0 \\
\hline 1945 VH & & 0 & & & & & & & & мa. & $v_{1}$ & 0 & Reg. & \begin{tabular}{|l|l} 
Asim. \\
\end{tabular} & Adap. & 0 & 0 & \begin{tabular}{|l|l}
0 \\
\end{tabular} & 0 & 0 & 0 \\
\hline $1945, k \in k 00$ & \begin{tabular}{|l} 
Dic. \\
\end{tabular} & Naranja & м & M & в & Negro & M & м & M & ма & $\mathrm{vI}$ & 0 & Negra & Asim. & obli. & ма. & VIIII & 0 & Reg. & 0 & obli. \\
\hline 1946_B_[1]00 & \begin{tabular}{|l} 
Real. \\
\end{tabular} & $\begin{array}{l}\text { Amari- } \\
\text { tlori }\end{array}$ & M & M & B & Rojo & M & M & B & мe & " & 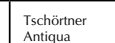 & Reg. & Cent. & \begin{tabular}{|l} 
Hori. \\
\end{tabular} & Me. & $" 1$ & \begin{tabular}{|l|l|} 
Tschätner \\
Anstiuna
\end{tabular} & Curs. & Cent. & Hori. \\
\hline 1996 - F. 000 & T.pl. & \begin{tabular}{|l|} 
Rojo \\
\end{tabular} & o & $M$ & A & Negro & 0 & M & A & Ma & $\mathrm{vI}$ & 0 & Cond. & \begin{tabular}{|l|l|}
129. \\
\end{tabular} & Hori. & & & & & & \\
\hline $1916, m \infty x$ & \begin{tabular}{|l} 
Dic. \\
\end{tabular} & \begin{tabular}{|l|l|} 
Rojo \\
\end{tabular} & M & M & A & Negro & 0 & M & A & $\mathrm{Ma}$ & $\mathrm{vi}_{1}$ & 0 & Deco. & 129. & Hori. & ме. & $v_{1}$ & $\mid \begin{array}{c}\text { Noma } \\
\text { Steinachitit }\end{array}$ & Reg. & 0 & Hori: \\
\hline 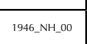 & & 0 & & & & & & & & мa & vi & 0 & Reg. & 0 & Obli. & 0 & 0 & 0 & 0 & 0 & 0 \\
\hline 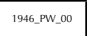 & \begin{tabular}{|l} 
Dic. \\
\end{tabular} & Rojo & M & M & A & Negro & M & м & A & Me & $v_{1}$ & 0 & Reg. & Asim. & Hori. & ма. & VIII & 0 & \begin{tabular}{|l} 
Reg. \\
\end{tabular} & 0 & Hori: \\
\hline 1946 QRW $=0$ & & 0 & & & & & & & & ма & $\mathrm{v}_{1}$ & 0 & 0 & 124. & Hori. & 0 & 0 & 0 & 0 & 0 & 0 \\
\hline $1946.5 \mathrm{sm}, 00$ & & 0 & & & & & & & & мe & vil & 0 & Reg. & \begin{tabular}{|l|} 
Asim. \\
\end{tabular} & Hori. & \begin{tabular}{|l}
0 \\
\end{tabular} & 0 & \begin{tabular}{|l}
0 \\
\end{tabular} & 0 & 0 & 0 \\
\hline 1946 Sw 00 & 3 Col. & Rojo & M & M & A & Blanco & $M$ & M & B & Me & $v_{1}$ & 0 & $\begin{array}{l}\text { Negra } \\
\end{array}$ & \begin{tabular}{|l} 
Cent. \\
\end{tabular} & Hori. & Ma. & VIII & 0 & \begin{tabular}{|l|} 
Reg. \\
\end{tabular} & 0 & \begin{tabular}{|l|l|} 
Hori. \\
\end{tabular} \\
\hline $194, B, B, 000$ & \begin{tabular}{|l|} 
Dic. \\
\end{tabular} & \begin{tabular}{|l|} 
Rojo \\
\end{tabular} & M & M & A & \begin{tabular}{|l|l|} 
Negro \\
\end{tabular} & o & M & A & $\mathrm{Ma}$ & $v_{1}$ & o & Reg. & \begin{tabular}{|l|} 
Just. \\
\end{tabular} & \begin{tabular}{|l|} 
Hori. \\
\end{tabular} & & & & & & \\
\hline $1997, B, 0,01$ & \begin{tabular}{|l|l}
3 col. \\
\end{tabular} & Azul & M & M & A & Negro & 0 & м & A & Ма & $\mathrm{v}_{1}$ & 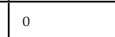 & Rege. & 129. & \begin{tabular}{|l} 
Adap. \\
\end{tabular} & Ma. & $\mathrm{vi}_{1}$ & 0 & \begin{tabular}{|l|l|} 
Negra \\
\end{tabular} & \begin{tabular}{|l|l} 
Cent. \\
\end{tabular} & Hori. \\
\hline 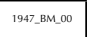 & \begin{tabular}{|l|} 
T.pl. \\
\end{tabular} & Verde & o & $M$ & A & Rojo & M & B & M & ма. & VIII & o & Reg. & \begin{tabular}{|l} 
Cent. \\
.
\end{tabular} & Hori. & & & & & & \\
\hline 1947-onves & \begin{tabular}{|l|} 
Dic. \\
\end{tabular} & \begin{tabular}{|l|l|} 
Negro \\
\end{tabular} & o & M & A & Rojo & M & M & B & Me & $\mathrm{v}_{1}$ & Super Grotesk & \begin{tabular}{|l|} 
Semi. \\
\end{tabular} & \begin{tabular}{|l|} 
Just. \\
\end{tabular} & \begin{tabular}{|l|} 
Hori. \\
\end{tabular} & 0 & 0 & 0 & 0 & 0 & 0 \\
\hline $1947 x$ Re 0 on & 3 col. & \begin{tabular}{|l|} 
Azzul \\
\end{tabular} & $M$ & M & A & \begin{tabular}{|l|} 
Rojo \\
\end{tabular} & M & M & A & $\mathrm{Ma}$ & VIII & 0 & \begin{tabular}{|l|} 
Reg. \\
\end{tabular} & 0 & Hori. & ма. & $\mathrm{v}$ & \begin{tabular}{|l|}
0 \\
\end{tabular} & \begin{tabular}{|l|l|} 
Negraa \\
\end{tabular} & \begin{tabular}{|l|l} 
Just. \\
\end{tabular} & Hori. \\
\hline 198 on on 00 & \begin{tabular}{|l|l|} 
Dic. \\
\end{tabular} & Rojo & M & M & A & Negro & 0 & M & A & ме & $v$ & 0 & Seni. & 0 & Hori. & ме. & v & 0 & \begin{tabular}{|l|} 
Reg. \\
\end{tabular} & \begin{tabular}{|l} 
Cent. \\
\end{tabular} & Hori. \\
\hline 1948, H, & \begin{tabular}{|l|l} 
Mono. \\
\end{tabular} & \begin{tabular}{|l|l|} 
Negro \\
\end{tabular} & $M$ & M & A & Blanco & M & M & B & $\mathrm{Ma}$ & vil & o & 0 & 0 & \begin{tabular}{|l|} 
Adap. \\
\end{tabular} & Ma. & VIII & 0 & \begin{tabular}{|l|} 
Reg. \\
\end{tabular} & \begin{tabular}{|c|} 
Cent. \\
\end{tabular} & \begin{tabular}{|l|} 
Hori. \\
\end{tabular} \\
\hline 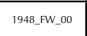 & \begin{tabular}{|l|} 
Dic. \\
\end{tabular} & Rojo & M & B & в & Negro & o & M & A & Ma & $\mathrm{v}_{1}$ & o & Extra & 112q. & Hori. & M. & $v_{1}$ & 0 & \begin{tabular}{|l|} 
Reg. \\
\end{tabular} & 124. & \begin{tabular}{|l|l} 
Hori. \\
\end{tabular} \\
\hline $1946, C F, D=0$ & \begin{tabular}{|l} 
Dic. \\
\end{tabular} & Rojo & M & M & в & Negro & 0 & м & A & ме & $v_{1}$ & o & $\begin{array}{l}\text { Negra } \\
\text { N }\end{array}$ & \begin{tabular}{|l|l|} 
Just. \\
\end{tabular} & Hori. & 0 & 0 & 0 & 0 & 0 & 0 \\
\hline 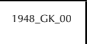 & $3 \mathrm{Col}$. & \begin{tabular}{|l|l|} 
Rojo \\
\end{tabular} & M & M & A & \begin{tabular}{|c|c|c|} 
Amala \\
riflo
\end{tabular} & c & M & M & Ma & $v_{1}$ & 0 & Negra & o & \begin{tabular}{|l} 
Adap. \\
\end{tabular} & Ma. & v & 0 & \begin{tabular}{|l|} 
Deco. \\
\end{tabular} & 0 & Hori. \\
\hline 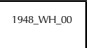 & $3 \mathrm{col}$. & $\begin{array}{l}\text { Rojo } \\
\end{array}$ & M & M & A & $\begin{array}{c}\text { Ama- } \\
\text { rillo }\end{array}$ & M & M & M & ме & X.A & o & Reg. & Cent. & Hori. & м. & VIII & 0 & \begin{tabular}{|l} 
Reg. \\
\end{tabular} & Cent. & Hori. \\
\hline 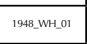 & \begin{tabular}{|l|l}
3 Col. \\
\end{tabular} & Azul & c & M & B & Rojo & 0 & M & B & Me & $\mathrm{vi}_{1}$ & 0 & Reg. & \begin{tabular}{|l|l|} 
ust. \\
\end{tabular} & \begin{tabular}{|l|} 
obli. \\
\end{tabular} & Ma. & $v_{1}$ & 0 & \begin{tabular}{|l|l|} 
Negra \\
\end{tabular} & 0 & \begin{tabular}{|l|l|} 
obli. \\
\end{tabular} \\
\hline 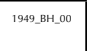 & \begin{tabular}{|l|} 
Real. \\
\end{tabular} & \begin{tabular}{|l|} 
Amamari- \\
Ilor
\end{tabular} & o & M & M & \begin{tabular}{|l|l|} 
Rojo \\
\end{tabular} & 0 & M & M & Me & I"II & 0 & $\begin{array}{ll}\text { Reg. } \\
\end{array}$ & \begin{tabular}{|l|l|} 
Drch \\
\end{tabular} & \begin{tabular}{|l|} 
Hori. \\
\end{tabular} & 0 & 0 & 0 & 0 & 0 & 0 \\
\hline 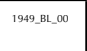 & $3 \mathrm{Col}$. & \begin{tabular}{|l|l|} 
Rojo \\
\end{tabular} & M & M & A & \begin{tabular}{|l|l} 
Negro \\
\end{tabular} & 0 & M & A & Me & $\mathrm{v}_{1}$ & $\begin{array}{l}\text { Fundemental } \\
\text { Grotesk }\end{array}$ & cond. & 0 & \begin{tabular}{|l} 
obli. \\
\end{tabular} & Me. & $\mathrm{vi}_{1}$ & 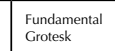 & \begin{tabular}{|l|} 
Curs. \\
\end{tabular} & 0 & obli. \\
\hline $1949 x, 0,00$ & \begin{tabular}{|l|} 
Dic. \\
\end{tabular} & Negro & o & M & A & $\begin{array}{l}\text { Ama- } \\
\text { rillo }\end{array}$ & o & M & B & Me & iv & 0 & Reg. & Cent. & Hori. & Me. & x.a & 0 & \begin{tabular}{|l} 
Reg. \\
Reg
\end{tabular} & 0 & Hori: \\
\hline 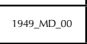 & 3 Col. & Blanco & M & $M$ & A & Negro & 0 & M & A & Мa. & VIII & 0 & Reg. & \begin{tabular}{|l} 
Cent. \\
\end{tabular} & \begin{tabular}{|l|} 
Obli. \\
\end{tabular} & Me. & IV & 0 & Semi. & Cent. & \begin{tabular}{|l|l} 
Hori. \\
\end{tabular} \\
\hline 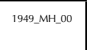 & $3 \mathrm{Col}$. & Verde & M & M & B & \begin{tabular}{|l|l} 
naranjia \\
\end{tabular} & 0 & M & B & мe & iv & 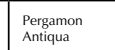 & Semi. & 129. & Hori. & Me. & iv & 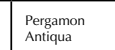 & Curs. & Cent. & \begin{tabular}{|l|l} 
Hori. \\
\end{tabular} \\
\hline 1990 accos & \begin{tabular}{|l|} 
Dic. \\
\end{tabular} & Negro & M & M & M & Rojo & c & M & B & Me & vil & 0 & Reg. & \begin{tabular}{|l} 
Cent. \\
\end{tabular} & \begin{tabular}{|l|} 
Hori. \\
\end{tabular} & 0 & 0 & 0 & 0 & 0 & 0 \\
\hline 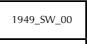 & & 0 & & & & & & & & Ma & VIII & 0 & Reg. & 0 & Hori. & Me. & $v_{1}$ & 0 & \begin{tabular}{|l} 
Reg. \\
\end{tabular} & \begin{tabular}{|l|l} 
Drch \\
\end{tabular} & Hori. \\
\hline 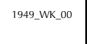 & 3 col. & \begin{tabular}{|l|} 
Amamar- \\
Ilor
\end{tabular} & M & M & M & Rojo & M & M & M & мe & iv & \begin{tabular}{|l|l} 
Pergamonon \\
Antituaa
\end{tabular} & Negra & 12q. & Hori. & 0 & 0 & 0 & 0 & 0 & 0 \\
\hline 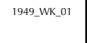 & & 0 & & & & & & & & мe & $v_{1}$ & 0 & Reg. & 0 & Hori. & Me. & $v_{1}$ & \begin{tabular}{|l|l} 
Fundamental \\
Grotesk
\end{tabular} & Rege. & |ust. & Hori. \\
\hline 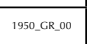 & \begin{tabular}{|l|l|} 
Real. \\
\end{tabular} & \begin{tabular}{|l|l|} 
Azzul \\
\end{tabular} & M & M & A & naranjia & M & M & B & Me & iv & 0 & Reg. & \begin{tabular}{|l|l|} 
Asim. \\
\end{tabular} & \begin{tabular}{|l|} 
Hori. \\
\end{tabular} & 0 & 0 & 0 & 0 & 0 & 0 \\
\hline 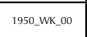 & Real. & $\begin{array}{l}\text { Blanco } \\
\end{array}$ & M & M & A & $\begin{array}{ll}\text { Azul } \\
\end{array}$ & o & B & A & Me & $\mathrm{vi}$ & 0 & Cond. & 124. & Hori. & Me. & $v_{1}$ & 0 & \begin{tabular}{|l|} 
Reg. \\
\end{tabular} & $\begin{array}{ll}\text { Just. } \\
\end{array}$ & Hori. \\
\hline 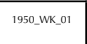 & $3 \mathrm{Col}$. & Rojo & o & M & в & \begin{tabular}{|l|l} 
Negro \\
\end{tabular} & o & M & B & Me & iv & $\begin{array}{l}\text { Pergamon } \\
\text { Anniuua }\end{array}$ & Reg. & 0 & obli. & Me. & vi & Super Grotesk & Negra & Cent. & \begin{tabular}{|l|l} 
obli. \\
\end{tabular} \\
\hline
\end{tabular}




\begin{tabular}{|c|c|c|c|c|c|c|c|c|c|c|c|c|c|c|c|c|c|c|c|c|c|c|}
\hline \multirow{2}{*}{ conico } & \multicolumn{10}{|c|}{ CÓDIGO CROMÁTICO } & \multicolumn{12}{|c|}{ CÓDIGO TPPOCRÁFCO } \\
\hline & uso & MATIZ & $\mathrm{v}$ & s & L & MATIZ & v & $\mathrm{s}$ & L & & REP. & $\mathrm{CLA}$ & FАМ̆LA & EsT. & ALIN & ORIE. & \begin{tabular}{|l|l} 
REP. \\
\end{tabular} & $\mathrm{cL}$ & FAMLIA & ЕT. & ALIN & ORIR \\
\hline 1550.we we on & & 0 & & & & & & & & & Me. & $\mathrm{v}_{1}$ & 0 & \begin{tabular}{|l|l|} 
Reg. \\
\end{tabular} & 129. & Hori. & 0 & 0 & 0 & 0 & 0 & 0 \\
\hline 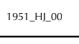 & $3 \mathrm{Col}$. & Negro & 0 & M & A & Rojo & o & M & A & & Me. & vil & 0 & Reg. & Cent. & Hori. & 0 & 0 & 0 & 0 & 0 & 0 \\
\hline 1951.1.5.00 & Dic. & \begin{tabular}{|l|l|l} 
Anarit- \\
Ilo
\end{tabular} & M & m & A & Negro & M & M & A & & ме. & vi & 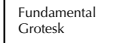 & Cond. & Asim. & Hori. & 0 & 0 & 0 & 0 & 0 & 0 \\
\hline silingen & T.p.l. & Azul & M & M & A & Rojo & M & M & A & & Me. & $\mathrm{v}_{1}$ & 0 & \begin{tabular}{|l|l} 
Deco. \\
\end{tabular} & Asim. & Hori. & ма. & vi & 0 & Semi. & Just. & Hori \\
\hline 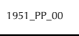 & $3 \mathrm{col}$. & Rojo & $\mathrm{o}$ & $M$ & $\mathrm{~A}$ & Azul & $\circ$ & B & A & & Ма. & vil & 0 & Reg. & kq. & Hori. & Me. & $\mathrm{vi}_{1}$ & Super Grotesk & \begin{tabular}{|l} 
Reg. \\
\end{tabular} & 12a. & Hori \\
\hline 1951,Lww_on & 3 col. & Naranja & o & M & в & Azul & M & B & n & & Me. & $v_{1}$ & 0 & Reg. & Just. & Hori. & 0 & 0 & 0 & 0 & 0 & 0 \\
\hline 1951-WK<_o & T.p.l. & Rojo & M & м & в & $\begin{array}{l}\text { Ama- } \\
\text { rillo- }\end{array}$ & M & M & $\mathrm{M}$ & & ме. & $v_{1}$ & 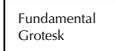 & Cond. & Just. & Hori. & 0 & 0 & 0 & 0 & 0 & 0 \\
\hline 1951-Wp_Lo & & 0 & & & & & & & & & ме. & $\mathrm{v}_{1}$ & 0 & \begin{tabular}{|l|l|} 
Reg. \\
\end{tabular} & $\mathrm{kq}$ & Obli. & 0 & 0 & 0 & 0 & 0 & 0 \\
\hline 1952_H & Real. & Blanco & M & M & A & Azul & o & B & A & & Me. & X.D. & \begin{tabular}{|l|l|l} 
Luthersche \\
Frakkur
\end{tabular} & Reg. & kq. & Hori. & м. & $"$ & 0 & Reg. & 0 & Hori \\
\hline 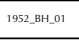 & Real. & Negro & M & M & A & rojo & c & M & $\mathrm{N}$ & & Me. & $\mathrm{v}_{1}$ & \begin{tabular}{|l|l|l|l} 
Super Grotesk \\
\end{tabular} & Semi. & $\mathrm{kq}$ & Hori. & 0 & 0 & 0 & 0 & 0 & 0 \\
\hline $1952+21-000$ & Dic. & Rojo & o & M & M & Negro & $M$ & M & $\mathrm{N}$ & & Me. & IV & 0 & Semi. & Cent. & Hori. & 0 & 0 & 0 & 0 & 0 & 0 \\
\hline $1952,2 \mathrm{WL}=0$ & $3 \mathrm{col}$. & Azul & 0 & M & A & $\begin{array}{l}\text { Anara- } \\
\text { rillo }\end{array}$ & M & M & M & & ме. & $v_{1}$ & 0 & Semi. & 124. & Hori. & Me. & $v_{1}$ & \begin{tabular}{|l}
$\begin{array}{l}\text { Fundamental } \\
\text { Grotesk }\end{array}$ \\
\end{tabular} & Cond. & Just & Hori \\
\hline 1953,150000 & $3 \mathrm{col}$. & Azzul & \begin{tabular}{|l}
$\circ$ \\
\end{tabular} & B & $\mathrm{A}$ & Rojo & M & B & A & & ме. & $v_{1}$ & \begin{tabular}{|l|} 
\\
\end{tabular} & Reg. & $\begin{array}{l}\text { Asim. } \\
\end{array}$ & Hori. & 0 & 0 & $\begin{array}{l} \\
\end{array}$ & 0 & 0 & 0 \\
\hline $1953,5 \mathrm{w}, \mathrm{wan}$ & & 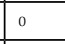 & - & & & & & & & & Me. & $\mathrm{iv}$ & 0 & \begin{tabular}{|l|l} 
Reg. \\
\end{tabular} & \begin{tabular}{|l|l|} 
Just. \\
\end{tabular} & Hori. & 0 & 0 & 0 & 0 & 0 & 0 \\
\hline 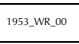 & Dic. & $\begin{array}{l}\text { Negro } \\
\end{array}$ & M & M & A & Rojo & o & M & B & & Me. & $v_{1}$ & 0 & \begin{tabular}{|l|l} 
Reg. \\
\end{tabular} & \begin{tabular}{|l} 
Cent. \\
\end{tabular} & Hori. & Мa. & VIIII & 0 & \begin{tabular}{|l} 
Reg. \\
\end{tabular} & \begin{tabular}{|l} 
Cent. \\
\end{tabular} & Hori \\
\hline $1954 \wedge ., 000$ & \begin{tabular}{|l} 
Real. \\
\end{tabular} & Rojo & o & M & B & Azzul & $\circ$ & M & B & & Me. & VIII & 0 & \begin{tabular}{|l} 
Reg. \\
\end{tabular} & \begin{tabular}{|l} 
Drch \\
\end{tabular} & Hori. & Ма. & VIII & 0 & \begin{tabular}{|l} 
Reg. \\
\end{tabular} & \begin{tabular}{|l} 
\\
\end{tabular} & Hori \\
\hline 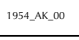 & $\begin{array}{l}\text { T.pl. } \\
\end{array}$ & Negro & M & M & M & Azzul & c & M & $\mathrm{M}$ & & ме. & v & Stentor & \begin{tabular}{|l|l} 
Reg. \\
\end{tabular} & Asim. & Hori. & 0 & 0 & 0 & 0 & 0 & 0 \\
\hline 1954. BH & $\begin{array}{l}\text { T.pl. } \\
\end{array}$ & Negro & 0 & B & $\mathrm{A}$ & naranjia & c & M & A & & Me. & III & 0 & Reg. & ejes & Hori. & Me. & \begin{tabular}{|l|l}
11 \\
\end{tabular} & 0 & \begin{tabular}{|c|c|c|} 
\\
Curs.
\end{tabular} & 0 & Hori \\
\hline 195_-BH_.00 & & 0 & & & & & & & & & Me. & v & 0 & \begin{tabular}{|l} 
Reg. \\
\end{tabular} & 0 & Hori. & Me. & v & 0 & \begin{tabular}{|l} 
Reg. \\
\end{tabular} & \begin{tabular}{|l} 
Cent. \\
\end{tabular} & Hori \\
\hline 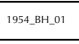 & Dic. & Negro & 0 & M & A & rojo & M & M & A & & мa. & III & 0 & \begin{tabular}{|l|l|} 
Reg. \\
\end{tabular} & \begin{tabular}{|l|l} 
Asim. \\
\end{tabular} & Hori. & 0 & 0 & 0 & 0 & $\begin{array}{l} \\
\end{array}$ & 0 \\
\hline 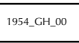 & Dic. & Azul & c & $M$ & $M$ & Blanco & M & M & $\mathrm{N}$ & & Me. & vil & 0 & \begin{tabular}{|l} 
Reg. \\
\end{tabular} & \begin{tabular}{|l|l} 
Asim. \\
\end{tabular} & Obli. & Me. & vil & 0 & \begin{tabular}{|l} 
Reg. \\
\end{tabular} & 0 & Hori \\
\hline 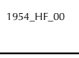 & $\begin{array}{l}\text { T.pl. } \\
\end{array}$ & 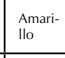 & c & M & B & Azzul & M & M & A & & Me. & IV & 0 & \begin{tabular}{|l|l|} 
Reg. \\
\end{tabular} & 129. & Hori. & Me. & $\mathrm{vu}$ & \begin{tabular}{|l|l|}
$\begin{array}{l}\text { Fundamental } \\
\text { Grotesk }\end{array}$ \\
\end{tabular} & \begin{tabular}{|l} 
Reg. \\
\end{tabular} & 129. & Hori \\
\hline $1954, H E-01$ & $\begin{array}{l}\text { T.pl. } \\
\end{array}$ & Negro & 0 & \begin{tabular}{|l} 
\\
\end{tabular} & A & Azul & c & M & $N$ & & Me. & X.D. & \begin{tabular}{|l}
0 \\
\end{tabular} & 0 & $\mathrm{kq}$ & Hori. & Me. & \begin{tabular}{|l}
$\mathrm{v}_{1}$ \\
\end{tabular} & $\begin{array}{l}0 \\
\end{array}$ & $\begin{array}{l}\text { Reg. } \\
\end{array}$ & 0 & Hori \\
\hline 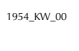 & T.p.l. & \begin{tabular}{|l|l|} 
Amarit- \\
ilo
\end{tabular} & M & B & M & Azul & M & B & A & & Ma. & vil & 0 & Reg. & Cent. & Hori. & Ма. & Ix & 0 & \begin{tabular}{|l} 
Reg. \\
\end{tabular} & Cent. & Hori \\
\hline $1954, R=0.00$ & $\begin{array}{l}\text { T.pl. } \\
\end{array}$ & \begin{tabular}{|l|l|} 
rojo \\
\end{tabular} & 0 & M & $\mathrm{A}$ & Verde & c & M & A & & Me. & iv & 0 & Deco. & Cent. & Adap. & 0 & 0 & 0 & 0 & 0 & 0 \\
\hline 1954,ARDol & & $0^{\circ}$ & & & & & & & & & Ma. & vil & 0 & \begin{tabular}{|l} 
Reg. \\
feg.
\end{tabular} & Drch & Hori. & Me. & $\mathrm{vv}_{1}$ & \begin{tabular}{|l|l|}
$\begin{array}{l}\text { Fundamental } \\
\text { Grotesk }\end{array}$ \\
\end{tabular} & \begin{tabular}{|l} 
cond. \\
\end{tabular} & Drch & Hoit \\
\hline $105+\mathrm{WHH}$ & Mono. & Negro & c & M & M & Verde & $\circ$ & M & $\mathrm{N}$ & & Me. & $\mathrm{v}_{1}$ & 0 & Seni. & 0 & Hori. & Me. & \begin{tabular}{|l}
$\mathrm{v}_{1}$ \\
\end{tabular} & 0 & Negra & 0 & Hori \\
\hline 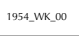 & $\begin{array}{l}\text { Real. } \\
\end{array}$ & Azul & M & B & B & Rojo & M & B & B & & ме. & $v_{1}$ & \begin{tabular}{|l|l|} 
\\
\end{tabular} & $\begin{array}{l}\text { Reg. } \\
\end{array}$ & 0 & Hori. & Мa. & v & 0 & \begin{tabular}{|l} 
Reg. \\
\end{tabular} & Cent. & \begin{tabular}{|l|l|} 
Adar \\
\end{tabular} \\
\hline 1554 W WR De & & 0 & & & & & & & & & $\mathrm{Ma}$ & VIII & 0 & Reg. & 0 & Hori. & \begin{tabular}{|l|} 
Me. \\
\end{tabular} & $v_{1}$ & $0^{\circ}$ & \begin{tabular}{|l} 
Reg. \\
\end{tabular} & \begin{tabular}{|l|l|} 
A \\
\end{tabular} & \begin{tabular}{|l|l|} 
Hori \\
\end{tabular} \\
\hline $1955 \wedge, \wedge 00$ & $\begin{array}{l}\text { T.pl. } \\
\end{array}$ & Rojo & M & M & A & Azul & $M$ & B & A & & ма. & VIII & 0 & Reg. & \begin{tabular}{|l} 
Asim. \\
\end{tabular} & Hori. & 0 & 0 & 0 & 0 & 0 & 0 \\
\hline $1955 \wedge .01$ & $\begin{array}{l}\text { Real. } \\
\end{array}$ & Rojo & M & M & A & Azul & M & B & A & & Ма. & IV & 0 & Curs. & Cent. & Hori. & Ма. & VIII & 0 & \begin{tabular}{|l} 
Reg. \\
\end{tabular} & Cent. & \begin{tabular}{|l|l} 
Hori \\
\end{tabular} \\
\hline $1955 \wedge .02$ & $\begin{array}{l}\text { Real. } \\
\end{array}$ & Rojo & M & M & A & Negro & M & B & A & & Ма. & IX & 0 & \begin{tabular}{|l|l} 
Reg. \\
\end{tabular} & 0 & Hori. & \begin{tabular}{|l|} 
Ma. \\
\end{tabular} & $\mathrm{vv}_{1}$ & 0 & \begin{tabular}{|l} 
Reg. \\
\end{tabular} & Cent. & Hori \\
\hline $1955, \ldots<\ldots<0$ & Dic. & Rojo & M & $M$ & M & Negro & $M$ & M & $\mathrm{A}$ & & ма. & III & 0 & Reg. & 0 & Hori. & Ма. & v & 0 & Reg. & 0 & \begin{tabular}{|l|} 
Hori \\
\end{tabular} \\
\hline 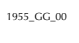 & Dic. & $\begin{array}{l}\text { Amari- } \\
\text { Ilo }_{10}\end{array}$ & 0 & M & M & Negro & o & M & A & & Ma. & vil & 0 & Reg. & Asim. & Hori. & Me. & X.E. & 0 & $\begin{array}{l}\text { Reg. } \\
\end{array}$ & Cent. & Hori \\
\hline 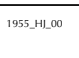 & Real. & Azul & c & M & M & $\begin{array}{c}\text { Amana- } \\
\text { rillo }\end{array}$ & M & B & A & & ме. & $v_{1}$ & 0 & Semi. & $\mathrm{kq}$ & Hori. & Ma. & vi & 0 & Deco. & Arra. & Adar \\
\hline 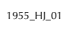 & Dic. & Negro & 0 & M & A & $\begin{array}{l}\text { Ama-ar } \\
\text { rillo }\end{array}$ & M & M & A & & Ма. & VIII & 0 & Reg. & Asim. & Hori. & 0 & 0 & 0 & 0 & 0 & 0 \\
\hline $1955 \mathrm{SH}, \mathrm{H}=2$ & Dic. & Negro & M & M & M & naranjia & M & M & A & & м. & IV & 0 & \begin{tabular}{|l} 
Reg. \\
\end{tabular} & 129. & Hori. & ма. & VIII & 0 & $\begin{array}{l}\text { Deco. } \\
\end{array}$ & 0 & Hori \\
\hline 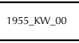 & Dic. & $\begin{array}{l}\text { Rojo } \\
\end{array}$ & $M$ & $B$ & B & Negro & $M$ & $\mathrm{M}$ & A & & мa. & "I & 0 & \begin{tabular}{|l|l|} 
Curs. \\
\end{tabular} & 124. & Hori. & $0_{0}$ & 0 & 0 & $\begin{array}{l} \\
\end{array}$ & 0 & 0 \\
\hline 1955 , wW Oor & 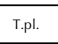 & Rojo & M & B & $\mathrm{A}$ & Azul & M & $M$ & A & & $\mathrm{Ma}$ & $\begin{array}{ll}x . A \\
\end{array}$ & \begin{tabular}{|l|}
0 \\
\end{tabular} & \begin{tabular}{|l|} 
Reg. \\
\end{tabular} & \begin{tabular}{|l|} 
Cent. \\
\end{tabular} & Hori. & Ma. & \begin{tabular}{|l|}
$1 x$ \\
\end{tabular} & 0 & \begin{tabular}{|l} 
Reg. \\
\end{tabular} & \begin{tabular}{|l|} 
Cent. \\
\end{tabular} & Hori \\
\hline 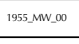 & Dic. & $\begin{array}{l}\text { Negro } \\
\end{array}$ & 0 & M & A & Blanco & M & M & A & & Me. & $\begin{array}{l}\text { x.c. } \\
\end{array}$ & 0 & \begin{tabular}{|l|} 
Reg. \\
\end{tabular} & Cent. & Hori. & Ма. & "I & $0^{\circ}$ & \begin{tabular}{|l} 
Reg. \\
\end{tabular} & 0 & Hori \\
\hline $10555.5-5000$ & $\begin{array}{l}\text { T.pl. } \\
\end{array}$ & Azul & M & M & A & Negro & o & M & A & & Me. & v & Technotyp & 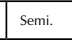 & 0 & Obli. & ма. & $v_{1}$ & 0 & Negra & o & Obli \\
\hline $1955.54=00$ & 3 col. & Naranja & c & M & M & Negro & o & M & A & & ма. & VIII & 0 & \begin{tabular}{|l} 
Reg. \\
\end{tabular} & \begin{tabular}{|l|} 
Asim. \\
\end{tabular} & Hori. & ма. & $v_{1}$ & 0 & \begin{tabular}{|l|l|} 
Reg. \\
\end{tabular} & 0 & obli \\
\hline $195, \ldots, \ldots 00$ & \begin{tabular}{|l|l|} 
T.pl. \\
\end{tabular} & \begin{tabular}{|l|l|} 
rojo \\
\end{tabular} & 0 & M & A & Verde & c & M & $\mathrm{N}$ & & Me. & IV & 0 & \begin{tabular}{|l|} 
Reg. \\
\end{tabular} & \begin{tabular}{|l|} 
Asim. \\
\end{tabular} & Obli. & Me. & Ix & o & \begin{tabular}{|l|} 
Reg. \\
\end{tabular} & $\begin{array}{l}\text { Asim. } \\
\end{array}$ & obli \\
\hline 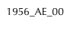 & Dic. & Negro & 0 & M & A & Rojo & M & M & B & & Me. & iv & $\begin{array}{l}\text { schmalietere } \\
\text { Anniquat }\end{array}$ & Reg. & o & Hori. & Ма. & iv & 0 & Curs. & 0 & Hori \\
\hline
\end{tabular}

\begin{tabular}{|c|c|c|c|c|c|c|c|c|c|c|c|c|c|c|c|c|c|c|c|c|c|}
\hline \multirow{2}{*}{ conco } & \multicolumn{9}{|c|}{ CÓDIGO CROMÁTICO } & \multicolumn{12}{|c|}{ CÓDICO TIPOGRÁFCO } \\
\hline & uso & MATZ & $\mathrm{v}$ & $\mathrm{s}$ & L & MATIZ & $\mathrm{v}$ & s & L & REP. & CLA & FAMLIA & EST. & ALIN & ORELE. & \begin{tabular}{|l|l} 
REP. \\
\end{tabular} & $\mathrm{c}$ & ғамLА & EsT. & ALIN & ORIE \\
\hline 1956_CK. 00 & T.p.l. & $\begin{array}{l}\text { amari- } \\
l_{10}\end{array}$ & M & M & м & verde & $\circ$ & м & M & ма. & vi & 0 & Deco. & 129. & obli. & 0 & 0 & 0 & 0 & 0 & 10 \\
\hline 105600.000 & $3 \mathrm{col}$. & Rojo & M & B & A & 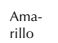 & M & м & A & ме. & vi & 0 & Reg. & Cent. & Hori. & o & 0 & 0 & 0 & 0 & 0 \\
\hline 1050 H. & T.p.l. & Negro & $\mathrm{o}$ & M & A & Rojo & $\circ$ & M & A & Ма. & VIII & 0 & 0 & 0 & obli. & Ма. & vi & 0 & Semi. & 0 & Adap \\
\hline 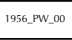 & Real. & $\begin{array}{l}\text { Verde } \\
\end{array}$ & M & B & B & Azul & м & M & B & Me. & $v_{1}$ & 0 & Reg. & Cent. & Hori. & ма. & VIII & 0 & Reg. & 0 & Hori. \\
\hline 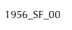 & T.pl. & Naramia & o & M & B & Verde & M & M & B & ма. & ix & 0 & Reg. & 0 & Obbi. & ма. & $v_{1}$ & 0 & Negata & 0 & Oobli. \\
\hline 1956.56,000 & T.p.l. & Azul & c & B & M & naranja & c & M & M & ма. & ix & ${ }^{\circ}$ & Reg. & 0 & obli. & Me. & vi & 0 & Reg. & 0 & Hori. \\
\hline 1956.5M & T.phl. & Azul & M & B & A & $\begin{array}{c}\text { Amaa- } \\
\text { rillo }\end{array}$ & c & в & M & ме. & vi & $\begin{array}{l}\text { Fundammenal } \\
\text { Grotesk }\end{array}$ & Semi. & Drch & Hori. & 0 & 0 & 0 & 0 & 0 & 0 \\
\hline 1956.5M 01 & T.p.l. & Azul & o & M & A & Rojo & $\circ$ & м & A & ма. & vilI & 0 & Reg. & Cent. & Hori. & 0 & 0 & 0 & 0 & 0 & 0 \\
\hline 1956-VG_.00 & 3 col. & $\begin{array}{l}\text { Amari- } \\
\text { Ilo }\end{array}$ & m & M & A & Rojo & M & M & A & м. & iv & 0 & Reg. & Asim. & Obli. & Me. & vi & 0 & Reg. & 0 & obli. \\
\hline 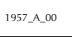 & Real. & Rojo & M & M & A & Azul & c & в & A & Me. & VIII & 0 & Reg. & Cent. & Vert. & 0 & 0 & 0 & 0 & 0 & 0 \\
\hline 1957_CH.DO & $3 \mathrm{Col}$. & Rojo & M & M & M & Azzul & M & M & M & мe. & VII & 0 & Negra & 0 & Obli. & мe. & vIII & 0 & Curs. & 0 & obli. \\
\hline 1957_CH.01 & Mono. & Negro & M & M & M & $\begin{array}{l}\text { Anaa- } \\
\text { rillo }\end{array}$ & c & M & M & мe. & vilI & ${ }^{\circ}$ & Reg. & 0 & Obli. & мe. & $v_{1}$ & Super Grotesk & Negra & Drch & Hori. \\
\hline 1957_CH..02 & Dic. & Negro & M & M & A & Rojo & M & M & B & ме. & iv & Fetete Aniquala & Reg. & $\mathrm{kzq}$ & Hori. & 0 & 0 & 0 & 0 & 0 & 0 \\
\hline 1957CKR, Do & & 0 & & & & & & & & ма. & VII & 0 & Reg. & 12q. & Hori. & ме. & $v_{1}$ & 0 & Reg. & Cent. & Hori. \\
\hline 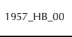 & $3 \mathrm{Col}$. & Negro & o & M & A & Azul & c & M & A & ма. & III & ${ }^{\circ}$ & Reg. & Arra. & Hori. & 0 & 0 & 0 & 0 & 0 & 0 \\
\hline 1957개 1000 & & 0 & & & & & & & & ма. & VIII & 0 & Reg. & $\mathrm{kzq}$ & Hori. & 0 & 0 & 0 & 0 & 0 & 0 \\
\hline 1957_मК. о0 & $3 \mathrm{col}$. & Blanco & M & $M$ & M & Rojo & $M$ & M & в & ма. & III & 0 & Deco. & 1zq. & Hori. & ма. & VIIII & 0 & Reg. & 0 & Hori. \\
\hline 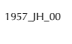 & T.pl. & Rojo & M & M & A & $\begin{array}{l}\text { Ama- } \\
\text { rillo- }\end{array}$ & M & M & A & м. & vil & 0 & Reg. & 0 & Hori. & Me. & $v_{1}$ & $\begin{array}{l}\text { Fundamental } \\
\text { Grotesk }\end{array}$ & Reg. & 129. & Hori. \\
\hline 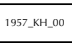 & T.p. & Naranjia & M & M & B & Verde & c & M & B & м. & vi & 0 & Reg. & Cent. & Hori. & 0 & 0 & 0 & 0 & 0 & 0 \\
\hline 1957_KWLEO & Dic. & Negro & o & M & A & Rojo & o & M & M & ме. & x.A. & ${ }^{\circ}$ & Reg. & Arra. & Hori. & мe. & $v_{1}$ & $\begin{array}{l}\text { Fundamental } \\
\text { Grotresk }\end{array}$ & Semi. & Drch & Horit \\
\hline 1957_\&W.01 & 3 Col. & Azul & M & M & A & riojo & o & м & A & мe. & iv & 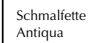 & Reg. & 0 & Hori. & Me. & vi & 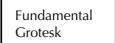 & \begin{tabular}{|l} 
Reg. \\
|
\end{tabular} & 0 & Horit \\
\hline 1957_RW.02 & T.phl. & Rojo & c & B & A & 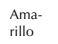 & M & M & A & мa. & vilI & 0 & Reg. & Asim. & Hori. & ме. & $v_{1}$ & $\begin{array}{l}\text { Fundamental } \\
\text { Grotresk }\end{array}$ & Reg. & 0 & Horit \\
\hline 1957 & & 0 & & & & & & & & ма. & VIII & 0 & Reg. & 12q. & Hori. & 0 & 0 & 0 & 0 & 0 & 0 \\
\hline 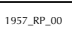 & & 0 & & & & & & & & ма. & vin & $\circ$ & Deco. & 0 & Hori. & Me. & vi & $\begin{array}{l}\text { Fundamental } \\
\text { CGroferk }\end{array}$ & Cond. & 0 & Hori. \\
\hline 1957.5C.00 & T.pl. & Rojo & M & M & A & $\begin{array}{l}\text { Ailla- } \\
\text { rillo }\end{array}$ & M & M & M & ма. & vill & 0 & Reg. & Asim. & obli. & Me. & $v_{1}$ & 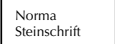 & Reg. & 0 & Hori. \\
\hline 1957.5R_.00 & Dic. & Rojo & M & M & M & $\begin{array}{l}\text { Amaa- } \\
\text { rillo }\end{array}$ & c & M & M & Me. & X.D. & 0 & Reg. & Cent. & Hori. & 0 & 0 & 0 & 0 & 0 & 0 \\
\hline 1957_sw.00 & & 0 & & & & & & & & м.. & vi & 0 & Reg. & Just. & obli. & 0 & 0 & 0 & 0 & 0 & 0 \\
\hline 1957_VC__Co & T.p.l. & Azul & M & B & A & $\begin{array}{l}\text { Ama- } \\
\text { rillo }\end{array}$ & M & в & M & мe. & vin & 0 & Rege. & Just. & Hori. & 0 & 0 & 0 & 0 & 0 & 0 \\
\hline 1957_WKட. & $3 \mathrm{Col}$. & Rojo & o & M & A & Negro & M & M & A & Me. & vi & o & Reg. & Just. & Hori. & 0 & 0 & 0 & 0 & 0 & 0 \\
\hline 1957_.KK.01 & Dic. & Negro & M & M & A & $\begin{array}{l}\text { AAla- } \\
\text { rillo }\end{array}$ & M & B & A & ме. & vi & Super Grotesk & fina & $\mathrm{kq}$ & Hori. & 0 & 0 & 0 & 0 & 0 & 0 \\
\hline 1957_WP_. 200 & T.pl. & $\begin{array}{l}\text { Amari- } \\
\text { lio }\end{array}$ & $\circ$ & M & A & Rojo & o & M & B & ме. & vi & 0 & Reg. & kzq. & Hori. & 0 & 0 & 0 & 0 & 0 & 0 \\
\hline 1958คـ..00 & Real. & Rojo & M & M & A & Blanco & c & м & B & ма. & VIII & 0 & Reg. & Asim. & Adap. & Me. & vi & Super Grotesk & \begin{tabular}{|l|} 
Reg. \\
\end{tabular} & Cent. & Hori. \\
\hline 1958 . $\mathrm{BH}$. 00 & Dic. & Rojo & c & B & B & Negro & $\circ$ & M & M & $\mathrm{Ma}$ & vi & 0 & Negra & 0 & Hori. & Me. & $v_{1}$ & 0 & Semi. & Cent. & Hori. \\
\hline 1958 . AW 200 & T.pl. & $\begin{array}{l}\text { Amari- } \\
\text { Ilo }\end{array}$ & M & B & A & Negro & o & M & A & ме. & X.D. & 0 & Reg. & Arra. & Hori. & 0 & 0 & 0 & 0 & 0 & 0 \\
\hline 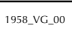 & & 0 & & & & & & & & мe. & $\mathrm{vl}^{2}$ & 0 & Reg. & 0 & obli. & 0 & 0 & 0 & 0 & 0 & 0 \\
\hline 1958_.WKLo & & 0 & & & & & & & & ме. & vi & $\begin{array}{l}\text { Fundemental } \\
\text { Crorosek }\end{array}$ & \begin{tabular}{|c|} 
Cond. \\
\end{tabular} & 0 & Hori. & 0 & 0 & 0 & 0 & 0 & 0 \\
\hline 1958 WR & T.pl. & Rojo & c & M & м & Azul & $\circ$ & B & A & мe. & 1 & 0 & Reg. & Cent. & Hori. & 0 & 0 & 0 & 0 & 0 & 0 \\
\hline 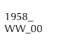 & Dic. & Rojo & M & M & A & Negro & o & в & A & мa. & VIII & 0 & 0 & Arra. & obli. & 0 & 0 & 0 & 0 & 0 & 0 \\
\hline $1059, \wedge 00$ & Real. & Rojo & M & B & A & Azzul & M & M & M & Me. & VIII & Aktuell & Reg. & 129. & Hori. & Me. & vi & Super Grotesk & Negra & 0 & 0 \\
\hline 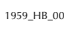 & Dic. & Rojo & o & M & в & Blanco & M & в & A & ма. & $v_{1}$ & 0 & Reg. & Drch & Hori. & Me. & $v_{1}$ & Super Grotesk & $\begin{array}{l}\mid \text { Reg. } \\
\end{array}$ & 0 & Horit \\
\hline 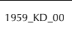 & $\begin{array}{l}\text { Dic. } \\
\end{array}$ & Rojo & M & $M$ & B & Blanco & M & B & B & мa. & vi & 0 & Reg. & Just. & Hori. & 0 & 0 & 0 & 0 & 0 & 0 \\
\hline
\end{tabular}




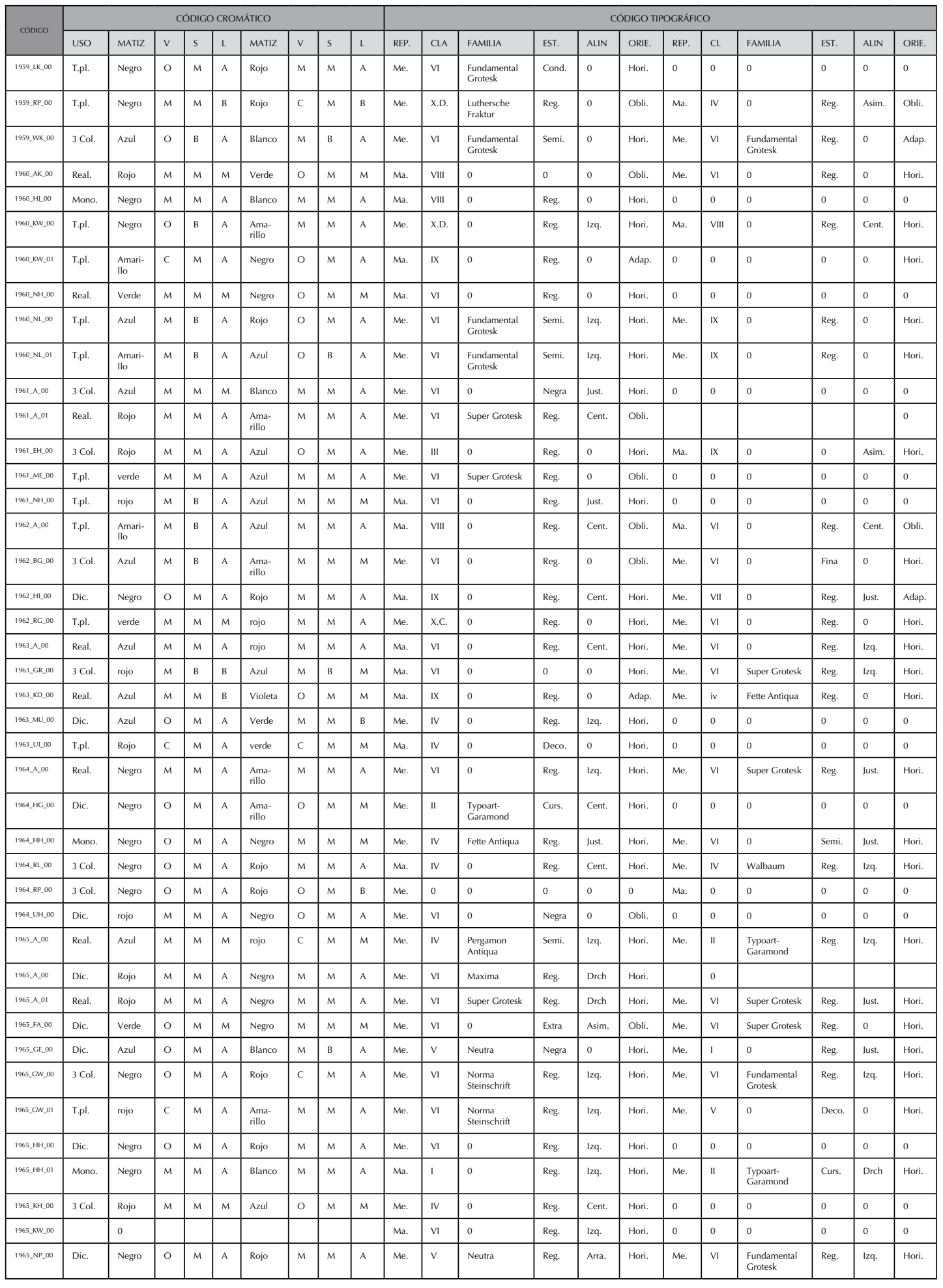

\begin{tabular}{|c|c|c|c|c|c|c|c|c|c|c|c|c|c|c|c|c|c|c|c|c|c|}
\hline & & & & ग1600 & & & & & & & & & & & & & & & & & \\
\hline & uso & MTIZ & & & & MurI & & & & $\begin{array}{l}\text { REP. } \\
\end{array}$ & $\mathrm{CLA}$ & FАMLIL & \begin{tabular}{|l|} 
EsT. \\
\end{tabular} & \begin{tabular}{|l|l|} 
AIN \\
\end{tabular} & OOEE & \begin{tabular}{|l|l|} 
RTPR \\
\end{tabular} & & 1 ғммини & & & \\
\hline & & 。 & & & & & & & & Me. & " & Nomam & Regeg. & & Hori. & 0 & & & & & \\
\hline secos & \begin{tabular}{|l|l|} 
T.pht \\
\end{tabular} & Nego & & M & & Rojo & & M & & Me. & $n_{n}$ & & Reg & kaq & Hori. & Ne & & 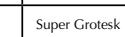 & \begin{tabular}{|l|l|} 
Regg \\
\end{tabular} & 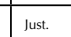 & Hor \\
\hline sisteon & \begin{tabular}{|l|l|} 
Dici. \\
\end{tabular} & Amaxid & o & M & & Negro & & M & ^ & ме. & v & (o & \begin{tabular}{|l|l|} 
Regeg \\
\end{tabular} & 。 & Hori. & ме. & v & 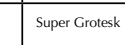 & \begin{tabular}{|l|l|} 
Rege \\
\end{tabular} & 0 & Hori. \\
\hline & 3 3 colt & NzW & & s. & & Rojo & & M & & Mata & vin & & Reg & 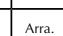 & Adap. & Mat & & 0 & \begin{tabular}{|l|l|} 
Regeg \\
\end{tabular} & & \begin{tabular}{|l|} 
Hori. \\
\end{tabular} \\
\hline (1) & \begin{tabular}{|l|l|} 
Real \\
\end{tabular} & ${ }_{\lambda z u}$ & 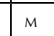 & M & & rijo & $\bar{M}$ & M & & Ne. & vin & & & 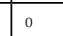 & Horit. & м.. & & & Begg, & & 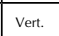 \\
\hline What & 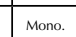 & \begin{tabular}{|l|l|} 
Nego \\
\end{tabular} & & M & & 8 Bance & $\bar{M}$ & & & Ne. & $\bar{v}$ & Maxima & $R_{R}$ & kqq & Hori. & Ne. & & Maxima & fina & Drch & Hori. \\
\hline 10 & \begin{tabular}{|l|l} 
T.pl. \\
\end{tabular} & $\begin{array}{ll}\text { Rojo } \\
\end{array}$ & M & 8 & A & Nego & 。 & $M$ & M & Ma. & vII & & & \begin{tabular}{|l|l|} 
Arac \\
\end{tabular} & \begin{tabular}{|c|c|} 
Adap. \\
\end{tabular} & \begin{tabular}{|l} 
м. \\
\end{tabular} & & Maxima & & & Hori. \\
\hline 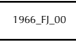 & \begin{tabular}{|l|l|} 
Dic. \\
\end{tabular} & \begin{tabular}{|l|l|} 
rojo \\
\end{tabular} & c & M & & Nego & & M & B & ме. & 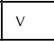 & Nevera & semit. & Cont. & Hori. & \begin{tabular}{|l|l} 
\\
\end{tabular} & & & \begin{tabular}{|l|l|} 
Regeg \\
\end{tabular} & Cont. & Hori. \\
\hline 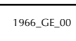 & & Rogic & & M & & Negoro & & M & & мa & vin & & \begin{tabular}{|l|l|} 
Regeg \\
\end{tabular} & Just. & Horit & | & & & & . & o \\
\hline 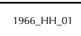 & $\mid \mathrm{T}_{\mathrm{rpl} \mathrm{t}}$ & AzW & c & M & & Verde & M & M & M & Na. & vin & & & 0 & obli. & Me. & & Maxim & Reg. & ${ }_{184}$ & \begin{tabular}{|l|l|} 
obli. \\
\end{tabular} \\
\hline HK-Oo & $\mathrm{D}$ & Rojic & $\sqrt{N}$ & M & & Negro & 。 & M & A & Ne. & n & & & & Hori. & & & & & & | \\
\hline & $3 \mathrm{col}$. & Axul| & M & M & & Rojo & M & M & A & Ne. & ${ }_{0}$ & & & & & & & & & & \\
\hline $1506 \times 6 x+1000$ & \begin{tabular}{|l} 
Dic. \\
\end{tabular} & $\begin{array}{ll}\text { Riojo } \\
\end{array}$ & M & M & & Balaco & & B & B & Me. & $v_{1}$ & & \begin{tabular}{|l|l|} 
Regt \\
|ege
\end{tabular} & . & Hori. & 10 & & & \begin{tabular}{|l|} 
\\
\end{tabular} & & \\
\hline 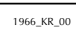 & \begin{tabular}{|l|l} 
col. \\
\end{tabular} & \begin{tabular}{|l|l|} 
Rojo \\
\end{tabular} & M & B & M & Azal & M & B & M & ме. & " & 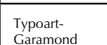 & \begin{tabular}{|l|l|} 
Curs: \\
\end{tabular} & 。 & Hori. & \begin{tabular}{|l} 
ме. \\
\end{tabular} & I & 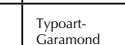 & $\begin{array}{ll}\text { Fina } \\
\end{array}$ & \begin{tabular}{|l|l|} 
Just. \\
\end{tabular} & \begin{tabular}{|l|l|} 
Hori. \\
\end{tabular} \\
\hline Dastrean & \begin{tabular}{|l|l|} 
Reall \\
\end{tabular} & \begin{tabular}{|l|l|} 
Rojo \\
\end{tabular} & o & M & & $\begin{array}{l}\text { Azzul } \\
\end{array}$ & 。 & M & A & Me. & " & 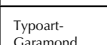 & fina & \begin{tabular}{|l|l|} 
Just. \\
\end{tabular} & Hori. & o & 0 & 10 & 0 & 10 & 0 \\
\hline secscos & \begin{tabular}{|l|l|} 
Real. \\
\end{tabular} & AxzW & M & B & & Rojo & M & M & A & \begin{tabular}{|l} 
Me. \\
\end{tabular} & $v_{1}$ & o & \begin{tabular}{|l|} 
Nega \\
\end{tabular} & Just. & Hori. & . & 0 & 0 & 0 & 0 & \begin{tabular}{|l|l}
0 \\
\end{tabular} \\
\hline wiven & $\begin{array}{l}\text { Trpl. } \\
\end{array}$ & Negro & 0 & M & & Rojo & M & M & A & Ne. & n & $\begin{array}{l}\text { Nomana } \\
\text { Scleshrith }\end{array}$ & \begin{tabular}{|l|l|} 
Reg \\
\end{tabular} & $\begin{array}{l}\text { Arata. } \\
\end{array}$ & \begin{tabular}{|l|l} 
obli. \\
\end{tabular} & 10 & 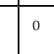 & 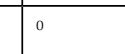 & . & $0^{\circ}$ & 0 \\
\hline 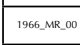 & \begin{tabular}{|l|} 
Mona. \\
\end{tabular} & Neggo & M & B] & & & & 0 & 0 & Me. & $v_{11}$ & 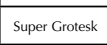 & Seni. & 164. & Horti. & Me. & & 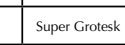 & & prat & \begin{tabular}{|l|l|} 
\\
\end{tabular} \\
\hline 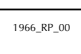 & \begin{tabular}{|l|l} 
T.pl. \\
\end{tabular} & \begin{tabular}{|l|l|} 
Rogo \\
\end{tabular} & M & B & B & $\begin{array}{l}\text { verde } \\
\text { veld }\end{array}$ & M & ${ }^{B}$ & ${ }^{B}$ & Ne. & n & 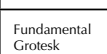 & \begin{tabular}{|l} 
Seni. \\
\end{tabular} & \begin{tabular}{|l|l|} 
Asim: \\
\end{tabular} & Hori. & \begin{tabular}{|l} 
Me. \\
\end{tabular} & 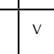 & $\circ$ & \begin{tabular}{|l|} 
Deco. \\
\end{tabular} & 0 & 0 \\
\hline 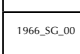 & \begin{tabular}{|l|l} 
Trph \\
\end{tabular} & 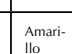 & M & 8 & & Azzul & 。 & M & A & \begin{tabular}{|l|} 
Ma. \\
\end{tabular} & n & $\circ$ & Regeg: & \begin{tabular}{|l|l} 
Arra. \\
\end{tabular} & Adap. & $\circ$ & 0 & 10 & $0^{\circ}$ & 10 & $0^{\circ}$ \\
\hline wass & \begin{tabular}{|l} 
Tppl. \\
\end{tabular} & Negro & & M & & Rojo & M & M & A & ма. & $v_{1}$ & 0 & \begin{tabular}{|l|l|} 
Rege. \\
\end{tabular} & 0 & Hori. & \begin{tabular}{|l|} 
м. \\
\end{tabular} & & 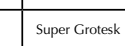 & $\begin{array}{l}\text { frima } \\
\end{array}$ & just & \begin{tabular}{|l|l|} 
\\
\end{tabular} \\
\hline 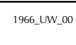 & Dic & $\begin{array}{l}\text { Negro } \\
\end{array}$ & o & 8 & & Rojo & M & M & B & мe. & IV & 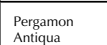 & \begin{tabular}{|l|l} 
cond. \\
\end{tabular} & 0 & Hort. & 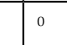 & 0 & o & 10 & o & 0 \\
\hline 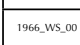 & $3 \mathrm{col}$ & \begin{tabular}{|l|l|}
$R_{j o j o}$ \\
\end{tabular} & o & M & & Negro & & M & A & мe. & \begin{tabular}{|l|l|} 
IV \\
\end{tabular} & & | & . & \begin{tabular}{|l|l|} 
Hori. \\
\end{tabular} & 0 & & . & 0 & . & \begin{tabular}{|l|}
0 \\
\end{tabular} \\
\hline$x \wedge 1,00$ & \begin{tabular}{|l|l|} 
Real \\
\end{tabular} & $\sqrt{12}$ & $M$ & & & pijo & & M & M & Ne. & n & 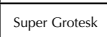 & \begin{tabular}{|l|l|}
$\operatorname{Reg}$ \\
\end{tabular} & $\mid$ & Hori. & $\begin{array}{ll}\text { Me. } \\
\end{array}$ & & & \begin{tabular}{|l|l|l|l|} 
Rege \\
\end{tabular} & & Hori. \\
\hline 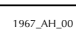 & Re & Naul & & M & & trijo & & M & $\bar{B}$ & Mara & v & o & $R_{R}$ & \begin{tabular}{|l|l|} 
Drth \\
\end{tabular} & Hori. & 10 & & $\sigma_{0}$ & o & 10 & 0 \\
\hline serpecon & Real. & 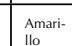 & N & M & А & rojo & M & M & A & $\begin{array}{l}\text { Ma. } \\
\text { nat }\end{array}$ & VIIII & o & \begin{tabular}{|l|l|} 
Rege \\
\end{tabular} & 0 & Hori. & ме. & $v_{1}$ & 0 & $\begin{array}{ll}\text { Rege } \\
\end{array}$ & 0 & Hori. \\
\hline$x, y, n$ & Dice & \begin{tabular}{|l|l} 
Ammati \\
itlo
\end{tabular} & м & M & & Negro & o & M & ^ & Me. & $v_{1}$ & $1^{\circ}$ & $\begin{array}{l}\text { Regeg } \\
\end{array}$ & Cont & Hori. & 0 & 0 & 0 & 0 & 10 & 10 \\
\hline 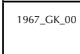 & Dic. & $\begin{array}{l}\text { Negro } \\
\end{array}$ & & M & m & Rojo & M & M & ${ }^{B}$ & Мa. & vi & 10 & $\begin{array}{l}\text { Reg } \\
\end{array}$ & Drch & Hori. & \begin{tabular}{|l|} 
M.e. \\
\end{tabular} & $v_{1}$ & 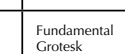 & \begin{tabular}{|l|l|} 
ereg \\
\end{tabular} & Drhh & Hori. \\
\hline 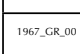 & Mono. & 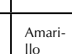 & & M & & Negro & 。 & M & A & Me. & $\mathrm{v}_{1}$ & 10 & \begin{tabular}{|l|} 
Regeg \\
\end{tabular} & Araa. & Hori. & $\begin{array}{l}0 \\
\end{array}$ & 0 & 0 & 0 & ${ }^{\circ}$ & 0 \\
\hline 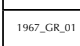 & Dicic & Rojo & M & B & & Negro & 。 & M & 8 & Ne. & n & 0 & \begin{tabular}{|l|l|} 
Rege. \\
\end{tabular} & 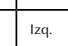 & Hori. & ме. & $v_{1}$ & $s$ swer crover & \begin{tabular}{|l|} 
Regeg \\
\end{tabular} & Drch & \begin{tabular}{|l|l|} 
Hori \\
\end{tabular} \\
\hline 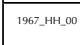 & & 0 & & & & & & & & Me. & " & 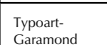 & \begin{tabular}{|l|l|l} 
Curs. \\
\end{tabular} & $\begin{array}{l}\text { Drch } \\
\end{array}$ & Hori. & 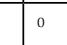 & 0 & o & 10 & \% & 0 \\
\hline 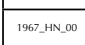 & , Real & Azull & & & & Neggo & & M & & ме. & 1"1" & Prinus & Reg & 0 & Hori. & 10 & & . & 0 & 0 & 0 \\
\hline 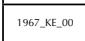 & $T_{T_{\mathrm{p}}}$ & & & & & Viveta & & M & & Ne. & & \begin{tabular}{|l|l|l|l|} 
Nent \\
\end{tabular} & & Asim & obli. & & & & & & \\
\hline $\mid$ & 3 col. & rijo & & & & Vvolat & & M & & Me. & $v_{1}$ & & & & Hori. & & & & & & 0 \\
\hline 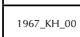 & Dic & \begin{tabular}{|l|l|} 
Negro \\
\end{tabular} & & M. & & verde & & $\bar{\mu}$ & $\lambda$ & sa. & 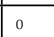 & & Condt & & Adap. & Me. & $x$ & & Regeg & kqq & \begin{tabular}{|l|l} 
Hori. \\
\end{tabular} \\
\hline 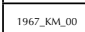 & Disi & 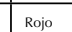 & & 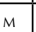 & & Blanco & & B & & м. & & Super Grove & & Drch & 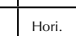 & & & & & & \\
\hline 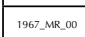 & $\tau_{\tau p p}$ & Negoo & & $\bar{M}$ & & $\begin{array}{ll}\text { Rojo } \\
\end{array}$ & & B. & 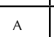 & sa. & vit & & & & Hoir. & \begin{tabular}{|l|l} 
м. \\
\end{tabular} & & $s$ sinectiones & $\mid \begin{array}{l}\mid \text { Rege } \\
\end{array}$ & & \begin{tabular}{|l} 
Hor \\
\end{tabular} \\
\hline 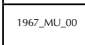 & Real. & \begin{tabular}{|l|l|} 
Negro \\
\end{tabular} & & $\bar{M}$ & & Rojo & m & M & B & ме. & $v_{1}$ & Nomam & \begin{tabular}{|l|} 
Rege. \\
\end{tabular} & 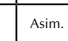 & Adap. & м. & $v_{v_{1}}$ & Maxima & \begin{tabular}{|l|l|} 
Rege \\
\end{tabular} & 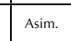 & 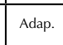 \\
\hline worymen & & Rojo & & & & Batarce & & M & & Me. & & Nentara & Rege. & Cent. & Horit & 0 & & & 0 & 0 & \begin{tabular}{|l|}
0 \\
\end{tabular} \\
\hline $\operatorname{sog}_{n}, N_{x} \infty$ & T.pl & \begin{tabular}{|l|l|} 
Negero \\
\end{tabular} & & & & Blanco & & M & & мa. & VIII & & & $\frac{169}{129}$ & Hori. & $\overline{0}$ & & & & & \\
\hline 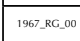 & Dic & Rojo & & M & & Nego & & M & & м.. & $\mathrm{vi}_{\mathrm{v}}$ & & & Cont & Horit & 10 & & & & 10 & 0 \\
\hline 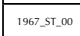 & Dic & Blanco & & & & $\begin{array}{l}\text { Negro } \\
\end{array}$ & & $\begin{array}{c}B \\
\end{array}$ & & Nee & & Walaba & ${ }_{R}$ & cont & Hori. & & & & & & 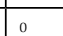 \\
\hline 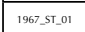 & & & & & & & & & & & & & & & & & & & & & \\
\hline
\end{tabular}




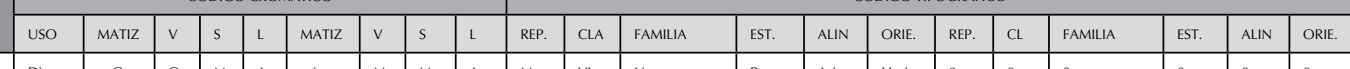

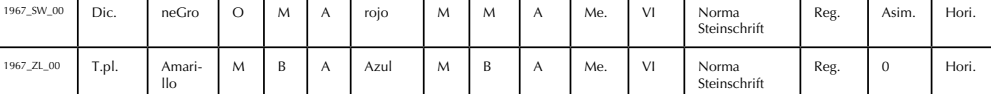

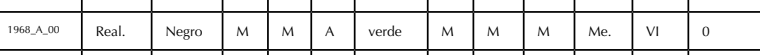

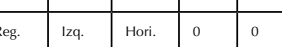

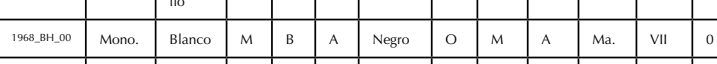

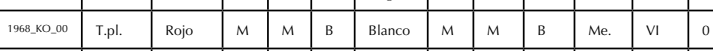

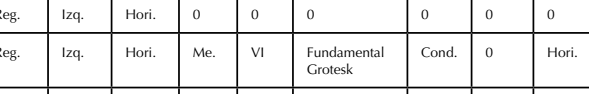

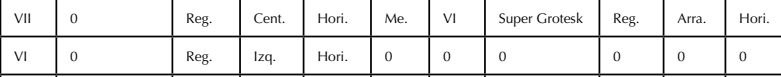

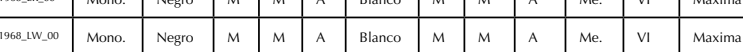

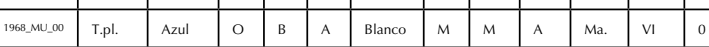

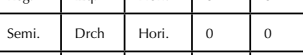

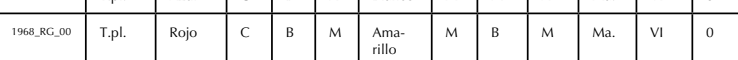

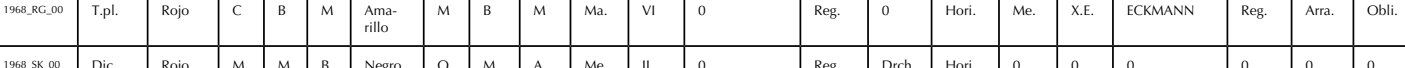

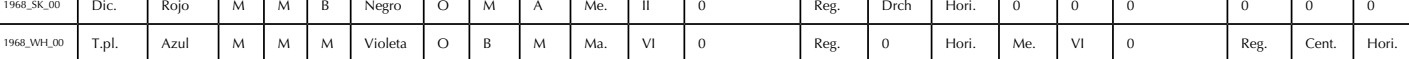

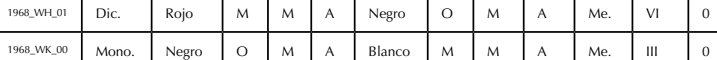

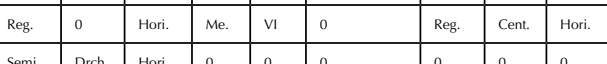
\begin{tabular}{|l|l|l|l|l|l|l|l|l|l|}
\hline Semi- & Drch & Hori. & 0 & 0 & 0 & 0 & 0 & 0 \\
\hline Ree & 0 & Hori. & 0 & 0 & 0 & 0 & 0 & 0 \\
\hline
\end{tabular}

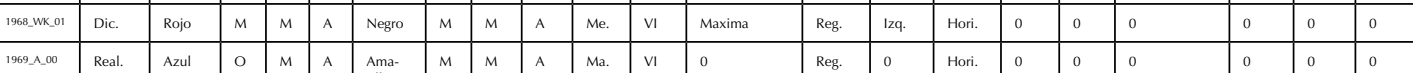

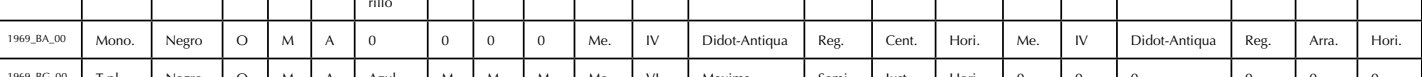

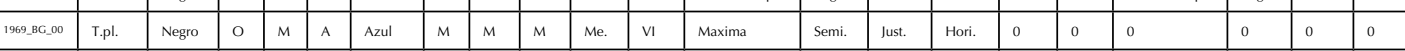

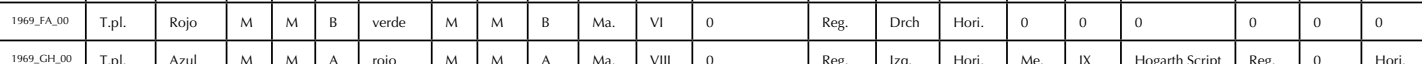

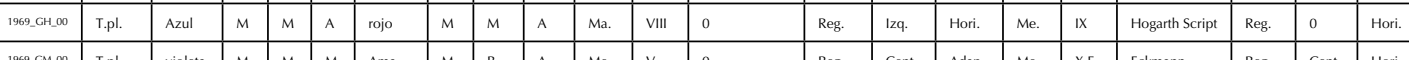

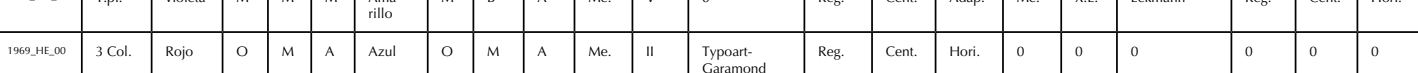

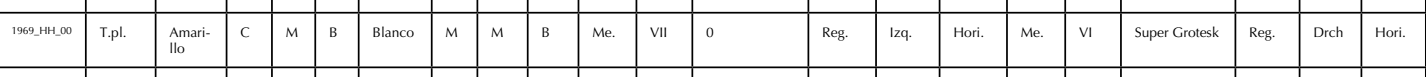

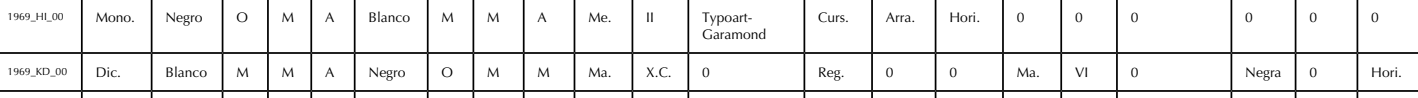

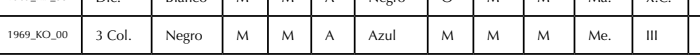

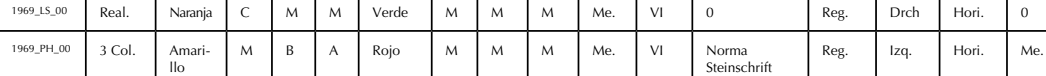

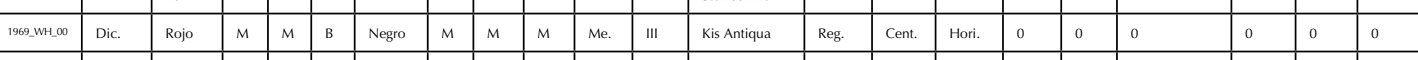

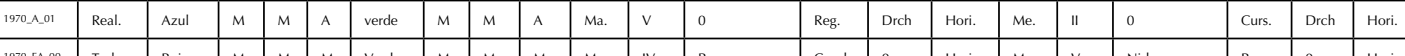

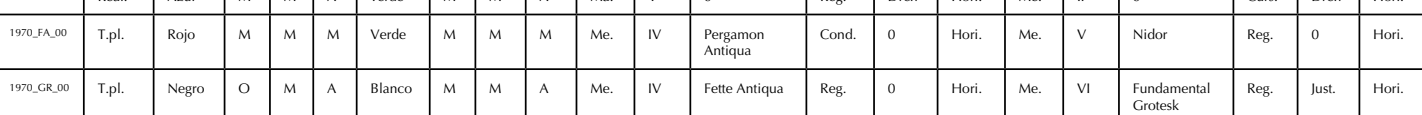

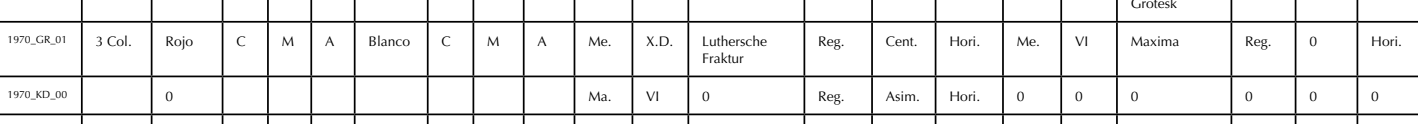

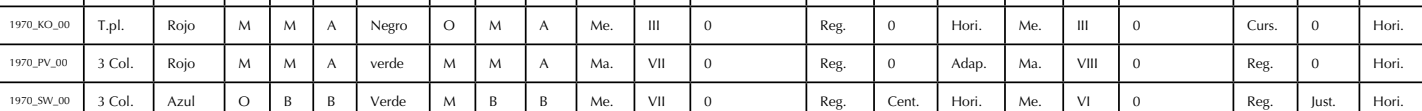

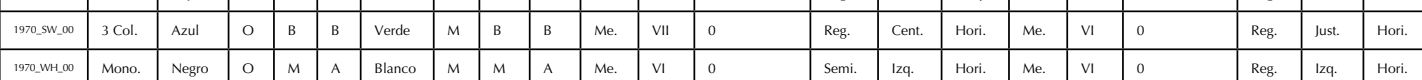

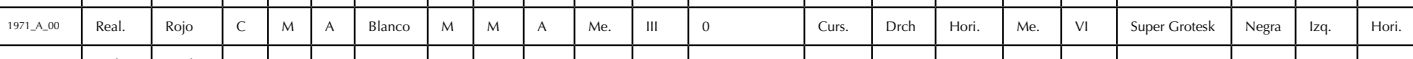

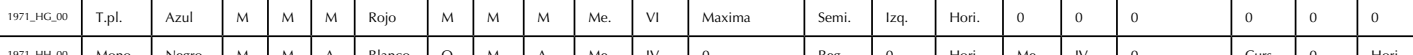

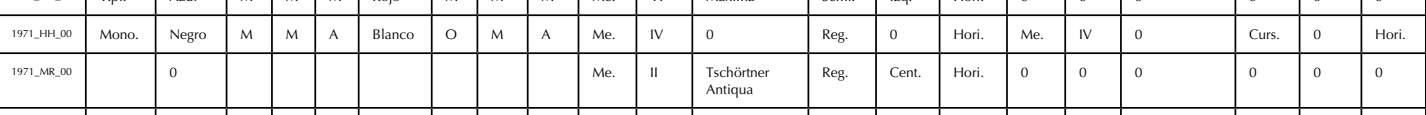

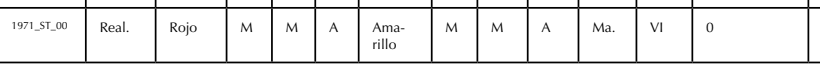

Hori.
NEUTRA

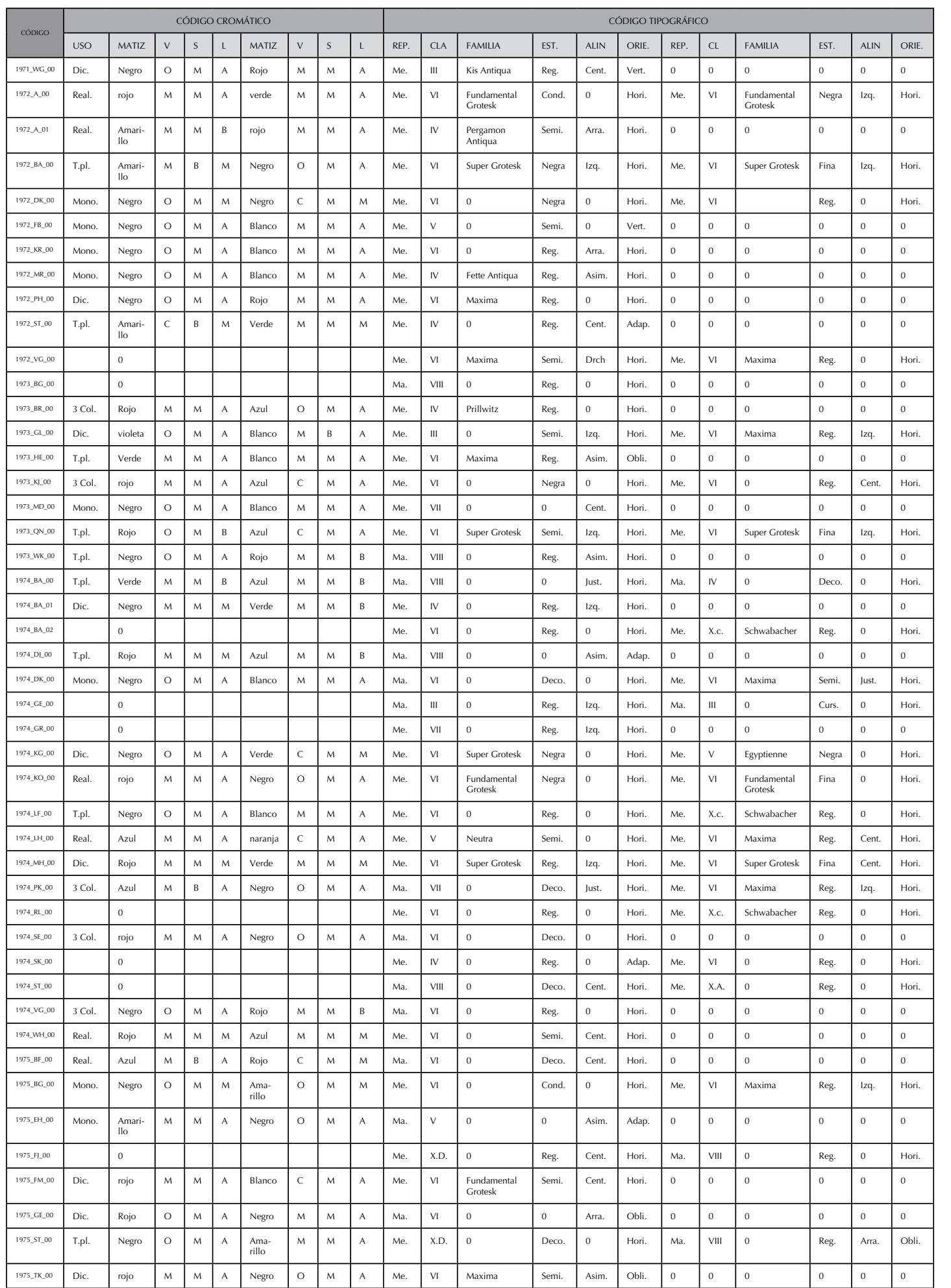




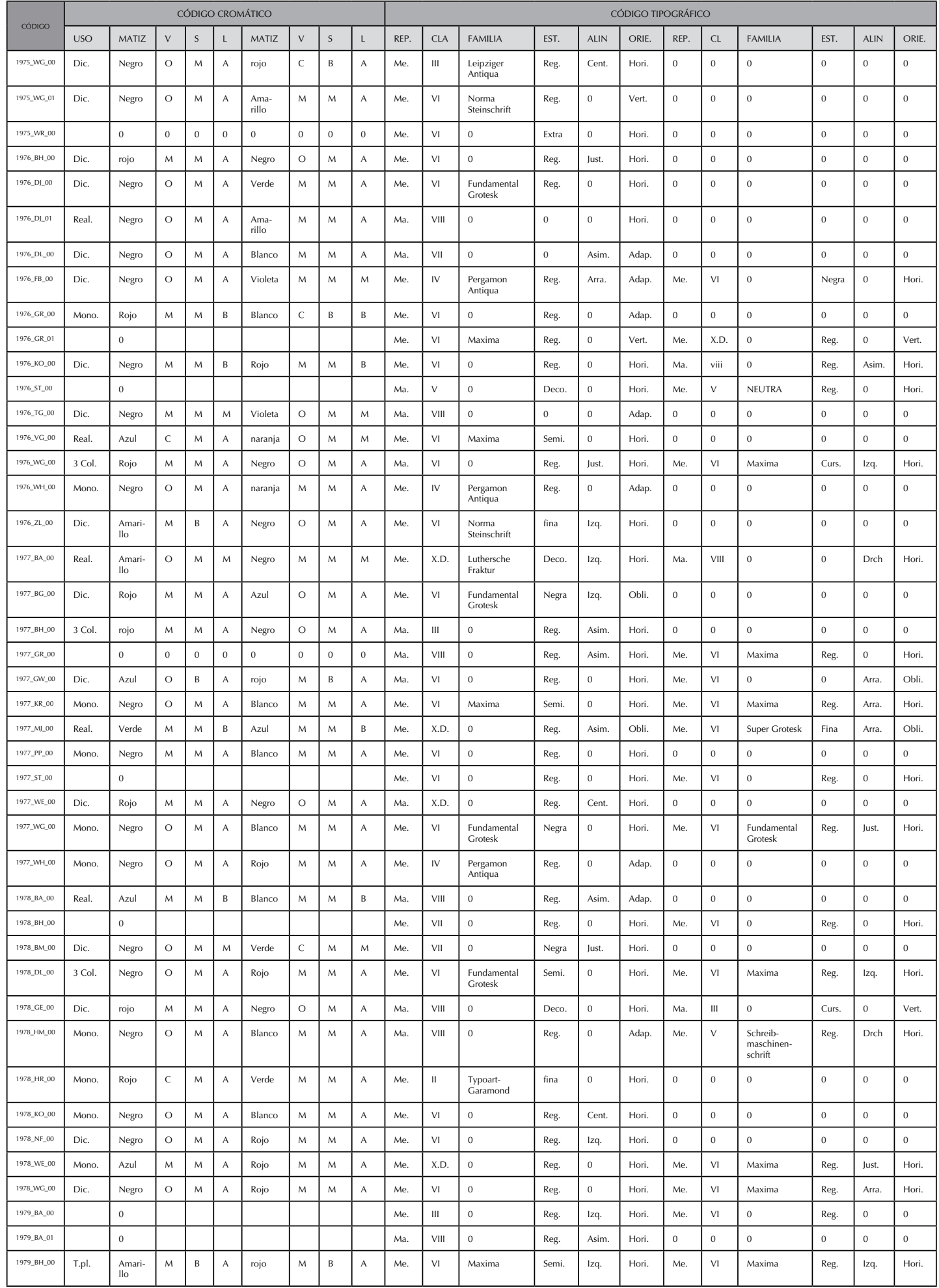

\begin{tabular}{|c|c|c|c|c|c|c|c|c|c|c|c|c|c|c|c|c|c|c|c|c|c|}
\hline \multirow{2}{*}{ conco } & \multicolumn{9}{|c|}{ CÓDIGO CROMÁTICO } & \multicolumn{12}{|c|}{ CÓDIGO TIPOGRÁFICO } \\
\hline & uso & MATIZ & $\mathrm{v}$ & $\mathrm{s}$ & L & MATIZ & v & s & t & REP & $\mathrm{CLA}$ & FAMLIA & EST. & \begin{tabular}{|l|l|} 
ALIN \\
\end{tabular} & \begin{tabular}{|l|l|} 
ORIE. \\
\end{tabular} & RFP. & $\mathrm{cL}$ & FAMLLA & \begin{tabular}{|l|l} 
EST. \\
\end{tabular} & ALIN & ORIE \\
\hline 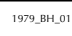 & \begin{tabular}{|l|l} 
Dic. \\
\end{tabular} & Negro & o & M & A & Rojo & M & M & A & ме. & vi & Maxima & Seni. & 129. & Hori. & ме. & $v_{1}$ & Maxima & \begin{tabular}{|l|l|} 
Reg. \\
\end{tabular} & 124. & \begin{tabular}{|l|l|} 
vert. \\
\end{tabular} \\
\hline 1999.9H,-02 & \begin{tabular}{|l|l} 
T.ppl. \\
\end{tabular} & Azul & M & в & A & Rojo & M & M & м & ме. & v & 0 & Reg. & 0 & Hori. & Me. & $v_{1}$ & $\begin{array}{l}\text { Fundamental } \\
\text { Croterk }\end{array}$ & Semi. & 129. & Hori. \\
\hline 1999-BK-0.00 & Real. & \begin{tabular}{|l|l} 
Amari- \\
Ilo
\end{tabular} & $\circ$ & M & M & Negro & o & M & A & ме. & $v_{1}$ & \begin{tabular}{|l|l} 
Fundamental \\
Groterk
\end{tabular} & Negra & Asim. & Hori. & м.. & $v_{1}$ & $\begin{array}{l}\text { Fundamental } \\
\text { Crorese }\end{array}$ & Fina & Arra. & Hori. \\
\hline 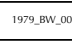 & & 0 & & & & & & & & Ма. & VIII & 0 & Reg. & \begin{tabular}{|l|l} 
Asim. \\
\end{tabular} & Hori. & 0 & 0 & 0 & 0 & 0 & 0 \\
\hline 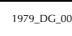 & \begin{tabular}{|l|}
$3 \mathrm{Col}$. \\
\end{tabular} & Negro & o & M & B & Verde & $M$ & M & в & ме. & $\mathrm{iv}$ & 0 & Reg. & 0 & Hori. & м. & $\mathrm{v} 11_{1}$ & Maxima & Reg. & Just. & Hori. \\
\hline $1997-F=000$ & & 0 & & & & & & & & ме. & $v_{1}$ & Maxima & Extra & 0 & Hori. & м.. & $\mathrm{v}_{1}$ & Maxima & \begin{tabular}{|l|l} 
Negra \\
\end{tabular} & Dreh & Hori. \\
\hline 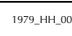 & & 0 & & & & & & & & ма. & VIIII & 0 & Reg. & 12q. & Hori. & 0 & 0 & 0 & 0 & 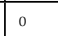 & 0 \\
\hline 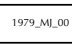 & \begin{tabular}{|l} 
Real. \\
\end{tabular} & Rojo & $\circ$ & M & B & Azul & 0 & M & м & ма. & III & 0 & Reg. & Arra. & Hori. & мa. & $\mathrm{vi}$ & 0 & 0 & 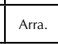 & Hori. \\
\hline 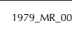 & \begin{tabular}{|l|l} 
Mono. \\
\end{tabular} & $\begin{array}{l}\text { Amari- } \\
\text { Ilori }\end{array}$ & m & B & A & Negro & 0 & M & A & м. & $\mathrm{v}_{1}$ & \begin{tabular}{|l|l|}
$\begin{array}{l}\text { Fundamental } \\
\text { Croterk }\end{array}$ \\
\end{tabular} & fina & \begin{tabular}{|l|l} 
Iust. \\
\end{tabular} & Hori. & мe. & $v_{1}$ & $\begin{array}{l}\text { Fundamental } \\
\text { Croterk }\end{array}$ & Negra & \begin{tabular}{|l|l} 
Just. \\
\end{tabular} & Hori. \\
\hline 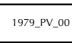 & \begin{tabular}{|l|l} 
Dic. \\
\end{tabular} & Negro & M & M & M & rojo & M & M & м & ма. & X.D. & 0 & Reg. & Arra. & Hori. & ма. & $v_{1}$ & 0 & 0 & 0 & Hori. \\
\hline $1900,1,160$ & \begin{tabular}{|l|l|} 
T.pl. \\
\end{tabular} & \begin{tabular}{|l|l} 
Naranjia \\
\end{tabular} & M & B & $M$ & 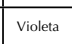 & o & \begin{tabular}{|l|} 
B \\
\end{tabular} & м & Ma. & $\mathrm{vv}_{1}$ & 0 & 0 & \begin{tabular}{|l|} 
Drch \\
\end{tabular} & \begin{tabular}{|l|} 
Hori. \\
\end{tabular} & 0 & 0 & 0 & 0 & 0 & 0 \\
\hline $1980, B E=0.0$ & \begin{tabular}{|l|} 
T.pl. \\
\end{tabular} & 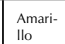 & c & в & A & \begin{tabular}{|l|l|} 
Rojo \\
\end{tabular} & M & M & A & ме. & " & 0 & Semi. & 0 & \begin{tabular}{|l|} 
Hori. \\
\end{tabular} & мe. & $v_{1}$ & Maxima & \begin{tabular}{|l} 
Reg. \\
Re
\end{tabular} & \begin{tabular}{|l|} 
Arra. \\
\end{tabular} & \begin{tabular}{|l|} 
Hori. \\
\end{tabular} \\
\hline 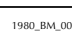 & \begin{tabular}{|l|l|} 
T.pl. \\
\end{tabular} & \begin{tabular}{|l|} 
Azul \\
\end{tabular} & м & B & A & Rojo & M & B & A & ма. & VIII & 0 & Reg. & 0 & Hori. & мe. & $\mathrm{vi}_{1}$ & 0 & \begin{tabular}{|l|} 
Curs. \\
\end{tabular} & 0 & \begin{tabular}{|l|l|} 
Hori. \\
\end{tabular} \\
\hline vecociven & \begin{tabular}{|l|l} 
Dic. \\
\end{tabular} & Negro & $M$ & $M$ & A & $\begin{array}{ll}\text { Rojo } \\
\end{array}$ & c & B & A & ма. & $v_{1}$ & o & Curs. & \begin{tabular}{|l} 
Cent. \\
\end{tabular} & \begin{tabular}{|l|} 
obli. \\
\end{tabular} & 0 & 0 & 0 & 0 & 0 & 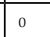 \\
\hline $1800,4=000$ & \begin{tabular}{|l|} 
Mono. \\
\end{tabular} & \begin{tabular}{|l|} 
Neggro \\
\end{tabular} & o & $M$ & A & Blanco & M & M & $\mathrm{A}$ & ма. & VIIII & 0 & Rege. & 0 & \begin{tabular}{|l} 
Hori. \\
\end{tabular} & 0 & 0 & 0 & 0 & 0 & 0 \\
\hline 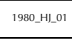 & & 0 & & & & & & & & мa. & vili & 0 & Reg. & \begin{tabular}{|l|l|} 
Asim. \\
\end{tabular} & \begin{tabular}{|l} 
Hori. \\
\end{tabular} & 0 & 0 & 0 & 0 & 0 & 0 \\
\hline $1900,0,0.000$ & \begin{tabular}{|l|l} 
Mono. \\
\end{tabular} & Negro & M & M & A & Blanco & M & м & A & м. & $\mathrm{vu}_{1}$ & o & Reg. & 129. & \begin{tabular}{|l|} 
Hori. \\
\end{tabular} & 0 & 0 & 0 & 0 & 0 & 0 \\
\hline $1900 \times x=000$ & \begin{tabular}{|l|} 
T.p.p. \\
\end{tabular} & \begin{tabular}{|l|l|} 
Azzul \\
\end{tabular} & M & B & B & Verde & M & м & в & ме. & III & 0 & Reg. & 0 & Hori. & ме. & $v_{1}$ & Maxima & \begin{tabular}{|l|} 
Fina \\
\end{tabular} & \begin{tabular}{|l|l|} 
Drch \\
\end{tabular} & \begin{tabular}{|l|} 
Hori. \\
\end{tabular} \\
\hline 1980,MLEDen & & 0 & & & & & & & & ма. & VIII & 0 & Reg. & 0 & \begin{tabular}{|l} 
Hori. \\
\end{tabular} & 0 & 0 & 0 & 0 & 0 & 0 \\
\hline 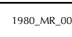 & & 0 & & & & & & & & ма. & VIIII & o & Reg. & \begin{tabular}{|c|} 
Cent. \\
\end{tabular} & \begin{tabular}{|l|l} 
Hori. \\
\end{tabular} & 0 & 0 & 0 & 0 & 0 & 0 \\
\hline 1980,py on & & 0 & & & & & & & & м. & iv & Fetere Aniqual & Reg. & 0 & Hori. & ма. & VIII & 0 & \begin{tabular}{|l|} 
Reg. \\
\end{tabular} & Cent. & \begin{tabular}{|l|} 
Hori. \\
\end{tabular} \\
\hline 1980.5 SR oo & \begin{tabular}{|l} 
Real. \\
|
\end{tabular} & \begin{tabular}{|l|l|} 
Rojo \\
\end{tabular} & c & M & M & $\begin{array}{l}\text { Ama- } \\
\text { rillo }\end{array}$ & c & M & в & ме. & iv & $\begin{array}{l}\text { Pergamon } \\
\text { Anniuar }\end{array}$ & Reg. & 0 & \begin{tabular}{|l} 
Hori. \\
\end{tabular} & ме. & Ix & 0 & \begin{tabular}{|l|l} 
Reg. \\
\end{tabular} & 0 & \begin{tabular}{|l|} 
Hori. \\
\end{tabular} \\
\hline 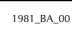 & \begin{tabular}{|l|} 
Real. \\
\end{tabular} & \begin{tabular}{|l|} 
Negro \\
\end{tabular} & M & M & A & $\begin{array}{l}\text { Ama- } \\
\text { rillo }\end{array}$ & M & M & A & ма. & VIII & 0 & Reg. & \begin{tabular}{|l|}
129. \\
\end{tabular} & Hori. & 0 & 0 & 0 & 0 & 0 & 0 \\
\hline 1981_EH_.00 & Dic. & Negro & o & M & A & $\begin{array}{l}\text { Anala- } \\
\text { rillo }\end{array}$ & M & M & A & ме. & v & 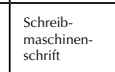 & Negra & \begin{tabular}{|l|l|}
124. \\
\end{tabular} & Hori. & 0 & 0 & 0 & 0 & 0 & 10 \\
\hline 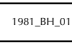 & & 0 & & & & & & & & Me. & $\mathrm{IV}$ & 0 & Reg. & \begin{tabular}{|l|l|}
129. \\
\end{tabular} & \begin{tabular}{|l|} 
Hori. \\
\end{tabular} & 0 & 0 & 0 & 0 & 0 & $\begin{array}{l}0 \\
\end{array}$ \\
\hline 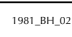 & & 0 & & & & & & & & ме. & iv & o & Reg. & Cent. & $\begin{array}{l}\text { Hori. } \\
\end{array}$ & 0 & 0 & 0 & 0 & 0 & 0 \\
\hline 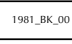 & \begin{tabular}{|l|l|} 
Dic. \\
\end{tabular} & \begin{tabular}{|l|l|} 
Negro \\
\end{tabular} & M & M & A & \begin{tabular}{|l|l|} 
Rojio \\
\end{tabular} & M & M & A & Ma. & VIII & 0 & $\begin{array}{l}\text { Negra } \\
\end{array}$ & 129. & \begin{tabular}{|l|} 
Hori. \\
\end{tabular} & 0 & 0 & 0 & 0 & 0 & 0 \\
\hline val. & \begin{tabular}{|l|l|} 
Real. \\
\end{tabular} & $\begin{array}{l}\text { Azul } \\
\end{array}$ & c & M & A & Negro & 0 & M & A & ме. & $\mathrm{v}_{1}$ & Maxima & Reg. & 0 & Hori. & 0 & 0 & 0 & 0 & 0 & 0 \\
\hline 1981 DLL_.00 & \begin{tabular}{|l} 
Dic. \\
\end{tabular} & \begin{tabular}{|l|} 
Rojo \\
\end{tabular} & $M$ & $M$ & A & Negro & 0 & M & A & Ma. & VIIII & ${ }_{0}$ & 0 & \begin{tabular}{|l|l|} 
Asim. \\
\end{tabular} & \begin{tabular}{|l|} 
Hori. \\
\end{tabular} & 0 & 0 & 0 & 0 & 0 & 0 \\
\hline 1981 FE__of & \begin{tabular}{|l} 
Dic. \\
\end{tabular} & \begin{tabular}{|l|} 
Negro \\
\end{tabular} & o & M & A & \begin{tabular}{|c|} 
Ama- \\
rillo \\
\end{tabular} & M & M & A & Me. & $\mathrm{v}$ & 0 & Reg. & 0 & Hori. & 0 & 0 & 0 & 0 & 0 & 0 \\
\hline $1901,1, y=0$ & \begin{tabular}{|l|l|} 
Dic. \\
\end{tabular} & Negro & o & M & A & Blanco & M & B & A & 0 & 0 & 0 & 0 & 0 & 0 & 0 & 0 & 0 & 0 & 0 & 0 \\
\hline 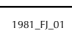 & \begin{tabular}{|l|} 
Real. \\
\end{tabular} & \begin{tabular}{|l|l|} 
Azzul \\
\end{tabular} & M & M & A & Rojo & o & M & м & ма. & $v_{1}$ & 0 & Reg. & \begin{tabular}{|l|}
129. \\
\end{tabular} & \begin{tabular}{|l|} 
Adap. \\
\end{tabular} & 0 & 0 & 0 & \begin{tabular}{|l}
0 \\
\end{tabular} & 0 & 0 \\
\hline 198__CE, Do & & ${ }_{0}^{\circ}$ & & & & & & & & Ma. & VIII & 0 & Reg. & \begin{tabular}{|l|l|} 
Asim. \\
\end{tabular} & $\begin{array}{l}\text { Hori. } \\
\end{array}$ & 0 & 0 & 0 & 0 & 0 & 0 \\
\hline 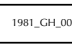 & \begin{tabular}{|l} 
Mono. \\
\end{tabular} & \begin{tabular}{|l|l|} 
Neggro \\
\end{tabular} & o & M & A & Blanco & M & M & A & ме. & vi & Maxima & Reg. & 1129. & \begin{tabular}{|l} 
Hori. \\
\end{tabular} & 0 & 0 & 0 & 0 & 0 & 0 \\
\hline 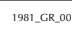 & \begin{tabular}{|l|} 
Real. \\
\end{tabular} & 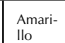 & c & M & A & \begin{tabular}{|l|l|} 
naranija \\
\end{tabular} & c & M & A & Ма. & VIII & ${ }^{\circ}$ & Deco. & 0 & \begin{tabular}{|l|l} 
Adap. \\
\end{tabular} & 0 & 0 & 0 & 0 & 0 & 0 \\
\hline 1981 CKR_or & \begin{tabular}{|l|} 
Real. \\
\end{tabular} & \begin{tabular}{|l|l|} 
Rojo \\
\end{tabular} & c & M & A & \begin{tabular}{|l|l} 
Verde \\
\end{tabular} & C & M & A & ма. & VIII & 0 & Reg. & \begin{tabular}{|l|} 
kq. \\
\end{tabular} & \begin{tabular}{|l|} 
Hori. \\
\end{tabular} & Me. & $v_{1}$ & Maxima & \begin{tabular}{|l|} 
Reg. \\
\end{tabular} & 129. & Hori. \\
\hline 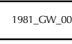 & \begin{tabular}{|l|} 
Real. \\
\end{tabular} & \begin{tabular}{|l|l|l|l} 
Azull \\
\end{tabular} & M & M & A & \begin{tabular}{|l|} 
naranjia \\
\end{tabular} & M & м & \begin{tabular}{|l} 
B \\
\end{tabular} & ме. & $\mathrm{vl}_{1}$ & Super Grotesk & $\begin{array}{l}\text { Negra } \\
\end{array}$ & 0 & \begin{tabular}{|l} 
Hori. \\
\end{tabular} & Me. & $\mathrm{vv}_{1}$ & Super Grotesk & \begin{tabular}{|l|} 
Reg. \\
\end{tabular} & \begin{tabular}{|l|l|} 
1zq. \\
\end{tabular} & Hori. \\
\hline $1891,10,0,0$ & 3 col. & 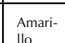 & c & M & $A$ & \begin{tabular}{|l|l} 
Negro \\
\end{tabular} & o & M & A & м. & III & 0 & $\begin{array}{l}\text { Negra } \\
\end{array}$ & \begin{tabular}{|l|l|} 
Drch \\
\end{tabular} & \begin{tabular}{|l} 
Hori. \\
\end{tabular} & ме. & $v_{1}$ & 0 & \begin{tabular}{|l|} 
Reg. \\
\end{tabular} & \begin{tabular}{|l|l} 
Drch \\
\end{tabular} & \begin{tabular}{|l|} 
Hori. \\
\end{tabular} \\
\hline 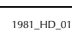 & \begin{tabular}{|l|} 
Real. \\
\end{tabular} & Verde & o & $M$ & A & Blanco & c & M & A & ме. & iv & 0 & Negra & 0 & Hori. & 0 & 0 & 0 & 0 & 0 & 0 \\
\hline 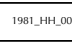 & \begin{tabular}{|l|l|} 
T.pl. \\
\end{tabular} & \begin{tabular}{|l|} 
Verde \\
\end{tabular} & $M$ & $M$ & $\mathrm{~A}$ & Rojo & $M$ & M & A & ма. & $\mathrm{vi}$ & 0 & Deco. & \begin{tabular}{|l|l|} 
Asim. \\
\end{tabular} & $\begin{array}{l}\text { Hori. } \\
\end{array}$ & Me. & $\mathrm{v}_{1}$ & Maxima & \begin{tabular}{|l|} 
Reg. \\
\end{tabular} & 124. & \begin{tabular}{|l} 
Hori. \\
\end{tabular} \\
\hline 1981_Hu_on & \begin{tabular}{|l|} 
Real. \\
\end{tabular} & \begin{tabular}{|l|l|} 
Rojo \\
\end{tabular} & $\circ$ & $M$ & B & 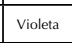 & 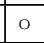 & M & B & ме. & vIII & 0 & Reg. & 0 & Hori. & 0 & 0 & 0 & 0 & 0 & 0 \\
\hline 19811,200 & Mono. & Negro & o & $M$ & A & Blanco & $M$ & M & A & м. & $v_{11}$ & Maxima & $\begin{array}{l}\text { Negra } \\
\end{array}$ & 124. & Hori. & 0 & 0 & 0 & 0 & 0 & 0 \\
\hline 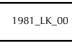 & \begin{tabular}{|c|} 
Mono. \\
\end{tabular} & Rojo & M & $M$ & $\mathrm{~A}$ & Blanco & $M$ & M & A & м. & $\mathrm{vi}$ & $0_{0}$ & Reg. & 0 & $\begin{array}{ll}\text { Hori. } \\
\end{array}$ & 0 & 0 & 0 & 0 & 0 & 0 \\
\hline 198__MR_.0D & \begin{tabular}{|l} 
Dic. \\
D
\end{tabular} & \begin{tabular}{|l|} 
Negro \\
\end{tabular} & o & M & A & 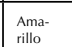 & M & M & A & ме. & v1 & Super Grotesk & $\begin{array}{ll}\text { Reg. } \\
\end{array}$ & 0 & Hori. & 0 & 0 & 0 & 0 & 0 & 0 \\
\hline
\end{tabular}




\begin{tabular}{|c|c|c|c|c|c|c|c|c|c|c|c|c|c|c|c|c|c|c|c|c|c|c|}
\hline \multirow{2}{*}{ conco } & \multicolumn{9}{|c|}{ CÓDIGO CROḾ́tICO } & \multicolumn{13}{|c|}{ CÓDIGO TIPOCRŔFICO } \\
\hline & uso & MATIZ & $\mathrm{v}$ & $\mathrm{s}$ & & MATIZ & $v$ & $\mathrm{~s}$ & 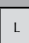 & & EP. & CAA & FAMLIA & EST. & ALIN & ORE. & REP. & $\mathrm{cL}$ & FAMLIA & Еsт. & ALIN & ORE. \\
\hline 198__PH_Lo & Mono. & Negro & o & в & A & 0 & 0 & 0 & 0 & 8 & & 0 & 0 & 0 & 0 & 0 & 0 & 0 & 0 & 0 & 0 & 0 \\
\hline 1981_St_oo & T.p. & $\begin{array}{l}\text { Amari- } \\
\text { Io }\end{array}$ & м & ${ }^{B}$ & A & rojo & c & M & A & & ne. & vi & Maxima & Cond. & 0 & Hori. & 0 & 0 & 0 & 0 & 0 & 0 \\
\hline PBI, IH, & T.pl. & Rojo & o & M & M & Azul & M & M & м & & ne. & IV & Wallaum & Semi. & Cent. & Adap. & 0 & 0 & 0 & 0 & 0 & 0 \\
\hline 188_WG_.oo & $3 \mathrm{Col}$. & Rojo & м & M & A & Negro & M & M & A & & a. & vill & 0 & Reg. & Asim. & Adap. & 0 & 0 & 0 & 0 & 0 & 0 \\
\hline 198_-WS $\leq 00$ & Dic. & Rojo & M & M & A & Negro & o & M & A & s & s & 0 & 0 & 0 & 0 & 0 & 0 & 0 & 0 & 0 & 0 & 0 \\
\hline 1982.-BH -00 & T.pl. & $\begin{array}{l}\text { Amari- } \\
\text { lio }\end{array}$ & м & в & A & Rojo & M & м & A & & ne. & vi & 0 & & Just. & Hori. & 0 & o & 0 & 0 & 0 & 0 \\
\hline 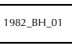 & Mono. & Negro & o & M & A & Blanco & M & M & A & & ne. & $v_{1}$ & Super Grotesk & Semi. & \begin{tabular}{|l|} 
Dreh \\
\end{tabular} & Hori. & 0 & 0 & 0 & 0 & 0 & 0 \\
\hline 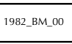 & T.pl. & verde & o & м & A & Rojo & M & M & M & & a. & vili & 0 & Reg. & Cent. & Hori. & 0 & 0 & 0 & 0 & 0 & 0 \\
\hline 1982_EK,00 & & 0 & & & & & & & & & a. & vilI & 0 & Reg. & 0 & Adap. & ма. & $v_{1}$ & 0 & Rege. & Cent. & Hori. \\
\hline $1982-F \mathrm{~B}, 00$ & & 0 & & & & & & & & & ne. & $\mathrm{vi}^{2}$ & 0 & Reg. & 0 & Adap. & 0 & 0 & 0 & 0 & 0 & 0 \\
\hline 198_CE_ED & Dic. & Negro & o & м & A & Rojo & M & M & B & & a. & VIII & 0 & Reg. & Asim. & Hori. & 0 & 0 & 0 & 0 & 0 & 0 \\
\hline 182-CWNon & Dic. & Negro & $\circ$ & м & A & Rojo & o & M & в & & ve. & $v_{1}$ & 0 & Semi. & \begin{tabular}{|l|} 
izq. \\
\end{tabular} & Hori. & 0 & $\circ$ & 0 & 0 & 0 & 0 \\
\hline 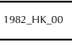 & Mono. & Negro & o & M & A & Blanco & M & M & A & & a. & VIIII & 0 & Reg. & 0 & Obli. & Me. & $\mathrm{v}$ & 0 & Curs. & Arra. & Hori. \\
\hline 1982_K0._oo & \begin{tabular}{|l} 
Dic. \\
\end{tabular} & Negro & o & м & A & Rojo & M & м & A & & ne. & $\begin{array}{ll}\text { X.D. } \\
\text {. }\end{array}$ & 0 & Reg. & 0 & Hori. & Me. & $v_{1}$ & 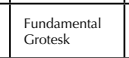 & Reg. & Asim. & Hori. \\
\hline 1982,pvoo & T.p. & Negro & $\circ$ & M & A & Rojo & M & м & B & & Ua. & VIII & 0 & Reg. & Drch & Hori. & 0 & 0 & 0 & 0 & 0 & 0 \\
\hline $1982.54,200$ & \begin{tabular}{|l|} 
Real. \\
\end{tabular} & Rojo & M & M & A & $\begin{array}{l}\text { Ama- } \\
\text { rillo }\end{array}$ & M & M & A & & ne. & vil & 0 & Reg. & 0 & Hori. & Me. & $v_{1}$ & 0 & Reg. & 0 & Hori. \\
\hline 1982_VC__ao & $3 \mathrm{col}$. & Negro & o & M & A & Verde & M & M & A & & ne. & vi & Super Grotesk & Semi. & \begin{tabular}{|l|l|} 
Cent. \\
\end{tabular} & Hori. & 0 & 0 & 0 & 0 & 0 & 0 \\
\hline 1982,WH_- 100 & Mono. & Negro & M & M & M & Blanco & M & M & A & & ne. & IIII & 0 & Extra & \begin{tabular}{|l|l|} 
Cent. & \\
\end{tabular} & Hori. & o & 0 & 0 & 0 & 0 & 0 \\
\hline 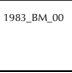 & 3 col. & $\begin{array}{l}\text { Amari- } \\
{ }_{110}\end{array}$ & o & M & A & Rojo & M & м & A & & a. & vi & 0 & Negra & 0 & Hori. & Me. & v & 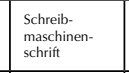 & Reg. & 0 & obli. \\
\hline 198_.zM__or & \begin{tabular}{|l|l} 
T.pl. \\
\end{tabular} & $\begin{array}{l}\text { Amari- } \\
\text { Ilo }\end{array}$ & м & ${ }^{\text {B }}$ & M & Azul & M & в & M & & ua. & vIII & 0 & Reg. & Asim. & Hori. & 0 & 0 & 0 & 0 & 0 & 0 \\
\hline 1983_DK_.00 & & 0 & & & & & & & & & ne. & $\mathrm{vi}$ & Super Grotesk & Semi. & Cent. & Hori. & 0 & 0 & 0 & 0 & 0 & 0 \\
\hline $183, F=0.00$ & Dic. & Negro & o & M & B & Rojo & M & M & B & & a. & VIII & 0 & Reg. & 0 & obli. & 0 & 0 & 0 & 0 & 0 & 0 \\
\hline 1983.-H.100 & Dic. & $\begin{array}{l}\text { Negro } \\
\end{array}$ & M & M & A & $\begin{array}{l}\text { Rojo } \\
\end{array}$ & M & M & A & & ne. & $v^{v}$ & $\begin{array}{l}\text { Schreib- } \\
\text { caschinen- } \\
\text { schritit }\end{array}$ & Reg. & kaq. & Hori. & 0 & 0 & 0 & 0 & 0 & 0 \\
\hline 1983-HU-Do & \begin{tabular}{|l|} 
T.pl. \\
\end{tabular} & $\begin{array}{l}\text { Amari- } \\
\text { Iloo }\end{array}$ & c & в & A & Negro & 0 & M & A & & ne. & $\mathrm{vi}$ & 0 & Negra & Asim. & Hori. & мe. & iv & 0 & Cond. & $\mid$ | 129. & Hori. \\
\hline $1983,1,00$ & \begin{tabular}{|l} 
Dic. \\
\end{tabular} & Negro & $\circ$ & M & A & Blanco & $M$ & M & $\mathrm{A}$ & & ne. & $\mathrm{iv}$ & 0 & 0 & Just. & Hori. & Me. & $v_{1}$ & Maxima & Reg. & Cent. & Hori. \\
\hline 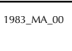 & Mono. & Blanco & c & m & A & Negro & o & M & A & & ne. & vi & $\begin{array}{l}\text { Fundanental } \\
\text { Crotrese }\end{array}$ & Reg. & Just. & Hori. & 0 & 0 & 0 & 0 & 0 & 0 \\
\hline 1983_NEEDOD & Mono. & Negro & $\circ$ & M & м & Blanco & 0 & M & м & & ne. & IV & 0 & Reg. & Cent. & Hori. & мa. & viII & 0 & Reg. & 0 & Hori. \\
\hline 1983_NE.01 & & 0 & & & & & & & & & ve. & " & $\begin{array}{l}\text { Typoart } \\
\text { Caramond }\end{array}$ & Reg. & Cent. & Hori. & 0 & 0 & 0 & 0 & 0 & 0 \\
\hline 1983_py-0o & Real. & Rojo & м & м & A & $\begin{array}{l}\text { Ama- } \\
\text { rilio }\end{array}$ & M & M & A & & Ma. & vIII & 0 & Reg. & Arra. & Hori. & 0 & 0 & 0 & 0 & 0 & 0 \\
\hline 1983_WC._.oo & Dic. & Negro & o & м & A & Rojo & м & м & A & & ne. & vi & $\begin{array}{c}\text { Noma } \\
\text { Steinshrhitt }\end{array}$ & Reg. & Asim. & vert. & Me. & vi & Maxima & Semi. & Arra. & Hori. \\
\hline $1984 \_$B. $\triangle 200$ & Mono. & Negro & $\circ$ & M & A & Blanco & M & M & A & & ne. & iv & 0 & Reg. & 0 & Adap. & 0 & 0 & 0 & 0 & 0 & 0 \\
\hline 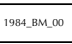 & \begin{tabular}{|l|l|} 
Real. \\
\end{tabular} & Azul & c & м & M & rojo & c & M & м & & a. & VIII & 0 & Reg. & Asim. & Hori. & 0 & 0 & 0 & 0 & 0 & 0 \\
\hline 1984_DL_Do & Dic. & Negro & o & M & A & Azul & M & M & A & & ne. & $\mathrm{v}$ & 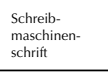 & Reg. & 129. & Hori. & 0 & 0 & 0 & 0 & 0 & 0 \\
\hline 1984_EA-DOD & 3 col. & $\begin{array}{l}\text { Amari- } \\
\text { Ilo }\end{array}$ & м & в & A & Negro & o & M & A & & ne. & vIII & 0 & Reg. & 0 & obli. & Me. & vi & Maxima & Reg. & 0 & obli. \\
\hline 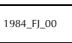 & Mono. & Negro & м & M & м & Blanco & 0 & M & B & & a. & VIII & 0 & 0 & $\begin{array}{l}\text { Asim. } \\
\end{array}$ & Adap. & 0 & 0 & 0 & 0 & 0 & 0 \\
\hline 1984_CR_.00 & Dic. & Rojo & M & M & A & Negro & o & M & A & & ve. & v & 0 & Reg. & 0 & Vert. & 0 & 0 & 0 & 0 & 0 & 0 \\
\hline 1984.HH_.60 & & 0 & & & & & & & & & ne. & vi & Maxima & Negra & \begin{tabular}{|l|l|} 
Izq. \\
\end{tabular} & Hori. & 0 & 0 & 0 & 0 & 0 & 0 \\
\hline 1084 MRE & $3 \mathrm{col}$. & Rojo & o & M & A & Azul & M & M & м & & ve. & $\mathrm{iv}$ & 0 & Reg. & 0 & Hori. & 0 & 0 & 0 & 0 & 0 & 0 \\
\hline 1984,py-00 & \begin{tabular}{|l|l} 
T.pl. \\
\end{tabular} & $\begin{array}{l}\text { Amari- } \\
\text { Iloris }\end{array}$ & M & в & M & \begin{tabular}{|l|l|l} 
Azzul \\
\end{tabular} & M & M & M & & na. & vill & 0 & Reg. & 129. & Hori. & 0 & 0 & 0 & 0 & 0 & 0 \\
\hline 1984 .5B . oo & T.p. & $\begin{array}{ll}\text { Rojo } \\
\end{array}$ & M & M & в & Azul & M & M & M & & ne. & $\mathrm{Ix}$ & Hogarth Script & $\begin{array}{l}\text { Semi. } \\
\end{array}$ & 0 & Hori. & Me. & ix & Hogarth Script & Reg. & 124. & Hori. \\
\hline 1984,5_-100 & Real. & $\begin{array}{l}\text { Amari- } \\
\text { Ilo }\end{array}$ & м & M & M & Azul & M & M & м & & va. & vIII & 0 & Reg. & Ara. & Hori. & 0 & $\circ$ & ${ }^{\circ}$ & 0 & 0 & 0 \\
\hline
\end{tabular}

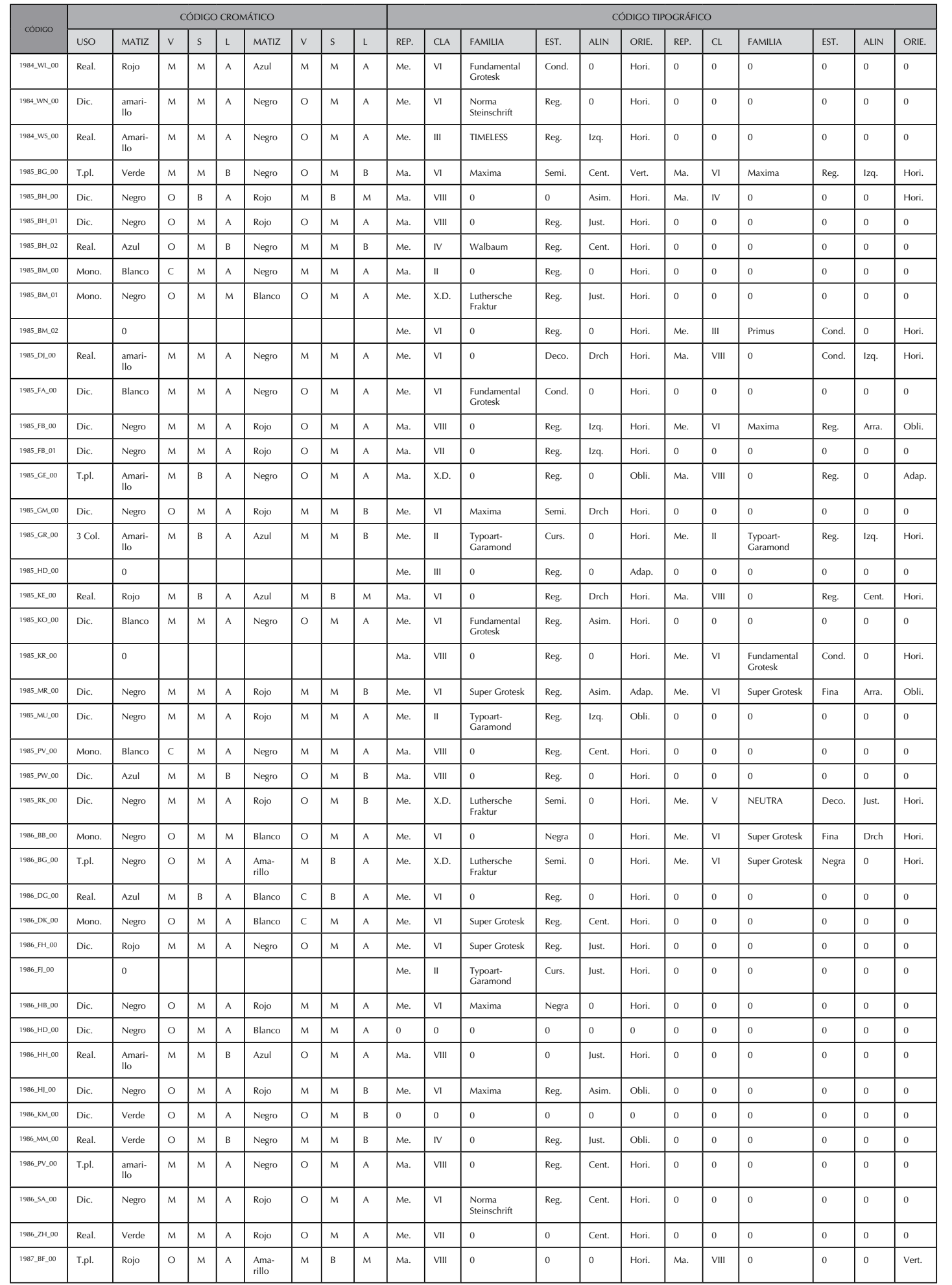

\begin{tabular}{|c|c|c|c|c|c|c|c|c|c|c|c|c|c|c|c|c|c|c|c|c|c|}
\hline \multirow{2}{*}{ ćnoco } & \multicolumn{9}{|c|}{ СООСОО СвОМӒTLO } & \multicolumn{12}{|c|}{ 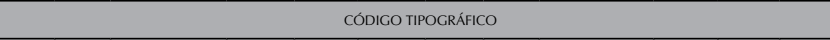 } \\
\hline & uso & MATIZ & $\mathrm{v}$ & $\mathrm{s}$ & $T_{\mathrm{L}}$ & матz & v & $\mathrm{s}$ & L & REP. & CLA & FAMLIA & ЕST. & ALN & \begin{tabular}{|l|l} 
ORIE. \\
\end{tabular} & \begin{tabular}{|l|l} 
REP. \\
\end{tabular} & $\mathrm{ct}$ & FAMLLA & \begin{tabular}{|l|l} 
EsT. \\
.
\end{tabular} & ALIN & ORIE \\
\hline 1984_m_on & \begin{tabular}{|l} 
Real. \\
\end{tabular} & Rojo & м & M & A & Azul & M & M & A & м. & vi & $\begin{array}{l}\text { Fundamental } \\
\text { Croterk }\end{array}$ & Cond. & 0 & Hori. & 0 & 0 & 0 & 0 & 0 & 0 \\
\hline vestuncos & Dic. & \begin{tabular}{|l} 
amarif \\
Ilo
\end{tabular} & м & M & A & Negro & o & M & A & ме. & $v_{1}$ & 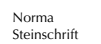 & Reg. & 0 & \begin{tabular}{|l} 
Hori. \\
\end{tabular} & 0 & 0 & 0 & 0 & 0 & 0 \\
\hline 184tws 00 & \begin{tabular}{|l} 
Real. \\
\end{tabular} & \begin{tabular}{|l|l} 
Amari- \\
Ilori
\end{tabular} & м & M & A & Negro & 0 & M & A & м.. & III & TIMEEESS & Reg. & $12 \mathrm{q}$. & Hori. & 0 & 0 & 0 & 0 & 0 & 0 \\
\hline 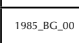 & T.pl. & Verde & м & M & B & Negro & o & м & B & ма. & $v_{1}$ & Maxima & Semi. & Cent. & ver. & ма. & vi & Maxima & Reg. & 129. & Hori. \\
\hline 1095 . & \begin{tabular}{|l|l} 
Dic. \\
\end{tabular} & Negro & o & в & A & Rojo & M & B & м & ма. & VIII & 0 & 0 & Asim. & Hori. & ма. & $\mathrm{iv}$ & 0 & 0 & 0 & Hori. \\
\hline 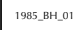 & Dic. & \begin{tabular}{|l|l|l|} 
Negro \\
\end{tabular} & o & M & A & Rojo & o & м & A & ма. & VIII & 0 & Reg. & Just. & Hori. & 0 & 0 & 0 & 0 & 0 & 0 \\
\hline 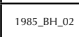 & \begin{tabular}{|l|l|} 
Real. \\
\end{tabular} & Azul & o & M & в & $\begin{array}{l}\text { Negro } \\
\end{array}$ & $M$ & M & в & м. & IV & Walbaum & Reg. & Cent. & Hori. & 0 & 0 & 0 & \begin{tabular}{|l|}
0 \\
\end{tabular} & 0 & 0 \\
\hline 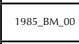 & \begin{tabular}{|l|l} 
Mono. \\
\end{tabular} & Blanco & $\mathrm{c}$ & $M$ & A & Neggro & M & M & A & ма. & 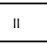 & 0 & Reg. & 0 & Hori. & 0 & 0 & 0 & 0 & 0 & 0 \\
\hline 1995_.8M_.01 & \begin{tabular}{|l} 
Mono. \\
\end{tabular} & Negro & o & M & м & Blanco & o & M & A & м. & X.D. & $\begin{array}{l}\text { Luthersche } \\
\text { Fraktur }\end{array}$ & Reg. & Just. & \begin{tabular}{|l} 
Hori. \\
\end{tabular} & 0 & 0 & 0 & 0 & 0 & 0 \\
\hline 1995 ВвM.02 & & 0 & & & & & & & & м.. & $v_{1}$ & ${ }_{0}$ & Reg. & 0 & Hori. & м.. & IIII & Primus & Cond. & 0 & Hori. \\
\hline 1985.DDD.00 & \begin{tabular}{|l|l} 
Real. \\
\end{tabular} & $\begin{array}{l}\text { amari- } \\
\text { lloil }\end{array}$ & м & M & A & Negro & $m$ & M & A & ме. & $\mathrm{vi}$ & 0 & Deco. & Drch & Hori. & Ma. & vil & 0 & Cond. & 129. & Hori. \\
\hline 1055,5000 & \begin{tabular}{|l|} 
Dic. \\
\end{tabular} & Blanco & M & M & A & $\begin{array}{l}\text { Negro } \\
\end{array}$ & 0 & M & A & м. & $v_{1}$ & $\begin{array}{c}\text { Fundamenal } \\
\text { Groterk }\end{array}$ & cond. & 0 & Hori. & 0 & 0 & 0 & 0 & 0 & 0 \\
\hline 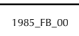 & \begin{tabular}{|l|} 
Dic. \\
\end{tabular} & $\begin{array}{l}\text { Negro } \\
\end{array}$ & m $>>>$ & $M$ & A & $\begin{array}{ll}\text { Rojo } \\
\end{array}$ & 0 & M & A & ма. & VIIII & 0 & Reg. & zzq. & Hori. & м.. & $v_{1}>-2$ & Maxima & \begin{tabular}{|l|} 
Reg. \\
\end{tabular} & Arra. & obli. \\
\hline 1995 F $\mathrm{FB}, 01$ & \begin{tabular}{|l|} 
Dic. \\
\end{tabular} & Negro & M & $M$ & A & $\begin{array}{ll}\text { Rojo } \\
\end{array}$ & 0 & M & A & ма. & VII & o & Reg. & 129. & Hori. & \begin{tabular}{|l|}
0 \\
\end{tabular} & 0 & 0 & 0 & 0 & 0 \\
\hline 1985 CGE 000 & \begin{tabular}{|l|} 
T.ppl. \\
T.
\end{tabular} & 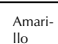 & M & B & A & \begin{tabular}{|l|} 
Negroo \\
\end{tabular} & 0 & M & A & ма. & X.D. & o & Reg. & 0 & \begin{tabular}{|l|} 
obli. \\
\end{tabular} & Ма. & vil & 0 & \begin{tabular}{|l|} 
Reg. \\
\end{tabular} & 0 & Adap \\
\hline 1985 19M-COCO & Dic. & Negro & o & M & A & Rojo & $M$ & м & B & м. & vi & Maxima & Semi. & Drch & Hori. & 0 & 0 & 0 & 0 & 0 & 0 \\
\hline 1995 CRR. 00 & \begin{tabular}{|l|l} 
Col. \\
\end{tabular} & 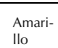 & M & B & A & \begin{tabular}{|l|l|} 
A Azul \\
\end{tabular} & M & M & B & мe. & " & $\begin{array}{l}\text { Typoart- } \\
\text { Cararand }\end{array}$ & curs. & 0 & Hori. & Me. & $"$ & $\begin{array}{l}\text { Typoant } \\
\text { Cramanond }\end{array}$ & \begin{tabular}{|l|l} 
Reg. \\
\end{tabular} & 129. & Hori. \\
\hline 1955 HD 200 & & 0 & & & & & & & & м. & III & 0 & Reg. & 0 & \begin{tabular}{|l|} 
Adap. \\
\end{tabular} & $\begin{array}{ll} \\
\end{array}$ & 0 & 0 & 0 & 0 & 0 \\
\hline $1995, K \in 00$ & Real. & Rojo & M & B & A & Azul & M & B & M & ма. & $\mathrm{v}_{1}$ & o & \begin{tabular}{|l|} 
Reg. \\
\end{tabular} & $\begin{array}{l}\text { Drch } \\
\text { Din }\end{array}$ & Hori. & ма. & vil & 0 & \begin{tabular}{|l|} 
Reg. \\
\end{tabular} & $\begin{array}{ll}\text { Cent. } \\
\end{array}$ & Hori. \\
\hline 19855 KO. 000 & \begin{tabular}{|l|} 
Dic. \\
\end{tabular} & Blanco & M & M & A & \begin{tabular}{|l|} 
Neggoo \\
\end{tabular} & 0 & м & A & ме. & $v_{1}$ & $\begin{array}{c}\text { Fundamental } \\
\text { Crorotek }\end{array}$ & \begin{tabular}{|l|l} 
Reg. \\
\end{tabular} & Asim. & Hori. & 0 & 0 & 0 & 0 & 0 & 0 \\
\hline $1995 \leq$ KR & & 0 & & & & & & & & ма. & VIII & 0 & Reg. & 0 & Hori. & Me. & $\mathrm{vi}$ & $\begin{array}{l}\text { Fundamental } \\
\text { Crofosk }\end{array}$ & \begin{tabular}{|c|} 
Cond. \\
\end{tabular} & $\begin{array}{l}0 \\
\end{array}$ & Hori. \\
\hline 1985 MNR D. 00 & \begin{tabular}{|l|} 
Dic. \\
\end{tabular} & Negro & M & M & A & Rojo & M & м & B & м. & $v_{11}$ & Super Grotesk & \begin{tabular}{|l|l|} 
Reg. \\
\end{tabular} & Asim. & Adap. & м.. & $\mathrm{v}_{1}$ & Super Groterk & Fina & Arra. & obli. \\
\hline 1985_MU_on & \begin{tabular}{|l} 
Dic. \\
\end{tabular} & Negro & M & M & A & \begin{tabular}{|l|l|} 
Rojo \\
\end{tabular} & $M$ & M & A & Me. & " & $\begin{array}{l}\text { Typoart } \\
\text { cararond }\end{array}$ & $\begin{array}{ll}\text { Reg. } \\
\end{array}$ & 129. & obli. & 0 & 0 & 0 & 0 & 0 & 0 \\
\hline 1995 S. PV 000 & \begin{tabular}{|l|} 
Mono. \\
\end{tabular} & Blanco & c & $M$ & A & $\begin{array}{l}\text { Negro } \\
\end{array}$ & $M$ & M & A & ма. & VIIII & 0 & $\begin{array}{l}\text { Reg. } \\
\end{array}$ & Cent. & Hori. & 0 & 0 & 0 & $\begin{array}{ll} \\
\end{array}$ & 0 & 0 \\
\hline 1005 P PW. & \begin{tabular}{|l|} 
Dic. \\
\end{tabular} & 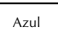 & M & $M$ & B & $\begin{array}{l}\text { Negro } \\
\end{array}$ & 0 & M & B & мa. & VIIII & 0 & $\begin{array}{ll}\text { Reg. } \\
\text { nat }\end{array}$ & 0 & \begin{tabular}{|l|} 
Hori. \\
\end{tabular} & 0 & 0 & 0 & 0 & 0 & 0 \\
\hline 1995 SRK $\angle 00$ & \begin{tabular}{|l} 
Dic. \\
\end{tabular} & Negro & M & M & A & Rojo & 0 & M & B & м. & \begin{tabular}{|l|l|} 
X.D. \\
\end{tabular} & $\begin{array}{l}\text { Luthersche } \\
\text { Frakuru }\end{array}$ & \begin{tabular}{|l|} 
Semi. \\
S
\end{tabular} & 0 & Hori. & Me. & $\mathrm{v}$ & NEUTRA & \begin{tabular}{|l|} 
Deco. \\
\end{tabular} & \begin{tabular}{|l|l|} 
Just. \\
\end{tabular} & Hori. \\
\hline 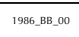 & Mono. & Negro & o & M & м & Blanco & 0 & M & A & ме. & vi & 0 & Negra & 0 & Hori. & ме. & $v_{1}$ & Super Groterk & Fina & Drch & Hori. \\
\hline $1966, B G, 00$ & \begin{tabular}{|l|l|} 
T.ppl \\
\end{tabular} & \begin{tabular}{|l|} 
Negro \\
\end{tabular} & o & M & A & \begin{tabular}{|l} 
Ama- \\
riflo
\end{tabular} & M & B & A & Me. & X.D. & $\begin{array}{l}\text { Luthersche } \\
\text { Fraktur }\end{array}$ & Semi. & 0 & \begin{tabular}{|l|} 
Hori. \\
\end{tabular} & Me. & $v_{11}$ & Super Groterk & Negra & 0 & Hori. \\
\hline $1996, D C, D C, 000$ & \begin{tabular}{|l|} 
Real. \\
\end{tabular} & Azul & M & B & A & Blanco & $\begin{array}{ll}\text { c } \\
\end{array}$ & B & A & ме. & $\mathrm{v}_{1}$ & 0 & Reg. & 0 & Hori. & 0 & 0 & 0 & 0 & $\begin{array}{ll}0 \\
\end{array}$ & 0 \\
\hline 1996_DK.00 & Mono. & Negro & o & M & A & $\begin{array}{l}\text { Blanco } \\
\end{array}$ & c & M & A & Me. & $v_{1}$ & Super Grotesk & \begin{tabular}{|l|l|} 
Reg. \\
\end{tabular} & Cent. & Hori. & \begin{tabular}{|l|}
0 \\
\end{tabular} & 0 & 0 & 0 & \begin{tabular}{|l|}
0 \\
\end{tabular} & 0 \\
\hline 1986 . FH 000 & \begin{tabular}{|l|} 
Dic. \\
\end{tabular} & Rojo & M & M & A & $\begin{array}{l}\text { Negro } \\
\end{array}$ & 0 & M & A & Me. & $\mathrm{v1}$ & Super Grotesk & \begin{tabular}{|l|} 
Reg. \\
\end{tabular} & Just. & Hori. & 0 & 0 & 0 & 0 & 0 & 0 \\
\hline $1986, F, E 00$ & & . & & & & & & & & м. & " & $\begin{array}{l}\text { Trpoart } \\
\text { Cararond }\end{array}$ & \begin{tabular}{|l|} 
Curs. \\
\end{tabular} & Just. & \begin{tabular}{|l|} 
Hori. \\
\end{tabular} & \begin{tabular}{|l|} 
\\
\end{tabular} & 0 & 0 & \begin{tabular}{|l|}
0 \\
\end{tabular} & \begin{tabular}{|l|l} 
\\
\end{tabular} & 0 \\
\hline 1986, H. & Dic. & 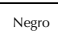 & $\mathrm{o}$ & M & A & Rejo & M & M & A & м. & $\mathrm{v}_{1}$ & Maxima & Negaa & 0 & Hori. & 0 & 0 & 0 & $\begin{array}{ll} \\
\end{array}$ & 0 & 0 \\
\hline 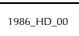 & \begin{tabular}{|l|l} 
Dic. \\
\end{tabular} & Negro & o & M & A & Blanco & M & M & A & 0 & 0 & o & 0 & 0 & 0 & 0 & 0 & 0 & \begin{tabular}{|l|} 
\\
\end{tabular} & \begin{tabular}{|l|} 
\\
\end{tabular} & o \\
\hline 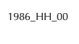 & \begin{tabular}{|l|l} 
Real. \\
\end{tabular} & \begin{tabular}{|l|} 
Amarif \\
10
\end{tabular} & M & M & B & \begin{tabular}{|l|l|} 
Azul \\
\end{tabular} & 0 & M & A & мa. & vill & 0 & 0 & Just. & \begin{tabular}{|l|} 
Hori. \\
\end{tabular} & 0 & 0 & 0 & \begin{tabular}{|l|}
0 \\
\end{tabular} & 0 & 0 \\
\hline 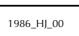 & \begin{tabular}{|l|} 
Dic. \\
\end{tabular} & Negro & o & $M$ & $\mathrm{~A}$ & Rojo & $M$ & M & в & Me. & $\mathrm{v}_{1}$ & Maxima & Reg. & Asim. & \begin{tabular}{|l|} 
obli. \\
\end{tabular} & 0 & 0 & 0 & \begin{tabular}{|l|}
0 \\
\end{tabular} & \begin{tabular}{|l|}
0 \\
\end{tabular} & 0 \\
\hline 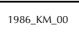 & \begin{tabular}{|l|l|} 
Dic. \\
\end{tabular} & Verde & o & M & A & Negro & 0 & M & B & 0 & 0 & 0 & 0 & 0 & 0 & \begin{tabular}{|l|} 
\\
\end{tabular} & 0 & 0 & \begin{tabular}{|l|} 
\\
\end{tabular} & \begin{tabular}{|l|} 
\\
\end{tabular} & 0 \\
\hline 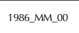 & \begin{tabular}{|l|l} 
Real. \\
\end{tabular} & Verde & o & M & B & Negro & $M$ & $M$ & B & ме. & IV & 0 & $\begin{array}{l}\text { Reg. } \\
\end{array}$ & Just. & Obli. & 0 & 0 & 0 & \begin{tabular}{|l|} 
\\
\end{tabular} & $\begin{array}{ll} \\
\end{array}$ & 0 \\
\hline 1986, fvV 00 & \begin{tabular}{|l|l} 
T.ppl \\
|
\end{tabular} & 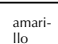 & M & M & A & Negroo & 0 & M & A & ма. & VIIII & 0 & \begin{tabular}{|l} 
Reg. \\
\end{tabular} & Cent. & Hori. & \begin{tabular}{|l|} 
\\
\end{tabular} & 0 & 0 & \begin{tabular}{|l|} 
\\
\end{tabular} & \begin{tabular}{|l|l|} 
\\
\end{tabular} & 0 \\
\hline 10605,5000 & Dic. & Negro & M & M & A & Rojo & 0 & M & A & Me. & $v_{1}$ & $\begin{array}{l}\text { Noma } \\
\text { Seleschintit }\end{array}$ & \begin{tabular}{|l|} 
Reg. \\
\end{tabular} & Cent. & Hori. & 0 & 0 & 0 & \begin{tabular}{|l|} 
\\
\end{tabular} & 0 & 0 \\
\hline $1986, \angle 4.500$ & $\begin{array}{l}\text { Real. } \\
\text { Real }\end{array}$ & Verde & M & M & A & Rojo & o & $M$ & A & ме. & VIII & 0 & 0 & Cent. & Hori. & 0 & 0 & 0 & \begin{tabular}{|l|}
0 \\
\end{tabular} & 0 & 0 \\
\hline 1987, BE $=00$ & T.pl. & \begin{tabular}{|l|l|} 
Rojo \\
\end{tabular} & o & M & $\mathrm{A}, \mathrm{C}, \mathrm{C}$ & 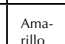 & M & B & M & ма. & VIII & 0 & 0 & 0 & \begin{tabular}{|l} 
Hori. \\
\end{tabular} & Ma. & vil & 0 & 0 & 0 & vert. \\
\hline
\end{tabular}




\begin{tabular}{|c|c|c|c|c|c|c|c|c|c|c|c|c|c|c|c|c|c|c|c|c|c|c|}
\hline \multirow{2}{*}{ conco } & \multicolumn{9}{|c|}{ CÓDIGO CROMÁTICO } & \multicolumn{13}{|c|}{ CÓDIGO TIPOGRÁFICO } \\
\hline & uso & MATZ & $\mathrm{v}$ & s & L & MATIZ & v & $\mathrm{s}$ & L & & RPP. & CLA & \begin{tabular}{|l|l} 
FАМІLA \\
\end{tabular} & EST. & ALIN & ORRE. & REP. & $\mathrm{al}$ & FAMLLA & \begin{tabular}{|l|l} 
EST. \\
\end{tabular} & ALIN & ORIE \\
\hline 1987_B BE.01 & $3 \mathrm{col}$. & Negro & o & M & A & 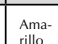 & M & в & B & & Мa. & vill & 0 & Reg. & Cent. & obli. & м. & $\mathrm{vi}$ & Maxima & Semi. & \begin{tabular}{|c|} 
Cent. \\
\end{tabular} & obli. \\
\hline 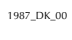 & Mono. & Negro & o & M & M & Blance & M & м & A & & ve. & vi & $\begin{array}{l}\text { Fundamental } \\
\text { Crocerk }\end{array}$ & Semi. & \begin{tabular}{|l|l|} 
Just. \\
\end{tabular} & Hori. & 0 & 0 & 0 & 0 & 0 & 0 \\
\hline 1987-1, Loo & T.p.l. & Negro & o & M & A & Violete. & c & в & M & & Ne. & vi & 0 & Semi. & 0 & Hori. & Me. & $\mathrm{vi}^{2}$ & \begin{tabular}{|l|l|} 
Fundamental \\
Croterk
\end{tabular} & Semi. & 0 & Adap \\
\hline tarz & Real. & Negro & м & M & A & $\begin{array}{l}\text { Rojo } \\
\end{array}$ & o & м & B & & М.. & VIII & 0 & Reg. & Cent. & Hori. & 0 & 0 & 0 & 0 & 0 & 0 \\
\hline 198_CR Doo & T.p. & Amari- & m & B & A & Negro & c c & M & A & & Na. & VIII & 0 & Reg. & $\mathrm{zq}$. & Hori. & 0 & 0 & 0 & 0 & 0 & 0 \\
\hline 1987-H.H.00 & T.pl. & Naranja & m & M & B & Verde & c & м & B & & мe. & II" & Kis Aniqua & Reg. & Cent. & obli. & 0 & 0 & 0 & 0 & 0 & 0 \\
\hline 1987-14.600 & Dic. & Negro & M & M & A & Rojo & M & M & $M$ & & M.. & VIII & 0 & $\begin{array}{l}\text { Reg. } \\
\end{array}$ & 0 & Hori. & 0 & 0 & $\mid$ & $\mid$ & 0 & o \\
\hline 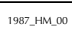 & Mono. & 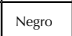 & o & M & A & Blance & м & M & A & & ve. & $v_{1}$ & Maxima & Cond. & 1zq. & Hori. & м. & 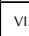 & Super Grotesk & \begin{tabular}{|l|l} 
Negra \\
\end{tabular} & Drch & Hori. \\
\hline 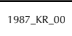 & Real. & Negro & o & M & A & Blance & m & M & A & & Ma. & VIII & 0 & Reg. & Arra. & Obli. & 0 & 0 & 0 & 0 & 0 & 0 \\
\hline $1987 \_1<-00$ & & 0 & & & & & & & & & м. & $v_{1}$ & 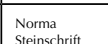 & $\begin{array}{ll}\text { Reg. } \\
\text {. }\end{array}$ & 0 & Hori. & 0 & 0 & 0 & 0 & 0 & 0 \\
\hline 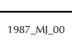 & $3 \mathrm{col}$. & Azul & o & M & M & $\begin{array}{l}\text { Rojo } \\
\end{array}$ & c & м & A & & мa. & VIII & 0 & Reg. & Just. & Hori. & 0 & 0 & 0 & 0 & 0 & 0 \\
\hline 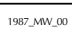 & Dic. & $\begin{array}{l}\text { amari- } \\
\text { lio }\end{array}$ & m & B & A & Negro & o & м & A & & ме. & $v_{1}$ & Maxima & Reg. & 0 & Vert. & 0 & 0 & ${ }^{\circ}$ & 0 & 0 & 0 \\
\hline 1987-7H 00 & T.p. & Rojo & M & M & A & \begin{tabular}{|l|l|} 
Rojo \\
\end{tabular} & c & м & A & & ме. & vi & $\begin{array}{l}\text { Fundamental } \\
\text { Crofork }\end{array}$ & Semi. & Ara. & Hori. & 0 & 0 & 0 & 0 & 0 & 0 \\
\hline 1987 새이 & $3 \mathrm{Col}$. & Azul & o & M & A & rojo & c & M & A & & мa. & VIII & 0 & Reg. & Just. & Hori. & 0 & 0 & 0 & 0 & 0 & 0 \\
\hline 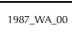 & Real. & Naranja & o & M & B & \begin{tabular}{|l|l|} 
Rojo \\
\end{tabular} & M & B & B & & мe. & $v_{1}$ & 0 & Reg. & Cent. & Hori. & 0 & 0 & 0 & 0 & $\begin{array}{ll}0 \\
\end{array}$ & 0 \\
\hline 1087 쓰이 & Real. & Rojo & m & B & B & Azul & M & B & B & & ме. & $v_{1}$ & $\begin{array}{l}\text { Fundamental } \\
\text { Croroesk }\end{array}$ & Semi. & 0 & Hori. & 0 & 0 & 0 & 0 & 0 & 0 \\
\hline 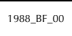 & Real. & Azul & M & M & M & rojo & M & м & m & & Ma. & VIII & 0 & Reg. & 0 & vert. & 0 & 0 & 0 & 0 & 0 & 0 \\
\hline 1988_BH_OO & \begin{tabular}{|l|} 
Dic. \\
\end{tabular} & Rojo & M & M & A & Negro & 0 & M & A & & ме. & v & $\begin{array}{l}\text { Manutus } \\
\text { Annitias }\end{array}$ & Reg. & Just. & Hori. & 0 & 0 & 0 & 0 & 0 & 0 \\
\hline 1986. & & 0 & & & & & & & & & Ма. & ix & 0 & Deco. & $\mathrm{kzq}$ & Hori. & 0 & 0 & 0 & 0 & 0 & 0 \\
\hline 19868 . & Dic. & $\begin{array}{l}\text { amari- } \\
\text { illate }\end{array}$ & M & $M$ & A & Negro & 0 & M & A & & мe. & $\mathrm{v}$ & Technoryp & Reg. & Asim. & \begin{tabular}{|l} 
Hori. \\
\end{tabular} & 0 & 0 & ${ }^{\circ}$ & 0 & 0 & 0 \\
\hline 1983 & T.pl. & Rjoio & M & M & A & $\begin{array}{l}\text { Verde } \\
\end{array}$ & M & M & A & & м.. & VIII & s & Reg & Cent. & Hori. & 0 & 0 & 0 & 0 & 0 & 0 \\
\hline 1988_ER . Fo 00 & $3 \mathrm{Col}$. & verde & M & M & A & \begin{tabular}{|l|l|} 
Rojio \\
\end{tabular} & $M$ & м & A & & Me. & $v_{1}$ & 0 & $\begin{array}{l}\text { Reg. } \\
\text { Ren }\end{array}$ & Drch & Hori. & 0 & 0 & 0 & 0 & 0 & 0 \\
\hline $1988 \_$EDD_Do & 3 col. & $\begin{array}{ll}\text { Azul } \\
\end{array}$ & o & $M$ & B & \begin{tabular}{|l|l|} 
Rojo \\
\end{tabular} & $M$ & M & B & & мe. & $v_{1}$ & $\begin{array}{c}\text { Noma } \\
\text { Steinchriti }\end{array}$ & $\begin{array}{ll}\text { Reg. } \\
\text { Ren }\end{array}$ & Just. & Hori. & Me. & $\mathrm{v}_{1}$ & Super Grotesk & \begin{tabular}{|l} 
Seni. \\
Sol
\end{tabular} & 1zq. & Hori. \\
\hline 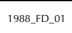 & Mono. & $\begin{array}{l}\text { Negro } \\
\text { Not }\end{array}$ & o & $M$ & M & Blance & o & $\mathrm{M}$ & $\mathrm{M}$ & & Me. & $v_{1}$ & 0 & $\begin{array}{l}\text { Negra } \\
\end{array}$ & \begin{tabular}{|l|l|} 
Just. \\
\end{tabular} & Hori. & м. & $\mathrm{vi}_{1}$ & 0 & Cond. & Just. & Hori. \\
\hline 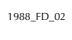 & Mono. & $\begin{array}{l}\text { Negro } \\
\end{array}$ & m & $m$ & A & \begin{tabular}{|l} 
Ama- \\
riflo
\end{tabular} & M & M & A & & мe. & $v_{1}$ & $\begin{array}{l}\text { Noma } \\
\text { Steinchrit }\end{array}$ & Reg. & 0 & Hori. & 0 & 0 & 0 & 0 & 0 & 0 \\
\hline 1988 H. Hoo & & 0 & & & & & & & & & ме. & $v_{11}$ & Maxima & \begin{tabular}{|l|l|} 
Negra \\
\end{tabular} & \begin{tabular}{|l|l|} 
Drch \\
\end{tabular} & Hori. & 0 & 0 & 0 & 0 & 0 & $\begin{array}{l} \\
\end{array}$ \\
\hline $1988 \_$CEE_CO & Mono. & Blanco & M & M & A & Negro & o & м & A & & Ma. & VIII & 0 & Reg. & Asim. & Hori. & 0 & 0 & 0 & 0 & 0 & 0 \\
\hline 1988 19E_.01 & T.pl. & Negro & M & $M$ & A & \begin{tabular}{|l|l} 
Ama- \\
rivlo
\end{tabular} & M & M & A & & мa. & VIII & 0 & Reg. & o & \begin{tabular}{|l|l} 
Addap. \\
\end{tabular} & ме. & vi & 0 & \begin{tabular}{|l|} 
Reg. \\
\end{tabular} & 129. & Hori. \\
\hline 1988 ссм_о & 0 & 0 & & & & & & & & & м. & v & 0 & Reg. & 0 & Hori. & м. & vi & Maxima & Semi. & Just. & Hori. \\
\hline 1988 CRR_oo & Dic. & Rojo & M & M & A & Blance & M & м & A & & ме. & vi & $\begin{array}{l}\text { Cundemental } \\
\text { Groferk }\end{array}$ & \begin{tabular}{|l|l|} 
Reg. \\
\end{tabular} & Asim. & $\begin{array}{ll}\text { Hori. } \\
\end{array}$ & ме. & $\mathrm{vi}^{2}$ & $\begin{array}{l}\text { Fundamental } \\
\text { chroses }\end{array}$ & Cond. & 12q. & Hori. \\
\hline 1988_Cw_on & Mono. & $\begin{array}{l}\text { Negro } \\
\end{array}$ & o & M & M & \begin{tabular}{|l|l|l|l} 
Blance & \\
\end{tabular} & 0 & M & A & & ме. & " & $\begin{array}{l}\text { Tschörtuer } \\
\text { Anntiouar }\end{array}$ & Reg. & Cent. & Hori. & 0 & 0 & 0 & 0 & 0 & 0 \\
\hline 198scavor or & Dic. & Negro & o & $M$ & A & $\begin{array}{l}\text { Rojo } \\
\end{array}$ & M & M & A & & ме. & 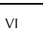 & Super Grotesk & Negra & 127. & Hori. & м. & iv & $\begin{array}{l}\text { Walbaum } \\
\end{array}$ & Reg. & 0 & Hori. \\
\hline 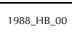 & Mono. & Blanco & o & $M$ & M & Negro & M & M & $M$ & & ме. & $v_{1}$ & Maxima & Reg. & 0 & Hori. & 0 & 0 & 0 & 0 & 0 & 0 \\
\hline 1988 BHE-OO & \begin{tabular}{|l|l|} 
T.p.p. \\
\end{tabular} & $\begin{array}{l}\text { Amarit- } \\
\text { Ilo }\end{array}$ & M & B & A & \begin{tabular}{|l|} 
Azul \\
\end{tabular} & M & м & A & & ме. & $\mathrm{vi}^{2}$ & Super Grotesk & \begin{tabular}{|l|} 
Negra \\
\end{tabular} & Drch & \begin{tabular}{|l|} 
Hori. \\
\end{tabular} & Me. & $\mathrm{vl}_{1}$ & Super Grotesk & Reg. & 129. & Hori. \\
\hline 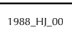 & & 0 & & & & & & & & & мa. & VIII & 0 & Reg. & 12q. & Hori. & 0 & 0 & 0 & 0 & 0 & 0 \\
\hline $198 \mathrm{sen}$. & Mono. & Verde & o & $m$ & B & Negro & o & м & B & & ме. & $v_{1}$ & $\begin{array}{l}\text { Norma } \\
\text { Steinchrift }\end{array}$ & Reg. & 0 & Hori. & ме. & $\mathrm{vi}^{2}$ & Maxima & \begin{tabular}{|l|l} 
Reg. \\
\end{tabular} & 1zq. & Hori. \\
\hline 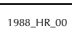 & Real. & Verde & c & M & B & $\begin{array}{c}\text { Ama- } \\
\text { riflo }\end{array}$ & M & м & B & & ме. & iv & $\begin{array}{l}\text { Pergamon } \\
\text { Annuiuan }\end{array}$ & Reg. & Cent. & Hori. & 0 & 0 & 0 & 0 & 0 & 0 \\
\hline 1988_ HU_of & Real. & Naranja & c & M & B & Negro & o & м & A & & мe. & $v_{1}$ & 0 & Reg. & Drch & Hori. & мe. & vi & Super Grotesk & \begin{tabular}{|l|l|} 
Reg. \\
\end{tabular} & Drch & Hori. \\
\hline 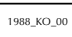 & & 0 & & & & & & & & & Ма. & VIII & 0 & Reg. & Just. & Hori. & 0 & 0 & 0 & 0 & 0 & 0 \\
\hline 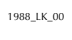 & Dic. & $\begin{array}{l}\text { amari- } \\
\text { Ilari }\end{array}$ & M & M & A & verde & M & M & A & & м.. & $v_{1}$ & 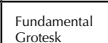 & $\begin{array}{ll}\text { Reg. } \\
\text { Ren }\end{array}$ & 0 & Hori. & 0 & 0 & 0 & 0 & 0 & 0 \\
\hline ses & $3 \mathrm{col}$. & Negro & o & M & A & Rojo & M & M & A & & ме. & III & Kis Antiqua & Reg. & 12a. & Hori. & 0 & 0 & 0 & 0 & 0 & 0 \\
\hline
\end{tabular}

\begin{tabular}{|c|c|c|c|c|c|c|c|c|c|c|c|c|c|c|c|c|c|c|c|c|c|}
\hline \multirow{2}{*}{ conco } & \multicolumn{9}{|c|}{ CÓDIGO CROMÁTICO } & \multicolumn{12}{|c|}{ CÓDIGO TIPOCRAFILO } \\
\hline & uso & MATIZ & $\mathrm{v}$ & $\mathrm{s}$ & $\mathrm{L}$ & MATIZ & v & s & L & REP. & CLA & FAMLIA & EST. & ALIN & ORIE. & \begin{tabular}{|l|l} 
REP. \\
\end{tabular} & $\mathrm{aL}$ & FAMLILA & EST. & ALIN & \begin{tabular}{|l|l|} 
ORIE. \\
\end{tabular} \\
\hline 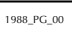 & & 0 & & & & & & & & ме. & $\mathrm{vu}_{1}$ & Maxima & Reg. & 0 & Hori. & 0 & 0 & 0 & 0 & 0 & 0 \\
\hline 1986 P PH 000 & & 0 & & & & & & & & мe. & $v_{1}$ & Super Grotesesk & Semi. & Asim. & Hori. & 0 & 0 & 0 & 0 & 0 & 0 \\
\hline 1988P. P. 00 & Dic. & Negro & 0 & M & A & Rojo & M & M & A & Me. & $v_{1}$ & Super Grotesk & Negra & $\mathrm{kq}$ & Hori. & 0 & 0 & 0 & 0 & 0 & 0 \\
\hline 1988 p p v oo & & 0 & & & & & & & & ма. & VIII & 0 & Reg. & 0 & Hori. & 0 & 0 & 0 & 0 & 0 & 0 \\
\hline 1968 \& 4 H 500 & Dic. & negro & o & M & A & amarillo & м & в & A & ма. & vin & 0 & Reg. & Cent. & Hori. & м. & $\mathrm{vi}_{1}$ & Super Grotesk & \begin{tabular}{|l} 
Semi. \\
\end{tabular} & 0 & Hori. \\
\hline 198B_R_LOOO & T.p.l. & Negro & $\circ$ & м & A & Rojo & M & м & A & Me. & " & 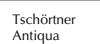 & Reg. & Cent. & Hori. & 0 & 0 & 0 & 0 & 0 & 0 \\
\hline 1998 S SH & T.pl. & Rojo & M & м & M & Negro & o & м & A & ма. & vi & 0 & Reg. & Just. & Hori. & ме. & $v_{1}$ & 0 & Reg. & 0 & Hori. \\
\hline 1998 SHH.01 & T.pl. & Narania & M & м & A & $\begin{array}{l}\text { Verde } \\
\end{array}$ & м & м & в & м. & $v_{1}$ & o & Reg. & 0 & Hori. & ме. & Ix & 0 & Reg. & Cent. & Hori. \\
\hline 1088 WhH -00 & $3 \mathrm{Col}$. & $\begin{array}{l}\text { amari } \\
{ }_{110}\end{array}$ & M & M & A & $\begin{array}{ll}\text { Negro } \\
\end{array}$ & o & M & A & Me. & vi & Super Grotesk & Curs. & Just. & obli. & 0 & 0 & 0 & 0 & 0 & 0 \\
\hline 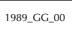 & Mono. & Negro & M & M & A & Blanco & o & м & A & мe. & $v_{1}$ & 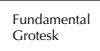 & cond. & Cent. & Hori. & 0 & 0 & ${ }^{0}$ & 0 & 0 & 0 \\
\hline 1989.CM CMo & Dic. & Negro & 0 & M & A & $\begin{array}{l}\text { Aimaa- } \\
\text { rillo }\end{array}$ & o & M & 0 & ме. & $v_{1}$ & Maxima & Cond. & Drch & Obli. & o & 0 & 0 & 0 & 0 & 0 \\
\hline 1989_C.M. & Mono. & Negro & M & M & B & Negro & c & M & \begin{tabular}{|l|} 
B \\
\end{tabular} & Me. & \begin{tabular}{|l|} 
X.D. \\
\end{tabular} & $\begin{array}{l}\text { Luthersche } \\
\text { fraturur }\end{array}$ & Reg. & 0 & Adap. & 0 & 0 & 0 & 0 & 0 & 0 \\
\hline 1989PV PV_oo & Real. & $\begin{array}{l}\text { Amarit } \\
\text { Ilot }\end{array}$ & M & M & A & Negro & м & M & A & Мa. & vil' & 0 & Reg. & Cent. & Hori. & 0 & 0 & 0 & 0 & 0 & 0 \\
\hline 1989.RH_. & Real. & $\begin{array}{l}\text { Amari- } \\
\text { Ilori }\end{array}$ & 0 & м & в & Rojo & o & M & A & ме. & $\mathrm{vu}_{1}$ & Maxima & Semi. & Just. & Hori. & ме. & $v_{1}$ & Maxima & Reg. & 129. & Hori. \\
\hline 1929 SB_bo & T.pl. & Azul & c & B & A & Rojo & c & B & A & Ma. & \begin{tabular}{|l|l|} 
VIII \\
\end{tabular} & 0 & Deco. & 0 & Hori. & Ма. & VIII & 0 & Reg. & 12q. & Hori. \\
\hline 1989.50_. 00 & Mono. & Negro & o & M & A & Blanco & M & M & A & ма. & vi & 0 & Reg. & 0 & 0 & M. & " & $\begin{array}{l}\text { Typoart- } \\
\text { Cararanond }\end{array}$ & 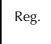 & Asim. & Hori. \\
\hline 1098 WC., 00 & Dic. & $\begin{array}{l}\text { Amari- } \\
\text { Ilori- }\end{array}$ & M & B & A & Rojo & M & ${ }^{\text {в }}$ & A & ме. & $v_{1}$ & Maxima & Negra & Just. & Hori. & 0 & 0 & 0 & 0 & 0 & 0 \\
\hline
\end{tabular}




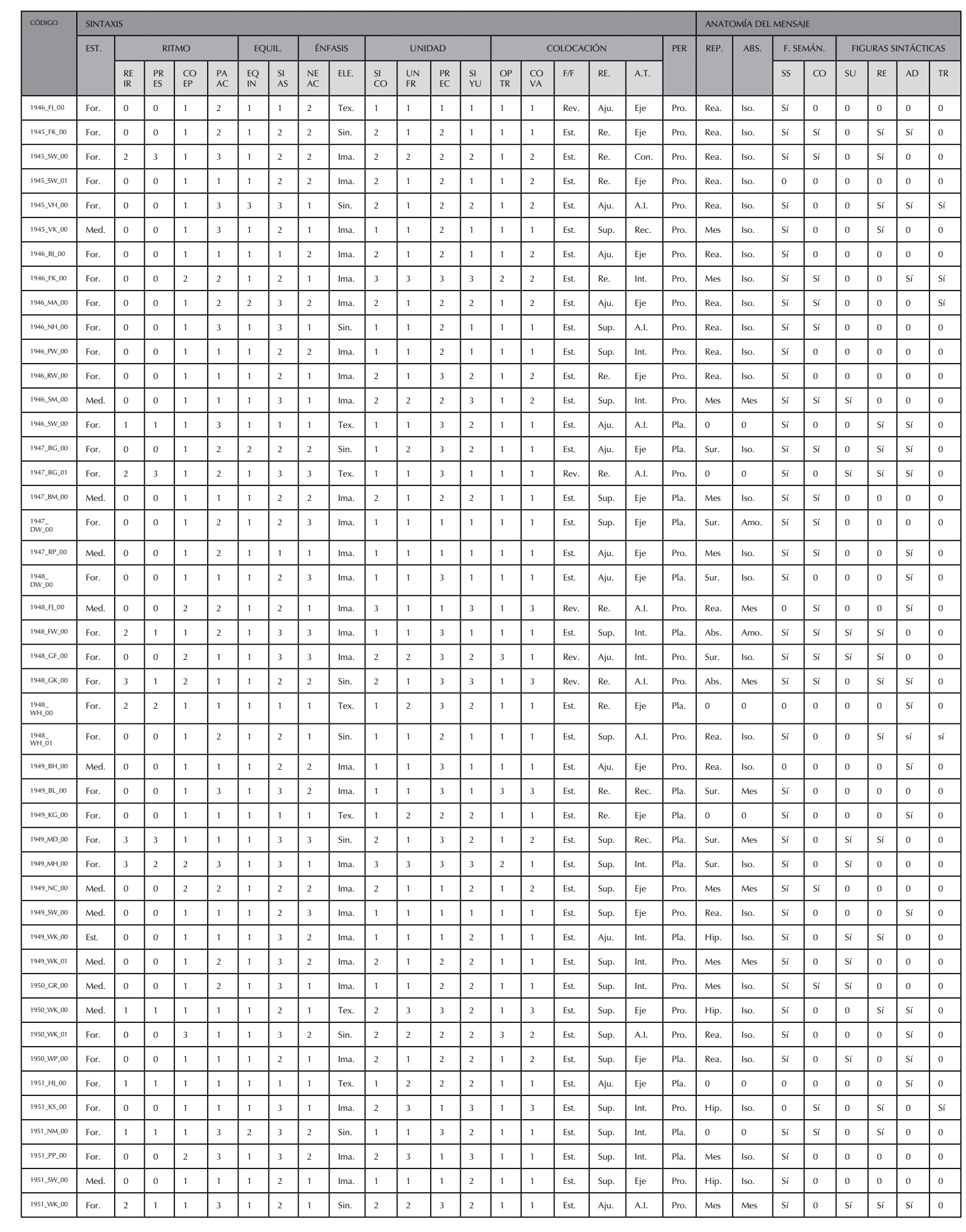

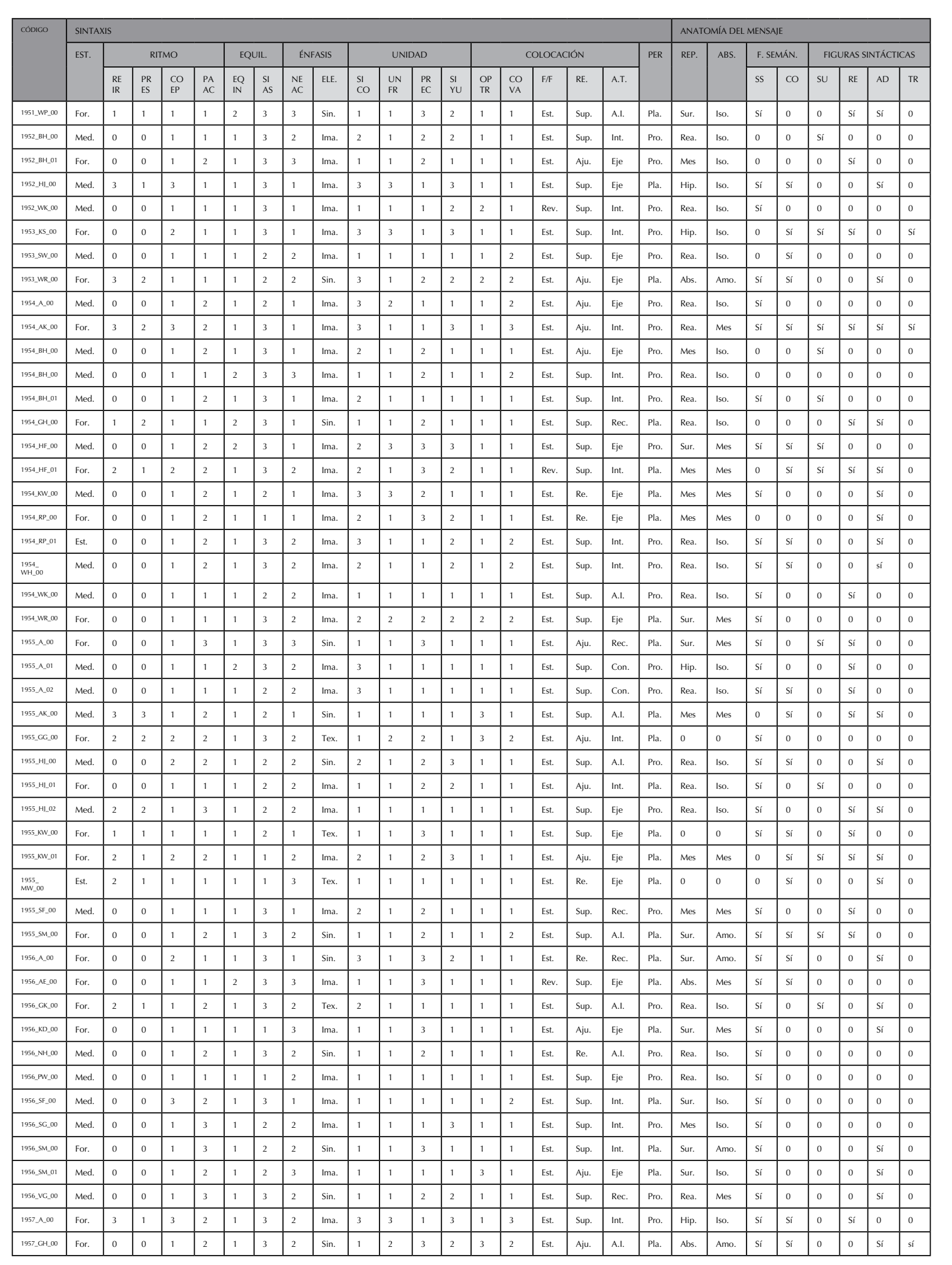




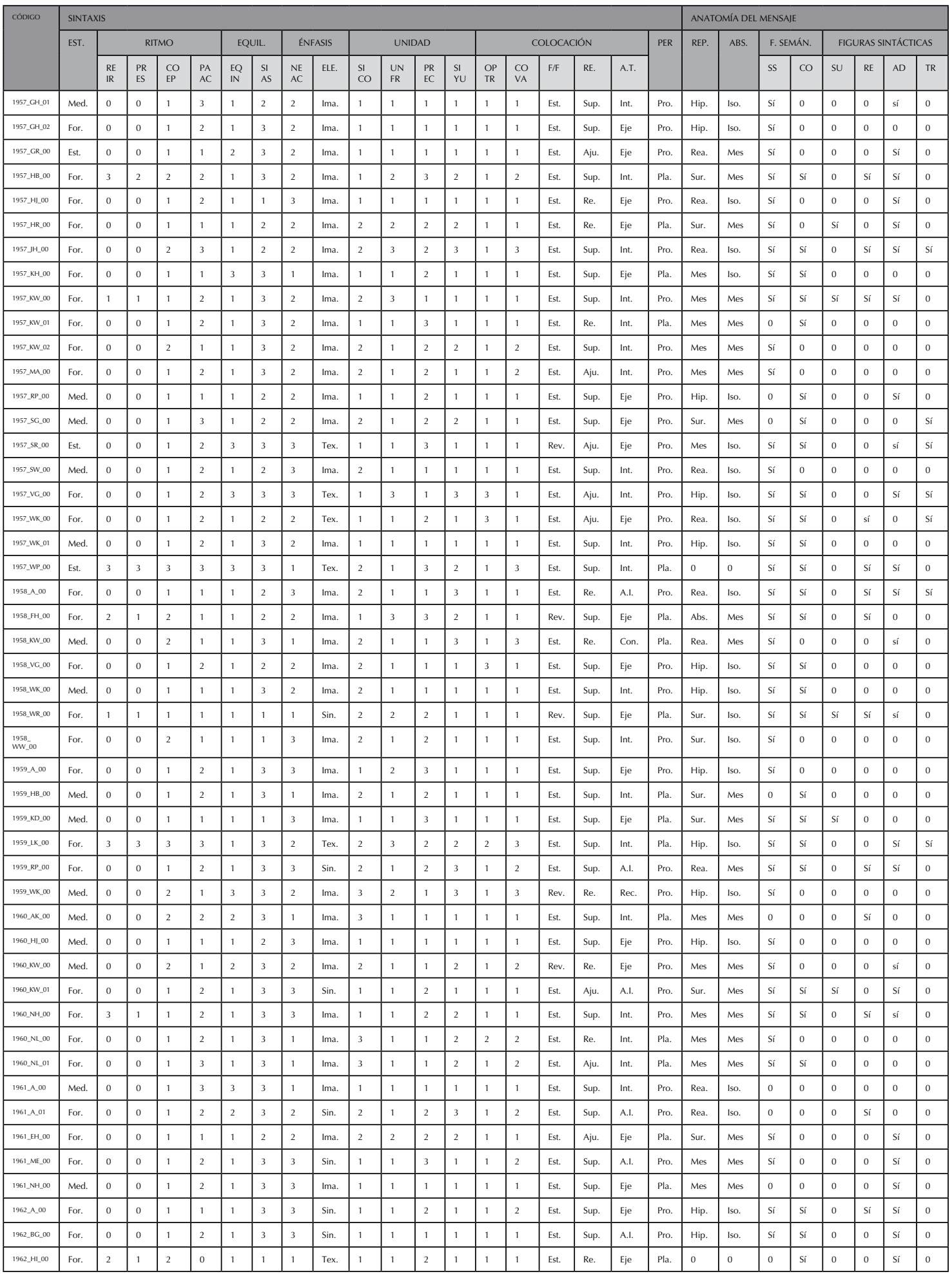

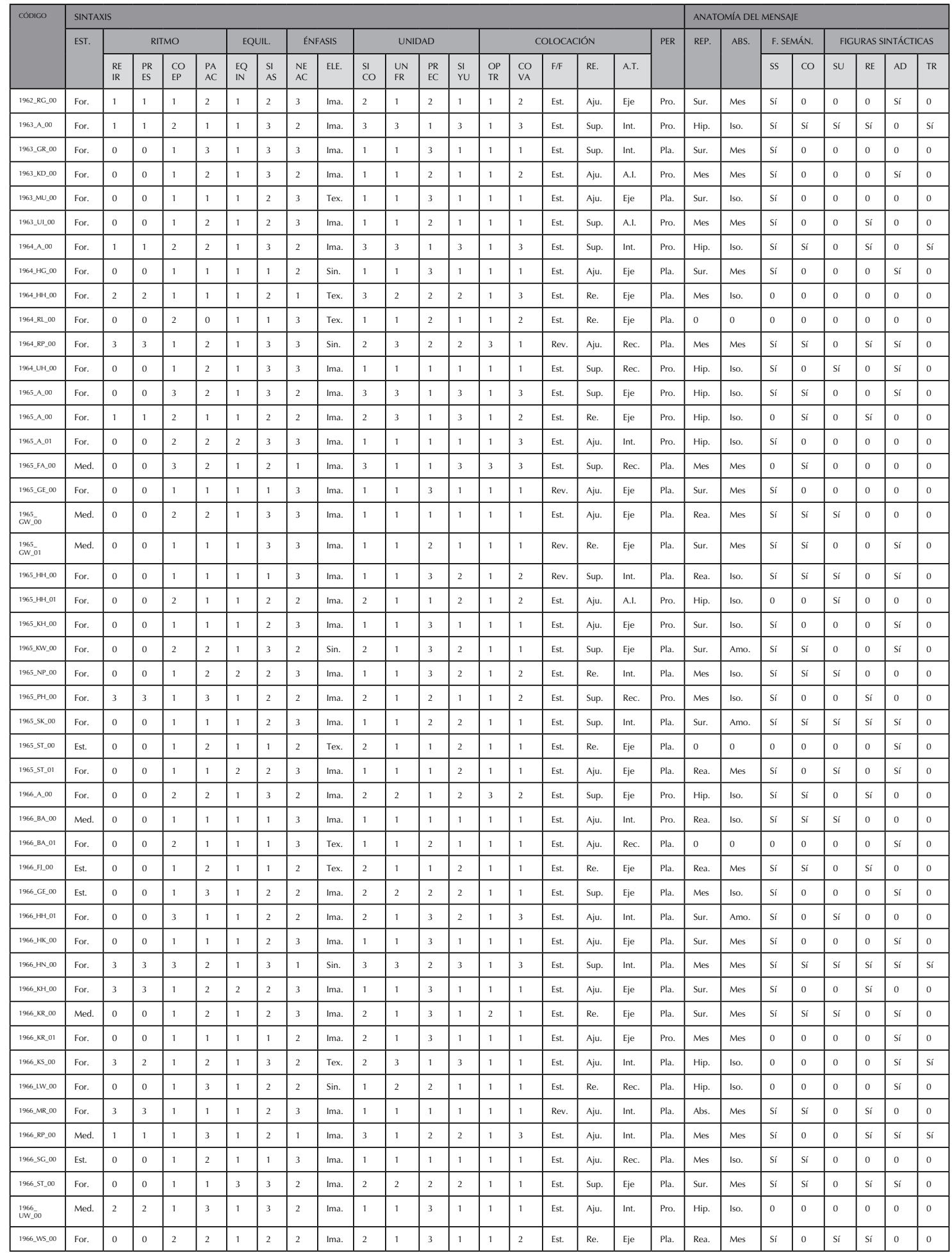




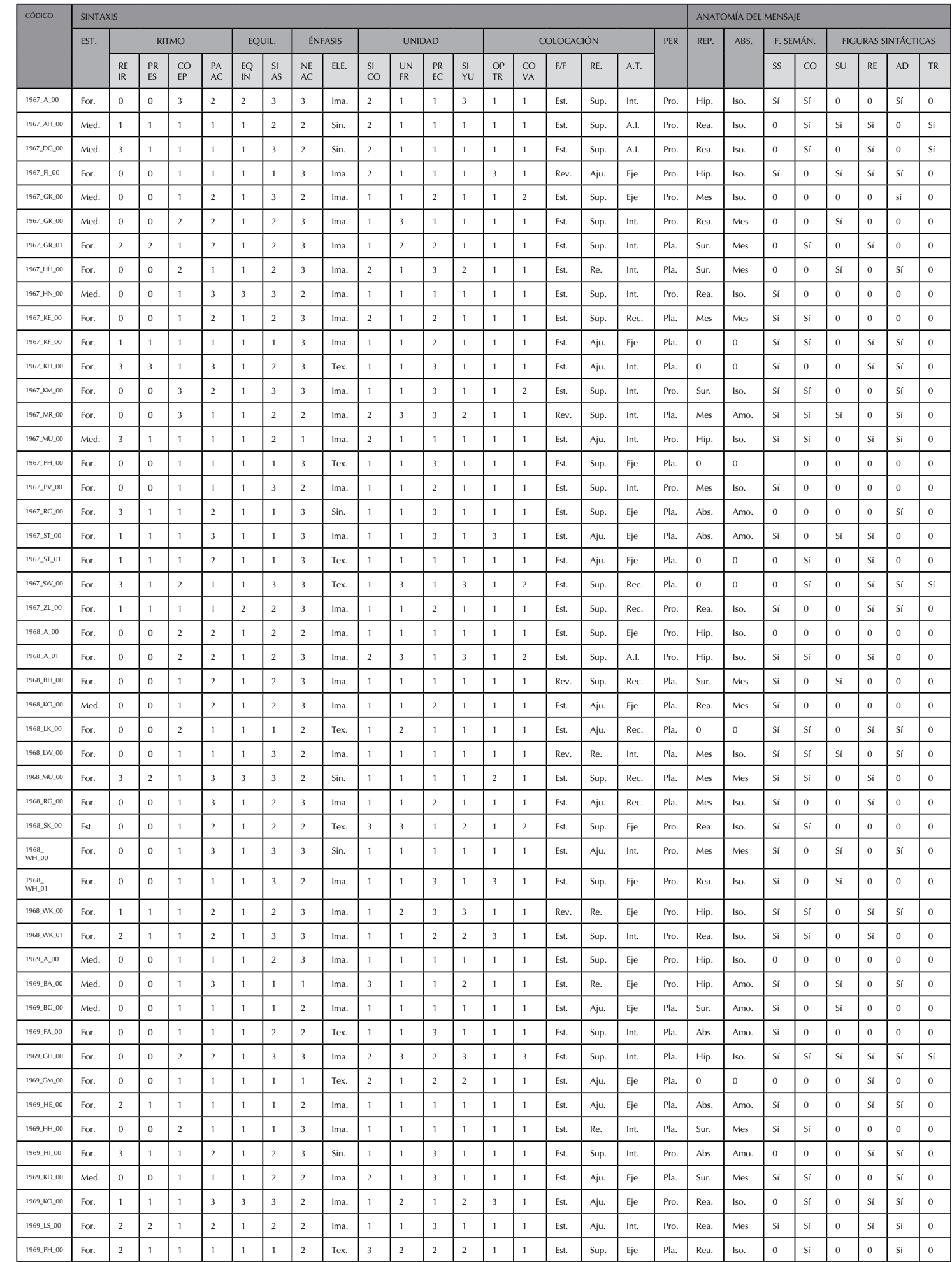

510

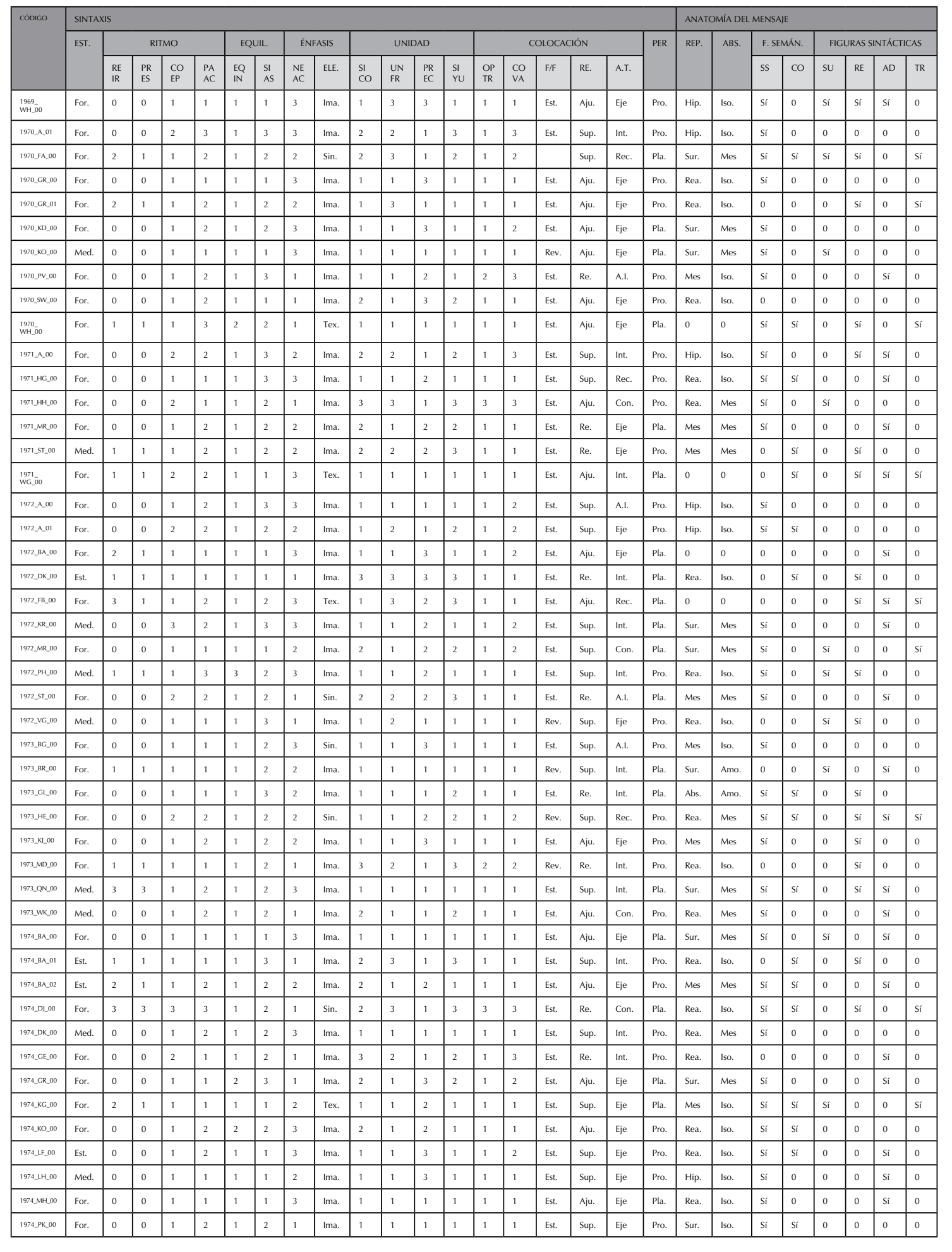




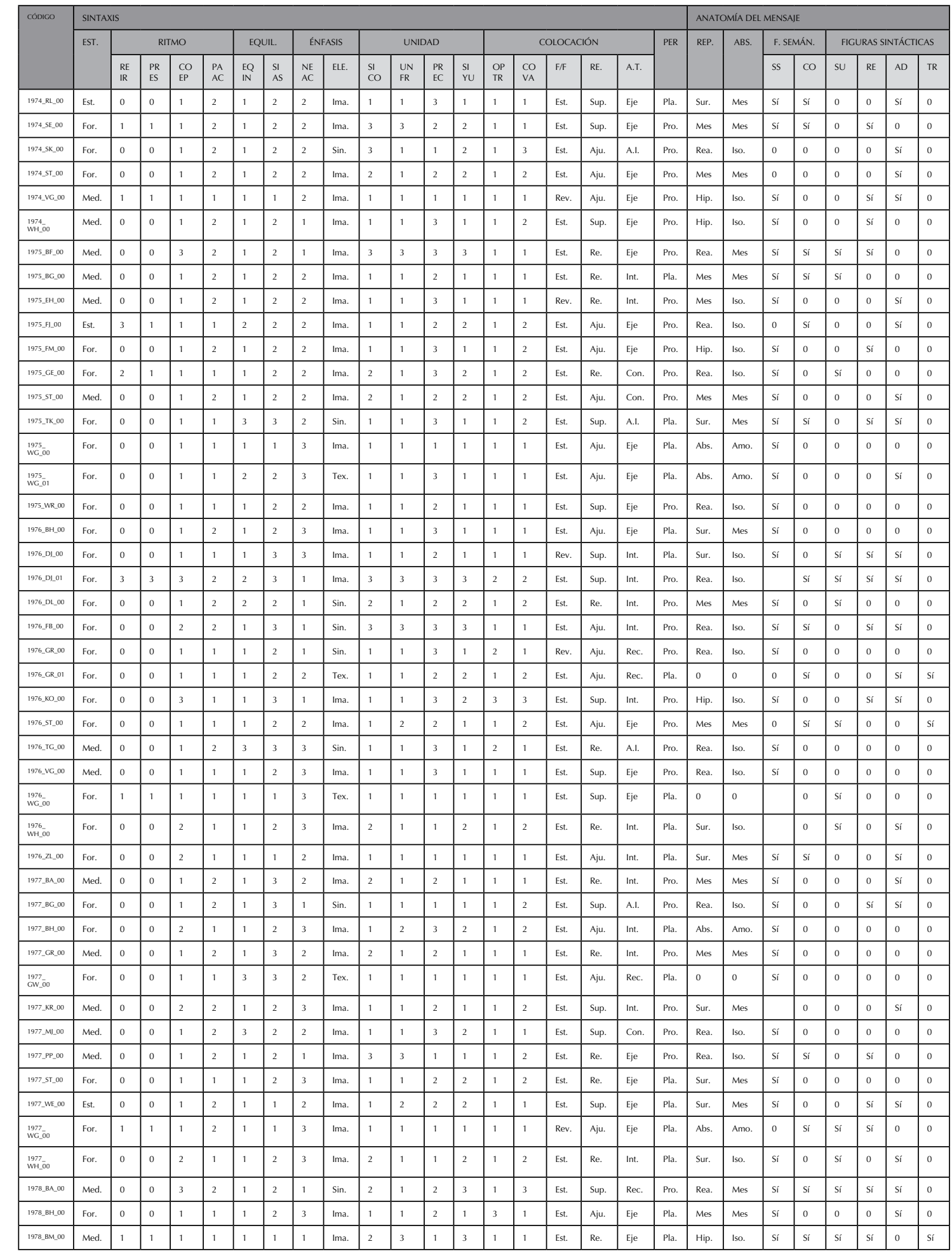

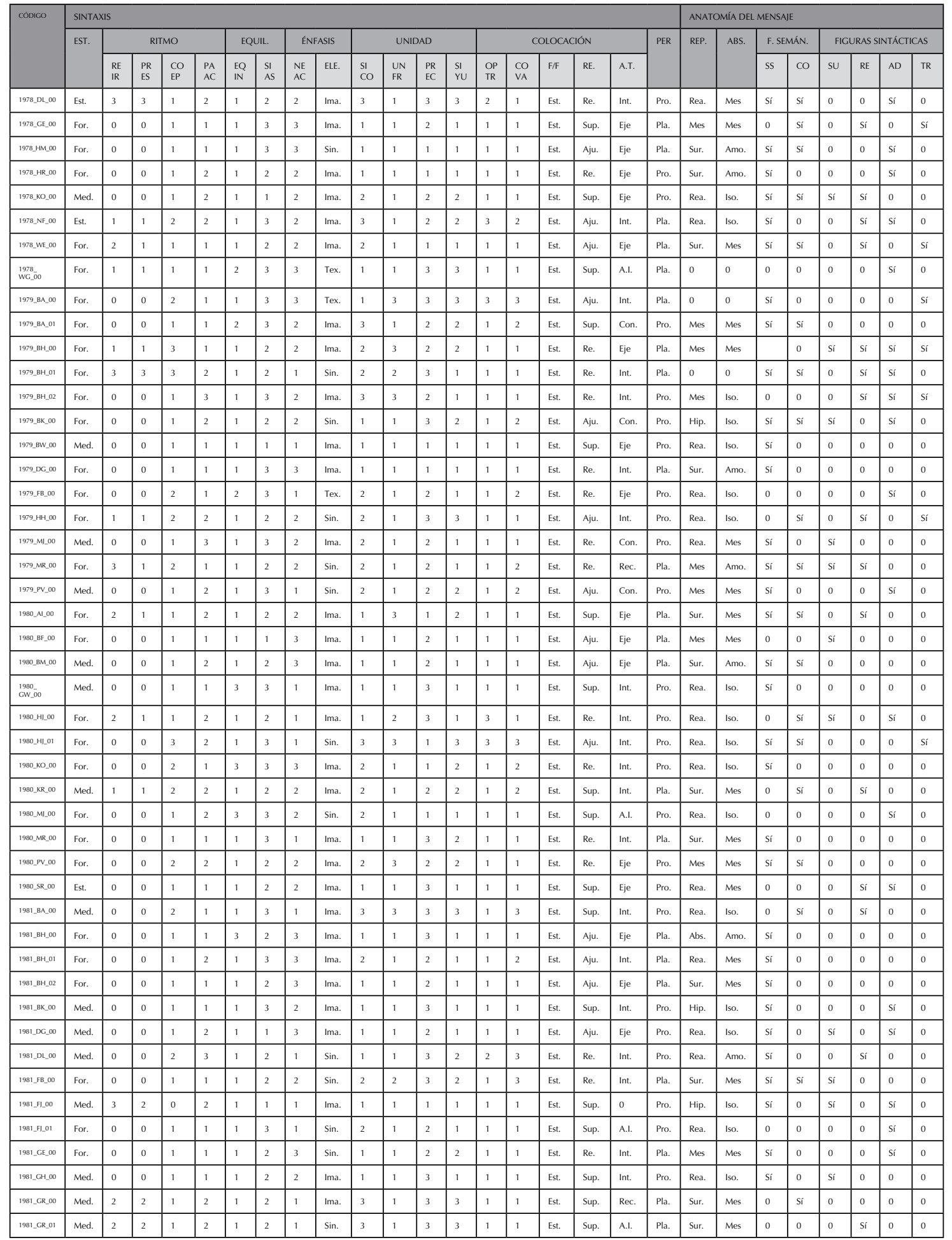




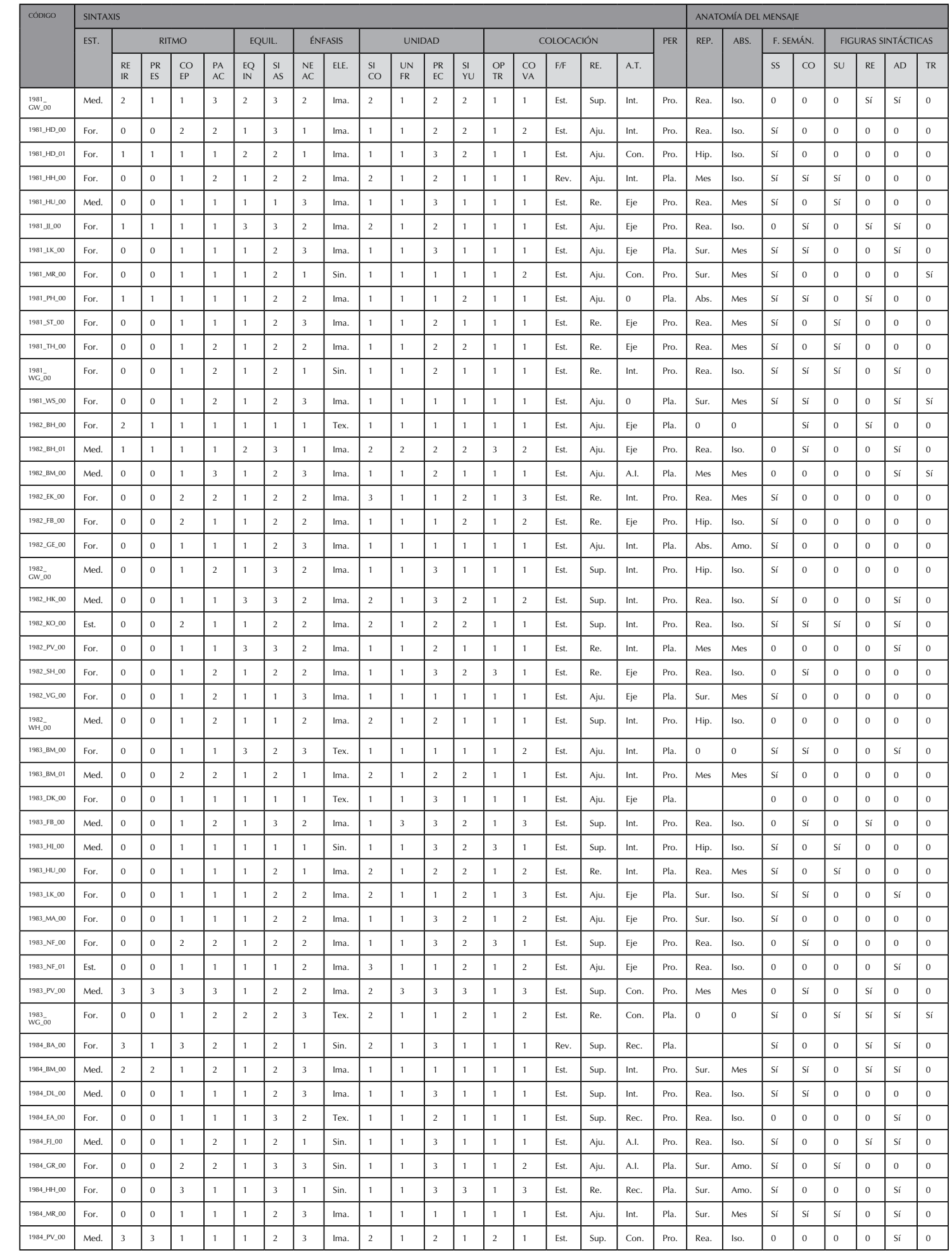

514

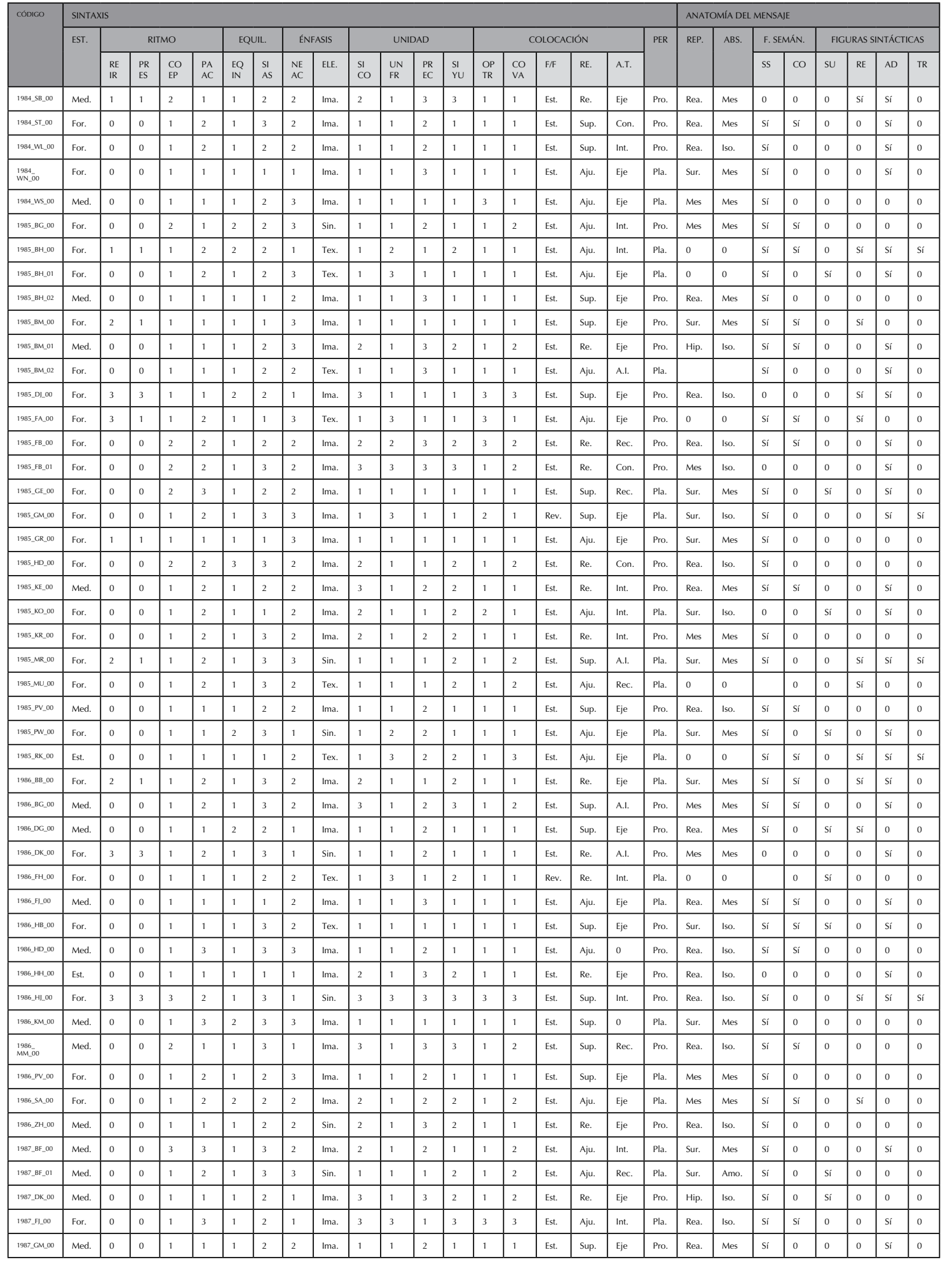



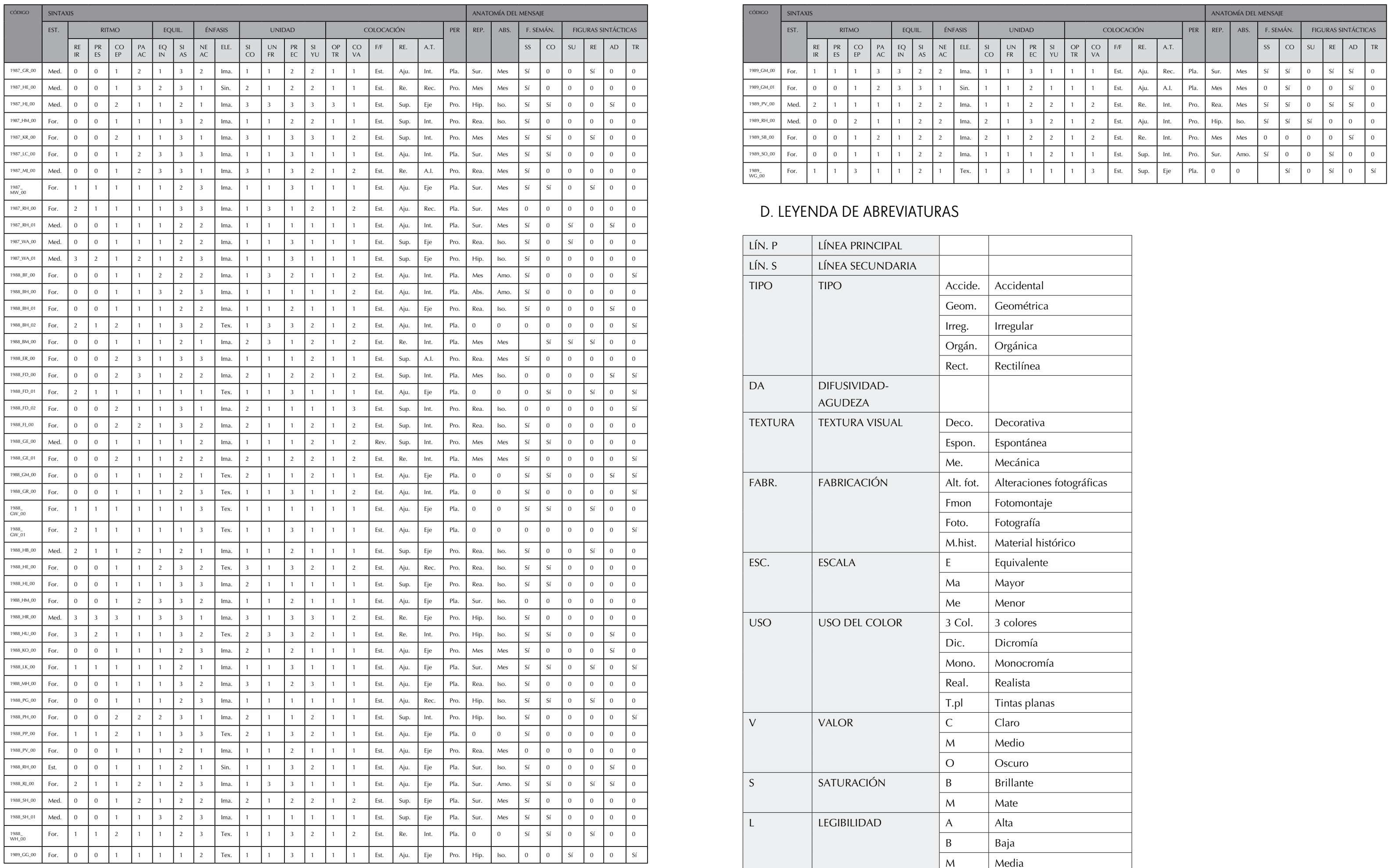

\section{LEYENDA DE ABREVIATURAS}

\begin{tabular}{|c|c|c|c|}
\hline LíN. P & LÍNEA PRINCIPAL & & \\
\hline LíN. S & LIINEA SECUNDARIA & & \\
\hline \multirow[t]{5}{*}{ TIPO } & \multirow[t]{5}{*}{ TIPO } & Accide. & Accidental \\
\hline & & Geom. & Geométrica \\
\hline & & Irreg. & Irregular \\
\hline & & Orgán. & Orgánica \\
\hline & & Rect. & Rectilínea \\
\hline DA & $\begin{array}{l}\text { DIFUSIVIDAD- } \\
\text { AGUDEZA }\end{array}$ & & \\
\hline \multirow[t]{3}{*}{ TEXTURA } & \multirow[t]{3}{*}{ TEXTURA VISUAL } & Deco. & Decorativa \\
\hline & & Espon. & Espontánea \\
\hline & & Me. & Mecánica \\
\hline \multirow[t]{4}{*}{ FABR. } & \multirow[t]{4}{*}{ FABRICACIÓN } & Alt. fot. & Alteraciones fotográficas \\
\hline & & Fmon & Fotomontaje \\
\hline & & Foto. & Fotografía \\
\hline & & M.hist. & Material histórico \\
\hline \multirow[t]{3}{*}{ ESC. } & \multirow[t]{3}{*}{ ESCALA } & E & Equivalente \\
\hline & & $\mathrm{Ma}$ & Mayor \\
\hline & & Me & Menor \\
\hline \multirow[t]{5}{*}{ USO } & \multirow[t]{5}{*}{ USO DEL COLOR } & 3 Col. & 3 colores \\
\hline & & Dic. & Dicromía \\
\hline & & Mono. & Monocromía \\
\hline & & Real. & Realista \\
\hline & & T.pl & Tintas planas \\
\hline \multirow[t]{3}{*}{$\mathrm{v}$} & \multirow[t]{3}{*}{ VALOR } & C & Claro \\
\hline & & M & Medio \\
\hline & & $\mathrm{O}$ & Oscuro \\
\hline \multirow[t]{2}{*}{ S } & \multirow[t]{2}{*}{ SATURACIÓN } & B & Brillante \\
\hline & & M & Mate \\
\hline \multirow[t]{3}{*}{ L } & \multirow[t]{3}{*}{ LEGIBILIDAD } & A & Alta \\
\hline & & $\mathrm{B}$ & Baja \\
\hline & & M & Media \\
\hline
\end{tabular}




\begin{tabular}{|c|c|c|c|}
\hline \multirow[t]{2}{*}{ REP. } & \multirow{2}{*}{$\begin{array}{l}\text { TIPO DE } \\
\text { REPRODUCCIÓN }\end{array}$} & Ma & Manual \\
\hline & & Me & Mecánica \\
\hline CLA. & CLASIFICACIÓN & & \\
\hline \multirow[t]{6}{*}{ EST. } & \multirow[t]{6}{*}{ ESTILO } & Reg. & Regular \\
\hline & & Cond. & Condensada \\
\hline & & Curs. & Cursiva \\
\hline & & Deco. & Decorada \\
\hline & & Extra. & Extragruesa \\
\hline & & Semi. & Seminegra \\
\hline \multirow[t]{6}{*}{ ALIN. } & \multirow[t]{6}{*}{ ALINEACIÓN } & Asim. & Asimétrica \\
\hline & & Arra. & Arracada \\
\hline & & Cent. & Centrada \\
\hline & & Drch. & Derecha \\
\hline & & Izq. & Izquierda \\
\hline & & Just & Justificada \\
\hline \multirow[t]{4}{*}{ ORIE. } & \multirow[t]{4}{*}{ ORIENTACIÓN } & Adap. & Adaptada \\
\hline & & Hori. & Horizontal \\
\hline & & Obli. & Oblicua \\
\hline & & Vert. & Vertical \\
\hline \multirow[t]{3}{*}{ EST. } & \multirow[t]{3}{*}{ ESTRATEGIA } & Est. & Conducido por el estilo \\
\hline & & For. & Conducido formalmente \\
\hline & & Med. & Conducido por el medio \\
\hline RE-IR & $\begin{array}{l}\text { REGULARIDAD- } \\
\text { IRREGULARIDAD }\end{array}$ & & \\
\hline PR-ES & $\begin{array}{l}\text { PREDICTIBILIDAD- } \\
\text { ESPONTANEIDAD }\end{array}$ & & \\
\hline CO-EP & $\begin{array}{l}\text { CONTINUIDAD- } \\
\text { EPISODICIDAD }\end{array}$ & & \\
\hline PA-AC & PASIVIDAD-ACTIVIDAD & & \\
\hline EQUIL. & EQUILIBRIO & & \\
\hline EQ-IN & $\begin{array}{l}\text { EQUILIBRIO- } \\
\text { INESTABILIDAD }\end{array}$ & & \\
\hline SI-AS & SIMETRÍA-ASIMETRÍA & & \\
\hline NE-AC & $\begin{array}{l}\text { NEUTRALIDAD- } \\
\text { ACENTO }\end{array}$ & & \\
\hline \multirow[t]{3}{*}{ ELE. } & \multirow[t]{3}{*}{ ELEMENTO } & Ima. & Imagen \\
\hline & & Tex. & Texto \\
\hline & & Sin. & Sinergia \\
\hline $\mathrm{SI}-\mathrm{CO}$ & $\begin{array}{l}\text { SIMPLICIDAD- } \\
\text { COMPLEIIDAD }\end{array}$ & & \\
\hline UN-FR & $\begin{array}{l}\text { UNIDAD- } \\
\text { FRAGMENTACIÓN }\end{array}$ & & \\
\hline PR-EC & $\begin{array}{l}\text { PROFUSIÓN- } \\
\text { ECONOMIÍA }\end{array}$ & & \\
\hline
\end{tabular}

\begin{tabular}{|c|c|c|c|}
\hline SI-YU & $\begin{array}{l}\text { SINGULARIDAD- } \\
\text { YUXTAPOSICIÓN }\end{array}$ & & \\
\hline OP-TR & $\begin{array}{l}\text { OPACIDAD- } \\
\text { TRANSPARENCIA }\end{array}$ & & \\
\hline CO-VA & $\begin{array}{l}\text { COHERENCIA- } \\
\text { VARIACIÓN }\end{array}$ & & \\
\hline \multirow[t]{2}{*}{$\mathrm{F} / \mathrm{F}$} & \multirow[t]{2}{*}{ FIGURA/FONDO } & Est. & Estable \\
\hline & & Rev. & Reversible \\
\hline \multirow[t]{3}{*}{ RE. } & \multirow{3}{*}{$\begin{array}{l}\text { RELACIÓN CON EL } \\
\text { FORMATO }\end{array}$} & Aju. & Ajusta \\
\hline & & Re. & Remarca \\
\hline & & Sup. & Supera \\
\hline \multirow[t]{5}{*}{ A.T. } & \multirow{5}{*}{$\begin{array}{l}\text { ALINEACION } \\
\text { TIPOGRÁFICA }\end{array}$} & A.I. & Alineaciones Internas \\
\hline & & Con. & Contorno \\
\hline & & Eje & Ejes \\
\hline & & Int. & Intuitivas \\
\hline & & Rec. & Receptivas \\
\hline \multirow[t]{2}{*}{ PER. } & \multirow[t]{2}{*}{ PERSPECTIVA } & Pla. & Plana \\
\hline & & Pro. & Profunda \\
\hline \multirow[t]{5}{*}{ REP. } & \multirow[t]{5}{*}{ REPRESENTACIÓN } & Abs. & Abstraccionismo \\
\hline & & Hip. & Hiperrealismo \\
\hline & & Mes. & Mesorrealismo \\
\hline & & Rea. & Realismo \\
\hline & & Sur. & Surrealismo \\
\hline \multirow[t]{3}{*}{ ABS } & \multirow[t]{3}{*}{ ABSTRACCIÓN } & Amo. & Amorfismo \\
\hline & & Iso. & Isomorfismo \\
\hline & & Mes. & Mesomorfismo \\
\hline F. SEMÁN & FIGURAS SEMÁNTICAS & & \\
\hline SS & DE SUSTITUCIÓN & & \\
\hline $\mathrm{CO}$ & DE COMPARACIÓN & & \\
\hline su & DE SUPRESIÓN & & \\
\hline RE & REPETITIVAS & & \\
\hline $\mathrm{AD}$ & DE ADJUNCIÓN & & \\
\hline TR & DE TRANSPOSICIÓN & & \\
\hline
\end{tabular}




\section{ANEXO IV. ÍNDICE DE TABLAS Y GRÁFICOS}

\section{A. ÍNDICE DE TABLAS}

Cap. 1

Tabla 1.1

Tabla 1.2

Tabla 1.3

Tabla 1.4

Tabla 1.5

Tabla 1.6

Tabla 1.7

Tabla 1.8

Tabla 1.9

Tabla 1.10

Tabla 1.11

Cap. 2

Tabla 2.1

Tabla 2.2

Cap. 3

Tabla 3.1

Tabla 3.2

Tabla 3.3

Tabla 3.4

Tabla 3.5

Tabla 3.6

Tabla 3.7

Tabla 3.8

Tabla 3.9

Tabla 3.10

Tabla 3.11

Tabla 3.12

Cap. 4

Tabla 4.1

Cap. 5

Tabla 5.1

Cap. 6

Tabla 6.1
Estructura de análisis según Luz Vilchis Esquivel. Elaboración propia Estructura de análisis según Wucius Wong. Elaboración propia Estructura de análisis según Donis A. Dondis. Elaboración propia Estructura de análisis según Robin Landa . Elaboración propia Estructura de análisis según Ellen Lupton y Jennifer Cole . Elaboración propia

Estructura de análisis según María Acaso. Elaboración propia Comparación entre estructuras de análisis . Elaboración propia Taxonomía de análisis según Luz Vilchis Esquivel. Elaboración propia Dipolos. Fuente: Dondis (2008:130)

Clasificación de figuras retóricas según Gui Bonsiepe . Elaboración propia Clasificación de figuras retóricas según María Acaso . Elaboración propia

Periodos y características de la escuela de la Bauhaus. Elaboración propia Periodos en la aceptación de la Bauhaus en la RDA. Elaboración propia

Cronología de la RDA. Elaboración propia

Cronología y periodos de las relaciones internacionales. Elaboración propia Cronología y periodos de las relaciones entre las dos Alemanias. Elaboración propia Cronología y periodos de la identidad alemana y la "cuestión nacional». Elaboración propia Periodos en la evolución histórica de la RDA según diversos autores. Elaboración propia Periodos históricos y de relaciones nacionales e internacionales de la RDA. Elaboración propia Reparto de escaños de la Cámara del Pueblo según datos de Herbst, Ranke y Winker (1994:10174-10176). Elaboración propia

Estructura para la promoción y propaganda. Elaboración propia Cronología de los planes económicos. Elaboración propia

Periodos económicos según diversos autores. Elaboración propia Comparación de porcentaje de población activa masculina y femenina según grupos de sueldo. Fuente: Zentrales Forschungsinstitut für Arbeit (1989).

Hitos de la RDA en la carrera espacial. Elaboración propia

Listado de tipografías producidas por la VEB Typoart. Elaboración propia

Cuadro resumen de las características tipográficas según la clasificación DIN 16.518. Elaboración propia

Legibilidad de los colores por contraste. Fuente: Favre y November (1979:50) 
Tabla 6.2 Ficha técnica de la muestra código 1946_MA_00. Elaboración propia

Tabla 6.3

Tabla 6.4

Tabla 6.5

Tabla 6.6

Tabla 6.7

Tabla 6.8

Tabla 6.9

Tabla 6.10

Tabla 6.11

Tabla 6.12

Tabla 6.13

Tabla 6.14

Tabla 6.15

Tabla 6.16

Tabla 6.17

Tabla 6.18

Tabla 6.19

Tabla 6.20

Tabla 6.2

Tabla 6.22

Tabla 6.23

Tabla 6.24

Tabla 6.25

Tabla 6.26

Tabla 6.27

Tabla 6.28

Tabla 6.29

Tabla 6.30

Tabla 6.3

Tabla 6.32

Tabla 6.33

Tabla 6.34

Tabla 6.35

Tabla 6.36

Tabla 6.37

Tabla 6.38

Tabla 6.39

Tabla 6.40

Tabla 6.41

Tabla 6.42

Esquemas formales abstractos de la muestra código 1946_MA_00. Elaboración propia Esquemas formales figurativos de la muestra código 1946_MA_00. Elaboración propia Código cromático de la muestra código 1946_MA_00. Elaboración propia Código tipográfico de la muestra código 1946_MA_00. Elaboración propia Estrategia de la muestra código 1946_MA_00. Elaboración propia Ritmo de la muestra código 1946_MA_00. Elaboración propia Equilibrio de la muestra código 1946_MA_00. Elaboración propia Énfasis de la muestra código 1946_MA_00. Elaboración propia Unidad de la muestra código 1946_MA_00. Elaboración propia Colocación de la muestra código 1946_MA_00. Elaboración propia Perspectiva de la muestra código 1946_MA_00. Elaboración propia Representación y abstracción de la muestra código 1946_MA_00. Elaboración propia Retórica visual de la muestra código 1946_MA_00. Elaboración propia Ficha técnica de la muestra código 1958_A_00. Elaboración propia

Esquemas formales abstractos de la muestra código 1958_A_00. Elaboración propia Esquemas formales figurativos de la muestra código 1958_A_00. Elaboración propia Código cromático de la muestra código 1958_A_00. Elaboración propia Código tipográfico de la muestra código 1958_A_00. Elaboración propia Estrategia de la muestra código 1958_A_00. Elaboración propia Ritmo de la muestra código 1958_A_00. Elaboración propi Equilibrio de la muestra código 1958_A_00. Elaboración propia Énfasis de la muestra código 1958_A_00. Elaboración propia Unidad de la muestra código 1958_A_00. Elaboración propia

Colocación de la muestra código 1958_A_00. Elaboración propia Perspectiva de la muestra código 1958_A_00. Elaboración propia Representación y abstracción de la muestra código 1958_A_00. Elaboración propia Retórica visual de la muestra código 1958_A_00. Elaboración propia Ficha técnica de la muestra código 1965_KH_00. Elaboración propia

Esquemas formales abstractos de la muestra código 1965_KH_00. Elaboración propia Esquemas formales figurativos de la muestra código 1965_KH_00. Elaboración propia Código cromático de la muestra código 1965_KH_00. Elaboración propia Código tipográfico de la muestra código 1965_KH_00. Elaboración propia Estrategia de la muestra código 1965_KH_00. Elaboración propia Ritmo de la muestra código 1965_KH_00. Elaboración propia Equilibrio de la muestra código 1965_KH_00. Elaboración propia Énfasis de la muestra código 1965_KH_00. Elaboración propia Unidad de la muestra código 1965_KH_00. Elaboración propia Colocación de la muestra código 1965_KH_00. Elaboración propia Perspectiva de la muestra código 1965_KH_00. Elaboración propia Representación y abstracción de la muestra código 1965_KH_00. Elaboración propia
Tabla 6.43

Tabla 6.44

Tabla 6.45

Tabla 6.46

Tabla 6.47

Tabla 6.48

Tabla 6.49

Tabla 6.50

Tabla 6.51

Tabla 6.52

Tabla 6.53

Tabla 6.54

Tabla 6.55

Tabla 6.56

Tabla 6.57

Tabla 6.58

Tabla 6.59

Tabla 6.60

Tabla 6.61

Tabla 6.62

Tabla 6.63

Tabla 6.64

Tabla 6.65

Tabla 6.66

Tabla 6.67

Tabla 6.68

Tabla 6.69

Tabla 6.70

Tabla 6.71
Retórica visual de la muestra código 1965_KH_00. Elaboración propia Ficha técnica de la muestra código 1970_FA_00. Elaboración propia

Esquemas formales abstractos de la muestra código 1970_FA_00. Elaboración propia Esquemas formales figurativos de la muestra código 1970_FA_00. Elaboración propia Código cromático de la muestra código 1970_FA_00. Elaboración propia Código tipográfico de la muestra código 1970_FA_00. Elaboración propia Estrategia de la muestra código 1970_FA_00. Elaboración propia Ritmo de la muestra código 1970_FA_00. Elaboración propia Equilibrio de la muestra código 1970_FA_00. Elaboración propia Énfasis de la muestra código 1970_FA_00. Elaboración propia Unidad de la muestra código 1970_FA_00. Elaboración propia Colocación de la muestra código 1970_FA_00. Elaboración propia Perspectiva de la muestra código 1970_FA_00. Elaboración propia Representación y abstracción de la muestra código 1970_FA_00. Elaboración propia Retórica visual de la muestra código 1970_FA_00. Elaboración propia Ficha técnica de la muestra código 1988_RJ_00. Elaboración propia Esquemas formales abstractos de la muestra código 1988_RJ_00. Elaboración propia Esquemas formales figurativos de la muestra código 1988_RJ_00. Elaboración propia Código cromático de la muestra código 1988_RJ_00. Elaboración propia Código tipográfico de la muestra código 1988_RJ_00. Elaboración propia Estrategia de la muestra código 1988_RJ_00. Elaboración propia Ritmo de la muestra código 1988_RJ_00. Elaboración propia Equilibrio de la muestra código 1988_RJ_00. Elaboración propia Énfasis de la muestra código 1988_RJ_00. Elaboración propia Unidad de la muestra código 1988_RJ_00. Elaboración propia Colocación de la muestra código 1988_R__00. Elaboración propia Perspectiva de la muestra código 1988_R__00. Elaboración propia Representación y abstracción de la muestra código 1988_RJ_00. Elaboración propia Retórica visual de la muestra código 1988_R__00. Elaboración propia 


\section{B. ÍNDICE DE GRÁFICOS}

Cap. 0

Gráfico $0.1 \quad$ Esquema de la investigación. Elaboración propia

\section{Cap. 2}

Gráfico 2.1 Esquemas compositivos de los carteles analizados. Elaboración propia

Gráfico 2.2 Evolución de los esquemas compositivos. Elaboración propia

Gráfico 2.3 Análisis tipográfico de tipografías previas a 1945. Elaboración propia

Gráfico 2.4 Evolución de los remates tipográficos previos a 1945. Elaboración propia

Gráfico 2.5 Evolución de la geometría tipográfica previa a 1945. Elaboración propia

Gráfico 2.6 Propuesta de análisis de la imagen. Elaboración propia

Gráfico 2.7 Análisis de la imagen de los periodos previos a 1945. Elaboración propia

Gráfico 2.8 Resumen de las características de la imagen de los periodos previos a 1945. Elaboración propia

Gráfico 2.9 Propuesta de cuadro de características de los periodos previos a 1945. Elaboración propia

Gráfico 2.10 Características de los periodos previos a 1945. Elaboración propia

Gráfico 2.11 Evolución y tendencias en la composición de los periodos previos a 1945. Elaboración propia

Gráfico 2.12 Evolución y tendencias en la tipografía de los periodos previos a 1945. Elaboración propia

Gráfico 2.13 Evolución y tendencias en la imagen de los periodos previos a 1945. Elaboración propia

Cap. 3

Gráfico 3.1 Esquema de la estructura política de la RDA. Elaboración propia

Gráfico 3.2 Demografía poblacional por sexos en 1982. Fuente: Statistisches Jahrbuch der DDR (1983), citado en LUDZ (2000).

Gráfico 3.3 Movimiento poblacional natural entre 1946 y 1982. Fuente: Ludz (2000).

Gráfico 3.4 Esquema del sistema de formación de la RDA. Fuente: Vogt (2000)

Cap. 6

Gráfico 6.1

Cap. 7

Gráfico 7.1

Gráfico $7.2 \mathrm{a}$

Gráfico $7.2 \mathrm{~b}$

Gráfico 7.3

Gráfico 7.4

Gráfico 7.5

Gráfico 7.6

Gráfico 7.7

Gráfico 7.8

Gráfico 7.9

Gráfico 7.10

Gráfico 7.11

Gráfico 7.12

\section{Estructura básica de la propuesta de análisis para la investigación. Elaboración propia}

Distribución de la muestra a lo largo del periodo analizado. Elaboración propia Hitos históricos y periodos artísticos. Elaboración propia

Resumen de hitos históricos y periodos artísticos. Elaboración propia

Distribución de la muestra según género: político, cultural y económico. Elaboración propia

Distribución de la muestra según tipo de reproducción. Elaboración propia

Distribución de la muestra según tipos de esquemas formales. Elaboración propia

Presencia de los diferentes tipos de esquemas formales no figurativos. Elaboración propia

Presencia de los diferentes tipos de esquemas formales figurativos. Elaboración propia

Porcentaje de los diferentes tipos de usos del color. Elaboración propia

Presencia del color rojo. Elaboración propia

Presencia del color rojo como uso principal. Elaboración propia

Nivel de legibilidad por contraste. Elaboración propia

Distribución de la muestra según tipo de reproducción tipográfica. Elaboración propia
Gráfico 7.13 Presencia de tipografías manuales de clase VII y IX del total de las tipografías utilizadas. Elaboración propia

Gráfico 7.14 Presencia de tipografías manuales de clase VII y IX en los carteles de la muestra. Elaboración propia

Gráfico 7.15 Porcentaje de tipografía mecánica producida por la VEB Typoart dentro del total de las tipografías utilizadas. Elaboración propia

Gráfico 7.16 Porcentaje de tipografía mecánica producida por la VEB Typoart en los carteles de la muestra. Elaboración propia

Gráfico 7.17 Distribución del uso de tipografías según su clasificación. Elaboración propia

Gráfico 7.18 Distribución del uso de tipografías según diferentes categorías de clasificación. Elaboración propia

Gráfico 7.19 Distribución del tipo de reproducción de cada clase tipográfica. Elaboración propia

Gráfico 7.20 Originalidad de los diseños de la VEB Typoart utilizados en los carteles. Elaboración propia

Gráfico 7.21 Número de carteles con presencia de cada una de las tipografías diseñadas por la VEB Typoart. Elaboración propia

Gráfico 7.22 Distribución de la estrategia utilizada en los carteles de la muestra. Elaboración propia

Gráfico 7.23 Distribución del elemento en el que recae el énfasis en los carteles de la muestra. Elaboración propia

Gráfico 7.24 Nivel de énfasis. Elaboración propia

Gráfico 7.25 Regularidad en el ritmo. Elaboración propia

Gráfico 7.26 Predictibilidad en el ritmo. Elaboración propia

Gráfico 7.27 Continuidad entre elementos. Elaboración propia

Gráfico 7.28 Nivel de actividad. Elaboración propia

Gráfico 7.29 Nivel de armonía en el ritmo. Elaboración propia

Gráfico 7.30 Nivel de equilibrio. Elaboración propia

Gráfico 7.31 Nivel de simetría. Elaboración propia

Gráfico 7.32 Armonía en el ritmo. Elaboración propia

Gráfico 7.33 Nivel de simplicidad en la comunicación. Elaboración propia

Gráfico 7.34 Nivel de unidad. Elaboración propia

Gráfico 7.35 Nivel de profusión de detalle. Elaboración propia

Gráfico 7.36 Nivel de singularidad en la comunicación. Elaboración propia

Gráfico 7.37 Armonía en la unidad. Elaboración propia

Gráfico 7.38 Nivel de opacidad. Elaboración propia

Gráfico 7.39 Nivel de coherencia. Elaboración propia

Gráfico 7.40 Relación entre figura y fondo. Elaboración propia

Gráfico 7.41 Relación de los elementos con el marco. Elaboración propia

Gráfico 7.42 Distribución de los diferentes tipos de alineaciones tipográficas. Elaboración propia

Gráfico 7.43 Nivel de armonía en la colocación. Elaboración propia

Gráfico 7.44 Distribución de los diferentes tipos de representación. Elaboración propia

Gráfico 7.45 Nivel de representación. Elaboración propia

Gráfico 7.46 Distribución de los diferentes tipos de abstracción. Elaboración propia

Gráfico 7.47 Nivel de abstracción. Elaboración propia 
Gráfico 7.48 Distribución de la perspectiva. Elaboración propia

Gráfico 7.49 Distribución de los diferentes tipos de figuras retóricas. Elaboración propia

Cap. 8

Gráfico 8.1 Características de los diferentes periodos del diseño gráfico en el ámbito cultural. Elaboración propia

Gráfico 8.2 Características de los diferentes periodos del diseño gráfico en el ámbito económico. Elaboración propia

Gráfico 8.3 Características de los diferentes periodos del diseño gráfico en el ámbito político. Elaboración propia

Gráfico 8.4 Características de los diferentes periodos del diseño gráfico. Elaboración propia

Gráfico 8.5 Evolución de las características del diseño gráfico. Elaboración propia

Gráfico 8.6 Evolución de las características del diseño gráfico en el ámbito cultural. Elaboración propia

Gráfico 8.7 Evolución de las características del diseño gráfico en el ámbito económico. Elaboración propia

Gráfico 8.8 Evolución de las características del diseño gráfico en el ámbito político. Elaboración propia 


\section{ANEXO V. DIN 16518 SEGÚN JOSEP M. PUJOL (pendiente de publicación)}

Josep M Pujol La classificació DiN 16518 [1959/1964] de les Iletres tipogràfiques Consulta del Termcat (3.22010)

So conec cap versió catalanna de la norma industriala lemanya DIN 16518 , sobre la cassfíració de les Iletres tipograifiques. Jo fecia en tenia feta la seguient, que be revisat per a aquesta ocasió

I Romana renaixentista veneciana / Venezianische Renalssance-Antiqua

II Romana renaixentista francesa / Französische Renaissance-Antiqua

III Romana barroca / Barock Antiqua

Iv Romana neoclàssica / Klassizistische Antiqua

v Egipcia / Serifenbetonte Linear-Antiqua

v1 L.Jetra de pal sec - Lineal / Serifenlose Linear-Antiqua

(II Altres / Antiqua-Varianten

VIII Manuscrites / Schreibschriften

IX L.etra cal-ligràtica / Handschriftliche Antiqua

$x$ Gòtiques / Gebrochene Schriften

a gìtica / Gotisch

$b$ gibtca rodona (rotunda) / Rundgotisch (Rotanda)

$c$ schwabacher/Schwabach

fraktur / Fraktur

政

XI Escriptures no llatines

COMENTARIS

-17 Sense discutir ara la classificacóó DIN, que presenta molts problemes i tampoc no s'ba imposat, cal reconèixer d'entrada que ofe Uingocistics de l'alemany, una llengua "digrafíca" (com si digǘssim una economia única amb dues monedes differents), que tradicionalment havia oposat Antiquu (la lletra llatina de tradicić humanistic

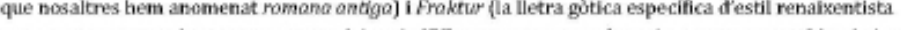
que es va imposar a la primera mettat de sege XVVi ies va mantenir fins a la segona guerra Murdial, per

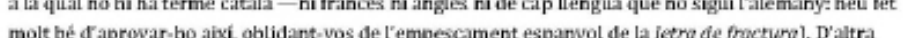

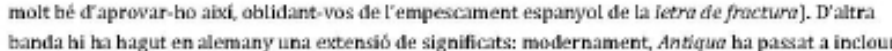
en determinats sistemes terminológis (entre els quals el de la norma DIN] totes les Letres que tenen

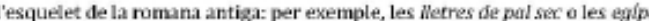
variants de l'Antiogud, mentre Frakhur va tendir a usar-se ja des d'antic amb dos significats, un de

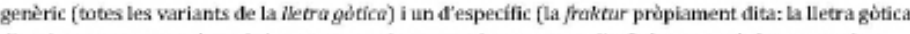

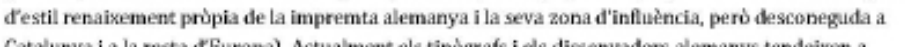

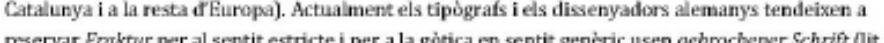

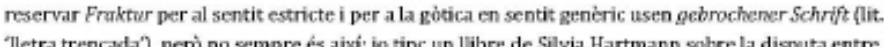

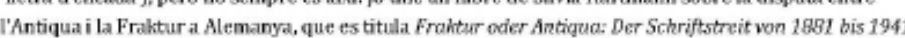
[1998] i a La portada el que es va encarregar de fer -la - que devia ser dels que no filen prim- va posar a paraula Frakitur amb una ostentosas schwabacher. 
Josep M Pujol La classificació DIN 16518 [1959/1964] de les lletres tipogrànfques

La nostra terminologia consistia fins fa ben poca a qualificar de romanes tetes les lletres que tenen serif, distingint només entre la momena antiga (del renaixement al barroc, amb serifs de costats buidats letres de pal sec (que no tenen serii) nil les equipdes (que no és ben bé un serif el que tenen] no han estat mai consideral

alemany.
D'altra banda, a classifficació DIN prescindeix del contrast romana antiga / romana moderna: tot són romanes, amb un adiectiu que correspon al periode artistic que toca. No hỉ ha dubte que śs un

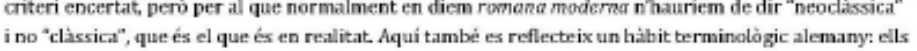
tenen un periode de la seva literatura que en diuen Khassik o més predisament Weimarer Klassik (Irèpoca de Wieland, Herder, Goethe i Schiller, de 1794 a 1805), que és la d'aquesta romanai correspon al nostre neoclassicisme

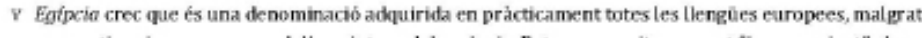

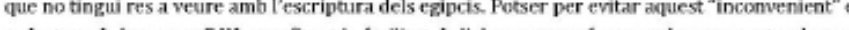

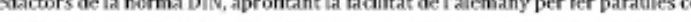

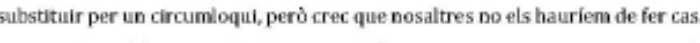

v1 Tots sabern que és una lietra de pal Isec, perì no hi ha dubte que la denominací de vegades és incomoda de manejar, perque obliga a fer servir el substantiu leetra: lietro de parf o de pal sece, que de

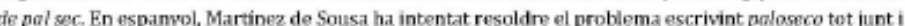

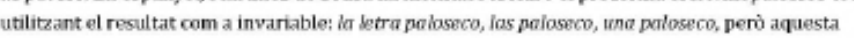
denominacíb violenta els hàbuts lingoistics de lespanyol I jo em resistelexo a ferla servir.

Sense discuatr de cap manera el correcte inormal fletra de pai sec, seria mot tort aprofitar

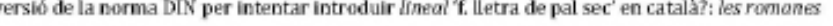

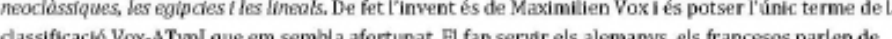
dassifictiaciw Vox-ATypr que en sembla afortunat, Hi fan servir els alemanys, els francesos parlen de

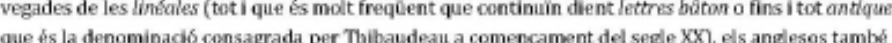
"han coplaten la seva versíj de la norma DIN fencara que continuen preferint absolutament sons-serlf Iels italians ia fa temps que parlen amb bastanta tranquililitiat de caratteri litineari, terme que va adoptar Aldo Novarese, autor que fallei entre ells. Aqui no s' ha fet servir, però jo ho dic de tant en tanta les meves classes i conferències, toti que no recondo si he arribat a imprimir-ho mal.

vil No sé com dilr-ne de les Antriqua-Varionten. En realiktat no vol dir altra cosa que 'lletres que no

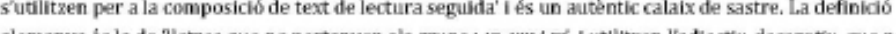

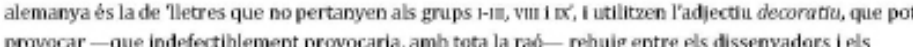
provocar -que indefectiblement provocaria, anb tota la rad-rebuig entre els dilissenyadors iets

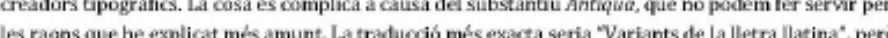
is que en alemany tampor no em sembla gens afortunat ipodriem sortir per la tangent dient-ne

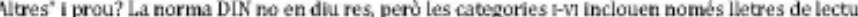
seguida.

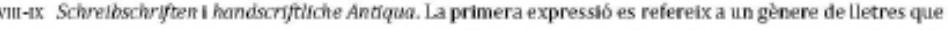
sha prodigat sobretet en l'era digitall ivol dir' 'Lereses que s'assemblen a les que escriuen a mì per al seu

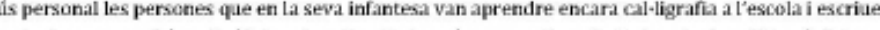

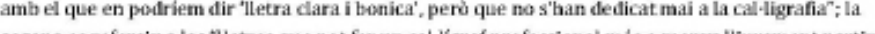

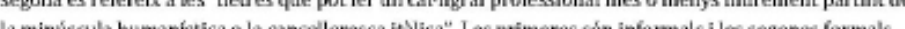

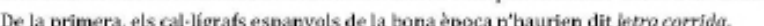

X.

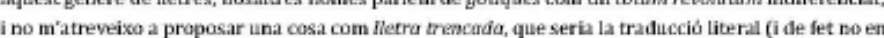

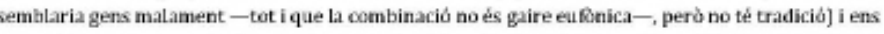
permetria precisar com to fan els alemanys. Ara bé, gotisch en lalemany tipografific dara significa, no losep M Pujol La classificació DIN 16518 [1959/1964] de les Iletres tipogrànfiques

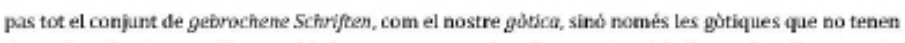
denominatives de l'alemany, ino m'hi trencaria a gaire el cap. Donos sota aquest epiegraf les categories

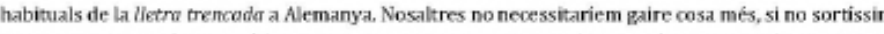

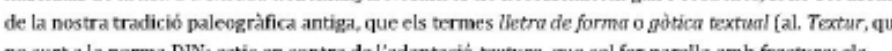

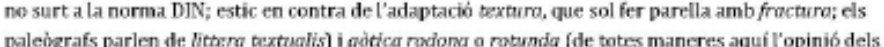

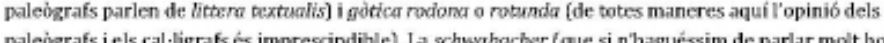

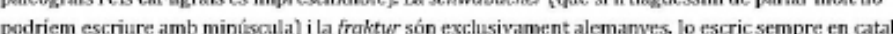
fraktar amb minuiscula i sense curiviva

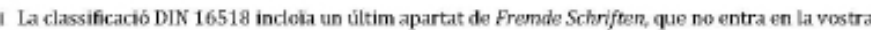

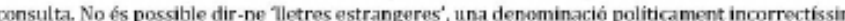

